





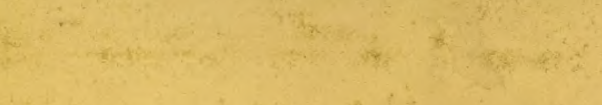
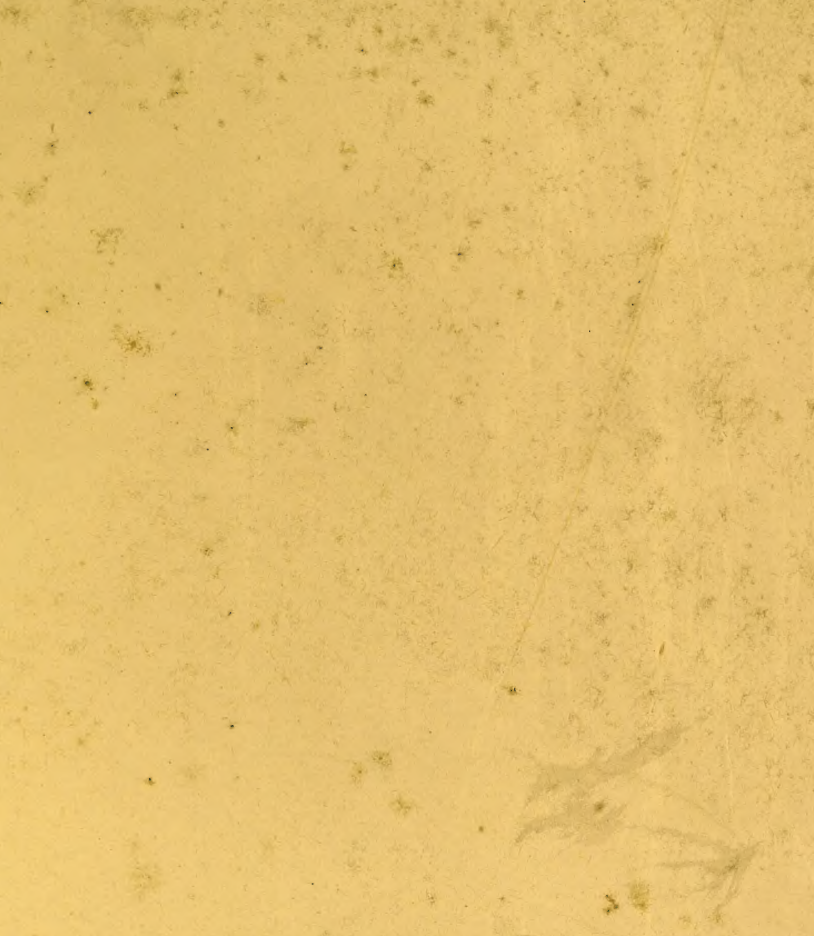

$-7$
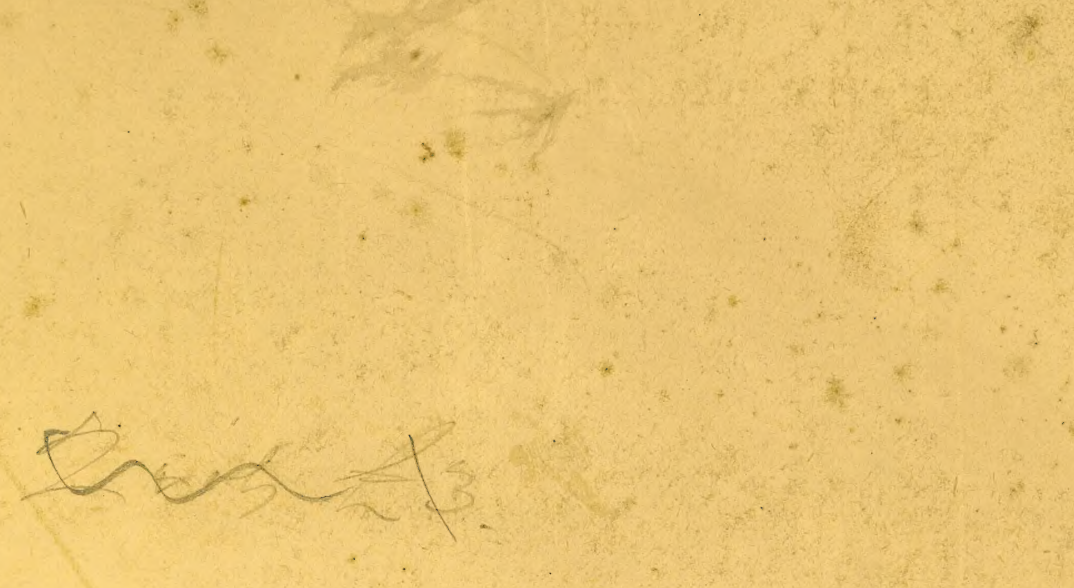


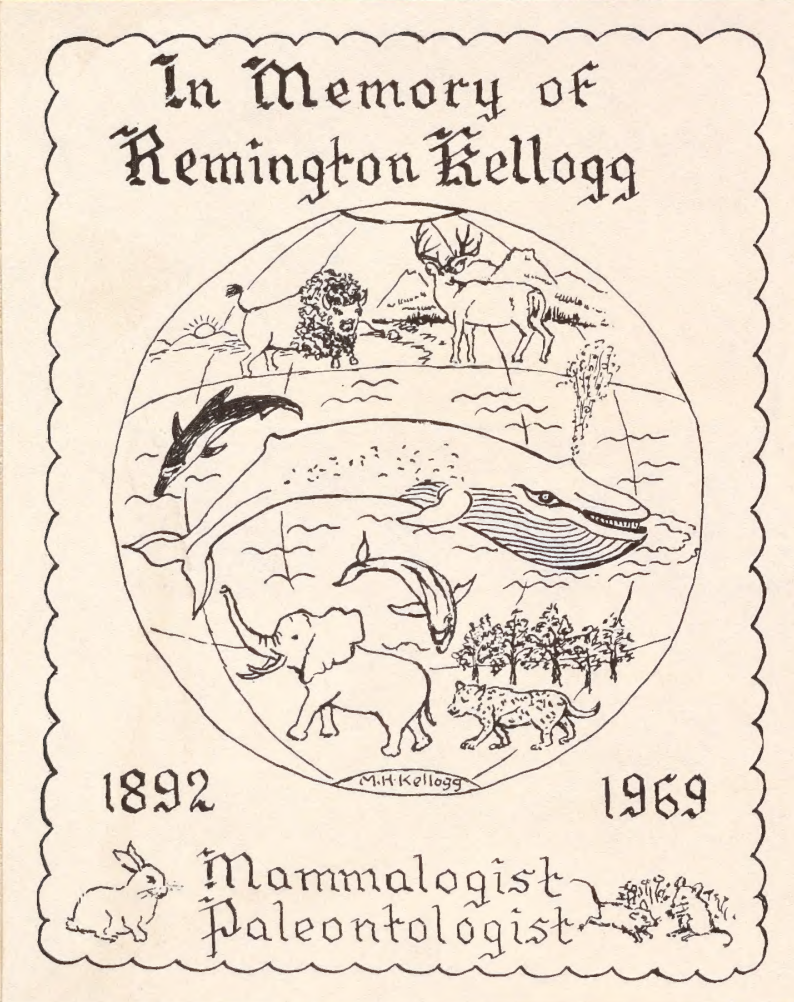






\section{ZOOLOGICAL RESULTS Of: THE TWO EXPEDITIONS}

TO

\section{WESTERN YUNNAN \\ IN \\ 1868 AND 1875;}

AND

A MONOGRAPH OF THE TWO CETACEAN GENERA, PLATANISTA AND ORCELLA.

BY

JOHN ANDERSON, M.D., EDIN.,

SUPERINTENDENT INDIAN MUSEUM, AND PROFESSOR OF COMPARATIYE ANATOMY, MEDICAL COLLEGE, CÁLCUTTA; MEDICAL OFFICER TO THE EXPEDITIONS.

First VOLUME-TEXT.

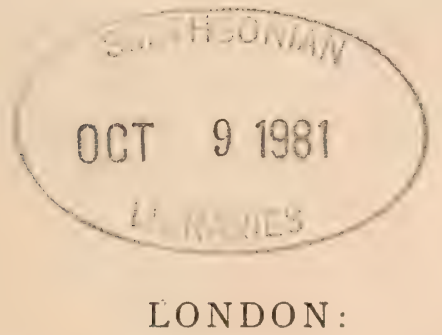

BERNARD QUARITCH, I5, PICCADILLY.

I878. 

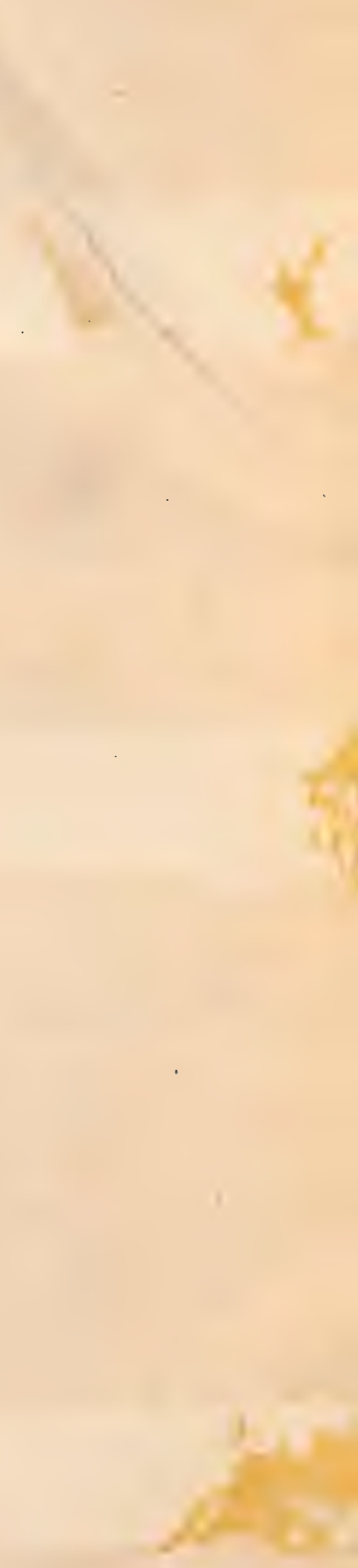


\section{ANATOMICAL AND ZOOLOGICAL RESEARCHES,}

AND

\section{ZOOLOGICAL RESULTS OF THE YUNNAN EXPEDITIONS.}

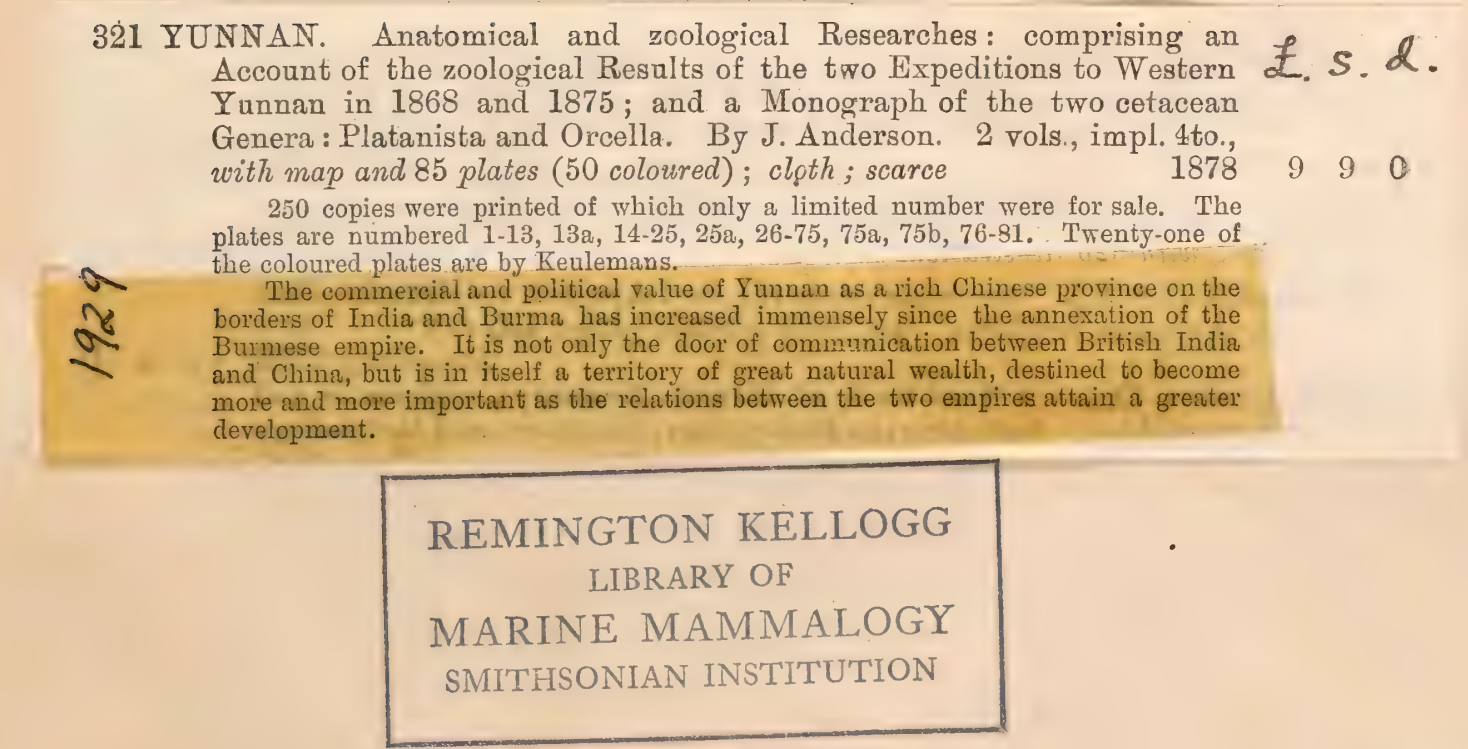


CALCUTTA :

OFEICE OF THE SUPERINTENDENT OF GOVERNMENT PRINTING 8, HASTINGS STREET. 


\title{
Remingtor Kellogg
}

\section{SYSTEMATIC INDEX;}

\author{
ALSO
}

\section{A LIST OF GENERA AND SPECIES OBTAINED ON THE EXPEDITIONS TO WESTERN YUNNAN.**}

\author{
SECTION I.-VERTEBRATA.
}

\section{FIRST PART 0F MAMMALIA.}

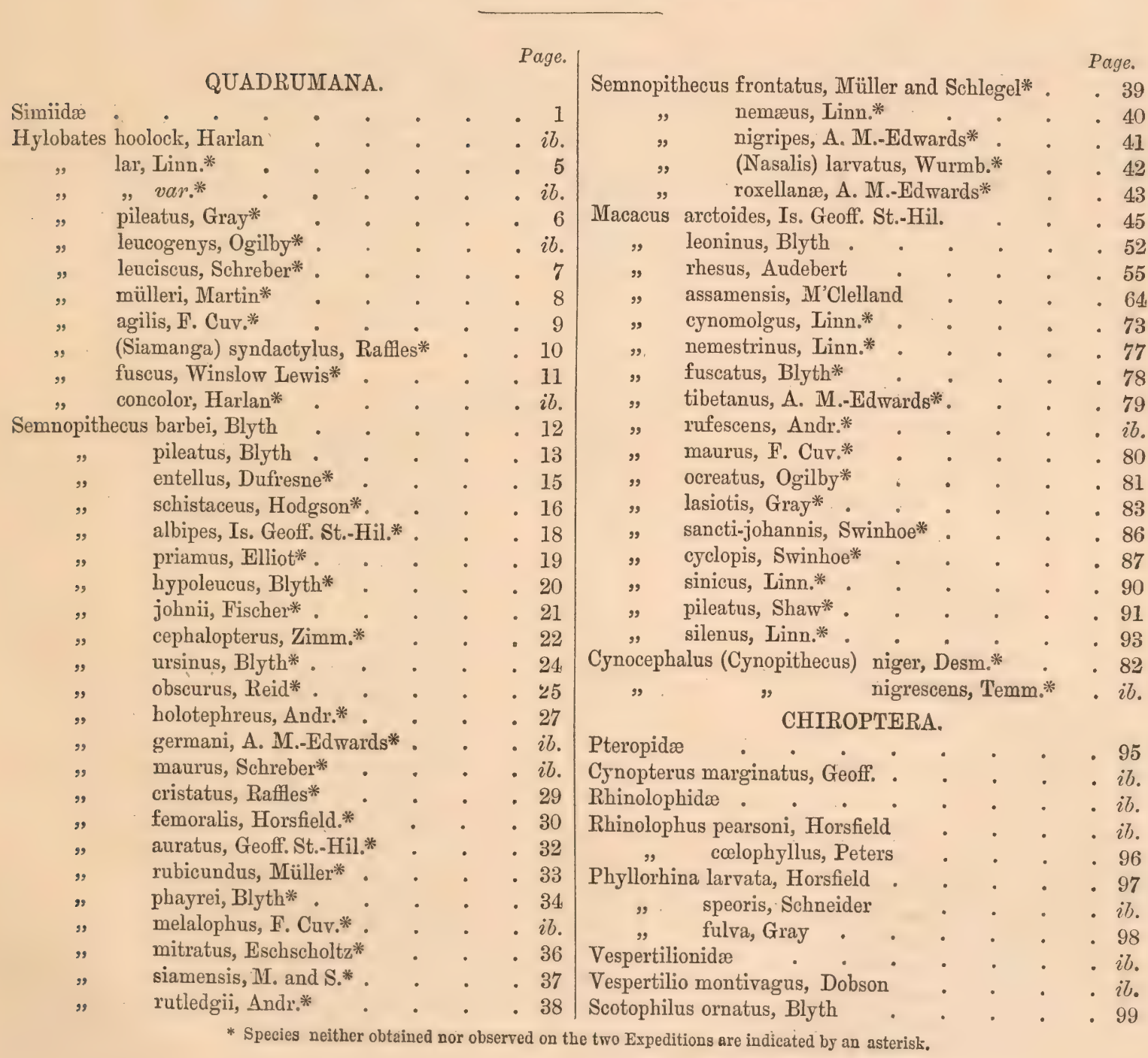


Vesperugo affinis, Dobson

Emballonuridæ andersoni, Dobson

Taphozous longimanus, Hardwicke

\section{INSECTIVORA.}

Nycticibidæ

Nycticebus cinereus, A. M.-Edwards

Tupaiidæ .

Dendrogale murina, M. and S.*

Tupaia frenata, Gray*
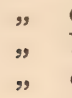

,

"

,

"

Hylomidx ellioti, Waterhouse* belangeri, Wagner chinensis, Andr. ferruginea, Raffles* splendidula, Gray* javanica, Horsfield* walaccana, Andr.* tana, Raffles* nicobarica, Zelebor*

Hylomys peguensis, Blyth

Soricidæ .

Chimarrogale himalaica, Gray

Anurosorex assamensis, Andr.*

CARNIVORA.

Felidæ

Felis tigris, Linn.

" pardus, Linn.

, bengalensis, Desm.

domesticus, Auct.

Viverridæ

Viverricula malaccensis, Gmelin

Prionodon pardicolor, Hodgson

Herpestidæ

Herpestes auropunctatus, Hodgson persicus, Gray* smithi, Gray*

maccarthiæ, Gray*

pallidus, Wagner*

ferrugineus, Blanford* jerdoni, Gray*

fuscus, Waterhouse*

javanicus, Geoffroy*

brachyurus, Gray*

vitticollis, Bennett*.

urva, Hodgson*

Mustelidx semitorquatus, Gray*

Helictis moschatus, Gray

Meles (Arctonyx) collaris, F. Cuv.

Iutra

\section{RODENTIA.}

Sciuridæ .

Sciurus bicolor, Sparmann*
" giganteus, M'Clelland
" indicus, Erxleben*
"maximus, Gmelin*
" macrourus, Pennant*
" pygerythrus, Is. Geoff. St.-Hil.
" caniceps, Gray

Page.

- 100

- 101

102

- $i b$.

103

- $i b$.

- 107

- 110

- $i b$.

- 111

- 124

- 126

- 129

130

132

134

- $i b$.

- 136

- $i b$.

- 138

- $i b$.

- 139

$i b$.

- 150

- 100

- 160

- 161

- 164

- 165

- 166

- $\quad i b$.

- $i b$.

- 168

- 172

- 174

- 176

- 178

- 181

182

183

184

185

187

188

189

- 191

193

it.

196

- 200

- 214

- 215

- 220

- 222

- 223

- 224

- 227

- 229
Sciurus phayrei, Blyth

, blanfordi, Blyth . . . . . . $i b$.

griseimanus, A. M.-Edwards* . . . 233

atrodorsalis, Gray . . . . . $i b$.

bimaculatus, Temm.* . . . . . 235

erythræus, Pallas _ . . . . 236

castaneoventris, Graj* . . . . . 238

gordoni, Andr. . . . . . . 240

hippurus, Is. Geoff. St.-Hil.* . . . 241

sladeni, Andr. • . . • . . 242

ferrugineus, F. Cuv.* . . . . . 243

lokroides, Hodgson . . . . . 247

lokriah, Hodgson* . . . . . 250

leucomus, M. and S.* . . . . . 251

alstoni, Andr.* . . . . . . 252

pernyi, A. M.-Edwards . . . . 253

modestus, M. and S.* . . . . ib.

" chinensis, Gray* . . . . . . 254

philippensis, Waterhouse* . . . . 255

tenuis, Horsfield* . . . . . ib.

murinus, M. and S.* . . , . . 256

exilis, S. Müller* . • . . . . 257

palmarum, Linn. . . . . . $i b$.

tristriatus, Waterhouse* . . . . 258

sublineatus, Waterhouse* . . . . 260

layardi, Blyth* . . . . . . $i b$.

berdmorei, Blyth* . . . . . 261

insignis, F. Cuv.* • . . . . 262

" maclellandi, Horsfield . . . . . 263

soricinus, Waterhouse* . . . . 265

" quinquestriatus, Andr. . . . . . . 266

" vittatus, Raffles* . • . . . . . $i b$.

" plantani, Ljung* . . • . . . 267

" deschinschicus, Gmelin* . . . . 269

" prevosti, Desmarest* . . . . . $i b$.

" (Rhinosciurus) tupaoides, Gray* . . . 275

" " macrotis, Gray* . . . 277

Pteromidæ • • • • . 278

- 279

- 281

- 282

- 283

- $i b$.

- 284

- 285

- 286

- 287

- 289

- 290

- 291

- 292

- 293

- 294

- 295

- 296

- 297

- $i b$.

- 298

- $i b$.

- 299

- $i b$.

- 300

- 301 
Pteromys volans, Linn.* . Muridæ momonga, Temm.*

Mus bowersi, Andr.

" sladeni, Andr.

" rubricosa, Andr.

" yunnanensis, Andr. .

" kakhyenensis, Andr. .

" viculorum, Andr.

Vandeleuria

Mus (Vandeleuria) oleraceus, Bennett

Rhizomys

Rhizomys sumatrensis, Raffles* " erythrogenys, Andr.* " pruinosus, Blyth
Page.

- 302

- 303

- 304

- $i b$.

- 305

- 306

- $i b$.

307

308

309

313

314

322

324

325
Rhizomys minor, Gray* _ _ . $\quad 327$

327

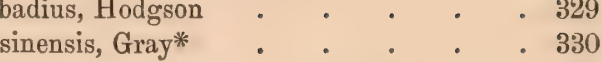

332

Hystricidæ

Hystrix yunnanensis, Andr. . $\quad$. $\quad . \quad$. $i b$.

Nemorhedus bubalina, Hodgson . . . . 333

, edwardsi, David . • . . . $i b$

Cervus porcinus, Zimm. .

Edentata . . . . . . . . 341

Manis $\cdot 0^{\circ}$

Manis aurita, Hodgson . . . . . . 352

" javanica, Desm. . . . . . . . 353

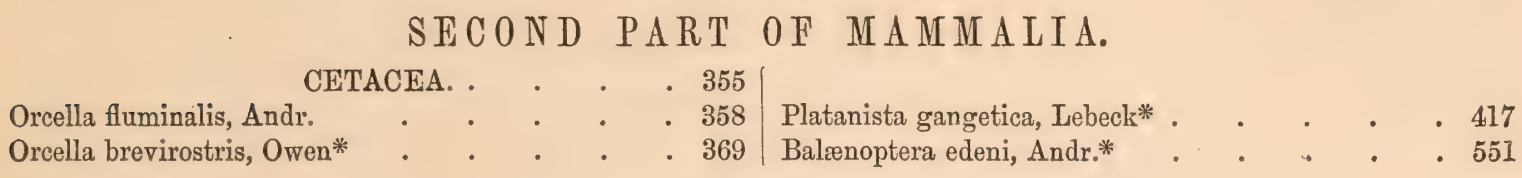

PSITTACI.

Palæornis eupatrius, Linn. torquatus, Bodd. cyanocephalus, Wagler

melanorhynchus, Wagler . ACCIPITRES.

Falconidæ

Falco subbuteo, Linn. saturatus, Blyth

Microhierax cærulescens, Linn.

Pernis ptilorhynchus, Temm.

Elanus cæruleus, Desf.

Circus melanoleucus, Forster

Astur poliopsis, Hume

Haliætus leucoryphus, Pallas

Milvus melanotis, $\mathrm{T}$. and $\mathrm{S}$.

Pandion haliætus, Linn.

STRIGES.

Bubonidæ

Bubo ignavus, Forster

Carine pulchra, Hume

Ninox lugubris, Tickell

PICARIA

Bucerotidæ

Hydrocissa albirostris, Shaw

Upupidæ

Upupa indica, Bonap.

Alcedinidæ

Halcyon smyrnensis, Linn.

Alcedo bengalensis, Gmelin

Ceryle rudis, Linn.

Coraciidæ

Coracias affinis, McClelland

Meropidæ

\section{A VES.}

Merops philippensis, Linn. . . . . . 587

" viridis, Linn. . . . . . . 582

" leschenaulti, Vieill. . . . $i b$

Nyctiornis athertoni, Jardine and Selby . . . 583

Capitonidæ . . . . $i b$

Megalæma hodgsoni, Bonap. . . . . . $i b$.

" asiatica, Lath. . . . . . . 584

Picidæ

Chrysocolaptes sultaneus, Hodgson . . . . $i b$

Gecinus striolatus, Blyth . . . 585

Yungipicus rubricatus, Blyth . . . . . $i b$.

Chrysonotus shorei, Vigors • • • . 586

Cuculidæ . . . . . . . . $i b$.

Cuculus canorus, Linn. $\quad$ • $\quad$. $\quad$ • . . $i b$.

" sonnerati, Lath. • • • • . . 587

Cacomantis rufiventris, Jerdon . . . . $i b$.

Surniculus lugubris, Hodgson . . . . - ib

Caprimulgidæ . . . . . . 588

Caprimulgus jotaka, Temm. and Schlegel . . . . ib.

- 576 " macrurus, Horsfield . . . $i b$.

- $i b$.

- $i b$.

- 577

Corvus insolens, Hume

" levaillanti, Lesson . . . . . . $i b$.

Pica rustica, Scop. . . . . . . 590

Dendrocitta rufa, Scop. . . . . . 591

Urocissa magnirostris, Blyth . . . . 592

Sturnidæ . . . . . 593

Acridotheres tristis, Linn. $\quad . \quad$. $\quad . \quad i b$.

$580 \quad$, fuscus, Wagler . . . . 594

- ib. $"$ siamensis, Swinhoe $\quad . \quad . \quad . \quad$ ib.

- 581 Sturnopastor contra, Linn., var. superciliaris, Blyth . ib.

- ib. $\quad$ " nigricollis, Payk. . . . 595

- i3. Temenuchus burmanicus, Jerdon $\quad$ • $\quad \cdot \quad \cdot \quad \cdot 596$ 
Temenuchus malabaricus, Blyth

Ploceidæ .

Ploceus baya, Blyth . manyar, Horsfield

Munia atricapilla, Vieill.

, punctularia Linn.

undulata, Latham

Estrilda flavidiventris, Wallace

Fringillidæ

Passer montanus, Linn.

" flaveolus, Blyth

" cinnamomeus, Gould

Emberiza aureola, Pallas

" fucata, Palias pusilla, Pallas

Melophus melanicterus, Gmelin

Alaudidæ

Alauda gulgula, Franklin

Alaudula raytal, Blyth

Mirafra assamica, MeClelland

Motacillidæ

Corydalla richardi, Vieillot ubiquitaria, Hodgson

Pipastes maculatus, Hodgson

Budytes viridis, Bonap. " calcaratus, Hodgson

Motacilla luzonensis, Scop.

Henicuridx maderaspatensis, Gmelin

Henicurus immaculatus, Hodgson Turdidæ

Monticola cyanea, Linn.

Copsychus saularis, Linn.

Chimarrhornis leucocephala, Vigors

Cyanecula suecica, Lath.

Calliope kamschatleensis, Gmelin pectoralis, Gould

Pratincola jerdoni, Blyth .

" ferrea, Hodgson

" caprata, Horsfield

, indica, Blyth .

Muscicapidæ .

Muscicapula sapphira, Blyth

Cyornis rubeculoides, Vigors , tickelli, Blyth

Siphia strophiata, Hodgson

Erythrosterna albicilla, Pallas .

Eumyias melanops, Vigors

Sylviidæ

Acrocephalus dumetorum, Blyth

Neornis brevicaudatus, Blyth

Phylloscopus fuscatus, Blyth lugubris, Blyth viridanus, Blyth affinis, Tickell superciliosus, Gmelin viridipennis, Blyth occipitalis, Jerdon

Abrornis superciliaris, Tickell

Culicipeta tephrocephalus, Andr. Merulidæ

Garrulax moniliger, Hodgson . „ sannio, Swinhoe
Page.

596

597

ib.

- 598

- $i b$.

599

600

ib.

601

ib.

602

$i b$.

603

$i b$.

604

605

ib.

- 606

- ib.

- ib.

607

608

$i b$.

609

ib.

610

$i b$.

ib.

611

ib.

613

ih.

- 614

- 615

ib.

616

617

ib.

- 618

- 619

- ib.

ib.

620

- it.

- 621

- 622

- $i b$.

- ib.

- 623

- 624

- $i b$.

- 625

ib.

- 626

$i b$.

ib.

$i 6$.

627

ib.

ib.
Actinodura nipalensis, Hodgson .

egertoni, Gould

Pteruthius æralatus, Tickell . . . . $i b$.

Leiothrichidæ . . • • • . . . . . 629

Leiothrix callipyga, Hodgson . . . . . $i b$.

, argentauris, Hodgson ... . 630

" cyanuropterus, Hodgson . . • . . $i b$.

Herpornis xantholeuca, Hodgson . . . . $i b$.

Zosteropidæ . . . . . . . . 631

Zosterops palpebrosa, Temm. . . . . . $i b$.

" simplex, Swinhoe . . . . . $i b$.

Paridæ . . . . . . . . . 632

Melanochlora sultanea, Hodgson . . . . $i b$.

Parus commixtus, Swinhoe . . . . . $i b$.

" nipalensis, Hodgson . . . . . . $i b$.

Sittidæ • • • • • • • • • 633

Dendrophila corallina, Hodgson . . . . $i b$.

Timaliidæ $\bullet \quad i b$.

Pomatorhinus ruficollis, Hodgson . . . . $i b$.

" erythrogenys, Vigors . • • . 634

Mixornis rubricapill field $\cdot{ }^{\circ} \cdot{ }^{\circ} i b$.

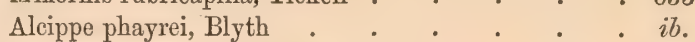

Stachyris nigriceps, Hodgson . . . . . 636

" chrysæa, Hodgson . • • • . $i b$.

Pyctorhis sinensis, Gmelin . . . . . 637

Chleuasicus ruficeps, Blyth . • • • 638

Suthora brunnea, Andr. . . . . . . . $\quad$ il.

Megaluridæ . . . . . . . . . 639

Chatarrhæa gularis, Blyth . • • . . . $i b$.

Megalurus palustris, Horsfield . . . . . $i b$.

Drymoipus inornatus, Syles • • • . 640

Prinia rufescens, Blyth . . . . . . $i b$.

"gracilis, Franklin . • . . . 641

hodgsoni, Blyth • • • • • ib.

Cisticola melanocephala, Andr. $\quad \cdot \quad \cdot \quad, \quad$, ib.

Suya crinigera, Hodgson $\quad$. . . . 642

" superciliaris, Andr. $\cdot .+\quad . \quad i b$.

Orthotomus sutorius, Forster . . . . . . $i b$.

Laniidæ . . . . . . . . . 643

Lanius tephronotus, Vigors . . . . . . $i b$.

, nigriceps, Franklin . . . . . 644

" cristatus, Linn. • • • • • . 645

" collurioides, Lesson . . . . . 646

Tephrodornis pondiceriana, Gmelin . . . . $i b$.

Hemipus capitalis, McClelland . . . . . 647

Graucalidæ • • • • • • . . $i b$.

Graucalus macei, Lesson • • • . . . $i b$.

Pericrocotus elegans, McClelland . • • • 648

Hirundinidæ . . . . . . . . $i b$

Hirundo rustica, Linn. . $\quad . \quad+\quad . \quad . \quad$. $i b$.

- 650

- $i b$.

- 651

. $i b$.

. $i b$.

. 652

- $i b$.

. 653

. 654

$i b$. 
Terpsiphone affinis, Blyth

Hypothymis azurea, Bodd.

Rhipidura albofrontata, Franklin " albicollis, Vieill.

Brachypodiidæ

Hypsipetes yunnanensis, Andr.

Hemixus flavala, Hodgson

Otocompsa emeria, Linn.

Pycnonotus nigripileus, Blyth

, xanthorrhous, Andr.

blanfordi, Jerdon flavescens, Blyth

Phyllornis aurifrons, Temm.

Iora typhia, Linn.

Oriolidæ

Oriolus melanocephalus, Linn.

Nectarinidæ

Arachnechthe

Ethopyga miles, Hodgson dabryi, Verr.

Chalcoparia cingalensis, Gmelin

Dicæum cruentatum, Linn. " chrysorrhæum, Temm.

GEMITORES.

Treronidx

Crocopus viridifrons, Blyth

Columbidæ

Turtur tigrina, Temm.

meena, Sykes

, risorius, linn.

orientalis, Lath.

Chalcophaps indica, Linn.

GALLINAE.

Phasianidæ

Pavo muticus, Linn.

Gallus ferrugineus, Gmelin

Euplocamus lineatus, Vigors andersoni, Elliot

Thaumalea amherstix, Leadb.

Phasianus sladeni, Andr.

Tetraonidæ

Francolinus perlatus, Gmelin

Arboricola atrogularis, Blyth

Bambusicola fytchii, Andr.

Turnicidæ

Turnix plumbipes, Hodgson

GRALLATORES

Charadridæ

CEdicnemus crepitans, Temm.

Lobivanellus atronuchalis, Blyth

\section{Page.}

- 654

- 655

ib.

- 656

ib.

$i b$.

657

$i b$.

- 658

$i b$.

659

ib.

660

$i b$.

ib.

$i b$.

661

$i b$.

$i b$

662

$i b$.

663

ib.

664

$i b$.

665

$i b$.

$i b$.

666

$i b$.

667

- 668

$i b$.

669

$i b$.

670

671

$i b$.

672

$i b$.

673

$i b$.

$i b$.

$i b$.

674

ib.

675

Hoplopterus ventralis, Wagler

Erialitis fulvus, Gmelin . • •

Scolopacidæ.$\quad \cdot \quad \cdot \quad \cdot 677$

Totanus canescens, Gmelin - . . . . ib

. glareola, Gmelin . • . . 678

" ochropus, Temm. . . . . . 679

Tringa temmincki, Lieissl. • . . . 680

Actitis hypoleucus, Linn. . . . . . 681

Scolopıx gallinago, Linn. $i b$.

Rhynchæa bengalensis, Linn. . . . . . 683

Parridæ . . $i b$.

Metopidius indicus, Lath. . . . . . $i b$.

Gruidæ . . . . . . . . . 684

Grus antigone, Pallas . . . . . $i b$.

Ibididæ . . . . . . . . . $i b$.

Falcinellus rufus, Scop. - . . . . . $i b$.

Ardeidæ . . . • . . • . 686

Ardea cinnamomea, Gmelin . . . . . $i b$.

" purpurea, Linn. . . . $i b$.

Herodias intermedia, Wagler . . . . . 687

" garzetta, Linn. . . . . . . 688

Buphus coromandus, Bodd. . . . . . $i b$.

Ardeola prasinosceles, Swinhoe . . . . 689

Butorides javanica, Horsfd. $\quad i b$.

Nycticorax griseus, Iinn. $\quad . \quad$ • $\quad . \quad$. 690

Rallidæe • • • • • • 691

Erythra phœnicura, Forster . . . . . $i b$.

Rallina fusca, Linn. . . . . . . $i b$.

Hypotænidia striata, Linn. . . . . . 692

Gallinula chloropus, Linn. . . . . . $i b$.

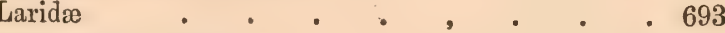

Sterna seena, Sykes _. $\quad . \quad . \quad . \quad . \quad . \quad i b$.

" javanica, Horsfield . . . . 694

Hydrochelidon hybrida, Pallas . . . . $i b$.

NATATORES

Pelecanidæ $\bullet . . .695$

Pelecanus philippinensis, Gmelin . . . . $i b$.

Graculidæ . . . . . • . . 696

Phalacrocorax carbo, Linn. . . . . . $i b$.

" pygmæus, Pallas • • • 697

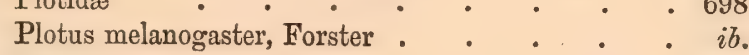

Anatidæ . • . . . . . . $i b$.

Anser indicus, Latham . . . . . . $i b$.

Anas pœcilorhyncha, Forster . . . . . 699

Tadorna casarca, Linn. • • • • . . $i b$.

Spatula clypeata, Linn. . . . . 700

Querquedula crecca, Linn. . . . . . $i b$.

" falcata, Pallas . • , . . 701

Podiceps philippensis, Bonn. and Vieill. . $\cdot{ }^{\circ} \quad$ ib

\section{REPTILIA.}

Testudinida

CHELONIA.

705 Chaibassia theobaldi, Andr** . . . . 718

ib. Geoemyda depressa, Andr.* . . . . . 721

ib. Emys . . . . . . . . 722

706 Emý trijuga, Dum. and Bib., var. burmana . . 723

- 712 Bataguridæ . . . . . . . . 729

- 716 Batagur . . . . . . . . ib.

Emydidæe

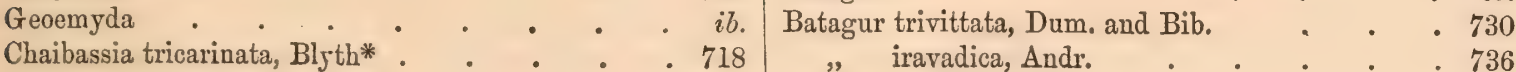




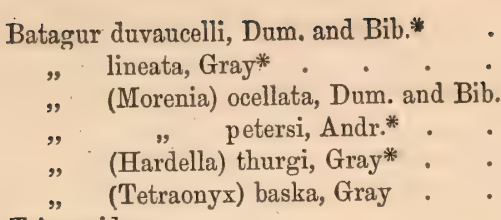

\section{SAURIA.}

Varanidæ

Hydrosaurus salvator, Laur.

Zonuridx

Pseudopus gracilis, Gray •

Scincidæ

Tropidophorus berdmorei, Blyth

Mocoa, Gray

Mocoa exigua, Andr.

Geckotidæ

Gecko guttatus, Daudin

Hemidactylus (Peripia) meyeri, Bleeker .

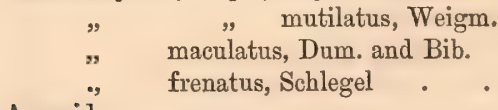

Agamidæ

Draco maculatus, Gray

Japalura yunnanensis, Andr.

Calotes versicolor, Daudin

, mystaceus, Dum. and Bib.

, maria, Gray

, emma, Gray

Oriocalotes kakhienensis, Andr.

Tortricidæ

\section{OPHIDIA.}

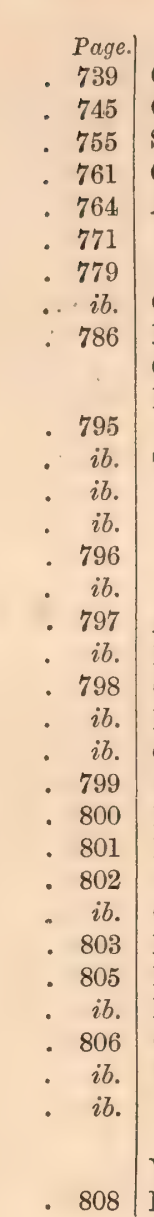

Cylindrophis rufus, Wagler . $\quad . \quad$ Page. 808

Oligontidæ . . . . . . 809

Simotes theobaldi, Günther . . . . . $i b$.

Colubridæ . . • • . . . . $i b$.

Ablabes bicolor, Blyth . . . . . . $i b$.

" collaris, Gray ... . 810

, bistrigatus, Günther • . . 811

Coluber porphyraceus, Cantor .. _ . . . . . 812

Elaphis yunnanensis, Dum. and Bib. . . . 813

Compsosoma radiatum, Boie . . . . . 815

Ptyas mucosus, Linn. $\quad$ - . $i b$.

„ korros, Reinwardt . . . . . . 816

Tropidonotus stolatus, Linn. . . . . $i b$.

. 817

. 819

. 821

. 822

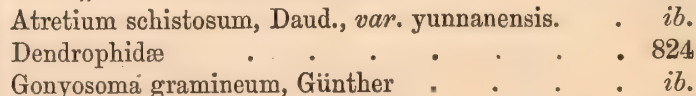

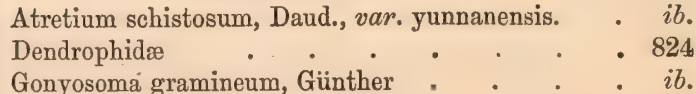

Dendrophis picta, Gmelin $\quad \cdot \quad \cdot \quad \cdot \quad \cdot \quad i b$.

Chrysopelea ornata, Shaw . . . . . . 825

Dryiophidæ . . . . . . . . 826

Passerita myeterizans, Linn. . . . . $i b$.

Lycodontidæ • • • • • • • • $i b$.

Lycodon aulicus, Linn. - . . . . . $i b$.

Ophites fasciatus, Andr. $\quad$ • . . . 827

Elapidæ . . . . . . . 828

50 Naja tripudians, Merr. . . . . . $i b$,

Bungarus fasciatus, Schneider $\quad . \quad$. $\quad . \quad i b$,

Crotalidæ . . . . . . . $i b$.

Trimeresurus gramineus, Shaw - . , . $i b$.

" erythrurus, Cantor . . . . 830

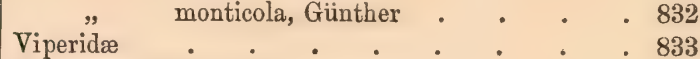

. 808 Daboin russellii, Shaw . . . . . . ib.

\section{A M P H IB I A.}

ANURA.

Ranidæ

Rana tigrina, Daud.

fusca, Blyth

, kuhlii, Schlegel

, yunnanensis, Andr.

, gracilis, Wiegm.

Engystomatidæ

Diplopelma carnaticum, Jerdon

Callula pulchra, Gray

Bufonidæ

Bufo melanostictus, Schneid.

Polypedatidæ

Polypedates marmoratus, Blyth . . . . 841

" yunnanensis, Andr. . . . . 843

Ixalus lateralis, Andr. . . . . . . . 844

" kakhienensis, Andr. . . . . . 845

" tuberculatus, Andr. . . . . . $i b$,

Hylarana erythræa, Schlegel . $\quad . \quad$ • $\quad . \quad$. 846

" margariana, Andr. . . . . . ib.

Hylidæ . • • • . . . . 847

Hyla chinensis, Günther $\quad$. . . . $\quad$. $i b$.

Salamandrida Mecodonta . . . . . 848

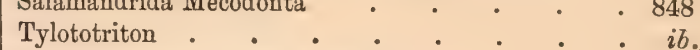

842 Tylototriton verrucosus, Andr. . . . . $i b$.

\section{PIS C ES.}

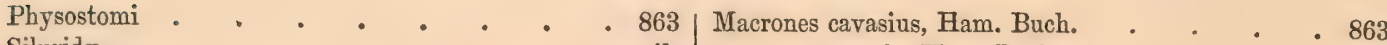

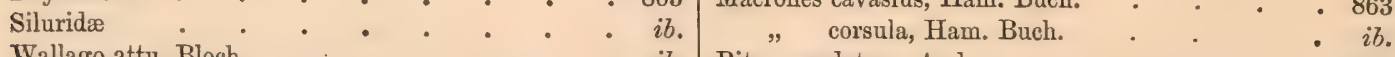

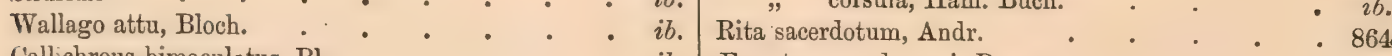

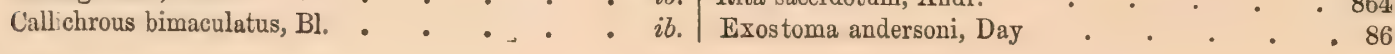


Cyprinidæ

Carassius auratus, Linn.

Catla buchanani, C. and $\mathrm{V}$.

Cirrhina mrigala, Ham. Buch.

Labeo calbasu, Ham. Buch.

, curchius, Ham. Buch.

Barbus sarana, Ham. Buch.

" apogon, C. and V.

, margarianus, Andr.
Page. Page.

866 Barbus mosal, Ham. Buch. ․ . • • . 868

ib. Oreinus richardsoni, Gray . . . . . $i b$.

ib. Danio kakhienensis, Andr. . . . . . ib.

ib. Barilius interrupta, Day . . . . . 869

867 Osteobrama, Heckel . . . . . . ib.

ib. $\quad$ microlepis, Blyth $\quad \therefore \quad$ - $i b$.

ib. Misgurnus anguillicaudatus, Cantor . . . ib.

ib. Notopteridæ . . . . . . . $i b$.

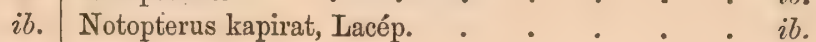

\section{SECTION II.-INVERTEBRATA.}

\section{0 L L USCA.}

Gasteropoda pulmonata.

CEPHALOPHORA .

Helicidæ

Trochomorpha percompressa, Blanf.

Nanina (Rotula) arata, Blanf.

$$
\text { pansa, Bens. }
$$

(Macrochlamys) resplendens, Phil.

" $\quad$ " hypoleuca, Blanf.

" (Durgella) honesta, Gld., var. andersoniana, Nevill

(Sitala) attegia, Bens.

diplodon, Bens.

" (Microcystis) barakporensis, Pfi.

Helix (Plectopylis) andersoni, Blanf.

" (Plectotropis) tapeina, Bens.

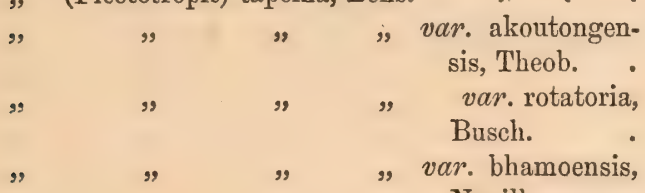

" $\quad$ " $\quad$ var. bhamoensis

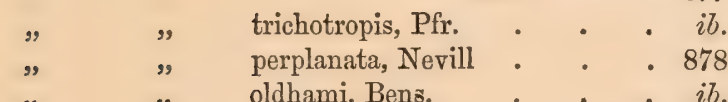

" catostoma, Blanf. -

" $\quad$ huttoni, Pfr., var. savadiensis,

phayrei, T Nevill _. . . . 879

(Trachia) delibrata, Bens.

(Ganesella) capitium, Bens. • • • • $\quad$ • 880

(Dorcasia) similaris, Fer. . . . . ib.

" bolus, Bens. • . . . 881

zoroaster, Theob.

"scalpturita, Bens.

Pupa (Cylindrus) insularis, Ehr.

" (Lieucochila) conopicta, Hutton

" (Scopelophila) sal winiana, Theob.

Succinea acuminata, Blanf.

Veronicella, n. sp. birmanica, Theob.

Helicarion resplendens, Nevill

gigas, Bens., var.
$\Rightarrow \quad$ magnificum, God.-Aust. and Nevill
venustum, Theob.
(Cryptosoma) præstans, Gould
nea (Huttonella) bicolor, Hutton
reptaxis theobaldi, Bens.

Stenogyra (Opeas) gracilis, Hutton

\begin{tabular}{|c|c|c|c|c|c|c|}
\hline 873 & Glessula obtusa, Blanf. & - & - & - & - & 886 \\
\hline$i b$. & subfusiformis, Blanf. & - & • & - & - & $i b$. \\
\hline$i b$. & pyramis, Bens. & - & - & - & - & $i b$. \\
\hline$i b$. & blanfordiana, Nevill & - & - & - & - & $i b$. \\
\hline$i b$. & Limnæidæ & - & - & - & - & $i b$. \\
\hline 874 & Limnæa andersoniana, Nevill & & - & 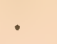 & $\cdot$ & $i b$. \\
\hline$i b$. & yunnanensis, Nevill & & $\therefore$ & - & - & - 887 \\
\hline$i t$ & acuminata, Lamk., vas & $r$ & fescen & & ray & - $\quad i b$. \\
\hline & ", luteola, Lamk., var. & - & - & - & - & - 888 \\
\hline 875 & Planorbis exustus, Desh. & - & - & & - & - \\
\hline 875 & ', compressus, Hutton & & - & - & - & - \\
\hline$i b$. & Prosobranchia & - & - & - & - & - \\
\hline$i b$. & Neurobranchia & - & • & - & - & $i b$. \\
\hline 876 & Cyclophoridæ & - & - & - & - & - \\
\hline$i b$. & Cyclophorus sublævigatus, Bla & & - & & & $i b$. \\
\hline$i b$. & $\begin{array}{ll} & \text { fulguratus, Ptr. } \\
, \quad & \text { zebrinus, Bens., vo }\end{array}$ & & - & • & • & $\begin{array}{c}\text { - } 889 \\
\text { - } \quad i b .\end{array}$ \\
\hline & Spiraculum andersoni, Blf. & - & . & - & - & - \\
\hline$i b$. & $" \quad$ avanum, Blf. & - & - & - & - & $i b$. \\
\hline & Pterocyclus insignis, Theob., $v$ & ar. & - & - & - & $i b$. \\
\hline 877 & " $\quad$ feddeni, Blf. & - & - & - & - & - 890 \\
\hline$i b$. & Alycæus amphora, Benson & - & - & - & - & $i b$. \\
\hline 878 & Ctenobranchia & . & - & - & - & - \\
\hline$i b$. & Paludinidæ . & • & - & - & - & $i b$. \\
\hline$i l$ & Bithynia goniomphalus, Morl. & & . & - & . & - \\
\hline 879 & turrita, Blanf. & • & • & - & - & $i 6$. \\
\hline$i b$. & $\begin{array}{l}\text { "goreletiana, Nevill } \\
\text { Margarya melanioides, Nevill }\end{array}$ & - & - & & : & - 891 \\
\hline$i b$. & Paludina chinensis, Gray, var & an & pullif & formi & is, Eyc & $\dot{d}$ \\
\hline 880 & et Soul. $\quad$ : & & - & - & - & 892 \\
\hline$i b$ & dissimilis, Müll., var. & dec & ussaty & ula, & lanf. & . \\
\hline 881 & ,,$\quad$ var. & $\operatorname{vir}$ & dis, $\mathrm{R}$ & Rv. & & - 893 \\
\hline$i b$. & siamensis, Fr., var.? & & $\therefore$ & & - & - $\quad i b$ \\
\hline$i b$. & " bengalensis, Lam., va & $r$ & liaris, & , Gld & & \\
\hline 882 & Paludomus andersoniana, Nevi & & - & • & - & - 89 \\
\hline$i b$. & var. & peg & ensis & & - & - \\
\hline$i b$. & ornata, Benson & . & . & . & • & - 895 \\
\hline it & burmanica, Nevill & & • & - & - & • \\
\hline 883 & blanfordiana, Nevi & & - & - & - & - 896 \\
\hline$i b$. & Melanidæ & • & : & - & • & - \\
\hline$i l$. & Melania (Striatella) tuberculata & $\mathrm{M}$ & & - & - & $i b$. \\
\hline 884 & (Melanoides) jugicosti & & enson & - & - & 897 \\
\hline$i b$. & iravadica, & & anf. & - & - & $i b$. \\
\hline 80 & eevei, Bi & & & & & - 898 \\
\hline 885 & " $" v a$ & & mbrica & ata, $]$ & Hanl. & $i b$. \\
\hline$i b$. & " (Plotia) scabra, Müll. & & - & - & • & $i 6$. \\
\hline$i b$. & Ampullaridæ $\quad:$ & & - & - & - & - 898 \\
\hline$i b$. & Ampullaria theobaldi, Hanl. & & - & & - & - $\quad i b$ \\
\hline
\end{tabular}




\section{ACEPHALA.}

Unionidx

Unio marginalis, Lamk., var. savadiensis, Nevill

,

feddeni,

eobald

, foliaceus, Gld., var. fragilis, Nevill burmanus, Blanf.

bhamoensis, Theob

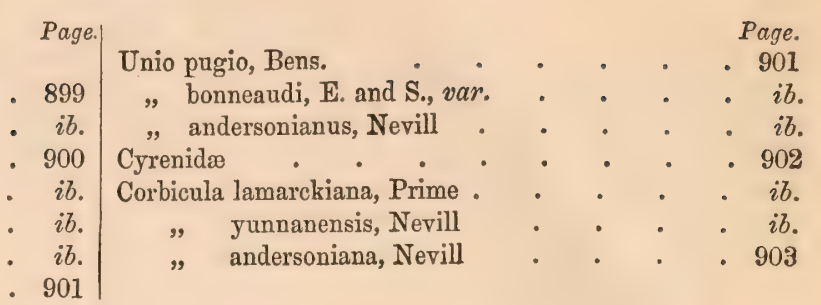

\section{N SECTA.}

COLEOPTERA.

Cicindelidæ

Cicindela chloris, Hope

himaleyica, Redt.

Carabidæ

flavomaculata, Kollar

Chlæmis

Omaseus

Harpalus

Dytiscidx

Dineutes lateralis, Leach

Scarabæidæ

Copris sagax, Schönh

Onthophagus

Oniticellus brama, Redt.

Melolonthidæ

Serica micans, Fabr.

Apogonia

Schizonycha

Lepidiota bimaculata, Saunders

Ancylonycha .

Mimelidæ

Anomala splendens, Hope

Mimela glabra, Hope

Euchlora perplexa, Hope

$$
\text { monochroa, Reiche. }
$$

Popilia biguttata, Wieden

Dynastidæ

Heteronychus piceus, Fabr.

Eupatorus hardwickii, Hope

Cetoniidæ

Rhomborrhina

Glycyphana marginicollis, Gory et Perch.

Cetonia

Malacodermidæ

Dictyoptera

Lampyris

Buprestidæ

Argilus

Elateridæ

Melanotus

Bostrychidæ

Apate

Rhipidophoridæ

Rhipidophorus

Lagriidæ

Lagria basalis, Hope

Tenebrionidæ .

Opatrum

Epilampus

Nylabrida
Lytta nepalensis, Hope

Curculionidæ

ib. Apoderus

ib. Arrhenodes

ib. Cyrtotrachelus

$i b$. Cleonus

ib. Lixus

ib. Blosyrus

ib. Sipalus granulatus, Fabr.

ib. Sipalus

ib. Cerambycidæ

ib. Batocera roylei, Hope

ib. Ceroplesis tricincta, Dej.

ib. Lamia wallichi, Hope

ib. Rosalia

ib. Blepephaeus succinctor, Cherrol

ib. Purpuricenus temmincki, Guer.

Eurybatus 9-punctatus, Westw.

908 Apomecyna albomaculatus, Perrond.

ib. Clytus

$i b$. Glenea

ib. Sagridæ

ib. Sagra mouhoti, Baly

ib. Crioceridæ

ib. Temnaspis mouhoti; Baly

ib. Crioceris impressa, Fabr.

ib. Hispidæ

ib. Anisodera excavata, Baly

ib. Craspedonta leayana, Latr.

ib. Halticidæ

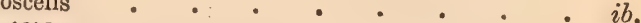

ib. Aspidomorpha sanctæcrucis, Fabr. . . . . . ib.

ib. Coptocycla catinata, Bohem. . . . . . $i b$.

ib. Eumolpidæ . . . . . . . . . $i b_{\text {. }}$

ib. Corynodes peregrinus, Herbst. . . . . $i b$.

ib. Eumolpus

ib. Chrysomelidæ

909 Paralina cyanicollis,

ib. Lina $\cdot 0^{\circ} \cdot i b$.

$\cdot \cdot \cdot i b$

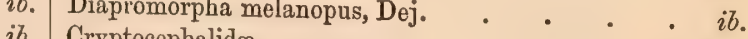

. 911

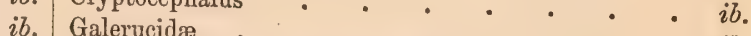

ib. Haplosonys smaragdipennis, Chev. :

ib.

ib. Callopistria fulminans, Falderm . • . . $i b$.

ib. Rhaphia cyanipennis, Baly • • . . $i b$.

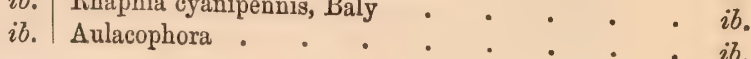

ib. Cassidid $x$. 
Rhaphidopalpa sexmaculata, Hope
Phyllotreta cyanura, Hope
$\begin{aligned} & \text { Adorium maculiventris, Cher. } \\ & \text { Adorium }\end{aligned}$.
Galeruca
Coccinellidæ
Harmonia septempunctata, Linn.

ORTHOPTERA.

\section{Phasmidx}

Bacteria

Mantida

Mantis

Gryllidæ

Gryllotalpa vulgaris, Geoffr

Gryllus consimilis, Walker

Locustidæ

Phaneroptera diversa, Walker Acrididx

Pyrgomorpha crenulata, Fabr.

Opomala tenebrosa, Walker

Phymateus miliaris, Linn.

Cyrtacanthacris ferrina, Walker punctipennis, Walker

Acridium virescens, Walker

$$
\text { angustifrons, Walker }
$$

Epæromia vulnerata, De Haan varia, Walker

Mastax innotata, Walker

Tetrix exultans, Stäl.

Oxya diminuta, Walker

Caloptinus incomptus, Walker

inamœnus, Walker

Blattidæ

Leucophæa

Epilampra

Periplaneta

Forficulidæ

Forficula

Tubia

\section{NEUROPTERA.}

Libellulidæ

Matrona basilaris, De Selys

Neurobasis chinensis, Linn.

Neurothemis sophronia, Drury equestris, Fabr.

Vestalis gracilis, Rambur

Brachybasis coromandeliana, Fabr.

Lestes nodalis, De Selys

Lepthemis sabina, Drury

Crocothemis servilia, Drury

Libellula
Page.l

Page.

911 Libellula dalei, De Selys . 915

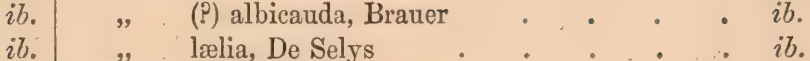

ib. Pantala flavescens, Fabr. . . . . ib

ib. Rhyothemis variegata, Linn. . . . . ib.

ib. Rhinocypha cuneata, De Selys . . . . ib.

ib. Palpopleura sexmaculata, Fabr. . $\cdot{ }^{-} \cdot{ }^{\circ} i$.

ib. Mnais andersoni, Mclachlan . • . 916

ib. Myrmeleontidæ . . . . . . . $i b$.

ib. Formicales . . . . . . ib.

ib. Phryganidæ . . . . . . . $i b$.

ib. Stenopsyche griseipennis, McLachlan . . . . $i b$.

$i b$.

ib. Hymenoptera . • . . . . 916

ib. Dorylidæ . . . . . . . . ib.

ib. Dorylus longicornis, Schnck. . . . . $i b$.

ib. Scoliadæ . . , . . . . . ib.

Scolia (Triliacos) dimidiata, Guér. . . . . $i b$.

",$\quad$ instabilis, Smith . . . $i b$.

912 , , rubiginosa, Fabr. . . . . $i b$.

ib. .. (Dielis) annulata, Fabr. . . . . $i b$.

ib. Pompilidæ . . ib.

ib. Pompilus dorsalis, St. Farg. $\quad \cdot \quad \cdot \quad \cdot \quad i b$.

ib. Ponpilus . . . . ib.

ib. Macromeris violacea . . . . . . ib.

ib. Mygnimia aureosericea, Guér. . . . . ib.

ib. Sphegidæ . . . . . . . . io.

ib. Ammophila . . . . : . . .

ij. Larridæ . . . 917

ib. Larrada . . . . . . . . $i b$.

ib. Eumenidæ . . $i b$.

ib. Rhynchium carnaticum, Sauss. . . . . $i b$.

ib. Vespidæ . . . . . . . ib.

913 Polistes hebiæus, Fabr. . . . . . . $i b$.

ib. Polistes . . . . $i b$.

ib. Vespa basalis, Smith . . . . . ib.

ib., bellona, Smith . . . . . . $i b$.

ib. Apidæ . . . . . ib.

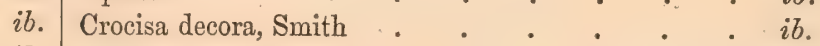

ib. Anthophora . . . . . . ib.

914.,$\quad$ zonata, Linn. . . . . $i b$.

ib. Xylocopa tenuiscapa, Westw. . . . . . $i b$.

ib. Xylocopa . . . . . . . $i b$.

915 Bombus impetuosus, Smith • • • : . 918

ib. Apis indica, Fabr. . . , . . . $i b$.

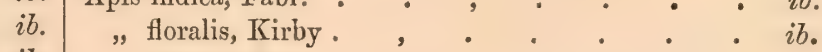

ib. ", dorsata, Fabr. . . . . . $i b$.

ib. "laboriosa, Smith . . . . . . $\quad$. $i b$.

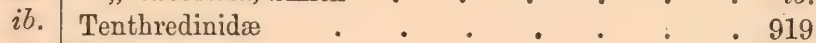

ib. Tenthredo . . . . . . : . $i b$.

Ichneumonidæ $\quad . \quad+\quad . \quad+\quad . \quad \ddots \quad i b$.

915

$i b$.

Tipularidæ • • • • • • 919

ib. Pterocosmus velutinus, Walker.$\quad \cdot \quad \cdot \quad \cdot \quad i b$.

ib. Tabanidæ $. \quad . \quad . \quad . \quad \cdot \quad i b$.

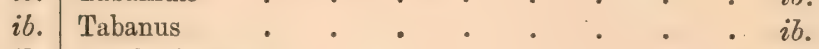

ib. Bombyliaridæ . . . , . . . ib.

ib. Anthrax semiscita? . . . . . . ib.

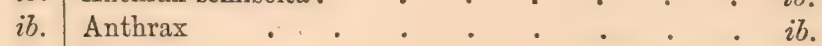

ib. Trichopthalmia . . . . . . . $i b$.

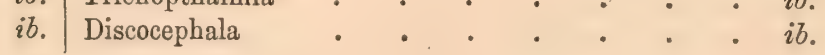


Asilidx

Dasypogon

Nusa

Laphria

Syrphidæ

Eristalis andræmon, Walker

, amphicrates, Walker

Eristalis?

Muscidæ

Tachina fusiformis, Walker

Tachina

Musca.

\section{HEMIPTERA.}

Pachycoridæ

Cantao ocellatus, Thumb.

Solenosthedium rubropunctatum, Guér.

Pentatomides

Asopidæ

Zicrona cærulea, Linn

Halydidæ

Dalpada clavata, Fabr.

Dalpada

Edessidæ

Aspongopus nigriventris, Hope

Eusthenes

Mictidæ

Dalader planiventris, Hope

Thysomerus, sp. ?

Harpactor

Coreidæ

Macrocheraia grandis, Gray

Dysdercus kœnigi, Linn.

Scrinetha augur

Physopelta gutta, B

Nepidæ

Ranatra grossa, Fabr

Naucoris

HOMOPTERA.

Stridulantidæ

Dundubia cinctimanus, Walker

Cicada

Platypleura nobilis, Germ.

Cicadellidæ

Urophora hardwickii, Gray

Cercopidæ

Cercopis nigripennis, Fabr.

Cercopis

septempunctata, Walke

Tettignnidæ

Tettigonia

LEPIDOPTERA

Rhopalocera

Satyridæ

Melanitis ismene, Cram. vamana, Moore

Neope pulaha, Moore

Orinoma damaris, Gray

Debis europa, Fabr.

y. verma, Kollar

, rohria, Fabr.

" chandica, Moore

, latiaris, Hewitson
Page.

919 Debis dyrta, Feld

Zophessa andersoni, Atkinson

Mycalesis otrea, Cram. . . . . , it.

Mycalesis runeka, Moore . . . ib

" malsara, Moore . ... ib.

"nala, Feld. . , . .,$\quad i b$

Yphthima sakra, Moore . . . . . . . ib.

920 " methora, Hewits. . . . • . ib.

ib. ", newara, Moore . . . . ib.

ib. Danaidæ . . . . . . ib.

Euplœa midamus, Linn. $\quad . \quad$. . . $\quad$ ib.

, klugii, Moore . . . . . . ib

". siamensis, Feld. . . . . 923

Danais tytia, Gray

" plexippus, Iinn. . . .

" chrysippus, Linn. . . . .

, limniace, Cram. . . . . . ib.

" melissa, Cram. . . . . . ib.

, aglea, Cram. . . . . . . ib.

Acræa vesta, Fabr. $\quad$ - . . . . $i b$.

Papilionidæ . . . . . . . ib

Papilio dissimilis, Linn. . . . . . . . ib

" panope, Linn. . . . . . ib.

" castor, Westw. . . . . . ib.

" pammon, Linn. . . . . . $i b$

" erithonius, Cram. . . . . . ib.

, antiphates, Cram. . . . . . ib.

" chiron, Wallace . . . . . . $i b$.

" cloanthus, Westw. . . . . . ib.

xuthus, Linn. $\cdot \quad \cdot \quad \cdot{ }^{\circ}$

Pyrameis cardui, Linn. . . . . . it.

, indica. Herbst. . . . . . ib.

Vanessa cashmirensis, Kollar . . . . . ib.

, charonia, Drury . . . . . $i b$.

Junonia orathyia, Linn. . . . . . ib.

" laomedia, Linn. . . . . . ib.

" lemonias, Linn. . . . . . ib.

" almana, Linn. . . . . $i b$.

" asterie, Linn. . . . . . . $i b$.

, œnone, Linn. . . . . . . $i b$.

Precis iphita, Cram. . . . . . . ib

" hara, Moore . . . . . . $i b$.

Ergolis ariadne, Linn. . . . . . . $i b$.

Cyrestis thyodamus, Boisd. . . . . . ib

Symbrenthia hyppocla, Cram. . . . ib.

Cethosia cyane, Fabr. . . . . . . $i b$

" biblis, Drury . . . . . . $i b$.

Cirrochroa aoris, Doubleday and Hervits. - . 924

A mithila, Moore . . . . . ib.

Atella phalanta, Drury . . . . . . . $i b$.

Argynnis niphe, Linn. . . . . . . . $i b$,

921 " rudra, Moore • . . . . ib.

Diadema childreni, Gray . . . . . ib,

Diadema bolina, Linn. . . . . . ib.

Euripus halitherses, Doubleday and Hewits. : . ib.

Hestina nama, Doubleday and Hewits. . . . ib.

", persimilis, Westw. . . . . . . $i b$.

Castalia chandra, Moore . . . . . . $i b$.

Neptis ananta, Moore . . . . . . ib.

nandina, Moore . . . . . . . $i b$.

" hordonia, Stoll. . . . . . . $i b$.

emodes, Moore . . . . . . $\quad$ ib. 
Neptis soma, Moore

Athyma leucothoe, Linn.

" cama, Moore

Athyma selenophora, Kollar

Limenitis daraxa, Doubleday and Hevit

Adolias lepidea, Butler

Neurosigma siva, Westrt.

Adolias garuda, Moore

" francæ, Gray

boisduvalii, Gray

Symphædra dirtea, Fabr.

Charaxes athamas, Drury

Kallima inachis, $\mathrm{Bd}$.

\#mona lena, Atkinson

Pieridæ

Prioneris thestylis, Doubleday

Thyca pasithoë, Linn.

Eronia hippia, Fabr.

Pieris nama, Doubleday

" glicirin, Cram.

". nelete, Menétr. var.?

Tachyris lalage, Doubleday and Herits

" zelmira, Cram

, hippo, Cram.

Gonepteryx verhuellii, Van der Hoev.

Callidryas hilaria, Cram. pyranthe, Linn. " alcmeone, Cram.

Colias fieldii, Menetr.
Page.

924

ib. Hebomoia glaucippe, Linn

$i b$. Terias hecabe, Linn.

" silhetana, Wallace

venata, Moore

ib. Erycinid

ib. Zemeros flegyas, Cram.

ib. Dodona fylla, Boisd

ib. Sospita neophron, Boisd. .

ib. Lycænidæ

ib. Polyommatus puspa, Horsf

$i b$.

$i b$.

925

$i b$.

$i b$.

$i b$.

$i b$.

$i b$.

$i b$.

it.

$i b$.

$i b$.

$i b$.

$i b$.

$i b$.

$i b$.

$i b$.

Myrina jafra, Godt.

mblypodia quercetorum,

- fytchei, Moore

Hesperidæ . . . . . . .

Tagiades dasahara, Moore . . . . . $i b$

Pamphila mæsa, Moore _ . . . . $i b$.

Hesperia chaya, Moore . . . . . . $i b$.

" eltola, Hewits. • • . . . . ib

$\cdot \cdot \cdot{ }^{\circ} \cdot i b^{\circ}$

HETEROCERA.

Syntomis andersoni, Moore . . . . . it.

" sladeni, Moore . . . . . 927

, atkinsoni, Moore . . . . .

" grotei, Moore $\quad . \quad$. $\quad . \quad$. $i b$

\section{RUSTACEA.}

CRUSTACEA CANCROIDEA.

Cancroidea grapsidica

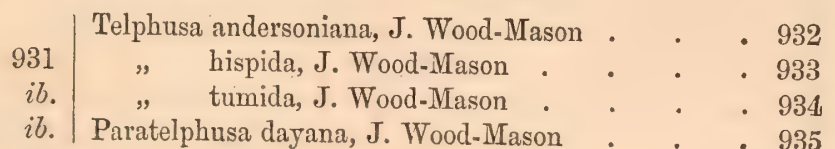

Telphusa edwardsi, J. Wood-Mason 


\section{CORRIGENDA.}

Introduction: page xvii, line 12, for "Mr. Allan" read "Mr. Allen."

Page 368, line 3, for " Orea" read "Globicephatus."

" 377 , line 33, for " fig. $5 b$ " read " fig. $15 . "$

" 399, line 32, for " ug" read "gl."

" 441, line 21, for " $\mathrm{Pl}$. XXV" read " $\mathrm{Pl}$. XXVI."

" 449, line 3, for "PI. XXXVI" read "Pl. XXVI."

" 449, line 38, insert "Pl. XXV, fig. 2 " before "Pl. XXVII, fig. 1."

" 454, line 19, for " fig. 2 " read "fig. 4."

" 480, line 20, for " Pl. XXXII" read "Pl. XXXIII."

" 613, line 2, for "Wagler" read "Linn."

" 626, line 33, for "TEPHROCEPHALA " read "TEPHROCEPHALUS."

"656, line 40, omit "n. s."

" 673 , line 21 , omit "n. s."

" 686, line 4, for "Cones" read "Coues."

", 706, line 9, for "Elegans" réad "'Actinodes,"

" 886, footnote, for " S. fusiformis" read " G. fusiformis."

The sanguine expectation that this work would have been issued during the past year has led to 1878 appearing on the title-page instead of 1879, the delay having arisen from circumstances over which the author had no control. 



\section{INTRODUCTION.}

TWHIS work was originally intended to be confined to a description of the Zoological Results of the two Yunnan Expeditions. In working them out, however, I was led to examine certain Asiatic genera as a whole; and having done so, I have embraced the opportunity to incorporate these observations along with the results of the Expeditions, as they were founded, in the majority of cases, on the actual comparison of the types of the individual species; hence the descriptions of the various species of Hylobates, Macacus, Semnopithecus, Sciurus, \&c.

In the same way, in dealing with the Cetacean of the Irawady, I. was led to compare it with its near ally occasionally found in the estuary streams of the Ganges, and, as this latter form had never been fully described, to include an account of its placentation and anatomy generally alongside of the former. Moreover, as both of these Cetaceans are more or less fluviatile in their habits, I was further induced, from the circumstance that $I$ had already devoted some time to an examination of the placentation and anatomy of Platanista, to add a history of its distribution and structure to that of the two former, and thus to give a Monograph of the known fluviatile Cetacea of Asia.

It will be observed that for special sections of the work I am indebted to naturalists who are recognized authorities in the departments which they describe.

It is necessary that I should here give a short account of the two Expeditions, in order to bring out the difficulties with which I was beset as a naturalist, and which, to my great regret, were of so formidable a nature, that they restricted my Anvestigations within the narrowest limits in a country the fauna of which is extremely rich and all but unknown.

The First Expedition was despatched in the end of 1867 from Calcutta, and returned in November 1868; and the Second Expedition left Mandalay on the 3rd January 1875, and returned thither on the 10th March of the same year.

By the permission of the Trustees of the Indian Museum, my services were placed at the disposal of the Government of India to accompany the two Missions as Naturalist and Medical Officer.

With regard to the scope of the First Expedition, it was intended that it should penetrate from Mandalay into the Province of Yunnan, viâ Bhamô, and, if possible, 
continue its progress from thence to Canton. Its instructions were to explore the trade routes which proceed from Bhamô to China, and to report on their capabilities for commerce, and to collect information on the resources of the countries through which it passed.

The duty especially entrusted to me was the investigation of the natural-historical, physical and ethnological features of the country traversed.

This Expedition was under the command of Lieutenant-Colonel Edward B. Sladen, then British Political Resident at the Court of Mandalay.

When the Mission reached Bhamô, a point which it attained by proceeding up the Irawady in one of the steamers of the King of Burma, it was ascertained that the country lying immediately to the east, and which had never before been entered by Europeans from the west, was in a state of anarchy. This condition of affairs was the means of detaining the Expedition at Bhamô more than a month, a period which permitted me partially to investigate the fauna of that district, having previously, as far as lay in my power, made every use of the frequent detentions, during our progress up the river from Mandalay, for the same object. My movements, however, were much circumscribed, being limited only to a few miles' radius around Bhamô itself, owing to the very unsettled condition of the neighbourhood from the continual raids made at that period by the Kakhyens, who inhabit the adjoining mountains, and who bear among the Burmese a most unenviable notoriety for treachery. It was inexpedient to go beyond the stockade which encircled the town without being fully armed; and even the report of a fowling-piece, heard in the town from without, created alarm amongst the inhabitants.

Erom Bhamô, the Mission proceeded on the 26th February to a small stockaded village on the right bank of the Tapeng, immediately below the Kakhyen mountains; a few day's there were also deroted to collecting natural history specimens.

The Mission was met at this point by certain Hill Chiefs, who undertook to give it a safe convoy as far as the Shan States in the Province of Yunnan. Starting under this promised protection, the Expedition left Tsitkaw on the 21st of March, accompanied by a large escort of hillmen, and by about 100 mules carrying the baggage. After three marches up these mountains, we reached Ponsee, a Kakhyen village, at an elevation a little over 3,000 feet. The marches thither were most unfarourable to any attempt at collecting, as the forest was excessively dense, and the route a mere mule-track along precipitous mountain sides, from the neighbourhood of which nearly all animal life was scared by the tread of the mules, the shouts of their drivers, and the constant firing of matchlocks by unruly and inebriated Kakhyens. On the 2nd March, the whole Expedition was brought to a halt by a threatened attack in front; and on the morning of the 3rd not a Chief or Tsawbwa 
would move until the guard had fired a volley to frighten away the Nâts and any ill-disposed persons.

At Ponsee, we were deserted by the muleteers, who carried off all the mules; and, pitching our tents, we were detained there over two months by the hostile attitude of the Hill Chiefs, and the constant reports of open opposition to be looked for, if we attempted to advance. It was only when we arrived at Ponsee that we ascertained the real political condition of the country to the east, and that in crossing a small stream on the 2nd March, we had entered the Empire of China and the Province of Yunnan, which was then in open rebellion.

Two months in such a locality, under more favourable circumstances, would have yielded a rich harvest of zoological results; but during the period we resided at Ponsee, we lived in constant expectation of being attacked; and on one occasion the headmen of even the village of Ponsee itself had the audacity to fire into our camp, which was completely commanded by their village. There was also always an element of uncertainty regarding our possible advance, as a portion of each day was generally occupied in treating with the hillmen and with Shans from beyond for carriage to take us forward; and if this had been found, our only chance of proceeding was to have availed ourselves of it at once. Every day when I went out, there was the constant expectation of finding on my return the camp struck, and the Mission prepared to start. This state of things, of course, materially restricted my movements, and interfered with my researches. Apart, however, from these circumstances, the precipitous character of the hillsides, the dense nature of the jungle clothing them, and the paucity of hill paths, made collecting a most difficult undertaking.

Leaving Ponsee, a descent of nearly 1,000 feet brought us into the valley of Sanda, inhabited by Shans.

On this march the same difficulties had to be contended with as on the previous marches; and at Manwyne, the first town at which the Expedition halted, the inhabitants objected strongly to the use of firearms, and our movements there were jealously watched, and when going out anywhere we were followed by a crowd of inquisitive natives. Proceeding from Manwyne along the level valley which, at the season we travelled through it, was completely under rice cultivation, irrigated by artificial channels from the Tahô river, the Expedition was attacked within one hour of its departure from Manwyne; and the result was that we had to use the greatest circumspection until Sanda (Sanda-foo of the maps) was reached.

At Sanda, there was the same objection to the use of firearms as at Manwyne; and on my return to this town, about two months afterwards, I was especially asked not to fire on the hillside behind the town, as my doing so would certainly induces 
the Tiger-nât to kill the then reigning Chief. It was therefore impossible under these circumstances to do much at Sanda in investigating its natural history. As the same liability to attack was anticipated on the march from Sanda to Muangla as had been experienced between Manwyne and the former place, the Mission had to keep well together, and to be on the alert. At Muangla, we were warned not to go any distance from the town, and I had therefore to confine my observations to a radius of about two miles.

From Muangla to Nantin, and from thence to Teng-yue-chow (Momien), a large caravan of merchandise, which had long been delayed in its progress by reason of the dangers of the road, took advantage of the fancied protection afforded by the Mission. A short way from Muangla, however, the advance of the caravan and Mission was retarded for a few hours, as the Panthay Officers who had met us at the latter town reported that a large body of armed men had assembled to oppose our progress, at the head of the narrow defile which closes in the valley. This report, however, proved to be erroneous, and to have had its origin in a murderous attack which had been committed on a poor Shan trader, whom we passed lying dying on the road. Beyond the defile, our advance was protected by bodies of armed Mahomedan rebels (Panthays), who beat their gongs and fired their matchlocks as we passed, in honour of the Mission and to scare away the robber bands of hillmen. At Nantin, we remained only two days, during which I had to show all my alcoholic collections in order to remove an impression from the minds of the officials that we carried about with us flying dragons, to let loose on the people. A few miles beyond the town, we were attacked by Chinese, and lost three of our Panthay guard, and two mule-loads, chiefly consisting of my property, and which entailed on me the irreparable loss of most of my notes on Natural History.

As it became evident that the further progress of the Mission beyond Momien would be at once dangerous, and, in the existing state of things, liable to embroil it with the Chinese constituted authorities, it was resolved not to attempt the prosecution of our enquiries beyond Momien. During our residence there, we were not permitted to go beyond sight of the town without the protection of an armed guard, and were only once allowed this doubtful privilege. The marches back to Manwyne were nearly a repetition of our advance, but without experiencing any open hostilities.

From Manwyne we diverged and crossed the mountain range on the south of the Sanda Valley into the sequestered valley of Hotha and Latha, where. we remained about three weeks, still bearing with us the unenviable reputation of bringing flying dragons and other evils upon the inhabitants, who alleged that a person had died, in every village we had visited. In this valley I shot neither bird nor mammal. 
From Hotha, we marched direct to the plains, without encountering any further difficulties, and, from Bhamô, returned to Mandalay by boat.

The Second Expedition was appointed to leave Burma in January, 1875, in order to accomplish the passage of the hill country before the setting in of the rainy season.

The command was entrusted to Colonel Horace Browne, of the Burmese Commission. The post of geographer was filled by Mr. Ney Elias. Mr. Margary, a most promising member of the Consular Service, thoroughly versed in the Chinese language and etiquette, had also been appointed to accompany the Mission, and had crossed China from Shanghai to Bhamô for the express purpose. The Mission had also the services of Mr. Allan, another officer of Her Majesty's Chinese Consular Service. The preparations for ensuring the success of this Mission in every department were made as complete as foresight could make them.

The Mission was despatched with the intention of thoroughly examining the country to the east of Teng-yue-chow, and of traversing China to Shanghai. Its history, however, was excessively brief and most disastrous. After vainly attempting to penetrate into Yunnan by the Sawady route, a few miles to the south of Bhamô, Colonel Browne resolved to revert to the route pursued by the First Expedition under Colonel Sladen.

The Mission, however, was only permitted to make three marches, when it was attacked by a large body of Chinese, and compelled to make a precipitate retreat to Burma; Margary, who had preceded the mission by one march, having with four of his followers been treacherously murdered at Manwyne.

It is evident, from the foregoing brief summary of the history of these Missions, that the opportunities they afforded for the prosecution of Natural History inquiries, and for the investigation of the subjects that were allotted to me, were very few indeed. I have thought it desirable to bring these difficulties out prominently, because there can be little doubt but that the area traversed is very rich in animal life. Its geographical position, along with the little knowledge we have gained of it, leads to the conclusion that, when facilities are offered for its thorough examination, it will yield many new specific forms of great interest.

I have elsewhere ${ }^{1}$ described in detail the physical features of the country traversed, and have given some illustrations of these in another work, ${ }^{2}$ from photographs and sketches taken on the Expeditions. It is therefore unnecessary that I should again re-enter on this subject.

\footnotetext{
1 Report on the Expedition to Western Yunnan viâ Bhamô. Calcutta, 1871.

${ }^{2}$ Mandalay to Momein : a narrative of the Two Expeditions to Western China of 1868 and 1875. London: Macmillan \& Co.; 1876.
} 
Owing to the circumstances already indicated, materials were not collected on a scale sufficient to permit of any extended comparison between the fauna of the area traversed and that of the surrounding countries; but it may be as well to direct attention to certain facts ascertained on the Expeditions.

A marked feature of the mammalian fauna of the Kakhyen hills, of the hill range to the east of Bhamô, and of the hilly country through which the Irawady flows below Bhamô, is the presence of Hylobates hoolook, a species of a thoroughly Indo-Malayan type, associated with Macacus assamensis, which is a nearly allied form to the common Indian monkey, $M$. rhesus. A short way to the south of the second defile of the Irawady, another hilly tract occurs in which IndoMalayan species of Semnopithecus are to be found, viz., S. pileatus and S. barbei, the former extending into Tenasserim and into Assam, where it is a prevalent species, occurring at no great altitude, and the latter penetrating the valleys of the Kakhyen mountains to the east, where it is associated with the Indo-Malayan genus Nycticebus, which is represented by $N$. cinereus, a species which was first described from Siam by M. A. M.-Edwards. The range of this species also embraces Cachar, Sylhet, the Garo hills, and Assam; whilst the genus is represented in Arracan and the Chittagong hill tracts by the allied species $N$. tardigradus.

Macacus rhesus, Audebert, which has hitherto been regarded as essentially characteristic of the fauna of Bengal and Upper India, would appear to have its range extending much further to the east than has hitherto been acknowledged. It occurs in the valleys of the mountain systems to the north and east of Akyab, from whence I have received many living examples from Colonel Sladen. Its eastward distribution, however, is not limited to that region; but it may be traced across the range of mountains that defines Arracan from Burma; and, moreover, it would appear to extend as far east as the left bank of the Irawady below Mandalay, the capital of Independent Burma. Another instance of distribution, almost a parallel to the foregoing, is to be found in Herpestes auropunctatus, a species which is profusely distributed over Upper India and Bengal, but which is also very prevalent at Chittagong, ranging into Upper Burma, about Bhamô; whereas it does not appear to enter Pegu. It occurs also in Cachar, where, as in Upper Burma, it differs only from the individuals found in Bengal in its darker colour.

In the Kakhyen hills, and in the valley of Sanda, that remarkable Indo-Malayan insectivorous genus Tupaia, which in its external appearance and partially arboreal habits mimies the grizzled squirrels of the Malayan fauna, is not at all uncommon. It is represented by one species which appears to be new, and which I have designated T. chinensis. This genus, however, has a westward distribution as far as the Sikkim Himalaya, where I have observed it at Kurseong, at an eleva- 
tion of 4,500 feet. Associated in the Kakhyen hills with this Indo-Malayan type, is that peculiar, and comparatively short-tailed, so-called Tree-shrew, Hylomys, which was first discovered in Borneo, and afterwards by Major Berdmore in Tenasserim.

The Palæartic Manchurian genus Chimarrogale, which was first discovered in Japan and afterwards in the Himalaya, occurs also in the Kakhyen mountains at Ponsee. The species is closely allied to that found in Japan. It is probable that in the Kakhyen hills it will be ascertained to be associated with the genus Anurosorex, which is also a member of the same section of the Palrartic fauna, and the occurrence of which on the hill ranges of Northern Assam was recently established by the researches of Mr. E. S. Peal of Sibságar.

The genus Talpa, which is represented in the Himalayas and in the Assam region by two species, one of which occurs in the valley of the Sittang, will also doubtless be found in the high region to the east of Bhamô.

Another instance of an Indian mammal extending its range to Western Yunnan is to be found in Vandeleuria, a subgeneric type of $M u s$, occurring in Southern and Central India and in the valleys of the Himalaya, and which I obtained in the valley of the Nampoung, within the Chinese frontier, the animal being apparently identical with the species found in Central India. The squirrels, on the other hand, are peculiar in the circumstance that not only certain species of the valley of the Irawady about Bhamô, but others also of the hill region to the east, manifest types of coloration which do not occur to the west or to the south; for example, the squirrels which are distinguished by one or more lines on the ventral aspect of the body. The squirrel with more than one line on the belly occurs, as far as my observations go, only in the hills, and does not extend into the valley of the Irawady; whereas the squirrel with a single ventral line occurs not only in the valley, but extends into the mountain ranges to the east; and in connection with this, it is noteworthy that squirrels with analogous ventral lineation are found as far as the eastern sea-board of China. The large flying squirrel of Western Yunnan is also specifically distinct from the Himalayan species, and also from the voltant squirrels of Eastern China; whereas the smaller form $P$. pearsoni is found on the mountain ranges of Assam and Yunnan.

That peculiar rodent type Rhizomys, which is allied to the Palæartic type Spalax, has its maximum specific development in the Indo-Chinese region, and is represented in the high area to the east of Bhamô by two species, $R$. pruinosus and $R$. badius, which are also found on the mountainous region to the west of the Irawady, constituting one of its zoological features, the former species having a further westward extension as far as the Sikkim-Himalaya. 
The species of porcupine which occurs in Western Yunnan seems to be intermediate between the Eastern Chinese short-crested porcupine and an allied species in the Himalaya, both of which are nearly related to the small short-crested porcupine of Bengal, which, in its form as in its pronounced burrowing habits, is very distinct from the long-crested porcupine of Southern and Western India-a species which is hardly specifically separable from the large porcupine of Southern Europe and of North and North-Western Africa.

The musteline genus Helictis is represented in Western Yunnan by a species, H. moschata, specifically distinct from $H$. nipalensis of the Himalaya. It would appear probable that the species of the genus Lutra and its sub-genus Aonyx are specifically identical with the species found in the Himalaya. The different species of otter, however, found in the Indian section of the Oriental region are not at all rightly understood. An otter occurs in Bengal and in the Himalaya with a considerably flattened head and a somewhat spatulate muzzle, the skull of which is hardly distinguishable from the skull of the European otter; and this form would appear to be the Lutra nair of Cuvier, with which the L. indica, Gray, is identical. Another otter also occurs in Bengal with a deep head and a short deep muzzle, and a skull quite distinct from that of $L$. nair, as the postorbital portion is long and tumid, and in these features markedly different from the skull of $L$.nair, in which the postorbital region is contracted. Both of these otters are very closely allied to species which occur in the mountain streams of Western Yunnan associated with $L$. (Aonyx) leptonyx, an otter which has a wide distribution in the Indo-Malayan and Indo-Chinese regions. The musteline genus Meles (Arctonyx) is represented in Western Yunnan by the same species which occurs in the Assam region.

On the higher mountain ranges to the east, in the neighbourhood of Sanda and Teng-yue-chow, and associated with a number of Palæartic types, is found Allums, specifically identical with the so-called Cat-bear of the Himalaya. From the number of skins which are used for the decoration of the head-dresses of the Military officials, the species would appear to be very prevalent, and to have a much greater numerical development than in the Himalaya.

I learned of the existence of a black bear in the Kakhyen hills, and indeed of its occurrence also in the mountain ranges generally to the east of Bhamô, and observed one skin which, from its general character, led me to conclude that it might probably be Ursus tibetanus; but as there was, however, some doubt regarding this skin, I resolved to omit any reference to the species, except in this Introduction. Since the last Expedition, however, I have instituted enquiries on the eastern frontier of Burma regarding the species of bear said to occur there, and, as a result, the 
Zoological Garden of Calcutta received from Mr. Rivers Thompson, C.S.I., then Chief Commissioner of British Burma, a living example of Ursus tibetanus from the hilly region at Tonghoo, in nearly the $19^{\circ}$ parallel of latitude; and from this circumstance I am disposed to conclude that my observation in the Kakhyen hills was correct. This species has been recorded by M. L'Abbé A. David from Shensi, and by Swinhoe from Hainan and Formosa. ${ }^{1}$

The tiger and leopard are prevalent at Bhamô, and equally so in the elevated valleys about Sanda and in the mountain ranges to the east, whereas in the Kakhyen hills the black variety of the latter animal is found; and associated with these species is another but much smaller cat, $F$. bengalensis, and which occurs in the valleys of the elevated region about Momien and also at Bhamô. The Himalayan species of Prionodon also occurs in the Kakhyen hills, and associated with it is that widely distributed species Viverricula malaccensis.

At Momien, which is enclosed by rounded hills, covered only with grass and patches of bracken, I observed a small yellow fox; but as I have not been able to determine the species satisfactorily, having obtained only one young individual, I have omitted the species from the text. In association with it, there is a hare, which, for a similar reason, I have not been able to determine specifically.

In the region of Teng-yue-chow, the Himalayan and Chinese species of Goat Antelopes, $N$. bubulina and $N$. edwardsi, would appear to meet; and on the very high mountain ranges to the north of Teng-yue-chow that Palæartic type Moschus occurs. Cervus porcinus is prevalent at the base of the Kakhyen hills, and on them the cry of the barking deer, C. vaginalis, is a familiar sound.

Wild elephants, the Singphos or Kakhyens assert, are occasional visitors to the mountains, ascending from the neighbourhood of Bhamô to an elevation of 5,000 feet.

The Shans of Bhamô are familiar with the existence of a two-horned Rhinoceros, which occurs on the right bank of the Irawady, in the district of Mogoung; but I could not obtain any reliable information to serve as a guide to the identification of the species, whether it might be $R$. niger, or the species which I some years ago described as $R$. sumatrensis of Bell, but which Dr. Sclater considered to be a distinct species and named $R$. lasiotis. $R$. sumatrensis, as understood by me, occurs at Chittagong, and is apparently the animal found in the valleys of Tipperah and Munipur to the north, and therefore is in all likelihood the species said to occur at Mogoung.

\footnotetext{
1 The bear referred to by Blyth in his Catalogue of the Mammals and Birds of Burma under the name of $U$. malayanus as occurring at Tonghoo, on the authority of Mason, is doubtless $U$. tibetanus, which would also appear to extend north. wards through the Himalaya to Balúchistán and to the confines of Sind and Persia, from whence Blanford at first described it as a new species, U. gedrosianus (Journ. As. Soc., Bengal, Vol. XLVI, Pt. II, 1877, p. 317), afterwards, however, acknowledging the specific identity of the Baláchistán black bear with $U$. tibetanus.
} 
The Himalayan Ant-eater is the species which occurs in the high valleys of Sanda and Momien; whereas, at Bhamô, the Indo-Malayan species Manis javanica is found.

When the Avine fauna is examined, it may also be observed that the comparatively low region about Bhamô, the area of the Kakhyen hills, and the elevated region beyond them to the east, is each characterized by distinct features. The fauna of Bhamô and its immediate neighbourhood is essentially Burmese; but a consideration of the species reveals the existence in it of a slight intermixture of species, more or less distinctive of the high country to the east, associated with others which partake more of the Malayan fauna. In the same way, in the Kakhyen hills, the fauna is markedly Burmese, but it, at the same time, has distinct Himalayan and Khasia-hill affinities, with a much larger intermixture of Chinese species than is to be found in the area about Bhamô. To the east of the Kakhyen hills, it becomes more Chinese, and species are met.with which are only sparsely represented in the Bhamô area, while many occur which do not extend into the valley of the Irawady. Some of these, however, have a considerable distribution to the western side of the Irawady valley, into the mountainous region of Assam, Munipur, and the Khasia hills. In this elevated region, it is found that this section of the fauna as well has a strongly pronounced Palæartic aspect, e.g., one of the most characteristic birds of the hills around Momien is a true pheasant, $P$. sladeni, with another allied form Thaumalea, whereas this group of birds is represented in the Kakhyen hills and around Bhamô by Euplocamus.

The Chelonian fauna, both terrestrial and fluviatile, around Bhamô, would appear to be perfectly distinct from that of India. So far as the species are concerned, none of those that are Indian extend into the valley of the Upper Irawady, while certain Indo-Chinese and Indo-Malayan forms, such as Pyxidea and Geoemyda, range as far westwards as the Garo hills and Assam. That remarkable Indo-Chinese genus Platysternum is found at some considerable distance to the south of Bhamô, viz., at Tonghoo, where it is associated with Cyclemys and with the Indo-Chinese type Geoemyda, which finds the western limit of its distribution in Arracan. It is therefore probable that further research about Bhamô, and in the neighbouring mountains to the east, will reveal the existence of kindred forms in these regions. In the Sittang valley to the south, Hylomys, which, as has been seen, occurs also in the Kakhyen hills, is associated in the former locality with Tropidophorous, an IndoMalayan type of lizard which ranges northwards into the Hotha valley, to an elevation of 4,500 feet; and such a fact as this goes to strengthen the anticipation which has been just expressed. Not only, however, do none of the Indian species of Chelonia find their way into Upper Burma, so far as is at present known, but the land-tortoise 
is specifically distinct from that which is so prevalent in Pegu, viz., T. elongata. The affinity, however, manifested by the northern species, $T$. platynota, is more towards $T$. actinodes than to $T$. elongata; and it is a remarkable circumstance that, whilst T. platynota does not extend either into Assam or into Bengal, T. elonguta is found on the outskirts of the eastern border of the plateau of Central India, and would also appear to exist in the Terai region of the Sikkim-Himalaya.

But certain reptiles, which are highly characteristic of the Indian fauna, are also found at Bhamô, viz., Calotes versicolor, Tropidonotus stolatus, and Passerita mycterizans, associated with such Indo-Malayan forms as Calotes mystaceus, the first and the last occurring together also at Mandalay. In the Kakhyen hills, and in the country beyond, $T$. stolatus is supplanted by $T$. dipsas, a Himalo-Chinese species.

In the Kakhyen hills, that Malayan type Draco is found, but rarely; while in the valleys to the east, the fauna is characterized by such forms as Pseudopus, which also occurs in Lower Pegu, the Khasia hills and the Sikkim-Himalaya, and others, e.g., Japalura, Oriocalotes, Ablabes, Coluber, Elaphis, which are essentially Himalayan forms; and with these is associated the Malayan type Ophites. Even the individual species of these genera are either identical with, or are very closely allied to, the species occurring in the Eastern Himalayas, while the Trimeresurus of the high valleys of Western Yunnan is identical with T. monticola.

Occurring along with these Ophidian forms in the area to the east of the Kakhyen hills, and chiefly to the east of Muangla, are found the Palrartic types Tylototriton, and Carassius as represented by the gold carp; and it is especially worthy of note that all of these forms, with the exception of Carassius, are also distinctive of the fauna of the Sikkim-Himalaya.

The sudden transition from the valley of the Irawady to the high country of Yunnan is very striking, because the traveller, after three marches over the Kakhyen mountains, is suddenly introduced from a Burmese-speaking population, clad in the light, many-coloured flimsy garments of a tropical people, into a Chinese-speaking race, clothed in the thick, dull-blue habiliments of a mountain people. This change of scene, however, is not more marked than that which distinguishes the faunæ and floræ. After the dense vegetation and Burmese fauna of the valley of the Irawady are left behind, and the Burmio-Himalayan flora and mixed Burmese Indo-Malayan and Himalayan fauna of the Kakhyen hills have been passed, the elevated country becomes bare and grassy, and Burmese and Malayo-Himalayan species give way before others which are essentially Chinese and Palæartic. The physical features, however, of these regions have, as I have already said, been described in detail in my previous works on the scientific results of the two Expeditions to Western Yunnan. 
In concluding these introductory remarks to a volume which has greatly exceeded my original intention regarding its scope, I embrace the opportunity to record my thanks to Dr. Murie for much valuable assistance accorded to me in its progress through the press. During my absence from Europe, he undertook the supervision of the drawing, printing and colouring of the plates which illustrate this volume; and moreover I had the advantage of his opinion and advice in some anatomical details, and in the identification of certain species. To the artist Mr. Berjeau, who has faithfully reproduced the anatomical features of the objects described and the distinctive characters of the species represented, my thanks are also due.

I am specially indebted to Dr. Dobson for having undertaken the description of the Chiroptera.

The identifications of the birds were verified by Mr. R. Bowdler Sharpe, who has carefully worked out the literature.

To Dr. Günther and Mr. Francis Day I am obliged for their aid in identifying the few fish obtained; and more especially to the latter Ichthyologist, who favoured me with a list of the fish collected on the First Expedition, and undertook the description of certain species.

I have also the pleasure to express my thanks to Mr. W. T. Blanford, who described the new species of Mollusca collected on the First Expedition; and to Mr. G. Nevill for the account of all the species of this group which were brought together on the two Expeditions.

In the list and description of certain insects, I am particularly indebted to Mr. Frederick Moore; whilst I have also to acknowledge the assistance of Mr. Frederick Smith and Mr. Maclachlan in the description of others. The late Mr. W. S. Atkinson and the late Mr. Francis Walker identified and described the new species of those groups, to which they had specially devoted their attention.

My thanks are due to Mr. J. Wood-Mason for having worked out the Crustacea, an account of which originally appeared in the Journal of the Asiatic Society of Bengal.

I acknowledge with pleasure my indebtedness to Professor A. C. Brown for the opportunity of figuring in this work a series of the ear-labyrinth of various Cetacean genera, taken from casts made by himself.

To Professors Günther, Flower, Turner, Schlegel, A. M.-Edwards, and Paul Gervais, I am under great obligations for the facilities they afforded me in examining the collections under their individual charge ; and to Professor Peters for his advice regarding certain species described in this work. 
Among others who gave me the benefit of thcir assistance, I am under obligation to Lieutenant-Colonel H. H. Godwin-Austen for the plate of Rhizomys erythrogenys, reproduced from a sketch made by him from the living animal.

In conclusion, I must tender my thanks to the Trustees of the Indian Museum for permission to use for the illustration of this work many original drawings in their possession.

\section{Calcutta;}

The 21st December 1878. $\}$ 

FIRST PART.

M A M M A I A. 



\title{
QUADRUMANA.
}

\author{
SIMIID旡. \\ Genus Hyцоватеs, Illiger. \\ * Hrlobates Hoolock, ${ }^{1}$ Harlan.
}

The Fifé, Nieuhoff, Recueil des Voyages, \&c. vol. iii. 1716, p. 168.

The Golock, De Visme, Philosoph. Trans. vol. lix. 1769, p. 72.

The Gutok, Pennant, Hist. Quad. vol. i. 3rd ed. 1793, p. 185.

The Voulock Allamand, Buffon, Hist. Nat. (Sonnini) vol. xxxv. (1809), p. 140.

Simia lar, Philosoph. Trans. vol. lix. 1769, p. 607.

Simia hoolock, Harlan, Trans. Amer. Phil. Soc. vol. iv. new ser. 1834, p. 52, pl. 2 (animal and skull). Hylobates choromandus, Ogilby, Proc. Zool. Soc. 1837, p. 689; London and Edinb. Phil. Mag. 1838, p. 531; Waterhouse, Cat. Mamm. Mus. Zool. Soc. Lond. 2nd ed. 1838, p. 3 ; Lesson, Sp. des Mammif. 1840, p. 54; Martin, Hist. Quad. 1841, pp. 415, 442 (plate); Is. Geoff. St.-Hil. Arch. du Mus. vol. ii. 1843, p. 535; Schinz, Syn. Mamm. vol. i. 1844, p. 31 ; Blyth, Journ. As. Soc. Beng. vol. xiii. (1844), p. 464; Gervais, Hist. Nat. des Mammif. 1854, p. 55.

Hylobates hoolock, Waterhouse, Cat. Mamm. Mus. Zool. Soc. Lond. 2nd ed. 1838, p. 3; M'Clelland, Proc. Zool. Soc. 1839, p. 148 ; Is. Geoff, St.-Hil. Arch. du Mus. vol. ii. 1841, p. 535 ; Martin, Nat. Hist. Quad. 1841, pp. 416, 4.38 (fig. of head) ; Blyth, Journ. As. Soc. Beng. vol. x. 1841, p. 838 ; vol. xiii. 1844, pp. 464, 476; vol. xliv. ex. no. 1875, p. 1 ; Cat. Mamm. As. Soc. Beng. 1863, p. 4; Gray, Hand-list Mamm. B. M. 1843, p. 2 ; Cat. Monkeys and Lemurs, B. M. 1870, p. 11 ; Schinz, Syn. Mamm. vol. ii. 1844, p. 29 ; Is. Geoff. St.-Hil. Cat. Méthod. des Mammif. 1851, p. 9; Horsf. Cat. Mamm. E. Ind. Co. Mus. 1851, p. 2 ; Gervais, Hist. Nat. des Mammif. 1856, p. 54 (fig. of head) ; Dahlbom, Stud. Zool. Fam. Reg. An. 1856, pp. 73, 76 ; Beyrich, Abhandl. der Berl. Akad. der Wiss. 1860, p. 7 ; Sclater, Proc. Zool. Soc. 1860 , p. 86 , pl. v.

Hylobates scyritus, ${ }^{2}$ Ogilby, Mamm. Himalaya, Royle's Ill. Him. Bot. 1839, p. LX; Madr. Journ. Lit. \& Sc. vol. xii. 1840 .

Hylobates hulok, Wagner, Schreber, Säugeth. Suppl. vol. i. (1840), p. 76, vol. v. 1855, p. 20.

Hylobates houlock, Lesson, Sp. des. Mammif. 1840, p. 54.

? Hylobates niger, Ogilby, Proc. Zool. Soc. 1840, p. 20. ${ }^{3}$

1 An asterisk prefixed to a species mentioned in this work indicates that it was obtained or observed on one or other of the two Expeditions to Western China.

${ }^{2}$ A reference to this term, $H$. scyritus, Ogilby, has been given by Waterhouse in his Cat. Mamm. Zool. Soc. Lond. 1838, p. 3, to the Proc. Zool. Soc. 1837, but I have failed to discover it. Waterhouse appears to have been followed by succeeding authors, who have quoted his reference without verifying it. Ogilby, too, himself, in his "Natural History of Monkeys, Lemurs, and Opossums" (Charles Knight's Library Ent. Know. "Menageries," vol. i. 1838, p. 144), refers to the Zool. Trans. vol. iv., p. 109, for the description of H. scyritus; but in the reference in question no such species is named.

${ }^{3}$ Ogilby mentions a Gibbon described by Harlan as H. niger; but I have not been able to discover that any Gibbon has ever been described under that name. 
I first met with this species in Upper Burma, in passing through the magnificent defile of the Irawady, below Bhamô, where the river is enclosed by high hills, covered with dense forest, for about fifteen miles of its course. It was early morning and the air was resonant with the loud calls of this Gibbon; large troops were answering each other from the opposite banks, and the hills echoed and re-echoed the sound. The Hoolock is also common on the Kakhyen hills, on the eastern frontier of Yunnan; and, there, too, my attention was called to them at daybreak when they passed up from their sheltered sleeping-ground in the deep and warm valleys to heights of about 4,000 feet. We, in the middle distance, first caught a faint murmur of voices; but every minute it became more and more distinct, till at last the whole troop rushed past in a storm of sound, vociferating "whoko!" "whoko!" and in a few more minutes their cry was heard far up the mountain-side. Considering that their progress is almost exclusively arboreal; the rapidity with which they make their ascent is wonderful.

Associated with this arboreal habit of progression, we find that $H$. hoolock derives its nourishment from leaves, insects, eggs and birds, the essential features of sylvan life. From a series of observations made in the Zoological Gardens, Calcutta, on the food of this species, we learn that it eats, with evident satisfaction, the leaves of the following trees: Moringa pterygosperma, Gaertn., Spondias mangifera, Pers., and Ficus religiosa, Linn. Like the leaf-eating monkeys, such as Semnopithecus entellus, it devours with avidity the leaves of Beta vulgaris, Mog., and those of the aquatic convolvulus, I. reptans, Poir. With the Ourang-outan it also manifests a decided predilection for the bright-coloured flowers of Canna indica, Linn.

It is no new fact that $H$. hoolock, like its congener $H$. lar, has a marked partiality for spiders and their webs, which become tangled in its long slim fingers, and that orthopterous insects are regarded by it with special favour, over which it utters its peculiar cry of satisfaction. Eggrs also are to it a bonne bouche. It was first in the Calcutta gardens that I became aware of the circumstance that small living birds were devoured by it with a method and eagerness which has left no doubt in my mind that this species, in its natural state, must be a scourge to the feathery tribe. The living bird being seized by the body, the work of destruction is begun at the head. The hoolock in so doing forcibly reminded me of the course pursued by that nocturnal nest-harrier Nycticebus tardigradus.

As is well known, this species has the most westerly distribution of the members of the genus. Pemberton, ${ }^{1}$ who was an accurate observer, records that it occurs in the lower ranges of Bhutan; and a remark of Hodgson's ${ }^{2}$ would seem to favour the supposition that it occasionally finds its way even to the sheltered valleys of Nepal, as he mentions that his collectors were alarmed in the Kachar ${ }^{3}$ by the

\footnotetext{
1 Journ. As. Soc. Beng, vol. viii. 1839, p. 272.

${ }^{2}$ L. c., 1832, p. 339, foot-note.
}

${ }^{3}$ L. c., p. 339 . Hodgson applied the name Kachar to the northern region of Nepal. 
apparition of a wild man, from which, instead of shooting it, they fled away. This animal, they said, moved erectly, and was covered with long 'dark hair, and had no tail. Blyth ${ }^{1}$ also observes that it exists in the hill ranges to the eastward of Upper Assam, in the region inhabited by the Nagas and Ahors, where it abounds in the upland forests in parties of from 100 to 150 individuals. From thence it ranges in a south-westerly direction through the hill region of Assam to Sylhet and Kachar, and the Khasia and Garo hills, in the last of which it is prevalent; ${ }^{2}$ it is also apparently found in some parts of Mymensing. It spreads through the mountains to the north and east of Chittagong, through Arracan, and is distributed southwards as far as Martaban. From Assam and Munipore it crosses the valley of the Irawady, and penetrates into the range of mountains that define its eastern limit; but it does not pass into the high, but treeless, country to the east of Nantin. Swinhoe ${ }^{3}$ mentions a species of Black Gibbon said to exist in the country to the west of Canton, and suggests that it may be the same as the animal found in Hainan, and which he had attempted to identify with H. pileatus. ${ }^{4}$

In Arracan and Martaban it is associated with $H$. lar; the latter, however, does not appear to extend into the northern portion of the Irawady valley. ${ }^{5}$

The variation of colour, which is so observable in this species throughout the area of its range, seems to be more distinctive of the female than of the male sex, as it would appear to be a rare circumstance to find an adult male otherwise than deep black, whereas females of mature age are not unfrequently pale yellow. At the same time it is a well-ascertained fact that young males occasionally present a similar variation, but whether they become black as they grow older has not been determined. Even in females adhering most to the characteristic hue of the species, the black is always of a less deep tint than in the adult male, and they generally have a brownish tinge.

I have observed females from Assam and Cachar in which the upper parts were pale yellow and the under parts and the sides of the head brown, whilst the area immediately surrounding the nude parts of the face was so white as to contrast with the surrounding yellow. This type of coloration approaches that of the "Ungka puti" or H. agilis. In other females from the same region, the fur instead of being pure yellow is greyish yellow, and their resemblance to H. leuciscus is such that I have seen hoolocks of this type referred to that species by able zoologists.

Black would seem to be the prevailing colour of the young at birth, but the not unfrequent occurrence of bright yellow individuals in a species the adults of

\footnotetext{
1 Journ. As. Soc. Beng. 1844, p. 464.

2 The type was probably obtained from these hills, as Dr. Harlan's specimen came from Goalpara.

3 Proc. Zool. Soc. Lond. 1870, p. 615.

${ }^{4}$ Ibid, p. 225. Du Halde (Descrip. Emp. Chin. vol. 1, p. 118), in his description of the kingdom of Mansi, mentions a great black ape.

5 Tickell states that $H$. lar extends to the northern confines of Pegu, and limits its westerly distribution to the east of the spur dividing British Burma from Arracan (Journ. As. Soc. Beng. 1864, p. 196).
} 
which are generally black, and the persistence of the former colour throughout life in some females, and perhaps also in some males, are facts of considerable interest, and should not be lost sight of in studying the various species of Semnopitheci. Some of the species of this tailed group appear only to be distinguishable from each other by differences of colour, some of them being deep black and others bright red. The dark-coloured species have their young born yellow or red.

The leading features of the skull of $H$. hoolock as compared with $H$. lar are its less prominent orbital ridges, longer muzzle, more elongated nasal orifice, and considerably larger teeth, associated with a much longer palate than in H. lar. Such a series of structural characters occurring in the skull along with peripheral distinctions by which alone it is possible to separate H. hoolock from H. lar clearly indicate the two as distinct species.

On the other hand, the skull of H. agilis has the prominent ridges surrounding the orbits, the short snout and palate and small teeth of $H$. lar, to which in external characters it is closely allied. The skulls also of $H$. leuciscus and of H. mülleri do not appear to me to present any very marked structural modification on the skull of $H$. lar.

There is occasionally considerable asymmetry between the two sides of the facial bones of $H$. hoolock, due to a lateral twisting which I have generally observed to be towards the right side. It is quite apparent in life, and sometimes produces a most ludicrous appearance. This asymmetry does not appear to affect the rest of the skull.

The canine teeth, unlike those of the higher anthropoid apes, appear to be equally well developed in both sexes of all the species, if the specimens on which these observations are founded have been correctly sexed, which I have no reason to doubt, as I have as far as possible persionally verified the sex in each instance.

Dahlbom, in his comparatively recent revision of the genus, has placed, it appears to me, undue stress on the character of the absence or presence of a tubercle on the clavicle, for the existence of such a nodule can hardly be regarded in the light of a structural character, as it simply indicates that the muscle has had a more powerful attachment to the bone than in those cases in which the nodule is only feebly developed. Such a character would be largely influenced by the life the animal led, and unless all the individuals on which his observation rests were thoroughly ferine, its value is much lessened. Dahlbom accepts H. agilis as distinct from $H$. rafflesii, and $H$. entelloides as separable from $H$. lar.

I append a synopsis of the species after a careful comparison and study of the various types in Europe and the exarnination of a very extensive series in India. 


\section{HyLobates LAR, Linn.}

Le grand Gibbon, Buffon, Hist. Nat. vol. xiv. 1766, pl. ii.; Ibid, Daubenton, p. 96.

Le petit Gibbon, Buffon, Hist. Nat. vol. xiv. 1766, pl. iii.; Daubenton, p. 102 ; Latr. Hist. Nat. Buffon (Sonnini ed.), vol. xxxv. 1809, p. 206, pl. ix.

The Long-armed Ape, Pennant, Syn. Mamm. 1771, p. 99; Hist. Quad. vol. i. (3rd ed.) 1793, p. 181 (in part); Shaw, Gen. Zool. vol. i. pt. i. 1800, p. 12, pl. v.

The Lesser Long-armed Ape, Pennant, Syn. Mamm. 1771, p. 100.

Le Gibbon, Hist. Nat. des Singes, 1797, $1^{\text {re }}$ fam. sect. ii. pl. i. ; Latr. Hist. Nat. de Buffon (Sonnini ed.), vol. xxxv. (1809) p. 197, pl. viii.

Homo lar, Linn. Mantissa Plant. 1771, Append. p. 521.

Simia longimana, Schreber, Säugeth. vol. i. 1775, p. 66, pl. iii. figs. 1 \& 2 (Buffon); Erxleben, Syst. Reg. An. 177, p. 9 ; Zimm. Geograph. Gesch. vol. ii. 1780, p. 174.

Simia lar, Boddaert, Elench. An. 1785, p. 55 ; Gmelin, Linn. Syst. Nat. (13th ed.) 1788, p. 29 ; Fischer, Syn. Mamm. 1829, p. 12 (in part).

Pithecus lar, Latr. Hist. Nat. de Buffon (Sonnini ed.), vol. xxxvi. 1809, p. 276.

Pithecus varius, Latr. Hist. Nat. Buffon (Sonnini ed.), vol. xxxvi. 1809, p. 276.

Pithecus variegatus, Geoff. St.-Hil. Ann. du Mus, vol. xix. 1812, p. 88.

Hybolates lar, Illiger, Abhand. der Akad. der Wiss. Berlin, 1815, p. 88; Kuhl, Beitr. zur Zool. 1820, p. 5 ; Desmarest, Mamm. 1820, p. 50 ; pl. 5 . fig. 3 (Buffon); Wagner, Schreber, Säugeth. Suppl. vol. i. 1840, p. 71, vol. v. 1855, p. 15; Lesson, Sp. des Mammif. (Mastol. Méth.) 1840, p. 52 ; Martin, Hist. Quad. or Monkeys, 1841, pp. 416, 417, 433 (plate) ; Blyth, Journ. As. Soc. vol. x. 1841, p. 838 ; vol. xii. 1843, p. 176 ; vol. xiv. 1845, p. 463 ; vol. xv. 1846, p. 172 ; vol. xvi. 1847, pp. 729, 730 ; vol. xliv. 1875, ex. no. p. 1; Cat. Mamm. As. Soc. Mus. 1863, p. 5; Gray, Hand-list Mamm. B. M. 1843, p. 2; Cat. Monkeys and Lemurs, B. M. 1870, p. 10. Cantor, Journ. As. Soc. Beng. vol. xv. 1846, p. 172 ; Fry, Proc. Zool. Soc. 1846, p. 15 ; Ann. \& Mag. Nat. Hist. vol. xvii. 1846, p. 487 ; Is. Geoff. St.-Hil. Cat. Méthod. des Mammif. 1851, p. 8; Gervais, Hist. Nat. des Mammif. 1854, p. 52 (fig. of head); Dahlbom, Stud. Zool. Fam. Reg. Anim. 1856, pp. 73, 77 ; Tickell, Journ. As. Soc. Beng. vol. xxviii. 1859, p. 428 ; Ann. and Mag. Nat. Hist. vol. xiv. 1869, p. 360 ; Sclater, Proc. Zool. Soc. 1860, p. 86, pl. v.

Hylobates variegatus, Kuhl, Beitr. zur Zool. 1820, p. 5 ; Desmarest, Mamm. 1820, p. 51 ; Lesson, Man. de Mamm. 1827, p. 31 ; Griffith, An. King. vol. v. 1827, p. 6 ; Bory de St. Vincent, Dict. Class. d'Hist. Nat. vol. xii. 1827, p. 285 ; Is. Geoff. St.-Hil. Zool. Voy. de Bélanger, 1834, p. 27; Waterhouse, Cat. Mamm. Mus. Zool. Soc. 1838, 2nd ed. p. 4; Schinz, Syn. Mamm. vol. i. 1844, p. 30 (in part).

Simia albimana, Vigors \& Horsfield, Zool. Journ. no. 13, 1828, vol, iv. p. 107.

Simia variegatus, Fischer, Syn. Mamm. 1829, p. 11.

Hylobates albimanus, Is. Geoff. St.-Hil. Zool. du Voyage de Bélanger, 1834, p. 29; Schinz, Syn. Mamm. vol. i. 1844, p. 28 ; Schlegel, Essai sur la Physion. des Serpens, Pt. Gén. 1837, p. 237. Hylobates leuciscus, Cantor, Ann. \& Mag. Nat. Hist. vol. xvii. 1846, p. 338.

\section{Pale Variety.}

Hylobates entelloides, Is. Geoff. St.-Hil. Compt. Rend. vol, xv. 1842, p. 717 ; Zool. Voy. de Jacquemont, vol. iv. 1844, p. 13 ; Archiv. du Mus. vol. ii. 184-? p. 582, pl. xxix.; Cat. Méthod. des Mammif. 1851, p. 9; Gervais, Hist. Nat. des Mammif. 1854, p. 52 (fig. of head); Dahlbom, Stud. Zool. Fam. Reg. An. 1856, pp. 73, 76 ; Blyth, Journ. As. Soc. Beng. vol. xliv. 1875, ex. no. p. 2.

This species is generally easily recognisable by its pale yellowish, almost white, hands and feet, by the grey, almost white, supercilium, whiskers, and beard, and by the deep black of the rest of the pelage. 
It is the subject, however, of considerable variation, the most extreme variety being that in which the general colour of the animal, instead of being black, becomes wholly pale yellow (H. entelloides, Is. Geoff. St.-Hil.). It may be observed, however, that, even in these very pale animals, which as in $H$. hoolock are generally females, the paler colour of the hands and feet can to a certain extent be detected. Between these two well-defined extremes every variety of colour is exhibited by the species, but the characteristic specific markings of the face, hands, and feet are preserved.

In some individuals the index and middle tues of the foot become united by a web, as in H. syndactylus.

Its voice is perfectly distinct from that of $H$. hoolock.

It appears to be confined to Arracan, Lower Pegu, Tenasserim, and to the Malayan peninsula.

\section{Hylobates pileatus, Gray.}

Hylobates pileatus, Gray, Proc. Zool. Soc. 1861, p. 136, pl. xxi.; Cat. Monkeys and Lemurs, B. M. 1871, p. 10.

Hylobates lar, Blyth, Journ. As. Soc. Beng. vol, xliv. 1875, ex. no. p. 2.

The individuals of this species are generally distinguished by a black area on the top of the head resembling a cap, and by the chest being almost wholly of the same colour, which, however, in some instances extends on to the throat and belly. The back of the head, the upper surface of the trunk, the limbs, the circumference of the black spot on the crown, are greyish, usually paler in the latter area, all the remaining portions being black. Other specimens are all white, with the exception of the back which is brownish, and the top of the head and the chest which are black; while some are brownish, with the chest, belly, and sides of the face black, the throat also partaking more or less of the latter colour. In some examples the whole of the under parts are black and the whiskers are white.

It is a most variable Gibbon, and the circumstance that it is to a certain extent resembled by $H$. agilis, $H$. leuciscus, and $H$. mülleri, in the distribution of their colours, has suggested to the minds of some zoologists, and with a show of probability, that they may all ultimately prove to be referable to one species.

Inhabits Siam.

\section{Hylobates letcogenys, Ogilby.}

L'Onke, Tabraca, Hist. Civile et Nat. de Siam, vol. ii. 1771, p. 308.

Hylobates leucogenys, Ogilby, Proc. Zool. Soc. 1840, p. 20; Blyth, Journ. As. Soc. vol. x. 1841, p. 838 ; Martin, Nat. Hist. Quadrumana, 1841, p. 445 (plate and fig. of skull) ; Is. Geoff. St.-Hil. Comptes Rendus, 1842, vol. xv. p. 717, Arch. du Mus. vol. ii. 1843, p. 535 ; Schinz, Syn. Mamm. vol. i. 1844, p. 28 ; Gervais, Hist. Nat. des Mammif. 1854, p. 54; Wagner, Schreber, Säugeth. Suppl. vol. v. 1855, p. 20; Gray, Cat. Monkeys and Lemurs, B. M. 1870, p. 11.

This species is entirely black, with the exception of the area below the ears, the cheeks, and the part of the throat immediately behind the chin, which are white. 
The specimens in London and Paris exactly agree with each other.

This species inhabits Siam (Paris Museum), and is probably closely allied to those forms of $H$. pileatus in which the animals are wholly black with the exception of the whiskers; so that it seems to be so closely related to H. pileatus that the two may ultimately prove to be identical.

\section{HyLobates leuciscus, Schreber.}

The Wow Wow, Camper, Allgemeene Vaterland. Letterfn. i. p. 18.

The Long-armed Ape, Pennant, Hist. Quad. vol. i. 3rd ed. 1793, pl. xxxviii.

The Long-armed Ape (var. B), Pennant, Hist. Quad. vol. i. 3rd ed. 1793, p. 184.

Le Moloch, Audebert, Hist. Nat. des Singes, $1^{\text {re }}$ fam. sect. ii. pl. ii.

The Long-armed Ape (white var.), Shaw, Gen. Zool. vol. i. pt. 1, 1840, p. 12, pl. vi.

Le Gibbon cendré, Latr. Hist. Nat. Buffon (Sonnini ed.), vol. xxxv. (1809) p. 207, pl. x.

Simia leucisca, Schreber, Säugeth. tab. iii. b, 1775.

Pithecus leuciscus, Geoff. St.-Hil. Ann. du Mus. vol. xix. 1812, p. 89.

Hylobates leuciscus, Kuhl, Beitr. zur Zool. 1820, p. 6; Desmarest, Mamm. 1820, p. 51 ; F. Cuvier, Dict. des Sc. Nat. xxxvi. 1825, p. 289; Lesson. Man. de Mamm. 1827, p. 31; Griffith, An. Kingd. vol. v. 1827, p. 6 ; Bory de St. Vincent, Dict. Class. d'Hist. Nat. vol. xii. 1827, p. 284; G. Cuv. Règ. An. vol. i. (nouv. éd.) 1829, p. 90 ; Fischer, Syn. Mamm. 1829, p. 12 ; Is. Geoff. St.-Hil. Bélanger's Voy. aux Ind. Orient., Zool. 1834, p. 26 ; Compt. Rend. vol. xv. 1842, p. 716 ; Cat. Méthod. des Mammif. 1851, p. 7; Arch. du Mus. vol. v. 1852, p. 534; Müller, Tijdsch. voor Natuur. Gesch. en Phys. vol. ii. 1835, p. 327; Schlegel, Essai sur la Physion. des Serpens, Pt. Gén. 1837, p. 237 ; Waterhouse, Cat. Mamm. Mus. Zool. Soc. Lond. 1838, 2nd ed. p. 4; Wagner, Schreber, Säugeth. Suppl. vol. i. 1840, p. 78 , pl. iii. B; Lesson, Sp. des Mammif. 1840, p. 51; Martin, Hist. Quad. or Monkeys, 1841, pp. 416, 4i17, 436; S. Müller, Verhandl. over de Zool. van den indisch. Arch. 1839-44, p. 15 ; Gray, Hand-list Mamm. B. M. 1843, p. 2 ; Cat. Monkeys and Lemurs, B. M. 1870, p. 12 ; Müller und Schlegel, Verhandl. 1839-44, p. 48; Blyth, Journ. As. Soc. Beng. vol. xiii. 1844, p. 465 ; Ibid, vol. xliv. 1875, ex. no. p. 4; Cat. Mamm. As. Soc. Mus. 1863, p. 5 ; Schinz. Syn. Mamm. vol. i. 1842, p. 31 ; Cantor, Journ. As. Soc. Beng. vol. xv. 1846, p. 173; Gervais, Hist. Nat. des Mammif. 1854, p. 53 (fig. of head); Wagner, Schreber, Säugeth. Suppl. vol. v. 1855, p. 16 ; Dahlbom, Stud. Zool. Fam. Regn. An. 1856, pp. 73, 74; Giebel, Zeitschr. ges. Ntrwiss. 1876, p. 168 (skull) ; Bischoff, Abh. Bayr. Ak. Wiss. vol. x. 1870, p. 119, 5 plates (pl. i. head).

General colour, uniform grey, paler on the lower region of the back; area around the face paler than the other parts, with the exception of the frontal streak, which is more or less conspicuous. The top of the head is occasionally blackish or dark brown, forming a kind of cap, but in others it is very obscure; the fingers and toes tend to blackish. The fur is dense, profuse, and rather long and woolly.

Inhabits Java.

The Bornean Gibbon (H. mülleri, Martii) appears to be closely allied to this species, but the materials at our disposal are not yet sufficient to determine whether the two are specifically identical.

It is, however, noteworthy that two animals corresponding to H. leuciscus and to $H$. mülleri, now living together in the Calcutta gardens, both utter undistin- 
guishably the peculiar "Wow Wow" of the former, both in its slow and in its remarkably rapid, trilling scale.

\section{Hrlobates mülleri, Martin.}

Hylobates concolor, Müller, Verhandl. over de Zool. ind. Archipel, 1841, p. 48; Blyth, Journ. As. Soc. Beng. vol. x. 1841, p. 838; Martin, Nat. Hist. Quadr. 1841, p. 417; Schinz, Syn. Mamm. vol. i. 1844, p. 31 ; 'Temminck, Coup d'œil sur les Possess. Neerland. vol. iii. 1849 p. 403 ; Hist. Nat. des Mammif. 1854, p. 55 (fig. of head); Wagner, Schreber, Säugeth. Suppl. vol. v. 1855, p. 17 (in part).

Hylobates mülleri, Martin, Nat. Hist. Quadr. 1841, p. 444; Temminck, Coup d'œil sur les Possess. Neerland. vól. iii. 1849, p. 403 ; Is. Geoff. St.-Hil. Cat. Méthod des Mammif. 1851, p. 7 ; Arch. du Mus. vol. v. 1852, p. 534; Dahlbom, Stud. Zool. Fam. Reg. An. 1856, pp. 73, 75. Hylobates funereus, Is. Geoff. St.-Hil. Compt. Rend. vol. xxxi. Dec. 1850, p. 874; Cat. Méthod. des Mammif. 1851, p. 7 ; Arch. du Mus. vol. v. 1852, p. 532, pl. xxvi; Gervais, Hist. Nat. des Mammif. 1854, p. 53, figure; Wagner, Schreber, Säugeth. Suppl. vol. v. 1855, p. 18.

This species varies from grey to dark yellowish brown, but the grey in certain lights appears pure ashy, and in others of a brownish tint. In some the chest and abdomen are frequently of a lighter colour than the other parts, and of a brownish yellow, and this seems to be the character of individuals met with on the west coast of Borneo, while those inhabiting the meridional parts of the island have the hands and fore part of the body of a black-brown or reddish brown. In both of these varieties there is a yellowish white supercilium. The last of them leads into the Hylobates from the neighbouring islands of Sulu to the north-east of Borneo, in which case the upper parts of the body are either grey or brownish, the lower part of the back and the loins being a little more clear than the rest. The outer surface of the limbs, the feet, less the toes, the back part of the head, a narrow supraorbital band, and the sides of the face, are paler than the other parts, and generally are ashy grey, more or less pure. The anterior portion of the upper surface of the head and the ventral aspect of the body are more or less brownish black, and the inner aspect of the limbs is of the same tint in the greater part of its extent. The upper surfaces of the hands and the toes are of the same colour, but the blackish brown is markedly mixed with grey. The face and under parts are black and the eyes are brown.

Inhabits Borneo and the neighbouring islands of Sulu.

As has been remarked by Müller, this species is closely allied to H. leuciscus, the general type of colouring being the same in both; and this observation is also applicable to $H$. pileatus, and in a more modified degree to $H$. agilis, all of these Gibbons being characterised by the tendency to form a dark skull-cap, so to speak, and by the colour of the dorsal region to pale on the loins; while in H. mülleri and H. pileatus there is the further disposition for the breast, belly, and inside of the limbs to become darker than the back; but as this is also the character of the lightcoloured females of $\boldsymbol{H}$. hoolock, much specific importance cannot be attached to it. 


\section{Hylobates agilis, F. Cuv.}

The Ounko, F. Cuv. Hist. Nat. des Mammif. June 1824, pls. vii, viii.

Pithecus lar, Geoff. St.-Hil. Ann. du Mus. vol. xix. 1812, p. 88.

Hylobates agilis, F. Cuv. Hist. Nat. des Mammif. Sept. 1821, pls. v, vi ; F. Cuv. Dict. des Sc. Nat. vol. xxxvi. 1825, p. 288 ; Lesson, Man. de Mamm.1827, p. 31; Temm. Monogr. de Mamm. vol. i. 1827, p. 13; Griffith, An. King. vol. v. 1827, p. 7; G. Cuv. Règ. An. nouv. éd. 1829, vol. i. p. 90 ; Yarrell, Zool. Journ. vol. v. 1835, p. 137 ; Müller, Tijdsch. voor Natuur. Gesch. en Phys. vol. ii. 1835, p. 326 ; Waterhouse, Cat. Mamm. Mus. Zool. Soc. Lond. 1838, 2nd ed. p. 3 ; Blyth, Journ. As. Soc. Beng. vol. x. 1841, p. 838 ; vol. xiii. 1844, p. 465 ; vol. xliv. 1875, ex. no. p. 3 ; Cat. Mamm. As. Soc. Mus. 1863, p. 5 ; Martin, Nat. Hist. Quad. 1841, pp. 416, 417, 425 (plate) ; Gray, Hand-list Mamm. B. M. 1843, p. 2 ; Müller und Schlegel, Verhand. 1839-44, p. 48; Cantor, Journ. As. Soc. vol. xv. 1846, p. 173 ; Fry, Proc. Zool. Soc. 1846, p. 11 ; Ann. \& Mag. Nat. Hist. vol. xvii. 1846, p. 484; Is. Geoff. St.-Hil. Cat. Méthod. des Mammif. 1851, p. 7; Gervais, Hist. Nat. des Mammif. 1854, p. 53 (figure); Dahlbom, Stud. Zool. Fam. Reg. An. 1856, pp. 74, 78, pl. iii. fig. 9 (clavicle); Gray, Cat. Monkeys and Lemurs, B. M. 1870, p. 12.

Pithecus agilis, Desmarest, Mamm. 1820, p. 532.1

Simia lar, Raffles, Trans. Linn. Soc. vol. xiii. 1822, p. 242 ; Vigors \& Horsfield, Zool. Journ. vol. iv. 1828-29, p. 106 ; Fischer, Syn. Mamm. 1829 (in part), p. 12.

Bylobates lar, F. Cuv. Hist. Nat. des Mamm. June 1824, pls. 7, 8 ; Dict. des Sc. Nat. vol. xxxvi. 1825, p. 289 ; Lesson, Man. de Mamm. 1827, p. 30; Griffith, An. King. vol. v. 1827, p. 5 ; Bory de St. Vincent, Dict. Class. d'Hist. Nat. vol. xii. 1827, p. 284; Is. Geoff. St.-Hil. Cours de l'Hist. Nat. des Mammif. 1829, p. 33 ; G. Cuv. Règ. An. nouv. éd. vol.i. 1829, p. 90 ; Schlegel, Essai sur la Physion. des Serpens, Pt. Gén. 1837, p. 237.

Hylobates variegatus, Temminck, Monogr. de Mamm. vol. i. 1827, p. xiii ; Müller, Tijdschr. voor Natuur. Gesch. en Phys. vol. ii. 1835, p. 326 ; Wagner, Schreber, Säugeth. Suppl. vol. i. 1840, p. 74; Lesson, Sp. des Mammif. 1840, p. 52; S. Müller, Verhandl. over de Zool. van den Indisch. Arch. 1841, p. 15 ; Müller, Verhandl. 1839-44, p. 47; Horsfield, Cat. Mamm. E. Ind. Co. Mus. 1851, p. 3; Wagner, Schreber, Säugeth. Suppl. vol. v. 1855, p. 16.

Hylobates rafflei, Geoff. St.-Hil. Cours de l'Hist. Nat. des Mammif. 1829, p. 34; Zool. du Voyage de Bélanger, 1834, p. 28 ; Compt. Rend. vol. xv. 1842, p. 716 ; Arch. du Mus. vol. ii. 1843, p. 535 ; Müller, Tijdschr. voor Natuur. Gesch. en Phys. vol. ii. 1835, p. 326 ; Müll. und Schlegel, Verhandl. 1839-44, p. 48; Wagner, Schreber, Säugreth. Suppl. vol. i. 1840, p 73.

Hylobates unko, Lesson (in part) Sp. des Mammif. 1840, p. 53.

Hylobates rafflesii, Is. Geoff. St.-Hil. Cat. Méthod. des Mammif. 1851, p. 8 ; Gervais, Hist. Nat. des Mammif. 1854, p. 53 (fig. of head); Dahlbom, Stud. Zool. Fam. Reg. An. 1856, pp. 74, 80; Gray, Cat. Monkeys and Lemurs, B. M. 1870, p. 11.

The occiput, the back from immediately behind the shoulders, the flanks, the hips, and the outer surfaces of the fore and hind limbs, pale yellow. The shoulders, chest, and belly, and the inside of the limbs and feet, dark brown. The eyebrows and whiskers pale greyish. A few reddish hairs in the region of the genitalia.

Animals presenting the foregoing characters constitute the "Ungka puti," or H. agilis, F. Cuv.; but the Gibbons which are distinguished by the following particulars, and which are known to the natives as "Ungka etam" (H. rafflesii, Geoff.), appear to be only a dark variety of $H$. agilis.

The type of this variety, which I have carefully compared with that of $H$. agilis,

1 From the circumstance that Desmarest quotes F. Cuvier as the first zoologist to recognise this species, it is evident that the "Mammologie," although dated 1820, did not appear before September 1821. 
is wholly black, with the exception of a white streak over the eyes and the cheeks, which are ashy grey; but in another example in the Paris Museum, also regarded as a type, the ashy grey of the cheeks is absent, and the supraorbital pale line is reduced to a mere trace.

In this species, as in $H$. lar, the index and middle toes of the hind feet are occasionally united by a web.

Inhabits Sumatra.

\section{Hrlobates (Siajianga) syndactrlus, Raffles.}

Simia Gibbon, C. Miller, Phil. Trans. vol. xiv. (abridged ed.) 1778, p. 318.

Pithecus syndactylus, Desmarest, Mamm. 1820, p. 531 ; Lesson, Man. de Mamm. 1827, p. 30.

Hylobates syndactylus, F. Cuv. Hist. Nat. des Mammif. var. 1821, pl. iv.; Dict. des Sc. Nat. vol. xxxvi. 1825, p. 287; Griffith, An. King. vol. v. (1827) p. 6; Bory de St. Vincent, Dict. Class. d'Hist. Nat. vol. xii. 1827, p. 283 ; G. Cuv. Reg. An. nouv. éd. vol. i. 1829, p. 90 ; Is. Geoff. St.-Hil. Voy, aux Indes Orient. Bélanger, 1834, Zool. p. 30 ; Cat. Méthod. des Mamm. 1851, p. 9 ; G. Bennett, Wanderings in New South Wales, 1834, vol. ii. p. 151; Müller, Tijdschr. voor Natuur. Gesch. en Phys. vol. ii. 1835, p. 324; Schlegel, Essai sur la Phys. des Serpens, Pt. Gén. 1837, p. 236 ; Waterhouse, Cat. Mus. Zool. Soc. Lond. 1838, p. 4; Wagner, Schreber, Säugeth. Suppl. vol. i. 1840, p. 69, Suppl. vol. v. 1855, p. 15 ; Lesson, Sp. des Mammif. 1840, p. 50; Is. Geoff. St.-Hil. Arch. du Mus. vol. ii. 1841, p. 535 ; Comptes Rendus, vol. xv 1842, p. 717 ; Martin, Hist. of Quadr. (Monkeys) 1841, p. 420 (plate) ; S. Müller (und Schlegel), Verhandel. over de Zool. 1839-44, p. 15 ; Sandifort, Müller und Schlegel, Verhandl. 1839-44, pp. 31, 33, pl. ii. figs. 3-5 (brain) pl. vii. figs. 1-3 (larynx \& sac) ; Blyth, Journ. As. Soc. Beng. vol. xiii. 1844, pp. 463, 474; vol. xliv. ex. no. 1875, p. 3 ; Schinz, Syn. Mamm. vol.i. 1844, p. 28; Gervais, Hist. Nat. des Mammif. 1854, p. 51, figure; Flower, Nat. Hist. Review, 1863, p. 279 (plate); Giebel, Zeitsch. ges. Ntrwiss. 1866, p. 186.

Simia syndactytus, Raffles, Trans. Linn. Soc. vol. xiii. 1822, p. 241 ; Horsfield, Zool. Res. in Java, 1824, plate; Fischer, Syn. Mamm. 1829, p. 11 ; Helfer, Journ. As. Soc. Beng. vol. vii. 1838, p. 858.

Siamanga syndactyla, Gray, Cat. Mamm. B. M. 1843, p. 1; Cat. Monkeys and Lemurs, B. M. 1870, p. 9 ; Horsfield, Cat. Mamm. E. Ind. Co. Mus. 1851, p. 1; Dahlbom, Stud. Zool. Fam. Reg. An. 1856, p. 71.

Body more robust than in Hylobates hoolock : pelage deep, woolly, black, with no pale supercilium, nor white around the face. A bare area on the throat corresponding to the position of a large dilatable laryngeal sac. The index and middle toes of the foot united to the last phalange.

Inhabits the Island of Sumatra; the Malayan peninsula (Wallace); Tenasserim (Helfer).

The skull of H. syndactylus is distinguished from the skull of the other Hylobates by the greater forward projection of its supraorbital ridges and by its much deeper face. It is also the largest skull of the genus. The occipital region appears to be more abruptly truncated than in the other species, but the brain cavity does not seem to be relatively broader than in the shorter and smaller skulls of H. hoolock and H. lar. The skulls of all Hylobates are more or less depressed, but the truncation of the central portion is more distinctive of $H$. syndactylus than of the other species. 
(Doubtful species.)

Hrlobates fuscus, Winslow Lewis.

Hylobates fuscus, Winslow Lewis, Boston Journal, Nat. Hist. vol. i. Pt. i. May 1834, p. 32 ; pls. i. and ii. (skeleton and skull).

General colour, dirty brown. Face and hands black.

Such is the brief description of this animal, a male and female of which were purchased in Calcutta from the menagerie of a Rajah, who stated that he had obtained them from the vicinity of the Himalaya.

The animal from which the above description was taken was an adult female with mature dentition.

'I'he upper canines were enormously projecting, extending nearly to the mental foramina when the jaws were closed; the inferior canines projecting upwards as far as the alveolar processes of the upper jaw.

The vertebral formula was C. $7:$ D. $13:$ L. $5:$ S. $3:$ C. $1:=29$.

The sternum had three pieces and there were six false ribs.

From the locality assigned to this species, we would have looked for the characters of $H$. hoolock, but among the very many examples of the latter species which have passed under my notice, I have never met with any in which the characteristic white supercilium was absent.

On the other hand, the description of $H$. fuscus suggests that it may be a brownish example of the wholly black Gibbon from Borneo, which was described by Dr. Harlan as $H$. concolor, but from a hermaphrodite individual, and which appears to have been a very different animal from the $H$. concolor, Müller, which was afterwards named $H$. mülleri by Martin.

I attach no importance whatever to the locality assigned to this Gibbon, because my experience of Rajahs" menageries in Calcutta has taught me that the owners have no means of ascertaining with any degree of accuracy the localities from whence their specimens are obtained.

\section{Hylobates concolor, Harlan.}

Simia concolor, Harlan, Journ. Acad. Nat. Sc. Philad. 1827, vol. v. pl. ii. p. 229.

Hylobates concolur, Schlegel, Essai sur la Physion. des Serpens, Pt. Génl. 1837, p. 237; Wagner, Schreber, Säugeth. Suppl. vol. i. 1840, p. 79 ; vol. v. 1855, p. 17 (in part); Blyth. Journ. As. Soc. Bengal, vol. x. 184I, p. 838; Fry, Proc. Zool. Soc. 1846, p. 15 ; Ann. and Mag. Nat. Hist. vol. xvii. 1846, p. 487.

Hylobates harlani, Lesson, Bull. des Sc. Nat. (Terrusac) vol. xiii. 1827, p. 111.

This Gibbon was a hermaphrodite from the Island of Borneo, described as having the fur full, crisp, and universally black. Considering the abnormal construction of this animal, it must be left to future research to determine whether or not such a species exists in Borneo distinct from H. mülleri, Martin. 


\section{Genus Semnopithects, F. Cuv. ${ }^{1}$}

* Semnopithecus Barbei, Blyth.

? Semnopithecus maurus, Helfer, Journ. As. Soc. Bengal, vol. xii. 1843, p. 358.

Presbytis Barbei, Blyth, Journ. As. Soc. Bengal, vol. xvi. 1847, p. 734; vol. xliv. 1875, ex. no. p. 11 ; Cat. Mamm. As. Soc. Mus. 1863, p. 14.

This species has no crest, nor is the hair so elongated on the occiput as in S. obscurus, Reid, but the hair on the side of the head, before the ears, is long and outwardly projecting. The adults of both sexes are alike in colour, and the general hue is dark blackish-fuliginous, but the shoulders, fore-limbs, exclusive of the hands, the front of the tibial portions of the hind limbs, the back and sides of the head and the tail, are feebly washed with silvery grey over the dark fur. The hands, feet, eyebrows, and whiskers are black. The under parts are concolorous with the general tint of the body. There is no trace of a white stripe on the inside of the limbs. The hair on the vertex is moderately long and directed backwards; on the lips there is a narrow fringe of short yellowish hairs, and there is a short beard. The skin of the face is bluish black.

Length of body 1 foot $7 \frac{1}{2}$ inches, tail 2 feet 5 inches.

The skull of $S$. barbei has the comparatively elongated interorbital region of S. obscurus, but its nasals are very much broader and form a considerable suture with the frontal, and the facial portion of the skull is also less forwardly projected than in that species. The orbits in both of these species are more or less rounded, while in $S$. siamensis they are transversely broader than high, and contracted towards their inner side and associated with a short interorbital septum.

There is a very close similarity between the under surfaces of the skulls of S. obscurus and $S$. barbei, but the latter is distinguished by a much shorter palate and by a somewhat more curved dental line than in S. obscurus.

The teeth of $S$. barbei are somewhat smaller than in $S$. obscurus. The last molar of the lower jaw of $S$. barbei and $S$. obscurus has a well-developed fifth talon, as in the majority of the Semnopitheci.

The symphysis of the lower jaw of $S . b a r b e i$ is not so deep as in $S$. obscurus, but it is much broader in front and more flattened than in $S$. obscurus.

1 The genera Semnopithecus and Presbytis were both created in 1821, the first by F. Cuvier (Hist. Nat. des Mammif. vol. ii. Juillet 1821) for the reception of $S$. melalophus and $S$. entellus, which, like the majority of their allies, are distinguished by having three tubercles or cusps on the last inferior molar, while the second, Presbytis, was founded by Eschscholtz on S. mitratus, which has only four tubercles on the last inferior molar. Mivart, ${ }^{2}$ however, has recently shown that certain individuals of $S$. siamensis agree with $S$. mitratus in the absence of the fifth talon, and that much importance cannot be attached to its absence or presence, as we find Gallago (Otogale) pallida, Gray, subject to a similar variation, and also Nycticibus juvanicus, Is. Geoff., as recorded by Huxley. ${ }^{3}$ The circumstance, therefore, that the genus Semnopithecus more accurately portrays the general characters of the group than Presbytis, and the fact that it has been adopted by the great majority of naturalists, in preference to the latter term, are the reasons which lead me to adopt it. 
An adult female (type) skull, when compared with a male skull with the dentition perfect, presents these characters; it is considerably larger and has the interorbital region much more vertical. I observe that in S. obscurus, a female of that species is also distinguished from the male skull not only by amore vertical but by a longer and narrower interorbital region. Indeed, the differences that exist in these respects between the skulls of well-authenticated examples of the two sexes are greater than are generally found to exist between the same sexes of different species!

Taking the characters of this form as a whole, there can be no doubt that its nearest ally is $S$. obscurus. In his original description of the species, Blyth stated that his types were from the province of Ye in Tenasserim, but in his catalogue of mammals ${ }^{1}$ he afterwards assigned them to the Tippera hills on the authority of the Reverend Mr. Barbe, the original discoverer of this monkey.

I observed this species in 1868 in the valley of the Tapeng in the centre of the Kakhyen hills, in troops of about thirty to fifty monkeys, usually distributed over three or four high forest trees overhanging the mountain streams that debouch into the Tapeng. Being seldom disturbed they permitted a near approach.

In the defile of the Irawady above Mandalay on the left bank of the river this species is also met with in the patches of thick forest which occur in that locality.

\section{* Semnopithecus Pileatus, Blyth.}

The Assam entellus monkey, Blyth, Journ. As. Soc. vol. xvi. 1847, p. 732.

Semnopithecus pileatus, Blyth, Journ. As. Soc. Bengal, vol. xii. 1843, p. 174; Ibid, vol. xiii. 1844, pp. 467, 476 ; Horsfield, Cat. Mam. E. Ind. Co. Mus. 1857, p. 7; Wagner, Schreber, Säugeth. Suppl. vol. v. 1855, p. 30 ; Hutton, Proc. Zool. Soc. 1867, pp. $946,950$.

Presbytis pileatus, Blyth, Journ. As. Soc. Bengal, vol. xvi. 1847, pp. 735, 1271, pl. xxvi. fig. 3; vol. xliv. 1875, ex. no. p. 11 ; Cat. Mamm. As. Soc. Mus. 1863, p. 12.

Presbytis chrysogaster, Licht. Peters, Proc. Zool. Soc. 1866, p. 429.

Semnopithecus potenziani, Pr. Bonap. Comptes Rendus, vol. xliii. 1856, p. 412.

A black-faced crestless monkey, somewhat smaller than S. entellus. Long, black supraciliary hairs outwardly divergent. Hairs on the vertex not elongated, but somewhat longer than those on the occiput and temples, which they impend and produce a capped appearance. The whiskers before the ears long and outwardly divergent and liding the lower half of these organs, and continued down the sides of the cheek to the chin as a short but distinct ruff. The upper surface of the bead dark ashy grey, tending to black, and contrasting with the reddishyellow whiskers and beard, but more or less tinged with ferruginous, which is vccasionally rather well marked on the front of the forehead. The rest of the upper parts, including the neck, the upper half of the brachium, and the lower half of the limb below the elbow, the outside of the thighs, and the whole of the tail dark

$$
{ }^{1} \text { L. .., p. 14, }
$$


ashy grey, passing into black on the extremity of the tail, which is tufted. The fingers are dark, almost blackish, and the distal half of the foot is almost wholly black, especially the toes: the whole of these parts, with the exception of the hands and feet, although ashy grey, has a slight ferruginous tinge in the fully mature animal: the remainder of the limbs is more or less ferruginous or yellowish grey, palest on the lower portion of the hind limb. The throat and the whole of the chest and upper part of the belly rich orange or golden-yellow, paling to yellowish on the rest of the under parts and on the inside of the limbs. Tail about one-third longer than the body.

The skull of $S$. pileatus is considerably smaller than that of S. entellus, but is about the same size as the skull of $S$. priamus. Unlike the Indian Semnotes, it has the supraorbital ridges only moderately developed and the lambdoidal ridge but feebly prominent. The brain-case is more globular than in the other species owing to the absence of the last-mentioned character. The facial portion slopes considerably forwards, as in S. schistaceus, and, like that species, the nasal bones are straight, but flattened, so that they project but little anterior to the orbits. The face has thus a much-flattened aspect in life. The muzzle is moderately long and broad. The teeth are about the same size as in $S$. priamus; and, as in Semnopitheci generally, the teeth of the female are considerably smaller than those of the male, and the palate in that sex is somewhat shorter than in the male. In the latter it is moderately deep with the alveolar borders slightly posteriorly convergent. The posterior palatine foramen is compressed.

In a male that had been kept in confinement from youth to maturity the maxillary series of teeth occupies a space measuring $1 \cdot 50$, whereas in a ferine male the teeth are somewhat smaller, occupying an area of only 1.30 inch, the palate being deeper and shorter than in the former individual. Although the ferine male is older than the domesticated individual, its supraorbital ridges are less developed. The breadth across the fronto-malar suture equals the distance between the anterior border of the foramen magnum to the outer margin of the premaxillary foramen, and the greatest zygomatic breadth falls short of that interval half the length of the premaxillary foramen.

This is a common monkey in Northern Assam, from whence it ranges south to 'Tippera, and through Arracan and Upper Burma to Tenasserim. The type of S. potenziani came from Tenasserim, but Blyth's S. pileatus was a halfgrown specimen in the Barrackpore menagerie near Calcutta, and alleged to be of Malayan origin. It is now, however, well ascertained that this monkey is not at all uncommon in Tippera and Assam, and I am therefore disposed to think that the locality originally assigned to $S$. pileatus was erroneous, and that the animal came either from Tippera or Assam. In this respect it would be analogous to the case of $M$. speciosus (arctoides) also described from a Barrackpore specimen said to have been brought from Japan, but probably procured in the same region as $S$, pileatus. I observed a troop of this species at Tsingu Myo 
on the left bank of the Irawady at the entrance or lower end of the first defile. The young are much paler than the adults, and are a soft delicate grey, the areas which are ferruginous or orange-yellow in the mature animal being albescent or only slightly fulvous. The fur is soft, silky, and rather long; and the tail is tufted, and in the young is almost grey.

A specimen which I had alive for some time, and which was caught in Northern Assam; was, like young Semnopitheci generally, of a mild disposition. This, however, is not the character of these animals in the adult state, for their tempers become unreliable, and the males when irritated are very fierce and determined in attack.

This species in the general distribution of its colouring and in the strong projecting supraorbital ridge of hairs more closely resembles S. entellus and its near allies than any of the other Semnopitheci.

Having had the opportunity to examine nearly all the types of the different species of Semnopithecus, I subjoin the results of my observations.

\section{Semnopithecus entelitus, Dufresne.}

L'entelle, Audebert, Hist. Nat. des Singes, 1797, Fam. iv. sec. ii. fig. 2; Latr. Hist. Nat. de Buffon (Sonnini) vol. xxxvi. (1809), p. 85, pl. lvi.

Simia entellus, Dufresne, Bull. Soc. Philom. vol. i. 1797, p. 49 ; Mag. Encyclop. vol. iv. 1797 ; F. Cuv. Dict. des Sc. Nat. vol. xx. 1821, p. 33.

Cercopithecus entellus, Latr. Hist. Nat. de Buffon, vol. xxxvi. (Sonnini ed.) 1809, p. 283 ; Nouv. Dict. d’Hist. Nat. vol. xv. 1817, p. 581 ; Kuhl. Beitr. zu Zool. 1820, p. 12 ; Desmarest, Mamm. 1820, p. 59.

Semnopithecus entellus, Desmoulins, Dict. Class d'Hist. Nat. vol. vii. (1825), p. 568; Lesson, Man. de Mamm. 1827, p. 40 ; Griffith, An. King. vol. v. 1827, p. 10 ; Cuv. Règ. An. nouv. éd. vol. i. 1829, p. 94; Fischer, Syn. Mamm. 1829, p. 14; E. T. Bennett, Garden and Monog. Zool. Soc. vol. i. 1831, p. 81 ; Sykes, Proc. Zool. Soc. 1831, p. 199 ; Owen, Proc. Zool. Soc. 1833, p. 75 ; Is. Geoff. St.-Hil. Zool. Voy. de Bélanger, 1834, p. 38 ; Waterhouse, Cat. Mamm. Mus. Zool. Soc. Lond. 1838 (second ed.), p. 4; Martin, Charlesworth's Mag. Nat. Hist. new ser. vol. ii. 1838, p. 435 ; Elliot, Madr. Journ. Lit. and Sc. vol. x. 1839, p. 95 ; Nat. Hist. Monkeys, 1841, p. 461; Wagner, Schreber, Säugeth. Suppl. vol. i. 1840, p. 99, pl. xxiii. B ; Suppl. vol. v. 1855, p. 32 ; Lesson, Sp. des Mammif. 1840, p. 56 ; Martin, Nat. Hist. Quadr. 1841, p. 461 (plate); Blyth, Journ. As. Soc. vol. xii. 1843, pp. 169, 172 ; vol. xiii. 1844, pp. 470, 476; Müller und Schlegel, Verhandl. 1839, pp. 44, 59; Schinz, Syn. Mamm. vol. i. 1840, p. 42 ; Is. Geoff. St.-Hil. Cat. Méthod. des Mammif. 1851, p. 13 ; Arch. du Mus. vol. v. 1852, pp. 537, 538; Horsf. Cat. Mamm. E. Ind. Co. Mus. 1851, p. 4; Gervais, Hist. Nat. des Mammif. 1854, p. 60 ; Dahlbom, Stud. Zool. Fam. Reg. An. 1856, pp. 87, 89; Beyrich, Abhandl. der Berl. Akad. der Wiss. 1860, p. 7; Roy. Lankester Quart. Journ. Sc. 1865, p. 562; Hutton, Proc. Znol. Soc. 1867, p. 944; Gray, Cat. Monkeys and Lemurs, B. M. 1870, p. 14, var. 1; A. M.-Edwards, Arch. des Mammif. 1868-74, p. 242 .

Presbytis entellus, Gray, Hand-list, B. M. 1843; p. 4 (in part) ; Blyth, Journ. As. Soc, vol. xvi. (1847), p. 732; Ann. and Mag. Nat. Hist. vol. xx. (1851), p. 313 ; Cat. Mamm. Mus. As. Soc. Bengal, 1863, p. 11 ; Jerdon, Mamm. Ind. 1867, p. 4.

Semnopithecus albogularis, Müller und Schlegel, Verhandl. 1839-44, p. 58. 
Presbytis anchises, Elliot, Blyth, Journ. As. Soc. vol. xiii. 1844, pp. 470, 476 ; Ibid, vol. xvi. 1847, p. 733 ; Ann. \& Mag. Nat. Hist. vol. xx. 1851, p. 313 ; Horsfield, Cat. Mamm. E. Ind. Co. Mus. 1851, p. 14; Wagner, Schreber, Säugeth. Suppl. vol. v. 1855, p. 32.

General colour of the body pale yellow, washed with ashy grey or brownish on the nape and back, and with a darker tint of the same colour on the shoulders and the outside of the limbs. A strong line of black supraorbital hairs, as in all its Indian allies: no crest. Hands and feet and their under surfaces and the skin of the face and ears black. The tail is concolorous with the back, but paling towards its tip : it is about one-fourth longer than the body.

This form is most nearly allied to S. schistaceus, but I have observed individuals which in their bright colours approached closely to the allied form occurring in Assam, viz. S. pileatus. A consideration of the types of S. schistaceus, S. pileatus, $S$. hypoleucus, and $S$. priamus, in conjunction with a large series of $S$. entellus, leads me to believe that in the following synopsis of the group we have the species arranged according to their affinities. I have examined the entelloid monkeys which Colonel Sykes obtained in the Deccan, and which I do not consider to differ specifically from this species. Sir Walter Elliot was inclined to regard the entelloid monkey from Southern and Central India as belonging to a distinct form which he named $S$. anchises, and an example of which in the shape of a skin was sent to Blyth at Calcutta, who considered it to be S. entellus. Unfortunately this skin no longer exists in the Indian Museum, and there are no materials at present available for the settlement of this point; but having every reliance on Blyth's judgment in such a matter, I accept his views regarding $S$. anchises.

The characters of the skull of this species I enumerate under S. schistaceus.

This species appears to range from the Deccan northwards to the right bank of the Ganges, but what are the limits of its distribution to the west and north-west is not accurately known, but it reaches to the seaboard to the east, and in the Himalayas is replaced by S. schistaceus, to the south-east by $S$. hypoleucus, and to the south-west by S.priamus. In Assam it is represented by S. pileatus.

The food of the entelloid monkey appears to consist very largely of the leaves of forest trees.

\section{Semnopithecus schistaceus, Hodgson.}

The Langâr, Hodgson, Journ. As. Soc. 1832, vol. i. p. 339.

The Long-tailed Monkey, Pemberton, Journ. As. Soc. Beng. vol. viii. 1839, p. 722.

The Masuri Langâr, Hutton, Journ. As. Soc. Beng. vol. xiii. 1844, p. 471.

Semnopithecus entellus, Hodgson, Proc. Zool. Soc. 1834, p. 95 ; Oggilby, Madr. Journ. Lit. and Sc. vol. xii. 1840 , p. 144 .

Semnopithecus schistacens, Hodgson, Journ. As. Soc. Beng. vol. ix. 1840, p. 1212; vol. x. 1841, p. 907 ; Cal. Journ. Nat. Hist. vol. ii. 1842, p. 212 ; vol. iv. 1844, p. 285 ; Ann. and Mag. Nat. Hist. vol. viii. 1842, p. 314; Blyth, Journ. As. Soc. Beng. vol. xii. 1843, pp. 171, 172; vol: xiii. 1844, p. 4.71; I6id, p. 476 ; Horsfd. Cat. Mamm. E. Ind. Co. Mus. 1851, p. 5 ; Wagner, Schreber, Säugeth. Suppl. vol. v. 1855, p. 33 ; Schlagenw. Proc. As. Soc. Beng. 1866, p. 23 ; Hutton, Proc. Zool. Soc. 1867, p. 948. 
Semnopithecus nepalensis, Hodgson, Journ. As. Soc. Beng. vol. ix. 1840, p. 1212; Cal. Journ. Nat. Hist. vol. ii. 1842, p. 212.

Presbytis entellus, Gray, Cat. Hodgson, Nepal Mamm. \&c. 1846, p. 1, var. 2 ; Cat. Monkeys and Lemurs, B. M. 1870, pp. 14, 15 .

Presbytis schistaceus, Blyth, Ann. and Mag. Nat. Hist. vol. xx. 1851, p. 313 ; Cat. Mamm. As. Soc. Mus. 1863, p. 11 ; Jerdon, Mamm. India, 1867, p. 6; Blanford, Journ. As. Soc. Beng. vol. xli. 1872, p. 32 .

General colour of the upper parts, except the head, dark slaty, darkest on the outside of the fore-limbs; dark on the thighs, but paling towards the ankle; hands and feet concolorous with the limbs. Head pale yellow, nearly white; chin, throat, chest, and under parts and inside of limbs yellowish. The tail is concolorous with the back, darkening towards its tip. The ears, palms, and soles are black. The fur long, wavy, and profuse.

In old individuals the general colour is paler, inclining to grey and even to white on the head, while in the young and adolescents the feet are occasionally darker than in adults.

Hab.-Bhutan, to the north-west Himalaya, west of Simla, at elevations from 4,000 to 13,000 feet.

The skulls of S. entellus and S. schistaceus present certain features by which they can be separated the one from the other, and the differences that exist between them are greater than those which subsist between $S$. entellus and S. priamus. The skull of $S$. schistaceus is somewhat larger than that of $S$. entellus. The supraorbital ridge of $S$. schistaceus does not form so thick and wide a pent roof as it does in $S$. entellus, and it is less forwardly projected. But the most marked distinction is to be observed in the much longer facial portion of the skull of S. schistaceus, $i_{. e}$., in the interspace existing between the middle of the supraorbital ridge to the extremity (alveolar) of the premaxillaries, an interval which is considerably longer than in S. entellus. When the skulls of the two forms are placed in natural position, it is observed that the supraorbital ridges of S. entellus are projected more anteriorly to the lower margin of the orbit than in S. schistaceus. This character is brought out when a line is produced from the middle of the supraorbital ridge to the tip of the premaxillaries. In S. entellus the line rests against the supraorbital margin, and may either touch or not touch the distal ends of the nasals and the extremities of the premaxillaries, thus including two well-marked concavities, one the fronto-nasal and the other the naso-premaxillary, the latter being the larger and the best defined of the two concavities. In $S$. schistaceus the line does not touch the extremity of the premaxillaries, but owing to the almost straightforward projection of the nasals passes a long way anterior to the alveolar margin of the premaxillaries, and if it were not that the supraorbital ridge is swollen, the line would be almost wholly in contact with the nasals. This forward projection of these bones gives rise to a much greater breadth of the maxillæ, between the inner border of the orbit and the nasal portion of the premaxillary, than occurs in S. entellus. The external nasal orifice, owing to the forward projection of the facial bones to a much greater 
extent than prevails in S. entellus, is much longer than in that species, and the depth of the face from the distal extremity of the nasals to the alveolar border is much greater. The premaxillaries also are more anteriorly rounded and produced than in S. entellus, thus conferring greater length on the muzzle. Associated with the shorter muzzle of $S$. entellus and its more downwardly compressed face is a considerable concavity immediately below the orbit, at the base of the muzzle, external to the maxillo-malar suture, but little marked in S. schistaceus. The transverse breadth of the face is proportionally greater than in S. schistaceus, which is also true of the zygomatic breadth, so that the head of $S$. entellus is more rounded than in the mountain species. The palate of $S$. schistaceus is relatively narrower and deeper, and its alveolar borders are more parallel. The teeth of $S$. schistaceus are somewhat larger than in S. entellus, and the palate, therefore, is somewhat longer. The petrous bones, also, are not so prominent in the former as in the latter. The symphysis of the lower jaw is considerably longer and broader than in $S$. entellus, and the lower jaw itself is generally more massive and deep.

\section{Semnopithecus albipes, Is. Geoff. St.-Hil.}

Semnopithecus albipes, Is. Geoff. Cat. Méthod. des Mammif. 1851, p. 14; Arch. du Mus. vol. v. 1852, p. 536 ; Gervais, Hist. Nat. des Mammif. 1854, p. 61 ; Wagner, Schreber, Säugeth. Suppl. vol. v. 1855, p. 34; Dahlbom, Stud. Fam. Reg. An. 1856, pp. 87, 89.

The animal is brownish grey on the body, and more or less yellowish on the head: the anterior extremities are tawny grey and the hind limbs sullied white, the tail is greyish or brownish, and the under parts of the body are whitish. The face is black, the hair on the head towards the occiput is raised into a kind of short tuft, which is prolonged backwards to near the nape as a small median crest, but it is possible that this may be artificially produced.

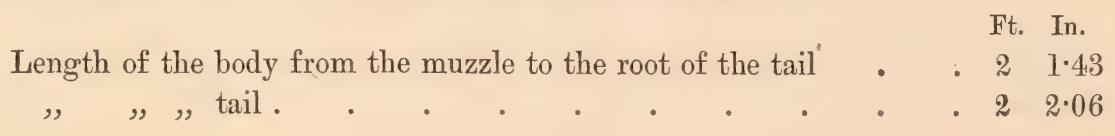

This species, the types of which I have examined in Paris, has all the characters of the entelloid group of Semnopitheci, and notwithstanding its wide separation geographically from the race of $S$. entellus which has been designated S. priamus and afterwards S. pallipes by Blyth, it is most closely allied to it, - so much so that Gray has regarded the latter as synonymous with S. albipes, but Is. Geoff. St.-Hilaire has distinctly stated that this species is peculiar to Manilla. In its rudimentary crest he saw in it an affinity to the crested Malayan species, but I agree with A. M.-Edwards that Is. Geoff. St.-Hilaire attached too much importance to the radiation of the hair on the vertex. Had it not been distinctly stated that $S$. albipes is an inhabitant of Manilla, I should have followed Dr. Gray's example and regarded the two as identical. 


\section{Semnopithecus priamus, Elliot.}

Semnopithecus prian, Elliot, Blyth, Journ. As. Soc. Beng. vol. xiii. (1844), pp. 470, 476.

Semnopithecus pallipes, Blyth, Ann. \& Mag. Nat. Hist. 1844, p. 312.

Presbytis priamus, Blyth, Journ. As. Soc. Beng. vol. xvi. 1847, p. 732, pl. liv. fig. 1 ; Ibid, p. 1271 ; vol. xx. 1851, p. 313 ; Ann. \& Mag. Nat. Hist. vol. i. new ser. 1848, p. 454; Cat. Mamm. As. Soc. Mus. 1863, p. 12 ; Horsfield, Cat. Mamm. E. Ind. Soc.'s Mus. 1851, p. 5 ; Kelaart, Fauna Zeylanica, 1852, p. 3 ; Wagner, Schreber, Säugeth. Suppl. vol. v. (1855), p. 33 ; Sir E. Tennent, Nat. Hist. of Ceylon, 1861, p. 5, fig. 2, not fig. 3; Jerdon, Mamm. Ind. 1867, p. 7.

Presbytis thersites, Elliot, Blyth, Journ. As. Soc. Beng. vol. xvi. 1847, p. 1271, pl. liv. fig. 3 ; Horsfield, Cat. Mamm. E. Ind. Co. Mus. 1851, p. 14; Kelaart, Prod. Faun. Zeylan. 1852, p. 5 ; Wagner, Schreber, Säugeth. Suppl. vol. v. 1855, p. 34; Tennent, Ceylon, Hist. of, 1860, p. 132, plate, fig. 1, not fig. 2 ; Hutton, Proc. Zool. Soc. 1867, p. 949.

Semnopithecus albipes, Gray, Cat. Monkeys and Lemurs, B. M. 1870, p. 15.

Pale ashy grey on the upper parts, darkest on the back. The sides of the head, nape, lower half of the thigh, and the hands and feet yellowish. The outside of the fore-limb and the remainder of the thigh are pale ashy like the trunk. The under parts and the inside of the limbs are yellowish. The tail is concolorous with the back, but paler towards its somewhat tufted extremity. The face, ears, and under surface of the feet black.

Such are the characters of specimens from the Coromandel Coast.

Those from Ceylon are much darker, being of a pale vinaceous brown on the upper parts, except on the sides and front of the head, and on the nape and back of thighs which are yellowish. The vertex, the outside of the limbs, and the tail are also vinaceous brown. The under parts and the inside of the limbs are yellowish.

Blyth described S. priamus as having a compressed, high, vertical crest, but as one of the specimens in the Indian Museum referred by Blyth to $S$. priamus shows no sign of a crest, and as Blyth states that this individual did not possess a crest in life, I removed the skulls of the two types of $S$. priamus (No. $30 \mathrm{~A} \& \mathrm{~B}$ of Blyth's Cat. of Mamm.), and in A, which has a short erect crest, I found that the skin on the vertex had been cut open and cotton-wool introduced between the skull and the skin, and that where the cotton-wool was, there the crest existed. In the other specimen, $B$, the short crest occurred exactly over the point of a wire which perforated the skull and pressed against the skin. Therefore, until the crest has been observed in the living animal, I am inclined to believe that it had been produced in these stuffed specimens by the bad preparation of the skins in mounting them.

The type of $S$. thersites was from Ceylon, and does not differ in any essentials from the Ceylon individual referred by Blyth to S. priamus.

The skull of $S$. priamus in its adult condition is considerably smaller than that of $S$. entellus; the vertical depth of its face is relatively. less than in that species, while, on the other hand, it is proportionately broader across the orbits. 
Its fronto-nasal depth also is less than in $S$. entellus, the nasals being short and broad, and the nasal opening considerably shorter than in that species. A line drawn through the centre of the face, from the alveolar border of the premaxillaries to the supraorbital ridge, does not touch the distal ends of the nasals, these bones being rather flattened and broad and slightly concave. These differences in the details of the configuration must confer on $S$. priamus a very different visage from that of $S$. entellus. There is not much difference in the teeth of the two forms, but in $S$. priamus they are relatively larger than in $S$. entellus, except the canines, which are smaller. The palate has the general characters of that of $S$. entellus, and, like it, is of variable depth. The differences in the relative sizes of these two skulls are indicated in the following measurements :-

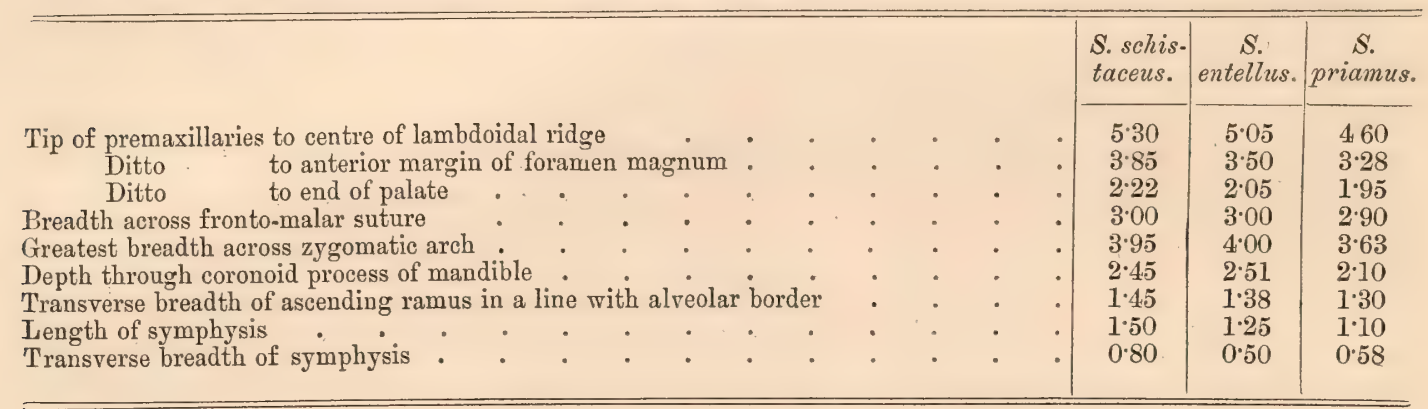

From the foregoing measurements it will be observed that the lower jaw of S. schistaceus is characterised by great depth and breadth of symphysis, and that $S$. priamus resembles it in having a symphysis relatively broader than S. entellus.

This species inhabits the Eastern Ghâts of India, and Northern Ceylon.

\section{Semropithecus Hypoleucus, Blyth.}

Semnopithecus hypolencus, Blyth, Journ. As. Soc. Beng. vol. x. 184l, p. 839; vol. xii. 1843, pp. 170, 172 ; vol. xiii. 1844, pp. 470, 476 ; vol. xvi. 1847, p. 733, pl. xxvi. fig. 1, and p. 1271 ; Ann. \& Mag. Nat. Hist. vol. xx. 1851, p. 313; Horsfield, Cat. Mamm. E. Ind. Co. Mus. 1851, p. 14; Wagner, Schreber, Säugeth. Suppl. vol. v. 1855, p. 31.

Semnopithecus johnii, var. Martin, Nat. Hist. Quad. 1841, p. 489 ; Gray, Cat. Monkeys and Lemurs, 1870 , p. 14 .

Semnopithecus dussumieri, Is. Geoff. St.-Hil. Comptes Rendus, 1842, vol. xv. p. 719 ; Arch. du. Mus. vol. ii. 1843, p. 538, pl. xxx. ; vol. v. 1852, p. 537 ; Cat. Méthod des Mammif. 1851, p. 13 ; Gervais, Hist. Nat. des Mammif. 1854, p. 61, pl. iv.; Dahlbom, Stud. Zool. Fam. Reg. An. 1856, pp. 87, 89 .

Presbytis johnii, Blyth, Journ. As. Soc. Beng. vol. xxviii. 1859, p. 283 ; Cat. Mam. As. Soc. Mus. 1863, p. 12 ; Jerdon, Mam. Ind. 1867, p. 7.

Brown from the shoulders to the root of the tail, darkest on the middle of the back, paler on the sides and the posterior half of the outside of the thighs. Antibrachium, front of the thighs and lower half of leg black, and light brownish on the front of the tibia; hands and feet black. Head, throat, under parts, and inside of brachium and thighs yellow, and especially bright on the chest and belly. Tail 
black, brownish towards its tip. Hair of head semi-erect and backwardly directed. A few black hairs before the ears, which, like the face and under surface of hands and feet, are black.

The skull of $S$. hypoleucus has the general features of $S$. priamus, but it is smaller and characterised by much less prominent supraorbital ridges, and by considerably less interorbital breadth, with narrow, rather compressed nasals, in this respect conforming to the female of $S$. priamus. A mature male skull taken from the type of Blyth's S. hypoleucus resembles in its size and frontal ridges an adolescent male of S. priamus, cutting its permanent canines and last molar; the teeth of this example of $S$. priamus being considerably larger than those of $S$. hypoleucus. The skull of the type is entire, with the exception of the occipital and basi-occipital portion, and its length from the premaxillaries to the lambdoidal ridge is $4 \cdot 26$; the palate measures $1 \cdot 73$. The fronto-malar and greatest zygomatic breadth are respectively $2 \cdot 55$ and $3 \cdot 30$. These measurements show that this is the smallest of all these species. The lower jaw has a similar symphysis to $S$. priamus, only a little narrower, and the coronoid process has much the same proportion.

This species inhabits the forests of the Malabar Coast, and does not extend to Ceylon.

\section{Sempopithecus Johnit, Fischer.}

Eiginer affenarten, C. J. John. Berlin, Ges. Nat. Freunde N. Schr. vol. i. 1795, pp. 211, 218. Cercopithecus johnii, Fischer, Syn. Mamm. 1829, p. 25.

Semnopithecus cucullatus, Is. Geoff. St.-Hil. Zool. Voy. de Bélanger, 1834, p. 38; Comptes Rendus, 1842, vol. xv. p. 719 ; Arch. du Mus. vol. ii. 1843, p. 541 ; Lesson, Sp. des Mammif. 1840, p. 59 ; Müller und Schl. Verhandl. 1839-44, p. 59 ; Wagner, Schreber, Säugeth. Suppl. vol. i. 1846, p. 98 ; Schinz, Syn. Mam. vol. i. 1844, p. 41; Is. Geoff. St.-Hil. Cat. Méthod. des Mammif. 1851, p. 13; Arch. du Mus. vol. v. 1852, p. 538; Gervais, Hist. Nat. des Mammif. 1854, p. 61. (fig. head); Wagner, Schreber, Säugeth. Suppl. vol. v. 1855, p. 26 ; Dahlbom, Stud. Zool. Fam. Reg. An. 1856, pp. 87, 89; Gray, Cat. Monkeys and Lemurs, B. M. 1870, p. 14.

Semnopithecus johnii, Waterhouse, Cat. Mamm. Mus. Zool. Soc. Lond. 2nd ed. 1838, p. 5 ; Martin, Charlesworth's Mag. Nat. Hist. vol. ii. new ser. 1838, p. 439; Hist. Nat. Quadr. 1841 (in part), p. 487; Blyth, Journ. As. Soc. Beng. vol. xii. 1843, p. 169; Ibid, vol. xxvi. 1847, pp. 734, 1272 ; Ann. \& Mag. Nat. Hist. vol. ii. new ser. 1848, p. 454 ; Gray, Hand-list Mamm. B. M. 1843, p. 3 ; Horsfield, Cat. Mamm. E. Ind. Co. Mus. 1851, p. 8.

Semnopithecus jubatus, Wagner, Schreber, Säugeth. Suppl. vol. i. 1840, p. 305 ; vol. v. 1855, p. 26 ; Schinz, Syn. Mamm. vol. i. 1844, p. 41; Horsfield, Cat. Mamm. E. Ind. Co. Mus. 1851, p. 14 .

Semnopithecus cephalopterus, Blyth, Journ. As. Soc. vol. xiii. 1844 p. 469 (in part).

Presbytis cucullatus, Blyth, Journ. As. Soc. Beng. vol. xxviii. 1859, p. 283 ; Cat. Mamm. As. Soc. Mus. 1863, p. 14 .

Presbytis jubatus, Jerdon, Mamm. Ind. 1867, p. 7.

Wholly black or brownish black, generally deep black in the adult, with the exception of the long undulating hairs of the head, which at all ages are some 
tint of yellowish brown. The rump and the base of the tail, which, even occasionally in the young, but generally in the adult, are grey.

The tail is about one-sixth longer than the body.

Length of body to root of tail 26 inches, length of tail 30 inches.

The skull of $S$. johnii is about the same size as that of $S$. cephalopterus, to which it is closely affined, but the muzzle is considerably narrower and somewhat shorter, and the interval between the eyes is not so broad. Owing to the narrow muzzle, the palate is more contracted than in either S. cephalopterus or $S$. ursinus, but the teeth are somewhat larger. The supraorbital ridges are but little developed, and the breadth across the fronto-malar suture is about the same as in S. cephalopterus, also the breadth of the skull. The symphysis of the lower jaw is much shorter than in S. cephalopterus, but the distance between the angles of the jaw is much greater than in that species, and the dental ramus is not nearly so deep, nor is the transverse breadth of the ascending ramus so great.

It inhabits the high country from the Nilgiris to Travancore.

Its nearest allies are the white-whiskered $S$. cephalopterus of Ceylon, and Semnopithecus obscurus on the eastern side of the Bay of Bengal.

S. johnii is usually found in small troops, and leaps with amazing agility and has a loud call like S. entellus.

Müller and Schlegel regarded S. johnï as simply a climatic race of S. cephalopterus, an opinion which was at one time held by Blyth, but with other limitations.

\section{Semnopithedus Cephalopterds, Zimmermann.}

The Lion-tailed Monkey (ß), Pennant, Syn. Mamm. 1771, p. 109, pl. 108, fig. 2.

La guenon à face purpre, Buffon, Hist. Nat. Suppl. vol. vii. 1789, p. 80, pl. xxi.; Latr. Buffon. Hist. Nat. (Sonnini) vol. xxxv. 1809, p. 292, pl. xxvii.

The Purple-faced Monkey, Pennant, Hist. Quad. vol. i. 3rd ed. 1793, p. 199, pl. xliii.; Shaw, Gen. Zool. vol. i. pt. 1. (1800), pl. xiii.

Cercopithecus kephalopterus, Zimm. Geograph. Gesch. vol. ii. 1780, p. 185.

Cercopithecus cephalopterus, Boddaert, Elench. Animal. 1785, p. 58; Fischer, Syn. Mamm. 1829, p. 17.

Simia veter, Shaw, Gen. Zool..vol. i. pt. i. (1800), p. 36.

Cercopithecus leucoprymnus, Otto. Nova. Acta. Acad. Nat. Cur., vol. xii. 1825, p. 505; Lesson, Man. de Mamm. 1827, p. 37.

Semnopithecus futvogriseus, Desmoulins, Dict. Class d'Hist. Nat. vol. vii. 1825, p. 570; Is. Geoff. St.-Hil. Voy. de. Bélanger, Zool. 1834, p. 36 (in part) ; Comptes Rendus, vol. xv. 1842, p. 719; Martin, Charlesworth's Mag. Nat. Hist. (new series), vol. ii. 1838, p. 439.

Semnopithecus leucoprymnus, Desm. Dict. des Sc. Nat. vol. xlviii. 1827, p. 439 ; Geoff. St.-Hil. Cours de. l'Hist. Nat. des. Mammif. (1828) lect. 8, p. 10; Fischer, Syn. Mamm. 1829, p. 16; Lesson, Compl. des Euvres de Buffon, 1828-30, vol. iv. p. 22 ; Sp. des Mammif. 1830, p. 57; Is. Geoff. St.-Hil. Voy. aux Indes. Orient. Bélanger, Zool. 1834 (in part), p. 36 ; Cat. Méthod. des Mammif. 1851, p. 12; Wagner, Schreber, Säugeth. Suppl. vol. i. 1840, p. 96; Ibid, Suppl. vol. v. 1855, p. 25 ; Müller und Schlegel, Verhandl. 1839-44, p. 59 ; Schinz, Syn. Mamm. vol. i. 1844, p. 40 ; Gervais, Hist. Nat. des Mammif. 1844, p. 60; Dahlbom, Stud. Zool. Fam. Reg. An. 1856, pp. 87-89; Gray, Cat. Monkeys and Lemurs, B. M. 1870, p. 14. 
Semnopithecus nestor, Bennett, Proc. Zool. Soc. 1833, p. 67 ; Lesson, Sp. des Mammif. 1840, p. 60 ; Waterhouse, Proc. Zool. Soc. 1844, p. 1 ; Fitzinger, Sitzr. der Math. Natur. vol. xvii. 1855, p. 242 .

Semnopithecus cephalopterus, Martin, Nat. Hist. Quadr. 1841, p. 482, plate 286 ; Blyth, Journ. As. Soc. Beng. vol. X. 1841, p. 839 ; vol. xii. 1843, p. 169 ; vol. xiii. 1844, p. 468 (in part), p. 476 (in part).

Presbytis cephalopterus, Gray, Hand-list Mamm. 1843, p. 4; Waterhouse, Proc. Zool. Soc. 1844, p. 130 ; Blyth, Journ. As. Soc. Beng. vol. xvi. 1847, pp. 734 \& 1271 (plate); vol. xliv. 1875 ex. no.p. 11 ; Cat. Mamm. As. Soc. Mus. 1862, p. 13 ; Kelaart, Fauna Zeylanica, 1852, p. 1; Sir E. Tennent, Nat. Hist. Ceylon, 1861, p. 5, plate, fig. 3, not fig. 1, which is S. thersites.

The general colour of this species is uniform greyish black, becoming black on the hands and feet; the lower part of the back, the base of the tail, and the outside of the upper part of the thighs are grey, tinged with brown in younger specimens, and the hair is rather short. The tail is tufted, becoming albescent towards its tip. The top of the head and the back of the neck are greyish brown; strong, black, supraorbital hairs extending outwards to near the ear. A ruff of white hairs, more or less tinged with brown, encircling the face and extending on to the throat and under surface of neck; the hairs on the sides of the face long, soft, and pointed upwards, forming a conspicuous whisker. The skin of the face black, with a purplish tinge; the palms and soles dull black. The under parts are dusky grey or only paler than the back, but generally the insides of the thighs anterior to the callosities are pale yellowish, almost white.

Length of body 1 foot 9 inches, and tail 2 feet 7 inches.

Habitat.-Ceylon, but to no great altitude.

The young of $S$. cephalopterus generally resembles the parents, but I have before me a young female from Ceylon, uniform pale yellowish, the top of the head being faintly washed with brownish and the shoulder and the middle of the back tinged with dusky. There can be no doubt of the identity of the race or variety with S. cephalopterus. ${ }^{1}$

The characters of the skull and wherein they differ from S. ursinus, the most nearly allied form, will be found stated under that species.

I have examined the type of Desmarest's S. leucoprymnus in the Paris Museum, which exactly agrees with the foregoing description, but I cannot say as much for the type of $S$. latibarbatus, which is quite a baby; it is wholly yellow, with paler cheeks and chin, but the locality from whence it came was unknown. In the Cat. Méthod. des Mammiféres this monkey has still been retained as distinct from $S$. cephalopterus, and it is there remarked that the individual is unfortunately very young, but that the examination of it and Pennant's figure furnishes many arguments in

\footnotetext{
1 The following references appear to relate to the white var. of S. cephalopterus :Another sort of monkey, Knox, Hist. Relation of Ceylon, p. i. ch. vi. p. 25 (1681).

The Lion-tailed Monkey, var. $(\gamma)$, Pennant's Syn. Quad. 1771, p. 110.

The Purple-faced Monkey, Pennant, Hist. Quad. vol. i. 3rd ed. 1793, p. 199, (white var.)

Cercopithecus senex, Erxleben, Syst. Reg. An. 1777, p. 24; Zimm. Geograph. Gesch. vol. ii. 1780, p. 183; Boddaert, Elench. An. vol. i. 1785 , p. 57.

Macacus silenus, var. alba, Fischer, Syn. Mam. 1829, p. 28.

Presbytis albinus, Kelaart, Fauna Zeylanica, 1852, p. 7.
} 
favour of the existence of a distinct species with a shorter tail, tufted at its extremity, and with a pelage more uniform, notably so in the posterior region of the body. The specimen, however, is so young that I do not consider it to be sufficient for the establishment of a species. I have therefore separated the references to it as a foot-note. ${ }^{1}$

Blyth, writing in $1844,{ }^{2}$ stated that he was quite satisfied of the specitical identity of S. cephalopterus and S. johnii, as he had seen many monkeys intermediate between these two, and from his previous remarks we are led to believe that he regarded S.cephalopterus as the type usually distinctive of the female and $S$. johnii as that more characteristic of the male, but this view he appears to have afterwards abandoned.

There can be no doubt, however, that $S$. cephalopterus, S. ursinus, and S. johnii are closely allied, and whether or not they are to be regarded as distinct species or only local races of one and the same species depends solely on the meaning attached to the term species. In separating these animals, which are genetically extremely closely allied to each other and also to S. obscurus, I have followed the generally accepted estimate of the term species, in our days, but which to my own mind has more the significance of a local race. It is, however, extremely difficult to draw the line; even in two such groups as the monkeys represented by $S$. entellus and $S$. cephalopterus (the first including under it $S$. schistaceus, S. pileatus, and S. priamus, and the second comprising S. ursinus and S. johnii), the types are separated from each other by well-marked characters, but when S. hypoleucus is studied, these two groups are seen to be linked together by it, as that form partakes of the characters of the two representative species $S$. entellus and S. cephalopterus.

\section{Semnopithecus ursinds, Blyth.}

Presbytis ursinus, Blyth, Journ. As. Soc. Beng. vol. xx. 1851, p. 155 ; Cat. Mamm. As. Soc. Mus. 1863, p. 13; Kelaart, Faun. Zeylan. 1852, p. 2.

Somewhat larger than S. cephalopterus.

Fur profuse, nearly $3 \frac{1}{2}$ inches long in the adult, dark brown, passing into black on the hands and feet and into slightly more rufous-brown on the head. The sacral region and thighs are not grey either in the young or adult, the former being coloured exactly like the latter, except that the head is more rufous. Eyebrows long and black, and the beard, throat, chest and whiskers are white or yellowish brown.

${ }^{1}$ Cercopithecus latibarbatus, Geoff. St.-Hil. Ann. du Mus. vol. xix. 1812, p. 94; Desmarest and Verey, Nouv. Dict. d'Hist. Nat. vol. xv. 1817, p. 578; Kuhl. Beitr. zur Zool. 1820, p. 10; Desmarest, Mamm. 1820, p. 57; Desmoulins, Dict. Class d'Hist. Nat. vol. vii. 1825, p. 568; Lesson, Man. de Mamm. 1827, p. 35; Griffith, An. King. vol. v. 1827, p. 11; Simia latibarbata, 1. Cuv. Dict. des Sc. Nat. vol. xx. 1821, p. 32 ; Semnopithecus latibarbatus, Martin, Charlesworth's Mag, Nat. Hist. new ser. vol. ii. 1838, p. 439; Waterhouse, Cat. Mamm. Mus. Zool. Soc. Lond. 1838, 2nd ed. p. 4; I.. Geoff. St.-Hil. Cat, Méthod des Mammif. 1851, p. 12; Dahlbom, Stud. Fam, Zool. Reg. An. 1856,
pp. 87, 89.

${ }^{2}$ L. c. 
The remaining under parts are concolorous with the upper surface, except that there is occasionally a yellowish area inside the base of the thighs, as in S. cephálopterus.

This species is confined to the mountains of Ceylon. ${ }^{1}$ Its skull is closely allied to that of S. cephalopterus, but in the only adult $\delta$ skull at my disposal for observation, the face is shorter than in it, and the nasals are somewhat longer. In the same skull the supraorbital ridges are more strongly marked than in the skull of $S$. cephalopterus, but the latter is somewhat younger. The palate of $S$. cephalopterus is narrower and longer than that of $S$. ursinus and more posteriorly contracted, the posterior palatine foramina being more compressed and reduced in capacity than in $S$. ursinus, in which the anterior palatine foramina are much larger than in $S$. cephalopterus. In these two forms the firstmentioned foramina, instead of being round as in the other Indian Semnopitheci, are laterally compressed. The skull of $S$. ursinus is shorter and more rounded than S. cephalopterus, with a greater zygomatic breadth. Associated with these characters we find $S$. ursinus with nearly uniform brown fur and whitish whiskers and beard, with only the faintest trace of a paler tint on the sacral region.

The skulls of $S$. cephalopterus and $S$. ursinus are more closely allied to the skull of S. johnii than to any other Indian Semnopithecus.

\section{* Semnopithecus obscurus, Reid.}

Semnopithecus obscurus, Reid, Proc. Zool. Soc. 1837, p, 14; Martin, Charlesworth's Mag. Nat. Hist. new ser. vol. ii. 1838, p. 440 ; Nat. Hist. Quadrumana, 1841, p. 486 ; Is. Geoff. St.-Hil. Comptes Rendus, 1842, vol.xv. p. 719 ; Blyth, Journ. As. Soc. Bengal, vol. xii. 1843, p. 176 ; Cantor, Journ. As. Soc. Bengal, vol. xv. 1846, p. 174; Horsfield, Ann. and Mag. Nat. Hist. vol. xvii. 1846, p. 335 ; Blyth, Journ. As. Soc. Bengal, vol. xvi. 1847, p. 734; Is. Geoff. St.-Hil. Cat. Méthod des Mammif. 1851, p. 12 ; Wagner, Schreber, Säugeth. Suppl. vol. v. 1855, p. 27, plate ii. ; Dahlbom, Stud. Fam. Zool. Reg. An. 1856, pp. 86, 89; Murie, Proc. Zool. Soc. 1865, p. 742 ; Gray, Cat. Monkeys and Lemurs, B. M. 1870, p. 14.

Semnopithecus albocinereus, ${ }^{2}$ Lesson Sp. des Mammif. 1840, p. 65 ; Gervais, Voy. autour du Monde, Zool. vol. i. Mammif. p. 4; Plate (animal and skull); Schinz, Syn. Mamm, vol. i. 1844, p. 42 ; Gervais, Hist. Nat. des Mammif. 1854, p. 61 ; Wagner, Schreber, Säugeth. Suppl.vol. v. 1855, p. 39 (in part).

Presbytis obscura, Gray, Hand-list Mamm. B. M. 1843, p. 3 ; Blyth, Journ. As. Soc. vol. xiii. 1844, p. 467 ; 16id, 1875, 'vol. xliv. ex. no., p. 10 ; Cat. Mamm. As. Soc. Mus. 1863, p. 14.

Semnopithecus lencomystax, Müller und Schlegel, Verhandl. 1839-44, p. 59.

Semnopithecus halonifer, Cantor, Proc. Zool. Soc. 1845, vol. i. 1849, p. 235 ; Ann. and Mag. Nat. Hist. vol. xv. 1845, p. 497 ; Ibid, 1846, vol. xvii. p. 335 .

The adults of this species are ashy or brownish black, darkest on the forehead and the sides of the face, shoulder, and sides of the body; the hands and feet being

1 Forbes' Eleven Years in Ceylon, vol. ii. p. 144

2 As the monkey on which Desmarest's description of $S$. albocinereus was founded is unknown, I shall not complicate the synonymy by giving the references to it in the text, but they are as follows :-

S. albocinereus, Desm. Mam. Suppl. (1822), p. 534; Griffith, An. King. vol. v. (1827), p. 14; Fischer, Syn. Mamm. 1829 (in part), p. 20; Lesson Man. de Mamm. 1820, p. 38. 
deep black. There are no parietal whorls; but the hair on the head is long and directed backwards, and originates in a peak as far down as the glabella, and is smoothed down on the top of the head from the occipital crest backwards, and is whitish with a yellowish tint. On the back of the neck and between the shoulders the colour tends to ashy brown, and the rest of the body posteriorly is somewhat paler than the sides. The tail is concolorous with the hind part of the back and much longer than the body, but not tufted. The under parts and inside of the limbs and outside of the thighs are of a slightly paler tint than the upper parts. The mouth and eyelids are whitish, but the rest of the face is black. The newlyborn young is bright fulvous, but the fur soon changes, and in specimens with the body 11.50 inches in length, the fur is dark ashy brown, very faintly paler on the top of the head, which tends to grey. The hair above the orbits and on the sides of the cheeks is black, which is also the colour of the hands and feet. The rufous colour of the young is most slow to disappear from the head, throat, flanks, thighs, and the terminal half of the tail. Length of the adult male body 1 foot 9 inches, tail 2 feet 8 inches. Although there is a somewhat strong resemblance between the colouring of this species, excluding the pale hairs on the head, and that of S. siamensis which is associated with it in Malacca, as is proved by Cantor's catalogue and specimens, yet the S. siamensis (S. albocinereus, Cantor), in the presence of its crest, is more closely allied to $S$. mitratus, of which it appears to be the continental representative. S. obscurus, on the other hand, presents some general characters which affine it to the somewhat similarly coloured species on the opposite side of the Bay of Bengal, viz., S. johnii.

The skull of $S$. obscurus is distinguished from that of $S$. siamensis by the narrower character of its face, the less outward projection of the external orbital process of the frontal, and by its less capacious orbits. The frontal region also is much narrower than that of $S$. siamensis, in which the area between the temporal ridges is broad and expanded, whereas it is much more limited in this species. The orbital septum anteriorly is longer and broader than in $S$. siamensis. It differs also from the skull of true $S$. maurus, by the greater flattening and expansion of the occipital region and the longer and less obtuse character of the brain-case and the greater breadth of its base.

This species occurs in Siam and the Malayan peninsula, and is not unfrequently offered for sale in the Singapore market. I have examined the types of S. obscurus, S. leucomytax, and S. halonifer, all of which in no way differ from one another.

Cantor has doubtfully referred the Simia maura, Raffles, to this species, and explains the circumstance that Raffles described the face as black on the supposition that he had never seen $S$. maura alive; but the typical example in the Indian Museum, London, is a monkey in no way resembling this species and constitutes the type of $S$. femoralis, Horsfield, a specimen of which from Cantor exists in the same Museum, and is in no way separable from S. sumatranus, Müller and Schlegel. 


\section{SEMNOPITHECUS HOLOTEPHREUS, $n$. $s$.}

Uniform dark slaty gray passing into black on the fore-arm and hands, and also on the feet. Under parts and inside of front limb and thighs pale-yellowish grey. Head slightly crested over vertex, but only with a feeble tendency to lateral compression. Supraorbital hairs moderately long and black. Whiskers rather long, directed backwards and outwards, hiding the ears in front. Face bluish black; area around the eyes and the lips white.

The nasal region of the skull is rather prominent, nearly straight, and moderately broad, with the orifice narrow and rather long. Supraorbital ridges are well developed, and the orbits are nearly round and of moderate size. The premaxillaries form a slightly expanded suture with the nasals. The last-mentioned bones are about half the lateral length of the premaxillaries. The palate has moderately broad margins, very slightly posteriorly convergent.

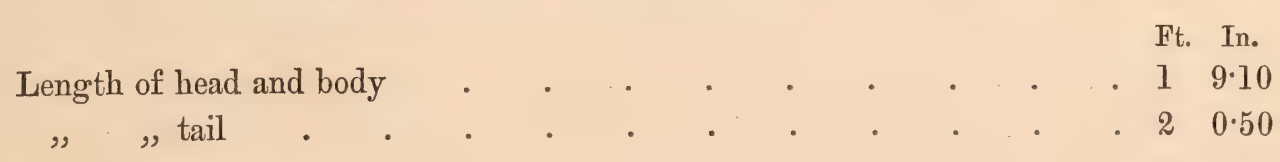

Habitat.-Unknown.

\section{Semnopithecus germant, A. M.-Edwards.}

Semnopithecus germani, A. M.-Edwards, L’Institut, Soc. Phil. Séance du 12 Fev. 1876.

The pelage of the types of this species is pale silvery grey on a darkish background which passes into deep black on the hands and feet. There is a strong supraorbital line of black hairs which, however, project outwards and backwards, and the cheeks are covered with long grey hairs. The hairs on the flanks are long, silky and grey. The under parts are greyish. The tail is longer than the body and grey. The young is bright orange-yellow, except on the top of the head, the antibrachium and feet, which are blackish. The colour of the face in life is not known.

Habitat.-Cochin China.

\section{Semnopithecus madrus, Schreber.}

The Middle-sized Black Monkey, Edwards' Gleanings Nat. Hist. 1764, part iii. p. 221, pl. 311 ; Pennant's Syn. Mam. 1771, p. 119.

La guenon négre, Buffon, Hist. Nat. Suppl, vol. vii. 1789, p. 83.

The Negro Monkey, Pennant, Hist. Quad. vol. i. 3rd ed.1793, p. 206 ; Shaw, Genl. Zool. vol. i. pt. i. 1800, p. 47.

Simia maura, Schreber, Säugeth. vol. i. 1775, p. 107, pl. xxii. B.; Gmelin, Lin. Syst. Nat. 13th ed. 1788, p. 35 ; Shaw, Genl. Zool. vol. i. pt. i. 1800, p. 47 ; F. Cuv. Dict. des Sc. Nat. vol. xx. 1821 , p. 33. 
Cercopithecus maurus, Erxleben, Syst. Reg. An. 1777, p. 41; Zimmermann, Geograph. Gesch. 1780, vol. ii. p. 193 ; Boddaert. Elench. An. 1785, p. 60 ; Geoff. St.-Hil. Ann. du Mus. vol. xix. (1812), p. 93; Desmarest, Nouv. Dict. d'Hist. Nat. vol. xv. 1817, p. 576; Mamm. 1820, p. 55 ; Kuhl. Beitr. zur Zool. 1820, p. 12.

Semnopithecus maurus, F. Cuv. Hist. Nat. des Mamm. Nov. 1822, pl. xii.; Horsfd. Zool. Resch. Java, pl. (1824) ; Desmoulins, Dict. Class. d'Hist. Nat. vol. vii. 1825, p. 570; Lesson, Man. de Mamm. 1827, p. 4.0; Compl. des Euvres de Buffon, vol. iv. 1828-30; Griffith, An. King. vol. v. 1827, p. 9 ; G. Cuvier, Règn. An. vol. i. nouv. éd. 1829, p. 94; Fischer, Syn. Mamm. 1829 (in part), p. 15; Is. Geoff. St.-Hil. Zool. Voy. de Bélanger, 1832, p. 42; Schlegel, Essai sur la Phys. des Serpens, Pt. Gén. 1837, p. 237; Waterhouse, Cat. Mamm. Mus. Zool. Soc. Lond. 2nd ed. 1838, p. 5 ; Martin, Charlesworth's Mag. Nat. Hist. vol. ii. new ser. 1838, p. 436 ; Nat. Hist. Monkeys, 1841, p. 478; Wagner, Schreber, Säugeth. Suppl. vol. i. 1840, p. 91 ; Ibid, vol. v. 1855, p. 23 ; Lesson, Sp. des Mammif. 1840, p. 63 ; Müller und Schlegel, Verhandl., 1839-44, pp. 61, 76, tab. 12 bis.; Schinz, Syn. Mamm. 1844, vol. ii. p. 39 ; Is. Geoff. Cat. des Mammif. 1851, p. 14; Horsfield, Cat. Mamm. East Ind. Co. Mus. (1851), p. 9; Jacquemont et Pucheran, Voy. au Pole Sud. Zool. vol; iii. 1853, p. 22 ; Gervais, Hist. Nat. de Mamm. 1856, p. 62 (fig. of head); Dahlbom, Stud. Zool. Fam. Reg. An. 1856, pp. 88, 90 ; Martens, Die Preus. Exped. nach Ost. Asien, Zool. 1865, p. 52; Gray, Cat. Monkeys and Lemurs, 1870, p. 15.

Simia ceylonicus, Desmoulins, Dict. Class. d’Hist. Nat. vol. vii. 1825, p. 572.

Semnopithecus edwardsii, Fischer, Syn. Mamm. 1829, p. 15.

Presbytis maura, Gray, Hand-list Mamm. B. M. 1843, p. 3.

Presbytis maurus, Blyth, Journ. As. Soc. Beng. vol. xvi. 1847, p. 735 ; Cat. Mamm. As. Soc. Mus. 1863, p. 13.

Semnopithecus pyrr/hus, Horsfd., Horsfield, Zool. Resch. Java, 1821 (plate); Cat. Mamm. E. Ind. Co. Mus. Zool. Soc. 1838, 2nd ed. p. 5 ; Martin, Charlesworth's Mag. Nat. Hist. new ser. vol. ii. 1838, p. 438 ; Wagner, Schreber, Säugeth. Suppl. vol. i. 1840, p. 94; Lesson, Sp. des Mammif. 1840, p. 64 ; Is. Geoff. St.-Hil. Cat. Méthod. des Mammif. 1851, p. 15.

Presbytis pyrrhus, Gray, Hand-list Mamm. B. M. 1843, p. 3; Blyth, Journ. As. Soc. Beng. vol. xliv. 1875 , ex. no. p. 10.

The body, generally, covered with rather long deep black hair in the adult, which becomes tipped or intermixed with silvery white in the old animal. The under surface of the body is less densely covered than the back, and the abdomen is nearly naked. The hair on the head is either erectly divergent all round the face and over the upper front of the head, or in some it may radiate from a centre, being long and bushy on the sides of the face, becoming directed backwards on the cheeks, and passing under the ears in the form of pointed whiskers. In some animals there is a white spot at the base of the tail beneath, but this character is very variable. The face is black, with a kind of warm tint, and is rather flat.

Length of body 1 foot 5.50 inches, length of tail 1 font 11.50 inches.

The young are uniform reddish brown, but the change from this colour to that of the adult is soon inaugurated and begins first on the extremities of the animal as grey, and afterwards shows itself on the upper surface of the head, on the shoulders and flanks, which become black, this colour rapidly spreading all over the body and last disappearing on the whiskers.

The form described by Horsfield as S. pyrrtus, and which is associated in Java with $S$. maurus, appears to be only a variety of the latter species, as its form and 
proportions are alike, and because the distribution of the hair on the head is the same in both. It would seem to be only a persistent condition of the colour characters of youth, the fur, instead of changing to black, becoming a deeper tint of the colour distinctive of the animal at birth. It has not been satisfactorily established that this rufous variation is solely characteristic of the female, as has been suggested by some authors. Whatever may be the true nature of this remarkable variation or persistence of the youthful type, it is not at all a common circumstance, and such individuals are highly prized in Java.

One of the leading features of the skull as compared with the skulls of the other species of Semnopitheci is the narrowness of the external nasal orifice and the little marked concavity that exists between the extremity of the nasals and the premaxillaries. The latter bones are somewhat contracted over the root of the second incisor, so that if the line of their suture with the maxillary at that point were produced downwards, it would cut through the middle of that tooth. Such being the limited character of the premaxillaries at that part, they suddenly expand between the roots of the second incisor and the canine. The orbits are small compared with the skulls of such forms as S. melalophus, and their greatest diameter is oblique, passing downwards and outwards from the nasal process of the frontal to the lower third of the orbital surface of the malars. The frontal is full and arched, and the interorbital septum is of moderate breadth and length. The inferior margin of the nasals is but little above the lower margin of the orbits, which is very different from what is the case in $S$. femoralis, in which the orbits are very large with the lower or free margins of the nasals only a little below the level of their centres. Associated with this character is a more forwardly projected muzzle with the front border of the nasals nearly in the same plane as the dental portion of the premaxillaries.

Habitat.-Malayan peninsula, Sumatra, neighbouring islands and Java.

\section{Semnopithects CRISTAtus, Raffles.}

Simia cristatus, Raffles, Trans. Linn. Soc. vol. xiii. 1822, p. 245.

Semnopithecus pruinosus, Desmarest, Mamm. 1820, Suppl. p. 333 ; Desmoulins, Dict. Class. d'Hist. Nat. vol. vii. 1825, p. 569 ; Griffith, An. King. vol. v. 1827, p. 10 ; Lesson, Man. de Mamm. 1827, p. 41 ; Is. Geoff. St.-Hil. Zool. du Voy. de Bélanger, 1834, p. 4; Waterhouse, Cat. Zool. Soc. Mus. Lond. 1838, '2nd ed.p. 5 ; Wagner, Schreber, Säugeth. Suppl. vol. i. 1840, p. 92 ; Ibid, vol. v. Suppl. 1855, p. 24; Lesson, Sp. des Mammif. 1840, p. 62 ; Gervais, Hist. Nat. des Mammif. 1854, p. 62 (fig. head).

Semnopithecus mitratus, Cuv. Règ. Animal, 1829, nouv. éd. vol. i. p. 4 (in part).

Semnopithecus maurus, Fischer, Syn. Mamm. 1829, p. 15 (in part).

Semnopithecus cristatus, Müller, Tijdschr. voor Natuur. Gesch. en. Phys. vol. ii. 1835, pp. 316, 328; Schlegel, Essai sur la Phys. des Serpens, Pt. Gén. 1837, p. 237 ; Martin, Charlesworth's Mag. Nat. Hist. new ser. vol. ii. 1838, p. 435 ; Nat. Hist. Quadr. 1841, p. 476 ; Gray, Hand-list Mamm. B. M. 1843, p. 3 ; Müller und Schlegel, Verhandl. 1839-44, pp. 61, 77, tab. 12, fig. 1 (young); Schinz, Syn. Mamm. vol. i. 1844, p. 39 ; Cantor, Journ. As. Soc. vol. xvi. 1846, p. 175 ; Is. Geoff. St.-Hil. Cat. Méthod. des Mammif. 1851, p. 11 ; Horsfield, Cat. Mamm. E. Ind. Co. 
Mus. 1851, pp. 13, 14; Jacquemont et Pucheran, Voy. au Pole Sud. Zool. vol. iii. 1853, p. 22, Pls. 3 and 4; Dahlbom, Stud. Zool. Fam. Reg. An. 1856, pp. 88, 89; Gray, Cat. Monkeys and Lemurs, B. M. 1870, p. 15.

The specimen of $S$. cristatus in the Indian Museum, London, presented by Sir Stamford Raffles as an example of this species, and which may therefore be regarded as the type, is a brownish-black monkey tinged with fuliginous on the flanks, fore-arm, and crest, but not more so than examples of $S$. maurus are oceasionally with grey. Raffles describes the species as dark grey, the hairs being in general black, with white tips. The face, fore-arms, hands and feet are black, and the upper surface of the tail nearly black, the under parts of the body paler, the hair of the head diverging round the face and forming on the top a kind of crest. Müller and Schlegel describe the face, ears, and under surface of hands coal black, as in S. maurus, which supports Raffles' statement as to the colour of the face and which has been questioned by some naturalists. Raffles also describes a variety of this animal as light grey or whitish.

In the size and proportions of its parts the species closely resembles $S$. maurus, and many zoologists have considered it merely as a local race of that form, an opinion justifiable from the mere consideration of their external characters, but it remains to be ascertained whether these views are supported by the structure of their skeletons. There can be no doubt that S. cristatus is much more variable than $S$. maurus, but at the same time monkeys from Sumatra are found quite as black as $S$. maurus, and with the essential features of that species. Müller and Schlegel were of the opinion that $S$. cristatus was only recognisable from the latter by its grey fur, and they extend its distribution to Borneo as well as Sumatra. The monkeys of this group from these islands are characterised by their black faces, black or blackish-brown fur, nearly similarly crested heads and like proportions of body. Much, however, has yet to be learned regarding them and the changes they undergo from youth to age in both sexes.

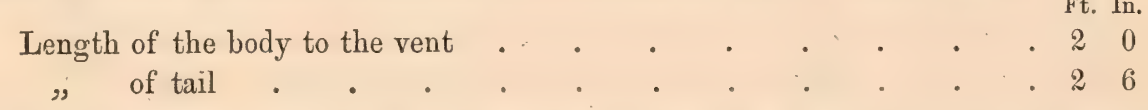

The young are reddish fawn, but the hands and feet gradually change through greyish brown to the colour of the adult, the crest also with increasing age becoming directed forwards.

I have not had an opportunity to examine the skull of this species, which has large orbits. ${ }^{1}$

Habitat.-Sumatra and Borneo.

Semnopithecus femoralis, Horsfield.

Simia maura, Raffles, Trans. Lin. Soc. vol. xiii. 1822, p. 247.

Semnopithecus femoralis, Horsfield, Appendix, Life, Sir T. S. Raftles, 1830, p. 643 ; Waterhouse, Cat. Zool. Soc. Mus. Lond. 1838, 2nd ed. p. 5; Martin, Charlesworth's Mag. Nat. Hist. new

1 Martin, $l . c ., \mathrm{p} .476$. 
ser. vol. ii. 1838, p. 436 ; Nat. Hist. Quadrumana, 1841, p. 480 (in part) ; Horsfield, Cat. Mamm. E. Ind. Co. Mus. 1851, p. 10 ; Is. Geoff. St.-Hil. Cat. Méthod des Mammif. 1851, p. 15 ; Gervais, Hist. Nat. des Mammif. 1854, p. 62 ; Dahlbom, Stud. Fam. Zool. Reg. An. 1856; pp. 88, 90 ; Gray, Cat. Monkeys and Lemurs, B. M. 1870, p. 16.

Semnopithecus chrysomelas, Müller, Tijdsch. voor. Natuur. Gesch. vol. v. pt. i. and ii. (1838), (Plate), p. 138; Müller und Schlegel, Verhandl. 1839-44, p. 61. Ap. 71, tab. 10, figs. 1 and

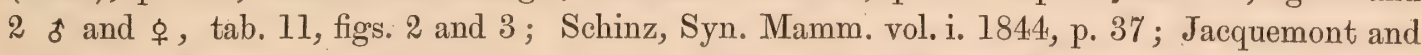
Pucheran, Voy. au Pole Sud. Zool. vol. iii. 1853, p. 22; Wagner, Schreber, Säugeth. Suppl. vol. i. 1840, p. 22, Suppl. vol. v. 1855, in part, p. 22.

Semnopithecus sumatranus, Müller und Schlegel, Verhandl. 1839-44, pp. 6, 73, tab. 10 bis, fig. 1 s; Schinz, Syn. Mamm. vol. i. 1844, p. 39 ; Horsfield, Cat. Manm. E. Ind. Co. Mus. 1851, p. 15; Wagner, Schreber, Säugeth. Suppl. vol. v. 1855, p. 23.

Simia femoralis, Cantor, Journ. As. Soc. vol. xv. 1846, p. 174.

S. femoralis is a uniformly brownish-black monkey, the limbs, head, and tail being almost wholly black, but the difference between the colours is not well defined, and the fore-limb is grizzled with whitish hairs. The tail is slightly tufted at its extremity. There is a rather short, vertical crest directed backwards, the hair anterior to it projecting forwards over the eyebrows. The ears are moderately large and partially exposed. The hair on the front and side of the head and on the middle of the crest is blackish or dull brown. The upper lip and chin are clad with short whitish hairs, with longer black hairs intermixed on the chin. Along the flanks the hair is short, sparse, brown, and somewhat grizzled, which is the character also on the belly. The throat, sides of the neck and chest are concolorous with the upper parts. A narrow, well-defined white line passes along the middle of the under surface from the chest in the adult to the hinder portion of the abdomen, but in young specimens this line is obscure, as the throat, chest and abdomen are yellowish white, and where it dies away on the inside of the limb, the white line is prolonged as a fine line to the wrist and ankle. In the adult the brachium is greyish, but there is a distinct tendency visible to the formation of a narrow obscure greyish line along the inner aspect of the antibrachium, but of variable intensity. Between and inside of the thighs is also white or pale grey, and this colour extends a short way below the knee. The face, ears, and the palms of the hands and sides of the feet black. ${ }^{1}$

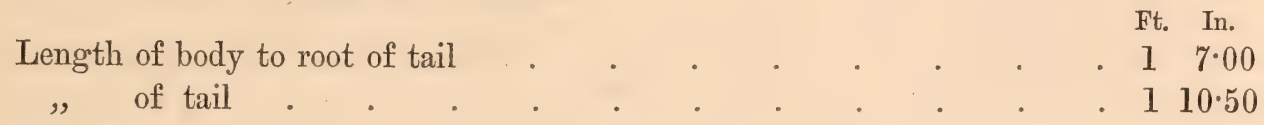

Inhabits Borneo and Sumatra.

As has been pointed out by previous authors, there do not appear to be any facts relating to the structure of the so-called S. chrysomelas from Borneo that would sanction its recognition as a species distinct from S. femoralis of Sumatra, and I have arrived at this opinion after an examination of the type specimens. Müller and Schlegel described as a female of this species a monkey of a yellowish colour, but which must have been originally much brighter, seeing it had been

\footnotetext{
1 Müller and Schlegel have represented the face of S. chrysomelas as bluish, but they state that it is quite hypothetical, as the colour of the face of this Bornean monkey in life is not known.
} 
preserved for some time in alcohol. It agreed in its form and general dimensions with the undoubted females of S.chrysomelas of the same type of colouring as the males. Intermixed among the yellowish hairs on the head, tail, and limbs are numerous black hairs, a character which occurring also in S. auratus, Is. Geoff., with which this animal agrees in every respect except its lighter colouring, has suggested the probability that these reddish monkeys of the $S$. auratus type are females of S. chrysomelas either in a transitional or in a seasonal tinge of pelage. So little, however, is known regarding the life, history, and pelage changes of the Semnopitheci, and especially of $S$. femoralis, that the evidence regarding the specific identity of $S$. femoralis with $S$. auratus must still be regarded as an open question. There is also a remarkable similarity between the skulls of $S$. rubicundus and $S$. femoralis, both of which are from Borneo, the former in its colouring being closely allied to $S$. auratus.

The skull of an adult female has the orbits very large and outwardly expanded, the forehead moderately arched and expanded. The orbital septum is rather long and broad, more especially at its upper end, the extremity of the nasals being but little below the middle of the orbit. There is a slight nodosity at the nasofrontal : suture. The hinder border of the last molar is on a line with the posterior margin of the palate. The fifth talon of the last inferior molar is but feebly developed.

\section{Semnopithecus aUratus, Geoff. St.-Hilaire.}

Cercopithecus auratus, Geoff. St.-Hil. Ann. du Mus. 1812, vol. xix. p. 93 ; Desmarest, Nouv. Dict. d'Hist. Nat. vol. xv. 1817, p. 576 ; Mamm. 1820, p. 56 ; Kuhl. Beitr. zur. Zool. 1820, p. 10 ; Lesson, Man. de Mamm. 1827, p. 35 ; Temminck, Monogr. de Mamm. vol. i. 1827, p. 14; Griffith, An. King. vol. v. 1827, p. 11.

Simia auratus, F. Cuvier, Dict. des Sc. Nat. vol. xx. 1821, p. 34.

Semnopithecus auratus, Desmoulins, Dict. Class. d'Hist. Nat. vol. vii. 1825, p. 570; Fischer, Syn. Mamm. 1829, p. 15 ; Lesson, Compl. des Euvres de Buffon, 1828-30, vol. iii. p. 18 ; Geoff. St.-Hil. Zool. Voy. de Bélanger, 1834, p. 44; Schlegel, Essai sur la Physion. des Serpenș, Pt. Gén. 1837, p. 237; Martin, Charlesworth's Mag. Nat. Hist. new ser. vol. ii. 1838, p. 439; Lesson, Sp.des Mammif. 1840, p. 63; Martin, Nat. Hist. Quadrumana or Monkeys, 1841 (in part), p. 4.74 (plate) ; Is. Geoff. St.-Hil. Cat. Méthod des Mammif. 1851, p. 15; Gervais, Hist. Nat. des. Mammif. 1854, p. 62 ; Dahlbom, Stud. Zool. Fam. Reg. An. 1856, pp. 88-90 ; Blyth, Jour. As. Soc. Bengal, vol. Ixvi. 1875, p. 10.

Semnopithecus chrysomelas, Wagner, Schreber, Sängeth. Suppl. vol. v. 1855, p. 22 (in part).

The type of this form is a pale golden-yellow monkey with the hair on the head rather long and erect. All the under parts are yellow. A large black patch on the knee, and intermingled black hairs on the yellow tail and hind feet. The colour of the face in life is unknown.

Habitat.-Said to inhabit the Moluceas.

The proportions and character of the crest of this monkey seem to me to point in the direction of its being a variety of $S$. femoralis, either depending on intermediate pelage distinctive of the female at a period of her history or attributable 
to seasonal changes, but, as I have already remarked, these suppositions are purely conjectural. Martin referred the S. pyrrhus, Horsfield, to this species, but the general characters of the animal and nature of its crest, and the locality, Java, from whence it was obtained, appear to me clearly to indicate it as a variety of S. maurus.

\section{Semnopithecus Rubicundus, Müller.}

Semnopithecus rubicundus, Müller, Tijdsch. voor Natuur. Gesch. vol. v. pts. 1 and 11, 1838, p. 137 (Plate); Martin, Nat. Hist. Quadr. 1841, p. 473 ; Müller und Schlegel, Verhandl. 1839-44, pp. 61, 69, Tab. 9, figs. 1 \& 2 ; figs. 3 \& 4 (skull), tab. 11, fig. 1 (juv.); Schinz, Syn. Mamm. vol. i. 1844, p. 36 ; Is. Geoff. St.-Hil. Cat. Méthod des Mammif. 1851, p. 16 ; Gervais, Hist. Nat. des Mammif. 1854, p. 63 (fig. head); Wagner, Schreber, Säugeth. Suppl. vol. v. 1855, p. 22 ; Beyrich, Abhandl. der Berl. Akad. der Wiss. 1860, p. 7 ; Gray, Cat. Monkeys and Lemurs, 1870, p. 17 ; Blyth, Journ. As. Soc. Bengal, vol. xliv. 1875, ex. no. p. 11.

In the type of this species, all the animal is deep maroon-red, with the exception of the hands and feet, which are sullied with blackish. The hair on the frontal region is markedly radiated in all directions, that in front overshadowing the eyes, the eyebrows in the adults, wanting the remarkably long bristles which occur in them in the young. The hair on the vertex is laterally compressed, long, semi-erect, being thrown somewhat backwards and tending to become recumbent. Whiskers but little developed. Face and ears bluish black; lips dull, flesh-coloured. Nose depressed and slightly wrinkled. Tail concolorous with body, or darker, and tufted. Hair on sides of body rather long. Under parts slightly paler than the upper surface.

In the young, the general colour of the upper parts is purplish-red or brown, paler on the back, where it is mixed with yellowish hair, and still lighter on the head; the remaining parts being yellowish grey or white, except the tail, which is rather darker than the back.

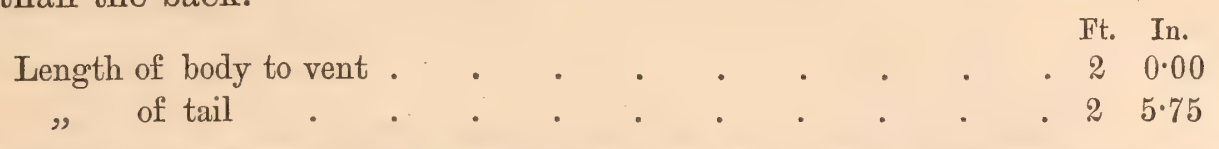

The leading features of this species are its rich dark maroon colour, radiating hair on forehead, and compressed, semi-erect crest tending to become recumbent. It is the only known member of the genus with radiating hair on the forehead, but in other respects it has a marked general resemblance to the Bornean Semnopitheci, which have been described under the names of S. melalophus and S. Alavimanus; of which Müller and Schlegel considered it to be the representative in Borneo. These zoologists have also directed attention to certain details in which the skulls of these supposed species resemble each other, more particularly to the forward bulging of their interorbital portion. But while these resemblances exist there are so many other points of difference between these Bornean and Sumatran monkeys as do not justify their being regarded even in the light of varieties of a common species.

S. rubicundus has been found hitherto only in Borneo. 


\section{Semnopithecus phayrei, Blyth.}

Semnopithecus phayrei, Blyth, Journ. As. Soc. vol. xvi. 1847, p. 733, pl. xxxi. fig. 3; Ibid, p. 1271 ; Wagner, Schreber, Säugeth. Suppl. vol. v. 1855, p. 28 ; Tickell, Journ. As. Soc. Bengal, vol. xxviii. 1859 , p. 428.

A somewhat peaked median crest on the vertex, long outwardly-directed whiskers, and white eyelids and lips.

The general colour is brown, passing into blackish brown on the antibrachium and on the hands, and into the same colour on the anterior two-thirds of the feet and on the last third of the tail. The back between the shoulders to the loins is faintly washed with yellowish brown. The chin, chest, and belly are pale yellow, passing on the inside of the brachium and thigh into brownish. No pale streak on the inside of the limbs. Lips and area around the eyes pinkish white, the remainder of the face dark leaden.

Length of body $\mathbf{1}^{\prime} 6 \cdot 20$, tail $\mathbf{1}^{\prime} 9 \cdot 20$.

The skull has the interorbital space of moderate length, the forehead rather full, but the supraorbital ridges are not strongly developed, whilst the external orbital angle of the frontal is rather prominent in adults.

The greatest breadth of the orbits is from the internal frontal angle obliquely downwards and outwards across the orbit, whereas in S. barbei and S. obscurus the orbits are nearly round.

In the fully adult ferine male type, the ridges marking the attachments of the temporal muscles do not meet in the middle line, but are separated by about an interval of 1 inch. The brain-case is upwardly tilted, so that the occipital region is nearly rertical: Associated with this upward tilting of the brain-case is a downward slope of the facial region.

This species has hitherto been recorded only from Arracan.

\section{Semnopithecus melalophus, F. Cuv. ${ }^{1}$}

Semnopithecus melalophus, F. Cuv. Hist. Nat. des Mammif. July 1821, pl. ix.; Desmarest, Mamm. 1822, Suppl. p. 533; Raffles, Trans. Lin. Soc. vol. xxii. 1822, p. 245; Desmoulins, Dict. Class. d’Hist. Nat. vol. vii. 1825, p. 569; Griffith, An. King. vol. v. 1827, p. 10 ; G. Cuvier, Règ. An. (nouv. éd.) vol. i. 1829, p. 94; Lesson, Man. de Mamm. 1827, p. 41 ; Desmarest, Dict. des Sc. Nat. vol. xlviii. 1827, p. 38; Fischer, Syn. Mamm. 1829, p. 14; Is. Geoff. St.-Hil. Zool. du Voy. de Bélanger, 1834, p. 40 ; Müller, Tijdschr. voor Natuur. Gesch. en Phys. vol. ii. 1835, p. 327 ; Waterhouse, Cat. Mamm. Zool. Soc. Mus. 1838, p. 4; Martin, Charlesworth's Mag. Nat. Hist. (new ser.) vol. ii. 1838, p. 438; Wagner, Schreber, Säugeth. Suppl. vol. i. 1840, p. 85 ; Lesson, Sp. des Mammif. 1840, p. 61; Martin, Nat. Hist. Quad. 1841, p. 470 ; Müller und Schlegel, Verhandl. 1839-44, pp. 60, 66, tab. 12 bis (fig. head); Schinz, Syn. Mamm. 1844, vol. i. p. 36 ; Is. Geoff. St.-Hil. Cat. Méthod. des Mammif. 1851, p. 16 ; Gervais, Hist. Nat. des Mammif. 1854, p. 63, (fig. head); Wagner, Schreber,

\footnotetext{
1 In Hist. Nat. de Mammif., this name is written melalophas, and in the Index melanophus', so bnth these terms
have come to be applied.
} 
Säugeth. Suppl. vol. v. 1855, p. 21 ; Dahlbom, Stud. Zool. Fam. Reg. An. 1856, pp. 88, 90 ; Gray, Cat. Monkeys and Lemurs, B. M. 1870, p. 16 ; Blyth, Journ. As. Soc. vol. xliv. 1875, ex. no. p. 10.

Semnopithecus flavimanus, Lesson, Cent. Zool. 1830, Augt. p. 109, pl. xl.; Is. Geoff. St.-Hil. Zool. du Voy. de Bélanger, 1834, p. 39 ; Waterhouse, Cat. Mus. Zool. Soc. Lond. 2nd ed. 1838, p. 4; Martin, Charlesworth's Mag. Nat. Hist. (new ser.) vol. ii. 1838, p. 438; Lesson, Sp. des Mammif. 1840, p. 60 ; Martin, Nat. Hist. Quad. 1841, p. 470, fig. 284; Is. Geoff. St.-Hil. Comptes Rendus, vol. xv. 1842, p. 719; Arch. du Mus. vol. ii. 1843, p. 543; Müller und Schlegel, Verhandl. 1839-44, pp. 61, 67; Schinz, Syn. Mamm. vol. i. 1844, p. 37 ; Horsfield, Cat. Mamm. E. Ind. Co. Mus. 1851, pp. 11-14; Is. Geoff. St.-Hil. Cat. Méthod. des Mammif. 1851, p. 16 ; Gervais, Hist. Nat. des Mammif. 1854, p. 63 ; Dahlbom, Stud. Zool. Fam. Reg. An. 1856, pp. 88-90.

Semnopithecus sumatranus, var. aurata, Müller und Schlegel, Verhandl. 1839-44, pl. x. bis, fig. 2, head of $q$.

Presbytes melanophus, Gray, Hand-list Mämm. B. M. 1843, p. 2.

Presbytes flavimana, Gray, Hand-list Mamm. B. M. 1843, p. 2.

Presbytes nobilis, Gray, Hand-list Mamm. B. M. 1843, p. 3 ; Is. Geoff. St.-Hil. Arch. du Mus. vol. ii. 1843, p. 545 ; Blyth, Journ. As. Soc. vol. xiii. 1844, p. 476 ; Ibid, 1875, vol. xliv. ex. no, p. 11. Semnopithecus nobilis, Gray, Cat. Monkeys and Lemurs, B. M. 1870, p. 17 ; Gervais, Hist. Nat. des Mammif. 1854, p. 63.

A careful consideration of the typical specimens of the monkeys which have been described under the names S. melalophus, Raffles, S.flavimanus, S. sumatranus 우 var. aurata, Müller and Schlegel, and S. nobilis, Gray, has led me to form the opinion that they are all referable to one species which is found in Sumatra and in the Malayan peninsula. The key which opens out this view of their relations is the form which has been described by Müller and Schlegel as the female of S. sumatranus under the name of variety aurata. But apart altogether from that specimen, a comparison of the types of $S$. melalophus and $S$. flavimanus which I made in Paris, has convinced me that the latter is only a variety of the former, as it has a similarly formed crest which in its dusky tipping conforms to the character which has been selected by Raffles as distinctive of the species; and in another specimen referred in the Paris Museum to S. flavimanus, the forehead is pale yellowish, and, as in $S$. melalophus, the crest and a narrow line over the ear to the external orbital angle are dark brown. The upper surface and shoulder of the type specimen are reddish washed with pale brown, the rest of the fore-limbs and the whole of the hinder extremities and the tail are pale orange-red or a paler tint of the same colour as S. melalophus. All of these specimens have the same proportions, and their crests are alike. An examination of the type of S. nobilis in the British Museum does not reveal any differences between it and $S$. melalophus.

S. sumatranus var. aurata is generally yellowish throughout, with the exception of a few brownish hairs which tend sometimes to group themselves irregularly-a circumstance which Müller and Schlegel thought indicated that this yellow garb was transitional. But I am inclined to think that this will be found not to be the case, as numerous adult male and female monkeys exhibiting these characters with but little variation have been under my observation dead and alive, and all of them appeared to be specifically identical with $S$. melalophus. 
The skull of $S$. melalophus, like others of the Semnopitheci, is characterised by a slight swelling or nodosity of the nasal processes or internal orbital angles of the frontals. This feature is most developed in an adult female skull before me, and to such an extent compared with an adult male that had not the skulis been removed under my direct supervision from the two individuals which yielded them, I would have been puzzled to regard them as belonging to one and the same species. But the external characters of these two animals were identical, both belonging to the variety named S. sumatranus var. aurata, Müller and Schlegel. The occipital regions of these skulls are also remarkably unlike, as in the female it is very much produced backwards and downwardly directed, while in the male it is much more vertical, thus considerably reducing the length of the brain-case.

The frontal region is broad and the orbits large and obliquely oval.

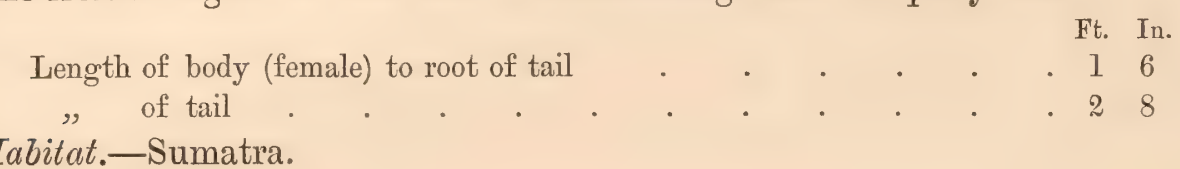

\section{Semnopithects Mitratus, Eschscholtz.}

Presbytis mitrata, Eschscholtz, Kozebue Reise Sud See und Berings-Strasse, 1821, p. 196, plate, (figs. 1 and 2, skull), (fig. 3, hand); Lesson, Man. de Mamm. 1827, p. 44.

Semnopithecus comatus, Desmarest, Mamm. Suppl. 1822, p. 533; F. Cuv. Hist. Nat. des Mammif 1825, March, pl. xiii. ; Desmoulins, Dict. Class. d'Hist. Nat. vol. vii. 1825, p. 569 ; Lesson, Man. de Mamm. 1827, p. 41 ; Temminck, Monogr. de Mamm. vol. i. 1827, p. 14.; Desmarest, Dict. de Sc. Nat. vol. xlviii. 1827, p. 438; Griffith, An. King. vol. v. 1827, p. 10; G. Cuv. Règ, An. (nouv. éd.) 1829, vol. i. p. 94 (in part) ; Fischer, Syn. Mamm. 1829, p. 16 (exclusive of S. fascicularis, Raffles); Is. Geoff. St.-Hil. Zool. Voy. de Bélanger, 1834; p. 40; Wagner, Schreber, Säugeth. Suppl. vol. i. 1840, p. 87, pl. xxiv. A ; Lesson, Sp. des Mammif. 1840, p. 61 ; Martin, Nat. Hist. Quadr. 1841, p. 468; Schinz, Syn. Mamm. vol. i. 1844, p. 38 ; Gervais, Hist. Nat. des Mammif. 1854, p. 63 ; Wagner, Schreber, Säugeth. Suppl. vol. v. 1855, p. 24; Beyrich, Abhandl. der Berl. Akad. der Wiss. 1860, p. $\%$.

Semnopithecus fulvogriseus, Desmoulins, Dict. Class. d'Hist. Nat. vol. vii. (1825), 570 (in part, skeleton); Fischer, Syn. Mamm. 1829, p. 15 ; Is. Geoff. St.-Hil. Zool. du Voy. de Bélanger, 1834, p. 36 ; Martin, Charlesworth's Mag. Nat. Hist. vol. ii. new ser. 1838, p. 439.

Presbytis mitrula, Griffith, An. King. vol. v. 1827, p. 7.

Semnopithecus fascicularis, Owen, Proc. Zool. Soc. 1833, p. 75.

Semnopithecus mitratus, Schlegel, Essai sur la Physion. des Serpens, Pt. Gén. 1837, p. 237 ; Müller und Schlegel, Verhandl. 1839-44, pp. 60, 65, pl. xii. fig. 2 (juv.), pl. xii. bis fig. 1; Is. Geoff. St.-Hil. Cat. Méthod des Mammif. 1851, p. 16; Horsfield, Cat. Mamm. E. Ind. Co. Mus. 1851, p. 15 ; Dahlbom, Stud. Zool. Fam. Reg. An. 1856, pp. 88, 90 ; Mivart, Proc. Zool. Soc. 1864, p. 626 ; Gray, Cat. Monkeys and Lemurs, B. M. 1870, p. 16.

Presbytis mitratus, Blainville, Osteo. des Mammif. vol. i. 1839-64, p. 23.

General colour dark greyish, darker on the back and the external surface of the limbs, but paler on the feet, on which a few reddish hairs are sometimes intermixed. The flanks, the under parts, and inside of limbs are yellowish or sullied white. The upper surface of the tail dark greyish and its extremity occasionally 
paling to grey, and tufted. These colours of the upper and under parts are clearly marked. A well-defined, vertically compressed crest on the vertex, expanding on the occiput, where the hairs are shorter. On the forehead the hairs tend to radiate from a centre outwards and forwards and project considerably over the eyes. The hair of the crest and upper parts of the head is blackish, but on the front of the crest it is darker. The face is sparsely covered with fine hairs, which are whitish on the lips, black on the cheeks, and grey on the nose. The whitish hair of the chin and throat is rather sparse, but the hair on the back and flanks is rather long. Ears and face sooty black; lips somewhat flesh-coloured.

The young during the first few weeks is covered with rather woolly hair, which is light grey, tipped with white, on the head, back, and upper surface of the tail. On the remaining parts of the body, and on the forehead, cheeks, and chin, it is greyish white. The face is dark leaden.

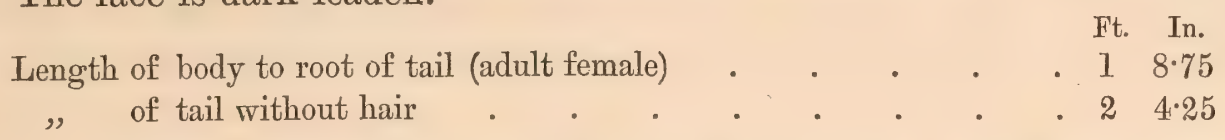

Habitat.-Java. The S. comatus, Desmarest, having by mistake been assigned to Sumatra.

The skull of this species is closely allied to that of $S$. siamensis, so much so that Müller and Schlegel state that the two are perfectly similar, and since they wrote Is. Geoffroy has pointed out that this species is always distinguished by only four tubercles on the last inferior molar. The Dutch naturalists were of the opinion that $S$. siamensis was only a climatic and continental race of this species, and this view of their affinity is further strengthened by Mivart's observation that the same tooth in S.nigrimanus and S. cinereus, which are in no way separable from S. siamensis, - a statement which I make after a careful examination of these types and of the specimen on which Mivart's observation rests, - are also distinguished by the presence of only four tubercles on the last inferior molar. There are, however, two striking features of $S$. siamensis, viz., the white area around the eyes and the white mouth which are almost absent in S. mitratus, the colours of the fur of which are also not those of $S$. mitratus. The proof of their identity being as yet not satisfactorily established, I have therefore indicated the two as distinct species.

\section{Semnopithecus siamensis, Müller \& Schlegel.}

Semnopithecus siamensis, Müller und Schlegel, Verhandl. 1841, p. 60 ; Schinz. Syn. Mamm. vol. i. 1844, p. 40 ; Is. Geoff. St.-Hil. Cat. Méth. des. Mammif. 1851; p. 16 ; Gervais, Hist. Nat. des Mammif. 1854, p. 63 ; Wagner, Schreber, Säugeth, Suppl. vol. v. 1855, p. 25 ; Dahlbom, Stud. Zool. Fam. Reg. An. 1856, pp. 88 and 90 ; Gray, Cat. Monkeys and Lemurs, B. M. 1870, p. 16 ; Blyth, Journ. As. Soc. Beng. vol. xliv. 1875, ex. no. p. 9.

Semnopithecus albocinereus, Blyth, Journ. As. Soc. Beng. vol. xii, 1843, p. 175 ; vol. xvi (1847), p. 733 ; Cat. Mam. As. Soc. Mus. 1863, p. 15 ; Cantor, Journ. As. Soc. Beng. vol. xv., 1846, p. 174; Wagner, Schreber, Säugeth. Suppl. vol. v., 1855, p. 29. 
Presbytes cinerea, Gray, Hand-list. Mam. B. M. 1843, p. 193.

Semnopithecus nigrimanus, Is. Geoff. St.-Hil. Arch. du Mus. vol. ii. 1843, p. 545 ; Mivart, Proc.

Zool. Soc. 1864, p. 626 : Blyth, Journ. As. Soc. Beng. vol. xliv, 1875, ex. no. p. 9.

Semnopithecus argentatus, Blyth, Horsfd. Cat. Mam. E. Ind. Co. Mus. 1851, p. 7.

Semnopithecus cinereus, Mivart, Proc. Zool. Soc. 1864, p. 626.

Presbytes cristatus (nec. Raffles), Blyth, Journ. As. Soc. Bengal, vol. xliv. 1875, ex. no. p. 9.

Presbytes melanophus, Blyth, Journ. As. Soc. 1875, ex. no. p. 9.

Prevailing colour, clear ashy grey, on the upper parts more or less tinged with brown, passing into black on the hands and feet, and to blackish brown on the front of the crest, and to pale-yellowish brown on the cheeks. A whitish line along the inside of the foot. The tail uniformly dark brown or blackish. A moderately long, erect, compressed crest, and the hairs on the parietal bones forming a whorl, the anterior hairs being directed forwards, projecting beyond the eyebrows. The under parts are less dark than those of the upper surface, and tend to greyish or yellowish grey. The face is dull black, with the region around the eyes and the mouth fleshy white.

In the young, some months old, the forehead, temporal region, sides of the face and behind the ear, the flanks, the outside of the thighs, and the under parts are pale grey, the remaining parts being pale brownish.

Inhabits Siam and the Malayan peninsula.

I have examined all the specimens on which the above synonomy is based.

Under $S$. mitratus, I have mentioned that this species has generally only four tubercles on the last molar of the lower jaw, but in a specimen in the Indian Museum there is a distinct rudimentary fifth talon-rudimentary as compared with the ordinary dimensions attained by that structure; and Mivart mentions that he has observed a Semnopithecus with six talons on the last inferior molar.

\section{SeMnopitheCUS RUtLedgit, $\mathrm{n}$. $\mathrm{s}$.}

Form slender; black, the hairs tipped with lustrous grey on the head and trunk, and with a somewhat yellowish grey on the limbs, except on the hands and feet, which are jet black. The under parts are paler and more broadly tipped with grey. The crest is very well defined, erect, median, much compressed and not bent forward in front, with the hair external to it on the parietal region very short and broadly tipped with lustrous grey, as is also the crest posteriorly, giving a whitish appearance to the sides and back of head when seen in certain lights. Hairs on the front of the forehead short and not divergent over the face. Whiskers long, backwardly and upwardly divided and broadly tipped with yellowish grey. Beard greyish, face dark-bluish black. The tail black above, tipped with grey, but yellow on the under surface, especially at the root.

The foregoing description is drawn up from a female cutting her last molar above and below; the latter tooth has four cusps. The skull in its general form and 
character resembles the skull of S.maurus, but is distinguished from it by its gradually expanding premaxillaries.

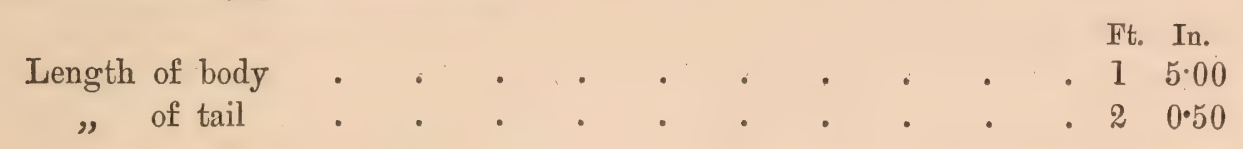

Habitat unknown.

\section{Semnopithecus frontatus, Müller.}

Semnopithecus frontatus, Müller, Tijdsch. von Natuur. Gesch., vol. v. pl. I \& II, 1838, p. 136 ; Martin, Nat. Hist. Quad., 1841, p. 475 (fig. 285, head); Müller und Schlegel, Verhandl. 1839-44, pp. 62 \& 78; Tab. 8, fig. ô ; fig. 2, head; figs. 3 and 4, skull; Schinz, Syn. Mamm., vol. i. 1844, p. 38 ; Is. Geoff. St.-Hil. Cat. Méthod des Mammif., 1851, p. 15 ; Gervais, Hist. Nat. des Mammif., 1854, p. 63; Wagner, Schreber, Säugeth, Suppl. vol. v. 1855, p. 24; Dahlbom, Stud. Zool. Fam. Reg. An., 1856, pp. 88 \& 90 ; Gray, Cat. Monkeys and Lemurs, B. M. 1870 , p. 16 .

Form slender; the face broad across the eyes, but compressed from above downwards; the trunk of the body dark-yellowish brown, with a tinge of red on the flanks in some individuals, but passing into dark brown and then into black on the greater part of the outside of the limbs, on the back part of the thighs and on the root of the tail; the remainder of the tail being greyish or yellowish brown and tufted. The neck and head are yellow-brown, but the latter colour passes into black on the haired portion of the forehead, sides of the head, and on the crest. The under parts are pale reddish, lighter on the throat, extending as a narrow band down the inside of the fore-limbs to near the wrist, and also on the hind limbs, but stopping short of the ankle. A bald, triangular area between the eyebrows, ascending to the middle of the forehead and in reality occupying the glabella, reaching at its upper end that part where the radiation of the hair of the other species usually takes place, of a milky-white colour and wrinkled; the rest of the face being deep black, except the lower lip and a narrow line along the upper lip which are fleshcoloured and sparsely covered with yellowish brown hairs. Along the upper margin of the bare area are arranged long and black hairs, which, being directed downwards and outwards, commingle with the long, bristly, black eyebrows, and reach as far back as the ears, as a marked lateral tuft or pencil, the hair on the side of the head above these lengthened hairs being short. The hairs on the cheeks from near the nose along the malar region to the anterior root of the zygomatic arch are long and black, increasing in length on the hindmost part of the cheek to such a degree that they depend nearly to the shoulder. The crest is erect, high and compressed, occupying the middle line of the head like the ridge of a helmet, over-arching the forehead, where it is slightly contracted, and reaching backwards to the occiput, where it decreases and mingles with the hairs on the upper part of the neck. 
The young do not appear to differ much in colour from the adults.

$$
\begin{aligned}
& \text { Length of body to root of tail }
\end{aligned}
$$

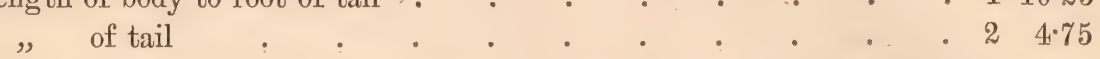

The skull of this remarkable animal is distinguished from the skulls of the other Semnopitheci, by its highly arched, but rather narrow, retreating forehead; by the great breadth of its orbits, the little marked prominence or arching of the interorbital space compared with that of the other crested species in which it is narrower than in $S$. frontatus; by its broad but short and truncated facial portion; and by the more retreating character and less depth of the symphysis of the lower jaw.

This species is at once recognised by the bare, milky-coloured, nude area on its forehead, by its remarkable, blunt-shaped crest, and by the long dependent tufts from the forehead and sides of the face.

Inhabits Borneo.

\section{Semnopithecus nemaeds, Linn.}

Le douc, Buffon, Hist. Nat., vol. xiv. 1766, p. 298, pl. xxi. ; Suppl., vol. vii. 1789, p. 85, pl. vii. ; Audebert, Hist. Nat. des Singes, 1797, iv. Fam. Sect. i. pl. i.; Latreille, Hist. Nat. de Buffon, (Sonnini), vol. xxxvi. (1809), p. 65, pls. li. et lii.

The Cochin China Monkey, Penn. Hist. Quad. 3rd ed. 1793, vol. i. p. 211; Shaw, Genl. Zool., vol. i. pt. i. pl. 23.

Simia nemaeus, Lin. Mantissa Plant., 1771, p. 521; Schreber, Säugeth, vol. i. 1775, p. 110, pl. xxiv.; Gmelin, Linn. Syst. Nat., vol. i. (13 ed.) 1788, p. 31; Shaw, Genl. Zool., vol. i. pt. i. 1800 , p. 56 ; F. Cuv. Dict. des Sc. Nat., vol. xx. 1821, p. 32.

Cercopithecus nemaeus, Erxleben, Syst. Règ. 'An. 1777, p. 42. ; Zimm. Geograph. Gesch., vol. ii. 1870, p. 194; Boddaert, Elench. An. 1785, p. 60 ; Desmarest, Nouv. Dict. d’Hist. Nat., vol. xv. 1817, p. 574; Kuhl. Beitr. zur. Zool., 1820, p. 8.

Pygathrix nemaeus, Geoff. St.-Hil. Ann. des Mus., vol. xix. 1812, p. 90.

Lasiopyga nemaeus, Desmarest, Mamm. 1820, p. 54; Lesson, Man. de Mamm., 1820, p. 39 ; Griffith, An. Kingd., vol. v. 1827, p. 8; Dahlbom, Stud. Zoo. Fam. Reg. An. 1856, p. 84; Gray, Cat. Monkeys and Lemurs, B. M. 1870, p. 13.

Semnopithecus nemaeus, F. Cuv. Hist. Nat. des Mammif., May 1825, pl. 14; Desmoulins, Dict. Class. d’ Hist. Nat., vol. vii. 1825, p. 570 ; Cuv. Règ. An. (nouv. éd.) vol. i. 1829, p. 93 ; Fischer, Syn. Mamm. 1829, p. 13; Is. Geoff. St.-Hil. Zool. des voy. de Bélanger, 1834, p. 34; Waterhouse, Cat. Mamm. Mus. Zool. Soc. Lond., 2nd ed. 1838, p. 4; Martin, Charlesworth's Mag. Nat. Hist., new. ser. vol. ii. 1838, p. 434; Nat. Hist. Quad., 1841, p. 459, fig. 283; Wagner, Schreber, Säugeth. Suppl. vol. i. 1840, p. 101; Suppl. vol. v. 1855, p. 35; Lesson, Sp. des Mammif., 1840, p. 55 ; Müller und Schlegel, Verhandl. 1839-44, p. 62; Schinz, Syn. Mamm., vol. i. 1844, p. 43 ; Is. Geoff. St.-Hil. Cat. Méthod des Mammif., 1851, p. 12; Gervais, Hist. Nat. des Mammif., 1856, p. 60, pl. iii ; A. M.-Edwards, Rech. des Mammif., 1868-74, p. 242.

Presbytes nemaeus, Blyth, Journ. As. Soc. Beng., vol. xliv. 1875, ex. no. p. 11.

Upper surface of the body and sides greyish, passing into blackish on the forehead, and into black on the base of the neck, front of the breast, shoulder, brachium, 
thighs, hands and feet; the anti-brachium white, and the lower half of the hind limb red or reddish brown. A large area on the rump immediately above the tail involving its base and passing round to the groin, white, all the tail being similarly coloured. Head brown, with a narrow band of chestnut passing under the ears backwards, and a broader band of the same colour, margined with black, posteriorly passing over the chest from shoulder to shoulder; the whiskers long, white, and directed backwards. The face naked and lemon-coloured; the callosities, palms, and soles yellow. The hairs of the trunk are annulated with from 10 to 12 rings of white and blackish.

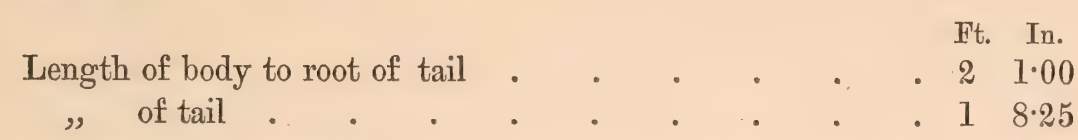

Both sexes in this beautiful monkey, and in its near ally, S. nigripes, are alike in colour, and the young differ but little from the adult.

The skull has the forehead rather low and the interorbital space rather broad. The facial portion is broad at the base, but rounded anteriorly.

As is now well known, this animal presents all the structural features of Semnopithecus.

Inhabits the northern portion of Cochin China. The naturalists of the 'Bonite' encountered it in numerous troops near Tourane.

\section{Semnopithecus NigRIPEs, A. M.-Edwards.}

Semnopithecus nigripes, A. M.-Edwards, Nouv. Arch. du. Mus. vol. vi, 1871, Bull, p. 7., Plate i.; Blyth., Jour. As. Soc. Beng. 1875, vol. xliv., ex. no. p. 11.

In $S$. nigripes the posterior extremities are uniformly blackish from the origin of the tail downwards, while in $S$. nemaeus the lower half of the limb is brown. The anterior limbs are greyish black, uniformly speckled with white, whereas in S. nemaeus the anti-brachium is white. The same general distribution of colour prevails as in the last-mentioned species. The face is nude and appears to be yellow as in the douc, and there is a frontal band of black hairs directed a little forwards, but which, however, in S. nemaeus is less intense and more backwardly recumbent. It also resembles the douc in having the base of the neck and front of the breast surrounded by a black collar which is bordered with red, but the whiskers of $S$. nigripes are black and shorter.

The back, the flanks, and the belly are covered with clear brilliant grey hairs, tending to fawn, and finely annulated with deep grey, often black. The precaudal area is pure white, and contracts towards the tail, which is entirely white and very long.

The proportions between the skeleton of $S$. nigripes and $S$. nemaeus appear to be very different, the limbs of the former being more elongated than those of the latter. The skull is relatively much smaller and the brain-case is more depressed and 
less high ; the occipital region being prolonged less backwards, and the lambdoidal suture is thrown upwards. The face is short, and the nasal portion is narrow and depressed, wanting the interorbital swelling that occurs in so many of the crested Semnopitheci. The orbits are rather large.

The proportions of the limbs in these two species have been stated by A. M.-Edwards as follows : taking for the two as a unit of measure the total length of the vertebral column comprised between the head and the end of the sacrum:

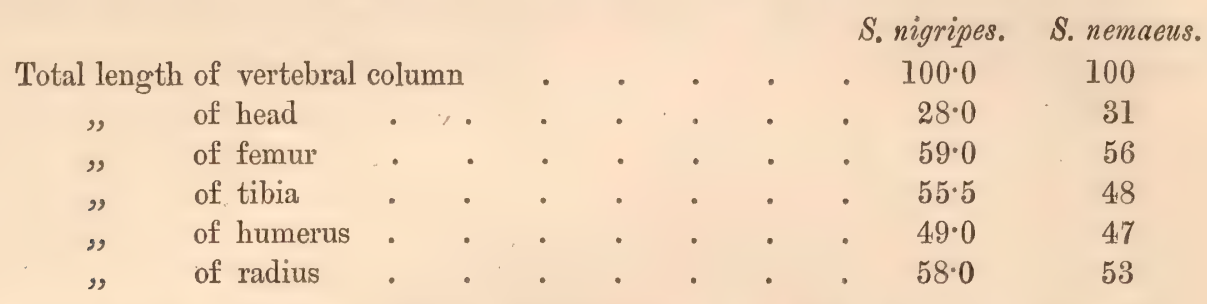

Inhabits Saigon and the forests bordering the Mekong towards its mouth.

This species, from what has been stated, is evidently closely allied to $S$. nemaeus, which is a parallel species inhabiting the more northerly portion of Cochin China, the first being recognised by its black hinder extremities and the latter by the lower half of the hind limbs being reddish-brown or red.

\section{SemiopitheCUs (NASALIS) IARVATUS, Wurmb.}

De Kakaw, Wurmb. Batav. Genootsch. Verhand. vol. iii. (1781), p. 145.

La guenon à long nez, Buffon, Hist. Nat. Suppl. vol. vii. 1789, p. 53, Pls. xi. and xii.; Latreille, Buff. Hist. Nat. (ed. Sonnini) vol. xxxv. (1809), p. 294, Pls. xxix and xxx.

Le Kakaw, Audebert, Hist. Nat. des Singes, Fam. iv. Sect. 11, fig. 1 (1797).

The Proboscis Monkey, Shaw. Genl. Zool., vol. i. Pt. 1 (1800), plate 22.

Cercopithecus larvatus, Wurmb. Batav. Genootsch. Verhand. vol. iii. 1781, p. 145; Kuhl, Beitr. zur Zool. 1820, p. 12.

Nasalis larvatus, Geoff. St.-Hil. Ann. du Mus., vol. xix, 1812, p. 90 ; Lesson, Man. de Mamm. 1820, p. 39 ; Griffith, An. Kingd., vol. v. 1827, p. 9; Geoff. Cours de l'Hist. Nat. des Mamm. 1828 ; Is. Geoff. St.-Hil. Zool. Voy. du Bélanger, 1834, p. 47; Cat. M. Mamm. 1831, p. 11; Waterhouse, Cat. Mamm. Mus. Zool. Soc. Lond. 1838, 2nd ed. p. 5; Lesson, Sp. des Mammif. 1840, p. 66 ; Jacquemot and Pucheran, Voy. au Pole Sud. Zool., vol. iii. 1853, p. 17, Pls. 2, 2A, 2B ; Gray, Cat. Monkeys and Lemurs, 1870, p. 13.

Cercopithecus nasicus, Desmarest and Virey, Nouv. Dict. d'Hist. Nat., vol. xv. 1817, p. 574; Cuv. Règn. An. nouv. éd. vol. i. 1829, p. 94; Wagner, Schreber, Säugeth. Suppl.vol. i. 1840, p. 102, Pl. x. B.

Lasiopyga nasicus, Desmarest, Mamm. 1820, p. 54.

Simia nasica, F. Cuv. Dict. des Sc. Nat. vol. xx. 1821, p. 32.

Semnopithecus nasicus, Desmoulins, Dict. Class. d'Hist. Nat. vol. vii. 1825, p. 570; Martin, Charlesworth's Mag. Nat. Hist. vol. ii. new ser. 1838, p. 440; S. Müller (Verhandl.), Over de Zool. van den Indsch. Arch. 1841, p. 15; Müller und Schlegel, Verhandl. 1839-44, pp. 62, 80, tab. 12, fig. 3 (juv.); Schinz, Syn. Mamm. vol. i. 1844, p. 43 ; Wagner, Schreber, Säugeth. Suppl. vol. v. 1855, p. 35.

Nasalis recurvus, Vigors and Horsfield, Zool. Journ. vol. iv. 1828-29, p. 109 (fig. head) ; Martin, Proc. Zool. Soc. 1837, p. 71 ; Charlesworth's Mag. Nat. Hist. new ser. vol. ii. 1838, p. 440. 
Semnopithecus larvatus, Fischer, Syn. Mam. 1829, p. 16 ; Martin, Nat. Hist. Quadrumana, 1841, p. 453, figs. 279, 280, 281, 282 ; Gervais, Hist. Nat. des Mammif. 1854, p. 58, head juv., fig. adult.

Simia nasalis, Martin, Proc. Zool. Soc. 1837, p. 70.

Rhynochopithecus larvatus, Dahlbom, Stud. Zool. Fam. Reg. An. 1856, p. 93, pl. iv.

The upper surface of the head, neck, back and flanks dark red-brown, passing into greyish yellow on the crupper, tail, and limbs. A yellow stripe on the shoulder. The hair on the sides of the face, neck, and shoulder is long and of a yellowish tint variegated with reddish brown, and the chin is well bearded. The under parts are yellowish white, and the tail is tufted. The face is a dirty yellow merging with the white around the lips. The under surfaces of the extremities are blackish, and the ears are of the same colour, and small. Nose produced into a proboscis with large nostrils opening downwards and separated from each other by a septun, but only developed in its characteristic form at a very advanced age in both sexes, being much shorter in the young and turned upwards (S. recurvus, Vig. and Horsfd.). The eyes are rather widely apart; the neck short, and the throat rather swollen from the presence of a laryngeal sack.

The colours of both sexes are the same, but the female is smaller than the male. Its colour as it advances in age is the subject of considerable change. In early youth, the mouth and the area around the eyes are bluish, and the cheeks are curiously wrinkled, and the rest of the face is sullied brownish white, and the ear flesh-coloured, but intensely black around the margin. The hands are black; and the head with the exception of the crown, the neck, the upper part of the chest, and the front of the upper arm, are dark red-brown, the rest of the pelage being sullied, pale-yellowish brown. Through a series of changes during which the red-brown of the upper parts first increases in strength and the greybrown of the hips and upper side of the tail change to yellowish white, the adult pelage is reached.

$$
\begin{aligned}
& \text { Length of adult, muzzle to base of tail . . . . . } \quad \text { Ft. In. } \\
& " \text { of tail . . . . . . . } 22
\end{aligned}
$$

This peculiar form, which has all the structural characters of Semnopithecus, appears to be restricted to the Island of Borneo.

\section{Semnopithecus (Nasalis) Roxellane, A. M.-Edwards.}

Semnopithecus roxellana, A. M.-Edwards, Comptes Rendus, 14 Fev. 1870, vol. Ixx. 1870, p. 341. Rhinopithecus ${ }^{1}$ roscellance, A. M.-Edwards, Rech. des Mammif. 1868-74, p. 233, pls. xxxvi. et xxxvii ; Blyth, Journ. As. Soc. Beng. vol. xliv. 1875, ex. no. p. 11.

Face much depressed in the nasal portion, nearly nude and turquoise-green. Nose much upturned and terminating in a point shaped as two follicles. Fáce

${ }^{1}$ In 1856 the genus Rhynochopithecus was created by Dahlbom for $S$. (nasalis) larvatus. 
surrounded by a dense ruff of hair which clothes the cheeks and the malar and superciliary arches, and which is prolonged on towards the nose as a fine line separating the muzzle from the circumorbital area. Superciliary region, sides of face and of the neck to the shoulder, the area around the ears, the chin, throat, and under surface of fore-limbs and upper surface of feet yellow, brightest on the ears, the upper surface of the hands being more grey. A few black hairs on the supercilium, and dark hairs on the forehead tipped with blackish, which become more frequent on the vertex, and constitute a kind of skull-cap tending to grey, with shining ferruginous hairs intermixed. The same colour is prolonged on to the nape and the upper surface of the shoulders, but on the back it assumes a lustrous silvery hue, the ends of the hairs becoming very brilliant yellowish grey, and this tint increases on the hinder part of the trunk. The outside of the fore-limb is almost concolorous with the shoulder. Front of thighs and legs yellowish grey. Callosities and outer posterior margin of the thighs clear yellow. Under surface clear grey, lightly washed with yellow. Tail strong, tufted, and deep grey at the base, mixed with yellowish grey as it approaches the extremity, which is clad with long hairs of that colour. Female coloured as the male, but less brilliant. In the young, the top of the head is paler, and the yellowish grey of the sides of the neck spreads above and before the ears, and the whiskers are black. In the very young there is no trace of a skull-cap. Thumb extremely short.

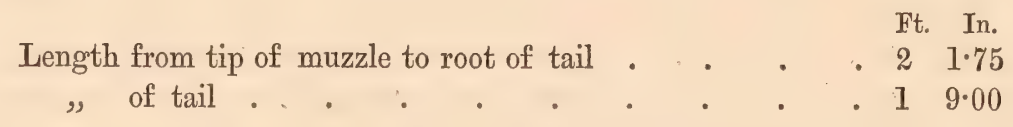

Inhabits Moupin (western portion) to Kokinoor.

This species, one of the many remarkable animals discovered by that distinguished traveller M. l'Abbé A. David, was first described by A. M.-Edwards as a Semnopithecus, but after reconsideration was elevated to generic rank, chiefly on the ground of the different proportions of its limbs to the vertebral column as compared with Semnopithecus and the greater length of the humeral over the radial portion of the limb, which is the inverse of what prevails in Semnopithecus. Nothing is known regarding the digestive organs, but the animal has no cheek pouches, and A. M.-Edwards assumes from the absence of these structures that the stomach will probably prove multilocular. I do not think that the disproportions of the limbs indicated by A. M.-Edwards outweigh the structural characters in which this form resembles Semnopithecus and more especially $S_{\circ}$ (nasalis) larvatus, and if the stomach should ultimately prove to be multilocular, a most important point in organic similarity is established between it and Seminopithecus. 


\section{Genus Macacus, Desmarest.}

* Macacus arctoides, Is. Geoff. St.-Hilaire, Plates I and II.

Macacus speciosus, F. Cuv. Hist. Nat. des Mammif. Fev. 1825, pl. xlvi. ; Lesson, Man. de Mamm. 1827, p. 43 ; Fischer, Syn. Mamm. 1829, p. 30 ; Is. Geoff. St.-Hil. Zool. Voy. de Bélanger, 1834, p. 63; Wagner, Schreber, Säugeth. Suppl. vol. i. 1840, p. 146 (in part) ; Lesson, Sp. des Mammif. 1840, p. 102 ; Gervais, Hist. Nat. des Mammif. 1854 (in part), p. 93 ; Blyth, Journ. As. Soc. Beng. vol. xliv. 1875, ex. no. p. 6.

Macacus arctoides, Is. Geoff. St.-Hil. Mag. de Zool. 1833, cli. pl. ii. (adult) ; Zool. du Voy. de Bélanger, 1834, p. 61 ; Arch. du Mus. vol. ii. 1843 (in part), p. 575; Méthod. des Mammif. 1851, p. 31 ; Schinz, Syn. Mamm. vol. i. 1844, p. 58; A. M.-Edwards, Rech. des Mammif. 1868-74, p. 246 ; Sclater, Proc. Zool. Soc. 1872, p. 203 ; Murie, Proc. Zool. Soc. 1872, pp. 770,771 .

Macacus maurus, Is. Geoff. St.-Hil. Voy. de Bélanger, Zool. 1834, p. 63 ; Lesson, Sp. des Mammif. 1840, p. 98.

Papio melanotus, Ogilby, Proc. Zool. Soc. 1839, p. 31 ; Schinz, Syn. Mamm. vol. i. p. 59 (in part). Cynopithecus speciosus, Lesson, Sp. des Mammif. 1840, p. 102.

Inuus (Maimon) arctoides, Wagner, Schreber, Säugeth. Suppl. vol. i. 1840, p. 146.

Macacus ursinus, Gervais, Hist. Nat. des Mammif. 1854, p. 93.

Inuиs (Inuus) arctoideus, Wagner, Schreber, Säugeth. Suppl. vol. v. 1855, p. 57.

Pithecus (Macacus) arctoides, Dahlbom, Stud. Zool. Fam. Reg. An. 1856, pp. 116, 118.

Pithecus arctoides, Blainville, Ostéogr. Mamm. vol. i. p. 44, 1839-64, atlas ii. pl. vii. (skull).

Macacus melanotus, Gray, Cat. Monkeys and Lemurs, B. M. 1870, p. 29.

Macacus brunneus, Anders. Proc. Zool. Soc. 1871, p. 628 ; 1872, p. 203, pl. xii. (juv.) ; 1874, p. 652 . Inuus speciosus, Blyth, Journ. As. Soc. Beng. vol. xliv. 1875, ex. no. p. 6.

The type of $\mathbb{M}$. arctoides was an adult male from Cochin China, characterised by a red face, very short, stumpy tail, and by long hair, each individual hair being "plusieurs fois annelés de brun et de roux clair." The type of $\boldsymbol{M}$. melanotus, Ogilby, was a young male said to have been obtained from Madras, also distinguished by the first two characters of the previous specimen, but with apparently uniformly brown fur, passing nearly into black on the head and back. The type of M. brunneus had also a short, stumpy tail and red face, and when it was described, the fur was wholly brown without annulations, the animal having been brought from the hill region on the western frontier of the province of Yunnan, China.

When I described the last-mentioned monkey, I had not access to Geoff. St.Hilaire's figure of $M$. arctoides in the "Magasin de Zoologie," as the volume was not in any Indian library; and I hesitated to regard it as identical with $M$. melanotus, Ogilby, considering that the locality from whence $M$. melanotus was said to have come has a fauna perfectly distinct from the hill region of Western China. ${ }^{1}$

\footnotetext{
1 Dr. Sclater has recently directed my attention to a monkey from Siam in the Zoological Gardens, which exactly agrees with $M$. melanotus and $M$. brunneus, and, like these types, it is quite a young individual. When describing $\mathbb{M}$. brunneus, I pointed out the structurally rudimentary character of the terminal caudal vertebræ, and that the individual which manifested these characters was in the habit of sitting on its tail. This observation was called in question by Dr. Muris; but a careful observation of this Siamese individual reveals a similar habit, and doubtless associated with it will be ultimately found a like degradation of the terminal caudal vertebræ.
} 
The British Museum contains the type of $M$. melanotus and the specimen of MI. brunneus which was figured in the Zoological Society's "Proceedings," whilst the type from which the external characters of $M$. brunneus and the details of its anatomy were drawn up is deposited in the Indian Museum, Calcutta. With the skin and skull of the type of $M$. melanotus I have compared the first-named specimen of $M$. brunneus and its skull, also the skull of the type of the species in Calcutta. I cannot detect a single character by which to separate them. The question now suggests itself, Is this monkey really to be regarded as a native of Southern India? I think not, and that the probable history of $M$. melanotus is that it had been taken to Madras from Burma in one of the ships that traded between that town and Rangoon,- - two ports which have had for a very long period regular and frequent communication with each other. And what strengthens this supposition is the circumstance that this form of monkey is unknown in Southern India. It appears to be a case similar to that of the $M$. leoninus, Blyth, a female of which was imported into the Andaman Islands from Burma, and was described as $M$. andamanensis.

The type of $\mathbb{M}$. melanotus and the specimen of $M$. brunneus in the British Museum are both examples of the male sex and of nearly equal size and age, with similarly formed short tails, and in these respects agree with the type of $M$. brunneus, which was only slightly younger. On the upper surface of the head and along the back the fur is dark brown, approaching to blackish; the sides and limbs are dark brown, being slightly paler in $M$. brunneus. In $M$. melanotus there is a distinct tendency to annulation on the sides of the neck and body, on the shoulders, and on the limbs, the annuli being pale golden-yellow and brown, and rather numerous on each hair, the terminal points being dark brown or blackish. These annuli are but feebly developed, and require the aid of reflected light to make them clearly visible. The type which I described was a younger animal, and did not show any signs of annulation; but the other example in the British Museum, and which had shown no annulation, so far as I am aware, before it left Calcutta, had evidently developed it afterwards during its life in the London Zoological Gardens.

A large, red-faced monkey, with a stumpy tail like the previous specimens, was purchased by the Zoological Society from a dealer in Liverpool, who could give no information regarding its habitat. After living for some years in the Society's Gardens it died, and was deposited in the British Múseum, where it is now stuffed, and the skeleton and skull are preserved. In its general form it is exactly like MI. brunneus, but only much larger, and it differs from it and M. melanotus in the general annulation of its hair all over the body even to the under parts, which, however, are not so distinctly annulated as the upper surface. The characteristic feature of the fur is the regularity and uniformity of the annulation, and the great number of annuli which occur on each individual hair; I have counted as many as twelve or fourteen. These rings are of the same type as those I have indicated as existing in a subordinate degree in $M$. melanotus and $\mathbb{M}$. brunneus. It is 
also distinguished by the great length of its fur, which is generally $4 \frac{1}{2}$ inches long. But $M$. brunneus and $M$. melanotus are also remarkable as young monkeys for the length of their fur; and the idea at once presents itself on a close comparison that they are only the young of this larger monkey. It would further seem that M. brunneus (type specimen) represents the youngest stage, before annulation has commenced, the young being born with a purely uniform brown fur; the II. brunneus of the British Museum and $\boldsymbol{M}$. melanotus showing the commencement and progress of annulation, which in them is confined to certain parts, but in the end would have involved the whole of the fur as in the adult.

This large monkey was, I believe, correctly named by Dr. Sclater, in the printed list of the animals living in the Society's Gardens, as $\mathbb{M}$. speciosus, F. Cuvier. Mr. Gerrard informs me that Dr. Gray never examined this specimen, and that during his life-time it stood in the British Museum as $\mathbb{M}$. speciosus, so that Dr. Gray's IM. melanotus of Ogilby referred only to that type; but this large monkey has now been placed under the same specific name. Its red face, short, stumpy tail, little more than an inch long and sparsely clad, its long fur " plusieurs fois annelés de brun et de roux clair," at once suggest its affinity to $\mathbb{M}$. arctoides, Geoff. St.-Hilaire, which is verified by comparing it with the figure of that type of this species given in the "Magasin de Zoologie ;" and the evidence of its identity with it is conclusive when its skull is compared with the skull of $M$. arctoides figured by Blainville, the British Museum skull of this specimen agreeing in every respect with the skull of the type; and I am further convinced of the identity of the two by the personal observation of both.

I now propose to consider whether the characters manifested by the skull of M. melanotus, Ogilby, and the skulls of $M$. brunneus, Andr., so agree as to entitle us to regard them as of one species; and if so, whether the details in which they differ from $\mathbb{M}$. arctoides, Is. Geoff., are to be viewed in any other light than as appertaining to youth.

Here I may remark that all these specimens belong to the male sex.

The skull of the Liverpool specimen has the bicuspids and two permanent molars fully through the jaw, but the incisors are only half exposed; the last molar is not above the margin of its alveolus. The palate is 2.18 inches long, and from the internal alveolar margin of one side to that of the other, it is 0.97 in breadth at its middle, and of equal breadth as far forwards as the hinder border of the canines, anterior to which it slightly contracts.

In the type of $\mathbb{M}$. melanotus the permanent teeth which have cut the upper jaw thoroughly, are the first molar, the first incisors, and the bicuspids; the second incisors are well exposed, but not to their whole length, which is also the case with the second molar. The milk-canines have not been shed, and their successors have not pierced the bone; but the tip of the left is visible in its socket internal to the milk-tooth, but on the right side the permanent tooth is not visible. The alveolar arch over the last molar is only feebly perforated, and the tooth, which can be 
detected far back in its socket, is still very rudimentary and much less developed than in the more adult skull of the previous specimen.

In the British Museum example of $\mathbb{M}$. brunneus the only permanent teeth in the upper jaw are the first molar and the first incisors, which are only partially exposed; the second pair of permanent incisors are only appearing behind and internal to the milk pair; the two milk-molars have not been shed. The second permanent molar is seen deep in its alveolus, but only imperfectly developed. In the type of $\boldsymbol{M}$. brunneus the only permanent tooth is the first molar.

In the lower jaw of the Liverpool monkey the permanent teeth are through the jaws, but the canines and the last molar are only partially so. The type of MI. melanotus has all its permanent teeth in the lower jaw except its canines and the last molar; the former are only on a level with the jaw, and it appears as if the milk-incisors had been shed, or, it may be, lost in the preparation of the skull. The last molar is only very imperfectly developed and far back in its socket. In the lower jaw of the British Museum specimen of $\boldsymbol{M}$. brunneus the milk-canines and two molars are still in the jaw; the second permanent molar is not above the surface and is only a shell ; there is no trace of the last tooth. The lower jaw of the type of $M$. brunneus has all its milk-teeth and its first molar.

The dentition of $\boldsymbol{M}$. melanotus, Ogilby, thus proves it to be an older specimen than the British Museum example of $\mathbb{M}$. brunneus, which in its turn is older than the type in India. The skull characters of the last mentioned have been elsewhere described, ${ }^{1}$ and the second example agrees with it except in a few trifling details which do not merit enumeration. The skull of $\mathbb{M}$. melanotus also is in no wise separable from these two skulls - a statement which is horne out by the tabulated measurements which I here give, any little differences that do exist being legitimately referable to individual peculiarities :-

Occipital to premaxillæ

Anterior margin of occipital foramen to premaxillæ Anterior margin of occipital foramen to palate .

Fronto-nasal process to premaxillæ.

Auditory process to auditory process

Auditory process to tip of premaxillæ, in straight line

Greatest breadth of skull behind root of zygoma

Breadth across orbito-malar suture

Least breadth in temporal fossa
Breadth across zygomatic arch, at middle

Breadth of muzzle at base below maxillo-malar suture

Breadth of muzzle at middle, anterior end opposite nasa

Height of orbit

Length of orbit

Length of lower jaw in line with alveolar margin

\begin{tabular}{|c|c|c|c|c|}
\hline \multicolumn{4}{|c|}{ Macacus arctoides, Is. Geoff. St.-Hil. } & \multirow[b]{2}{*}{$\begin{array}{c}M . \\
\text { rufescens. }\end{array}$} \\
\hline $\begin{array}{c}\boldsymbol{M} . \\
\text { brunneus, } \\
\text { type sp. }\end{array}$ & $\begin{array}{c}\text { M. } \\
\text { brunneus, } \\
\text { B. M. sp. }\end{array}$ & $\begin{array}{c}\text { M. } \\
\text { melano- } \\
\text { tus, } \\
\text { B. M. sp. }\end{array}$ & $\begin{array}{c}\text { M. } \\
\text { arctoides. } \\
\text { B. M. sp. }\end{array}$ & \\
\hline In. & In. & In. & In. & In. \\
\hline $4: 30$ & $4: 40$ & 446 & $5 \cdot 30$ & $4: 25$ \\
\hline 265 & 2.90 & $2 \cdot 99$ & $3 \cdot 70$ & $2 \cdot 95$ \\
\hline $1 \cdot 15$ & $1 \cdot 15$ & $1 \cdot 27$ & 1.52 & $1 \cdot 23$ \\
\hline $1 \cdot 77$ & 1.60 & $1 \cdot 81$ & 2.05 & $1 \cdot 62$ \\
\hline $2 \cdot 14$ & 2.52 & $2 \cdot 40$ & 2.78 & $2 \cdot 30$ \\
\hline $2 \cdot 50$ & $2 \cdot 75$ & 2.90 & $3 \cdot 60$ & 2.90 \\
\hline $2 \cdot 65$ & $2 \cdot 80$ & $2 \cdot 68$ & $3 \cdot 04$ & $2 \cdot 60$ \\
\hline $2 \cdot 45$ & $2 \cdot 52$ & $2 \cdot 50$ & $3 \cdot 03$ & $2 \cdot 40$ \\
\hline $1 \cdot 90$ & $1 \cdot 87$ & $1 \cdot 87$ & $1 \cdot 90$ & 1.80 \\
\hline $2 \cdot 73$ & $3 \cdot 10$ & 2.95 & 3.50 & $2 \cdot 25$ \\
\hline $1 \cdot 60$ & $1 \cdot 66$ & 1.65 & 1.96 & $1 \cdot 65$ \\
\hline $1 \cdot 25$ & $1 \cdot 40$ & $1 \cdot 30$ & 1.48 & $1 \cdot 25$ \\
\hline 83 & .77 & .82 & 80 & .71 \\
\hline $1 \cdot 00$ & .95 & .95 & $1 \cdot 20$ & .90 \\
\hline $2 \cdot 30$ & 2.82 & $2 \cdot 76$ & $3 \cdot 35$ & $2 \cdot 75$ \\
\hline
\end{tabular}

${ }^{1}$ Proc. Zool. Soc. 1872, pp. 203-212. 
The skull of the adult specimen in the British Museum, agreeing with Blainville's figure of the skull of $M$. arctoides, is distinguished from the others by the great development of its orbital ridges and the depth of its temporal fossa; the former are of great thickness and are thrown forwards, so that the orbits are considerably broader than high. The skull is longer from the frontal to the occipital than in $M$. melanotus and $M$. brunneus. The facial portion is more developed than in these latter in proportion to the more advanced state of its dentition. The base of the skull is also broader and the basicranial axis more anteriorly projected than in $M$. nelarotus or $M$. brunneus. The zygomatic arch is also of great strength as compared with these skulls. In all these characters it only evinces its greater maturity, and there are no others that present themselves that would indicate any specific distinction between it and these two supposed species; and these remarks seem to be verified by the table of measurements, when due allowance is made for its greater age.

The bones of the skull of the adult $M$. arctoides are unnaturally thick, as are also those of $\mathbb{M}$. brunneus; and this condition is in all likelihood attributable to confinement; whereas the skull of $M$. melanotus has no more than the thickness generally characteristic of healthy animals, although it was also a specimen kept in confinement.

A comparison of the bones of $M$. brunneus and of $M$. arctoides in the British Nuseum, while it does not reveal any difference in their forms, yet shows them to be notably smaller in the specimen of $M$. brunneus. But a consideration of the relative ages of the bones as revealed by the conditions of their epiphyses fully accounts for their difference of size.

The following table gives the relative measurements of their bones :-

Total length of scapula along crest .

Length of scapula along inferior margin of articular surface Greatest breadth

Length of humerus

Length of radius

Length of ulna

Length of os innominatum

Anterior angle of symphysis pubis to superior angle of callositie

Breadth across ilium at middle. .

Length of femur

Length of tibia

\begin{tabular}{|c|c|c|}
\hline \multicolumn{3}{|c|}{ Macacus arctoides, Is. Geoff. St.-Hil. } \\
\hline $\begin{array}{l}\text { M. brunneus, } \\
\text { type sp., đ. }\end{array}$ & $\begin{array}{l}\text { M. brunneus, } \\
\text { B. M. sp., ठే. }\end{array}$ & M. arctoides, \\
\hline In. & In. & In. \\
\hline $2 \cdot 49$ & $2 \cdot 80$ & $3 \cdot 60$ \\
\hline $2 \cdot 10$ & $2 \cdot 40$ & $3 \cdot 20$ \\
\hline 1.70 & $1 \cdot 72$ & $2 \cdot 83$ \\
\hline $4 \cdot 13$ & 4.55 & $5 \cdot 88$ \\
\hline 3.95 & $4 \cdot 55$ & $5 \cdot 80$ \\
\hline 4.37 & $5 \cdot 08$ & $6 \cdot 20^{1}$ \\
\hline $3 \cdot 96$ & 470 & $5 \cdot 70$ \\
\hline $1 \cdot 70$ & $2 \cdot 20$ & $2 \cdot 87$ \\
\hline $1 \cdot 01$ & $1: 39$ & $1 \cdot 70$ \\
\hline $4: 20$ & $4 \cdot 96$ & $6 \cdot 40$ \\
\hline $3 \cdot 90$ & $4: 56$ & $5 \cdot 88$ \\
\hline
\end{tabular}

The credit is due to Dr. Sclater of being the first to point out that $M$. melanotus, ${ }^{2}$ Ogilby, and the monkey from the Kakhyen hills and Cachar, ${ }^{3}$ are not different from $M$. arctoides, Is. Geoff.; and Dr. Murie ${ }^{4}$ shortly afterwards adopted a similar

${ }^{1}$ Epiphyses lost.

${ }^{3}$ Proc. Zool. Soc. 1872, p. 203.

\footnotetext{
2 Proc. Zool. Soc. 1860, p. 420.

4 Ibid, pp. 770, 771 .
} 
opinion. The four examples referable to M. brunneus that had passed under my observation were all uniformly brown monkeys, and in this respect in strong contrast to the description of the species given by, M. Is. Geoff. St.-Hilaire, who characterised it as being distinguished "par ses long poils, plusieurs fois annélés de brun et de roux clair, par l'extrême brièveté de sa queue," \&c. ${ }^{1}$ Now, these monkeys without trace of annulation I hesitated to regard as the same as Is. Geoffroy's species, more especially as, the person who presented me with the specimens had assured me that the adult was also devoid of annulated fur. On examining the type of $M$. arctoides in Paris, I found, as I expected, a monkey remarkable for the pronounced annulation of its fur, and in the same case along with it there was a specimen labelled $\mathbb{M}$. brunneus, uniformly brown-one of the animals that had been forwarded to the Zoological Society of London from Calcutta. The cursory comparison of the two confirmed me in my former view, which $I$ again reiterated." ${ }^{2}$ But after having again looked at the type of $\mathbb{M}$. melanotus, and the older specimen of $\boldsymbol{M}$. brunneus in the British Museum which served to connect the type of the latter in Calcutta with the former monkey, all the difficulty of grouping these individuals together under one species, $\boldsymbol{M}$. arctoides, seemed removed.

I am even disposed to go further and to adopt the view recently promulgated by that distinguished naturalist and my predecessor the late $\mathrm{Mr}$. Blyth, ${ }^{3}$ that all these monkeys are referable to the species described by F. Cuvier in 1825 as M. speciosus. It is true that this form was founded merely on a drawing made by Duvaucel of an animal in the zoological collection at the Barrackpore Park, fifteen miles from Calcutta. Temminck, apparently from the circumstance that Cuvier's drawing had a resemblance to the Japan ape, was led to suggest that the Barrackpore individual had also come from Japan and had been taken to Calcutta from some of the entrepôts of commerce in Java. There is, however, no evidence to support such a view; and within the last few years, since my attention has been directed to this subject, four examples of these brown, red-faced, and stump-tailed monkeys have passed under my notice in the Calcutta market, and all of them had come from the Assam region or Cachar. As F. Cuvier's drawing of $M$. speciosus is a better representation of these monkeys, all of which are referable to $\mathbb{M}$. brunneus and $\boldsymbol{M}$. melanotus, than it is of the Japan ape, with its differently coloured fur and rather longer and well-clad tail, so markedly distinct from the tail of $M$, arctoides, it seems highly probable that F. Cuvier's drawing is founded on an animal of the Assam or Cachar region that had probably been presented to the Viceregal collection at Barrackpore by some Government official-a source from which that menagerie has been frequently enriched, and to which it has always been more or less indebted from its commencement. The second example of $M$. brunneus that came into my hands was given to me with the option of presenting it to the Barrackpore collection.

$$
{ }^{1} \text { Loc. cit. }{ }^{2} \text { Proc. Zool. Soc. 1874, p. 652. } \quad{ }^{3} \text { Loc. cit. }
$$


There can be no doubt that while the drawing of $\boldsymbol{M}$. speciosus is not a good representation of the Japan monkey, it is so of the form from Cachar and the Kakhyen hills on the frontier of Yunnan; and as $M$. arcioides, which I hold to be the adult, is from Cochin China, if my hypothesis of the origin of the type of $\mathbb{M}$. speciosus is rejected, there is the further alternative, as suggested by Temminck, that it may have come from some Javan port. If so, the probability would appear to be that it was carried to Java by one of the trading vessels between that island and Cochin China, and not from Japan.

Some doubts regarding the identity of the Japan ape with $\mathbb{M}$. speciosus seem, moreover, to have existed in the minds of the Leyden naturalists, as the former stood for some time in the Leyden Museum under the name of $\boldsymbol{M}$. fuscatus, the term which Blyth has proposed should be applied to it; for there can be no doubt that it is quite distinct from its southern representative, to which the term $\mathbb{M}$. speciosus would appear to be applicable. The differences which subsist between the two forms are not merely those which $\mathrm{I}$ have indicated, but there are other details of a more specific character, such as in the form of the skull, proportions of the limbs, and structure of the generative organs of the male, which separate the one from the other, although at the same time there can be no doubt that they are closely allied.

I have adopted the term $\mathbb{M}$. arctoides in preference to $\mathbb{M}$ speciosus, because the type of the former exists in the Paris Museum, whereas the latter solely rests on a drawing by Duvaucel reproduced by F. Cuvier. By relegating the term $M$. speciosus to the rank of a synonym of $M$. arctoides, and by applying the term fuscatus to the Japanese ape, an element of confusion is for ever removed.

III. arctoides would appear to have a considerable range of distribution, in which, however, it conforms to that which is distinctive of a large series of the mammalian forms which occur in the same region. It has been obtained in Cachar, and I have learned of its existence in Upper Assam, and have procured it alive in the Kakhyen hills on the frontier of Yunnan, beyond which it spreads to the southeast to Cochin China. It seems essentially to be a hill or mountain form-that is, occurring only in the mountainous regions of Cachar, absent in the valley of the Irawady, but stretching round it into Yunnan from Upper Assam, being doubtless distributed over the mountainous region that intervenes between the Irawady and Cochin China.

A few parallels to the north of the most western portion of its distribution it is represented by a closely allied species, the M. tibetanus, A. M.-Edwards, which is even a larger and more powerful ape than $\mathbb{M}$. arctoides, and clad with long and dense fur, uniformly brown, the colour, texture, and length of its pelage being in keeping with the more sombre and severe character of the climate of its area of distribution. It is also closely affined to $M$. fuscatus, but its relationship is most evident in the young state, when it presents a strong resemblance to that species, in this respect conforming to what appears to be the case generally between the young of nearly 
allied forms. For example, in a neighbouring group, the black-faced stump-tailed monkeys, $M$. ocreatus and $M$. maurus, Dr. Sclater ${ }^{1}$ states that it is hardly possible to distinguish the one from the other.

* Macacus leoninus, Blyth.

Macacus nemestrinus (?) Blyth, Journ. As. Soc. Beng. 1844, vol. xiii. p. 473.

Innuns arctoides (?) Blyth, Journ. As. Soc. Beng. 1847, vol. xvi. p. 731.

Macacus leoninus, Blyth, Cat. Mamm. Mus. As. Soc. Beng. 1863, p. 7 ; Journ. As. Soc. Beng. 1875, vol. xliv. ex. no. p. 6 ; Sclater, Proc. Zool. Soc. 1870, p. 663, pl. xxxv (male and female). Cercopithecus, Helfer, Journ. As. Soc. Beng. vol. vii. 1838, p. 858.

Macacus andamanensis, Bartlett, Land and Water, July 24, 1869, vol. viii. p. 57 ; Sclater, Proc. Zool. Soc. 1869, p. 467 et fig. (female); Hamilton, Proc. Zool. Soc. 1870, p. 220.

Tnnuus leoninus, Blyth, Journ. As. Soc. Beng. vol. xliv. 1875, ex. no. p. 2.

A thick-set powerful animal, with a broad, rather flattened head above, and a moderately short, well-clad, upturned tail, about one-third the length of the body and head. The female considerably smaller.

In the male, on the shoulders, the back of the neck, and on the upper part of the humerus, the hairs are long and annulated with orange and black, so that these portions of the animal are more brightly coloured than the others on which annulation also prevails. On the former localities the hairs measure fully three inches in length and their basal halves are greyish, and the remainder annulated with eleven alternate bands of dark brown and orange, the apical ring being of the former colour. Behind the shoulder the hair is shorter, especially on the rump. On the middle line of the back the terminal dark brown ends of the hairs change into black and increase in extent, and as they are traced backwards the last halves of the hairs become wholly black and the yellow annuli disappear; so that on the lumbar and upper surface of the sacral region, the exposed portion of the fur is black, and this colour is prolonged on to the upper surface of the tail. On the sides of the body anterior to the blackish area occupying the loins, the hair is annulated, but more or less blacktipped. The orange-olive of the shoulder pales on the lower two-thirds of the fore-limb into a yellowish olive; but all the hairs are annulated. On the outside of the thighs also and on the sides of the sacral region the hair is annulated; but on the latter area the annuli are rather obscure, and the colour is greyish, more or less washed with black; the thighs partaking of the annulation and colour of the arms, but paler, and with a more dusky tinge. The upper sides of the hands are somewhat dusky, but the feet are more so. The buttocks, even to the sides of the tail, are sparsely clad with grey fur wanting annulations; and the tail on its under surface is pale grey, except towards its end, where the black of the upper surface extends downwards and has a rusty tinge. The tail is somewhat tufted. The hair on the chest is annulated, but paler than on the shoulders, and it is especially dense on the lower part of the chest. The lower half of the insides of the anterior and pos-

\footnotetext{
1 Proc. Zool. Soc. 1871, p. 223.
} 
terior limbs is well clad with annulated fur like their outsides; but their upper halves internally and the belly are only sparsely clad with long brownish grey unannulated hairs. The upper surface of the head is densely clad with short, dark, radiating yellowish brown fur, broadly tipped with black, the hair radiating from the vertex. On and around the ear the hair is very pale grey. Above the external orbital angle and on the sides of the face the hair is dense and pale greyish, but obscurely annulated with dusky brown and grey and directed backwards, and similarly coloured hair is prolonged downwards on to the middle of the throat. These hairs are rather long and dense, but they pass inwards as very short hairs below the eye on to the hollow of the cheek, and in this region they are yellowish brown. The face generally is sparsely clad with fine hairs, and with longer hairs on the cheeks, with black hairs interspersed, and the upper and lower lips are similarly clad; and the hairs on the chin are blackish, but there is no long beard; there is a line of black, bristly, supraorbital hairs. The face is fleshy brownish on the muzzle and between the eyes; the circumorbital area and the forehead are almost white, with a bluish tinge, the line of the eyebrows being brownish, and a narrow line from the external angle of the eye outwards, reddish.

The female differs from the male in the absence of the black on the head and back, and in the hair of the under parts being brownish grey without annulations. The shoulders are somewhat brighter than the rest of the fur, which is yellowish olive; this passes into greyish olive on the outside of the limbs, into dusky on the upper surface of the hands and feet, and into black on the upper surface of the tail.

Length of male, from muzzle to root of tail 23 inches; length of tail without hair 8 inches, with hair 10 inches.

Inhabits the southern portion of Arracan and the valley of the Irawady.

The Burmese pig-tailed monkey, $M$. leoninus, is intermediate between $M$. rhesus and the pig-tailed Macaque, $M$. nemestrinus, which is its nearest ally. These two pig-tailed monkeys constitute two well-marked species, apparently much more differentiated than the species more specially allied to $\boldsymbol{M}$. rhesus are from each other, so that there is no difficulty in seizing their particular characters.

The fully matured skull (figs. 1 and 2) is considerably smaller (see following table, page 55) than that of $M$. nemestrinus. It differs from it in its very much less forwardly projected muzzle, which has more of the characters of the downwardly shelving muzzle of $M$. lasiotis, with little or no indication of an interorbital depression; the slope from the supraorbital ridge to the extremities of the nasals and premaxillæ being in a nearly straight line downwards and forwards.

It is altogether a much shorter, more globular, and more compact skull than that of Macacus nemestrinus; but, as in that species, the orbital ridges are very strongly developed, and project considerably above and outside the orbits. The upper margins are on a level with the vertex, so much so that there is a considerable depression on the frontal region behind them. The orbits are rather large, and the interorbital portion of the skull is narrow. The muzzle is moderately developed, 
and not much tapered anteriorly. The occipital is much uptilted, and the symphisis of the lower jaw is rather receding.

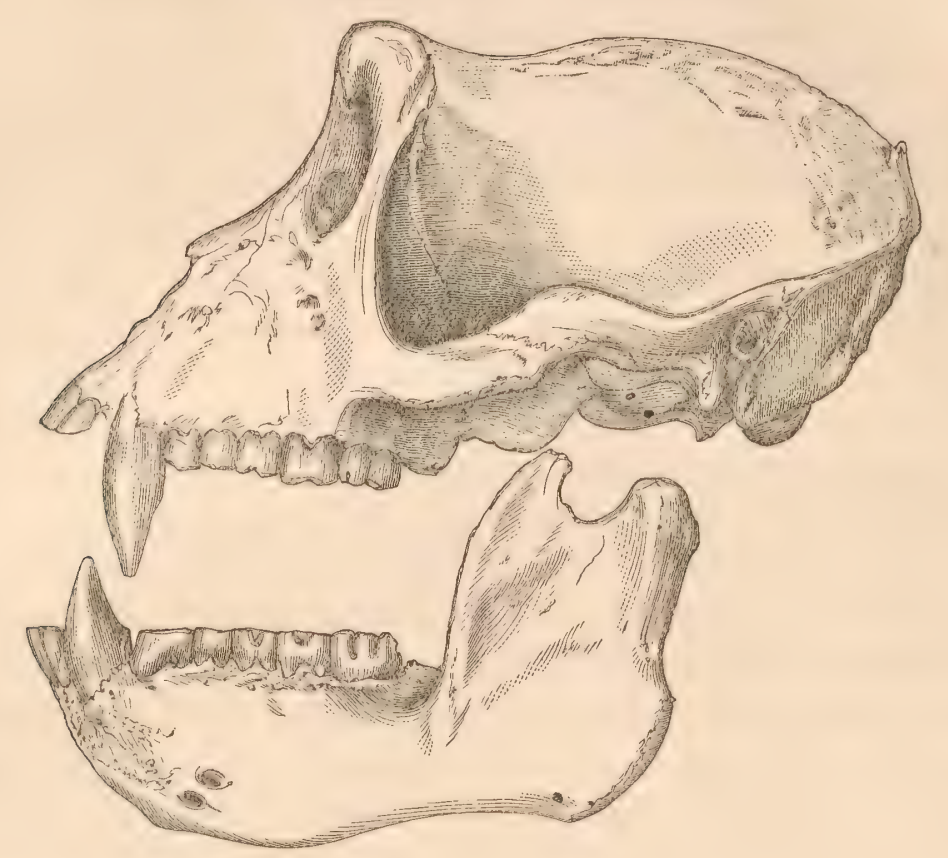

Fig. 1.-Profile of the skull of the male Leonine Monkey (Macacus leoninus) from Burma. $\frac{3}{4}$ nat. size.

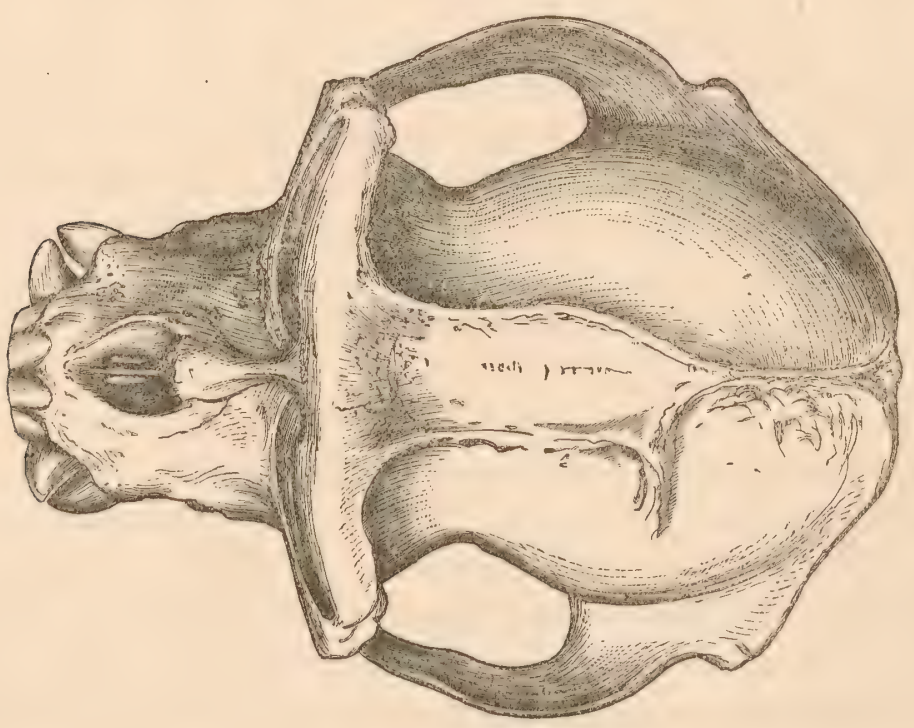

Fig. 2.-Upper view of skull of $M$. leoninus 8 , from Burma. $\frac{3}{4}$ nat. size.

The female is considerably smaller than the male skull, the ridges are but little developed, and the muzzle is less heavy, shorter, and more pointed. The occipital region also is much less uptilted. 
In $\boldsymbol{M}$. leoninus the vertebral formula is C. 7, D. 12, L. 6 to 7, S. 3, and caudal 17 to 18 . The caudal vertebræ to the sixth are very short, the sixth and seventh especially so; beyond the seventh, the segments decrease in length more rapidly than in $M$. rhesus. Hæmapophyses first begin to show themselves between the fourth and fifth caudals, and can be traced at least as far as the tenth segment. Transverse processes cease on the fourth, and the neural canal on the fifth caudal. The caudal vertebræ have all the appearance, so to speak, of degradation, and look as if they were in the process of becoming reduced to the rudimentary character which they assume in the stump-tailed monkeys.

The following are the measurements of the main regions of the vertebral column and of its caudal portion :-

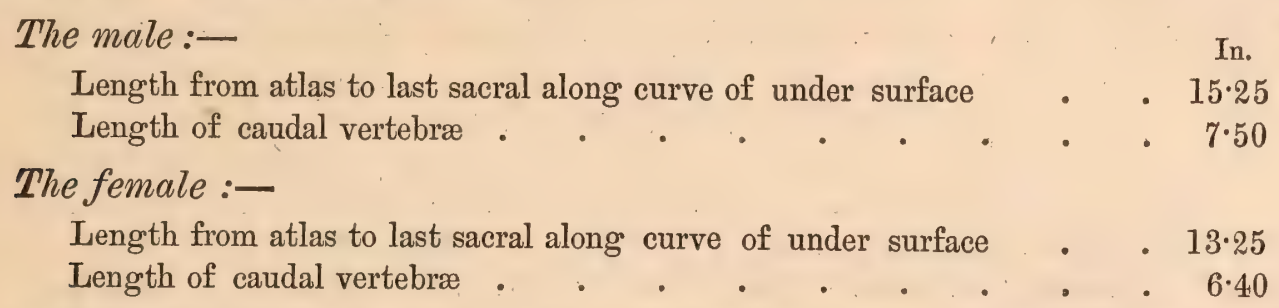

In the male the humerus is $6 \cdot 40$ inches in length, the radius $6 \cdot 15$, and the ulna 6.75 , whilst in the hind limb the femur measures $7 \cdot 20$, the tibia 6.60 , and the fibula $6 \cdot 15$ inches; the length of the manus being 4.75 and the pes $6 \cdot 15$ inches.

Measurements of the skulls of $\mathrm{M}$. leoninus and M. nemestrinus.

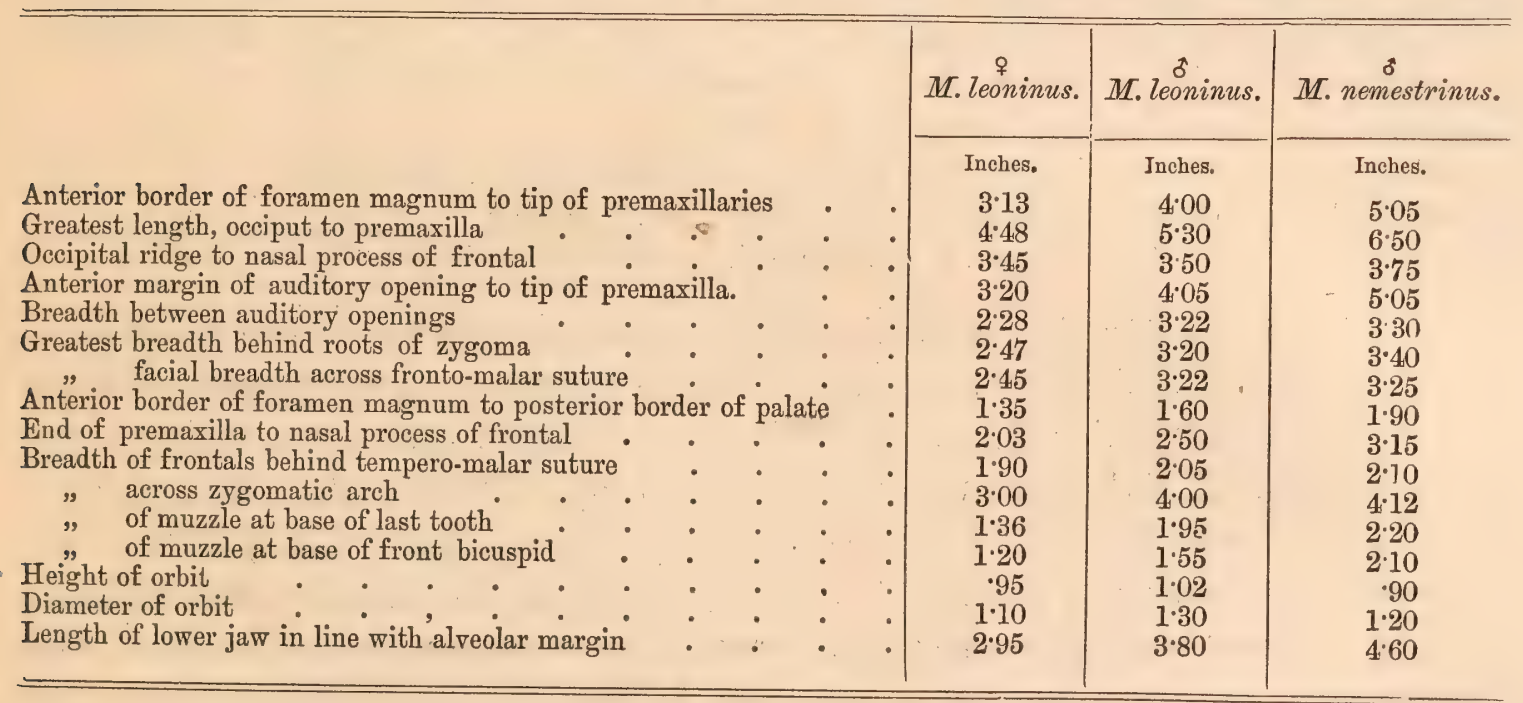

\section{*. Macacus RHesus, Audebert, var. Plate III.}

Le macaque à queue courte, Buffon, Hist. Nat. Suppl. vol. vii. 1789, p. 56, pl. xiii.; Latr. Hist. Nat. de Buffon (Sonnini), vol. xxxv. 1809, p. 312, pl. xxxiv.

Le rhesus (Simia rhesus), Audebert, Hist. Nat. des Singes, 1797, Fam. ii. sect. i. pl. 1; Latr. Hist.

Nat. de Buffon (Sonnini), 1809, vol. xxxv. p. 314; Cuvier, La Ménagerie du Mus. d’Hist.

Nat. 1809, pl. 4; Règ. An. vol i. nouv. éd. 1817, p. 109. 
The Wrinkled Baboon, Shaw, Gen. Zool. vol. i. pt. 1, 1800, p. 33.

The Bandar, Hodgson, Journ. As. Soc. 1832, vol. i. p. 339.

Simia erythrcea, Schreber, Säugeth. Suppl. pl. viii. c. fig. Buffon.

Innus (?) Simia fulva, ${ }^{1}$ Shaw, Gen. Zool. vol. i. pt. 1,1800, p. 51.

Innuus rhesus, Geoffroy St.-Hil. Ann. du Mus. vol. xix. 1812, p. 101 ; Kuhl. Beitr. zur. Zool, 1820, p. 17 ; Blyth, Journ. As. Soc. vol. xvi. 1847, p. 731 ; Cat. Mamm. As. Soc. Bengal. 1863, p. 8 ; Jerdon, Mamm. Ind. 1867, p. 11.

Pithecus rhesus, Desm. nouv. Dict. d'Hist. Nat. vol. xviii. 1817, p. 325; Griffith, An. Kingd. vol. v. 1827, p. 18.

Macacus erythrous, Cuv. Hist. Nat. des Mamm. Oct. 1819, pl. xxxviii, juv.; March 1821, pl. 36 \& ; May 1821, pl. xxxix; March 1825, pl. xl; Is. Geoff. St.-Hil. Zool. du Voy. de Bélanger, 1834, p. 59 ; Cat. Méthod. des Mammif. 1851, p. 30 ; Gervais, Hist. Nat. des Mammif. 1834, p. 91, fig. head to et 후; Swinhoe, Proc. Zool. Soc. 1870, p. 226.

Macacus rhesus, Desmarest, Mamm. 1820, p. 66, pl. vii. fig. 2 (Buffon); Dict. des Sc. Nat. vol. xxvii. 1823, p. 468; Lesson, Man. de Mamm. 1827, p. 42; G. Cuv. Règ. An. nouv. éd. vol. i. 1829, p. 95 ; Fischer, Syn. Mam. 1829, p. 29 ; Waterhouse, Cat. Mam. Mus. Zool. Soc. Lond. 1838, 2nd ed. p. 8; Lesson, Sp. des Mammif. 1840, p. 95 ; Gray, Hand-list Mamm. B. M. 1843, p. 8; Blyth, Journ. As. Soc. Beng. vol. xii. 1843, p. 174; vol. xiii. 1844, pp. 471-476 ; Schinz, Syn. Mamm. vol. i. 1844, p. 57 ; Gray, Hodg. List, Nepal, Mamm. 1846, p. 2 ; Horsfield, Cat. Mam. E. Ind. Co. Mus. 1851, p. 19 ; Hutton, Proc. Zool. Soc. 1867, p. 951; Gray, Cat. Monkeys and Lemurs, B. M. 1870, p. 31 ; Sclater, Proc. Zool. Soc. 1871, p. 222.

Innuиs (Maimon) erythrcus, Wagner, Schreber, Säugeth. Suppl. vol. i. 1840, pl. 142, p. viii. c. fig. Buffon.

Papio rhesus, Ogilby, Madr. Journ. Lit. \& Sc. vol. xii. 1840, p. 144.

Macacus (Pithex) oinops, Hodgson, Journ. As. Soc. Beng. vol. ix. 1840, p. 1212, fig. head, p. 1213 ; vol. x. 1841, p. 908 ; Cal. Journ. Nat. Hist. vol. ii. 1842, p. 212 ; Ann. \& Mag. Nat. Hist. vol. viii. 1842, p. 3]5, fig. head; Cal. Journ. Nat. Hist. vol. iv. 1844, p. 285.

Macacus oinops, Gray, Hand-list Mamm. B. M. 1843, p. 8.

Innuns (Rhesus) erythrcus, Wagner, Schreber, Säugeth. Suppl. vol. v. 1855, p. 56.

Pithecus (Macacus) erythrceus, Dahlbom, Stud. Zool. Fam. Reg. Ann. 1856, pp. 116, 119.

Innuus assamensis, Blyth, Journ. As. Soc. Beng. vol. xxxiv. 1865, p. 192.

I obtained at Momien a monkey so closely resembling $\mathbb{M}$. rhesus, that I have no course left but to describe it as such, although it exhibits at the same time some variation from the Indian form. It is also not unlike $M$. assamensis, but is distin. guished from it by its longer body and tail and more slender limbs. This animal, (Plate III), it was alleged, had been recently caught in the Momien district, but I am disposed to discredit the statement, as the country in the immediate neighbourhood of Momien appears to be quite unsuited to monkeys, being devoid of trees and at an elevation over 5,000 feet. My impression, therefore, is that it had been brought from some neighbouring forest region to the south and from a lower elevation.

I also procured in the Hotha valley another monkey, even more intimately affined to the common Indian race than the previous individual, so much so

\footnotetext{
1 To this may perhaps be prefixed Cercopithecus malatta, Zimmermann, Geograph. Gesch. vol. ii, 1780, p. 1195 ; Boddaert, Elench. Animal, 1785, p. 61 ; Fischer, Syn. Mam. 1829, p. 29, and which is founded on the tawny monkey of Pennant, Syn. Mam. 1771, p. 120, Tab. 13, fig. 2, and Shaw, Gen. Zool。 vol. i. pt. I (1800), p. 57.
} 
that there seems no doubt that it is an example of this species. It had been also in captivity, but I could gather no information as to the locality whence it had been obtained.

Besiảes these two monkeys I am indebted to Dr. Marfels, Conservator of Forests to the King of Burma, for a Mracaque agreeing in every respect with $M$. rhesus, from living examples of which in the Zoological Gardens, London, where it now is, it cannot be distinguished. Dr. Marfels unfortunately could not give me the locality from whence he obtained it and another of the same species, except that they had been brought to him by some of his employés who were engaged in forest work at no great distance from the capital. On my way up the river in 1875, I observed a large troop of monkeys exactly resembling $\mathbb{M}$. rhesus feeding among the stunted bushes that occur on the high sandy cliffs that overhang the left bank of the river, below Yenangyoung.

The only wild monkey allied to $M$. rhesus that is observed in the northern portion of the country, viz., about Bhamô, is the monkey which I have referred to $M$. assamensis, so that it appears probable that $\mathbb{M}$. rhesus has a distribution to the south of that of the former. It is extremely difficult to offer any satisfactory explanation of the occurrence of these monkeys in the high valleys of Momien and Hotha. I think it highly improbable that they were taken from Burma, as in 1868, when I procured these specimens, the country had for years been convulsed by revolution, and any communication with Burma, except for the necessities of life, had been for years denied to the unfortunate inhabitants of that high region.

Both of these first-mentioned monkeys I had alive in my possession in Calcutta for fully two years, and during that period I more than once compared them with living examples of the Bengal monkey of their own sex (female) and of various ages; the only differences I could detect between them were that they seemed more slightly built than $M$. rhesus, that their hair was rather shorter, softer, and more adpressed and slightly more brilliant in colouring; also, that the Momien specimen had a duskier face, and that the area external to and below its callosities was densely clad, whereas the other animal had it semi-nude, as in $M$. rhesus, associated with a somewhat shorter tail. While I regarded the Hotha monkey as a local race of this species, I was still so dubious about the other as to watch carefully during the two years of its captivity in the expectation that time might reveal some determining feature, but none developed itself.

One description, in which I shall compare and contrast the external characters, may sufice for both these Yunnanese monkeys, and I shall refer to the specimen from Hotha as $\alpha$ and to the duskier-faced form as $\beta$. The basal portion of the hair is greyish brown, so to speak, succeeded by a rich yellowish area, terminating in a dark brown or blackish tip. This richly rufous, annulated appearance is confined to the upper surface of the animal on its anterior half, extending on to the fore-limbs of $\beta$, but only down the brachium of $\alpha$, the 
antibrachium of which is gray. On the hinder quarters and outsides of the thighs the terminal half of the hairs are wholly rufous-yellow, so that these portions contrast forcibly with the former. In $\beta$, the cheeks and supraorbital ridges are surrounded with a fringe of long black hairs which are continued down to the angle of the mouth, whereas in the other female there are only a few very short black hairs in these situations. In both, the hairs half-way between the ear and the angle of the mouth tend to form a whorl. The hair behind the ears and the back part of the cheek are in $\beta$ annulated in the former and yellowish in the latter locality, but in $\alpha$ they are uniformly yellowish grey, and longer and more wavy than in the former. In life, the face of $\beta$ was seen to be more dusky ${ }^{1}$ than is generally the case in $M$. rhesus, while in $\alpha$ it was pale, as in this species, and periodically flushed with crimson, which did not occur in $\beta$. The hair on the top of the head in both is directed backwards. In both, the under parts and insides of the limbs are very pale yellowish white with a silky lustre. In $\alpha$ there is an extensive area external to and below the callosities, which is only sparsely covered with very short obscure white hairs, while in $\beta$ the region below and around the callosities is clad with long rufous hairs.

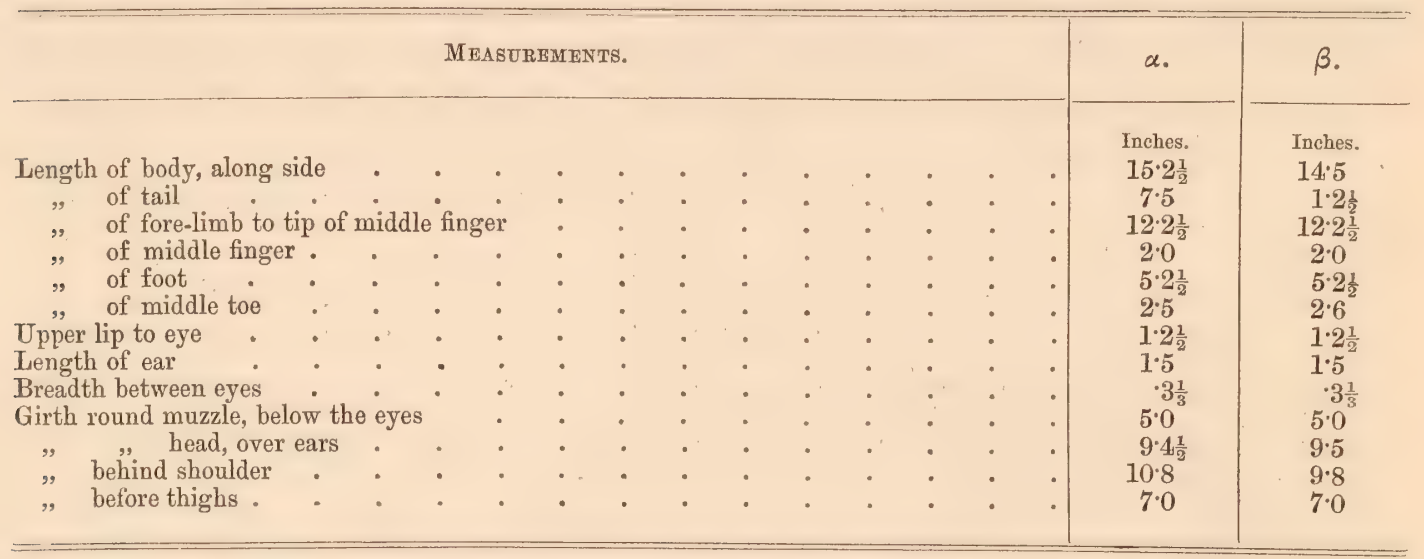

The above table shows that while the larger individual had a slightly shorter tail, they agree in other respects, allowance being made for the greater age of $\alpha$, and this harmony prevails in the bones, the measurements of which follow. The only differences of form observable in the skeleton of $\beta$, as compared with $\alpha$, are the greater forward curvature of the proximal end of the humerus and more prominent character of the deltoid ridge. But we are met with the fact that the skeleton of $\beta$ has 13 ribs, its vertebral elements being-cervical 7, dorsal 13, lumbar 6, sacral 3, caudal 20 -forty-nine in all, while in a the normal number of ribs prevails with 6 lumbar

1 Darwin records that $\mathrm{Mr}$. Bartlett has observed that in all species of monkey known, in which the adults of both sexes have strongly-coloured faces, the colours are dull and absent during early youth, and he remarks that this likewise bolds good of M. rhesus. This animal may, therefore, have been longer in reaching maturity than the other, which seems probable from the circumstance that the occasional temporal flushing and enlargement of its buttocks was very much less intense. Mr. Bartlett has also observed that the naked surfaces extend with ageDescent of Man, vol. ii, pp. 310 and 377. 
vertebræ and 18 caudal $=$ only forty-six vertebræ. The skeletons are ligamentous and perfectly entire, even to the last caudal ossicle. The 13th rib of the former specimen is a short straight bone, an inch in length. There are eight true ribs in each. In $\beta$, the mammillary processes appear on the 11th dorsal and in $\alpha$ on the 10 th ; in the former the anapophyses first show themselves on the 13th dorsal and gradually decrease in size from the 3rd lumbar vertebra, these processes following a similar course in the twelve-ribbed specimen, $i$. e., commencing on the 21 st segment. The caudal vertebræ gradually increase in length from before backwards as far as the 8th, beyond which they again shorten. The last trace of the neural arch occurs in the 5th caudal vertebra, on which the laminse are prolonged for only two-thirds of its extent. In a there is a tubercular-like neural spine on the 1st caudal only, but in $\beta$ there is no trace of it. The transverse process of the 1st caudal has considerable antero-posterior expansion, but in the succeeding vertebræ it gradually decreases, and disappears on the 6th. In both examples, chevron bones well developed occur first between the 2nd and 3rd caudals up to the 5th and 6th, beyond which they do not extend, although a pair of hyperpophyses can be detected for some distance backwards. In both these females, the manubrium is followed by seven osseous segments terminated by the xiphoid, which is much longer and more expanded in $\beta$ than in $\alpha$. The sternal elements also immediately preceding the xiphoid are considerably longer in the latter than in the former, in which the total sternum is $3 \cdot 36$, whilst in $\beta$ it is $3 \cdot 66$. The manubrium of $\beta$ is unsymmetrical, being larger in its left than in its right half, to the former of which the cartilages of the 1st and 2nd ribs are together attached, whilst the opposite bears only the 1st rib. The clavicle of $\beta$ is a shorter and stouter bone than that of $\alpha$, measuring 1.84 as compared with $2 \cdot 08$.

The pelvis of $\alpha$ has greater capacity and posterior breadth than $\beta$, in which the distance between the callosities at their middle is only 75 , in a being $1 \cdot 18$, while between the position of the ischial spines the pelvis of a has a breadth of 1.22 and $\beta$ of 1.52 . These little differences, however, can hardly be regarded as more than individual.

These skeletons do not present any anatomical features which would entitle them to be regarded as specifically distinct from $M$. rhesus. The existence of 13 dorsal vertebræ in $\beta$ being associated with only 6 lumbar vertebræ shows that this monkey, which in its external characters differs somewhat from $\boldsymbol{M}$. rhesus, is by its osteology more allied to it than $\alpha$, which, in its peripheral features, differs in no respect from $M$. rhesus. I have referred to the existence of only 18 trunk vertebræ in the latter specimen under $M$. assamensis, the Burmese example of which is also distinguished by a similar number of trunk vertebræ.

In three skeletons of $\mathbb{M}$. rhesus in the Royal College of Surgeons in which the tail is entire there are from 17 to 18 caudal vertebræ, the specimen No. $4991^{1}$ having the tail imperfect; but as the foregoing monkey $\beta$ has 20 tail segments, the varia- 
tion of the caudal vertebræ of $\boldsymbol{M}$. rhesus is greater than has been generally supposed.

The skulls of these two monkeys so resemble each other in age and general dimensions that there can be no question as to their specific identity, and, moreover, they do not present a single anatomical feature by which they can be separated from M. rhesus, and in support of the latter statement I figure the skull of a (figs. 3 and 4) and append the measurements of both. It will also be observed that this skull

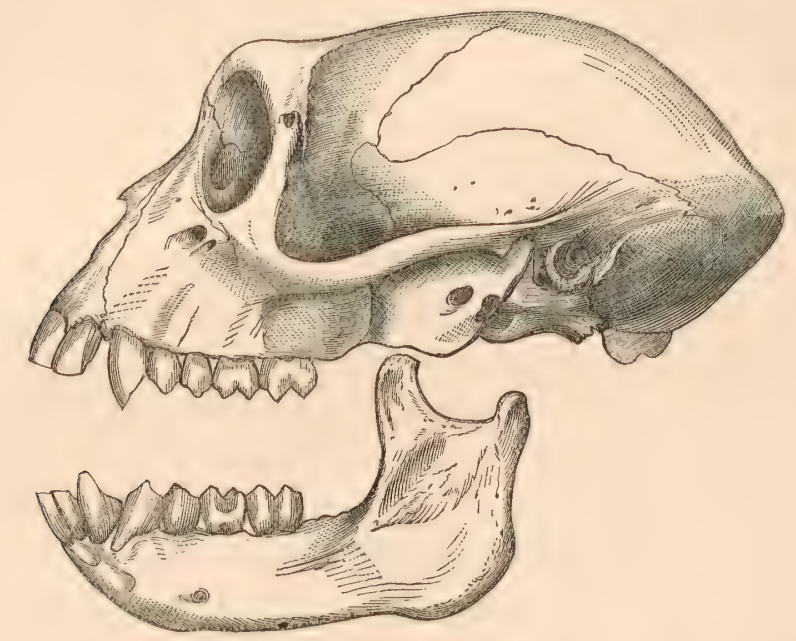

Fig. 3.-Lateral aspect of the cranium of the variety of $M$. rhesus, Desm., found in Yunnan. $\frac{3}{4}$ nat. size.

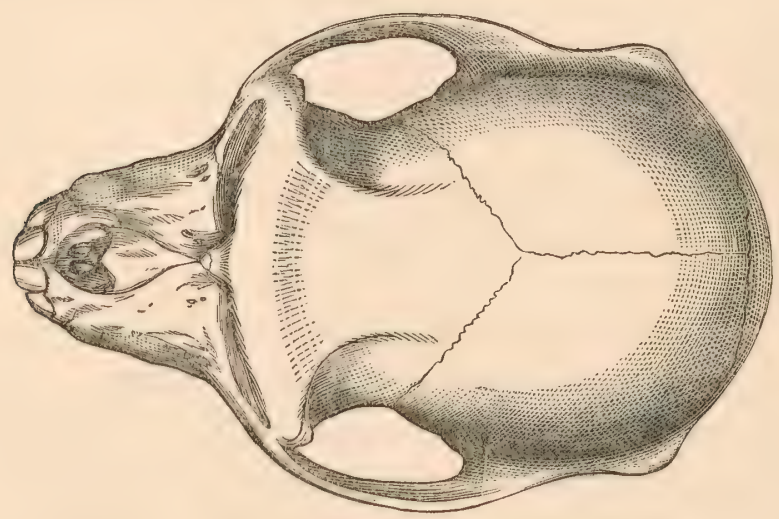

Fig. 4.-Upper aspect of the cranium of the variety of $M$. rhesus, Desm., found in Yunnan. $\frac{3}{4}$ nat. size.

is extremely closely allied to the female skull of $\mathbb{M}$. tcheliensis (= M. lasiotis, Gray) as figured by A. M.-Edwards in his able work on the Mammals of China and Tibet, and from which it is chiefly distinguished by the depression of the frontal region and its greater contraction in the temporal fossa and by the lesser rotundity of the parietals. Moreover, although it appears to be of the same age as $\boldsymbol{M}$. tcheliensis, the last tooth having not pierced the jaw in either, itis an appreciably smaller skull. 


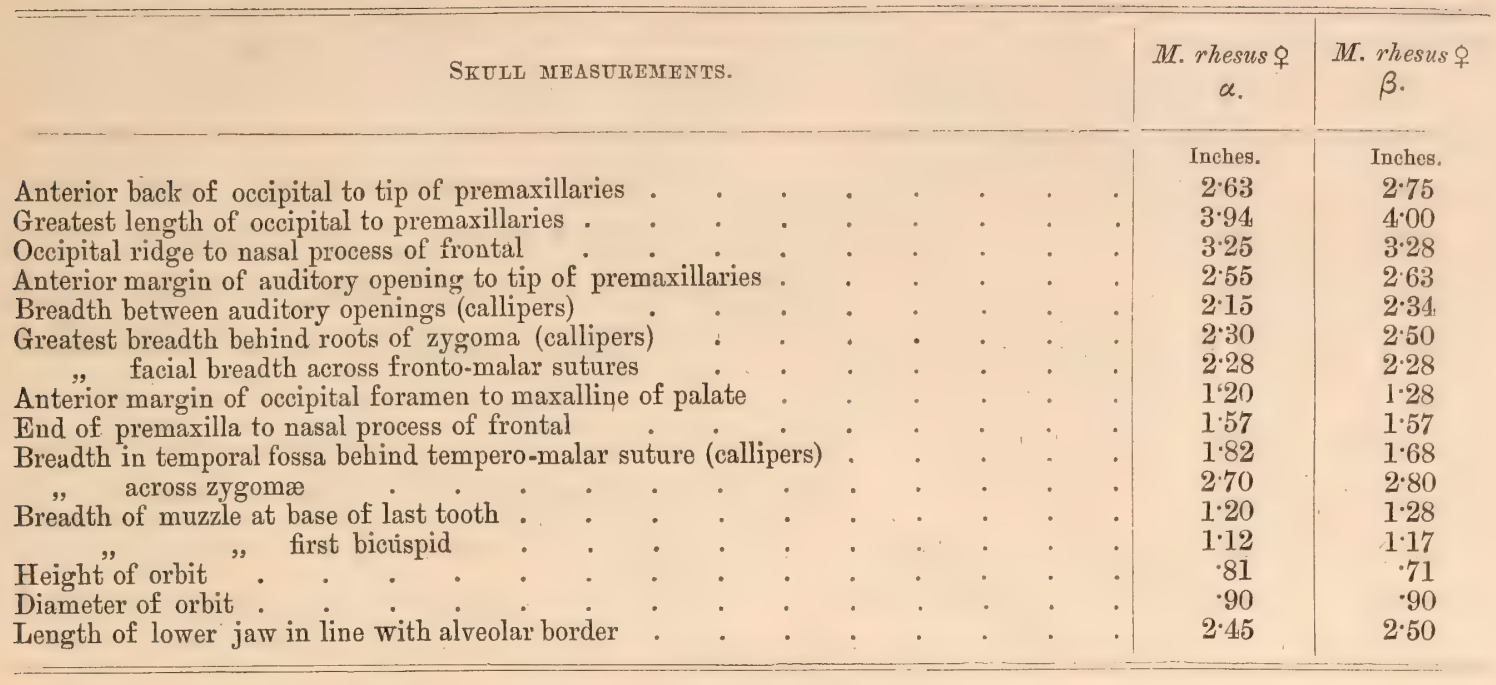

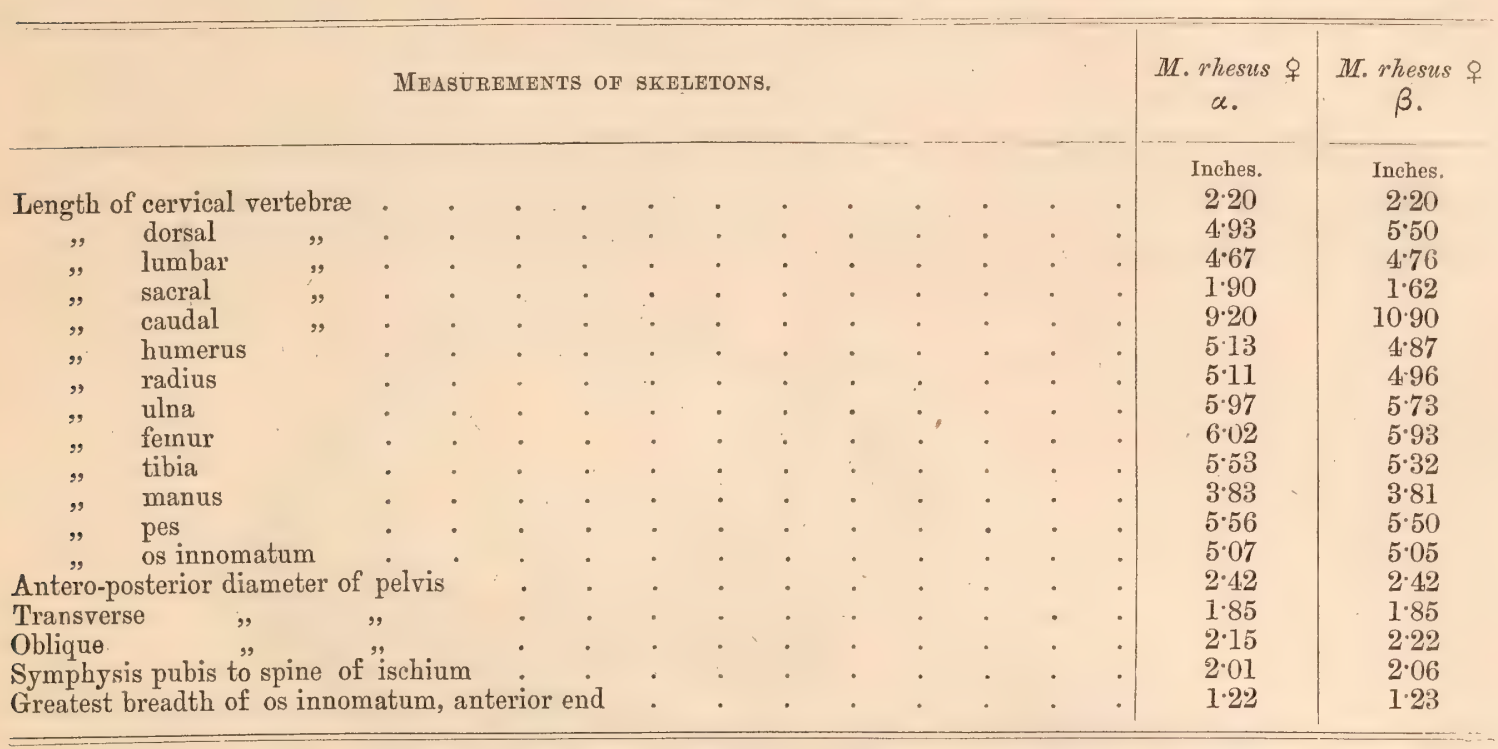

Neither Mr. rhesus nor $M$. assamensis were included in Blyth's posthumous Catalogue of the Mammals of Burma, ${ }^{1}$ because it was not until the expedition of 1875 that I received the first from the valley of the Irawady on the authority of Dr. Marfels, the Conservator of Forests to the King of Burma, and it was only on the same occasion that I procured an example of the last from the second defile of the Irawady below Bhamô.

A monkey thus in no way separable from the Indian M. rhesus would appear to stretch across Burma to the hills defining the left bank of the valley of the Irawady, and to be associated in the same region with the next species, the distribution of which, however, would appear to be more restricted to the northern portion of the valley.

With regard to $M$. oinops, a careful consideration of the characters assigned to it by Hodgson does not reveal a single feature by which it may be separated 
from $M$. rhesus, and when the various specimens which were forwarded by Hodgson from the southern region of Nepal to the British Museum are critically examined and compared with the common bandar of Hindustan, the observer searches in vain for any character of specific importance by which to separate them. Also, when the close proximity of the southern portion of Nepal to the Terai is kept in view, along with the circumstance that $\boldsymbol{M}$. rhesus is widely distributed over the latter region, there is nothing remarkable in the fact that the animals of both localities agree.

In the British Museum there are two skulls of M. oinops presented by Hodgson, but unaccompanied by their skins. The one is a male and the other a female. In the male, the naso-orbital process of the maxilla is nearly vertical and the nasals are rather deeply concave, and the portions of the maxilla lying between the nasals and the orbital margins are concave or depressed; the breadth across the base of the muzzle being but little in excess of its breadth over the anterior margins of the canine alveoli: but all of these characters belong to a not uncommon type of M. rhesus, in which, however, the relative breadth of the muzzle at its base and at its extremity is the subject of considerable diversity, apart altogether from the effects of age. This skull is fully adult, and as it is interesting as a ferine example of this species, I give the accompanying figures of it (figs. 5 and 6).

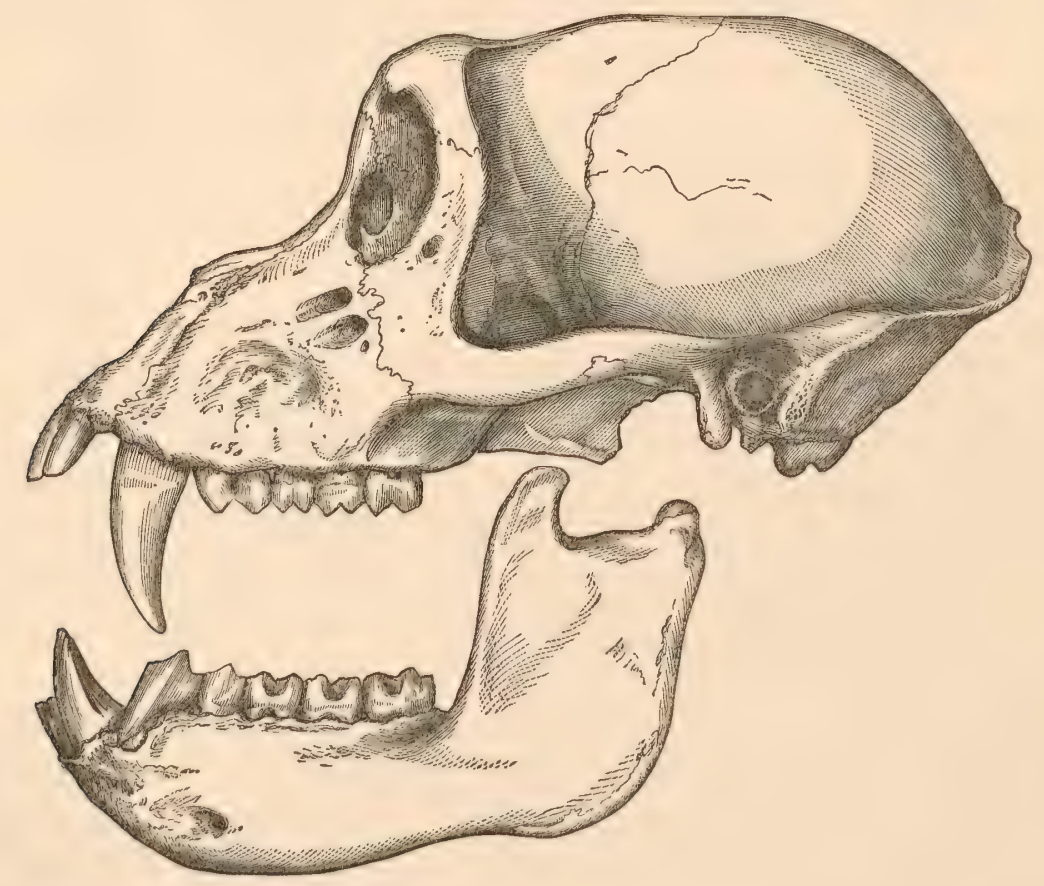

Fig. 5. - Skull of $M$. rhesus, from Nepal, the type of Hodgson's $M$. (pithex) oinops. $\frac{3}{4}$ nat. size. 


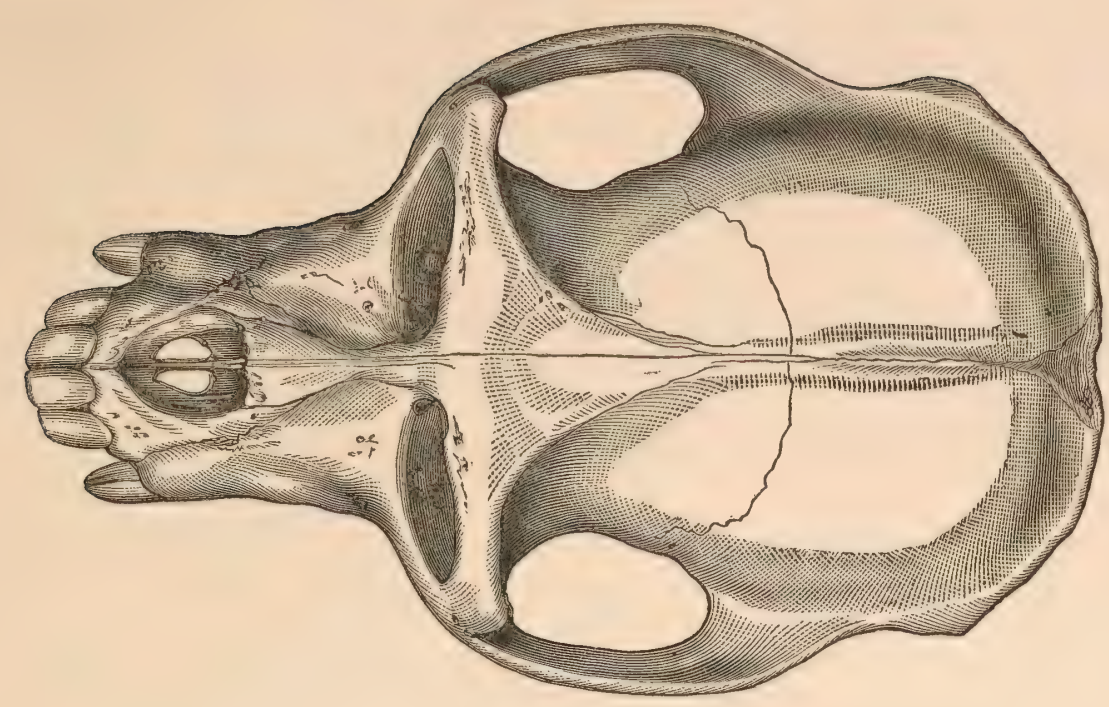

Fig. 6.-Upper aspect of the skull fig. 5. $\frac{3}{4}$ nat. size.

The female skull also is fully adult, and it differs from the male in its much smaller size, and in being smooth and rounded, the frontals arching upwards and backwards from the supraorbital margins, which do not form ridges. In aged females, however, the supraorbital ridges become well marked, also the temporal ridges.

A monkey resembling $M$. rhesus occurs in Kashmir, and is sometimes found at an elevation of 10,000 feet. It is described as being a redder monkey than $M$. rhesus, with a perfectly distinct cry. It is called by the natives the Prinj or Ponj. Its specific characters are unknown, but should it resemble the monkey which lived a few years ago in the Zoological Gardens, London, where it was known as the Kashmir monkey (M. pelops), it would appear not to differ specifically from $M$. rhesus. This animal, however, supposed to be from Kashmir, was purchased either at Agra or Delhi from a native who asserted that it came from Kashmir; but knowing how freely the term "Kashmir" is employed by natives who consider that the value of an object is enhanced in the eyes of Europeans by its being assigned to Kashmir, no reliance can be placed on the alleged habitat. At the same time this so-called Kashmir monkey now deposited in the British Museum (71. 3. 3. 5.) has the rufous colouring of the hinder half of the body more brilliant than in the generality of examples of $M$. rhesus from the plains, but with the colours conforming to the same kind and distribution, so that the differences between them are only of that grade which is generally considered as distinctive of a race.

Hodgson has also figured in his manuscript drawings a pale, almost albino-like, Macaque from Sikhim, but no definite information regarding it has been recorded. 


\section{* Macacus assamensis, M'Clelland.}

A supposed new monkey, Andr. Proc. Zool. Soc. Lond. 1872, p. 529 (figs. of skull).

Macacus assamensis, M'Clelland, Proc. Zool. Soc. Lond. 1839, p. 148 ; Walker, Cal. Journ. Nat. Hist. vol. ii. 1842, p. 265 ; Schinz, Syn. Mamm. vol. i. 1844, p. 57 ; Blyth, Journ. As. Soc. Beng. 1844, vol. xiii. p. 476 ; Ann. and Mag. Nat. Hist. vol. xx. 1851, p. 313 ; Cat. Mamm. Mus. As. Soc. Beng. 1863, p. 8; Horsfield, Cat. Mamm. E. Ind. Co. Mus. 1851, p. 2 l ; Sclater, Proc. Zool. Soc. 1868, p. 566 ; Ibid, 1871, p. 222; Blyth, Journ. As. Soc. Beng. vol. xliv. 1875, ex. no. p. 5 .

Papio assamensis, Ogillby, Royle's Ill. Him. Bot. Mamm. 1840, p. 6 ; Madr. Journ. Lit. and Se. vol. xii. 1840, p. 144 .

Macacus (Pithex) pelops, Hodgson, Journ. As. Soc. Beng. vol. ix. 1840, p. 1213; Ibid, vol. x. p. 908 ; Cal. Journ. Nat. Hist. vol. ii. 1842, p. 212 ; Ann. and Mag. Nat. Hist. vol. viii. 1842, p. 315 ; Cal. Journ. Nat. Hist. vol. iv. 1844, p. 285.

Macacus pelops, Schinz, Syn. Mamm. vol. i. 1844, p. 60 ; Gray, Hodgson, Coll. Nepal, Mamm. \&c. 1846, p. 2; Blyth, Ann. and Mag. Nat. Hist. vol. xx. 1851, p. 313 ; Gray, Cat. Monkeys and Lemurs (in part), 1870, p. 30.

Inuus (rhesus) pelops, Wagner, Schreber, Säugeth. Suppl. vol. v. 1855, p. 56.

Inuиs (rhesus) assamensis, Wagner, Schreber, Säugeth. Suppl. vol. v. 1855, p. 57.

Inuus assamensis, Hutton, Journ. As. Soc. Beng. vol. xxxiii. 1864, Appendix, p. xiii.

Inuus pelops, Hutton, Journ. As. Soc. Beng. vol. xxxiii. 1864, Appendix, p. xiii.; Jerdon, Mamm. Ind. 1867, p. 11 ; Blyth, Journ. As. Soc. Beng. vol. xliv. 1875, ex. no. p. 6.

Macacus problematicus, Gray, Cat. Monkeys and Lemurs, B. M. 1870, p. 128; Sclater, Proc. Zool. Soc. 1871, p. 222.

Macacus rheso-similis, Sclater, Proc. Zool. Soc. Lond. 1872, p. 495, Pl. xxv. juv.

The type of $M$. assamensis in the Indian Museum, London, is an adult male. It is a stuffed specimen, but the skull has been removed from the skin and is not in the Museum. This monkey differs from all adult examples of the common monkey of the plains of India which have come under my observation in the anterior half of the body wanting the ashy tint which is so characteristic of the adults, and in the hinder portion of the body being in no way rufous. The fur, too, is almost completely devoid of amnulations, and the hair around the face and on the chin is longer than in animals from the plains. The general colour of this old specimen may be described as brown, washed over the outer side of the fore-limbs, and more especially between the shoulders and the back of the neck, with yellowish, which appears in certain lights as a pale golden, passing on the upper surface of the head into a pale-yellowish brown. The general brownish tint is darkest on the flanks, where it has a fuliginous tinge, and down the front margin of the fore-limbs, over the outer surface of the thighs, the dorsi of the feet and on the tail. The inside of the limbs and the under surface generally are much paler than the upper parts, and have a yellowish tint, inclining to grey. Behind the angle of the mouth, and below and behind the ears and on the chin, the hair is rather long and nearly of the same colour as the under surface, but slightly tipped with blackish. 'There is a moderately dense line of rather long supraorbital hairs with a pencil of similar hairs extending backwards from the external orbital angle of the frontals. 
The hair generally is wavy, and on the shoulders and between them above and on the sides of the chest it is much longer than on the hind part of the body, with the exception of the dark hairs on the lower part of the flanks, which are also rather long. The hair on the vertex radiates from a point about one inch above the level of the supraorbital ridge, and a few of the front hairs are directed forwards, but the mass outwards and slightly backwards, which is also the direction of the hairs external to the radiating point. There are a few long black supraciliary hairs, also others on the upper lip and chin. The callosities are closely surrounded by the fur. The length of the animal along the curve of the head and back is 26.75 inches, the tail measuring $9 \frac{1}{4}$ inches.

I obtained on the right bank of the Irawady, about twenty to twenty-five miles below Bhamô, a female monkey which closely agrees with the type of $M$. assamensis,so much so that it is impossible to resist the conclusion that they are one and the same race. It was one of a large colony living below the huge Deva-faced, limestone cliff, at the foot of which lies the small pagoda of Sessoungan. The crews of passing boats and pious visitors generally throw rice and fruits to these monkeys as a work of merit. I observed another and similar colony some miles further down the river on the same bank. At the time, I noted that the adults are apparently larger and more powerful than $\boldsymbol{M}$. rhesus. They have moderately long tails; their bodies are dark brown above, the under parts palish, but contrasting decidedly with the former colour.

The solitary specimen I succeeded in obtaining at that colony was a gravid female, of which the following is a description.

This monkey is uniformly brown, with a rufous golden tinge over the shoulders and neck, the latter tint paling on the head, more especially over the external angle of the forehead. It is pale yellowish behind the ears and on the back part of the cheeks, where there are a few intermixed black hairs. There are a few black supraorbital hairs, and the ears are tufted with hairs of similar colour besides being well clad internally. The face is surrounded, from behind the ears to the chin, by long pale yellowish hairs, and the beard is well developed, the hairs having a well-defined, almost black, subapical band. The limbs externally and the upper surfaces of the feet are concolorous with the hinder quarters of the animal. The under surface of the body and limbs are of a pale yellowish. The tail is dark brown at the base, paling somewhat towards the tip, which is slightly tufted. The face and ears are dusky. The buttocks are densely clad with hair to the sides of the callosities, but below the vulva there is a small bare area which in life is suffused with dark purple. This, however, is a gravid female, and I do not know what may be the characters of this region in the female in heat.

The hair on the vertex radiates more or less; on the forehead it is erect and rather short and dense, tending to divide outwards and forwards, and on the shoulders it is longer than on the hind part of the body. 
The following are the measurements of this female :-

\begin{tabular}{|c|c|c|c|c|c|c|c|}
\hline Tip of muzzle to root of tail along side & & . & . & • & . & . & $17 \cdot 2$ \\
\hline Length of the tail & . & . & . & . & . & . & $7 \cdot 6$ \\
\hline$"$ of hand to tip of middle finger & . & . & . & . & . & . & $4: 0$ \\
\hline$"$ of foot to tip of middle toe & 0 & . & . & . & . & - & $60^{\circ}$ \\
\hline Breadth between inner angles of eyes & • & . & . & . & . & . & 5 \\
\hline „, across outer angles . & . & . & . & 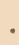 & . & & $1 \cdot 8$ \\
\hline
\end{tabular}

The accompanying figures (figs. 7 and 8) of the skull, reduced to three-fourths

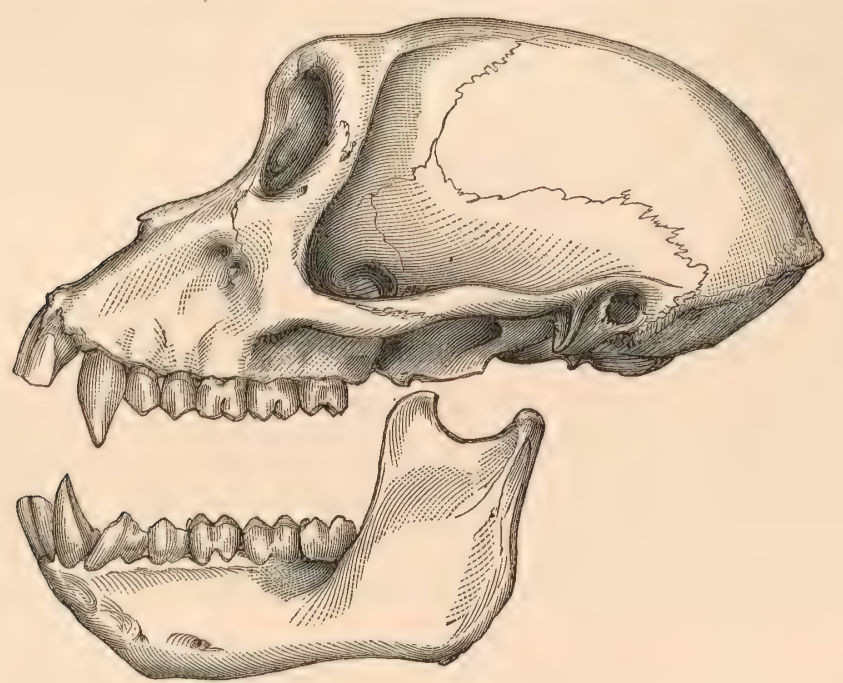

Fig. 7.-Lateral view of the skull of the Irawady monkey ( ㅇ) M. assamensis.

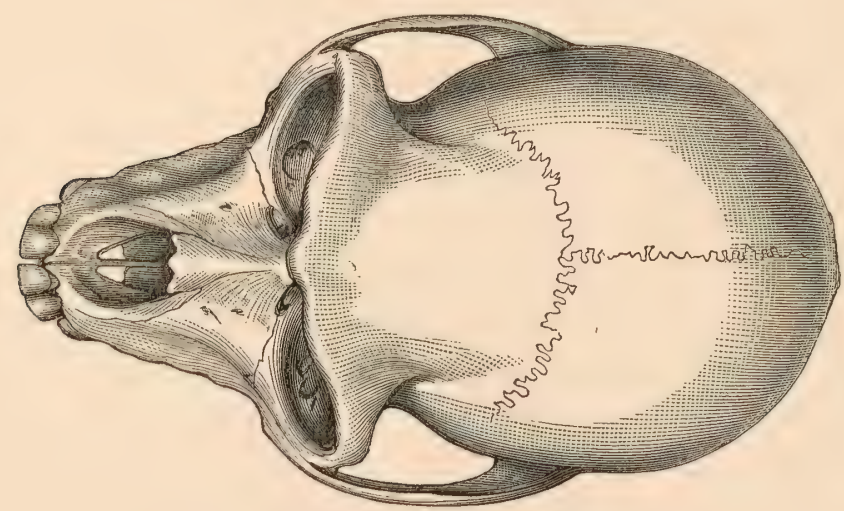

Fig. 8.-Upper view of the same skull as fig. 7 .

natural size; will exemplify its characters, while the column of measurements, alongside of which $I$ have given the corresponding dimensions of a ferine individual of the same sex of $\mathbb{M}$. rhesus, will illustrate wherein the two appear to differ; but as there are not sufficient materials wherewith to generalise, these must be regarded more as a record of facts to aid further research than as an attempt to draw any rigid line between the two species. 
The characters of the pelvis of this thoroughly ferine example of this species are worthy of being noted in view of Dr. Murie's remarks on the pelvis of the female of $\boldsymbol{M}$. cyclopis. The pseudo-sacral vertebra and the first caudal are in the same plane with the sacrum, and from the uptilting characterising them and the sacrum more capacity is conferred on the cavity of the pelvis than in M. cyclopis. The bone anterior to and behind the thyroid foramen is thin and transparent, but of great hardness, and thus contrasts much with the generally thickened and opaque character of these parts in monkeys kept in confinement, and on what is so marked a feature in the pelvis of $M$. cyclopis. The vertebræ and all the long bones correspond to those of $\boldsymbol{M}$. rhesus. The manubrium also has the same form as in the latter monkey, but there are only five sternal pieces behind it.

Measurements of skulls of the Irawady Monkey $q$, and of $M$. rhesus 8 , and M. rhesus \&:

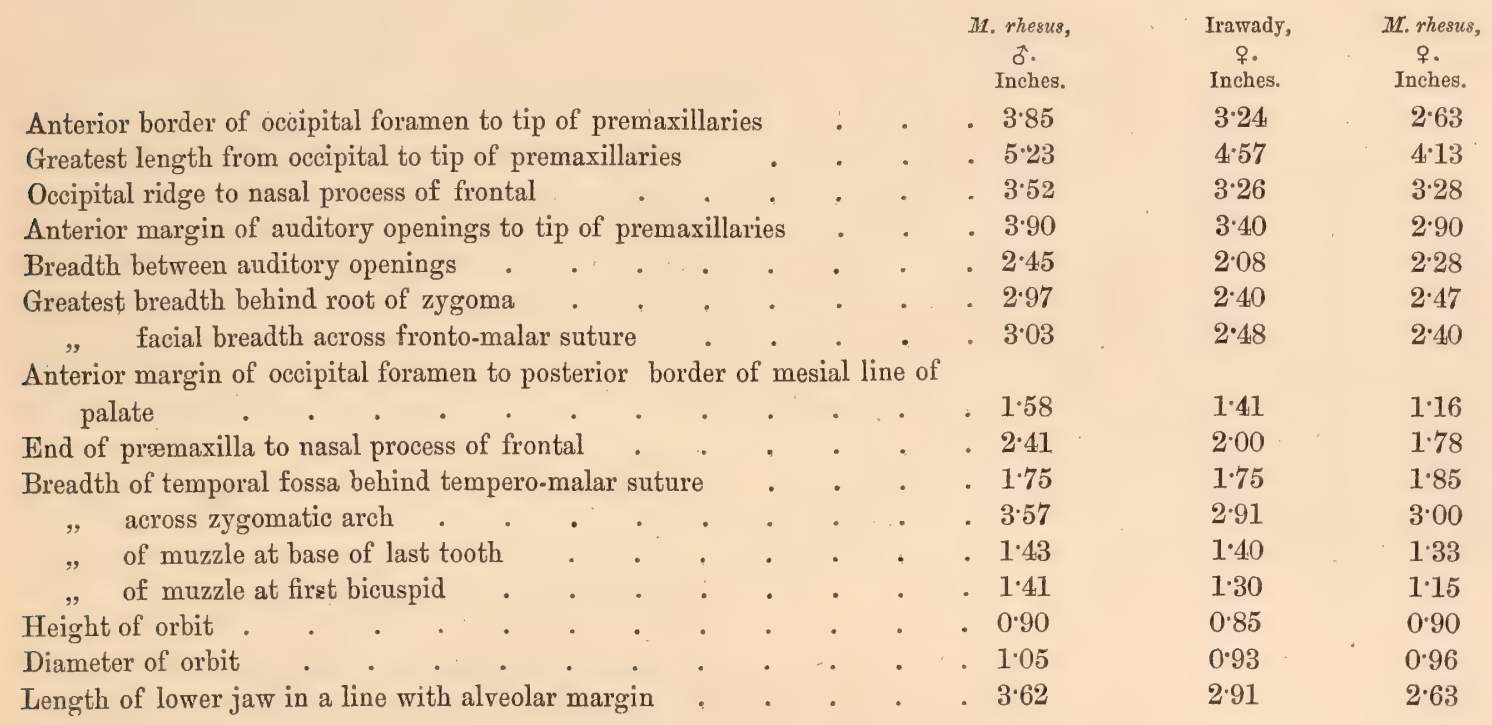

Measurements of skeleton :

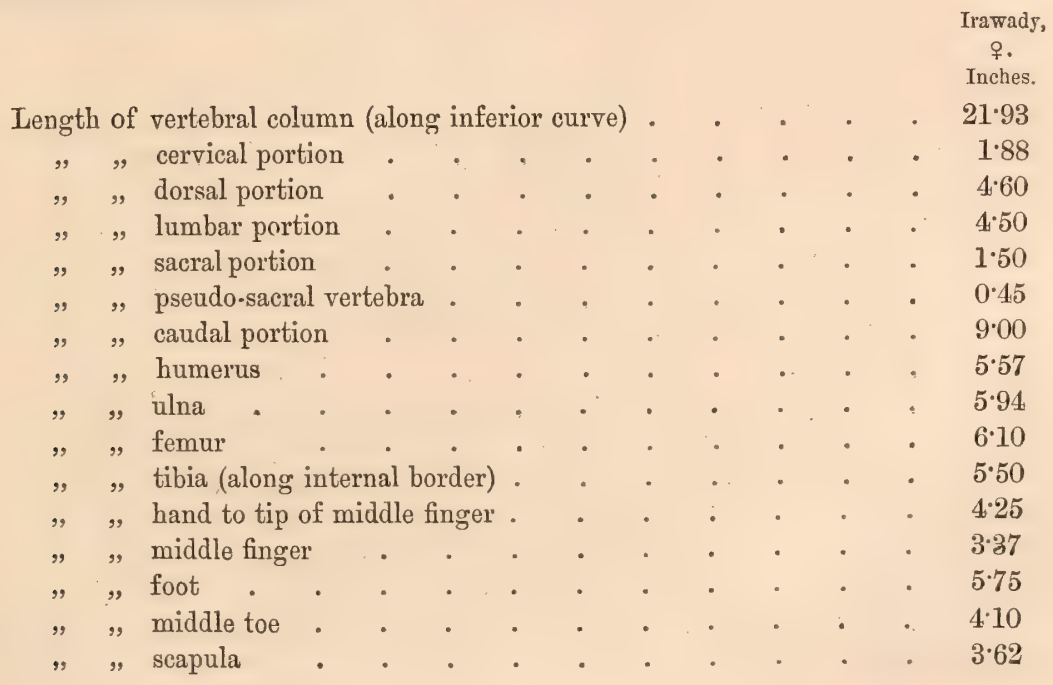




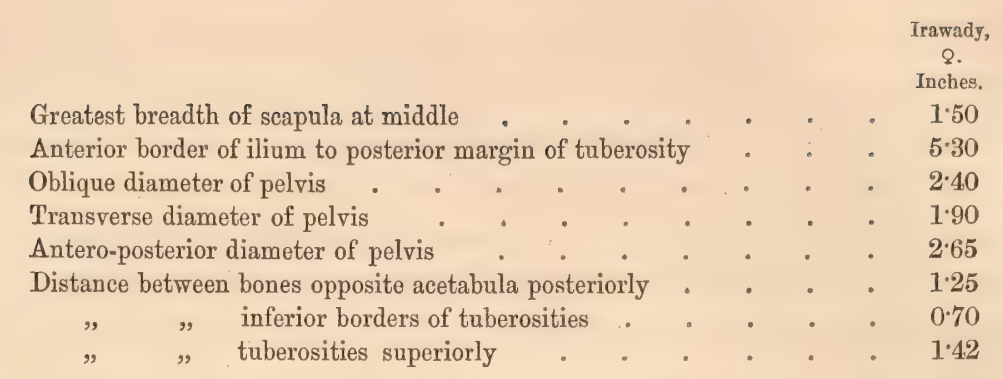

In the neighbourhood of Bhamô a young male was brought to me which unfortunately had had nearly the whole of its tail chopped off by the Kakhyens. I took it alive to London, and presented it to the Zoological Gardens, Regent's Park. When I procured it, it differed from the young of $M$. rhesus in the more uniformly brown colour of its pelage, and after an interval of three months, when it had reached England, these characters had become more pronounced. It was then uniformly reddish brown, the rufous paling on the outside of the thighs and on the fore-arms, but becoming dusky brown on the feet. The face and ears were dusky, contrasting with the paler face and ears of the generality of the males of $M$. rhesus from Bengal. The hair on the vertex tended to radiate, that on the forehead being directed forwards, and the hair around the area of radiation being darker than that on the sides of the head. The under parts were rather thickly clad, the thoracic and ventral portions were more or less washed with pale golden-yellow. The skin around the callosities was thickly clad. Now, six months afterwards, the characters of its coloration separate it much more distinctly from $M$. rhesus. The coat generally has become much darker, and on the head and along the dorsal surface it is more or less washed with dark brown or blackish, and the feet are dark brown. The under surface, too, has the golden-yellow more pronounced, and long, pale, yellow-brown hairs are beginning to be developed behind the ears. The shoulders are sensibly washed with yellowish, the fur seems devoid of annulations, and the hind quarters have none of the characteristic red colour which generally distinguishes the common monkey of India. In these latter characters it resembles the type of $M$. assamensis, and in them exactly corresponds to the monkey which was described by Sclater as $M$. rheso-similis. ${ }^{1}$. As no young $M$. rhesus has ever shown such an assemblage of characters in confinement, and as they closely correspond to the general and distinctive features of the type of $M$. assamensis which is a ferine example of a monkey, these facts would seem to point to the existence of a marked race of rhesus-like Macaque, ranging through the Himalaya, Assam, and Upper Burma.

This is further supported by the circumstance that Hodgson has referred to M. pelops, a monkey, apparently not adult, from which the $M$. rheso-similis, Sclater, and my young monkey from Bhamô, are in no way separable-a statement which is made on the strength of a careful comparison of these materials.

1 The figure in the Proc. Zool. Soc. 1872, pl. 25, is not coloured sufficiently rufous; the latter should be more of the shade depicted in $M$. mufescens, pl. 24 of the same volume. 
But before considering $M$. pelops and its relationship to $M$. assamensis, I have to remark that the former has long been a puzzle to zoologists owing to a variety of circumstances, among which may be mentioned the following: first, that the characters which distinguish it were not clearly defined by its describer; second, that the distribution which he assigned it was drawn with an unnatural precision, inapplicable moreover to species with the roving habits which more or less characterise monkeys; ${ }^{1}$ and third, the difficulty of procuring ferine examples of monkeys, more particularly of animals inhabiting the Himalayan region.

Hodgson, writing in 1832, observed that there were no monkeys in the northern and central regions of Nepal, and that those of the southern region were identical, so far as he knew, with the ordinary species of the plains, or the langur and the bandar. In a foot-note, however, he stated that religion had introduced the latter (IM. rhesus) into the central regions, where it seemed to flourish half domesticated in the neighbourhood of temples in the populous valley of Nepal Proper. It is important to observe that he divided Nepal into three climatic provinces, each of which he considered to be distinguished by certain well-marked physical and geological features. The first of these was the lower region, which he held had the climate of the plains of Nepal with some increase of heat and a great excess of moisture. This tract included the Tarai or marshes, the Bhawar or forest, and the lower hills. The second region he termed the central, and defined as a clusterous succession of mountains varying in elevation from 3,000 to 10,000 feet, and having a temperature of from 10 to 20 degrees lower than that of the plains. The third tract he denominated the juxta-Himalayan or Kachar, consisting of high mountains, the summits of which were covered for half the year in snow, and the climate of the region he described as having nothing tropical about it but the successions of the seasons.

Nine years afterwards his opinion regarding the non-existence of wild monkeys in the central and northern regions of Nepal was abandoned, as in $184 \mathrm{I}$ he described Semnopithecus schistaceus and M. oinops from the southern or Tarai region, and $M$. pelops from the northern region of hills exclusively. But he held that the first of these occasionally ranged through the central to the northern region. This latter observation has been fully verified by other naturalists having observed $P$. schistaceus at 12,000 feet, and the late Captain Hutton records that he had seen the same species at an elevation of 11,000 feet, while the fir trees among which they sported were laden with snow. But there is no evidence that any species of monkey in the Himalaya is naturally resident at those heights at which snow annually lies, as was supposed by Hodgson, and it is the rarity of their occurrence at these high elevations and during winter that has directed so much attention to their hibernal wanderings. In the summer they are much more widely distributed than in the winter, when, as a rule, they are driven to lower heights and into the warmer valleys. I have said naturally resident because it is a well-known

\footnotetext{
1 In the neighbourhood of Calcutta (Botanical Gardens) large troops of S. entellus make their appearance for a few days in spring and are not to be seen there at other seasons of the year.
} 
fact that Macaques are found in the Himalaya associated with temples at elevations at which snow annually falls.

This example of $M$. pelops, which is of much more recent origin than the type, having been presented to the Museum thirteen years after it, stands in the British Museum Catalogue as 58. 6. 24. 67. It is a deep, rich-brown monkey, without any trace of annulation on the hair. It is an adolescent male measuring 23.8 inches from the tip of the muzzle to the root of the tail along the curve of the head and along the back, while the tail is 9.8 inches; but as it is simply a skin without the vertebral column, these measurements in all likelihood do not give an accurate idea of the proportion of the tail to the body. The under surface of the body and the inside of the limbs are white, but the thoracic and abdominal regions are washed with golden-yellow. The general direction of the hair on the head is backwards and outwards, exhibiting a distinct tendency to radiation. The hairs behind the ears and extending down the back part of the side of the face are paler than the rest of the upper parts. The fur, as in my young Kakhyen monkey and in $M$. rheso-similis, is short and thick, and clothes the skin up to the sides of the callosities.

The characters which I have enumerated clearly prove it to be identical with the M. rheso-similis, which was procured from a Calcutta dealer, and with the young Kakhyen male, which I have no hesitation in regarding as the young of the Irawady female.

The type of $M$. pelops, Hodgson, the sex of which has not been recorded, is described as having the same structure and aspect as $M$. oinops, but the colours are stated to be more sordid and purpurescent, the slaty grey of the anterior quarters being partially merged in rusty, which is one of the marked features of M. assamensis as compared with M. rhesus. The posterior quarters, however, the description continues, are deep rusty and the anterior quarters are nearly slaty grey; but the now much-faded type shows a rufous tinge on the shoulder, as in $M$. assamensis. The buttocks are described as being partially clad, except the callosities, whereas, on the other hand, M. oinops ( $=M$. rhesus) is described as having them nude. After a careful consideration of the available materials, -namely, the original descriptions of the two supposed species and of the salient characters of the specimens on which they were based,-it seems to me that the mass of evidence points in the direction of the identity of $M$. pelops with $M$. assamensis.

The skulls of the types of $M$. pelops have not been removed from their skins, and no crania exist of these Nepal monkeys in the British Museum other than these. Hodgson's figure represents a brown, dusky-faced, rump-clad animal, but the details have not been carefully worked out in the drawing. All the information I have collected in Sikhim and obtained regarding the fauna of Nepal has not coincided with Hodgson's generalisation that any one species of Macaque is confined exclusively to the northern region of mountains. 
There is still another monkey from the Himalayas (Dalamcote, Bhutan), which, although not quite so rufous as $M$. rheso-similis and the youngish monkey referred by Hodgson to $M$. pelops, seems to me to differ from $M$. rhesus in the same direction that these do, and to be an immature female of $M$. assamensis. I refer to the $M$. problematicus, Gray. This opinion has been first expressed by Dr. Sclater. ${ }^{1}$ It is a dark-brown monkey, all the upper parts being of a nearly uniform tint. The individual hairs pale into reddish yellow towards their extremities, which are tipped with dark brown, but not truly annulated, their lighter-coloured subterminal areas producing a very faintly speckled appearance, giving it at the same time a warm rufous tint. The hair on the inside of the limbs and on the ventral aspect is a somewhat sullied white, without the golden tinge of the previous specimens, than which, however, it is older, and, unlike them, belongs to the female sex. The hair behind and below the ears is not much longer than that of the neighbouring parts, but paler, and without any rufous tinge. The hair on the vertex radiates from a point, that on the forehead being directed forwards and on the sides of the head outwards and backwards. There are long black hairs on the internal angle of the frontal and eyebrows, and on the moustache and beard. The feet, especially those of the hind extremities, are dusky. The hair, as in the female of $M$. assamensis from the Irawady, approaches close to the sides of the callosities, and, as in that specimen, the bare area is confined to a restricted region immediately around and below the vaginal orifice. In the stuffed specimen now in the British Museum (69.3. 5. 15) the body measures 22 inches and the tail 11 inches. With regard to the proportion of the tail to the body, it is self-evident that the measurements of dried skins do not give any correct idea of the relative proportions of these parts in life, and moreover the examination of a large series of specimens of $M$. rhesus conclusively proves that the length of the tail in that species is the subject of variation.

The skull of $M$. problematicus, Gray, belongs to one of those unsatisfactory instances of an animal that had lived the greater part of its life in confinement. It is immature, as the last molar is only just appearing. The basi-cranial axis is somewhat thrown forwards, so that the posterior nares are very narrow both vertically and transversely. The pterygoid fossæ are shallow and rather more laterally compressed than in $M$. rhesus. The skull of $M$. rheso-similis, Sclater, belongs to the same unreliable category as the former and is very young; the occipital and sphenoid being intact, and the first bicuspid and second molar only just issuing through the jaw. Unlike the skull of $M$. problematicus, it belongs to a male, and is somewhat larger than the generality of examples of the same sex in $M$. rhesus, than which it is also rather more elongated and narrower; in these characters and in that of its basi-cranial surface it resembles $\boldsymbol{M}$. problematicus.

Some years ago I drew attention to a monkey from the Bengal Sunderbunds which seemed to be distinct from $\mathbb{M}$. rhesus. After a careful comparison of it with the type of $M$. assamensis in conjunction with the foregoing monkeys, it appears 
to me that it is in no way separable from them. The general colour of this Sunderbund monkey is the same, but the hair on the head shows no tendency to the radiate character which occurred in the Irawady female when alive and in the young male in the Zoological Gardens. But experience of other Macaques, e.g., M.cynomolgus, in which the distribution of the hair on the vertex is most variable, sometimes assuming the form of a radiating tuft, whereas in the generality of specimens it is directed, as a rule, backwards, would seemingly indicate that much reliance cannot be placed on radiation as a specific character, and, moreover, there can be no doubt that the prepared skins of monkeys not unfrequently exhibit radiation on the vertex whilst no such character existed in life. This latter remark I make, not because $I$ am in any doubt regarding the nature of the distribution of the hair on the Sunderbund monkey, but because we do not know how the hair on the vertex of $M$. problematicus was distributed in life, nor what the characters of this part may have been in the type of $M$. assamensis when alive, and in $M$. pelops. ${ }^{1}$

I shall here summarise the views which have been expressed regarding this species by other zoologists.

Horsfield relegated M. pelops, Hodgson, to M. assamensis, and Blyth, ${ }^{2}$ on his authority, at first adopted a similar course; but, writing in 1865, he states that he had examined the original specimen of $\not M$. assamensis, but could not perceive that it differed in any respect from the common M.rhesus, "excepting that the hind part of the body is not as usual strongly tinged with bright ferruginous or tawny, being uniformly coloured with the rest; and my present impression (liable to correction) is that it is merely an individual variety of the common animal of Lower Bengal." The late Captain Hutton, on the ground of the supposed diversity of geographical distribution of $\mathbb{M}$. assamensis and $\boldsymbol{M}$. pelops, recorded it as his opinion that they are totally distinct species. Dr. Jerdon doubtfully regarded the two as identical, and suggested that the monkey figured by Hodgson in his manuscript unpublished drawings as $M$. sikkimensis might also be the same species. Dr. Sclater in 1868, in referring to $M$. problematicus, stated that the animal appeared to be $\boldsymbol{M}$. assamensis, but he hesitated to pass any decided opinion whether it were $\boldsymbol{M}$. oinops, Hodgson, or M. pelops, Hodgson, which could only be determined by an accurate examination of the animal when dead, and comparison of it with Hodgson's type specimens. It seemed, however, to Dr. Sclater to be specifically distinct from the common $M$. rhesus, and in 1871 he again stated that he thought "there could be no question that M'Clelland's M. assamensis belongs to the rhesus group of Macaques, and that it is in all probability the same as the so-called M. problematicus." Dr. Gray included in his catalogue a monkey which he designated $M$. assamensis, but Dr. Sclater has shown that this identification was erroneous, and that the animal was $M$. cynomolgus

1 Dr. Gray regarded the radiation of the hair on the vertex as one of the leading characters of $\boldsymbol{M}$. pelops, but Hodgson makes no mention of such a feature, and is careful to record of $\boldsymbol{M}$. oinops, with which he says $\boldsymbol{M}$. $p e l o p s$ agrees in structure and aspect, that it does not occur in it; but Dr. Gray, on the strength of one of the specimens sent to the British Museum by Hodgson as $M$. oinops having its hair radiated, referred it to $M$. pelops.

2 Journ. As. Soc. Beng., vol. xxxiv. 1865, p. 192. Blyth's latest opinion regarding $M$. pelops was that it was not unlikely to provo identical with $M$. tibetanus, A. M.-Edwards, Journ. As. Soc. Bengal, xliv. 1875, ex. no. p. 6. 
or a nearly allied species from Siam, with the tail longer than the body, whereas in the rhesus-like Macaques the tail rarely exceeds one-half the length of the trunk, and when it does, it is only to a very limited extent, as I have never observed a single instance in which it ever equalled three-quarters the length of the body.

When Dr. Sclater described $M$. rheso-similis, he considered it to be most nearly allied to $M$. rhesus and $M$. radiatus, and he then stated that Mr. Blyth had suggested that it might even be a hybrid between these species; but when Dr. Sclater had read my description of the Sunderbund monkey, he recognised in it the adult of $M$. rheso-similis, while Blyth surmised that the Sunderbund form was the long unknown $M$. assamensis, $\mathbf{M}^{\circ}$ Clelland, so that the views which have been here stated with regard to the affinities of these monkeys is in no way novel ; they have, however, been arrived at after an independent consideration of the various typical specimens.

To determine with exactitude the essential characters of this Himalo-Burman race, or sub-species of rhesus-like monkey, it will be necessary to have the command of a much more extensive series of specimens than it has fallen to my lot to examine ; but such materials do not exist in any museum that $I$ am aware of, and, moreover, museum specimens of themselves, however extensive, will not settle the questions relating to the appearance and character of the living animal in its ferine condition.

The evidence, however, which I have adduced would seem to prove that there is a monkey different from, but closely allied to, $M$. rhesus extending eastwards from the Nepal region of the Himalaya through Assam and the north-eastern portion of Bengal into the upper or hilly portion of the valley of the Irawady, and that this monkey is probably the Macacus assamensis, $\mathbf{M}^{\circ}$ Clelland.

\section{* Macacus crnomolgus, Linn.}

Le Macaque, Buffon, Hist. Nat. vol. xiv. 1766, p. 190; Daubenton, ibid, p. 194, pl. xx. (animal), pl. xxiv. (skeleton); F. Cuv. Hist. Nat. des Mammif. Fev. 1819, Pls. 30 and 31.

The Philippine Monkey, Pennant, Syn. Mam. 1771, p. 121; Hist. Quad. vol. i. 3rd ed. 1793, p. 213 ; Is. Geoff. St.-Hil. Arch. du Mus. vol. ii. 1843, p. 568, pl. v.

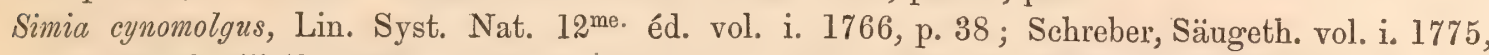
p. 91, pl. xiii (fig. Buffon) ; Gmelin, Lin. Syst. Nat. 13 ${ }^{\text {mee }}$ éd. 1788, p. 31; Cuv. Règ. An. vol. i. 1817, p. 109 ; Hugues, Storia Nat. delle Scimiæ; Tav. xxvi. 1823-24 (Buffon's fig. enlarged); Fischer, Syn. Mam. 1829, p. 25.

Cercopithecus cynomolgus, Erxleben, Syst. Règ. Animal, 1777, p. 28 ; Zimm. Geograph. Gesch. vol.ii. 1780, p. 186 ; Boddaert, Elench. Animal, 1785, p. 58 ; Kuhl. Beitr. zur Zool. 1820, p. 16 ; Müller und Sehlegel, Verhandl. 1839-44, p. 48 ; Cantor, Journ. As. Soc. vol. xv. 1846, p. 176.

Cynocephalus cynomolgus, Latr. Hist. Nat. de Buffon (Sonnini) vol. xxxvi. 1809, p. 292.

Cercocebus cynomolgus, Geoff. St.-Hil. Ann. du Mus. vol. xix. (1812), p. 99.

Pithecus cynomolgus, Desmarest, Nouv. Dict. d'Hist. Nat. vol. xviii. 1817, p. 323.

Macacus cynomolgus, F. Cuv. Hist. Nat. des Mammif. Fev. 1819, Pls. 30 and 31; Desmarest, Mamm. 1820, p. 65 ; Nouv. Dict. des Sc. Nat. vol. xxvii. 1823, p. 4.67 ; Lesson, Man. de Mam. 1827, p. 42 ; Griffith, An. Kingd. vol. v. 1827, p. 17 ; Cuvier, Règ. An. 1829, vol. i. (nouv. éd.), p. 95 ; Fischer, Syn. Mam. 1829, p. 25 ; Is. Geoff. St.-Hil. Zool. du Voy. de Bélanger, 1834, p. 56; Waterhouse, Cat. Mam. Mus. Zool. Soc. Lond. 1838 (2nd ed.) p. 7 ; Lesson, 
Sp. des Mamm. 1840, p. 90 ; Gervais, Voy. Autour. du Monde, Zool. vol. ii, 1841. p. 6 ; Gray, Hand-list Mamm. B. M. 1843, p. 7 ; Blyth, Journ. As. Soc. Beng. vol. xiii. 1844, p. 474; Ibid, p. 476 ; Schinz, Syn. Mamm. vol. ii. 1844, p. 55 ; Blyth, Journ. As. Soc. vol. xvi. 1847, p. 731 ; Is. Geoff. St.-Hil. Cat. Méthod. des Mammif. 1854, p. 27 ; Horsfield, Cat. Mam. E. Ind. Co. Mus. 1851, p. 17; Gervais, Hist. Nat. des Mammif. 1854, p. 85 (figure) ; Blyth, Cat. Mam. As. Soc. Mus. 1863, p. 9 ; Martens, Der Preuss. Exped. nach. Ost. Asien, Zool. 1865, p. 52 ; Gray, Cat. Monkeys and Lemurs, B. M. 1870, p. 30 ; Blyth, Journ. As. Soc. 1875, vol. xliv. ex. no. p. 7.

Simia fascicularis, Raffles, Trans. Linn. Soc. vol. xiii. 1822, p. 246.

Macacus carbonarius, F. Cuv. Hist. Nat. des Mammif. Oct. 1825, pl. xxxii.; Fischer, Syn. Mamm. 1829, p. 26 ; Is. Geoff. St.-Hil. Voy. de Bélanger, Zool. 1834, p. 63 ; Müller und Schlegel, Verhandl. 1839-44, p. 49; Lesson, Sp. des Mammif. 1840, p. 92 ; Blyth, Journ. As. Soc. Beng. vol. xvi. 1847, pp. 731, 732 ; Cat. Mamm. As. Soc. Mus. 1863, p. 9 ; Gervais, Hist. Nat. des Mammif. 1854, p. 87 (figure of head).

Macacus aureus, Is. Geoff. St.-Hil. Zool. Voy. de Bélanger, 1834, p. 58; Lesson, Sp. des Mammif. 1840, p. 92 ; Arch. des Mus. vol. ii. 1841, p. 566 ; Cat. Méthod. des Mammif. 1851, p. 27 ; Schinz, Syn. Mamm. vol. i. 1844, p. 55; Gervais, Hist. Nat. des Mammif. 1854, p. 87 (figure of head).

Circopithecus cynosurus, Helfer, Journ. As. Soc. Beng. vol. vii. 1838, p. 858; Blyth, ibid, vol. xiii. 1844, p. 472 .

Seminopithecus buku, Martin, Mag. Nat. Hist. (Charlesworth), vol. ii. new ser. 1838, p. 435.

Semnopithecus fascicularis, Waterhouse, Cat. Mamm. Zool. Soc. Mus. Lond. 1838 (2nd. ed.), p. 4.

Innuus (Cercocebus) cynomolgus, Wagner, Schreber, Säugeth. Suppl. vol. i. 1840, p. 135.

Innuns (Cercocebus) aureus, Wagner, Schreber, Säugeth. Suppl. vol. i. 1840, p. 138.

Semnopithecus kra, Lesson, Sp. des Mammif. 1840, p. 65.

Macacus auratus, Müller und Schlegel, Verhandl. 1839-44, p. 49.

Macacus philippensis, Is. Geoff. St.-Hil. Cat. Méthod. des Mammif. 1851, p. 29 ; Gervais, Hist. Nat. des Mammif. 1854, p. 88 (figure of head).

Innuus (Macacus) cynomolgus, Wagner, Schreber, Säugeth. Suppl. vol. v. 1855, p. 52.

Innuиs (Macacus) palpebrosus, Wagner, Schreber, Säugeth. Suppl. vol. v. 1855, p. 54.

Pithecus (Macacus) cynomolgus, Dahlbom, Stud. Zool. Fam. Reg. An. 1856, pp. 118, 120.

Pithecus (Macacus) aureus, Dahlbom, Stud. Zool. Fam. Reg. An. 1856, pp. 118, 120.

Pithecus (Macacus) philippensis, Dahlbom, Stud. Zool. Fam. Reg. An. 1856, pp. 118, 120.

Macacus fur, Slack, Proc. Acad. Nat. Sc. Philadelph. 1867, p. 36 (plate).

Macacus cristatus, Gray, Cat. Monkeys and Lemurs, B. M. 1870,p. 30.

Macacus assamensis, Gray, Cat. Monkeys and Lemurs, B. M. 1870, p. 31.

I obtained a monkey of this species from the late Dr. Marfels, who had got it from a Buddhist priest on the right bank of the Irawady to the north-west of Mandalay, of which locality it was said to be a native. However, it had been a captive in the monastery for many years. My first impression on seeing it was that it was an old male of M. cynomolgus, but after it had reached London and I saw it side by side with living examples of that form in the Zoological Gardens, I began to doubt the correctness of my opinion, because the animal so much exceeded in size any representative of that species in the collection, and showed a much flatter and broader head with a considerably more developed muzzle; however, a growing familiarity with this old male and its younger companions in the Zoological Gardens and a frequent comparison of them ultimately led me to return to my original conclusion. And I have since been able to verify the correctness of my conclusion 
by the observation of the skins and skeletons of several adult ferine males shot towards the east of Moulmein.

The leading features of this animal are, its massive form, its large head closely set on the shoulders, its stout and rather short legs, its slender loins and heavy buttocks, its tail thick at the base, and its very full and prominent scrotum. The general colour of the monkey does not call for any remark, as it conforms to that of the species, and it has the bluish white area internal to the eyes and palish eyelids. The great development of the temporal muscles confers considerable breadth to the head and gives rise to a well-marked mesial furrow, extending backwards from behind the supraorbital crests, indicating that the temporal ridges are confluent. The supraorbital ridges are well defined, the forehead behind them being slightly concave; but they do not much overhang the eyes, which are moderately large. The muzzle is long, full, and downwardly tending, with a rather heavy bearded chin. The nose is but little raised above the level of the face, which is pale brownish, while the ears, which are erect, pointed, and nearly nude, are blackish. The hands and feet are also blackish. The skin of the chest and upper part of the belly is bluish, most intense in the region of the nipple. The scrotum is brownish, blotched with livid blue.

The distinguishing features assigned to $M$. carbonarius by $F$. Cuvier are its blackish brown face and ears, the same colour pervading the naked skin of the hands, the feet, and the callosities. The upper eyelids are described as white-an occurrence which, he remarks, is singularly common among monkeys. The scrotum is a tawny yellow. MI. cynomolgus, on the other hand, is livid-faced, with a white area between the eyes, which Cuvier notices as one of the most remarkable peculiarities of the species. The hands and feet are black and the scrotum flesh-coloured. He states that the Macaque à face noire resembles the Macaque à face tannée in the character and coloration of its fur.

With regard to the white area between the eyes, a series of dark and lividfaced Macaques will generally be found to illustrate that this character is not restricted to the Macaque à face tannée, or essentially peculiar to it. Dark-faced Macaques may often be observed, with the bluish white area internal to the eyes quite as well developed as in those with livid faces; for examples of the latter are not uncommon, in which it is either almost entirely absent or existing only to a feeble degree. Even in individuals in which it constitutes a prominent facial character, it will be seen that it generally distributes itself to a greater or less extent on to the upper eyelids, so that those of typical $M$. cynomolgus almost invariably partake of the character of the eyelids of $M$. carbonarius. Moreover, it would appear that in either type of face when the internal pale area is feebly marked, the bluish white is not so well defined on the eyelids, and vice versâ; but at the same time Macaques of these types are met with in which the bluish white colour is equally intense, both internal to the eyes and on the upper eyelids. It is therefore conclusive that this local coloration is subject to considerable variation. The observation 
of many living Macaques from various parts of Burma and the Malayan peninsula does not support the line of distinction that Cuvier has drawn between the Macaque $\grave{a}$ face noire and the Macaque à face tannée, for among these there are faces so coloured as to lead from the one of these extremes into the other.

Cuvier also states that the head of $\mathbb{M}$. cynomolgus has neither tuft nor crest, and that the hair of the summit lies uniformly backwards, which are also the features of $M$. carbonarius as represented by him. But both livid and dusky-faced Macaques may not unfrequently be observed in which the hair on the vertex has a distinct tendency to assume an erect character, and others in which it shows an inclination to radiate from a centre. One example has come under my notice in which there were two such areas of radiation, one on each side of the centre of the mesial line, gathering, as it were, the hair between them, and directing it upwards and forwards in a kind of crest. The cresting of the head thus appears to be a variable feature.

Specimens have been observed intermediate between $M$. carbonarius and $M$. aureus, differing only in inconsiderable modifications of colour; some have associated with the dark face of $M$. carbonarius the rufous colour of $M$. aureus. Those monkeys which are referable to $M$. carbonarius appear to be more distinctive of the Nicobars, Sumatra, the neighbouring islands, and the Malayan peninsula, than of Burma, in which the more typical form of $\mathbb{M}$. cynomolgus prevails, and of which the foregoing male described by me is a characteristic example.

The monkeys referable to $\mathbb{M}$. aureus which are found in the Calcutta market are brought, as a rule, from Singapore, but we do not possess any exact information regarding the habitat of this race. The type of $\boldsymbol{M}$. aureus described by M. Is. Geoff. St.-Hilaire as a native of Bengal was in all probability a market specimen, as no monkey resembling $\boldsymbol{M}$. cynomolgus is indigenous to Bengal.

A race nearly allied to that of $M$. aureus has lately been described by Dr. Gray from Borneo under the name of $M$. cristatus. The fur, in its light yellow colour, approaches the albino race from the Philippines, which has also occasionally a central top-knot, to which Is. Geoff. St. Hil. attached considerable importance. In the Negris Islands, the Macaque has likewise the hair on the vertex somewhat erect, with pale temples, the fur generally being rather rich brownish olive, and the tail blackish brown. This race approaches $M$. carbonarius. Another race of the widely-distributed species is found in Timor and in the Celebes.

The Siamese race of this species, which was erroneously regarded by Dr. Gray

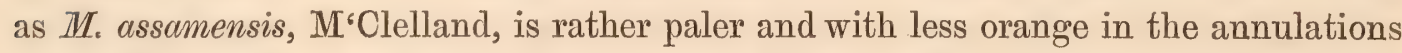
of the fur than is generally the case in its Burmese and Malayan representatives, and in its general colour it is resembled by examples from the Island of Flores.

The Macaque, M. fur, Slack, which has been described from the Island of Luzon, to which locality the late M. Jules Verraux informed Mr. Slack that it was confined, is so doubtfully distinct from $\mathbb{M}$. cynomolgus that $I$ have included it as a synonym. 
I append the following synopsis of the remaining Asiatic Macaques :

\section{MaCaCUS Nemestrints, Linn.}

The Pig-tailed Monkey, Edwards, Gleanings, \&c., 1758, tab. 214, vol. v. pp. 8-10.

Le Maimon ou Singe à queue de cochon, Buffon, Hist. Nat. vol. xiv. 1766, pp. 176 et 179, pl. xix.

The Pig-tailed Baboon, Pennant, Syn. Mamm. 1771, p. 105; Hist. Quad vol. i. 3rd ed. 1793, p. 193.

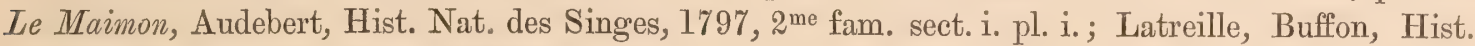
Nat. (Sonnini)., vol, xxv. 1809, p. 298.

Simia nemestrina, Linn. Syst. Nat. 12th ed. vol. i. 1766, p. 35 ; Schreber, Säugeth. vol. i. 1775, p. 79, pl. ix. ; Boddaert, Elench. An. 1785, p. 57 ; Gmelin, Linn. Syst. Nat. 13th ed. 1788, p. 28; Shaw, Gen. Zool. vol. i. pt. i. 1830, p. 25, pl. xiv.

Papio nemestrinus, Erxleben, Syst. Reg. An. 1777, p. 20 ; Zimmermann, Geograph. Gesch. vol. ii. 1780 ; Cantor, Journ. As. Soc. Beng. vol. xv. 1846, p. 176.

Cynocephahus nemestrinus, Latreille, Hist. Nat. de Buffon (Sonnini) 1809, p. 291.

Innuиs nemestrinus, Geoff. St.-Hil. Ann. du Mus. 1812, vol. xix. p. 101 ; Kuhl, Beitr. zur Zool. 1820, p. 17 ; Blyth, Journ. As. Soc. Beng. vol. xvi. 1847, p. 731 ; Cat. Mamm. As. Soc. Mus. 1863, p. 7.

Pithecus nemestrinus, Desmarest, Nouv. Dict. d'Hist. Nat. 1817, vol. xviii. p. 325 ; Griffith, An. Kingd. vol. v. 1827, p. 18.

Macacus nemestrinus, F. Cuv., Hist. Nat. des Mammif. Août 1820, pl. xlii. Jan. 1822, pl. xliv.; Desmarest, Mamm. 1820, p. 66 ; Dict. des Sc. Nat. 1823, vol. xxvii. p. 469 ; Lesson, Man. des Mamm. 1827, p. 43 ; Sp. des Mammif. 1840, p. 96 ; G. Cuv., Règn. An. nouv. éd. vol. i. 1829, p. 95 ; Fischer, Syn. Mamm. 1829, p. 29 ; Is. Geoff. St.-Hil. Voy. de Bélanger, Zool. 1834, p. 60 ; Waterhouse, Cat. Mamm. Zool. Soc. Mus. 2nd ed. 1838, p. 8; Wagner, Schreber, Säugeth. Suppl. vol. i. 1840. p. 143 ; Gray, Hand-list. Mamm. B. M. 1843, p. 7 ; Schinz, Syn. Mamm. vol. ii. 1844, p. 58 ; Horsfield, Cat. Mamm. E. Ind. Co. Mus. 1851, p. 12 ; Gervais, Hist. Nat. des Mammif. 1854, p. 92 (figure of head) ; Cat. Monkeys and Lemurs, B. M. 1870 , p. 29.

Simia carpolegus, Raffles, Trans. Linn. Soc. 1822, p. 243.

Innuus (Rhesus) nemestrinus, Wagner, Schreber, Säugeth. Suppl. vol. v. 1855, p. $5 \%$.

Pithecus. (Macacus) nemestrinus, Dahlbom, Stud. Zool. Fam. Reg. An. 1856, pp. 115, 118.

'The general colour is a decided olive, tending in some animals to brown, the variation in colour being due to the relative development of the yellow and black rings on the hair. The rings occur on the exposed portion of the hair, the hidden part of which is grey. The upper surface of the head, the mesial line of the back, and the upper surface of the tail near its base, are deep brown or even blackish, more especially on the head and over the hind quarters. The extremities pale towards the hands and feet, which are light olive-brown. The outsides of the thighs have an olive-grey tint. Some animals, however, especially the fully grown ones, are almost uniformly coloured deep olive-brown, except on the blackish head and the middle line of the back. The sides of the face and the under surfaces generally are greyish, tending to white; but on the sides of the face the hair is washed with a dark, almost blackish, grey. The face is nude, of a dusky flesh-colour, which is the tint also pervading the almost naked ears and the callosities. A few scattered hairs occur about the mouth. On the top of the head, especially on the dark-coloured area, the hairs in the adult are short, rather erect and profuse; on the under parts they are rather sparse, especially on the belly. The muzzle is rather 
long and dog-like; the body is short, compact, and broad-chested, with moderately long, powerful limbs. The head is somewhat flattened above, with pronounced supraorbital ridges. The limbs are relatively longer than in $\mathbf{M}$. leoninus. The tail is a little more than one-third the length of the body and head, and is rather sparsely clad, contracting somewhat rapidly to a point and carried erect, being somewhat downwardly curved near the tip.

There are not the marked differences that distinguish the sexes of $M$. leoninus, Blyth, to which this form is most closely allied, the males and females being alike, and the young are only a little more richly coloured than the adults. These latter attain to a great size, as is evinced by the dimensions of the cranium of the adult (see table, p. 55). I have seen specimens standing at the shoulder as high as a goodsized mastiff and quite as powerful.

The chief feature of the skull is the great development of the facial portion, which is thrown much forwards.

It inhabits the Malayan peninsula to the south of Tenasserim, Sumatra, and Borneo.

\section{Macacus Fuscatus, Blyth. ${ }^{1}$}

Innuns speciosus, Temminck, Fauna Japonica, Zool. Mamm. 1847, p. 9, pl. i. figs. 1-8 (animal and details), pl. ii. figs. 1-6 (skull) ; Wagner, Schreber, Säugeth. Suppl. vol. i. 1840, p. 146 (in part) ; Gray, Hand-list Mamm. B. M. 1843, p. 8 ; Schinz, Syn. Mamm. vol. i. 1844, p. 59 ; Is. Geoff. St.-Hil. Cat. Méthod. des Mammif. 1851, p. 31 ; Gervais, Hist. Nat. des Mammif. 1854 (in part), p. 93, fig. 94 (Cuvier in part); Wagner, Schreber, Säugeth. Suppl. vol. v. 1855, p. 58, pl. v. (Temminck's figure) ; Dahlbom, Stud. Fam. Reg. An. 1856, pp. 116, 119 ; Mivart, Proc. Zool. Soc. 1865, p. 563; Gray, Cat. Monkeys and Lemurs, B. M. 1870, p. 32 ; Murie, Proc. Zool. Soc. 1872, pp. 780, 787, fig. 1, a \& $b$ (pelvis), fig. 2, a, b, \& c (penis ). Innuns fuscatus, MS. Leyden Museum; Blyth, Journ. As. Soc. Beng. vol. xliv. 1875, ex, no. p. 6.

Face red; tail short and stumpy, well clad and tufted. General colour, dark yellowish brown.

The face is nude, with the exception of a few straggling hairs on the upper lip and back part of the cheeks, and a moderately long, yellowish-brown beard. The colour of the face is intense red with a purplish hue; but the area of the nose and the lower lip is more or less tinged with brown. The colour of the face is most intense during the rutting season. T'he callosities and the genitalia of the male are also more or less red. The ears are large and covered entirely with long silky hairs, which, however, disappear on their margins. The sparse silky hairs which surround the face are black or dark brown. The fur of the upper parts is darkest on the dorsal line, and of a yellowish brown, as the hairs are annulated with these two colours. The sides of the head, the breast, the under surface of the limbs and tail, and the belly, are greyish. In the adult and old individuals the hair is long, soft, silky, and

1 In 1838, Ogilby, in his anonymous "Treatise on the Natural History of Monkeys, Lemurs, and Opossums," published in the "Library of Entertaining Knowledge" (Charles Knight, "Menageries," 1838), recognised that the Japan monkey was distinct from the $M$. speciosus, F. Cuvier (=M. arctoides), and proposed for it the name of Papio japonicus; and he mentions that he had observed a living example of true $M$. speciosus. 
very thick throughout, but more sparse on the under parts. The tail is short, and equally clad with long hairs, which form a depressed terminal tuft.

Length of body from muzzle to root of tail 2 feet; length of tail 3 inches.

Inhabits Japan.

Macacus tibetands, A. M.-Edwards.

Macacus tibetanus, A. M.-Edwards, Comptes Rendus, Juillet 14, 1870, vol. 1xx. p. 341; Rech. des Mammif. 1868-74, p. 244, pls. xxxiv. et xxxv. ; Blyth, Journ. As. Soc. Beng. vol. xliv. 1875, ex. no. p. 7.

Head large and whiskered; form robust; tail stumpy and clad. General colour of the animal brown; whiskers greyish.

Face almost nude, flesh-coloured, with a flush of deep crimson around the eyes, the nasal region and upper lip being brown as in $M$. arctoides. Face rather elongated. Callosities large. Hairs below the ears and behind the cheeks extremely long, forming tufted whiskers of a greyish white, some of the hairs being tipped with dark brown. Hair on the forehead and top of head short and of a dull tawny brown; but on the nape, over the shoulders, and upper part of trunk, this colour becomes deeper, but paler on the limbs. The under surface generally is a whitish grey. The fur is especially long over the shoulders and upper part of the trunk. The tail is short and stumpy, but well clad, especially at its base, and darker above than below.

Length from the muzzle to root of tail 2 feet 9 inches; length of tail (carried erect) 3.9 inches with the hair.

Inhabits the mountains of Moupin.

The resemblances which this monkey presents to $\mathbb{M}$. arctoides are not confined to the young, but can be traced in the skull of the adults.

\section{Macacus rufescens, Anderson.}

Macacus rufescens, Anderson, Proc. Zool. Soc. 1872, p. 204; Sclater, Proc. Zool, Soc. 1872, p. 495, pl. xxiv. ; 1873, p. 194.

Face red, more brilliant around the orbits, and brownish on the nose and lips. Tail stumpy and poorly clad. Fur rather brilliant brick-red.

This form is closely allied to M. arctoides, which it resembles in its build and in the proportions of its parts; but this comparison is solely based on the young of the species, as this red, stump-tailed monkey, is known only from young specimens,

The colouring of the face is the same as in the young of $\boldsymbol{M}$. arctoides. The colour of the animal, as in the latter species, increases in depth of tint on the mesial line of the dorsal surface, the hairs along that region being tipped with black. The brick-red colour is especially brilliant on the flanks and on the outside of the limbs and on the cheeks. The beard, throat, chest, and under parts generally, and the inside of the limbs, are also brick-red. The hair on the top of the head is short and 
directed forwards, and on the vertex inclines to radiate. The tail has the same proportion and characters as the tail of $M$. arctoides.

The skull of the type specimen of this supposed species is nearly in the same state as the skulls of those forms of $\mathbb{M}$. arctoides which have been described as $\boldsymbol{M}$. melanotus and $\mathbb{M}$. brunneus, and the skull, if the downward compression and less depth of the face are left out of view, has a strong resemblance to $M$. arctoides. In the type $\boldsymbol{M}$. melanotus, the depth through the orbital and supra-nasal margins of the frontals to the palate is $1.80 \mathrm{inch}$, and in $M T$. rufescens 1.55 inch ; in the specimen in the British Museum referred to $\boldsymbol{M}$. brunneus it is $\mathbf{1} \cdot 85$, while in the adult $\boldsymbol{M}$. arctoides it is $2 \cdot 25$. The measurements in the table $(p .48)$ also show that it is a shorter and narrower skull than the skull of the type of $M$. melanotus; but still the differences between them in these respects are so slight that were it not for the vertical compression of the skull, and hence the peculiar type of physiognomy of this stump-tailed monkey, I would have hesitated to have regarded it as distinct from $\mathbb{M}$. arctoides, of which it may ultimately prove to be only a more southern race or variety.

Inhabits the Malayan peninsula.

Macacus maurus, F. Cuvier.

Macacus maurus, F. Cuv. Hist. Nat. des Mamm. 1823, Avril, pl. xlv.; Wagner, Schreber, Säugeth. Suppl. vol. i. 1840, p. 146 ; Lesson, Sp. des Mammif. 1840 (in part), p. 99 ; Schinz, Syn. Mamm. vol. i. 1844, p. 61 ; Is. Geoff. St.-Hil. Cat. Méthod. des Mamm. 1851, p. 31 ; Sclater, Proc. Zool. Soc. 1860, p. 420, 1871, p. 222; Murie, Proc. Zool. Soc. 1872, p. 721, 4 woodcuts (pelvis and skull) ; A. M.-Edwards, Rech. des Mammif. 1868-74, p. 228 ; Blyth, Journ. As. Soc. Beng. vol. xliv. 1875, p. 7, ex. no.

Mugus maurus, Lesson, Man. de Mamm. 1827, p. 44.

Simia cuvieri, Fischer, Syn. Mamm. 1829, p. 30.

Cynocephalus niger (?), Quoy \& Gaimard, Voy. de l’Astrolabe, Zool. vol. i. 1830, p. 67.

Macacus arctoides, Is. Geoff. St.-Hil. Zool. du Voyage de Bélanger, 1834, p. 61 (in part) ; Lesson,

Sp. des Mammif. 1840, p. 98 (in part); Is. Geoff. St.-Hil. Arch. du Mus. vol. ii. (in part) 1843, p. 573.

Macacus melanotus, Schinz (in part), Syn. Mamm. vol. i. 1844, p. 59.

Innus maurus, Vrolik, Todd's Cyclop. Anat. \& Phys. 1852, vol. iv. p. 197.

Macacus (Gymnopyga) inornatus, Gray, Proc. Zool. Soc. 1866, p. 202, pl. xix.; Cat. Monkeys and Lemurs, B. M. 1870, p. 129.

Face and ears black. Buttocks, surrounding ischia, flesh-coloured or rosy. General colour of the animal sooty black, paler on the under surface and darker on the head. Tail short and stumpy.

The face is black, nearly nude, but sparsely covered with short black hairs on the upper lip. The nose is rather flat, and the nostrils slant outwards. The ears are moderately sized and rounded, and only very sparsely covered with short black hairs. On the side of the face the hairs extend inwards along the malar bone and form a moderate whisker tuft. The hair on the cheeks, temporal region, and 
occiput has a sooty tinge, but on the frontal region it is short and nearly black. The general tint of the trunk is sooty black; but it pales on the lower side of the neck, on the rump, and on the under parts of the budy and on the inside of the limbs, passing almost into gray on the inner side of the antibrachium and interior femoral region and back of the thighs. Hair sparse on the groins and pubic region and external to the callosities, this semi-nude area even extending on to the base of the thighs. The tail is very short and rudimentary, and frequently more or less twisted, black and almost nude, but slightly upwardly curved, and about the same length as in $M$. arctoides.

In the young state the animal is less black than in the adult.

Length of body from muzzle to root of tail 21 inches; length of tail 1 inch.

Inhabits Borneo. ${ }^{1}$

The skull of $M$. maurus is at once distinguished from the skulls of the preceding Macaques by the flattening of the outer surface of the exterior margin of the orbits, which is nearly vertical instead of being outwardly rounded, and the external margins are high. This confers a narrow, elongated character to the face of the animal, very characteristic of the species. Moreover, the malar portion of the zygomatic arch is thrown forwards much more than in $\boldsymbol{M}$. arctoides. The region above the orbits is flat, and may either be concave or convex, depending on difference of age. The nasal region is broad, with short, rather abruptly expanded nasals. Dr. Murie has dèscribed the osteological features of this species in detail.

The Aru Islands are inhabited by a monkey which, if not identical with II. maurus, is at least so closely allied to it that I hesitate to separate it. It is distinguished from $\mathbb{M}$. maurus, not by any difference in colouring, but by the profuse character, great length, and density of its fur on its ventral aspect, which is quite as dense and long as on the upper surface. A skull deposited in the British Museum along with the skin presents certain differences from the skull of $M$. maurus, and it is mature, and, apparently from the size of its canines, the individual was a female. The muzzle is long and narrow and much thrown forwards, and the orbits are more rounded and open than in $\mathbb{Z}$. maurus, and the nasal portion is more compressed and ridge-like, and the nasals are narrow and elongated and markedly different from those of that species. The palate also is very deep, and the base of the skull is broader than that of $M$. maurus.

\section{Macacus ocreatus, Ogilby.}

Papio ocreatus, Ogilby, Proc. Zool. Soc. 1840, p. 56 ; Ann. Nat. Hist. 1841, vol. vi. p. 517.

Macacus fusco-ater, Schinz, Syn. Mamm. vol. i. 1844, p. 58 ; Sclater, Proc. Zool. Soc. 1860, p. 420 ; Blyth, Journ. As. Soc. vol. xliv. 1875, ex. no. p. 7.

Inuıs (Inuus) fusco-ater, Wagner, Schreber, Säugeth. Suppl. vol. v. 1855, p. 59.

This monkey is not unfrequently brought to Calcutta from Singapore, which port it reaches in steamers from Pontiana, on the west coast of Borneo. 
Macacus ocreatus, Proc. Zool. Soc. 1860, p. 420, pl. xxxii.; Wolf \& Sclater, Zoological Sketches, 1865, pl. i.; Gray, Cat. Monkeys and Lemurs, B. M. 1870, p. 32 ; Murie, Proc. Zool. Soc. 1872, pp. 723 and 726.

Macacus ochreatus, Blyth, Journ. As. Soc. vol. xliv. 1875, ex. no. p. 7.

Face and ears nude and black. The trunk generally, above and below, brownish black, or tinged below with greyish. Arms and legs greyish externally on their radial and tibial portions. Tail short and stumpy.

Inhabits Celebes. ${ }^{1}$ 1 inch.

Length of body from muzzle to root of tail 1 foot 6 inches; length of tail

There are the remains of a skeleton of this species in the British Museum, but they are so fragmentary that little or no information can be derived from them. They belong to an individual that lived in the Zoological Society's Gardens some years ago; and it is interesting to observe that the pelvis manifests the same type of deformity as that which has been described by Dr. Murie as characteristic of the normal pelvis of $\boldsymbol{M}$. cyclopis.

1 Confined to this island and to the Philippines and the small neighbouring island of Batchian is the following remarkable genus Cynopithecus, generally regarded as sub-generic to the African genus Cynocephalus.

Cynocephalds (Ctropithects) niger, Desmarest.

Cynocephalus niger, Desmarest, Mamm. 1822, Suppl. p. 534; Lesson, Man. de Mamm. 1827, p. 45; Fischer, Syn. Mamm. 1829, p. 32 ; Gray, Spicilegia Zoologica, pt. i. 1829, p. 1, pl. i, fig. 2; Quoy \& Gaimard, Voy. de 1 'Astrolabe. Zool. vol. i. 1830, p. 67, pls. vi. \& vii.; Lesson, Sp. des Mammif. 1840, p. 101. Schinz, Syn. Mamm. vol. i. 1844, p. 66.

Cynocephalus malayanus, Desmoulins, Dict. Class. d'Hist. Nat. vol. v. 1824, p. 262.

Papio niger, Griffith, An. Kingd. vol. v. (1847), p. 23; Temminck, Neerland. dans l'Inde Archip. vol. iii. 1847, p. 111. Macacus maurus (?), Quoy \& Gaimard, Voy. de 1'Astrolabe, Zool. vol. i. 1831, p. 67.

Macacus niger, Waterhouse, Cat. Mamm. Zool. Soc. Lond. Mus. 1838, 2nd ed. p.8; Gray, Hand-list Mamm. B. M. 1843, p. 8.

Inuus (Mainon) niger, Wagner, Schreber, Säugeth. Suppl. vol. i. 1840, p. 147.

Cynopithecus niger, Is. Geoff. St.-Hil. Zool. du Voy. de Bélanger, 1834, p. 66; Leçons de Mamm. (Gervais) 1836 , p. 16; Arch. du Mus. vol. ii. 1843, p. 574; Lesson, Sp. des Mammif. 1840, p. 101 ; Hergt, Natuur. Tijdschr. von Nederl. Ind. 1851, p. 337 ; Is. Geoff. St.-Hil. Cat. Méthod. des Mammif. 1851, p. 32; Gervais, Hist. Nat. des Mammif. 1854, pp. 99, 100, two figs. head, one fig. animal (bad); Dahlbom, Stud. Zool. Fam. Reg. An. 1856, p. 122; Gray, Cat. Monkeys and Lemurs, B. M. 1870, p. 33; Blyth, Journ. As. Soc. Beng. vol. xliv: 1875 , ex. no., p. 7.

Cynocephalus (Cynopithecus) niger, Wagner, Sehreber, Säugeth. Suppl. vol. v. 1855, p. 61.

General colour, deep, dull-black. The tail is excessively small, being reduced to a mere tubercle, or to only a faint indication externally of its existence. The vertex is surmounted by a cresi of long hairs, which droop somewhat over the occiput. The face is blackish, and the lips and callosities are livid fleshy. The body is short, and the limbs rather long.

Length of body 1 foot 9 inches.

Inhabits Celebes and Philippines.

The occurrence of this ape in the Australo-Malayan region, with its strong affinities to the African Cynocephali and its structural isolation, so to speak, from all the south-eastern Asiatic forms, or those distinctive of the Indo-Malayan region, are facts most difficult of explanation, but of great interest in geographical distribution.

Cynocephalus (Cynopithecus) nigrescens, Temminck.

Papio nigrescens, Temminck, Possess. Neerland, dans l'Inde Archip. vol, iii. 1847, p. 111.

Cyncpithecus nigrescens, Is. Geoff. St.-Hil. Cat. Méthod. des Mammif. 1851, p. 32.

Cynocephalus (Cynopithecus) nigrescens, Wagner, Schreber, Säugeth. Suppl. vol. v. 1855, p. 61, pl. vi.; Gray, Proc. Zool. Soc. 1860, p. 2; Mohnike, Verhandl. des Naturhist. Vereines der Preuss., Rhein. und Wesph. 1872 (Sitzungsb.), pp. 35, 36. 


\section{Macacus lastotis, Gray.}

Macacus lasiotus, Gray, Proc. Zool. Soc. 1868, p. 61, p1. vi.; Cat. Monkeys and Lemurs, B. M. 1870, p. 129 ; Sclater, Proc. Zool. Soc. 1871, p. 221 ; A. M.-Edwards, Rech. des Mammif. 1868-74, p. 229.

Macacus tcheliensis, A. M.-Edwards, Rech. des Mammif. 1868-74, p. 227, pls. xxxii. et xxxiii. p. 229 ; Blyth, As. Soc. Bengal, vol. xliv. 1875, ex. no. p. 6.

Macacus rhesus, Sclater, Proc. Zool, Soc. 1871, p. 222.

Inuus lasiotus, Blyth, Journ. As. Soc. Bengal, vol. xliv. 1875, ex. no. p. 5.

Larger and more powerful than the Indian $M$. rhesus, with longer and more richly coloured fur. In the male, dark, rich, olive-yellowish, with a tint of slaty olive on the head, neck, and anterior half of the trunk, brick-red on the hinder quarters, the slaty olive of the extremities passing almost into black on the hands and feet. Under parts greyish. The female is a brilliant fawn, with a tinge of reddish, this colour being most marked on the hind quarters. Face in both sexes flesh-coloured, richest in the female. Tail of the latter about one-fourth the length of the body.

The type of $M$. lasiotis, Gray, ${ }^{1}$ is said to have been procured from the province of Tse-chuen, but the circumstance that it was a captive during the greater part of its life somewhat detracts from its value as an example of the rhesus-like monkey of that portion of China.

The measurements of the skin now in the British Museum prove that it must have been about the same size as $M$. assamensis, as it measures $25 \cdot 3$ inches from the muzzle to the root of the tail, a fragment of which only exists, as has been conclusively shown by Dr. Sclater. ${ }^{2}$

The characters of this monkey prove it to be closely affined to $M$. rhesus, but at the same time the leading features of $M$. rhesus are so modified that it is apparently entitled to rank as a species seemingly attaining to a greater size. The fur is long, fine, and silky, longest on the shoulders, neck, and upper surface of the feet. The annulation of the hair has, however, the same character as in Bengal examples of M. rhesus. The basal portion is slaty, while the sub-terminal band is rich orange or brick-red, but the latter colour is more brilliant than in the Indian monkey, more especially on the hinder quarters, where it is so intense as effectually to obscure the underlying slaty and the narrow black tips, but on the shoulders, neck, head, and on the fore-legs it is not so marked, and does not hide the underlying slaty colour of the fur which, mixed with the paler orange-red bands, confers a slaty-olive

According to the short account which has been published of this species, it differs from $C$. niger in being of a brownish black tint, most prevalent on the shoulders and back. The ischiatic callosities are also stated to differ from those of $C$.niger.

Inhabits Celebes, Moluccas, and the small adjacent Island of Batchian, into which Mr. Wallace considers it has probably been introduced. Proc. Zool. Soc. 1864, p. 276.

1 Gray, Proc. Zool. Soc. 1868, p. 60, pl, vi.; Cat. Monkeys and Lemurs, \&c., B. M. 1870, p. 129; A. M.-Edwards, Rech. des Mammif. 1868-74, p. 229.

2 Sclater, Proc. Zool. Soc. 1871, p. 221. 
hue on these parts, darker and richer in tone than in $\mathbb{M}$. rhesus, and becoming almost black on the hands. Below the ear and on the sides of the face the hair is long and more or less annulated, but of a greyish tint. As in $M$. rhesus, and the generality of Macaques, there is a line of black scattered hairs along the supraorbital ridges and a patch over the orbital angle of the malar. The chin, throat, and chest and inside of the fore-limbs are greyish, washed with pale rufous above the wrists, while the abdomen and inside of the hind-legs are greyish, suffused with pale orange-red, the fur being silky. The hair on the vertex is not radiated, and the ear does not appear to be more thickly clad with hair than in M. assamensis. The skin around the callosities is described by Dr. Gray as crimson, and the face he characterises as pale flesh-coloured. The area around the callosities is well clad. Dr. Gray also describes a small naked red spot at the outer angle of each eye, which is occasionally feebly developed in $M$. rhesus, and which occurs also in M. leoninus, Blyth.

A. M.-Edwards, in the Rech. des Mammifères, ${ }^{1}$ states that he is disposed to regard $M$. lasiotis and $M$. tcheliensis as of the same specific type, if the normal dimensions of the tail are the same in both. In $M$. tcheliensis the tail only equals nearly the length of the hind-foot, and is also distinguished from the tail of M. rhesus by being clothed with thick long hair. The skull of $M$. tcheliensis, which I have examined, so agrees with the skull of $\mathbb{M}$. lasiotis that, making due allowance for the difference of sex, there seems to be every probability that A. M.-Edwards' supposition is correct. He describes $\boldsymbol{M}$. tcheliensis as having the hair thick and rather long, soft, and silky. The general colour is a brilliant reddish fawn, especially on the hinder parts, becoming greyish on the shoulders and on the sides of the cheeks, where the yellow is lost. The hands and feet are greyish fawn, the under parts are almost grey, and the tail is con. colorous with the back.

It will be observed that A. M.-Edwards makes no mention of the ears of II. tcheliensis, but these organs in $M$. lasiotis have been described by Dr. Gray as ovate, prominent, exposed, and covered with hair. These characters, however, cannot now be detected in the dried skin, any more than they can be in the type of M. tcheliensis.

The skull of $\boldsymbol{M}$. lasiotis (figs. 9 and 10 ) is distinguished from the skull of M. rhesus by its more massive character, greater rotundity, shorter, deeper, and more vertical muzzle, and greater facial breadth. The frontal area lying behind the supraorbital ridges is much more expanded than in II. rhesus, and the occipital region is broader. A comparison of the measurement of the skull of the male $M$. rhesus ( $M$. oinops) which I have given under $\mathbb{M}$. assamensis with the measurements in the following table proves that there is very little relative difference between the dimensions of the two skulls, while the accompanying woodcut will

1 L. c., pp, 227-229, 
show clearly wherein they differ. The principal difference lies in the much greater transverse breadth of the base of the skull of $M$. lasiotis, which is 3 inches to

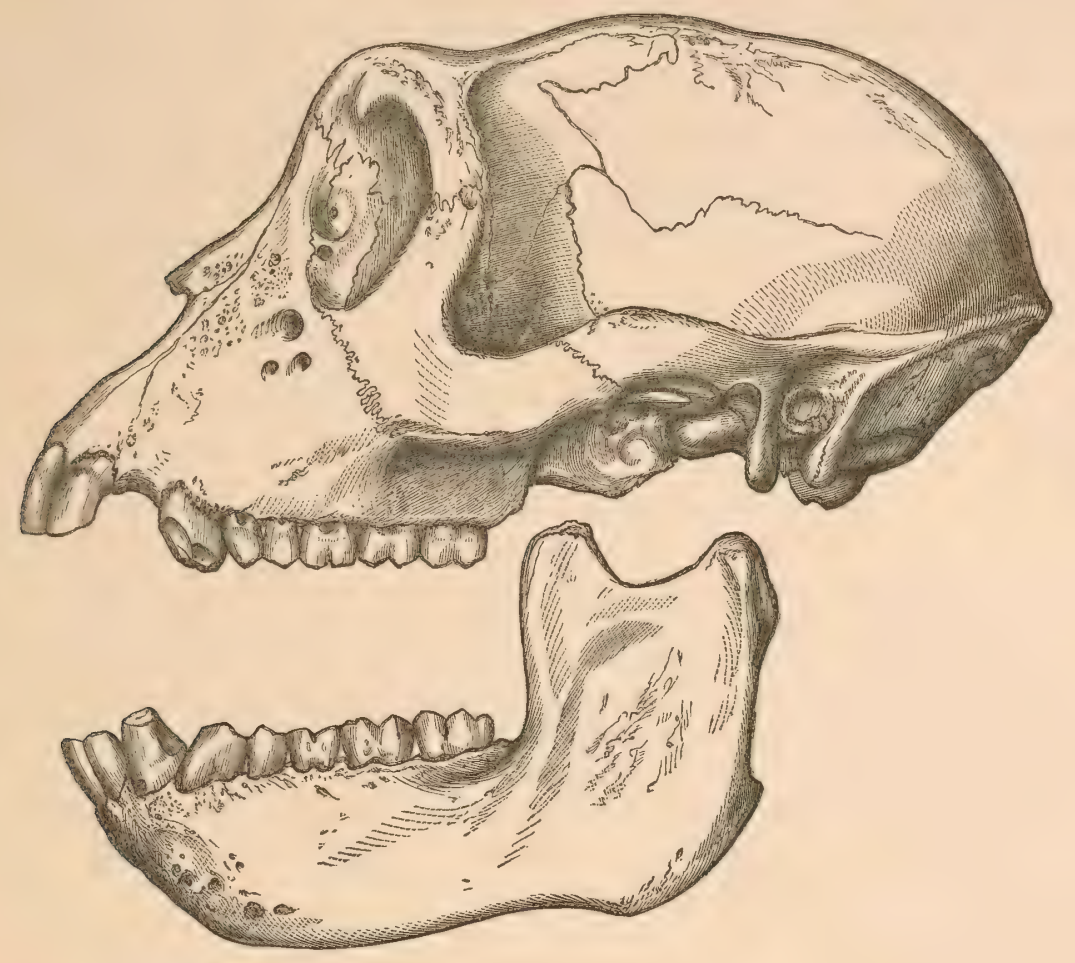

Fig. 9.-Skull of Macacus lasiotis, $\frac{3}{4}$ nat. size.

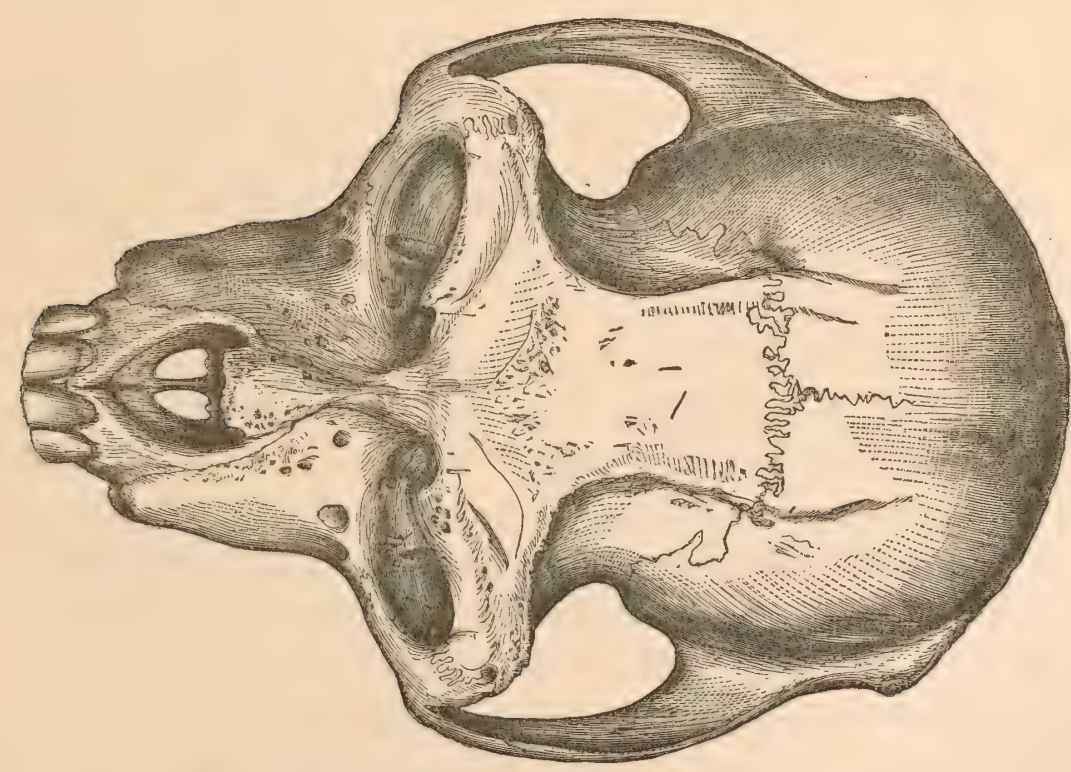

Fig. 10.-Upper view of skull of M. lasiotis, $\frac{3}{4}$ nat. size.

$2 \cdot 45$ in $M$. rhesus, the greatest length of the skull of the former being 5.30 and that of the latter $5 \cdot 23$, the two then being of nearly equal length. But the circum- 
stances attending the life of $\mathbb{M}$. lasiotis were unfavourable to the full development of the animal, and it is possible, as A. M.-Edwards says, that it may attain to a considerable size, but it can hardly equal $M$. nemestrinus. The scapula, one of the few bones of the male which have been preserved, indicates a large and powerful animal, and considerably exceeds in size any scapula of $\boldsymbol{M}$. rhesus that has come under my observation, from which it is chiefly distinguished by its greater breadth.

The male, as stated, is supposed to have come from Tse. chuen, which is a very mountainous province of Western China, and the female from the mountains of Tcheli to the north-east.

Measurements of slull of M. lasiotis, Gray.

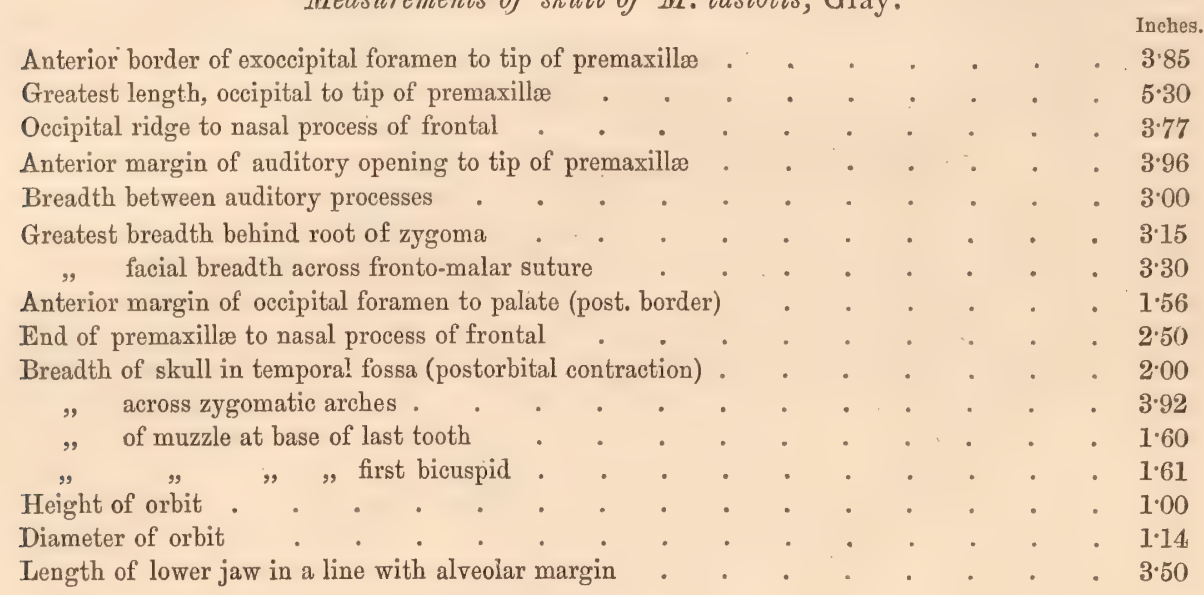

\section{MaCacus Sancti-Johannis, Swinhoe.}

Inuus sancti-johannis, Swinhoe, Proc. Zool. Soc. 1865, p. 556; Blyth, Journ. As. Soc. Bengal, xliv. (1875), ex. no. p. 5.

Macacus sancti-johannis, Gray, Cat. Monkeys and Lemurs, B. M. 1870, Append. p. 129 (in part) ; Sclater, Proc. Zool. Soc. 1871, p. 222.

Macacus rhesus, Sclater, Proc. Zool. Soc. 1871, p. 222.

Swinhoe, in a letter addressed to Dr. Sclater ${ }^{1}$ on the 7th September 1866, described a monkey from North Lena Island, Hong-Kong, under the name of Sanctijohannis, after Commander St. John, from whom he had received the animal alive, and which was forwarded to the Collection in Regent's Park, London. Commander St. John described it as a female about four months old, and Swinhoe characterised it thus: "Eyes bright hazel; face and ears flesh-coloured; cheeks with a black tuft on either cheek like whiskers; skin of nude parts tinted with blue and sparsely greyish brown, covered with hairs of a light grey; the hairs on the belly, buff; fur of upper parts washed with buff, which is lighter on the head, and brickdust-red round and about the rump. Tail $4 \frac{1}{2}$ inches, blackish; callosities flesh-coloured. Face narrow, somewhat projecting."

${ }^{1}$ Proc. Zool. Soc. 1866, 13th December, p. 356. 
This specimen was after its death deposited in the British Museum (68. 12. 29. 10.), in which collection it has been preserved in alcohol. It is to be regretted that Swinhoe did not record the measurements of the body as well as the length of the tail, as we would thus have been in a position to gain some idea of the growth of the animal during its two years of confinement. As it is, the tail now measures 5 inches and a half, thus indicating that this member had added an inch to its length in two years.

A careful consideration of this specimen seems to me to point in the direction of $M$. lasiotis, more so than towards any other Eástern Asiatic monkey, but from its youthful character and from the circumstance that the individual members of the rhesus group of Macaques are all so very closely allied to each other and doubtless have a strong common likeness in early youth, any decided opinion regarding the true nature of $M$. sancti-johannis is hardly warranted. These remarks are equally applicable to the young female monkeys from the Island of Hainan, which have been referred by Swinhoe and Sclater to Macacus rhesus. Blyth has suggested that these Hainan monkeys may be M. lasiotis; but if $M$. tcheliensis is the female of the latter and the species is distinguished by the tail equalling only one-fourth the length of the body, these Hainan monkeys can hardly be regarded as the same species, as the tail of the female in question equals one-half the length of the body. No males of these Hainan monkeys are known.

Some years ago a male monkey was presented to the Zoological Gardens by T. J. Fawcett, Esq., of the Hartlepool Hospital, as having come from China. It was regarded while alive in the Gardens as an example of $\mathbb{M}$. sancti-johannis, Swinhoe, and after its death it passed to the British Museum, under that name, which was adopted by Dr. Gray as appertaining to it, and who appears to have regarded the specimen as the type of the species, because in the appendix to his catalogue we find him remarking, on the strength of this identification, that $M$. sancti-johannis is very like $\mathbb{M}$. cyclopis, and perhaps only a younger specimen-an observation which is inapplicable to the type of $M$. sancti-johannis, so far at least as regards any resemblance to $I M$. cyclopis, as it has none. Mr. Fawcett's monkey, however, has all the characters of $M$. cyclopis, with the exception that the annulation of the hair is less distinct than in that species; but this seems to be attributable to youth, for in other respects the coloration is identical with M. cyclopis. The exact locality from whence the specimen was obtained is unknown, and although I have tried to trace it, I have failed to do so.

\section{MaCaCUs CrClopis, Swinhoe.}

The Large Formosan Monkey, Swinhoe, Blyth, Journ. As. Soc. Beng. vol. xxix. (1860), p. 88.

Macacus cyclopis, Swinhoe, Proc. Zool. Soc. 1862, p. 353, pl. xiii.; Sclater, ibid, 1871, p. 222 ; Proc. Zool. Soc. 1864, p. 710 ; Gray, Cat. Monkeys and Lemurs, B. M. 1870, p. 31 ; et Append. p. 128; Murie, Proc. Zool. Soc. 1872; pp. 771, 780. figs. $]$ and $2 a, b$, and $a, b$, and $c$ (pelves), $\delta$ and $q$. 
Macacus sancti-johannis, Gray (in part), Cat. Monkeys and Lemurs, B. M. 1870, Appendix, p. 129. Macacus rhesus, Sclater, Proc. Zool. Soc. 1871, p. 222.

Fur thick and dense, dark olive-green throughout, finely yellow-speckled; no rufous on the hind quarters. Ears small and clad, a strong ruff-like beard. Tail in adult about a foot long and well clad.

This Macaque appears to be restricted to the Island of Formosa, where it was discovered by Swinhoe. Its round, flat face, dark olive-green, uniformly annulated fur, and the complete absence of any rufous tint on its hind quarters, are the external characters which separate it from $M$. rhesus and its near ally II. lasiotis from the mainland of China, while, by these features, with the exception of the last, it is distinguished from $\boldsymbol{M}$. assamensis, which, moreover, unlike $\mathbb{I}$. cyclopis, has the shoulders suffused with yellowish. The tail has much the same proportions to the body as in $M$. rhesus, but it is more bushy. It is doubtful that the forehead is any more entitled to be called bare than is the forehead of $\mathbb{M}$. rhesus, as it is clad to the supraorbital ridges, along which also occur a few long black hairs, as in the rhesus group of Macaques generally. Unlike Mr. rhesus, the hair behind the mouth, and below and behind the ears, is markedly annulated, and there is a strong ruff-like beard, as in $M$. assamensis. The ears are moderately large, well clad and tufted. The fur generally is fine and dense, moderately long, and not longer on the shoulders than on the rest of the body.

Dr. Murie, in discussing the affinities of this form, has favoured the view that the female, during the period of heat, is subject to a much greater tumidity and swelling of the hinder parts than ever occurs in M. rhesus, but the description which he has given of this curious phenomenon as it occurs in $\mathbb{M}$. cyclopis is no exaggerated account of what I have observed in $\mathbb{M}$. rhesus on a number of occasions in different animals. In some of these, great tumour-like swellings had attained such dimensions, and had so involved the whole of the sacral region, the upper portion of the thighs, the base of the tail, and all the back parts of the limbs even to near the heel, that the hinder quarters seemed so weighed down with the burden as to give the animal a waddling gait. This monstrous development I have observed both in animals in confinement in India and also among semi-ferine monkeys living in colonies that had attached themselves to villages in the NorthWest Provinces. In $M$. rhesus there is no modification or particular adaptation of the pelvis for the support of these temporary enlargements of the subcutaneous tissues which invest it posteriorly in the female, but Dr. Murie holds that such an adaptation of the pelvis does occur in $M$. cyclopis. The materials, however, from which Dr. Murie's deduction is derived are not so reliable as could be wished, and he mentions that the modifications which these pelves of $\boldsymbol{M}$. cyclopis manifest on the ordinary type of the healthy Macaque pelvis might suggest the possibility that they are the product of disease, and he states that the long bones of the male skeleton are unusually porous, but that the female skeleton is solid, and does not exhibit any signs of mollities ossium. But the very circumstance that it should have occurred to Dr. Murie that his statements might be objected to on the ground that a softening 
or other diseased condition of the bones might suggest itself to other observers as the cause of the abnormality of the pelvis of $M$. cyclopis is in itself an acknowledgment of the weakness of the facts on which his generalisation is based. Either the abnormality conforms to one of the forms of pelvis generally induced by disease, or he was not perfectly convinced that the bones of the female pelvis were perfectly healthy, although, as he states, they were free from mollities ossium. The circumstance, moreover, that he describes the long bones of the male skeleton as more than usually porous and soft, and that its pelvis was not so firm as to be consistent with robust health, naturally detracts from the value of his statement regarding the curvature of the long bones which he considers to distinguish the monkey from $\mathbb{M}$. rhesus, and it thus can hardly be acceded that he has demonstrated that $I I$. cyclopis possesses characters decidedly differing from those of the ordinary rhesus monkey.

I have examined the same materials on which Dr. Murie has founded his generalisations regarding the supposed anatomical differences of $\boldsymbol{M}$. cyclopis from II. rhesus. The male skeleton is unusually porous and soft, and the female bones, although they have none of the porous character of those of the male, are extremely light, and the pelvis appears to me so deficient in earthy constituents that it has a membranous appearance. The pelvis of the male, on the other hand, is very porous, and has almost a friable aspect, which condition seems to explain its less divergence from the normal pelvis, whereas the more membranous character of the female pelvis fully accounts for its greater divergence from the rhesus type. The bony substance, however, of each is very different in consistence from the hard, heavy, compact structure of a healthy pelvis.

In the normal pelvis of $\mathbb{M}$. rhesus and its allies, a straight line drawn from the anterior superior angle of the iliac portion of the bone to the inferior end of the tuberosity of the ischium conforms to the external border of the ilium and cuts off the lower third or nearly so of the acetabulum and the upper third or middle of the thyroid foramen, according as the tuberosity of the ischium is thrown upwards.

In these details of its course across the acetabulum and thyroid foramen it conforms to the course pursued by a line drawn between similar extreme points in the human pelvis.

In $\mathbb{M}$. cyclopis, however, such a line does not run parallel to and touch the anterior border of the iliac portion of the bone, but encloses between it and itself in the female an elongated oval space, and this occurring also in the male, but to a more limited extent, proves that both pelves have the same kind of abnormality depending on the downward and inward bending of the iliac portion of the bone on itself. There can be no doubt that this alteration in the normal relations of the constituent parts of the pelvis gives rise to a greater interval between the root of the tail and the tuberosity of the ischium, but, on the other hand, there is a narrowing of the interval between the callosities associated with a marked general contraction of the hinder portion of the pelvis, thus reducing instead 
of extending the expansion of the osseous frame for the support of the hymeneal swellings. There is a marked inward bending of the posterior half of the ilium without any corresponding eversion of the ischium, and the acetabula are thus thrown more inwards towards the mesial line, and by these modifications, which are most marked in the female pelvis, the span of the pubic arch and the expansibility of the surrounding parts are considerably reduced, and the outlet of the pelvis to that extent that it seems improbable that it could permit of the discharge of the young of the size given birth to by Macaques of the dimensions of $M$. cyclopis.

Dr. Murie also describes the ilium as anteriorly overriding the sacrum far more than is ordinarily the case, $i . e$, that the sacrum is projected into the pelvis. This condition would seem to be analogous to that deformity of the human pelvis arising from insufficient strength of its walls, ${ }^{1}$ in which the sacrum is projected into the outlet of the pelvis, and the acetabula (as before described in $\boldsymbol{M}$. cyclopis) approach the middle line, while the pelvic bones are pressed forwards and downwards between them.

Such considerations as the foregoing would seem to indicate that the conditions of these pelves may have a different explanation than that given by Dr. Murie.

Dr. Gray, in the appendix to his Catalogues of Monkeys, ${ }^{2}$ compares $M$. sanctijohannis to $M$. cyclopis, but the origin of this comparison I have explained under M. sancti-johannis.

\section{Macacus sinrcus, Linn.}

Le bonnet chinois, Buffon, Hist. Nat. vol. xiv. 1766, pp. 224, 241, pl. xxx.

The Chinese Monkey, Pennant, Hist. Quad. 3rd ed. vol. i. 1793, p. 209.

Simia sinica, Linn. Mantissa Plant. 1771, p. 521 ; Schreber, Säugeth. vol. i. 1775, p. 108, pl. xxiii.;

Gmelin, Linn. Syst. Nat. 13th ed. vol. i. 1788, p. 34; Shaw. Genl. Zool. vol. i. pt. 1. (1800), p. 50, pl. xx. fig. 1 .

Cercopithecus sinicus, Erxleben, Syst. Reg. Animal. 1777, p. 41 ; Zimm. Geograph. Gesch, vol. ii (1780), p. 193 ; Boddaert, Elench. Animal, 1785, p. 60.

Cynocephalus sinensis, Latr. Hist. Nat. de Buffon (Sonnini), vol. xxxvi. (1809), p. 293.

Cercocebus radiatus, Geoff. St.-Hil. Ann. du Mus. 1812, vol. xix. p. 98.

Pithecus radiatus, Desmarest, Nouv. Dict. d'Hist. Nat. vol. xviii. (1817), p. 325.

Macaces radiatus, F. Cuv. Hist. Nat.'des Mammif. Juin 1820, pl. xxxiii.; Desmarest, Mamm. 1820, p. 64; Dict. des Sc. Nat. vol. xxvii. (1823), p. 466 ; Lesson, Man. de Mamm. 1820, p. 42; Griffith, An. Kingd. vol. v. 1827, p. 17 ; Cuv. Règ. An. nouv. éd. 1829, vol. i. p. 95 ; Fischer, Syn. Mamm. 1829, pp. 27 and 56; Sykes, Proc. Zool. Soc. 1831, p. 99 ; Is. Geoff. St.-Hil. Zool. du Voy. de Bélanger, 1834, p. 54; Waterhouse, Cat. Mamm. Mus. Zool. Soc. Lond. 1838, 2nd ed. p. 7 ; Elliot, Madr. Journ. Lit: \& Sc. vol. x. 1839, p. 95 ; Lesson, Sp. des Mammif. 1840, p. 89; Gray, Hand-list Mamm. 1843, p. 7 ; Blyth, Journ. As. Soc. Beng. vol, xiii. 1844, p. 476 ; vol. xvi. 1847, p. 732 ; vol. xxix. 1864, p. 88 ; Horsfield, Cat. Mamm. E. Ind. Co. Mus. 1851, p. 18; Gervais, Hist. Nat. des Mammif. 1856, p. 88 (fig. head) ; Jerdon, Mamm. Ind. 1867, p. 12.

Cercopithecus radiatus, Kuhl. Beitr. zur Zool. 1820, p. 13 ; Ogilby, Madr. Journ. Lit. \& Sc. vol. xii. 1840 , p. 145.

1 Quains. Anat. 7th Ser. vol. i, p. 98.

${ }^{2}$ Cat. Monkeys and Lemurs, B. M. 1870, p. 129. 
Inuus (Cercocebus) radiatus, Wagner, Schreber, Säugeth. Suppl. vol. i. 1840, p. 140.

Macacus sinicus, Blyth, Journ. As. Soc. Beng. vol. xvi. 1847, p. 1272; Is. Geoff. St.-Hil. Cat.

Méthod. des Mammif. 1851, p. 26 ; Gray, Cat. Monkeys and Lemurs, B. M. 1870, p. 28.

Inuus (Macacus) sinicus, Wagner, Schreber, Säugeth. Suppl. vol. v. 1855, p. 56.

Pithecus (Macacus) sinicus, Dahlbom, Stud. Zool. Fam. Reg. An. 1856, pp. 117, 119.

General colour brownish olive, tending to olive-grey on the outside of the limb. The hairs are grey at the base, but the terminal halves are annulated with black and dull yellow. Under surface of the body and tail and the inside of the limbs whitish, the upper surface of the tail being concolorous with the back. The hairs on the head radiated. Face nude, with the exception of a few hairs on the upper lip and on the sparsely clad forehead, which is permanently wrinkled even in the young. The face and the other nude parts are livid flesh-coloured, the ear somewhat prominent. The cheeks are hollowed, and the muzzle is rather narrow and somewhat protuberant.

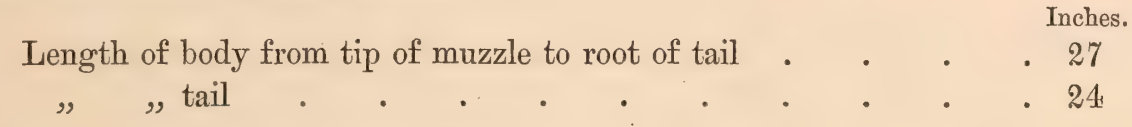

An adult female recently sent to the Zoological Gardens in Calcutta by Dr. Bidie of Madras has her face and ears more suffused with bright scarlet than any $M$. rhesus $I$ have seen. She has not been sufficiently long under observation to permit of it being ascertained for what length of time this flushing will last. Her nipples are very large and pendent.

Inhabits the southern parts of India.

The variety alluded to by Jerdon as existing on the Eastern Ghâts seems to me to be only the adult of this species.

The undermentioned species, ${ }^{1}$ which is extremely doubtful, has been included by Blyth in his Catalogue of Mammals, but there is no evidence that such a form exists in Formosa beyond what is here stated.

\section{Macacus pileatus, Shaw.}

The Rilawa, Knox, Hist. Rel. Ceylon, 1681, ch. vi. p. 25 ; Tennent, Nat. Hist. Ceylon, 1861, p. 5, plate, fig. 4 .

La guenon couronnée, Buffon, Hist. Nat. Suppl. vol. vii. 1789, p. 61, pl. xvi. (juv.)

The Rillow, Pennant, Hist. Quad. vol. i. 3rd ed. 1793, p. 206.

Le bonnet chinois, Audebert, Hist. Nat. des Singes, 1797, Fam. iv. sect. ii. fig. 11.

1 Macacos (sinicus), affinis, Blyth.

The Small Formosan Monkey, Swinhoe, Blyth, Journ. As. Soc. Beng. vol. xxix. (1860), p. 87.

Macacus speciosus, Swinhoe, Blyth, Journ. As. Soc. Beng. vol. xxix. (1860), p. 88.

Macacus radiatus, Blyth, Journ. As. Soc. Beng. vol. xxix. (1860), p. 88.

Macacus (radiatus) affinis, Blyth, Cat. Mamm. As. Soc. Mus. 1863, p. 8.

The only information regarding this monkey is contained in a letter from $\mathrm{Mr}$. Swinhoe to $\mathrm{Mr}$. Blyth, published fifteen years ago, and a note by the latter naturalist on a living specimen said to have been procured from the Island of Formosa.

Mr. Swinhoe, in forwarding to the Calcutta Museum the skull of a Macaque which he had received from Formosa and had kept alive for several months, designated the animal the small Formosan monkey and described it as a native 
The Rollewai, Blyth, Journ. As. Soc. Beng. vol, xiii. 1844, p. 476.

Simia pileata, Shaw, Genl. Zool. vol. i. pt. i. 1800, p. 53.

Cercocebus sinicus, Geoff. St.-Hil. Ann. du Mus. vol. xix. 1812, p. 98.

Pithecus sinicus, Desmarest, Nouv. Dict. d'Hist. Nat. vol. xvii. 1817, p. 324.

Cercopithecus sinicus, Kuhl. Beitr. zur Zool. 1820, p. 12.

Macacus sinicus, Desmarest, Mamm. 1820, p. 64; Dict. des Sc. Nat. vol. xxvii. 1823, p. 465 ; F. Cuv.

Hist. Nat. des Mamm. May 1825, pl. xxxiv ; Lesson, Man. de Mamm. 1827, p. 42 ; Griffith,

An. Kingd. vol. v. (1827), p. 17 ; G. Cuv. Règ. An. nouv. éd. vol. i. (1829), p. 95 ; Fischer,

Syn. Mamm. 1829, p. 27; Is. Geoff. St.-Hil. Voy. de Bélanger, Zool. 1834, p. 55; Waterhouse,

Cat. Mamm. Zool. Soc. Lond. 1838, 2nd ed. p. 7 ; Lesson, Sp. des Mammif. 1840, p. 89; Gray

Hand-list Mamm. 1843, p. 7 ; Blyth, Journ. As. Soc. vol. xiii. 1844, p. 476 ; Sehinz, Syn.

Mamm. vol. i. 1844, p. 56 ; Templeton, An. and Mag. Nat. Hist. vol. xiv. 1844, p. 361 ;

Kelaart, Fauna Zeylanica, 1852, p. 8.

Inuns (Cercocebus) sinicus, Wagner, Schreber, Säugeth. Suppl. vol. i. 1840, p. 139.

Macacus piteatus, Blyth, Journ. As. Soc. Beng. vol. xvi. 1847, p. 1272; Is. Geoff. St.-Hil. Cat.

Méthod des Mammif. 1851, p. 27; Gervais; Hist. Nat. des Mammif. 1856, p. 89 ; E. Tennent,

Hist. Ceylon, vol. i. 1860, p. 130 ; Blyth, Cat. Mamm. As, Soc. Mus. 1863, p. 9; Gray, Cat.

Monkeys and Lemurs, B. M. 1870, p. 29.

Inuus (Macacus) pileatus, Wagner, Schreber, Säugeth. Suppl. vol. v. (1855), p. 55.

Pithecus (Macacus) pileatus, Dahlbom, Stud. Zool. Fam. Reg. An. 1856, pp. 117 \& 119.

All the upper parts are rufous, but this colour passes into blackish on the hands, feet, and ears, and into brown on the upper surface of the tail. The hairs are grey at their base, as in $M$. sinicus, and are annulated as in that species, but the difference of colour that exists between the two is produced by the greater intensity and richer colouring of the annuli of the individual hairs of $M$. pileatus. The under surfaces generally are whitish. The forehead is sparsely covered with hair and wrinkled, and the muzzle is narrow and prolongated, the colour of the nude parts being livid fleshy, except along the lower lip, the margin of which is blackish. The hair on the head is rather long, forming a radiated, and occasionally somewhat erect, tuft.

$\begin{array}{cc}\text { Length of the body from the muzzle to the root of the tail } & \begin{array}{c}\text { Inches. } \\ 13.00\end{array} \\ \text {. } & \text { tail } . \quad 14.75\end{array}$

This species is closely allied to the Toque (M. sinicus), which it represents in Ceylon, but the differentiation between the two forms has proceeded further than between S. entellus and its insular representative, so much so that there is no difficulty in recognising their individual peculiarities.

Inhabits Ceylon.

of the camphor forests of the mountains of that island. Its colour he characterised as grey with the under parts pale and the eyes yellowish brown.

Mr. Blyth remarked of the foregoing skull that it was so young, the second true molars not having been developed, as not to exhibit any special characteristic, and he observes of a living specimen of the small Formosan monkey which had been sent to him by Swinhoe that it was a half-grown female, and that it differed in no respect that he could perceive from the common $M$. radiatus of the peninsula of India, except in being a shade or two darker with a nigrescent wash on the face and ears.

Swinhoe, however, in $1863,{ }^{1}$ observes, in writing of $M$. cyclopis : "This, as far as I could learn, was the only species of monkey in the Island of Formosa," so that it is probable he had discovered that the monkey resembling $M$. rudiatus bad been taken thither in the course of commerce.

\footnotetext{
1 Proc, Zool, Soc. 1803, p. 4.
} 


\section{Macacus silenus, Linn.}

L'Ouanderou, Buffon, Hist. Nat. vol. xiv. 1766, pp. 169, 174, plate xviii.; Audebert, Hist. Nat. des Singes, 1797, Fam. ii. sect. i. pl. iii.; Latr. Hist. Nat. de Buffon (Sonnini éd.) 1809, p. 273, pl. xxiii.

The Lion-tailed Monkey (a), Pennant, Syn. Mamm. 1771, p. 109, pl. 120, fig. 1; Hist. Quad. vol. i. 1793, p. 198, pl. xliv.

The Lion-tailed Baboon, Shaw, Genl. Zool. i. pl. i. 1800, p. 33.

Simia silenus, Linn. Syst. Nat. 12 ed. vol. i. 1766, p. 35; Schreber, Säugeth, vol. i. 1775, p. 87, tab. xi.; Gmelin, Linn. Syst. Nat. 13 ed. 1788, p. 31.

Simia veter, Gmelin, Linn. Syst. Nat. vol. i. 13 ed. 1788, p. 30.

Cercopithecus silenus, Erxleben, Syst. Reg. An. 1777 (in part), p. 26 ; Zimm. Geograph. Gesch. vol. ii. 1870, p. 184; L Latr. Hist. Nat. de Buffon (éd. Sonnini), 1809, vol. xxxvi. p. 283.

Cercopithecus veter, Erxleben, Syst. Reg. An. 1777, p. 24; Boddaert, Elench. An. 1785, p. 58.

Cercopithecus vetulus, Erxleben, Syst. Reg. An. 1777, p. 25 ; Boddaert, Elench An. 1785, p. 57.

Simia ferox, Shaw, Genl. Zool. vol. i. pt. i, (1800), p. 30, pl. xvi.

Papio silenus, Geoff. St.-Hil. Ann. du Mus. vol. xix. 1812, p. 102 ; Kuhl. Beitr. zur Zool. 1820, p. 18.

Pithecus silenus, Desmarest, Nouv. D’Hist. Nat. vol. xviii. (1817), p. 321.

Macacus silenus, Desmarest, Mamm. 1820, p. 63; F. Cuv. Hist. Nat. des Mammif. Jan. 1822, pl. xliv.; Desmarest, Dict. des Sc. Nat. vol. xxvii. (1823), p. 472 ; Lesson, Man. de Mamm. 1827, p. 41; Griffith, An. Kingd. vol. v. 1827, p. 16; G. Cuv. Règ. An. nouv. éd. vol. i. (1829), p. 95 ; Fischer, Syn. Mamm. 1829, p. 28 ; E. T. Bennett, Garden, Menag. Zool. Soc. Del. vel. i. 1831, p. 21 ; Is. Geoff. St.-Hil. Zool. Voy. de Bélanger, 1834, p. 58 ; F. Cuv. Hist. Nat. des Mammif. Août 1837, pl. xliii.; Waterhouse, Cat. Mamm. Mus. Zool. Soc. Lond. 1838, 2nd ed. p. 7 ; Lesson, Sp. des Mammif. 1840, p. 93 ; Blyth, Journ. As. Soc. Beng. vol. xiii. 1844, p. 476; Blyth, Journ. As. Soc. Beng. vol. xvi. 1847, p. 1272 ; Ibid, vol. xxviii. 1859, p. 283 ; Schinz, Syn. Mamm. 1840, vol. ii. p. 57 ; Is. Geoff. St.-Hil. Cat. Méth. des Mammif. 1851, p. 30; Gervais, Hist. Nat. des Mammif. 1854, p. 89 (figure of animal and head). Inuus (Maimon) silenus, Wagner, Schreber, Säugeth. vol. i. 1840, p. 141, pl. viii. C. and xi. B.; Blyth, Journ. As. Soc. Beng. vol. xvi. 1847, p. 731.

Silenus veter, Gray, Hand-list Mamm. B. M. 1843, p. 8; Horsfield, Cat. Mam. E. Ind. Co. Mus. 1851, p. 22 ; Cat. Monkeys and Lemurs, B. M. 1870, p. 32.

Pithecus (Macacus) silenus, Dahlbom, Ind. Zool. Fam. Reg. An. 1856, pp. 116, 119.

Inuus silenus, Blyth, Cat. Mamm. As. Soc. Mus. 1863, p. 7 ; Jerd. Mamm. of Ind. 1867, p. 10.

General colour of the body, limbs, and tail, deep black; the hair on the top of the head is very short, and the face is encircled with long hairs in front of the ears, continued downwards round the throat and of a greyish dun colour; the end of the tail is tufted and tipped with greyish or white, which is the colour that occurs on the chest, all the rest of the under parts being deep black in the adult. The face and the skin of the hands are black, but the callosities have a fleshy tinge.

$$
\begin{aligned}
& \text { Length of the body from the muzzle to the root of the tail } \quad \begin{array}{c}
\text { Ft. In. } \\
2
\end{array} \\
& \text { " } " \text { tail . . . . } 010
\end{aligned}
$$

It inhabits the Western Ghâts from below Goa to Comorin, but there is no authentic record of its existence in a wild state in Ceylon.

The structure of this animal is essentially that of the ordinary Macaques, although it differs from them so much in external physiognomy. 
The skull is chiefly distinguished by its rotundity, due to the outward bulging of the zygomatic arches; by the contraction of the muzzle at its base; by the concavity below the orbits; by the anterior expansion of the muzzle; by its rather round than vertically elongated posterior nares; by the great development of the orbital ridges; by the expanded frontal depression behind them; and, lastly, by its relatively rather small molars and premolars.

The vertebral formula is C. 7, D. 12, L. 7, S. 3, caudal 17. The neural arch ceases on the fifth caudal, beyond which the vertebræ rapidly increase in length to the ninth, after which they again gradually diminish in size. 


\section{CHIROPTERA.}

Br G. E. DOBSON, M.A., M.B., F.L.S., \&c.

PTEROPIDA.

Genus: Crnopterus, F. Cuv.

* Crnopterus marginatus, Geoffroy.

Pteropus marginatus, Geoffroy, Ann. du Mus. 1809, xiv. p. 97.

A specimen of this species, which is very common in the peninsula of India and in Burma, wherever fruit is abundant, was obtained at Bhamô. In this specimen I find two lower incisors only, which do not rise above the level of the gum. The lower inner incisors have probably fallen out, and their former position become hidden by the gum closing in above, while the interval naturally existing on each side between the canines and the incisors, causes the remaining two incisors to appear symmetrically placed between the canines, each incisor occupying the centre of each half space.

RHINOLOPHID (Dobson).1

Genus: Rhinolophus, Geoffroy.

* Rhinolophus pearsonir, Horsfield, Pl. iv. fig. 1.

Rhinolophus pearsonii, Horsfield, Cat. Mamm. E. Ind. Co. Mus. 1851, p. 33.

Rhinolophus larvatus, Milne-Edwards (non Horsfield), Resch. Mammif. du Tibet, 1872, pp. 248249, pl. xxxvii. fig. 1, xxxvii.c, fig. 1.

Rhinolophus yunanensis, Dobson, Journ. As. Soc. Beng., 1872, vol. xli. p. 336.

Ears large, acutely pointed, outer margin deeply hollowed out beneath the tip; antitragus large, separated from the outer margin of the ear by an acute angular notch; nose-leaf well developed, anterior horizontal portion broad, projecting laterally, and in front beyond the upper lip, so as to completely conceal the muzzle when viewed from above; the anterior flattened portion of the central nose-leaf is moderately broad below, the upper part slightly narrowed and rounded off above; terminal portion of the hinder nose-leaf short, sides almost straight, slightly convex.

Wing-membrane attached to the ankles; tail short, and contained, with the exception of the extreme tip, within the interfemoral membrane, the posterior free margin of which is concave. 
Fur above and beneath uniformly dark brown, very long and dense. Of three well-preserved spirit specimens, two males and one female, the measurements of all parts, except the tail, correspond to the twentieth of an inch. In one male the tail measures $1 \cdot 10$ inch.

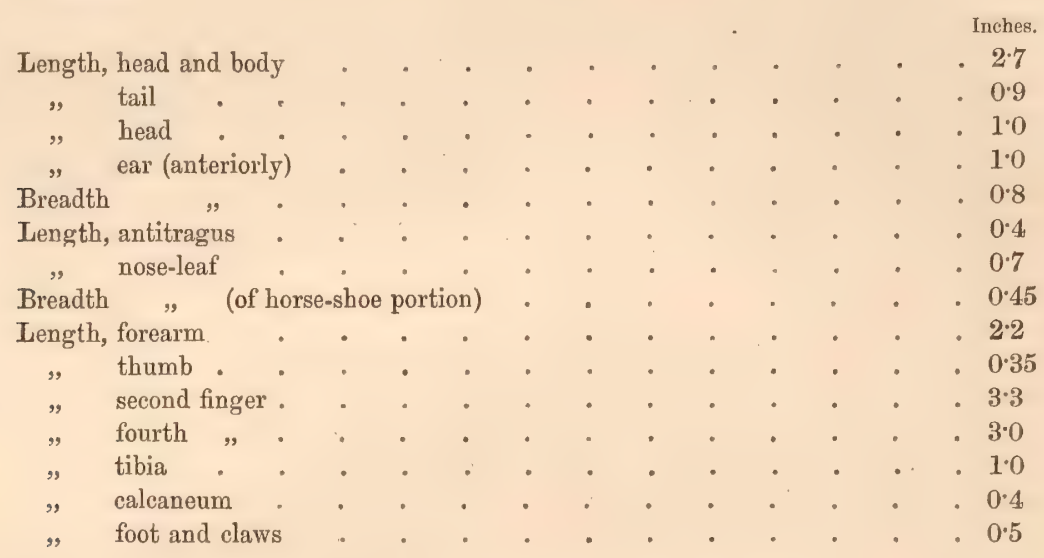

Locality.-Hotha, Yunnan. Elevation about 4,500 feet.

*Rhinolophus cœlophyllus, Peters.

Rhinolophus celophyllus, Peters, Proc. Zool. Soc. 1866, p. 426, pl. xxxv.

This extremely interesting species, which differs in the form of the nose-leaf from all other species of the genus, has hitherto been represented by only a single specimen collected by the late Lieutenant Beavan at Moulmein, and preserved in the Berlin Museum. Among the collection made by Dr. Anderson during the second Yunnan Expedition, I find specimens which differ in no respect from the type which I have examined in the Berlin Museum.

In this species (which has been very fully described and figured by Professor Peters) the posterior terminal leaf is shortly triangular in outline, formed of very thick integument, and its surface is marked by a crucial aperture leading into a deep cavity lined by hairs; the lower part of this aperture receives the posterior extremity of the connecting laterally flattened portion of the central nose-leaf or sella.

Length of the largest specimen preserved in alcohol :-

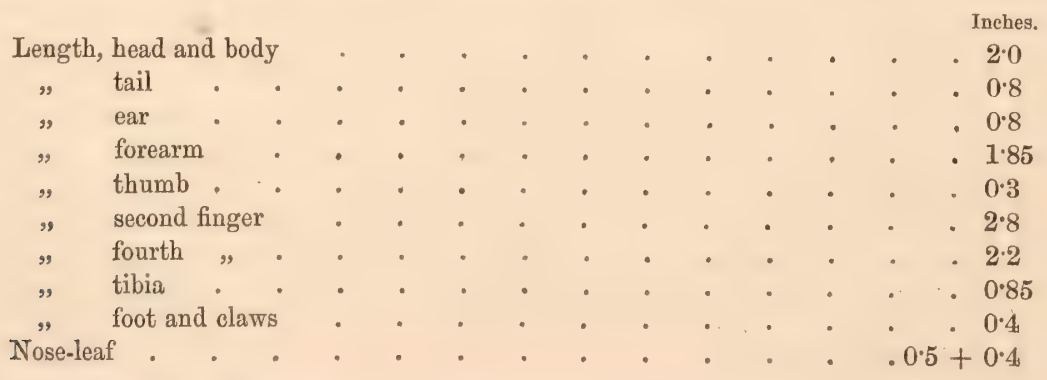

Habitat.-Burma (Moulmein; Tsagain, Upper Burma). In caves. 
Genus Phyllorhina, Bonap.

* Phyllorhina iarvata, Horsfield.

Rhinolophus larvatus, Horsfd. Zoolog. Research. in Java.

The collection contained a large number of specimens, male and female, of this species. The fur of all was similarly coloured, rich golden chestnut, contrasting remarkably with the sombre hues of other individuals of the same species from Assam. The same colour was observed in the type specimens from Java described by Horsfield, so that the Burmese forms more closely resemble the Javanese than the Assamese.

The measurements of twelve adult individuals gave the following average result:-

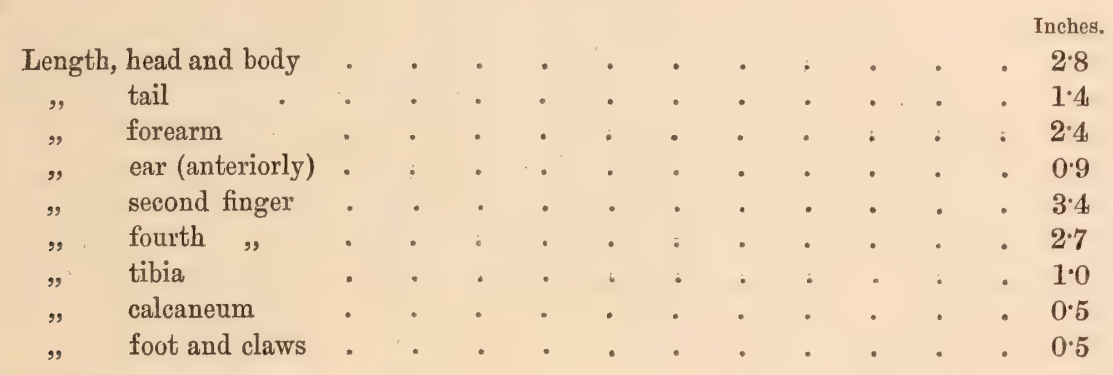

Locality.-Prome, Burma.

* Phyllorhina speoris, Schneider.

Tespertilio speoris, Schneider, Suppl. Schreber. Säugeth. Atlas 1, pl. 59B.

A single male specimen of considerably larger dimensions than hitherto recorded for this species. Colour of the fur precisely similar to that of the specimens of $P h$. larvata described above, with which it was at first confounded. The species is closely allied to $P$ h. larvata, which it resembles in the form of the nose-leaf and frontal sac, but may be readily distinguished by the last caudal vertebra being completely free from the interfemoral membrane and by the smaller ears.

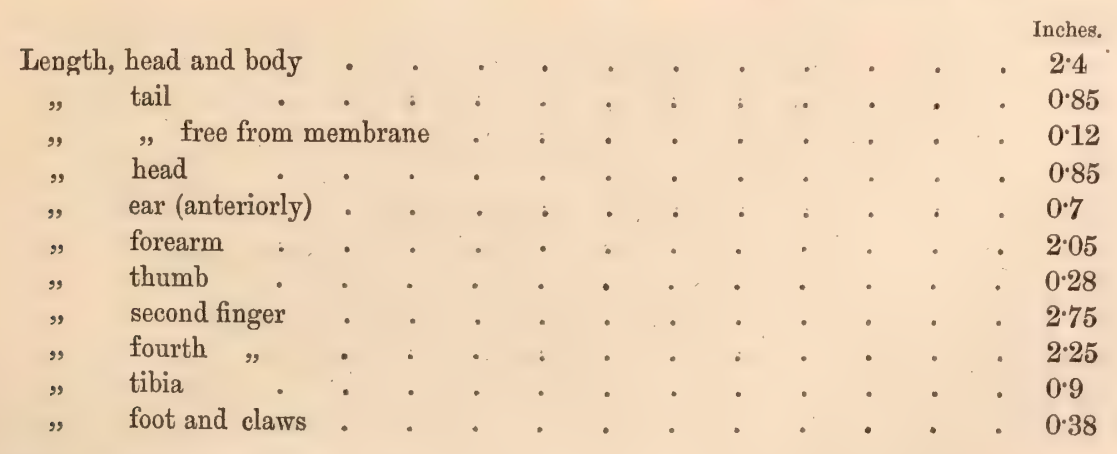

Locality.-Prome, Burma. 


\section{* Phyllorhina fulva, Gray.}

Hipposideros fulvus, Gray, Mag. Zool. and Bot. 1838, ii. p. 492.

Rhinolophus murinus et fulgens, Elliot, Cat. Mamm. South Mahratta Country, 1840, p. 8. Phyllorkina aurita, Tomes. Proc. Zool. Soc. 1859, Pl. 76.

Phyllorhina fulva, Peters, M. B. Akad. Berl. 1871, p. 322. Dobson, Proc. As. Soc. Beng. 1872, p. 155.

The brilliant golden yellow colour of the fur which is occasionally found replacing the common white and black, and from which the specific names "fulva" and "fulgens" have been derived, is not restricted to this species, but appears in about the same proportion among specimens of other species of both Phyllorhina and Rhinolophus. I have expressed my opinion ${ }^{1}$ that this golden yellow colour is analogous to the breeding plumage in birds, and that it is restricted to females during the breeding season. However, during the second Yunnan Expedition, Dr. Anderson obtained several males of this species, in the same cave, all of which possessed this golden yellow colour, while males and females obtained at the same time in adjoining caves were of the common black and white kind. These very differently coloured animals differed, however, in no other respect, agreeing in structure in all respects and in measurements. The conditions under which this remarkable difference in colour occurs are, therefore, still unexplained, but the golden yellow colour may be developed equally in males and females when the sexes come together, which may not occur at the same season for all.

As $P h$. fulva can be distinguished from $P h$. bicolor by its larger ears only, I am unable to consider it more than a sub-species of Ph. bicolor, Temm.

Habitat.-Burma (Prome, Tsagain, Upper Burma; Ponsee and Kakhyen Hills). In caves.

VESPERTILIONID 丑, Dobson. ${ }^{2}$

Genus Vespertilio, Keys. Blas. Wiegm. Archiv. 1839.

* Vespertilito montivagus, Dobson.

Vespertilio montivagus, Dobson, Journ. As. Soc. Beng. 1874, vol. xliii. p. 237.

Head very slightly elevated above the face line; muzzle obtuse; ears narrow, tapering, with rounded tips; outer side flatly emarginate immediately beneath the tip for about quarter its length, then slightly convex; lower down opposite the base of the tragus with a small emargination, terminating beyond this in a small rounded lobe; tragus long, narrow, and acutely pointed; inner margin straight, outer slightly convex upwards with a small rounded lobe at the base.

Feet very small; toes two-thirds the length of the whole foot; tail wholly contained within the interfemoral membrane; wings from the base of the toes.

\footnotetext{
1 Proc. Zool. Soc., 1873, p. 250.

2 Ann. Mag. Nat Hist. Nov. 1875, p, 347.
} 
Fur, above, dark brown, the extreme points of the hairs paler and shining; beneath, much darker brown or black for three-fourths its length, the remaining portion ashy.

In front the face is everywhere densely covered, the long hairs concealing the eyes, and leaving the tip of the nose above naked; on each side of the nose two or three small warts may be seen through the hairs. The ears are quite naked anteriorly; posteriorly, their bases only are covered. On the wing-membrane the fur of the back extends as far as a line drawn from the junction of the proximal and middle thirds of the humerus to the commencement of the distal third of the femur; on the interfemoral membrane it ceases abruptly at the end of the second caudal vertebra; the remainder of the membrane is quite naked. Beneath, the abdominal fur extends upon the wing-membrane as far as a line drawn from the elbow to the knee-joint; posteriorly, the extent of the fur of the body on the wing-membranes is similar to that on the upper surface, but three-fourths of the membrane is dusted over with a few very fine hairs arising from the transverse dotted lines. The backs of the toes are covered with a few very short hairs.

Incisors on each side parallel, acutely pointed; inner incisors longest with a small acutely pointed talon near their extremities on the outer side. In the lower jaw the second premolar is small, but distinctly visible, standing in the tooth-row; in the upper jaw the space between the canines and third premolar is small, and the second premolar is very minute, placed in the angle between the first and third premolars, and with difficulty distinguishable in recent specimens even with the aid of a lens.

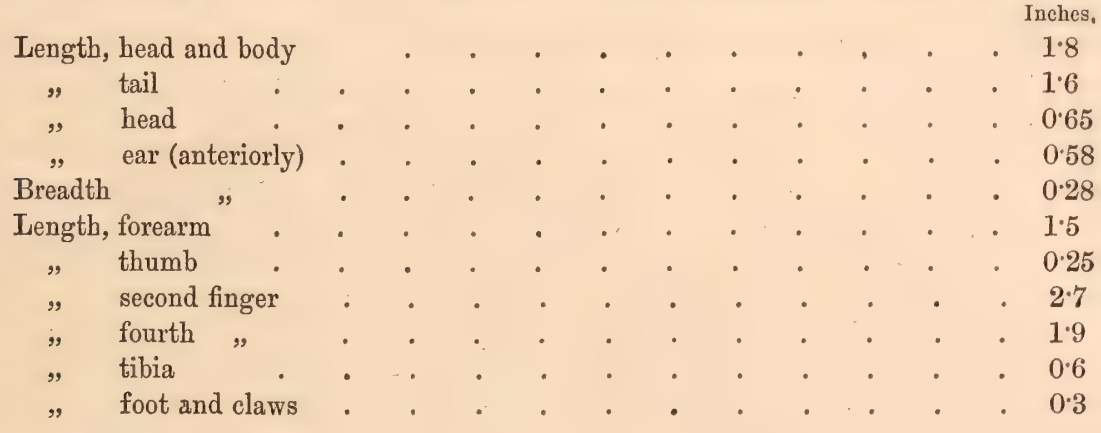

Habitat.-Hotha, Yunnan.

Genus Sсоторнilus, Leach.

* Scotophilus ornatus, Blyth.

Nycticejus ornatus, Blyth, Journ. As. Soc. Bengal, 1851, vol. xx. p. 517.

Scotophilus ornatus, Dobson, Proc. Zool. Soc. 1875, p. 371.

Specimens of this remarkably coloured species were obtained at Nantin and in the Sanda Valley. Among the Vespertilionida of the eastern hemisphere this species appears to be most nearly allied to the American species of the genus Atalapha, with which it agrees remarkably in its general characters. 
Genus VesperUgo, Keys. et Blas.

* Vesperdgo affinis, Dobson, Pl. IV, figs. 7, 8.

Pipistrellus affinis, Dobson, Proc. As. Soc. Bengal, 1871, p. 211.

Head flat; glands of the upper lip so developed as to cause a deep depression between them on the face, behind the nostrils. Measured from behind, the ears are as broad as long; their inner margins are convex, and the tips broadly rounded. The outer margin of the ear extends from the tip to its termination near the angle of the mouth, without emargination, and without forming a lobe of any kind; from the angle of the mouth it is separated by a small wart covered with long hairs. The tragus is of the shape so common in the species of this sub-genus; its inner margin is straight, its outer convex upwards, and at the base the usual small triangular lobe is found. The nostrils open sublaterally, and in the centre of the slightly emarginate space between them a narrow ridge passes down to the upper lip, as in the greater number of the species of Pipistrellus.

The wing-membrane is attached to the base of the outer toe, which is shorter than the others. The tail is long, of nine vertebræ, the last free.

The feet are small, the toes very slender and almost naked.

Above, the fur of the head extends upon the face above the eyes as far as the glandular prominences of the upper lip, the remaining parts of the face are almost naked; anteriorly, the ear conch has a few, fine, scattered hairs ; posteriorly, about half the posterior surface from the base upwards is densely covered. The distribution of the fur upon the wing-membranes is very limited, on the upper surface being confined to a narrow space along the sides of the body; beneath, its extent is greater, and a few, fine, greyish hairs are ranged along parallel lines nearly as far outwards as a line joining the elbow and knee-joints. The fur of the body does not extend upon the interfemoral membrane, which has but a few almost invisible hairs scattered over the anterior half of its upper surface, and is covered, beneath, by very fine, short, greyish hairs arising from the dots on the transverse dotted lines.

On the upper surface chocolate brown, lighter on the head and neck; beneath, dark brown, with light brown or ashy tips; on the pubes and along the thighs dirty white or very pale buff.

Incisors equal in vertical extent; outer incisors acutely pointed, inner obtuse; first upper premolar minute, acutely pointed, placed inside the line of teeth and not distinguishable from without.

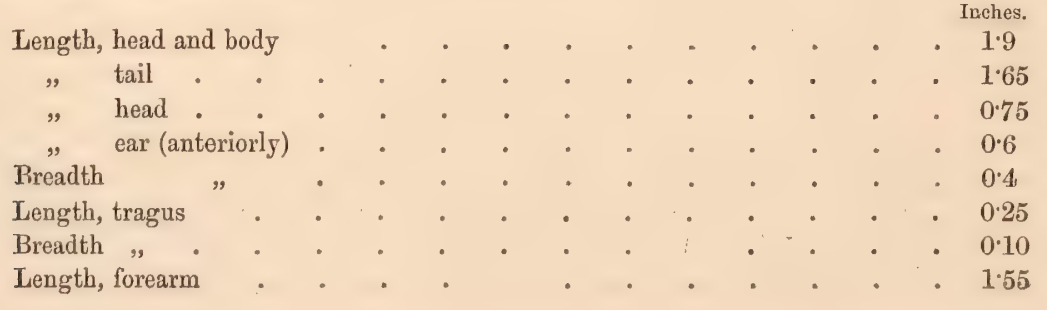




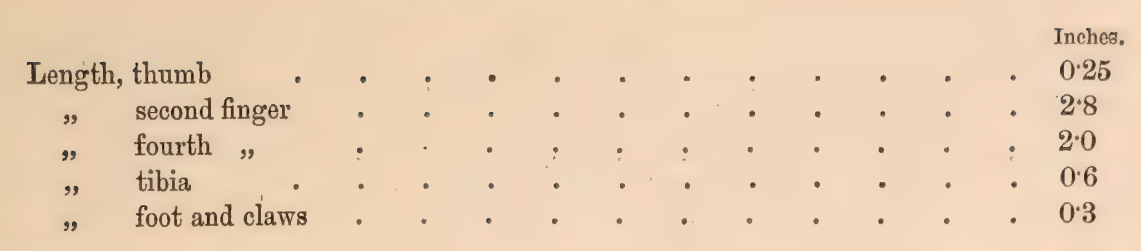

Locality.-Bhamô.

This species is allied to $V$. maurus, Blas., from which it may be distinguished, however, by the absence of an emargination on the outer side of the ear, and by the distribution of the fur.

Sub-genus Vesperus, Keys. et Blas.

* Vesperugo andersoni, Dobson, Pl. IV, figs. 2, 6.

Tesperus andersoni, Dobson, Proc. As. Soc. Bengal, Sept. 1871, p. 211.

Head broad and flat; muzzle thick; nostrils opening sublaterally without intervening emargination; ears moderate with rounded tips ; inner margin convex, outer with a shallow but wide emargination beneath the tip, then convex, and again emarginate opposite the base of the tragus, terminating by forming a small lobe midway between the base of the tragus and the angle of the mouth; tragus obtusely pointed, broadest in the middle, inner margin straight, outer with a small rounded lobe at the base succeeded by a shallow emargination, then convex upwards to its junction with the inner margin.

Toes larger than half the whole foot; tail of eight vertebræ, the last free.

The fur of the body and head is moderately long and dense; anteriorly it passes forwards upon the face in front of the eyes as far as the commencement of the glandular prominences of the upper lip, from which only a few long hairs arise; that portion of the face about the eye and in front of the base of the inner margin of the ear is also naked, but the space between the base of the tragus and the angle of the mouth is covered with long hair. In front the ears are naked, except where a few very short hairs appear on the upper and inner side of the conch; posteriorly, the fur of the head encroaches on their bases, but more than one-half of their posterior surfaces is naked. On the upper surface, the fur of the back extends upon the wing-membrane as far as a line drawn from the junction of the proximal and middle thirds of the humerus to the middle of the femur; posteriorly, it extends as far only as the root of the tail, and the interfemoral membrane has but a few very fine hairs dusted over its anterior surface, as far as the end of the second caudal vertebræ. Beneath, the distribution of the fur on the wing-membranes is similar to that on the upper surface, but somewhat more extended; a line of fine thinly-spread hairs passes out along the posterior margin of the humerus and forearm to the carpus; posteriorly, the fur of the abdomen covers the root of the tail only, and three-fourths of the surface of the interfemoral membrane is occupied by a few, thinly spread, very fine, minute hairs. 
Fur above, dark brown with greyish tips; beneath, light greyish brown for twothirds the length of the hairs, the remaining portion ashy.

- Inner incisors slanting inwards, long and bifid; outer incisors very short and acutely pointed, placed in front of the inner incisors, and lying on their outer sides.

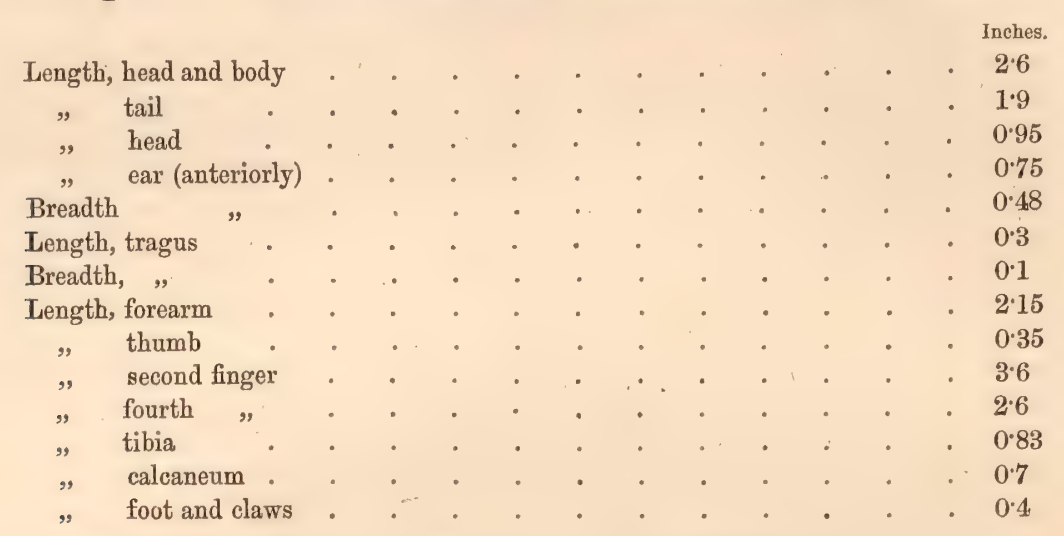

Habitat.-Momein, Yunnan. Elevation about.5,000 feet.

EMBALLONURID压, Dobson. ${ }^{1}$

Genus : Taphozous, Geoffroy.

* Taphozous longrmanus, Hardwicke.

Taphozous longimanus, Hardwicke, Linn. Trans. vol. xiv. 1826, p. 525; Dobson, Proc. Zool. Soc. 1875 , p. 551.

This species appears to be widely distributed throughout the Burmese Provinces. $T$. melanopogon inhabits the same localities generally, and resembles it very closely in size. It may be distinguished readily from that species by the possession in males of a submental pouch, and, in females, by traces of the margins of this pouch. As the black beard is not always present in the males of T. melanopogon, a careful examination is always necessary to distinguish the species.

1 Ann. Mag. Nat. Hist. Nov. 1875, p. 347. 


\section{INSECTIVORA.}

\section{NYCTICIBID $A$.}

Genus Nrcticebus, Geoffr.

* Nycticebus cinereus, A. M. Edwards.

Nycticebus cinereus, A. M. Edwards, Nouv. Arch. du Mus. vol. iii. p. 867; Bull. 1869, p. 7, pl. III, figs. $1-5$.

Nycticebus tardigradus, Blyth, var. A, Cat. Mamm. As. Soc. Mus. 1863, p. 18.

A Nycticebus, which agrees with M. A. M. Edwards' figure of the Siam form, occurs in the Kakhyen Hills to the east of Bhamô. I procured an adult male, and it agrees with $N$. cinereus, A. M. Edw., viz., in colouring, in the form of the skull, and in the number of incisors in the upper jaw. A. M. Edwards remarks that "les yeux sont entourés d'un cercle de poils généralement blonds;" but in his figure the eyes are surrounded with brown, whilst a white band occurs between the eye and the ear, external to the brown area surrounding the eyes, and joining above and below with the central white area of the face, and the Bhamô specimen in these respects resembles the figure.

It is the form which is found in the Assam region, from whence I have frequently obtained it alive, of both sexes, young and adult. The specimens received by me have generally come from the Garo Hills, but Blyth ${ }^{1}$ records it from Tippera and Arracan, but with regard to the latter locality, it may be mentioned that he recognised only one species, $N$. tardigradus, ${ }^{2}$ to which, however, he referred three varieties distinguished by the colour of the fur and the number of the incisors. 'His variety $A$ was this species; his variety $B$ the darker-coloured and more rufous Malayan form without well-defined markings on the head and with four upper incisors, which he received from Malacca; and $C$, the Java variety, with only two upper incisors and with four well-defined broad head-bands of dark brown.

The varieties $A$ and $B$ are not unfrequently offered for sale in Calcutta, but the latter is rare in Eastern Bengal, the explanation of its occasional presence in the Calcutta mart being that it is brought thither in the course of trade between Calcutta and the ports of Arracan, Burma, the Malayan peninsula, and Singapore. The light-coloured form $A$, on the other hand, is from Assam, and consequently is

1 Journ. As. Soc. Bengal, vol. xvi. 1847, p. 735.

2 L. c. et Cat. Mamm. As. Soc. Mus. Bengal, 1863, p. 18. 
more frequently seen in Calcutta than the previous one, and, as already stated, it seems to me to be identical with $N$. cinereus, A. M. Edwards.

Vosmaer $^{1}$ has described what he has denominated the Bengaalische Luijnard, and which he characterises thus: "Le poils est assez long, fin et laineux, mais rude au toucher. Sa couleur est, en générale, le gris ou cendré jaunâtre clair, un peu plus roux sur les flancs et aux jambes. Autour des yeux et des oreilles, la couleur est aussi un peu plus foncée, et depuis la tête tout le long du dos règne rai brune." 2 A description in every way applicable to the example from Bhamô and to the Assam specimens of this race which have come under my observation, and therefore also embracing the Cochin-China form $N$. cinereus, A. M. Edwards.

Geoffroy's ${ }^{3}$ description of $N$. bengalensis is founded on "le paresseux pentadactyle du Bengale" of Vosmaer, of which he gives Bengal as the natural abode, and mentions that the animal has four upper incisors, whereas Vosmaer had stated it had only two premaxillary teeth. Audebert, ${ }^{4}$ however, in his work on Monkeys and Lemurs, remarks that Vosmaer had overlooked the two small outer incisors, the existence of which Geoff. St.-Hilaire had determined by a personal inspection of Vosmaer's specimen which is now in the Paris Museum, where it is ranked in the Catalogue under $N$. javanicus, and Bennett ${ }^{5}$ also repeats this statement. Vosmaer's figure, if a correct representation of his specimen, certainly conforms more to the Assam than to the Javan form, the latter being markedly distinguished by the presence of two ocular and two aural brown bands, and generally by there being only two upper incisors, whereas the head of Vosmaer's figure is a very good representation of the Assam Nycticebus with four upper incisors.

I am therefore disposed to consider that the Assam, Bhamô, and Siam Nycticebi, which appear to be one species, belong to the form described by Vosmaer, but the correctness of this suggestion can only be ascertained by the actual comparison of specimens from the foregoing localities with the type.

The figure which M. Audebert ${ }^{6}$ has given of $N$. tardigradus is a life-sized representation of Blyth's variety $B$. It is uniformly rusty-brown with no bands from the eyes, which have the brown area around them but very little darker than the body colour. The ears are dark, and no brown bands proceed from them to the vertex, and the white which in other species exists between the eyes surrounding their brown margin is here replaced by a rufous tint. This is the BurmoMalayan form, and is smaller than the Assam Nycticebus. Audebert states that the specimen was in the Paris Museum under the Malayan name "Poucan," which is apparently the same as the "Kukung," figured and described by Raffles" under the names $N$. tardigradus and $N$. bengalensis, an animal without head-bands, of the

\footnotetext{
${ }_{1}^{1}$ Natuurkundige Besch. \&e. in Oost. en West-indische, 1766-1804, p. 19, pl. xx.

2 Buffon, Hist. Nat. (1789), Suppl. vol. vii. pl. xxxvi. p. 2125.

3 Ann. du Mus. 1812, vol, xix. pp. 163-164.

${ }^{4}$ Singes et Makis, p. 21.

${ }^{5}$ Gardens and Menagerie Zool. Soc. Lond. 1831, vol. i. pp. 139, 144.

${ }^{6}$ L. c. pl. i.

7 Trans. Linn. Soc. Lond. (1822), vol. xiii. p. 247.
} 
same type as Audebert's specimen. Audebert appears to have been in doubt regarding its natural habitat, because he says: "Celle (figure) que nous donnons, nous a été envoyé du Bengale par M. Alfred Duvaucel sous le nom de Lori Poucan, nom que cet animal reçoit des Malais." The probability, therefore, is that this specimen was of Malayan origin, and that M. Duvaucel had previously obtained it or had purchased it when in Calcutta and there appended the Malayan name to it; and, moreover, as strengthening this supposition, is the circumstance that no Eastern Bengal example of this animal is registered in the Catalogue of the Paris Museum published in 1851. Both Audebert's and Cuvier's specimens belong to the type without head-bands figured by Van der Hoeven, ${ }^{2}$ and which is in strong contrast with the Assam form, although it has the same number of upper incisors. This is the form to which Temminck ${ }^{3}$ also applied the term $N$. tardigradus, Linn., and it is likewise classed in the Paris Catalogue under $N$. tardigradus, ${ }^{4}$ and is recorded from Borneo.

Geoffroy characterised $N$. bengalensis ${ }^{5}$ as having a large muzzle with four upper incisors, and distinguished his $N$. javanicus, the Kukong of Temminck, by its short muzzle with two upper premaxillary teeth, but he makes no mention of the four permanent brown bands on the front of the head, and which are so well shown in the head figured by Van der Hoeven, which corresponds to the variety $C$ of Blyth. The muzzle of $N$. javanicus more resembles in breadth and shortness that of $N$. cinereus than that of the Burmo-Malayan Nycticebus.

Geoffroy's specimens were obtained in Java ${ }^{6}$ by M. Leschenault. Guerin ${ }^{7}$ in his "Iconographie" figures this form and its skull and incisor teeth as $N$. tardigradus.

The chief characters by which these various Nycticebi have been separated from each other are the differences of coloration and the number of incisors in the upper jaw, which may be either two or four, but this latter character is the subject of variation as has been shown by A. M.-Edwards, who has met with skulls of $N$.javanicus with only one upper incisor on one side of the jaw and two on the opposite side. This being the case, he is inclined to regard $N$. javanicus as only a synonym of $N$. tardigradus. However, the coloration of the former is markedly distinct from that of the latter; and the two upper incisors are rarely supplemented by one, and I am not aware that an instance has been met with in which four have been present. Van der Hoeven ${ }^{8}$ states that he has never observed an example of $N$. tardigradus with only two incisors, but he agrees with A. M.-Edwards that $N$. javanicus and $N$. tardigradus do not materially differ in their dentition. And an observation of Huxley's ${ }^{9}$ on the dentition of Nycticebus javanicus verifies the more recent observations of these zoologists, and proves satisfactorily that the teeth in that form are liable to considerable variation.

${ }^{1}$ Cat. Méthod. des Mamm. 1851, p. 78.

2 Arch. Neerland, vol. iii. 1868, pl. vi. fig. 8.

${ }^{3}$ Les Possess. Neerland, t. I. p. 323, 1846.

${ }^{4}$ L. c.

5 Ann. Mus. 1812, pl. xix. p. 164.
${ }^{6}$ L. $c$.

7 Iconographie Mamm. vol, i, pl. 6.

s $L . c .$, p. 95 .

${ }^{2}$ Proc. Zool. Soc. Lond. 1864, p. 323. 
With regard to Van der Hoeven's' observation that the second upper premolar and last three molars of $N$. javanicus have a talon directed inwards, - in a young example, the second upper premolar has such a structure well developed, but in an adult it is worn away to the base; but in both, the two first molars are quadricuspidate, and the fourth tricuspidate, according to the normal pattern, and as it occurs in $N$. tardigradus and $N$. cinereus.

The affinities manifested by this genus towards certain African forms is a fact full of interest, and is all the more remarkable, because in some respects it approaches more closely to them than to the Asiatic Loris, L. gracilis. Huxley ${ }^{2}$ has pointed out that, in its dentition, it approaches Arctocebus, or rather that the latter differs more from the African Perodicticus than from this genus, while it also has a certain resemblance to the Loris. Mivart, ${ }^{3}$. too, has insisted on a kindred affinity between Nycticebus and Perodicticus much more than between it and Loris.

Measurements of Bhamô specimen:-

$$
\begin{aligned}
& \text { Muzzle to vent . . . . . . . . . . } 1320 \\
& \text { Length of tail . . . . . . . . . . . . }{ }_{75} \\
& \text { " fore limb from head of humerus to tip of fourth finger : . } 7 \cdot 20 \\
& \text { " hind limb from head of femur to tip of fourth toe . . . } 9.00 \\
& \text { Tip of thumb to tip of fourth finger (expanded). . . . . } 280 \\
& \text { " great toe to fourth toe } " \text {. . . . . } 360
\end{aligned}
$$




\section{TUPAIID $A .{ }^{1}$}

While Sir Thomas Stamford Raffles was Lieutenant-Governor of Fort Marlborough, as is well known, he engaged the services of MM. Diard and Duvaucel to assist in the collection and preservation of his zoological specimens, and to conduct any anatomical observations which he might wish made on recent subjects: the whole of these observations and collections were to be the property of the East India Company. M.M. Diard and Duvaucel, however, according to Raffles, before the expiry of the first year of their engagement, advanced pretensions so inconsistent with the letter of their agreement that he had to discontinue his arrangement with them. From what Raffles states, it appears probable that they had claimed the independent right of publishing their observations, because he mentions that he had no alternative left but to undertake an immediate description of the collection himself, or allow the results of all his endeavours and exertions to be carried to a foreign country. Whatever may have been his views regarding their duties before his disagreement with them, we find him presenting the Asiatic Society of Bengal with a figure and description of the so-called Sorex-glis drawn up by them. This paper was read before the Society on the 10th March $1820,{ }^{2}$ and as Raffles' own description was not laid before the Linnæan Society until the 5th December of that year, ${ }^{3}$ nor published until two years later, the credit belongs to MM. Diard and Duvaucel of having first brought to light this remarkable insectivorous group. To the contribution to the Asiatic Researches Sir T. Raffles makes no allusion whatever in his communication to the Linnæan Society. The only explanation of this seeming oversight is to be found in the introductory remarks to his Descriptive Catalogue of the Zoology of Sumatra and its neighbourhood.

MM. Diard and Duvaucel regarded the animal they described as a true shrew disguised in the habits, and, I may add, in the garb, of a squirrel, but that it was possible that it might be taken as the type of a new sub-division, for which, however, they did not propose any name beyond the term Sorex-glis. After mentioning that it was distinguished from the shrews by its teeth and crecum, they still spoke of it as "Ce veritable sorex," and appended the specific term glis to indicate its Sciurine habit of body. It is not until we turn to Horsfield's "Java" that we find the compound word Sorex-glis applied to the animal in question. For better Latinity and for the sake of euphony, Desmarest ${ }^{5}$ proposed the term Gli-sorex, which Giebel ${ }^{6}$ has recently altered to Glisosorex. Raffles, however, in his description of two species

${ }^{1}$ Dr. Gray has pointed out (Ann. and Mag. Nat. Hist. (1860), Vol. V, p. 71,) that there is a figure and a descrip. tion of a Tupaia in Ellis's MS. papers and drawings of the animals observed in Captain Cook's third voyage, and which are now deposited in the Zoological Department of the British Museum.

The Tupaia was apparently first obtained at the Island of Condore (Pulo Condore), which is about one hundred miles to sea from Saigon, and where Cook was on the 20th January 1780 . The animal is described and figured in that - collection of drawings as Sciurus dissimilis, but it would be impossible from the crude nature of the sketch to hazard a ny opinion regarding the species.

${ }^{2}$ Asiatic Researches, Vol. XIV, 1822.

${ }^{3}$ Linnæan Transactions, 1821, Vol. XIII, p. 239.

${ }_{5}^{5}$ Mammologie, p. 536.

* Horsfd. Research., Java, 1824. 
of the genus, so early as 1820, designated them under the generic name Tupaia, a term derived from the Malay word Tupai, which is applied generally by the people to "various small animals which have the external form and the agility of the squirrel." This term was strongly objected to by F. Cuvier on the ground of its origin from the language of a semi-civilised people, and he proposed the name Cladobates instead. I do not, however, see any very grave objection to the term Tupaia, more especially as it was used by Raffles in no ambiguous sense, but was accompanied by a definition of the genus. Temminck also protested against the adoption of the term Tupaia, which was doubtless an unfortunate one, and proposed Hylogale in the interests of science, and under the belief that it would be accepted.

In consequence of the rejection of the first generic term applied by the naturalist who first defined the group, and had a fair knowledge for his time of its affinities, we have this small group of animals now overburdened by those generic terms, Tupaia, Glisosorex, Cladobates, and Hylogale; one body of naturalists accepting Cladobates, and the English naturalists adhering to the name first applied to it by one of their own countrymen. It is much to be deplored that some common principle as to the acceptance or rejection of terms, generic and specific, has not been laid down for the guidance of naturalists; but I hold that if a classical origin is to be insisted on, those naturalists who reject Tupaia on the ground of its being derived from a savage tongue, should be consistent, and refuse their sanction to all specific names having a similar origin. They accept, however, tana, a Malay word, and reject Tupaia, a term derived from the same language.

The term Tupaia has been adopted by Horsfield, ${ }^{2}$ Is. Geoff. St. Hilaire, ${ }^{3}$ Desmarest, ${ }^{4}$ Fischer, ${ }^{5}$ Gray, ${ }^{6}$ Waterhouse, ${ }^{7}$ Reichenbach, ${ }^{8}$ Cantor, ${ }^{9}$ Blyth, ${ }^{10}$ Jerdon, ${ }^{11}$ and Mivart; ${ }^{12}$ whilst Cladobates, the rival term, has been used by Wagner, ${ }^{13}$ Giebel, ${ }^{14}$ Zelebor, ${ }^{15}$ and Fitzinger. ${ }^{16}$ I shall add one more to the first list of names by using the original generic term Tupaia.

The most important contributors to the history of this group are Horsfield, S. Müller and Schlegel, and Wagner, but their descriptions chiefly related to accounts of the species. The first-mentioned author gave figures of the teeth, head, and limbs; and Müller and Schlegel figured the skulls of the species they described. The skeleton, skull, and dentition of Tupaia, however, had been figured by Blainville, ${ }^{17}$ and the dentition by Cuvier, ${ }^{18}$ and, more recently, by Owen. ${ }^{19}$ The most exhaustive
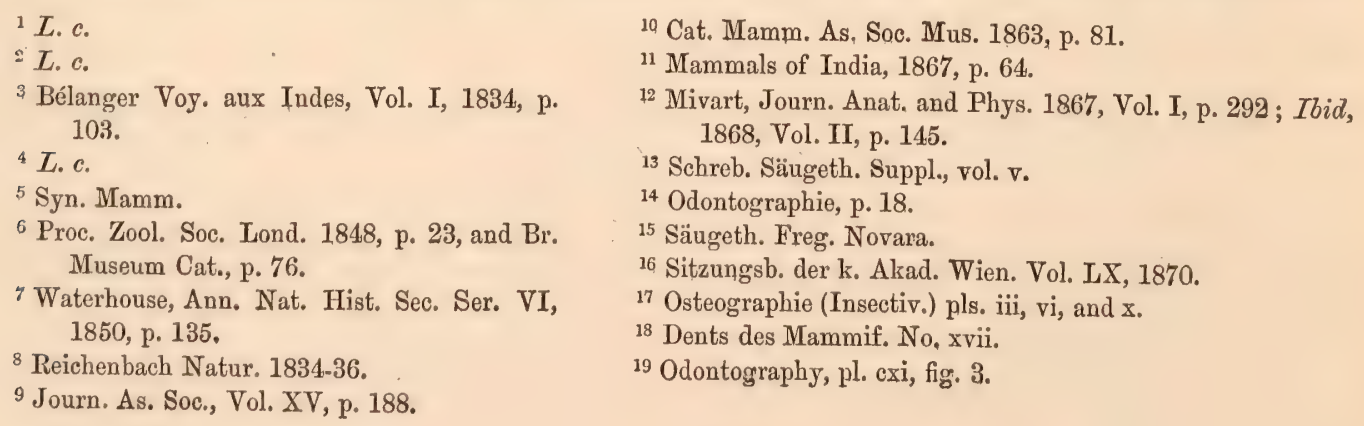
description of the skull is to be found in Mivart's ${ }^{1}$ valuable dissertation on the Osteology of the Insectivora, in which he indicates the affinites of this remarkable group, taking the genus as the type of a natural family "Tupaiida," to which he also refers Ptilocereus and Hylomys, and in this arrangement he agrees with Professor Peters. ${ }^{2}$ The most recent writer on this group is Dr. L. J. Fitzinger, ${ }^{3}$ who does not appear to have been aware of Professor Mivart's and Dr. Peters' researches, as he makes no mention of either of these naturalists' observations. He regards it as nearly allied to Mracroscelides, but on a very imperfect consideration of the structural characters of those two well-marked types. Dr. Fitzinger states that the Tupaice are more nearly affined to the foregoing group than to the Soricesa comparison which would scarcely have been made by one having a practical acquaintance with the subject. He designates a family Cladobate and refers to it Ptilocercus and Hylomys. He makes the observation that the front incisors of aged Tupaice fall out; but in the majority of animals there is a tendency for the jaws to become edentulous when the animal is aged. He also states that Hylomys has four molars, and that the tibia and fibula are distinct. In Hylomys, however, these bones are united as in Erinaceus and in Gymnura, to which, by dentition and skull characters, it seems to be more affined.

Dr. Gray, writing in 1848, ${ }^{4}$ separated the Bornean Insectivorous Mammal Hylogale murina, Müller and Schlegel, ${ }^{5}$ from the genus Tupaia, and it appears to me that he did so on valid grounds, as the two forms are clearly distinct, the former having apparently a closer affinity to Ptilocercus than to the latter. He created the genus Dendrogale for its reception, but since then he has described another species from Camboja under the name of Tupaia frenata, Gray. There is an example of the skull of this species in the British Museum, but nothing is known regarding the condition of the tibia and fibula. These two species, which are perfectly distinct from each other, are distinguished from all Tupaice by their round, short-haired, and tufted tails, which, in these characters, are like Ptilocercus, with which they also agree in the absence of a shoulder stripe. Unlike any known Tupaia, the two species of Dendrogale resemble Ptilocercus in having a dark band from the snout through the eyes.

The dentition is much the same as in Tupaia, but the cingulum of the second incisor forms a kind of posterior talon. The skull is intermediate in form between that of Ptilocercus and Tupaia. The orbit is perfect; and in the zygomatic arch the large imperfection of ossification which occurs in Tupaia is very much reduced in capacity. The skull in the British Museum is unfortunately imperfect, so that the basicranial characters cannot be determined, but the palate has two imperfections of ossification.

The skull of D. frenata, Gray, would seem to indicate that this species attained a greater size than the Bornean D. murina, M. and S., because, although the perma-

1 L.c.

2 Abhandl. Akad. Wiss. Berl. 1864.

s Sitzgsber. Akad. Wien, vol. lx. (1870), p. 263.
${ }^{4}$ Proc. Zool. Soc. Lond. 1848, p. 23.

5 Verhandl., I, p. 167, tab. 26, fig. 5, et tab. 27. figs. $17 \& 18$ 
nent canine is only appearing, the skull is considerably larger than that of the latter, and also broader.

D. frenata, Gray, also differs from D. murina, M. and S., in its paler colour, which is olive-brown, produced by the annulation of the hair. The under parts, also, instead of being white as in the latter, are pale fawn. The black band from the snout through the eye, behind which it expands backwards to the ear, where it ceases, is less defined than in D. murina. There is a pale whitish, somewhat rufous streak or band above this dark one, extending from the snout over the eye and ear, ceasing behind the latter, but in $D$. murina the post-ocular portion expands into a large white spot. There is also in both species a similar pale band below the black one, but in neither is it expanded into a white spot, and it is more obscure in $D$. murina than in D. frenata.

These two species stand as follows:-

Dendrogale murina, M. \& S., Plate VII, figs. 18 and 19, skull.

Hylogale murina, M. \& S., Verhandl. (1839-44), i, p. 167, tab. 26, fig. 5; tab. 27, figs. 17 and 18. Cladobates (Dendrogale, Gray) murinus, M. \& S., Wagner, Schreber, Säugeth. (1855), vol. v, p. 528.

Habitat.-Borneo.

Dendrogale frenata, Gray, Plate VII, figs. 20 and 21, skull.

Tupaia frenata, Gray, Ann. Mag. Nat. Hist., 1860, vol. vi, p. 217.

Habitat.-Camboja.

Measurements of specimens in the British Museum :

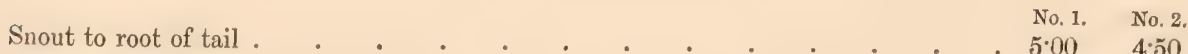

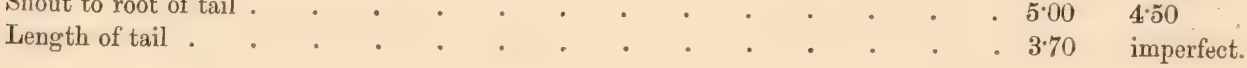

Skull of Dendrogale frenata, Gray:

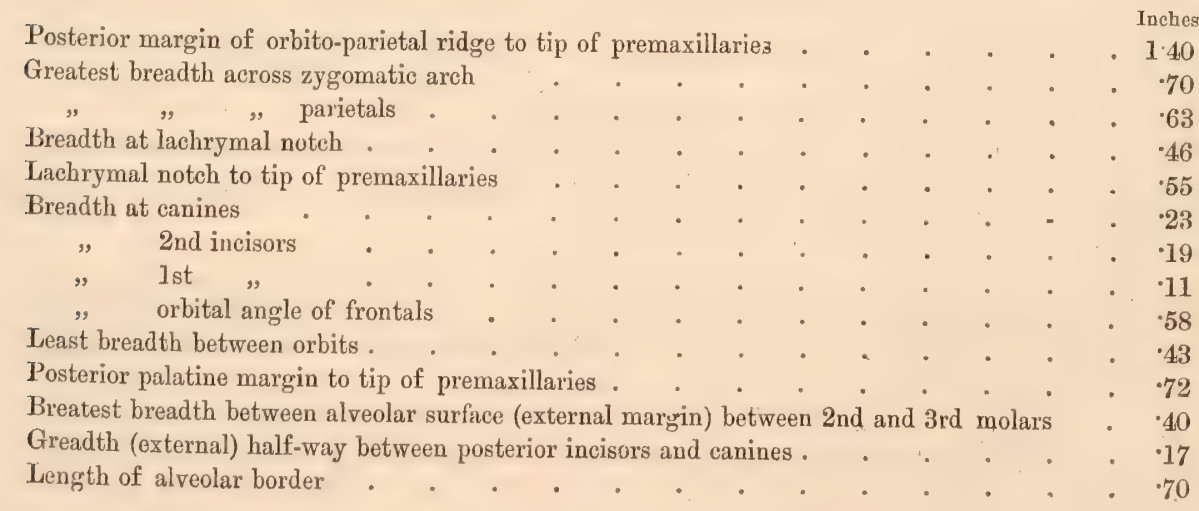




Depth of premaxillary surface to anterior extremity of nasals
Depth through posterior margin of palate

Habitat.-Camboja.

But to return to the genus Tupaia. As I have had the opportunity, owing to the rich materials in the Indian Museum, Calcutta, to examine the osteological features of this group in detail, I shall here record the result of my observations.

The skull of Tupaia is moderately elongated, and neither truncated before nor behind, and is most tapered in the facial portion. - The parietals are rather full and round, but they do not project much beyond the base of the zygoma, which arches outwardly at right angles as a thin plate of bone which has the glenoid articular surface on its under aspect. The zygoma then bends forward to join the malar, but the temporal fossa defined by it is not large. The orbit is large, circular, and directed outwards and wholly surrounded by bone, and the malar has a large hole or longitudinally extended imperfection of ossification, anterior to its junction with the orbital process of the frontal and the zygoma. The malar is about twice as high as the zygoma, and, before the perforation, is scooped out, as it were, externally. The post-orbital process closing in the orbit behind is flattened from before backwards, so that its external margin is a thin plate of bone, the margins being directed outwards and inwards, and the surfaces looking backwards and forwards. The anterior, inferior angle of the orbit is marked by a triangular process overhanging the lachrymal notch. There is no ridge before the orbit, immediately in front of which the maxillæ are convex as far as the first premolar, from which to the second incisor the face is concave on either side, and tapers to the premaxillæ, the sides of which are rounded. Over the nasals, the facial portion is convex from side to side. The nasals are long narrow bones of nearly equal width throughout, uniting with each other and with the frontals after the permanent dentition. The premaxillaries reach backwards only about half-way between the anterior extremity of the nasals and the frontals, and the greater part of their maxillary suture disappears with age. From the post-orbital process of the temporal, a ridge passes backwards and inwards to the posterior extremity of the parietals to join its fellow of the opposite side, defining a triangular space, and where the two become merged in a short sagittal crest which terminates posteriorly with the lambdoidal suture. The frontals are convex, and the skull is slightly contracted between the orbits, the constriction culminating at the supra-orbital foramen. The greatest breadth of the skull occurs at the root of the zygomatic arch. The occipital region is directed downwards and backwards, 
and the foramen magnum looks downwards and backwards, but much more in the latter than in the former direction. The condyles look outwards, forwards, and downwards. There is a very minute rudiment of a para-occipital process, ${ }^{1}$ and more distinct indications of a mastoid protuberance. The meatus auditorius externus looks outwards and slightly upwards. The tympanic bullæ are entire, and no portion of the basi-sphenoid contributes to form them. There is a distinct basi-occipital ridge, but it is not continuous with the well-marked ridge of the mesopterygoid fossa. A small post-glenoid process contributes to complete the anterior border of the meatus auditorius externus. The auditory bullæ are placed obliquely across the base of the skull, being divergent posteriorly and convergent anteriorly, in which direction they taper to a point which is in the same line with the lateral wall of the mesopterygoid fossa. The glenoid articular surface is almost flat, but slightly concave, where it is overlooked by the post-glenoid process. The mesopterygoid fossa contracts from before backwards, but its broadest diameter corresponds to the interval between the anterior extremities of the auditory bullæ. Its anterior two-thirds is marked by a pronounced median vomerine ridge, which is partially prolonged on to the basi-sphenoid. The ectopterygoid plate is small, pointed and falcate, and is directed downwards, backwards and outwards, and is perforated at its base by a canal. The pterygoid fossa is small, and is separated from the palate by a ridge of bone as long as the longitudinal extent of the fossa. There are one or two minute circular imperfections in the basi-sphenoid. The palatal surface is concave from before backwards, and from side to side, and an obscure osseous ridge runs along the median line.

There are a number of imperfections in the posterior third of the palatal surface. The posterior margin of the palate is distinctly thickened, forming a ridge of more compact osseous tissue than the rest of the palatal surface. That portion of the margin corresponding to the mesopterygoid fossa is doubly concave from behind forwards, each concavity corresponding to one-half of the fossa. The portion of the margin external to this is convex from before backwards, and projects backwards about half the diameter of the last molar beyond that tooth. The first and second premolars are separated by a short interval corresponding to the distance, or nearly so, that intervenes between the first and second incisors, and the canine is removed from the second incisor by about double that distance. Viewing the skull sideways, the alveolar margin arches upwards as far as the canine, and then, in a long, slightly convex sweep, goes downwards as far as the posterior margin of the second molar, beyond which it is directed upwards and inwards.

There is a rather large supra-orbital foramen at the point where the contraction between the orbits is most marked, and a smaller infra-orbital foramen above the second premolar. There are two small foramina placed one above the other on the parietal above the zygoma and the meatus auditorius externus, and both open into the moderately large foramen behind the post-glenoid process. A similar foramen

\footnotetext{
${ }^{1}$ Mivart did not observe one in the skulls he examined.
} 
occurs in Hylomys and Erinaceus. Posterior to the lowest of these foramina there is another small foramen on the lambdoidal ridge which opens almost directly into the skull in Tupaia and the above-mentioned genera. There is a distinct foramen. below and internal to the mastoid process (the stylo-mastoid foramen ?) and internal to it, and on the hinder third of the auditory bulla a small rounded foramen with well-defined osseous walls occurs opposite to the middle of the occipital condyle, and interrogatively mentioned by Mivart as the carotoid foramen, which it is in all probability. Posterior and slightly external to it, and internal to the posterior extremity of the auditory bulla and the mastoid, is a rather large foramen formed by the arching over of the inferior external angle of the occipital to these bones, and constituting the foramen lacerum posterius, which is directed upwards and slightly backwards as a short bony canal. Internal and slightly posterior to it is the anterior condyloid foramen. Between the auditory bulla and basi-occipital there is a rather long groove running above the carotoid foramen, forwards from the opening of the foramen jugulare, ultimately forming a closed canal foramen lacerum anterius between the bulla and basi-occipital and basi-sphenoid. The foramen ovale is situated at the middle of the anterior aspect of the bulla, and is formed externally by that bone and the sphenoid, the former constituting the under margin of the opening. External and slightly posterior to the foramen ovale, anterior to the base of the tympanic plate, between the squamous and the bulla, there is a minute foramen, or rather fissure, in the position of the fissure of Glaser. At the anterior wall of the bulla, immediately internal to the foramen ovale and on a lower level, is a round foramen which escapes observation unless the skull is held sideways. It passes directly outwards and backwards, and a fine wire passed through it comes out at the meatus auditorius externus in a macerated skull. The external pterygoid plate is perforated by a canal at its base. Anterior, internal, and superior to the forward termination of this canal, is the foramen rotundum, separated by a marked interval from the sphenoid fissure which is directed outwards, forwards and upwards, and separated from the optic foramen by a narrow spicule of bone. There are two foramina external to the sphenoidal fissure, the most external the being smaller. The infra-orbital foramen opens internally at the most anterior portion of the lower angle of the orbit, and the external orifice is 0.20 of an inch in advance of it. The lachrymal canal opens rather external than internal to the orbit below the backwardly projecting process at the anterior margin of the orbit, above which there is also another small foramen leading into a canal opening into the nasal cavity. The posterior palatine foramen is at some distance external to the orbital opening of the infra-orbital foramen; and the anterior palatine foramen is still larger.

The longitudinal ramus of the mandible has a long, gentle, downward and upward curve as far forwards as the second premolar, anterior to which the alveolar border shows a slight downward curve. The dental portion of the jaw is laterally compressed, but the portion at the base of the ascending ramus is contracted, and more or less rounded. The coronoid process is directed upwards and backwards, and its posterior margin overlooks the condyle, from which it is distinctly removed, the 
notch between the two being of considerable depth. From the condyle there is a nearly vertical line to the posterior process of the angle of the jaw, which is a strong hook curved downwards, upwards and inwards, with a central ridge on its inner aspect with a groove above and below it. The dental canal commences below and slightly anterior to the condyle, and opens externally below the first premolar.

The replacement of the deciduous by the permanent teeth I have been able to trace in three specimens, one of which is remarkable from the circumstance that it presents eleven teeth on one side of the upper jaw and ten on the opposite side-an abnormality full of interest.

The first skull has all its deciduous teeth intact, except one, and yet, contrary to what prevails among Insectivora generally in which the deciduous teeth are shed at an early period, it is nearly the size of a full-grown cranium, and the individual as a mounted specimen has all the appearance of full age. From these skulls it would appear that Horsfield's representations of the dentition of $T$ : ferruginea and T. javanica exhibit deciduous dentition, and that Müller and Schlegel's figure 8, plate 27, does the same. Professor Mivart has fully described the characters of the grinding surface of the molars, and pointed out, what these specimens fully verify, that the third deciduous premolar resembles the true molars, but is replaced by a tooth of a markedly different character.

I shall describe the deciduous teeth, and indicate in passing in what respects the permanent teeth differ from them.

Commencing with the third premolar, that tooth has three external small cusps on a line, and resembles a molar, the central cusp showing indications of a minute cusp at its hinder extremity, two median pointed cusps, and a large internal cusp almost embracing the other two with a small supplementary cusp at its base on its posterior surface. The two external fangs are long and fine, and spring from the two internal cusps; the inner fang is stronger and stouter than the other. The long central cusp of the permanent premolar is wedged in between the two long external fangs of the deciduous tooth, and by the pressure on the tooth push it outwards, even causing it to decay.

The second premolar consists of a long laniar-like central cusp with an internal and a postero-external cusp, the last connected to the large cusp by a wellmarked ridge. The large cusp corresponds to the long median cusp of the third deciduous premolar and to the median cusp of a molar. It is flattened on its inner aspect, and at its base it has the projecting ridge or inner cusp of the faintly developed cingulum. This cusp and the two others are fastened in the jaw by a corresponding number of long fangs, the two outer of which are divergent.

The first premolar has two cusps ; the large anterior cusp partakes more of the character of the head of the canine than of the large cusp of the other premolars, and has a small posterior prolongation not nearly so high as itself, sloping off to the gum; each cusp is supported by a long and strong fang. There is no internal cusp, This deciduous tooth is the first to fall out. 
The milk incisor is a long tooth, more or less compressed laterally, with a crown resembling the anterior cusp of the first premolar. The second incisor is more pointed than the canine, but preserving to a certain extent the same character of crown. The first incisor is cylindrical, with its crown slightly outwardly divergent, as in Crocidura. The canine and the two incisors are curved downwards, forwards, and backwards.

These deciduous teeth are succeeded by the permanent teeth in the following order. The third premolar supplants its molar-like predecessor by having its large and strong cutting edge wedged in between the outer fangs-a space which it completely fills. The second premolar has its long cusp wedged in in a similar way between the long, slender, external fangs of its antecedent. The large cusps of the foregoing teeth are more external to the fangs of the deciduous teeth than equally between or internal to them. In the first premolar, however, the permanent cusp is internal to the fangs of the deciduous teeth rather than between them. The permanent canine is placed right in front of the tooth it supplants, whilst this arrangement is reversed in the case of the first and second incisors.

The third permanent premolar presents two prominent cusps, one corresponding to the median cusps of the molars, and the other to the internal cusp of these teeth. The cingulum is continuous along the outer surface of the base of the crown, and is prolonged into a cusp at its anterior and posterior extremities. The large cusp is conical and twice as large as any of the corresponding cusps of the molars : it is convex on its internal and external surfaces, but hollowed out or deeply concave on its postero-external aspect. The second premolar has not the cingulum continuous externally, for it occurs only along the posterior half of the external surface, where it developes a cusp nearly as large as in the preceding tooth. The cingulum is continuous-internally from the posterior to the anterior margin, and in the latter situation it terminates in a small prominence. The central conical cusp which forms the bulk of the tooth is nearly as large, but slightly more pointed than in the previous tooth, and viewed internally is a little concave from above downwards, while it is pronouncedly convex from before backwards. This tooth and the former have three fangs, as in the deciduous teeth. The first premolar has a conical cusp resembling those of the third and second premolars; but there is no trace of a cingulum, and it wants the postero-external concavity or groove: there are very obscure prominences on the anterior and posterior margins corresponding to the anterior and posterior cusps of the third molar: two fangs correspond to these prominences. The internal aspect of the tooth is markedly convex, and the internal surface, especially near the tip, is flattened from above downwards, and slightly concave; however, it is strongly convex from before backwards. This is the smallest of all the teeth, and has the least vertical extension of the premolar and incisor teeth.

The canine has a straight posterior margin, and the anterior margin is parallel to it throughout the upper half of its extent, but below that it is bevelled off from before backwards to the posterior margin. ' It is slightly compressed from side to 
side, convex externally and concave internally. The root of the tooth curves back abruptly from the crown.

The second incisor partakes somewhat of the character of the canine in having its anterior and posterior margins parallel for a certain length, and in the bevelling off of the anterior to the posterior margin. Opposite to where this takes place, there is a faint concavity on the posterior margin of the tooth. It is also laterally compressed and broadest from before backwards. It is directed forwards and downwards, and is shorter than the canine, which has a nearly similar but more vertical course.

The first incisor is also broadest from before backwards with a similar curve, combined with a divergence or outward curve of the tooth; so that when viewed in front, its external margin is concave and its internal margin is convex. The crown and root together of these incisor teeth form a considerable curve. They are directed forwards and backwards.

The third deciduous premolar in the lower jaw resembles the molars in every respect, only it is considerably smaller than the first. Internally it shows three cusps, of which the central one has the greatest vertical length; and externally it is composed of two large triangular cusps, the anterior of which, the most vertically elongated of all, is connected to the two anterior of the internal cusps by a ridge running to the anterior border of the foremost and to the posterior margin of the hindmost, enclosing a triangular hollow. The cusps posterior to this are on a much lower level and below all the upper cusps. Besides the external and internal cusps, there is another which may be termed posterior, and which is behind and external to the last internal cusp. It is connected to the external cusp by a concave ridge, and it has little or no vertical extension. It corresponds to the middle cusp of the internal series, to which it rightly belongs. It is separated from the hindmost internal cusp by a deep notch; it has only two fangs corresponding to the two triangular surfaces of the crown.

The second premolar (in lower jaw) is a bi-cuspidate tooth, consisting of one large anterior sub-triangular cusp with a rather prominent talon at its base posteriorly. The large cusp is concave posteriorly and convex anteriorly, where its upper surface is bevelled off from before backwards, producing a rather prominent angle. The inner surface is convex in the middle line, but grooved on either side of it. It has two divergent fangs which partially embrace the crown of the permanent tooth, but are so external to it that it cannot be detected when the roots of the teeth are laid bare from without. This tooth differs little from the permanent tooth, which is larger.

The first premolar (lower jaw) is laterally compressed, convex anteriorly and concave posteriorly, in profile, the latter margin running nearly to the tip or point of the crown of the tooth, from which it is separated by a short bevelled surface: the point rounds off to the anterior margin. At the posterior margin, the angle formed by the crown of the tooth and the single cylindrical tapering fang, corresponds to the posterior talon of the second premolar. Its permanent tooth lies immediately below its root. 
The canine has the greatest vertical extension of all the teeth in the lower jaw, and the deciduous tooth has a shorter and more obtuse crown than the permanent tooth. It is laterally compressed, and its posterior margin, viewing it in profile, has a slight swelling near its base, corresponding to the talon of the second premolar, the area or margin above it, to the point of the tooth, being concave. The anterior margin is rounded forwards to the point, which is almost in the same line with the posterior margin, and is directed forwards and upwards. The permanent tooth lies internal to it, resting upon the base of the fang, or nearly so.

The crown of the third incisor, as, to a certain extent, the crowns of the canine and first premolar, is set on obtusely to the fang, the latter being directed downwards and backwards, the former upwards and forwards to a greater degree than the fang is in its course. The tooth is laterally compressed and its crown rounded; its posterior margin convex from before backwards and almost straight; but where the latter joins the fang an angular point is formed corresponding to the angle in the canine and first premolar, and to the talon of the second premolar. Its permanent tooth is very difficult to demonstrate; but I believe I have detected it lying at its base externally, on the same plane as itself. On the internal aspect of the jaw the young permanent canine and second incisor are so close, and the latter is placed so obliquely from behind forwards, that there is no room for it in that direction, and it has therefore to be sought for by removing the bone from the outer surface of the jaw.

The second incisor has its anterior or external surface somewhat convex from behind forwards with its lateral margins parallel and abruptly rounded off to the points. The internal surface, concave from before backwards, has a convex longitudinal ridge with a well-marked groove in the same direction external to it, and a more indistinct one internally. The base of the crown forms an angular prominence externally with the fang, from the circumstance that the crown is placed slightly obtusely to the root of the tooth. The fang is long and reaches back to nearly on a line with the posterior border of the symphysis. The permanent tooth lies internal to it, and above, it is separated from the permanent first incisor by a longitudinal, or nearly longitudinal, osseous ridge; it is chiefly distinguished from the deciduous tooth by its larger size.

The first deciduous incisor is a narrower and more pointed tooth than the previous one, but of the same structure, and is distinguished from its permanent tooth, which lies internal to and resting on it, by its greater size. ${ }^{1}$

1 The specimen with abnormal dentition was received from Darjeeling, and is an example of $T$. belangeri. It is young, and on laying bare the roots of the teeth of the upper jaw, I have been able to demonstrate which are the superfluous teeth. None of the permanent teeth, except the three molars, are through the gum. As the dentition is different in the two sides, I shall describe them separately. On the right side, above, there are ten teeth, the abnormal tooth being small, partaking of the character of a diminutive canine wedged in between the deciduous cavine and the deciduous first premolar. The young permanent teeth are in their positions in front and at the base of their respective teeth, but no young tooth exists to take the place of the superfluous one. On the left side no less than eleven teeth occur, one anterior to the canine and one behind it. These teeth are placed at equal distances from each other and are of equal size, and all resemble diminutive canines. The middle tooth is the true canine, as is shown by the presence of the young permanent tooth in front of it. The abnormal teeth on either side of the canine are not represented by any young tooth, so that the normal dentition would be attained in the adult state. 
I have never seen the skeleton of Ptilocercus, which Mivart refers to the family Tupaiide along with Hylomys; but as an inspection of the skeleton of the latter has not verified his presumption that it agreed with Tupaia in having its tibia and fibula distinct, it is impossible to say what characters Ptilocereus may present in that respect.

The vertebral column of Tupaia has an upward curve in the cervical portion, and the dorso-lumbar region is curved convexly-an arrangement of the vertebræ which would lead to the conclusion that the animal was in the habit of sitting with its body raised as the squirrels do, and which I have observed to be the case. The leading features which first present themselves are: the moderately broad, thin, spinous plate of the axis, which appears large owing to its close apposition to the narrow and rather short spinous processes of the cervical and dorsal vertebræ; the depressed, overlapping spinous process of the three dorsal vertebræ bearing free ribs, and of the lumbar with their well-developed transverse processes; the rapid enlargement of the vertebræ in the lumbar region; the rather small sacrum, consisting of three vertebræ; and, lastly, the long and tapering tail.

There are 13 dorsal and 6 lumbar vertebræ with 23 caudal vertebræ or more. The spinous process, if we except the axis, is fully developed in the cervical region. It first becomes distinctly visible in the 5th vertebra, increasing in size to the 7th. The spinous process of the 1st dorsal is nearly erect, whilst the 2nd is slightly stronger and broader antero-posteriorly, but about the same length and directed slightly backwards. The 3rd is still stronger and a little more lengthened and backward in its direction, while the 4th is almost its fellow. The 5th is not so broad from before backwards as the 4th, which it exceeds in length; and the 6th shows a distinctly more marked backward inclination and is also narrower than the process on either, side of it. The 7th, 8th, and 9th processes increase gradually in antero-posterior expansion, but diminish in length, the 9th being almost triangular, with a broad base. The 10th process is smaller than the 9th, with a sharp triangular point with its apex directed forwards. The 11th is quite distinct from those preceding it, and has its apex extended from before backwards, and directed forwards over the lower two-thirds of the hinder margin of the 10th process. It is short and rather broad antero-posteriorly. The 12th and 13th spinous processes are low and broad from before backwards, and overlap the vertebræ in front of them. The first lumbar process resembles the last mentioned, but the one succeeding it is not so depressed, and is every way larger. As the processes are traced backwards to the last lumbar vertebræ they become larger and more erect, although still directed forwards. The spinous process of the 1st sacral is low and ridge-like, but in the 2nd vertebra it is moderately large and bent slightly forwards. In the 3 rd sacral it is lower than in the last and slopes faintly backwards, and the process, although moderately developed in the 1st caudal, rapidly diminishes in size and disappears in the $3 \mathrm{rd}$, being continued to the 6 th as an obscure ridge which is lost in the 7th segment. 
The transverse process is most strongly developed in the 5th lumbar vertebra where it has the most antero-posterior extension, as a thin, almost transparent plate of bone directed much forwards. The process is very small in the 1st lumbar vertebra, and in the last dorsal it is reduced to an obscure ridge above the articulation of the rib and disappears in the 12th dorsal. It again shows itself in the 11th dorsal, projecting as an obscure ridge over the head of the rib. It increases in size to the 9th vertebra, after which it maintains a nearly uniform size to the 6th dorsal segment, anterior to which it is more extended outwards, attaining its maximum extension in the 7th cervical. The pleuropophysial plate of the 6th cervical vertebra is contracted from before backwards at its base, its free extremity being considerably extended in that direction. The pleuropophysial processes occur in the 5th and 4th vertebræ, and are directed forwards and inwards, and they can be traced as a ridge in the $3 r d$ vertebra. The transverse processes of the 1st and 2 nd caudal vertebro are at right angles to the centrum and do not project beyond the lateral line of the sacrum. They have a moderate antero-posterior extension and are slightly dilated at their extremities. The processes of the 3rd and 4th caudals are curved backwards, convex anteriorly and concave posteriorly. The 5th of either side forms an almost quadrangular figure, but with concave sides and slightly concave posteriorly. In the succeeding vertebra the concavity of the sides is so great as to reach the centrum, so that only the anterior and posterior extremities of the process remain at either extremity of the vertebra, one directed forwards and the other backwards, becoming very obscure as they are traced towards the extremity of the tail.

In the lumbar region the metapophyses only become to be distinguished and separate from the zygapophyses about the 1st or 2nd vertebra, and anterior to that they become stronger; but gradually, from the more ventral disposition of the zygapophyses which they follow, they come in contact with the transverse process at the 10 th vertebra, and in the 9 th are in close connection with it. They can be traced as far forwards as the 4th dorsal vertebra. The zygapophysis of the 1st sacral vertebra is well developed, and it is succeeded by two small processes on a line with it, one behind the other, suggesting that they are more of the nature of rudimentary zygapophyses than metapophyses. In the tail the metapophyses reach their greatest development while in connection with the zygapophysis at the 4th caudal vertebra, and as beyond that segment there are no posterior zygapophysial facets, the metapophysis becomes well marked in a few vertebræ, but rapidly dwindles away as we trace it backwards.

The anapophyses first show themselves in the 4th lumbar vertebra as small, almost styliform processes, increasing in size to the 12th dorsal, before which they decrease in size, and are brought into close contact with the metapophyses, but they can be detected as far forwards as the fourth dorsal.

Hyperapophyses begin to show in the 11th dorsal, increasing in size to the 4th lumbar, decreasing in size to the 5th, and entirely absent in the 6th. In the 3rd cervical vertebra of $T$. belangeri there is a small process corresponding in position to 
a hyperapophysis, and in the $3 \mathrm{rd}$, 4th, and 5 th cervical vertebræ of one skeleton of $T$. ellioti there are more distinct indications of this process.

A pair of autogenous hypapophyses occur on the 2nd, 3rd, and 4th cervical vertebræ, and a single tubercular exogenous hypapophysis on the atlas and a bifurcate one on the axis. The double processes are rather widely apart and loosely attached to the posterior margin of each of the three vertebræ.

In the caudal region the hypapophyses are well developed and bear hæmapophyses. The latter are autogenous products arranged in pairs in the two first caudal vertebræ, but forming a perfect osseous autogenous arch in the following four or five vertebræ, posterior to which they become united to the hypapophysis. The 12th dorsal vertebra, and the vertebræ intervening between it and the last lumbar, have the mesial line of the under surface of each marked by a more or less prominent ridge, which is most so in the 2nd, 3rd, and 4th lumbar vertebræ, becoming hardly perceptible in the 5th and 6th. In the $3 \mathrm{rd}$ it is projected downwards at its anterior half as a distinct process. The nutrient foramina of the centra lie on either side of these ridges about the middle of the vertebræ, but become more widely apart as they are traced to the dorsal vertebræ, where they disappear at the 12th.

The articular surfaces of the atlas for union with the condyles of the skull are rather deep, owing to the forward prolongation of the antero-external angles of the vertebra which form their upper extremities. The facets are directed downwards, backwards, and inwards, and their upper extremities are most markedly concave and defined externally by a notch.

The base of each transverse process is perforated by a foramen for the vertebral artery, which opens internally on the inner aspect of the articular facets from the condyles of the skull. This inner foramen is the termination of three other foramina, one of which is situated at the base of the neural lamina close to the ridge of the process, and looks forwards and outwards; another occurs below the transverse process, and is directed forwards and downwards; while a third, leading through a very short osseous canal, is situated externally on the posterior margin of the base of the neural lamina. The articular surfaces from the axis are broad above, but taper to a point below.

The odontoid process of the axis is short and slightly curved upwards and forwards. There is a well-marked tubercular swelling in the position of the metapophyses. The transverse processes are very fully developed. Posterior to the odontoid process, there is a short feeble ridge which bifurcates posteriorly, terminating in a pair of small processes, a small foramen occurring in the angle of the fork.

The pre-sternum is a half longer than the first meso-sternal piece, and is dilated anteriorly into two wings separated by a median ridge, the posterior half being contracted to a narrow rod, along which the ridge is continued. The wings are slightly concave anteriorly and flat posteriorly, with the first rib attached to the external angle of their posterior margin. 
The meso-sternum consists of five nearly equally large and broad rod-like pieces, the $2 \mathrm{nd}, 3 \mathrm{rd}, 4 \mathrm{th}$, and 5th showing more or less distinct traces of a median groove, which is most marked on the 4th. The xiphi-sternum is a long rod-like bone the length of two and one-half of the meso-sternal elements, and is slightly dilated at its free end. The cartilage of the ninth rib runs close up to the last segment of the meso-sternum along the cartilage of the 8th rib, but stops short of being connected to the sternum.

The outline of the scapula is a figure resembling the half of a moderately rotund oval, divided unequally by the meso-scapula or spine, which is extended nearly as far outwards as the breadth of the middle portion of the post-scapular plate. It rises in a gentle slope from the supra-scapular border as far as the upper third of the distance between the last-mentioned border and the tip of the acromion process. Anterior to that it forms a sharp, outwardly directed ridge parallel with the postand pre-scapular surfaces, less in extent than one-fourth of the before-defined area. It is then bent slightly backwards, the margin of the ridge being directed backwards and slightly upwards, giving rise to a flattened convex surface roofing in the subscapular fossa and continuous with the acromion process. Posteriorly, the inferior hinder margin of this flattened surface forms a well-defined angle, and the acromion joins the meso-scapula by a slightly constricted surface common to both.

The acromion is moderately broad, and is directed more forwards than downwards, being bent also inwards over the coracoid. The coracoid is a small hook of bone directed forwards, downwards, and backwards, till its tip is on a line with the anterior border of the glenoid facet. The glenoid facet is cup-shaped, but a pointed articular surface from its anterior margin is prolonged on to the base, as it were, of the coracoid process. The sub-scapular fossa presents nothing worthy of note. The coracoid border is contracted at its base above its process; it then bends forwards, upwards, and backwards in a moderate sweep to the superior extremity of the meso-scapula, beyond which it is continued upwards and backwards as the supra-scapular border. The margin is slightly thickened.

The pre-scapular plate is marked by a long, shallow depression, almost constituting a groove, which commences at the inferior anterior extremity of the meso-scapula, and is directed upwards and slightly outwards, terminating externally at the upper third of its border. The post-scapular plate has its glenoid border turned slightly forwards, and a little above its upper half it bifurcates to the posterior supra-scapular angle, enclosing a narrow concave surface. From the outward and slightly forward prolongation of the border, the postscapular plate is concave along the border. The inner aspect of the two plates presents two ridges and a median groove or hollow, the latter corresponding to the course of the meso-scapula; the anterior of the ridges, to the groove on the external surface of the pre-scapula; and the posterior, to the line marking 
the forward folding of the post-scapular border. The surface between the coracoid border and its posterior ridge forms a long, oval, concave area, with the surface behind it defined posteriorly by the meso-scapular groove shelving down from before backwards. The surface between the groove and the ridge of the glenoid border is flat.

The clavicle is convex from behind forwards and concave from above downwards. A short ridge marks the anterior surface close to the pre-sternal head of the bone with a corresponding concavity above it. The acromial head of the bone is bent slightly backwards, and is flattened and dilated at its extremity.

The humerus is elongated and cylindrical. The articular surface is irregularly rounded. The internal tuberosity is small and much separated from its fellow by a shallow bicipital groove. The external tuberosity is moderately large, and is more or less continuous below with the deltoid ridge, which arches upwards, backwards, and outwards, to terminate immediately below the head of the bone on its external aspect. The deltoid ridge begins a little above the middle of the bone as a sharp, laterally compressed ridge, projecting slightly forwards, but not much beyond the surface of the shaft below it. The ecto-condylar ridge is not prominent, and it terminates below the level of the deltoid attachment, but no groove for the musculospiral nerve can be detected. The internal condyle is little more than half the breadth of the trochlear surface, but the margin of the bone above it is perforated by a supra-condylar foramen of considerable size. The acromial fossa is not so deep as its fellow in front, and the two are separated from each other by a plate of bone as thin as the finest tissue paper.

The radius has an outward and forward curve which begins below the process for the attachment of the biceps flexor muscle, and is continued as far as the middle of the bone, while the direction is inwards, so that the two extremities of the bone are in the same line.

The ulna is more or less laterally compressed, and its anterior margin forms a sharp ridge which expands from behind forwards a little above its middle, so that it comes into close contact with the ulna to such an extent that the two bones at first sight, in some specimens of $T$. belangeri and $T$. ellioti, appear to be almost united in that region. There is an open space between the two bones above and below that part, but below that again they are in close contact. On both aspects the ulna is concave external to the anterior ridge, but the concavities stop short a little way above the inferior extremity. The internal concavity runs from the coronoid process anteriorly, and the external from the upper margin of the sigmoid cavity. The olecranon is produced considerably behind the sigmoid cavity, and is marked externally by a groove and superiorly by a depression for the triceps extensor muscle. Its posterior margin is narrow and rounded.

The carpus has a scapho-lunar bone and an os intermedium with a well-developed pisiform, which, along with the process of the first-mentioned, makes the under 
surface of the carpus markedly concave. The phalanges are of moderate length and cylindrical.

The pelvis is remarkably distinct from the pelvis of Hylomys, Crocidurce, or Talpa, and approaches more to the pelvis of Erinaceus.

The ilium is rather narrowly expanded, concave externally, with a nearly straight supra-iliac border. The sacral surface of the bone is rather small, and the bone rises above the sacrum, bending upwards, forwards, and outwards, the inner surface being nearly flat. The iliac border is rather broad, especially near the acetabulum, owing to the development of a pre-acetabular process. The pubic border is very sharp. The thyroid foramen is very large and a short oval, and the posterior margin of the ischium rounds off forwards and inwards from the tuberosity, which does not project as a distinct process. In two skeletons before me, and both of which have adult dentition, but with the epiphyses of the inferior articular extremity of the femur distinct, the symphyses of the sacrum are not united.

The femur is a long bone with the 3rd trochanter forming a rather elongately triangular, prominent, thin plate of bone more or less concave on its two sides. The internal trochanter forms a well-marked process, and the digital fossa is small, triangular, but deep.

The tibia and fibula are quite distinct, and only come in contact with each other at their extremities.

The calcaneum is narrow and laterally compressed in its posterior half, and broad anteriorly. The under surface is nearly flat in the middle line, but slopes off at the sides. The sustentaculum tali forms a very prominent process projecting inwards nearly at right angles to the bone. The tubercle for the attachment of the calcaneo-cuboid ligaments forms a distinct minute process external, anterior, and immediately below the sustentaculum tati.

The astragalus presents no features worthy of special remark. The cuboid bone has the form of a very much shortened metatarsal, broadest in its posterior and suddenly narrowing to its anterior half, which is shortly cylindrical and is deeply grooved beneath for the tendon of the peroneus longus. The short and broad scaphoid presents a rather rounded eminence above, and the tubercle for the tibialis posticus muscle is well developed. The internal cuneiform is broadest from above downwards, narrow and rather pointed behind for articulation with the scaphoid, being laterally compressed from without inwards. The second cuneiform is laterally compressed, and presents a dorsal concave surface which looks inwards and upwards. The third is shortly cylindrical and rather deeply grooved below. The metatarsal bones are long and slender, the second and fourth being nearly of equal length, and the third very slightly longer than the other two; the first and fifth are nearly equal, the latter, however, being the larger. The proximal process of the fifth forms a hook, which projects backwards and outwards. 
The following appear to be the different species of this genus, but it is highly probable that other intermediate forms will yet be discovered in the Malayan region :-

Tupata ellioti, Waterhouse, Plate VII, figs. 12 and 13, skull.

Tupaia ellioti, Waterhouse, Proc. Zool. Soc. 1849, pp. 106, 108, pl. xiii; Jerdon, Mamm. India, 1867, p. 64 ; Ball. Ṕ́oc. As. Soc. Beng. 1874, p. 95.

Cladobates ellioti, Wagner, Schreber, Säugeth. Suppl., v. 1855, p. 526 ; Giebel, Säugeth., 1859, p. 914 ; Fitzinger, Sitzgsbr. der K. Akad. Wien. 1870, vol. 1x, p. 278.

Fur soft and moderately thick, pale rufous brown, darkest on the back, and paler on the sides. Length of fur $0 \cdot 46$; the basal black band not exceeding $0 \cdot 15$, and succeeded by yellow, black, yellow-and-black bands. The light-coloured bands are pale yellow on the sides and pale ferruginous on the back. The longest hairs, which, as in the other species, occur on the hind quarters, are 0.75 inch in length. The upper surface of the tail is concolorous with the upper surface of the body. The upper surface of the head is more brown than rufescent, and is more finely annulated than the rest of the fur. There is a pale line from the muzzle over the eye and a similar area below the eye. The shoulder stripe is also pale. The feet are clothed with yellow unannulated hairs. The under surface of the body is white, tinged with yellowish. The median line of short hairs on the tail is a darker yellow than the feet.

The species is about the same size as $T$. ferruginea and $T$. belangeri, but the tail appears to be a little longer than in these species.

Waterhouse states that it is about the same size as $T$. tana, but his measurements of the body are $2 \cdot 66$ inches less than those of the latter species as given by Horsfield.

Measurements of an adult male in alcohol :

Snout to vent
Vent to tip of tail
Snout to anterior angle of eye
Eye
Posterior angle of eye to upper angle of ear
Greatest depth of ear
Fore foot, and nail
Middle toe
Length of hind foot
$\quad$ of middle toe

Measurements of 3 skulls of $T$. ellioti :

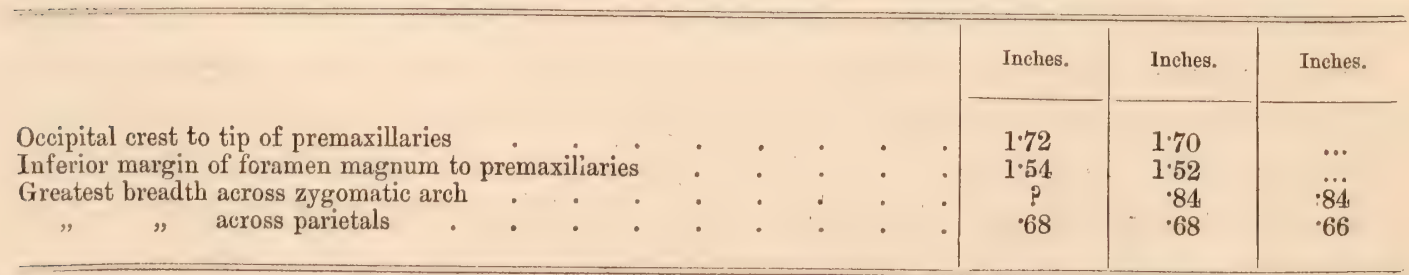




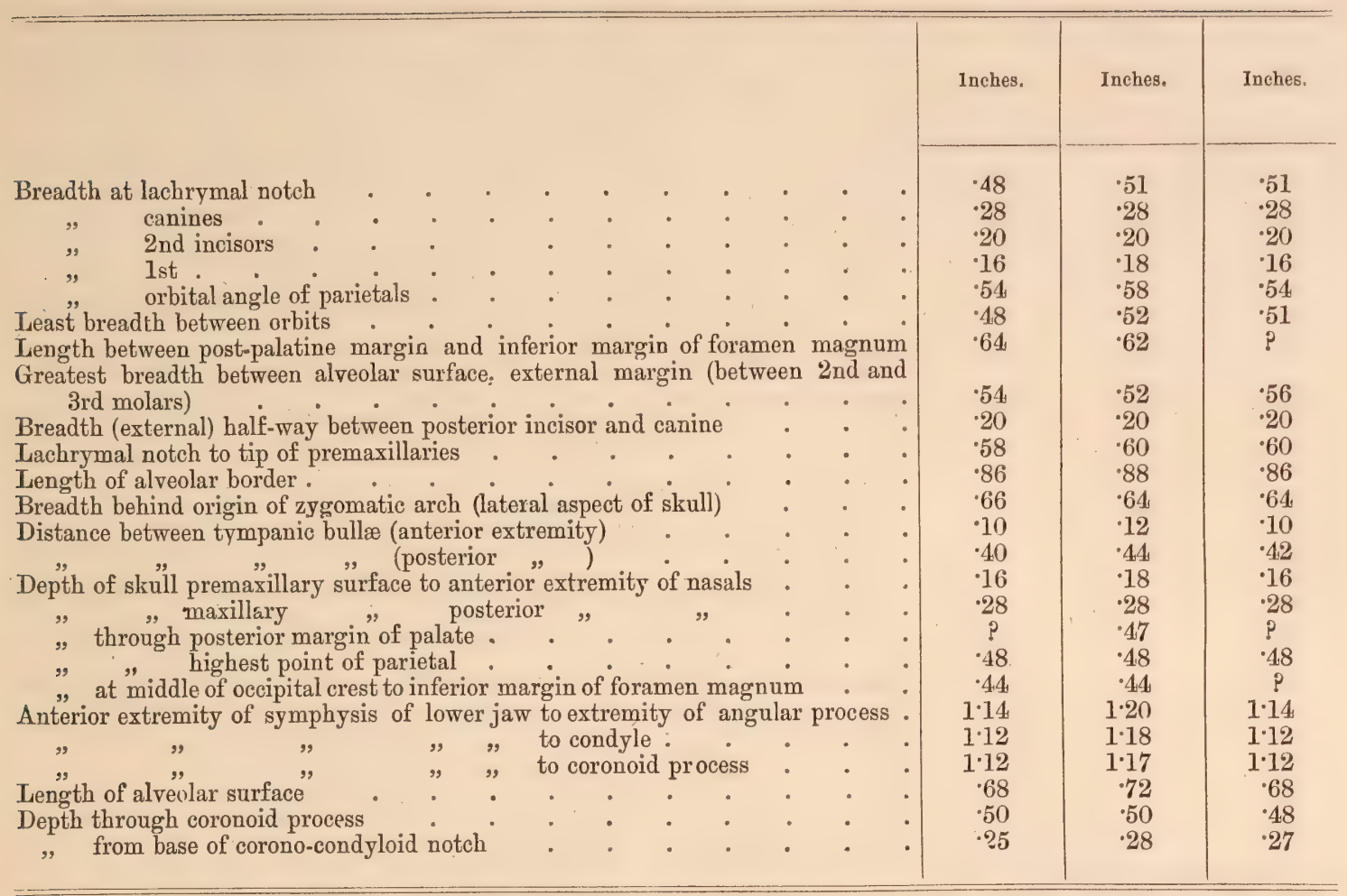

The skull is much narrower than in either T. ferruginea, T. belangeri, or T. chinensis, and is slightly smaller than the skull of the last-mentioned species. Its most striking peculiarities are the depressed character of the snout, which arches downwards, and the regularly tapering form of the same part, the absence of a constriction between the orbits or concavity in the upper margin of the orbit, which is straight and continuous with the lateral margin of the snout. The nasals are proportionately broader than in the foregoing species, and very little expanded posteriorly. The supra-orbital foramen is distinctly removed from the orbital margin. The intra-orbital region is not so constricted as in the other species. The base of the malar is proportionately broader than in the species enumerated, and the perforation of the same bone is very small and situated on the ridge at the union of the zygomatic process of the squamosal with the malar. The auditory bullæ are rounder and fuller than in the before-mentioned species. The teeth are smaller, and the second incisor when fresh through the gum is more pointed than in any of the other species, and closely resembles the canine, which, however, is broader and more erect and nearly allied in form to the central cusp of the premolars. The first incisor shows the anterior and posterior rudiments of the cingulum more distinctly than in $T$. ferruginea, T. belangeri, or T. chinensis, and it is nearly equal in length to the canine. The 2nd premolar, as pointed out by Waterhouse, has a distinct inner lobe, but it is not peculiar to the species as its original describer supposed, for it occurs also in T. ferruginea, although not nearly so prominently developed, and it is also faintly indicated in T. belangeri and $T$. chinensis. The 
3rd premolar is only a larger repetition of the 2 nd. The posterior internal cusp of the 1st and 2nd molars are much larger than in either of the three species enumerated above. The cusps of the lower molars are more slender and pointed, and the canine is not longer nor much stronger than the 1st premolar, and only slightly larger than the 3rd incisor.

The intestine is $24 \mathrm{in}$. long, and the cæecum long and narrow, and $1 \cdot 17$ in length. The walls of the stomach, as in Erinaceus, are thickened on the pyloric half. One stomach was full of the imperfectly-digested remains of a small yellow lady-bird with a sprinkling of the elytra of small beetles. There were also small masses of a jelly-like substance with very fine fibres.

The species was originally described from the hills to the west of Madras. It has also lately been obtained by Mr. W. T. Blanford at Gondalpuda in the Godavery valley. Mr. Baker informs me that he has been told that it is also found in Kuttack. It may probably extend to Ceylon, and be the Tupaia referred to by Kelaart. Günther records it from Bombay, and to the east it extends as far as Monghyr, in the neighbourhood of which it is abundant.

* Tupaia belangeri, Wagner, Plate VII, figs. 6 and 7 .

Tupaia de Pégou, Is. Geoff. Zool. de Bélanger, 1834, p. 105, tab. 4; Müller und Schlegel, VerhandI. 1839-4.4, p. 160.

Tupaia of Pegu, Waterhouse, Proc. Zool. Soc. 1849, p. 107.

Cladobates belangeri, Wagner, Schreber, Säugeth. Suppl. 1841-42, pl. ii; vol. v. p. 527; Giebel, Säugeth. 1859, p. 915; Fitzinger, Sitzgsbr. der K. Akad. Wien. 1870, vol. lx. pp. $276,27 \%$.

Tupaia ferruginea, Blyth, Cat. As. Soc. Mus. Caleutta, 1863, pp. 81, 82 (in part).

Tupaia peguana, Jerdon, Mamm. India, 1867, pp. 65, 66.

Basal half of the fur black; the remaining half banded with yellow and black. The fur is composed of two kinds of hairs; the first and most prevalent kind forms the bulk of the fur, and is very fine and wavy near its extremity; it has its terminal half banded with black, yellow and black, the last band forming a narrow black tip. The second kind of hair is rather strong and somewhat bristly, and is longer than the previous kind, beyond which it projects a considerable way and is usually banded in its free half with yellow succeeding the basal black, followed by black, yellow and black: some of the hairs, however, have only a yellow and black terminal band. The black basal half of the fur being hidden, the banding of the hair produces a rufous olive-grey tint over the whole of the upper surface of the animal, including the tail, which is concolorous with the body, the slight rufous tint being most marked on the hind quarters. There is a short, pale, narrow line before the shoulder-a character common to some of the species. The under surface from the chin to the vent, including the insides of the limbs, is yellowish. The hairs on the feet are olive-greyish or brownish, grizzled with yellowish. On the under surface of the tail, on the mesial line, the hairs are very short, adpressed, 
yellowish, and unbanded. Although the tail is concolorous with the body, the colours are very differently arranged. The basal fifth of the hair is yellow, and is succeeded by a black followed by a yellow band, succeeded in its turn by a black, terminating in a yellow band which may or may not have a yellow tip. The fur on the body averages 0.50 in length, but the longest hairs, which occur chiefly on the hind quarters, are as much as 0.80 . The hair on the head from between the ears forwards is dense and about 0.33 in length. The moustachial hairs, black and not very numerous, are rather short, but some of them reach to the posterior angle of the eye. There are a few long bristly hairs in groups on the throat and behind the angle of the mouth.

The head is considerably shorter than the head of $T$. tana, slightly shorter than T. ferruginea, and the muzzle fuller and much shorter than in the first-mentioned species, the distance between the eye and the snout being 0.90 , from the posterior angle of the eye to the hinder margin of the tragus being 0.68 ; the nostrils are crescentic slits directed obliquely backwards, the concavity being turned upwards and forwards; they measure 0.20 in extreme length, and a groove from their posterior margin runs downwards to the lip, as in all the other species of Tupaiæ. The ear is moderately large. The upper anterior angle of the helix is folded on itself till it reaches the vertex of the ear, behind and below which the margin of the helix is simple, concave in its upper half and rounded below. The anti-helix is very distinct, and the anti-tragus is prominent and projecting above the tragus. The general form of the ear and its external appearance in T. ellioti may be taken as characteristic of the other species of the genus. The hinder surface of the ear is sparsely clad with hairs similar to those on the front parts. The toes are of moderate length; the 1st the shortest, and the tip of its claw is on a line with the base of the 3rd and 4th toes; the 2nd is shorter than the 4th, and the latter is slightly shorter than the $3 \mathrm{rd}$, which is the longest; and the 5th reaches only to about the middle of the 4th. Four pads, as in the other species, occur between the bases of the four toes, and a very large one behind the pad between the 4 th and 5th toes, and a much smaller, partially-divided pad behind the cushion at the bases of the 1st and 2 nd toes. The claws are strong, much laterally compressed, deep at the base, yellowish, and of moderate length.

In the hind foot, the 3rd and 4th toes are of equal length; the dimensions of the other toes are the same as in the fore foot. The cushion between the 1st and 2nd toes has no pad behind it, but is continued backwards along the margin of the sole as a long, narrow, linear pad. The cushion between the 4th and 5th toes has another behind it, also linear in its character and distribution. The claws are stronger than on the front toes, but of the same description. The balls of the toes are prominent and laterally compressed.

The young are dark ferruginous, above finely speckled; the tail the same colour as the body; the under surface rather lightly ferruginous than yellowish, and the outside of the limbs darker than in the adults. 
Measurements of 4 specimens, 2 males and females, T: belangeri, Wagner :

\begin{tabular}{|c|c|c|c|c|c|c|c|}
\hline \multirow{3}{*}{ Tip of snout to vent } & \multirow[b]{3}{*}{... } & \multirow[b]{3}{*}{$\cdots$} & \multirow{3}{*}{$\begin{array}{c}\begin{array}{c}\text { Male } \\
\Lambda .\end{array} \\
\begin{array}{c}\text { Inches. } \\
7 \cdot 33\end{array}\end{array}$} & \multirow{3}{*}{$\begin{array}{c}\begin{array}{c}\text { Male } \\
\mathrm{B} .\end{array} \\
\begin{array}{c}\text { Inches. } \\
6.50\end{array}\end{array}$} & \multirow{3}{*}{$\begin{array}{c}\begin{array}{c}\text { Female } \\
\text { C. }\end{array} \\
\begin{array}{r}\text { Inches, } \\
675\end{array}\end{array}$} & \multirow{3}{*}{$\begin{array}{c}\begin{array}{c}\text { Female } \\
\text { juv. D. }\end{array} \\
\text { Inches. } \\
5.50\end{array}$} & RHMARK8. \\
\hline & & & & & & & \\
\hline & & & & & & & A. is an adult male with perfect denti- \\
\hline $\begin{array}{l}\text { Vent to tip of tail } \\
\text { Snout to posterior mar }\end{array}$ & ö of $t$ & $\cdots$ & 6.80 & $6 \cdot 16$ & $5 \cdot 16^{1}$ & $4: 22$ & tion. \\
\hline Vertical height of ear & rgin of $t$ & gus & $\begin{array}{r}1.93 \\
.64\end{array}$ & $\begin{array}{r}1.77 \\
.60\end{array}$ & $\begin{array}{r}1.80 \\
.60\end{array}$ & $\begin{array}{r}1.44 \\
.50\end{array}$ & B. Male with milk dentition, but with \\
\hline Diameter of ear (greate & est) & $\ldots$ & .58 & .58 & .50 & $\cdot 42$ & adult $A$. \\
\hline Snout to anterior angle & e of eye & ... & $1 \cdot 00$ & $\cdot 88$ & $\cdot 88$ & $\cdot 70$ & C. Adult female with perfect dentition \\
\hline Length of fore foot & $\ldots$ & $\ldots$ & $1 \cdot 50$ & $\cdot 96$ & $\cdot 88$ & $\cdot 80$ & and light-coloured fur." \\
\hline " of middle toe & ... & ... & $\cdot 50$ & $\cdot 47$ & $\cdot 41$ & 39 & D. Young female with milk teeth and \\
\hline of hind foot & ... & ... & $1 \cdot 75$ & $1 \cdot 60$ & $1 \cdot 66$ & $1 \cdot 50$ & dark ferruginous fur. \\
\hline of middle toe & ... & $\ldots$ & •66 & $\cdot 55$ & $\cdot 55$ & 34 & \\
\hline
\end{tabular}

Measurements of adult skull of T. belangeri, Wagner : $\quad$ Inches.

Occipital crest to tip of premaxillaries . . . . . . . . . . . 1.90

Inferior margin of foramen magnum to tip of premaxillaries . $\quad . \quad$ : $\quad . \quad . \quad . \quad$ : 1.71

Greatest breadth across zygomatic arch . . . . . . . . . . . . 1.03

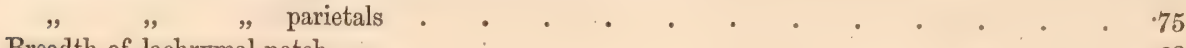

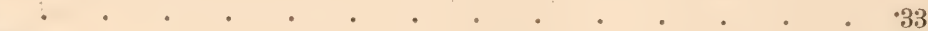

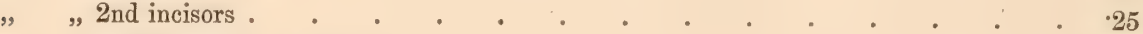

" " lst incisors . . . . . . . . . . . . . . 20

" , orbital angle of parietals . . . . . . . . . . . . . . 60

Least breadth between orbits . . . . . . . . . . . . . . . . 55

Length between post-palatine margin and inferior margin of foramen magnum . $\quad . \quad 65$

Posterior palatine margin to tip of premaxillaries $\quad . \quad$. . . . . $\quad .103$

Greatest breadth between alveolar surface (external margin) between 2nd and 3rd molars $\quad \cdot 65$

Breadth (external) half-way between posterior incisor and canine . . . . . . . 25

Lachrymal notch to tip of premaxillaries . . . . . . . . . . . 75

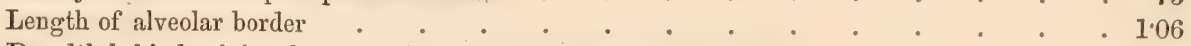

Breadth behind origin of zygomatic arch (inferior aspect of skull) _ . . . . 71

Distance between tympanic bullæ (anterior extremity) . $. \quad . \quad . \quad . \quad . \quad$. $~ .14$

" " $"$ " $"$ (posteriorly) . . . . . . . . . . . . . 43

Depth of skull, premaxillary surface to anterior extremity of nasals . . . . . . 20

" maxillary $"$ posterior . . . . . . . . . 32

" through posterior margin of palate . . . . . . . . . . . . . . 50

" , highest point of parietal . . . . . . . . . . . 52

" at middle of occipital crest to inferior margin of foramen magnum _ . . . . . 46

Anterior extremity of symphysis of lower jaw to extremity of angular process _ . . $\quad$ 1.33

" $"$ " $"$ " $"$ coronoid process * . . . . . . 16

Depth through coronoid process

" from base of corono-condyloid notch.

The skull of this species is distinguished from the skull of $T$. ferruginea by the less elongated character of the facial portion and by its smaller size. The postorbital parietal ridge is more distinct than in $T$. ferruginea, and the molar perforation is smaller than in the latter species. The teeth are smaller than in T. ferruginea, and the second upper premolar wants the internal cusp and the cusp on the anterior margin, both of which are unmistakeably developed in the last-mentioned species; but these structures nevertheless are represented in the present species by 
little more than a ridge in the first, and in the second by an obscure tubercle. The third premolar has only a simple internal lobe. The posterior internal process of the first molar is well developed and sometimes bifurcate. The same process on the third molar is a mere ridge. The teeth of the lower jaw are shorter and not so broad as in T. ferruginea.

This species ranges from Darjeeling through Arracan to Tenasserim, where it meets with $T$. ferruginea.

In the British Museum there is a specimen of this species from Nepal, from whence it was obtained by Hodgson many years ago. It bore no name.

* Tupaia chinensis, n. sp., Plate VII, figs. 8 and 9.

Fur slightly paler than in $T$. ferruginea, its basal two-thirds being blackish, succeeded by a yellow, a black, and then a yellow-and-black band, which is terminal: long hairs are numerous and broadly black-tipped. The length of hair generally is 0.58 inch, of which the basal black portion is over 0.33 . The longest hairs measure $0 \cdot 83$. There is a faint shoulder streak washed with yellowish; the chest is pale orange-yellowish, which hue extends along the middle of the belly as a narrow line. The region of the under surface and the inside of the limbs are more or less faintly grizzled as on the back, but paler and almost yellowish. The upper surface of the tail is concolorous with the dorsum. The head is shorter than in T. ferruginea, and the animal is altogether smaller. Its teeth are considerably smaller than those of $T$. ferruginea, but larger than those of T. javanica and T. ellioti. The following are the measurements of an adult male :-

\begin{tabular}{|c|c|c|c|c|c|c|c|c|c|c|c|c|c|c|}
\hline Tip of snout to vent & . & , & . & • & , & - & , & , & " & - & ? & $\bullet$ & 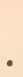 & $\begin{array}{r}\text { Inches. } \\
. \quad 6.50\end{array}$ \\
\hline Vent to tip of tail & - & - & - & • & - & - & - & • & - & - & - & - & • & - $6 \cdot 16$ \\
\hline fore foot & . & . & - & ${ }^{\circ}$ & . & . & . & . & - & . & - & . & - & . 0.90 \\
\hline middle toe & . & - & . & - & , & - & • & - & • & - & • & - & • & . 0.37 \\
\hline hind foot .. & . & . & . & . & . & . & . & . & . & . & . & - & . & 1.58 \\
\hline middle toe & - & - & - & . & • & . & • & . & . & . & . & . & . & . 0.45 \\
\hline
\end{tabular}

Measurements of two adult skulls :

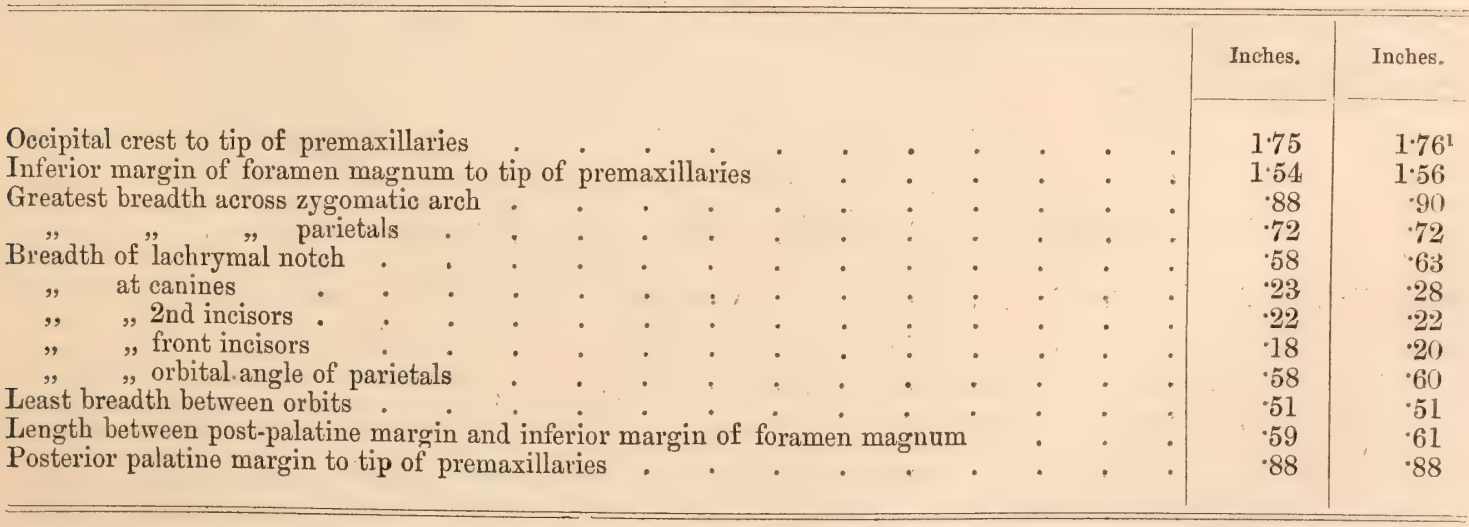

${ }^{1}$ Skull of specimen whose measurements are given above. 


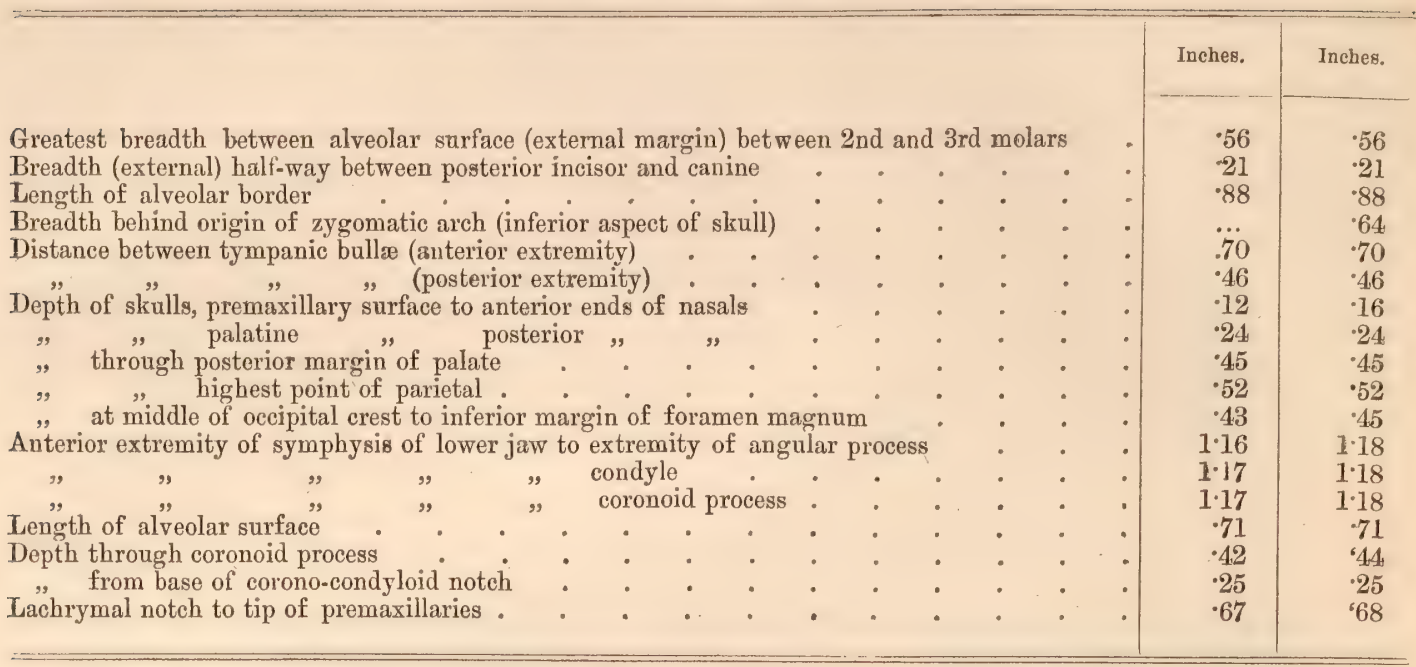

The skull is considerably smaller than the skull of $T$. belangeri, to which the species is most nearly allied. The frontals are slightly more arched from side to side than in that species and the teeth are considerably smaller, so much so that this character of itself is sufficient to separate it from Tupaia belangeri. In this character, and in its smaller size, it approaches $T$. ellioti and $T$. javanica, but by the form of its skull it is easily distinguished from these two species. The eanine is not much larger than the 1st premolar, and is smaller than the last incisor. The posterior internal cusp of the 1st molar, which is large in T. belangeri, is very small in this species. The middle two of the four external cusps are all but blended into one, so much so that only the faintest indication of a second cusp is perceptible, which is indicated by a slight depression, and this entirely disappears with age. In $T$. belangeri this additional external process is moderately developed.

I procured the species first at an elevation of 3,185 feet above the sea on the Kakhyen hills, twenty miles to the east of the valley of the Irawady, and again, at 2,400 feet, eighty miles to the eastward of that range. When I first observed the animal it was on a grassy clearing close to patches of fruit, and was so comporting itself that in the distance I mistook it for a squirrel. The next time I noticed it was in hedge-rows.

Tupaia ferruginea, Raffles, Plate VII, figs. 4 and 5, skull.

Sorex-glis, Diard and Duvaucel, Asiatic Researches, vol. xiv. 1822, pp. 471, 475, pl. ix. Glisorex, Desmarest, Mammologie, 1820-22, pp. 536, 826.

? Le Press, F. Cuv. Mammif. 1822, vol. ii. pl. xxxvi. (juv.).

Cladobates, F. Cuv. Dents des Mammif. 1820-25, p. 60.

Hylogale, Temminck, Monog. des Mamm. (Tab. Method.) 1827, vol, i, p. xix.

Herpestes, Cal. Journ. Nat. Hist. vol. ii. 1842, p. 458, pl. xiii $\frac{1}{2}$, fig. 1.

Glisosorex, Giebel, Odont. (1855), p. 18, pl. v. fig. 6. 
Tupaia ferruginea, Raffles, Linn. Trans. vol. xiii. 1822, p. 256 ; Horsfield, Researches in Java (in part), 1824, figs. C. M. \& N.; Fischer, Syn. Mamm. 1829, p. 260 (in part) ; Reichenbach, Naturg. Raubth. 1834-36, p. 320, fig. 449 ; Cantor, Journ. As. Soc. Bengal, vol. xv. 1846, pp. 188, 189; Blyth. Cat. Mamm. Mus., As. Soc. Beng. 1863, p. 81 (in part).

Cladobates ferrugineus, Raffles, Giebel, Odont. 1855, p. 18, pl.v. fig. 18 a. b., et Säugeth. 1859, p. 914; Wagner, Schreber, Säugeth. Supp. vol. v. 1855, p. 526, pl. xxxiv.; Fitzinger, Sitzgsbr. der k. Akad. der Wien, vol. lx. 1870, pp. 273, 276.

Rather rich dark ferruginous above, yellowish below, with a wash of pale ferruginous. Tail not concolorous with the body, but greyish. Shoulder streak more or less rufous. Fur rather short, 0.62 inch in length, the basal portion 0.20 inch, blackish, succeeded by an orange-red, a black, and an orange-red and black band, the last being terminal. The longest hairs do not exceed 0.70 in length; they are banded the same as the other hairs, but the black terminal band is broad. The tail hairs average $0 \cdot 80$, and are banded, either very pale grey, black, grey and black, or black, grey-black, grey and black. The short adpressed hairs on the under surface are marked in the same way.

The snout is longer than in T. belangeri, and the species is larger. ${ }^{1}$

The young are even more brightly ferruginous than the adults, and have the tail nearly as dark as the body.

The teeth are larger than in $T$. belangeri, broader, more elongated, and pointed. The 2nd upper premolar has a distinct process on its anterior margin near the base, as in T. ellioti, and a longer pointed internal process. The internal lobe of the 3rd premolar has a well-marked, second, sharp-pointed fang, like, but much smaller than, the lobe itself, at the base of its posterior margin. This process in T. belangeri is indicated merely by an eminence on the posterior margin of the internal lobe. In the lower jaw the canine is not so erect as in T. belangeri, being directed more forwards, and the anterior and posterior lobes of the 3rd premolar are more strongly developed than in that species.

The more elongated character of the snout is seen in the skull, the facial portion of which is more pointed and longer than in $T$. belangeri, and is hardly perceptibly arched downwards towards the tip. The nasals, too, are slightly broader, and the skull is considerably longer; the pre-orbital foramen is not so far removed from the eye, and the malar perforation is larger than in T. belangeri. On a line with the posterior region of the palate and at the posterior angle of the zygomatic arch $T$. ferruginea is not so broad as $T$. belangeri; the orbito-parietal ridge is but slightly or not at all developed in five skulls of this species before me; four, however, have not yet gained their permanent dentition, although but little below the size of the adult.

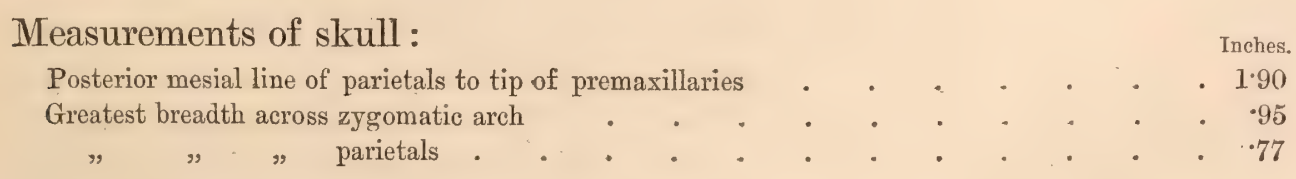

${ }^{1}$ As the specimens before me are all prepared and mounted, I hesitate to give any measurements. 


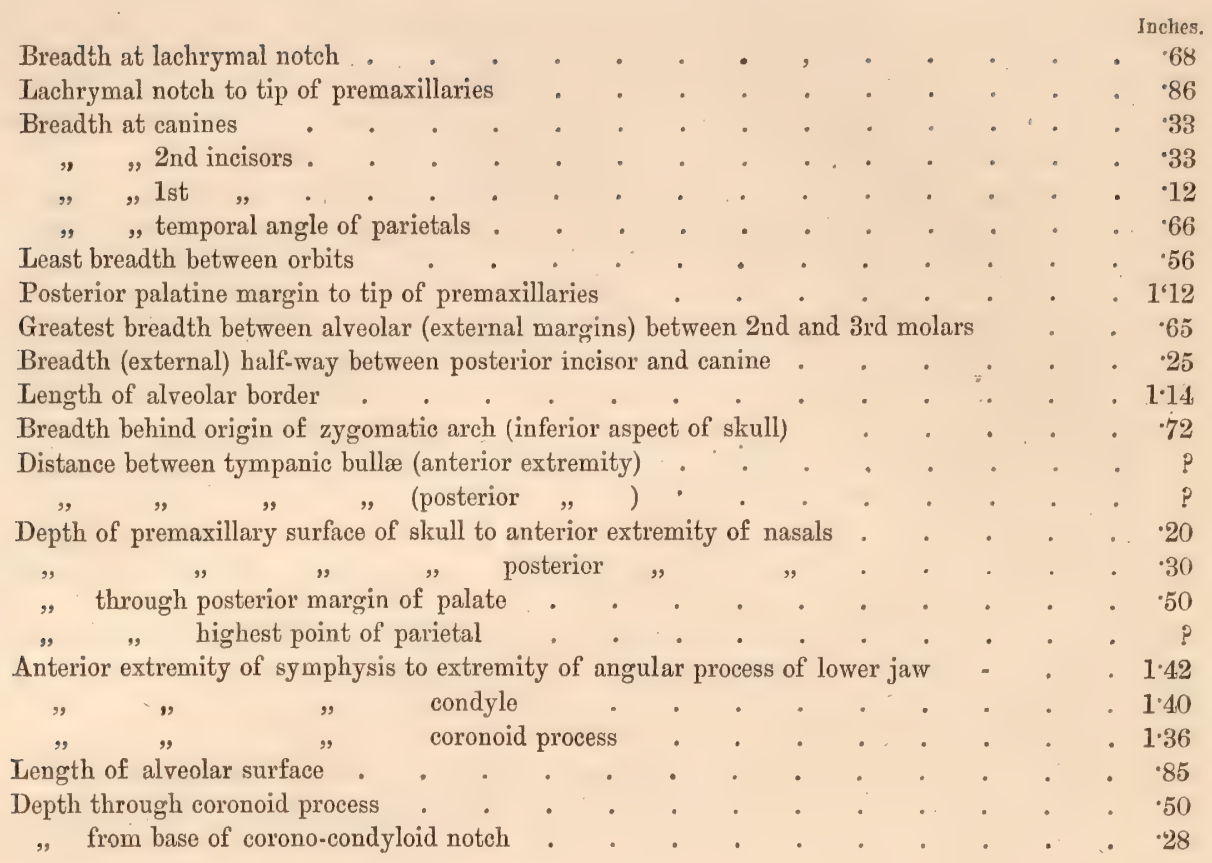

This species appears to be distributed over the Malayan peninsula and the islands in its neighbourhood, such as Sumatra, Borneo, and Java.

Diard and Duvaucel's figure in the Asiatic Researches appears to have been copied in a slightly reduced form into the Calcutta Journal of Natural History, where it is regarded as a Herpestes!

Tupata splendidula, Gray, Pl. VII, figs. 10 and 11, skull.

Trupaia splendidula, Gray, Proc. Zool. Soc. Lond. 1865, p. 322, pl. xii.

I'upaia ruficaudata, Gray, MS. Mivart, Journ. Anat. \& Phys. vol. i. 1867, p. 293 (foot-note).

There are two specimens of this species in the British Museum, and Gray states that they had at first been regarded as varieties of $T$. tana, to which in coloration they have a strong resemblance. Their skulls, however, are perfectly distinct from that species, and in their general characters approach more to $T$. ferruginea than to T. tana, from which it is at once distinguished by its short muzzle, which is even shorter than in the former species. As the skull could never be mistaken for that of $T$. tana, I shall merely point out wherein it differs from $T$. ferruginea. It is rather smaller than the skull of that species, and the facial portion, besides being smaller, has the premaxillaries bent downwards to a greater degree. The frontal region also is more flattened, and the breadth across the zygomatic arch is in excess of $T$. ferruginea, as is also the depth of the brain-case through the highest point of the parietals. The rami of the lower jaw are more divergent opposite to the end of the alveolar border than in $T$. ferruginea, which is in keeping with the greater breadth across the zygomatic arch. The teeth also present certain differences, and one of 
the most observable is the greater size of the first as compared with the second incisor-a peculiarity which separates it from other Tupaice. In the upper molar, which is smaller than that of $T$. ferruginea, the cusps are only feebly developed, and the two following molars have their inner talon flattened instead of being cuspidate, as in T. ferruginea, and the anterior external cusp of these teeth is not well indicated, and the teeth generally are smaller. In' the lower jaw the first molar is more flattened than in T. ferruginea, and the cusps but little developed, and the two anterior cusps of the antecedent molars are all but absent, and the inner and anterior pair of cusps are less prominent than in T. ferruginea.

The tail of the animal is less than the length of the body and head, and is blackish chestnut and in strong contrast to the tail of T. ferruginea, which is, so to speak, of a blackish olive, while the tail of $T$. tana may either be rich chestnut red or deep black. As in the latter, the fur is especially shining on the flanks and rump. Dr. Gray describes the species as follows:-

"Fur dark brown, blackish washed. Tail dark red-brown, pale red beneath, longer than the body and head; the shoulder strata yellow; no bands between the shoulders. The head conical, about twice as long as wide behind."

The head is large, compared with the size of the body; the ears rounded, with several ridges on the conch, and a well-developed convex tragus not unlike the human ear.

The palm and soles are bald to the wrist and heels. The skull resembles the skull of $T$. ferruginea in the character of its facial portion.

This form inhabits Borneo.

\section{Measurements of skull of T. splendidula, Gray:}

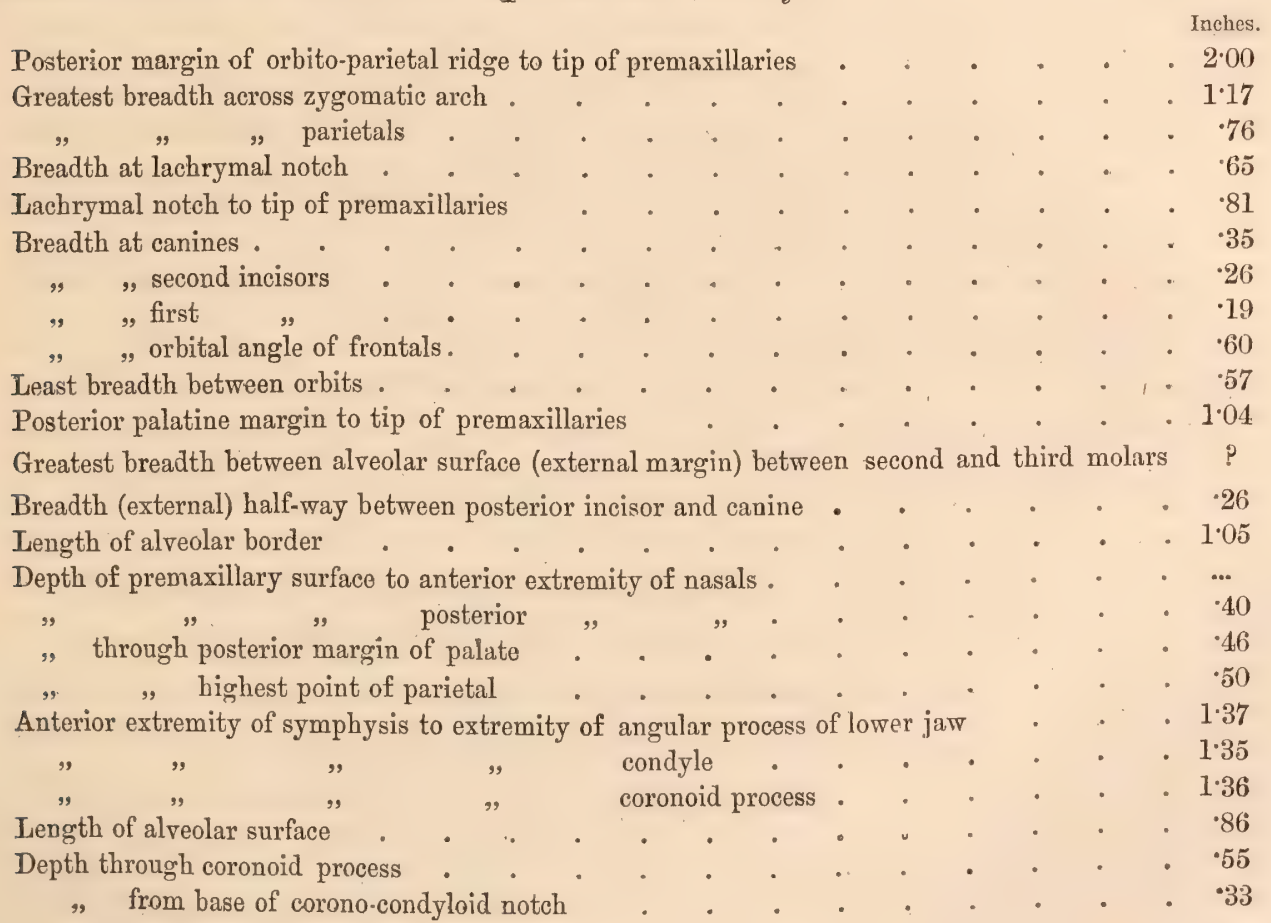




\section{Tupata JaVANICA, Horsfield, Plate VII, figs. 14 and 15, skull.}

Tupaia javanica, Horsfd. Zool. Resch. in Java, 1822, fig.; Desmarest, Mamm. 1822, pp. 536, 825 ; Fischer, Syn. Mamm. 1829, p. 260 ; Gray, Griffith's An. Kingd. vol. v. (1827), p. 306 ; Reichenbach, Natur. Raubth. 1834-36, p. 321, fig. 451.

Cladobates javanicus, Lesson, Man. de Mamm. 1827, p. 122; Wagner, Schreber, Säugeth. Suppl. vol. v. 1855, p. 527; Fitzinger, Sitzgsbr. der k. Akad. Wien, vol. 1x. 1870, pp. 282, 283.

Hylogale javanica, Müller und Schlegel, Verhandl. 1839-44, pp. 165, 166, pl. xxvi. fig. 3 ; pl. xxvii. figs. 7 to 10.

The skulls of the specimens referred by Blyth to. T. javanica are totally different from the skull of that species as depicted by Müller and Schlegel, and must be regarded as belonging to a hitherto unrecognised form, T. malaccana. T. javanica is distributed over Java, Borneo, and Sumatra, according to Müller and Schlegel. Externally, T. javanica and T. malaccana appear to be much alike, and it may be that the small Tupaia from Sumatra, referred by other authors to this species, is the Malayan form T. malaccana.

Tupaia malaccana, n. s., Plate VII, figs. 16 and 17, skull.

Sorex-glis press, F. Cuv. Mammif. vol. ii. Livr. xxxv. Dec. 1821.

Tupaia javanica, Blyth, Cat. Mamm. Mus. As. Soc. Beng. 1863, p. 82.

About the same colour as $T$. belangeri. Fur short and fine, and measures on an average 0.38 inch long, the more rigid and longer hairs being 0.58 or 0.55 inch in length. The basal black region measures 0.19 in extent, and the annulation is the same as in the other species, only the bands are not so broad. The pale bands are rich yellow. The tail above is concolorous with the body. The shoulder stripe is yellowish or nearly pure white. The feet are rufous-yellowish. The under surface is white, richly washed with rufous-yellow: the under surface of tail is richer and darker rufous-yellow.

Rather smaller, or of the size of T.javanica. Muzzle short; tail longer than the body. Length of the body and head 5*40, tail $6 \cdot 70$, hind foot $1 \cdot 25$.

The characters of this species are best seen in its skull, of which there are two in the Indian Museum, Calcutta, agreeing in all essential particulars with each other. One was removed by Blyth from an adult of this species from Malacca, and the other from a younger animal with milk dentition.

The most striking features of the skull are its small size, its breadth, and the shortness of the facial portion as compared with the figure of $T$. javanica given by Müller and Schlegel. Its orbito-parietal ridges form a broad, rounded arch, quite different from what occurs in the skull of any of the other species of Tupaia; and hence we find associated with the same portion of the skull a breadth and flatness which is also specific and characteristic of this form. The muzzle rapidly contracts from the orbit to its middle, beyond which it maintairs an almost equal 
width. Behind the nasals, the skull is concave from before backwards, and the frontals are rather swollen.

The upper margin of the orbit is directed inwards as far as the supra-orbital foramen, from whence it passes outwards and downwards. The lachrymal notch is well marked, and the malar perforation large.

Measurements of skull of T. malaccana:

Posterior margin of orbito-parietal ridge to tip of premaxillaries
Greatest breadth across zygomatic arch
Breadth at lachrymal notch

The most particular feature in the dentition of this species is the close proximity of the canine to the 1st premolar, the two teeth being placed side by side without any appreciable interval. The 1st premolar is little more than one-half the size of the canine. The 2nd premolar has no internal cusp, but has an anterior one feebly developed. The 3rd premolar is as in the other species. The posterior internal cusp of the molars is only indicated by a faint swelling on the first molar, the others showing no trace of it. The canine of the mandible is not so procumbent as in the other species, and is much higher than any of the surrounding teeth. $T$. belangeri resembles it somewhat in this character.

The two specimens from which the foregoing description is taken were procured at Malacca and referred by Blyth to T. javanica, but it is impossible to reconcile their short, round skulls with Horsfield's figures of the head, nor with the drawing of the skull of that species given by Müller and Schlegel.

The figure given by F. Cuvier of the Cerp or Banxring as T. javanica agrees so closely with the specimens before me in its coloration, short muzzle, and long tail, that I am disposed to refer it to the present species, as it is apparently not $T$. ferruginea.

Habitat.-Malacca : ? Sumatra. 
Tupata tana, Raffles, Plate VII, figs. 1 and 2, skull.

Tupaia tana, Raffles, Trans. Linn. Soc. vol. xiii. 1821, p. 257 ; Horsfd. Zool. Resch. Java, 1824, plate; Gray, Griffith's An. Kingd. vol. v, p. 305; Fischer, Syn. Mamm. 1829, p. 260 ; Blyth, Cat. Mamm. Mus. As. Soc. Beng. 1863, p. 81.

Cladobates tana, F. Cuv. Dict. des Se. vol. xlv.; Lesson, Man. de Mamm. 1827, pp. 122, 329, Wagner, Schreber, Säugeth. Suppl. vol. v. 1855, p. 525 ; Giebel, Odont. 1855, p. 186, pl. v. fig. 17; Säugeth. vol. v. 1859, p. 914 .

Hylogale tana, Müller und Schlegel, Verhandl. 1839-44, pp. 161, 162, pl. xxvi. fig. 2; pl. xxvii. figs. 1-16.

Cladobates speciosus, Wagner, Schreber, Säugeth. vol. ii. 1841, pp. 43, 44.

Erinaceus (Glisorex) tana, Blainville, Osteog. (Insectiv.) pI. vi.

The fur is fine and moderately long. It consists of two kinds of hairslong, entirely black, rather stiff hairs, and shorter hairs with a subapical orange or dark rufous-brown band. The former kind occurs most numerously on the interscapular black band and on the hind quarters; the orange-banded hairs cover the head, where they are very short the shoulder band, and a rather broad area below the interscapular band. The dark rufous-brown hairs occur chiefly on the sides, the colour of which and of the limbs is a deep ferruginous chestnut gradually passing into the black of the back. The tail is dark, very deep ferruginous-chestnut and bright rusty on the under surface. The chin and the throat are rusty brown, the chest and belly being paler chestnut than the upper parts.

The skull is at once distinguished from the skulls of all known Tupaice by the long attenuated character of the pre-ocuiar portion.

The animal is much larger than any of the other species, and has a considerably longer snout. The tail is about the length of the body, exclusive of the head.

Habitat.-Borneo.

Tupata nicobarica, Zelebor, Plate VII, fig. 3, skull.

Cladobates nicobaricus, Zelebor, Reise der Novara, Säugeth. vol. i. p. 17, pl. i. et ii. 1868 ; Fitzinger, Sitzungsbr. der Akad. Wienn, 1870, vol. 1x. p. 279.

The face is moderately long, but not nearly so pointed as in $T$. tana, to which the species is allied, and the anterior portion is somewhat depressed. The two first incisors are prominent and project downwards anterior to the lower lip. The feet are large and the claws strongly developed. The ear is moderately large and quadrangular. The front and sides of the face, the outside of the fore limbs, the throat and chest, are golden yellow, with an ochrey tint deepening on the sides and abdomen, and on the inside of the hind limbs to a rich rufous brown, which is also the colour of the outside of the hind limbs and hind feet. The top of the head is rich dark brown, almost chestnut brown, with shining golden hairs intermixed. An oblong, pale golden brown area on the back between the shoulders, with a dark 
almost maroon band on each side between it and the fore limbs, and passing forwards over the ears. The rest of the back and the upper surface of the tail dark, almost black, but with a maroon tint and with shining black hairs intermixed; the under surface of the tail with a yellowish brown central band of short hairs. All through the fur, which is of moderate length, there are numerous shining hairs; those on the upper surface, except on the pale areas, being lustrous black, whilst those on the pale areas and on the under surface are shining golden yellow, and they are most numerous along the mesial line.

Measurements of alcoholic specimen :

$$
\begin{aligned}
& \text { Body and head . . . . . . . . . . . } 7 \cdot 10 \\
& \text { Tail without hair . . . . . . . . . . . } 8.00 \\
& \text { Hind foot without claws }
\end{aligned}
$$

This species does not appear to have the shoulder-stripe developed.

The skull, although the animal, by its general features, would appear to be more closely allied to $T$. tana than $T$. ferruginea, has nevertheless the much shorter facial region of the latter.

This species appears to be confined to the Nicobars. 


\section{HYLOMID 2.}

Characters.-Head elongate; ears round; feet arboreal, naked below; tail semi-nude ; pelage not spiny; orbit imperfect; rudimentary post-orbital process present; no zygomatic imperfections of ossification; pelvis posteriorly depressed; symphysis pubis very short; tibia and fibula united; dentition $1 \frac{3 \times 3}{3 \times 3} c \frac{1 \times 1}{1 \times 1} \mathrm{pm} \frac{4 \times 4}{4 \times 4} \mathrm{~m} \frac{3 \times 3}{3 \times 3}=44$.

Genus Hrцoмrs, Müller.

* Hrlomys Peguensis, Blyth, Plate VI.

Hylomys peguensis, Blyth, Journ. As. Soc. Beng. vol. xxxviii. 1859, p. 294; Ibid, p. 286 ; Anderson, Trans. Zool. Soc. Lond. vol. viii. 1874, p. 453, plate lxiv.

The general configuration and details of the structure of this Insectivore are so anomalous that it cannot, with propriety, be classed either with the Tupaiide or Erinaceida, as it has characters in common with both of these groups. Its skull has the general form of the skull of Tupaia, but in its imperfect orbit, in the rudiment of a post-orbital process, and in the absence of any imperfections of the zygomatic arch, and in the position of its lachrymal foramen, it resembles the skull of Erinaceus, to which it has a general resemblance, although at the same time it is a much lighter skull, in keeping with the arboreal habit of the animal. As I have elsewhere shown, it also differs from Tupaia in the skull having an imperfect tympanic bulla, an excavated basi-sphenoid, and paroccipital and mastoid processes. In these details of its skull structure it is more nearly related to the Erinaceide than to the Tupaiide, but it does not approach either of these groups to that degree of affinity that would entitle it to be ranked under either of them.

Its teeth also show proclivities with the Erinaceida, whilst at the same time they exhibit undoubted relations to the teeth of Tupaia. The form of its scapula is intermediate between that of Tupaia, and even Erinaceus itself. Its united tibia and fibula affine it to the Erinaceida, and the form of its pelvis, moreover, is markedly distinct from the pelvis of Tupaia, whereas it is closely resembled by the pelves of Gymnura and Erinaceus. In its short rudimentary tail it also exhibits a character the very opposite of any Tupaia.

Considering all these facts, this animal appears to present an assemblage of characters which excludes it from any known family of vertebrates, and to place it intermediate between Tupaia and Erinaceus. I have therefore named the family Hylomida for its reception.

This animal was obtained at Ponsee, in the Kakhyen hills, at an elevation of about 3,000 feet. 


\section{SORICID $A$.}

Genus Chimarrogale, n. g.

Feet scaly, ciliated, with short, coarse, rigid hairs along their margins and the sides of the toes; toes not webbed. Tail long, scaly, quadrangular, thickly covered with coarse adpressed hairs; snout elongate; ears almost wholly hidden, valvular. Teeth white $\frac{2+4}{2}+\frac{2}{2}+{ }_{2+6}^{8}=28$. A talon on the inside of the first upper incisors. Three intermediate teeth of nearly equal size.

* Chimarrogale himalatca, Gray, Plate v, figs. 17-30.

Crossopus himalayicus, Gray, Ann. \& Mag. Nat. Hist. 1842, p. 261; Blyth, Journ. As. Soc. Beng. 1855, p. 37.

Crossopus himalaicus, Tomes, Ann. \& Mag. Nat. Hist. 2nd Ser. 1856, vol. xvii. p. 26; Jerdon, Mamm. of India, 1867, p. 60.; Andr. Proc. Zool. Soc. 1873, p. 230.

Crocidura himalaica, Andr., Proc. Zool. Soc. Lond. 1873, p. 231.

I caught a specimen of this remarkable water-shrew in a mountain stream behind our camp at Ponsee, in the Kakhyen hills, at an elevation of 3,500 feet. I observed it running about over the stones in the bed of the stream and plunging freely into the water. It was evidently engaged in feeding, and in addition to insects and aquatic larvæ, it is probable that, like Crossopus fodiens and C. remiger, ${ }^{1}$ it may kill young fish.

I have examined the type of this species in the British Museum, but with the exception of its somewhat greater length of body and tail, I do. not see that this Yunnan specimen differs from it in any of its essential features. The type being a stuffed specimen, its somewhat greater size may safely be attributed to the stretching of the skin in mounting.

The animal has a rather elongated body and snout. The fur is soft, dense and velvety, and the general colour of the upper parts is a dark grey, richly washed with a dark brown, almost black, fuliginous or blackish brown which nearly obscures the grey colour. When the fur is pulled aside, it is seen to be uniformly slaty, but all the hairs terminate in fine brown or blackish brown tips, with the exception of scattered, stronger, and longer hairs which have broad white tips. These hairs are especially numerous on the hind quarters, where they are also much longer

\footnotetext{
' Land and Water, No. 14, p. 328, and No. 17, p. 398.
} 
than on any other part of the body, and they correspond exactly to the white-tipped hairs of Nectogale. The under surface is greyish with a silvery sheen, washed with rusty on the throat and the middle of the belly. The whiskers are blackish or even white. The hind feet are large, but much smaller than in Nectogale; the fore $\operatorname{limb}$ is clothed to the wrist, the hind limb in the lower half of the tibia is scaly and partially clad with short hairs. The upper surface of the feet is naked, with the exception of that portion over the metacarpals and metatarsals, which is sparsely covered with short, flattened, stiff, adpressed, almost white hairs. The upper surface of the toes is scaly, and bare, except that from one to six broad, stiff, rather long hairs occur at the base of the claws. The toes are ciliated along each of their sides with a line of broad stiff hairs of equal length forming a dense short fringe. The line along the entire margin of the internal and external toes is continued along the sides of the feet as a strongly ciliated fringe of white hairs; the claws are yellowish, moderately long and curved. From the vent to the tip of the tail equals from the vent to nearly the eye. The tail is long, and quadrangular in transverse section. The under surface and sides are densely covered with longish, adpressed, broadish, coarse, rigid hairs of the same character as those on the sides of the toes and feet, but longer. The upper surface of the tail, for two-thirds, is only sparsely covered with short, strong, blackish hairs, not obscuring the scaly rings as in the last third, where it is clad much as on the under surface and sides. The hairs on the under surface of the tail are white, and on the sides and upper surface dark brown.

The eye is small, almost hidden; the ear is all but completely concealed in the fur. It is a transversely oval slit 0.26 of an inch long, distinctly valvular; the lower posterior half, fleshy, irregularly oval, bare on its internal surface, except at its margin, which has a fine covering of very minute, short, almost microscopic, white hairs. The portion immediately above the fleshy antitragus is thin and membranous, and covered on its inner surface with ordinary fur, except at a small spot at its upper extremity, which is quite bare. The antitragus, when applied to the front surface of the ear, which is quite bare, effectually closes the orifice; and from the circumstance that when this happens the membranous portion is folded upon itself, the orifice is even still more certainly shut against the entrance of water. The orifice of the nostrils is completely hidden from sight below an almost cartilaginous valve formed by the external angle of the bare fleshy portion of the nose, and which can evidently be pressed against the orifice; and from the fact that the valve is anterior to the opening of the nostril, the pressure of the water when the animal takes to a mountain stream must tend to keep the valve closely applied. Even although the aquatic habits of this shrew had not been observed, its economy, as I have described it, would have indicated what its habits truly were.

Measurements of Chimarrogale himalaica, Gray.

\begin{tabular}{|c|c|c|c|c|c|c|c|c|c|c|}
\hline Tip of snout to vent & - & - & - & - & - & 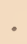 & : & - & , & $\begin{array}{r}\text { Inches } \\
\text { - } 3.83\end{array}$ \\
\hline Vent to tip of tail. & . & $\therefore$ & - & - & - & $\cdot$ & . & $\cdot$ & . & - $3 \cdot 00$ \\
\hline Snout to anterior margin & of exter & al meatus & . & . & . & - & . & - & - & - 1.04 \\
\hline
\end{tabular}




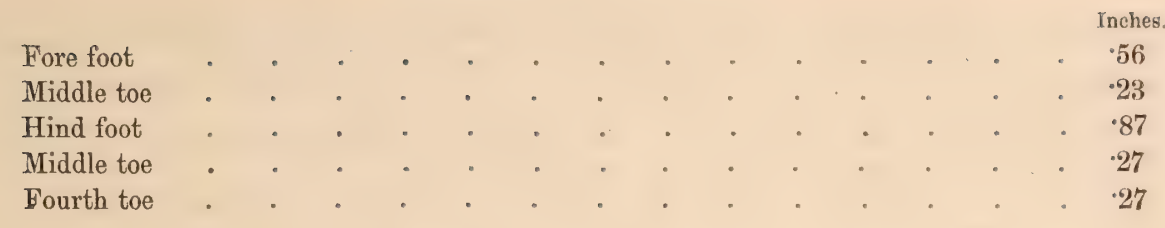

Measurements of skull.

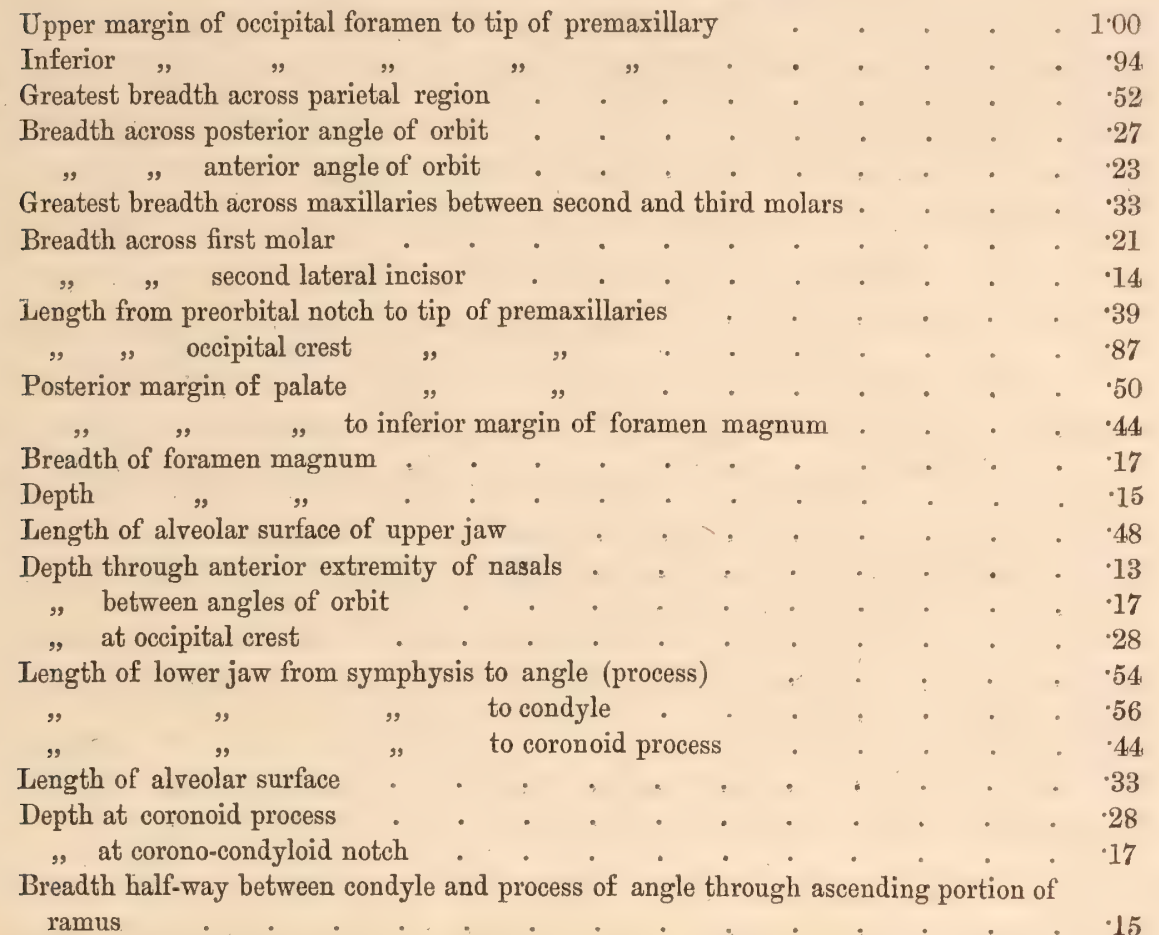

The skull is distinguished from the skull of Crocidura by the greater relative breadth of the brain-case, by its more arched character from side to side, by the shorter character of the temporal contraction of the skull, by the marked depression of the frontal area, and by the less breadth of its maxillary region. The skull is also devoid of the strong ridges which characterise the skulls of terrestrial shrews generally. In its form it is closely related to Crossopus and also to Soriculus. Its occipital region is extensive and forwardly uptilted, and in this and in such other particulars as breadth and arching of the brain-case it is allied to Crossopus and perhaps more so to Soriculus. The skull is generically identical with the skull of the aquatic shrew of Japan, Sorex (Crossopus) platycephalus, Temminck. It is also undoubtedly closely allied to the skull of Nectogale, from which it differs, however, in being more elongated, and in having considerably less breadth across the parietal region and in having a more elongated facial portion.

Viewing the skull from above, the occipital region is all exposed, with the exception of that portion of it on the basal aspect of the skull, and the condyles are seen defining almost its greatest breadth. The occipital area is convex, and slopes considerably backwards. The foramen magnum is very large and rather transversely oval, its transverse breadth nearly equalling the antero-posterior length of 
the occipital region above it. The lambdoidal ridge is well marked, and a feeble sagittal crest is prolonged forwards from it. The post-glenoid process is perforated by a well-defined foramen close to its anterior or inferior margin, directed backwards, upwards, and slightly inwards, and on its inner margin there is a small, inwardly projecting process. In Soriculus there is a similar foramen in the same position, whereas in Crocidura and Pachyura it is always placed internally at the base of the glenoid process. The condyle of the mandible consists of two distinct articular facets separated from each other by a deep notch. The lower articular surface is a transverse process projecting inwards, considerably beyond the upper division, which is in a line with the coronoid process, and its facet looks downwards, backwards, and inwards. The upper division is narrow, obliquely transverse, looking backwards and inwards. It is separated by a very wide notch from the coronoid. The lowermost of these surfaces is received into the articular concavity defined by the post-glenoid process, and the uppermost is applied to the articular surface occurring on the under aspect of the lateral ridge of the skull that corresponds to the zygomatic ridge of the squamous, so that the summit of the coronoid is on a level with the upper surface of the skull at the frontal depression. In Crocidura this tendency to the division of the condyle shows itself to a certain degree, but not to the marked extent that occurs in this form and in Anurosorex, while in Talpa there is no trace of it. The palate projects behind the last molar, and is defined by a well-marked, antero-posteriorly concave ridge, and there are no imperfections of ossification. Looking at the skull sideways, there is a considerable depression in the inter-orbital region, before which the facial portion is first slightly convex and then straight, flattened from above.

The teeth, as in Nectogale, are white, ${ }^{1}$ and 28 in number, as in Crocidura. The front incisors, rather widely apart at their bases, bend so much inwards and slightly forwards that they touch each other, defining a triangular space between them. They are curved forwards, downwards, and backwards, round at their bases, but with sharp, slightly, laterally compressed points. Some little distance above the tips, on the inner side of the teeth, there is a small process developed on each, as in Crossopus and Sorex, but which is absent in Nectogale, and it is at this point that the two teeth are in contact. The posterior basal process is not strongly developed, and is smaller than any of the small lateral teeth. It is shortly conical, with flattened sides to its crown, which has a longitudinal cutting ridge with a visible cingulum. The lateral teeth are of moderate size, but with little vertical extension. They are more or less oval from before backwards, and each has the cingulum strongly marked for lateral teeth, and it is so prominent on the inner margin of the second tooth as to produce the appearance of a cusp, the cingulum being separated from the crown of the tooth by a deep groove. The crown is elongately oval and

\footnotetext{
1 Tomes, writing on the type specimen of Crossopus himalayicus, Gray, says: "The teeth of this example are those of a restricted Sorex, and I feel no hesitation in saying, after a careful examination, that they have been introduced by the stuffer."-Ann. and Mag. Nat. Hist. 2nd ser. xvii (1856), p. 25. As the two spirit specimens, however, of this shrew which have come under my observation have both pure white teeth, there can now be no doubt that Dr, Gray was quite correct in describing the teeth of his type as white.
} 
marked by two obscure ridges from before backwards, the surface between them being rather flat. The canine tooth has no character of its own to separate it from the foregoing. All these teeth overlap each other by their anterior extremities. The first molar has the greatest vertical extension of any of the teeth except the front incisors. Externally it has two cusps, the anterior small, and the one behind it much larger and trenchant, with a long ridge running backwards that might almost be regarded as another cusp. At a higher level internally there are two other cusps, the anterior the most vertically extended of the two, but rounded, while the posterior cusp has a longish, posterior ridge. The second molar has three external, two median, and two internal cusps; the posterior median cusp being the longest. The anterior median cusp is very small, and is connected with the anterior and middle external cusps by a low ridge to each. The posterior internal cusp is about half the size of its fellow in front of it. In the third molar, the middle external cusp is much smaller than the anterior, and the posterior median cusp has but slight vertical extension. The last molar is less than half the size of the tooth before it. Its crown is triangular, with its base inwards and backwards and its apex forwards and outwards. Externally there are very obscure indications of the tricuspidate nature of that margin, and internally the existence of two very feeble cusps can be detected with difficulty.

The lower incisors are not marked by any ridges, they arch forwards and upwards. The canine is the smallest tooth, minute, and like an upper lateral incisor. The premolar is conical, with two cusps viewed from without, the anterior forming the body of the crown with a small prominence on its hinder margin. The first molar has the greatest height. It has three external cusps, of which the middle cusp is the highest, and is closely applied to its fellow of the outside. The anterior, external cusps form the front end of the teeth, and are on a line with the internal cusps on the molars. The second molar only differs from the first in being slightly smaller, and the third from the second in being little more than half its size, with much more feebly developed cusps.

The dental formula may be stated thus, judging from analogy, viz.,$\frac{2+4}{2}+\frac{2}{2}+\frac{8}{2+6}=28$.

This aquatic mammal in its white teeth and in their number is closely allied to the terrestrial Crocidure, but it differs from them, as stated, in having a process on the inside of the front incisors. The existence, however, of such a structure by itself would not have been of sufficient importance to separate it from Crocidura; but when it is taken in connection with the modifications of the skeleton which adapt the Soricine type of structure which it retains, to an aquatic habit, we are entitled to separate it generically: although judging it, by its teeth alone, it would scarcely be entitled to generic rank.

The skeleton of this animal is of extremely light construction compared with the heavy skeleton of terrestrial shrews attaining similar dimensions, but in its general character it conforms to the shrew type of skeleton. The character which 
most strikes one in observing it is a feature connected with its caudal vertebræ to be mentioned hereafter.

The vertebræ are C. $7,{ }^{1}$ D. 14, L. 5, S. 4, C. 20. The spinous processes of the last five cervical and first dorsal vertebræ are only rudimentary, and the neural arches are antero-posteriorly narrow. The spine of the second dorsal is only moderately developed and directed upwards and backwards, but the spines behind it, as far as the tenth vertebra, decrease in size, and are very much depressed and confined to the posterior margin of the neural arch. The spinous processes of the remaining dorsal vertebræ have an antero-posterior extension co-extensive with the breadth of the neural arch, and all are directed forwards, and, with the exception of the first which is thin and plate-like, they are transversely thick and low, with flattened summits. The spines of the lumbar region preserve the same characters with the last mentioned. A minute process occurs on the side of the neural arch of each of the last five cervical and first and second dorsal vertebræ; it is placed nearer to the spinous process than to the zygapophysis. In the fifth dorsal a minute hyperapophysis makes its appearance and rapidly increases in size, attaining its maximum in the last lumbar. The lateral neural processes of the cervical appear to be serially homologous with these dorsal and lumbar hyperapophyses.

The transverse processes of the cervical vertebræ are short and rod-like, and overlap, but without touching each other; their inferior lamellæ are shorter and more pointed. The transverse process of the sixth is long, its anterior portion being stouter than the lamellæ in front of it, and its hinder half projects downwards and backwards below, but rather widely separated from the head of the first rib, and is long and somewhat sickle-shaped. A small eminence makes its appearance posteriorly on the summit of the short transverse process of the third dorsal vertebra. On the fourth vertebra it is a prominent, forwardly projecting process, occupying the middle of the lateral surface of the neural arch above, and remote from the slight projection on the side of the vertebra at the union of the lamina and centrum to which the tubercle of the rib is articulated. As it is traced backwards to the eleventh dorsal vertebra it approaches more and more to the anterior zygapophysis, till at last it is closely in contact with it and touches the hinder margin of the posterior zygapophysis of the vertebra in front of it, thus meriting to be regarded as a metapophysis. In all these vertebræ its base is parallel with the spinal axis. In the twelfth dorsal a small process appears between the anterior and posterior zygapophysis, slightly below the level of the process I have just decribed on the eleventh dorsal, but on a line with the articular surface of the anterior zygapophysis, but, unlike the previous process, it is directed backwards, yet so gradual is the change in level that the two appear to be continuations of one and the same element. On the thirteenth dorsal a similar process occurs, but it is slightly more posterior in its position, being nearer the posterior than the anterior zygapophysis, and at a relatively lower level, being on a line with the inferior, anterior margin of the latter

${ }^{1} O$ wing to an accident, the atlas and axis were lost in removing the skull for examination. 
zygapophysis. In the fourteenth, it is nearly as far back as and below the posterior zygapophysis, with the very feebly developed transverse process of that vertebra below it. In the first lumbar, the same process has become, as it were, the upward and backwardly projecting process of the little-developed transverse process of that vertebra. In the second lumbar it is still more developed, and indicates a decided tendency to separate from the transverse process, which, although far from being strongly pronounced, is directed downwards and forwards. In the third lumbar the transverse process is slightly more marked than in the preceding vertebra, but the process in question is reduced to a mere trace on its posterior margin, and in the following lumbar vertebræ, in which the transverse processes increase in size from before backwards, with, however, only a rod-like antero-posterior expansion, all trace of it is lost. It would thus appear, from the twelfth dorsal to the third lumbar, to be entitled to be regarded as an anapophysial process, but its gradual transition from a metapophysial to an anapophysial position is very suggestive. A true metapophysis may be detected in the second lumbar, and the same process occurs more intensified in the third and fourth, but is reduced in the fifth. A well-developed, posteriorly bifurcate hypapophysis occurs on the third and fourth cervical, and a ridge-like hypapophysis on the vertebræ behind them to the second dorsal. Two rather widely separated hypapophysial processes occur on the thirteenth and fourteenth dorsal and first and second lumbar vertebræ, the remaining lumbar vertebræ having a ventral longitudinal ridge on their centra.

The dorsal spines of the four sacral vertebræ are united into a rather prominent ridge with a thickened margin, but the spine of the fourth is rather deeply separated from the others. All the sacral vertebræ are firmly united together, but only the first and one-half of the second are applied to the ilium. The first vertebra developes on the sides of the sacral crest what appears to be a trace of united zygapophysial and hyperapophysial elements, and a well-developed, bifurcate hypapophysis on the anterior margin of its centrum : the remainder of the sacral vertebræ being ventrally ridged, the third and fourth developing a feeble transverse process. The spinous processes of the first and second caudals are well developed and halbert-shaped, and backwardly projecting, while only a trace of the process can be observed on the third caudal, whereas it cannot be detected on the following vertebræ. The processes which support the anterior zygapophyses of the first caudal are very long and twice as much so as those of the second caudal. Both processes arise from the anterior surface of the base of the spinous process, and the articular surfaces which they carry on the inner aspect of their extremities are applied, as it were, to each side of the hinder end of the spinous process in front, so sessile are the posterior zygapophyses. On the second caudal there are no traces of these last-mentioned processes, but the last remnant of a neural arch can be detected passing below the spinous process. All the caudal vertebræ, from the third inclusive, are distinguished by the presence of two rod-like processes on the upper surface of their anterior and posterior ends, with another process in close apposition to each externally; the superior processes doubtless are probably serially homologous with the anterior and posterior zygapo- 
physes, and the inferior and the lower with the transverse processes. There are chevron bones between each of the caudal vertebræ to the extremity of the tail, each resting directly on its vertebra without the apparent intervention of hypapophyses. The form of these chevron bones is very remarkable. The first eight consist of a central transverse rod resting on the articulation of two vertebræ, and terminating externally on either side in a transversely narrow, but longitudinally long: expansion, so that when viewed from before backwards, they resemble the letter $\mathbf{H}$. In the remaining vertebræ, except the last four, the rod is mesially divided into two equal halves, which are, however, in close apposition, while in the terminal vertebræ the connecting rod is reduced to a mere rudiment. In the first two vertebræ the lateral portions are much more ventrally and laterally expanded than in the others behind them, and in the first vertebra they are directed slightly backwards. In the remaining vertebræ they do not project below their transverse rods, and they are thus the cause of the flattened under surface of the tail in life, and moreover contribute to produce the similar character which distinguishes its sides, the flattened upper surface being due to a like character in the upper aspect of the vertebræ and to the anterior and posterior dorsal processes. The lateral expansions appear as if they were convoluted, osseous laminæ, for they are marked by two, deep, longitudinal sulci on their outer aspect, over the most internal of which there is a thin projecting rim on its inner margin. This character is observable in the terminal chevron, but to a less extent than in those before it. I am not aware that similar bones occur in any of the other Soricida, but it is probable that they will be found in Nectogale.

The sternum consists of a presternal, four mesosternal pieces, the xiphisternum. equalling in length the last mesosternal segment and terminating in a rather long, lingulate cartilage. The presternum is laterally expanded, its rod-like extremity being prolonged on to the expansion as a well-marked median ridge.

There are seven sternal and seven nonsternal ribs, and their cartilages are all ossified. The cartilage of the first rib is expanded at its sternal end, and its outer surface is much concave.

The scapula is narrow, as in Pachyura, and the metacromion and acromion are well developed, as in shrews generally, but the former has a hook-like extremity towards the acromion. The clavicle is attached to the ends of the acromion without resting on it, and the latter is closely in contact with the outer side of the head of the humerus which has the same form as in Sorex, with a well-marked, supra-condyloid foramen. The carpus has a radiale, intermedium, ulnare, and pisiform, but no centrale, and the fourth and fifth carpels are confluent. The metacarpal bones are a little longer than the first phalanges, which are rather feeble, the manus being to the pes in the proportion of 54 to 87 . The ilium is narrow, and its anterior extremity diverges outwards and forwards, being concave on its external surface, with a slight upward process on its superior border. The thyroid foramen is very long from before backwards and moderately broad, its ischial and pubic borders being narrow and thin. The symphysis pubis is widely separate and divergent from below backwards. 
The tibia and fibula are united throughout one-half their extent. The head of the fibula arches forwards and outwards as a thin plate, and between it and the articular surface of the external condyle is a rather large, somewhat irregularly oval ossicle attached by its upper surface by a strong ligament, which is inserted into a rather deep pit on the outer side of the external condyle immediately above its articular surface. The groove or concavity on the front aspect of the lower end of the conjoint tibia and fibula, and which marks the line of union of the two bones at that part, is crossed from within, outwards and downwards, some little way above the ankle, by a strong process from the tibial section, and of such length that it almost touches the fibular side of the groove, to which it is connected by a strong ligament forming an arch which confines the deep tendons.

The metatarsus is considerably longer than the tarsus which is complete, but wants the tibial sesamoid of Talpa and Anurosorex, and the os tarsus is but little prolonged posteriorly. The digital phalanges, including the ungual, are but little longer than the metacarpus, and the ungual phalanges are well developed and much laterally compressed.

The curves of the bones of the lower leg are evidently specially adapted to the aquatic habits of the animal, and confer great strength on that member, combined with lightness. The tibia, and the fibula to a less extent, are curved outwards to the junction of the two bones, and from the latter point the united two are curved inwards, but associated with this curve is the gentle backward and forward curving of the lower leg generally.

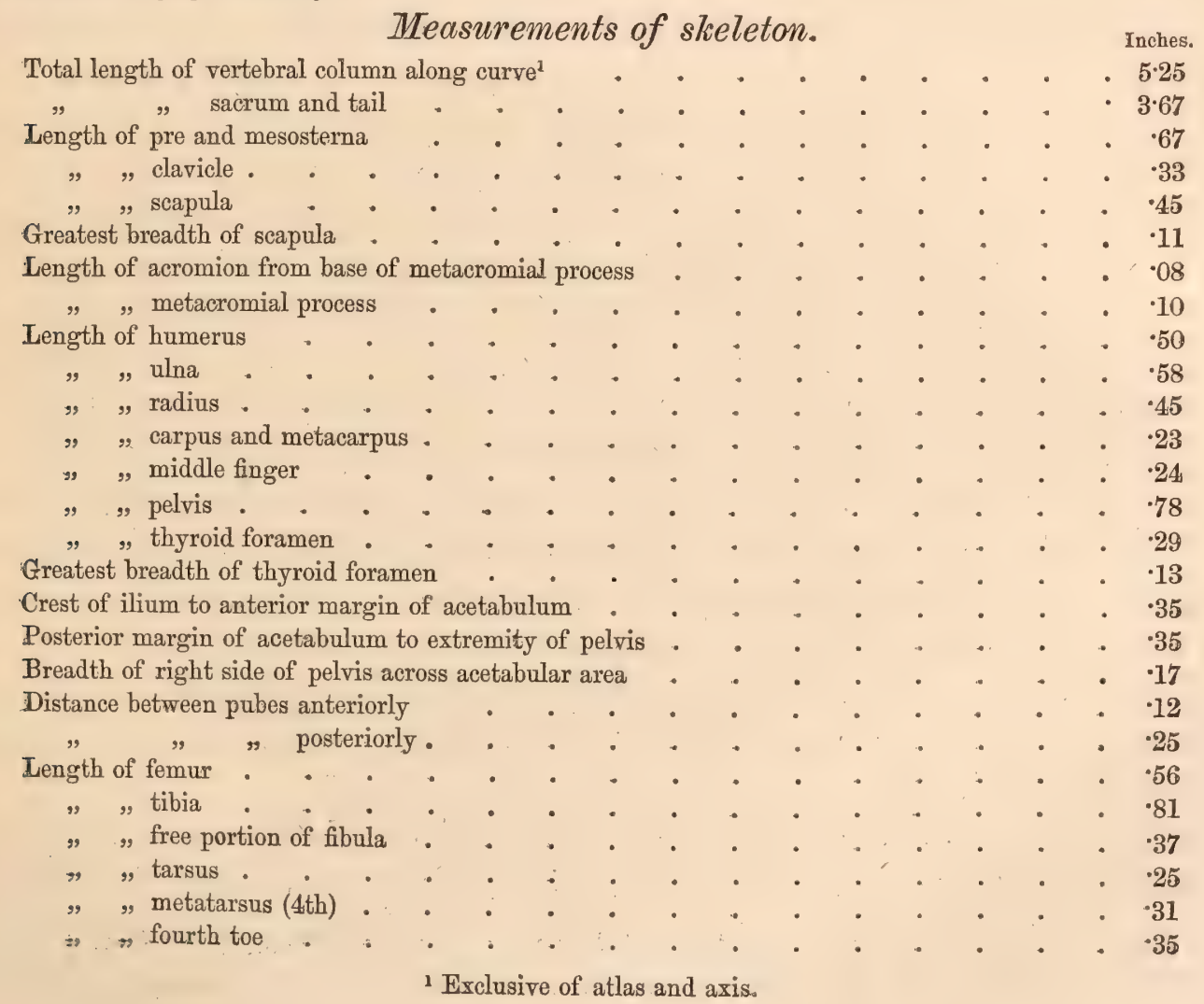


The stomach, when inflated, has its apex directed downwards, outwards, and forwards, and the greatest breadth is obliquely across the abdominal cavity from left to right, the apex of the cardiac portion lying close to the vertebral column, directed to the right side, with the pyloric extremity immediately below it ventrally and in the mesial line of the body. The greater curvature of the stomach is thus from behind forwards, which is also the course of the extremely short, lower curvature, which is only one-third the length of the backwardly projecting, upper margin of the cardiac portion. Viewed from the left side, the stomach is seen to be deeper than broad, and to be a truncated cone. Viewing the viscera from behind, the stomach, being inflated, is seen lying below the left kidney, and the latter is almost completely invested on its external half by the large spleen, the outer margin of which nearly describes half a circle. The transverse portion of the pancreas passes upwards to the pyloric angle, at which point a long lobule is prolonged along the greater curvature of the stomach, half-way between the pylorus and the apex. A long process follows the curve of the duodenum as far as to the apex of the right kidney; the pancreatic duct opens into the duodenum a short distance beyond the pylorus. The right kidney is at a higher level than the left, and there is a deep hepatic impressio-renalis. The supra-renal bodies are well developed, rather rounded, with one broad and one sharp border, with two flattened external surfaces. The total length of the intestine is about 11 inches, and it has considerable capacity and is of nearly equal width thronghout, without any cæcum. The heart is elongately pyramidal, and is only covered in its middle posteriorly by the left lobe of the lung. The middle lobe of the right lung is only applied to a small area of the right cardiac border, below the right auricle and to the right side of the latter structure in one-half of its extent, the remainder of the auricle having the upper lobe of the right lung on its external aspect. The heart is very large, the upper border of the right auricle being nearly, in a spirit specimen, on a level with the apex of the right lung, the cardiac apex being nearly on the same level with the inferior border of the left lung. The ventricular portion of the heart is half an inch long with a transverse breadth of three lines. The right is considerably larger than the left auricle. The right lung, as observed, consists of three well-marked, deeply-incised lobes, the uppermost lobe being the smallest and the lowest the largest. The left lung is unilobular. The azygos lung is large, more than equalling the right lobe of the right lung. It consists of three parts, an anterior, rounded lobule which bends round in front of the ascending cava, a posterior, curved lobule between the right and left lungs, and a left lobule between the heart and the left lung. The liver has the right and left lateral fissures deeply incised, but there is no cystic fissure, nor can I detect the presence of a gall bladder. The caudate and Spigelian lobes are well developed.

By its dentition, if the small process on the inside of the first upper incisors were left out of consideration, this aquatic shrew is a Crocidura, whilst if its systematic position were to be determined by its ciliated extremities and almost completely hidden ear, it would be a Crossopus, but the European water-shrew has 32 red. 
tipped teeth and a differently clad tail, so that it is impossible to regard them as generically identical. An examination of the skull proves that although by the number and white character of its teeth it is allied to Crocidura, it is nevertheless remarkably distinct from these non-aquatic shrews. The skull, like that of Crossopus and Soriculus, is light and not marked by the strong ridges which characterise the skull of Crocidura. The brain-case is relatively broader than in Crocidura, and, like the skulls of Crossopus and Soriculus, and especially Nectogale, has a much shorter temporal fossa than Crocidura. The occipital region, as in Crossopus, Soriculus, and Nectogale, is considerably uptilted, and the frontal region, as in the two first, is considerably depressed. The marked double condyle is a character in which it is resembled to a certain extent by Crocidura, in which, however, the separation of the condyle into two facets is carried to only a very limited extent, whereas in Soriculus and Anurosorex it is as strongly developed as in this watershrew, and it seems also that this remarkable modification is quite as well marked in Nectogale. The foramen ovale (?) occupies the same position in this shrew as in Soriculus. It is separated from Crossopus by the character of its teeth, which in their colour and number resemble those of Nectogale, except that the inner side of each of the first upper incisors is furnished with a talon. From Crossopus it is also separated by the peculiar character of its tail, which in Crossopus is almost mouselike, whilst in the shrew it is densely clad with flattened, coarse and rigid hairs. The ciliation of the feet also of this form approaches more to what occurs in Nectogale than in Crossopus. From Nectogale it is distinguished by the different arrangement of the hair on the tail and by its unwebbed hind feet and longer snout; and as it is thus impossible to classify this and the Japan water-shrew with any existing genus, I have created the genus Chimarrogale ${ }^{1}$ for their reception.

In its general form and structure it is more closely allied to Nectogale than to any other genus of Insectivora, and it thus appears to me that these two genera, Nectogale and Chimarrogale, are entitled to rank as a distinct sub-Family, Nectogaline.

In connection with these observations on the structure of this remarkable watershrew, I embrace the opportunity of here describing and figuring on the same plate with Chimarrogale, by way of comparison, an equally remarkable, but terrestrial, burrowing shrew exhibiting certain affinities, with Talpa, from the neighbouring region of Northern Assam, which has a fauna intimately allied to that of Yunnan, viz., Anurosorex assamensis, Andr.

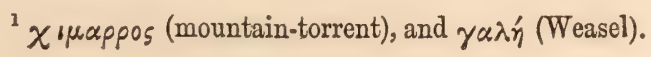


Genus Androsorex, ${ }^{1}$ A. M.-Edwards.

Anurosorex assamensis, Andr., Plate v, figs. 1-16.

Anurosorex assamensis, Andr. Ann. and Mag. Nat. Hist, 1875, vol. xvi. p. 282.

This remarkable modification of the ordinary type of Soricine structure was first made known by Adolphe M.-Edwards in his admirable Memoir on the Fauna of Tibet.

Before his description of the genus had reached Calcutta, Mr. S. E. Peal had obtained in Assam, between Seebsaugor and Jeypur, in about $27^{\circ}$ north latitude, a small shrew-like animal remarkable for the great size of its head, its nude, scaly extremities, and its extremely short, nude, scaly tail, which he forwarded to the Indian Museum, Calcutta. I recognised it as a new generic form ${ }^{2}$ allied by its dentition to Diplomesodon, Brandt.

The type of the genus, $A$. squamipes, A. M.-Edwards, is very abundant in the plains and mountains of Tibet and Sé-tchouan, but as the physical characters and climatological conditions of these two provinces of China are very different from those which distinguish Assam, it was to be expected if the same generic type occurred in Assam that it would present certain specific modifications on its more northern fellow - a conclusion which is fully borne out by a careful comparison of the two.

The structure of the ear, limbs, and tail has special reference to a burrowing habit of the animal, the ear being valvular, so that it may be effectually closed against the entrance of foreign substances, and the feet devoid of hair, but scaly, and the tail reduced to very small dimensions. The eye also is excessively small and buried deep in the dense silky fur. The hind feet, contrary to what is almost invariably the case in burrowing mammals, are larger than the fore feet.

The Assam form appears to be considerably smaller than the Tibetan species, and to differ from it in its proportionally greater head, slightly longer tail, and in the fore feet not exceeding the hind feet in breadth and strength : moreover it is distinguished by a differently coloured fur.

The semi-nude parts of the snout, the scaly limbs, and tail, are flesh-coloured. The claws are yellow. The fur is set nearly erect, is fine, dense, and silky. It is longest on the rump, where it projects backwards a considerable way over the tail, almost hiding it. Numerous strong hairs protrude beyond the general mass of the fur, and are brown with obscure pale tips. Whiskers well developed. Shorter hairs above and between the eyes. The general colour of the fur is dark slaty, faintly washed with brownish rusty on the long hairs of the rump.

Total length: snout to vent, 2.92 inches; fore foot, 50 ; hind foot, 75 ; tail, $\cdot 50$.

1 Anurosorex, A. M.-Edwards, Compt. Rend. 1870, 1xx. p. 341, et Rech. des Mammif. 1868,-74, p. 264.

2 Pygmura, Andr, Proc. Zool. Soc. Lond. 1873, p. 9. 
Skull.-The skull is not so elongated as in Pachyura, but it is more so than in Soriculus nigrescens, and it is remarkable in being nearly half as long as the vertebral column measured from the atlas to the end of the sacral vertebræ. The facial is relatively shorter to the cranial portion of the skull than in the former, and these two regions bear about the same proportion to each other as in the skull of the latter. The molar portions of the maxillæ have not the same lateral expansion that they have in Pachyura, and in this respect the skull is also affiliated to Soriculus. The greatest breadth of the cerebral portion, which is more arched than in Pachyura and Soriculus, is attained between the mastoid processes, which are well developed and project outwards and forwards in a marked degree. The frontal is fuller than in any shrew I have examined, and the occipital region is not directed so much forwards as in Pachyura and Soriculus. There is a rather strong sagittal ridge with a small foramen on each side of its anterior termination. The lambdoidal ridge is not very strongly developed. There is an obscure, but at the same time easily recognisable, process in the region corresponding to the post-orbital process. It is placed at the posterior termination of a short concavity in the outline of the orbito-temporal fossa, and defines a space corresponding to the capacity of the orbit.

When viewed in profile, the parietal region is seen to be arched more than in the generality of Soricine skulls, and that the anterior extremity of the sagittal ridge terminates in a depression over the inter-orbital, temporal contraction, from which point the facial portion is arched forwards in a more marked degree than in Pachyura or Crocidura, and, unlike these skulls, the nasals are not flattened above. In this view of the skull the occipital region is nearly vertical. The palate is not so long, deep, or broad as in Pachyura, and increases in width from before backwards, being prolonged behind the last molar and terminating in a sharp ridge with a minute, acute, external process. There is only one anterior palatine foramen, without any trace of a septum, and it is nearly as large as the infra-orbital foramen. The mesopterygoid fossa is shorter and broader than in Pachyura or Sorex, and is somewhat lyre-shaped, broader in front than behind. At the junction of the basioccipital and basi-sphenoid, there is a central ridge with a slight depression on either side of it, and it sends back a ridge to the external, anterior angle of the occipital condyles.

The post-glenoid process is closely adherent to the outside of the posterior extremity of the pterygoids which terminate in a hamular-like process, projecting outwards and backwards, and it is widely separated from the glenoid surface for the articulation of the upper section of the condyle. The post-glenoid process has the foramen ovale completely hidden on its inner side by the arch formed by its junction with the pterygoid, so that this foramen can only be seen in front. This process, owing to the greater depth of the skull, is also at a lower level than in other Indian shrews, its lower margin being on a level with the lower third of the front incisor, while in $P$. indica the lower margin of the process is on a higher level than the pasterior alveolar margin of the last molar but one. The anterior 
and articular aspect of the process is deeply concave and looks forwards and outwards, and is oval with a narrow upper end. A deep and wide concavity occurs immediately above it, on the same line with the mastoid process, but separated from the latter by a convexity. Above the concavity there is an outwardly projecting ridge (part of the ridge which arises from the upper border of the mastoid process), the under surface of which is covered with an elongated articular surface for the upper articular facet of the lower jaw.

The tympanic is more than a mere ring, as its internal margin is a thin plate arching outwards over one-third of the space defined by the ring itself. The imperfection of the cranial wall covered by the tympanic is more reduced in size than in most Soricine skulls. The occipital condyles are of moderate size, and look downwards, outwards, and backwards, and there is a well-marked precondylar foramen with the foramen lacerum posterius, anterior and external to it, and behind and external to this foramen an obscure, but, at the same time, distinct par-occipital ${ }^{1}$ process, anterior to which and separated by a rather deep fossa is a (carotid?) foramen. Immediately above this process, which is continuous with the lambdoidal ridge, and posterior to the latter, and above the level of the condylar surface, there is a well-marked foramen leading directly into the lateral sinus, at the junction of the supra-occipital and the petromastoid. Immediately external to the tympanic, there is a strong (mastoid?) process directed forwards and outwards formed by projections from the petro-mastoid and squamous. Above and external to this process there is a ridge running forwards along the side of the skull and terminating anteriorly in the facet for the articulation of the superior division of the condyle of the lower jaw. This ridge is immediately below the line of union of the squamous and parietal bones. Behind it, there is a small foramen leading directly into the lateral sinus. Posterior to the facet which looks outwards, forwards, and downwards, there is a shallow notch, immediately above which, on the parietal, are one or two venous foramina. Below the anterior extremity of the superior of the two facets for the mandible are two or three large foramina, placed one above the other, and a very minute foramen associated with them. The most superior of these foramina leading over the posterior, external angle of the cribriform plate passes through the ridge of the ali-sphenoid opening on its posterior margin, anterior to and slightly below the orifice of the small venous foramen above the posterior end of the superior, condylar facet. The second and middle foramen, when there are three, communicates directly with the cribriform plate of the ethmoid, and the third opens into the optic foramen internally. These two or three foramina are situated immediately behind the sphenoidal fissure, and between the superior extremity of the inferior, glenoid, articular surface and the anterior end of the facet above it. The sphenoidal fissure and foramen rotundum are represented both by a single opening which is also common to the optic nerve. There is a minute foramen in the centre of the interspace between the two optic foramina. The posterior palatine

\footnotetext{
1 In the skull of a Pachyura from Amoy, the paroccipital process is rather strongly developed.
} 
canal is situated above and external to the root of the last molar. The sphenopalatine foramen is large and placed in front of the foregoing canal, and in the posterior termination of the infra-orbital foramen. The latter, placed over the anterior margin of the first molar, opens into a long canal, relatively longer than in Erinaceus, and the lachrymal canal, instead of being situated as in that genus at the anterior margin of the orbit, is placed on the anterior border of the external long wall of the infra-orbital foramen, the canal being directed upwards, forwards and downwards.

The lower jaw is shorter than in the generality of known shrews, and the angular process is less strongly developed. The horizontal ramus is short and thick, hardly equalling the height of the ascending ramus. The condyle is divided into two, its lower half being placed on the inside of the ascending ramus, immediately above the angular process, and separated from its upper division by a wide notch, the general direction of the inferior articular surface being backwards, downwards, and inwards, and that of the superior half upwards and inwards. The excavation of the inner surface of the ascending ramus is smaller than in Pachyura, and the coronoid process is lower, being only a little elevated above the superior facet of the divided condyle.

Dentition.-Young, new-born individuals show the premaxillary suture between the first and second small lateral teeth, so that the dental formula is $\frac{2+2}{2}+\frac{2}{2}+\frac{8}{2+6}=26$.

The teeth are white. The first incisor of the upper jaw is curved downwards and forwards, and the process at the posterior aspect of its base is laterally compressed and longitudinally grooved, almost dividing it into two, the inner division being the smaller, the groove being continued on to the posterior aspect of the long crown of the tooth. The crown of the second incisor is laterally compressed and triangular, with its point directed backwards. The inner aspect of the crown is little prolonged beyond the neck of the tooth, and is more or less flattened, with a small tubercle about the middle of its internal margin. The canine has much the form of the foregoing tooth, but is smaller, and the inner surface also shows a trace of a tubercle as in the former. The first molar has the greatest vertical extension of the permanent teeth. It has two external cusps, the anterior very small, the other deep and cutting, with its point directed slightly backwards, and a long prominent ridge continued outwards and posteriorly from its hinder margin, also two, short, sharply conical internal cusps, a short low ridge passing forwards and outwards from the posterior of the two. The second molar has one external cusp on its anterior outer angle: a short ridge passing internally connects it with the first of the median line of cusps which form a triapical, zigzag ridge, the last cusp marking the posterior external angle of the tooth. There are two internal and much shorter cusps of which the anterior is twice as large as the posterior: the former gives off a short low ridge that ends on the inner side of the centre cusp of the middle triapical ridge. The third molar is only half the size of 
the second, and differs from it in having only two apices to the middle ridge, and only one internal cusp. The fourth molar is extremely minute, and presents only two obscure cusps, one anterior and the other posterior.

The first incisors of the lower jaw project forwards and upwards, the terminal fourth of their crowns being directed nearly upwards, and their tips are slightly divergent, and their posterior surfaces more or less concave, but quite smooth. The crown of the second incisor is the lowest of all the mandibular teeth, and is elongately oblong when viewed externally, and is laterally compressed. The canine is a little longer and more pyramidal, the crown being surmounted by a conical point. The first molar has three external cusps, the first and last being nearly on the same level, and the central being pyramidal and directed backwards. The latter by its inner margin is connected by a short ridge to the anterior inner cusp, which is immediately internal to it, rather sharply pointed, and nearly as high as itself. The posterior internal cusp is opposite the last external cusp, but has on its outer margin another short cusp between itself and that cusp, so that this tooth has six cusps in all. The second molar is formed exactly like the first, but is much smaller. The third molar is about one-third the size of the second, and the cingulum is well marked along its outer side. It developes two cusps, one small, anterior, and one large, posterior and conical, and connected to the former by a short ridge more internal than external to it.

Measurements of the skull.

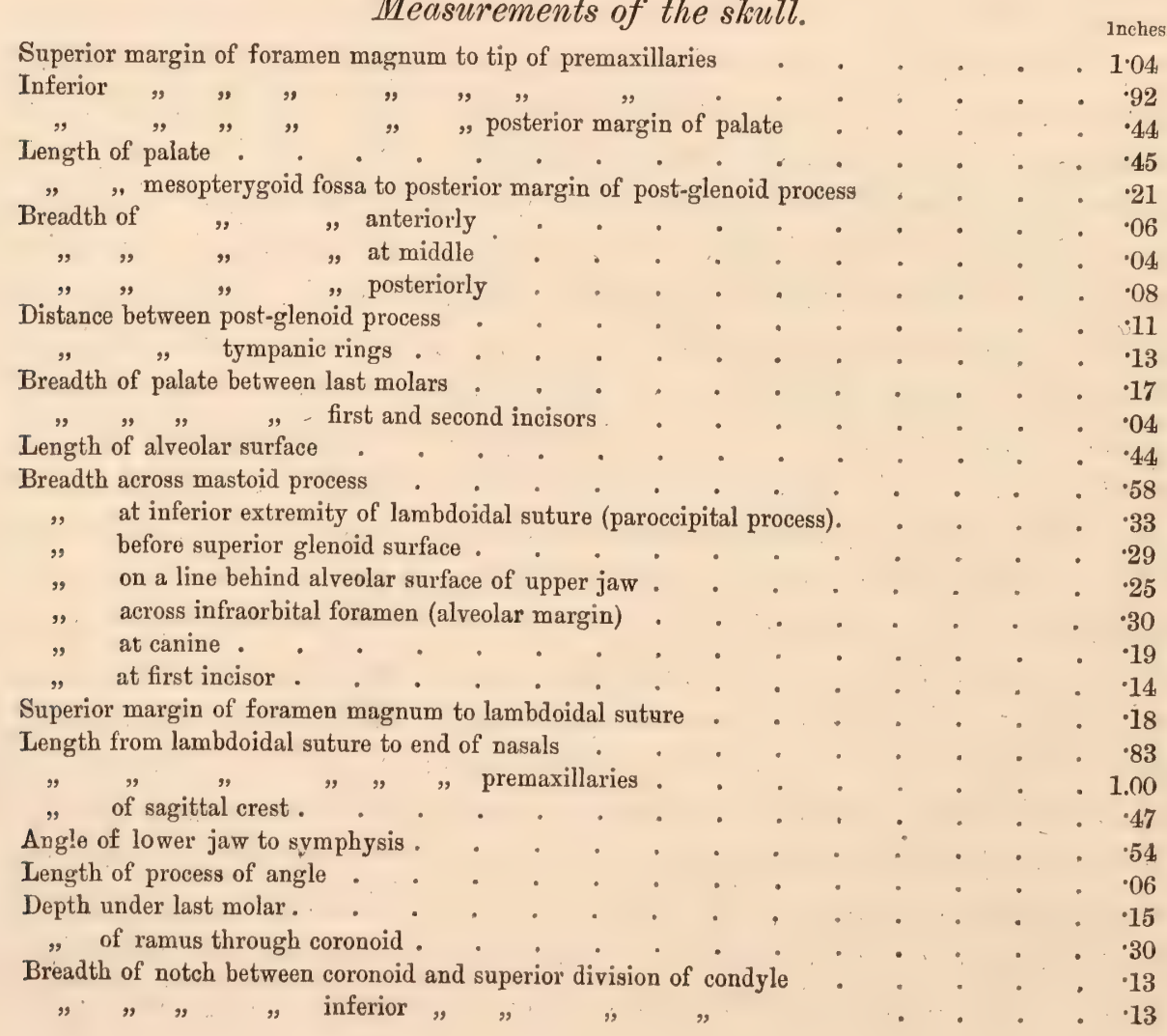


Vertebral column.-There are 15 dorsal, 6 lumbar, 5 sacral, and 9 caudal vertebræ. The spinous process of the axis has considerable antero-posterior extension, is posteriorly falcate, and overreaches the very small spinous process of the third cervical vertebra. The remaining cervical and dorsal vertebræ may be said to have no spinous processes, the indications of their existence are so feebly developed. Traces of them, however, can be observed in the sixth and seventh cervical and on the first to the fifth dorsal, the neural arches of which are quite as narrow rods as those of the former vertebræ, in which they appear as minute processes in the middle of the hinder margin of the arch. In the seventh to the ninth dorsal, the neural arches of which have much more antero-posterior expansion than those preceding them, the obscure representatives of the spinous processes are not more developed, but there is a faint ridge marking the line of union of the laminæ. In the tenth to the fifteenth vertebræ, inclusive, there is a rather broad and slightly raised, but flat, roughened surface corresponding to the spinous process on the dorsum of the laminæ, broadest in front and rather narrower behind. It becomes most markedly developed in the fifteenth, in which it is narrower than in the preceding, and in the first lumbar it is still more laterally compressed, and in the remaining lumbar vertebræ the spinous process is a thin, low ridge, high in front, but shelving away posteriorly. In the fourteenth dorsal vertebra is the first trace of a process that becomes strongly developed in the lumbar region. It occurs on the dorsum of the posterior zygapophysis, and, on the lumbar vertebræ, becomes a marked process connected by a ridge to the side of the spinous process, and would therefore seem to be the equivalent of a hyperapophysis.

The transverse process of the atlas is a small thin plate only, slightly projecting beyond the outer margin of the condylar facet. In the axis, it is a small, backwardly projecting process, perforated at its base by the vertebrarterial canal. The transverse processes increase in length to the fifth vertebra, but in the sixth and seventh they are shorter. To the fifth vertebra the process is directed backwards, but in the sixth it is placed outwards, bringing its extremity in close contact with the process before it, and in the seventh it is outwards and slightly backwards. The pleurapophysial processes of the fourth and fifth cervicals are longest in the former and shortest in the latter, and are directed very much forwards, but slightly downwards. The same process of the sixth vertebra has great antero-posterior extension, being as long as the combined centra of the sixth and seventh cervical and first dorsal vertebræ. Its posterior half arches below the seventh cervical and the head of the first rib. The transverse processes of the thoracic vertebræ only merit the term of process in the first and second, as in the remaining vertebræ, the rib is applied directly over the point of union of the pedicle and lamina, without any apparent intervening projection. The outer end of the laminæ of the fourth dorsal vertebra above the anterior zygapophyses is capped by a small upwardly and anteriorly projecting process (metapophysis) which attains its greatest development about the seventh or eighth, beyond which it becomes rapidly smaller. The lumbar, transverse processes are mere rudiments and are slightly backwardly projected, without any trace 
of metapophyses. The zygapophyses are well developed. The hypapophysis of the atlas is more or less bifurcate and well developed, but in the axis this process is very small. In the third cervical it is large and triangular, and nearly twice as great as in the succeeding vertebræ, beyond which it rapidly decreases, but can be traced as far backwards as the second dorsal, where it is resolved into two rudimentary eminences on the posterior margin of the centrum. Hypapophysial ossicles occur between the twelfth and thirteenth dorsal and succeeding vertebræ, as far as the last dorsal and first lumbar vertebræ. A strong hypapophysial ridge is developed on the second and third sacral vertebræ, dividing the very much contracted pelvic orifice into two. The caudal vertebræ, nine in number, are very simple, being rather long, cylindrical ossicles, with rudiments of metapophyses. There are well developed hæmapophyses between the first and second and the other caudal vertebræ. Without separating the much contracted pelvis which is so compressed on the sacral vertebræ that they cannot be observed with precision, there appear to be four of these vertebral elements united together with one vertebra anterior to them free, but applied by very short transverse processes to the side of the ilium. The spinous processes of the sacral vertebra form a low compressed ridge which is posteriorly firmly soldered to the ischia, but anterior to this attachment and internal to the acetabulæ there is a very narrow, elongated, sacro-sciatic foramen. The united spinous ridge bears two tubercular processes on its side, in a position corresponding to the line of union of the vertebræ, and they appear to be homologous with the hyperapophyses of the lumbar vertebræ.

The ribs are fifteen in number. The first rib is short and thick, and a small epiphysial ossicle occurs between it and its rather compactly ossified, sternal portion, which rapidly dilates to be attached to the whole of the side of the expanded portion of the presternum, and is deeply concave on its external surface. Eight ribs are attached to the sternum, the sternal portion of the seventh being directly applied to the side of the last third of the terminal mesosternal segment, while the broad sternal end of the eighth is also applied to it and to the anterior extremity of the xiphisternum. All the sternal ribs are ossified, and the lower halves of those that do not directly join the sternum overlap each other to a remarkable degree, that of the ninth overlying the middle of the sternal half of the eighth, that of the tenth over the same section of the ninth, while in the four succeeding ribs the sternal halves of their ossified cartilages cross over the corresponding halves of two ribs in front of them, so that the distal third of a cartilage lies along the upper margin of the cartilage of the rib in front of it, not below it. This arrangement must confer great respiratory power on the animal. The cartilage of the fifteenth rib only is unossified. The thoracic cavity is pyramidal, narrow above and much expanded below, a circumstance which would also confer great respiratory power.

The presternum is somewhat $\mathbf{T}$-shaped with an obscure trace of a ridge which is the continuation of its much compressed stalk, which has in fact the appearance of a narrow rod, but when viewed sideways has considerable antero-posterior extension. There is a slight concavity on either side of the ridge. The first mesosternal 
segment resembles the stalk of the presternum, but the other four presternal segments increase in breadth as they are traced backwards. The first three show traces of a keel. The xiphisternum is a short cylinder, capped with cartilage.

The scapula is very narrow, almost rod-like; the post-scapula being reduced to a very narrow fossa, and the prescapula to an extremely narrow, slightly externally reverted ridge. The spine is deep and strong, and marked at its middle by a feebly tuberous eminence from which the spine shelves off above to the thick and rounded, but very narrow, supra-scapular border. The acromion and metacromial processes resemble Crocidura. The former is applied to the outer side of the head of the humerus immediately below the anterior surface, to which it is attached by ligament, and forms with the thin supra-glenoid rod of the scapula a complete and rather high arch, the external end of the clavicle being placed over it. The coracoid is represented by the anterior projection of the glenoid surface of the scapula. The external half of the clavicle has a slightly downward curve. Its outer end is curved backwards to be applied to the upper surface of the acromion, and it terminates in a small meso-scapular ossicle, its inner end having the rudiment of a precoracoid. The humerus is about one-fifth shorter than the ulna, and it has the form of the humerus of Crocidura. The antero-posterior, flattened and laterally extended upper half of the bone is curved backwards, and the deltoid ridge is very prominent and begins at the middle of the anterior margin of the articular surface of the head, half-way between each tuberosity. The supracondyloid foramen is well developed, but there is no supra-trochlear foramen, but the anconeal fossa is deep, and both condyles are prominent. The olecranon is well developed and rather flattened on its outer surface. The radius and ulna are distinct.

The carpus has a radiale, intermedium, ulnare, and pisiform, a united fourth and fifth carpale, but no centrale, as in Crocidura.

The pelvis is very narrow and is considerably curved backwards, downwards, and forwards, and is much contracted, the symphysis being separated from the sacrum by so restricted an interspace, and being so filled up by the sacral hypapophyses, as in Talpa, that there is no room for the pelvic viscera to pass internally, so that they are continued out below the pelvic symphysis as in that genus. The ilium is rod-like and parallel to the vertebral column, its anterior, half being only slightly divergent. The acetabulum, placed about the middle of the pelvis, is immediately opposite and close to the pelvic symphysis, which is very short, but the bones are closely in contact with each other. Behind the symphysis, the pubes and ischia are externally divergent, but less so than in Talpa, and they enclose a long, rather narrow, thyroid foramen, the lower or pelvic wall of which is rod-like, the upper or ischial wall being prolonged downwards and forwards, the pubes forming a well marked, flattened spine which projects in that direction, the tuberosity of the ischium being rounded off and scarcely determinable. The bodies of the sacral vertebræ almost fill up the space that intervenes between the thyroid foramina. The dorsal surface of the ischium of either side is amalgamated with 
the termination of the long sacro-spinal ridge, and in so close apposition that the two bones appear to meet and form an arch over the commencement of the caudal vertebræ, in this respect differing remarkably from Talpa and Crocidura.

The femur is short and cylindrical, as in Talpa and Crocidura, flattened behind between the two trochanters with the rudiment of a third trochanter. The tibia and fibula are anchylosed throughout more than their lower halves. The former is shaped as in Crocidura, but the lower anterior extremity of the amalgamated bones is rather deeply concave below, and from the tibial side of the concavity a well marked process projects downwards and outwards across the concavity to the fibular side, in which there is a marked anterior process, and these two are connected by a ligament, so that the underlying tendons are securely held in position. The metatarsus is slightly shorter than the tarsus. The latter is normal, but it has a well developed, falciform sesamoid on the tibial side, as in Talpa.

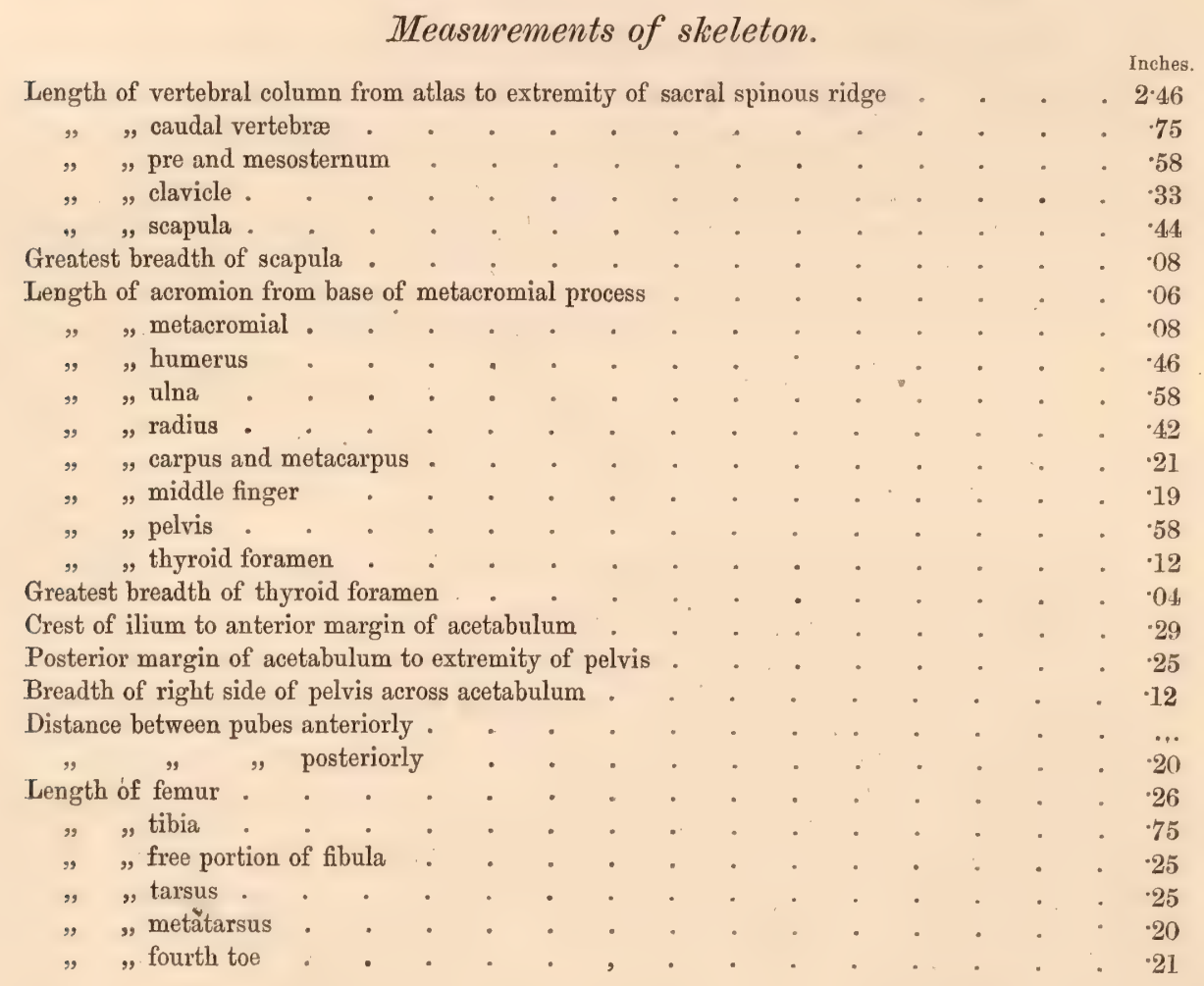

There is no cæcum, and the intestine is $12 \cdot 75^{\prime \prime}$ in length. The stomach when inflated has a greater transverse than longitudinal capacity, and the oesophageal and pyloric extremities approach close to each other and are nearly on the same level, the former being almost in the middle line of the viscus. The cardiac half projects considerably to the left, and there is a much narrower projection to the right of the pylorus.

The sub-maxillary glands are very large, $0^{\prime \prime} \cdot 36$ long by $0^{\prime \prime} \cdot 18$ in breadth, and they reach as far back as on a line with the anterior margin of the axilla. 
Conclusion.-The skull and dentition of this remarkable animal are essentially Soricine, and by its dentition it is allied to Diplomesodon; it is, however, so anomalous in its form and in the rudimentary character of its tail and in the great size of its head, and so Talpine in the structure of its pelvis, that it merits being placed apart from all other genera of shrews, whether terrestrial or aquatic, in a subfamily, Anurosoricince. 


\section{CARNIVORA. \\ FELID E}

Genus FELIS, Linn.

* Felis tigris, Linn.

Felis tigris, Linn., Syst. Nat. Halae, 10 ed. 1760, p. 41.

Tigris regalis, Gray, Proc. Zool. Soc. Lond. 1867, p. 623, et Cat. Carniv. etc., Brit. Mus. 1869, p. 10.

The tiger is very prevalent in the neighbourhood of Bhamô on both banks of the Irawady and of its affluent, the Tapeng; it is of less frequent occurrence in the Kakhyen hills, but it ascends there to an elevation of 4,000 feet, and is far from uncommon on the hills and in the valleys to the east wherever it can find sufficient cover. Bhamô is enclosed by a stockade about 9 feet high, but this is no protection against the inroads of tigers, which not unfrequently enter the town at night after the gates have been closed at sundown. One tigress, the townspeople asserted, was seen to clear the stockade with a man in her mouth. During my short stay in the town I was present at the hunt after a tigress with her cub which had entered the town and carried off an old woman while sitting making thatch in the verandah of her hut, which was closely surrounded by other dwellings. They are especially numerous about Tsitkaw, where the long jungle grass of the level plain affords them ample cover, and out of two closely adjoining villages six people had been killed by tigers in as many months. But notwithstanding the prevalence of this animal, and although it was my habit to spend the greater part of the day in the jungle outside Bhamô and Tsitkaw, I never yet came across a tiger, but saw frequent evidences of their presence in their footprints.

The skins of newly killed animals were frequently brought to me for sale in the Sanda valley, also skulls and the bones of the legs, and these materials enabled me to determine that the tigers of these elevated districts of Western Yunnan differ in no perceptible way from the tiger of India.

The tiger found in the northern portions of China, as pointed out by Swinhoe, ${ }^{1}$ is a pale race with few stripes and distinguished by the long character of its fur, which is also more pliable and softer than that of the southern race which, he says, resembles the Bengal tiger, and which is found as far north as Shanghai, and 
has also been obtained at Amoy, Canton, ${ }^{1}$ and Ningpo. ${ }^{2}$ The long-haired race with the stripes fully marked is found in Manchuria, where, A. M.-Edwards ${ }^{3}$ states, it is subject to considerable variation, as L'Abbé David had observed nearly brownish black and nearly perfectly white individuals. Swinhoe ${ }^{4}$ is not convinced of the specific identity of these northern and southern types of the Chinese tiger, but A. M.-Edwards ${ }^{5}$ states that the differences that exist between them are too slight to permit of their identity being doubted. He has compared a cast of the skull of the north China race with a skull from Siam, and has only been able to detect a few insignificant variations. The wide distribution of the species has been indicated by Blyth ${ }^{6}$ and Swinhoe.

In the Kakhyen hills, as in Assam, the tiger is killed with bamboo arrows poisoned by the juice of a species of Aconite which is widely distributed over the eastern Himalaya, Assam, and the Kakhyen hills, and which is well known to the different hill tribes of these countries.

\section{* Felis pardus, Linn.}

Felis pardus, Linn. Syst. Nat. 12th ed. 1766, vol. i. p. 61, et itid. 13th ed. Gmelin, vol. i. 1788, p. 77 ; Erxleben, Syst. Reg. Ann. 1777, p. 505; Schreber, Säugeth. vol. iii. 1778, p. 384, pl. xcix. ; Zimmermann, Geograph. Gesch. 1780, vol. ii. p. 261 ; Fischer, Syn. Mamm. 1829, p. 200 ; Temminck, Monogr. Mamm. vol. i. p. 99.

Felis leopardus, Linn. Syst. Nat. Gmelin, 13th ed. 1788, vol. i. p. 77 ; Erxleben, Syst. Reg. Ann. 1777, p. 509; Schreber, Säugeth. vol. iii. 1778, p. 387, pl. ci.; Zimmermann, Geograph. Gesch. vol. ii. 1780, p. 263 ; Fischer, Syn. Mamm. 1829, p. 199 ; Temminck, Monogr. Mamm. 1827, vol. i. p. 92.

Felis panthera, Erxleben, Syst. Reg. Ann. 1777, p. 508; Pallas, Geograph. Rosso-Asia, vol. i. 1831, p. 18.

Leopardus pardus, Gray, Proc. Zool. Soc. 1867, p. 263; Cat. Carniv. \&c. Brit. Mus. 1869, p. 10.

Felis melas (Péron), Desmarest. Nouv. Dict. d’ Hist. Nat. vol. vi. 1816, p. 104; Mamm. 1820, p. 223.

The leopard is not uncommon on the hills along the Sanda valley, whence I obtained a young specimen in the flesh and many skins. I also observed it in the neighbourhood of old water-courses behind Tamelone on the Tapeng river in Upper Burma.

Swinhoe distinguishes two races of leopard in China; the southern form, by its shorter hair and more regular markings, conforming to the Indian leopards; and the northern, by its long shaggy hair and the greater amount of white about it, by the confused massing together of the black spots and circles on its body and tail, and by a paler colour, differing considerably from the former. He is inclined to regard them as distinct species, and the latter, which is found in the neighbourhood of Pekin and in the north of China generally, and Manchuria, he considers to be identical with the Felis japanensis, Gray, ${ }^{7}$ which species was

${ }^{1}$ Proc. Zool. Soc. 1870, pp. 3 and 4.

\& Ibid. 1872, p. 817.

${ }^{4}$ Proc. Zool. Soc. 1870, p. 3.

5 L.c.

3 Rech. Mamm. p. 207.

6 Proc. Zool. Soc. 1863, p. 182.

7 Proc. Zool. Soc. Lond. 1867, p. 264, et Cat. Carniv. etc. B. M. 1869, p. 11, et A. M.-Edwards, Rech. Mammif. 1868-74, p. 211. 
founded on a tanned skin, and from the circumstance that it had the stamp of a Japanese trader, it was considered by Dr. Gray to be an inhabitant of that island, but Swinhoe strongly suspects that it was procured by the Japanese from one of the trading stations in China. It is impossible to say whether this species is identical with the Felis fontanieri, A. M.-Edwards, which is founded on specimens obtained by M. Fontanier, who was resident in or near Pekin, but judging by Gray's description, it would appear to be so closely affined to it that I hesitate to pronounce them distinct, having reference only to the character of the fur. Felis fontanieri is characterised by the confluence of the black spots which form rather large, complete rings in the adult, as in the Jaguar, but without a central black spot. The fur is also long, soft, and dense. This latter character is also assigned by Swinhoe to the northern race of Chinese leopards, the fur of which, he states, is confusedly spotted and marked with black rings. Gray also states that the coat of his F. japanensis is distinguished by its roundish and unequal-sized spots and by black rings with no central black spot, and which are distributed over the shoulders, back, and sides, while A. M.-Edwards describes these rings as very distinct on the scapular region and on the upper parts of the sides and on the back. It does not appear to me that there is any character yielded by these descriptions that would enable us to separate the so-called F. japanensis, Gray, from F. fontanieri, A. M.-Edwards, but as the materials for the identification of Gray's species are insufficient, being only a tanned skin, it would be as well not to burden zoological literature with the term $F$. japanensis. There can be no doubt, however, that $F$. fontanieri is at least a wellmarked race if not a distinct species. I have had the opportunity to examine the type of this beautiful leopard.

A. M.-Edwards has pointed out certain characters by which he considers $F$. fontanieri to be distinguished from the leopards of India and Africa, and from the skull figured by Gray as Leopardus chinensis. He attaches great importance to the short muzzle of the northern leopard, and states that the distance between the anterior border of the alveolus of the canine and the summit of the frontonasal process of the superior maxilla equals the breadth between the external borders of the infra-orbital foramina, while in Felis pardus the former measurement considerably exceeds the latter, and he records that the relative proportion between these parts is equally observable in the young as in the adults of $F$. fontanieri. I have examined a series of five skulls of $F$. pardus from India, all with reliable histories and of different ages, but without any record of their sex; and although they support the generalisation of the accomplished French naturalist regarding the greater length of the first interval as compared with the second in Felis pardus, the tabulated measurements which I here give suggest that considerable changes take place with advancing age in the proportions between these two areas of the face in $F$. pardus, because in the youngest example they are nearly equal, as in $F$. fontanieri, so that these measurements are not very reliable guides to separate the species in youth. At the same time, there can be no doubt that in the adult Felis pardus of India, the muzzle is not so deep, but is more elongated than in 
F. fontanieri, in which the frontals are more arched with the nasals in the same curve. In Leopardus chinensis, Gray, a fully adult animal, there is the same short muzzle as in $F$. fontanieri, and the foregoing two facial measurements are for practical purposes equal.

Table of measurements.

\begin{tabular}{|c|c|c|c|c|c|c|c|c|c|c|c|c|c|c|}
\hline & & & & & & & & & & & & & First. & Second. \\
\hline 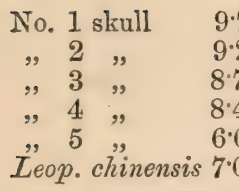 & $\begin{array}{l}75 \text { in } \\
25 \\
75 \\
42 \\
00 \\
00\end{array}$ & $\begin{array}{l}\text { s in } \\
\text { " } \\
" \\
"\end{array}$ & $\begin{array}{l}\text { eme length } \\
\text { " } \\
" \\
" \\
"\end{array}$ & : & $\begin{array}{l}\dot{:} \\
\dot{5} \\
\dot{\cdot}\end{array}$ & $\begin{array}{l}\dot{:} \\
\dot{:} \\
\dot{0}\end{array}$ & $\dot{:}$ & $\begin{array}{l}\dot{ } \\
\dot{.} \\
\dot{.}\end{array}$ & $\begin{array}{l}\dot{:} \\
\dot{:} \\
\dot{5}\end{array}$ & $:$ & $:$ & \begin{tabular}{ll|}
$:$ & $:$ \\
$\vdots$ & $:$ \\
$\vdots$ & $:$
\end{tabular} & $\begin{array}{l}3 \cdot 61 \\
3 \cdot 69 \\
3 \cdot 07 \\
2 \cdot 90 \\
2 \cdot 38 \\
2 \cdot 50\end{array}$ & $\begin{array}{l}3 \cdot 17 \\
3 \cdot 11 \\
2 \cdot 88 \\
2 \cdot 78 \\
2 \cdot 37 \\
2 \cdot 47\end{array}$ \\
\hline
\end{tabular}

This table also shows that the character is a variable one, at least in the leopards of India, as is further found by A. M.-Edwards' observations on the skulls in the Paris Museum.

The other character by which the skull of Felis fontanieri is said to be distinguished from $F$. pardus is the different proportions in which the length from the posterior border of the occipital condyles to the orbito-sphenoid foramina stands to the total length of the alveolar border of the superior maxillary, the former measurement in Felis fontanieri equalling the latter, while in the $F$. pardus the superior, alveolar, maxillary length is notably longer. But in this detail, the skull of Leopardus chinensis conforms to the Indian type, in which, however, these proportions seem to change with age and to be otherwise variable. In the abovementioned leopard skulls these measurements stand to each other in the following proportions :-

No. $1,3 \cdot 10$ to 3.25 ; No. $2,2.90$ to $2 \cdot 96$; No. $3,2 \cdot 80$ to $2 \cdot 83$; No. $4,2 \cdot 76$ to $2 \cdot 83$; and in Leopardus chinensis, $2 \cdot 35$ to $2 \cdot 55$.

The Yunnan skull is young, measuring only 5.75 inches in extreme length. The facial portion is more downwardly arched than in the skull of $F$. fontanieri figured by A. M.-Edwards, or in Leopardus chinensis, Gray, but the distance, as already stated, between the anterior border of the canine alveolus to the tip of the fronto-nasal process of the superior maxilla is less than the space comprised between the external margins of the infra-orbital foramina, falling in the centre of these openings. In this respect, the skull more closely resembles $F$. fontanieri than $F$. pardus. On the other hand, the frontal region is broad, the breadth between the external orbital angles much exceeding the distance from the summit of the median suture of the nose to the lower border of the infra-orbital foramen, and in this respect it agrees with skulls of Indian leopards. Turning to the basal portion, the interval between the posterior border of the occipital condyles and the spheno-orbital foramina is more than the length of the alveolar border of the superior maxilla, but these proportions would probably alter with the growth of the skull. I am also inclined to think that the 
foregoing facial proportions are in all likelihood the subject of considerable changes as the bones expand and elongate with advancing dentition. The auditory bullæ are large, as in F. pardus, while in F. chinensis they are not so inflated.

The black leopard is also found in the Kakhyen hills and in the valleys to the eastward, and I obtained two skins at Momien or Teng-yue-chow.

\section{* Felis bengalensis, Desmarest.}

Felis bengalensis, Desmarest, Mamm. Suppl. 1820, p. 541 ; Fischer, Syn. Mamm. 1829, p. 205 (in part) ; Blyth, Proc. Zool. Soc. 1863, p. 184 (in part) ; Cat. Mamm. As. Soc. Mus. Beng. 1863, p. 60 ; Jerdon, Mamm. Ind. 1867, p. 105 (in part).

Felis sumatrana, Horsfd., Zool. Resch. Java, 1824, (plate); Cat. Mamm. E. Ind. Co. Mus. 1851, p. 48; Gray, Cat. Mamm. B. M. 1843, p. 4.3.

Felis minuta, Temminck, Monogr. Mamm. vol. i. 1827, p. 230; Wagner, Schreber, Säugeth. Suppl. vol. ii. 1841, p. 509 ; Gray, Cat. Carniv. \&c. Brit. Mus. 1869, p. 26.

Felis nipalensis, Horsfd. and Vigors, Zool. Journ. vol. iv. 1829, p. 282; Hodgson, Journ. As. Soc. vol. i. 1832, p. 342 ; Wagner, Schreber, Säugeth. Suppl. vol. ii. 1841, p. 511 ; Schinz, Syn. Mamm. vol. i. 1844, p. 449; Gray, Proc. Zool. Soc. 1867, p. 272 ; Cat. Carniv. etc. B. M. 1869, p. 27.

Felis — ? Elliot, Madras Journ. Lit. and Sc. July 1839, p. 108.

Felis horsfieldii, Gray, Ann. and Mag. Nat. Hist. vol. x. 1842, p. 260 ; Horsfd. Cat. Mamm. E. Ind. Co. Mus. 1851, p. 47.

Felis pardichroa, Hodgson, Cal. Journ. Nat. Hist. vol. iv. 1844; p. 286; Horsfd. Proc. Zool. Soc. 1856, p. 396 ; Gray, Proc. Zool. Soc. 1867, p. 273, fig. 7 ; Cat. Carniv. etc. B. M. 1869, p. 28.

? Felis undata, Desmarest, Nouv. Dict. d'Hist. Nat. vol. vi. 1816, p, 115; Mamm. 1820, p. 230 (nec Chat Sauvage des Indes, Vosmaer); Fischer, var. Sumatrana, Syn. Mamm. 1829, p. 205.

This species is not uncommon in the Kakhyen hills and also at Momien, but specimens from the latter locality have longer fur, probably due to the colder region which they inhabit. The animals, however, from both areas agree with the type of F. pardichroa, Hodgson.

It is essentially arboreal in its habits, and its prey, the natives assert, consists chiefly of birds and small mammals, such as squirrels and Tupaice.

It is a variable species, and even although some of Hodgson's type specimens appear at first sight remarkably distinct, still with a large series under examination, strongly marked varieties will be seen to be linked together by intermediate forms. In the India Museum, London, one of Hodgson's types is a rich yellow, rather densely spotted cat, the spots tending to form rosettes, the small black spots being clustered round yellowish-brown areas which are darker than the pale yellow ground colour which surrounds these rosettes. Of the four black bands on the head, the two outer bands expand on the shoulder and then divide into two, enclosing a brown area like the rosettes, and then pass more or less round the neck. This specimen is from Nepal, and the body measures 19.50 inches in length and the tail 10.75 inches. Another and more typical specimen also from Nepal is distinguished by the less profuse spotting of the trunk and in the spots being large and black and not tending 
to form rosettes. The dorsal spots do not unite in lines, but they have a linear arrangement. Major-General Strachey obtained in Kumaon a cat of this species which has even larger spots than this second Nepal specimen, from which it differs in the paler tint of the ground colour. In its large spots it closely resembles the so-called Wagati of Southern India, and some of the Yunnan skins belong to this and to the previous form. The F. horsfieldii, Gray, is another cat resembling the Kumaon specimen, as is also the Felis sumatrana, Horsfd., which is, however, immature.

The Javan cat first indicated by. George Cuvier ${ }^{1}$ appears to be more nearly allied to this species than to $F$. viverrina, Bennett, with which the $F$. bengalensis, Horsfield, ${ }^{2}$ is identical.

\section{* Felis domesticus, Auct.}

The domestic eat of Western Yunnan is not at all prevalent, and those I observed were small and of a uniform grey colour, dark-spotted, and with the cheeks obscurely lineated. They resemble the form described by Dr. Gray as Felis chinensis.

\footnotetext{
${ }^{1}$ Ann du Mus. vol. xiv. 1809, p. 159; Desmarest, Nouv. Dict. d'Hist. Nat. vol. vi. 1816, p. 115.
${ }^{2}$ l. c., p. 49.
} 


\section{VIVERRID $\pi$.}

\section{Genus Viverricula, Hodgson. \\ * Viverricula mataccensis, Gmelin.}

Civette de Malacca, Sonnerat, Voy. Ind. Orient. 1782, vol. ii. p. 144, pl. 'xci.

Viverra malaccensis, Gmelin, Linn. Syst. Nat. vol. i. 1788, p. 92 ; Gray, Cat. Mamm. B. M. 1843, p. 48 ; Jerdon, Mamm. Ind. 1867, p. 122.

Viverra indica, Geoffr. Collect. du.Mus.; Desmarest, Nouv. Dict. d'Hist. Nat. vol. vii. p. 170 ; Mammal. 1820, p. 210 ; F. Cuv. Dict. des Sc. Nat. vol. xviii. p. 322;. Desmoulins, Dict. Class d'Hist. Nat. vol. iv. p. 176 ; Fischer, Syn. Mamm. 1829, p. 171 ; Sykes, Proc. Zool. Soc. 1831, p. 101 ; Elliot, Madr. Journ. Lit. and Sc. vol. x. 1839, p. 102.

Genetta indica, Lesson, Man. de Mamm. 1827, p. 174.

Viverra bengalensis, Gray and Hardwicke, Ill. Ind. Zool. vol. i. 1832, pl.iv.

Viverra rasse, Horsfield, Resch. Zool. Java (plate); Proc. Zool. Soc. 1832, p. 23; E. Ind. Co. Mus. 1851, p. 59 , Wagner, Schreber, Säugeth. Suppl. vol. ii. 1841, p. 284, plate cxiiiA; Gray, Cat. Mamm. B. M. 1843, p. 48; Schinz, Syn. Mamm. vol. i. 1844, p. 362.

Viverra pallida, Gray, Proc. Zool. Soc. 1832, p. 63 ; 1864, p. 514 ; Ill. Ind. Zool. vol. ii. pl. vi. Vivervicula indica, Hodgson, Journ. As. Soc. Bengal, vol. x. 1841, p. 909; Horsfield, Cat. Mamm. E. Ind. Co. Mus. 1851, p. 58.

Viverricula malaccensis, Cantor, Journ. As. Soc. Bengal, vol. xv. 1846, p. 199; Blyth, Cat. Mamm. As. Soc. Mus. Bengal, 1863, p. 45 ; Gray, Proc. Zool. Soc. 1864, p. 513 ; Cat. Carniv. etc. B. M. 1869, p. 47.

In the one specimen procured at Bhamô there are only seven dorsal lines, but the external lines are not very distinct, and each consists of a chain of spots, Six lines commence behind the shoulder, but the two central lines soon unite, so that the number is reduced to five, the outer linear arrangements of spots only commencing about the middle of the flanks on which the spotting is very distinct. The fur generally has a warm rufous tinge, and the specimen in its general character corresponds to the $V$. rasse of Horsfield. The barring of the tail with brown and yellowish-white is very distinct, and ten brown bars may be detected, becoming narrower and more indistinct as they are traced backwards, the tip being white, tinged with yellowish, a colour which is rather marked on the upper surface of the tail generally.

$$
\text { Length of body . . . . . . . . . . . } 20
$$

This species is not at all uncommon in Upper Burma and in the Kakhyen hills.

Genus Prionodon, Horsfield.

* Prionodon pardicolor, Hodgson.

Prionodon pardicolor, Hodgson, Cal. Journ. Nat. Hist. 1841, vol. ii. p. 37, pl. ii. figs. 3 to 6 ; Horsfield, Cat. Mamm. E. Ind. Co. Mus. 1851, p. 52 ; Blyth, Cat. Mamm. As. Soc. Mus. Bengal, 1863, p. 46 ; Jerdon, Mamm. Ind. 1867, p. 124.

Lingsang pardicolor, Gray, Cat. Mamm. B. M. 1843, p. 49, et Cat. Carniv. etc. B. M. 1869, p. 53. Tiverra perdicator, Schinz, Syn. Mamm. 1844, vol, i, p. 366. 
I obtained a skin of this remarkable animal in the Kakhyen hills, where it appears to be as rare as it is in the Himalaya. It is very seldom seen or captured by the natives. I have no information to communicate regarding its habits, which are but little known.

The allied species, P. gracilis, Horsfield, occurs in Tenasserim and Malacca, and Dr. Horsfield records it from Sumatra, Siam, and Java; in the British Museum there are two specimens from Borneo.

The skulls, as remarked by Dr. Gray, are very much alike, but that of $P$. gracilis is distinguished by the greater length and breadth of the hinder part of its palate, as far back as the pterygoids, and by its broader muzzle. 


\section{HERPESTID压.}

Genus Herpestes, Illiger.

The Mungooses of India, Ceylon, Burma, Malaya, and Cochin China, and the Islands of Sumatra, Java, and Borneo, are all referable to this genus, the members of which, in these parts of Eastern Asia, differ among themselves much in the same way as the Eastern Asiatic squirrels. Eleven of the species have annulated fur without any special markings on either the shoulder, sides, or belly, while three species are distinguished by neck markings, and another by uniformly coloured, unpunctulated fur. The first of these sections is the parallel of the grizzled, unlineated squirrels, such as S. Zokriah; the second, the equivalent of the lineated group illustrated by such forms as S. macclellandi and H. plantani; and the third may be said to conform to the type of colouring which is distinctive of S. ferrugineus. As in the squirrels, so in the Herpestes, the presence or absence of lineation carries with it no generic difference of skull, skeleton or teeth: all the characters yielded by their structures contribute to prove that the following species are closely allied to each other in the following sequence, viz., H. auropunctatus, H. persicus, H. smithi, H. maccarthice, H. pallidus, H. ferrugineus, H. jerdoni, $H$. fuscus, $H$. javanicus, $H$. brachyurus, $H$. vitticollis, $H$. urva, and $H$. semitorquatus. The last mentioned appears to be most closely allied to the African forms H. badius and H. melanurus. I have not examined the skull of $H$. javanicus, but the skulls of all the others have passed under my observation, and I am enabled to speak with some confidence, as I have examined not only the skulls of the types of the different Asiatic genera, to which these species have been referred, but also the specimens which yielded the external characters, besides the skeletons of the three forms which have been referred to Calogale, Onychogale, and Calictis, and all of which are preserved in the British Museum.

With regard to the external characters of these species, they all carry their lithe and vermiform bodies low, and are very quick in their movements. The fur, with one exception, is annulated by different shades of yellow and brown, the alternate rings varying from four to twelve in number. The skin is more or less thickly clad on the body and neck, with a fine, silky almost woolly under-pile, generally of two colours, and among which are interspersed the numerous, long, annulated hairs, which effectually conceal it. The tail is either pencilled or unpencilled, and in the former case, the base, which is always thick and muscular, is clad with long hairs which slightly shorten as the terminal pencil of hairs is reached, the latter being as long, or longer, than the basal hairs, whereas in the unpencilled tails the hair also is long at the base, longer in some (H. pallidus) than others ( H. auropunctatus), and becomes gradually shorter towards the tip, which in all is well clad. The tail also is much longer in some species than others, equalling little more than half the length of the body and head in one (H. brachyurus), while in another ( H. pallidus) with the hair, it nearly equals the length of the trunk and head. All 
the species have short, rounded ears; the head rather long, and the nose nude and prominent, and marked by a vertical groove that runs to the upper lip. The legs are rather short, and in all the species they are provided with five claws on each foot. The claws are of variable strength, and they never present any'marked modification on the common type, which is that of a fossorial claw. Any departure from the normal type that has been hitherto observed seems to have been entirely due to disuse, the result of the animal having been kept in confinement. The tarsus in its mesial line may either be wholly nude to the heel, or partially clad; but this character, taken alone, is an unreliable guide to specific affinity, because two such widely different species as $H$. auropunctatus and $H$. vitticollis agree in this detail, while the nearly allied species, H. pallidus and H. fuscus, are separated by this character of their tarsus.

In all the species already named, there are 40 teeth, any apparent exception to the rule being satisfactorily explained as a result of age. The dental formula of the milk teeth is $\frac{3}{3} \frac{3}{3} \frac{1}{1} \frac{1}{1} \frac{4}{4} \frac{4}{4}=32$, and of the permanent teeth $\frac{3}{3} \frac{3}{3} \frac{1}{1} \frac{1}{1} \cdot \frac{4}{4} \frac{4}{4} \frac{2}{2} \frac{2}{2}=\frac{2}{2} \frac{0}{0}=40$, and the description of the teeth of one species will suffice to give a general idea of the dental characters of the genus.

The two middle pair of upper incisors are considerably smaller than the external pair. The upper half of the crown of these teeth, posteriorly, is concave from above downwards, the tip of the crown being laterally rounded. The margin defining this concavity from the basal portion of the crown shows a distinct tendency to form two rounded cusps. The posterior, concave surface of the crown of the second incisor is placed obliquely; and at the inner margin of the base, or upper end of the concavity, there is a somewhat prominent, mammillary cusp. The canines are well developed, and do not present any special characters. The first premolar is the smallest and shortest tooth of its kind, and is somewhat laterally compressed, the base of the crown forming a slight protuberance posteriorly, which is more developed in some species than in others. The second and third premolars are about the same size, and both have the triangular, pointed crown laterally compressed, with a sharp anterior and posterior border; the cingulum of the second premolar forms a slight ridge at the base of the anterior border and a more prominent cusp-like eminence at the base of the posterior margin, these portions of the cingulum being more developed in the third premolar which is distinguished from the second by the cingulum forming a prominent projection, on the inner aspect of the base of the crown, over the most external fang. The fourth premolar is the largest of all the teeth, and is only an intensified development of the characters presented by its immediate predecessor. In this tooth, the inner prominence of the cingulum has become converted into a triangular cusp placed nearly on a line with the anterior margin of the tooth, and the cusp at the posterior aspect of the base of the crown constitutes an oblique, elongated, somewhat bitubercular ridge, whilst the cingulum at the anterior border of the tooth forms a prominent ridge, the triangular central crown of the tooth being broad anteroposteriorly and situated between the inner and posterior cusps. There is a large vacant space internally, between the last premolar and the first molar, for the 
reception of the crown of the first molar of the lower jaw. The first molar is a transversely elongated, antero-posteriorly compressed tooth, with a small external cusp, with two others internal to it at its base, the inner half of the tooth, which is at a still higher level, slightly exceeding in size the external half of the crown, having its free surface concave from without inwards and terminating internally in a rather sharp point. The last molar is also transversely elongated, but very small and only about one-fourth the size of the preceding tooth. It is very simple, being generally bicuspidate, one cusp being external and the other internal.

The central pair of inferior incisors are the smallest teeth in the lower jaw, and have simple, flattened crowns. The pair external to them are slightly larger and tend to become bitubercular, while the internal pair are considerably larger and have the bitubercular character more pronounced. The canines do not call for remark, and the first premolar is very much laterally compressed and simple. In an example of $H$. auropunctatus, there are, so to speak, two first premolars on the left side of the jaw, having the appearance as if the tooth had been divided in two. It is not an instance of the presence of the milk and permanent teeth in the jaw at the same time, for it is apparent that they are both newly through the gum. Moreover, the more posterior of the two is considerably longer than the first permanent premolar should be, so that it would appear that the posterior of the two is the abnormal tooth. This condition is in no way akin to the observation recorded by Ogilby and accepted by Dr. Gray with regard to the supposed occurrence of two additional teeth in the lower jaw of $H$. vitticollis, and which I have explained in another part of this Memoir. The crowns of the first, second, and third inferior premolars are triangular, long, and laterally compressed, and at the base of the crown anteriorly, and posteriorly in the first, there is a slight eminence due to a swelling of the cingulum, but on the third premolar a small cusp is developed over the last mentioned of these eminences, both of which are more prominent in it than in its predecessor. In the fourth premolar the cusp has become considerably enlarged, and the anterior and posterior processes of the cingulum form prominent ridges. The first molar has the anterior two-thirds of the crown carrying three strong, triangular, divergent cusps, one external, one anterior, and one internal, the first of these being the largest and longest. The posterior third of the crown is at a much lower level, concave, shelving upwards and outwards, its external margin, in some, showing a tendency to division. The last molar is small, and generally with two anterior and one posterior cusp. But it appears to be the most variable of the teeth, and in H. brachyurus is quadricuspidate, there being three external and one internal cusp.

The skull is narrow and elongated, the brain-case equalling about two-thirds of its entire length, and it is marked anteriorly by a well-defined, post-orbital contraction. The lambdoidal ridge forms a prominent crest truncated above, but with lateral sides, while the sagittal suture is but little elevated, and it is joined immediately behind the post-orbital contraction by the obscure ridges from the tips of the external angular processes of the frontal. The latter processes are very prominent, and are opposed to the inferior, posterior, orbital processes of the maxilla, the tendency being 
for these two processes to unite in adult life and to enclose the orbit posteriorly, complete union of these processes generally taking place when the sutures of the cranium are all amalgamated. I know of only one species of the Asiatic Herpestes I have examined, in which these two processes probably do not unite, viz., H. semitorquatus, and in which the orbit is always imperfect. The infra-orbital foramen is well defined. The palatal surface is triangular, with the palatines prolonged backwards beyond the alveolar border, as in the skulls of allied families, and with the pterygoids forming the lateral angles of the posterior nares, the commencement of which is opposite to the articular surface of the squamous. The palatal border of the posterior nares may be either simply arched, or the arched portion may contract to a narrow notch, or the palatine border may be transverse. The tympanic bullæ are prominent, and project below and external to the opening of their osseous tube. The lower jaw has a prominent, ascending ramus, and a somewhat upwardly reverted, backwardly projecting, posterior angle. I have tabulated the measurements of the skulls of the different species, and an inspection of the table and accompanying figures shows how uniform the skull characters are, and how closely some of the species are related.

Dr. Gray included in the genus Herpestes, of which H. ichneumon may be taken as the type, Herpestes jerdonii, H. pallidus, H. persicus, H. fuscus, H. javanicus, $H$. semitorquatus, H. exilis, H. malaccensis, and H. brachyurus. The foregoing is the order pursued in the Catalogue of Carnivora, \&c., in the British Museum, in which the Madras Herpestes jerdonii, which is closely allied to H. pallidus, is placed along with the African forms, although the genus Herpestes is divided by Dr. Gray into an African and Asiatic sub-division. That this arrangement is thoroughly artificial is evinced by the circumstance that the small Mungoose, $H$. persicus, which is apparently only a local form of $H$. auropunctatus, is placed between H. pallidus and H. fuscus, two large forms nearly allied to each other, but markedly distinct from H. persicus, whose nearest ally, $H$. auropunctatus, is located in a separate genus Calogale, to which Herpestes pallidus is also referred under Hodgson's specific name of nyula. Again, H. exilis, Gervais, which is identical with H. rutilus, Gray, and H. javanicus, is classified along with $H$. semitorquatus and $H$. malaccensis, the former being a Mungoose nearly affined to $H$. urva and $H$. vitticollis, while $H$. malaccensis is evidently the same as $H$. pallidus. The Ceylon Mungoose, H. maccarthie, is ranked as a distinct genus, Onychogale, on account of the length of its claws, which is undoubtedly a result of the animal having been kept in confinement; while the other Ceylon form, H. smithii, which has a complete and not "rather incomplete" orbit as mentioned in the foregoing Catalogue, is also placed in a separate genus Calictis, apparently also founded on claw characters, the result of confinement. The large Madras Mungoose, H. vitticollis, which has its nearest affines in $H$. urva and H. semitorquatus, is regarded as the type of a distinct genus Taniogale, whilst $H$. urva has also its own genus Urva, and the Bornean, neck-banded Mungoose, which is closely allied to these, is allocated to Herpestes.

The genus Taniogale is founded on altogether fallacious grounds, viz., the supposed presence of 42 teeth. Ogilby, in 1835, described the skull, now in the 
British Museum, and fell into the error that it had the foregoing number of teeth, but an inspection of the skull conclusively proves that the supposed additional tooth is only one of the exposed fangs of the penultimate molar, the crown of the tooth having been worn away. This is evident, as on the left side of the lower jaw onehalf of the crown remains attached to the anterior fang and still shows the fracture where the crown has been broken across about its middle, the posterior fang being quite distinct. After I had examined the specimen, I observed a nearly similar condition in H. jerdonii, in which the penultimate molar of the lower jaw had lost its crown on one side, the fangs remaining in their sockets and being worn and smooth, while on the opposite side the tooth was intact. The Urva cancrivora, Hodgson, which has the skull and dentition of Herpestes, appears to me in no way separable from this genus. Its fur is long and loose, but in this it resembles $H$. vitticollis, and its neck-streak, although white, does not in other respects differ from the neck-band of the latter species; whereas in H. semitorquatus there is a similar mark, but less pronounced than in these species: but all are nearly related.

The skeletons of Calictis smithii and Onychogale maccarthice are structurally identical with each other and with Herpestes, as is evident from the notice I have given of them under the respective species.

\section{Measurements of skulls of Eastern Asiatic Herpestes.}

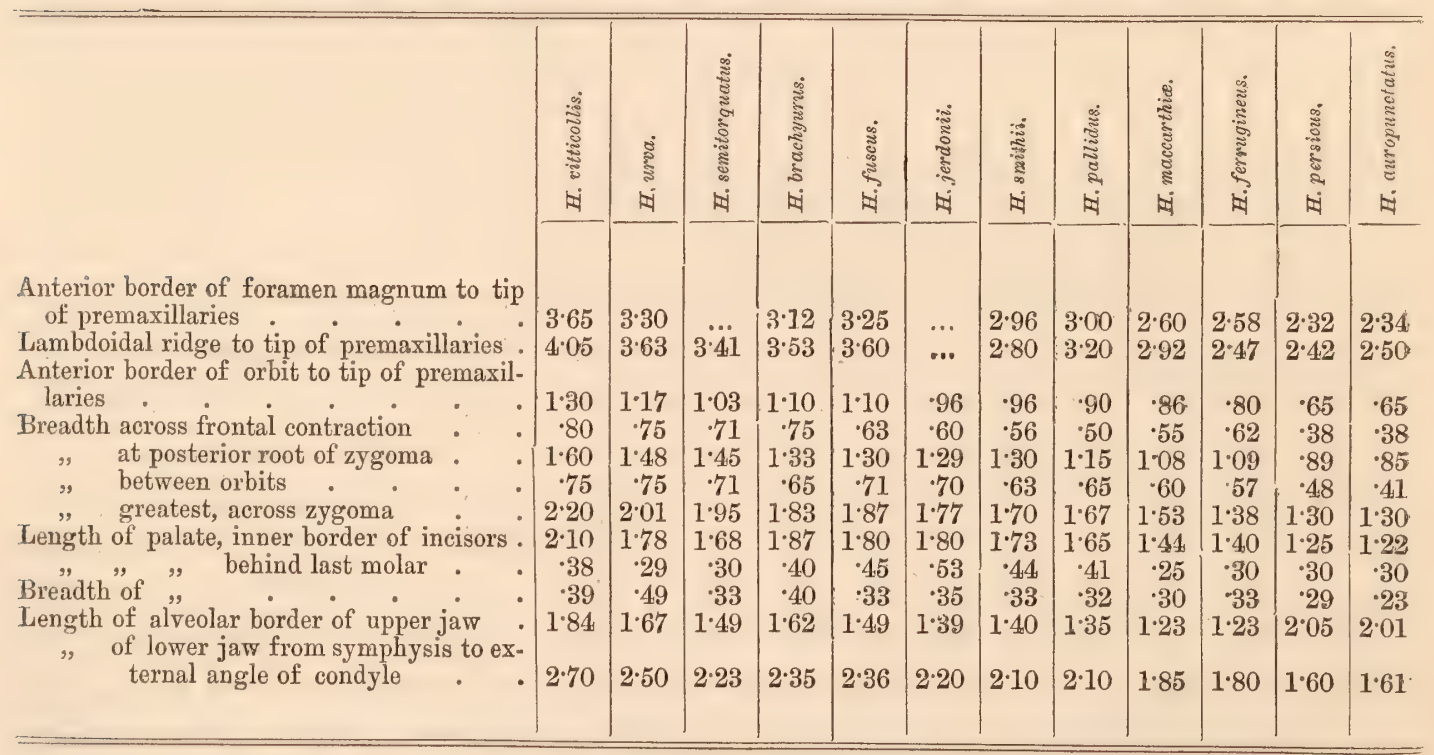

* Herpestes auropunctatus, Hodgson, Plate XI, figs. 11 \& 12.

Herpestes auropunctatus, Hodgson, Journ. As. Soc. Bengal, No. 52, April 1836, vol. v. p. 235; Wagner, Schreb. Säugeth. Suppl. vol. ii. 1841, p. 346; Schinz, Syn. Mamm. vol. i. 1844, p. 372 ; Cantor, Journ. As. Soc. Bengal, 1846, vol. xv. p. 242.

Herpestes nipalensis, Gray, Mag. Nat. Hist. New Series, vol. i. 1837, p. 578; List of Mamm.

B. M. 1843, p. 52; Cat. Hodgs, Coll. Mamm. \&c. Nepal, 1846, p. 9 ; Voy. Samarang, Zool. 
1850, p. 15; McClelland, Proc. Zool. Soc. Lond. 1839, p. 150 ; Horsfield, Cat. Mamm.

E. Ind. Co. Mus. 1851, p. 91 ; Blyth, Journ. As. Soc. Bengal, 1852, p. 349 ; Cat. Mamm.

As. Soc. Mus. Bengal, 1863, p. 51 ; Jerdon, Mamm. Ind. 1867, p. 136, et Append. p. iii. Herpestes javanicus, Blyth, Journ. As. Soc. Bengal, 1852, p. 349.

I shot a specimen of this Mungoose on the banks of the Irawady at Bhamô, which is the first recorded instance of this species having been procured in Upper Burma, and I am not aware that it has ever been as yet detected in British or Lower Burma. Cantor, however, has stated that it inhabits the Malayan peninsula, so that it will also probably be found to inhabit Burma generally.

This and $H$. persicus are the smallest of the Mungooses. The types of $H$. auropunctatus and $H$. nipalensis are in the British Museum, and I have examined both and compared them with a series of similar Mungooses shot at Calcutta by myself at different seasons of the year, and also with others procured in Cachar, and with the specimen shot in Upper Burma. All of these examples lead from one to the other, but, as I shall have occasion to indicate under H. persicus, the changes of fur which these animals exhibit are not at all understood, although at the same time the series under consideration does not reveal a single character by which the Nepal, Calcutta, Cachar, and Burman animals can be specifically separated from each other.

In the typical example of $H$. auropunctatus, and the exact equivalents of which have been killed by me in the cold weather on the banks of the Hughli at Calcutta, along with examples at other seasons identical in all respects with the type of H. nipalensis, Gray, the general colour is olive-brown, with a golden hue due to the fine yellow annulation of the fur. The sides of the body are slightly paler than the back and not so yellow. The under parts are dirty yellowish-white, faintly annulated on the posterior half of the under surface of the neck and on the belly. The limbs are concolorous with the body. The short hair or pile is purplish brown in its lower two-thirds and pale yellow in its terminal third. It is more profuse than in the type of $H$. nipalensis, which is represented in the British Museum by a single specimen, and in which it is shorter, but, at the same time, the coloration is identical with H. airropunctatus. The yellow annulation of the fur of the former is not so distinctly marked as in the latter, and its under parts are less bright, but these differences are so slight that they may be ascribed either to age, sex, or to seasonal changes. The long hair in both is smooth, fine, short, and adpressed, while in a lightcoloured yellowish-white example of the species from Agra the fur is much harsher and the annulation is almost wholly faded. The tips of the hairs are dark brown, also their bases, the central brown band being separated from its terminal fellows by two yellow bands, but occasionally a yellow band is added to the base. In the Agra specimen, the brown tip is alone preserved, the rest of the hair being pure yellowish-white, but occasionally the central brown band can be detected. In the example of the species from Upper Burma, the fur is nearly the same as in the dark Calcutta and Nepal examples, only the yellow bands are rather narrower and more orange, and this is the case also with the Cachar specimens ; but these differences are so very slight as to be scarcely perceptible. In the tail, 
there are generally eight alternate bands, with the terminal band dark brown, and it is clad with long hairs at its base, which gradually decrease in length and become more adpressed towards its tip, which is unpencilled, as in H. persicus. The external surface of the upper angle of the ear is clad with longish, annulated hairs, which partially cover the anterior half of the organ, while the exposed, posterior portion is clothed with very fine, unannulated hairs. The limbs are generally concolorous with the body. The tarsus has the central nude area extending to the heel. The claws are moderately strong.

Cantor's example from Malacca in the India Museum agrees with the type of H. auropunctatus, but it is slightly more yellowish. The dark Calcutta specimen, however, is more yellowish than either of these, while another specimen from the latter locality is the exact facsimile of the first mentioned.

$$
\begin{aligned}
& \text { Length from muzzle to vent . . . . . . Inches. } \\
& \text { Length of tail (shrivelled) . . . . . . . . . } 8550 \\
& \text { " }, \text { with hair . . . . . . . . . 10.25 }
\end{aligned}
$$

The skull of $H$. auropunctatus is generally distinguished by the narrow and elongated character of its facial portion, but some skulls of this species have shorter and broader muzzles, and it may be that these differences are sexual. The nasal portion of the palate is generally broader than in $H$. persicus, in the skulls I have examined, but this portion is subject to considerable variation. The orbit is perfect in the adult. The last molar has two anterior and one posterior cusp, with the tendency to form a cusp between the external, anterior and posterior cusps.

There are 26. ribs, and the sternum has 7 mesosternal pieces. There are 27 caudal vertebræ.

This species ranges from Nepal and the north-west of India to the eastwards through Bengal, Cachar and Assam into Northern Burma, and extends southwards to the Malayan peninsula.

The Mungoose figured by Edwards ${ }^{1}$ represents an Herpestes, which, it is stated, was the size of a polecat or ferret, and came from the East Indies. Geoffroy drew up his description of $H$. edwardsii from that figure, but it appears to me impossible to say, with any attempt at accuracy, whether $H$. edwardsii is identical with H. pallidus or H. auropunctatus, but the size of the animal and the colour given of it would seemingly indicate that it was the latter species, an opinion which Ogilby entertained.

Herpestes perstcus, Gray. Plate IX, figs. 9 and 10.

Herpestes persicus, Gray, Proc. Zool. Soc. Lond. 1864, p. 554, et Cat. Carniv. Mamm. Brit. Mus. 1869, p. 151 ; Blanford, Proc. Zool. Soc. Lond. 1874, p. 662.

Herpestes pallipes, Blyth, Journ. As. Soc. Bengal, 1845, vol. xiv. p. 346 (foot-note).

Herpestes griseus, Hutton, Journ. As. Soc. Bengal, 1845, vol. xiv. p. 346.

${ }^{1}$ Nat. Hist, vol, iv. (1751), pl, cxcir. 
The types of this species are in the British Museum, and are two in number, but besides these I have had the opportunity to examine two other examples which were kindly submitted to me for investigation by Dr. Day; and Mr. Moore of the India Museum has shown me Blyth's type of H.pallipes.

It is so closely allied to H. auropunctatus that some of Hodgson's examples of that species are scarcely separable from it, the only appreciable external difference being that the under-surface is not quite so white in H. auropunctatus, which has always a slight yellowish tinge on these parts. Otherwise, the fur of the two socalled species is identical, and their form similar. I observe also that a specimen of H. auropunctatus shot by me in the neighbourhood of Calcutta in the month of January, and which is very pale compared with other examples from the same local. ity, so closely resembles $H$. persicus in its fur and general appearance that I would have hesitated to indicate $H$. persicus as a sub-species had not the skulls of the two types differed from the skulls of $H$. auropunctatus in being less elongated, with shorter and broader muzzles, wider palates and broader frontal areas between the orbits. The circumstance that the pale-coloured specimen from Calcutta was shot in the cold weather should not be lost sight of when we remember that these Mungooses are the southern representatives of the ferrets. Such an isolated instance does not prove that Herpestes auropunctatus is subjected to seasonal changes of fur, but such a possibility should not be disregarded in studying these animals where there are any extremes of climate, such as are found in Bengal, and it is also noteworthy that the examples of so-called H. persicus have all been obtained in winter.

In H. persicus, the fur is annulated in the same way as in H. auropunctatus, i.e., there are five to six alternate, dark brown and yellow bands, the apical being of the former, and the basal ring of the latter colour. In the tail, there are generally eight alternate bands with the apical ring dark brown. The hair, as in the pale-yellow examples of $H$. auropunctatus, is much adpressed and rather harsh. On the flanks the hair is 0.75 long, and on the base of the tail 1.05. The under parts are pale greyish-white. The tarsus has the fur distributed as it is in H. auropunctatus, and the lower last molar is the same as in that species. The dimensions of $H$. persicus and $H$. auropunctatus are very similar, as the following measurements show :-

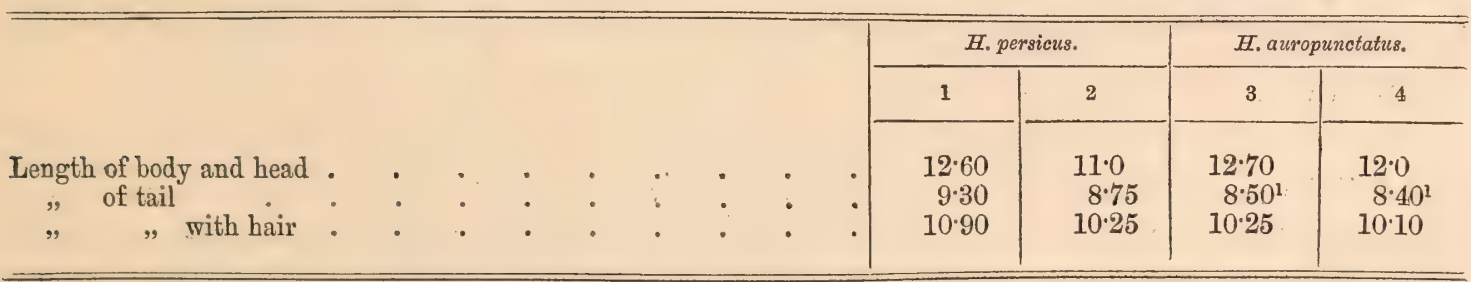

No. 1 is one of Hodgson's types of H. auropunctatus, and it agrees remarkably with H. persicus in the character of its fur; and No. 2 is an example slightly darker than the preceding one, and approaching to a Nepal specimen.

This species is the western representative of $H$. auropunctatus and extends to Persia.

\footnotetext{
${ }^{1}$ Caudal vertebræ removed, and skin, therefore, somerwhat shrivelled.
} 


\section{Herpestes smithin, Gray. Plate VIII, figs. 5 \& 6.}

Herpestes smithii, Gray (Charlesworth), Mag. Nat. Hist. vol. i. New Series, 1837, p. 578; Proc. Zool. Soc. Lond. 1851, p. 131, pl. łxx.; Temm. Esquisses Zool. pt. i. 1853, p. 97 ; Blyth, Cat. Mamm. As. Soc. Mus. Beng. 1863, p. 50 ; Jerdon, Mamm. India, 1867, p. 135.

Crossarchus rubiginosus, Wagner, Schreber, Säugeth. Suppl. ii. 1841, p. 329 ; Schinz, Syn. Mamm. 1844, vol. i. p. 378.

Herpestes ellioti, Blyth, Journ. As. Soc. Beng. 1851, vol. xx. p. 162 (foot-note).

Herpestes rubiginosus, Kelaart, Prod. Fauna, Zeylan. 1852, p. 43; Blyth, Journ. As. Soc. Beng. vol. xx. 1851, p. 182 ; vol. xxi. 1852, p. 349.

Calictis smithii, Gray, Proc. Zool. Soc. Lond. 1862, p. 565; Cat. Carniv. Mamm. Brit. Mus. 1867, p. 162.

This species appears to be peculiar to Ceylon, and the type is in the British Museum, London.

It is a long-haired Mungoose, with well-grizzled fur, somewhat after the fashion of $H$. pallidus, Wagner, and $H$. jerdonii, Gray, but the colour is very much darker and richer. Unlike the former, it has a long black tip to its tail, but in this respect it resembles the latter species, which is pale compared with it and slightly darker than H. pallidus. The insular form differs from these more essentially continental species in its rich, ferruginous, and dense fur, and in its relatively larger and heavier head. The woolly underlying pile is pale-brownish. There are from four to five dark-brown, almost black, bands on each of the hairs of the visible fur, and the apical band is brown at its tip, but near its base it passes into a deep orange or rich rufous, and the succeeding dark bands have more or less of this tint at each of their ends. The dark-brown rings are separated from each other by a narrow, pale-yellowish band, and there are from four to five of these. To the two-fold coloured, apical rings and to these vellow bands is due the speckled character of the fur. The orange or rich rufous is especially well developed on the nape of the neck, so that when the head of the animal is thrown upwards a kind of rufous collar is produced. The fine hairs around the eye and in front of it to the nose are rich rufous, and the head generally has a rufous tint, and the grizzling is very fine. The whiskers are black. The ears at their upper thirds, externally, are clad with a patch of short grizzled hairs like those on the sides of the face, while below this the hairs are uniformly pale-rufous and extremely short. The feet are unspeckled and dark-brown. The chin is very finely speckled, and the chest more coarsely so. The claws are moderately developed, and the tarsus, in its centre line, is nude to the heel. The tail for about two-thirds of its length is concolorous with the body, but as its black latter third is reached the rufous is more marked. At its base it is clad with long hairs, but the hairs become shorter as the black end is approached, the hairs of which, however, are longer than those immediately preceding them. On the middle of the sides of the body the fur is about 1.75 inch long, and at the base of the tail it is 2 inches and near its end 1.50 inch, while the black hairs of the tip are 2.75 inches long.

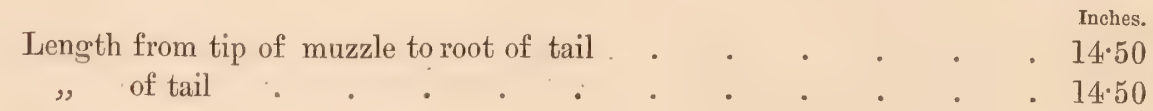


The skull of H. smithii is closely allied to those of $H$. pallidus, $H$. jerdonii, and H. maccarthia, but it differs from the first in its wider brain-case and the slightly greater width between the orbits and the longer alveolar border; but the most marked features are the basal breadth of the skull and the character of the palatal margin of the posterior nares, which is concave from behind forwards, and not marked by any median ridge or backwardly projecting spine, as sometimes occurs in $H$. pallidus. The hinder portion of the suture of the nasals and the whole of the premaxillary suture have disappeared. The orbit is entire. The skull is large for the dimensions of the animal. The last lower molar has two prominent anterior cusps, with the margin of the posterior division of the tooth somewhat divided.

The skeleton of the type of this species is in the British Museum, and having carefully examined it, I am in a position to state that it in no way differs generically from the skeletons of Herpestes auropunctatus and $H$. maccarthia. A rudimentary, hypapophysial ridge is developed on the cervical vertebræ, becoming very obscure on the last segment, but in the fifth the posterior nodular end is partially bifid. The spinous processes of the dorsal vertebræ are long and strongly developed. On the transverse process of the sixth dorsal a small tubercle is developed, which gradually becomes transferred to the back of the process and nearer to its root, so that on the eleventh vertebra it occupies the position of an anapophysis. It is distinctly bifurcated on the twelfth, and is a true anapophysis on the thirteenth vertebra, whilst it suddenly disappears on the fifth lumbar. Mammillary processes begin to show themselves on the eleventh dorsal segment. There are in all 26 ribs, and the vertebral formula is C. 7 , D. 13, L. 7, S. 3, C. $29=59$. The primary transverse processes of the caudal vertebræ are strongly developed to the seventh, beyond which they become more and more transferred to the hinder extremity of the centrum, and are all but lost on the twelfth segment. The secondary transverse processes begin to develope, as in all Herpestes, on the anterior border of the primary transverse processes, and on the part of the centrum immediately in front of them, and gradually more forwards, at last occupying the anterior portion of the centrum, and disappearing after the primary transverse processes have been lost. The spinous or neural ridge exists as far backwards as the tenth caudal vertebra, but, beyond that, it becomes reduced to a posterior eminence on the bodies as far as the seventeenth segment. The remains of the zygapophyses and metapophyses can be detected as far as the twenty-first segment of the tail. The caudal bodies increase in length to the fourteenth vertebra, beyond which they more quickly diminish in diameter than in length. Chevron bones begin as a pair of nodules on the second vertebra, but, between the third and fourth, they are developed into an osseous canal, and retain this character to the ninth vertebra, where they are again resolved into two pieces and gradually revert to their original, nodular character. The shoulder and pelvic girdles conform essentially to the structure of these parts in Herpestes, as also the limb bones and the sternum. 
Kelaart states ${ }^{1}$ that the type of $H$. rubiginosus was forwarded to Blyth, who had published the description of H. ellioti subsequent to Kelaart's account of the species, but Blyth, after he was in possession of $H$. rubiginosus, regarded $H$. ellioti as identical with it.

This species is apparently confined to Ceylon, but the two specimens in the Leyden Museum are doubtfully labelled as coming from Cape Coast and from the Congo in Africa. These specimens, however, were purchased in London from a dealer, and the localities assigned to them are unquestionably erroneous.

\section{Herpestes macCarthiж, Gray. Plate IX, figs. 7 \& 8.}

Cynictis maccarthia, Gray, Proc. Zool. Soc. Lond. 185l, p. 131, Mamm. pl. xxxi. ; Ann. and Mag. Nat. Hist. 1853, vol. xii. p. 47; Kelaart, Prod. Faun. Zeylan. 1853, vol. ii. pt. i. Append. p. xvi. Herpestes fulvescens, Kelaart (Blyth), Journ. As. Soc. Bengal, 1851, vol. xx. pp. 162 \& 184; vol. xxi. 1852, pp. 348 \& 349 ; Cat. Mamm. As. Soc. Mus. 1863, p. 52 ; Prod. Faun. Zeylan. vol. ii. pt. i. 1853, Append. p. xvi.

Herpestes flavidens, Kelaart, Prod. Faun. Zeylan. 1852, p. 44; Blyth, Journ. As. Soe. Bengal, 1851, vol. xx. p. 162.

Onychogale maccarthia, Gray, Proc. Zool. Soc. Lond. 1864, p. 570, et Cat. Carniv. Mamm. 1869, p. 168.

The type of this species which is in the British Museum lived for some time in the Zoological Society's Garden, London. The chief characteristic of the genus Onychogale, which Dr. Gray founded for its reception, was the long, compressed and curved nature of the front claws, which, however, appears to have no other explanation than that it was the result of disuse induced by a life of confinement. The other generic character stated by Dr. Gray in his catalogue, is in the following terms: "The hinder end of the skull deeply and sharply notched instead of being transversely truncated, as in the small Herpestes. The notch in the living animal filled up with a cartilaginous septum." This refers to the form of the posterior narial border of the palatines, ${ }^{2}$ which is subject to considerable variation in this, as in other groups of animals. These seeming characters being thus explained away, it does not appear that this Ceylonese form differs in any respect from Herpestes.

In the British Museum there are two other Mungooses from Ceylon, both of which differ from the type of $H$. maccarthice in the general character of their coloration, but agree with it in the texture, length, and density of their fur. One is a larger individual than H. maccarthice, and stands under the name of H. fulvescens, Kelaart, whereas the other is smaller, darker and unnamed. The former is a paleyellow Mungoose, whereas the latter is a darkish olive-brown Herpestes. My

Prod. Fauna, Zeylan. 1852, pp. 43 \& 44.

${ }^{2}$ In Dr. Gray's original description in the Proc. Zool. Soc. 1864, p. 570, he is made to say that the back of the nape is deeply and sharply notched, the word I have italicised being evidently a misprint for nose, or, perhaps more accurately, palate. 
impression is that they are examples of one and the same species, and that the smaller size of the type, H. maccarthia, as compared with the larger fulvescent specimen (for the skull of the former proves it to be fully adult), is to be accounted for by its having been kept in confinement, whereas, on the other hand, the darker colour of the smaller specimen seems to be attributable to youth, or it may be that these differences of coloration are explained by the wide diversities of physical conditions which are met with in the little, compact island of which they are the inhabitants. This seems probable, because I observe that Kelaart records that he obtained a darker variety of his $H$. fulvescens from Newera Elia, which must be at an elevation of from 6,000 to 7,000 feet above the sea, and which he sent either to Calcutta, or to the Zoological Society, London.

In these specimens, the fur is long, dense, soft and adpressed, as in H. auropunctatus, but much more profuse and still more so than in the Mungooses which are allied to $H$. pallidus. The underlying pile is also abundant, and about one inch long in the type, and it is pale purplish-brown at its base and yellowish-orange in its two terminal thirds. The tips of the long hairs are pale orange-brown, succeeded by a yellow band of variable extent which is much broader in the Mungoose referred to $H$. fulvescens, than in $H$. maccarthice and in the dark specimen. In the two latter the pale orange-brown tip is succeeded by a bright yellow band, while in the larger $H$. fulvescens the sub-apical yellow band is much paler, and there are, below, four alternate brown and yellow bands, the basal portion of the hair being broadly pale-yellow, almost white. In the type, although smaller than the so-called H. fulvescens, a circumstance, I have said, either the result of confinement, or explicable on the supposition that it is the hill form, there are also four alternate brown and yellow bands, but much narrower than in $H$. fulvescens. In the darkbrown example there are generally six alternate brown and yellow bands, the last being pale-yellow or white, and not much broader than the others, and the face has the peculiarity that long white hairs are interspersed over it. This is the youngest of the specimens, and in its more numerous bands it adheres to the hair colouring, apparently distinctive of young as compared with adult Herpestes. In the type, the hair of the tail is generally six-banded, and the brown bands in all decrease in breadth towards the tip. On the flanks the hair is 1.70 inches in length, and on the base of the tail 1.90 and at its tip 1.30. In the adult H. fulvescens the hair is somewhat longer. In these three Mungooses the tail has no dark tip, and it gradually decreases in width towards the end, which is not tufted as in H. smithii and $H$. jerdonir, and in these respects it resembles $H$. auropunctatus, but it has a slight rufous tinge which increases towards the tip. It is evident that the similarity in the pelage of these Mungooses is so marked as not to yield any feature to separate them specifically from each other. The claws of the ferine specimens are much the same as in H. pallidus, and the upper third of their tarsi is clad. The large specimen ( $H$. fulvescens) measures from muzzle to root of tail 16.25, and the tail without the hair 11.50 , and with it 14 inches. The type of $H$. maccarthice is 12.20 from muzzle to root of tail, the tail being 9 inches long, the hair at the 
tip being abraded. The dark-coloured example is 13.30 inches from the muzzle to the root of the tail, and the tail is $9 \cdot 20$ inches long.

In the type, the sutures of the skull have all disappeared, and yet the orbit is incomplete; but, from the circumstances in which the animal lived, it would be premature to accept the character of the orbit as determined by the skull of this captive Mungoose. The skull has a strong resemblance to the skull of H. pallidus, to which and $H$. auropunctatus it is very closely allied, and for which it might even be mistaken if the orbits were complete. The notched character of the posterior border of the palate is only a modification of the arched form which occurs in this genus, and which may be traced in a series of specimens leading into and ending in a straight, transverse border as in H. auropunctatus. But the form of the posterior border of the palate is so variable that I would hesitate to resort to it even for specific characters. The last inferior molar is markedly tricuspidate.

The vertebral formula is C. 7, D. 13 , L. 7 , S. 3, C. $26=56$. The axis is strongly ridged inferiorly, the ridge terminating posteriorly in a tubercle which is partially divided in the succeeding vertebræ, but both cease on the sixth segment. The spinous processes of the dorsal vertebræ are proportionally longer and more backwardly directed than in the much smaller $H$. auropunctatus. Anapophyses begin on the tenth and metapophyses on the eleventh dorsal vertebra, the former disappearing on the penultimate lumbar. In the caudals, the transverse processes become gradually transferred from the middle to the posterior ends of the bodies, which latter position they occupy in the sixth vertebra, on which the secondary transverse process makes its appearance, finding its fullest development in the tenth caudal and disappearing later than the true transverse processes. The latter are strong and well developed to the sixth, and bear a small process on their upper surface, near their free ends, which first shows itself on the third caudal, and gradually approaches the base of the transverse process as it shortens, till at last on the eighth caudal it is transferred to the posterior end of the centrum and occupies the position of an anapophysis and can be detected to the tenth vertebra. The zygapophysial facets cease on the sixth, but processes serially homologous with them can be detected as far as the seventeenth vertebra. The neural canal ceases at the sixth segment. Hæmapophysial nodules begin on the seventh caudal, and occur to near the extremity of the tail, but it is probable that the anterior chevron bones have been lost in the preparation of the skeleton. The sternum has seven pieces, in addition to the manubrium which is essentially Herpestine, but with the anterior projection not so long as in H. smithii. The limb bones are generically the same as in other Herpestes.

This species, as far as is known, is peculiar to Ceylon. 


\section{Herpestes Patlidus, Wagner. Plate VIII, figs. 9 \& 10.'}

Mangouste de Malacca, F. Cuv. Hist. Nat. des Mammif. Tome I'. Livr. ve . Avril 1819.

? Ichneumon griseus, Geoff. Descript. de l'Egypte Hist. Nat. vol. ii. (1813), p. 138.

Herpestes griseus, Desm. Mamm. 1820, p. 212; Sykes, Proc. Zool. Soc. Lond. 1831, p. 102 ; Ogilby,

Proc. Zool. Soc. Lond. 1835, p. 101 ; Cantor, Journ. As. Soc. Beng. 1846, p. 242 ; Gray, Voy.

Samarang Zool. 1850, p. 15; Proc. Zool. Soc. Lond. 1864, p. 553, et Cat. Carniv. Mamm.

B. M. 1869, p. 151; Horsf. Cat. Mamm. E. Ind. Co.'s Mus. 1851, p. 90 ; Kelaart, Prod.

Faun. Zey. 1852, p. 41; Blyth, Journ. As. Soc. Beng. 1852, p. 349 ; Cat. Mamm. As. Soc.

Mus. 1863, p. 51 ; Jerdon, Mamm. of Ind. 1867, p. 152 ; Stoliczka, Journ. As. Soc. Beng.

1872, p. 682 ; Blanford, Proc. Zool. Soc. Lond. 1874, p. 662.

Herpestes frederici, Desm. Dict. Sc. Nat. 1823, vol. xxix. p. 60.

Mangusta malaccensis, Fischer, Syn. Mamm. 1829, p. 164.

Mangusta grisea, Fischer, Syn. Mamm. 1829, p. 164.

Herpestes nyula, Hodgson, Journ. As. Soc. Beng. vol. v. (April 1836), p. 236 ; Calcutta, Journ. Nat.

Hist. 1844, vol. iv. p. 287 ; Gray, List, Mamm. Brit. Mus. 1843, p. 52 ; Cat. Mamm. Nepal and Tibet, Brit. Mus. 1846, p. 8; Horsfield, Cat. Mamm. E. Ind. Co. Mus. 1851, p. 92.

Mangusta mungos (et Caffra?), Elliot, Madras Journ. Lit. and Sc. 1839, vol. x. p. 102.

Herpestes pallidus, Wagner, Schreber, Säugeth. Suppl. vol. ii. 1841, p. 311, pl. cxvi. G; Schinz, Syn. Mamm. 1844, vol. i. p. 373.

Herpestes malaccensis, Blyth, Journ. As. Soc. Beng. vol. xxi. 1852, p. 349 (in part) ; Cat. Mamm. As.

Soc. Mus. 1863, p. 51 (in part); Gray, Proc. Zool. Soc. Lond. 1864, p. 555 ; Cat. Carniv.

Mamm. Brit. Mus. 1869, p. 153.

Calogale nyula, Gray, Proc. Zool. Soc. Lond. 1864, p. 560, et Cat. Carniv. Mamm. B. M. 1869, p. 158.

Herpestes fimbriatus, Temm. Esquisses Zool. 1853, p. 112.

A careful consideration of the types of $H$. nyula in London, leads to the conclusion that they are only young examples of $H$. pallidus, Wagner; and the series of H. pallidus in the British Museum and in the India Museum, London, as also in the Indian Museum, Calcutta, prove that the species is the subject of considerable variation in colour and in the character of the banding of the hair. The fur of the young has seemingly finer and more numerous annuli than in the adult, and this appears to hold true of the other Asiatic Herpestes, whereas the difference of colour manifested by this species may be due to seasonal changes which may present subordinate modifications distinctive of the two sexes. But, moreover, the colour of the fur of the animal is also influenced by the surroundings among which it lives, because this is undoubtedly the case with $H$. auropunctatus, which is rich olive-brown in Nepal; pale, almost yellow-white, about Agra; and dark olive-brown in Cachar and Upper Burma.

In this species, the hair is rather harsh and much longer on the hind quarters than on the anterior portion of the body, and in its loose, open character, it is very different from the soft, adpressed hair of $H$. auropunctatus. On the hind quarters, in the adult, it is 2.50 inches long, and on the root of the tail 3 inches, slightly diminishing in length towards the tip, which is in no way tufted, and on which the hair is 2.50 inches long. The silky pile is brownish towards its base and yellowish

\footnotetext{
2. On the plate the skull of this speeies is figured under the name $H$. griseus.
} 
in its upper half. The long hairs have brown tips, succeeded by nine alternate, pale yellowish or almost white, and brown bands, of nearly equal width, except the basal band, which belongs to the pale series, and is generally broad. On the base of the tail, the annuli are much broader, but generally of the same number as on the body, according to the age of the individual. The upper surface of the head is generally suffused with rufous brown, as are also the lower parts of the legs. The centre of the hind foot is nude to the heel.

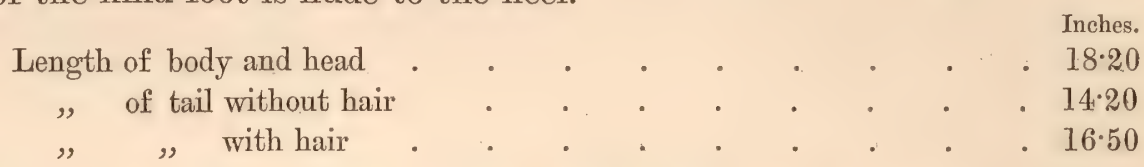

The skull of $H$. pallidus agrees exactly with skulls sent by Hodgson to the British Museum as examples of $H$. nyula. The skulls of pale-coloured and those of more ferruginous skins all so agree with each other that they do not afford any grounds of separation, although the more dusky examples from Bengal have been regarded as H. malaccensis, F. Cuv, The teeth are the same in all. The two processes behind the orbit never unite until the animal is fully adult, and until the other sutures of the skull have disappeared by a normal synostosis, $i . e$, until the skull has ceased to grow. The last lower molar has two anterior and one posterior cusp, with the tendency to form a cusp between the former two. This species is distributed over India from the Punjab and Sindh southwards to Ceylon, and eastwards through Assam and the Malayan peninsula from whence it has been sent by Cantor.

I have adopted Wagner's name H. pallidus for this species in preference to H. griseus, as this latter name originally included an African species. The term H. malaccensis is also objectionable, because it is misleading as to the geographical distribution of the species, and moreover it has been but seldom recognised, and H. nyula likewise is unsuitable from the circumstance that it is a native term applicable to Indian Mungooses generally.

\section{Herpestes ferrdgineus, Blanford. Plate VIII, figs. 11 \& 12.}

Herpestes ferrugineus, Blanford, Proc. Zool. Soc. Lond. 1874, p. 661, pl. lxxxi.

This Mungoose closely resembles rufous examples of the previous species, II. pallidus, and had it not been for certain characters presented by the skull, I should have been disposed to regard the two as identical; but it may be that even those supposed, distinctive, cranial features will be satisfactorily explained if a larger series of skulls of all ages were examined. The characters in which it differs most from H. pallidus are the greater breadth of the post-orbital contraction of the frontals, the shorter and broader muzzle, and more particularly the greater breadth and shortness of the posterior or nasal portion of the palate. The orbit, judging from the growth of the skull, is in all probability perfect in the adult. The last lower molar has the same character as in H.pallidus. The annulation 
of the fur is the same as in that species, but the distinctive external features of the animal are its slightly more rufous tint than the generality of the examples of H. pallidus, and the end of the tail being entirely rather bright red. The mesial nude line of the tarsus extends quite to the heel as in the former species. The type was procured by Mr. Day at Larkhana in Sindh.

\section{Herpestes Jerdonit, Gray. Plate VIII, figs، 7 \& 8.}

Herpestes jerdonii, Gray, Proc. Zool. Soc. Lond. 1864, p. 550, et Cat. Carniv. Mamm, Brit. Mus. 1869, p. 148.

Herpestes monticolus, Jerdon, Mamm. of Ind. 1867, p. 135.

Calogale thysanurus, Wagner, München, gelehrt. Anzeig. ix. p. 449; Schreber, Säugeth. Suppl. vol. ii. 1841, p. 301 ; Schinz, Syn. Mamm. 1844, vol. i. p. 564; Gray, Proc. Zool. Soc. Lond. 1864, p. 564, et Cat. Carniv. Mamm. M. B. 1869, p. 161.

The type of this species is in the British Museum. The species belongs to the same group as $H$. pallidus, $H$. fuscus, H. smithii, and H. maccarthice. It is most nearly allied to the first of those, from which it is only distinguishable by its slightly darker colour and less finely grizzled fur, and by the broad, black tip of the tail, which is slightly rufous at its commencement: in these characters it approaches $H$. widringtonii and $H$. ichneumon.

The hair is long, especially on the hinder parts of the body and tail, as in H. pallidus and H. smithii. The underlying, woolly fur is pale-yellowish. The long hairs are broadly pale-brown tipped, darkest at the apex of the terminal ring, but paling towards its base. This apical, dark ring is succeeded by a moderately broad, nearly white band, followed by three brown bands, which are also pale at their extremities, and each is separated from its fellow by a white band, the base of the hair being broadly white. On the long hairs of the tail there is an additional brown band, but the apices and bases preserve the same colours as the body hairs. The head hairs are short and much more finely annulated than on the body; and on the muzzle, anterior to the eyes, the apical bands are rufous, so that this area is more or less rufous. The upper surface of the fore and hind feet is dark-brown, and its under surface is naked to the heel. The ears externally are uniformly clad with very short, yellowish-grey hairs. On the flanks, the hairs are about 1.75 inches long, and on the base of the tail 3 inches in length, but they become much shorter towards the black tip, being barely 2 inches, which is the character of $H$. smithii, whilst the black terminal hairs are 3 inches, so that the tip of the tail is tufted. The under surface of the throat and chin is pale yellowish-grey, and the inferior aspect of the neck is grizzled; the belly being of nearly the same colour as the sides.

Length from tip of muzzle to root of tail $15 \cdot 50$; length of tail $14 \cdot 90$; the terminal hairs reaching $2 \cdot 75$ inches beyond this.

The skull of this species is chiefly distinguished by the breadth of the frontal region both across the post-orbital processes and between the anterior margins of 
the orbits. The length of the alveolar surface is greater than in either H. pallidus, or $H$. maccarthix, and slightly in excess of that of $H$. smithii. The teeth are also larger than in these two species, especially the canines, which are considerably larger than in the last mentioned. The posterior prolongation of the palate is slightly longer and broader than in $H$. maccarthie, although in this respect $H$. smithii closely approaches $H$. jerdonii. Its posterior margin, instead of forming a transverse line, or an arched border, as in H. pallidus, sends out a slightly backward projecting shelf of bone with a rugged margin, whereas in a specimen of $H$. smithii the same border is somewhat similarly formed, but concave instead of being convex, whilst in H. maccarthice it is rather deeply notched; but this is only a modification of the arched palatine border which occurs in $H$. pallidus, and does not merit the importance which Dr. Gray has attached to it. The ridges from the post-orbital processes of the frontals curve first forwards and inwards, and then inwards and backwards, the two ridges only meeting behind the post-orbital contraction, and this, be it remembered, occurs in a fully adult skull. However, it is improbable that this is a specific character, as this part of the skull from the very nature of the ridges must be the subject of considerable variation; doubtless the extent to which the post-orbital contraction is carried is also variable. These are the only features which seemingly separate the skull of H. jerdonii from the skulls of the other species, and these little-pronounced characters indicate how closely all these forms are related to each other. All the sutures of the skull have disappeared with age and the orbit is entire.

It would appear from a statement of Kelaart's ${ }^{1}$ that Sir Walter Elliot was the first to recognise this species which, so long ago as 1852, he had indicated in M.S. as $H$. monticolus, the name adopted for it by Jerdon.?

This form occurs in Southern India, and is apparently the Mungoose which ranges to the north-west, even to Kashmir, where it constitutes the $\mathbb{H}$. thysanurus, Wagner, which has been described as "H. minor, pilis fusco et pallide luteoannulatis ; pedibus fuscis, cauda longa pencillio magno aterrimo terminata." It has also been obtained in Singhbhoom by Mr. V. Ball.

\section{Herpestes fuscus, Waterhouse. Plate VIII, figs. 1 \& 2.}

Herpestes fuscus, Waterhouse, Proc. Zool. Soc. Lond. 1838, p. 55; Ann. Nat. Hist. vol. ii. p. 466 ; Wagner, Schreber, Säugeth. Suppl. vol. ii. (1841), p. 308; Schinz, Syn. Mamm. vol. i. (1844), p. 372; Blyth, Journ. As. Soc. Beng. 1852, vol. xx. p. 349 ; Cat. Mamm. As. Soc. Mus. Beng. 1863, p. 52 ; Gray, Proc. Zool. Soc. Lond. 1864, p. 554; Cat. Carniv. Mamm. 1869, p. 152; Jerdon, Mamm. of Ind. 1867, p. 136.

The type of this species is in the British Museum. It is a large Mungoose measuring 17.50 inches from the tip of the muzzle to the root of the

${ }^{1}$ Prod. Fauna, Zeylan. 1852, p. 44.

${ }^{2}$ It is closely allied to $H$. ichneumon, Wagner, from Egypt, which is apparently identical with $H$. pharoeensis, Desm., which does not appear to differ from $H$. cafra, Licht. (Säugeth.) from North Africa, nor from $H$. widringtoniz, Gray, from Spain. The fur is alike on all of these supposed species, and the tail is black-tipped in all. 
tail. The tail without its terminal hair is 13.25 inches, and with it $2 \cdot 25$ inches longer.

The coloration is dark, as in Herpestes brachyurus of Malacca, but the fur is much longer and resembles that of H.pallidus, to which it is much more closely allied. The under pile is thick, and the long hairs have their tips all black, preceded by a narrow yellow band, followed by three, broad, black bands separated from each other by two, narrow, yellow bands, the base of the hair being yellow. The narrow character of the yellow bands is the cause of the dark colour of the fur, which is markedly speckled. The yellow bands are broader on the tail, and there are seven brown bands, including the narrow apical ring, and six yellow bands, the base of the hair being yellow. The hairs on the head are very short and the annulation very fine. The upper surface of the fore feet is darker than the rest of the body, and the hair is scarcely annulated, while on the hind feet it is wholly darkbrown. The claws on the fore feet are elongated and curved,-doubtless the result of confinement,- -while the hind claws are short and strong. The upper two-thirds of the tarsus are clad. The under surface of the throat is rufous-yellow, very faintly speckled, but the hairs of the chest and belly are nearly as much annulated as on the upper parts, and they are more rufous. The hairs on the sides are 1.50 inch in length, while on the base of the tail they are 3.25 inches long. The tail is concolorous throughout, and like the body, and is of the same character as in H. pallidus.

The skull is an enlarged representation of $H$. pallidus, and the orbit is doubtless perfect in the adult, as the two processes are closely opposed in this skull and touching, although the sutures are not entirely obliterated; the frontal, squamomalar, maxillo-frontal, and nasal sutures being more or less intact, whereas all the others have disappeared. The nasal portion of the palate is rather short and broad. There is a small cusp at the anterior border of the second and third premolars, but the tendency to form such a cusp is evinced by other species of the group, but to a much less extent. The last lower molar has three permanent, anterior cusps, behind which is the posterior half of the tooth. The skull conforms more to H. pallidus, Wagner, than to H. vitticollis, Bennett, and H. brachyurus, Gray, and it is closely allied to H. jerdonii, Gray.

This species inhabits Southern India and Ceylon.

\section{Herpestes Javanicus, Geoffroy.}

Iclneumon javanicus, Geoff. Descript. de 1' Egypte, 1813, Hist. Nat. vol. ii. p. 138, No. 5 ; Desmarest, Nouv. Dict. d' Hist. Nat. 1818, vol. xix. p. 214.

Ichneumon ruber, Geoff. Descript. de l' Egypte, 1813, Hist. Nat. vol. ii. p. 139, No. 6; Desm. Nouv. Dict. 1818, vol. xix. p. 215 ; Mamm. 1820, p. 213 ; Desmoulins, Dict. Class. vol. iv. p. 179.

Herpestes javanicus, Desm. Mamm. 1820, p. 212 ; Müller, Over. de Zool. van den Ind. Arch. 1839, p. 28; Wagner, Schreber, Säugeth. Suppl. 1841, vol. ii. p. 309, pl. 116e; Schinz, Syn. Mamm. vol. ii. (1844), p. 372 ; Cantor, Journ. As. Soc. Beng. vol. xv. 1846, p. 241 ; Gray, Voy. of 
Samarang, Zool. (1850), p. 15 ; Proc. Zool. Soc. Lond. 1864, p. 554, et Cat. Carniv, Mamm. 1869, p. 152 ; Horsfield, Cat. Mamm. E. Ind. Co.'s Mus. 1852, p. 88 ; Blyth, Journ. As. Soe, Beng. vol. xx. (1852), p. 319.

Ichneumon javanicus, F. Cuv. Hist. Nat. des. Mamm. T. ii. Feb. 1821, livr. xxv ${ }^{\mathrm{e}}$, plate.

Mangusta javanicus, Horsfield, Zool. Research. in Java, 1822 (plate) ; Fischer, Syn. Mamm. 1829.

Mangusta rubra, Fischer, Syn. Mamm. 1829, p. 165.

Herpestes exilis, Gervais, Zool. de Bonite, 1841, pp. 32-33, pl. iii. figs. 7-9; Schinz, Syn. Mamm.

1844, vol. i. p. 375 ; Gray, Proc. Zool. Soc. 1864, p. 555 ; Cat. Carniv. Mamm. B. M. 1869, p. 153.

Herpestes rutilus, Gray, Proc. Zool. Soc. 1861, p. 136.

Calogale rutila, Gray, Proc. Zool. Soc. 1864, p. 561 ; Cat. Carniv. Mamm. 1869, p. 159.

This is a large species having the punctulated hair of $H$. auropunctatus, like which the pelage is adpressed and short compared with H. pallidus, but much more dense. The tail is about half the length of the body and longer than in $H$. brachyurus, to which the species in its size and form is closely allied.

The general colour is rather rufous olive-brown, dark on the back, and still darker and more rufous on the upper surface of the head and on the cheeks, on which regions the annulation of the hair is much finer than on the body. The body is very uniformly punctulated, but the lower halves of the limbs are altogether darkbrown. The under surface of the neck from the chin and also the chest are rufousyellow without annulation, but the belly is punctulated like the sides, the hair, however, being much more sparse. The ears are clothed with fine rufous-brown hairs. The fur is not much longer on the hind quarters than it is on the body generally, and on the base of the tail it is not much longer than at its tip. On the flanks the hair is 1.25 inch, the base of the tail 1.70, and near its tip 1.60 inch in length. The underlying pile is sparse, and dark-brown at its base, and bright, rather goldenrusty at its tip, and it is less woolly than in the other species. The long hairs. on the body have broad, brown tips, the succeeding brownish-yellow band being about half the width of the former, and it is generally followed in the longer hairs by three brown bands, one of which is basal, each of these rings being separated from its fellow by a yellow band, half the breadth of the brown rings. In the shorter hairs, the brown bands are reduced to three. The dark colour of the animal is due to the greater breadth of the brown as compared with the yellow bands, and to the subdued colour of the latter. On the tail, there may be either four or five brown bands on each hair, but in the former case the apical band is very feeble and extremely narrow; the usual number, however, is four of either colour, the basal band being yellow. In all, the apical yellow band is but little distinguished from the brown band before it, and the others are but half the breadth of the brown bands. The annulation is uniform to the tips of the individual hairs, but it is not so generally marked as on the body. The claws are of moderate strength and proportionate to the size of the animal. The central line of the tarsus is nude nearly to the heel.

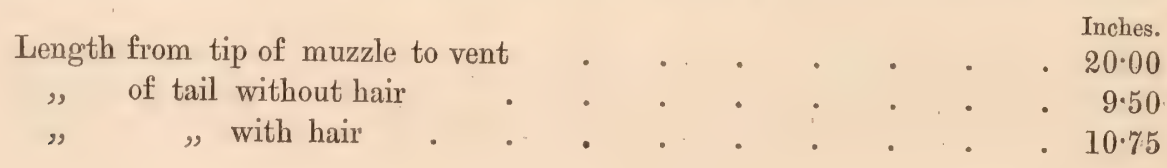


I have not seen the skull of this species, but Horsfield in his Zoological Researches has figured it in profile. His figure was taken from the skull of the largest specimen in the India Museum, London, and it was probably the skull of the example of this species now in the British Museum. Dr. Horsfield, however, only gave the generic characters.

Horsfield's specimen was from Java and Cantor's from Penang, and the type of H. exilis, Gervais, is the young of this species, and H. rutilus, Gray, is an immature specimen obtained by Mouhot in Cambodja. A specimen in the Paris Museum, which I have seen since the preceding remarks were written, stands in that collection under the name of $H$. exilis, Gervais; it was obtained in Cochin China, and is identical with H. rutilus, Gray, and with five other specimens from Java and Sumatra, all of which agree with a fine series in the Leyden Museum referred to $H$. javanicus. I have also examined the type of H. ruber, which is a pale-reddish Herpestes, evidently the adult of this species.

\section{Herpestes brachyurus, Gray. Plate VIII, figs. 3 \& 4.}

Herpestes trachyums, Gray, Mag. Nat. Hist. (New Series,) i. 1837, p. 578; Voy. of Samarang, Mamm. pl. iv. p. 15 (1850); Proc. Zool. Soc. Lond. 1864, p. 556 ; Blainv. Ostéogr. Atlas, pl. vi. ; Cantor, Journ. As. Soc. Beng. 1846, vol. xv. p. 243 ; Blyth, Journ. As. Soc. 1852, p. 349; Cat. Mamm. As. Soc. Mus. Beng. 1863, p. 52.

The type of this species is also in the British Museum. The general colour is dark blackish-brown, finely punctulated with yellow; more especially on the anterior half of the body and on the shoulders, the caudal hairs being broadly black-tipped, and the head paler and more olive-brown than the rest of the body. The fore limbs and the lower half of the hind legs are dark-brown and unspeckled. The chin and throat are rusty yellowish-brown, the chest and belly are brown, and the hairs are banded much as on the back. The underlying pile is yellowish-brown. The long hairs of the fur have indistinct, pale-brown tips, which merge into clear yellow bands, which are succeeded by brown bands, three times as broad as the former, and which are followed by three alternate, yellow and brown bands. The very broad middle area to the hair and the dark tip give the dark colour to the fur, and the bright yellow, sub-apical band produces the yellow-speckled appearance, but in many of the dorsal hairs this band entirely disappears. On the head, the dark bands are pale-brown, and the yellow bands also are paler than on the trunk, so that the head is considerably lighter-coloured. The sides of the face, before the eyes, and the dorsum of the muzzle are pale yellowish-brown, and the cheeks are also of the same colour, but grizzled. The punctulation of the tail is almost obscured by the black. The tail also is untufted, and it is broader at its base, from which it gradually tapers to the tip. The hair of the flanks is $1 \cdot 20$ long, and on the base of the tail an inch longer. The whiskers are rather feeble and pale-brown. The claws are moderately strong, and one-half of the under surface of the tarsus is bare. 
Length from tip of muzzle to root of tail $17 \cdot 50$. Length of tail without hair 7 inches, but Cantor records a male 18.50 inches long, and with the tail 9 inches, and he states that $H$. brachyurus is distinguished from the other species not only by its colour and comparatively short tail, but by its larger size and much more robust make.

The skull figured by Dr. Gray is that of an immature animal, with the orbit incomplete and all the sutures of the skull intact, which, however, is not shown in the figure, although they exist in the specimen which it represents. The posterior portion of the palate is broad and short, the breadth nearly equalling that of $H$. urva, to which the skull has so strong a resemblance that it might be taken for that species, so that there are no skull characters which would entitle us to separate the species generically. The last lower molar is quadricuspidate. This species has been recorded from Borneo and Malacca.

\section{Herpestes vitticollis, Bennett. Plate IX, figs. 3 \& 4.}

Herpestes vitticollis, Bennett, Proc. Zool. Soc. 1835, p. 67; Schinz, Syn. Mamm. vol. i. (1844), p. 374 ; Wagner, Schreber, Säugeth. Suppl. vol. ii. (1841), p. 317 ; Fraser, Zool. Typica, 1849, pl. viii. ; Kelaart, Prod. Faun. Zeylan. 1852, p. 42 ; Blyth, Journ. As. Soc. Beng. 1852, p. 349 ; Cat. Mamm. As. Soc. Mus. Bengal, 1863, p. 159; Giebel, Säugeth. vol. ii. 1859, p. 316; Jerdon, Mamm. of Ind. 1867, p. 137.

Mungos vitticollis, Ogilby, Proc. Zool. Soc. Lond.1835, p. 103.

Mangusta vitticollis, Elliot, Madr. Journ. Lit. and Sc. vol. x. 1839, p. 103, pl. ii.; DeBlainv. Ostéogr. p. 48, pl. xevi.

Taniogale vitticollis, Gray, Proc. Zool. Soc. Lond. 1864, p. 569 ; Cat. Carniv. Mamm. p. 167.

The most striking characters of this large species are the black band behind the ear, the dark-brown, unspeckled limbs, the fiery red and long hair on the hind quarters and tail, and the black tip to the latter. In these respects it differs from every other Asiatic Mungoose. The head is purplish-brown, darkest on the forehead and vertex, which have a rufous tint, and paler on the sides of the head, which tend to greyish, all the head and its sides being finely speckled with yellow from the banding of the hair. The general colour of the front part of the animal may be described as a reddish-yellow, much grizzled with brown, the former colour passing into intense, almost fiery, orange-red on the remainder of the body, but obscurely grizzled. The black band behind the ears runs along the sides of the neck to the shoulders, and below it there is a patch of orange-yellow extending round its posterior end, and over the shoulder is a kind of collar, but not very distinct. The chin and throat are the same colour as the sides of the face, but less grizzled; and the under surface of the neck and chest and over the humerus are vinous brownyellow and punctulated. The belly is nearly concolorous with the orange-yellow sides, but it is not abruptly defined from the colour of the chest, as the yellow bands from before backwards gradually increase in size, until, on the abdomen, they almost completely replace the brown of the hairs. The basal pile is sparse, and it is a rich, pale yellowish-brown. The hairs on the sides have long, orange-red tips nearly one- 
third the length of the hair, and these are succeeded by three brown bands alternating with as many yellow bands. The hairs on the flanks are 2.50 inches in length. Many of the caudal hairs have long, rich orange-red tips, equalling nearly one-half their length and followed by about six alternate, brown and orange-yellow bands. Numerous other hairs have only a narrow, basal, brown band, the rest of the hair being brilliant orange-red, and so long that the banding of the other hairs is hidden by it, and the general colour of the tail is orange-red, except for 3.50 inches which are jet black. The hair at the base of the tail is $3.60 \mathrm{long}$, but it slightly decreases in length as the tip is reached. The ears are covered with short, fine, reddish-brown hairs, and there is a tuft of annulated hairs at their middle, like the hairs on the side of the face. The front limbs are dark purplish-brown, and the front of the hind leg and the tarsus are of the same colour. The claws are moderately developed. The centre line of the tarsus is nude.

From the tip of the muzzle to the root of the tail is 19 inches, and the tail without the hair is 10.50 inches.

The skull of this species is recognised by its large size and by its flattened and expanded frontal region, also by its projected, rather narrow and long muzzle, and powerful teeth. The skull in the British Museum has lost all trace of the sutures, and the orbit is entire. The nasal portion of the palate is moderately broad, and the nasal border tends to form a notch, as in H. maccarthice. The sagittal ridge does not form a crest, and the lines from the post-orbital angles of the frontals meet opposite the frontal contraction, which is moderate. The teeth are the same as in other Asiatic Herpestes, only larger, the last molar being proportionally greater than in the other species.

This form is an inhabitant of Southern India and Ceylon, and is not uncommon.

Herpestes urva, Hodgson. Plate IX, figs. 5 \& 6.

Guio uva, Hodgson, Journ. As. Soc. Beng. vol. v. (1836), p. 238; Cal. Journ. Nat. Hist. vol. ii.

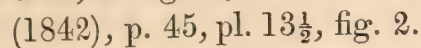

Urva cancrivora, Hodg. Journ. As. Soc. Bengal, vol. vi. (1837), p. 560 ; Gray, List of Mamm. Brit. Mus. 1843, p. 50; Cat. Hodg. Coll. Brit. Mus. 1846, p. 8; Proc. Zool. Soc. Lond. 1864, p. 568, et Cat. Carniv. Mamm. 1869, p. 166 ; Blyth, Journ. As. Soc. Bengal, 1852, vol. xx. p. 349, et Cat. Mamm. As. Soe. Mus. p. 49 (1863); Horsfield, Cat. Mamm. E. Ind. Co. Mus. 1851, p. 93 ; Giebel, Säugeth. vol. ii. 1859, p. 794; Jerdon, Mamm. of Ind. 1867, p. 139 ; Swinhoe, Proc. Zool. Soc. Lond. 1870, p. 630.

Viverra fusca, Gray, Hardwicke's Ill. Ind. Zool. vol. i. pl. iii. (bad figure not described). Mesobema cancrivora, Hodgson, Journ. As. Soc. Bengal, vol. x. (1841), p. 910.

Osmetictis fusca, Gray, Ann. and Mag. Nat. Hist. vol. x. 1842, p. 260.

This animal is about the same size as H. vitticollis, which it resembles in the long, loose character of its fur which is harsh as in that species, and longest on the hind quarters and on the base of the tail. The tail is rather bushy, somewhat more so than in H. vitticollis. The white band below and behind the ear distinguishes it at once from any other known Herpestes. The fur is described by Hodgson as being 
"fulvous iron-grey," many of the hairs being white-tipped, those on the tail so much so that the last half is nearly white. The chest and legs are vinous-brown, the chin is white, and the throat greyish, the belly being greyish-yellow and concolorous with the sides. The top of the head is pale greyish-brown, finely white-speckled, and the muzzle is pale-yellowish. A white area runs along the upper lip and expands over the face behind the eye, but below its level, and stretches backwards to the ear, below and behind which it becomes defined into a pure white band that reaches along the side of the neck, nearly to the shoulder. It is the equivalent of the black band in the same region in $H$. vitticollis. The ears are finely clad with very short, greyish hairs, and there is a pencil of hair external to and within their upper angles as in many other Herpestes. The claws are moderately developed, and not quite so much compressed as in some other Asiatic Herpestes. The upper twothirds of the tarsus, as in $H$. fuscus and $H$. semitorquatus, are thickly clad with hair.

The fur on the sides is $2.70 \mathrm{long}$, and on the bas $\mathrm{e}$ of the tail 3.50 inches. The underlying pile is very fine and woolly, and about 1.20 long, the lower portion of it being pale purplish-brown, and the tip pale-yellowish. It is rather profuse. The long hairs have generally five broad bands, the terminal band being pure white, below which there is a very broad, brown band, equalling more than one-third the length of the hair, followed by a white band of nearly similar width, after which there is a narrower brown and then a basal white band. On the tail hairs, there are generally seven bands, but, near the end, there are only three, consisting of a broad white band at each extremity of the hairs with a narrow, pale, intervening brown band, the basal band having more or less rufous about it.

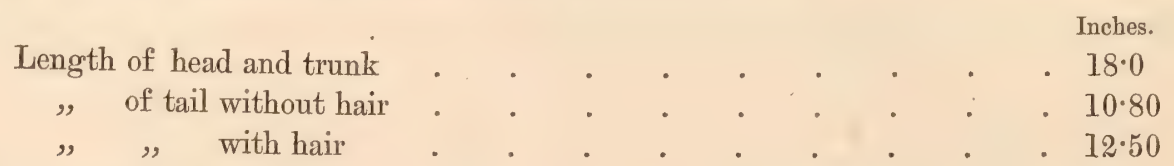

The skull and muzzle are narrower and more elongated than in $H$. semitorquatus. The skull differs from those of $H$. vitticollis, H. pallidus, H. smithii, and H. jerdonii in the concave character of the upper surface of the muzzle, and in this respect it resembles $H$. semitorquatus. The post-orbital contraction is less marked than in these species, and the brain-case is broader and does not contract to the same extent posteriorly, in front of the lambdoidal ridge, as in H. pallidus, H. maccarthice, H. smithii, and H. jerdonii, and in these particulars it is resembled by H. vitticollis, H. brachyurus, and H. semitorquatus. The orbit in the skull of Hodgson's type in the British Museum is imperfect, but the sutures are all intact and the post-orbital processes are well developed, so that it appears probable that the orbit is closed in adult life. The leading features of the under surface of the skull are the shortness of the nasal portion of the palate, and its comparatively great breadth, which equals the transverse diameter of the foramen magnum. The palatal border of the posterior nares is arched. The last lower molar is quadricuspidate, with three external cusps and one internal cusp. 
Hodgson ${ }^{1}$ describes, on either side of the root of the tail, a "round, hollow, smooth-lined gland secreting an aqueous, fotid humour which the animal squirts out posteally (sic) with great force." This species ranges from Nepal along the Himalayas to Assam, through Arracan and Burma to Tenasserim, and extends into the south of China, Swinhoe having obtained it from the Fokien hills, near Amoy, and there is an example in the Paris Museum from Kiangse. Its habits have been said to be somewhat aquatic, but they do not appear to be more so than those of $H$. auropunctatus, which is generally found on the banks of rivers and tanks, where doubtless its food is much the same as that of this so-called crab-eating Mungoose.

\section{Herpestes semitorquatus, Gray. Plate IX, figs. 1 \& 2.}

Herpestes semitorquatus, Gray, Ann. and Mag. Nat. Hist. 1846, vol.xviii. p. 211 ; Voy. of Samarang, Zool. 1850, p. 15, pl. iii.; Proc. Zool. Soc. Lond. 1864, p. 555 ; Cat. Carniv. Mamm. 1869, p. 153.

This species is easily distinguished by the pale area along the side of the neck, from whence it derives its specific name.

The general colour of the animal is a rich orange-brown, most intensely rufous on the sides of the body, the back and upper parts of the side being finely marked with yellow, which becomes very indistinct on the shoulders and outside of the thighs; the fore legs and the lower half of the hind legs are dark purplish-brown. The lower half of the sides of the neck from the extremity of the muzzle backwards below the ear to the front of the shoulder, is a rufous-yellow and clearly marked off from the colour of the upper part of the neck, which is dark rufous-brown and punctulated, while the underlying neck-band is not, and the rufous tint of which increases from before backwards.

The upper surface of the head is finely punctulated, and is much less rufous than the dorsal surface. The chest and belly are rich rusty-brown without any trace of annulation, and are of the same colour as the sides. The tail is not tufted, and is about two-thirds the length of the body. It is much grizzled, as the hairs have long pale-yellow tips succeeding their black sub-apical bands. The tip is concolorous with the pale ends to the hairs, the black bands having disappeared. The claws are moderately strong. The basal pile is rather profuse, pale yellowish-brown at its base and orange-yellow towards its tip. The apices of the hairs on the sides are broadly rich orange-red succeeded by a narrower brown band not very distinct from the former, while the basal portion of the hair is pale-brownish or yellow. On these parts, the hairs are about one inch long. On the back, where the yellow banding is more distinct, the hairs are about the same length as the former. Here they terminate in a narrow, brown tip succeeded by a yellow band followed by a very broad, dark-brown, almost blackish band which embraces about one-half the length of each hair, the base of which is yellow. The hairs below the root of the tail are only 1.30 to 1.50 long, and have the same colour as the preceding, only the 
subterminal and basal yellow bands are broad, especially the latter, while the blackish band diminishes in size as it is traced backwards, so that the tail is a dirty rufous-yellow. The ears are clothed with short, finely-speckled hairs. The tarsus of this species is completely clad in its upper two-thirds, but the inner portion of the lower half over the metatarsus is bare. In H. brachyurus the tarsus has much the same character, whilst in $H$. vitticollis it is wholly nude on its under surface, as in H.pallidus. The claws are moderately developed.

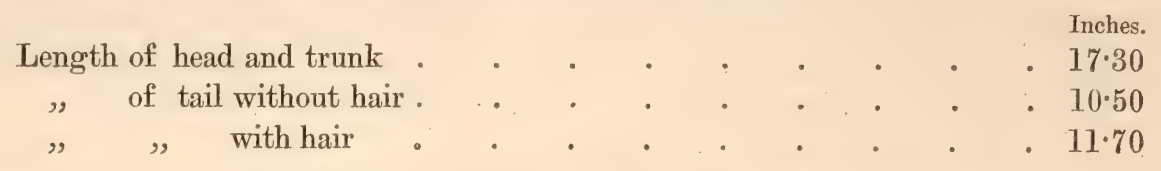

The skull of this species is distinguished by its short, rather broad muzzle, and by apparently an imperfect orbit, as all the sutures are lost, and yet the two processes are far apart. The nasal portion of the palate is rather short and moderately broad, considerably less so than in H. urva. The post-orbital contraction is well marked. The ridges from the orbital processes of the frontal are separate to the middle of the parietals, but form two prominent lines.

Habitat.-Borneo. 


\section{MUSTELID压.}

Genus Helictis, Gray.

* Helictis moschata, Gray.

Helictis moschata, Gray, Proc. Zool. Soc. 1831, p. 94, et ibid, 1865, p. 153; Cat. Mamm. Carniv. \&c., B. M. 1869, p. 142 (in part); Schinz, Syn. Mamm. 1844, vol. i. p. 328.

Melogale personata, Is. Geoff. Zool. Voy. de Bélanger, 1834, p. 137, pl. v. ; Blainv. Ostéogr. G. Mrustela, pl. xiii.

At Teng-yue-chow in Yunnan, at an elevation of 5,000 feet, I obtained a wolverine which I refer to this species, and to which the Formosan form $H$. subaurantiaca, Swinhoe, is very closely allied. Two other species have been described, viz., H. orientalis, Horsfd. (=H. fusca, Is. Geoff. St.-Hil. $)^{1}$, and H. nipalensis, Hodg. They have all a strong resemblance to each other in their external characters, all of them being distinguished by certain head-markings which are wonderfully persistent in the different species, although they are, at the same time, the subjects of modifications which, however, are not merely distinctive of the species, but involve subordinate variations in the individuals composing them, the tendency being either for the white head-markings to become intensified by extension, or obliterated by the encroachment of the general colour of the fur, the general plan, however, of their distribution being adhered to in all.

If no other characters than those yielded by these modifications of the external colour of the animals had existed for discriminating the species, I would not have hesitated to regard them all as only local varieties of a common specific type, but this apparent similarity masks certain osteological differences which clearly indicate that the divergence from the original stock from which these animals have sprung has been in a two-fold direction, if one or other of them is not the existing representative of the peculiar features of the primitive stock. Reliable characters for distinguishing the species are only yielded by the skulls, and they have been brought prominently forward by Dr. Gray. ${ }^{2}$ The skulls belong to different types, the first distinguished by its shortness, large teeth, short palate, and the small, rounded character of its infra-orbital foramen $=H$. orientalis; the second by its greater length, long palate, large teeth, and small infra-orbital foramen $=H$. nipalensis; and the third by its long skull and palate, small teeth, and large infra-orbital foramen $=H$. moschata. But another species has been recognised, the H. subaurantiaca, Swinhoe, described from Formosa. Swinhoe ${ }^{3}$ was under the impression, judging from external characters, that this insular form displayed stronger affinities towards the Himalayan H. nipalensis, Hodg., than to the neighbouring continental H. moschata, Gray, but the consideration of the characters of the skull conclusively proves

1 Guerin. Mag. 1835, pl. xvi.

2 Cat. Carniv. Mamm. B. M. 1869, p. 141.

3 Proc. Zool, Soc. Lond. 1862, p. 349, et ibid, p. 355, pl. xliv. 
that any affinity which it manifests in the direction of $H$. nipalensis is through the intermediately lying form $H$. moschata, which by its geographical position and doubtless by its genesis is related much more to $H$. nipalensis than to $H$. subaurantiaca, Swinhoe, the skull of which in its dentition and the size of its infraorbital foramen belongs to the same type as $H$. moschata, Gray, whereas the skull of $H$. nipalensis, Hodg., in these details is closely allied to $H$. orientalis, Horsfd. The following are some of the details by which these species may be recognised. $H$. orientalis is distinguished from $H$. nipalensis by the shortness of its alveolar border, including that of the premaxilla, so that the former has a shorter muzzle than the latter; whereas in $H$. moschata and $H$. subaurantiaca the alveolar length is almost equal, and considerably in excess of $H$. orientalis and shorter than H. nipalensis, and the posterior portion of the palate in all the species, except $H$. orientalis, is concave, and the portion behind the last molar is longer and broader in H. moschata. In all, with the exception of $H$. nipalensis, the external margin of the palatines where they project behind, forming the wall of the posterior nares, present a faint ridge externally, with a convex surface outside it which is wanting in H. nipalensis. The skull of H. orientalis is distinguished by the shortness of the interval between the narial margin of the palatines and the tip of the hook-like process of the pterygoids, which is less than in any of the other species. The skull of H. nipalensis is considerably broader across the zygomatic arch, external to the condyle, than in H. orientalis ; the former also has a longer muzzle than the latter, as is shown by the distance from the external orbital angle to the tip of the pre. maxillaries, and from the front of the penultimate molar to the same point, both of which distances in $H$. nipalensis exceed those of $H$. orientalis. In the former, the muzzle is also narrower across its middle than in the latter, and the nasals are contracted about the same position in their length, and rounded, and somewhat expanded and pointed posteriorly. The premaxillaries of $H$. orientalis nearly touch the nasals, but in $H$. nipalensis they are considerably removed from these bones. The tympanic bullæ of the latter are somewhat less distended and smaller than in the former.

The skull of $H$. moschata is long, and in this respect resembles $H$. nipalensis, and differs from the short skull of $H$. orientalis ; it is, however, markedly separated from these two species by its small teeth and by the great capacity of its infraorbital foramen. Its muzzle has about the same length and proportions as H. nipalensis, but the long posterior portion of the palate, which is broader and more decidedly concave than in that species, has a ridged and rounded lateral border. In $H$. moschata and $H$. subaurantiaca the length of the two skulls is about the same, and the two palates are nearly of equal dimensions, that of the former being slightly in excess of the latter, but not to a greater extent than would be accounted for by difference of sex or age, for in other respects the skulls are essentially alike. In the length of the palate, $H$. moschata agrees with $H$. nipalensis, which, on the other hand, is considerably in excess of the palatal length of $H$. orientalis. The difference in length of palate that exists between $H$. moschata and $H$. sub. 
aurantiaca is not greater than that between different skulls of undoubted $H$. orientalis. It is also observable that the last-mentioned species presents two types of skull, one in which the orbital contraction of the frontals is not so narrow as in the other type, and associated with the greater width at this point, the skull, across the anterior border of the squamosal suture, is also broader than in the narrower type, and the ridges of the external orbital angle are much further apart than in the narrow skulls, the upper surface being therefore more flattened than in the narrow form. These differences are in all likelihood due to sex, and it is probable that the broad type represents the male, and the other and more slender skull the female sex. In the British Museum there is only one skull of $H$. moschata and one of $H$. subaurantiaca, and it is interesting to observe that the former belongs to the same type of skull as the broad skull of $H$. orientalis, and the latter to the narrow form of the skull of that species, and that these two skulls are as intimately related to each other as the supposed male and female skulls of H. orientalis. With these scanty materials, however, it would be premature to say that the Formosan form is not specifically distinct from the continental wolverine, but it seems to me that the remarkable similarity that exists between the skulls of the type specimens of the species points in the direction of the insular form being only a local variety whose distinguishing characters are as yet confined to its pelage.

After a careful consideration of Is. Geoffroy's description of H. personata, which was procured in the neighbourhood of Rangoon, and which Blyth regarded as H. orientalis, I am disposed to think that it is more applicable to H. moschata, in which the colour accords with that ascribed by Geoffroy to his species, in which also, as in H. moschata, the hair, especially on the thighs and fore arms, is tipped with white, which is not the case in H. nipalensis, which is a dark-coloured form. This species was originally described from Cantor's specimens, and Swinhoe $^{1}$ has observed it in Hainan, Amoy, and Shanghai, so that it has a wide distribution over Eastern Asia. With regard to Shanghai specimens, the latter naturalist remarks that they are more tinged with orange-yellow on the under parts, and that in colour they approach the Formosan species.

Swinhoe has mentioned the crepuscular habits of the Formosan wolverine, and from personal knowledge I am aware that H. nipalensis appears to be essentially ructurnal in its habits, being only seen at night, when it comes out to feed, and it not unfrequently enters the huts of the Bhooteas and Lepchas of Darjeeling. On one occasion, in a Bhootea hut, I killed a Nepal wolverine, having mistaken it for a large rat; but my host was much chagrined at my successful raid on the supposed intruder, as he informed me the animal had been nightly in the habit of visiting him, and that it was not only inoffensive, but most useful in destroying cockroaches and other insects. 


\section{Genus MeLes, Gesner.}

\section{* Meles (Arctonyx) collaris, F. Cutier.}

Arctonyx collaris, F. Cuv. Hist. Nat. des Mammif. p. 220, Sept. 1825; Fischer's Syn. Mamm. 1829, p. 152 ; Horsfield, Cat. Mamm. East Ind. Co. Mus. 1851, p. 114; Blyth, Cat. Mamm. As. Soc. Beng. Mus. 1863, p. 71 ; Jerdon, Mamm. of India, 1867, pp. 77 and 78; Gray (in part), Cat. Carniv. Mamm. B. M. 1869, pp. 123 and 124.

Mydaus collaris, Gray, Wagner, Schreber, Säugeth. vol. ii. 1841, pp. 186, 187 ; Gray and Hardwicke's Ill. Ind. Zool. vol. i. tab. vi.; Cat. Mammif. Brit. Mus. p. 70 ; Schinz, Syn. Mamm. 1844, i. p. 317.

This species ranges as far as Teng-yue-chow, where I obtained a skin. It is distinguished from the nearly allied species $A$. taxoides, Blyth, ${ }^{1}$ by its shorter and rougher fur, its broader muzzle, larger ears, and longer tail; also by its colour and markings being less intense than in that species. ${ }^{2}$ It is also larger than $A$. taxoides, the skull of which in the adult female is only 4.75 inches in length, while in the female of $M$. collaris the skull is 6.38 inches long. There is also much greater breadth, and the palatal region is considerably longer and of greater transverse capacity than in A.taxoides, as has been fully proved by Blyth's ${ }^{3}$ measurements of the respective skulls. In this species the greatest breadth across the zygomatic arch is 3.64 to $2 \cdot 38$ in $A$. taxoides, and the length of the palate in the former is 3.88 to 2.75 in the latter. The narrow character of the snout in $A$. taxoides is borne out by the relative breadth of the palate as compared with the palate of this species, in which the diameter at the last molar is $1 \cdot 07$, whilst in the former it is only 0.81 . And in connection with these measurements it is noteworthy that the species $\mathbb{M}$. leucurus, Hodg., ${ }^{4}$ and $\mathbb{M}$. taxus are distinguished from each other by similar differences in the relative breadth and development of their palatine surfaces, which, of course, influence the character of the muzzle in these different badgers, which are also separated by the differences they present in the breadth of their skulls both across the zygomatic arch and basal portion of the brain-case. As pointed out by Blyth, these two species have a nearly similar distribution, ranging eastwards from Nepal to Assam, Sylhet, and Arracan. M. (A.) collaris, as I have observed, extends to Western Yunnan.

The badger of Eastern China ${ }^{5}$ closely resembles Meles taxus in external appearance, but is separated from it by the pronouncedly different characters of its skull. It has been fully described by A. M.-Edwards from specimens obtained by the late M. Fontanier in the vicinity of Pekin, and has been satisfactorily identified by him with II. chinensis, Gray. Dr. Gray has stated that he saw no appreciable

${ }^{1}$ Journ. As. Soc. Beng. 1853, p. 591.

${ }^{2}$ Proc. Zool. Soc. Lond. 1856, p. 398, pl. L.

${ }^{3}$ L. $c$.

4 Journ. As. Soc. Beng. 1847, vol. xvi. p. 763, pl. xxix.

5 Rech. Mammif. 1868-74, pp. 190-195, pls. xxv. to xxviii.; Ann. des Sc. Nat. 1867, $5^{\text {me }}$ Série, vol, viii. p. 374 ; Gray, Proc. Zool. Soc. 1868, p. 207, fig. of skull, et Cat. Carniv. B. M. 1869, p. 126; Swinhoe, Proc. Zool. Soc. 1870,
p. 622 . 
difference between the skull of M. leucurus, Hodg., from Lassa, in Tibet, and the skull of $\not{M}$. chinensis, ${ }^{1}$ Gray; and after a careful examination of the skull of the type M. leucurus ${ }^{2}$ with four skulls of M. chinensis, I see no reason to differ from Dr. Gray. I have also compared the skin of Hodgson's typical specimen of M. leucurus with the figure and account of $M$. leptorhynchus, A. M.-Edwards, and they seem to me identical-a conclusion which I have arrived at from a consideration of osteological as well as external characters. I have also carefully examined the types of $\mathbb{M}$. leptorhynchus. The skull of $M$. chinensis which Dr. Gray figured belonged to a slightly immature female, and is somewhat smaller than the skull of $M$. leucurus, which belonged to the same sex. The only difference that I can detect between them is, that the contraction of the brain-case behind the external orbital angle is less in the latter than in the former, but the difference is so slight that no importance can be attached to it, more especially as the other skulls of M. chinensis vary quite as much among themselves, as is demonstrated in the accompanying table. These skulls also show considerable variation in their basal breadth when measured between the auditory processes. Any little variation manifested by the skull of M. leucurus seems to me to have its counterpart in one or other of these skulls of M. chinensis.

The skull of $M$. leucurus, ${ }^{3}$ which in its basicranial length exceeds only by a very little that of the skull of $M$. leptorhynchus, practically agrees with it in the length of the palate, in the breadth across the infra-orbital foramina, across the zygomata, at the condyles, and across the base of the skull between the auditory processes. The zygomatic arch, however, of $M$. leptorhynchus is considerably stronger, but this may be a sexual character, or individual variation. The depth, too, through the coronoid process of these skulls of $M$. chinensis, in the females, is less than in $M$. leptorhynchus, and the female skull of $\boldsymbol{M}$. leucurus resembles them also in this respect.

Measurements of skulls of $\boldsymbol{M}$. leucurus, Hodgson, and of $\boldsymbol{M}$. chinensis, Gray:

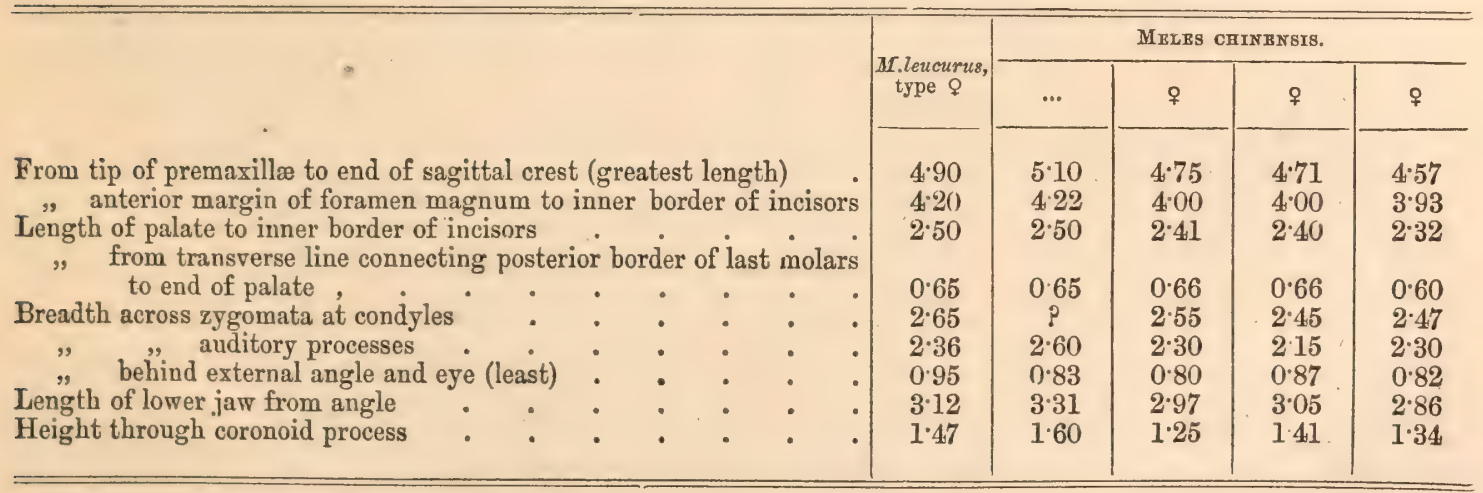

${ }^{1}$ Cat. Carniv., B. M., 1869, pp. 127 and 128.

2 Journ. As. Soc, Bengal, 1847, pp. 763-770, pls. xxix, $x \times x$ et xxxi, fig. B.

${ }^{3}$ Dr. Gray, writing on $M$. leucurus, Proc. Zool. Soc., 1853, p. 190, says that he had compared the skull with those of the various badgers in the India Museum Collection, and that having mentioned to Hodgson that it was very distinct from the Taxidea of North America, Hodgson had proposed to name it Pseudo-meles leucurus, under which name it now stands in the India Museum, London. 
Hodgson states that the tail of $M$. leucurus was only one-fourth the length of the body and head, while, including the hair of its extremity, it was half the length of the animal. But as his specimen was a flat skin, not much reliance can be placed on the relative proportions of the tail to the body. A. M.-Edwards and Dr. Gray have suggested that this is the species referred to by Middendorff and Schrenck as varieties of the European badger.

Another species has been described from Tibet by Blyth as Meles albogularis, ${ }^{1}$ and although he had never seen the skull, he was of the opinion that Hodgson in describing and figuring his Taxidea leucurus had depicted its body' but the skull of the Tibetan Meles albogularis as that of T. leucurus. He also states, and in this I agree with him, that there can be no doubt of the specific distinction of the two animals. $\mathbf{M I}$. leucurus has a black throat and no band passing up from the angle of the mouth to the ear, while $\boldsymbol{M}$. albogularis has a white throat and a dark-brown band from the gape to the ear. Hodgson has also described from Tibet $M$. isony $x,{ }^{2}$ a badger of the same size and general characters as $M$. albogularis, also distinguished by its white throat and by a brown band from the gape to the ear. I have examined the types of both of these species, and do not find that they differ in any respect from each other, and both of them are from Tibet. The characters of these species have been fully described by Blyth and Hodgson. I have examined the types of $\mathbb{M}$. leucolamus, ${ }^{3}$ A. M.-Edwards, and A. obscurus, A. M.-Edwards, both of which are white-throated badgers, one from China and the other from Tibet. The last is about half the size of the first mentioned, but so closely resembles it in its head-markings and general characters, that it appears to me that it will in all probability prove to be a young individual of $\mathbb{M}$. leucolamus, which, I think, will also be found to be identical with $M$. albogularis, Blyth. A. M.Edwards states that $A$. obscurus is characterised by a shorter and less bushy tail than $A$. collaris, by the fronto-nasal band ceasing on the middle of the sinciput, by its brown cheeks, and by the white of the throat not being prolonged all round the base of the neck. A white spot also is mentioned as existing below the eye. A dark-brown band extends from the base of the ear to behind the angle of the mouth and spreads itself on to the chin. $\mathbb{M}$. albogularis, Blyth, has a shorter tail than the European badger, the fronto-nasal band contracts between the eyes, and is not continued further back than between the ears. The dark lateral bands of the head expand behind the eyes and merge on the occiput, with the grizzled hue of the back; the cheeks have little white below the eye, and any that there is, is ill defined, and is bounded below by a narrow, dark-brown stripe from the ear to the angle of the mouth; the throat is white. The striking similarity of these two descriptions and the observation of the animals lead me, as I have said, to believe in their specific identity.

Journ. As. Soc., Bengal, vol. xxii (1853), p. 590.

2 Proc. Zool. Soc., 1856, p. 398, pl. i.

${ }^{3}$ Rech. des Mamm. (1868-74), pp. 195-205, pls. xxiv and xxviii, et Ann. des Sc. Nat, 5th Series, 1867, vol. viii,

${ }^{4}$ Rech. des Mamm. (1868-74, pp. 338-341, pl. Ixii et pl. Iviii, fig. 2. 
The two examples of $M$. leucolcemus in the Paris Museum, which I have examined, somewhat differ from each other. The specimen figured by A. M.-Edwards is not so dark as the other, which is larger and has the dark-brown band through the eye very much less defined, and the white of the cheek more intense, and covering a much larger area than in the type. In both, a dark-brown band or line extends from the angle of the mouth upwards in the direction of the ear. In the type this band is more expanded than in the other, and joins the dark area between the eye and ear, whereas in the latter it does not join the dark aural area, and the white of the cheek is thus in this specimen prolonged directly backwards to the white on the side of the neck, whereas in the type the white below the eye is closed in posteriorly by the band from the mouth to the ear. In the non-figured example, the white of the naso-frontal region is prolonged beyond the eyes on to the vertex, where it spreads itself, even between the eyes and ears, as the dark-brown band from the snout backwards is interrupted between the eyes and ears, although the eyes are encircled with dark-brown, whereas in the type this latter band is continuous from the snout to the ears, and the white naso-frontal band contracts on the vertex, beyond which it is backwardly prolonged as a narrow line. The figured specimen, which is the smaller of the two, more closely resembles $\mathbb{M}$. obscurus than the adult, but the differences between the three are so slight, that they appear to be examples of one species, differing only in age. The type of $\mathbb{M}$. isony $x$ closely corresponds with them. The white, naso-frontal band extends backwards over the vertex and passes gradually into the colour of the nape. The narrow, dark-brown band from the snout passes backwards to the ears, surrounds the eye, and expands behind it and involves the ear, which is white-tipped, as in $\mathbb{M}$. leucolcemus and $\mathbb{M}$. albogularis. A narrow, dark-brown hand passes from the angle of the mouth to the dark area below the ear, and a white area is thus enclosed on the cheeks below the eyes. The throat is white, and this hue passes upwards on to the side of the neck, as in M. leucolamus, behind the brown band from the angle of the mouth. The limbs, chests, and belly are black, of variable intensity on the last two regions. The tail is white, and apparently shorter than in $M$. leucurus, Hodgson.

Allied to Meles taxus is the M. anakuma, ${ }^{1}$ Temm., from Japan, and which Dr. Gray ${ }^{2}$ also regarded as identical with the $\mathbb{M}$. taxus var. of Middendorff, and the M. taxus var. amurensis, Schrenck, whilst at the same time he thought it probable that the latter might turn out to be $M$. chinensis.

A. M.-Edwards ${ }^{3}$ has given a very just estimate of the relations in which the badgers with short and with long palates stand to each other, and has pointed out that there are no sufficient reasons for regarding the unimportant modifications of structure which these long-palated forms exhibit as of generic importance, and he would therefore rank them as of sub-generic value.

\footnotetext{
Fauna Japonica (1842), p. 30. pl. vi. figs. 1-6.

Cat. Carniv. Mamm. B. M. 1869, p. 125.

I. c.
} 


\section{* Genus Lutra, Linn.}

Dr. Gray, in the Catalogue of Carnivorous Mámmalia, ${ }^{1}$ separates Enhydris lutris, or the Sea Otter, as a distinct tribe from the true Otters, under the name Enhydrina. The Lutrina or true Otters he refers to two groups depending on the character of their tails; the first having the tail rounded on the sides, and the second having the tail with a cord-like ridge on each side. The first of the groups is broken up into genera, viz., Barangia, Lontra, Lutra, Nutria, Lutronectes, Aonyx, Hydrogale, and Latax; and the second group contains only the genus Pteronura. These first eight genera are again referred to sub-divisions: one, including the first six genera, is said to be distinguished by the palms and soles of the feet being bald between the pads, and the palm pads, without any small circular warts on their hinder edges; the other, which includes the last two genera, has the under surface of the feet, between the finger pads and palms, sprinkled with scattered, soft hairs, and the inner part of the under surface of the two inner hind toes with a band of close, short, soft hairs. In some of the animals of the first group, the nose is clothed with hair, while in others it is bald, which is also the character of the nose of the animals of the second group.

The ridge-like cord on the tail of Pteronura, Gray, or Pterura of Wiegmann, ${ }^{2}$ is of a doubtful nature, and is not a sufficient character to give the animal generic rank, as the tails of other Otters are not rounded, but have sharp margins ; and Dr. Gray seems ultimately to have allowed this. The cranium and teeth also exactly conform to the true Lutrine type, the only remarkable feature of the skull being its great size; but other Otters-e.g., Lutra inunguis and Lutra braziliensis-are quite as remarkable in this respect.

On examining the feet of the Otters referred by Gray to the secondary subdivision of the Lutrina, I observe that the greater number were characterised by the presence of scattered small hairs on the under surface of the webs, so that the absence or presence of scattered hairs on the palms and soles must be abandoned as a means of separating the genera.

The sub-division of the first of the two primary groups is again sub-divided into two minor groups, the first distinguished by its hairy, and the second by its bald nose. But the first of these is subjected to a further sub-division, in which the nose is said to be perfectly hairy in one, and partially bald in the other. To the hairy sub-division the genus Barangia is referred, but I observe that the nose of the type of this genus is not perfectly clad, as the centre between the nostrils is bare, and Cantor mentions that the hair becomes partially rubbed off with age; but in a full-grown animal in the India Museum, London, the nose is still hairy.

Before adverting to these genera more particularly, it may be stated that the teeth of all exhibit a remarkable conformity of structure, and that they do not offer,

\footnotetext{
${ }^{1}$ Cat. Carniv. \&c., B. M. 1869, pp. 100-118. 2 Archiv. fur Naturgesch. 1838, p. 392, pl. 10.
} 
as far as my observations go, and I have examined each genus, a single character by which to separate them generically one from the other, the only difference being, as was to be looked for, that in such large animals as Lutra braziliensis and L. sandbachii, the teeth are very much larger than in the skulls of the smaller Otters, such as $L$. vulgaris; the only exception being that the molar teeth of the small-clawed Otters are proportionally larger than in their compeers with long claws.

With regard to the cranial characters which Dr. Gray regarded as distinctive of Barangia, it must be remarked that the skull from which he derived them is that of a young animal, and that the little definition of the orbital processes is entirely a character of youth-a view of the question which is fully borne out by an inspection of the skull of an adult animal which I have had the opportunity of examining, as Mr. Moore of the India Museum, London, permitted me to remove the skull from Cantor's specimen, Plate XII, figs. 4 to 6. This skull has the orbital processes quite as well developed as in Lutra vulgaris, from which it does not differ generically. The nasal bones of Otters, as of other allied forms, are subject to considerable variation, and I cannot detect that they materially differ in this species from those of the ordinary Otter, or that the premaxillæ are more slender than in Lutra. I do not therefore see any character by which this hairy-nosed species can be separated generically from Lutra, because the singular fact of a hairy nose is not sufficient of itself to give the animal generic rank, while at the same time it is a good specific character by which the animal can be recognised among Asiatic Otters.

Dr. Gray in his Catalogue ${ }^{1}$ describes under the genus Barangia a small Otter skull from Nepal with abraded, superior orbital processes, but regarding which there is no evidence that it belongs to an Otter with a haired nose, because the skull of the hairy-nosed Otter does not differ generically from the skull of Lutra. This form he doubtfully referred to Barangia under the specific term nepalensis.

The skull of the genus Lontra of Dr. Gray's catalogue ${ }^{2}$ resembles that of Aonyx in its general form and the proportions of its different parts, but on an enlarged scale. The molars, also, in their relative proportions conform to Aonyx, but the other structural features of the animal do not entitle it to be separated from Lutra. The skull of Lontra brasiliensis, Gray, is so closely allied to a skull that stands in the British Museum as Nutria felina ${ }^{3}$ that they might be one and the same species, and I fail to detect the characters by which this genus is said to be at once known from the others. The dentition of Nutria is identical with that of Lutra.

The cranium of the genus Latax, Gray, ${ }^{4}$ is essentially that of Lutra. The concavity of the palate ascribed to it is very little more than may not unfrequently be observed in Lutra vulgaris, and the last molar holds the proportion to the penultimate tooth that exists in Aonyx.

The skull of the South African Hydrogale is intermediate between that of Lutra and Aonyx, and its distinguishing features are the narrow character of the inter-orbital portion and the absence of the post-orbital frontal process, the lower or

$$
\text { L.c., p. 101. } \quad{ }^{2} \text { L. c., p. } 102 . \quad{ }^{3} \text { L.c., p. } 106 . \quad{ }^{4} \text { L. c., p. } 112 .
$$


malar process being developed. In this character it is distinguished both from Aonyx and Lutra, but its dentition is essentially that of Lutra. Dr. Gray referred Hydrogale to that division of the Lutrina which he considered to be distinguished by the under surface of the feet being sprinkled with scattered, soft hairs, but the artificial nature of this character is evident by the fact that in the supposed naked-palmed and nude-soled section, a semi-adult Otter (No.45, 1, 8, 367) referred by Dr. Gray to L. monticola, Hodgson, has its palms and soles sprinkled with hairs as in Hydrogale; and this is also the case in a small-clawed Otter from Madras (No. 67, 11, 14, 2). It would seem, therefore, that the characters which Dr. Gray selected to separate Hydrogale do not belong exclusively to it, but occur also in the genus Lutra.

Temminck ${ }^{1}$ considered the Otter of Japan as identical with the European species, but Dr. Gray went so far in the opposite direction as to regard it as a distinct genus, which he called Lutronectes. ${ }^{2}$ The two skulls on which this genus has been founded are in the British Museum. They are both young skulls, but the orbital processes, for their age, are not less developed than in examples of Lutra vulgaris of corresponding age, and I cannot see that the flesh-tooth differs in any essential particular from the flesh-tooth of Lutra. The arrangement of the intermaxillaries and the character of the nasals are the same as in the common Otter; -in short, these skulls do not yield any characters by which they can be separated generically from Lutra.

The distinctive features of the genus Aonyx which would appear to give it sub-generic rank are the shorter and more globose cranium as compared with Lutra; the relatively greater size of the molars $;^{3}$ and the inner portion of the last molar being the largest part of the tooth, while in Lutra the outer exceeds the inner half; the almost general absence of the first upper premolar; and the rudimentary claws which are associated with much more feebly developed finger and toe bones, which are much tapered to a point, while in Lutra these bones are strong and well developed. The skeleton generally of the Asiatic species is also of a much lighter build than in Lutra. The modification of its extremities as it penetrates to the skeleton is quite as important a character generically considered as the remarkable flattening of the phalanges of the hind feet of Enhydris lutris. Unfortunately we do not possess any information regarding the special habits of Aonyx as contrasted with those of the longer-clawed Otters. The genus Aonyx, ${ }^{4}$ as is well known, was founded by Lesson ${ }^{5}$ for the reception of the large African Otter, Lutra inunguis, F. Cuv., which greatly exceeds in size any example of Lutra (Aonyx) leptonyx.

Dr. Gray ${ }^{6}$ was of the opinion that there were two distinct Otters in Formosa, one which he referred to L. chinensis, and another, of which he obtained only the front part of the upper jaw, with the teeth in change from the milk to the permanent series.

${ }^{1}$ Fauna Japonica, Mamm. 1847, p. 35.

2 Proc. Zool. Soc. 1867, p. 180, woodeut.

${ }^{3}$ Giebel Odontog. 1855, pl. xii, fig. 10, milk-teeth. Zeits. Ges. Naturwissen., 1868, vol. xxsi. p. 217.

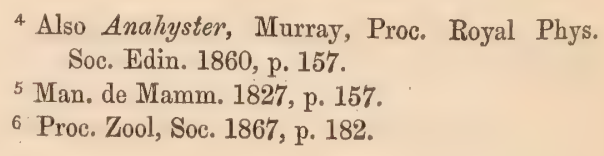


I have examined this fragment, and the short truncated palate and the relatively large molars enabled me, without reference to Swinhoe's description, to assign it unhesitatingly to the sub-genus Aonyx. Dr. Gray first referred this animal to his second section Hyajrogale, ${ }^{1}$ and afterwards in his Catalogue ${ }^{2}$ to Lutrogale, under which sub-generic name the fragment stands in the National Collection.

I propose now to indicate briefly the Southern Asiatic species of Otter.

The different species of Southern Asiatic Otters are very imperfectly known, and great confusion has arisen from the misapplication of the native names.

Marsden in his great work on Sumatra ${ }^{3}$ figures two Otters from that island. The first ${ }^{4}$ is a strongly clawed species, which, judging from the figure, appears to have had a haired nose, but there is no allusion in the text to this character. The tail is proportionally longer than in the common Otter of India, and the animal is referred to Mustela lutra. The second figure ${ }^{5}$ represents a smaller animal with a relatively shorter tail than the previous one, a naked nose, and small claws. The native term Anjing Ayer, "water dog," is applied to both of these animals.

Raffles ${ }^{6}$ also mentions two species of Otter from Sumatra known by the common appellation of Anjing Ayer. The larger he distinguished under the name of Simung, and the smaller by that of Barang-Barang, or Ambarang. The latter, according to Raffles, appeared to be nearly allied to Lutra lutreola, being almost a foot and a half in length and of a glossy, brown colour, and white on the mouth and throat. The feet he described as being covered with hair and the toes as of unequal length, but he makes no mention of the character of the claws in either of the species. The tail is stated to be shorter than the body and covered with hair, thick at the base and tapering to a point. The type of the Simung of Raffles still exists in the India Museum, London, but the skin is not in a good state of preservation, so that the result of a comparison of it with some of the other species is not very satisfactory. On certain points of structure, however, it is an important record, for its extremities, which are perfect, prove that it is a long-clawed Otter like L. nair, F. Cuvier, from which it does not differ in any of the details of the structure of its feet, and, like that species, its nose is bald, and the tail holds the same proportion to the body as in that form, which it also resembles in its colouring.

As no specimens of the Otter of Sumatra named Barang by Raffles exist either in the British Museum or in the India Museum as donations from that distinguished man, his published description is the only guide to the characters of the animal, but, as already indicated, it is too vague to be satisfactory. The majority of naturalists, however, have regarded the Barang of Raffles as the smallclawed Otter figured by Marsden, and, I think, in all likelihood, that this view of the question is correct, but Cantor applied the term Barang to an entirely different animal.

P. Z. S., 1867, p. 182.

\& Cat. Carniv. Mamm. \&c. B. M. 1869, p. 105; and Proc. Zool. Soc. 1870 , pp. 624 \& 625.

3 Hist. of Sumatra, 3rd ed. 1811.
${ }^{4}$ L. c., pl. xi. No. 1.

5 L. c. pl. xi. No. 2.

6 Trans. Linn. Soc. Lond. 1822, vol. xiii. p. 254. 
Horsfield, in his Zoological researches in Java, described the small-clawed Otter of that island as Lutra leptonyx, erroneously regarding it as the Simung of Rafflesan error which he afterwards rectified in his Catalogue of Mammalia.

In 1823, F. Cuvier described $L$. nair, ${ }^{1}$ a species which I shall have occasion to refer to more particularly hereafter, and, at the same time, drew attention to and named a young Otter $L$. barang, received from Java from M. Diard, who was F. Cuvier's authority for the Javanese native name of the species.

I have examined this latter type, which does not prove to be an Aonyx, as has been generally supposed, but a true Lutra with a naked nose and well-developed claws, as in $L$. nair, the common Otter of India. The fur, as in young Otters, is long and loose, and F. Cuvier, who seems to have examined the skull, states that the specimen was immature, and that the great size of its cranium led him to believe that the adult animal attained to the size of the Simung, and that it was probably the young of that animal and not the young of $L$. nair. The type of $L$. barang in its peripheral characters resembles the young of $L$. nair. I was unable to find the skull of this specimen in the Paris Museum, although in my search I was kindly assisted by M. Paul Gervais, unless a skull which now stands in the Catalogue under the name of $L$. perspicillata, Is. Geoff. St.-Hil., is it-a supposition which seems probable from the circumstance that on the skull is written $L$. barang, under which name M. Paul Gervais included it in his manuscript Catalogue. This skull, considering its youth, is of such dimensions that the adult animal must attain to a considerable size, and might be, as Frederick Cuvier has suggested, the young of the Simung. But, as I have already observed, the skull of the type of $L$. simung has been lost if it was ever deposited in the India Museum. The type of $L$. barang, however, conclusively proves that it is neither an Aonyx nor an Otter resembling the hairy-nosed species of Malacea which Cantor considered to be L. barang, Cuvier, and which Gray elevated to generic rank under the name of Barangia.

Horsfield, ${ }^{2}$ in his Catalogue of Mammalia, does not indicate to which of the species therein described the $L$. barang of F. Cuvier is referable, but, as already mentioned, he corrects his original error regarding his Simung of Raffles as the equivalent of his Lutra (Aonyx) leptonyx, but erred in considering the $L$. barang of Cantor as a synonym of that species, as I have ascertained by a personal inspection of Cantor's specimens. Fischer, ${ }^{3}$ in his synopsis, perpetuated Horsfield's first error in assigning the Simung of Raffles as a synonym to $L$. $(A$.) leptonyx, with which it has no affinity, while he was apparently correct in considering $L$. perspicillata, Is. Geoff. St.-Hilaire, as identical with $L$. leptonyx, under which species Horsfield makes no reference to $L$. perspicillata, although it appears to be identical with the short-clawed Otter of Java.

$L$. perspicillata was described by Is. Geoff. St.-Hilaire in $1826^{4}$ under the impression that he was dealing with the Simung. Having examined the type of this supposed species, I am in a position to state that it is in all probability the young of

1 Dict. Sc. Nat. vol. xxvii. 1823, p. 247.

2 Cat. Mamm. E. Ind. Co. Mus. 1851, p. 117.

3 Syn. Mamm. 1829, p. 227.

4 Dict. Class. d’Hist. Nat. vol. ix. 1826, p. 519, 
I. (Aonyx) leptonyx. The claws, however, appear to be rather longer than in the generality of young specimens of this species, but it must be remembered that at an early age the claws are more pointed than in the adult. The specimen, moreover, has the characteristic markings of the species in the white on the cheeks and on the sides of the neck and throat, and in the brown moustachial band. The tentative opinion which I have formed regarding the nature of $L$. perspicillata coincides with Dr. Gray's view of the question, but as there is no properly authenticated skull of the specimen which is quite young, it is extremely difficult and almost impossible to determine its affinities with accuracy.

Schinz in his synopsis ${ }^{1}$ regarded the Barang as a small-clawed Otter, and as the equivalent of the $L$. barang of Raffles and of the L. leptony $x$ as described by Wagner; ${ }^{2}$ but, as I have indicated, the L. barang of Frederick Cuvier from Java is a species with long claws and apparently the young of the Simung, which Schinz correctly states is distinguished by strong claws.

Before I refer to the Otters that have been described from India proper, the Otter from the Malayan peninsula which Cantor ${ }^{3}$ has indicated must be mentioned. $\mathrm{He}$ described it under the name of $L$. barang, Raffles, but apparently erred in so doing, as Raffles' description of the feet of the Barang would seem to point in the direction of the small Otter figured by Marsden and described by Horsfield and Is. Geoff. St.-Hilaire respectively as $L$. leptonyx and $L$. perspicillata. The Barang of Cantor is a strongly clawed Otter distinguished from all other known Asiatic Otters by its hairy nose, resembling in this particular $A$. delalandii, Lesson, and Pteronura sandbachii, Gray. It is quite distinct from the $L$. barang, F. Cuvier, which, as already stated, has a bald nose and agrees with the Simung. Cantor states that in old individuals the hairs become rubbed off, but in an adult specimen presented by him to the India Museum, the hairy character of the nose is well marked, although at the same time it is not so thickly clothed as in the young. In the type of L. simung in the same Museum, the bare nose shows no indication whatever that it was ever clad, and the rough character of the skin resembles that of the bald-nosed species. As already mentioned, one of the Otters figured by Marsden and referred by him to IIstela lutra appears to be represented in the plate as having a haired nose, and the drawing seems to me to be a good representation of this, the supposed Barang of Cantor, while Marsden's other figure is a characteristic representative of $L$. (A.) leptonyx, which I consider, along with Müller and Horsfield, to be the Barang of Raffles. Some of Cantor's specimens of this Otter found their way to the British Museum, and Dr. Gray, apparently without enquiring whether they had been correctly identified by Cantor, adopted the name under which they had been sent, and elevated the species to generic rank under the erroneous name of Barangia, and specific term sumatrana, although the specimens he was dealing with came from Malacea.

\footnotetext{
${ }^{1}$ Syn. Mlamm. vol. ii. 1844, p. $35 . \quad 2$ Schreb. Säugeth. Suppl. vol. ii. 1841, p. 265 ,
}

${ }^{3}$ Journ. As. Soc. Beng. 1846, vol. xv. p. 195. 
The following are the characters of this species which I figure (Plates $\mathrm{X}$ and XII, figs. 4 to 6) from the fine, adult, male example in the India Museum, London. The upper surface of the type of L. sumatrana, Gray, is dark rich brown, darkest on the head, passing into a paler, but slightly more rufous brown on the ventral aspect. The area below the nose, the upper lip, the angle of the mouth, and the chin backwards along the throat, until on a line below the ears, are yellowishwhite. The ears are small, broad antero-posteriorly, low, rounded, and with an obscure $^{1}$ apical point. The colour of the moustachial and other hairs generally, corresponds to the colour of the region in which they are situated, but occasionally white bristles are met with. The upper surface of the webs is clad with hair, and the palms and soles are sprinkled with hairs. The claws are of moderate size, larger on the fore than on the hind limbs. The tail is rather narrow and pointed in the type, and the body to the vent measures 21 inches, and the tail 10 inches. The nose is completely covered with hair, except on the centre, where it has been slightly abraded. The specimen of this Otter in the India Museum, London, measures from the muzzle to the vent $29 \cdot 50$ inches, the tail being 19 inches long. The fur is short, glossy, and adpressed, and the colour is a rich, rather dark, reddish brown, darkest on the head. The upper lip, chin, and anterior part of the throat are white, the white in the middle line being encroached on by the brown of the chest. The cheeks and the sides of the neck are pale brown. The under parts are slightly paler brown than the sides. The tail is narrow and much tapered, and very dark brown in its latter half. The ear's are small, and the nose is haired, but partially abraded. The claws are strongly developed. The specimen is from Malacca, and differs in no respect from Gray's type of Barangia just described. The skull (Plate X, figs. 4 to 6 ) is allied to the skull I have figured as $L$. monticola in its post-orbital swelling, but in its other characters it is affined to $L$. nair.

The Otter of India first separated by F. Cuvier as distinct from the European species under the name of $L$. nair, was described from a specimen procured at Pondicherry by M. Leschenault.

In $1837^{2}$ Dr. Gray indicated a strong-clawed and naked-nosed Otter from India as $L$. indica. He at first erroneously mentioned Bombay as the locality from whence it had been obtained, whereas the specimens had been procured by Sir Walter Elliot in the Madras Presidency, and constituted the Lutra noir of that naturalist's Catalogue of the Mammals of the Southern Mahratta Country, ${ }^{3}$ and were therefore, in reality, from the same zoological province in which $L$. nair had been originally found. On the same occasion ${ }^{4}$ Dr. Gray indicated a very young Otter from China under the name of $L$. chinensis. Hodgson, writing in $1839,{ }^{5}$ held that no less than seven species of Otter were found in Nepal, five of which he considered differed from the $L$. nair, F. Cuv., and L. indica, Gray, and four of them he regarded as new; and in 1839

1 Proc. Zool. Soc. Lond. 1865, p. 123.

2 Charlesworth's Mag. Nat. Hist. Oct. 1837, vol. i. new ser., p. 580.

${ }^{3}$ Madras, Journ. Lit. and Sc. vol. x. 1839, p. 100.

4 L. c., p. 580.

5 Journ. As. Soc. Beng. vol, viii. 1839, p. 319 : et Ann, and Mag. Nat. Hist. vol. iv. 1840, p. 28. 
he described these supposed new species under the names of $L$. tarayensis, $L$. monticola, $L$. indigitata, and $L$. aurobrunnea.

In $1843^{1}$ Dr. Gray regarded Lutra indica as identical with the young animal from China, and placed the former as a synonym of $L$. chinensis, and he adopted a similar view with regard to $L$. tarayensis, which was afterwards shared by Hodgson. Twenty-two years afterwards, however, he altered his opinion, and revived the species $L$. indica, placing $L$. tarayensis as a synonym of it, and doubtfully regarded I. nair, F. Cuv., in the same light, and retained the Chinese Otter as a distinct species, accepting Hodgson's species L. monticola; and this course has been followed in his most recent work on the Carnivora, ${ }^{2}$ in which $L$. indigitata, Hodg., and Lutra aurobrunnea, Hodg., are referred to the genus Aonyx, Dr. Gray having overlooked the circumstance that $L$. aurobrumea is a strong-clawed Otter of the type of $L$.nair, while $L$. indigitata is apparently an example of $L$. (Aonyx) leptonyx, Horsfield.

Hodgson forwarded the types of his various species of Otter to the British Museum, but unfortunately seemingly without names, and along with them a series of Otter skulls the species of which were not stated, ${ }^{3}$ nor are the skins to which they belonged at present indicated. The only statement on record regarding the characters of the skull of Lutra tarayensis is, that it is much depressed, with the lower incisors ranged nearly in a line, but beyond this brief and vague description none else exists regarding these Nepal skulls. Under these circumstances, there are as yet no reliable materials to enable us to distinguish between the skulls of the two supposed species. Doubtless a skull bearing the name of $L$. monticola exists in the Museum of the Royal College of Surgeons, London, but it is not quite certain that Hodgson presented it as an example of $L$. monticola. This skull, however, exactly agrees with certain skulls in the British Museum bearing the name of L. monticola, but, as Dr. Gray remarks, and I have personally verified his observation, the skulls of two distinct species of Otter exist in the National Collection under the name of L. monticola. I have figured (Plate XII, figs. 1 to 3) the type of skull named L. monticola in the Royal College of Surgeons' Museum, not because there is any decisive evidence that it is the skull of the Otter described as $L$. monticola, but with the purpose of illustrating one of the types of skull distinctive of the large, longclawed Otters of India and the Himalaya. The other type of skull, and which was one of the forms referred to by Dr. Gray under L. monticola, is very closely allied to the Otter of Europe; but, as I have said, there are no means at present of identifying one or other of these two types of skull with any of the skulls of the large Otters described by Hodgson, and, moreover, unfortunately his descriptions of the peripheral characters of $L$.tarayensis and $L$. monticola are not sufficiently detailed to permit of the undoubted recognition of these species.

Two large, long-clawed species of Otter occur in the neighbourhood of Calcutta, one with a skull resembling the skull of $L$. vulgaris, and another with a skull of

1 List Mamm. B. M. 1843, p. 71.

2 Cat. Carniv. Mamm. 1869.

3 His drawings of the species exist as a means of identifying the forms he described, but they are of little use in determining which of the skins in the British Museum are referable to $L$. monticola and which to $L$. tarayensis. The skulls of the species were not figured. 
the type I have figured under the name $L$. monticola. The skull of the first of these is so closely allied to the skull of $L$. vulgaris that it is difficust to detect the points wherein it differs from the skull of the European Otter. But, even in external appearance, the Otter of this type is so alike to $L$. vulgaris that Blyth ${ }^{1}$ regarded an Otter from Algiers, which has the skull of the European Otter, as identical with this Otter of India. Blyth, however, does not appear to have been aware of the circumstance that the great majority of the Bengal Otters with which he was dealing were distinguished by skulls resembling the skull of the European Otter, because all the skulls mentioned in his Catalogue of Mammals were of the form figured in this work (Plate XII, figs. 1 to 3), whereas only one of his specimens had a skull resembling that figure; the skulls of all the other Otters he was dealing with, having, unknown to him, resembled the skull of the European Otter, and being identical specifically with the skull of the Otter first described by F. Cuvier as $L$. nair.

The only differences that can be detected between these skulls and the skull of the European Otter.are these: that the latter is slightly broader across the external meatus and between the tympanics on the base of the skull, that the zygomatic arch is more upwardly curved in its first portion, and that the teeth are smaller than in the Nepal and Bengal skulls. The differences, however, that exist between these skulls are almost equalled by the differences that subsist between the skull of the Algerian Otter and the skulls of Otters from Europe.

The type of $L$. nair, F. Cuvier, is in the Paris Museum, and M. Alphonse M.-Edwards obligingly had the skull removed from the skin for my inspection, and permitted me to have the accompanying faithful figure of it (Plate XI) executed for this work. A comparison of this figure with that of the adult skull of the European Otter (Blainville, Ostéog. vol. ii. fig. 8) will be sufficient to convince the observer that it is closely allied to that species, and it will be noticed that $L$. nair, like the skull of L. vulgaris, has no post-orbital swelling. Mature, but not old, skulls from Bengal and the Himalaya have generally a lengthened post-orbital area, and in skulls of $L$. vulgaris, of the same age, a similar lengthened interval occurs between the post-orbital process and the brain-case; and it is only in old animals that the European Otter skull assumes the form depicted by Blainville, in which the post-orbital interval is very much reduced and concave; and only in similarly old individuals that the skull of the Indian Otter takes on the characters of the type (Plate XI). I am indebted to Dr. Günther for the opportunity to examine the skull of $L$. indica, Gray, which he had specially extracted from the type specimen to assist me in these observations. After a careful consideration of the characters of this skull, it appears to me to be specifically identical with the skull of $L$. nair, F. Cuv.

The general colour of the animal is umber-brown, but there is always a tendency in the fur to a slight grizzling, as there is an area immediately below the tip of each hair paler than the rest of the hair. This character appears to increase with age, so that in the old animal the grizzling of the fur becomes intensified, and is further 
added to by the occurrence of nearly white hairs. The side of the muzzle, the area below the eye and the ear, the side of the neck to the fore limb, and more or less across it, the chin, throat, and under surface of the neck, and the sides and under surface of the trunk and tail, are pale silvery grey. In adolescents, the outsides of the fore limbs are concolorous with the upper parts, and the silvery grey is not so defined on the sides and belly, but it is markedly so on the sides of the face and along the neck. The young animal is much paler brown than the adult, and in the adolescent the colour of the upper part is darkest. The ears are moderately pointed, and in an adult, stuffed male, measuring from the muzzle to the vent 27 inches, and the tail $15 \cdot 75$, the ear is 0.85 high, by 0.80 broad.

The differences subsisting between the skulls of this and the other large species of Otter occasionally found in Bengal, suggest the likelihood that $L$. nair is distinguished from it by a very different physiognomy, having in all probability less breadth across the frontal or post-orbital region and a longer muzzle. The extent, however, of these differences, if they exist, can only be satisfactorily determined by the observation of the two species in life.

L. nair is distributed over India from the Himalaya to Cape Comorin and to Ceylon; an Otter with a skull resembling the skull of $L$. nair occurring in that island up to 4,500 feet. ${ }^{1}$ It is prevalent in Bengal and in Assam, but it does not appear to extend into Arracan and Burma, where its place would appear to be taken by another species with a different type of skull. It is largely employed by the fishermen of the Jessore district and of the Sunderbunds to drive fish into their nets, and it is frequently hunted in the neighbourhood of Calcutta by native boys who go in pursuit of it with small packs of pariah dogs, trained also to attack and kill Felis viverrina and Viverra zibetha.

The other large species of Otter occurring in Bengal is known to me by only one specimen in the Indian Museum, Calcutta, which Blyth states was obtained in the vicinity of the city, and in the British Museum there is a skull of an Otter from Behar identical with the skull of this specimen. The skeleton, as well as the stuffed specimen, has been preserved. This skull is specifically identical with the skull which I have figured as $L$. monticola, and is markedly distinct from the skull of the previously described Otter, in which there is a complete absence of the post-orbital swelling which is so characteristic a feature of this skull, and than which it is also much more depressed over the parietal region and with a muzzle of much less depth ; indeed, the two are distinguished from each other by the very leading differences that would suggest themselves were this skull with the post-orbital swelling compared with the skull of the European Otter. Before describing the peripheral characters of this second species of Bengal, Himalayan, and probably Malayan Otter, it may be well to mention that the specimen in question is No. 214 B of Blyth's Catalogue. ${ }^{2}$ Blyth noticed the difference of colour by which it is distinguished from specimen $\mathrm{A}$ of his Catalogue, which belongs to the form allied to the European Otter, but the skull of which Blyth had not removed for examination. His explana- 
tion, however, of the cause of the difference of colour does not appear to be sanctioned by the condition of the fur in a large series of specimens of $L$. nair, in all of which there is the distinct indication of a pale, subterminal area which produces the grizzling, whereas the assumption that the absence of grizzling in this other Otter is due to the shedding of the light-coloured area is without any facts to support it; and the probability is that if Blyth had been aware of the cranial differences which marked these two specimens $A$ and $B$ of his supposed $L$. nair, the explanation he has offered of the cause of the difference in the colour of the pelage would probably have been modified, if not abandoned.

This Otter, for reasons hereafter to be stated, appears to attain to a greater size than $L$. nair. The colour is more rufous umber-brown than $L$. nair, and does not exhibit any tendency to grizzling, and the under surface is only somewhat hoary, well washed with brownish. The chin and the edge of the lips are whitish, and the silvery hoary on the sides of the head, on the throat, and on the under surface of the neck and on the chest, is marked. The tail, above and below, is concolorous with the trunk. The length of the skeleton of an adult female, measured from the tip of the premaxillaries to the end of the sacral vertebræ, is $23 \cdot 25$, and the tail measures $17 \cdot 75$ inches.

The distinctive features of its skull, as compared with the skull of $L$. nair, are the considerable swelling of the post-orbital contraction of the frontal, the more arched character of the anterior extremity of the frontals and of the supranasal region, which is flattened in the previous species, the rather shorter muzzle measured from between the post-orbital processes to the extremities of the premaxillaries, the more rotund character of the parietals, the greater depth and breadth of the braincase, the short and broad post-palatine region with the much outwardly curved processes of the pterygoids, and the large teeth. The accompanying table will illustrate wherein these skulls differ from one another, and as the three specimens measured are about the same age, the table conclusively proves that the skull of the female of this Otter is not only considerably larger than that of the corresponding sex of $L$. nair, but that it also exceeds in size the male of that species :-

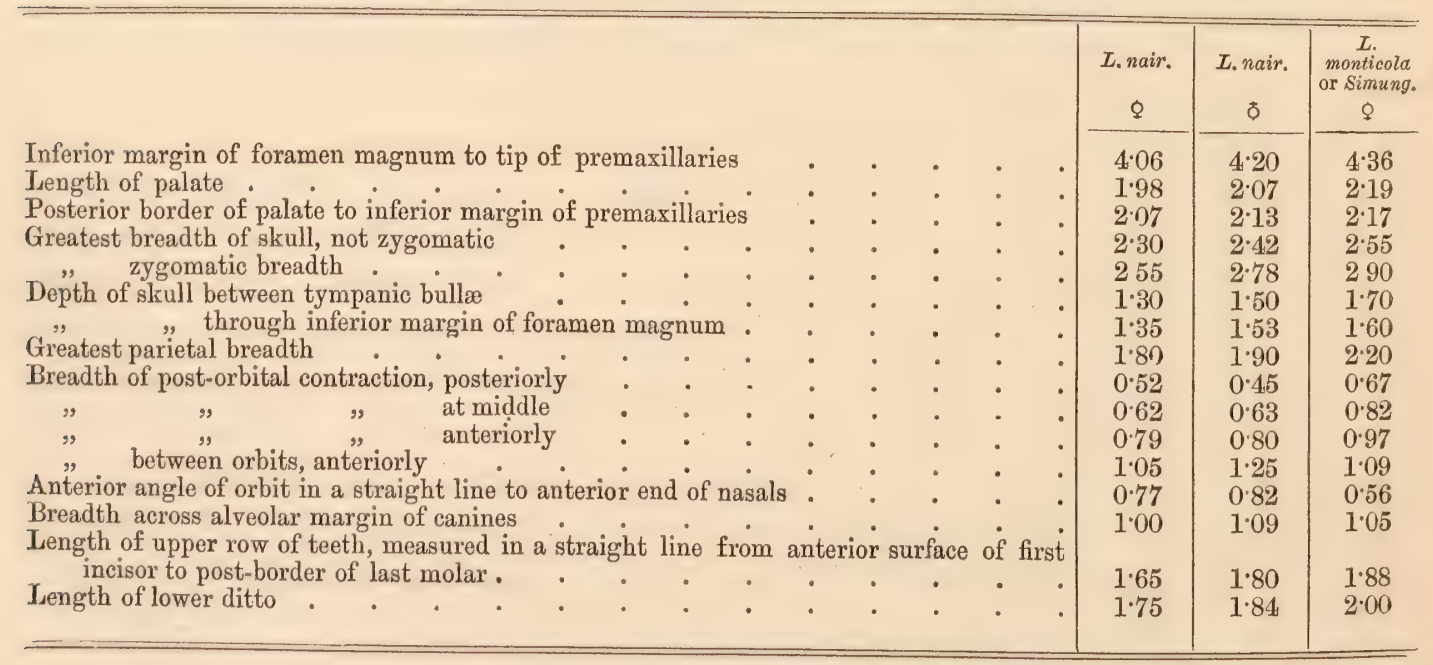


It is probable that these differences in the dimensions of the skulls extend also to the other parts, and that there are two large, long-clawed Otters in Bengal distinguished from each other by difference of size. The measurements, however, which I have given of the mounted specimen of $L$. nair do not support this suggestion, but mounted skins are not to be relied on as accurately indicating the dimensions of animals.

The type of $L$. simung, Raffles, in the India Museum, London, is evidently closely allied to, if not identical with, this species; but, as its skull has been lost, it is impossible to do more than conjecture, yet it is improbable that the simung is I. nair, and from the nature of the skull of $L$. chinensis, it does not appear to be that species which is probably a distinct form allied to $L$. nair. This Otter is distinguished from $L$. sumatrana (Plate XII, figs. 4 to 6 ) by the different configuration of its skull, and by its hairless nose. I am disposed to consider that it will be found to be the Simung of Raffles and the Barang of F. Cuvier, and that it is one of those members of the Malayan fauna which range north-westwards through Tenasserim, Burma, Arracan, and Assam to the Himalaya, and that those individuals which have been found in the streams of the plains of Bengal are merely occasional stragglers. It is probable that it has a considerable westerly range in the Himalayas, but the Otter of Kashmir ${ }^{1}$ is probably $L$. vulgaris, or a very nearly allied form.

In Western Yunnan, I obtained numerous, perfect Otter skins belonging to two distinct species, but unfortunately no skulls. The larger of the two was a species evidently closely allied to the Simung, and was procured at altitudes varying from 2,000 to 4,000 feet.

Sir W. Elliot, ${ }^{2}$ in his Catalogue of the Mammals inhabiting the Mahratta country, distinguished only one species of Otter which he regarded as $L$. nair, but some years afterwards he forwarded to the Calcutta Museum the skull of an Otter which he considered to be distinct from the $L$. nair of his Catalogue, a specimen of which he had also presented to the same Museum. I have had the skull of this specimen removed, and although it has only its milk teeth, it is yet of much greater size than specimens of corresponding age belonging to $L$. nair. The general characters which distinguish this young skull from the skull of $L$. nair are those which separate $L$. nair from the supposed Simung $(?=L$. monticola $)$ in adult life, and the mature skull proves the species to be very closely allied to the Otter the skull of which I have figured under the name, $L$. monticola. It is perfectly distinct from the skull of the type of L. nair, as it has the post-orbital swelling. It presents, however, certain characters by which it differs from the supposed Simung $(?=L$. monticola $)$, and chief among these are its relatively smaller and shorter brain-case, the much greater forward arching of the malar branch of the superior maxillary, its much shallower muzzle, and the slightly more elongated character of the post-palatine prolongation; and these features are so well pronounced that I do not hesitate to regard it as a species of Southern India Otter quite distinct from $L$. nair, but sub-specific to the supposed 
$L$. simung ( $L$. monticola). This Otter may be indicated as $L$. ellioti. One peculiarity of the milk dentition of this species is the presence on the hinder margin of the canine, near its base, of a prominent, well-defined cusp, above which the tooth is thickened; no such cusp exists in the milk-teeth of a young example of $L$. nair before me, but I have never seen a young skull of the Simung.

The colour of this Otter is much the same as in the Simung, only a little darker, and the distribution of the silvery white is the same. The more depressed and shallower character of the muzzle must confer a different character on the head of the living animal as compared with $L$. Simung, and both these species are doubtless distinguished from $L$. nair by broader and more arched heads and shorter muzzles.

It may be that this Otter has a north-westerly distribution, and that it is the species which occurs in the lake at Mount Abu, in Rajputana, and also in Sindh and in the Indus.

The skull in the British Museum (No. 214e, 48, 6, 11, 14) referred by Dr. Gray to the genus Barangia under the name nepalensis is considerably smaller than the previous skulls. The obscure character of the frontal angles of the orbit appears to be due to abrasion, and the skull has all the characters of a true Lutra. The teeth are much smaller than in L. simung, and the skull is seemingly fully adult, as the sutures have all disappeared. It belongs, then, to a small Otter, and as the skull was forwarded by Hodgson and is quite distinct from the other skulls sent by him, it is possible that it may be the skull of the smallest of his true Lutra, viz., L. aurobrunnea, which Gray ${ }^{1}$ has erroneously referred to the genus Aonyx. The type specimen is in the British Museum, and is a true, long-clawed Otter. There is no evidence whatever that a hirsute-nosed Otter exists in the Himalaya.

The type of the species $L$. aurobrunnea is a very badly preserved skin of a rich, ferruginous, brown colour of almost equal intensity above and below and on all parts of the head and neck, the upper surface of the head being deeper brown than the back. The nose is bare, and the ears are small, and rather pointed posteriorly. All the strong bristles of the moustache, eyes, cheeks, and chin are dark brown. The claws are developed, as in true Lutra, and the upper surface of the webs are semi-nude, and on their under surfaces there are a few scattered hairs. Hodgson describes this species as having a more vermiform habit of body than any of the other Asiatic Otters; the tail is less than two-thirds of the length of the body; the nails and toes are feebly developed; the fur is rather long and rough, and the colour rich chestnut-brown above, and golden red below and on the extremities.

$$
\begin{aligned}
& \text { Length from muzzle to root of tail . Inches. } \\
& \text {, of tail . . . . } 12 \text { to } 13
\end{aligned}
$$

Nothing is known regarding the distribution of this form beyond that it is a mountain species. 
It would thus appear that in the Himalaya and India there are four distinct species of long-clawed Otters,-viz., L. nair, L. simung (=L. monticola), L. ellioti, and $L$. aurobrunnea; and one species distinguished by its short claws,-viz., $L$. $(A$.) leptonyx. The Himalayan small-clawed Otter, the Lutra $(A$.) indigitata of Hodgson, is seemingly identical with $L$. leptonyx, Horsfield, but this point cannot be definitely settled until a skull of the former has been compared with Malayan examples of the latter species. I have compared the type of $L$. (A.) horsfieldii, Gray, with the type of $L$. (A.) leptonyx, and do not detect any difference either in the skins or skulls by which they might be separated. It may be that the Southern Indian variety of $L$. (A.) leptonyx may prove to be a distinct species, and that it may extend into Ceylon, because two species apparently occur in that island, the larger of the two being $L$. nair. In the Malayan peninsula and Sumatra, L. (Aonyx) leptony $x$ and $L$. simung are associated with the hirsute-nosed Otter $L$. sumatrana, Gray. $L$. (A.) leptonyx occurs in Formosa, judging from the fragment of the skull referred by Dr. Gray to Lutrogale, to Hydrogale, and to Lutra swinhoei, and is apparently distributed over Southern China, and occurs also in Hainan, ${ }^{1}$ the Malayan peninsula, Burma, Assam, Bengal, and the Himalaya.

Among the Otter skins procured in Yunnan, there are two much more brightly coloured than the generality of skins of $L$. (A.) leptonyx, but in the absence of skulls, I can throw no further light on them. The species occurs in the hills and valleys to the east of Bhamô.

\footnotetext{
${ }^{1}$ Swinhoe, Proc. Zool. Soc. 1870, p. 229.
} 


\section{RODENTIA.}

SCIURID A.

\section{Genus Sciurus, Linn.}

In identifying the squirrels collected on the two Expeditions to Western China, I was led to examine the whole group of the south-eastern Asiatic species of the genus Sciurus, and the results are here recorded.

That remarkable Malayan and Bornean form, with the long snout, which has been elevated by Dr. Gray to a separate genus under the term Rhinosciurus, I have made the subject of a few observations at the end of this Memoir. It seems to me that its structural features are not so much differentiated from the ordinary squirrels as to warrant its being apportioned more than sub-generic rank, and if the other squirrel, also from Borneo, which Dr. Gray first described as Sciurus macrotis and afterwards raised to generic rank as Rheithrosciurus, does not present any other modifications on the ordinary Sciurine type beyond the longitudinal grooving of the incisors, its claims to more than sub-generic distinctness would seem to be doubtful.

With regard to the genus Sciurus itself, it forms a natural and well-defined group, containing a large assemblage of forms which differ in details of merely specific value. With the two exceptions just mentioned, I fail to detect any characters to favour the view, that variation in dentition, or in the tufting of their ears, occurs to a degree sufficient to entitle them to be separated into sub-genera. The dentition and the form of the skull throughout the group rather present a remarkable uniformity. The tufting of the ears is apparently not a seasonal or climatic circumstance, such as that to which the common squirrel of Europe is well known to be subject. Certain modifications in the external appearance of the animals are doubtless produced by the stage of their growth; the pelage of some, in whole or in part, becoming darker or lighter, as they pass from youth to maturity, and occasionally there is a complete change of colour. The young of $S$. rafflesii, for example, I have frequently observed to be born with a pure white tail which gradually changes to black in the adult, showing a slight tendency to rufous tipping; apparently also S. ferrugineus has annulated hair in youth which becomes brilliant red at maturity. But the diversity in the physical conditions of the countries which the squirrels inhabit, and the nature and relative abundance of their food, exercise a most potent influence on their organisms, leading to variations in size, form, and intensity of colour. The species S. maclellandi affords a good illustration of this. It ranges over a wide geographical area, and when a series of individuals are brought 
together from the Himalaya, the Malayan peninsula, Formosa, Central China, and Tibet, however divergent those from the extreme limits of distribution may appear, the races from the intermediate localities show a connecting, gradational series. But besides these, there are evidently other and occult causes at work producing local modifications in the pelage of certain species and which are the occasion of much perplexity to the systematist. This is especially observable in such squirrels as S. pygerythrus, S. phayrei, S. blanfordii, S. caniceps, and S. ferrugineus.

In the following pages it has been attempted to indicate the transitional phases, varieties, or local races, whichever they may ultimately prove to be, that appear referable to given species, but the following interpretation of the similarities which some of them manifest to certain species may not be considered as conclusive evidence of their identity, yet the facts generally would seem to prove that the course followed is one in the right direction.

\section{ScIURU⿻ BICOLOR, Sparrmann.}

The Javan Squirrel, Pennant, Hist. Quad. 1793, 3rd ed. p. 142.

Sciurus bicolor, Sparr. Gotheb. Wet. Sevensk. Handl. vol. i. 1778, p. 70 ; Pallas, Hist. Nat. Quad. Glir. 1778, p. 377; Gmelin, Syst. Nat. 13th ed. vol. i. 1788, p. 148 ; Pennant, Hist. Quad. 3rd ed. 1793, p. 142 ; Shaw, Genl. Zool. vol. ii. pl. i. 1801, p. 130 ; Desmarest, Nouv. Dict. d'Hist. Nat. vol. x. 1817, p. 105 ; Mamm. 1820, p. 336, pl. Ixxv. fig. 3 (Schreber's figure of S. javensis) ; Kuhl. Beitr. Zur. Zool. und Anat. 1820, p. 68; Horsfield's Zool. Resch. Java, 1824, plate; Proc. Zool. Soc. 1839, p. 150 ; Cat. Mamm. E. Ind. Co.'s Mus. 1851, p. 155 (in part) ; Desmoulins, Dict. Class. d'Hist. Nat. vol. vi. 1842, p. 72 ; Lesson, Man. de Zool. 1827, p. 236 ; Fischer, Syn. Quad. 1829, p. 357 (in part) ; Wagner, Schreber, Säugeth. Suppl. vol. iii. 1843, p. 189 (in part), plate cexvi. A; Müller und Schlegel, Verhandl. 1839-44, pp. 85, 88 (in part); Schinz, Syn. Mamm. vol. ii. 1845, p. 32 (in part); Blyth, Cat. Mamm. As. Soc. Mus. 1863, p. 99 (in part).

Sciurus javensis, Zimmermann, Geograph. Gesch. 1780, vol. ii. p. 342 ; Schreber, Säugeth. vol. iv. 1792, p. 781, pl. 216 ; Gray, Hand-List Mamm. B. M. 1843, p. 136; Proc. Zool. Soc. 1861, p. 137 ; Blyth, Journ. As. Soc. Bengal, vol. xvi. 1847, p. 870.

Sciurus albiceps, Desmarest, Nouv. Dict. d’Hist. Nat. vol. x. 1817, p. 105 ; Desmoulins, Dict. Class. d'Hist. Nat. vol. vi. 1824, p. 72 ; Gray, Griffith's An. Kingd. vol. iii. 1827, plate opposite to p. 180.

Sciurus leschenaultii, Desmarest, Mamm. 1820, p. 335 ; Horsfield, Zool. Resch. Java ; Gray, Griffith's An. Kingd. vol. iii. 1827, p. 180, (plate S. albiceps) ; Lesson, Man. de Zool. 1827, p. 236; Fischer, Syn. Mamm. 1829, p. 356 ; Schinz, Syn. Mamm. vol. ii. 1845, p. 33.

Sciurus affinis, Raffles (nec Horsfd.) Trans. Linn. Soc. vol. xiii. 1822, p. 259 ; Lesson, Man. de Zool. 1827; p. 234; Fischer, Syn. Mamm. 1829, p. 355 (in part) ; Wagner, Schreber, Säugeth. Suppl. vol. iii. 1843, p. 202 ; Schinz, Syn. Mamm. vol. ii. 1845 (in part), p. 44; Blyth, Ann. and Mag. Nat. Hist. vol. xx. 1847, p. 314.

Sciurus hypolencus, Horsfield, Zool. Resch. Java, 1824; Cat. Mamm. E. Ind. Co.'s Mus. 1851, p. 156; Müller und Schlegel, Verhandl. 1839-44, pp. 85, 90; Gray, Hand-List Mamm. B. M. 1843, p. 137; Wagner, Schreber, Säugeth. Suppl. vol. iii.1843, p. 189; Blyth, Journ. As. Soc. Beng. vol. xvi. 1847, p. 870 ; Cat. Mamm. As. Soc. Mus. 1863, p. 99.

Sciurus auriventer, Is. Geoff. St.-Hil. Mag. de Zool. 1832, cl. i. pl. v. ; Voy. des Ind. Orient. Bélanger, Zool. 1834, p. 150 ; Coulon, Mém. de la Soc. des. Sc. Nat. de Neufchat. vol. i. 1835, p. 123, pl. ix. ; Gervais, Eyd. et Soul. Voy. autour du Monde, Zool. vol. i. 1.841, p. 41 ; Mag. de 
Zool. 1842, pl. xxxiii. (skull) ; Wagner, Schreber, Säugeth. Suppl. vol. iii. 1843, p. 193; Gray, Hand-List Mamm. B. M. 1843, p. 136; Schinz, Syn. Mamm. vol. ii. 1845, p. 31 ; Blyth, Journ. As. Soc. Beng. vol. xvi. 1847, p. 870.

Sciurus humeralis, Coulon, Mém. de la Soc. des Sc. Nat. Neufchat. vol. i. 1835, p. 122, pl. viii.

Sciurus ephippium, Müller, Tydschr. Over. Nat. Gesch. 1838-39, p. 147; Müller und Schlegel,

Verhandl. Nat. Gesch. 1839-44, pp. 86 \& 91, pl. xiii. fig. 4 (skull, figs. 2 \& 3) ; Waterhouse,

Proc. Zool. Soc. 1842, p. 116; Wagner, Schreber, Säugeth. Suppl. vol. iii. 1843, p. 193;

Schinz, Syn. Mamm. vol. ii. 1845, p. 40 ; Blyth, Journ. As. Soc. Beng. vol. xvi. 1847, p. 870 ;

Cat. Mamm. Mus. As. Soe. Beng. 1863, p. 100 ; Motley and Dillwyn, Contrib. Fauna, Borneo and Labuan, 1855, p. 3.

Sciurus rubriventer, Forster, Müller \& Schlegel, Verhandl. Nat. Gesch. 1839-44, p. 86; Gray, Ann. and Mag. Nat. Hist. vol. xx. 1867, p. 283.

Sciurus (Rukaia) ephippium, Gray, Ann. and Mag. Nat. Hist. vol. xx. 1867, p. 276.

Macroxus (Rulcaia) bicolor, Gray, Ann. Nat. Hist. vol. xx. 1867, p. 276 (in part).

A great deal of misunderstanding has for long existed regarding the true nature of S.bicolor, Sparrmann. The type of this species is stated to have been captured alive in Java by the sailors of a Swedish ship, and was stuffed and deposited in the Collection at Göthenburg and afterwards was described by Sparrmann as "S. supra niger, infra fulvus, auriculis acutis imberbibus, palmarum ungue pollicari magno rotundato." Schreber received from Linnæus a drawing of the animal and reproduced it in his Säugethiere with the following description, altering the name to S. javensis, because he was of the opinion that the term bicolor was misleading: "Light brown, tending to fox-red (fulvous) on the chin, throat, and breast, the inner side of the fore limb, the belly, and two-thirds of the tail from the tip backwards. The upper portion of the animal from the nose backwards, including the hinder third of the tail, black, besides the eyelids, ears, and exterior of the fore limbs, and the feet. The hind limbs, externally and internally, are black all over. The ears do not much exceed half an inch in length, are somewhat pointed, and clad on both aspects with rather short, black hairs. The bristles of the moustache are black and from two to three inches long. The extreme points of several of the hairs on the head, sides, and back are somewhat reddish, and on a careful examination one finds all the light-brown hairs on the tail wholly black at their bases. The fore feet have four toes and a rudimentary thumb. Length from tip of snout to tail twelve inches, the tail equalling the length of the body, the hairs of the tail scarcely more than an inch long." It is evident that these two descriptions convey entirely different conceptions of the characters of the animal, but as Schreber took the precaution to consult with Linnæus before publishing his description, it is highly probable that the latter in forwarding the drawing of the type to Schreber also communicated its essential characters, because the foregoing account professes to be a description of the type of $S$. bicolor. The most important part of Schreber's description, and that which modifies the idea conveyed by the statement that the upper parts were wholly black, is the reference which he makes to the red-tipped character of both the hairs on the head and sides of the back, the mention of which at once recalls the characters of the common large squirrel of Java. But, at first sight, so inapplicable is Sparrmann's description to the generality of the individuals of the 
large Javan squirrel that Müller and Schlegel went so far as to state, that were it not that Sparrmann insisted upon the fact that his specimen was caught alive in Java, they would sooner have applied his description to S. hippurus than to S. bicolor, and they thought that this view of the question was rather supported by the sketch sent by Linnæus; but more extended research has shown that the large squirrel of Java not unfrequently merits the term bicolor, and that it is distinguished by its ears being untufted, whereas the larger black squirrel with the yellow under parts, found from the Himalaya to Borneo, has its ears generally tufted. I have examined the types of $S$. albiceps, Desm., S. leschenaultii, Desm., S. auriventer, Is. Geoff. St. Hil., S. hypoleucus, Horsfd., S. bicolor var. sondaica, Horsfd., and S. ephippium, M. and S., and an extensive series of squirrels belonging to these types and to many intermediate forms, and a careful consideration of these materials has led me to regard them only as varieties of one species, depending chiefly on local circumstances, the right understanding of which is probably complicated by differences in age and seasonal changes of fur.

The Javan forms referable to $S$. leschenaultii, S. albiceps, and S. javensis, are very variable. The general colour of the fur on the upper parts is brown, and in some this colour extends on to the head, which is nearly concolorous with the body; but the head exhibits many shades of brown, passing even into yellowish-grey, in which condition it is S. albiceps, whereas in others it may be only tinged with greyish-brown. In some its upper surface is dark brown, and the sides of the head and face are greyish-yellow. The fur of the upper parts, although described as reddish or maroon-brown, is in some squirrels broadly tipped with yellowish-brown or even pale yellow, - so much so, that the general colour is of that tint, except on the hind quarters, which are usually dark, almost blackish-brown, frequently, however, grizzled with pale-yellowish; the feet, anterior and posterior, being generally deep black. The sides of the neck, shoulder, and outside of fore and hind limbs are always dark maroon or blackish-brown. On the radial portion of the fore limb, the outer, brown surfaces are more or less yellow-grizzled, but the dark colour is, at the same time, definitely marked, and there is no approach to the formation of the encircling white of $S$. macrourus. The under parts from the chin to the vent, and the inside and front of the fore limbs, are yellowish, or orange-white of various degrees of intensity. The ears are moderately sized, rounded anteriorly, nearly straight behind, but not tufted. The tail at the base is usually blackish, or brownish-black, slightly grizzled, but the remainder is so broadly tipped with yellow that this is the prevailing colour, although the basal two-thirds of the hairs are, in general, dark brown, or black. In one Javan specimen the tip of the tail is black. The middle of the under, divided surface, owing to the bases of the hairs being exposed, is brown, the outer portion yellow. In two Sumatran animals, the heads are dark brownish-black on the vertex, and only a little paler before the eyes; and the croup, shoulders, and outside of the fore limbs and the thighs are blackish-maroon; the body behind the shoulders to the root of the tail being palish-rufous, or yellowish-brown. The tail 
is blackish-brown, only slightly and sparsely tipped with yellowish on the sides. The under surface of the tail is brown, the hairs with yellow tips. The chin to the vent, the inside of the limbs and anterior surface of the fore limbs, are rich yellow-white, the white spreading externally on the fore limbs above the wrist, but not encircling the limbs. The feet are black. The cheeks, below the eye, are concolorous with the throat.

I have observed another type of colour in a squirrel the locality of which is unknown, but which agrees with the Javan race in its pale head and nearly yellow tail. The head is yellowish-brown, only slightly darker than the under parts. The back of the neck, the shoulders, outside of the fore limb, and the rump and outside of the hind limb, are blackish-brown; the feet black; but the rump and hind quarters are sparsely white-grizzled. The rest of the upper surface of the trunk is rather rich chestnut, grizzled on the lower margin of the sides, where the colour, as it joins the white, becomes blackish-brown. The chin, the cheeks, and under parts are yellowish-white; the middle of the outside of the limb is white-grizzled; the root of the tail is concolorous with the rump, and the remainder is yellowish. In young individuals, the fur is darker and more richly coloured, the upper surface of the head being concolorous with the back. The hind quarters and the outside of the hind limbs and shoulders, and the outside of the fore limbs, are black, the first being slightly white-grizzled; the intervening portion of the trunk reddish and black, with which the rest of the tail is concolorous. The under parts are yellowishwhite, and this colour extends on to the front of the wrist.

The type of $S$. albiceps is nearly as pale as $S$. hypoleucus, but the hind limbs are dark brown, and also the fore feet and the proximal two-thirds of the tail, but the head and neck are pure white, and also the inside of the front of the lower half of the limbs. The under parts are pale-yellowish, as in S. hypoleucus and S. auriventer, and the last third of the tail is broadly washed with yellow. In others, the head is whitish, while the body and limbs are dark brown and slightly grizzled with yellow and white; the front of the fore legs being whitish, but all the rest of the limbs, dark brown. The base of the tail is dark brown, washed with whitish, and in all the remainder of its extent it is broadly washed with yellow.

The S. hypoleucus, Horsfield, like S. auriventer, Is. Geoff. St.-Hil., was obtained from Sumatra, and both of these correspond to squirrels referred by Horsfield to a variety of $S$. bicolor, which he called sondaica. Squirrels of this variety (sondaica) have been obtained from Java, Sumatra, Borneo, Malacca, and Siam. They vary from almost pure white to rich, dark, rusty brown, generally with pale heads, white or yellow before and between the eyes, on the sides of the face and neck, and on the front of the margin of the thigh at the groin : the outer surface of the extremities and the upper surface of the tail being concolorous with the upper parts of the body. The back is sometimes darker than the limbs in the dark forms and lighter than them in the pale forms, such as $S$. hypoleucus and var. sondaica. The under surface and the inner side of the limbs and the lower surface of the tail in the middle line, vary from pure white to yellow and yellowish-red, 
and even orange-yellow. I have examined about thirty to forty specimens of this variety.

The squirrel from the Celebes, referred by Dr. Gray to M. ephippium and also regarded by him as $S$. auriventer, belongs to the same type as $S$. hypoleucus, only a little darker, but with the colours similarly distributed, and the colour also of the under surface is pale reddish-white. The front of the head, from between the eyes to the muzzle, the sides of the face below the ear, the sides of the neck, the chin, throat and under parts, and the margin of the thigh at the groin, are reddish-white; the hairs on the light area of the head having dark-brown tips. The general colour of the upper parts is a rich reddish-brown, the hair showing a distinct tendency to annulation in the formation of a narrow, pale yellowish, suib-apical band with a brown tip. The colour gets darker and more chestnut along the line of demarcation from the white of the under parts, and along the margins of the limbs and on the lower part of the hind leg. The basal half of the hairs of the tail is yellowish-white, and the remainder, dark reddish-brown, darker than the body and more brown. The moustachial and other bristles are black, and the body-bristles, orange-brown. The mesial line of the tail is concolorous with the under parts, but the short, mesial hairs are darker.

I have examined the type of $S$. ephippium and numerous other specimens, all from Borneo, the majority having been obtained in the north part of the island. The ears are not pencilled as in Bornean examples of $S$. giganteus. The tail is considerably longer than the body. The general colour of the upper parts is dark, rusty brown, but a broad, darker area runs, from near the nape, along the middle line of the back to the tail. In some, this dark colour is restricted to the hinder half of the body, while, in others, it is entirely absent. The rest of the upper surface of the animal is grizzled, and the dorsal, dark list gradually passes externally into the colour of the sides. The sides of the face and neck, and the chin and throat, are always, more or less, rather bright ferruginous, which may or may not extend on to the outer surfaces of the fore limbs. All the rest of the under parts and the inside of the limbs are white, more or less tinged with yellowish, or with pale ferruginous on the chest and on the middle of the belly. Such is the general distribution of colour, but the animal is subject to marked variations. Occasionally the head is whitish-grey, and the dark list is reduced to a deep brown area on the hinder quarters, the limbs being pale-yellow and the white on the front of the thighs well defined. The tail is uniformly brownish-black, paling at the tip to yellowish-brown. The sides of the neck, the shoulders, and flanks are orange-yellow. The chin, throat, and chest are pale orange; the belly white. This variety leads directly into $S$. hypoleucus from Java, Sumatra, Malacca, and the Celebes, and through it into S. bicolor var. sondaica, Horsfd., which is the S'. auriventer, Is. Geoff.

The skull of $S$. bicolor is very much smaller than the skull of S.giganteus, an adult skull of the former measuring only $2^{\prime \prime} \cdot 56$ to $2^{\prime \prime} \cdot 97$ the length in $S$. giganteus 
from Assam. The molar row, in the upper jaw, measures only $0^{\prime \prime} \cdot 50$ to $0^{\prime \prime} \cdot 59$ in the latter species and the upper incisors also are much narrower. The breadth of the frontal region of $S$. bicolor is proportionally greater than in S. giganteus, and the upper portion of the nasals is more expanded. No character, as far as I can see, can be drawn from the premaxillary foramina, which vary in length. The skull is subject to considerable variation; in two skulls of the pale variety the facial portion of one skull is narrower than the other. The skull of S. ephippium, as figured by Müller and Schlegel, has a much more pointed muzzle than S. auriventer, as figured by Is. Geoff., which has also greater antero-orbital breadth and depth: but in these respects the skull of the latter agrees with a skull removed from an undoubted example of $S$. ephippium, whereas the skull of a specimen of $S$. hypoleucus agrees with Müller and Schlegel's figure of the skull of S. ephippium!

This species appears to be generally distributed over the southern portion of the Malayan peninsula and over the neighbouring Islands of Sumatra, Java, Borneo, and the Celebes and the adjacent smaller islands.

\section{* Sciurus giganteus, MrClelland.}

Sciurus giganteus, M`Clelland, Proc. Zool. Soc. 1839, p. 150.

Sciurus bicolor, Wagner, Schreber, Säugeth. Suppl. vol. iii. 1843, p. 191 (in part) ; Blyth, Journ. As. Soc. Beng. vol. x. 1841, p. 919 (in part) ; vol. xvi. 1847, p. 870 (in part) ; vol. xxiv, 1855 , p. 472 (in part) ; vol. xxxi. J862, p. 334 (in part) ; Ann. and Mag. Nat. Hist. vol. xx. 1847, p. 314 (in part) ; Cat. Mamm. As. Soc. Mus. 1863, p. 99 (in part) ; Cantor, Journ. As. Soc. Beng. vol. xvi. 1846, p. 246 (in part) ; Jerdon, Mamm. Ind. 1867, p. 168 (in part).

Sciurus macruroides, Hodgson, Journ. As. Soc. Beng. vol. x. 1841, p. 915 (not described); Cal. Journ. Nat. Hist. vol. iv. 1844, p. 293 ; Proc. Zool. Soc. Lond. 1853, p. 126 ; Gray, HandList Mamm. B. M. 1843, p. 136 ; Cat. Mamm. Nepal, B. M. 1846, p. 22 ; Blyth, Ann. \& Mag. Nat. Hist. vol. xx. 1847, p. 314 (in part) ; Horsfield, Proc. Zool. Soc. Lond. 1856, p. 402. Macroxus (Rukaia) bicolor, Gray, Ann. \& Mag. Nat. Hist. vol, xx. 3rd ser. 1867, p. 276 (in part).

This species has well-tufted ears: the upper surface is either wholly black or reddish-brown, without any trace of white; the tail generally is jet black, also the outside of the fore and hind limbs and the upper surface of the feet. An elongated black spot is almost invariably found below the eye from behind the moustache, and the eye is encircled with black. There are generally two black spots on the under surface of the chin. The under parts and the inside of the limbs vary from pale yellowish-white to a rich rufous-orange; the basal portion of the hairs of the under parts is dark brown, or black, and the ventral area has frequently a dull hue where the yellow tips are sparse. The coats of these squirrels are generally sleek, glossy, and deep black, and while in this condition the under surface is most brilliant, especially at its line of junction with the black, along the sides of the body and limbs tending to form a kind of bright band. In some, the upper parts have a brownish hue, but this is not characteristic of any particular locality, as two individuals, one from Nepal and the other from Borneo, are equally brown. When 
the fur is of this colour, it is long and coarse, and the under parts are less brilliant. These phases are probably seasonal and connected with the breeding period. Certain skins obtained by me at Teng-yue-chow in Yunnan belonged to the black, glossy kind, with rather bright, yellow under surfaces.

A race found in Arracan, Pegu, and Tenasserim, has generally the dorsal region, from behind the shoulders to the sacral region, and the sides, pale brown or yellowishbrown, nearly as pale as in S. bicolor var. sondaica, Horsfd., the rest of the upper parts being dark or blackish-brown, and the tail almost black, but sometimes washed with yellowish. In some, the pale colour even extends to the upper surface of the head and neck. These squirrels have all the characters of being transitional between $S$. bicolor var. sondaica and S. giganteus, $\mathrm{M}^{`} \mathrm{Clelland}$. They are, however, larger than the former, and they are connected with the latter by their skulls and the size of their teeth, but their nasals are most variable, and they appear to be generally longer and narrower than in typical S. giganteus. Some examples, however, have the short and broad nasals of that species, so that it is impossible to separate them specifically, although they appear to be a well-marked race of the giant squirrels, more nearly affined to $S$. giganteus than to $S$. bicolor, though perhaps in its peripheral characters this race more resembles the latter than the former.

The skull of $S$. giganteus is about the same size as the skull of $S$. maximus. Its most distinctive feature, in specimens from Sikkim and Assam, is the broad character of the inferior end of the nasals, their upper ends being but little expanded. This confers great breadth on the muzzle, which is markedly different from the muzzle of skulls corresponding to $S$. bicolor var. sondaica, Horsfd., $S$. hypoleucus, Horsfd., S. auriventer, Geoff., and S. ephippium, M. \& S., than all of which the skull of $S$. giganteus is much larger. Specimens from Tenasserim, Pegu, and Arracan with pale backs, have their skulls distinguished by much less dilated nasals, as a rule, but examples occur in which these bones resemble the dilated nasals of typical S. giganteus, and the occurrence of such skulls serves to connect the more aberrant forms with the type. Not only the nasals of these skulls vary, but also the length of their molar line. The skulls and teeth, however, conform in size to $S$. giganteus and not to $S$. bicolor. It is important to note that these Tenasserim, Pegu, and Arracan specimens which show a tendency to resemble the skulls of squirrels referable to $S$. bicolor var. sondaica, S. hypoleucus, S. auriventer, and S. ephippium also manifest a disposition to resemble them in the colour of their fur; but the animals in the aggregate of their external characters are more allied to S. giganteus than to S. bicolor. Some examples of S. giganteus from Upper Burma, otherwise inseparable from the type, show an intermixture of pale-brownish hairs on the back, and thus a tendency to conform to the features of these Tenasserim, Pegu, and Arracan squirrels, which on their part manifest a tendency to pass into S. bicolor, var. sondaica, \&c.; and had it not been that the skulls of squirrels from these latter localities conformed more to the type of S.giganteus than to S.bicolor, I would have been inclined to regard them as a variety of that species. As it is, they seem to me to link the two forms together. At first, and before I had observed a 
large series of skulls of these varieties, I had placed all these squirrels, including S. giganteus, under one common denomination, viz., S. bicolor.

The skull of the large black squirrel from Borneo with the under parts yellowish and with tufted ears, and in no way separable from squirrels of the same kind from the Sikkim, Himalaya, and Assam, has broad nasals agreeing with typical S. giganteus.

This species ranges from the North-Western Himalaya through Assam, the Garo Hills, Sylhet, and Cachar, and from Northern Assam across to Yunnan, and spreading southwards also through Arracan and Burma to Tenasserim and the Malayan peninsula and Borneo.

\section{Sciurus INDicus, Erxleben.}

Bombay Squirrel, Pennant, Syn. Mamm. 1771, p. 281 ; Hist. Quad. vol. ii. 1793, 3rd ed. p. 143, (in part).

Sciurus indicus, Erxleben, Syst. Reg. Animal, 1777, p. 400; Zimmermann, Geograph. Gesch. 1780, p. 340 ; Gmelin, Linn. Syst. Nat. 13th ed. 1788, tab. i. pt. i. p. 149; Pennant, Quadr. vol. ii. 1793 (in part), p. 143; Shaw, Genl. Zool. vol. ii. pt. i. 1801, p. 133 ; Desmoulins, Dict. Class D’Hist. Nat. vol. vi. 1824, p. 74; Lesson, Man. de Zool. 1827, p. 234; var. elphinstonii, Gray, Ann. and Mag. Nat. Hist. vol. xx. 1867, p. 273.

Sciurus purpureus, Zimmermann, Sp. Zool. Geo. Quadr. 1778, p. 518; Gray, Hand-List, Mamm.

B. M. 1843, p. 136 (in part); Blyth, Journ. As. Soc. Bengal, vol. xvi. 1847, p. 868.

Sciurus bombayanus, Boddaert, Elench. Animal, 1785, p. 117.

Sciurus maximus, Horsfd. Zool. Resch. Java (in part); Wagner, Schreber, Säugeth. vol, iii. Suppl. 1843, p. 188 (in part); Fischer, Syn. Mamm. 1829 (in part), p. 335.

Sciurus elphinstonii, Sykes, Proc. Zool. Soc. 1831, p. 103; Schinz, Syn. Mamm. vol. ii. 1845, p. 33 ; Fraser, Zool. Typica, 1849, pl. xxvi.; Horsfd. Cat. Mamm. E. Ind. Co.'s Mus. 1851, p. 157; Jerdon, Mamm. Ind. 1867, p. 167.

Sciurus malabaricus, Schinz, Syn. Mamm. vol. ii. 1845, p. 32 (in part).

Sciurus (Ratufa) indicus, Gray, Ann. and Mag. Nat. Hist. vol. xx. 1867, p. 273.

Pennant described the Bombay squirrel from a stuffed skin in the cabinet of Dr. Hunter, and he characterised it as a squirrel with tufted ears, with the head, back, sides, upper part of the legs and thighs, and the tail, of a dull purple; the lower part of the legs and thighs and the belly yellow; the end of the tail being orange. The length of the body he gives as 16 inches, and that of the tail 17. He states that it inhabits Bombay. From the entire absence of any allusion to the occurrence of black in the animal he was describing, and which is always present in the Malabar squirrel, it appears to me that this Bombay squirrel is the species described by Sykes as S. elphinstonii from the Western Ghâts and Deccan. Pennant, in his History of Quadrupeds, refers to Buffon's figure of the Malabar squirrel, and states that he suspected it to be only a variety. He also mentions that the Bombay squirrel extends to Balisere (Balisore?) on the opposite part of the peninsula of India. Erxleben applied the term S. indicus to Pennant's Bombay squirrel, and in this was followed by Gmelin, who afterwards separated the purple and black Malabar form as S. maximus. 
Sykes, who gave the first detailed description of this species, states that it does not change its colour at any period of life, but he afterwards observes that, like the Malabar squirrel, it passes through some gradations of colour.

I have examined the specimen from which he drew up his account of the animal, and which was figured in Fraser's Zoologia Typica, and also about thirty other individuals of different ages, which presented but little variation.

The upper surface of the body is dark maroon-red, with the exception of the sacral region and outside of the shoulder and humeral portion of the fore limb, which are black. The outside of the hind legs, and half-way down the outside of the fore legs, are of a uniform, rich maroon-red. The whole under surface of the body, from the chin to the vent, inside of limbs, and lower part of the fore legs, the interaural region and the cheeks, are of a bright orange-yellow; the two colours on the side being separated by a defined line, and not merging into each other. The forehead and down to the nose is reddish-brown, with white hairs intermixed; ears always tufted. A narrow, maroon line from the anterior angle of the ear extends downwards to the side of the neck, with a yellow line behind it. Whiskers and bristles black. Tail black, ending in a broad, brownishyellow tip.

$$
\begin{aligned}
& \text { Length of male, tip of muses. } \\
& \text {. . } 20 \cdot 00 \\
& \text { " of tail . . . . . . . . . . } \quad . \quad 15 \cdot 25
\end{aligned}
$$

The skull of $S$. indicus, besides being considerably smaller than the skull of $S$. maximus, is also distinguished from the latter by a narrower and less concave, inter-orbital space. The nasals also are differently formed, having their posterior ends much broader than in S. maximus and much less dilated anteriorly. The upper dental line also of $S$. indicus is much shorter than in the larger species.

This species is found in the lofty and dense forests of the Western Ghâts, but it has also an easterly distribution as far as Midnapur and Kuttack.

\section{Scturus maxtmus, Gmelin.}

Tie grand Ecureuil de la côte de Malabar, Sonnerat, Voyage aux Indes Orient. \&c. vol. ii. 1782, p. 139, pl. lxxxvii.; Buffon, Hist. Nat. Suppl. vol. vii. p. 254, 1789, pl. lxii.

Sciurus maximus, Gmelin, Linn. Syst. Nat. vol. i. pl. i. 1788, p. 149; Pennant, Hist. Quadr. 1792 3rd ed. p. 141 ; Schreber, Säugeth. vol. iv. 1792, p. 784, pl. 217B (Sonnerat's figure) ; Shaw, Genl. Zool. vol. ii. pt. i. p. 127 ; Desmarest, Nouv. Dict. d' Hist. Nat. vol. x. 1817, p. 104 (in part) ; Mamm. 1820, p. 334; Horsfd. Zool. Resch. Java, 1824 (in part) ; Cat. Mamm. E. Ind. Co.'s Mus. 1851, p. 156 (in part) ; Lesson, Man. de Zool. 1827, p. 235 ; Fischer, Syn. Mamm. 1829, p. 355 (in part) ; Is Geoff. St.-Hil. Bélanger's Voy. aux Indes Orient. Zool. 1834, p. 151; Wagner, Schreber, Säugeth. Suppl. vol. iii. 1843, p. 188 (in part); Blyth, Journ. As. Soc. Beng. vol. xxviii. 1859, p. 286 ; Cat. Mamm. As. Soc. Mus. 1863, p. 98 ; Jerdon, Mamm. Ind. 1867, p. 166 . 
Sciurus macrourus, F. Cuv. Dict. des Se. Nat. vol. xiv. 1819, p. 246 (in part); Fischer, Syn. Mamm. 1829, pp. 355-356 (in part).

Sciurus purpureus, Gray, Hand-List Mamm. B. M. 1843, p. 136 (in part) ; Blyth, Journ. As. Soc. Beng. vol. xvi. 1847, p. 868 ; Hodgson, Proc. Zool. Soc. 1855, p. 126.

Sciurus malabaricus, Schinz, Syn. Mamm. vol. ii. 1845, p. 32 (in part); Jerdon, Mamm. Ind. 1857, p. 166.

Sciurus (Ratufa) indicus, Gray, Ann. and Mag. Nat. Hist. vol. xx. 1867, p. 273.

The characters of the Malabar form, the literature regarding which heads this notice, may be briefly summed up as follows :-

The upper surface and the sides of the neck, the shoulders and the outside of the fore limbs, the lumbar and sacral regions, the outside of the thighs and the tail, are black, the black of the hind quarters being prolonged forwards along the mesial line towards the black of the shoulders. A large, dark, maroon spot on the vertex separated from the maroon of the nape by a yellowish, inter-aural area, which extends downwards and forwards to the cheeks. A maroon-coloured line passes downwards from the front of the ear, with a yellow area behind it. The sides of the face and muzzle are pale-yellowish, the latter being flesh-coloured. The other portions of the trunk and the lower half of the tibial portion of the hind limb are maroon. The tail is either black or maroon-black, sometimes tipped with yellowishbrown. The whole of the under parts and inside of the limbs, and the hands and feet, are rich yellowish. The ears strongly maroon, and tufted.

This species occurs on the Malabar Coast, and extends into Central India, and in the southern portion of the former region it appears to be associated with S. macrourus. Hodgson records it from the Terai region of the Himalaya.

\section{Scrurus Macrourus, Pennant.}

Sciurus macroums, Pennant, Ind. Zool. 1769, Ist ed. p. 31, pl. i. ; Syn. Quad. 1771, p. 281 ; Hist. Quad. 3rd ed. 1792, p. 140 ; Erxleben, Syst. Reg. An. 1777, p. 400 ; Zimm. Sp. Zool. Geogr. 1777, p. 518; Geogr. Gesch. vol. ii. 1780, p. 340; Forster, Indische Zool. 1781, p. 11, pl. i.; Bodd. Elench. An. 1785, p. 117 ; Gmelin, Linn. Syst. Nat. vol. i. 1788, p. 148; Schreber, Säugeth. vol. iv. 1792, p. 783, pl. 217 (Pennant's figure) ; Shaw, Gen. Zool. vol. ii. 1801, p. 129, pl. i.; Desmarest, Nouv. Dict. d'Hist. Nat. vol. x. 1817, p. 104 (in part) ; F. Cuv. Dict. des Sc. Nat. vol. xiv. 1819, p. 246 (in part) ; Is. Geoff. St.-Hilaire, Dict. Class. d'Hist. Nat. vol. vi. 1829, p. 71; Fischer, Syn. Mamm. 1829, p. 355 (in part); Gray's Hand-List, Mamm. B. M. 1843, p. 137; Blyth, Journ. As. Soc. Beng. 1847, vol. xvi. p. 869, pl. xxxvi. fig. 2 ; ibid. 1849, vol. xviii. p. 601 ; ibid. vol. xx. 1851, p. 165 ; Cat. Mamm. As. Soc. Mus. 1863, p. 100 ; Horsfield, Zool. Resch. Journ. 1824; Cat. Mamm. E. Ind. Co.'s Mus. 1851, p. 158 ; Kelaart, Proc. Zool. Soc. 1850, p. 157 ; Prod. Faun. Zeyl. 1852, p. 49 ; Jerdon, Mamm. Ind. 1867, p. 168; Gray, Ann. and Mag. Nat. Hist. 1867, p. 275.

? Sciurus vulgaris, var. ceylonicus, Erxleben, Syst. Reg. An. 1777, p. 416.

Sciurus ceylonicus, Erxleben, Syst. Reg. An. 1777, p. 416; Desmoulins, Dict. Class. d'Hist. Nat. vol. vi. 1824, p. 71.

Sciurus ceilonensis, Bodd. Elench. An. 1785, p. 117 ; Desmarest, Mamm. 1822, p. 335, pl. lxxv. fig. 4; Lesson, Man. de Zool. 1827, p. 235.

Sciurus maximus, Wagner, Schreb. Säugeth. Suppl. vol. iii. 1843, p. 188 (in part).

Sciurus bicoior, Schinz, Syn. Mamm. vol. ii. 1845, p. 33 (in part). 
Sciurus tennentii, Layard, Blyth, Journ. As. Soc. Beng. vol. xviii. 1849, p. 600 ; ibid. vol, xx. 1851, p. 165 ; Cat. Mamm. As. Soc. Mus. 1863, p. 100 ; Kelaart, Prod. Faun. Zeyl. 1852, p. 50.

Sciurus albiceps, ${ }^{1}$ Blyth, Journ. As. Soc. Beng. vol. xxviii. 1859, p. 287 ; Cat. Mamm. Mus. As. Soc. 1863, p. 100.

Macroxus (Rukaia) macrourus, Gray, Ann. and Mag. Nat. Hist. vol. xx. 1867, p. 275 (in part).

From the description given by Ray ${ }^{2}$ of his Ceylon squirrel, there does not appear to be any doubt that the animal to be hereafter described was the species to which he referred. After him, Pennant re-described and figured the animal, and was followed by Erxleben and Zimmermann, and more particularly by Forster, who adopted Pennant's name of $S$. macrourus, although it had been erroneously stated that the tail was twice the length of the body. Boddaert re-described the species as the Ceylon squirrel, but altered the name to ceilonensis, and gave a more correct estimate of the relative proportions of the body and tail, viz., "cauda longitudine corporis." Gmelin in the 13th edition of the Syst. Nat. accepted Pennant's name and referred to Schreber's figure, which is a reproduction of Pennant's. Pennant in his 2nd edition of the Indian Zoology extended the distribution to Malabar, and it is interesting to remark, in connection with this, that Blyth and Jerdon record examples from Travancore, the Nilgiris, and Bangalore.

The figure given by Pennant does not show the tail to be so long as he makes it to be in his description; nevertheless, in this error he was followed by Shaw. After this, Desmarest introduced an element of confusion as far as the term macrourus is concerned, for he applied it also to the large, maroon-coloured squirrel of Malabar, first brought to light by Sonnerat, and in this view he was followed by F. Cuvier. Desmarest, however, rectified his error in his Mammalogie, and distinguished between the two species and reproduced Pennant's figure.

Is. Geoff. St.-Hilaire also separated the Ceylon form as S. ceylonensis, and Fischer kept it distinct under the name $S$. macrourus, but erroneously regarded it as the same as the Java squirrel described by Horsfield.

The Ceylon specimen figured by Blyth ${ }^{3}$ (from Dr. R. Templeton of Colombo) measured 2 feet long, of which the tail was half, its hair reaching $1 \cdot 50$ inch further. Colour of the upper parts dull brownish-black, much grizzled with whitish tips on the sides, croup and haunches, and slightly on the back and shoulders, the croup having numerous buffy-white hairs intermixed; basal three-fifths of the tail black, with long, white tips to the hairs, and a white, median line underneath, the rest, or terminal portion, brown, with less conspicuously developed, white tips, except at the very end, where they gradually disappear; cheeks, under parts and limbs almost pure white, with a slightly fulvescent tinge; but there is an abruptly defined, blackish patch on the upper portion of the fore limbs externally, passing upward to the shoulder; a corresponding, grizzled patch on the hind limbs continuous with the colouring of the croup and haunches; the toes of all the feet are blackish; there is also a black patch on the crown of the head, and a few blackish hairs on 1 This term had been previously applied by Wagner to a Mexican squirrel. Abhandl. Akad. Munschen, vol. ii,
Schreber, pl. ccxsiii. D.

\footnotetext{
2 Quad. (1693), p. 215 . $\quad{ }^{3}$ L. c., p. 869.
} 
the white cheeks, a dull, whitish band behind the ears, and the short fur upon the outside of the ears is whitish, excepting a slightly black pencil anteriorly.

There are two specimens from Ceylon in the British Museum; one is a female and the other apparently a male: the former is pale-brownish, and the latter is blackish, much grizzled, both corresponding, more or less, to Blyth's figure. The male agrees with Pennant's description. In the dark specimen, a black band runs down in front of the ear, separated from it by a narrow, pale area, but in the other there is no trace of a band. In other respects, they are identical, it being impossible but to regard them as one and the same.

A well-marked, large variety of $S$. macrourus is generally distributed over the higher parts of the Island of Ceylon. It was originally separated by Blyth as a distinct species under the name $S$. tennentii suggested for it by Mr. Layard. It differs from the generality of specimens of $S$. macrourus in being wholly black on the upper parts, except on the vertex, but Kelaart mentions that some individuals of S. macrourus occasionally assume that colour, and from the foregoing description of the male $S$. macrourus, it is evident that that animal is intermediate between true S. macrourus and S. tennentii. The area on the vertex is pale rufous-yellow. The tail is black at its base, as in some examples of S.macrourus, but the rest of the hairs are broadly tipped with white, with the exception of those at the end, which are wholly black, or somewhat rufous, which are also characters of $S$. macrourus. The mesial line of the under surface of the tail is yellowish. The ears are strongly tufted. The black patch behind the eye is more defined than in $S$. macrourus, but it is liable to considerable variation. The muzzle, anterior to the eye, all the under parts, and the lower half of the extremities, except the feet, which are black, are fulvous-yellow.

The skull of the type of 'S. tennentii, besides being larger than any skulls of S. macrourus I have examined, has also greater inter-orbital breadth, but the general form of the two skulls is alike, and the shape of the nasals is the same in both, but the muzzle of $S$. tennentii is broader than in $S$. macrourus. The two are, however, so connected together by intermediate forms that I hesitate to regard S. tennentii as a sub-species, notwithstanding these seeming, cranial differences, because these in all likelihood will be found to be variable, when a series of skulls is examined.

It is hardly necessary to remark that the Ceylon squirrel and its variety S. tennentii are quite distinct from the Malabar squirrel of Sonnerat, although Cuvier was inclined to see a similarity between Pennant's and Sonnerat's figures, but a comparison of the two animals, side by side, dispels such a supposition. Horsfield was under the impression that a good character by which to distinguish the Ceylon squirrel from the large, maroon and black Indian squirrel, was, that in the animal figured by Pennant the cheek-band was double, while in $S$. indicus it was single; but this character, although seemingly persistent in $S$. indicus, is a variable one in S. macrourus; some have no cheek-band, while others have it only feebly developed, and others have it double. S. indicus is a larger animal, with its 
coat varying but little from a deep maroon and black, the former colour being never approached by $S$. macrourus.

It seems to me that the animal figured by Gray and Hardwicke ${ }^{1}$ as $S$. macrourus is a variety of $S$. indicus badly drawn and coloured, with the ears disproportionately large for a squirrel.

In the British Museum, there is a squirrel said to have come from Java, so different from the other squirrels from that island that if the locality is correct it is of great interest, as its affinities are more in the direction of $S$. indicus and S. macrourus than of $S$. bicolor. It has its short ears with distinct pencillings projecting 0.40 inch beyond the tip of the ear, and it has two prominent, black cheekmarks, and the anterior and posterior limbs white for a short way above the wrists and ankles, the anterior half of the face also being whitish. There is a white spot on the occiput, with a pale yellow or rusty-brown area below it. The top of the head is black, with scattered white hairs in front, and the area around the eye and before the ear is yellowish-white, but the blackish-brown of the head is prolonged downwards between the eye and the ear, partially dividing into two, one portion stretching downwards below the ear, and the other, smaller and triangular, passing below the eye; these being akin to the cheek-markings of S. giganteus and S. macrourus; and it is allied to $S$. indicus by its colouring, and by an occipital mark which is also visible in $S$. macrourus, but never occurs in $S$. giganteus. The ear-tuft is black. The general colour of the upper parts is dark maroon, darkest on the shoulders and upper half of the fore leg and on the rump, which is sparsely white-grizzled, as is the lower portion of the dark colour of the outside of the thighs, also the lower portion of the sides where the dark colour comes in contact with the white. As in $S$. indicus and $S$. macrourus, the radial or lower half of the fore limb is yellowish-white; the lower portion of the hind limb above the ankle and the first third of the hind foot are yellowish-white, the fore foot and the two terminal thirds of the hind foot being blackish-brown or black. All the under parts are yellow-white, also the inside of the thighs. The tail is bushy and black, many of the hairs being white-tipped; its extremity being slightly rufous, and in this also it conforms to $S$. indicus, which has occasionally a pale rufous tip.

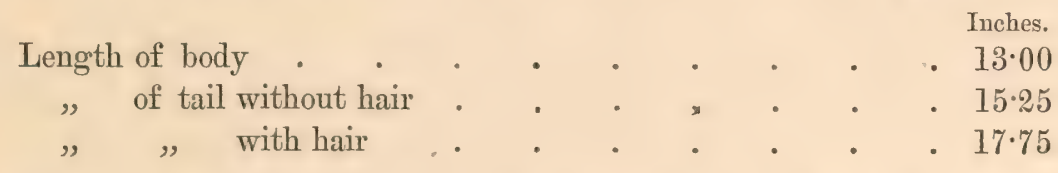

As the specimen is badly stuffed, the measurements are only approximate.

* Scidrus Pygerythrus, Is. Geoff. St.-Hil.

Sciurnspygerythrus, Is. Geoff. St.-Hil. Mag. de Zool. 1832, Cl. i.; Voy. aux Indes Orient. Bélanger, Zool. 1834, p. 145, pl. vii.; Wagner, Schreber, Säugeth. Suppl. vol. iii. 1843, p. 199 (in part); Schinz, Syn. Mamm. vol. ii. 1845, p. 34; Blyth, Journ. As. Soc. Beng. vol. xvi. 1847, p. 827

\footnotetext{
${ }^{1}$ Gray and Hardwicke, Ill. Ind. Zool. vol. ii. (1834), pl. No. 19.
} 
(note) : ibid. vol. xvii. 1848 , p. 345 ; ibid. vol. xxiv. 1855 , p. 475 ; ibid. vol. xxviii. 1859 , p. 275 ; ibid. vol. xliv. 1875 , ex. no. p. 37 ; Cat. Mamm. As. Soc. Mus. 1863, p. 103.

Sciurus flavimanus, Schinz, Syn. Mamm. vol. ii. 1845, p. 34 (in part).

Macroxus vittatus, Gray, Ann. and Mag. Nat. Hist. vol, xx. 1867 (in part), p. 278.

The squirrel described by Is. Geoff. St.-Hilaire from Pegu as S.pygerythrus has the upper parts dark olive-grey, the basal third of the tail being concolorous with the back, and its latter two-thirds, except the black tip, ringed with oliveyellowish and black. The feet are like the upper parts, but they are sometimes washed with yellowish. The under surface from the chin to the vent, and the inside of the limbs, are orange-yellow, which extends along the middle line of the under surface of the tail. The hairs of the upper fur have five to seven alternate, dark brown or even black and yellow bands, the apical band being black, the yellow bands being rather pale and narrower than the dark bands.

There is a squirrel common at Ava, in Upper Burma, that appears to be a pale variety of this species. The upper parts are pale olive-grey, but with the same kind of annulation that characterises S. pygerythrus, and the tail also is marked exactly like the Southern Pegu squirrel. The colour of the feet, as in $S$. pygerythrus, is variable, but it appears to be more generally of a yellowish tint than concolorous with the back, but both kinds are met with. The under parts have a pale yellowish tint of variable intensity. In the localities in which it occurs it is associated with $S$. blanfordii. In the Leyden Museum there are squirrels from Tounghu in Upper Burma which exactly resemble this form, except that they are even more greyish.

Two adult of skulls of the pale variety, from the dry country of Upper Burma, and one adult skull of the darker typical form, are alike. They are distinguished from the skulls of S. caniceps, S. phayrei, and S. blanfordii by their much smaller size. Among themselves they are much about the same size, but one of the skulls of the pale variety is a little longer than the other skull of the same variety when measured from the lambdoidal ridge to the tip of the nasals, but, in both, the length from the inferior border of the foramen magnum to the root of the upper incisors is the same. The difference in length in the former measurement appears to be due to the nasals of the one being longer than the nasals of the other. These bones, however, in the three skulls are much alike, moderately broad posteriorly and slightly expanded anteriorly. In all, there is a slight depression over the frontals. In two of the larger skulls, one being of the pale variety and the other typical, the teeth are larger than in the smaller example of the pale variety, but the difference does not exceed more than 0.03 of an inch. These skulls are miniature representations of the skull of $S$. blanfordii, but all of them are fully adult. The longer of the two skulls belonging to the pale variety measures from its lambdoidal ridge to the extremity of the nasals $1 \cdot 81$ to $2 \cdot 10$ inches in a female S. blanfordii. They have also a close resemblance to the skulls of $S$. caniceps and to S. phayrei, but they are very much smaller. 


\section{ScIURUs CANICEPS, Gray.}

Sciurus caniceps, Gray, Ann. and Mag. Nat. Hist. vol. x. 1842, p. 263; Hand-List Mamm. B. M. 1848 , p. 143; Blyth, Journ. As. Soc. Bengal, vol. xxiv. 1855, p. 477; ibid. 1875, vol. xliv. ex. no. p. 36 ; Horsfield's Cat. Mamm. E. Ind. Co.'s Mus. 1851, p. 155.

Sciurus-1? (?), Blyth, Journ. As. Soc. Beng. vol. x. 1841, p. 920.

Sciurus chrysonotus, Blyth, Journ. As. Soc. Beng. vol. xvi. 1847, p. 873, pl. xxxvii.; ibid. vol. xviii. 1849, pp. 602 and 603 ; ibid. vol. xxiv. 1855, p. 474; Cat. Mamm. As. Soc. Beng. Mus. 1863, p. 103 ; Horsfield, Cat. Mamm. E. Ind. Co.’s Mus. 1851, p. 159 ; Peters, Proc. Zool. Soc. Lond. 1866, p. 429; Gray, Ann. and Mag. Nat. Hist. vol. xx. 1867, p. 281; W. T. Blanford, Ann. and Mag. Nat. Hist. 4th ser. vol. i. 1868, p. 152.

Macroxus caniceps, Gray, Ann. and Mag. Nat. Hist. vol. xx. 1867, p. 280.

The red-backed squirrel, which occurs in Pegu with S. pygerythrus and S. phayrei, and which was described first by Dr. Gray under the name of S. caniceps, and afterwards by Blyth as S. chrysonotus, has the general colour grey, or fulvous above; the outsides of the limbs, with the exception of the feet, are grizzled grey; the feet yellowish-grey : each hair being annulated with from five to seven alternate black and grey, or black and fulvescent rings ; the tail grey-grizzled with an abruptly defined, black tip, as in $S$. pygerythrus, S. phayrei, and S. blanfordii. Under parts and inside of limbs pale-greyish, sometimes with a faint yellowish flush. In certain specimens the nape, shoulders, and upper parts of the back are vivid, light ferruginous or golden fulvous, sometimes continued on to the base of the tail; in some it occurs only to a very limited extent, and in others there is no trace of this colour, all the upper parts being grey-grizzled, exactly as in S. blanfordii. The whiskers are long and black, and there are slight, albescent pencils to the ears.

The skull of an adult male S. caniceps, which had the bright, red, golden colour of the back well developed, presents so strong a resemblance to the skull of $S$. blanfordii that it is extremely difficult to seize on any point wherein they differ. The character of the occipital region is apt to vary, as in two fully adult and male skulls of this species it slopes much more forwards and downwards in one than in the other. The nasals vary, being longer and broader in some than in others. The shape of the premaxillary portion of the skull is much the same as in S. blanfordii. The teeth are a little larger than those of that form, but not more so than could be explained on the ground of individual variation. This skull has also a strong resemblance to the skull of S. griseimanus, but it is somewhat larger. It also has all the leading features of the skull of $S$. phayrei, only the teeth are larger than those of any of the skulls of the types, but they are not larger than the teeth of a skull which Blyth referred to this species and which he obtained in Lower Martaban. Such facts, taken in conjunction with those to be mentioned under $S$. blanfordii, suggest that there is a very intimate connection between all of these forms, if they do not ultimately prove to be identical.

This species occurs in Upper Tenasserim and has been found also at Tavoy.

${ }^{1}$ Temminck, in Les Esq. Zool. sur la Côte de Guiné (1853), has described a squirrel from the West Coast of Africa under this name, so that this African species remains to be re-named and may stand as $S$. temminckib. 


\section{ScIURUS PHAYreI, Blyth.}

Sciurus phayrei, Blyth, Journ. As. Soc. Beng. vol. xxiv. 1855, p. 472 et p. 476 ; ibid. vol. xxviii. 1859, p. 275; ibid. vol. xliv. (ex. no.) 1875, p. 36 ; Cat. Mamm. As. Soc. Mus. 1863, p. 104; Peters, Proc. Zool. Soc. 1866, p. 429 ; W. T. Blanford, Ann. and Mag. Nat. Hist. vol. i. 4th ser. 1868, p. 152 .

Sciurus pygerythrus, Blyth, var. Journ. As. Soc. Beng. vol. xvii. 1848, p. 345; ibid. vol. xviii. 1849, p. 602 .

Macroxus phayrei, Gray, Ann. and Mag. Nat. Hist. vol. xx. 1867, p. 277.

The laterally banded squirrel from Martaban, described by Blyth as S. phayrei, resembles S. pygerythrus in the colour of its upper parts and in the character of its tail, which has a well-defined, black tip. The lower parts are rich orange-red, but of variable intensity, and this colour is continued, more or less, along the under surface of the tail. The insides of the limbs are of the same colour, and this is continued on to the front of the thigh and upon the feet; the fore limbs are tinged with dusky, externally, above the pale rufous or yellowish feet. It is distinguished from S. pygerythrus by a broad, well-defined, blackish band upon the flanks, separating the colours on the back and belly.

The skull of this species has much the same characters as the skulls of $S$. blanfordii and S. caniceps, but it is somewhat smaller. A skull, however, referred by Blyth to this species, but unverified by a skin, is considerably larger than the skull of these two species, and remarkably resembles the skull of S. blanfordii.

This form occurs in Martaban, and extends northwards to Upper Burma, having been obtained at Tounghu.

\section{* Scturus blanfordiI, Blyth, Plate XVIII.}

Sciurus blanfordii, Blyth, Journ. As. Soc. Beng, vol. xxxi. 1862, p. 333 et p. 391; ibid. vol. xxxii. 1863, p. 73 ; ibid. vol. xliv. (1875 ex. no.), p. 36 ; Cat. Mamm. As. Soc. Mus. 1863, p. 104; W. T. Blanford, Ann. and Mag. Nat. Hist. 4th ser. vol. i. 1868, p. 152. Macroxus blanfordii, Gray, Ann. and Mag. Nat. Hist. 1867, vol. xx. p. 284.

This grey, but orange-bellied squirrel, first discovered in Upper Burma, in the vicinity of Ava, is pale grey above, the fur being finely punctulated with black and grey, which is also the colour of the tail, which has a well-marked black tip. The hands and feet are yellow. The under surface is pale orange-yellow from the chin to the vent. It is of the same size as $S$. caniceps and $S$. phayrei, with the same proportions of tail to body, and its ears are alike in shape and size to those of these two forms; and a female shot by me at Pudeepyoo in Upper Burma, in the beginning of January, has a distinct tendency to the formation of a dusky lateral stripe, and the under parts are much more rich orange than in the type.

The skeleton of this individual has 12 ribs, and 7 lumbar and 26 caudal vertebræ. There are five meso-sternal elements in addition to the manubrium. The 
under surfaces of the bodies of the cervical vertebræ are marked by a feeble median ridge, and external to it, on the hinder margin on each side, a small welldefined nodule is present. The under surfaces of the lumbar vertebræ, with the exception of the last, are strongly ridged, and the ridge is prolonged forwards more feebly along the dorsal vertebræ and is almost lost on the second dorsal.

I have examined a very extensive series of squirrels belonging to the various forms above described, viz., S. pygerythrus, S.caniceps, S. phayrei, and S.blanfordii, and of others, which appear to indicate at least, if not to prove, that all of them are in some way related to each other.

Out of a large series of specimens referable to $S$. caniceps, the males illustrate three phases of colouring associated with a difference in the character of the fur. The first is a grey, the second a yellowish, and the third a phase in which the back becomes brilliant yellowish-red.

In the grey phase,-and the squirrels presenting it are all adults,- the fur of the upper parts is so identical with that of $S$. blanfordii that it is impossible to distinguish between the two forms, in a series of skins laid out belly downwards. The fur is grey all over, very finely speckled with black and greyish; and the tails of the two forms also are identical, being annulated with greyish and black in such a way that there is a tendency to a ringing of the tail with these colours, the tip in both being black. The feet also are nearly white or pale yellowish, as in S. blanfordii. But on examining the under parts, it is found that in these phases of $S$. caniceps they are grey, whereas in $S$. blanfordii they are a beautiful rich orange, and the feet are yellow. I have never observed a specimen with the under parts similarly coloured to those of $S$. blanfordii, but there is one example from Moulmein, which has a blush of yellowish all over the under parts, but very pale and of a different tint from that of $S$. blanfordii.

In the grey phase the fur is rather short and not so soft and long as in the next phase. A specimen illustrates the transition from the grey to the yellowish phase, the fur becoming longer and the pale bands of the hairs changing to yellowish, commencing from below upwards and showing itself through the fur, which, when pulled aside, is seen to be yellowish underneath, although the sub-apical, pale bands have not yet changed from grey to yellow. It would appear that this change may either take place generally over the upper parts or commence at first in a restricted area, from which it gradually spreads and at last involves the whole of the upper parts; the change may progress more rapidly in some localities than in others. This is shown in a specimen in which the underlying, yellowish tinge is distinctly visible over the upper parts, but in the dorsal line from the base of the tail to the middle of the back, the change has proceeded more rapidly, and the fur is long, and distinctly annulated throughout, yellow and black. Ultimately, the yellow and black annulation involves the whole of the fur, and in this stage the under parts have changed from grey to dusky yellowish and the feet are dusky grey. But in those instances in which the fur changes from a dorsal 
centre, there seems to be a tendency to deposit brilliant pigment in the hair, and for the change to progress less rapidly in the surrounding parts, the activity of action seeming to be concentrated in, and to be diffused from, the original area of change. We have, thus, squirrels with brilliant, red, dorsal areas of different sizes and with long hair, while the surrounding parts have not as yet emerged, or only partially so, from the grey stage; and these forms constitute the S. caniceps, Gray, and the S. chrysonotus, Blyth. The former term is explained by the circumstance that the red never appears to involve the head. The change of colour is also sometimes inaugurated from the base of the tail, spreading upwards on to the rump. These metamorphoses are the exact counterparts in red of those which take place in S. atrodorsalis in black.

S. phayrei corresponds in the colour of the upper fur to the yellow phase of $S$. caniceps, and the tail is the same as in it, having a black tip, which is the character also that that appendage has in S. pygerythrus. In some examples of $S$. phayrei, the dusky or blackish is not confined to the lateral line, but extends over the outside of the fore limbs, the feet being always yellow in squirrels presenting these characters. Some specimens of S. pygerythrus show a distinct tendency to have yellow feet, and further research will probably prove $S$. phayrei to be only a variety of $S$. pygerythrus. When Blyth first encountered this form he simply regarded it as a variety of $S$. pygerythrus, and I believe his first opinion will be ultimately found to be more in accordance with the real interpretation of the facts than the conclusion he afterwards adopted.

In the Paris Museum, there is an example of $S$. blanfordii from Upper Burma, which distinctly shows a dark, lateral streak, so that, taking into consideration the other examples to which I have already referred, there seems to be a presumption that it and S. phayrei are one and the same species, and that they are probably identical with $S$. pygerythrus. Moreover, my impression is that a more extensive series will establish their identity with $S$. caniceps. This view of the question is also supported by a small series of these squirrels in the Leyden Museum from Tounghu, in Upper Burma, presented by the Marquis of Tweedale. From the characters manifested by these squirrels, and the circumstance that they were all shot in one locality, they are of great interest. One is an adult, and in its upper parts it exactly resembles S. blanfordii, also in its yellow feet and black tip to its tail, but, like S. phayrei, it has a broad, blackish-brown, lateral stripe. The others are smaller and resemble the foregoing specimen in all their characters, except that they have no dark, lateral streak, and that the feet of two are concolorous with the upper parts, while in the remaining squirrel the feet appear to be changing to yellow, as in the adult. The two former of these, therefore, conform to the type of $S$. pygerythrus, but the fur of the upper parts is greyer and not so richly coloured as in it, but the annulation of the fur has the same character in both. The remaining specimen in its features is distinctly referable to S. blanfordii. 


\section{Sciurus Grisetmanus, A. M.-Edwards.}

Sciurus griseimanus, A. M.-Edwards, Rev. et Mag. Zool. Juin. 1867, p. 195; Rech. des Mammif. 1868-74, p. 164.

Macroxus inornatus, Gray, Ann. and Mag. Nat. Hist. Oct. 1867, vol. xx. p. 282.

Macroxus lencopus, Gray, Ann. and Mag. Nat. Hist. Oct. 1867, vol. xx. p. 282.

It appears highly probable that the squirrels to which the above synonymy refers will be found to be specifically identical with S. caniceps. S. griseimanus has a very strong resemblance to the grey phase or variety of that species,-indeed so marked that when it is laid beside a series, it is hardly possible to distinguish the one from the other.

Moreover, I cannot point to a single character by which to separate the skull of typical $S$. caniceps from the skull of a specimen of $S$. griseimanus obtained from Prof. A. M.-Edwards.

S. leucopus, Gray, is identical with S.griseimanus, and S. inornatus corresponds to the grey phase of $S$. caniceps.

These squirrels are from Saigon, the Laos mountains, and Cambodja.

\section{Sciurus atrodorsalis, Gray.}

? Sciurus flavimanus, Is. Geoff. St.-Hil. Guern. Mag. de Zool. 1832, Voy. aux Ind. Orient. (Bélanger) Zool. 1834, p. 148; Gervais, Voy. au tour du Monde (Eyd. et Soul.) Zool. vol. i. 1841, p. 40 ; Schinz, Syn. Mamm. vol. ii. 1845, p. 34; Blyth, Journ. As. Soc. Beng. vol. xvi. 1947, p. 872 .

Sciurus atrodorsalis, Gray, Ann. and Mag. Nat. Hist. vol. x. 1842, p. 263; Hand-List Mamm. B. M. 1843, p. 143 ; Blyth, Journ. As. Soc. Beng. vol. xvi. 1847, p. 872, pl. xxxvii. fig. 2 ; ibid. vol. xvii. 1848, p. 345 ; ibid. vol. xviii. 1849, p. 602; ibid. vol. xxiv. 1855, p. 477 ; ibid. vol. xxviii. 1859, p. 276 ; ibil. vol. xliv. (ex. no.) 1875, p. 36 ; Cat. Mamm. As. Soc. Mus. 1863, p. 105 ; Horsfield, Cat. Mamm. E. Ind. Co.'s Mus. 1851, p. 154; Peters, Proc. Zool. Soc. 1866, p. 428 ; W. T. Blanford, Ann. and Mag. Nat. Hist. vol. i. 1868, p. 152.

Sciurns vittatus, Wagner, Schreber, Säugeth. Suppl. vol. iii. 1843 (in part), p. 199 ; Cantor, Journ. As. Soc. Beng. vol. xv. 1846, p. 250 (in part).

Sciurus hyperythrus, Blyth, Journ. As. Soc. Beng. vol. xxiv. 1855, p. 474; Cat. Mamm. As. Soc. Mus. 1863, p. 182.

In $S$. atrodorsalis there are two well-marked phases of pelage, one in which the black on the back is present and another in which it is entirely absent. Young and adult animals alike are met with exhibiting each of these phases.

In the phase in which no black is developed, the upper parts of the animal and the feet are a yellowish-rufous, the upper surface of the head, as far backwards as the ears inclusive, is generally orange-red, the under surface from the chest backwards and the inside of the limbs being more or less chestnut; the under surface of the neck is orange-yellow, or almost concolorous with the fulvous upper parts, the orange-yellow tending to form a mesial line on the chest. The tail is very variable; in a young specimen it has seven, alternate, orange and black bands, the orange being 
terminal ; the banding is so regular that the tail has a ringed appearance, except at the base and tip, where the banding is interrupted. In two fully adult animals there are only five, alternate, yellow and black bands, but the apical yellow band is so broad that the tail is rich orange, while the hairs at the tip are almost entirely yellow, or nearly white. I have examined a very large series of individuals of this type, all from a limited area, and the characters as just described are wonderfully persistent, but they lead directly into the black backs by the not unfrequent occurrence of squirrels of this type with commencing indications of a. black back which in others is still more defined until individuals of this fulvous phase are found which have intensely black backs. The fulvous squirrels without black backs have generally white whiskers, but in a set of three selected without reference to the colour of the whiskers, one-the young example with the ringed tail just described-has the whiskers wholly black, with the exception of three, short, white hairs on each side.

In the generality of squirrels with black backs, the prevailing colour of the upper fur is less fulvous than in the phase just described; the chestnut of the under parts is darker, and extends, in some, on to the under surface of the neck, while in others that part is concolorous with the sides of the body, and the colour passes backwards for a short way as a mesial line on to the chest, while in others it forms a mesial line along the abdomen, and is punctulated like the sides. The colour of the head is variable, in some rusty red, in others concolorous with the trunk. The tails also are very variable, in some the hairs being broadly tipped with orange-yellow or pale yellow, while in others, with the exception of the base, it is wholly black and unannulated. In specimens with a cold grey-yellow, punctulated fur, the tail is yellowishgrey and black, interruptedly banded. In these squirrels the head is yellowish, and the under surface of the trunk and the inside of the limbs are deep, rich chestnut, with a grizzled line over the chest. The S. hyperythrus, Blyth, is a phase near this, but with no black on the back, and with the paler bands of the tail dark, rich orange, instead of yellowish-grey, and the whiskers are wholly black.

There can be no doubt whatever of the specific identity of these very differently coloured squirrels, and that the two leading phases which I have described correspond to the two phases manifested by $S$. caniceps, but their causation is quite unknown. Of a series of eight specimens before me, four belong to animals in which no black is developed on the back, and two of these are males and two females; and, moreover, two are fully adult. Another four belong to squirrels in which the black of the back is strongly developed, and two are females, while one is a male and the sex of the other is undetermined; and these squirrels also are of different ages, as is evinced by the condition of their skeletons which accompany their skins. One of the latter series is younger than any of the four in which no black had developed on the back, so that it would appear that age is not the determining cause of the presence or absence of black in this species, and if so, it is also probable that it does not influence the occurrence or absence of golden red on the back of $S$. caniceps. Further, these eight squirrels tend to prove that the differences of coloration are not sexual. 
These specimens were all killed within a limited distance of each other, viz., between the Siamese frontier, to the east of Moulmein, and Moulmein itself, and within the months of February and March. It is thus improbable that the differences of colour which they manifest are due to mere difference of locality. They may prove to be seasonal changes associated with the period of heat depending on the age the animal may have attained at the time, but, from what I have already stated, neither of the phases can be said to be the permanent pelage of the mature animal. But at the same time the majority of the squirrels that I have met with have been black-backed. From other observations I am disposed to believe that the under surfaces of certain species of Eastern Asiatic Squirrels will be found to be the subjects of quite as remarkable changes of colour.

The skull of $S$. atrodorsalis has a striking resemblance to the skull of S. caniceps, but it is slightly broader with a somewhat shorter muzzle, and judging from a male skull with the teeth well worn, it would appear to be smaller than that of $S$. caniceps. It is also distinguished from that species by its smaller teeth.

The ribs vary from 12 to 13 , and the lumbar vertebræ from 7 to 6 , and the caudal vertebræ would seem even to range from 24 to 28 in number.

The type of S'. flavimanus, Is. Geoff. St.-Hil., with the exception of its yellow feet, does not differ otherwise from S. hyperythrus, Blyth, which is undoubtedly a phase of S. atrodorsalis, Gray, and in the colour of its muzzle it also corresponds to S. atrodorsalis. The locality, however, from whence $S$. flavimanus was obtained is uncertain, as Geoff. St.-Hilaire did not know whether it came from Ceylon or Cochin China. As no squirrel of this type has hitherto been recorded from Ceylon, it is probable that S. flavimanus came from Cochin China, but as I only know of the form by the type, there is merely sufficient evidence to suggest that $S$. atrodorsalis may ultimately prove to be identical with it, and I therefore use the latter term until the identity of the two has been established, and in the sense I have here defined it; but, as I have said, I am disposed to think that, with the exception of the yellow feet, my definition of the species includes $S$. flavimanus.

S. atrodorsalis is very common in Martaban, and it apparently ranges southwards to Malacea, and probably extends its distribution to Cambodja and Cochin China.

\section{Scidrus bimaculatus, Temm.}

Sciurus bimaculatus, Temminck, Esq. de Zool. de Guiné, 1853 (Append.), p. 251.

Sciurus bilineatus (Temminck), A. M.-Edwards, Rech. des Mammif. 1868-74, p. 163.

This is a squirrel of the same size as $S$. atrodorsalis. It is a pale, greyish, olive-brown, washed with pale-yellowish ferruginous on the sides of the head, neck, shoulder, sides of body and thighs: The head is concolorous with the back. The fore feet are pale, tending to yellowish-white, but the hind feet are dark, much grizzled with black. The under parts are greyish-white. The tail at the root is concolorous with the back, but the banding rapidly increases, so that it is more or less banded yellow and blackish. The extreme tip is pure white, preceded by a broad, 1.50 inch, 
well-defined, black band. The ears are large and rounded, and their external surface is well clad, the hairs projecting nearly half an inch beyond their apical margins. The whiskers are jet black.

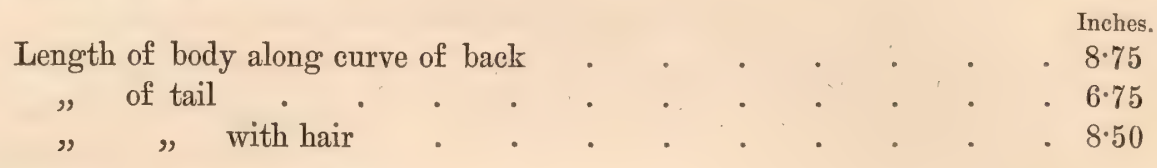

This species occurs in Malacca.

M. A. M.-Edwards has included this squirrel among the dorsally lineated species under the name $S$. bilineatus, Temminck, but there is no such squirrei described in Les Esquisses de Zoologie. Sciurus bimaculatus, Temminck, is not dorsally lineated, and derives its name from its tail ending in white and black.

\section{Sciurus erythremes, Pallas.}

Sciurus erythrous, Pallas, Nov. sp. Quad. e Glir. ord. 1778, p. 377 ; Zimm. Geograph. Gesch. vol. ii. 1780, p. 342 ; Boddaert, Elench. Animal, vol. i. 1785, p. 118 ; Gmelin, Linn. Syst. vol. i. 1788, p. 148; Pennant, Quad. vol. ii. 1792, p. 143; Schreber, Säugeth. vol. iv. 1792, p. 782 ; Shaw, Genl. Zool. vol. ii. pt. i. 1801, p. 132; Horsfd. Zool. Resch. Java, 124; Desmoulins, Dict. Class. d'Hist. Nat. vol. vi. 1824, p. 74; Lesson, Man. de Zool. 1827, p. 237 ; Fischer, Syn. Mamm. 1829, p. 361 ; Blyth, Journ. As. Soc. Beng. vol. xi. 1842 , p. 970 ; ibid. vol. xvi. 1847, p. 872; Cat. Mamm. As. Soc. Mus. 1863, p. 102 ; Wagner, Schreber, Säugeth. Suppl. vol. iii. 1843, p. 218; Gray, Hand-List Mamm. B. M. 1843, p. 142.

Sciurus erythrogaster, Blyth, Journ. As. Soc. Beng. vol. xi. 1842, p. 970 ; ibid. vol. xxiv. p. 473 (note); Cat. Mamm. As. Soc. Mus. 1863, p. 102.

Sciurus erythrcus, Gray, Hand-List Mamm. B. M. 1843, p. 142; Blyth, Journ. As. Soc. Beng. 1847, vol. xvi. p. 872.

? Sciurus hypopyrrhus, Wagler, Abhand. München. Akad. vol. ii.; Schinz, Syn. Mamm. vol. ii. 1845 , p. 20.

Sciurus rufiventer, Blyth, Journ. As. Soc. Beng. vol. xvi. 1847, p. 871.

Sciurus hippurus, Blyth, Journ. As. Soc. vol. xxiv. 1855, p. 473 (note); Walker, Cal. Journ. Nat. Hist. vol. ii. 1843, p. 266.

Macroxus erythrogaster, Gray, Ann. and Mag. Nat. Hist. vol. xx. 1867, p. 283 (in part).

Macroxus punctatissimus, Gray, Ann. and Mag. Nat. Hist. vol. xx. 1867, p. 283.

Pallas, in his description of new species of rodents in 1778, described a squirrel under the name of S. erythraus. This animal has long been a puzzle to zoologists from the characters he assigned to it. His type specimen, he states distinctly, came from India. The description given by him so agrees with the squirrels which have been indicated as $S$. erythrogaster and $S$. castaneoventris that his term erythrceus has not unfrequently been applied to them, although there has been prevailing a general misapprehension regarding its characters; the chief point of difficulty being the existence in Pallas' specimen of a black line along the upper surface of the tail. Blyth, with his usual quick perception of specific characters, referred a specimen from the hills of Lower Assam to S. erythraus, Pallas, and it appears to me that he was correct in so doing. In his enumeration of the characters of 
this Assam form, he remarks of the young, - a fact which I have also observed,-that it not unfrequently has a black area on the tail at some little distance from its base, the black passing more or less upwards and forming a dark, mesial line, as described by Pallas. This squirrel of Blyth's appears to be no other than the young of his S. erythrogaster which came from nearly the same locality, viz., from Muniporea statement which I make after carefully comparing the types.

Blyth ${ }^{1}$ describes $S$. erythrogaster as being of the size of the British squirrel, or a little larger, and having a much longer tail. The entire upper surface is glistening, deep reddish-black, minutely grizzled with light fulvous or yellowish-brown, each hair having thus two annulations; the whole under parts from the throat, and the inside of the limbs, rather dark, but not intense, reddish-maroon; feet black, with little trace of annulation; the fulvous predominating most about the head; tail similar to the back from the basal third, then gradually less grizzled, and the terminal half black, almost without grizzling, moderately bushy; whiskers black; ears not pencilled. Length nine or ten inches; the tail without its hair as much more and with it upwards of two inches additional; tarsus to the end of the claw of longest toe, two inches and a quarter.

Blyth $^{2}$ described another squirrel from the Khasia hills and the mountains of Lower Assam, under the name of S. erythreus, Pallas. M'Clelland and Horsfield, however, considered it to be S. hippurus, Is. Geoff., but it is duller and more bleached above, the ferruginous hue of the belly contrasting abruptly with the sides of the body, whereas in S. hippurus the sides are so rufous that the contrast is much less decided; moreover, S. hippurus does not appear to extend so far north. The ears are bright rufous, and the terminal two-thirds or more of the tail are nearly of the same colour as the belly, the tip generally being paler. There is also more or less rufous about the muzzle, extending sometimes wholly or partly over the crown, and the end of the tail is occasionally blackish. Gray's var. $b$ from Bhutan is undoubtedly the species.

The specimens in the British Museum referred by Dr. Gray first to S. erythraus, Pallas, and afterwards to S. erythrogaster, Blyth, are all distinguished by having the under parts uniformly rich maroon-chestnut, without any tendency to form a mesial ventral line, but occasionally a punctulated ventral line is developed in this species. The rufous extends over the chest and throat in all except a specimen said to be from Bhutan, in which the throat and chest are grizzled like the sides of the neck. This specimen, however, has the peculiarity noticed by Blyth, that the chin and face, between and anterior to the eyes, is not rufous, neither are the ears. The feet in all are dark blackish-brown. The upper fur is rich, dark olive-brown in the majority; but in two specimens, one from the Garo hills and another from Samagooting, Assam, the fur is pale olive-brown, whereas the typical squirrels from Munipore are always much darker. The tail is subject to considerable variation in its colouring, but even in squirrels in which it is brilliant

\footnotetext{
${ }^{1}$ Vol. xi. (1842), No. 130, p. 970.

2 Journ. As. Soc. Beng. 1855, vol. xvi. p. 473.
} 
red in its latter half (Garo hills), it is observed, when the hairs are pulled aside, that they are more or less annulated at their bases, and that the red colour is due to the great development of the red tip which hides the underlying annulation. In some specimens, however, the annulation of the hairs entirely disappears in the red area. In squirrels with black tips to their tails, or in which half of the tail is black, the same remarks are applicable as to the red-tailed forms. The Bhutan squirrel has a black tip to its tail not abruptly defined, but merging slowly from the preceding colour, which has a rufous tint about it, with the annulation of the hairs not at all well marked. In some squirrels from the Khasia hills the tip is occasionally whitish as in S.ferrugineus, var. keraudrenii. In Assam specimens the tail in its latter third is black, and the previous portion is richly annulated with yellow and black, and is pale like the upper parts. In a young animal, a few months old, in which the tail hairs are not yet lengthened, while the terminal half of the tail is red, the distal end of the basal half is jet black, as if nature were in doubt whether the tail should take on the red or black phase; but it would appear that these varieties in the colour of the tail are distinctive of localities.

The S. punctatissimus, Gray, resembles the type of S. erythrogaster, Blyth, but is more darkly punctulated, the yellow bands being so minute that the general colour of the upper parts is very dark. Its origin was unknown, but the type of S. erythrogaster was from Munipore.

The skull of $S$. erythrous has considerable breadth between the orbits, and the nasals are rather elongated and narrow posteriorly. It is a much larger skull than $S$. gordoni from Burma. The species is distributed all over Assam, the Garo and Khasia hills and Munipore, and extends eastwards to Bhutan (Gray).

\section{Scidrus Castaneoventris, Gray.}

Sciurus castaneoventris, Gray, Ann. \& Mag. Nat. Hist. vol. x. 1842, p. 263; Hand-List Mamm. B. M. 1843, p. 143 ; Blyth, Cat. Mamm. As. Soc. Mus. 1863, p. 102 ; Swinhoe, Proc. Zool. Soc. 1870 , pp. 631 \& 633 ; ibid. 1872, p. 818.

Sciurus griseopectus, Blyth, Journ. As. Soc. Bengal, vol. xxvi. 1855, p. 873, pl. xxxvii. fig. 3 ; Swinhoe, Proc. Zool. Soc. 1870, p. 634 ; ibid. 1873, p. 818.

Sciurus erythraus, Swinhoe, Proc. Zool. Soc. 1863, p. 257.

Sciurus cinnamomeoventris, Swinhoe, Proc. Zool. Soc. 1870, p. 634.

Macroxus griseopectus, Gray, Ann. \& Mag. Nat. Hist. vol. xx. 1867, p. 282.

Macroxus erythrogaster, Gray, Ann. \& Mag. Nat. Hist. vol. xx. I867, p. 283 (in part).

Macroxus castaneoventris, Gray, Ann. \& Mag. Nat. Hist. vol. xx. 1867, p. 283.

Sciurus lokriah, Swinhoe, Proc. Zool. Soc. p. 634.

Sciurus chinensis, Swinhoe, Proc. Zool. Soc. 1872, p. 818.

The types of S. castaneoventris in the British Museum are referred by Dr. Gray to both sexes. The female is evidently a young squirrel, and has a dark, chestnutcoloured belly, this colour extending forwards over the throat, but not on to the chin. The upper surface is olive-brown; the hair annulated as in the previous species, but 
the yellow bands are rather pale. The feet are dark brown. The tail is bushy, especially at its extremity, and is much the same colour as the upper parts, but in its latter third the annuli disappear and the hairs become wholly blackish-brown, tipped with yellowish. The ears are moderately-sized and rounded, and clad with short hairs externally, while the back of the posterior margin has a fringe of short, soft hairs. The tail is slightly shorter than the body and head.

In the male referred to this species, the colour of the upper parts is much the same as in the female, but the under parts are much paler, being light reddish. The tail is so denuded of hair that I can say nothing regarding its appearance.

Besides these two specimens, there are in the National Collection two squirrels from China referred by Dr. Gray to S. griseopectus of Blyth, and which are undoubtedly that species, as there is another squirrel agreeing with them named by Blyth himself as $S$.griseopectus. Of the first mentioned, one is young and the other adult, and both are distinguished by the throat and chest being greyish, while the under parts are rufous. In the young specimen the under parts are pale, yellowish red, while in the adult they are rich, reddish chestnut, as in the adult male S. castaneoventris, but much paler than in the female. The upper fur in both is exactly annulated as in the foregoing types, but the young is greyer, owing to the pale nature of the yellow bands, especially on the head, where they are nearly white, imparting a greyish olive tint to that part and an iron-grey to the sides of the face: in the adult, on the other hand, the yellow bands are richly coloured all over. The tails are more clearly annulated than in the types, but their black tips have yellowish ends to the hairs. There can be no doubt of the specific identity of these forms with $S$. castaneoventris, even although their throats and chests are greyish and coloured nearly as the upper parts.

The squirrel from China, referred by Blyth to S. griseopectus, in the distribution of the red of the under surface is intermediate between these typical examples of $S$. griseopectus and $S$. castaneoventris, the rufous extending up over the chest and throat nearly to the chin; the rufous having the same intensity as in the male type : thus presenting such a close similarity to each other that it is impossible to avoid the conclusion that they are one and the same.

There is an interesting series of five squirrels from Formosa, collected by Swinhoe, and which seem to me to be referable to this species. They are especially interesting in this respect, that while there can be little doubt they are all examples of a single species, they exhibit the most remarkable variation of the colouring of the under parts, while they agree in the colouring of the upper surfaces and of the tail. A male obtained in North-West Formosa in the month of April has the upper parts rich olive-brown, with almost a rufous tint on the sides, so brilliant are the yellow sub-apical bands of the hairs, while the under parts are dark red-chestnut of exactly the same colour as in the female type of the species, the tail being as in that specimen. The posterior half of the belly is marked by a mesial, dark, almost black line, and the rufous extends forwards on to the neck. Another specimen from the same island, but the date on which it 
was collected is not given, differs only from the last in the greater amount of pale yellow on the tail, which is so profuse on its latter two-thirds as almost to obscure the banding, but like all the other specimens it has a black tip. In another specimen from Formosa, obtained in March, the upper fur is slightly paler than in the dark-bellied specimen, and the under surface is almost concolorous with the back, but slightly washed with chestnut, especially over the hinder half of the belly, while it is entirely absent on the chest and on the anterior two-thirds of the mesial, ventral line, which is grizzled like the sides. Indeed, the whole of the belly is covered with annulated hairs like the upper parts, with chestnut hairs intermixed. The tail is the same as in the other examples, but with little yellow, the hairs on the posterior third being rather broadly black tipped. This form, then, is in the grey-chested phase. Another and still more interesting example from the same island, but without recorded date, has a broad, grizzled line down the ventral surface, the chestnut, which is dark and rich, being restricted to two narrow lines which do not extend anterior to the axilla, so that all the chest and throat are grizzled, like the upper surface. The tail is broadly black-tipped like the foregoing specimen. The last of the Formosan examples appears to be identical with the last-described squirrel, as they are exactly like each other, with this single remarkable exception, that in the former there is not the slightest trace of rufous on the under parts, which are grizzled exactly like the back. It is a male, but the date of its capture is not recorded. These two specimens resemble in their coats the squirrel obtained in March, with the rufous only faintly showing. The existence of red on the belly is not a matter of age, as the young and adults are both rufous on that area.

Two squirrels from the Island of Hainan, clearly referable to this species, differ in this respect, that the specimen shot in February has, as in the female type, the whole of the under parts rich chestnut, extending over the chest and throat; whereas, in the other, the throat and chest and a line down the middle of the belly are grizzled without rufous, the sides of the belly only being rich chestnut. The tails of these specimens are black-tipped, as in the types, but broadly washed over their ends with yellowish, as in one of the Formosan squirrels.

Blyth's S. griseopectus was described from a living specimen, the habitat of which was unknown, but it agrees with those squirrels which I have just described from China, Formosa, and Hainan.

This species appears to be confined to Western China and to the Islands of Formosa and Hainan.

* ScIUrus gordoni, Andr. Plate XIX.

Sciurus gordoni, Andr., Proc. Zool. Soc. Lond. 1871, p. 140; Blyth, Journ. As. Soc. Beng. vol. xliv. 1875 , ex. no., p. 37.

I have collected about twenty-five specimens of this squirrel from various parts of Burma, north of the capital, and have found only one type of variation, viz., the 
orange-red of the belly occasionally becoming pure yellowish-white, sometimes yellow. In all the individuals, however, that I have examined, the ventral aspect is distinguished by a grizzled mesial line, and the end of the tail is blackish, broadly tipped with orange-yellow. A pale-bellied individual was killed in September, but I have many others killed in the same locality on the same date and of both sexes, in which the belly has the characteristic orange-red of this species.

There is a race in Assam which agrees with S. gordoni in the general colour of the upper fur, but is considerably darker on the under surface, and the mesial, grizzled line is occasionally absent. The tail also closely approaches the character of $S$. gordoni, but it wants the sub-apical black band, but its extremity is washed with orange or yellow as in this species. The Assam form is larger and darker, and has sometimes been mistaken for S. hippurus and S. erythreus, Pallas, and stands, as it were, intermediate between the Chinese ventrilineated $S$. griseopectus and $S$. erythreus; and as it is doubtless quite as persistent as $S$. gordoni and sufficiently distinct from S. erythreus, it may be indicated as the Assam var. of S. gordoni, and, for reference, stand as var. intermedia. S. gordoni has the upper surface and a narrow line from between the fore limbs along the middle of the body grizzled olive-brown or greyish with a variable rufous tint; the annulations are not so fine as in S. erythraus. The chin and the sides of the throat are paler-grizzled than on the back and the lower part of the throat; the chest, belly, and inside of the limbs are either pale yellow or rich orange-yellow, or passing into pale chestnut in the Assam variety in which the belly is rarely lineated. The ears are feebly pencilled. The tail has the same proportions as in S. erythreus and S. castaneoventris, but it is more persistently and uniformly concolorous with the body than in these species, and is finely ringed with black and yellow, the rings being most distinct on the latter fourth; the tip is generally washed with orange-yellow.

Length 9 inches, tail 7 inches.

S. gordoni, in its lineated belly, displays a closer affinity to S. castaneoventris, which exhibits this character, than to S. erythrous.

The skull of this species, although considerably smaller than that of S. erythreus, yet resembles it in form, but differs from it in its smaller teeth.

This squirrel ranges over Upper Burma to the north of the capital, where it is very common about villages. Its var. intermedia occurs on the eastern side of Assam, and is found also at Sadiya.

\section{Sciurus hippurus, Is. Geoff.}

Sciurus hippurus, Is. Geoff. étub. Zool. i. 1832, n. 6, tab. 6; Zool. Voy. aux Ind. Orient. Bélanger, 1834, p. 149; Müller und Schlegel, Verhandl. 1839-44, pp. 86-92; Gervais, Voy. autour du Monde, Eyd. et Soul. Zool. vol. i. 1841, p. 39 ; Wagner, Schreber, Säugeth. Suppl. vol. iii. 1843, p. 201 ; Schinz, Syn. Mamm. vol. ii. 1845, p. 36 ; Cantor, Journ. As. Soc. Beng. vol. xv. 1846, p. 249 (in part); Blyth, Journ. As. Soc. Beng. vol. xvi. (in part), p. 171; ibid. vol. xxiv. 1855, p. 472, et p. 473 (note); Cat. Mamm. As. Soc. Mus. 1863, p. 102; Horsfield, Cat. Mamm. E. Ind. Co.'s Mus. 1851, p. 154. 
Sciurus rufogaster, Gray, Ann. and Mag. Nat. Hist. vol. x. 1842, p. 263; Hand-List Mamm.

B. M. 1843, p. 142 ; Blyth, Journ. As. Soc. Beng. vol. xxiv. 1855, p. 473.

Macroxus rufogaster, Gray, Ann. and Mag. Nat. Hist. vol. xx. 1847, p. 283.

Macroxus rufogaster, var. borneoensis, Gray, Ann. and Mag. Nat. Hist. vol. xx. 1867, p. 283.

This well-marked species approaches S. erythraus in size. The lower parts and inside of the limbs are deep ruddy ferruginous; the head, sides of neck, shoulder, outside of fore limb, thigh and outside of hind limb, being minutely speckled with white on a blackish ground; feet black, the rest of the upper parts of the body with the base of the tail yellowish-rufous, punctulated with yellow and black; tail bushy and black; whiskers black. The specimen in the British Museum referred by Dr. Gray to S.rufogaster var. borneoensis, differs from Malayan specimens in having portions of the upper parts unannulated and of deep rich chestnut, which embraces the upper surface of the base of the tail and is concolorous with the chestnut of the under parts. This, however, is evidently not a persistent form, because I have seen a specimen from the same island in which the red portion of the upper parts is grizzled and much of the same tint as Malayan individuals, except in the mesial line of the neck and back, where the colour is rich red-brown, extending along the dorsum of the tail for about three inches.

Müller and Schlegel mention a variety that I have not seen, and of which they state that the red colour of the under parts extends to the heel, the fore foot and the toes, while the colour of the upper parts passes into a uniform, lustrous black. They also remark, however, that the back not unfrequently assumes a pale yellowishbrown tint.

In the skull the orbit is rather large, and the muzzle is so contracted at its base that the extremity is but little narrower.

This species was stated by Is. Geoffroy to have been described from a specimen obtained in Java by Diard, and this type I have examined. It also occurs in the Malayan peninsula and Sumatra, but Schlegel and Müller likewise record it from Canton.

The squirrel observed in Assam by $M^{\circ}$ Clelland, and referred by him to this species, was another allied form, $S$. erythraus. Blyth was inclined to regard the S. castaneoventris, Gray, as the young of $S$. hippurus, but in this he was mistaken, as the two are quite distinct.

\section{* Sciurus sladeni, Andr. Plate XX.}

Sciurus sladeni, Andr. Proc. Zool. Soc. Lond. 1871, p. 139; Blyth, Journ. As. Soc. Beng. vol, xliv.

1875, ex. no. p. 37.

This species equals $S$. gordoni in size, to which it is closely related, but from which, as far as our present knowledge goes, it is distinguished by its orange-red head and feet, and by the bright brick-red tip to its tail; the colour of its under parts is the same as in S. gordoni, and they are concolorous with the head and feet. No ventral, grizzled line. The upper parts are grizzled rufous-olive and the annulation is 
fine, and the fur of moderate length; the forehead, face, chin, throat, belly, and inside of limbs, front of thighs, lower half of fore limbs, and the head and feet, are rich orange-red. The tail is rather bushy, as long as the body without the neck and head; it is concolorous with the upper surface of the body, but slightly more rufous, with a bright chestnut-red tip.

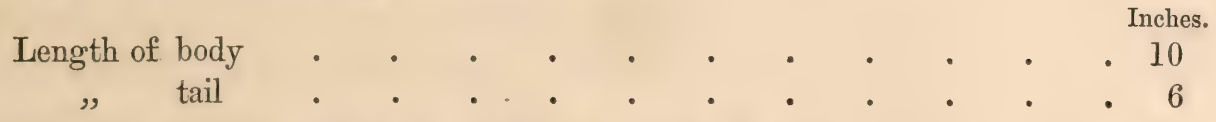

I obtained this species at Thigyain in Upper Burma.

The skull of S. sladeni has a rather short muzzle with considerable breadth across its base superiorly, and it is a shorter and broader skull than the skulls. of squirrels referred to $S$. blanfordii. Compared with the skull of the red-headed specimen of S. erythraus from Bhutan, there is a decided resemblance between the two, the chief distinction being the less breadth of the base of the muzzle of the latter; but the teeth of this specimen show it to be young, while the teeth of $S$. sladeni are much worn by use.

\section{* Scidrus ferrugineds, F. Cuvier.}

Ecureuil blane de Siam, Buffon, Hist. Nat. vol. vii. 1758, p. 256.

Sciurus finlaysoni, Horsfield, Zool. Resch. Java, 1824; Cat. Mamm. E. Ind. Co.'s Mus. 1851, p. 154; Fischer, Syn. Mamm. 1829, p. 354; Gray, Hand-List Mamm. B. M. 1843, p. 144; Wagner, Schreber, Suppl. vol. iii. 1843, p. 202 ; Schinz, Syn. Mamm. vol. ii. 1845, p. 39 ; Blanford, Ann. and Mag. Nat. Hist. vol. i. 4th ser. 1868, p. 152.

Sciurus ferruginens, F. Cuvier, Hist. Nat. des Mammif. vol. iii. January 1829, pl. 238; Wagner, Schreber, Säugeth. Suppl. vol. iii. 1843, p. 207 ; Blyth, Journ. As. Soc. Beng. vol. xvi. 1847, p. 872 ; ibid. vol. xxiv. 1855, p. 474 ; ibid. vol. xxxi. 1862, p. 332 ; ibid. vol. xxxii. 1863, p. 101 ; ibid. vol. xliv. 1875, p. 36 ; Cat. Mamm. As. Soc. Mus. 1863, p. 101.

Sciurns keraudrenii, Reynaud, Lesson, Curt. Zool. pl. i. October 1829; Schinz, Syn. Mamm. vol. ii. 1845, p. 37 ; Blyth, Journ. As. Soc. Beng. vol. xvi. 1847, p. 872 ; ibid. vol. xxiv. 1855, pp. 472-474 ; Horsfield, Cat. Mamm. E. Ind. Co.'s. Mus. 1851, p. 156.

Sciurus splendidus, Gray, Ann. and Mag. Nat. Hist. vol. x. 1842, p. 262.

Sciumus cinnamomeus, Temminck, Esq. Zool. sur la côte de Guiné, 1853, p. 250.

Sciurus siamensis, Gray, Ann. and Mag. Nat. Hist. vol. v. 3rd ser. 1860, p. 500 ; Proc. Zool. Soc. 1861, p. 137.

Sciurus splendens, Gray, Proc. Zool. Soc. 1861, p. 137.

Macroxus (Erythrosciumes) fermuineus, Gray, Ann. and Mag. Nat. Hist. vol. xx. 1867, p. 285.

Macroxus (Erythrosciurus) siamensis, Gray, Ann. and Mag. Nat. Hist. vol. xx. 1867, Oct. p. 286.

Macroxus (Erythrosciumes) finlaysoni, Gray, Ann. and Mag. Nat. Hist. vol. xx. 1867, p. 286.

Sciums germani, A. M.-Edwards, Rev. et Mag. de Zool. Juin 1867, p. 193; Rech. des Mammif. 1868-74, p. 164.

Scinorus bocourtii, A. M.-Edwards, Rev. et Mag. de Zool. Juin 1867, p. 193; Rech. des Mammif. 1868-74. p. 165.

Sciurus lencogaster, A. M.-Edwards, Rev. et Mag. de Zool. 1867, vol. xix. p. 196.

The following squirrels which have been described from Burma and Siam and from some of the small islands which lie off the latter country, appear to me to be only varieties of one and the same species. They are S.finlaysoni, S.ferrugineus, 
S. Reraudrenii, S. splendidus, S. cinnamomeus, S. siamensis, S. splendens, S.germani, $S$. bocourtii, and S. leucogaster. The extreme limit of their range is from Assam in a south-easterly direction through Burma and Siam to the Islands of Pulo Condor and Sichang. The colour of their fur is most diverse, varying from deep maroonchestnut to red, and from grey-grizzled to intense black and to pure white, while others are spotted with brown on a white ground. In all of these squirrels the relative proportions of the parts are the same, but all the grizzled forms are small, and their skulls prove that they are young. These immature forms are $S$. siamensis, Gray, and S. leucogaster, A. M.-Edwards. S. ferrugineus, S. keraudrenii, S. cinnamomeus, and $S$. splendidus are all rich red squirrels, while $S$. germani is a jet black and $S$. finlaysoni a pure white form; whereas $S$. bocourtii is also white, but marked by great brown spots. These differently coloured squirrels are thus far distinctive of localities or rather of geographical areas; none but the pure red forms have been found to the west of Assam and Burma. All the other phases or varieties are apparently confined to Siam.

As I have personally studied the types of all these supposed species, I propose to indicate their leading features and those tendencies which they show towards specific unity.

The type of S. finlaysoni was obtained in Siam by Dr. Finlayson, and another was procured by the same traveller in Sichang Island off the coast of Siam. These two specimens are exactly alike, being white squirrels with a yellowish tinge. The feet, however, show a tendency to become dark or even blackish, especially on the toes, which is a character of the red form of Assam and Burma, while it is seldom observed in the red squirrels of Siam. A few of the hairs on the head and tail have black tips, but their presence makes little impression on the pale fur, except on the tail. The whiskers are black. In other specimens from Siam, however, I have observed the white fur generally so intermixed with black hairs that a remarkable grey colour was communicated to the squirrels presenting this peculiarity. In these forms, the black occurs chiefly along the upper surface of the back, on the shoulder, outside of the fore limbs and thighs, and on the proximal third of the tail; the under parts being pure white. From the profusion with which these black hairs occur, the production of the black S. germani is only a question of degree, and, as it does not involve any structural difference between the two, but is solely brought about by the deposit of black pigment to a greater extent than in S. finlaysoni, there seems no reason why these white and black squirrels should be regarded in any other light than varieties.

There is much greater difficulty. attending the verbal explanation of the relations that exist between $S$. bocourtii and S. ferrugineus, but some additional light is thrown on them by considering the forms which have been referred to $S$. siamensis and $S$. leucogaster, both of which are young squirrels.

With regard to $S$. bocourtii, this squirrel can be best. described as a piebald S. finlaysoni. It is also from Siam, and is distinguished by the following leading features, which are subject, however, to considerable variation. The rich brown of 
the upper fur extends on to the outside of the limbs and to the tail, but the feet in some are white. The muzzle, and around the eyes, and the whole of the under parts, and inside of the limbs, are of a pure ermine tint, like that which distinguishes the under parts of $S$. finlaysoni, but in some specimens the head is wholly white to behind the eye. The ears are generally white, clothed with grey hairs on their backs, and with rufous hairs at their bases superiorly. The brown portion of the pelage is finely and sparsely punctulated with rich yellow. The tail is broadly ringed with black and yellowish, and the tip tends to become rufous; but in others, its under surface is wholly white, and its last third pure rich maroonchestnut, the tip tending to black; while, in one specimen, the last third of the tail, as in S. keraudrenii, is washed with white. This squirrel, therefore, is a mixture of the characters of $S$. finlaysoni, and, as we shall presently see, of those of immature examples of $S$. cinnamomeus, which is only a local race or variety of $S$. ferrugineus.

S. leucogaster is a young squirrel from Siam, which is undoubtedly the young of $S$. siamensis, with immature examples of which it agrees except in its white under parts, but, at the same time, it is apparently younger than the grizzled and brownish immature specimens of $S$. siamensis which have come under my observation. This young squirrel, besides having the under parts pure white, is marked above and below the eye with the same colour, but the white under surface is no more specific than would be the white under surface of $S$. gordoni or the occasional grey surface of $S$. lokriah. The fur of the body and tail generally is grizzled much as in S. lokroides, but there is a commencing blush of rufous on the head, from the muzzle backwards on to the tail. S. leucogaster is unmistakeably connected with $S$. siamensis by specimens with rufous under surfaces, and which do not differ from it in any other respect except in being slightly more rufous; but the evidence which these afford of the specific identity of $S$. leucogaster with them, although it cannot well be given in a written description, carries conviction through the eye. The feet in these apparently immature squirrels tend to black, which is a significant fact, considering the circumstance that, in the adults of the western red squirrel, the feet always partake more or less of that colour, whereas, in the adults from Siam, the extremities differ but little from the body colour. The conclusion arrived at from these facts is, that in the very young state of $S$. cinnamomeus the belly is, at least occasionally, white, and the upper parts grizzled, and that S. bocourtii is a grizzled brown variety, perpetuating the youthful character in its white belly and grizzled fur, but exhibiting a tendency also in its occasionally red tail to assume the pelage of $S$.ferrugineus, and in the spreading of the white on to the head, to put on the garb of S. finlaysoni.

The fur of the upper parts of S. siamensis is essentially annulated, but in the younger of two type specimens the annulation is slightly more marked, and the animal is not so rufous as in the more matured individual. In the latter, the annulation has almost disappeared on the head and neck; and in both, the posterior half of the tail is chestnut, without any annulation, and the under parts are similarly coloured. Some light is thrown on these small annulated specimens by an appa- 
rently adult squirrel, undoubtedly of this species, which has the sides of the head and neck, the shoulder and outer side of fore limb and the middle area of the thigh covered with dark, olive-grey, finely annulated hair, the surrounding parts being pale red; the upper surface of the head, back, and tail being deep ferruginous. The feet are dark, blackish-red. The presence of annulated hair in this specimen serves to connect the so-called S. siamensis with the uniformly rufous squirrels, and illustrates the last traces of the annulation of youth disappearing at maturity. It is also important to observe that the light rufous specimens have the ridges of the teeth not ground down whereas in the dark chestnut forms the teeth show signs of use by being worn smooth. The ears are alike in all the specimens. An examination of the skull of the Siam forms, originally regarded by Dr. Gray as distinct under the name of S.splendidus, does not bring to light any character by which to separate them; but I regret I have not had the opportunity to examine the skull of $S$. siamensis.

In the Leyden Museum there are six squirrels belonging to the $S$. ferrugineus or red type, exhibiting progressive stages of pelage. The first specimen of these is evidently in a transition stage, as there is a flush of red all over the body, especially marked on the ventral surface and on the head and neck, but of a much lighter tint than in the wholly red squirrels. The tail of this specimen is annulated in the ordinary way, but at its base a change is beginning in the fur, and also towards the end, but the extreme tip is wanting. In the second specimen, the upper surface of the head and a broad area down the back are deep rusty-brown, tending to black on the back, consequent on an intermixture of black grizzling-a fact of considerable interest in view of $S$. bocourtii-while, at the same time, the tail is coloured as in the uniformly rufous animals. The lateral aspect of the squirrel, from the muzzle, all along the face, neck, shoulder, flanks and thighs, is a dark grey, more or less grizzled with yellowish; the legs are the same colour, only darker, except on the fore feet which are becoming red; the chin, throat, and the under surface of the neck are also similarly coloured, but the chest and belly and the inside of the thighs are rich chestnut. In a third specimen, the grey of the sides has almost disappeared, but sufficient remains to connect it with the previous one, and the black grizzling of the back is all but lost. In still another specimen there is only the faintest trace of grey on the upper part of the fore limb and on the thigh, but on the side of the face it is more distinct. In this stage it would constitute the S. splendidus, Gray. In the two others, we have Siam squirrels wholly rich, ferruginous red, darker on the back, where there is a tendency to become black; this dark area still holding true to its first character, while the sides never assume a dark tint and are concolorous with the belly and with the limbs and head.

These mature individuals stand in the Leyden Museum as $S$. cinnamomeus, Temminck.

Two examples, one from Rangoon and the other from Upper Burma, belong to the variety with the white tip to the tail, described by Reynaud as S. keraudrenii. 
A. Siam specimen, however, named by Dr. Gray S. ferrugineus, is of considerable interest from the circumstance that the white does not occur at the tip of the tail, but appears as a great white patch a little way beyond its base, whereas in all the other specimens from Siam the tail is concolorous with the body, but slightly paler at its tip. The appearance of the white on this portion of the tail would seem to indicate that there is an inherent tendency to the production of that colour, probably explicable on the theory of reversion, because the young of many squirrels when born have their tails white, this colour disappearing with age. In connection with this specimen, it is also to be remarked that it is much darker than any of the others from Siam, but not darker than an example from Assam. All the Siam specimens have the feet concolorous with the body, whereas in the Burmese squirrels the toes are generally black, also the upper surface of the hind feet more or less so, but in other respects they are alike, and this slight difference cannot be regarded as more than a local variation, so that the only legitimate course seems to be to consider these uniformly red Siam squirrels as specifically identical with $S$. ferrugineus, the differences that exist between them not being greater than those which occur among the phases of S. caniceps and S. chrysonotus.

The skulls of typical examples of $S$.ferrugineus var. kercudrenii, appear to be distinguished by the contracted character of the posterior ends of the nasals. In other respects, however, they do not perceptibly differ from the general characters of such skulls as those of S. phayrei, S. blanfordii, S. caniceps, S. erythraus, and S. gordoni.

I have retained the term $S$. ferrugineus, as it has the sanction of long use and general recognition.

\section{* Scturus toKroldes, Hodgson.}

Sciums lokroides, Hodg. Journ. As. Soc. Beng. vol. v. 1836, p. 232 ; ibid. vol. x. 1841, p. 915; Horsfield, Proc. Zool. Soc. 1839, p. 152 ; Cat. Mamm. E. Ind. Co.'s Mus. 1851, p. 153; Proc. Zool. Soc. Lond. 1856, p. 402 ; Ogilby, Royle's Ill. Himal. Bot. 1840; Mem. Mamm. p. 13 ; Wagner, Schreber, Säugeth. Suppl. vol. iii. 1843, p. 202 ; Walker, Cal. Journ. Nat. Hist. vol. iii. 1843, p. 266 ; Gray, Cat. Mamm. Nepal Mamm. \&c. 1846, p. 23; Blyth, Journ. As. Soc. Beng. vol. xvi. 1847, pp. 873, 877 ; ibid. vol. xviii. 1849, p. 603; ibid. vol. xxiv. 1855, p. 475; Cat. Mamm. As. Soc. Mus. 1863, p. 104; Gray, Ann. and Mag. Nat. Hist. vol. xx. 1867, p. 274.

Sciurns locroides, Hodg. Journ. As. Soc. Beng. vol. x. 1841, p. 915 ; Cal. Journ. Nat. Hist. vol. iv. 1844, p. 293 ; Schinz, Syn. Mamm. vol. ii. 1845, p. 35.

Sciurus assamensis, M'Clelland, Gray, Hand-List Mamm. B. M. 1843 (in part), p. 143 ; Ann. and Mag. Nat. Hist. vol. xx. 1867, p. 274; Blyth, Journ. As. Soc. Beng. vol. xvi. 1847, pp. 873, 877 ; ibid. vol. xxiv. 1855, p. 475 ; Cat. Mamm. As. Soc. Mus. 1863, p. 103; Horsfield, Cat. Mamm. E. Ind. Co.'s Mus. 1851, p. 153.

Sciurus blythii, Tytler, Ann. and Mag. Nat. Hist. 2nd ser. vol. xiv. 1854, p. 172.

Macroxus similis, Gray, Ann. and Mag. Nat. Hist. vol. xx. 1867, p. 281.

I have before me sixty-two examples of various squirrels which have been referred to S. lokroides, S. assamensis, and S. blythii by Hodgson, $\mathrm{M}^{\circ} \mathrm{Clelland}$, and Tytler, also the types of S. similis, Gray, which were forwarded to the British Museum as S. lokroides by Hodgson. After a careful consideration of these materials, 
they appear to me to be referable to one species. Hodgson, who first described it, referred to it all those Himalayan squirrels slightly larger than S. lokriah, and which had the ventral surface either pale whitish or slightly washed with rufous, the sides also being sometimes suffused with this tinge, especially on the anterior half of the outside of the thigh which in many is bright orange-red; but this colour is variable, and some squirrels have this portion of the body white, of which S. blythii is an example, and others similar to it are before me from Bhutan and Assam, which do not differ from $S$. lokroides, except in the presence of this white area which is evidently only a variation on the red area, and probably a seasonal change, as many show merely a faint rufous tinge in the inguinal region, that colour being entirely absent on the outside of the thigh.

It is, however, worthy of note, that those squirrels which have a rufous tinge in the inguinal region, rarely or ever have the outside of the thigh bright red, and that the squirrels distinguished by white on their thighs are from Bhutan, Assam, and the Garo Hills. But I do not see that these latter differ in any other respect from the squirrels sent by Hodgson as $S$. lokroides, with and without red thighs. Moreover, one of Hodgson's specimens of S.lokroides shows a tendency in the thigh to become white.

The ventral surface is seldom alike in two specimens. It varies from pure white (young of Assam type) through grey to rufous grey generally suffused with rufous on the groin and sometimes along the side and over the belly, but in others the rufous is all but absent. In some there is a decided tendency to the formation of a median, ventral, grizzled streak or line. The tail also is very variable, being in some concolorous with the body, while in others it evinces a tendency to become banded, black and rufous yellow, and to have a black tip; but even this wide difference of tail-colouring occurs in two animals which, in other respects, are identical and from the same locality. The general tendency, however, for the tail is to resemble the back. The upper surface is of variable intensity, the prevailing colour being brownish-olive, minutely punctulated with yellow or rufous. On the character of the annulations depends the tinge of brown distinctive of the individual. The feet in some tend to become white, but in the greater number they are concolorous with the upper parts, or a little darker.

In a specimen from Bhamô, where the species is not at all common, the under surface is pale greyish, very faintly suffused with pale yellowish on the belly and on the groin; the upper surface is a rufous olive-brown, the tip of the tail showing a tendency to black and white banding, but the rest of it is concolorous with the back.

The species may be described as rufous olive-brown, the base of the hairs greyish-black, and their remainder banded with yellow, black and yellow, each hair terminating in a dark-brown or blackish point. The fur is slightly coarser and more broadly annulated than in S. lokriah. The chin, throat, and ventral surface are pale greyish or sullied white, more or less tinged with rufous, or the rufous may be confined to the inguinal region, with the rest of the under parts greyish, with occasionally 
a feeble, narrow, mesial, grizzled line. The ventral surface is never tinged with bright orange as in S. lokriah. The tail is generally the same as the back, but the hairs are more coarsely annulated, while in others the annuli tend to group themselves in black and yellow rings, the tip being black in some, obscurely annulated in others. The tail hairs have their bases yellow, instead of dark grey, and they have two to three additional annuli. The ears are clothed with short non-adpressed annulated hairs. No white tuft behind the ears. In the form referable to S. blythii, a white spot occurs on the inguinal region of the thigh in the position in which the rufous of the so-called red-legged squirrels is developed. The groin, in some of these squirrels, shows also a decided rufous tinge, while the remainder of the belly is sullied grey-white. If these forms were without the white thigh-spot they would exactly conform to the type of S. assamensis. A squirrel in the British Museum labelled S. tytleri, Verreau (Indes Orientales) agrees with S. blythii.

Blyth $^{1}$ states that he had seen a specimen of this species renewing its coat and acquiring its hymeneal dress, and describes it as assuming a variegated appearance, during the period of transition.

I have compared the skulls of those forms referable to $S$. assamensis, and S. blythii, with the skulls of Hodgson's types of $S$. lokroides, and do not detect any difference between them, whereas their skulls differ in the same respects from S. lokriah, which is altogether a smaller skull with an entirely differently formed facial portion. In S. lokroides, the inter-orbital portion of the skull is broad, more especially between the anterior angles of the orbits, and the muzzle is thus broad at the base and triangular, whereas in S. lokriah the inter-orbital portion of the skull is much narrower anteriorly and posteriorly, and the muzzle is narrow at the base, and of nearly equal breadth throughout. The muzzle of S. lokroides is also very much deeper than in $S$. lokriah. The nasals of the latter are long and narrow, while they are much shorter and broader in the former, and not reaching nearly so far back as in S. lokriah. There are many other differences, but these are sufficient to indicate that they are quite distinct species.

Blyth at first considered S. lokroides and S. assamensis as identical, and he stated that from an examination of a very considerable number of specimens collected at Darjeeling, and in different parts of Assam, Cherra Punji, Tippera, and Arracan, he could not perceive any diversity whatever in those from different localities, unless it might be, perhaps, that on the average the Himalayan specimens were somewhat more rufescent underneath; but every gradation was observed. Notwithstanding, in 1863, he separated $S$. assamensis and S. lokroides, regarding the squirrel S. blythii as identical with $S$. assamensis, but the type of the latter, which unfortunately is in a miserable condition, corresponds with $S$. lokroides, but differs from $S$. blythii in the absence of the white spot on the thigh. Horsfield, however, referred a specimen of the latter type to $S$. assamensis, and I believe correctly.

A jet-black squirrel of the same proportions as this species occurs in Sylhet and Cachar, and I am disposed to regard it as specifically identical with it. 
Gray referred S. griseiventer, Is. Geoff., from Java to the S. assamensis, M'Clelland, which, in 1843, he regarded as distinct from $S$. lokroides, but $S$. griseiventer is unquestionably S. nigrovittatus, Horsfield.

This species ranges from Nepal to Western Yunnan, and southward through Assam and the Garo Hills, Tippera, and Dacea, occurring in Sylhet, Cachar and Munipore, and the northern portion of Arracan: and from the Island of Preparis, the Indian Museum is indebted to Mr. V. Ball for a specimen.

\section{SciURUs LOKRTAH, Hodgson.}

Scinrus lokriah, Hodgson, Journ. As. Soc. Beng. vol. v. 1836, p. 232 ; Proc. Zool. Soc. 1855, p. 126 ; Ogilby, Horsfield, Proc. Zool. Soc. 1839, p. 151; Royles, 11l. Ind. Bot. Mem. Mamm. 1840, p. 13; Wagner, Schreber, Säugeth. Suppl. vol. iii. 1843, p. 202; Walker, Cal. Journ. Nat. Hist. vol. iii. 1843, p. 266 ; Blyth, Journ. As. Soc. Beng. vol. xvi. ]847, pp. 873, 874; ibid. vol. xviii. 1849, p. 603; ibid. vol. xx. 1851, p. 166 ; ibid. vol. xxiv. 1855, p. 475; ibid. vol. xliv. 1875, ex. No. p. 37 ; Cat. Mamm. As. Soc. Mus. 1863, p. 104; Horsfield, Cat. Mamm. E. Ind. Co.'s Mus. 1851, p. 153 ; Proc. Zool. Soc. 1856, p. 402.

Sciurus locria, Hodgson, Journ. As. Soc. Beng. vol. x. 1841, p. 915 ; Cal. Journ Nat. Hist. vol. iv. 1844, p. 293 ; Gray, Cat. Nepal Mamm. B. M. 1846, p. 143.

Sciurus subflaviventris, M‘Clelland, Gray, Hand-List Mamm. B. M. 1843, p. 144; Blyth, Journ. As. Soc. Beng. vol. xvi. 1847, p. 873 ; ibid. vol. xx. 1851, p. 166 ; ibid. vol. xxiv. 1855, p. 475 ; Horsfield, Cat. Mamm. E. Ind. Co.'s Mus. 1851, p. 152.

Macroxus lokriah, Gray, Ann. and Mag. Nat. Hist. vol. xxi. 1867, p. 284.

Hodgson described $S$. lokriah as, "above saturate brown, tipped with intense orange," and in his manuscript drawings he figures under the name of S. lokriah an animal of this description with deep orange under parts and no orange on the thighs, although in his description he says, "below and the thighs deep orange;" but on another plate he again figures two squirrels, one with the under parts deep orange and the outside of the thighs of the same colour, and thus agreeing with his description of S. lokriah, while the squirrel alongside of it has the under surface sullied white and no orange or white on the outside of the thighs; to the former of these he affixes the term S. lokriah and to the other S. lokroides. Dr. Gray, in his List of Mammalia in the British Museum, regarded S. lokriah as the red-thighed squirrel, and S. lokroides as the grey-thighed squirrel, but, in the Catalogue of Hodgson's Collection, ${ }^{1}$ we are informed that "the specimens were misnamed in the former sending, which has caused a mistake in the List of Mammalia," so that what was S. lokriah of Dr. Gray's List became in the Nepal Catalogue S. lokroides.

Dr. Gray, in his Synopsis of Asiatic squirrels, separated $S$. lokroides into two species, placing one section in the genus sciurus and the other in the genus Macroxus. The first he regarded as S.loleroides, and included in it those Himalayan and Assam squirrels with pale under parts, more or less sullied with rufousyellow, and without red thighs; and to the other group, he referred the Himalayan squirrel, $M$. similis, with reddish on the outside of the thighs. As I have already

$$
\text { i L. c., p. } 23 .
$$


stated, their skulls are in no way separable, whereas they are very distinct from the skull of S. lokriah, which is not so closely allied to S. lokroides, as would at first be supposed from a cursory examination; neither is $S$. lokriah subject to much variation. It is much more richly coloured than $S$. lokroides, with no rufous even on the thighs, and with generally a tuft of pure white hairs behind the ear, by which it can be recognised, as it occurs in twenty instances out of twenty-five, and even when absent the hairs in that locality have a paler colour. As this whitish tuft lies backwards, it is only seen when the ear is carefully examined. Besides these external distinctions, the two forms are markedly separated, as I have said, by the forms of their skulls.

The pelage of $S$. lokriah is deep rich rather ferruginous olive-brown, soft and silky; the under parts from the chin to the vent are rich orange, paler on the chin and throat, but sometimes pale yellow, restricted to the mesial line. The tail appears to be rather shorter than in S. lokroides, and the banding of the hair is much coarser and the paler bands are orange instead of yellow, but the distinguishing feature is the great breadth of the apical black band, which is, however, generally tipped orange or white; the hue of the tail being blackish, washed either with yellow or white, most generally the latter. In some, the annuli are very obscure, and the tail has an orange brownish hue; in others, owing to the distichous arrangement of the hairs, the mesial line of the under surface of the tail is more or less obscurely banded orange and black, with a blackish margin due to the broad terminal band.

In the Eastern Naga hills, Assam, there is a squirrel which agrees with S. lokriah, except that the under parts, instead of being orange-red, are bluish-grey, and thus may be indicated as var. tephrogaster. It has no white spot behind the ears, but its skull agrees with the skull of $S$. lokriah.

Dr. Gray included under S. lokriah a squirrel from Singapore which has a very strong external resemblance to it, with a rather bright orange belly and the upper fur and tail much as in $S$. lokriah, but it has longer and more pointed ears, with no white ear-tufts, and a skull remarkably distinct from S. lokriah, and which may probably prove to be $S$. chinensis.

This species has been obtained in Nepal, the Sikkim Himalaya, and the Naga hills, Assam; but I notice that Blyth, in his recent Catalogue of the Mammals and Birds of Burma, states that it also inhabits the Khasia hills and those of Arracan.

\section{Sciurus Ledconds, Müller \& Schlegel.}

Sciurus lencomus, Müller und Schlegel, Verhandl. 1839-44, p. 87; Gray, Ann. and Mag. Nat. Hist. vol. xx. 1867, p. 272.

This is an olive-brown squirrel, about the size of $S$. lokroides, the hair being grizzled or annulated in the usual way, but the bands are pale, especially on the 
sides. The muzzle is yellowish, but passing gradually into the colour of the upper parts. The head appears to be large for the size of the animal. The striking feature of this squirrel is the black tufting to the ears; the backs of these organs are clad with long jet-black hairs which forcibly contrast with the colour of the body, and the hair projects nearly half an inch beyond their margins, so that they are prominently pencilled. I know of no other Asiatic squirrel of the size of this species with similar ears. A beautiful violet-white patch occurs on the side of the neck, behind the black ears. The under parts are a rich orangered, like $S$. lokriah, to which, if the ear-tufts and lappets were omitted, the species has a strong resemblance. The tail is concolorous with the back, only the individual rings are broader, as is generally the case on the tails of all squirrels.

$$
\begin{aligned}
& \text { Inches. } \\
& \text { Length of body . . . . . . . . . . . } 675 \\
& \text { Tail without hair . . . . . . . . . . } 575 \\
& \text { " with hair . . . . . . . . . } 7550
\end{aligned}
$$

This species has been found only in the Celebes.

The series in the Leyden and Paris Museums from the Celebes prove that the white on the side of the neck is not always present, for one specimen shows it disappearing and in another there is no trace of it, and others lead from the one to the other extreme, but when this neck spot is fully developed it forms a great violetwhite lappet.

\section{Sciurus alstont, n. s. Plate XXI.}

This beautiful species, in the colouring of the upper parts and tail, closely resembles $S$. lokriah, whilst the under parts differ in being dusky chestnut instead of orange. The peculiarity of the species is the beautiful pure white tufting to the ears, which projects a considerable way backwards, in a pointed manner. The external surface of the tip of the ear is covered with short brown hairs which stand out against the white. The sub-apical brown, or rather black band of the hairs of the tail, is broad and rather deeply edged with whitish; the tip of the tail is blackish, and the remainder more or less obscurely tinged with black and orange.

The incisors are pale yellow, and narrow: the facial portion of the skull is rather short and moderately pointed, and the nasals are rather broad posteriorly.

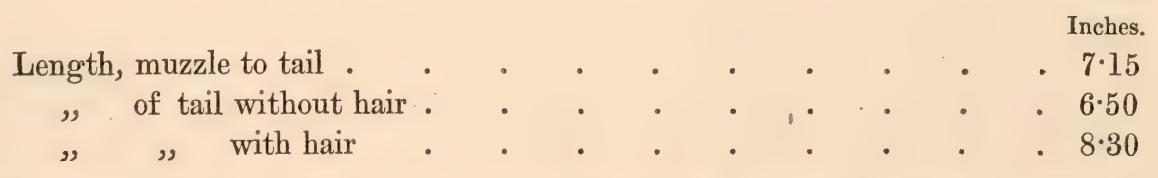

The locality from whence this species was obtained has not been accurately ascertained, but it is probably Borneo. 
ScIurus PERnYi, A. M.-Edwards.

Sciurus pernyi, A. M.-Edw. Rev. et Mag. de Zool. Juillet, 1867, p. 230, pl. xix.; Rech. des Mammif. 1868-74, p. 302.

The muzzle, the upper surface of the head, the nape, the back, the flanks and the outer surface of the limbs are black, punctulated with yellow. The throat, the chest, and the belly are white. The inside of the fore limbs is whitish, but on the hind limbs this colour is mixed with yellow on their anterior borders. Around the vent and on the adjacent parts of the base of the tail a brilliant red prevails, and is continued along within the posterior margin of the hind limbs, as far as the heel. The feet are black, punctulated with rufous. The cheeks have a grey tint, and the moustachial hairs are black. The eyes are encircled by short brown hairs. The ears are large, rounded, and not pencilled. Above the ears, and at their base, there is a clear orange-yellow spot. The tail is a little shorter than the body; the hairs are annulated black and red, but have long yellow or grey tips, a reddish tint prevailing on the under surface.

This species was discovered in the Province of Sé-tchouan, China.

\section{Sciurus modestus, Müller \& Schlegel.}

Sciurus modestus, Müller und Schlegel, Verhandl. 1839-44, pp. 87, 96, pl. xxiv. figs. 1-3 ; Wagner, Schreber, Säugeth. Suppl. vol. iii. 1843, p. 203 ; Schinz, Syn. Mamm. vol. ii. 1845, p. 40 ; Blyth, Journ. As. Soc. Beng. vol. xviii. 1849, p. 603 ; ibid. vol. xx. 1851, p. 166.

Sciurus affinis, Horsfield (not Raffles), Zool. Research. in Java, 1824; Fischer, Syn. Mamm. 1829 (in part), p. 355 ; Cat. Mamm. E. Ind. Co.'s Mus. 1851, p. 156 ; Lesson, Man. de Zool. 1827, p. 234 (in part) ; Schinz, Syn. Mamm. (in part), 1845, vol. ii. p. 44.

Sciurus tenuis, Blyth, Journ. As. Soc. vol. xvi. 1847, p. 874 (in part); Gray, Ann. and Mag. Nat. Hist. 1867 , vol. xx. p. 274 .

Sciurus concolor, Blyth, Journ. As. Soc. Beng. vol. xxiv. July 1855, p. 474; i ibid. vol. xx. 1851, p. 166 ; xxiv. 1855, p. 474; Cat. Mamm. As. Soc. Mus. 1863, p. 103.

The type of $S$. modestus in the Leyden Museum has the tail imperfect, but the body measures 6 inches. There is no grey on the head, and the feet are concolorous with the limbs, but slightly grizzled with black. The eye has a rufousyellow area around it like S. plantani, Ljung, S. vittatus, Raffles, S. tenuis, Horsfield, and S. philippensis, Waterhouse; but the pale, similarly coloured band in front of the eye which occurs in $S$. tenuis is not well defined. We may reasonably, however, conclude that $S$. modestus and S. affinis, Horsfield, are the same species, but the squirrel first described by Raffles from Singapore as $S$. affinis, and which he stated attained to nearly the size of $S$. bicolor, cannot be reconciled with this much smaller species. I have considered S. affinis, Raffles, as an immature example of S. bicolor.

The head is concolorous with the back, whilst in S. affinis, Horsfd., it is grey or whitish, but the two agree in the following characters: back olive-brown, passing 
into pale rufous on the sides of the neck, body, and thighs, the rufous not being much pronounced. The fore limbs externally are greyish-brown, the feet being dark brown, almost black, and the hind limbs are of the same colour. The hairs generally of the upper parts are annulated in the same way as in S. lokriah, there being about eight alternate black or brownish and yellow bands, the basal portion of the hair being dark blackish-grey. The upper light colour is produced by the pale nature of the bands and the admixture of many nearly white hairs. On the head, the annulation of the hairs has almost entirely disappeared. The tail is regularly annulated orange and black, the hair being broadly tipped with orange.

The specimen yielding the foregoing description was obtained in Sumatra by Raffles, and its body from the tip of the muzzle to the root of the tail measures 8 inches, and the tail 6 , and with hair 8 inches. The species has also been found in Malacea and in Pulo Panjang in the Gulf of Siam. The animals referred by Müller and Schlegel to Borneo and Canton seem to me to be examples of S. tenvis, Horsfd., if they are not the young of $S$. modestus.

Müller and Schlegel's figure is a good representation of the species.

\section{Scturus chinensis, Gray.}

Sciurus chinensis, Gray, List Mamm. B. M. 1843, p. 144; Horsfd. Cat. Mamm. E. Ind. Co.'s Mus. 1851, p. 159 ; Swinhoe, Proc. Zool. Soc. 1870, p. 634.

Macroxus chinensis, Gray, Ann. and Mag. Nat. Hist. vol. xx. 1867, p. 282.

The fur is rather short and coarse, and dark brown with glossy tips to the longer black hairs, as in S. philippensis. It is very finely punctulated with yellow. The two types of this species, both from the same locality, Canton, in China, differ considerably from one another; one is a male and the other appears to be a female. In the former, the upper surface of the head contrasts with the rest of the upper parts in being pale reddish-brown, passing gradually, however, into the colour of the surrounding parts. The hinder half of the side of the neck and the lower portion of the shoulder and the upper half of the fore leg are pale reddish-brown; the tail being uniformly pale brown without any annulations. In the supposed female, the head and shoulders agree with the rest of the upper surface, which is less punctulated and slightly darker than in the male. The tail is darker, and the hairs are slightly grey-tipped. In the male, the chin, throat, and chest are white, but the sides of the belly are slightly rufous, the latter having a white central streak. The chin, throat, and chest of the female are not so pure white, and the belly is slightly more rufous; in another specimen, there is also a tendency to form a pale mesial abdominal line. The ears are moderately long, and clad on their backs with short hairs.

The tail appears to be longer than the body, but in one specimen it is imperfect, and the other is so badly stuffed that its measurements would not give its correct proportions. 
This species is closely allied to $S$. philippensis, and it is a dark-brown squirrel larger than S. tenuis.

It has hitherto been obtained only from Canton.

\section{SCIURUS PHILIPPENSIS, Waterhouse.}

Sciurus plitippensis, Waterhouse, Proc. Zool. Soc. 1839, p. 117; Wagner, Schreber, Säugeth. Suppl. vol. iii. 1843, p. 209 ; Schinz, Syn. Mamm. vol. ii. 1845, p. 30 ; Blyth, Journ. As. Soc. Beng. vol: xvi. 1847, p. 874 .

Macroxus plitippensis, Gray, Ann. and Mag. Nat. Hist. 1867, vol. xx. p. 281.

Waterhouse describes this animal, which appears to be closely allied to $S$. temuis, and perhaps still more closely to S. chinensis, as having the general hue of the upper parts, sides of the body, and outer sides of the hind legs, deep brown; this tint being produced by the admixture of rust colour and black, the hairs being of the latter colour and rather broadly annulated with rusty red near the apex. The tail is not very bushy; its hairs are black, with two bright rusty bars. The under parts of the body are greyish-white, with a faint yellow tint; the head, shoulder, and brachium are greyish, and the feet are black, slightly grizzled with rust colour.

It is interesting to observe that the shoulder of the specimen, in the circumstance that its colour differs from that of the rest of the upper parts, conforms to the distribution of colour both in S. tenuis and S. chinensis, in which, however, the shoulder is more rufous than the rest of the upper parts.

Length, muzzle to vent 6.50 inches, tail 6.25 inches. In the length of its tail ic approaches to $S$. tenuis.

It was obtained in the Island of Mindanado in the Philippine group.

\section{ScIURUs tenuIs, Horsfield.}

Sciums tenuis, Horsfd. Zool. Resch. in Java, 1824; Cat. Mamm. E. Ind. Co.'s Mus. 1851, p. 153; Fischer, Syn. Mamm. 1829, p. 355 ; Cantor, Journ. As. Soc. vol. xv. 1846, p. 250 ; Gray's List Mamm. B. M. 1843, p. 144; Schinz, Syn. Mamm. vol. ii. 1845, p. 45; Blyth, Journ. As. Soc. Beng. 1847, vol. xvi. p. 874 (in part); ibid. vol. xx. 1851, p. 166 ; ibid. vol. xxiv. 1855, p. 476 ; Cat. Mamm. As. Soc. Mus. 1863, p. 104.

Sciurus modestus, Müller und Schlegel, Verhandl. 1839-44, pp. 87 and 96 (in part); Gray, Ann. and Mag. Nat. Hist. vol. xx. 1867, p. 274.

Macroxus tenuis, Gray, Ann. and Mag. Nat. Hist. vol. xx. 1867, p. 281.

Rufous olive-brown on the upper parts, the rufous more bright on the shoulder and outside of fore limbs and sometimes on the front of the thigh; the feet are concolorous with the upper surface of body; a pale rufous area around the eye and on the moustachial region and the sides of the muzzle. An oblique brownish band passes downwards from the upper surface of the muzzle, behind the moustache, with a pale rufous spot behind it. The sides of the face, below the eye, are concolorous with the sides of the neck. The under parts and insides of the limbs are pure white or yellowish, with a tendency to form a yellowish median ventral streak. The tail is 
banded yellow and black, the latter being the predominant hue, and the tip is black. The colours tend to an obscure arrangement in broad rings of yellow and black, but frequently many of the hairs are yellow-tipped, which hides this grouping of the colours. The tail is slightly shorter than the body. The ears are moderately large, with the basal hairs behind palish; their tips are rounded, and their backs are clad with silky hairs which project but little, if at all, beyond their margins; but intermixed with these are longer black hairs which extend beyond the tips, but they are so few as to be apt to be overlooked. The measurements of the type specimen are, from the muzzle to the root of the tail 5.75 ; length of the tail 5 inches. The type has all the characters of a young squirrel, and it so closely resembles S. chinensis, Gray, that it might be an immature example of that species. Müller and Schlegel referred a number of small squirrels of this type to $S$. modestus; those from Malacca and Sumatra correspond in size and other particulars to the foregoing example of S. tenuis, but, in some specimens from Borneo, the upper parts are darker, and the under parts are more richly coloured, being washed with yellowish-orange.

This species is also evidently closely allied to S. philippensis, Waterhouse, but the type of the latter is in such a bad state of preservation that its characters cannot now be well determined.

Blyth considered $S$. tenuis as identical with $S$. modestus, M. and S., and was inclined to regard it as the $S$. annulatus, Desmarest; ${ }^{1}$ but as the latter is described as having the tail longer than the body, it does not seem likely that it is S. tenuis. The locality from whence $S$. annulatus was procured is also unknown.

The type of this species was from Singapore, but squirrels of its kind have been found in the Malayan peninsula, Sumatra, Java, and Borneo.

\section{Sciurus murinus, Müller \& Schlegel.}

Sciurus murinus, Müller und Schlegel, Verhandl. Nat. Gesch. 1839-44, p. 87.

Sciurus murinus, Temminck, Esqu. Zool. de Guiné, 1853, p. 252.

This is a small species, distinguished by the sombre character of its colouring which is nearly uniform throughout.

The upper parts are dark brown, very finely speckled with rich yellow. The under parts are dark grey, slightly washed with yellowish, but the grey is generally so dark that there is no line of separation between the colours of the two surfaces. The tail is of the same colour as the body, but the hairs are more closely annulated, and the hairs at the tip are long and blackish. The ears are of moderate size and rounded, but not pencilled.

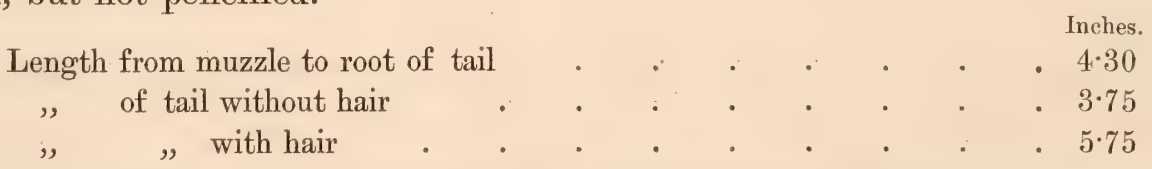

There are three examples of this species in the Leyden Museum, all from the Celebes. 


\section{ScIURus ExILIs, S. Müller.}

Sciurns exitis, S. Müller, Tydschrift voor Nat. Gesch. 1838-39, vol. v. p. 148; Müller und Schlegel, Verhandl. Natur. Gesch. 1839-44, p. 87 et p. 97, pl. xv. figs. 4-6 ; Wagner, Schreber, Säugeth. Suppl. vol. iii. 1843, p. 208 ; Schinz, Syn. Mamm. vol. ii. 1845, p. 41. Macroxus exilis, Gray, Ann. and Mag. Nat. Hist. vol. xx. 1867, p. 282.

In the Leyden Museum there are five small squirrels the bodies of which vary from 2.75 to $3 \cdot 20$ inches; and the tails, without the hair, are about $2 \cdot 20$ inches. They are squirrels about the size of $S$. melanotis. The type in the Leyden Museum is said to be an adult, and it certainly has not the characters of a young animal, although it is so very small. The general colour of the upper parts may be described as olive-brown, but the head, and the back especially over the neck and shoulders, are more or less suffused with reddish, which, however, is not very prominent nor contrasting much with the general colour. The muzzle is yellowish, and there is a similar ring round the eye, but the sides of the face from the moustache backwards, and the sides of the neck, resemble the sides of the body. The limbs also are concolorous with the body. The under parts are whitish or dusky, suffused, more or less, with rufous, and on the scrotum of the male, with bright orange. The hairs of the tail have a broad basal orange band succeeded by a broad black band which is tipped with yellowish; the under surface of the tail being rather brightly washed with orange. The ears are of moderate size and rounded, and clad with very short hairs. The whiskers are black; nearly one-half of the sole of the hind foot is clad.

The iris is brown; and the upper incisors are very pale yellow; the lower pair are nearly white. The skull is much arched behind; the facial portion is very broad at the base, becoming pointed towards the front, and moderately long.

This species has been found in Malacca, Sumatra, and Borneo.

\section{Sciurus palmarum, Linnæus.}

Ecureuil palmiste, Brisson, Regn. Anim. 1756, p. 158, No. 10.

Le palmiste, Buffon, Hist. Nat. vol. x. 1763, p. 131, pl. 126.

Palm squirrel, Pennant, Syn. Quad. 1771, p. 287 ; Hist. Quad. 1793, vol. ii. p. 149.

Sciurus palmarum, Linn. Syst. Nat. 1776, 12th ed. p. 86; Gmelin, 13th ed. ibid. 1788, p. 149; Erxleben, Syst. Reg. Ann. 1777 (in part), p. 423 ; Zimmermann, Geograph. Gesch. vol. ii. 1780, p. 343 ; Boddaert, Elench. Animal, 1785, p. 119; Schreber, Säugeth. vol. iv. 1792, p. 803, pl. 220 (fig. Buffon); Shaw, Genl. Zool. vol. ii. pt. i. 1801 (in part), p. 146; Leach, var. $\beta$, Zool. Miscell. vol. i. 1814 (addenda et corrig. p. 137).

Sciurus palmanum, Desmarest, Nouv. Dict. d'Hist. Nat. vol. x. 1817, p. 106; Mamm. 1820, p. 337, Tab. 76, fig. 2 ; F. Cuvier, Dict. des Sc. Nat. vol. xiv. 1819, p. 247 ; Desmoulins, Dict. Class. d'Hist. Nat. vol. vi. 1824, p. 72 ; Horsfield, Zool. Resch. Java; Cat. Mamm. E. Ind. Co.'s Mus. 1851, p. 152; Fischer, Syn. Mamm. 1829, p. 358 ; Waterhouse, Charlesworth's Mag. Nat. Hist. 1837, vol. i. p. 496 ; Ogilby, Royle's Ill. Him. Bot. Mem. Mamm. 1840, p. 13; Wagner, Beitr. zur Säugeth. Fauna von Kaschmir (Hugel Reise), 184k, p. 573; Wagner, Schrebe:, Säugeth. Suppl. vol. iii. 1843, p. 204 ; Gray, Hand-List Mamm. B. M. 18 43, p. 141 ; Schinz, 
Syn. Mamm. B.M. 1845, p. 38 ; Blyth, Journ. As. Soc. Beng. vol. xvı. 1847, p. 874; ibid. vol. xx. 1855, p. 166 ; Cat. Mamm. As. Soc. Mus. 1863, p. 106 ; Kelaart, Faun. Zeylanica, 1852, p. 52 ; Jerdon, Mamm. Ind. 1867, p. 170 ; Zelebor, Reise der Freg. Novara, Säugeth. 1868, p. 24.

Sciumus penicillatus, Leach, Zool. Miscell. vol. i. 1814, p. 6, pl. i. ; Desmarest, Nouv. Dict. d'Hist. Nat. vol. x. 1817, p. 112 ; Blyth, Journ. As. Soc. Beng. vol. xvi. 1847, p. 874; Horsfield, Cat. Mamm. E. Ind. Co.'s Mus. 1851, p. 152.

Macroxus (Palmista) palmarum, Gray, Ann. and Mag. Nat. Hist. vol. xx. 1867, p. 279.

Macroxus (Palmista) penicillatus, Gray, Ann. and Mag. Nat. Hist. vol. xx. 1867, p. 279.

This species is smaller and paler than S. tristriatus, Waterhouse. The pale lines extend more on to the neck and head than do the corresponding lines of S. tristriatus, and, unlike that species, the head, and the scrotal and anal regions, are not red, neither is the under surface of the tail of that colour which distinguishes S. tristriatus. The latter has only three well-defined, yellow, dorsal lines, whereas in S. palmarum there may be said to be five; but, as pointed out by Waterhouse, the outer white line on each side of the body is joined on the lower side by so pale a colour that it is not very evident as a line, but there is no white on the flanks of $S$. tristriatus, nor tendency to form white lines on the flanks, which are always grizzled like the thighs, the most external line being black. The differences manifested by the skulls are referred to under the allied form.

S. palmarum measures from 6.50 to 7 inches in length of body, from muzzle to vent, and the tail from $5 \cdot 50$ to 6 inches.

Leach first described this species as $S$. penicillatus, but afterwards, in the same volume, regarded it as identical with $S$. palmarum, or as a variety of that species, the chief character being the pencilling of the tail; but as no squirrel with a tufted tail has hitherto been discovered in India, and as it is highly improbable that such a species has been overlooked, the likelihood is that it was a specimen changing its fur. The figure given by Leach represents a squirrel agreeing more with $S$. palmarum as defined by Waterhouse than with $S$. tristriatus. Blyth also ${ }^{1}$ remarks that among very many continental examples of S. tristriatus which he had seen, he had never observed one with a terminal tuft to its tail.

This species occurs in Bengal, and ranges north-west to the Punjab and southwards to Central India; but it is not represented in Ceylon, and its place in Southern India is taken by S. tristriatus, Lesson.

\section{Sciurus tristriatus, Waterhouse.}

Funambulus indicus, Lesson, Ill. Zool. 1831, pl. xliii.

Sciurus tristriatus, Waterhouse, Charlesworth's Mag. Nat. Hist. 1837, p. 496; Proc. Zool. Soc. 1839, p. 118; Blyth, Journ. As. Soc. Beng. vol. xvi. 1847, pp. 874 and 1001 ; ibid. vol. xviii. 1849, p. 601 ; ibid. vol. xx. 1851, p. 166 ; vol. xxi. 1852, p. 350 ; Cat. Mamm. As. Soc. Beng. Mus. 1863, p. 106 ; Jerdon, Mamm. Ind. 1867, p. 171; Kelaart, Fauna Zeylanica, 1852, p. 51 .

Sciurus penicillatus, Gray, Hand-List Mamm. B. M. 1843, p. 141.

\footnotetext{
${ }^{1}$ Journ. As. Soc. Beng, vol, xvi. 1847, p. 874.
} 
Sciurus trilineatus, Kelaart, Proc. Zool. Soc. 1850, p. 157; Fauna Zeylanica, 1852, p. 54.

Sciurus palmarum, Elliot, Madras Journ. Lit. and Sc. vol. x. 1839, p. 218 ; Kelaart, Fauna Zeylanica, 1852, p. 19.

Sciurus brodiei, Blyth, Journ. As. Soc. vol. xviii. p. 602, 1849; ibid. vol. xx. 1851, p. 166 ; ibid. vol. xxi. 1852, p. 350 ; Layard, Ann. and Mag. Nat. Hist. vol. ix. 1852, p. 335.

Sciurus kelaarti, Layard, Journ. As. Soc. Mus. vol. xvi. 1847, p. 602 ; ibid. vol. xx. 1851, p. 166 ; ibid. vol. xxi. 1852, p. 350 ; Kelaart, Fauna Zeylanica, 1852, p. 53.

Macroxus penicillatus, Gray, Ann. and Mag. Nat. Hist. vol. xx. 1867, p. 279.

Sciurus dussumieri, A. M.-Edwards, Rev. et Mag. de Zool. 1867, vol. xix. p. 226; Rech. des Mammif. 1871, p. 163.

This squirrel attains to a larger size than S.palmarum. It manifests considerable variation, especially in the colour of the dark lines of the back. In some these lines are almost rufous, while in others they are dark brown or black throughout their whole extent, or black only from the shoulder to the lumbar region, the two mesial lines being rufous in the rest of their extent, or the black may be distributed irregularly in patches. The bands generally extend from the shoulder to the root of the tail, but in some they stop short of that distance. The prevailing colour of the sides and of the limbs varies from greyish-olive to olive-brown, or even brownish. The head generally is more or less tinged with rufous, especially on its upper surface, but one Madras specimen has the sides of the face and the whole of the upper surface of the head, from the muzzle to the ears, and the anal region and the under surface of the tail, bright rufous. In a Sikkim specimen, the head also is rather bright rufous over the muzzle. The under parts are white, but in some specimens the line of union of the dorsal and ventral colours is marked by a pale, yellowish line. The caudal hairs are banded with four alternate rings of either pale or rich orange-yellow and black, the first of these colours being basal; the first three rings are narrow, and the terminal black band nearly as broad as the united three, and it is broadly white-tipped.

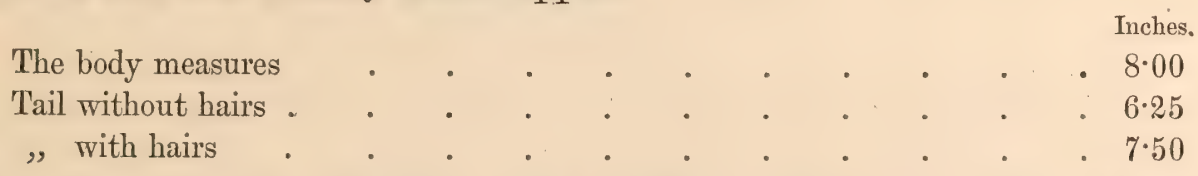

This species occurs in Ceylon and Southern India, and on the Nilgiris even as high as Ootacamund; it has also been obtained in Midnapore, and it ranges northward to the Himalaya.

Lesson was the first naturalist who figured and described this form, from a Pondicherry specimen, but he confounded it with the common palm squirrel. Waterhouse was the first who clearly distinguished between S. palmarum and S. tristriatus. He observes that the skull of the latter differs from the former " in being a little larger, considerably broader in proportion, and in having the upper surface less convex; the post-orbital process is larger, the width between the orbits is greater, and the nasal portion is more suddenly contracted, the nasal bones are longer, and narrower posteriorly."

\footnotetext{
${ }^{1}$ Proc. Zool. Soc. 1839, p. 118.
} 
I have examined all the types which have yielded the various specific appellations which head this notice, and do not find that they differ in any way from each other.

\section{Scturus sublineatus, Waterhouse.}

Sciurns sublineatus, Waterhouse, Proc. Zool. Soc. 1838, p. 19; Gray, Hand-List B. M. 1843, p. 142 ; Schinz, Syn. Mamm. vol. ii. 1845, p. 42 ; Blyth, Journ. As. Soc. Beng. vol. xvi. 1847, p. 875 ; Cat. Mamm. Mus. As. Soc. Beng. 1863, p. 107 ; Horsfield, Cat. Mamm. E. Ind. Co.'s Mus. 1851, p. 151 ; Jerdon, Mamm. Ind. 1867, p. 173.

Sciurus (Funambulus) delessertii, Gervais, Bull. de la Soc. Philom. 1841, dans 1'Instit. Journ. Gen. des Soc. Sc. 1st Sect. No. 386, May 1841; Guerin, Mag. de Zool. 1842, Mammif. pls. xxxi. and xxxii. figs. 1-4 (skull) ; Wagner, Schreber, Säugeth. Suppl. vol. iii. 1845, p. 205; Schinz, Syn. Mamm. vol. ii. 1845 , p. 43.

Scivorus tritineatus, Blyth, Journ. As. Soc. Beng. vol. xx. 1851, p. 165.

Macroxus sublineatus, Gray, Ann. and Mag. Nat. Hist. 1867, vol. xx. p. 280.

This little squirrel is smaller than the palm squirrel. It has very finely grizzled, rather dark olive-brown fur, the lineation of the upper parts being obscure, and reaching only from the shoulder to the commencement of the sacral region. The tail is concolorous with the upper parts, or darker, and it is obscurely annulated. The dorsal lines are seven in number, three being pale and four dark. The under parts are variable, but they are always dusky and never bright coloured, and vary from grey to dusky brown washed with rufous.

It inhabits the mountains of Southern India and of Ceylon. The body is 5 inches long, and the tail is 4.50 .

The type is in the British Museum, also a specimen of $S$. delesserti presented by Delessert himself; and the two are in no way distinguishable the one from the other.

I have examined both the types which have yielded the above synonymy.

\section{Sciurus LATARd, Blyth.}

Sciurus layardi, Blyth, Journ. As. Soc. Beng. vol. xviii. 1849, p. 602 ; Cat. Mamm. As. Soc. Mus. 1863, p. 107; Kelaart, Fauna Zeylanica, 1852, p. 53; Layard, Ann. and Mag. Nat. Hist. vol. ix. 1852, p. 335 ; Jerdon, Mamm. Ind. 1867, p. 172.

Macroxus (Palmista) layardi, Gray, Ann. and Mag. Nat. Hist. 1867, vol. xx. p. 280.

This species is about the same size as the palm squirrel, but in its general colour it approaches S. sublineatus; but the yellow dorsal lines, especially the mesial line, are much brighter than in that species, while the lateral pale streaks are not very well defined, but still much more so than in $S$. sublineatus. In some specimens, the mesial line is bright orange, extending from the nape even on to the base of the tail, and, in such instances, the two intervening dark bands are jet black, whereas, in those squirrels in which these light-coloured bands are pale, the intervening dark bands differ only from the surrounding fur in being darker, but are distinctly grizzled like it. The general colour is dark olive-brown on the upper 
parts. The caudal hairs are four times alternately banded, orange and black, the first colour being basal; and the first three rings are narrow, while the last black band is broader than the combined three, and effectually hides them, its apex being narrowly tipped with greyish or pale yellowish, which gives the tail the appearance as if it were washed by these colours. The tip of the tail is generally black. The under parts and the inside of the limbs are bright reddish-chestnut, and this colour extends all along the under surface of the tail, where the hairs are distichously arranged. There is a narrow rufous area around the eye. The whiskers are black.

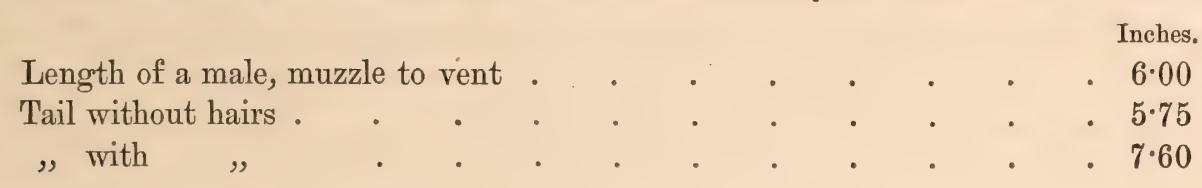

This species inhabits Ceylon.

\section{SCIURUS BeRDMOREI, Blyth.}

Sciurus berdmorei, Blyth, Journ. As. Soc. Beng. vol. xvii. 1849, p. 603 ; ibid. vol. xliv. 1875, ex. no. p. 37; Cat. Mamm. As. Soc. Mus. 1863, p. 106.

Sciurus mouhotii, Gray, Proc. Zool. Soc. 1861, p. 137.

Macroxus berdmorei, Gray, Ann. and Mag. Nat. Hist. 1867, vol. xx. p. 279.

Sciurus pyrrocephalus, A. M.-Edwards, Rev. et Mag. de Zool. Juillet 1867, vol. xix. p. 225; Rech. des Mammif. 1871, p. 163.

This species is considerably larger than $S$. tristriatus, to which it is nearly allied. It measures from the muzzle to the vent $7 \cdot 75$ inches, and the tail, without the hair, 5 inches.

The general colour of the fur is brownish, with a distinct rufous tint on the middle of the back. It is punctulated with yellowish on the head, on the sides of the face and body, and on the outside of the limbs, and with rich rufous on the middle of the back. The hairs are dark grey at the base, succeeded by four alternate yellow and black rings, the tip of the hair being always black, or dark brown, and constituting the last of these rings. The terminal ring varies greatly in its size, forming a broad tip in some, and a mere point in other hairs. A few of the hairs are wholly black, especially on the back, and there they tend to occur in groups, conferring a black, clouded aspect to that region. There is an obscure narrow black line along the middle of the back from between the shoulders, but it only extends about half-way along the trunk. On the sides of the back, a yellow line begins at the shoulder and is prolonged backwards to the articulation of the femur, where it ceases; there is a broad black band along its under side and of the same length as itself, and, along the upper margin, there is also an obscure dusky line. There is a broad, pale yellow, linear area below the former of these two dark bands, the portion of the side below it being concolorous with the thighs and fore limbs. The rufous area of the back is confined between the two uppermost yellow lines. 
The ears are rather large, and their inner surfaces are only very sparsely covered with very short, adpressed hairs, and the backs with short, soft, silky hair. All the under parts are white, very slightly washed here and there with yellowish. The tail is moderately bushy, and all the hairs are annulated with four alternate orange and black bands, the terminal black band being occasionally tipped with white and being as broad as the three remaining bands, so that the tail has a decidedly black tint washed with whitish, the orange bands, however, appearing through the black.

Blyth calls this a ground squirrel, but it is not so in the sense of being a Tamias, nor does it appear to be less arboreal in its habits than $S$. maclellandi or S. palmarum.

This species ranges southward through Martaban and Tenasserim to Cambodja and Cochin China.

I have examined the various types indicated in the above synonymy.

\section{Sciurus insignis, F. Cuvier.}

Macroxn insignis, F. Cuv. Hist. Nat. des Mammif. Nov. 1821, pl. 223; Lesson, Man. de Zool. 1827, p. 238; Gervais, Mag. de Zool. 1832, pl. xxxii. figs. 5, 8 (skull).

Sciurus insignis, Horsfield, Zool. Resch. in Java (plate) ; Cat. Mamm. E. Ind. Co.'s Mus. 1851, p. 151 ; Desmarest, Mamm. 1820, Suppl. p. 544; Fischer, Syn. Mamm. 1829, p. 359; Wagner, Schreber, Säugeth. Suppl. vol. iii. 1843, p. 205; Müller und Schlegel, Verhandl. 1839-44, pp. 87, 99 ; Gray, List Mamm. B. M. 1843, p. 141 ; Schinz, Syn. Mamm. vol. ii. 1845, p. 37. Macroxus (Laria ${ }^{1}$ ) insignis, Gray, Ann. and Mag. Nat. Hist. 1867, vol, xx. p. 276.

The young of this squirrel is dark brown, with a rather bright rufous tint on the front of the thighs, and, more or less also, on their outsides, and on the shoulder. There are three narrow black streaks from the shoulder converging slightly towards the root of the tail. The under parts and the insides of the fore limbs are white, washed with rufous. The inside of the lower part of the hind leg is dusky and tinted with the previous colour. The feet are dark, unpunctulated brown. The backs of the ears are clad with short hairs. The whiskers are black. The tail is dark brown with some of the hairs having very obscure greyish tips. The fur is very finely punctulated with rich yellow, the tips of the hairs being brown and their basal two-thirds greyish. The hairs of the tail, when pulled asunder, are also seen to be feebly annulated with yellowish-brown and dark brown, the subterminal (basal) ring being of the former colour, and the free end of the hair very broadly blackish-brown, occasionally with a greyish tip.

In the adult, the sides of the animal are rufous-brown, lightest on the thighs. The area between the black dorsal lines, on the two anterior thirds of the trunk, is much punctulated with yellowish which also extends on to the head. The hinder part of the back is rich red-brown, the under parts are clear mellow white, the insides of the limbs are washed with rufous.

${ }^{1}$ Mïller and Schlegel suggest that as they never heard the term "Lary" applied to this squirrel, as stated by Horsfield, the term perhaps was given in joke by some native, inasmuch as lar ie means to run! 
A specimen from Malacca differs from all the others in the yellowish-brown colour of the upper parts generally; and in the red tint of the thighs being but little pronounced and tending more to yellow than red; the under parts are pure white.

Length, from muzzle to tail 7.50 inches; tail reaching forwards to nearly the head.

The skull has a rather narrow and pointed facial portion, and no great breadth between the orbits.

In $S$. insignis the two wrist-pads are largely developed, especially the inner of the two, which is enlarged internally by a peculiar development, as it were, of the metacarpal of the thumb, which projects outwards; and the other bones of the digit appear as if they were bent inwards on themselves, towards the front end of the pad, acting as a kind of support to it. The small nail is flat and placed near the end of this hook. I have not observed a similar arrangement in any other squirrel. But in all the Southern Asiatic species the thumb can always be detected, generally, with a small flattened nail; but in some species, such as $S$. palmarum, it is most rudimentary.

This species occurs in Sumatra, Java, Borneo, and has also been found at Canton. In these islands it is essentially an inhabitant of the mountains, and is seldom found upon trees. Müller and Schlegel observe that it builds its nest in the trunks of fallen trees.

\section{* Sciurus maclelland, Horsfield.}

Sciurns maclellandi, Horsfu. Proc. Zool. Soc. 1839, p. 152; ibid. 1856, p. 402 ; Cat. Mamm. E. Ind. Co.'s Mus. 1851, p. 151 ; Ann. and Mag. Nat. Hist. vol. xvi. 2nd ser. 1855, p. 113 ; Wagner, Schreber, Säugeth. Suppl. vol. iii. 1843, p. 207 ; Gray, Hand-List Mamm. B. M. 1843, p. 142; Walker, Cal. Journ. Nat. Hist. vol. iii. 1843, p. 266 ; Schinz, Syn. Mamm. vol. ii. 1845, p. 34 ; Blyth, Journ. As. Soc. Beng. vol. xvi. 1847, p. 875 ; Cat. Mamm. As. Soc. Mus. 1863, p. 107; Gray, Proc. Zool. Soc. 1861, p. 137; Ann. and Mag. Nat. Hist. vol. xx. 1867, p. 274; Swinhoe, Proc. Zool. Soc. 1862, pp. 11, 357 ; ibid. 1870, p. 634; ibid. 1872, p. 818 ; Jerdon, Mamm. Ind. 1867, p. 173.

Sciurus pembertonii, Blyth, Journ. As. Soc. Beng. vol. xi. 1842, p. $88 \%$.

Sciurus barbei, Blyth, Journ. As. Soc. Beng. vol. xvi. 1847, p. 875, pl. xxxvi. fig. 3 ; ibid. vol. xviii. 1849, p. 603 ; ibid. vol. xliv. 1875, ex. no. p. 38 ; Cat. Mamm. As. Soc. Mus. Beng. 1863, p. 107.

Tamias lencotis, Temm. Esq. Zool. sur la Côte de Guiné, 1853, p. 252.

Sciurus (T'amias) rodolphi, A. M.-Edwards, Rev. et Mag. de Zool. Juillet 1867, vol. xix. p. 227; Rech. des Mammif. 1871, p. 162.

Scirurus barbei, Gray, Ann. and Mag. Nat. Hist. vol. xx. 1867, p. 280.

Sciurus maclellandi, var. Swinhoe, A. M.-Edwards, Rech. des Mammif. 1868-71, p. 308.

This small lineated squirrel, with white pencils to its ears, has the general colour of the fur olive-brown, each hair having a dark brown or nearly blackish tip, with a sub-apical yellow band, the base of the hair being slaty black. A pale, yellowish band commences in the types of $S$. maclellandi, S. pembertoni, and $S$. barbei on the side of the nose, and passing underneath the eye and ear along the side of the neck, is 
continued along the side of the back to the base of the tail. When below the eye it embraces the orbit. This lateral line is sometimes not very distinct on the head and sides of the neck, and in specimens from Tingehow (China) it is interrupted on the shoulder. Its upper margin, in the types, has a dusky line which is darkest in S. barbei, running parallel to it from the nose to the anterior margin of the eye, and from the hinder angle of that organ along the side of the neck and back; the area, below its lower margin on the back, being also more or less dusky. A narrow black dorsal line runs from between the shoulders over the vertebræ to the root of the tail. These bands, in some, are not prolonged on to the sacral region, and in Chinese specimens this is the case, and the bands are only feebly developed; but these slight differences cannot be regarded as more than instances of local variation. The ears are moderately large and pointed; and their internal surfaces are clad with short, adpressed hairs, and their backs with soft black broadly white-tipped hairs which project beyond the margin of the ears, as a distinct white pencil. The under parts of the type are dusky yellowish-white, whereas in Chinese specimens these parts are more greyish, and washed with pale yellow especially along the mesial line: in some Nepal examples they are pale orange-yellowish, a colour which is much more intense in $S$. barbei. In the type, the tail shows a tendency to pencillation, but this seems to be due to a change of fur, as the other hairs are short, whereas in other specimens the tail is bushy without any trace whatever of a pencil. The tail shows a distinct tendency to yellow and blackish annulations, the hairs being tipped with yellow, giving the appearance as if the tail were washed with this colour. The annulation is due to the presence of four alternate yellowish-orange and black bands; the basal yellow and penultimate black bands are generally narrow, and the two terminal bands of orange-yellow and of black being broad, it is to these last that the ringed character of the tail is attributable. The whiskers are black, and the limbs are concolorous with the upper parts. The tail is shorter than the body, the latter being 5 inches long, and the tail, without the hair, 4 inches.

This species has a wide distribution, ranging from Nepal and Tibet to the east of China and Formosa, and through Assam and Cachar south-eastward to Tenasserim and Siam.

I obtained it at Ponsee, at an elevation of 3,500 feet.

I have examined all the specimens which have given rise to the above synonymy, and although they differ among themselves, the divergence is so slight that it cannot in any instance be regarded as entitling them to specific rank. The Malayan form described by Blyth as $S$. barbei is only more brightly coloured than the Himalayan race, and was also named by Temminck Tamias leucotis, and by A. M.-Edwards, who obtained it from Cochin China, S. rodolphii; whereas the Formosan animals are duller in their colouring than $S$. maclellandi. The best-defined race is that which occurs in Tibet, S. maclellandi, var. swinhoei, and which A. M.-Edwards has indicated in his work on the animals of that region. The fur is longer and denser than in the more southern animals, and the longitudinal 
black and yellow bands are faint, especially the latter, and the most external line is almost obsolete.

In all their external characters these races appear to be one, and the general structure of the animal shows clearly that it is not a Tamias.

\section{ScruRus soricinds, Waterhouse.}

Sciurus soricinus, Waterhouse, Cat. Mamm. Zool. Soc. Lond. 1838, p. 46, No. 433.

Sciurus melanotis, Müller und Schlegel, Verhandl.1839-44, p. 87 and p. 98, pl, xiv. fig. 5; Wagner, Schreber, Säugeth. Suppl. vol. iii. 1845, p. 207 ; Schinz, Syn. Mamm. vol. ii. 1845, p. 41 ; Gray, Ann. and Mag. Nat. Hist. vol. xx. 1867, p. 274.

This species is the smallest of all the squirrels of Southern Asia. The head is rather broad, thick, and blunt for the size of the animal, while the muzzle is short, and very broad at its origin. The ears are slightly pointed at their tips, and have a somewhat elongated form, being one-third longer than broad; they are clad with short yellowish hairs on the inside, and on the back with long black hairs which extend beyond their margins.

The colour is subject to considerable variation. In Java, the species is a dull pale yellow-brown, passing into bright olive, variegated with black, which is produced by the black annulation of the fur. A moderately broad white stripe runs along both sides of the head, below the eyes and ears, suddenly ceasing at the shoulders. It is bordered above to the ear, and along its lower margin till just below the ear, by a narrow black band. In some specimens, the whole of the hinder portion of the head and neck is occupied by a large spot, which is paler than the ground colour; but it is obsolete in other Sumatran examples, and those from Borneo are nearly alike, and differ only in the following details from the Javan animals. The colour of the upper parts is brighter, and merges, principally on the head, into a red-brown. The under parts are pale yellow with a reddish tint, while in those from Java they are greyish-white, passing into yellow. The hairs of the ears are longer than in the Javan animals, and the spot on the neck is more clearly defined, and is generally of a pale yellow tint.

The skull resembles that of $S$, exilis, but the nasal bones are more forwardly arched, and, as a consequence, the muzzle is deeper and broader. This is essentially an arboreal squirrel, but the species is not numerically abundant in Java. In that island it is found up to 1,100 feet above the sea. It appears to be more numerous in Borneo, especially in the low-lying land. In Sumatra it is also not very common, and is found in similar situations to those in which it occurs in Borneo, especially on the west coast.

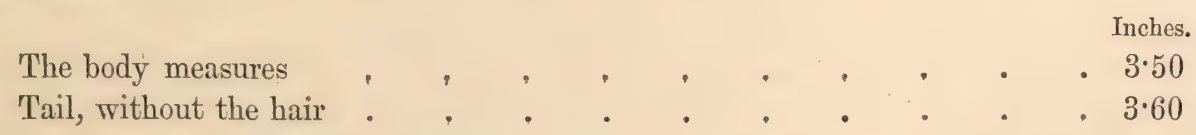

The specimen referred by Waterhouse to S. soricinus is in the British Museum, and agrees with fig. 4 of Müller and Schlegel's plate. It is a Javan specimen. 
* Sciurus quinquestriatus, Andr.

Sciurus quinquestriatus, Andr. Proc. Zool. Soc. Lond. 1871, p. 142, pl. x.; Blyth, Journ. As. Soc. Beng. vol. xliv. (1875, ex. No.), p. 37.

I obtained this species in April, in the Kakhyen hills, within the Chinese frontier, at an elevation of about 3,000 feet. On my second visit to the same locality, I found it in February, again at the same place, but I did not observe it elsewhere, so that it would appear probably to have a very local distribution.

It is grizzled above, olive brownish-grey, with a distinct rufous tint, deepest on the dorsal surface ; annulation fine, as in the grizzled squirrels generally; chin and throat obscurely grizzled greyish, washed with reddish; a rufous grizzled blackishbrown band from the chest along the middle line of the belly to the vent; external to this, on either side, a broad pure white well-defined band from the side of the chest along the belly and prolonged along the inguinal region to the vent; a broad black band from the hollow of the axilla along the side of the belly, expanding on the inside of the thighs, where it is faintly washed with greyish; inside of the fore limbs blackish, washed with greyish; toes black, with rufous annulations. Tail nearly as long as the body and head, concolorous with the body, but the black and rufous annulations much broader and more marked, assuming the form of indistinct rufous and black rings on the posterior third; tip of tail jet black, narrowly terminated with greyish.

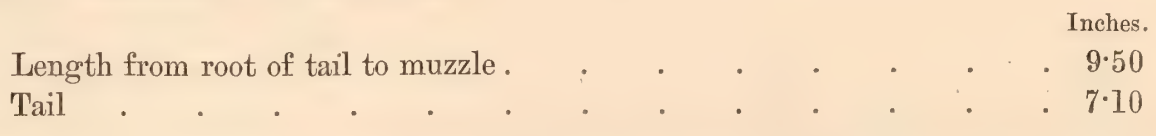

The skull is somewhat smaller than the skull of S.caniceps, and its muzzle is more pointed, with the nasals not presenting any lateral contraction, moderately broad posteriorly and gradually expanded. There are, however, no striking differences between the skulls of these widely distinct species.

$S$. quinquestriatus has only been as yet found in the above-mentioned hills.

\section{Sciurus vitTatus, Raffles.}

Sciurus vittatus, Raffles, Trans. Linn. Soc. vol. xiii. 1822, p. 259 ; F. Cuv. Hist. Nat. des Mammif. vol. ii. Octobre 1821, livraison xxiii.; Müller und Schlegel, Verhandl. 1839-44, pp. 86 and 94; Gray, Hand-List, Mamm. B. M. 1843, p. 141; Wagner, Schreber, Säugeth. Suppl. vol. iii. 1843, p. 199 (in part); Cantor, Journ. As. Soc. Beng. vol. xv. 1846, p. 250 (in part); Blyth, Journ. As. Soc. vol. xvi. 1847, p. 872 ; ibid. vol. xxiv. 1855, p. 476 ; Cat. Mamm. As. Soc. Mus. 1863, p. 104 (in part) ; Horsfield, Cat. Mamm. E. Ind. Co.'s Mus. 1851, p. 152 ; Schlegel, Nederl. Tijdschr. 1868, vol. i. p. 30, pl. ii. fig. 4; W. T. Blanford, Ann. and Mag. Nat. Hist. vol. i. 4th ser. 1868, p. 152.

Sciurus bivittatus, Desmarest, Mamm. 1820, Suppl. p. 543; Horsfield, Zool. Resch. Java, 1824; Fischer, Syn. Mamm. 1829, p. 358; Is. Geoff. St.-Hil. Bélanger, Voyage aux Ind. Orient. Zool. 1834, p. 147; Gervais, Mag. de Zool. 1842; Gray, Hand List, Mamm. B. M. 1843, p. 14i ; Blyth, Journ. As. Soc. Beng. vol. xvi. 1847, p. 872. 
Macroxus vittatus, F. Cuvier, Hist. Nat. des Mammif. Oct. 1821, pl. 234; Gray, Ann. and Mag. Nat. Hist. vol. xx. 1867, p. 278 (in part).

Macroxus toupai, Lesson, Man. de Zool. 1827, p. 238.

This squirrel is about the same size as. $S$. nigrovittatus. It is 8 inches long, and the tail nearly the same length. It differs from $S$. nigrovittatus in the rich brownish-red of its under parts, in the more defined character of the lateral white and black lines, in the generally slightly finer character of the annulations of the upper fur, and in the more coarsely annulated tail which has always a bright red tip. The ear is rounded and covered with short hairs.

In the type of $S$. vittatus, the lateral white streak is zery distinct, but the dark streak is not black, but only, a darker shade of the beny colour, not very well defined and grizzled orange-blackish.

This species does not appear to be subject to much variation, and any that it does exhibit cannot be said to be distinctive of, or confined to, a special locality. It is generally distributed over the Malayan peninsula, Sumatra, Borneo, and, according to Müller and Schlegel, Canton.

It would require a much more extensive series of specimens than is at my disposal to determine definitely whether or not $S$. vittatus is a local race of S. plantani. These facts, however, are to be borne in mind, first, that the grizzled annulation of the hair of the two so-called species conforms to a definite plan of distribution, and next, that the lineation of the side is also referable to a common type, the differences that exist between the two being only a question of the intensity of the colour of the pigment. They are both distinguished by the ventral area being distinct in its coloration from the back, from the colour of which it is separated by a dark and by a light-coloured band. This circumstance is also met with, that squirrels are found in Borneo and Western Java which the observer hesitates to refer to either of the species, because they seem equally referable to both. One variety leads into another, so that even extreme varieties are incontestably linked together by intermediate forms.

\section{Sciurus plantani, Ljung.}

Plantane Squirrel, Pennant, Hist. Quad. 2nd ed. 1792, vol. ii. p. 151.

? Sciums notatus, Boddaert, Elench. Animal, 1785, p. 119.

Sciurus plantani, S. I. Ljung, Kongl. Vetensk Acad. N. Handl. vol. xxii. 1801, p. 99, pl. i. ; Horsfield, Zool. Resch. Java, 1824 (plate) ; Cat. Mamm. E. Ind. Co.'s Mus. 1851, p. 151; Lesson, Man. de Zool. 1827, p. 236 ; Fischer, Syn. Mamm. 1829, p. 357 ; Wagner, Schreber, Säugeth. Suppl. vol. iii. 1843, p. 197 in part; Gray, Hand-List, B. M. 1843, p. 141 ; Ann. and Mag. Nat. Hist. vol. i. 4th ser. 1868, p. 309 ; Schinz, Syn. Mamm. vol. ii. 1845, p. 37 ; Zelebor, Reise der Freg. Nov. Säugeth. 1868, p. 24.

Sciums gingianus var. Plantane Squirrel, Shaw, Genl. Zool. vol. ii. pl. i. 1801, p. 147.

Sciurus bilineatus, Desmarest, Nouv. Dict. d'Hist. Nat. vol. x. 1817, p. 106 ; Mamm. 1823, p. 336; Desmoulins, Dict. Class. Sc. Nat. vol. vi. 1824, p. 72.

Sciumes nigrovittatus, Horsfield, Zool. Resch. Java, 1824; Cat. Mamm. E. Ind. Co.'s Mus. 1851, p. 152; Fischer, Syn. Mamm. 1829, p. 354; Gray, Hand-List Mamm. B. M. 1843, p. 141; 
Schinz, Syn. Mamm. vol. ii. 1845, p. 36 ; Müller und Schlegel, Verhandl. 1839-44, pp. 86, 95 ; Cantor, Journ. As. Soc. Beng. vol. xv. 1846, p. 250 ; Blyth, Journ. As. Soc. vol. xvi. 1847, p. 872 ; ibid. vol. xxiv. 1855, p. 476 ; Cat. Mamm. As. Soc. Mus. 1863, p. 105.

Sciurus griseiventer, Is. Geoff. St.-Hil. Mag. de Zool. 1832, cl. i.; Voy. aux Indes Orient. Bélanger,

Zool. 1834, p. 147 ; Coulon, Mem. de Soc. Neufchatel, vol. i. 1835, p. 124, pls. xi. and xii.;

Blyth, Journ. As. Soc. Beng. vol. xvi. 1847, p. 872 ; ibid. vol. xxiv. 1855, p. 476.

Sciurus affinis, Wagner, Schreber, Säugeth. Suppl. vol. iii. 1843, p. 202.

Sciurus assamensis, Gray, Hand-List, B. M. 1843, p. 143 (in part).

Macroxus nigrovittatus, Gray, Ann. and Mag. Nat. Hist. vol. xx. 1867, p. 278.

Macroxus (Baginia) plantani, Gray, Ann. and Mag. Nat. Hist. vol. xx. 1867, p. 279.

I have examined the type of $S$. nigrovittatus, Horsfd., and another specimen referred to the same species, besides three examples of $S$. plantani. The consideration of these had suggested to me, before I had read the remarks of Horsfield and of Müller and Schlegel on $S$, nigrovittatus, that the two so-called species were very closely allied.

Horsfield observed that $S$. nigrovittatus agreed with $S$. plantani in the distribution of the external marks, but that it was of somewhat larger size, and, as far as he had ascertained, was less abundant in Java. It had also, according to him, a darker tint above, while the under side was grey with a bluish cast: the transverse bands of the tail were broader and more strongly marked, and he considered that the black line along the sides afforded a clear specific distinction. The type, however, is not so dark as one of the examples of $S$. plantani, another of which shows quite as grey a belly as $S$. nigrovittatus. The only perceptible difference between the latter and the former is the more intense dark lateral line, and the less strongly marked yellow line in S. nigrovittatus; and Müller and Schlegel state that there is no distinction between these supposed species other than a deviation in colouring which is by no means constant.

Dr. Gray in his Synopsis of the Asiatic Squirrels regarded S. nigrovittatus and S. plantani as so distinct that he placed the former in his sub-division (b) characterised by "the pale lateral streak on the side of the body with a black streak beneath it; the fur black, blackish, or olive; beneath, red; tail as long as body and head;" the latter he classed in his sub-division (c), which he denominated Baginia and distinguished as follows: "The pale lateral streak, with a streak of the same colour as the back beneath it; fur olive, punctulated; tail elongate, as long as the body and head; hairs pale, ringed." The artificial nature of this arrangement is at once apparent from the circumstance that $S$. nigrovittatus has a bluish-grey belly, while one of the leading features of the sub-division in which Dr. Gray placed it was the red hue of the belly!

Two squirrels from Western Java obtained by Mr. Wallace and now in the Indian Museum are undoubtedly referable to S. plantani. The one is a young male and the other is an adult of the same sex. The character of the upper parts is the same as in light-bellied individuals. In the younger specimen, the under parts from the chin to the vent, the inside of the limbs and under surface of the tail, are pale orange-yellow in the adult; this colour is richer and of a much lighter and 
more orange tint than in S. vittatus, and the orange colour of the under parts does not extend on to the under surface of the tail.

The upper fur of $S$. plantani, in its light-coloured stage, is distinguished from that of $S$. vittatus by its less rufous and more olive tint, and by the greater paucity of the long shining dark-brown hairs which are so numerous in the fur of S. vittatus, also by the slightly larger size of the annuli.

Another specimen from Sarawak is in the rich, dark stage of the upper fur, in which condition it resembles $S$. vittatus, but the tail is uniformly and much more finely annulated throughout than in $S$. vittatus, and wants the rufous tip of unannulated hairs.

The squirrel referred to by Raffles as much smaller than $S$. vittatus, and differing from it by the absence of the white stripe on the sides, -in the under parts being of a greyish-white, not fulvous, - and in the tail wanting the fulvous hairs at its point, and having the light and dark colours more distinct and somewhat annulated,-is doubtless an example of $S$. nigrovittatus.

This is a very common species in almost all the large islands of the Indian Archipelago, but chiefly in Sumatra, Java, and Borneo.

\section{Sciurus Deschinschicus, Gmelin.}

L'Ecureuit de Gingi, Sonnerat, Voyage aux Indes Orient. vol. ii. 1782, p. 140.

Das Eichhornn aus Deschinschi, Schreber, Säugeth. vol. iv. 1792, p. 788.

Sciurus deschinschicus, Gmelin, Linn. Syst. Nat. vol. i. 1788, p. 151.

Sciurus gingianus, Shaw, Genl. Zool. vol. ii. pl. i. 1801, p. 147; Kuhl. Beitr. zur Zool. und Anat. 1820, p. 67.

Sciurus albovittatus, Desm. var. deschinschicus, Fischer, Syn. Mamm. 1829, p. 360 ; Gray, Ann. and Mag. Nat. Hist. 1868, 4th ser. vol. i. p. 309.

Sciurus plantani, Wagner, Schreber, Säugeth. vol. iii. 1843, Suppl. p. 197 (in part).

Dr. Gray has directed attention to Sonnerat's description of this squirrel from Gingi, near Pondicherry. If a laterally lineated squirrel exists in Southern India, it is a fact of considerable interest, as these forms have been found, hitherto, only in the Malayan peninsula.

\section{ScIURds PREvostir, Desmarest.}

Sciurus prevostii, Desmarest, Mamm. 1822, p. 335 ; Horsfd. Resch. Zool. Java, 1824; Desmoulins, Dict. Class. d'Hist. Nat. vol. vi. 1824, p. 72; Lesson, Man. de Mamm. 1827, p. 236 ; Fischer, Syn. Mamm. 1829, p. 356 ; Waterhouse, Proc. Zool. Soc. 1842, p. 116 ; Cat. Mamm. As. Soc. Mus. 1863, p. 101 ; Wagner, Schreber, Säugeth. Suppl. vol. iii. 1843, p. 195 ; Gray, List Mamm. B. M. 1843, p. 142 ; Schlegel, Nederland. Tijdschr. vol. i. 1863, p. 24, pl. i. fig. 1.

Sciurus raflesii, Vigors and Horsfield, Zool. Journ. No. xii. April and July 1828, vol. iv. pl. iv. p. 113 ; ibid. vol. v. May 1829 to February 1830, p. 141; Müll. \& Schleg. Verhandl. 1839-44, p. 93; Gervais, Mag. de Zool. 1842, pl. xxxiii. et Voyage autour du monde (Eyd. and Soul.) Zool. vol. i. 1841, p. 40; Waterhouse, Proc. Zool. Soc. 1842, p. 116 ; Gray, List Mamm. B. M. 
1843, p. 142 ; Schinz, Syn. Mamm. vol. ii. 1845, p. 31 ; Cantor, Journ. As. Soc. Beng. vol. xv. 1846, p. 248 ; Blyth, Journ. As. Soc. Beng. vol. xvi. 1847, p. 871; ibid. vol. xxiv. 1855, p. 472 ; Cat. Mamm. As. Soc. Mus. 1863, p. 101 ; Temm. Esquisses Zool. 1853, p. 242.

Sciums redimitus, Boon Mesch, Neu. Verhandl. Nederl. Inst. Amsterdam, 1829, vol. ii. p. 243

(plate); Wagner, Schreber, Säugeth. Suppl. vol. ii. 1843, p. 196 ; Schinz, Syn. Mamm. 1845, vol. ii. p. 39 ; Cantor, Journ. As. Soc. Beng. vol. xv. 1846, p. 249 ; Temm. Esq. Zool. de la Côte de Guiné, 1853, p. 245 ; Blyth, Journ. As. Soc. Beng. vol. xxiv. 1853, p. 472 ; Cat. Mamm. As. Soc. Mus. 1863, p. 100.

Sciumes rufogularis, Gray, Ann. and Mag. Nat. Hist. vol. x. 1842, p. 263; List Mamm. B. M. 1843, p. 142 ; Swinhoe, Proc. Zool. Soc. 1870, p. 634.

Sciurus rufonigra, Gray, Ann. and Mag. Nat. Hist. vol. x. 1842, p. 263; List Mamm. B. M. 1843, p. 142.

Sciurus rufoniger, Gray, List B. M. 1843, p. 142 ; Motley and Dillwyn, Cont. Faun. Borneo and

Labuan, 1855 , p. 6.

Sciurus erythromelas, Temm. Esq. Zool. 1853, p. 248 ; Schlegel, Tijdsch. Nederland. vol. i. 1863, p. 28, pl. ii. fig. 2; Gray, Ann. and Mag. Nat. Hist. vol. xx. 1867, p. 183.

Sciurus prevostii, var. sumatrana, Schl. Nederland. Tijdsch. 1863, p. 25.

Sciurus prevostii, var. bangkana, Schl. Nederland. Tijdsch. 1863, p. 26, pl. i. fig. 2.

Sciurus atricapillus, Schlegel, Nederland. Tijdsch. 1863, vol. i. p. 27, pl. ii. fig. 1.

Sciurus prevostii, var. borneoensis, Schlegel, Nederland. Tijdsch. vol. i. 1863, pl. i. fig. 3, p. 26.

Sciums erythrogenys, ${ }^{1}$ Schlegel, Nederland. Tijdsch. vol. i. 1863, p. 29, pl. ii. fig. 3.

Sciurus picens, Peters, Proc. Zool. Soc. Lond. 1866, p. 429.

Sciums borneoensis, Gray, Ann. and Mag. Nat. Hist. vol. xx. 1867, p. 277.

Macroxus (Callosciurus) raflesii, var. bangkanus, Gray, Ann. and Mag. Nat. Hist. 1867, vol. xx. p. 277.

Macroxus (Callosciurus) rufogularis, Gray, Ann. and Mag. Nat. Hist. vol. xx. 1867 (in part), p. 277.

Macroxus (Callosciumus) sarwakensis, Gray, Ann. and Mag. Nat. Hist. vol. xx. 1867, p. 277.

Macroxus rufoniger, Gray, Ann. and Mag. Nat. Hist. vol. xx. 1867, p. 278.

Macroxus pluto, Gray, Ann. and Mag. Nat. Hist. vol. xx. 1867, p. 283.

Macroxus atrocapillus, Gray, Ann. and Mag. Nat. Hist. vol. xx. 1867, p. 278.

Sciurus schlegelii, Gray, Ann. and Mag. Nat. Hist. 1867, p. 278.

Sciurus schlegelii, A. M.-Edwards, Rech. des Mammif. 1871, p. 163.

I have examined a very extensive series of squirrels ${ }^{2}$ from the Malayan peninsula and its neighbouring islands, and from the large Islands of Sumatra, Borneo, and the Celebes, and all of which appear to be referable to one specific form, which, however, is so modified in certain comparatively limited, areas as to assume the importance of local races. The attempt, howerer, to elucidate and define these races is complicated by the changes of fur to which these squirrels are subject before they reach maturity, and probably by alterations of pelage attending the breeding season. There appear to be three well-marked, local races,-one peculiar to Malacca and the mainland, another to Sumatra and Banka, and perhaps to some of the neighbouring smaller islands, and a third to Borneo and the Celebes.

The features which characterise the first race are as follows :-

The Malayan race.-The side of the face and lower jaw from the muzzle, below the eye, and through the lower third of the ear, and along the side of the neck

1 This term having been applied by Waterhouse in 1842 to an African squirrel, Dr. Gray in the Ann. and Mag. Nat. Hist. 1867, vol. xx. p. 278, re-named the Celebes squirrel as S. schlegelii, a term afterwards suggested by A. M. Edwards (Rech. des Mammif. 1871, p. 163) for the same reason, he being unaware that Dr. Gray had anticipated him.

${ }^{2}$ As far as possible, I have personally examined the type of each supposed species, and the only forms which have not been seen by me are $S$. redimitus and S. raflesi. 
and the shoulder and humeral region greyish-white, due to an intermixture of black and white hairs, the latter being by far the most numerous. A broad yellowishwhite line from the axilla runs along the side, and over the outside of the thigh to the heel. All the upper parts, from the tip of the muzzle, through the upper two-thirds of the ear and along the back and round the hips and back of hind legs to the tarsus, and the tail, are black, the tip of the latter tending to red. There is a dusky spot on the chin: all the rest of the animal is rich maroon-chestnut. The whiskers are black. Length of body 10.50; tail, without hair, 10.30 inches.

In the adolescent, the sides of the face are much greyer than in the adult, and approximate in colour to the cheeks of S. rafflesii, V. \& H., from Sumatra, but are much lighter, and, like it, the moustachial area, and the spot where the cheekbristles originate, are much purer white; the sides of the neck and the shoulders also are much more grey, and the shoulder is slightly washed with rufous. The lower portion of the tail is black above and brown below, the remainder being rather reddish-brown, paling towards its extremity. In a specimen referable to this race the red is much more intense on the fore limb and lower front part of the shoulder than in other individuals, and in these respects it approaches to S. prevostii var. bangkana, but it has only the faintest trace of red on the front of the shoulder, the shoulder generally being grey, while it is reddish in $S$. bangkanus.

A young squirrel stated to have come from China, accurately agreeing with the description and figure of S. raffesii, Vigors and Horsfield, was referred by Dr. Gray to a new species, $S$. rufogularis, but it also corresponds to the figure and description of S. redimitus, Boon Mesch, except that the greyish extends on to the side of the face and neck, whereas these areas in S. redimitus are the same as in the under parts. It also agrees, however, with the measurements given by Boon Mesch of his supposed species, and, like it, the moustachial region and area around the cheek-bristles are white. In its otherwise grey cheeks and sides of the neck it resembles the squirrel referred by Schlegel to S. prevostii var. bangkana. The fore legs are red, tending to become white on the upper part of the shoulder. There is a white line from the shoulder to the groin; and the outside of the thigh and the lower half of the leg are white. The tail is brownish-black tending to reddish-brown at the tip.

The Sumatran and Banka race.-The Sumatran race S. rafflesii is distinguished from the race of the mainland by a large white spot on the side of the muzzle, by its greyish or brownish cheeks and side of the neck, and by its red fore limb and shoulder. It closely approaches the other insular form from Borneo.

From the muzzle to the root of the tail along the upper parts is wholly black, and the hinder border of the thighs is of the same colour. The sides of the muzzle, the chin, the region of the cheek-bristles, a line along the side from the shoulder, and the outside of the thigh, are white. The three first-mentioned areas are obscurely greyish when the sides of the face and neck are grey, which they appear to be in the young animal. The region behind the ear has also generally a greyish tint. The side of the face and below the ear, in the adult, are greyish-brown. The throat, the sides of the lower jaw, the sides of the neck, the shoulder, the whole of the 
fore limb, the front of the hind leg, and the hind foot and all the under parts, are rich maroon-chestnut. The tail black, rufescent towards the tip.

The ears are moderately sized and pointed, and are not pencilled. The moustache and whiskers are long and black,

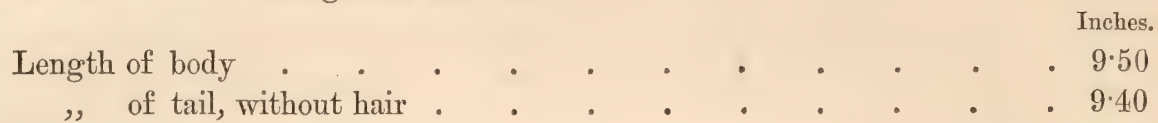

The squirrel from the Island of Banka differs from the type of S. raffesii in two respects : firstly, the shoulder is grey instead of being red; and secondly, the black of the upper parts is prolonged down in a narrow band before the shoulder, separating it from the grey of the side of the neck. The tail also wants the brownish tip. In all other respects it agrees most closely with the Sumatran race. In both of these, there is generally indicated an obscure dusky, or blackish line from the shoulder to the groin, underlying the white lateral band.

The Bornean and Celebean race.-The Islands of Borneo and the Celebes have yielded a number of squirrels which have been described at various intervals, during the last twenty-five years, as distinct species, with one single exception, viz., the S. rafflesii, var. borneoensis, which Müller and Schlegel justly regarded as only a local race of the laterally white-banded and red-bellied squirrel of the Malayan peninsula, Sumatra, and Banka, and which had been first described by Desmarest under the name of $S$. prevostii and afterwards by Horsfield and Vigors as S. raffesii, which latter term Müller and Schlegiel accepted in preference to the former, which had the claim of priority.- They did so in recognition of the services rendered by Raffles to the progress and development of knowledge regarding the islands over which he had been placed as ruler.

The following is a chronological list of these supposed species from Borneo and the Celebes, viz.: Sciurus rufogularis, Gray; S. rufoniger, Gray; S. erythromelas, Schlegel; S. atricapillus, Schlegel; S. schlegelii, Gray; S. pluto, Gray; and S. sarawakensis, Gray. Those from Borneo are S. rufoniger, Gray; S. atricapillus, Gray; S. pluto, Gray; S. sarawakensis, Gray; S. schlegelii, Gray; and those from the Celebes, S. erythromelas, Schlegel; and S. schlegelii, Gray; whilst the locality from whence S. rufogularis, Gray, was obtained is unknown.

That the Celebes form, S. erythromelas, Schlegel, is not a local race, or essentially distinctive of that group of islands, is fully proved by the circumstance that it is almost the exact equivalent of the Bornean S. rufoniger; S. schlegelii, on the other hand, approaches the squirrels which resemble $S$. atricapillus, Schlegel, in every respect but the presence of the black on the head. The skulls of these latter specimens clearly prove that they are young individuals. Their bodies are slatygrey, finely black and white speckled, the back being blackish, whereas the sides of the neck, the shoulders, and the lower half of the limbs, are much the same as the head in colour and speckling; the feet, however, tend to black in some, in which the outside of the thighs is pale greyish-white, whilst in others it has a yellowish tinge. The tail is occasionally banded grey and black, and in other instances yellowish and 
black, there being about thirteen alternate light and black rings, of which the terminal ring is pale. On the sacral region, the black of the back is contracted into a narrow band, well marked off from the pale colour of the thighs. The sides of the face and neck are commonly greyish, but in some they are washed with rufous, tending undoubtedly to assume the $S$. schlegelii garb which has been indicated by Schlegel as a distinct species. The red would appear to commence around the eye and to extend upwards from the throat, because in specimens with rufous on the cheek, the colour around the eye is more marked than in others which are younger. The white band extends from the axilla to the groin, and merges into the grey of the outside of the thighs. The black line, below the white lateral line, is broad, and is continued more or less along the external margin of the fore limb. The chin is almost blackish, with grey grizzling, while the under surface of the neck, the inside of the limbs, and the chest and belly, are rich chestnut.

In the true black-headed and grizzled phase, the head from the nose to between the eyes, the chin, the feet, the outer border of the fore limbs, a broad streak along the side of the rufous of the belly from the shoulder to the groin, and the tail, are black. All the remainder of the upper parts and the base of the tail and the sides of the face and neck and outsides of the limbs are greyish-black, grizzled with white, with the exception of a broad white band lying above the black band of the sides, and having a similar length. The under parts are deep chestnut. The ears are of moderate size and rounded, and clad with short adpressed hairs.

Many specimens of this phase from Borneo and the Celebes, agreeing in every detail with each other, have come under my observation. A specimen of $S$. atricapillus from Borneo, in the Leyden Museum, has the upper surface of the back nearly black, and is much darker than another and larger example from the same island. It closely approaches the type of $S$. erythromelas, only the extremities are jet black, and the bright-coloured lateral line is well developed and yellowish. It is undoubtedly intermediate between that type and $S$. atricapillus, and is only distinguished from $S$. schlegelii from the Celebes by its blacker head, its greyish cheeks, black tail, and its better-defined yellow lateral line. S. erythromelas and $S$. schlegelii from the Celebes are also so like each other in general characters that I cannot but regard them as marking some transitional phase intimately related to the atricapilline form. Temminck considered $S$. schlegelii as the winter pelage, S. erythromelas as the coat of the breeding season, and S. atricapillus to be the perfect livery.

In the type of $S$. erythromelas from the Celebes, we have a squirrel which is wholly black on the upper parts and tail, like S. rufoniger from Borneo, but with some red on the lower portion of the limbs, which does not occur in the latter. The black of the outside of the fore extremities is less marked than in the Bornean squirrels, but the fore feet are blotched with black, and the upper surface of one hind foot is nearly entirely black, while the other is red, blotched with black. The shoulder and thighs and the narrow line along the side are the same as in Sciurus rufoniger, and the colour of the under parts is identical in these squirrels from Borneo and 
the Celebes. The moustachial and cheek bristles are greyish, the cheeks being black, but finely grizzled with grey, a colour which does not occur in S. rufoniger. The type of S. rufoniger is black above, with a greyish tinge on the shoulder and outside of the thighs, and along the sides, in which latter locality this colour is distributed in a linear form, but in some Bornean examples the grey assumes the character of a white band between the axilla and groin; the grey being absent on the shoulder and thighs, while in others from the same locality, the white or grey is almost obsolete, being reduced to an obscure lateral line, while in another specimen there is no trace of it beyond a few greyish hairs along the position occupied by the lateral line in the others, and in this respect it resembles $S$. erythromelas. The grey or white lateral line is always separated from the deep chestnut of the under parts by an intense, but narrow black line. The chin, and all the upper parts and the outside of the limbs and the tail, are jet black. The throat and all the under parts are deep chestnut.

S. schlegelii is from Koma, also in the Celebes. The fur is wholly and finely, but sparsely grizzled with yellow on the upper parts and on the tail and on the outside of the limbs, but the feet are black. The sides of the face around the eye are rich chestnut, passing into deep maroon on the under parts. There is a pale yellowishgrey line from the shoulder to the groin, and below it a black band. The tail is black, sparsely grizzled with yellow, and terminating in a black tip.

All of these forms lead so gradually from one into the other that their specific identity seems unquestionable. The series here considered, yields indisputable evidence that the white or grey lateral streak occasionally disappears by the white being replaced by black hairs, but it is found in every stage of disappearance, and in some it is only indicated by the intermixture of a few white among the black hairs. Likewise, the underlying black streak is also the subject of analogous changes in those forms referable to S. prevostii, var. borneoensis, the black being replaced by the red of the under parts. The thighs and shoulders of the type of $S$. rufoniger from Borneo, which is essentially the same as S. prevostii, var. borneoensis, are also distinctly greyish, as in the forms referred to S. erythromelas, S. schlegelii, and S. atricapillus, all of which have the white lateral streak and a distribution of colour which has a well-defined general correspondence throughout them all.

The next modification is one which only differs from S. prevostii, var. borneoensis, Schl., by the absence of the white on the moustachial region, and in the complete disappearance of the black below the white lateral line, which is well marked in Schlegel's specimen. This example differs from the two first-described specimens in the upper surface of the head, neck, and shoulders being ungrizzled jet black. The sides of the face from the muzzle to the ear, and the sides of the neck, are greyish, more or less marked with rufous. The shoulder is reddish, paling upwards into yellowish, which is more or less continuous from behind with the white lateral line which extends backwards from the shoulder to the groin; the outside of the thighs and the legs to the ankle being grey. The fore limb is rufous, and more so than the shoulder, but it shows the remains, as it were, of grizzling, and the hind 
foot does the same, but much more distinctly, being decidedly greyish-black and rufous-grizzled, and is evidently in a transitional stage between the black feet of $S$. schlegelii and the bright red feet of what appears to me to be the fully mature animal $S$. prevostii, var. borneoensis, or S. sawarakensis. The under surface of this animal is even more lightly chestnut-red than in the previous specimens, and the annulation of the tail has disappeared, but it is here and there washed with greyish. Two other specimens, one of them referred by Dr. Gray to his S. rufogularis, are states of the pelage intermediate between S. schlegelii and S. erythromelas, and have the upper surface of the head, neck, and the back and sides, with the exception of the outside of the thighs, jet black, without any grizzling. The sides of the face and neck, the shoulder, the fore limbs and lower half of the hind limbs, and all the under parts, are bright chestnut. There is a white line from the shoulder to the groin, becoming grey on the outside of the thighs. The chin is black in one, and on it there is a faint trace of a black lateral line, but these black marks are absent in the other. The tail in both is black, washed with greyish, the tip in the squirrel with the black chin being wholly black. The red of the shoulder passes into yellowish above.

Another variety has the upper surface of the head and the middle line of the neck and above the shoulders, and the area between the shoulder and the groin, and a narrow space over the lumbar region jet black, also the tail, which is slightly washed with yellowish. The sides of the face and neck, the shoulder and fore limb, and the hind feet and all the under parts, are bright red. The upper portion of the shoulder passes into yellowish, and is more or less continuous with the lateral line which has a distinct, yellowish tinge and expands on the outside of the thigh, which is clear yellow, passing into rufous on the lower part of the leg. The black lateral line is obsolete. In all these squirrels the base of the tail, below and around the vent, remains greyish.

The squirrels from Borneo and the Celebes lead so perfectly from one into the other and into the brightly-marked adult, the $S$. sarawakensis, Gray, that it seems clear they are all, as I have already said, only phases of one species.

Apart altogether from local races, it would appear that, in the young stage, the pelage of this type of squirrel is grey; that this gradually changes into black on the back; that the rufous of the under parts "extends by degrees, more or less, on to the limbs, and spreads upwards on to the sides of the face and neck; and lastly, that the white lateral line and the grey of the thigh change into yellow, and occasionally the upper surface of the shoulder into yellowish-red, whilst the black lateral line, which is well developed in the grey stage, disappears in the adult.

\section{Sciurus (Rhinosciurus) tupaoides, Gray.}

Rhinosciume tupaoides, Gray, List Mamm. B. M. 1843, p. 195; Ann. and Mag. Nat. Hist. 1867, vol. xx. p. 286 ; Blyth, Journ. As. Soc. Beng. vol. xx. 1851, p. 167, et 1855, vol. xxiv. p. 477; Cat. Mamm. As. Soc. Mus. 1863, p. 108. 
Sciurns laticaudatus, Müller und Schlegel, Verhandl. 1839-44, pp. 100 and 215, figs. 1, 3 ; Wagner, Schreber, Säugeth. Suppl. vol. iii. 1843, p. 206 ; Schinz, Syn. Mamm. vol. ii. p. 40, 1845; Cantor, Journ. As. Soc. Beng. vol. xv. 1846, p. 251 ; ibid. vol. xx. 1851, p. 167.

Müller and Schlegel's description of S. laticaudatus would seem to leave no doubt but that the animal described and figured by them under that name is this species which is so remarkable, not so much on account of any character presented by its tail, as by reason of its deep and rather long muzzle, with which there is associated a correspondingly elongated and narrow skull, unlike the skulls of squirrels generally with their much compressed and rather feeble incisors, while the first of its five upper teeth is remarkable on account of its strong development and from the presence of four distinct cusps, the foremost of which is the largest, while in other squirrels there are only one or two small cusps. The skull of Tamias davidanus closely approaches it in its general character, but the muzzle is shorter; however, these two skulls are more closely related to each other than to the skulls of the other squirrels of Southern Asia.

Gray's type was purchased from a dealer and was entered in the British Museum Register as coming from Malacca, but Dr. Gray in his Synopsis gives Singapore as the habitat. Blyth received a specimen from the Malayan peninsula. The type of S. laticaudatus was procured by Diard, in 1827, on the west coast of Borneo near Pontinack, where this peculiar squirrel is not uncommon. Müller and Schlegel met with it in that island, along the banks of the rivers Baritto or Doeson, and in the mountain jungle.

As remarked by Müller and Schlegel, its pelage has a strong resemblance to the pelage of $S$. insignis, having much the same character, except that it has no black bands. The coloration, as in S. insignis, is more murine than in any other Asiatic squirrel, except perhaps $T$. davidanus, and it is very variable in its intensity, varying from light to dark, almost blackish brown. It is about the size of $S$. insignis, and the tail is shorter than the body, reaching to about the eye when laid forwards. The tail is moderately bushy, rather contracted at the base, but expanding towards the tip. The hairs are banded rather broadly with four alternate pale-brown and dark-brown bands, the last band being the darkest and broadest, with a pale-brown tip. The ears have the same form as in the squirrels, but the moustache is much more feeble. The under surface is nearly pure white in some, and rich orange-yellow in others.

The figure of the muzzle, as given by Müller and Schlegel, appears to have been taken from a stuffed specimen from which the skull had been removed, so that the true character of the muzzle in the living animal is not correctly represented.

I have examined the types of $R$. tupaioides and $R$. laticaudatus, and find that they belong to only one species.

This species is found in the Malayan peninsula and in Borneo. 


\section{Sciurus (Rheithrosciurus) macrotis, Gray.}

Sciurus macrotis, Gray, Proc. Zool. Soc. Lond. 1856, p. 341, pl. xlvi.

Rheithrosciurus macrotis, Gray, Ann. and Mag. Nat. Hist. vol. xx. 1867, p. 272.

The head is large, compressed, and short; the ears are large, with a pencil of elongated hairs at their tips; the feet are large and strong; and the sides of the animal are laterally banded.

The general colour is dark chestnut-brown, very minutely punctulated; the hind quarters, including the base of the tail, and the outsides of the fore and hind limbs, bright bay; the feet blackish. There is a brownish band from the axilla to the groin, with a yellowish-white band above it. The cheeks and inner sides of the limbs are pale brownish; the chin, throat, and under parts, white. Tail, broad and full, grizzled, and with long white tips to the hairs.

Habitat.-Sarawak, Borneo. 


\section{PTEROMID Æ.}

Genus Pteromys, Cuvier.

\section{Pteromys.}

Baron G. Cuvier ${ }^{1}$ was the first to separate the flying from the ordinary squirrels, under the genus Pteromys. No one will be found to dispute the correctness of this course, but while some naturalists have followed in the footsteps of Frederic Cuvier ${ }^{2}$ in sub-dividing the flying squirrels into two groups, one Pteromys and the other Sciuropterus, others have failed to appreciate the significance of the characters which he assigned to the genus Sciuropterus.

As is well known, F. Cuvier relegated to the genus Sciuropterus all the small flying squirrels which he considered to resemble the ordinary squirrels by the conformation of their teeth, in the less complex character of the folds of enamel in the molar series.

I have examined the dentition in the following species, viz.: $P$. teromys oral, $P$. caniceps, $P$. leucogenys, $P$. magnificus, $P$. melanotis, $P$. nitidus, $P$. punctatus, $P$. tephromelas, $P$. alboniger, $P$. fuscocapillus, and $P$. volans, - that is, in flying squirrels belonging to both of the two supposed genera; but, according to my observations, the form of the enamel folds in youth are essentially similar, consisting of a series of tubercular folds which are marked with wavy lines in some, and are smooth in others, but, in all, there is a marked conformity to a common type. The seemingly more complex character of the folds appears to depend on the extent to which the tubercular ridges are worn by use.

Since F. Cuvier wrote, many naturalists have been inclined to regard the distichous arrangement of the hairs of the tail, which is undoubtedly characteristic of some species, as a feature common to all the smaller flying squirrels, or to those which they have been wont to consider as belonging to the genus or sub-genus Sciuropterus; but, after a careful examination of this organ, in nearly all the members of the series, I have failed to detect that it is essentially distinctive of them-that is, that the distichous arrangement of the hairs is always associated with a diminutive species; but, at the same time, there can be no doubt that it is more prevalent among such. The tail is bushy in the following species, viz.: $P$. oral, $P$. cineraceus, 
$P$. elegans, $P$. punctatus, $P$. caniceps, $P$. albiventer, $P$. nitidus, $P$. magnificus, $P$. pheomelas, $P$. leucogenys, $P$. xanthipes, $P$. alborufus, $P$. melanopterus, $P$. tephromelas, $P$. layardii, $P$. fuscocapillus, and $P$. fimbriatus; whereas it is partially distichous in $P$. melanotis, and is wholly so in $P$.pearsonii, P. momonga, $P$. pulverulentus, $P$. alboniger, $P$. horsfieldii, $P$. genibarbis, $P$. lepidus, $P$. phayrei, $P$. spadiceus, and $P$. volans. The wing parachute, however, in all the members of the group is the same, although some naturalists have described it in $S$. sagitta as having an expansion in front of the fore limb, which does not exist in the other species, but this is unquestionably an error. I am therefore disposed to regard the flying squirrels generally as constituting a well-defined, generic group, the parallel of the genus Sciurus which consists of an extensive series of specific forms distinguished by a remarkable uniformity of structure both in their skulls and skeletons and in the formation of their soft parts.

\section{Pteromys oral, ${ }^{1}$ Tickell.}

Taguan ou grand Ecureuil volant, Buffon, Hist. Nat. Suppl. vol, iii. (in part), 1766, p. 150, pl. xxi. et xxi. bis ; Vosmaer, Reg. An. 1767, (in part) plate.

Pteromys petaurista, Schreber, Säugeth. vol. iv. 1792, p. 819, pl. 224A, fig. Buffon's (in part); Desmarest, Mamm. 1820 (in part), p. 342 ; Gray, Hand-List, Mamm. B. M. 1843, p. 133; Müller und Schlegel, Verhandl. 1839-44, p. 106 (in part); Schinz, Syn. Mamm. vol. ii. 1845, p. 50 (in part) ; Blyth, Journ. As. Soc. Beng. vol. xvi. 1847, p. 865 (in part); Cat. Mamm. As. Soc. Mus. 1863, p. 94; Horsfield, Cat. Mamm. E. Ind. Co.'s Mus. 1851. p. 159 (in part); Jerdon, Mamm. Ind. 1867, p. 174.

${ }^{1}$ As the term $P$. petaurista has been generally applied to large flying squirrels from the Noluccas, Philippines, Malayan islands and India, and to widely different forms, I have retained the term $P$. oral for the Indian species, as first clearly indicated by Tickell, and $P$. cineraceus for the Burmese and Malayan animal, which was first recognised by Blyth as a distinct species. It seems to me, however, very doubtful that the latter form is specifically separable from $P$. oral. The following are some of the chief references to the literature of the subject:-

Buffon, Hist. Nat. Suppl. vol. iii. 1766, p. 150; Pennant, Hist. Quad. vol. ii. 1792 (red) p. 151; Vosmaer, Reg. Ann. 1767; Pallas, Miscell. 1766, p. 54, pl. vi. figs. 1-2; Erxleben, Syst. An. 1777, p. 238; Zimmerman, Geograph. Gesch. 1780, vol. ii. p. 349 ; Boddaert, Elench. Animal, 1785, vol. i. p. 120; Gmelin, Lin. Syst. 1788, p. 155; Schreber, Säugeth. vol. iv. 1792, p. 819, pls. 224 A and B. (fig. Buffon); Shaw, Genl. Zool. 1801, vol. ii. pt. i. p. 160, pls. 152 et 153; Cuvier, Règ. Ann. vol. i. 1817, p. 207; Desmarest, Mamm. 1820, p. 341; F. Cuv. Dict. des Sc. Nat. vol. xliv. p. 41 ; Lesson, Man. de Zool. 1827, p. 241; Is. Geoff. St.-Hil. Dict. Class. d'Hist. Nat. vol. xiv. 1828, p. 341; Fischer, Syn. Mamm. 1829, p. 362; Wagner, Schreber, Säugeth. Suppl. vol. iii. 1843, p. 221, pl. 224B; Müller und Schlegel, Verhandl. 1839-44, p. 106; Schinz, Syn. Mamm. vol. ii. 1845, p. 865; Blyth, Journ. As. Soc. 1827, vol. xvi. p. 865.

In the Leyden Museum there is a large flying squirrel, of which, however, the history is unfortunately unknown; the tail also is imperfect. It is remarkable on account of the peculiar character of its colouring. The head, including the cheeks and the sides of the neck and throat, are brick-red; the upper surface of the head being grizzled with white. The same colour spreads over the shoulder, back, and sides to the end of the lumbar region, and on these parts it is also grizzled with whitish, which produces a pale yellowish-red tint. The middle of the back is marked by a transverse, dark narrow brown band. The rump, thighs and feet are pale yellowish-white. The middle of the membrane is paler than the back, and the portion external to the shoulder is reddish-yellow, tending to white, while the wrist elongation is rich red-brown. What remains of the tail resembles the colour of the lumbar region. All the under parts are red. There is a pale yellow area around the eye. The ears are small for the size of the animal and are sharply pointed. 'The cheek-bristles are only feebly developed. The body measures 23 inches along the back.

This is doubtless one of the many species which have been referred to $S$. petaurista, and it is interesting to recollect that the Leyden Museum contained some of the first flying squirrels referred to P. petaurista. 'This old specimen stands without a name. 
Pteromys phitippensis, Elliot, ${ }^{1}$ Madr. Journ. Lit. and Se. vol. x. 1839, p. $21 \%$.

Pteromys griseiventer, Gray, Hand-List Mamm. B. M. 1843, p. 133; Blyth, Journ. As. Soc. Beng. vol. xxviii. 1859 , p. 277.

Pteromys inornatus, Müller und Schlegel, Verhandl. 1839-44, p. 106.

Pteromys oral, Tickell, Cal. Journ. Nat. Hist. vol. ii. 1842, p. 401, pl. xi.; Schinz, Syn. Mamm. 1845, vol. ii. p. 59 ; Kelaart, Prod. Fauna Zeylanica, 1852, p. 55.

Pteromys nitidus, Kelaart, Proc. Zool. Soc. 1850, p. 157.

This is the only large flying squirrel, properly so called, occurring in India and in the Island of Ceylon.

The head is large, and the upper parts are dusky maroon-black, grizzled with whitish, due to the presence of a sub-apical white band, which terminates in an inconspicuous black point. The parachute and the limbs are much lighter and more rufous-maroon. The feet, muzzle, and around the eyes are black, and the male is distinguished by an irregular patch of rufous on the sides of the neck, which in the female is a sort of pale fawn. ${ }^{2}$ The tail, which is rather longer than the body, is bushy, and its terminal two-thirds or three-fourths are black or blackish, with rarely a little white at the extreme tip. The under parts are dingy brownish-grey, sometimes nearly greyish-white.

The Marquis of Tweedale procured in Travancore a specimen much paler than usual, being of a light maroon-brown above, and with yellowish-white, sub-apical bands; the long hair behind the ears being pale rufous instead of dark maroonbrown. The feet are only in part blackish, especially the fore feet; the muzzle and around the eyes are dark brown, and the tail has its terminal three-fifths uniformly rufous brown, a little darker at the tip, while its base is paler, and slightly whitegrizzled. The under parts are clad with scanty annulated hairs of a predominant pale colour; and two whitish streaks extend longitudinally along the mammæ.

In the British Museum, there are two examples of this species from Madras presented by Sir Walter Elliot; one is much darker than the other in the basal portion of its fur, which is dark blackish-brown, while in the paler individual the hidden portion of the fur is pale earthy-brown. In both, the hair of the head, neck, and upper surface of the parachute, has whitish sub-apical bands and black tips, but the white rings are much more pronounced in the dark than in the pale specimen. In the former, the hair on the parachute is very broadly banded with yellowish-brown and with rufous; whereas in the foregoing. Travancore specimen, which in other respects resembles it, the parachute is dark brown, with only a few hairs with pale sub-apical rings. There can, however, be no doubt of the specific identity of all these specimens.

\footnotetext{
I. I have not been able to trace the term $P$. philippensis beyond its occurrence in Sir Walter Elliot's Catalogue and the explanation which he gives of it. In writing of the specimens which he had forwarded to the British Museum, and which now stand there under the name $P$. petaurista, he says: "Mr. Gray designated the specimens of this species presented to the British Museum by the specific name of $P$. philippensis, and showed a former description of them under this title, the source of which I have mislaid. I cannot find any such species indicated in Griffith or Fischer's Synonyms nor in any work to which I have access." The name $P$. philippensis is probably founded on Buffon's description of the Taguan from the Philippines, $l$. $c$.

2 Elliot $(l . c$.$) .$
} 
Three specimens of this species exist in the Leyden Museum, two from Colombo, Ceylon, collected by Diard, and the other from the Himalaya. The only difference between them is that the former specimens have the tail not quite so black as the Himalayan individual. Both are much grizzled with white all over the upper parts, head, back, and wing membrane.

The two types of $P$. griseiventer are in the British Museum, but their habitat is unknown. They exactly agree with the specimen procured by the Marquis of Tweedale at Travancore, except that the under parts are slightly greyish.

This species ranges from Ceylon northwards to the Himalaya, and Tickell met with it in the Midnapore jungles and described it as $P$. oral. There is a specimen in the British Museum said to have come from Singapore, but as that port is the centre to which animals from all parts of Southern and Eastern Asia are carried for sale, it is highly probable that it was taken thither from Ceylon or Southern India.

Mr. Baker remarks ${ }^{1}$ that this species, like other flying squirrels, being nocturnal in its habits, is difficult to procure, except by watching under fruit-trees on moonlight nights, or, when the forest is cut down, by observing the hollow trunks and securing their tenants. The noise that this squirrel makes by night in the depths of old jungles, he states, is sometimes alarming to strangers.

Pteromys cineraceus, Blyth.

Pteromys petaurista, Walker, Cal. Journ. Nat. Hist. 1843, vol, iii. p. 266; Horsfield, Cat. Mamm. E. Ind. Co.'s Mus. 1851, p. 159 (in part).

Pteromys petaurista var. cineraceus, Blyth, Journ. As. Soc. Beng. 1847, vol. xvi. pt. ii. p. 865.

Pteromys cineraceus, Blyth, Journ. As. Soc. Beng. 1859, vol. xxviii. p. 276 ; ibid. vol. xliv. 1875, ext. No. p. 35 ; Cat. Mamm. As. Soc. Beng. 1863, p. 94.

This species is closely allied to $P$. oral, from which it is distinguished by the grey character of its fur, and its almost white, but black-tipped tail. In form it exactly resembles that species which it represents in Assam, Burma, and Tenasserim. Blyth describes it as differing from $P$. oral in the more predominating white tips to the hairs, which impart a hoary appearance to the whole upper surface, which is continued along the bushy tail to the blackish tip. The fur generally is an intermixture of pale greyish and brownish, the hairs of the back and head having a whitish sub-terminal band, whereas, on the tail, the pale greyish or hoary prevails, to the exclusion of the brown hairs. The upper surface of the parachute is reddishbrown and ungrizzled, if a few hairs are excepted which have a pale reddish-yellow sub-apical band. The under parts are pure white, or nearly so. The dimensions are the same as those of $P$. oral, Tickell, of which it will probably prove to be a local race.

In the India Museum, London, there are two examples of this flying squirrel, and in the Calcutta Museum there are two adults and a young specimen from

\footnotetext{
1 Journ. As. Soc. Beng. (1859), vol. xxviii. p. 287.
} 
Arracan and another adult from Tenasserim. The latter is unusually rufescent, and in its intermediate characters serves to connect the still more rufescent $P$. oral with $P$. cineraceus.

\section{* Pteronys yunnanensis, n. $\mathrm{s}$. Plate XXII.}

This is a large-headed flying squirrel belonging to the P. oral group, and apparently attains to larger size than any of its fellows.

It is a most richly coloured animal with fine, glossy, silky fur, the hair on the long black bushy tail being quite as fine in texture as the delicate covering of the body.

The general colour is a rich dark maroon-chestnut on all the upper parts, the head and back, in some, being finely speckled with white, which is most marked in the young, but is always most profuse on the posterior half of the back, which in some individuals has almost a hoary tinge from the extent to which the white annulation of the hairs is carried. In the adult, the upper surface of the parachute is of the same colour as the back, and the hairs are not annulated, except along its margin, but in younger specimens they are partially so on the upper surface, as are also the hairs on the first three or six inches of the tail, which are concolorous with the back, but broadly tipped with black, while the remaining portion of the tail is rich glossy black. The sides of the face, below the eye and ear, are yellowish-grey, mixed with chestnut, and the chin is dusky. The paws are rich black, also the margins of the limbs. The under surface is clad with a yellowish-white, rather woolly fur, which in some tends to a chestnut tint in the middle line, and to a darker tint of the same colour at the margin of the parachute.

The basal portion of the fur of the upper parts is a dark greyish-brown, the hairs at their base being wavy, then follows a palish chestnut band, succeeded by a dark maroon-chestnut, which either may or may not have a pure white sub-apical band, the tips of the hairs being glossy deep maroon-chestnut, in some, verging on black.

The ears are large and rounded, and very sparsely covered with black hairs externally, with chestnut-coloured hairs on the anterior, and black on the posterior half of the dorsal surface. The hairs on the outer side of the tarsus form a rather long and dense brush. The tail is moderately bushy.

As I succeeded in procuring only skins of this splendid squirrel, I cannot give any accurate dimensions, but the largest measures, from muzzle to root of tail, 24 inches; the length of the tail being the same.

The specimens were all obtained at Teng-yue-chow, but it is said to inhabit the forests of the Kananzan mountains to the east. 
Pteromys pectoralis, Swinhoe.

Pteromys pectoralis, Swinhoe, Proc. Zool. Soc. 1852, p. 61; Proc. Zool. Soc. Lond. 1870, p. 634 .

Swinhoe describes this flying squirrel, which I have not seen, as "general rich rufous; tail lighter with brown at tip; breast and streak down the centre of the belly white. Length from snout to root of tail 20 inches, tail 15 inches, soft and bushy. The red fur of the body is sparsely sprinkled with white hairs. The fur is soft, moderately long, and much in character with that of $P$. grandis; in some lights it shows very brown."

Confined to the southern mountains of Formosa.

This form is evidently closely allied to the foregoing species.

\section{Pteromys melanopterus, A. M.-Edwards.}

Pteromys melanopterus, A. M.-Edwards, Ann. des Sc. Nat. Zool. 5th ser. 1867, vol. viii. p. 375 ; Rech. des Mammif. 1868-74, p. 168, pl. xva, figs. 2, 2a, 26.

Pteromys wanthotis, A. M.-Edwards, Rech. des Mammif. 1868.74, p. 301.

This is a large species, of the dimensions of $P$. oral and $P$. albiventer, to the latter of which it is allied, as is evinced by the resemblance which the two forms have to each other before maturity. In its general colour it approaches more to $P$. cineraceus, Blyth, than to any other species. It is distinguished, however, from these and from all the south-eastern Asiatic flying squirrels by its densely clad tarsus - a character which A. M.-Edwards has not noticed in his description of this species nor of $P$. xanthipes, and which is also a character of $P$. leucogenys, all of which are northern forms.

The head in the type, below and anterior to the ears, is greyish tinged with brown, and there is a narrow brownish-yellow ring around the eyes. The back and the top of the head are covered with hairs which are leaden grey towards their bases, passing into yellowish, washed with brown in their sub-terminal part, then into a brilliant and clear greyish-white, frequently ending in a small black or deep brown point. A. M.-Edwards describes the general colour as "un gris jaune clair, presque argenté par plaques, sur lequel se détachent une multitude de petites touches d'un brun noirâtre." The upper surface of the parachute is almost wholly black, but some of the hairs are terminated by brilliant yellow points, whilst the border is well-defined greyish-white; on the under surface, it is entirely very clear yellow. The limbs are much like the back, and the feet are black. The belly is a clear greyish-ashy, less tinged with yellow than in $P$. oral. The tail is very bushy, and less brilliantly coloured than the back.

In the Paris Museum there is another example of this species which has been received since $\mathbf{A}$. M.-Edwards drew up his description. It is less grey than the type, and has the tail more brilliant yellow, washed with blackish. This specimen, 
which is more brown than grey, serves to connect the species with P. albiventer. Both of these flying squirrels are from Tcheli.

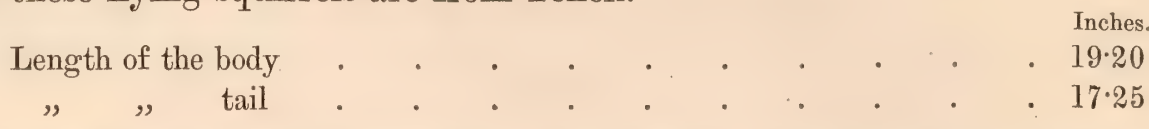

In the Leyden Museum there is a large grey squirrel, which seems to be a variety, or perhaps a seasonal (winter) phase of the species. Its history is not accurately known, but Prof. Schlegel informs me that it was received in a collection of animals, said to have been made in Tibet. The character of the fur, like that of the type, in its density, indicates that the animal must have been an inhabitant of a cold region, and its tarsus is thickly clad. Unlike any other Pteromys, except $P$. leucogenys, the ears are thickly clothed externally and internally with moderately long, rather woolly hairs, the external hairs projecting beyond the margin. The ears also are larger than in the generality of flying squirrels, and are triangular and pointed. The fur is extremely dense and soft, the long hairs measuring nearly 3 inches and the shorter hairs $1 \cdot 75$. The basal portion is deep slaty, succeeded by pale greyish-brown, followed by the exposed portion which is still paler and occasionally marked by white rings, narrowly tipped with blackish. These white rings confer a grizzled appearance on the pale fur. The general colour, including the tail, is pale greyish, all the upper surface, including the membranes, being grizzled with white. The muzzle and the hairs clothing the internal surface of the ears are pale yellowish, and those on the back of the ear pass into black at their tips. At the posterior border of the ear there is a whitish tuft. The fore and hind feet are brown, the hairs terminating in yellowish tips. 'The under parts are greyish, washed with yellowish on the under surface of the membrane. The tail unfortunately is imperfect, but it shows an obscure tendency to form alternate blackish and grey rings. Cheek-bristles fully developed. The specimen, which is male, measures 18.75 inches along the back, and the imperfect tail is 14 inches.

\section{Pteromys albordfus, A. M.-Edwards.}

Pteromys alborufus, A. M.-Edwards, Comptes Rend. 1870, vol. lxx. p. 341 ; Rech. des Mamm. 186874, p. 298, xlv.

This large and beautiful species, the type of which I have examined, has the head, the sides of the neck, the throat and upper part of the chest, variegated with white, through which the rich maroon of the ground colour is partially seen, and it forms a ring around the eye. The hinder part of the back is yellow, and the tail, immediately beyond its base, is also yellowish for a short way, fading into the deep maroon of its latter two-thirds. It has no black tip. The feet are concolorous with the body. The under parts are pale rich orange-yellow. The ears are large and moderately pointed.

Length of the body

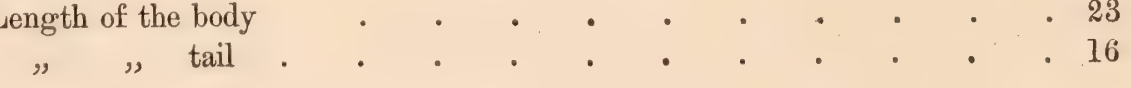


It is closely allied to $S$. nitidus.

A. M.-Edwards is inclined to interpret the difference of colour manifested by the head, back, and tail of this squirrel as probably due to a seasonal change.

This species is from the district of Moupin in Tibet.

\section{Pteromys magnificus, Hodgson.}

Pteromys magnificus, Hodgson, Journ. As. Soc. Beng. vol. v. 1836, p. 231; ibid. vol. x. 1841, p. 915; Cal. Journ. Nat. Hist. vol. iv. 1844, p. 293 ; Ogilby, Royle's Ill. Him. Bot. Mem. Mamm. 1840, p. 13; Gray, List Mamm. B. M. 1843, p. 134; Cat. Nepal Mamm. \&c. B. M. 1846, p. 22; Geoff. St.-Hilaire, Voy. aux Ind. Orient. Jacquemont Zool. 1844, p. 65; Blyth, Journ. As. Soc. Beng. vol. xvi. 1847, p. 866 ; ibid. vol. xxviii. 1859, p. 277 ; Cat. Mamm. As. Soc. Mus. 1863, p. 95 ; Horsfd. Cat. Mamm. E. Ind. Co.'s Mus. 1851, p. 161; Proc. Zool. Soc. 1856, p. 403 ; Jerdon, Mamm. Ind. 1867, p. 177.

Sciuropterus nitidus, Hodgson, Proc. Zool. Soc. vol. iv. 1835, p. 98.

Sciuropterus nobitis, Gray, Ann. and Mag. Nat. Hist. vol. x. 1842, p. 263 ; List Mamm. B. M. 1843, p. 134; Cat. Nepal Mamm. \&c., Hodgson's Coll. 1846, p. 22 ; Hodgson, Journ. As. Soc. Beng. vol. xiii. 1844, p. 67 ; Blyth, Journ. As. Soc. Beng. vol. xvi. 1847, p. 866 ; ibid. 1859, p. $27 \%$.

Sciuropterus chrysothryx, Hodgson, Journ. As. Soc. Beng. vol. xiii. 1844, p. 67, plate, fig. 1; Cal. Journ. Nat. Hist. vol. iv. 1844, p. 293.

Pteromys nobilis, Blyth, Journ. As. Soc. Beng. vol. xvi. 1847, p. 866 ; Horsfield, Cat. Mamm. E. Ind. Co.'s Mus. 1851, p. 160.

The typical specimens of $P$. magnificus, Hodg., $P$. nobilis, Gray, and $P$. chrysothryx, Hodg., are all squirrels equalling each other in size and found living together in the Himalayas. They present so many striking similarities and are so linked together by intermediate forms in the area of their distribution that little or no doubt can exist regarding their specific identity. There are no data, however, to guide us to the causation of these variations.

In a young specimen of $P$. magnificus, the characteristic golden dorsal line is well defined, whereas in an older individual it is absent, with the exception of two obscure pale diffused yellow patches, far separated from each other. In a specimen referred to $P$. nobilis the dorsal line is wholly wanting, while in others it is well defined. These specimens agree with each other in all other respects, so that the presence or absence of the dorsal line is a character of little importance on account of its variability. The back of the animal is rich lustrous dark maroon-chestnut, the hairs having black tips, and being finely but obscurely punctulated with dark orange. The body colour extends on to the upper surface of the neck and on to the head, but in the former of these localities the hairs are frequently broadly tipped with yellow, while many hairs on the forehead are also similarly marked, the hairs around the muzzle and eye being almost black. The ears are large, with the posterior margin nearly straight, and they are semi-nude, being only sparsely clad with pale red hairs on the external aspect, and with bright red hairs posteriorly, but the base of their upper surface is clad with long hairs. The sides of the face below the eye are yellowish. The upper surface of the 
parachute is yellow near the back, but orange-red towards its external margin. The yellow, which is brilliant, spreads forwards over the shoulders, so that the dark colour of the upper surface of the neck is much narrowed. This is a well-marked feature of this species, and is always more or less present. On the limbs and margin of the membrane, the colour is rich orange-red, and this colour is prolonged along the sides of the neck, below the yellow of that region. The tail is orangered, of variable intensity, tipped more or less broadly with black. The under parts are pale orange-fawn, or pale orange-red. The chin is blackish. In some specimens the hind feet are black, and the dark colour of the back extends more on to the sides than in others.

In a male referred by Hodgson to this species, there is no approach to the formation of a dorsal line, and the dark dorsal area and the head have the subapical bands to the hairs pure white, as in examples of $P$. oral, but the characteristic shoulder yellow is present. In this specimen there is no black on the chin, but its absence may also be remarked even in the most characteristic examples of the species.

In a very young individual, the dorsal line is absent, and the head and neck are concolorous with the body, also the upper surface of the parachute, which differs from the back in the absence of the black tips to the hairs. The tail at its base is concolorous with the back, but the remainder of it approaches to the yellow colour of the shoulder and collar, and the tip is nearly blackish-chestnut. The whole of the under surface of the body is pale yellowish-red. The lower half of the ear is yellowish, and its terminal half, dark chestnut-brown, approaching to black.

The body of the adult mences.

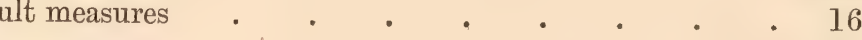

The skulls of $P$. magnificus and $P$.nobilis are identical, and they are closely allied to $P$. oral, the chief distinction between them and the latter being their shorter muzzles and the more elevated character of the interorbital depression.

The range of this species is not well ascertained; but it has been found in Nepal, Sikkim, and Assam.

\section{Pteromys albiventer, Gray.}

Pteromys albiventer, Gray and Hardwicke, Ill. In. Zool. 1834, vol. ii. No. 18 plate; Proc. Zool. Soc. Lond. 1836, p. 88; Charlesworth's Mag. Nat. Hist. new ser. vol. i. 1837; Hand-List Mamm. B. M. 1843, pp. 134, 584; Wagner, Beitr. zur Säugeth. Faun. von Kaschmir (Hugel), 1842, p. 573; Schreber, Süugeth. Suppl. vol. iii. 1843, p. 222 ; Blyth, Journ. As. Soc. Beng. 1847, vol. xvi. pt. ii. p. 865 ; Horsfield, Cat. Mamm. E. Ind. Co.'s Mus. 1851, p. 162.

Pteromys inornatus, Is. Geoff. St.-Hil. Descrip. Mamm. Voyage, Jaequemont, 184.2-43, p. 62, plate iv.; Wagner, Beitr. zur Säugeth. Faun. von Kaschmir (Hugel), 1842, p. 573; Schinz, Syn.

Mamm. vol. ii. 1845, p. 527; Blyth, Journ. As. Soc. Beng. 1859, vol. xxviii. pp. 277, 287 ;

Cat. Mamm. As. Soc. Mus. 1863, p. 95; Jerdon, Mamm. Ind. 1867, p. 176.

Pteromys petaurista, Müller und Schlegel, Verhandl. 1839-44, p. 106.

Pteromys magnificus, Sclater, Proc. Zool. Soc. 1872, p. 635, pl. 1. 
As remarked under $P$. caniceps, this species is closely allied to it,-so much so, that if the grey head and the apparently rather larger ears of the latter are omitted, one description would be equally applicable to both.

The fur has the same characters as in $P$. caniceps, in density, texture and colouring. The longer hairs have, as a rule, a sub-apical white band which can only be detected by careful observation, and they appear to be much more numerous than in $P$. caniceps. The general colour of the body and head is a reddish-bay, darker on the upper surface of the parachute and on the outside of the limbs. There is occasionally a dark-brown band over the nose, a similar area around the orbits, and at the base of the whiskers; and the feet are black in some, while in others they are the same colour as the legs. The cheeks are greyish.

Habitat.-Nepal, and the North-Western Himalaya to Kashmir.

In the Leyden Museum there is a large flying squirrel which was obtained by Dr. Jerdon in Kashmir and presented to the Museum by the Marquis of Tweedale. It is almost jet black on all the upper parts, but slightly brownish on the upper surface of the fore limbs and membrane. The cheeks are brownish. The only portions of the under parts that are not concolorous with the back are the chin, throat, chest and belly,-which are brownish. A line of grey extends along the middle of the belly. The tail is concolorous with the upper parts and is very bushy. This seems to be a melanoid variety of this species, equivalent to the like varieties which occur in the genus Sciurus, e. g., in S. palmarum and S. lokroides.

A writer in the Indian Sporting Review ${ }^{1}$ mentions that flying squirrels are numerous in the forests about Wurdán, in Kashmir, and that they live on the tops of the dead fir trees, where they make a hole in the bark and hollow out a nest for themselves inside. On scraping the bottom of the tree with a stick, the squirrel pops out its head like an owl.

I have examined the types of $P$. inornatus, Is. Geoff., and do not find that $P$. albiventer, Gray, differs from it in any respect. It is a half-grown example.

\section{Pteromys caniceps, Gray.}

Sciuropterus caniceps, Gray, Ann. and Mag. Nat. Hist. vol. x. 1842, p. 262 ; Hand List Mamm. B. M. 1843, p. 135; Hodgson, Journ. As. Soc. Beng. vol. xiii. 1844, p. 67; Blyth, ibid. vol. xvi. 1847, p. 866 ; ibid. vol. xx. 1851, p. 165; ibid. vol. xxviii. 1859, p. 278; Cat. Mamm. As. Soc. Mus. 1863, p. 96 ; Jerdon, Mamm. Ind. 1867, p. 178.

Pleromys caniceps, Gray, Cat. Nepal Mamm. B. M. Hodg. Coll. 1846, p. 21; Schinz, Syn. Mamm. 1845, vol. ii. p. 57 ; Horsfield, Cat. Mamm. E. Ind. Co.'s Mus. 1851, p. 160; Proc. Zool. Soc. 1856, p. 402 .

Sciuropterus senex, Hodgson, Cal. Journ. Nat. Hist. 1844, vol. iv. p. 293; Journ. As. Soc. Beng. vol. xiii. 1844, p. 68, plate fig. 2 ; ibid. vol. xvi. 1847, p. 866.

This species is closely allied to $P$. albiventer,-so much so, that at first I was inclined to regard them as one species, and to consider the grey head of this form as

\footnotetext{
${ }^{1}$ New Series, vol。 i. p. 35.
} 
a variation depending on a perpetuation, so to speak, of a character of youth. This supposition is favoured by the circumstance that the majority of flying squirrels referable to $P$. caniceps which have come under my observation have been young, and by the additional fact that there are, as it were, intermediate forms between it and $P$. albiventer in which the head is greyer than it generally is in the latter species, which is, as a rule, more or less distinguished by a certain amount of grey about the cheeks. But on a more critical examination of $P$. caniceps, it appears to me, judging from Hodgson's types of the species, that it has larger ears, and if this should prove to be a persistent character, then the grey head and the chestnut speck above and below the eye and the bright chestnut tuft behind the ears assume a specific importance which they would not otherwise have. But there is no description from life, or comparison of the ears of these two supposed species, and as my observation is founded on the stuffed specimens in the National Collection, I do not attach any great importance to it, but only mention it that it may be proved or disproved by naturalists who have the opportunity to examine the two forms in life. As the materials at present at our disposal are insufficient either to establish or disprove the existence of these two species, I tentatively accept each.

The animal is as large as $P$. magnificus, but the fur is much softer and denser than in that species and rather longer. It is about one inch and three quarters long, and in the first inch of its length it is slaty-grey and wavy; it then passes for about two-tenths of its length into brown, and then into reddish-bay, each hair generally ending in a narrow, dark-brown tip. Longer hairs are profusely scattered through the fur, and in these the slaty base passes into black instead of brown, and some of them have a sub-apical white band. The general colour of the upper parts is thus a rich reddish-bay, which is very glossy in reflected lights, and rather redder on the outside of the legs. The head is iron-grey, with longer black interspersed hairs, and the cheeks also are greyish; above and below the eye there is either a rich orange-brown spot, or a ring of that colour encircling that organ; and a similarly coloured tuft of hairs, but brighter, occurs at the base of the ears, behind their posterior angle. On the outer half of the membrane, the dark-brown tips to the hairs all but disappear, and the red-bay band increases in breadth and intensity, becoming rich orange-red on the margin of the parachute. The feet are also orangered. The tail is bushy and only very faintly distichous. It is greyish at its base, succeeded by dusky orange, followed by a broad black band which is generally terminal, yet not unfrequently tipped with rusty brown. The orange is paler in the young, but more prevalent. The chin is generally blackish, and the throat is whitish, and all the under parts reddish or rather decided orange-red.

The body measures . . . . . 14 inches, according to Hodgson.

And the tail . . . . . 15 " " ,

Gray's specimen was young, the body being only 9 inches and the tail $8 \frac{1}{2}$ inches.

The skull has a less expanded interorbital region then $P$. magnificus, and a rather longer and narrower muzzle. The frontal depression is much deeper in some than 
in others. The teeth in young individuals are rather strongly tubercular, but they gradually become worn with use and the tubercular character disappears, which is a generic character.

This flying squirrel has been found in Nepal and the neighbouring region of Sikkim.

Pteronys Leucogenys, Temminck.

Pteromys lencogenys, Temminck, Monogr. Mamm. Tab. Method. vol. i. 1827, p. 27; Temm. and Schlegel, Fauna Japonica, Mamm. 1847, p. 46, tab. xiii. ; Is. Geoff. St.-Hil. Dict. Class. vol. xiv. 1828, p. 131; Schinz, Syn. Mamm. 1845, vol. ii. p. 527.

This is a large squirrel with a rather shorter tail than the generality of the allied forms $P$. caniceps and $P$. oral, to which it is closely allied:

The fur is very soft and long, and the basal two-thirds of the hairs are slate or mouse coloured, passing into pale brownish-yellow in the lower portion of the terminal third, then into brownish, which is followed by a broad pale yellow band which is tipped with dark brown. These yellow bands are not so prevalent as to hide the underlying dark-brown and greyish, except on the anterior half of the body, which is pale yellow-brown, the hinder half having a grizzled appearance on a brownish slaty background. The head is concolorous with the front upper parts, but much more finely grizzled, and passes into pale violet-grey between the eyes, and on the upper surface of the nose. From the nose to the eye, and around and below the latter, the hair is dark rusty-brown. The upper lip and the area in front of and below the ear are pale violet-grey. The chin is dark brown. The under parts are pure snow-white, densely clad with fine fur, the white passing into orange on the under surface of the membrane. The inside of the front limb is brownish-black in its posterior half and orange-white anteriorly. An orange line runs from the front margin of the fore limb, bordering the white under parts, to the chin. The upper surface of the limbs is blackish-brown. The ears are clad with long hairs, and the whiskers or cheek-bristles are feeble. The tail is bushy and brownish-black, and the hairs slaty at the base, then yellowish-brown succeeded by the broad dark-brown tips, many of these near their extremities being broadly banded with yellowish. The greater part of the tarsus of this species, as in $P$. melanopterus and $P$. xanthipes, is densely clad.

The skull has a rather long and narrow muzzle, and it is very like the skull of $P$. caniceps.

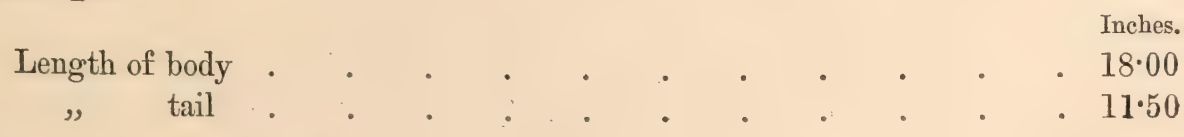

This species inhabits Japan. 


\section{Pteromys elegans, Temminck.}

Pteromys elegans, Temm. Coup d'œil, Faune des îles de la Sonde et de l'empire du Japon. Introduction, Faun. du Japon. 1836, p. xii. ; Müller und Schlegel, Verhandl. Natur. Gesch. 1839-44, pp. 107, 112, tab. 16, figs. 1 (skull), 2, 3 ; Is. Geoff. St.-Hil. Mamm. Voy. Jacquemont, 1842-43, p. 65 ; Wagner, Schreber, Säugeth. Suppl. vol. iii. 1843, p. 223 ; Blyth, Journ. As. Soc. Beng. vol. xvi. 1847, p. 865 ; itid. vol. xxviii. 1859, p. 277 ; Schinz, Syn. Mamm. vol. ii. 1845, p. 52 ; Giebel, Odontogr. p. 45, tab. 20, fig. 7 ; Säugeth. vol. ii. p. 641.

Pteromys punctatus, Gray, Ann. and Mag. Nat. Hist. vol. xviii. 1846, p. 211 ; Blyth, Journ. As. Soc. Beng. vol. xxviii. 1859, p. 277.

This flying squirrel was incidentally described by Temminck in his Introduction to the Fauna Japonica, and had been overlooked by naturalists until Is. Geoff. St.-Hilaire directed attention to it. It was discovered in the Island of Nusa Kambang, and when Temminck wrote was unknown in the Island of Java, but I now observe a number of specimens in the Leyden Museum marked as coming from the latter island.

It resembles $P$. nitidus in size and proportions, but is distinguished from it by the dorsal region, from the vertex to the root of the tail, and the sides, excluding the wing-membrane, being a mixture of greyish and blackish-purple, depending on the presence of a multitude of almost white hairs which are either generally interspersed among the dark hairs, or grouped together in spots. When these whitish or grey hairs are arranged in groups the animals constitute the $P$. punctatus, Gray. The parts surrounding the dorsal region are deep rich maroon-chestnut, as are also the fore limbs, thighs, and rump. The grey hairs frequently extend as spots on to the vertex, while in others they stop short on the nape, but the blackish-purple of the back, as a rule, which forms the ground colour, occasionally passes into chestnut on the front part of the head, the bases of the hair being a pale violet-grey, the sides of the face before and below the ears being also of the same colour, and, underneath the eye, the hairs are tipped with rich chestnut. The under parts are pale, but rich rufous-chestnut, darker on the under surface of the limbs and on the external half of the parachute. The base of the tail is somewhat contracted and is dusky chestnut, passing into black throughout the rest of its extent. The bushy, erect hairs that clothe the outer portion of the tarsus are pale violet-grey in some, and the carpal cartilage is bordered by the same colour. The ears are moderately large, and longer than broad, diminishing towards the tip and terminating in a rounded point. Their insides are clad with moderately long, but so very fine hairs, that they have a semi-nude appearance. Their outsides are covered with a few small hairs which become more numerous on the fore margin. The under surface of the fore feet, with the exception of the two proximal pads, is bald, while on the sole of the hind foot the bare area is narrowed posteriorly. The hair around the eyes is generally black, and there are some small irregular spots on the toes, especially on the hind feet, but frequently the feet are altogether black. smaller.

The skull of the species differs only from that of S. nitidus in being somewhat 
The species occurs in Nusa Kambang, Java, and Malacca, and from the last of these localities was obtained that spotted example which was described by Dr. Gray as $P$. punctatus. I have examined both types. This species measures-

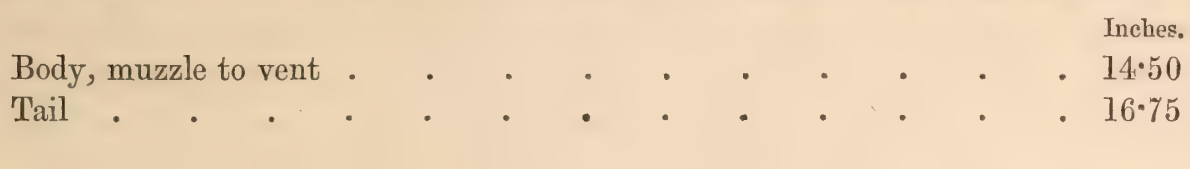

\section{Pteromys nitidus, Desmarest.}

Sciums petaurista, Pallas (

The Sailing Squirrel, Pennant, Quad. (in part); 1781, 3rd ed. vol. ii. p. 151, No. 349.

L' Ecureuil éclant, Is. Geoff. St.-Hil. Coll. Mus. d'Hist. Nat.

Pteromys nitidus, Desmarest, Nouv. Dict, d'Hist. Nat. vol. xxvii. 1818, p. 403; Lesson, Man. de Mamm. 1827, p. 241; Is. Geoff. St.-Hil. Dict. Class. 1828, vol. xiv. p. 131 ; Voy. dans l'Inde, Jacquemont Zool. 1844, p. 65; Desmarest, Mamm. 1820, p. 342; Fischer, Syn. Mamm. 1829, p. 363 ; Gray, Charlesworth's Mag. Nat. Hist. (new series), vol. i. 1837, p. 584; List Mamm. B. M. 1843, p. 134; Müller und Schlegel, Verhandl. 1839-44, pp. 107 \& 112; Schreb. Säugeth. Wagner, Suppl. vol. iv. 1843, p. 221, pl. 224c ; Schinz, Syn. Mamm. vol. ii. 1845, p. 50 ; Blyth, Journ. As. Soc. Beng. vol. xvi. 1847, p. 866 ; ibid. 1859, vol. xxviii. p. 277 ; Cat. Mamm. As. Soc. Beng. Mus. 1863, p. 96 ; Brandt, Mem. Acad. St. Petersb. 6th ser. vol. vii. 1850, p. 298 ; Zelebor, Säugeth. Novara, 1868, p. 25 ; Horsfield, Cat. Mamm. E. Ind. Co.'s Mus. 1851, p. 162.

Pteromys grandis, Swinhoe, Proc. Zool. Soc. 1862, p. 358, pl. xlv.; ibid. 1870, p. 634.

The colour of this animal may be described as a deep rich maroon-chestnut, inclining to black on the upper parts, the hairs being black-tipped on the back. On the base of the tail, which is bushy, the black tips are longer, and the chestnut portion of the hair becomes an obscure blackish chestnut, so that the tail, throughout by far the greater part of its length, is black, from the prevalence of the black tips and the dark underlying colour. The feet are concolorous with the body which presents no trace of grizzling. The under parts are rich red-chestnut, liable, however, to become paler, and the chin is blackish.

I have compared Swinhoe's examples of $P$. grandis with a Javan example of this species, and I cannot detect any external character by which to distinguish the one from the other, and a specimen of $P$. nitidus from Java in the Paris Museum might stand as $P$. grandis, as the tail, instead of being black-tipped as in the generality of specimens of $P$. nitidus, is nearly wholly black, as in $P$. grandis.

The skull of the type of $P$. grandis is in the British Museum, and is not quite so large as the skull figured by Brandt, than which it has less occipital and zygomatic breadth, being at the same time an altogether smaller skull, but it has the same broad muzzle as $P$. nitidus, and the other differences are so slight that they do not suffice to separate the Formosan from the Javan animal, more especially when the identity of their peripheral characters are taken into consideration. Moreover, a skull of $P$.nitidus in the National Collection, from Sumatra, agrees with Brandt's figure in every respect, while another and smaller skull from the same locality differs from the figure in question in the same way that the skull of $P$. grandis does. 
The probability, therefore, is that this latter skull from Sumatra is a female, and the former a male, because the first of these is identical with the skull of $P$. grandis, which is known beyond all doubt to belong to the female sex. Swinhoe observes that the young is darker than the adult, with more black, especially about the head, feet, and tail. The latter, as in all young Pteromys, has the hairs laterally adpressed and parted down the mesial line, above and below. The pupil, the same observer states, to be round and not linear, and the animal is nocturnal in its habits.

Its voice is in marked contrast to that of $P$. oral, its soft whistle being heard at the approach of twilight.

The length of the sucking young is, body 6.75 inches, and tail 6.20 : the adult animal is 2 feet long, and its tail is the same length.

Pennant describes the colour of the head, body, and tail to be bright bay, in some parts inclining to orange; breast and belly of a yellowish-white; the tail being covered with long hairs disposed horizontally. Length from muzzle to tail 18 inches, tail 15 inches. He states that it inhabits Java.

This species would therefore appear to have a wide range, being distributed over the Malayan peninsula, Sumatra, Java, Formosa, and Borneo.

In the Leyden Museum there is a large flying squirrel from Borneo, which appears to be a variety of this species. It is intermediate in its characters between $P$. nitidus and $P$. melanotis, but unlike the latter, to the colour of which it has a general resemblance, it has no black points.

The upper parts are rich ferruginous brown, finely grizzled with white on the back, from the shoulders downwards, but not on the parachute. The cheeks and feet are concolorous with the back, but the tail is darker, passing into a dark reddishbrown. The under parts are pale white, more or less washed with reddish. The cheek-bristles are well developed, and the tail is not bushy. The specimen is a female, and the body measures 14.40 , and the tail 15 inches.

\section{Pteromys melanotis, Gray.}

Pteromys melanotis, Gray, Proc. Zool. Soc. 1836, p. 88; Charlesworth's Mag. Nat. Hist. (new series), vol. i. 1837, p. 584; Hand-List Mamm. B. M. 1843, p. 1341' Horsfield, Cat. Mamm. E. Ind. Co.'s Mus. 1851, p. 162 ; Blyth, Journ. As. Soc. Beng. vol. xxviii. 1859, p. 277.

Pteromys nitidus, Gray, Gray and Hardw. Ill. Ind. Zool. vol. ii. 1834, pl. xvii. ; Cantor, Journ. As. Soc. Beng. vol. xv. 1846, p. 252.

Pteromys melanopis, Motley and Dillwyn, Contrib. Nat. Hist. Labuan and Borneo, 1855, p. 2.

This is a large flying squirrel with a relatively smaller head than $P$. oral and its Himalayan allies, $P$. magnificus, $P$. albiventer, and $P$. caniceps.

All the upper surface of the trunk is bright rich reddish-bay, paling to yellowish on the tail, but especially brilliant behind the ears, which are sharply pointed, and their posterior margins below the tip are concave. On the head the

${ }_{1}$ Dr. Gray mentions $P$. diardii, Temm., as a synonym of this species, but $\mathrm{I}$ have sought in vain for any other reference to such a name. 
reddish-bay fades into pale yellowish. There is a blackish area over the nose, another around the eyes, while the moustachial region is brownish. The feet and a line along one-half of the carpal cartilage, and a portion of the anterior border of the limb, and the tip of the tail, are black. Cheek-bristles are present. The chin is dark blackish-brown, and the front part of the throat and all the under parts are rich rufous yellowish, most intense on the mesial line, on the inside of the limbs and on the outer half of the parachute which is rich red. The tail is not very bushy, and apparently tends to become distichous. The body, in the Museum specimen, measures $21 \cdot 75$ inches, and the tail $14 \cdot 75$ inches, without the terminal hair.

The skull has a short muzzle, rather broader and shorter than in the other species. The molars are strongly tubercular, and the incisors rather narrow.

Dr. Gray at first assigned this animal to Nepal, but afterwards, in his List of Mammalia published in 1834, correctly referred it to Java. It occurs also in Borneo and Malacca, and in the latter locality is known as the "Tupai Terbang." Finlayson or Crawford's Mission to Cochin China obtained it in Siam.

One of Cantor's specimens from Malacca is in the India Museum, London, with his own label attached to it as $P$. nitidus, and he mentions that the part of the head anterior to the ears, the cheeks, chest and abdomen are white in some individuals of either sex.

The figure in Gray and Hardwicke's illustrations does not represent the Javan animal $P$. nitidus which has not a pale-coloured yellow head with a black ring around the eye, and black paws, the tail being lighter coloured than the body; these, however, are the characters of $P$. melanotis. The animal figured appears either to have had no black tip to its tail, or to have lost that portion.

\section{* Pteromys pearsonit, Gray. Plate XXIII.}

Pteromys pearsonii, Gray, Ann. and Mag. Nat. Hist. vol. x. 1842, p. 262; Schinz, Syn. Mamm. vol. ii. 1844, p. 57 ; Horsfd. Cat. Mamm. E. Ind. Co.'s Mus. 1851, p. 162.

Pteromys sagitta, Walker, Cal. Journ. Nat. Hist. vol, ii. 1843, p. 266.

Pteromys (Sciuropterus) setosus, Temm. Faun. Japon. Mamm. 1847, p. 49.

Sciuropterns villosus, Blyth, Journ. As. Soc. Beng. 1847, vol. xvi. pt. ii. p. 866 ; ibid. vol. xxxii. 1863, p. 96 ; Cat. Mamm. As. Soc. Mus. Beng. 1863, p. 96 ; Jerdon's Mamm. 1867 p. 179.

Sciuroptera villosa, Blyth, vol. xxviii. 1859, p. 278.

Sciuroptemes kaleensis, Swinhoe, Proc. Zool. Soc. 1862, p. 359 ; ibid. 1870, p. 634.

I have examined the type of $P$. pearsonii in the Indian Museum, also the type of $P$.villosus, Blyth, and of $P$. kaleensis, Swinhoe; and two skins from Teng-yue-chow in Yunnan exactly agree with $P$. pearsonii and $P$. villosus. This species is a small flying squirrel about the size of $P$. alboniger, but considerably more rufous than that species, and at once distinguished from it and $P$. fimbriatus by the long hairs that clothe the base of the ears, and from $P$. genibarbis by the absence of the postocular vibrissæ. The upper surface of the head, and the back are rich glossy reddish-brown, finely grizzled with black; the parachute being blackish-brown, faintly and sparsely washed with reddish-brown. The fur is very fine, soft and 
rather long; but adpressed, and the hidden portion is almost black, narrowly tipped with the reddish-brown, the sides of the hair being blackish-brown. On the parachute, only a few hairs have the reddish band, and these are most numerous towards the margin. The tail is rather bushy and but slightly distichous, and the hidden portion of its fur is pale fawn at the base, passing into pale chestnut-brown, washed with dusky-brown on the sides and upper surface. The margins of the eyelids are dark brown, and the sides of the face are pale rufous. The ears are moderately large and rounded, rather dark brown towards the tips, and pencilled at the base, anteriorly and posteriorly, with long delicate hairs. There are no true cheek-bristles, but the moustachial hairs are very long. The under surface is pale ferruginous, palest on the mesial line, and most rufescent on the outer half of the membrane, the margin of which inferiorly is pale-yellowish. The hairs on the membrane have dark slaty, almost black bases, the ferruginous being confined to the tips. The fur of the under parts is very soft and dense. The feet are well clad, more especially those of the hind limbs. The tail is half the length of the body which attains to about 8 inches. It is distinguished from $P$. alboniger by its more rufescent colouring and by the pencilling of its ears.

It occurs in Sikkim and Upper Assam, from whence Blyth first obtained it. Mr. Bonynage, who presented the typical specimens to the Asiatic Society of Bengal, also gave one to Mr. Walker, who referred it to $P$. sagitta. As already stated, I obtained two specimens of this species at Teng-yue-chow.

The type of $P$. kaleensis, Swinhoe, from Formosa is in the British Museum, and it agrees exactly in its colour and in the pencilling of its ears with this species, of which I believe it to be an example.

Dr. Gray described this flying squirrel as about one-third smaller in length and breadth than $P$. caniceps, of which he was at first inclined to regard it as the young, but he afterwards states that the bones of the typical specimen show no indication of youth. The type was procured at Darjeeling. Temminck also lays stress on the fine silky tufts at the base of the ears, by which he states it is distinguished from its congeners. He procured it in the Island of Sumatra.

I have examined the type of $P$. setosus, which agrees with $P$. pearsonii in the absence of cheek-bristles and in its general characters, but the specimen is not fully grown, measuring only, along the back to the root of the tail, $4 \cdot 75$, and the tail $3 \cdot 75$. It is less rufescent than the adult, and the under parts are whiter, as are also the cheeks.

\section{Pteromys fuscocapillus, Jerdon.}

Sciuropterus fuscocapillus, Jerdon, Blyth, Journ. As. Soc. Beng. vol. xvi. 1847, p. 867; ibid. vol. xxviii. 1859, p. 278 ; Cat. Mamm. As. Soc. Mus. Beng. 1863, p. 96.

Sciuropterus layardii, Kelaart, Blyth, Journ. As. Soc. Beng. vol. xx. 1851, p. 165 ; ibid. vol. xxviii. 1859, p. 278 ; Kelaart, Prod. Fauna Zeylanica, 1852, p. 56.

This is a medium-sized squirrel, about the dimensions of $P$. fimbriatus. It has a long pencil of blackish hairs at the base of the posterior margin of the ear 
and at the external surface of the upper angle. The cheek-bristles are well developed. The ears are moderately large, but not broad, and with their posterior borders slightly concave and the tip rounded. Around the eyes is blackish, and before the ears yellowish-grey, and the cheeks are white, washed with yellowish. The fur generally is very soft and dense, and two-thirds of its base is dusky ashy, the remainder being reddish-brown with a black tip. On the vertex, the sub-apical brown is paler than on the rest of the body, and the parachute is dark brown above, washed with pale brown and having a pale yellowish edge. The under surface of the membrane is very sparsely covered with fine, white hairs, and the lower parts of the animal and inside of the limbs are white, washed with yellowish. The feet are pale yellowish-brown. The tail is very bushy, and not distichous in the adult, but Blyth mentions that it is so in the young, but not markedly so. It is sometimes yellowish-brown, passing in others into dusky brown, especially on its latter half, the mesial line being dark brown. Its under surface at the base is pale brown, passing into blackish-brown beyond.

This species was originally described by Blyth from a half-grown specimen in rather abraded pelage, and the condition of the type led him to apply to it a not very appropriate name.

The skull reveals the species to be allied to $P$. phaomelas, and this not only in size and form, but in the character of its teeth, which present to a slight extent the ridging which distinguishes the teeth of that species. It differs, however, from it in many important characters, and the two forms constitute two well-defined species. On the other hand, it is more nearly related in its external characters to $P$. fimbriatus, from which, however, it is recognised by its pencilling of the ears at their bases; while from $P$. villosus, which also presents this latter character and is a closely affined species, it is distinguished by its larger size, bushy tail, and much less vivid colouring.

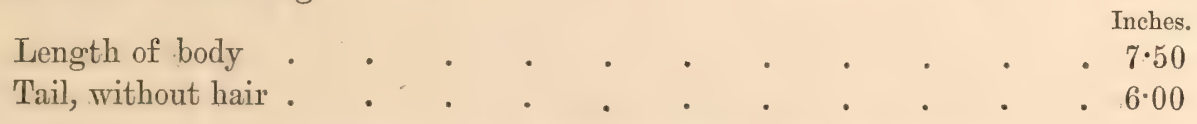

This species occurs in the Nilgiris, Southern India, and Ceylon.

\section{Pteromis xanthipes, A. M.-Edw.}

Pteromys : ranthipes, A. M.-Edw. Ann. des Sc. Nat. Zool. 5th ser. 1867, vol. viii. p. 375 ; Rech. des Mammif. p. 171, pl. xiv. et pl. xva figs. 3, $3 a, 3 b$.

This is a squirrel about the size of $P$. fimbriatus, and, like $P$. fuscocapillus and $P$. pearsonii, it has a long pencil of fine hairs before and below the ears, and its tarsus is clad as in $P$. melanopterus.

In colour it is rufous, almost orange-brown, which is most intense on the limbs, on the middle of the back, on the front of the face, and on the cheeks. The hairs of the back and occiput are terminated more or less by yellow points which rest on a basal ground of slaty. The area around the eyes and the muzzle is brown, 
and the moustache is long and black. The external surface of the fore limbs is brilliant yellowish-fawn, which hardly exists on the feet. The tail is long, and very bushy and grey washed with fawn. The under surface of the parachute is pale ferruginous, and a trace of this colour is mixed with the grey of the abdomen and neck.

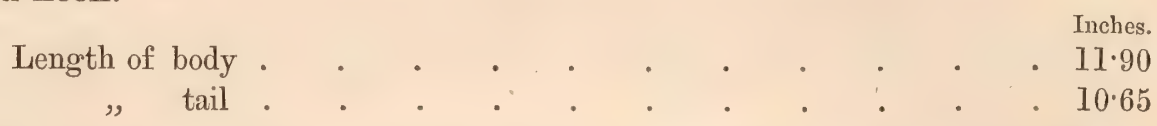

The face and interorbital space are relatively narrow and flattened, and the palate is prolonged a considerable way backwards.

This species inhabits the mountains of Tcheli.

\section{Pteromys fimbriatus, Gray.}

Sciuropterus fimbriatus, Gray, Charlesworth's Mag. Nat. Hist. vol. i. 1837 (new. ser.), p. 584; Proc. Zool. Soc. 1837, p. 67; List Mamm. B. M. 1843, p. 135; Blyth, Journ. As. Soc. Beng. 1847, vol. xvi. p. 866 ; ibid. 1859, vol. xxviii. p. 278 ; Cat. Mamm. As. Soc. Beng. Mamm. p. 96 ; Horsfield, Cat. Mamm. E. Ind. Co.'s Mus. 1851, p. 163; Jerdon, Mamm. of Ind. 1867, p. 178.

Pteromys fimbriatus, Wagner, Schreber, Säugeth. vol. iii. Suppl. 1843, p. 224; Schinz, Syn. Mamm. vol. ii. 1845 , p. 55.

Sciuropterus leachii, Gray, Proc. Zool. Soc. Lond. 1836, p. 88 ; Charlesworth's Mag. Nat. Hist. vol. i. New Ser. 1837, p. 584.

Pteromys leachii, Wagner, Schreber, Säugeth. vol. iii. Suppl. 1843, p. 222.

This species is very closely allied to $P$. alboniger, which it resembles in its colouring, but from which it, is separated by its much larger ears and feet. The posterior margin of the ear is nearly straight, whereas the ears of $P$. alboniger are rather narrowly oval, and rounded anteriorly and posteriorly. The cheek-bristles are feebly developed in both species. The tail of $P$. fimbriatus is very bushy, and nearly as long as the body, while in $P$. alboniger it is more or less distichous, and not so bushy and long. P. fimbriatus is the North-Western Fimalayan species, and $P$. alboniger its eastern representative.

The fur is long, soft and grey varied with black, and sometimes the upper parts have a brown instead of a greyish tinge. The hairs are all grey towards the base, brownish towards their free extremities, and generally black-tipped. The face is whitish, and the orbits are dark brown, which is the colour of the membrane. The whiskers are very long and black. The chin and under parts are white. The tail is broad, rather tapering and bushy, more or less fulvous, washed with black, and becoming more or less black towards its tip. The feet are broad, and Dr. Gray states that the outer edge of the hind feet has a broad fringe of hair, but it seems to me that this character is unreliable.

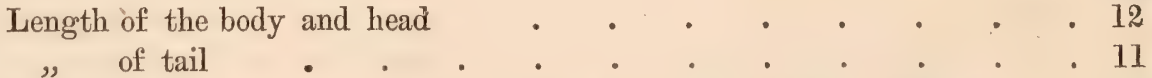

This species has been obtained in the North-Western Himalaya. 
Pteromys baberi, Blyth.

Sciuroptera baberi, Blyth, Journ. As. Soc. Beng. 1847, vol. xxvi. p. 866 ; ibid. vol. xviii. 1859, p. 278 .

This species is founded on a drawing of Sir Alex. Burnes' representing the Moosh-i-baldar of the mountainous districts of Nijrow, "and identified by him as the flying fox of the translation of Baber's Memoirs." Blyth states that the upper parts are pale, fulvescent, ashy brown, darker on the limbs; tail broad and bushy, and tipped with blackish; under parts, dull white, with a ferruginous margin to the membrane underneath. Blyth's reason for not identifying this figure with $P$. fimbriatus was because the animal was said to be $\mathbf{2}$ feet long, whereas he could not conceive of $P$. fimbriatus ever exceeding 19 inches.

\section{Pteromys pulverulentus, Günther.}

Sciuropterus pulverulentus, Gthr. Proc. Zool. Soc. Lond. 1873, p. 413, pl. xxxviii.

This is a small species, brownish-black, with many of the hairs grizzled with yellowish, due to the presence of sub-apical yellowish bands, as the tips of the hairs are black. The basal two-thirds of the fur are greyish, passing gradually into brownish-black, which is succeeded by the yellowish ring, ending in the black tips. This grizzling extends on to the parachute, but not to the same degree as on the body and head. The grizzling of the feet is carried to such an extent that they are light brownish. The under parts are yellowish-white, the yellowish being more marked on the mesial line, and on the scrotum and anal region, which are slightly orange. The sides of the belly and the under surface of the parachute are pale yellowish-brown, the inside of the limbs being more yellowish-orange. The undersurface of the margin of the membrane is pale yellowish-grey. The tail is distichous and bushy, the fur at its base being shorter than on the remainder, and it is pale greyish-brown, the hairs being blackish at the tips. The line above and the line below are brownish-black, and their hairs have sub-apical blackish bands. The under surface of the base of the tail is concolorous with the area around the vent.

Cheek-bristles are not observable. The ears are short and pointed, and covered behind with short black hairs. The incisors are pale yellow.

$$
\begin{aligned}
& \text { Length of body from muzzle to root of tail . . . . . . } 10
\end{aligned}
$$

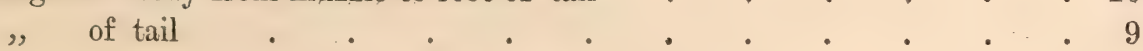

This species has been received from Pinang and Malacca. 


\section{* Pteromys alboniger, ${ }^{1}$ Hodgson.}

Sciuropterus alboniger, Hodgson, Journ. As. Soc. Beng. vol. v. 1836, p. 231; Cal. Journ. Nat. Hist. vol. iv. 1844, p. 293; Proc. Zool. Soc. 1856, p. 403; Ogilby, Royle's Ill. Himal. Bot. Mem. Mamm. 1840, p. 13 ; Gray, Hand List Mamm. B.M. 1843, p. 135; Cat. Nepal Mamm. Hodg. Coll. 1846, p. 22 ; Blyth, Jouin. As. Soc. Beng. 1847, vol. xvi. p. 866 ; ibid. 1859, vol. xxviii. p. 278 ; Cat. Mamm. As. Soc. Mus. 1863, p. 97 ; Horsfield, Cat. Mamm. E. Ind. Co.'s Mus. 1851, p. 163 ; Proc. Zool. Soc. 18£6, p. 403 ; Jerdon, Mamm. Ind. 1867, p. 179.

Sciuroptera turnbullii, Gray, Proc. Zool. Soc. 1837, p. 68; Blyth, Journ. As. Soc. 1847, vol. xvi. p. 866. Pteromys turnbullii, Gray, Charlesworth's Mag. Nat. Hist. (new series), vol. i. 1837, p. 584; Wagner, Schreber, Säugeth. Suppl. vol. iii. 1843, p. 224; Schinz, Syn. Mamm. vol. ii. 1845, p. 56.

I obtained skins of this species at Teng-yue-chow. It was first described from Nepal. The name applied to the species is not appropriate, as many individuals have the upper parts more or less yellowish-brown. The types are in the British Museum. The smallest is pale brownish-grey on all the upper parts and tail, and the parachute is dark rich brown on its outer half. The fur is soft, dense and moderately long, slaty grey at its base, then narrowly brown, followed by a pale-yellow band which is generally terminal, but in some the hairs are tipped with brown. Cheekbristles are present, but feeble. The tail presents no banding, and is pale dusky yellowish-brown, and in some specimens, it is more bushy than in others, and in this respect more resembles the tail of $P$. fimbriatus. The teeth both in this species and in $P$. fimbriatus are bright orange-red, and the molars are tuberculated, but not more so than in $P$. magnificus, $P$. caniceps, and $P$. leucogenys.

In the young, the base of the fur is nearly black, and the dark area around the eye is very well defined. The tail is nearly black and more distichous than in the adult.

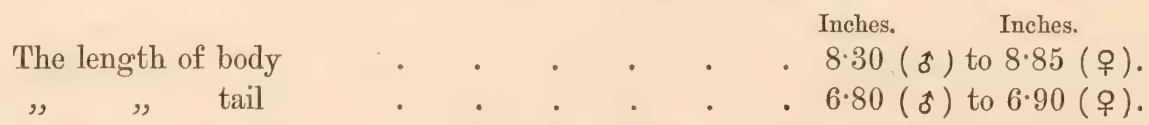

This species has been found in Nepal, Sikkim, Bhutan, Assam, Sylhet, Burma, Western Yunnan, and Cambodja.

\section{Pteromys Pheomelas, Günther.}

Pteromys phcomelas, Günther, Proc. Zool. Soc. Lond. 1873, p. 413.

This species is from Borneo. It is a small, brownish-black, flying squirrel with a very glossy back. The hairs on the hinder half of the back have a narrow, sub-

${ }_{1}$ There is a small flying squirrel in the British Museum which $\mathrm{I}$ have not been able to identify. It is from the Laos Mountains (Mouhot), and appears to be closely allied to $P$. alboniger. It is pale greyish-brown above, darker on the limbs and parachute which are grizzled, the feet being nearly white. The tail at its base is nearly the same colour as the back, but the remainder is as dark as the limbs, but ungrizzled, passing nearly into black; its under surface being greyish-brown. The under parts of the body are thickly clad with yellowish-white fur. The length of the body is 7 inches and the tail without the hair 5 inches. There are two small cheek-bristles, and the hind feet are whitish. The ears are smaller than those of $P$. alboniger, and the hinder margin is not so rounded. This is probably the flying squirrel referred by Gray to $P$. momonga,-vide Proc. Zool. Soc. 1861, p. 137. 
terminal grey or white band which produces a very obscure, but minutely punctulated appearance to the fur. The upper surface of the parachute is less glossy, and the hairs have no pale bands. The under surface is sparsely clad with woolly chestnut-brown fur; the throat, the centre of the belly and the outer part of the membrane being most thickly clad. Cheek-bristles are present, but they are feeble and few in number. The tail is bushy.

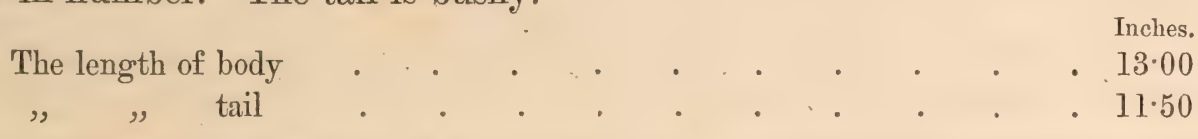

The edentulous interspace of the lower jaw is somewhat similarly shaped to $P$. elegans. The teeth differ from those of any other Pteromys I have observed, in the peculiar roughened character of the crown, which is covered with fine, wavy striæ which run down from the apices of the ridges and tubercles.

\section{Pteromys tephromelas, Günther.}

Pteromys tephromelas, Günther, Proc. Zool. Soc. Lond. 1873, p. 413, pl.'xxxviii.

This is also a small black species. The fur is brownish-black at its base, and greyish in its upper third, the hairs being broadly black-tipped and glossy. This grey under colour is restricted to the anterior half of the back and to the head; the hairs of the upper surface of the limbs, parachute and tail being wholly lustrous brown-black. The hair of the under surface is sparse, but thickest on the mesial line and on the outer portion of the wing-membrane. The central line is greyish, and also the under surface of the parachute. The cheek bristles are present, but they are feeble and not numerous. The tail is long and narrow, not distichous, and equalling or rather exceeding the length of the body. The skull is of moderate size, and the incisors are pale-yellow. The infra-orbital foramen is an oblique slit which is but little forwardly projected.

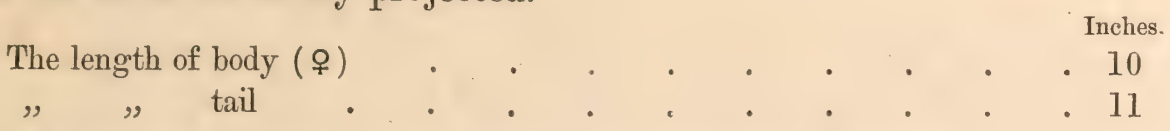

This flying squirrel has been found in Pinang and Malacea.

\section{Pteromys horsfieldi, Waterhouse.}

Pteromys horsfieldii, Waterhouse, Proc. Zool. Soc. 1837, p. 87; Wagner, Schreber, Säugeth. Suppl. vol. iii. 1843, p. 228 ; Schinz, Syn. Mamm. vol. ii. 1845, p. 52.

Pteromys aurantiacus, Wagner, München, Gelehrte. Anz. 1841, No. 54; Wagner, Schreber, Säugeth. Suppl. vol. iii. 1843, p. 225; Schinz, Syn. Mamm., vol. ii. 1845, p. 52 ; Blyth, Journ. As. Soc. Beng. vol. xvi. 1847, p. 867.

Sciuropterus horsfieldii, Gray, List Mamm. B. M. 1843, p. 134; Cantor, Journ. As. Soc. Beng. vol. xv. 1846, p. 253 ; Blyth, Journ. As. Soc. Beng. 1847, vol. xvi. p. 867 ; itid. vol. xxviii. 1859, p. 278.

Sciuroptemus sagitta, Müller und Schlegel, Verhandl. 1839-44 (in part), p. 109 ; Blyth, Journ. As. Soc. Beng. 1855, vol. xxiv. p. 187. 
Sciuroptera phayrei, Blyth, Journ. As. Soc. Beng. vol. xxviii. 1859, p. 278 ; ibid. vol. xliv. 1875, p. 35 ; Cat. Mamm. As. Soc. Mus. 1863, p. 97.

This species, which is a little larger than $P$.genibarbis, is recognised by the rich, uniform rufous-brown colour of the fur of the upper parts and tail, the latter being bright rusty beneath, bushy and distichous. The margin of the membrane and the sides of the face below the eye are reddish-yellow, and the dorsal surface of the parachute dark brown. On the upper surface of the body each hair is grey at the base; and the interspersed longer hairs which are numerous, are bright brown or reddish-yellow at their apices. The fur is dense and woolly. On the under parts and inside of the limbs the hairs are yellowish-white and not grey at their bases. Cheek-bristles absent.

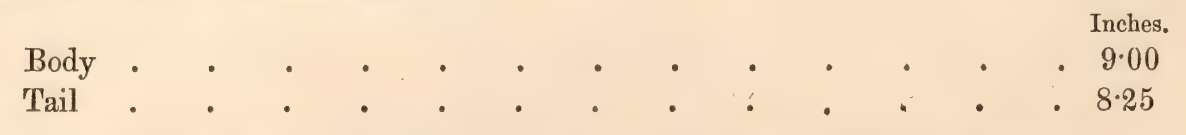

Animals from the Island of Banka appear to be paler than those from Java and the Malayan peninsula. The foregoing are the localities of its known distribution along with Tenasserim and Cambodja. The $P$. aurantiacus, Wagner, appears to be an immature animal from the Island of Banka; and the $P$. phayrei of Tenasserim, which Blyth at first regarded as $P$. sagitta, but afterwards as akin to $P$. horsfieldii, is also apparently an example of this species.

\section{Pteromys spadiceus, ${ }^{1}$ Blyth.}

Sciuroptera spadicea, Blyth, Journ. As. Soc. Beng. vol. xvi. 1847, p. 867, pl. xxxvi. fig. 1 ; ibid. vol. xxviii. 1859, p. 278.

Sciuropterus spadiceus, Blyth, Cat. Mamm. As. Soc. Mus. 1863, p. 97 ; Journ. As. Soc. Beng. vol. xliv. 1875 , p. 35 , ex. no.

This is a small species of a bright ferruginous bay colour on the upper surface, the under parts being woolly and dull white, with the membrane, limbs and tail dusky; the last third of the tail being pale rufous, inclining to pale yellowishwhite.

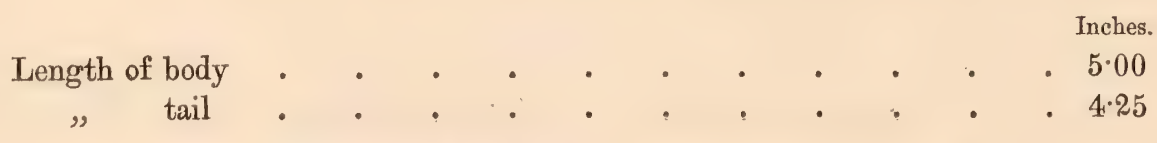

It is only known by Blyth's description of three specimens from Arracan.

\footnotetext{
"In the British Museum, there is a small flying squirrel from Cambodja, which appears to be closely allied to $P$. spadiceus, from which, however, it apparently only differs in having a white tip to its tail. The upper surface of the head and back is rufous brown, the parachute being dull blackish-brown washed with rufous on its inner half, but not externally. The sides of the face and below the eye and moustache are white, tipped with rufous. Chin, throat, sides of neck, and chest are pure white, passing into pale yellowish, almost ermine white, so to speak, on the belly. On the under surface of the parachute the bases of the hairs are grey, but they are broadly tipped with white, and on the rest of the under parts they are wholly white. The tail is distichous and pale yellowish-brown at its base, passing into brownish-black in the rest of its extent, except at the tip, which is white. Length of the body and head 4 inches, tail $3 \frac{3}{4}$ inches long.
} 


\section{Pteromys gentbarbis, Horsfield.}

Pteromys genibarbis, Horsfield, Resch. in Java, 1824 (plate) ; Cat. Mamm. E. Ind. Co.'s Mus. 1851, p. 163 ; Cantor, Journ. As. Soc. Beng. vol. xv. 1846, p. 253 ; Blyth, Journ. As. Soc. Beng. vol. xxviii. 1859, p. 278; Temm. Monog. vol. i. Tab. Method. 1827, p. 27 (in part) ; Fischer, Syn. Mamm. 1829, p. 363 (in part); Wagner, Schreber, Säugeth. Suppl. vol. iii. 1843, p. 224; Schinz, Syn. Mamm. vol. ii. 1845, p. 51.

Pteromys sagitta, Temm. Tab. Method. (in part), Mamm. Monog. vol. i. 1827, p. 27 ; Lesson, Man. de Zool. 1827, p. 242 (in part); Müller und Schleg. Verhandl. 1839-44, pp. 109 \& 113 (in part).

This species, which is of small size, is represented in the India Museum, London, by the type. It is distinguished from all other flying squirrels by the series of bristles or vibrissæ disposed on the cheeks in a radiated manner. The head is short, ovate, laterally compressed and attenuated to a short obtuse muzzle which projects beyond the lower jaw. The lobe of the ear at its base has a thick tuft of silky hair of a white colour. The tail is distichous, and equals in length nearly two-thirds of the body of the animal.

The general colour is grey above and white beneath, the upper surface of the head being purely grey. On the neck, the back, and the tail, the colour has a brownish tint, inclining to tawny. The anterior and middle parts of the membrane are sooty-brown diversified with greyish hairs.

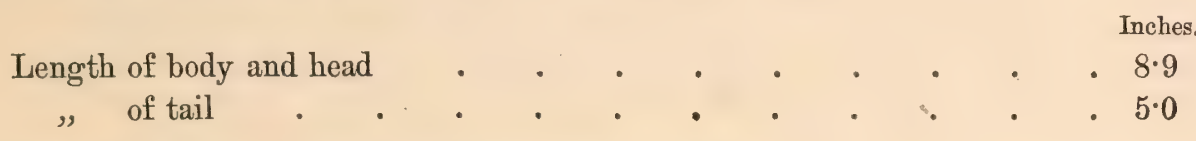

Found rarely in the eastern extremity of Java.

\section{Pteromys lepidus, Horsfield. ${ }^{1}$}

Sciuropterus lepidus, Horsfd. Zool. Resch. Java, plate, 1824; Cat. Mamm. E. Ind. Co.'s Mus. 1851, p. 163 ; Blyth, Journ. As. Soc. Beng. vol. xxviii. 1859, p. 278.

Pteromys genibarbis, $\beta$. lepidus, Fischer, Syn. Mamm. 1829, p. 363.

Pteromys lepidus, Wagner, Schreber, Säugeth, Suppl. vol. iii. 1843 (in part), p. 226 ; Schinz, Syn. Mamm. vol. ii. 1845, p. 51.

Pteromys (Sciuropterus) sagitta, Lesson, Man. de Zool. 1827, p. 242.

Pteromys sagitta, Temm. Monogr. Mamm. vol. i. Tab. Method. p. xxvii. 1827 (in part) ; Müller und Schlegel, Verhandl. 1839-44, pp. 109, 113 (in part).

1 I have not been able to reconcile any of the above small flying squirrels with the $S$. sagitta, Linn., but I here give the principal references to $S$. sagitta which was described from a Javan specimen-

Linn. Syst. Nat. 12th ed. 1776, p. 88; Erxleben, Syst. An. 1777, p. 439; Pallas, Nov. Sp. Ghr. 1778, p. 353; Boddaert, Elench. Anim. 1785, p. 120 ; Gmelin, Linn. Syst. Nat. 1788, p. 154; Schreber, Säugeth. vol. iv. 1792, p. 817, pl. 224; Shaw, Genl. Zool. vol. ii. pt. i. 1801, p. 158 (in part) ; Cuvier, Règne Anim. vol. i. 1817, p. 207 ;

Desmarest, Nouv. Dict. d'Hist. Nat. vol. xxvii. 1818, p. 403; Mamm. 1820, p. 342; F. Cuv. Dict. des Sc. Nat. vol. xxviii. 1827, p. 141; Temminck, Tab. Meth. Monogr. Mamm. vol. i. 1827, p. 27 (in part); Lesson Man. de Mamm. (in part), 1827, p. 242 ; Is. Ceoff. St.-Hilaire, Dict. Class d'Hist. Nat. vol. xxi. 1828, p. 152; Fischer, Syn. Mramm. 1829, p. 363 (in part); Müller und Schlegel, Verhandl. 1839-44, p. 109 (in part); Schinz, Syn. Mamm. vol. ii. 1845 , p. 50. 
The type of this species is in the India Museum, London. It is quite distinct from $P$. genibarbis, the typical example of which is in the same collection. The latter is distinguished from the former and indeed from all the small flying squirrels by its numerous and strong cheek-bristles, whereas there is no indication whatever that those hairs ever existed in P. lepidus. Müller and Schlegel were under the impression that the cheek-bristles of $P$.genibarbis were a character of youth, and that $P$. lepidus was an animal of the same species in which these hairs had fallen out, but $P$. lepidus is a smaller species than $P$. genibarbis. Moreover, there are certain flying squirrels in which the cheek-bristles are entirely absent, and others in which they are only developed to a limited extent, and some of the flying squirrels recently described by Günther exemplify these differences which have also attracted his attention.

This is one of the smallest of the Southern Asiatic flying squirrels. The upper surface is pale yellowish-brown. The tail is markedly distichous, pale yellowishgrey at its base, the remainder being pale brown and the under surface somewhat rufous. The upper surface of the parachute is dark brown, the fore feet being pale yellowish-brown, and the hind feet darker. The under parts are thickly clad with rather woolly hair, white, but with a faint yellowish tinge. The bases of the hairs on the sides of the belly and on the under surface of the parachute are slaty grey, and on the outer half of the membrane they are almost wholly brown, tipped with yellowish-white, but the dark colour is the prevalent tint. The moustache is long and black.

The sides of the face and neck are yellowish-white.

Length of body 3.90 ; tail 3.50 .

There are four examples of this species in the Leyden Museum; it has hitherto been found only in Java.

\section{Pteromys volans, Linnæus.}

Ecureuil volant de Siberie, Brisson, Règ. An. 1756, p. 159.

Polatouche, Buffon, Hist. Nat. vol. x. 1763, p. 95.

The Saiting Squirrel, Pennant, Quad. 1792, vol. ii. p. 151 (in part).

Sciurus volans, Linn. Syst. Nat. 12th ed. 1766, vol. i. p. 38 ; Pallas, Nov. Sp. Quad. Glirium, 1778, p. 355 ; Zoograph. vol. i. (ed. 1831), p. 190; Boddaert, Elench Animal, 1785, p. 120; Schreber, Säugeth. vol. iv. 1792, p. 813, Tab. 223; Blumenbach, Abbeld. 1810, p. 71 ; Fischer, Syn. Mamm. 1829, p. 364; Gray, List Mamm. B. M. 1843, p. 136; Schinz, Syn. Mamm. vol. ii. 1845, p. 53 ; Middendorff, Säugeth. Reise in Sib. 1851, p. 78 ; Schrenck, Reisen. Amur Land, 1859, p. 116 ; Radde., Reisen. in Sud. Ost. Siber. Säugeth. 1862, p. 131.

Pteromys russicus, Tiedemann, Zool. 1808, vol. i. p. 451.

Pteromys sibericus, Desmarest, Mamm. 1820, p. 342.

Pteromys volans, Fischer, Syn. Mamm. 1829, p. 365.

Pteromys vulgaris, Wagner, Schreber, Säugeth. Suppl. 1843, vol. iii. p. 228.

Sciuroptera volans, Blyth, Journ. As. Soc. vol. xxviii. 1859, p. 278.

This northern form is quite as variable as the common squirrel with which it is associated. It is pale greyish-white; the under parts white. Ears clad 
externally and internally. No cheek-bristles; tail distichously bushy, and dusky grey.

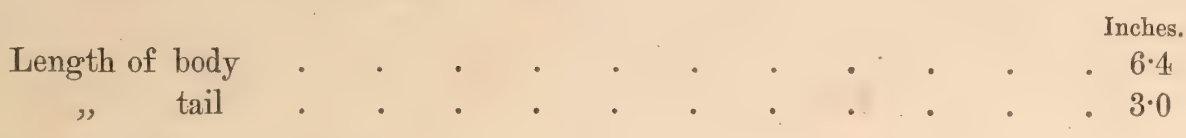

Northern Europe and Asia.

Pteromys momonga, Temminck. ${ }^{1}$

Pteromys momonga, Temminck, Mamm. Fauna Japon. 1847, p. 46, pl. xiv.; Müller und Schlegel, Verhandl. 1839-44, p. 111; Schinz, Syn. Mamm. vol. ii. 1845, p. 528.

Sciuroptera momoga, Blyth, Journ. As. Soc. Beng. vol. xxviii. 1859, p. 278.

This is a slightly larger species than $P$. volans, and differs from it in its dull reddish-brown upper fur. The under parts are white, and the central line of the tail above and below is dusky brownish-black. The tail is shorter than the body and distichous. The ears are rather short, broad at the base and not tufted. Cheekbristles are absent.

Length of body Inches.

. . . . . . . . . . $7 \cdot 08$

Inhabits Japan.

1 The specific name of this squirrel is often erroneously written $P$. momoga instead of $P$. momonga. 
MURIDA.

Genus Mus, Linn.

* MUs Bowersir, n. s. Plate XVII.

Uniformly grizzled blackish-brown above, paler on the sides and the fronts of the legs; pale yellow below and on the feet and on the tip of the tail, distinctly defined from the darker colour. Head rather long; muzzle long and pointed. Ears large, ovate, very sparsely covered with short brown hairs. The tail exceeds the length of the body and head and is finely ringed, three rings in one-tenth of an inch, with short brown hairs between the rings. The feet are strong, and the hind foot is long; the claws are short and strong, and the pads are well developed as in rats partially arboreal in their habits.

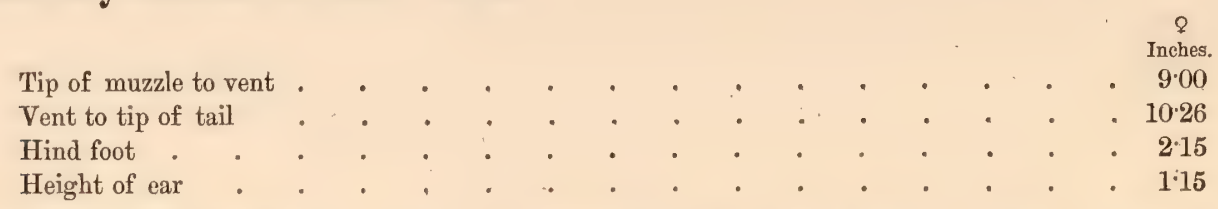

The hairs are rather coarse, but consist of two kinds; first, there are pale yellowish-grey and fine wavy hairs intermixed among the second kind which constitutes the general covering, and the individual hairs of which are strong and almost bristly, pale yellowish-grey below, and broadly tipped with blackish-brown, and in some cases with a narrow terminal band of pale yellowish-brown. The grizzling is produced by the yellowish wavy hairs appearing among the longer and stronger hairs.

The skull is remarkable for the long narrow facial portion, and for the little convexity of the fronto-nasal region, so that the skull from the vertex to the extremity of the nasals is very straight. The upper incisors are moderately broad, and the molars do not present any characters calling for remark beyond that the last molar consists of two folds, a very large broad anterior fold and a small one behind it.

Inferior border of formen magnum to tip of premaxillæ
Tip of premaxillæ to anterior end of palate
Length of palate
Length of molar line
Inferior margin of external border of infraorbital foramen to tip of premaxillæ
Breadth at frontal contraction
$\quad$ " across parietals.


This species is closely allied to those rats which are distinguished by yellow bellies and which are more or less arboreal in their habits, and in some of which the hairs become very coarse and broad, and convex on one side and concave on the other. I obtained one example at Hotha, in Yunnan, at an elevation of 4,500 feet.

\section{* Mus SLADENI, n. s.}

Head rather elongated; snout somewhat elongate, the distance between the inner canthus of the eye and the front of the muzzle equalling the distance between the external canthus of the eye and the back of the ear; muzzle rather deep. Ears large and rounded, sparsely clad with short hairs; the breadth of the ear across its middle, laid out flat, generally equalling the interval beween the inner canthus of the eye and the front of the muzzle, and its height from the lower margin of its external orifice to its highest point is the equivalent of the distance between the external canthus and the back or lower margin of the ear. The feet are well developed, and the hind feet are rather strong; the claws are moderately long and sharp, and the feet-pads are markedly developed, and would seem to indicate a partially arboreal habit of life. The tail slightly exceeds the length of the body and head; it is rather coarsely ringed, there being three rings to each one-tenth of an inch; the hairs are sparse and brown.

General colour of the upper surface reddish-brown, more rufous than brownish, palest on the head, many of the hairs with broad yellow tips ; cheeks greyish-rufous; chin, throat, and chest whitish, also the remaining under parts, but with a tinge of yellowish; feet pale yellowish-white; ears and tail pale brownish.

Measurements.

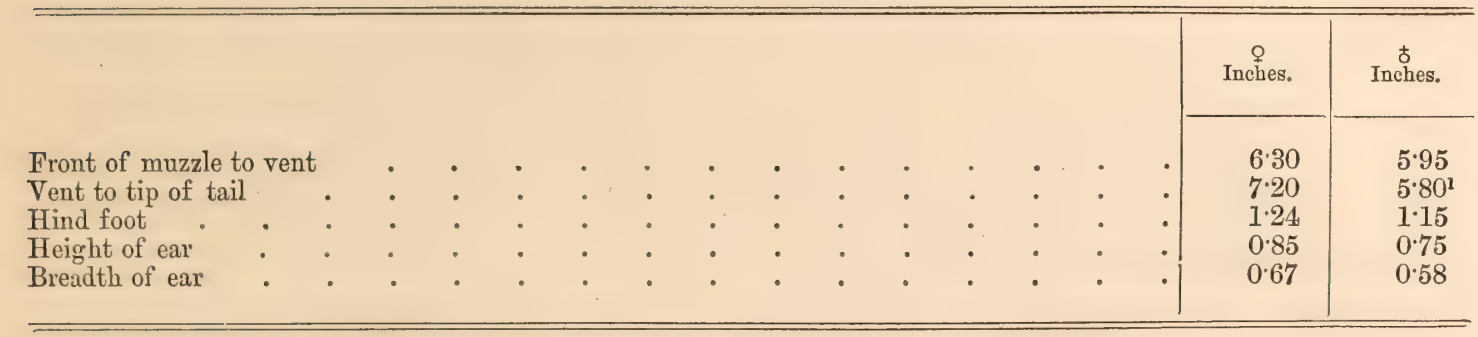

This species is closely allied to $M$. nitidus, Hodgson, but its skull is less elongated, with a shorter facial portion, with very much shorter nasals, and with a more abruptly defined frontal contraction than either in $M$. nitidus, or Mus rufescens so called.

Inferior border of foramen magnum to tip of premaxillæ
Tip of premaxillæ to anterior end of palate
Length of palate
$\quad$ molar line
Inferior margin of external border of supraorbital foramen to tip of premaxillæ
Breadth across parietals.


This appears to be both a house and tree rat, and it occurs in Burma as well as in the Kakhyen hills, where I first met with it at Ponsee, 3,500 feet.

\section{* Mus Rubricosa, n. s.}

Snout moderately pointed and long; ears small and somewhat pointed; hind foot long and narrow; claws moderately long, compressed and sharply pointed. Upper surface dark rusty-brown, darkest on the middle of the back and palest on the muzzle, head and shoulder; on the sides and lower part of shoulder the reddishbrown tends to pass into greyish; feet greyish. The sides of the snout greyish; all the under parts silvery-grey, tending to white, without any trace of rufous or but with a very faint yellowish blush. The tail, dull brown, is somewhat shorter than the body and head, and it is coarsely ringed, $2 \frac{1}{2}$ rings to one-tenth of an inch, the hair being short, sparse, and dark-brown.

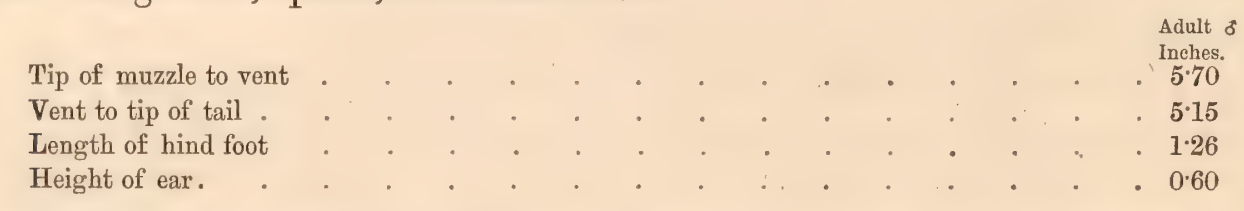

The skull is distinguished from that of the previous species by its elongated nasals which are prolonged backwards on a line behind the posterior border of the supraorbital foramen, while in the skull of the former these bones are only a little behind the anterior border of that foramen. It is also distinguished by the marked concavity on the sides of the frontal contraction, which does not occur in the former species, and its tympanics are notably smaller. The molar lines of teeth in the two species are of the same length and their upper incisors about the same breadth.

The most marked characters by which it is separated from the foregoing species are its sharper snout, smaller ears, and larger feet, and the much more rufous colouring of the upper parts and the silvery-grey of the under surface.

It is found in the villages of the Kakhyens at Ponsee, and in the houses of the Shan-Chinese at Hotha.

\section{* Mus yunnanensis, n. s.}

Muzzle rather short and broad; ear large and rounded, its height considerably exceeding the distance between the inner canthus and the front of the muzzle, sparsely clad with short hairs. Feet well developed; hind foot moderately long; pads prominent; claws compressed, strong, curved, and sharp. Tail coarsely ringed, three rings to one-tenth of an inch. Upper surface dark rich brown, with intermixed pale hairs with broad brown tips. The sides of the face, below the moustachial area, chin, throat, and all the under parts yellowish washed with rufous. The ears and tail dusky-brown; feet pale yellowish, and more or less brownish above. The 
tail varies in length, but it is generally longer than the body and head, although it may occasionally fall short of that length.

\begin{tabular}{|c|c|c|c|c|c|c|c|c|c|c|c|c|c|c|}
\hline & & & & & & & & & & & & & Adolescent o & Adult ? \\
\hline MIuzzle to vent & . & : & . & . & . & . & . & . & . & . & . & . & $5 \cdot 70$ & 5.45 \\
\hline Vent to tip of tail & . & $\because$ & : & . & : & : & $\dot{0}$ & $\dot{.}$ & : & . & . & : & $5 \cdot 65$ & $6 \cdot 15$ \\
\hline Hind foot & . & 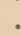 & . & . & . & . & . & . & . & . & . & . & $1 \cdot 16$ & $1 \cdot 11$ \\
\hline Height of ear . & . & . & . & . & . & . & . & . & . & . & . & . & 0.76 & 0.80 \\
\hline
\end{tabular}

The skull is distinguished from the skull of $M$. sladeni by its shorter muzzle, but in other respects the skulls are much alike.

Measurements of skull.

Inferior border of foramen magnum to tip of premaxilla Tip of premaxillæ to anterior end of palate Length of palate Length of molar line

Inferior margin of external border of infraorbital foramen to tip of premaxillæ Breadth across parietals

This is the common house rat at Ponsee, Hotha, and Teng-yue-chow.

\section{* Mus KakHyenensis, $\mathrm{n}$. $\mathrm{s}$.}

Muzzle moderately deep and short; ear large and rounded, greatly exceeding the distance between the inner canthus, and the front of the muzzle and also the interval between the external canthus and the lower margin of the external orifice of the ear; its breadth also exceeding the former measurement. Feet well developed, the hind foot rather long and slender, equalling the length from the front of the lower lip to the anterior margin of the external auditory meatus. Claws well developed, compressed, moderately curved and sharply pointed. The tail is considerably in excess of the length of the body and head; finely ringed, five rings to the one-tenth of an inch. Fur long, dense, and soft, reddish-brown on the upper parts, with a dark speckled appearance due to the stronger hairs having broad brown tips. Sides of the head dusky-greyish; chin to vent, and under parts greyish-white, with a silvery sheen. Feet dusky pale brown. Ears and upper surface of tail dark-brown; under surface of tail pale brown.

Tip of snout to vent
Vent to tip of tail
Hind foot
Height of ear
Breadth of ear

This mouse is distinguished from the common house mouse of Lower Bengal by its relatively shorter tail, longer hind feet, and larger ears; and from $\mathbb{M}$. homurus 
of the Himalaya by the entirely different character of its coloration, M. homurus having a yellow muzzle and brownish-yellow feet.

The skull has the parietal region more contracted than in $M$. urbanus, and much more so than in $M$. homurus, and the posterior margins of the frontals are backwardly prolonged into the parietals, more so than in $M$. homurus. The nasals of $M$. urbanus contract to a point posteriorly, while those of $M$. homurus are posteriorly truncated, but in this species these bones are more elongated than in either of these small mice, and their posterior ends are narrower and more backwardly prolonged. The molar lines of teeth are about the same length in these three species.

Inferior border of foramen magnum to tip of premaxillæ
Tip of premaxillæ to anterior end of palate
Length of palate

I procured only one example of this mouse at Ponsee, where it occurs on the old rice and Indian-corn clearings.

\section{*Mus VICULORUM, n. $\mathrm{s}$.}

Muzzle rather sharply pointed, moderately long and not deep. Ear moderately large, rounded, its height a little in excess of the distance between the inner canthus and the front of the muzzle, its breadth equalling that distance. Hind feet not long, equalling the interval between the tip of the lower lip and the base of the ear posteriorly; claws compressed, moderately long and sharp. Tail a little longer than the body and head; finely ringed, five rings to the one-tenth of an inch. Fur short, soft, and dense, dull dark-brown on the upper parts, tending to blackish on the back, paling to brownish on the side, and passing into pale dusky-brownish on the under parts, with a silvery sheen. Feet brownish; toes with shining greyish yellow hairs; ears and tail brown.

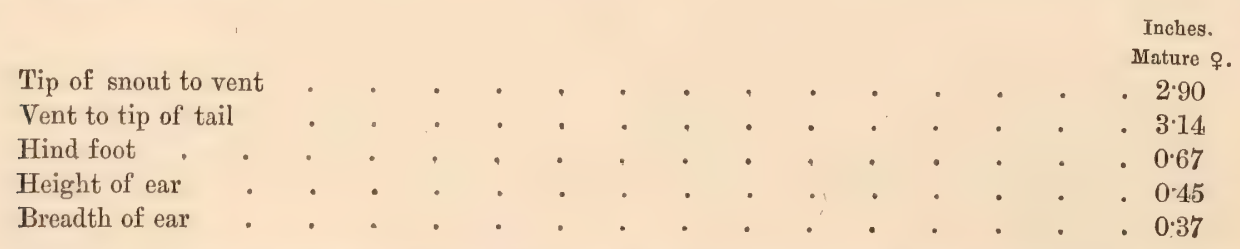

This mouse is perfectly distinct from $M$. homurus and $M$. urbanus and also from the previously described species. From the latter it is distinguished by its relatively shorter tail and smaller ears, and from $M$. homurus by its proportionally longer tail and larger feet.

The skull is very much less globose than the skull of $M$. homurus, and the posterior ends of the frontals are nearly transverse, and the molar line is a little 
shorter. The posterior portions of the anterior palatine foramina are much contracted.

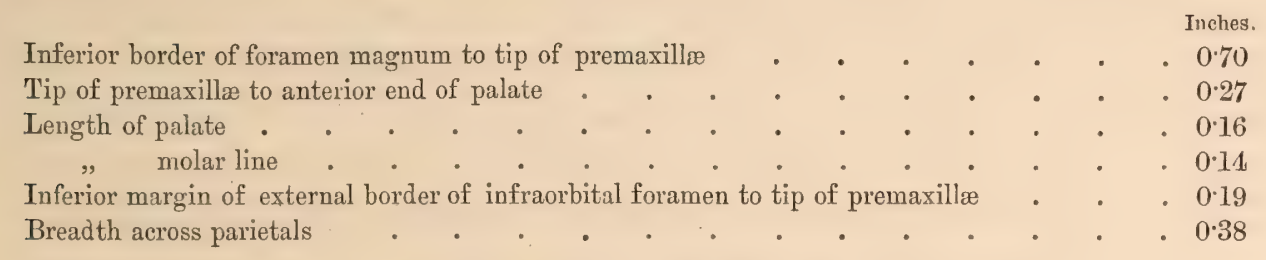

It frequents the villages and houses of the Kakhyens, and I obtained it at Ponsee.

\section{Sub-genus Vandeleuria, Gray, 1842.}

Sykes, in his Catalogue of Mammalia ${ }^{1}$ inhabiting the Deccan, published in 1831, mentioned a mouse which he believed to be new, and which he characterized as light chestnut above, reddish-white below, and with a tail much longer than the body. This little rodent he described as of the size of a field mouse, and as inhabiting only fields and gardens.

In the following year, his specimens of this mouse had been forwarded to London and were described by Mr. Bennett under the name of MIus oleraceus. The great length of the tail and the comparative length of the tarsus as compared with other mice were considered as characters sufficient to distinguish the species from all its congeners.

In 1839, Mr. now Sir Walter Elliot included this mouse in his tabular statement of his Catalogue of Mammalia ${ }^{2}$ inhabiting the Southern Mahratta country as Mus longicaudatus, but in the text he described it under the name of $M$. oleraceus, and explained that the foriner term had been applied by himself to the species many years before Bennett's description had appeared, but the name had never before been published. He did not give any information regarding its structure, but recorded that it lives exclusively in trees and bushes, up which it is able to run with great facility.

Sir Walter Elliot had forwarded specimens of this mouse to the British Museum, and in December $1842^{3}$ Dr. Gray proposed the genus $V$ andeleuria for their reception. About the same time Sir Walter Elliot sent to the Calcutta Museum a series of specimens of a small, very long-tailed mouse with grooved upper incisors, which Blyth regarded as Mus oleraceus and the Vandeleuria of Gray.

I obtained in the valley of the Nampoung, a frontier stream dividing Burma from China, a small mouse which agrees in its grooved incisors and other characters with the mice forwarded by Sir Walter Elliot.

This mouse being preserved in spirit has enabled me clearly to make out the characters of the feet which were not very distinguishable in the mounted specimens of the mouse from Southern India which, however, are structurally identical with the

\footnotetext{
1 Proc. Zool. Soc. July 1831, p. 99 ; Proc. Zool. Soc. June 1832, p. 121.

2 Madr. Journ. Lit. \& Sc. vol. x. July 1839, p. 94.

3 Ann. and Mag. Nat. Hist. vol. x. Dec. 1842, p. 265.
} 
animal from the frontier of China. But a grave difficulty arises, because the feet of this mouse do not agree with Dr. Gray's description of the feet of Vandeleuria. He says: "Hind feet very long, slender; soles bald beneath; toes 4.5 ; long, slender, compressed, the three middle subequal, the hinder middle very long; the front outer very rudimentary, scarcely visible; the front inner weak, the hinder outer longer than the inner; claws small." In the mouse from the Nampoung and which I have already said is identical with Elliot's specimens, the following is a description of the feet : hind feet rather long and somewhat expanded towards the toes; soles bald beneath, and the pads much more strongly developed than in ground mice, and having the form generally characteristic of arboreal rodents; toes rather long, slender, and compressed; toes $5 \cdot 5$; inner toe of fore foot quite rudimentary, but with a nail; the front outer toe rather feeble; the three middle hind toes are subequal and rather long; the hinder outer toe is longer than the inner. The inner and outer toes of both feet are furnished each with a small flattened nail which is so rudimentary on the outer toe of the fore foot that it may occasionally be lost; the remaining toes have short strong claws. From a comparison of this description with that of Dr. Gray's, it will be observed that there are important structural differences regarding the feet which make it doubtful that the mice sent by Sir Walter Elliot and regarded by Blyth and Jerdon as Vandeleuria, really belong to that genus if Dr. Gray's description is accurate. But it seems apparent from the internal evidence of Dr. Gray's description that some errors have crept into it, because the fore foot is said to have only four toes and yet to have the three middle toes subequal. Moreover, it will be remarkable if the front outer were the rudimentary, and not the inner toe.

Notwithstanding the difficulties of reconciling the description of Vandeleuria with Elliot's specimens and with this mouse from the Nampoung, I am still inclined to consider that this was the animal Dr. Gray had in view, but the doubt which I have expressed can only be solved by a reference to the type specimens in London. With regard to the characters of this mouse more in detail : I have mentioned the circumstance that true claws are restricted to the $2 \mathrm{nd}$, $3 \mathrm{rd}$, and 4 th digits, the 1 st and 5th digits of each foot being provided with a flattened nail. There is also another feature of the 1st and 5th digits, namely, the considerable development of the ungual cushions which are full and rounded and not laterally compressed like the cushions of the clawed digits, which are also much more prominent than in ground mice. The pads on the soles of the feet resemble in their form and levelopment the same structures on the feet of that long-tailed tree and ground rat which is generally known in India as Mus rufescens, and they are relatively much more developed than in the pads of such thoroughly ground mice as Mus urbanus. The transverse plates also resemble in character these plates in $M$. rufescens, and are very much more perfect and like the transverse plates on the under surface of a gecko's toes than the broken up plates on the toes of such small ground-mice as $M$. urbanus. With regard to the dentition: in the mice sent by Sir Walter Elliot, the upper incisors present a raised line down the longitudinal mesial line of the front aspect of the 
tooth, with a not very well-marked groove on either side of it, close to the sharp line defining the lateral margins. Dr. Gray, however, describes these teeth in Vandeleuria as having a deep groove near the middle on the oblique front edge. Such another discrepancy as this between the teeth of these mice $I$ am dealing with and Dr. Gray's Vandeleuria make me hesitate to pronounce them the same. I have before me mice agreeing with Elliot's specimens from the valley of the Upper Godavery, from Berar, Allahabad, Katmandu, Nepal, Assam, Burma, and the Kakhyen hills, and all of which have their upper incisors grooved as I have just described them. If the molar dentition is compared with that of $M$. homurus, a mouse about the same size, the characters wherein it differs from that of ordinary mice will be brought out. In $\mathbb{I}$. homurus there are transversely three cusps to the first and second folds, while there are only two cusps to the third fold, the inner cusp not being developed. In this long-tailed arboreal mouse the same number of cusps exist, but the outer cusp of the third fold is not developed, or only very feebly so. The folds are much more bent on themselves at their middle through the mesial cusp than in $M$. homurus and $\boldsymbol{M}$. urbanus. In the former there are two folds to the second molar and three cusps to each fold, the posterior external cusp being the least developed. In this mouse the second tooth has two mesial cusps, one behind the other, the posterior being somewhat backwardly elongated. External to the anterior of these cusps there are two small cusps, and internally one large cusp tending to divide in two. External to the posterior central cusp there is one small cusp, and at its internal border only a ledge of the cingulum. In the last molar of $M$. homurus there is one small central fold, the inner end of which tends to form a cusp, with another anterior to the latter internally and one behind it. In these supposed examples of Vandeleuria there is one fold so bent on itself that it encloses an islet in its centre, and externally it gives off a small cusp, a part of the fold nearly constricted off, and anterior to the hinder end of the external extremity of the fold. Behind the point where the two ends of the fold come in contact posteriorly, there is a well developed cusp (unicuspulate fold).

The first fold of the first lower molar of $\not M$. homurus is divided into two cusps, which is also the case more or less with these supposed examples of $V$ andeleuria, and the external cusp of the third fold of Vandeleuria is much less developed than in M. homurus. The other teeth differ but little. From this description it is evident that the dental characters by which these forms differ from ordinary mice are not at all well defined.

The form of the skull is much the same as in $M$ Ius, but the skull presents a structural difference at its base, which, taken in conjunction with the grooving of the incisors and the absence of a true claw on the 1st and 5th digits of both feet, would seem to entitle this form to sub-generic rank, but not to more.

The features to which I allude are the structure of the posterior nares, pterygoid fossa, and infraorbital foramen. The former, instead of being narrow and short, as in mice generally, are wide and long, and on looking into them from 
the under surface of the skull, instead of merely seeing the posterior end of the presphenoid and the foramen lacerum orbitale on each side of it, the presphenoid is seen not to be thrown so far forwards as in such mice as $M$. urbanus and $M$. homurus, and anterior to the foramen lacerum orbitale a spicule of bone is distinctly observable on each side of the presphenoid, passing outwards and expanding in the orbit as the orbital plate of the sphenoid, and anterior to each of these fine osseous rods the optic foramina are clearly visible.

The infraorbital foramen does not form an incision in the anterior margin of the maxillary root of the zygoma, as in Mus generally.

The pterygoid fossa is very shallow, and formed chiefly by the palatines, and its base or floor is flattened and expanded as in $M$. homurus and $M$. urbanus, but, unlike these mice, is marked by a number of imperfections of ossification. It is very shallow compared with what it is in such burrowing rats as Nesolia and the so-called bandicoot. M. giganteus, in which it is very deep and perforated at its base. The inner walls of the pterygoid fossa are entire, which is also the case in the small mice already mentioned, whereas in these larger species just named there are generally one or more large imperfections on the inner wall.

With regard to the number of species, Hodgson indicated another in addition to $M$. $(V$.) oleraceus, but the following table does not reveal any marked distinction between two Nepal specimens and examples from Central India, Chárápunji, Burma, and Western Yunnan; any differences that do occur are probably due to individual variation, or to the diversity in the physical conditions of the localities from whence the animals come. ' I am therefore disposed to recognize only one species. It will be observed that the upper dental line is the same in all.

I would also direct particular attention to the proportions which the tail holds to the body in the young animal, as it only slightly exceeds the length of the trunk, while in the adult it is nearly half as long again as the body and head. From this it is evident that the rapidity of the growth of the tail must be considerable, and this probably conduces to that variation in the length of the tail which is so observable in adult individuals of the same species. This would seem to be the case in the long-tailed rat which usually goes under the name of M.rufescens, in which the proportion of the tail to the body in the young and adult animals is much the same as in $M$. $(\boldsymbol{V}$.$) oleraceus.$

Measurements of Mus $(V$.$) oleraceus, Bennett.$

\begin{tabular}{|c|c|c|c|c|c|c|c|c|c|c|c|c|c|c|c|c|c|c|c|}
\hline & & & & 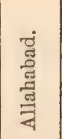 & 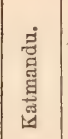 & 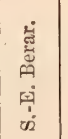 & 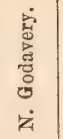 & 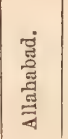 & 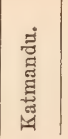 & $\begin{array}{l}\text { 它 } \\
\text { 营 } \\
\text { ठ் } \\
\dot{0} \\
\dot{z}\end{array}$ & 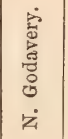 & $\begin{array}{l}\text { 莺 } \\
\text { ตี }\end{array}$ & 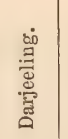 & 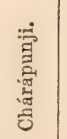 & 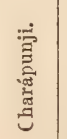 & 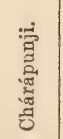 & 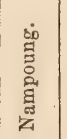 & 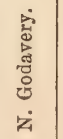 & 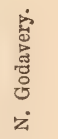 \\
\hline & & & & $\delta$ & $\hat{\sigma}$ & $\delta$ & $\hat{o}$ & Q & 우 & ᄋ & 웅 & q & 우 & ㅇ & 우 & q & 우 & juv. & juv. \\
\hline Tip of muzzle to vent & $\theta^{\circ}$ & & & $2 \cdot 75$ & $2 \cdot 80$ & $2 \cdot 83$ & $2 \cdot 22$ & 3.00 & $2 \cdot 65$ & $2 \cdot 65$ & $3: 81$ & $2 \cdot 41$ & $2: 70$ & $2 \cdot 73$ & $2 \cdot 83$ & 1.90 & $2 \cdot 43$ & 0.95 & 0.82 \\
\hline Length of tail & . & • & 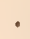 & $4 \cdot 20$ & $4 \cdot 20$ & $3: 90$ & 3.55 & $4 \cdot 50$ & $4: 20$ & $3 \cdot 72$ & $3 \cdot 90$ & $3 \cdot 65$ & $\ldots$ & $4: 58$ & $4: 50$ & $3 \cdot 35$ & $4: 35$ & 0.50 & 0.47 \\
\hline$"$ hind foot & - & $\bullet$ & - & 0.73 & 0.70 & 0.70 & 0.70 & 0.70 & 070 & 0.64 & 0.65 & $0 \cdot 69$ & 0.68 & 0.71 & 0.75 & 0.65 & 0.70 & 0.20 & $0 \cdot 20$ \\
\hline Height of ear & - & . & • & 0.57 & 0.55 & 0.55 & 0.50 & 0.55 & $0 \cdot 59$ & 0.48 & 0.55 & 0.48 & 0.55 & 0.66 & 0.65 & 0.411 & 0.53 & $\ldots$ & .. \\
\hline
\end{tabular}


MUS.

Measurements of skulls of foregoing.

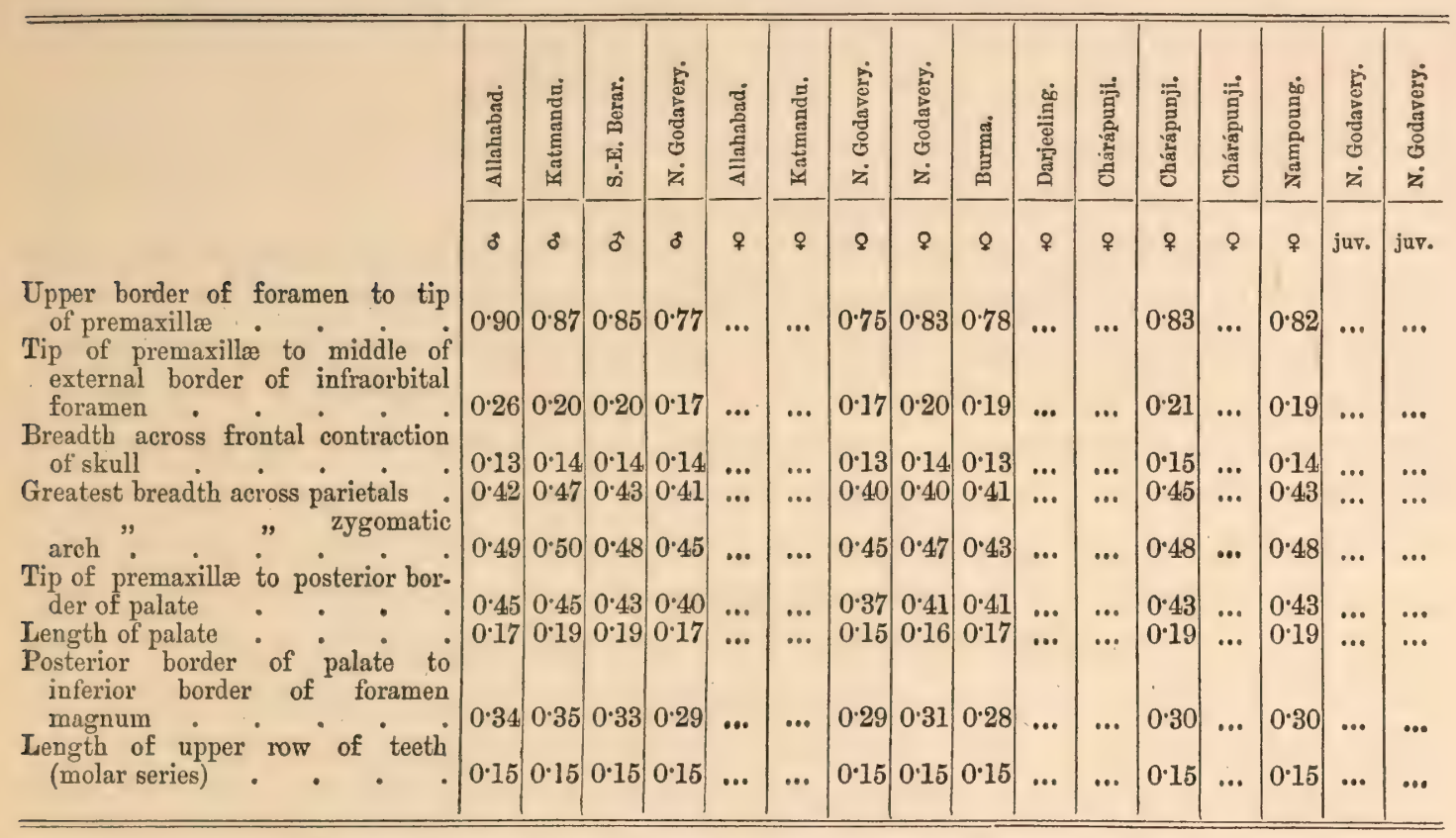

*Mus (Vandeleuria) oleraceus, Bennett.

Mus oleracens, Bennett, Proc. Zool. Soc., June 26, 1832, p. 121 ; Elliot, Madr. Journ. Lit. and Sc. Oct. 1839, p. 214; Wagner, Schreber, Säugeth. Suppl. pl. iii. 1843, p. 422 ; Schinz, Syn. Mamm., vol. ii., 1845, p. 150 ; Blyth, Cat. Mamm. As. Soc. Mus., 1863, p. 120 ; Journ. As. Soc., Beng., vol. xxxii., 1863, p. 344; Jerdon, Mamm. of Ind., 1867, p. 202.

Mus longicaudatus, Elliot, Madr. Journ. Lit. and Sc.. July 1839, p. 94, et p. 214.

Vandeleuria oleraceus, Gray, Ann. and Mag. Nat. Hist., vol. x., Dec. 1842, p. 265.

Mus (Vandeleuria) dumeticola, Hodgson, Ann. and Mag. Nat. Hist., vol. xv., April 1845, p. 268.

? Mus povensis, Hodgson, Ann. and Mag. Nat. Hist., vol. xv., April 1845, p. 269.

The muzzle is moderately long and slightly contracted behind the moustachial area. The eye is rather large, also the ears, which are sparsely clad and more or less rounded at the tips. In height they nearly equal the distance between the end of the muzzle and half-way between the eye and ear. The length of the head is about one-third the length of the body. The feet are moderately strong, and the toes are of nearly equal breadth throughout, and the claws are rather short. The tail is about one-half longer than the combined length of the head and body. It tapers to a point, is finely ringed, about thirty rings to the half inch, and is sparsely clad with short hairs between the rings. The hairs are more numerous and longer towards the end of the tail.

The upper surface is rich rufous, or chestnut-red, paling to brown on the ears and on the muzzle before the eyes; the sides of the face below the eyes and moustachial area, the chin, throat, and under parts generally are white, with a yellowish tinge. The feet pale-brown, passing almost into white on the toes. The pads and undersurface of the feet yellowish. The tail brownish or dusky; the hairs greyish. 


\section{SPALACID E.}

\section{Genus Rhizomis, Gray.}

The genus Rhizomys forms a small natural group, allied, on the one hand, to Arvicola, and, on the other, to Siphneus.

The dentition of these genera belongs to three types: in Rhizomys, the molar teeth are always rooted, even before they have appeared externally, and this character is retained through life, so that the crown, as the tooth is not a persistent grower, is the subject of considerable modification, depending on the extent to which the folds of enamel are worn down. In early stages, the anterior molar of $R$. chinensis, Gray, presents as many as four distinct folds, one internal and three external; but as age advances, and use wears them away, some portions of the folds form little islets of enamel, depending on differences in their vertical distribution; but in the wellworn teeth of old animals all traces of these folds and islets disappear, and the tooth becomes cylindrical, with a smooth, slightly concave crown, surrounded by a raised border of hard enamel. The dental conformation is much the same in all the species. In Arvicola the molars are occasionally rooted, but in some of the species they are unfurnished with roots in youth, to gain them, however, with advancing years, so that this group serves to connect Rhizomys with its permanently rooted teeth, to the allied genus Siphneus, in which the teeth are continuous growers.

However, there is a general type of dental structure which closely affines Rhizomys to Arvicola and Siphneus, the molar teeth of all these groups being resolvable to one type, but varying in the number and extent of the enamel folds; but, in the two last, the folds are more open and simple than in Rhizomys. Yet if the teeth of $R$. chinensis are compared with those of Siphneus armandii, it will be found that, although the former appear wonderfully complex, they can be reduced to the same structural type characteristic of the latter. In $R$. chinensis, in which the crowns of the molars are slightly worn, the plan of structure can be clearly traced to the presence of generally one fold on the inside of each molar, and three external folds on the first molar, two or three on the second, and one external fold on the third. According as the tooth is worn, these elementary folds, which are, so to speak, closely pressed together, form wavy outlines, at first more complicated, but ultimately, as the enamel folds rub down by use, becoming a simple circle of enamel. In Siphneus armandii, there is no complication of the elementary folds, all the molar teeth conforming to one plan, viz., one internal and two external folds ; that is to say, that the first molar has one external fold less than in R. chinensis, while the others agree in structure with the second and third molars of that species. A similar uniformity of structure pervades the inferior molars in both genera. The only difference presented by Arvicola is, that the folds are more open and deep, and more numerous on the inner than on the outer side of the tooth, 
There are also other characters, such as the form and internal structure of the stomach and cæcum, by which Rhizomys nearly approaches to Siphneus and Arvicola, besides many strong resemblances to each other manifested by the skeletons of the first two, and between their skulls and that of Arvicola. These considerations which will be amplified in the following sketch of the structural peculiarities of Rhizomys would seem to determine that this genus has its nearest allies in Siphneus and Arvicola, a fact which A. M.-Edwards ${ }^{1}$ has pointed out and on the strength of which he has instituted a small natural division represented by Arvicola, of which he regards Siphneus as a derivative type, modified by the external circumstances in which it is destined to live.

The leading feature of the vertebral column of Rhizomys, as in Siphneus, is, the more than usual breadth and strength of the cervical vertebræ, developed doubtless in relation to the heavy head and burrowing habits of the animal, but differing from that genus in that there is no amalgamation of any of the cervical vertebræ. The atlas has its spinous process reduced to two nodules, but in the axis this process is massive, as in Siphneus, having considerable antero-posterior expansion. From the third to the seventh cervical vertebra, Rhizomys, unlike Spalax, Georychus, Arvicola, and Bathyergus, has the spinous processes well developed and gradually increasing in size from before backwards. The transverse process of the atlas, contrary to that of Siphneus, is flattened and of considerable extent, as in Bathyergus; its lower or anterior aspect being rather deeply concave, its lower division being prolonged downwards as a well-marked ridge on to the inferior arch of the vertebra which bears a nodular hypapophysis, as in Siphneus, much more reduced than that which occurs in rats. From the axis to the sixth cervical, the two divisions of the transverse process increase in size from before backwards, the lower portion being placed somewhat anterior to the one above it, so that the artery is more protected than if the processes lay directly over each other. The extremity of the sixth process, as in Siphneus, is widely bifurcate, while only the upper division of the seventh process is developed. The spinous process of the first dorsal little exceeds in vertical extent that of the seventh cervical, but this process rapidly increases in length to the fourth dorsal, where it attains a length of half an inch; and as far as the twelfth dorsal, it is much directed backwards, diminishing in height, but gaining in antero-posterior extension to the penultimate lumbar.

Metapophyses begin to show themselves on the twelfth dorsal, and go on developing in size as they are traced backwards to the last lumbar, being also well developed on the first sacral and traceable throughout the sacral elements. Anapophyses begin on the thirteenth dorsal, and attain their maximum size on the second lumbar, disappearing on the last lumbar. The transverse process of the first lumbar vertebra exists only as a rudiment, but this process increases in size to the last lumbar, but it does not attain the same proportional development that it assumes in some Muride. The bodies of all these vertebræ are rounded on their under surfaces, and do not show any of the ridge-like hypapophyses which characterise the murine skeleton; no 
contraction of the bodies into a well-marked ridge occurs in these rodents in the sacral region. The sacrum, unlike that of the Muride, is very compact and strong, the pleurapophyses being considerably expanded and broadly applied to the ilium.

In $R$. badius, Hodgson, only two vertebræ are applied to the ilium, the third vertebra, although assuming the form of a sacral, is quite free and followed by another similar segment; so that if these two are regarded as pseudo-sacral, there are only sixteen caudal vertebræ. In $R$. pruinosus, the third sacral vertebra partially touches the ilium, and is amalgamated posteriorly with a pseudo-sacral vertebral element resembling itself; so that, leaving these out of view, there are 19 caudals. The pseudo-sacral element exists to give support to the thickened base of the tail. In these respects the skeleton of Rhizomys resembles that of Siphneus.

Broad transverse processes are well developed on the first five caudal vertebræ, but they disappear on the seventh, or are represented by a lateral ridge, as far back as the seventeenth. In R. badius, Hodgson, the transverse processes are distinctly visible as far back as the ninth vertebra, and their rudiments can be traced even to the thirteenth. In both these species, these processes are horizontally expanded. Also in both, the neural canal is perfect on the first four true caudals, and hæmapophyses are developed. from the sixth to the twelfth vertebra. Metapophyses occur from the first to the fifth caudal, and are well developed. The bodies diminish slightly in length from the first to the fifth eaudal, beyond which they lengthen to the ninth, after which they again decrease in length. Eight ribs are directly attached to the sternum, which consists of seven to eight osseous pieces, the last long and narrow, and occasionally amalgamating with the smallest of the segments which immediately precedes it. It is capped by a broad halbert-shaped xyphoid cartilage resembling the manubrium in form. The manubrium at its lower end, and the various segments of the mesosternum, have each a well-marked epiphysis, and the sternal tips of the rib cartilages are capped with little ossicles in $R$. badius. The clavicle is strong and slightly outwardly and downwardly curved in its inner half, this head of the bone being large and rounded, while its acromial end expands, and is flattened from above downwards. In one skeleton of $R$. pruinosus a small ossicle occurs at the sternal end of the clavicle. In $R$. badius there are only six sternal segments and seven sternal ribs. The manubrium in both species resembles that of Siphneus, and is short and much expanded, so much so that it is broader than long, and is rounded anteriorly; hence it is very different from the form of this bone in Bathyergus and Georychus. It has a ventral ridge, rather well marked in one female, but nearly obsolete in a male skeleton. In a female, also, the manubrium is longer than broad, the lower end or shaft being well defined, while in a male it is extremely short-nay, almost absent. Although these two bones are markedly distinct, there can be no doubt of the specific identity of the two sexes, as they were both killed together. The manubrium in a female of $R$. badius has the same form as in the male of both species. 
The scapula of $R$. pruinosus and of $R$. badius are essentially like that of Siphneus, and when they are described as only more elongated and broader across the neck of the bone than in ordinary rats, some idea of their form will have been conveyed. The acromio-scapular notch is not so deep as in the rat, and the acromion is more forwardly projected than in that animal and has great expansion.

The os innominatum conforms to the Arvicoline type, but the thyroid foramen is much longer than in Siphneus, and the pubic and ischial bones are weaker and less expanded, the former being reduced to a narrow rod. There are also certain remarkable differences between the pelves of these two forms. In $R$. badius the thyroid foramen is quite as small as in Siphneus, and the symphysis pubis, which is rather deep in $R$. pruinosus, is the very opposite in the former species. In both, anchylosis has taken place through the intervention of a triangular epiphysis, but, even with the aid of this, the symphysis is not so deep as in MIus decumanus.

The sexual characters of the pelves of these species are very well defined, the transverse breadth of the symphysis being much greater in the female than in the male.

The skull has been described by Temminck, and its general characters indicated by A. M.-Edwards, so that nothing remains to be said under this head, except that the periotic bullæ are well developed on the posterior aspect of the skull, behind the auditory osseous tube. Three prominent transverse grooves occur on the anterior portion of the palate, immediately before the molars, and are succeeded by four much more obscure furrows between the teeth.

In a young example of $R$. pruinosus, Blyth, the incisor teeth are well exposed, but none of the upper or under molars have pierced the mucous covering of the jaw.

The tongue is oblong, and broad at its tip. The œsophagus is rather narrow, but its mucous lining is thrown into many fine, almost lamellar-like folds, which are continued a short way into the stomach along its dorsal wall.

The stomach of $R$. pruinosus when dilated shows a tendency to division into four sections. The first occurs to the left of the opening of the œsophagus, and is a

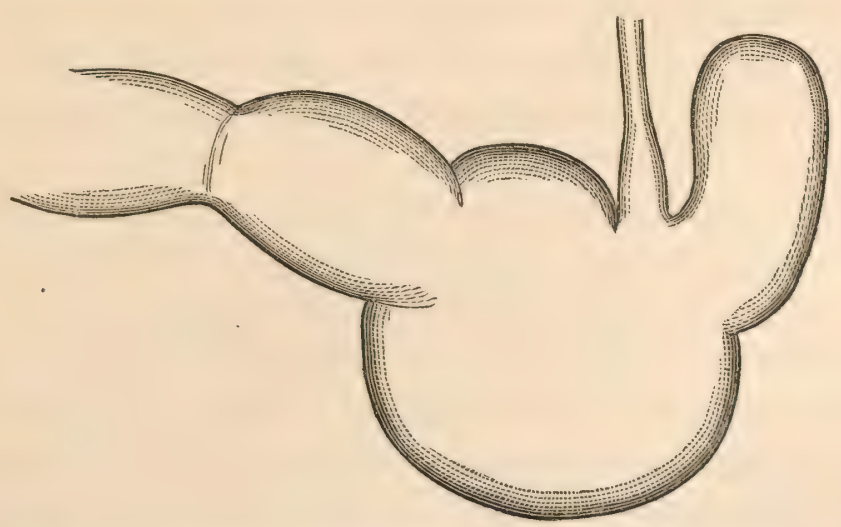

Fig. 11.-Stomach of Rhizomys pruinosus, Blyth. Nat. size, 
large $c u l$ de sac, which projects upwards along the side of the osophagus, and internally its walls are seen to be thick and to be quite different from the remainder of the stomachic wall. To the right of the œsophagus, there is a rounded eminence in the position of the sack which occurs in the stomach of the voles, and which probably will be detected also in fresh stomachs of Siphneus. Immediately below, and to the right of the swelling, there is a contraction which marks off the left limit of the pre-pyloric sack which is cylindrical and elongated. From this contraction to the base of the left cul de sac is the great cavity of the stomach.

The stomach of $R$. badius presents some well-marked modifications on these foregoing characters, and they are the more remarkable because the external features of the two species are so alike that they could not be supposed to imply internal structural differences of so considerable importance. In this form, the left cul de sac is evidently suppressed, and the swelling to the right of

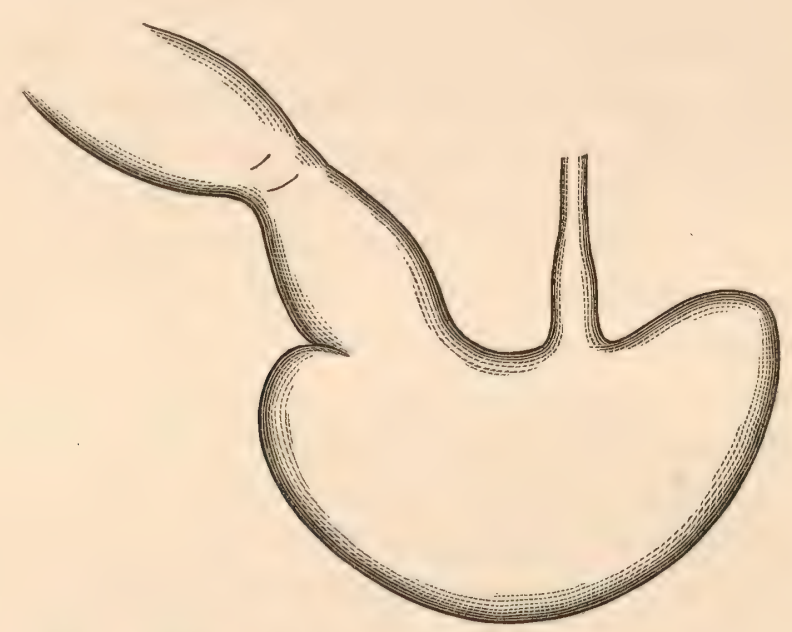

Fig. 12.-Stomach of Rhizomys badius, Hodg. Nat. size.

the osophagus is replaced by the lesser curvature which is extremely short, as there is a slight constriction at its right end and also on the right wall of the stomach on a level with the lesser curvature, marking the commencement of the pre-pyloric sack. With the exception of this last cavity, the stomach of $R$. badius is simple.

On laying open the stomach of $R$. pruinosus, the longitudinal folds of the cesophagus, as I have stated, are seen to be prolonged downwards, along the right margin of the base of the $\mathrm{cul}$ de sac, in the form of a distinct groove or canal similar to that which occurs in the stomach of Siphneus and of the Lemmings, and which is analogous to the canal in the ruminant stomach. The termination of the canal is marked by a raised border which is a continuation of the fringe which defines the limit to the right of the left cul de sac. A similar fringe occurs in the stomach of Siphneus. The walls of the left sack are thicker than any other part of the stomach, 
and the mucous membrane is very rough, being thrown into numerous fine tortuous rugæ, which are arranged more or less parallel to the long axis of the $c u l d e$ sac, and which become longer and better defined in parallel series, below the cardiac orifice. This structure exactly resembles that which A. M.-Edwards has described and figured in Siphneus.

In $R$. badius, on the other hand, although the $c u l$ de sac is absent, there is a decided, though partial, thickening of the walls to the left of the cardiac orifice, in the position in which the fringe occurs in $R$. pruinosus; but the inner surface, with the exception of a small area about a quarter of an inch square on the anterior wall of the cardiac end of the viscus, is quite smooth. This limited patch is covered with deep irregular rugæ.

The middle division, or general cavity of the stomach of $R$. pruinosus, is continuous with the swelling to the right of the asophagus, and both are glandular, but the walls are very thin and continuous with those of the prepyloric sack which is only separated from this cavity by a slight constriction. On the bulging to the right of the osophagus, there is a well-defined glandular patch, affined to that which occurs in the same locality in the stomach of the beaver. The pylorus is well indicated in both species by a decided thickening of the walls.

The first inch of the duodenum is covered with minute, leaf-shaped villi, and is studded over with solitary vesicular glands. As the small intestine approaches the cæcum, it contracts to half its general capacity. In an animal, $12 \cdot 25$ inches in length from the muzzle to the vent, the small intestine was only 30 inches in length, while the great gut attained to a length of 42.25 inches ; and in a female, measuring 11.50 inches long, the small intestine was 27.50 inches and the large 42.50 inches in length. In $R$.badius, however, there is not the same disproportion between the two sections of the digestive tube, because in a male of that species, 7 inches from muzzle to root of tail, the small intestine was 23.50 inches and the large intestine only 25 inches long. In the two foregoing examples of $R$. pruinosus, the cæecum, in the first, was 6.25 inches and in the latter 6 inches long, whilst in $R$. badius it was only $2 \cdot 10$ inches in length.

In both species, the structure of the cæcum is nearly the same, and it conforms to the characters displayed in Siphneus, and which recalls to mind the cæecum of the Leporida. The orifice of the small intestine is either an oval or rounded opening with a thickened rim or lip; and in $R$. pruinosus it is partially shut off from the cæcum by an arched fold of mucous membrane which arises from both sides of the wall of the large intestine, some way below the opening. The inner surface of the sack is marked by a broad fold describing from seven to eight spiral turns at regular intervals, the presence of the fold being indicated externally by spiral contractions of the wall of the cæcum. In $R$. badius the fold describes only four spiral turns. It commences on one side of the opening from the small intestine and arches closely over it, acting apparently as a kind of valve. Two folds arise close to each other from the lower margin of the orifice and pass downwards 
along the wall of the large intestines for a short distance, diverging as they pass downwards. These folds doubtless act in unison with the foregoing valve, and regulate the passage of the alimentary substances into the crecum. Between these spiral folds a few large and solitary dark-brown glandular bodies are scattered, and the apex of one is occupied by a puckering of the mucous membrane. length.

The pancreas is a long, almost filiform structure, nearly 2.50 inches in

The left segment of the liver in $R$. pruinosus consists of two lobes; the left lateral lobe is the largest and nearly twice the dimensions of the left central lobe which it underlies, its right margin underlapping the right central lobe of the right segment and abutting against the gall-bladder. It has a large auricular appendage. The left lateral fissure is very deep, nearly cutting through the organ. The left central lobe covers only one-half of the underlying lobe. The umbilical fissure is deep on the under surface of the organ. A cystic fissure is slightly indicated on the right central lobe, and the gall-bladder is small. The right lateral fissure is extremely deep, almost cutting off the right lobe of the right segment from its fellow. The right lateral lobe is cut by a fissure, which runs as a deep groove along its under surface. The Spigelian and caudate lobes are well defined.

The liver also of $R$. badius differs from that of $R$. pruinosus. The umbilical fissure is rather shallow, and the left lateral does not completely underlap the left central lobe. The gall-bladder is larger and lies at the base, but to the right of the umbilical fissure. The Spigelian lobe has a long auricular process, and the candate lobe gives off a small secondary lobe.

The heart of $R$. pruinosus is a rather elongated oval, with the left at a much lower level than the right auricle, both of these cavities being rather small; whereas in $R$. badius the heart is more oblong than oval, the apex being broad and partially bifid.

The left lung is simple, but the right lung is deeply divided into four lobes. The bronchial tube does not divide until it reaches the lung, and the bronchial cartilages are either simple or bifurcated plates, not meeting in the middle line posteriorly which is occupied by membrane.

The vagina is one and a half inches in length, and its wall is smooth; and the two horns of the uterus open into its fundus by separate os tince without the intervention of any common uterine cavity, so that in this respect Rhizomys conforms to the uterine structure of the Sciuridae and Leporide, and not to that of the Murida. The right horn in two examples-one of $R$. pruinosus and the other of $R$. badius-contained three embryos in the case of the former, and two in the case of the latter. Two large rounded superficial glands lie on each side of the vaginal orifice, and open at its lips, these orifices being marked by a long pencil of hairs.

In the male, the interval between the preputial orifice of the retracted penis and the anus is 0.70 inch, and the testicles show on each side of this interval as 
globular, nearly nude elevations, while the area around them is sparsely clad with long hairs. The equivalents of the vaginal glands lie on each side of the penis, and pour their buttery secretion into the bottom of the preputial fold, on the dorsal aspect of the penis. The glans penis is very minutely rugose, the rugosities tending to become spinous, as in some Murida, and it is coloured with a brown pigment. It is also supported by an ossicle 0.40 in length and which is much expanded at its base, and in form it has a great resemblance to a short metatarsal bone. The shaft is slender, but its upper border is concave from end to end. The vesicular glands are very large, and the Cowperian glands are compact and conical and opening into the bulbous portion of the urethra. The prostatic are small compared with the vesicular glands, and consist of flattened lobes. The uterus mascularis is about 0.10 of an inch in extent, and its orifice is situated in the centre of a small rounded papilla, on each side of which open the spermatic tubes.

With regard to external characters, there is a narrow nude area surrounding the eyes which are very small and buried in the fur and placed rather high on the head. The ears are simple, of moderate size and rounded; nude on their outer surface, with the exception of a dozen or so short or bristly hairs on their anterior margin, and their backs are very sparsely clad. They are of a pale flesh colour. The space between the superior incisors and the tip of the nose is perfectly nude, the skin being rosy flesh-coloured. A fold or furrow runs up from the outer margin of each incisor, the two converging in the middle, half-way between the incisors and the upper bare margin of the nose. From this convergence, a straight line passes upwards across the centre of the nose to the lip; but it gives off an upwardly and outwardly directed groove which passes to the inner margin of each nostril, and above this it is cut by a transverse furrow which connects the upper border of each nostril. The nostrils are rather small, and are directed upwards and outwards. The hair on the chin, and external to the nude nasal region is short and thick. The fore and hind limbs are well clad to the wrist and ankle, but beyond that the hairs are short and very sparse on the back of the feet and digits. The first finger is reduced to a tubercle, but is furnished with a claw. The first toe is moderately well developed, and has a claw like the other toes, the claws being longest on the hind feet. The digits generally are short and stout, and the inter-digital membrane extends to the extremity of the first phalanx. There is a small pad at the base of the 1st and 5th digits, and two smaller pads common to the other three. The pad at the base of the external toe is larger than the others. A very prominent globular cushion occupies the base of the wrist, and a pair of small tubercular cushions occur on the sole, side by side, immediately behind the digital pads. The tail is perfectly nude and there are no scales. It is thick at its root, and duskyfleshy in life. The under surface is markedly more imperfectly clad in the female than in the male, especially in the inguinal region and in the neighbourhood of the pectoral mammæ. There are five pairs of teats, three inguinal and two pectoral; but the anterior pair do not seem to be much used. In the male all the under parts are well clad. The colouring of the teeth is always most brilliant in the 
male, and more especially in the inferior incisors; while in the female the upper incisors are almost white, and the lower front teeth are richly coloured.

It has been stated that "the species of Rhizomys live on and not under the ground," but this account of their habits was given many years ago, and when no authentic information existed regarding their mode of life or distribution. Now, however, it is established that the members of this group are essentially burrowing animals. Their burrows are well known to the Kakhyens on the borders of Yunnan, who are great experts in unearthing them, digging and smoking them out of their subterranean dwellings for food. I have frequently been shown their burrows on the hill sides, and they were generally narrow tunnels run into the ground on the face of some little escarpment; but I can say nothing as to the details of their construction. These rats feed in the evening at sundown, and the contents of their stomachs reveal that their food is not confined to the tender shoots of the bamboo, as is generally supposed, but that the young shoots of other vegetable productions, as well as various grains, such as Indian-corn and rice, form considerable elements in their nutrition, and I have known them to eat mice in captivity.

The young are quiet and inoffensive, but the ferine adults, more especially the males, are very fierce and at once show fight without thinking of retreating, emitting a peculiar hissing grunt as they charge. The female also when in company of the young becomes greatly excited when captured; and I have seen one in these circumstances, when her own young were placed beside her, rapidly kill them off, one after the other, as they fondled her and searched for her teats to suck; but, on the other hand, in confinement I have known an adult female to be perfectly docile.

\section{Rhizomys sumatrensis, Raffles.}

Mus sumatrensis, Raffles, Trans. Linn. Soc. Lond. 1822 vol. xiii., p. 258.

Rhizomys sumatrensis, Raffles, Gray, Proc. Zool. Soc. Lond. 1831, p. 95.

Nyctocleptes dekan, Temminck, Bijdrag. Nat. Hist. vol. vii. Tab. i. figs. 1-5, et Monograph Mamm. 135-41 vol. ii., pp. 44 and 45; Gervais, Voyage de la Bonite, Zool. vol. i. 1841, p. 54, pl. x. et xi. figs. 1-3.

Spalax javanicus, Cuvier, Animal Kingdom, 2nd ed. 1829 vol. i., p. 211; Schreber's Säugeth. vol. iii., p. $367,1843$.

Rlizomys cinereus, M'Clelland, Cat. Journ. Nat. Hist. 1842 vol. ii., p. 457.

Rhizomys dekan, Temm., Schinz, Syn. Mamm., 1845 vol. ii., pp. 123-24 (in part).

Rhizonys sumatrensis, Rafles, Blyth, Cat. Mamm. As. Soc. Mus. Cal. 1863, p. 122.

This species was originally described by Raffles from a drawing made by Major Farquhar of a specimen obtained in Malacea, and which was forwarded, with the drawing, to Sir Stamford Raffles. Dr. MrClelland was under the impression that the drawing of Mus sumatrensis was deposited with the Asiatic Society of Bengal at Calcutta, and concluded; because he could not find it there, that it was lost. He also doubted the correctness of the identification of Dr. Gray's animal Rhizomys sumatrensis with that of Sir S. Raffles, and accordingly re-described the Malayan bamboo-rat or "dekan". under the name of $R$. cinereus. But Blyth, so 
long ago as 1841, pointed out that the drawing of Mis sumatrensis had not been deposited with the Calcutta Society, but with the Royal Asiatic Society of London, where it still remains, and where I have recently examined it. The specimen itself has not been traced.

Temminck considered that the term $R$. sumatrensis in being applied to the dekan was apt to mislead, as the typical specimen was from Malacca, and because the species had not been found to exist in Sumatra. He therefore changed the specific name, substituting the term dekan, the Malayan cognomen of the bamboo-rat; and in this change he has been followed by Gervais, Schinz, Giebel, and A. M.Edwards. But if the principle which guided Temminck were to be universally applied, it would only tend to burden the literature of these subjects with synonyms; and I do not think that this instance is so important as to call for a change of name. If there were any doubt regarding the identity of the form described by Raffles as Mus sumatrensis, and that described by Temminck as Nyctocleptes dekan, and all the records of the former were lost, the case would be different; but as the drawing of the former still exists, and is undoubtedly a representation of the dekan, it seems to me that the first name applied to the species should meet with the acceptance of zoologists. It must also be borne in mind that Raffles himself stated distinctly that the animal was found at Malacea, where it was known to the natives as dekan; but this term when applied to the species is liable even to a more serious objection than sumatrensis, because I have observed in an official catalogue that it has been construed and interpreted as indicating the habitat of the animal, assigning it to the Deccan of Central India, a province zoologically very distinct from Malayana, of which Sumatra forms a part. The British Museum specimens of this animal which I have examined leave no doubt as to their identity with the Mus sumatrensis of Raffles.

This species attains to a much greater size than any of the others: Raffles gives the dimensions of his animal as 17 inches, exclusive of the tail which was 6 inches long; and there are larger examples in the India Museum, London, and having much the same characters as those indicated by Raffles. In the young the head is more or less rufous, and sometimes even bright red; and the white spot on the vertex between the eyes is always present, either lying in, or succeeded by, the dark-brown band, which breaks up on the back into scattered brown hairs. The under parts are concolorous with the sides. In the adult, however, the rufous of the head and the white spot become fainter, and the brown band in some is either wholly lost or broken up into straggling hairs. In connection with the coloration of the head of the young, one is struck with its general resemblance to that of the nearly allied form, Siphneus.

The skull of $R$. sumatrensis, Raffles, is very large and massive, and distinguished from the other species of Rhizomys by the long, triangular, flattened and expanded frontal area, and the flattened and almost vertical character of the inner wall of the zygomatic fossa, which is rounded in $R$. pruinosus, Blyth, and more so in $R$. badius, Hodgson. The frontal contraction is also placed much posterior to 
the position which it occupies in R. pruinosus, Blyth, and much more so than in R. badius, Hodgson, so that the capacity of the posterior section of the braincase is relatively reduced to what that part attains in $R$. badius, Hodgson. The contraction occurs opposite to the posterior third of the zygomatic fossa in the adult, while in $R$. pruinosus it occupies the middle of that area. The nasals are more or less pointed posteriorly, and the premaxillary suture with the frontal, is anterior to their ends and nearly transverse. The muzzle is of variable breadth according to age and is perhaps also influenced by difference of sex, as adult skulls are met with in which it is broad in some and narrower in others.

This species extends from the Malayan peninsula northwards to Siam, where it has been obtained to the north of Bangkok. ${ }^{1}$

\section{RHIzomys erythrogenys, n. s. Plate XIITA.}

Quite recently, a living adult female bamboo-rat has been received by the Zoological Gardens, Calcutta, from Mr. A. H. Hildebrand, Assistant Commissioner, Burma. No details regarding the habitat of the animal have been as yet received, beyond that it had been found in the Salwin Hill Tracts.

McLelland's description of $R$. cinereus does not agree with this specimen, and is more applicable to $R$. sumatrensis. I have therefore indicated this species by its most distinctive feature, viz., its light red cheeks. I should not have done so on this an isolated example, but on looking over the specimens of bamboo-rats in the Indian Museum, I found a specimen, the counterpart of this living animal, apparently specifically distinct from $R$. sumatrensis. This specimen came from Tenasserim.

This form is distinguished from $S$. sumatrensis by its bright golden-red cheeks and sides of the head generally, by the absence of white spots on the forehead, and by the dark iron-grey of the upper parts (many of the hairs being white-tipped) becoming almost black on the top of the head, where it abruptly ceases between the eyes in a sharp well-defined point. The upper lip, chin, and upper part of throat are white, also the chest and belly, which are, however, more or less tinged with grey and reddish. The lower portion of throat is dark-grey. The feet are sparsely clad and leaden coloured, except the toes of hind foot, which are fleshy white. The tail is rather thick at the base, quite naked, not scaly, and of a leaden hue. Claws rather broad and moderately strong.

\section{Measurements of the living adult o specimen.}

Tip of nose to ending of hair over root of tail
Ending of hair of body to tip of tail




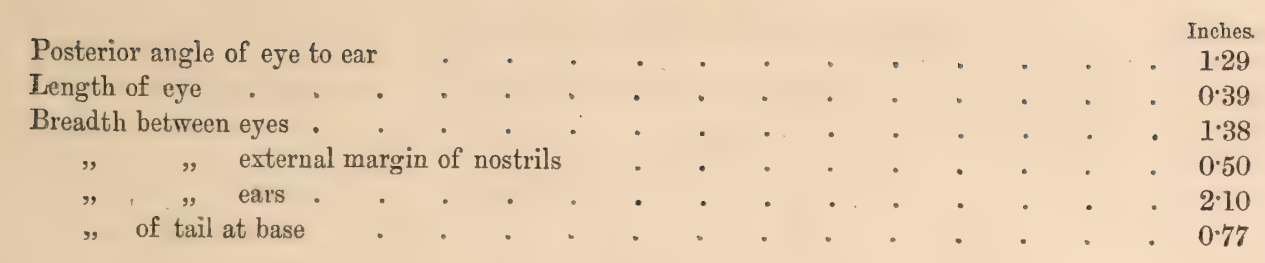

*Rhizomrs pruinosus, Blyth. Plates XIII \& XVI.

Rhizomys pruinosus, Blyth, Journ. As. Soc. Beng. 1851 vol. xx., p. 519, et Cat. Mamm. As. Soc. Beng. 1863, p. 122.

Blyth first obtained this species from Chárápunji, where it is extremely common, and I found it equally abundant on the Kakhyen hills to the east of Bhamô, where it is associated with $R$. castaneus, Blyth, which is only a brightly coloured eastern race of $R$. badius, Hodg., of Nepal. It ranges to the eastward as far as Cambodja, and is represented in the British Museum by two specimens which were obtained there by Mouhot. It does not appear to exist in the high, treeless region about Teng-yue-chow in the province of Yunnan, where the rounded hills are covered only with short grass and bracken.

In the India Museum, London, there is a specimen of a Rhizomys, which was obtained by the Schlagintweits on their mission to Tibet. It is now much faded in its colours, but it has all the external characters of $R$. pruinosus, Blyth. I have examined the list of Mammalia collected by these travellers, but although this bamboo-rat is mentioned, the locality from whence it is obtained is not stated. It measures 8.60 in length from muzzle to the root of the tail, the tail being 2.50 long.

The base of the fur is pale slaty, its terminal half being brown; but scattered very plentifully amongst it are longer hairs which have their ends terminating in broad white bands, so that the animal presents a grizzled appearance on the upper surface. On the under parts, the fur is nearly the same as superiorly, but the whitetipped hairs are shorter and much less numerous. The whiskers are dark-brown. On the head generally, but more especially on the sides of the face, the bases of the hairs, in the majority of specimens, pale into an almost whity-grey, and where the fur on the sides of the head is abraded, as it frequently is, this light under tint becomes visible. In some old females, the sides of the face, the muzzle and the chin, are very pale owing to the tips of the hair being of a light-brown tint, and in such examples the whole coat of fur is of a paler hue than in the generality of specimens, and as the white-tipped hairs are not so numerous, they have less of the mottled appearance and are of an almost uniform light greyish-brown with the under surfaces even paler. I have observed this only in old females, but whether it is sexual, I am not in a position to say. The ears, nose, feet, and tail have a dusky flesh tint, and the tail is about one-third the length of the body. The foot-pads are covered with flattened tubercles. In the young the teeth are but little coloured, except at the bases of the lower incisors, the tips of which are nearly white.

The female appears to produce from three to four at a birth. 


\begin{tabular}{|c|c|c|c|c|c|c|c|c|c|c|c|c|c|c|c|}
\hline \multirow[b]{3}{*}{ Muzzle to vent } & \multirow[b]{3}{*}{ • } & \multirow[b]{3}{*}{ - } & \multirow[b]{3}{*}{. } & \multirow[b]{3}{*}{ • } & \multirow{3}{*}{. } & \multirow[b]{3}{*}{. } & \multirow[b]{3}{*}{. } & \multirow[b]{3}{*}{ - } & \multirow[b]{3}{*}{. } & \multirow[b]{3}{*}{ • } & \multirow[b]{3}{*}{$\therefore$} & \multirow[b]{3}{*}{ - } & \multirow[b]{3}{*}{. } & \multirow{3}{*}{$\begin{array}{c}\text { ᄒ } \\
\text { Inches. } \\
13 \cdot 00\end{array}$} & \multirow{3}{*}{ 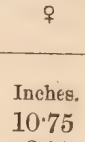 } \\
\hline & & & & & & & & & & & & & & & \\
\hline & & & & & & & & & & & & & & & \\
\hline Length of tail & . & - & - & - & . & - & - & - & - & - & . & . & . & $4: 00$ & $3 \cdot 75$ \\
\hline$"$ of fore foot. & - & . & - & . & - & - & - & - & - & . & • & . & - & $1 \cdot 60$ & 1.59 \\
\hline$"$ of first toe. & - &.$^{\cdot}$ & . & - & - & - & - & - & . & $\therefore$ & . & . & . & $0 \cdot 15$ & $0 \cdot 14$ \\
\hline " of middle finger & . & - & - & - & . & . & . & . & - & : & • & . & . & $0 \cdot 80$ & 0.71 \\
\hline ", of hind foot & - & . & . & - & . & . & . & . & . & . & . & . & . & $2 \cdot 20$ & 1.95 \\
\hline " of first toe & . & . & • & • & - & - & . & . & . & - & . & - & . & 0.40 & $0: 36$ \\
\hline " of middle toe & $\therefore$ & - & - & - & - & - & . & - & - & . & . & - & . & 0.75 & 0.70 \\
\hline Eye to eye, inner angle & (cal & ipers) & - & . & . & . & - & - & - & . & - & . & . & $1 \cdot 18$ & $1 \cdot 00$ \\
\hline "to ear (callipers) & . & . & - & . & - & - & - & - & . & • & . & . & - & $1 \cdot 20$ & $1 \cdot 10$ \\
\hline Ear to ear (callipers) & . & . & . & . & . & - & . & - & . & . & . & . & . & $2 \cdot 00$ & 1.70 \\
\hline
\end{tabular}

The skull of R.pruinosus, Blyth (see Plate XVI, figs. 1-3), is very distinct from that of $R$. badius, Hodg., from which it is distinguished by its much greater size and by the flattening and expansion of the frontal region behind the nasals and by the backward prolongation of the ridges from the external orbital angle of the frontal which form nearly one-half of the upper and inner margin of the zygomatic fossa, while in R. badius, Hodg., these ridges being directed inwards to the middle line unite immediately behind the nasal bones. In $R$. pruinosus, Blyth, the premaxillaries do not extend behind these bones, while in R. badius, Hodg., they do, and almost embrace their hinder extremities. The frontal contraction also of $R$. pruinosus, Blyth, is situated much farther back than in $R$. badius, Hodg., so that the posterior division of the brain-case is much more truncated than in the latter species. The zygomatic arch also is more rounded and outwardly projected in the latter. In R. pruinosus, Blyth, the surface of the palate, immediately behind the premaxillary foramina, is broad and rather deeply excavated, the concavity being laterally defined by two well marked ridges, while in $R$. badius, Hodg., there is no such concavity, the mesial line being occupied by the elevated and rounded margins of the palatine surfaces of the maxillæ. The palatine surfaces of the palatines of $R$. pruinosus, Blyth, are flat, and expanded, and on the same plane with the similar surface of the premaxillaries the mesial line of union of which is not marked by any median ridge, whereas in $R$. badius, Hodg., the palatine surface of the maxillaries is rather deeply concave from side to side, and the mesial line is occupied by a ridge, the same aspect of the palatines being considerably reduced, much transversely concave, and sloped upwards and backwards, the wings of the sphenoid being considerably less divergent than in $R$. pruinosus, Blyth. These differences at once suffice to separate $R$. badius, Hodg., and $R$. minor, Gray, from $R$. pruinosus, Blyth, and they confer an altogether different conformation on the opening of the posterior nares to that which distinguishes $R$. pruinosus, Blyth, in which the palatine margin is broad and transverse, while in these two other species it is narrow and arched. The nearest ally of the skull of $R$. prinosus, Blyth, would appear to be the skull of $R$. sinensis, Gray, which has the flattened palate and the expanded frontal region of this species, but differs from it in its narrower palate, shorter and broader muzzle, 
and in the ridges from the external angle of the frontal being divergent from each other as far back as the occipital ridge, whilst in $R$. pruinosus they are confluent at the anterior extremity of the parietals. It differs from $R$. sumatrensis, Raffles, in its less expanded frontal region, in the greater contraction of the frontoparietal area, which is much further forward than in that species, and the much narrower and less massive character of the skull. In $R$. sumatrensis, Raffles, the greatest breadth across the zygomatic arch considerably exceeds the distance between the anterior border of the premaxillaries and the hinder margin of the articular surface for the lower jaw, whilst in $R$. pruinosus, Blyth, it may fall short of that interval, but never exceeds it. The area behind the premaxillary foramina is much more concave than in $R$. sumatrensis, Raffles, and the palate of that species is concave and the posterior nares more expanded, but the palatine is in the same plane with the maxillaries. The nasals in $R$. sumatrensis are pointed posteriorly, with the maxillo-premaxillary suture some distance anterior to the extremities, and they are much more laterally expanded than in R. pruinosus, Blyth, and the sides of the osseous muzzle of the former are vertical from a ridge external to the nasals, whereas in $R$. pruinosus the ridge is absent, and the sides of the muzzle are convex. In these latter details regarding the muzzle, $R$. badius, Hodg., $R$. minor, Gray, and $R$. sinensis, Gray, agree more with this species than with $R$. sumatrensis. The alveolar border is longer in $R$. pruinosus than in the latter, and the teeth are larger.

This species does not appear to attain to the same size as $R$. sumatrensis, Raffles, but it greatly exceeds the dimensions of $R$. badius, and of course is greatly larger than R. minor, Gray.

Measurements of skulls of t and $q R$. pruinosus, Blyth, and $R$. badius, Hodgson :-

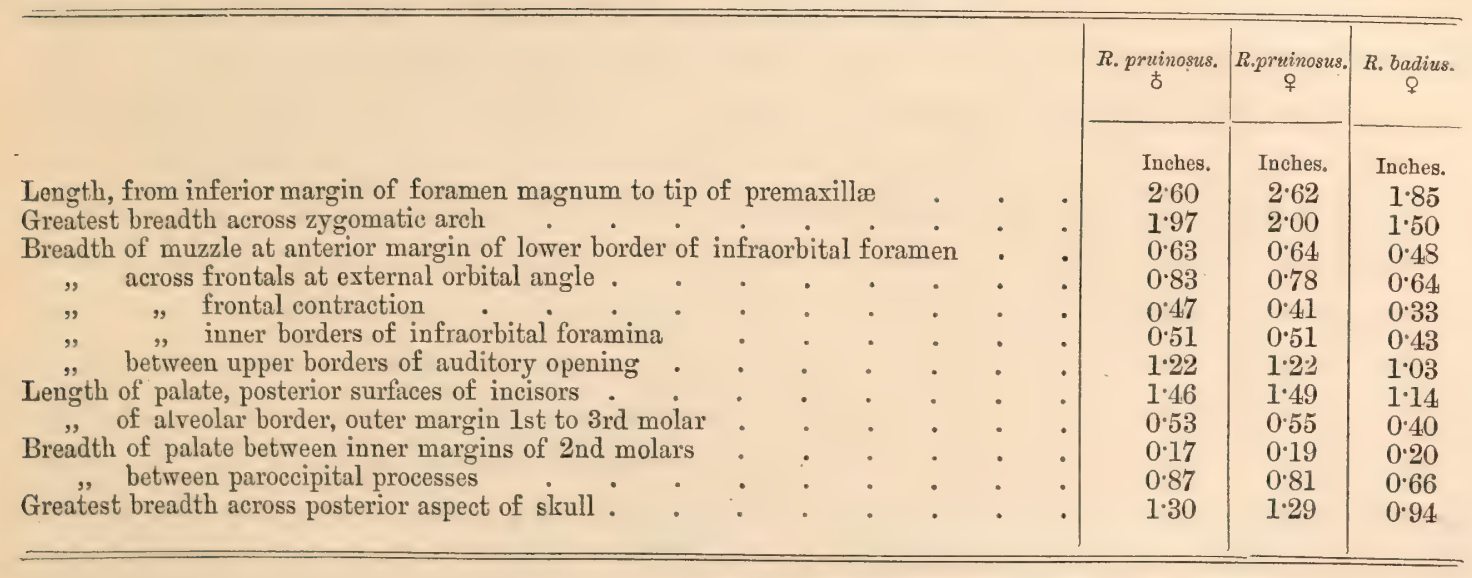

\section{Rhizonrys minor, Gray. Plates XV \& XVI.}

Rhizonys minor, Gray, Ann. and Mag. Nat. Hist. 1842 vol. x., p. 266.

Rhizomys minor, Horsfield, Cat. Mamm. E. Ind. Co.'s Mus. 1851, p. 165.

Rlizomys minor; Schinz, Syn. Mamm. 1845 vol, ii., p. 126. 
Dr. Gray, when he described this species, was uncertain whether it inhabited India or Cochin China, but in the India Museum, London, there is a bamboo-rat bearing this name of $R$. minor, Gray, and which was brought from Siam by Dr. Finlayson, a member of Crawford's mission to Cochin China and Siam. There is also in the British Museum a specimen resembling this Siam rat-mole, and which is stated to have been procured by M. Mouhot in Cambodja. Dr. Horsfield doubtfully includes the thur of the Siamese, which Dr. Gray had considered to be $R$. badius, as a synonym of $R$. minor, but he expresses no dubiety regarding the specific identity of his Siam animal with that of $R$. minor, Gray. Dr. Gray, in his communication to the Annals and Magazine of Natural History in 1842, mentions that only some of the new animals therein described were in the National Collection, and it may therefore be, as he suggested, that Cochin China was the habitat of $R$. minor, that the specimen now in the India Museum from Siam is the type of the species; and that Dr. Gray erroneously named Cochin China instead of Siam as the locality from whence it was obtained, as Crawford's embassy was known as a mission to Cochin China. This view of the question is strengthened by the circumstance that the India Museum specimen exactly agrees with Dr. Gray's measurements of his type and with his description.

Both specimens may be described as dark sooty-brown, slightly tinged with deep umber which is most distinct on the sides of the head and neck and in reflected lights, but is least marked in the Cambodja specimen. The under parts are like the upper, only the brown tint is almost absent. The whiskers are black, and the tail has been very sparsely haired, as in $R$. castaneus and $R$. badius.

Dr. Gray's type measured 6.50 inches from the muzzle to the root of the tail, and the tail was 1.75 inches in length, which are the measurements of the India Museum specimen. The example in the British Museum from Cambodja is 7.30 inches in the former, and $2 \cdot 20$ in the latter of these two measurements. The skull of the larger specimen is considerably smaller than the skull of adult examples of R. badius, so that it is probable that the species does not attain to the size of the latter. It is also closely allied to $R$. badius, as is evidenced by the strong similarity of the skull to the skull of that species, but the colour of the fur is pronouncedly different. The skull in the British Museum removed from the Cambodja specimen (Plate XVI, figs. 7-9) differs from the skull of $R$. badius in its smaller breadth across the zygomatic arch and in the expansion and flattening of the frontal region. The palatal surface across the premaxillary foramina is broader than in $R$. badius, and there is a rather prominent ridge running along its outer wall to the outside of the base of the front molar. The palatal surface is also broader than in $R$. badius, and the alveolar border is much longer than in that species, and the muzzle also is somewhat longer and the infraorbital foramen larger. The palatal border of the posterior nares is much more contracted than in the other species, the ends of the palatines being divergent at a very acute angle, and it is placed more anteriorly than in the other species, being opposite to the middle of the last molar. 
The small bamboo-rat obtained by M. Boucourt from Sarabari to the north of Bangkok and referred by A. M.-Edwards ${ }^{1}$ to $R$. badius appears to be this species.

\section{*Rhizomys badius, Hodgson. Plates XIV \& XVI.}

Rhizomys badius, Hodgson, Cal. Journ. Nat. Hist. 1842, vol. ii. pp. 60, 410; Gray, List Mamm. B. M. ]843, p. 150 ; Gray, Cat. Hodgson's Coll. 1845, p. 24; Blyth, Journ. As. Soc. Bengal, 1843, vol. xii. p. 925; Blyth, Cat. Mamm. As. Soc. Mus. Cal. 1863, p. 122 ; Horsfield, Cat. Mamm. E. Ind. Co.'s Mus. 1851, p. 165 ; Schinz, Syn. Mamm. 1845, vol. ii. p. 126 ; Jerdon, Mamm. Ind. 1867, p. 214.

Rhizomys castaneus, Blyth, Journ. As. Soc. Bengal, 184.3, vol. xii. p. 1007 ; Cat. Mamm. Mus. As. Soc. Bengal, 1863, p. 123.

This species was first discovered by Hodgson in Nepal and afterwards obtained by Blyth in Arracan. It would appear as if the Himalayan examples were generally somewhat duller in colour than those from Arracan and Burma, and this difference led Blyth to regard the eastern race as a distinct species, but there are no facts to support such a conclusion.

It does not attain to the size of $R$. pruinosus, and the tail is little more than one-third the length of the body, and has a more abruptly truncated end than $R$. pruinosus, from which it is also easily distinguished by its rather brightly coloured chestnut fur. It is also separated from that species by the absence of the tubercles on the feet.

The fur is fine, and uniformly grey in two-thirds of its extent, the apical third being some shade of chestnut which is especially brilliant in the animals I procured in the Kakhyen hills, most intense on the head, and dullest on the rump. The fur of the under parts, in these eastern examples of the species, is paler and more reddish than chestnut, whereas in some Nepal animals it inclines even to slatygrey, washed with reddish. The area immediately around the muzzle and the chin is pale brownish with a tinge of greyish, and the teeth are brilliant reddish, the nose, ears, feet, and tail being pale flesh-coloured.

Skulls of this species (Plate XVI, figs. 4-6) manifest considerable variation in some of the minor details of their structure, such as in the length of the facial portion of the premaxillaries and the extent of the backward prolongation of the nasals. In some skulls, the posterior ends of the latter bones are rounded, while in others they are rather abruptly truncated. Occasionally the premaxillaries are prolonged behind the nasals and touch the ridge proceeding from the external angle of the frontal, whilst in other skulls they do not extend so far back. The external angles of the frontals are also much less prominent and less nodular in some than in others in which they swell more into the area anterior to the frontal contraction. In some skulls also there is a somewhat flattened area between the superior orbital angles, which is all but lost in others. 
This is a not uncommon species in the Kakhyen hills to the east of Bhamô, where it is associated with $R$. pruinosus, which is more prevalent. It constructs its burrows among a rank and tall jungle grass, on the roots of which it is said to live. It is known to the Chingpaws or Kakhyens as the Yewcron.

Measurements of $R$. badius, Hodgson.

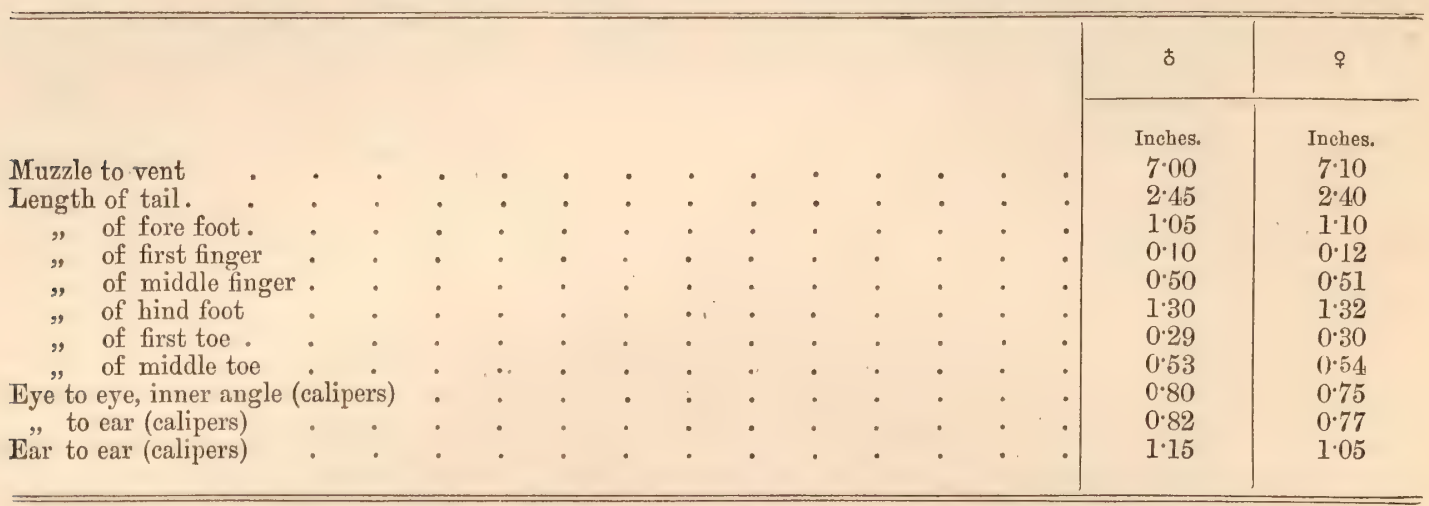

\section{Rhizomys sinensis, Gray.}

Rhizomys sinensis, Gray, Proc. Zool. Soc. Lond. 1831, p. 95, et Ill. Ind. Zool. ii. pl. xvi.; Schreber, Säugeth. 1843, vol. iii. p. 367 ; Swinhoe, Proc. Zool. Soc. 1870, p. 637.

Thizomys dekan, Schinz (in part), Syn. Mamm. 1845, vol. ii. p. 124.

Rhizomys vestitus, A. M.-Edwards, Nouv. Arch. du Mus. 1871, p. 93, et Rech. des Mammif. 1874, p. 292, pl. xlvi.

The fur is very thick and dense, easily reversible, fine and silky. The basal portion is pure grey, and the tips are pale brownish with a rich shining lustre. The brownish hue is most marked on the sides of the face below the ear, and on the front of the head, but in the younger example the area of the sides of the head and of the chin and throat to the side of the muzzle is grey, approaching to white. The under parts are much the same as the upper. The claws of both feet are strong and olive-brown. The foot-pads appear to be smooth.

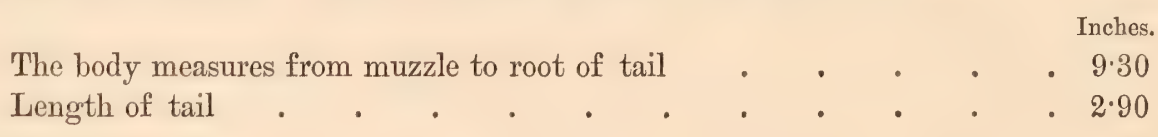

Dr. Günther obligingly had the skull of $R$. sinensis removed from the skin of the larger of Dr. Gray's types of this species, and I have carefully compared it with the figure of the skull of $R$. vestitus. The only perceptible difference that it presents on the skull as figured by A. M.-Edwards is that the post-orbital contraction is more marked, and that thus the temporal ridges are earlier confluent than in $R$. vestitus, but this contraction is not carried to a greater degree than occurs among skulls of $R$. pruinosus and the other species of Rhizomys. It agrees with $R$. vestitus in the long continuous transverse suture formed by the confluence of the nasal premaxillary and maxillary bones with the frontal, and 
which is a notable feature in $R$. vestitus. It also resembles that skull in the great breadth which it presents across the posterior roots of the zygomatic arches, in the form of its nasals and the palatal surface, and in its dentition. These facts, taken in conjunction with the similarity of the fur of $R$. sinensis and $R$. vestitus in colour and texture, the length of the tails of the two supposed species, and the circumstance that they are both inhabitants of China, $R$. sinensis having been procured at Canton, and $R$. vestitus in Central China, seem to me to indicate that they are one and the same.

Since the above remarks were written, I have examined the skull and the type specimen of $R$. vestitus, and my examination of these has confirmed me in the opinion I have just stated. 


\section{HYSTRICID AE.}

\section{Genus Hratrix, Linn.}

* HYSTRIX yUNNANENSIS, n. s.

The porcupine which occurs in the high valleys and on the mountains to the east of the Kakhyen hills resembles the common porcupine of Lower Bengal in the possession of a nuchal crest, but it is at the same time markedly distinct from it in the size and relations of its nasals which conform to the type represented by H. (Acanthion) javanica. It is thus closely allied to H. javanica, ${ }^{1}$ from which it is distinguished by the presence of its moderately well developed crest, which, however, is very small compared with the great crest of H. leucura, ${ }^{2}$ but large contrasted with the few seattered longer hairs of $H$. longicauda, ${ }^{3}$ and shorter than the crest of $H$. bengalensis." In its crest it apparently closely resembles $H$. subcristata, Swinhoe, ${ }^{5}$ from China, and had not Swinhoe stated that the skull of $H$. subcristata is very similar in form to the skull of $H$. hodgsoni, Gray, ${ }^{6} \mathrm{I}$ would have been disposed to consider this Western Yunnan porcupine as H. subcristata; but as its skull is that of an Acanthion, it is impossible, in view of Swinhoe's statement, to consider them as the same species. I have therefore no alternative but to describe the Yunnan form as distinct.

Dark brown on the head, neck, shoulders and sides, passing into deep black on the extremities, a very narrow white line passing backwards from behind the angle of the mouth to the shoulder; under surface brownish. The spiny hairs of the anterior part of the trunk flattened, grooved, or ungrooved. The crest begins behind the occiput and terminates before the shoulders; the hairs are long, slender, and backwardly curved, the generality of them being about $4 \frac{1}{2}$ inches long, while the longer hairs measure about 6 inches. They are all paler than the surrounding hairs, and the individual hairs are either broadly tipped with yellowish-white, or they have a broad sub-apical band of that colour. The short broad spiny hairs lying a short way in front of the quills are yellow at their bases, the remaining portion being deep brown, whereas those more quill-like spiny hairs, immediately before the quills, have both ends yellow-tipped. The quills are wholly yellow, with the exception of a dark brown, almost black band, of variable breadth and position. It is very broad in the shorter quills, and is nearer the free end of the quill than its base; whereas, in the long and slender quills, it is reduced to a narrow mesial band. The stout strong quills rarely exceed 6 inches in length, whilst the slender quills are 1 foot long. Posteriorly, above the tail and at its sides, many of the short quills are pure white. The modified quills on the tail, with dilated barb-like free ends, are not numerous, and are also white. There are three kinds of rattle-quills:

${ }^{1}$ F. Cuv. : Mém. du Mus., vol. ix, 1822, pp. 425 and 431, 'l'ab. 20, bis. figs. 3 and 4, skull.

${ }^{2}$ Proc. Zool. Soc., July 1831, p. 103.

Marsden: Hist. Sum., 1810, p. 118, Plate xiii, n. 1.
${ }^{4}$ Blyth : Journ. As. Soc. Bengal, vol. xx, 1852, p. 170.

${ }^{5}$ Proc. Zool. Soc., Lond., 1870, p. 638.

${ }^{6}$ Proc. Zool. Soc., Lond., June 1847, p. 101. 
the most numerous measure $0.65^{\prime \prime}$ in the length of the dilated hollow part, having a maximum breadth of $0.21^{\prime \prime}$, whilst there are a few short cups $0.38^{\prime \prime}$ in length and with a breadth of $0 \cdot 17^{\prime \prime}$, and besides these a very few more elongated and narrow cylinders occur. The hind foot measures 3 inches in length to the end of the claws.

The distinguishing features of the skull of this species, as in Hystrix (A.) javanica, are the nasals stopping short posteriorly, considerably anterior to the orbit, and even before the anterior angle of the external portion of the lachrymal; the nearly equal breadth maintained by the nasals throughout their length; also the greater breadth of the naso-frontal portion of the premaxillary, the posterior margin of which is considerably anterior to the first molar, whereas in $H$. bengalensis, as in H. longicauda, it is in a line with the posterior border of the first molar, the point in a line with which are the posterior borders of the nasals of $H$. yunnanensis. The posterior margins of the nasals of $H$. longicauda are in a line with the middle of the third molar, whilst in H. bengalensis they occupy nearly the same relation to the molar teeth. In $H$. longicauda they are much behind the posterior superior angle of the lachrymal, whereas in $H$. bengalensis they are in a line with it. The nasals of $L$. longicauda and $H$. bengalensis are considerably longer than the nasals of this species, and they are largest in H. bengalensis. In both they are considerably broader, more especially posteriorly, and in H. longicanda they are broader than in $H$. bengalensis. The skull is also distinguished from the skulls of both these porcupines by the much greater length of the frontals. Their greatest length on the upper surface nearly equals the length of the nasals, whereas in H. longicauda it falls short of one-half of the length of these bones, while in II. bengalensis it equals one-half. In H. yunnanensis the length of the parietals in the mesial line equals about one-half of the length of the frontals before them, whilst in H. longicauda that measurement is nearly as long as the frontals, whereas in $H$. bengalensis the parietals are shorter than in H. longicauda, indeed so short that their mesial length does not equal one-half of the length of the frontals.

The teeth do not appear to yield any characters that would enable us to distinguish this porcupine from the species with which I have compared it. The upper incisors show a tendency to longitudinal grooving and to the formation of nearly three distinct furrows, but this is also occasionally developed in H. leucura.

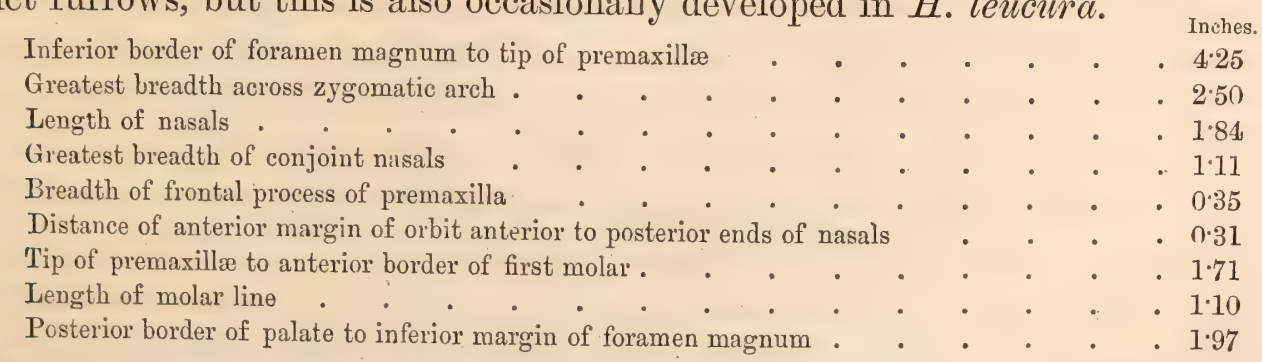

This species is not at all uncommon in the elevated region (2,000 to 4,500 feet) to the east of the Kakhyen hills.

In the Indian Museum, Calcutta, there is a specimen sent by Hodgson from Nepal of a poreupine which he named H. alophous. ${ }^{1}$ It is entirely destitute of a 'Journ, As. Soc. Beng. vol. xvi. 1847, p. 771, Plate 32. 
crest, with the exception of a few longer white-tipped bristly hairs which can be detected on the upper surface of the neck. These hairs are more feebly developed than in a porcupine from Malacea corresponding to the figure and description of Acanthochcrus grotei, Gray, ${ }^{1}$ and which appears to be identical with $H$. longicauda, Marsden, as pointed out by Dr. Sclater. ${ }^{2}$ There is also in the same Museum a fresh skin from Darjeeling with a rudimentary crest consisting of a line about three inches long of longer spiny hairs with white tips, the longest hair measuring $2 \cdot 75$ inches. The general colour of this skin is dark, rather blackish-brown, the white pectoral band not being very broad. The colour is distributed on the quills in the same way as in $H$. longicauda. The skull of this Nepal porcupine, however, presents some differences on the skull of H. longicauda from Malacca, chiefly in the form of the nasals. In the latter, the nasals extend backwards only a short way behind the lachrymal, whereas in the former, they extend backwards on a line nearly with the middle of the temporal fossa. The breadth, however, of these bones, opposite the frontal processes of the premaxillæ, is the same in both of these skulls, but anteriorly the nasals of the Malacca skull are much broader than those of the Nepal skull. In the latter, these bones also are considerably arched from side to side, whereas in the Malacca skull they are flattened both posteriorly and anteriorly. The skull of the skin from Darjeeling has the short nasals of the Malacea skull, and another skull from the same locality exactly resembles it, but these two Darjeeling skulls are imperfect. They both differ from the Malacca skull in the much less breadth of the muzzle at the base, and they are both remarkably distinct from the skull of the porcupine sent by Hodgson from Nepal as $H$. alophous, so much so that I am disposed to believe that there are two species of obscurely crested porcupines in the Himalaya, one an eastern and the other a western form. Hodgson, in his description of $H$. alophous from Nepal, refers to its long bluff nose, the length of the muzzle being a feature of the skull of the porcupine sent by him from Nepal under that name, and which I suppose is identical with the species from Nepal which he first enumerated under the name of H. nepalensis. Notwithstanding the difference in the breadth of their muzzles as compared with the Malacea porcupine $H$. longicauda, their distinctness from it is still doubtful, and I cannot determine with the limited materials at my disposal that they are specifically identical with these Darjeeling skulls, unless the nasals and facial portion of the skull of porcupines are subject to much greater variation in form th an has hitherto been supposed. This view of the question would seem to be suppor ted by the strong external resemblance which they present in the character and coloration of their armature generally. Even H. bengalensis, Blyth, would seem to differ from H. longicauda chiefly in the more marked crest which it developes, as the colour distribution is the same in both; and this remark is also applicable, as far as external characters go, to $H$. hodgsoni and to the Darjeeling porcupines, and also to $H$. yunnanensis.

$$
\text { ' Proc. Zool. Soc. Lond. 1866, Plate xxxi. p. } 306 . \quad \text { 2 Proc. Zool. Soc. Lond. 1871, p. } 23 .
$$




\section{RUMINANTIA.}

Genus Nemorhedus, Ham. Smith.

* Nemorhedus bubalina, Hodgson.

Antelope bubalina, Hodg. Proc. Zool. Soc. Lond. 1832, p. 12.

Antelope thar', Hodg. Proc. Zool. Soc. Lond. 1833, p. 105 ; ibid. 1834, p. 99 ; Journ. As. Soc. Beng. vol. i. 1832, p. 346 ; ibid. vol. iv. 1835 , p. 489.

Namorhedus thar, Hodg. Proc. Zool. Soc. Lond. 1834, p. 86 ; Journ. As. Soc. Beng. vol. iv. 1835, p. 489 .

Citpricornis thur, Ogilby, Proc. Zool. Soc. Lond. 1836, p. 139.

Kemas proclivus vel thar, Hodg. Journ. As. Soc. Beng. 1841, vol. x. p. 913 ; Cal. Journ. Nat. Hist. vol. iv. 1844, p. 291.

Capricornis bubalina, Gray, List Mamm. Brit. Mus. 1843, p. 166 et ibid.1873, p. 91 ; Cat. Mamm. etc. Nepal, 1846, p. 27 ; Ann. and Mag. Nat. Hist. 1846, vol. xviii. p. 232 ; Proc. Zool. Soc. Lond. 1850, p. 135 ; Cat. Mamm. pt. iii. Brit. Mus. 1852, p. 111 ; E. Ind. Co.'s Mus. 1851, p. 168; Horsfield, Cat. Mamm. Proc. Zool. Soc. Lond. 1856, p. 403; A. S. Adams, Proc. Zool. Soc. Lond. 1858, p. 522 ; Blyth, Cat. Mamm. As. Soc. Mus. 1863, p. 174.

Nemorhedus bubalina, Jerd. Mamm. Ind. 1867, p. 283.

In the valley of Sanda, in the western province of Yunnan, I obtained two skins of two species of goat-antelope, one of which agrees with Hodgson's type in the British Museum, with which I have compared it, whilst the other appears to be an example of the next species to be described. These goat-antelopes are not uncommon on the precipitous higher ranges of mountains which rise to an elevation of 6,000 to 7,000 feet, and which are only very partially clad with forest in the ravines and hollows.

The animal is known to the Leesaws of the Sanda valley as the Nga, to the Shans as Paypa, and to the Chinese as Shanli.

\section{* NeMorhedus EDWARDSII, David.}

Capricornis Milne-edwardsii, A. David, Nouv. Arch. du Mus. 1869, t. v. Bull. p. 10.

N'amorhedus edwardsii, A. David, Nouv. Arch. du Mus. t. vii. Bull. p. 90.

Antelope (Namorhedus) edwardsii, A. M.-Edw. Rech. des. Mammif. 1868 et 1874, p. 364, pls. xlii. et xliii.

This species is distinguished from $N$. bubalina by the uniform brownish-black colour of the upper parts, which tends to ferruginous on the thighs, and by the red colour of the lower parts of the legs, which are grey in H. bubalina. It is 
evidently very closely allied to the latter, so much so that A. M.-Edwards is inclined to consider it as only a local race of that species. But on comparing five skulls of the two sexes of $N$. bubalina as determined by Hodgson with A. Milne-Edwards' figure of the skull of $N$. edwardsii, I observe that all of these five crania agree in having less vertical depth through the preorbital area than $N$. edwardsii, which is due to the downwardly arched character of the alveolar border of the latter, especially at its middle, whereas in $N$. bubalina this border is nearly straight. The edentulous portion of the maxilla and premaxilla appears also to be longer in $N$. bubalina, but it is impossible to say whether the characters presented by the typical skull of $N$. edwardsii are persistently present.

Blyth has compared skulls of goat-antelopes from Sumatra, Arracan, and Mergui, but could not detect any distinguishing. characters, and he found that they differed little from $N$. bubalina of the Himalaya, except in being considerably smaller.

The coat of this supposed example of $N$. edwardsii is much more profuse and black than in any specimens of $N$. bubalina that have come under my observation, but on pulling the hair aside they are seen to pale towards their base, having a reddish-brown tint, whilst the remainder of each hair is intensely black. There is also a woolly under-pile which I cannot detect in the skin of H. bubalina, but which A. M.-Edwards also noticed in his example of $N$. edwardsii. It may be that this dense coat with its underlying pile is essentially seasonal and characteristic of winter, but whether $N$. bubalina undergoes such periodical mutation of pelage we do not know. Hodgson, however, remarks that in $N$. bubalina there is some little variation independent of that caused by sex and age, and he states that in the female the black of the upper parts is less full than in the male and sometimes mixed with grey.

M. l'Abbé David's' antelope was from Tibet. The other nearly allied species, $N$. sumatrensis, which is the type of the genus Ncmorhedus, is found alike in Sumatra and the Molayan peninsula; N. rubida, Blyth, occurs in the hilly region of Arracan; N. swinhoei, Gray, in the mountainous region of Central Formosa, and N. crispa, Gray, in Japan.

To the shoulder-bag or haversack of every Kakhyen, Shan, and Chinese peasant of Western Yunnan a horn of the goat-antelope is generally an indispensable adjunct. It is suspended from it, and is in constant requisition by the muledrivers as a kind of drill for making holes in their mule gear.

\footnotetext{
${ }^{1}$ Journ. d'Explor, dans l'Empire Chinois, par M. l'Abbé A. David, 1875, vol, ii, p. 332.
} 


\section{Genus Cervulus, Blainville.}

\section{* Cervulus muntjac, Zimm.}

Le chevrueit des Indes (Bengal), Buffon, Hist. Nat. Suppl. vol. vi. 1782, p. 193, pl. xxvi.

Rib-faced Deer, Pennant, Hist. Quad. 3rd ed. 1793, vol, i. p. 119.

Kijang, Marsden, Hist. Sum. 1810. Pl. xiv. n. 2, p. 117.

Cervus muntjak, Zimm. Geogr. Gesch. vol. ii. 1780, p. 131 ; Bodd. Elench. Animal, vol. i. 1785, p. 136 ; Ham. Smith. Griffith's edit. Cuv. Anim. Kingd. vol. v. 1827, p. 319.

Cervus muntjac, Gmelin, Linn. Syst. Nat. 1788, vol. i. p. 180 ; Horsfield, Zool. Res. Java, 1824; Müller und Schl. Verhandl. 1839-44, p. 225; Wagner, Schreber, Säugeth. Suppl. P1. v. 1855, p. 388 ; Sykes, Proc. Zool. Soc. Lond. 1831, p. 104; Ogilby, Royle’s Ill. Him. Bot. 1839, p. 72.

Cervus vaginatis, Bodd. Elench. Anim. 1785, p. 136.

Cervulus moschatus, Blainville, Nouv. Bull. Soc. Phil. 1816, p. 77 ; Ham. Smith. Griffith's ed. Cuv. Anim. Kingd. vol. v. 1827, p. 149 ; Horsfield, Cat. Mamm. E. Ind. Co.'s Mus. 1851, p. 190 ; Gray, Knowsely Hall Menag. 1850, p. 65; Proc. Zool. Soc. Lond. 1850, p. 234; Cat. Mamm. B. M. pt. iii. 1852, p. 218 ; Cat. Rumin. Mamm. 1872, p. 93; Hand-List Edent. and Rumin. Mamm. 1873, p. 163.

Cervns ratwa, Hodgson, Asiatic Researches, vol. xviii. 1833, pt. ii. p. 139, fig. head; Proc. Zool. Soc. 1834, p. 99; Ogilby, Royle's Ill. Him. Bot. 1839, p. lxxiii.; Schinz, Syn. Mamm. vol. ii. 1844, p. 549.

Cervulus muntjac, Zimm. Wagner, Schreber, Säugeth. 1836, pl. 254.

Cervus melas, Ogilby, Royle's Ill. Him. Bot. 1839, p. Ixxiii.

Stylocerus rutwa, Hodgson, As. Soc. Beng. vol. x. 1841, p. 914; Cal. Journ. Nat. Hist. 1843, p. 292.

IIuntjacus vaginalis, Gray, List Mamm. Brit. Mus. 1843, p. 173; Cat. Mamm. and Nepal, Hodg. Coll. 1846, p. 31.

Cervus albipes, Schinz, Syn. Mamm. vol. ii. 1844, p. 549.

Prox rutva, Sundevall, Kongl. Vetens. Akad. Handl. 1844, Stock. 1846, p. ]85, Nepal.

Prox albipes, Sundevall, ibid. p. 185, Malabar.

Prox stylocerus, Sundevall, ibid. p. 185, Nepal.

Cervus stylocerus, Schinz, Syn. Mamm. vol. ii. 1844, p. 549; Wagner, Schreber, Säugeth. 1855, Suppl. vol. v. p. 388.

Stylocerus muntjacus, Kelaart, Prod. Faun. Zeyl. 1852, p. 85.

Cervulus vaginalis, Blyth, Cat. Mamm. As. Soc. Mus. 1863, p. 154; Swinhoe, Proc. Zool. 1869, p. 652 ; ibid. 1870 , p. 644 .

Cervulus aureus, Jerdon, Mamm. of India, 1867, p. 264.

Cervulus curvostylis, Gray, Cat. Kumin. Mamm. Brit. Mus. 1872, p. 94; Hand-List Edent. and Rumin. Mamm. 1873, p. 165 (Deformity).

Cervulus tamulicus, Gray, Cat. Rumin. Mamm. B. M. 1872, p. 94; Hand-List Edent. and Rumin. Mamm. ]873, p. 165.

I obtained three skins of the adult and one of the young of this species, the latter presenting no trace of spots. It is not at all uncommon on the Kakhyen hills, where its call was nightly heard around our camp at Ponsee, at 3,500 feet above the sea. It is very abundant in the hill ranges to the north of Teng-yuechow, and at certain seasons its flesh is largely brought to the market for food, and its skin is held in high esteem as a leather, soft as the finest chamois.

I have compared these with Nepal specimens, with which they perfectly agree externally as well as in their skulls. 
Hodgson regarded the Nepal form as distinct, having described it as Stylocerus rutwa, and Sundevall adopted this opinion, but separated another from the same locality under the name of Prox stylocerus. This latter naturalist also considered the Central and Southern Indian barking-deer as a distinct species, and identified it with the Prox albipes, Wagner. This latter race Sykes had considered as $C$. muntjac, and more lately Gray re-named it under the designation of C.tamulicus. I have examined the types of Stylocerus rutwa and C. tamulicus, but I cannot detect that they differ specifically from Cervulus muntjac of other parts of India, and the specific name applied by Sundevall to the Malabar race seems to indicate that it also is the same. They appear to me to be only local races of one widely distributed species which ranges over the Himalaya, India, and Ceylon through Arracan and Burma to the Malayan peninsula, Sumatra, and Java, spreading from the Himalaya eastwards to the seaboard of China, and, according to Swinhoe, stretching to the Island of Hainan, where, he says, C. reevesii, Ogilby, is replaced by the allied Indian form.

The skull of the Sumatran barking-deer figured by Marsden ${ }^{1}$ C. muntjac, and which has for many years been deposited in the Museum of the Royal College of Surgeons, London (No. 3615), was described by Blainville as the type of his species Cervus moschatus. ${ }^{2}$ The only difference that can be detected, as is stated in the Catalogue of the Museum, ${ }^{3}$ is that the external ridge of the malar bone is thicker and more prominent than in Indian specimens of $C$. muntjac.

Cervulus curvostylis, Gray, is founded on a deformed pair of horns. The pedicle of each horn is abruptly bent downwards, backwards, and outwards at its origin, and the upper surface of the head is somewhat roughened. The pedicles of the horn are otherwise well developed, and the abnormality is akin to that downward bending and twisting of the horn which is occasionally observable in the Indian and in the Persian gazelles. The cheek-pit does not seem to be larger than in ordinary examples of the species.

It would appear that the real characters of the Chinese barking-deer C. reevesii, Ogilby, are not rightly understood, because Ogilby, who first described the animal, remarks that it is about the same size as the Indian muntjac, while other and more recent observers have recorded that it is nearly one-third smaller than the latter. A comparison of adult skulls of the species certainly confirms this opinion. The adult male skull of $C$. reevesii in the British Museum has its extreme length only 5.75 as compared with 8.25 inches, which are the dimensions of $C$. muntjac in the same collection. The nearly allied Chinese barking-deer, the C. lacrymans, A. M.-Edwards, the skull of which I have compared with the type of C. sclateri, Swinhoe, and with which it perfectly agrees, is seemingly also a larger animal than C. reevesii, the skull probably attaining to 7 inches in length; the largest specimen in the British Museum, which is not fully

\footnotetext{
Hist. of Sumatra, Atlas, pl. xiii. No. 2: No. 1, skull; pl. xiv. No. 2, animal.

2 Nouv. Bull. de la Soc. Phil. 1816, p. 77.

${ }^{3}$ Cat. Mus. Royal Coll. Surgeons, Lond. vol. ii. 1853, p. 598, No. 3615.
} 
adult, being 6.60 inches in extreme length. These two Chinese species, therefore, are considerably smaller than $C$. muntjac, with which these skulls can never be confounded, and I shall therefore only indicate wherein these two nearly allied barking-deer differ from each other in the cranial characters. The skull of $C$. reevesii, Ogilby, is distinguished from that of C. lacrymans, A. M.-Edwards, by its greater breadth and shortness, these characters being also distinctive of the muzzle of the animal as compared with that of C.lacrymans, which is also easily recognised, as pointed out by A. M.-Edwards, by the great size of its lachrymal fossa, which nearly equals the diameter of the orbit. ${ }^{1}$ The shortness of the muzzle chiefly depends on the less forward extension of the premaxillaries of $C$. reevesii, which so affects the length of the premaxillary foramen that that opening in C. lacrymans is one-third longer than in C. reevesii; of course it is also shown in the relative palatal lengths of the premaxillaries, which, when compared with the transverse breadth of the interspace between the canines and the premolars, brings out the distinctive features of the two skulls in these respects. In $C$. lacrymans the palatal length of the premaxillaries is considerably in excess of the breadth across the foregoing edentulous interspace, whereas in $C$. reevesii it falls short of the latter measurement. The form of the palatal surface, between the canines and premolars, is evidently liable to variation in C. lacrymans, as the breadth of the interspace between the curved ridges that run from the premolars to the canines is broader in the skull depicted by A. M.-Edwards than in the type of $C$. sclateri, while in other respects the skulls are identical and in no way separable specifically. In C. reevesii, on the other hand, this interspace is always broader than in C. lacrymans. The greater breadth of the skull of the former is due to the more outward shelving of the external supra-alveolar portion of the maxilla. In $C$. reevesii the transverse breadth of this region of the skull is considerably in excess of the width across the base of the skull opposite to the middle of the articular surface of the squamous, while in C. lacrymans that measurement only equals the latter. The preorbital fossa, besides being not so large or rounded in C. reevesii as in C. lacrymans, has the upper border formed by the lachrymal sharp and narrow, instead of being broad and flattened as in C. lacrymans.

I observe that there is occasionally an indication of tine-like processes on the sides of the pedicles, and there is an example of this kind in the British Museum in an adult skull of $C$. muntjac, in which a horny rosette, with a constricted osseous base, buds from the outside of one pedicle. The rugosities on the curve of the pedicles of the deformed skull described by Dr. Gray as C. curvostylis are akin to these growths.

C. lacrymans and other barking-deer have generally no trace of the black band on the nape which occurs in $C$. reevesii, but I observe in one specimen of $C$. muntjac from Nepal a faint indication of such a line.

1 Dr. Gray, in the Ann. and Mag. Nat. Hist. 1873, vol xii. p. 425, remarks that "an alteration in the size of the tear-pit is observable in the old and young of $C$. sclateri, in which the adult has the tear-pit very like that of $C$. reevesii, but larger, more circular, and deeper; but in the young of this species the pit is distinct, but more oblong and comparatively shallow, especially in the upper part." 


\section{Genus Cervus, Linn.}

* Cervus porcinus, Zimmerman.

The cerf cochon, Buffon, Hist. Nat. Suppl. vol, iii. 1776, p. 122, pl. xviii.; Pennant, Quad. vol. i. 1793, p. 119, pl. xix.; F. Cuv. Ossmen Foss. vol. iv. 1825, 3rd ed. p. 43, pl. v. fig. 31 (horns).

Cervus porcinus, Zimmerman, Geogr. Gesch. vol. ii. 1780, p. 131; Boddaert, Elench. Anim. vol. i. 1785 , p. 136 ; Gmelin, Linn. Syst. Nat. vol. i. 1788, 3rd ed. p. 179 ; F. Cuv. Hist. Nat. des Mammif. August 1824, pls. 259 et 260 t et o ; Fischer, Syn. Mamm. 1829, p. 454; Wagner, Schreber, Säugeth. 1836, 4th ed. p. 1097, pl. 151 (Buffon’s figure) ; Schinz, Syn. Mamm. 1844, vol. ii. p. 394; Monograph der Säugeth. p. 10, Tab. 11B. 1848.

Cervus (Hyelaphus) porcinus, Sundevall, Kongl. Vetens. Akad. Handl. 1844 (Stockh.) 1846, p, 180. Axis minor, Hodg. Journ. As. Soe. Beng. 1841, p. 914; Cal. Journ. Nat. Hist. vol. iv. 1844, p. 292. Axis porcinus, Brooks, Cat. Mus. 1828, p. 62 ; Hodgson, Journ. As. Soc. Beng. vol. x. 184], p. 914; Jerdon, Mamm. Ind. 1867, p. 262.

Axis niger, Blainville, Paris Soc. Philom.-Bull. 1816, p. 76 ; Fischer, Syn. Mamm. 1829, p. 454; Desmarest, Mamm. 1822, p. 437; Wagner, Schreber, Säugeth. 1836, p, 1133 ; Sundevall, Pecora, 60, 132 ; Schinz, Syn. Mamm. vol. ii. 1844, p. 393.

Hyelaphus porcinus, Gray, Glean. Menag. Knowsl. Hall. 1850, p. 64, pl. xlii.; Horsfield, Cat. Mamm. E. Ind. Co.'s Mus. 1851, p. 189; Blyth, Cat. Mamm. As. Soc. Beng. Mus. 1863, p. 153; Sclater, Proc. Zool. Soc. Lond. 1870, p. 115.

Axis orygus, Kelaart, Prod. Faun. Zeylan. 1852, p. 83; Journ. As. Soc. Beng. vol. xx. 1850, p. 174 .

The hog-deer is of general occurrence in the low-lying rice land of Upper Burma, and is numerous in the valley of the Tapeng at the base of the Kakhyen hills, but it does not appear to extend into the high country to the eastward. 


\section{EDENTATA.}

\section{Genus Manis, Linn.}

An ant-eater is generally distributed over India from Attock on the Indus to the south-east as far as Kuttack, and throughout the whole of Southern and Central India, and Ceylon. Another and distinct species ranges through the Himalaya eastward through Assam into Western Yunnan, and in a slightly modified form has been found by Swinhoe in the neighbourhood of Amoy and in the Islands of Hainan and Formosa, this variety being known so long ago as Seba's and Erxleben's time as the Formosan Devil. A third and equally well-marked species is spread over Arracan, Upper Burma, and the Malayan peninsula, and the larger islands, such as those of Sumatra, Java, \&c. I propose to point out briefly the characters by which these three species are distinguished from each other.

The Linnæan name $M$. pentadactyl $\alpha^{1}$ was originally applied to the Chinese form indicated by Dalmann, ${ }^{2}$ and also to Seba's ${ }^{3}$ representation of a Ceylon animal, but these ant-eaters have now been conclusively found to be distinct. The Indian and Ceylon species is distinguished by its light yellow-brown colour in the adult state, which is in marked contrast to the dark hue of its other two Asiatic allies. From these it is recognisable by its larger scales, which are less numerous, and more coarsely sculptured. I restrict the term $M$. aurita to the species first indicated by Dalmann, which appears to be specifically identical with the ant-eater of the Himalaya, and the term $M$. javanica to the ant-eater which occurs in Tippera, Arracan, Burma, the Malayan peninsula, and the neighbouring islands. The number of longitudinal rows of scales on the hinder part of the trunk in the Indian species varies from 11 to 13 in $M$. pentadactyla, while in $M$. aurita, it appears rarely to exceed 18 and seldom to fall short of 15 , whereas the general number is 17 . In twenty-six skins of $M$. aurita, 18 rows of scales occurred only in one, 16 in three, and 15 in another. In $M$. javanica the transverse longitudinal rows of scales are as many as 19 , so that $M$.pentadactyla is at once distinguished from it and $\boldsymbol{M}$. aurita by the smaller number of these scales. The Indian ant-eater has also a fewer number of scales from the upper part of the nose to the extremity of the tail, in the longitudinal mesial line, than either of the other two species. The general number may be taken at 42 , whereas in $M$. aurita it varies

\footnotetext{
1 Syst. Nat. 12th ed.

${ }^{2}$ Kongl. Svetens. Vetn. Acad. Handl. Stockh. p. 265, t. 6, fig. 3.

${ }^{3}$ Seba, vol. i. 1734 , t. 53 , fig. 5, p. 87.
} 
from 48 to 56 , and in $M$. javanica it may even be as high as 64 . The extent to which these scales occur on the tail in the different species also affords materials by which to separate the three forms. In $M$. pentadactyla the average number is $\mathbf{1 4}$, in $\boldsymbol{M}$. aurita 16 to 20 , and in $\boldsymbol{M}$. javanica as many as 30 . The Indian ant-eater has also much longer fore claws than $M$. javanica, and in this respect it is more closely allied to $\boldsymbol{M}$. aurita, but in all the species the hind claws are shorter than those on the fore feet, but in $M$. javanica the difference that exists between them is not at all well marked, and the claws are much less powerful than in the two others. $M$. pentadactyla is distinguished from $M$. javanica by its much broader and less tapered tail, and in this respect it is closely related to $\boldsymbol{M}$. aurita, the form to which it is most affined. In $M$. pentadactyla the tail stands to the body and head in the proportion of 100 to 100 , in $M$. aurita of 71 to 100 , and in M. javanica of 82 to 100 . These proportions are gathered from measurements taken from an authenticated skeleton of each species, as the limits of the tail are difficult of determination in Museum skins. It was once thought that the species might be recognised by differences in the size of the external ear, but I am doubtful that any reliance can be placed on this character. $M$. pentadactyla is also at once recognised from M. javanica by its broader and more conical head and less pointed muzzle, in which respects $\boldsymbol{M}$. aurita more or less resembles it, whereas the head of $M$. javanica is very narrow, and with a longer interval between the eye and the nose than in the other species.

To summarise the characters: $\boldsymbol{M}$. pentadactyla is known by its heavy body; by its tail which is broad at the base, tapering gradually to a point, and equalling the length of the head and the trunk; by its large light olive-brown scales, of which there are only from 11 to 13 longitudinal rows on the trunk and a mesial line of 14 on the tail; and by its powerful fore claws, the centre one of which is somewhat more than twice as long as the corresponding claw of the hinder extremity.

$M$. aurita is distinguished from $M$. pentadactyla by its less heavy body; by its rather shorter tail which has less basal breadth than $M$. pentadactyla; by its smaller and darker brown, almost black scales in the adult, which are more numerous, there being from 15 to 18 longitudinal rows on the trunk, 17 rows being the normal number, and 16 to 20 caudal plates in the mesial line; and by its strong fore claws, the middle one of which is not quite twice as long as the corresponding claw on the hind foot.

$M$. javanica is recognised by its body being longer and more attenuated than in the two foregoing species; by its narrower and more tapered tail; by its longer, more foliaceous and darker olive-brown scales, of which there are 19 longitudinal rows on the trunk, and as many as 30 along the mesial line of the tail; and by the claws of the fore feet being not nearly so long as in $\boldsymbol{M}$. aurita, and being but little in excess of the claws of the hind feet.

The variation in the number of longitudinal rows, more especially in the case of $M$. aurita, appears to be due to one or other of two causes. When 17 rows 
of scales occur, these structures are arranged in perfect longitudinal series, and increase in size from the central dorsal row to the line of scales occupying the middle of the side, but as the lines are traced downwards to the belly they decrease in size, and the last row is occasionally reduced to a line of three or four small, almost aborted scales on each side, whereas in well-formed individuals this terminal row is a reduction of the preceding row in the same ratio of diminution which characterises the rows preceding it. In those instances in which the lowest row of scales is more or less aborted, one row may be entirely lost on one side of the animal, thus giving rise to 16 longitudinal rows, while in other examples both may be suppressed, thus reducing the total of the longitudinal rows to 15 . When the number of longitudinal rows is in excess of 17, it appears to be due, not to the development of a fresh series of independent structures, but, as in the case of the multiplication of the normal number of scales in some reptiles, to be attributable to the division of the scales of either one or more of the normal series of longitudinal lines. When this occurs, the symmetry of longitudinal distribution is interfered with, and difficulty is experienced in tracing the lines. It usually takes place in one or other of the lateral rows, but a similar division of the head scales is not unfrequent, and in such instances the scales are smaller than in an animal with an undivided series. In all Asiatic species of Manis there are only five longitudinal rows of scales on the upper surface of the tail, the outermost row by its lower half entering into the formation of the under surface of the tail, which. has three longitudinal rows of scales internal to these halves of the dorsal row. These ventral rows are also frequently subject to division.

With regard to some general characters: In the young state in all the species, the three or four most inferior rows of scales on the sides of the body are generally keeled, as are also the scales on the hind leg, but more so in $\boldsymbol{M}$. javanica than in the other species, and in $M$. aurita than in $M$. pentadactyla. This keeling, however, is of variable intensity in individuals of the same species, and in the Indian and in the Himalo-Chinese forms it frequently disappears with age, as the direct result of abrasion; but in adults of $M$. javanica it is always more or less present, so that it would appear that the habits of the animal are somewhat different from those of the two previous ant-eaters. This supposition is also supported by the circumstance that its scales, instead of having their edges regularly worn off, as in $M$. pentadactyla and $M$. aurita, are generally chipped and broken. This, however, may be due to the more loose manner in which the scales are set on the body compared with the compact overlapping in the other two species; but this very laxity of arrangement of itself would suggest a difference of habit which the attenuated head and much longer muzzle as compared with $M$. pentadactyla and $M$. aurita would seem to render probable. The scales of the tail of all the species, but more especially of $M$. aurita, show a tendency to form an obtuse ridge or keel, and this is sometimes continued for a short way on to the back, but in other individuals of the same species this character is obscure or altogether absent. The fine striæ that mark the scales, and which are most prominent in $M$. pentadactyla, are nearly all 
obliterated before they reach the apex, which is almost smooth. Each scale also in the young state is marked by either one or three lines of growth. In $M$. pentadactyla, but more especially in $M$. aurita, the scales get worn down into hexagons, and the sharp points of the lateral line of scales in all the species, and which are especially prominent in young and semi-adult examples of $M$. javanica, get so abraded by friction that the sides of the tail become quite smooth.

In the young of all the species the scales are much more lightly coloured than in the adults, but neither $M$. aurita nor $M$. javanica is ever so pale yellow as M. pentadactyla. In the young of $M$. aurita the basal portion of the scales is dark brown, but the remainder is more or less variegated with horny yellow which in the tail scales is generally restricted to their margins. In $M$. pentadactyla there is little or no variation in the pale olive-brown, but $\boldsymbol{M}$. javanica resembles $\boldsymbol{M}$. aurita in the parti-colouring of its scales. In the adult of the latter, I have occasionally observed the perfectly smooth scales very regularly marked with rather clear concentric rings of pale yellow; whilst in others the centres of the scales outside the limbs and on the flanks are coloured pale yellowish, a similar distribution of colour occurring also in $\boldsymbol{M}$. javanica. In $\boldsymbol{M}$. javanica, moreover, there is a tendency in the yellow to spread over a series of scales involving considerable areas, and this is most prevalent on the extremity of the tail ; and it was this and some other characters that led Blyth to describe this form under the name of $M$. leucura.

As is well known, a number of strong yellowish hairs or bristles occur at the base of each scale, generally arranged in three or four groups and projecting outwards externally between the overlapping scales. In the adult the exposed portion of these hairs is worn away by abrasion.

The head-scales clothe the upper surface of the head as far forwards as on a line with the middle of the mouth, terminating in a single scale. Besides the sides of the head and neck, chin, throat, chest, belly, and inside of the limbs, and an extensive area around the vent, and all of which are destitute of scales, a scaleless area occurs on the hind leg in the region of the knee-joint along the outside of the limb, but it is more or less protected by the row of scales above it, but when the limb is backwardly expanded to its utmost limit, this scaleless patch is visible externally. No such patch occurs on the fore limb. Its function is to permit of the inward bending and stowing away of the limb when the animal is coiled up. All the scaleless parts are more or less clad with short reddishbrown or yellowish hairs, which appear to be most numerous in semi-adult individuals, but the upper part of the nose is bare and destitute of hairs. The tip of the nose over the nostril, the external skin of the nasal septum, the skin between the lower anterior third of the nostrils and the upper lip, and the tip of the lower lip, have a honeycombed appearance in $M$. pentadactyla, each cell, as it were, having a central depression resembling the entrance to a glandular duct. The skin behind and at the two posterior thirds of the nostrils and along the upper and the lower lip is quite smooth. This smooth space extends behind the posterior end of 
the nostril, where it impinges on the rough and haired skin of the scaleless portion of the face. There is also a smooth patch on the centre of the chin. The skin of the nose and lips in $M$. pentadactyla has a well-marked bluish colour contrasting with the pale colour of the scaleless parts.

The eye is small, and is situated rather close to the ear, and the iris is generally dark brown. The ear is moderately well developed, and more or less rounded in all the species, and is clad with short, rather stout hairs. The palmar surface of the fore feet has in its centre a few circular elevations marked by central depressions; the skin, however, in $M$. pentadactyla is of the same uniform pale yellow colour as the scaleless portions of the body. It is unhardened by use, as these animals walk on the terminal joints of the two outer toes and on the terminal halves of the claws of these toes, the inner toes not touching the ground. The under surface of the hind foot has a brown warty appearance, and the claws project only a short way beyond the thick pad which protects the bones of the feet. It is divided into an inner portion, swollen and round, and into an outer flattened portion. The whole of the plantar surface reaches the ground.

With reference to the general osteological features of the three species, the numerical variations in the vertebral column are not greater than what occur in many well-recognised species of mammalia. Thus in $M$. pentadactyla there are 26 cervical and trunk vertebræ, excluding the sacral; in $M$. aurita 28 to 30 ; and 28 in $M$. javanica. In the first of these there are 14 ribs; in the second 15 to 17 well-developed costal elements, with a small rudimentary rib in the animal with $\mathbf{1 5}$, and another has probably been lost; while in $M$. javanica there are 14 well-formed ribs, and a small terminal rib. The normal number of sacral vertebræ throughout the species appears to be three, but in the adults it is extremely difficult to decide in some instances between the sacral and pseudo-sacral elements; there would appear, however, to be from one to three of the caudal vertebræ that unite with those which are essentially sacral, and in such instances they become soldered to the pelvis. In M.pentadactyla, if the sacrum is regarded as consisting of only three vertebræ, then there are as many as 30 caudals, in $M$. aurita 27 , and in $M$. javanica 29.

It will be observed that the greater length of the tails of $M$. pentadactyla and of $M$. javanica is not solely due to the greater number of the vertebræ, as there are only two or three more than in $M$. aurita. This circumstance is brought out by comparing the respective lengths of the caudal vertebræ, as a whole, with the remainder of the vertebral column. In $M$. pentadactyla the tail segments measure $23 \cdot 75$ inches to $19 \cdot 25$, the length of all the remaining vertebræ; in $\mathbb{I}$. javanica 17.75 to 17.50 ; and in $M$. aurita 12.60 to 14 . As the greater length of the caudal portion in the two former cannot be accounted for by any increase in the number of the vertebræ, the explanation of the length of the tails of these species is found in the greater length and size of the bodies of the individual vertebræ, whereas the comparative shortness of the tail of $M$. aurita is explained by the short and feeble character of the vertebra themselves. 
In the foregoing examples of the species, the skulls of $M$. pentadactyla, M. aurita, and $\mathbb{M}$. javanica measured in extreme length, respectively, $4 \cdot 45$ inches, $3 \cdot 45$ inches, and 4 inches.

The skull of an undoubted example of the common ant-eater of India, $M$. pentadactyla (Plate XXIV, figs. 1 and 2) sent to me alive from Chota Nagpur by Colonel Dalton, C.S.I., is markedly distinct from either $M$. aurita or $M$. javanica, from both of which it differs in the greater relative breadth of its occipito-parietal region as compared with the facial portion, which is more abruptly and regularly tapered than in either of these species, and this is not, as might be supposed, attributable to youth, as the skull is fully adult. When viewed from above, the cranium does not exhibit the marked orbital concavity in the outline which distinguishes the skulls of these two species, and, moreover, the premaxillaries, which in both of them are widely apart from the frontal, generally touch the latter bone in $M$. pentadactyla. The zygomatic arch of the Indian form is only, as a rule, partially defined, and I have never observed a specimen in which it was entire, although at the same time it is probable that it may be so in old animals.

The skull of M. aurita (figs. 3 and 4) is distinguished from the skull of the foregoing species by a greater fullness in the facial region immediately anterior to the orbit and by a proportionally narrower occipito-parietal area than in $M$. pentadactyla. The nasal suture in Himalayan skulls is generally more rounded than in those from Eastern China and Formosa, in which the nasals meet, as a rule, in a point, but the character of this suture is most variable even in individuals from the same region, and in Yunnan skulls the suture is either straight or rounded. The skulls from Eastern China exactly agree in form with skulls from Darjeeling and from Western Yunnan, but it is noteworthy that the majority of the skulls sent by Swinhoe to the British Museum are not fully adult, and that the species attains to a much larger size than any of the animals from which these skulls have been extracted. Notwithstanding,-and this is a remarkable circumstance, - these comparatively young skulls, in a small percentage, form a distinct zygomatic arch by the complete union of the zygomatic processes of the superior maxilla and squamosal to a considerable degree of thickness. That these skulls are yet young is shown by the condition of their sutures, so that the formation of a zygomatic arch is not explicable by an overgrowth or undue ossific tendency after adult age had been reached; and it is interesting to observe that we do not find associated with this zygomatic arch any variation in the external characters of these ant-eaters from Eastern China by which they can be distinguished from $M$. aurita, Hodgson.

The skull of $M$. javanica (figs. 5 and 6 ) is at once distinguished from the skulls of the two foregoing species by its very narrow and elongated character, and in these respects it finds its equivalent in the skulls of $M$. leptura (fig. 7), and M. leucura (fig. 8), which are in no way separable from it; and to place this beyond a doubt, I have figured the skull of a specimen of $\mathbb{M}$. javanica from Java, and alongside of it the two skulls of the types of these supposed 
species. In external characters, also, these supposed species are the exact fellows of M. javanica.

As sufficient prominence has apparently not been given to the peculiar glandular sac in the stomach of the members of this genus, I take the opportunity to describe the stomach and the relation of the gland.

The stomach of Manis aurita presents a well-marked, downwwardly concave lesser curvature, the centre of which corresponds to the division of the stomach into two well-defined portions, the cardiac and the pyloric, the former of which considerably surpasses the latter in capacity, and is distinguished from it by the thinness of its muscular walls as compared with those of the pyloric section. The pyloric orifice is situated at a much lower level than the opening of the œosophagus into the stomach. On laying open the stomach the longitudinal folds of the œsophagus are prolonged along the inner wall of the lesser curvature as far as the base of the concavity. From this point the finer folds of the œsophagus are replaced by a strong mucous fold which is continued along the lesser curvature to near its end, where it suddenly enlarges into a rounded head which contracts and fits into the pylorus as a plug. The folds of the osophagus are also prolonged on to the right half of the anterior wall of the cardiac cavity, but the remainder of the inner wall of that sac is thrown into a dense mass of strongly convoluted mucous folds or rugæ. The pyloric portion has a thinner mucous membrane than the preceding, and is rough, almost tubercular, and nearly devoid of convolutions, and the plug of its duodenal orifice is covered by tubercles almost spinose. Situated on the greater curvature of the stomach, immediately opposite to the œsophageal orifice, is a large glandular swelling marked internally by a wide patulous orifice, which leads into a limited chamber in the glandular nodosity. This appears to correspond to the structure which has been described by Rapp ${ }^{1}$ as consisting of a series of glandular follicles, the ducts of which terminate in a common orifice, and which has also been referred to by Professor Flower in his lectures on the Organs of digestion of the mammalia. ${ }^{2}$ In the stomach are generally to be found small stones and gravel.

In a gravid uterus of $\boldsymbol{M}$. pentadactyla the fœtus was developed in the right horn, and the general form of the organ resulting from this circumstance was similar to what obtains in the Mare, Tapir, Camel, and Dolphin when the fœtus is developed in the same horn. The lips of the os uteri externum were composed of the free ends of a series of fine lamellar folds which lined the interval, three quarters of an inch in length, between it and the os uteri internum. These folds in their lamellar character resembled the folds which occur in the Cetacea, and are described by Prof. Turner ${ }^{3}$ in his admirable account of the arrangement of the fotal membranes of that group. The right horn of the uterus was enormously enlarged, and was directly continuous with that portion of the cavity of the viscus which lay between the opening into the right and left horns and the os uteri internum. The

1 Edentata, 1852, p. 16.

${ }^{2}$ Medical Times and Gazette, vol. ii, 1872, No. 1170, p. 592.

${ }^{3}$ Trans: Roy. Soc. Edin. vol. xxvi. 1871, p. 473. 
very limited common cavity of the uterus so defined had a length of little more than $0^{\prime \prime} .75$ and a similar maximum breadth. The length from the free border defining the entrance to the lelt unfecundated horn to the wall of the right horn facing the os uteri internum was $4^{\prime \prime} \cdot 25$. The left horn thus appeared as a diverticulum from the lower portion of the cavity, from which it passed off as a wide channel, the orifice being one inch in breadth from side to side. The septum between the two horns was $1^{\prime \prime} \cdot 25$ broad, with a maximum depth of $2^{\prime \prime} \cdot 50$, and it corresponded to the septum of the uterus of Orca gladiator described by Turner. ${ }^{1}$ A part, however, of the external wall of the left horn at its beginning, and which in the unfecundated uterus had been within the lips of the entrance to the horn, entered into the formation of the cavity containing the fœetus, but all the remainder of the left horn was excluded. The latter horn, as in such two-horned uteri generally, had become considerably enlarged during the gravid condition, but it had not attained to one-half the dimensions of the other horn. The portion of the cavity around the os uteri internum was slightly dilated on its dorsal surface. The form and relations of the two cornua of this gravid uterus of Manis pentadactyla were thus exactly the same as in the gravid uteri of Platanista and Orcella figured and described in this work. I mention this because Prof. Turner ${ }^{2}$ has described in the membranes of the Manis, originally examined by Sharpey, the existence of "two pouch-like recesses about the size of walnuts, one situated at each lateral extremity of the transversely elongated uterus." The fœetus which had arrived almost at maturity had unfortunately escaped by a rupture of the uterine wall at the Fallopian pole of the right horn. The membranes were, however, left investing the uterine cavity, and on laying open the uterine wall along its dorsal surface as far as the os uteri internum, the chorion was found closely adhering to the inner surface of the uterus and sending up a prolongation into the left horn, and from the point where this portion turned off into the left horn, another well-defined sac depended into the section of the cavity above and around the os uteri internum, but when the membranes were inflated with water, this sac was seen to be directly continuous with the portion of the membranes investing the gravid horn. The relations, therefore, of the membranes to the uterine wall were the same as those of the uterine membranes of the Equida, Rhinocerotide Tapiride, Camelide, and Cetacea.

On gently removing the chorion, it was found that the villi covering its surface were impacted in the spongy tissue which clothed the uterine wall; slight traction being exercised, they were drawn out of the investing glandular substance. As in the uteri of Platanista Orcella, and other diffuse placenta generally, bare areas occurred perfectly destitute of villi, and opposite to these bare spaces the surface of the chorion was deprived of villi; but I am not prepared to say that no bare space may not have had a few chorionic villi opposed to it. As is well known, these bare spots on the chorion of Manis were first described by Sharpey. ${ }^{3}$ On removing the entire

${ }^{1}$ L. c., p. 473.

2 Trans. Roy. Soc. Edin. vol. xxvii. 1873, p. 91.

${ }^{3}$ Elements of Comp. Anat. (Huxley), 1864, p. 112. 
chorion from both horns, the distribution of the spongy and bare spaces of the uterine wall could be studied. On the left margin of the os there was a prominent eminence of the mucosa, somewhat conical in form, and from its apex a broad and thick band of spongy substance, the broadest on the whole of the uterine surface, extended as far as on a level with the left angle of the orifice into the left horn where it ended in the commencement of a broad bare tract free from villi, and which ran along that portion of the inner surface of the uterus and along the short side of the septum already mentioned. A very narrow bare tract occurred on either side of the broad and thick cryptose band, but both were more or less broken up by minute villous tracts which crossed them, or they were here and there covered with small villi. Two broad bare tracts radiated forwards from the os uteri internum on the ventral wall, enclosing broad cryptose areas of the uterine mucosa broken up by smaller bare tracts. A similar arrangement occurred on the dorsal and lateral walls. As the bare tracts arose around the os uteri internum, the lips of that orifice were more or less bare, but the areas intervening were rugose. The bare tracts not interrupted by the orifice leading into the left horn ran forwards along the wall of the uterus, and when they reached the proper cavity of the right horn they were broad, but secondary bare tracts originated between them. The bare tracts were not so broad as the cryptose tracts. In some parts these bare tracts became broken up into round bare areas, much as in Orcella. On the remainder of the right horn the linear arrangement of the bare tracts was less, and that surface opposite to the os uteri internum was irregularly covered with broad bare areas and cryptose tracts. The area immediately around the orifice of the Fallopian tube was bare. The long bare tract corresponding much in position to the attachment of the broad ligament, divided as it approached the Fallopian pole of the gravid horn, but the right branch was very short and broad, whereas the left branch dilated at first considerably, and then broke up and lost itself among the surrounding feebly cryptose surface of the mucosa. The area at the bifurcation of the long bare tract was more cryptose than the surrounding parts. The general arrangement of the bare tracts was in the direction of the long axis of the right horn.

In the left horn, the distribution of the narrow bare tracts followed the same course as in the right horn. Immediately around the orifice of the Fallopian tube there was a great nude area extending almost over one-third of the surface of the mucosa, and there were numerous isolated bare spots among the surrounding cryptose tissue, some tending to form linear tracts.

In both horns, the surface of the bare tracts, in many places, I observed to be marked by minute depressions or pits easily visible with a hand-lens, and it appears probable that these will be found to be the orifices of the utricular glands. These structures, however, I failed to detect in fine sections under the microscope, but Professors Sharpey and Turner have demonstrated their presence in the uterine mucosa of the species of Manis which they both examined.

On tying the ruptured end of the right sac of the membranes and dilating the membranes with water, it was found on examining them under water that the 
form they assumed was exactly that of the two-horned uterus, with the horns, however, side by side, or *only slightly divergent. On floating the membranes thus distended into the opened uterus, the right horn was found to be fully occupied by the right sac, and the portion below the line of union of the sacs exactly filled up that portion of the uterine cavity lying above the os and formed by the common cavity of the uterus and a portion of the left horn. On forcing the dilated left sac into the left horn through the opening and channel, that cavity was also filled with its sac of membranes. The line of union of the two sacs corresponded to the opening into the left horn, and the space between the sacs at this point was occupied by the crescentic free margin of the septum dividing the horns at that point. The portion of the sac of the membranes which filled up the common cavity of the uterus had that portion which was opposed to the os uteri internum smooth, but bearing a short free fringe or fold on the surface of the chorion; commencing slightly dorsally towards this pole and then bending off at an obtuse angle, it ran forwards immediately towards the right side of the line of junction of the sacs of the left and right horns, where it bifurcated, one branch running for a short distance along the sac of the right horn, and the other and more prominent branch along the sac of the left horn. The fold on the pole was covered with fine villi. Professor Turner failed to detect the bare area opposite the os uteri internum in the Manis membranes originally described by Sharpey, but they do not appear to have been in a satisfactory condition. It is improbable that this bare patch will be found to characterise the membranes of all bi-horned uteri with a diffuse placentation. The remaining bare parts and villous areas were well seen in the inflated membranes, and a better idea was gained of their distribution than from the uterine surface. The bare tracts were seen to be along the direction of the long axis of the sac, but they were not at all numerous, there being only about eight originating in an irregular way from the pole opposite the os uteri internum. These bare tracts were of various widths, with a slight curvature along the sac, and they were more or less broken up by isolated offshoots from the intervening villous areas which were much broader than the bare tracts. As they were traced along the sac of the right horn, the bare tracts became wholly interrupted, and isolated bare areas of various forms were thus produced and at different intervals, the chorion being much more villous than bare. Some of these bare patches were branched, others were linear; some were elongated ovals, and others round. In the portion of the sac immediately opposite to the os uteri internum there was a large bare tract nearly circular communicating with other bare areas around it and nearly enclosing a round villous area with a bare portion in its centre. The Eallopian extremity of the sac was sparsely covered with villi, which were less developed than on the other parts, but as the portion immediately around the Fallopian end of the sac was injured by rupture, I am not in a position to say what its characters were. The broad bare tract or band described by Sharpey corresponded in this, as in Orcella, Platanista and the Tapir, to the course of the great vessels of the cord. It was prolonged forwards to near the 
Fallopian pole of the right sack, but divided into two at its extremity, and the other end of the tract ceased at the point where the chorion "was bent on itself to reach the left horn, although the great vessels were also found along that sack. The centre of the bare tract throughout the greater part of its extent was marked by two parallel longitudinal folds, which joined each other at their lower ends. I did not detect on this tract bodies resembling those which $\mathrm{I}$ have figured as occurring in Orcella. From the point where this bare tract ceased, a short narrow fringe was continued on to the left horn. The bare patches on this chorionic surface were much the same as in the right horn, but the last third or Fallopian extremity of the horn was destitute of villi; the surface of the chorion, however, opposed to the orifice of the Fallopian tube was thrown into a number of fine convolutions, which doubtless closed the orifice, but were also free of villi. The bare patches were much more irregularly distributed on this diffuse placenta than in Platanista or Orcella, and they were less numerous, but their structure was essentially similar.

The villi were distributed in irregular wavy lines, which freely anastomosed with each other, but I did not observe that the ridges of the chorion started from the margins of the bald stripe and ran round the horn as has been described by Sharpey in the membranes of the Manis he examined, but towards its margins there was a distinct but local convergence of the fine ridges of the chorion. They were all closely separated from each other by narrow interspaces destitute of villi. The villous surface viewed under a low power had the appearance of being composed of minute ridges, which gave off still much more minute secondary ridges, which anastomosed with their fellows surrounding them, so that a highly reticulated appearance was produced, the secondary ridges enclosing clear interspaces destitute of villi, but varying little in size, and proportionate to the size of the primary ridges; these primary ridges did not exceed $0.80^{\prime \prime}$ in length, and the interspaces had about the same dimensions. The surface of the mucosa had much the same appearance, the clear interspaces corresponding to the villous tufts of the chorion.

The amnion invested the whole of the inner surface of the chorion except that portion of it on which lay the allantois, which had much the same proportional capacity and relative arrangement as in Orca, Orcella, and Platanista, reaching from near the Fallopian end of the right horn into the first portion of the left horn, but how far into the latter I cannot say, as its walls had ruptured in the left sack. A small umbilical vesicle was present. The cord measured $2 \cdot 25^{\prime \prime}$ in length, and on its amniotic covering I observed two cyst-like bodies imbedded in its substance and doubtless glandular in their nature, and one oval-shaped pedunculated body with two processes near its extremity, from which a long filament hung down. This body probably corresponds to the hippomanes of the cord of the mare. The amnion nearer the allantois was covered with minute rounded bodies like those I have described on the amnion of Platanista.

It was by a mere accident that I became possessed of this uterus, and as the temperature at the time was $95^{\circ}$ Fah., I was not in a position to make any injections of the chorionic vessels to ascertain the character of the villi, nor of the 
uterine vessels to demonstrate the structure of the cryptose structure in which they were imbedded.

I here endeavour to give the synonymy of the two species of Manis which were obtained in the two Expeditions to Western Yunnan.

\section{* Manis aURita, Hodgson.}

Armodillus squamatus major; seu diabolus Tajovanicus Siamensium, ex Insulâ Formosa, Seba, vol. i. 1734 , t. 53 , fig. 5 , p. 87.

Manis Tchin Chian Kiapp (Chinese), Dalmann, Kongl. Svetens. Vetn. Acad. Handl. Stockh. 1749, p. 265, tab. 6; Chuen-shan-kia or Hill-borer (Chinese), Swinhoe, Proc. Zool. Soc. 1870, p. 237.

Manis pentadactyla, Syst. Nat. ed. 10th, 1758, p. 36 (in part) ; ibid. ed. 12th, 1766, p. 52 (in part); Gmelin, Linn. Syst. Nat. ed. 13th, vol. i. 1788, p. 53 (in part) ; Schreber's Säugeth. 1775, vol. i. p. 208 (in part); Ogilby, Royle, Ill. Him. Bot. 1839; Cantor, Ann. Mag. Nat. Hist. vol. ix. 1842, p. 482 (in part); Blyth, Journ. As. Soc. Beng. 1842, vol. xi. p. 453 (in part); ibid. 1860, vol. xxix. p. 93 (in part); Gray, Hand-List Mamm. B. M. 1843, p. 188 (in part); Cat. Mamm. \&e. Nepal, Hodg. Coll. B. M. 1846, p. 36.

Manis brachyura, Erxleben, Syst. Ann. 1777, p. 98 (in part) ; M`Clelland, Proc. Zool. Soc. 1839, p. 183.

Manis indica, Zimmermann, Geogr. Gesch. vol. ii. 1780 (in part) ; Lesson, Dict. Class. d'Hist. Nat. vol. xiii. 1828, p. 13 (in part).

Manis brevicaudata, Tiedemann, Zool. 1808, vol. i. p. 497 (in part).

Manis aurita, Hodg. Journ. As. Soc. Beng. vol. v. 1836, p. 234 ; ibid. vol. x. p. 911 ; Cal. Journ. Nat. Hist. vol. iv. 1844, p. 289; Blyth, Cat. Mam. As. Soc. Mus. ]863, p. 179; Jerdon's Mamm. Ind. 1867, p. 316, et App. p. iv.

Manis dalmanni, Kongl. Vetens. Acad. Handl. Stockh. 1842 (imp. 1843), p. 256, pl. iv. fig. 10 (claw-bone); Schinz, Syn. Mamm. vol. ii. 1845, p. 546 ; Rapp, Edent. 1852, p. 17; Gray, Proc. Zool. Soc. 1865, p. 366 (in part); Cat. Carniv. et Edent. Mamm. B. M. 1869, p. 371 (in part) ; Jerdon's Mamm. Ind. 1867, App. p. iv.; Swinhoe, Proc. Zool. Soc. 1870, p. 236.

Manis javanica, Adams, Proc. Zool. Soc. 1859, p. 132 ; Blyth, Journ. As. Soc. Beng. 1861, vol. xxx. p. 91 (in part).

This species is very common in all the hilly country immediately to the east of Bhamô and at the still higher elevation of Teng-yue-chow, and it extends from the Himalaya across to Eastern China.

* $\quad$ Manis JavanicA, Desmarest.

Pangolin, F. Cuv. Recherch. Oss. Foss. vol. viii. 4th ed. 1836, p. 189, pl. 209, figs. 2 to 5.

Manis javanica, Desmarest, Mamm. 1820, p. 377 ; Dict. Sc. Nat. vol. xxxvii. 1825, p. 331 ; Lesson, Dict. Class. vol. xiii. 1828, p. 15; Lesson, Man. de Zool. 1827, p. 316 ; Fischer, Syn. Mamm. ]829, p. 400 ; Blyth, Journ. As. Soc. 1842, vol. xi. p. 454; ibid. vol. xvi. 1847, p. 1274; Cat. Mamm. As. Soc. Mus. 1863, p. 179 ; Sundevall, Kongl. Vetensk. Acad. Handl. 1842, (Stockholm), 1843, p. 254, tab. iv. fig. 11 ; Schinz, Syn. Mamm. vol. ii. 1845, p. 325 ; Müller, Verhandl. 1839-44, p.

Manis javanica, Turner, Proc. Zool. Soc. 1851, p. 219 ; Horsfield, Cat. Mamm. E. Ind. Co.'s Mus. 1851, p. 107 ; Rapp, Edent. 1852, p. 16, pl. ii $a$ et pl. vi. figs. 1, 2 (skull).

Manis pentadactyla, Raffles, Trans. Linn. Soc. vol. xiii. p. 249.

Manis leptura, Blyth, Journ. As. Soc. Beng. vol. xi. 1842, p. 454; itid. vol. xvi. 1847, p. 1273 ; Cat. Mamm. As. Soc. Mus. 1863, p. 180. 
Manis aspera, Sundevall, Kongl. Vetensk. Acad. Handl. 1842 (Stockholm, 1843), p. 213; Rapp, Edent. 1852, p. 17; Schinz, Syn. Mamm. vol. ii. 1845, p. 546.

Manis lencura, Blyth, Journ. As. Soc. Beng. 1847, vol. xvi. p. 1274; ibid. 1861, vol. xxx. p. 91.

Pholidotus jaranicus, Gray, Proc. Zool. Soc. 1865, p. 366 ; Cat. Carniv. et Edent. Mamm. B. M. 1869, p. 370 .

This species appears to be restricted to the low country about Bhamô and to the outlying spurs of the Kakhyen mountains, not ascending to any great elevation like M. aurita. 
SECOND PART

OF

MAMMALIA.

C ET A C E A. 



\section{CETACEA.}

Previous to joining the First Expedition to Western Yunnan, my attention had been for some time directed to the investigation of the Cetacea inhabiting the rivers of India and Burma. The long time necessarily occupied by the Expedition in proceeding up that splendid river, the Irawady, which has been appropriately designated the Rhine of the East, afforded me a fitting opportunity of observing the dolphin which was known to inhabit its waters, but which was unknown to science.

On that occasion I was enabled to determine that it was a round-headed species, nearly allied to the globose-headed dolphin of the estuary streams of the Ganges, and shortly afterwards, through the exertions of my fellow-traveller, Captain Bowers, I became possessed of a specimen. On the Second Expedition to the same region, I was enabled to supplement my previous observations on the habits of the animal, and by the assistance of the Political Agent at Bhamô, Captain Cooke, to obtain two other specimens.

In the interval between these two Expeditions, I succeeded in procuring three specimens of Orcella brevirostris, Owen, and numerous examples of Platanista gangetica, Lebeck, which enabled me to work out the anatomy of these two dolphins, and I have considered it desirable to incorporate the results in this volume alongside of Orcella fluminalis, Andr., instead of publishing them in a separate form. Moreover, it is of importance that the anatomy of $O$. brevirostris should be here given, because I have not had sufficient materials to work out the soft anatomy of $O$. fuminalis; but the two species are so nearly allied that the anatomy of the one, in all ts essentials, doubtless corresponds to that of the other. 


\section{Genus Orcella, Gray.}

\section{* Orcella fluminalis, Andr. Plate XXV^.}

Dolphin of the Irawady, Andr., Proc. Zool. Soc. 1870, p. 220 et p. 544.

Orcella fluminalis, Andr. 1871, Proc. Zool. Soc., pp. 143-4, fig. 2; Blyth, Journ. As. Soc., vol. xliv. ex. no., 1875 , p. 34 .

The specimens which form the subject of this Memoir belong to the male sex. The first was found in a partially decayed condition by Captain Bowers on a sandbank at Bhamô. Decomposition, however, had not progressed so far as to render the skin unfit for preservation. He therefore had the carcass preserved in a mixture of spirit, salt, and arsenic, and had it forwarded to Calcutta, a distance of nearly 2,000 miles. When it reached its destination the skin was intact, although the epidermis had peeled off, but the muscles and viscera were much decayed; still I was enabled to take the following measurements of the specimen and to draw up a brief description of its external characters.

The general form, so far as I could make out from this then unique example, was the same as that of $O$. brevirostris, Owen. The fresher specimens afterwards obtained enabled me to determine that the species differs from O. brevirostris in its rather smaller, lower, and more falcate dorsal fin, its more pointed and less anteriorly bulging head, and rather shorter and broader pectoral fins: the colour in both is much alike, being pale slaty above and whitish on the under parts, ${ }^{1}$ but the skin of O. fuminalis is streaked somewhat as in Risso's dolphin.?

\section{Measurements of the first male, Orcella fluminalis, obtained by Captain Bowers.}

\begin{tabular}{|c|c|c|c|c|c|c|c|c|c|c|c|}
\hline \multirow{2}{*}{\multicolumn{4}{|c|}{$\begin{array}{l}\text { From tip of snout to fork of tail along the side } \\
, \quad, \quad \text { to dorsal fin following back curve }\end{array}$}} & . & & & • & . & . & • & $\begin{array}{r}\text { Inches. } \\
. \quad 90.00\end{array}$ \\
\hline & & & & & - & & 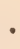 & - & - & - & - 55.75 \\
\hline Length of the dorsal fin . . & . & . & . & . & . & & 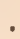 & . & . & . & $4: 75$ \\
\hline Tip of snout to base of pectoral flipper. & • & . & . & & - & & & . & - & . & . 18.75 \\
\hline Length of pectoral flipper along anterior & $\mathrm{r} \mathrm{m}$ & $\operatorname{argin}$ & . & & . & & & . & . & . & - $17 \cdot 00$ \\
\hline " posteric & ior & $"$ & . & & . & & • & . & - & - & - $11 \cdot 7$ \\
\hline Caudal flipper along its anterior margin & & & . & & & & & . & . & & . 13.0 \\
\hline Snout to the blow-hole on the forehead & & - & 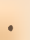 & & & & & - & . & & - $10 \cdot 0$ \\
\hline Transverse diameter of the blow-hole. & • & . & . & & . & & & - & - & • & $1 \cdot 50$ \\
\hline Snout to anterior margin of genital slit . & & . & . & & & & & . & . & & . $52 \cdot 75$ \\
\hline Length of the external genital orifice. & . & - & . & & & & & . & . & & 1.75 \\
\hline Distance between genital slit and nipple & & . & ${ }^{\circ}$ & & $\bullet$ & & & . & . & & $5 \cdot 00$ \\
\hline Nipples apart from each other & . & . & . & & • & & & . & . & & 0.7 \\
\hline Distance between the nipple and anus. & • & - & . & & • & " & & - & - & & $2 \cdot 50$ \\
\hline Length of the gape & . & . & . & & $\bullet$ & & & . & 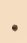 & & $5 \cdot 75$ \\
\hline Snout to anterior angle of eye & • & • & - & & • & 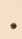 & & - & - & & $8 \cdot 00$ \\
\hline Longitudinal diameter of the eye & . & - & • & & & $\bullet$ & & - & . & & 0.7 \\
\hline From the eye to the ear-hole & . & - & . & & & & & . & . & & 3.7 \\
\hline Diameter of the external aural orifice. & . & . & . & & • & - & & - & - & & $0 \cdot 1$ \\
\hline Girth over the blow-hole . . . & - & - & . & $\bullet$ & • & • & • & - & - & ${ }^{\circ}$ & - $28 \cdot 2$ \\
\hline
\end{tabular}

${ }^{1}$ In the Proc. Zool. Soc. Lond. 1871, p. 144, I stated on the authority of Captain Bowers that the colour was uniform dirty white, but repeated views of these dolphins in my late journey up the Irawady convince me that the colours mentioned above are those natural to it.

2 Flower, Trans. Zool. Soc., vol. viii, 1872, p. 3. 


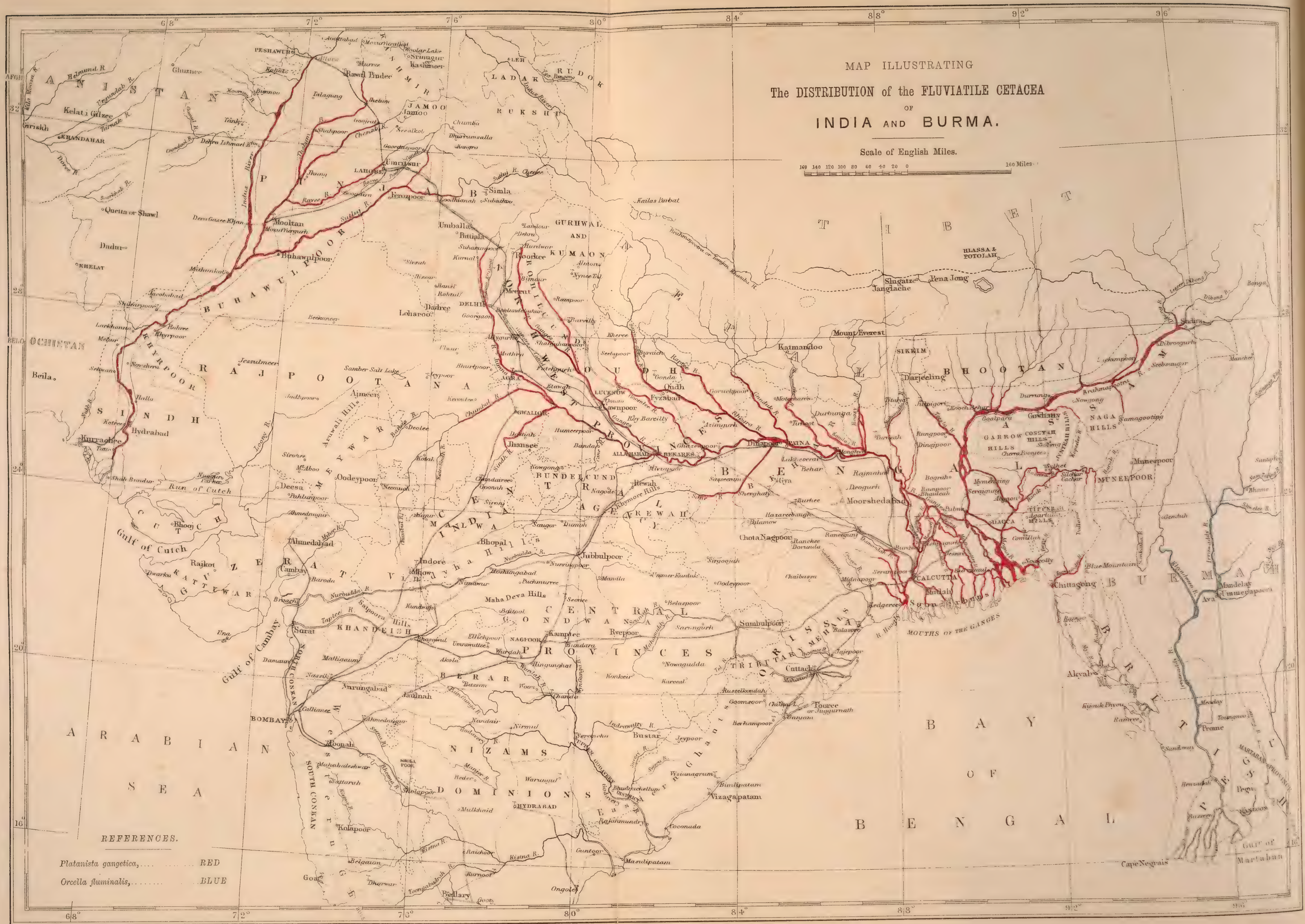



Inches

Girth just in front of pectoral flippers . . . . . . . . . . . . 3925

$"$ half-way between flippers to genital aperture . . . . . . . . 41:50

" round the anal region . . . . . . . . . . 2800

" at the base of the tail . . . . . . . . . . 900

Measurements of the second male, obtained by Captain Cooke at Bhamô, July 1876.

Tip of snout to notch of tail along the side : . . . . . . . . . 86*5

$"$ " to middle of dorsal fin along the side . • • • • • • . . 49.00

to tip of caudal flippers . . . . . . • • • . • . 2405

Length of pectoral flipper in straight line along centre . . . . . . . . 15.00

Greatest breadth of pectoral flipper . • . • • • • • • • . 6.05

Tip of snout along curve of head to centre of blow-hole . . . . . . . . 1000

Transverse breadth of blow-hole . . • • . • • • • • • . 1.05

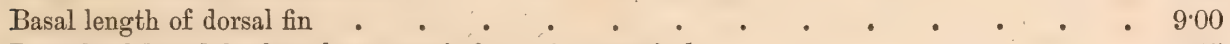

Length of dorsal fin from base anteriorly to tip posteriorly . . . . . . . 605

" $, \quad, \quad$, to centre of notch . . . . . . . 600

Depth through centre . . . . . . . . . . . . . . 207

Angle of mouth to anterior angle of eye . . . . . . . . . . . 1.08

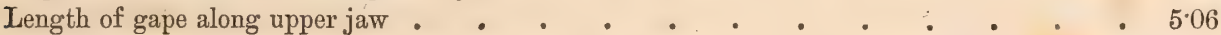

” of eye • • • • • • • • • • • • • •

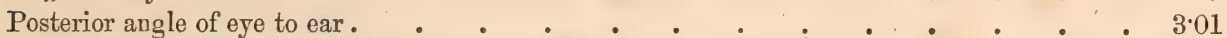

Tip of left horn of blow-hole to angle of mouth along curve of head . . . . . 7.00

" on right side . . . . . . . . . . . . . . . 708

" of left horn to left of mesial line of back . . . . . . . . . 1 .00

" of right horn to right of,$\quad$, . . . . . . . . . . . . 1.05

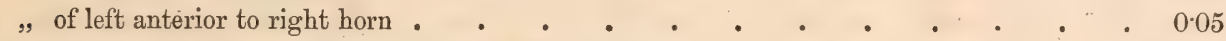

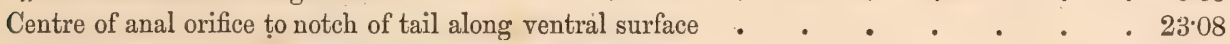

$" \quad, \quad$ " to middle of mammary slit . . . . . . . . . 304

" of mammary slit to posterior margin of genital slit . . . . . . . . . 306

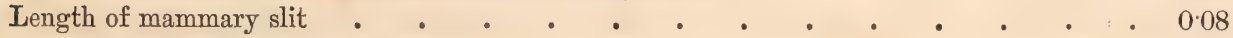

Distance (transverse) between mammary slits . . • . . . . . . 025

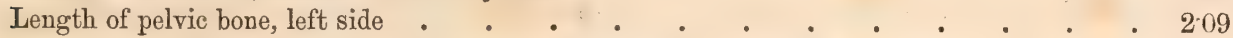

Anterior end of pelvic bone distant from cherron bone of 16 th lumbar vertebra . . . 1.01

$" \quad, \quad, \quad, \quad$. from centrum of 16 th lumbar vertebra . . . . 205

" extremity distant from external surface . • . . . . . . . 300

Posterior " $"$ "

Anterior $" \quad$ of pelvic bone nearer to the mesial line than the posterior end $. \quad+\quad . \quad 025$

Distribution.-It is a remarkable circumstance that this dolphin has never yet been observed in those portions of the Irawady under the influence of the tides, (see Map), which would seem to indicate that it is more strictly fluviatile than even Platanista. On the two different occasions I sailed up the river from Rangoon to Bhamô, my upward voyages were made in the months of December and January, and I returned in the months of September, October, and March, so that my observations have extended over nearly five months, embracing those periods when the river was at its highest and at its lowest level. On these occasions I had the question of the distribution of the Irawady dolphin steadily before me, and took the precaution daily to appoint certain of my Zoological collectors to observe, in our upward progress, the first appearance of this Cetacean, besides giving a considerable portion of my own time to the observation. In no instance have I seen a single example of this dolphin in the delta of the river; the lowest point at which I saw it on my first visit was in the deep 
water immediately below Prome, where the course of the river is well defined by high banks. On my second voyage, although a constant outlook was kept, dolphins were not met with until the steamer had reached Yenanyoung, about one hundred miles above Prome. After the first dolphins had been encountered, they were seen almost daily in the deep reaches of the river as far as our destination, Bhamô, which is about 550 miles in a straight line from the sea, and about 800 miles by the windings of the river. The Tapeng, which flows down from the high Chinese valleys to the east of Bhamô, joins the Irawady about a mile above the town, and at the mouth of the Tapeng many dolphins of all ages are generally to be seen disporting themselves in the long deep reach of the Irawady that occurs there. But during the rains, when the Tapeng and the other affluents of the great Burmese river, such as the Khyendwen and Shuaylee, are in flood, they are ascended by these dolphins. They are also numerous in the deep channels of the lower and middle defiles, and indeed may be generally observed in the majority of the deep reaches. The Shans of Upper Burma assert that the dolphins are not to be found beyond a point thirty miles above Bhamô, where the course of the river is interrupted by rocks, and which they style Labine, or Dolphin Point, from the circumstance that, according to them, it is the residence of certain Nats, who there impose so heavy a toll on dolphins as to deter them from proceeding upwards.

From very exhaustive reports forwarded to me by the Officers of the Burma Commission, in reply to a circular I had issued asking for information regarding the distribution of Cetacea in the rivers of Burma, it would appear that two species are met with, one a round-headed dolphin which is essentially fluviatile, and another with a longish snout which frequents the estuaries and is probably a Steno. The former seems restricted to the Irawady, in which it has the distribution I have just indicated; while the other enters all the estuaries, from Akyab to Mergui, which are of sufficient depth to admit it, and what appears to be this form has been observed at Rangoon, and in the estuary of the Sittang large schools are not of unfrequent occurrence.

Habits.-The Irawady dolphin has much the characters of its marine fellows, being generally seen in small schools which frequently accompany the river steamers, careering in front and alongside of them, as is the custom of dolphins of the sea. Occasionally, however, a solitary individual may be observed, but this is the exception, as two or three are usually associated together, hence this may be considered as a gregarious form. In the defile below Bhamô, where the river runs for ten miles over a deep bed 40 to 60 fathoms in depth and from 200 to 500 yards in width, and defined by high, wooded hills on either side, numerous troops of dolphins may be observed passing up and down, rising every minute or two to the surface to emit the short blowing sound, which ends in the more feeble one of inspiration, and all night through this sound may be heard. They never leave the deep water, and when they rise to breathe (which they do in periods varying from 70 to 150 seconds, although occasionally exceeded) the blow-hole is first seen, then at the end of inspiration the head disappears and the back comes into view, 
and is gradually exposed as far as the dorsal fin, but the tail flippers are rarely visible. The act of breathing is rapid, so much so indeed that it requires a very expert marksman to take aim and fire before the animal disappears. I have observed some of them disporting themselves in a way that has never yet been recorded of Cetacea, as far as I am aware. They swam with a rolling motion near the surface, with their heads half out of the water, and every now and then nearly fully exposed, when they ejected great volumes of water out of their mouths, generally straight before them, but sometimes nearly vertically. The sight of this curious habit at once recalled to me an incident in my voyage up the river when $I$ had been quite baffled to explain an exactly similar appearance seen at a distance, so that this remarkable habit would appear to be not uncommonly manifested. On one occasion I noticed an individual standing upright in the water, so much so that one-half of its pectoral fins was exposed, producing the appearance against the background as if the animal was supported on its flippers. It suddenly disappeared, and again, a little in advance of its former position, it bobbed up in the same attitude, and this it frequently repeated. The Shan boatmen who were with me seemed to connect these curious movements with the season-spring-in which the dolphins breed.

Food.-The food of the Irawady dolphin is apparently exclusively fish.

The fishermen believe that the dolphin purposely draws fish to their nets, and each fishing village has its particular guardian dolphin which receives a name common to all the fellows of his school; and it is this superstition which makes it so difficult to obtain specimens of this Cetacean. Colonel Sladen has told me that suits are not unfrequently brought into the Native Courts to recover a share in the capture of fish, in which a plaintiff's dolphin has been held to have filled the nets of a rival fisherman.

Buccal cavity.-At the angle of the mouth the buccal cavity is closed by a wellmarked fringe or fold of the lining membrane opposite to the root of the tongue and marking the point at which the skin-coloured palatal surface ceases. This fold has the appearance as if it were able to shut off the true buccal cavity from the portion immediately posterior and which is chiefly subservient to respiration. This arrangement and the circumstance that the teeth are ground down to flat surfaces would seem to indicate that the animals crush their food, and the presence of this fold may also account for the curious and remarkable habit mentioned above, as it would by shutting off the pharyngeal cavity permit of the mouth being filled with water. The base of the tongue opposite to the fold is defined by a concentric furrow backwardly directed, the two opposite extremities of which correspond to the angles of the mouth. In this furrow there are the large patulous orifices of racemose glands as in O.brevirostris. Posterior to the furrow, scattered over the floor and walls of the fauces, there are numerous minute orifices of racemose glands. Occupying a similar position to these structures, but confined chiefly to the middle of the tongue, there are many transverse fine wavy lines of different lengths, but not exceeding half an inch, while their breadth is about one-fortieth of an inch. To the touch they have a gritty feel, but in appearance they are wavy and moniliform, as if they were 
made up of fine gritty papillæ. Some of these structures also occur on the fauces. I have never observed them in $O$. brevirostris. They occur in a more scattered condition as far back as the posterior wall of the tube of the larynx. Isolated gritty papillse are also distributed over the tube of the larynx and the area immediately posterior to it, and they can be traced some way down the osophagus.

Pelvic bones and male organ.-The crura of the penis (Plate $\mathrm{XXV}^{\mathrm{A}}$, fig. 3, $c c$, and $\left.c c^{*}\right)$ are attached by a strong fibrous connection to the pelvic bones (fig. 3, $p$ and $p . *$ and fig. 4,ap.) which are placed opposite the 15th and 16th lumbar vertebræ (fig. 3, $c, t, s p$.), and the characters of these bones, their position and variability, are depicted in Plates $X X V^{\Lambda}$, fig. 4, and XLII, fig. 11. The retractor penis, which is highly contractile, lies between the two crura, and at its origin is expanded over the strong fibrous band connecting the two pelvic bones $\left(p p .^{1}\right)$. When pulled out it suddenly contracts to half its extended length. The penis is simple and without lobes, and from the base of the prepuce to the tip measures three inches in its quiescent state, but from the way the hinder portion of the organ is doubled on itself, it is evident that when distended with blood it is capable of considerable elongation, probably reaching nine inches in length. The glans or preputial portion is of nearly equal breadth throughout, its transverse exceeding its dorso-ventral diameter, as it is slightly flattened from above downwards. Its greatest diameter is about three-quarters of an inch. About threequarters of an inch from its extremity it tapers rapidly to a fine point with a slight intervening swelling, and this portion of the glans with the tip has a remarkable resemblance to the head and snout of a Trionyx. The orifice of the urethra is exceedingly small. The terminal inch constitutes the true glans, and it is coloured like the external skin of the animal, while the portion behind has a pinkish hue. The dorsal surface, unlike any other Cetacean or mammal that I am acquainted with, is marked by a mesial ridge, which begins at the base of the prepuce and extends to the tip of the organ, interrupting the somewhat concentric wavy transverse folds into which this part of the organ is thrown when at rest and which relate to extension. At the base of this long raphe on either side there is a rather large papilla marked at its tip by a patulous orifice, the opening of a gland. I am unable to say whether such a structure exists in the allied species O. brevirostris, as I have had the opportunity to examine only one badly preserved male.

Skull.-The skull (Plate XLII, figs. 1, 2, and 3) of the purely fluviatile dolphin of the Irawady has so very strong a likeness to that of the round-headed dolphin of the Bay of Bengal and its estuaries, first described by Professor Owen as Phocana brevirostris, ${ }^{2}$ that were the skulls the only materials for determining the species, considerable dubiety would inevitably be experienced in deciding on their specific distinctness. But when the animals are studied as a whole-the only reliable method-other characters gradually unfold themselves, which, when fig. 11.

1 The pelvic bones of this species are subject to considerable variation. See Plate XX^, fig. 4, and Plate XLII,

2 Trans. Zool. Soc., vol. vi , p. 24, pl. xix, figs. 1 to 3. 
duly weighed in conjunction with the perhaps otherwise unimportant differences manifested by the skulls, lead to the conclusion that the modification of structure has proceeded to that degree that in its totality it confers a specific character to this form-a result which was to be looked for in view of its peculiar habits of life.

The first point of difference between these skulls, in fully adult individuals, which strikes the observer is the more flattened occipital region of $O$. fluminalis, directed downwards and backwards, whilst in O. brevirostris it arches backwards, downwards, and slightly forwards. Another difference consists in the more depressed character of the super-occipital and interparietal region of the skull of Orcella fluminalis, an area which is considerably arched in O. brevirostris. This feature, however, is more pronounced in the skull figured by Owen than in fully adult skulls, and is doubtless a character of immaturity. The next distinctive feature is the shorter and broader snout of the former as compared with the latter, the specific name of which is inappropriate, seeing that it corresponds to no external character, and might therefore mislead to the supposition that the dolphin had a projecting snout in the flesh, of which there is no trace whatever. In Orcella brevirostris the snout tapers gradually to a point from a slight lateral bulging in the maxillaries, beginning in the adult skull about 0.88 inch anterior to the preorbital notch, but in $O$. Aluminalis the lateral margin tapers to a point much more gradually than in O. brevirostris. The maxillaries, too, in the snout of the former, are comparatively flat, and do not shelve downwards on the sides as in the latter species. In O. brevirostris the premaxillaries contract opposite to the preorbital notch, while no such marked contraction occurs in O. Auminalis, in which these bones, instead of varying in their breadth, as in the former species, preserve a nearly uniform width throughout. The intermaxillary space is also much wider in $O$. fluminalis than in O. brevirostris, and the nasals are more anterior and lower in the former than in the latter. Viewing the skulls in front, the breadth, on a level with the posterior extremities of the premaxillaries, is proportionally slightly greater in $O$. fluminalis than in $O$. brevirostris.

Turning to the base of the skull (fig. 3), we find that the relative size and form of the palatines are quite different in the two species. In $O$. brevirostris these bones, as figured in Owen's drawing of a rather young skull, form a very small portion, viz., 0.16 , of the posterior extremity of the mesial line of the palate, and in other skulls of this species before me they form even a still smaller surface. In an adolescent skull they are $0 \cdot 16$, but they do not form a suture, while in an adult cranium they are nearly on a level with the posterior extremity of the palatine surface of the maxillaries. In $O$. fuminalis, on the other hand, the sutures of the palatine, in an adolescent skull, are well defined, and the palatine is 0.52 inch in length, while in the adult it is 0.60 long and retains the same character. As is seen in Owen's figure of O. brevirostris, the tendency of the palatines is to contract in the middle towards the mesial line, and in two skulls of this species, young and adolescent, the contraction has been carried to complete division, while in the adult 
it is all but complete. In $O$. Auminalis the tendency to division also exists in the adolescent skull, but to a much less extent, while in the adult there is little or no indication of it. The measurements of these parts may be stated as follows :-

\begin{tabular}{|c|c|c|c|c|c|}
\hline \multirow[b]{2}{*}{$\begin{array}{l}\text { Sutures of palatines } \\
\text { Length of palatines obliquely across the palate } \\
\text { The distance between the bases of the pterygoids where the palatines } \\
\text { intervene is greater in } O \text {. fluminalis than in the other species, } \\
\text { and may be tabulated thus, viz. }\end{array}$} & \multicolumn{3}{|c|}{ O. brevirostris. } & \multicolumn{2}{|c|}{ o. fluminalis. } \\
\hline & $\begin{array}{l}0.16 \\
1 \cdot 24\end{array}$ & $\begin{array}{l}0 \cdot 16 \\
1 \cdot 32\end{array}$ & $\begin{array}{l}0.00 \\
1.24\end{array}$ & $\begin{array}{l}0.52 \\
1.80\end{array}$ & $\begin{array}{l}0.60 \\
1.88\end{array}$ \\
\hline
\end{tabular}

The form of the palatines differs somewhat in the two skulls. They are relatively larger in $O$. fuminalis, and their middle margins are first directed backwards and inwards and then markedly outwards and backwards, whilst in $O$. brevirostris the whole direction from their bases is outwards and backwards.

I lay considerable stress on the relations and form of the palatines, because the characters I have described are persistent in Orcella brevirostris and in two examples of $O$. fluminalis, and, moreover, on referring to the skulls of two species of an allied genus, Globicephalus, viz., G. svineval, Lacép., and G. indicus, Blyth, I find they also are distinguished from each other by well-marked and persistent characters in the form of their palatines. In $G$. indicus the pterygoids are only separated from each other by a very narrow plate of the palatines, while in G. svineval these bones are very broad and form a large surface widely separating the pterygoids. It is also a significant fact that one of the distinguishing features of $G$. indicus (G. macrorhynchus) from $G$. svineval is the relatively longer and narrower snout of the latter as compared with the former-a condition the exact reproduction of that which occurs in these small round-headed dolphins, in which the proportionally shorter snout of $O$. fluminalis has large palatines, while the longerbeaked skull of $O$. brevirostris has these bones feebly developed.

Another distinction may be noted, viz., the more marked concavity of the supraorbital plate of the maxillary of $O$. fluminalis as contrasted with $O$. brevirostris.

The tympanic and periotic are markedly distinct in the two species. In $O$. fluminalis, the latter (Plate XLIII, fig. 4), when viewed from above, is seen to have a different form from 0 . brevirostris (fig. 9) in the external half of its internal border, which is prolonged backwards and outwards to the mastoid process in a swollen outline, while the same part in O. brevirostris is concave. Anterior and internal to this border the periotic is pyramidal in O. fluminalis, while in O. brevirostris it is rounded and broad at its tip, and somewhat contracted at its base, and of much greater size. The tympanic of $O$. fuminalis is proportionally larger than in $O$. brevirostris, and slightly more pointed, and the posterior inferior border is flattened, instead of being rounded as in the latter. In O. brevirostris the posterior lobe of the tympanic is not so long as in the Irawady dolphin, in which it is not marked by the deep depression which occurs on the posterior surface of this part of the bone of the marine form. 
The dimensions of these bones are-

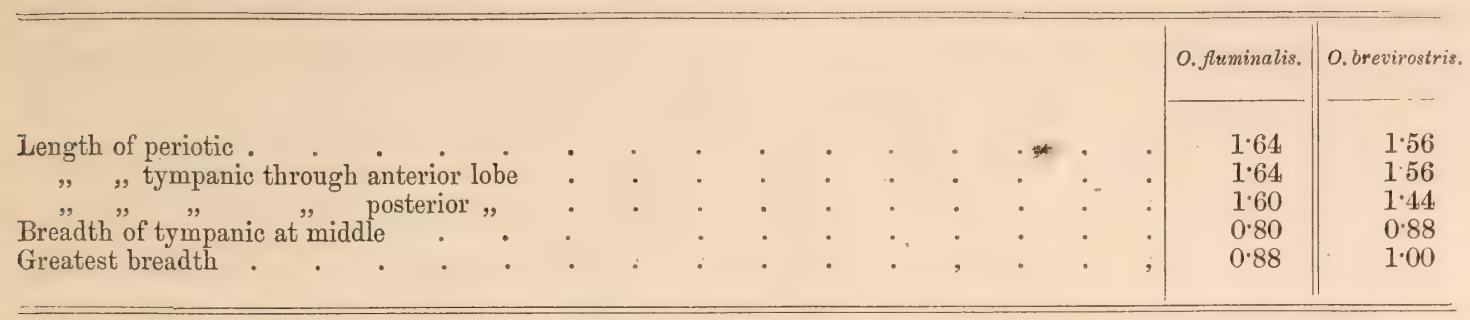

Table of measurements of the skulls of Orcella brevirostris and Orcella fluminalis.

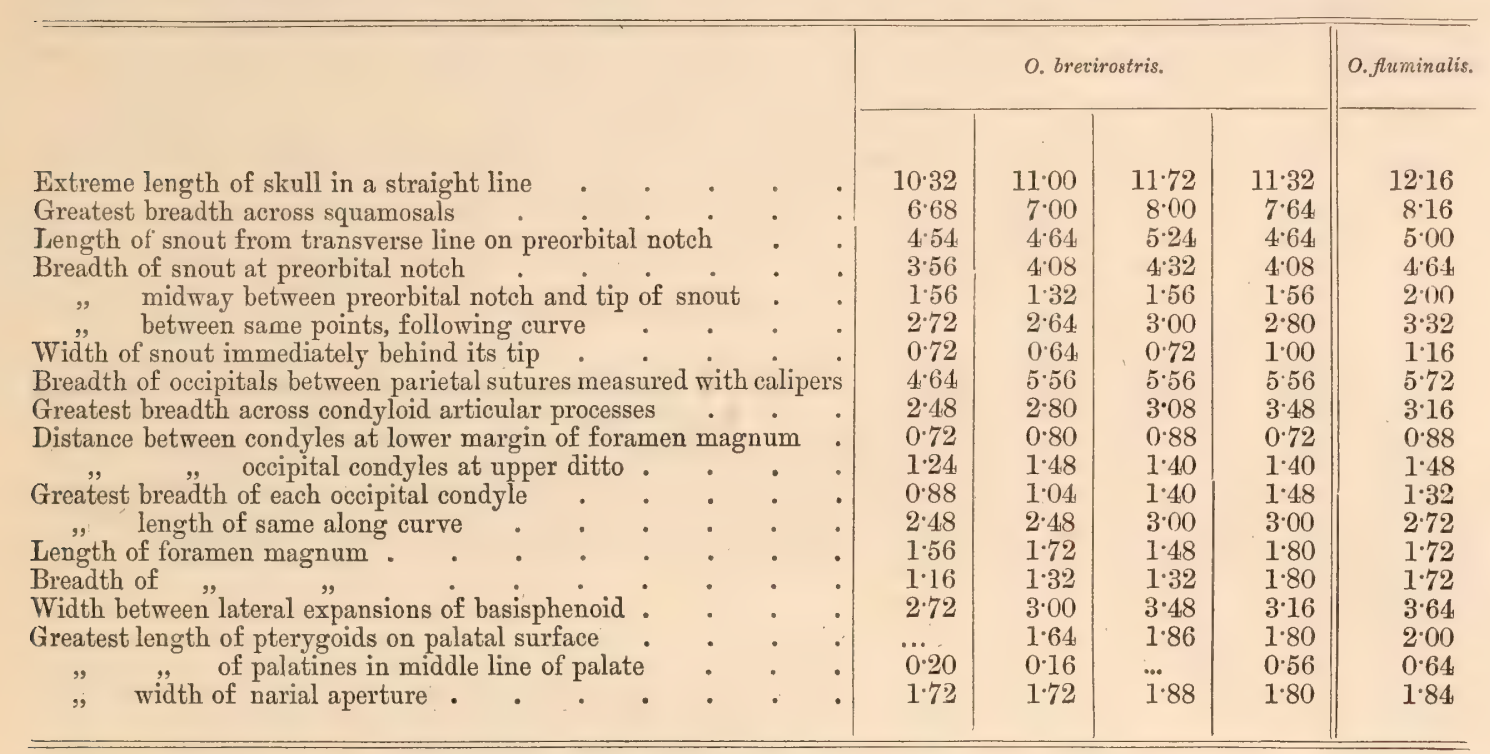

Dentition.-The visible teeth are ${ }_{\text {R. }}^{\text {R. } 13}$ L. L. 14 , but in the upper maxillary, after the flesh was removed, two on the right, and three additional sockets on the left side, were displayed. The anterior teeth are much larger than those behind them, and each is separated from its fellow by a very thin rough septum. In the left division of the lower jaw the sockets are larger and deeper than in the upper jaw, and on the right side fourteen sockets are well marked. Moreover, in the rough surface that succeeds the last tooth upon each side of the lower jaw, there are indications of what may have been the sockets of two other teeth. The first tooth in the upper jaw is fully $0^{\prime \prime} \cdot 28$ from the extremity of the premaxillaries, which are partially worn, as if they had been undergoing decay. In the adolescent skull these bones are almost intact at their tips. From the circumstance that the adult skull of O. brevirostris in the fresh state only contained eight teeth in the upper jaw; whilst when the jaws were freed of flesh they displayed a number of empty sockets on both sides, it is evident that that form, and in all probability its near ally, O. fuminalis, lose their teeth with age from behind forwards; likewise, that in the fully matured condition they only retain eight or nine of the anterior teeth on each side above and below. Decay seems to begin in the centre of the tooth, which is gradually destroyed, leaving only the hard shell, which continues to project for some 
time above the alveolus as a hard tube until it either breaks across or falls out. The teeth of the lower jaw, as already indicated, are much larger than those of the upper jaw, and are not so curved as the latter, the crowns of which are set in at a markedly obtuse angle to the root. The crowns of the teeth are worn flat from without inwards and downwards. The greatest diameter is obtained at the middle of the tooth, and the fourth of the upper jaw is the largest; the teeth behind it decreasing in size to the last, which has a double curve and a conical, almost unused crown. In the lower jaw the anterior tooth is quite as large as the teeth behind it.

Subjoined are the measurements of the teeth of the specimen of Orcella fuminalis under consideration :-

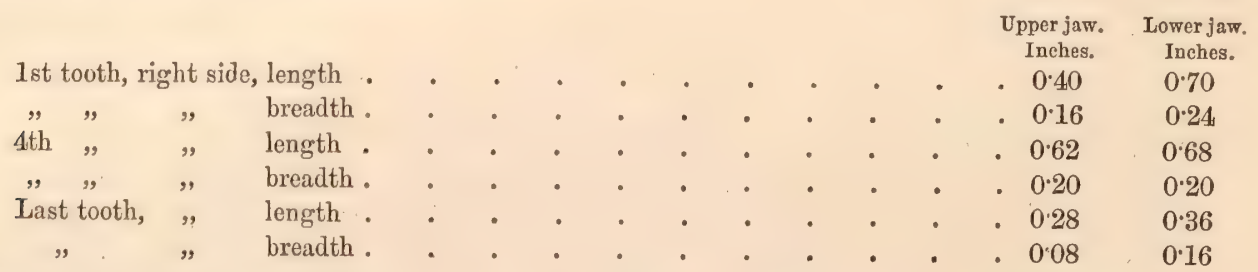

Vertebral column.-There are in all 63 vertebræ, viz., C $7:$ D $13:$ L 16 and Caudal 26. The atlas and axis are firmly soldered together (Plate XLIII, fig. 3), but all the others, with the exception of the last cervical vertebra, are perfectly free. The spinous process of these united vertebral elements is markedly bifurcate at its extremity.

These amalgamated bones of the two species (Plate XLIII, figs. 3 and 8) present certain characters by which they can be at once distinguished. In O. fluminalis the facets for the occipital are more widely divergent than in $O$. brevirostris, and are separated at their inferior border by a much narrower interval. In the Irawady dolphin the facets are almost oval, but in $O$. brevirostris they are much narrower below than above. The height and breadth of the neural arch in the latter are proportionally less than in the former, but the greatest breadth of the two bones is nearly the same in an individual of $O$. brevirostris with a skull measuring 11.72 inches, and in the specimen of $O$. fluminalis with its skull $12 \cdot 16$ inches in length. In the latter species the breadth of the spinous process below its bifurcation is much greater than in $O$. brevirostris, and the antero-posterior extent of the laminæe is much greater in $O$. fluminalis. The remaining indications of the odontoid process are also more strongiy marked in the Irawady dolphin.

The lateral laminæ of the cervical vertebræ are most expanded in the 5th segment, which is represented on Plate XLIJ, fig. 5, and which will suffice to give a general idea of the characters of these bones. The total length of the cervical region in the fresh skeleton is $4: 50$ inches.

The first dorsal vertebra is figured on Plate XLII, fig. 6, reduced to one-half natural size, and along with it the 7th dorsal and the 1st lumbar or that vertebra opposite to which occurs the 14th or free floating rib. In structure this vertebra belongs essentially to the lumbar region. The transition from the comparatively 
short transverse processes of the dorsal vertebræ to the long processes of the lumbar region is effected in the 13th dorsal in which the process suddenly lengthens, having its external half directed obliquely backwards. There is also a decided increase in the length of the spinous process of the 13th dorsal vertebra, and it, along with the transverse process, attains its maximum development on the 3rd lumbar, and from that point both gradually decrease in size until the spinous process is lost on the 15th caudal and the transverse process on the 11th caudal. The neural canal is perfect to the last process. From the 16 th caudal the vertebræ rapidly diminish in size, chiefly in their vertical depth, their transverse diameter more slowly decreasing, until in the last segment only a round nodule remains 0.15 inch in breadth. This little ossicle lies close below the skin in the notch between the caudal flippers. The 5th and 6th caudal vertebræ are perforated as usual by a canal passing through the base of the transverse processes, but in the succeeding vertebre the canal opens on the under surface of each segment in the broad vascular furrow protected by the chevron bones, but is also present in the 4th, 5th, and 6th caudals.

The chevron bones commence between the 12th and 13th lumbar vertebræ,- that is, anterior to the position of the pelvic bones,-and have the general Cetacean character. Their spines are well developed as far as the 14th caudal, but beyond that they become reduced to a ridge and the bones themselves to nodules that can be traced to near the end of the column.

Ribs.-There are in all thirteen true ribs (Plate XLII, I to XIII) on either side, but a free floating rib occurs on both sides considerably removed from the vertebral column and lying free in the lateral abdominal muscles. Five are attached to the sternum by thoroughly ossified sternal ribs, the last being attached to the posterior border of the sternum on either side of the notch. The 9 th rib and those following it are borne only on the transverse processes, the transition occurring rather suddenly at the 8 th vertebra.

Sternum.-This bone (Plate XLIII, fig. 10) differs considerably from that of O. brevirostris (fig. 5), more especially in the dilated character of that portion to which the first sternal rib is attached and in the full rounded sweep of that border which in $O$. brevirostris is concave. It is also distinguished from the latter by the presence of a deep notch which separates the anterior wings. In the sternum of O. brevirostris, however, there is a rounded hole occurring near the anterior margin of the sternum in the mesial line which may mark what may have been the base of a notch in the young skeleton afterwards closed in by the ossification of the neighbouring margins. In $O$. fluminalis the posterior end of the sternum is sometimes divided in two by a deep wide notch, and in $O$. brevirostris there is occasionally an indication of such a division. The sternum of the latter is also relatively broader than that of $O$. fluminalis.

Scapula.-The scapula of $O$. fuminalis differs from that of the marine form of Orcella (Plate XLIII, figs. 2 and 6) in the greater length and expansion of the post-scapular area, and in the more oval form (figs. 2 and 7 ) of the articular surface for the head of the humerus. 
Humerus, \&c.-The humerus, radius, and ulna (Plate XLII, fig. 9), do not call for special remark, as they have the characters generally presented by these bones in Orca, to the limb of which the limb of Orcella as a whole has a strong resemblance. Including the metacarpals the following numbers are distinctive of Orcella fluminalis: I, 2; II, 8 ; III, 6 ; IV, 3 ; the fifth finger is reduced to a cartilaginous rudiment with a bone at its base which appears to be the metacarpal of the digit, the bone internal to it being the cuneiform. Thus there are only five carpal bones consisting of two rows, three bones to the proximal and two to the distal row. They are largely imbedded in cartilage, and widely separated from each other.

Conclusion.-The facts here adduced are sufficient to establish the existence of two distinct species of small round-headed dolphins, one marine and the other fluviatile. The details of structure yet to be given under Orcella brevirostris, Owen, will clearly show that they are entitled to generic rank. 


\section{OrCELLA BREVIROSTRIS, Owen.}

Globiocephalus indicus, Blyth (in part), Journ. As. Soc: vol. xxi. 1852, p. 358; ibid. xxviii. 1859, p. 490 ; Cat. Mamm. As. Soc. Mus. 1863, p. 89, No. 274, C and D; Jerdon, Mamm. Ind. 1867, p. 160 (in part).

Phocana (Orca, Gray, Reinhart) brevirostris, Owen, Trans. Zool. Soc. Lond. vol. vi. 1869, p. 24, et. seq. pl. ix. figs. 1, 2, 3.

Orca (Orcaella, Gray) brevirostris, Owen, Gray, Cat. Seals and Whales, B. M. 1866, p. 285 ; Proc. Zool. Soc. Lond. 1870, p. 71.

Orcella brevirostris, Andr. Proc. Zool. Soc. Lond. 1871, p. 143, fig. 1.

In 1850 Blyth described a round-headed whale from a male and female belonging to a school numbering about 20 individuals, which was stranded in the salt lakes to the east of Calcutta, during an extraordinary high tide. This whale, which Blyth called Globiocephalus indicus, is closely allied to, although distinct from, the European $G$. deductor, which it equals in dimensions.

In 1852 he received another round-headed dolphin from Serampore, measuring only 78 inches in length and regarded it as the young of $G$.indicus, and in 1859 he obtained a small female in the Calcutta bazaar and converted it into a skeleton, considering it also to be the young of $G$. indicus. In this, however, he was mistaken, as the skeleton proves them to be nearly adult, and to be generically distinct from Globicephalus. Jerdon in his Mammals of India adopted Blyth's opinion regarding the identity of the Serampore dolphin with $G$. indicus.

Professor Owen was the first to describe this dolphin, but his only materials were the skull of an animal which was thrown ashore in the harbour of Vizagapatam in too decayed a state to be figured, but which Sir Walter Elliot's notes described as having a round head, without a beak. Mr. Blyth's Serampore dolphin is proved to be this species, as its skull and the skull of the specimen procured in the Calcutta bazaar agree with Owen's figure of 0 . brevirostris, and the condition of the bones of the skeleton and the state of the teeth of the latter specimen are those of an adolescent and not of a newly born female as supposed by Blyth.

Distribution.-This dolphin is apparently of frequent occurrence in the estuaries of the Ganges and Brahmaputra, but I am not aware that it has as yet been observed in portions of the rivers beyond the influence of the tides, and in this it markedly differs in its habits from Orcella fuminalis. It would appear to be a species confined as far as is at present known to the Bay of Bengal, and to frequent the estuaries of the larger rivers falling into it. It is probably to an estuarine habit that we have to look for an explanation of the origin of a round-headed dolphin in the Irawady rather than to the isolation of individuals from a marine stock by changes in the physical configuration of the estuaries themselves, although at the same time if these animals in estuaries become localised in their habits, the seaward extension of a delta and the slow change of the water from brackish to fresh might gradually give rise to a fluviatile species. It may be, however, that both these causes are contributing in the Ganges to the production of a river species of roundheaded dolphin like that of the Irawady. 
Description of external features ( $\mathrm{Pl}$. XXV, fig. 4).-The head is convex from the blow-hole to the upper lip, but its sides immediately before the angle of the mouth are somewhat anteriorly convergent, but rounded (fig. 5). The gape posteriorly has a long upward curve. The eye which is well developed, is near the angle of the gape, and in the adult is placed about one inch above it, with a slightly downward slope. The ear is nearly on the same level as the angle of the mouth, and it is extremely small, crescentic, and not measuring more than $0^{\prime \prime} \cdot 12$ in diameter. The posterior margin of the blow-hole is immediately behind the anterior angle of the eye. The blow-hole (fig. 5) is crescentic and unsymmetrical, being more to the left than to the right side. There are two slight eminences about one inch behind the blow-hole. The constriction of the neck occurs below the ear and slightly behind it. The pectoral flippers have their bases nearly on a level with the tip of the snout, and they are triangular structures moderately long and broad; the breadth equalling about one-half their length. Their anterior margins describe a gentle outward curve to the tip of the second finger; their greatest breadth is attained at the extremity of the 5 th digit, on the proximal side of which their posterior margins rapidly contract. The centre of the dorsal fin is situated behind the middle of the body, taking the caudal notch as the hindmost limit of the animal. The fin is falcate and curves upwards and backwards to a rounded point, below which the posterior margin is concave. From the base of the dorsal fin posteriorly to the caudal notch the median line of the back is sharp. The ventral line is also sharp for some inches behind the anus. The dorsal and ventral ridges stop short about five inches from the caudal notch. The caudal flippers are moderately broad with their posterior margins concave from behind forwards. The mammary slits (Pl. XXXIII, fig. $1, m$.) occur on each side of the vaginal orifice at a distance from each other of 2.75 inches. They are unsymmetrical in position, the left being placed further away from the vagina than that of the right side. The mammary slits are about one inch in length, and the nipple of each is almost completely hidden in its own furrow. Each nipple is about a quarter of an inch long and laterally compressed, the orifice occurring on the external side of an apical crenated ridge. The vaginal opening (fig. $1, v$.) is $3 \cdot 25$ inches long, and is separated from the anus (fig. $1, a$.) by a distinct perineal interval (fig. $1, p e$. ) $1^{1 \prime} \cdot 50$ in longitudinal extent, an interval which does not apparently exist to the same degree in Cetaceans devoid of pelvic bones.

The skin above, generally, is dark slaty-blue, nearly black, and very little paler on the ventral surface. None of the specimens that have come under my observation have ever presented those scratch-like streaks on the skin which I have referred to as occurring in O. fluminalis. The young have a distinct moustache occurring about one-half inch above the upper lip, and consisting of five brownish bristles; the first bristle being placed about one inch behind the tip of the snout, the line of bristles occupying an area of three-quarters of an inch (Plate XXXIII, fig. $1, h$ ).

The foregoing description was drawn up from a gravid female, the foetus of which (fig. 1) was nearly fully mature on the 1st June, the date of the death of the 
mother. A second female caught on the 16th July, and which proved to be a virgin, was rather emaciated; the neck being well defined and the angles of the ribs distinctly indicated. The under surface half-way between the pectoral flippers and the genital slit was marked by a deep longitudinal mesial furrow fully an inch in depth, and from the anterior extremity of this a branched depression was prolonged forwards widening into a rounded hollow over the sternum. The genital slit was $42^{\prime \prime} \cdot 80$ from the tip of the snout, and $4^{\prime \prime} \cdot 20$ in length, and the anus was $1^{\prime \prime} \cdot 50$ removed from its hinder end. The left mammary slit was the longer, measuring $0^{\prime \prime}: 38$ in length, and that of the right side was $0^{\prime \prime} \cdot 33$ long, the distance between them posteriorly being $1^{\prime \prime} \cdot 33$ and anteriorly $1^{\prime \prime} \cdot 46$. The anterior end of the left slit was $2^{\prime \prime} \cdot 06$ from the anterior end of the vulva. The right ear in this specimen was $0^{\prime \prime} \cdot 08$ in diameter, but on the left side it was so reduced that I did not detect it for some time, and it would hardly admit the passage of a fine bristle. The moustachial bristles had been shed, but their position was indicated by the pits in which they had stood.

This example yielded the following girth measurements :-

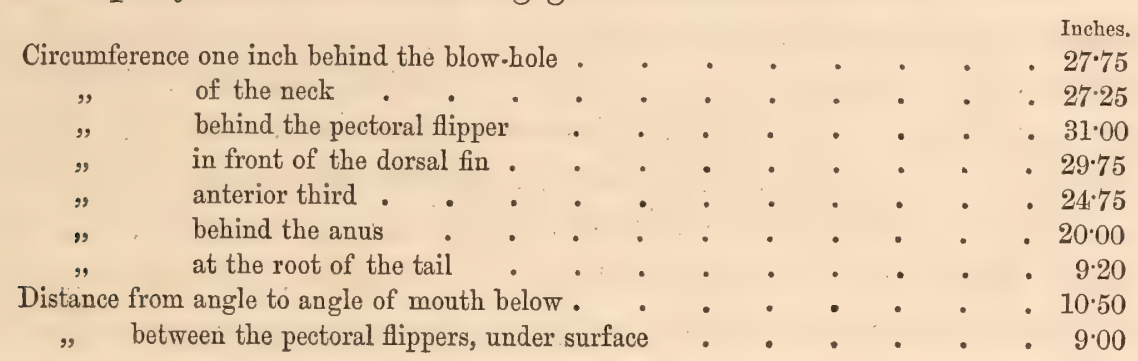

Measurements of two specimens of Orcella brevirostris.

From tip of snout to caudal notch, alongside

Snout to dorsal fin following curve of back

Length of the dorsal fin ( $i . e_{\text {., }}$, antero-posteriorly)

From tip of snout to base of pectoral flipper

Length, anterior margin of pectoral extremity

" posterior margin of same.

Caudal fin along its anterior border

Snout to blow-hole over forehead.

Breadth of the blow-hole

Height of the dorsal fin

Across from tip to tip of caudal fin

Depth of the caudal notch

Length of pectoral extremities in a straight line

Greatest breadth of pectoral flipper

From the tip of snout to angle of mouth

From angle of mouth to ear-hole in straight line

Distance between angle of mouth and eye .

Length of the eye

Distance from eye to eye taken round point of snout

Cavity of the mouth (Pl. XXVII, figs. 1 \& 2).-The pigment of the external skin occurs on the mucous membrane as far as the position of the frænum lingur, on the inside of the lower lips, and all over the upper lips and on the palate as far back as on a line with the angle of the mouth. The lower lip is rounded, but the 
upper lip has a sharp margin, and the interval between it and the line of upper teeth is concave from without inwards, broad behind at the last tooth and narrowing anteriorly to a point. A deep furrow runs from the symphysis of the lower jaw to the base of the tongue, and numerous folds pass from it along the sides of the tongue, to the angle of the mouth. The deep furrow and the folds in these localities like others presently to be described on the palate in the faucial and pharyngeal regions and œsophagus are all represented in the fotus, so that they are structural characters developed to confer expansibility on these portions of the digestive tube.

The tongue of this genus (figs. 1 and $2, t$.) is free as far back as the beginning of the posterior fourth of the interdental space of the lower jaw, and in this respect it differs remarkably from the character of this organ in Cetacea generally. It is a long spatulate structure with sharp free borders which shelve rapidly downwards and backwards, and it is slightly contracted opposite the angle of the mouth and somewhat dilated anterior to that, terminating in a rounded but pointed end, external to which the margin is crenulated for a short distance both in the fotus and in the adult. Behind the angle of the mouth, it is concave from before backwards and slightly raised and swollen into two basal eminences. In the fotus the anterior portion is more or less concave from side to side, which is to a certain extent also the character of the organ in the adult. In the fœetus there is a fold corresponding to the frænum linguæ, but it disappears when it is laterally stretched and returns when the parts regain their natural position. In the adult, however, there is no fold determinable in this locality. In the fotus the organ measures 4 inches from the anterior end of the frrenum epiglottidis to the tip, and it is free for one-third of its extent. In the adult, the tongue to its base is 6.85 inches long and $1 " \cdot 90$ in its greatest breadth. In the foetus there is no indication of a raphe, and indeed so far from such a furrow existing, the middle of the tongue anteriorly is slightly raised, as two shallow and feeble furrows run backwards from the first crenulation external to the triangular tip. In the adult, however, a short raphe begins opposite the angle of the mouth, and running backwards for about one inch terminates in a transverse fold, which curves forward from angle to angle of the mouth and corresponds to the limit of the extrinsic muscles of the organ, but which does not show in the fotus. On either side of the raphe there are many wavy longitudinal folds which become curved on the attached portion of the tongue, anterior to them the convexities of the curves being forward, and these folds are feebly marked in the foetus. Immediately posterior to the deep transverse fold there are similar feebler folds which also exist in utero, and before the basal eminences in the fotus, the dorsum of the organ, as in the adult, is covered with convoluted folds. I have failed to detect the orifices either of sublingual or submaxillary glands or the openings of any glands whatever on the under surface and sides of the free portion of the tongue. In the adult the margins of the tongue superiorly and the whole of the dorsum, within an inch of the tip, as far back as the transverse fold, are covered with the orifices of mucous glands. Behind the transverse fold, less numerous, but much larger and 
patulous orifices occur all over the posterior portion of the organ, and these are the terminations of large racemose glands. The openings are chiefly confined to the hollows between the folds or convolutions. Only filiform papillæ occur on the portion of the tongue anterior to the transverse fold, but behind that, as far back as the frænum epiglottidis, the dorsum is sparsely covered with pedunculated or sessile papillæ. The former are club-shaped eminences of the mucosa clad with filiform papillæ, and the longest measures about 0.20 of an inch in length, of which its head forms about $0^{\prime \prime} \cdot 10$. The sessile papillæ are the most prominent, and they are generally situated either singly or in pairs at the mouths of the larger racemose glands, where also but more rarely occur some of the pedunculated kind.

Palate (Pl. XXVII, fig. 1, p.).--Its surface is triangular, convex from side to side, and perfectly smooth in its anterior or interdental portion. It is thrown into transverse folds behind this in the region of the angle of the mouth, and into longitudinal folds in the remainder of its extent. The interdental portion is, however, traversed by a straight sharp longitudinal furrow, which begins with a bifurcate end embracing a triangular eminence at the anterior margin of the palate. It is deeply marked in the adult and also in the foetus, in which in the region of the transverse folds, it is interrupted by a transverse slit or mucous crypt (c.) situated over the end of the palatal portion of the maxillaries in a line with the inner angle of the mouth. I can throw no light on the nature of this recess beyond that it is lined with the mucous membrane of the palate, which, however, loses its pigment at the margin of the sac. It is 0.40 inch long, and leads into a short cul de sac 0.12 inch in length. The median furrow again shows itself a short way behind the slit and runs backwards for some distance.

At about 0.9 inch from the anterior margin of the posterior nares in the adult, and 0.5 inch in the fotus, there are two crescentic folds of the mucous membrane occurring on either side of the mesial line of the palate separated from each other in the adult by an interval of 0.45 inch and in the fœtus by an interspace of 0.1 inch. The convexity of the folds is directed forwards, and each defines a recess in the mucous covering of the palate 0.2 inch in breadth in the fotus, and but only a little larger in the adult. In the left recess of the fotus there is a nipple-shaped structure surmounted by a small round sessile papilla, and surrounded at its base by a distinct fold. It is not so well marked on the right side, which is due, however, to the more relaxed condition of the mucous membrane. In the adult when these recesses are laid open they are found to be studded over with small lobules or amygdaloid bodies. The structure, position and contents of these crypts lead to the supposition that they are probably the representatives of the tonsils. If this prove to be the case, they are the first instance on record of the occurrence of these glands in the Cetacea. On the palate, external to and behind the tonsils, are large openings of racemose mucous glands and sessile and pedunculated papillæ, the same as occur on the tongue.

Before leaving the palate, it may be stated, that in the fotus the line of teeth is indicated immediately internal to the groove that defines the palatal surface from 
the upper lip, by a wavy ridge containing fifteen small conical teeth on the right side completely hidden below the skin.

Faucial region.-This is marked by longitudinal folds continuous with those of the pharynx and at the base of the tongue. Papillæ like those of the tongue also occur on the sides of the fauces, where they have a similar relation to the orifices of the racemose glands (Pl. XXVII, fig. 3, go). These latter structures are numerous in the fauces, and their ducts are wide and patulous. When the mucous membrane is reflected they are found to cover not only the base of the tongue and sides of the fauces, but to invest the broader portion of the palate except in a narrow space in the middle line. They form a dense layer extending from the root of the epiglottis along twothirds of the distance between that point and the angle of the mouth, and when dissected out they resemble a little forest of glands on the reflected mucosa. These structures (fig. 4) measure on an average 0.70 inch in length. Each has the appearance of a flask with a long neck, and when cut open the duct is found to dilate into a large chamber in the body of the flask, into which the secretion of the lobules which invest the chamber is thrown by a few small ducts, the chamber resulting from the confluence of a number of smaller ducts. The lining membrane of the chamber is clear and glistening, and each receptacle was filled with a grumous mass.

Esophagus.-This tube is thrown into numerous longitudinal folds, and the surface generally is perforated by the minute orifices of mucous crypts. About 10 inches from its stomachal opening there are a few glandular masses about 0.06 inch in diameter, but I have not been able to detect more than four or five. They consist of little wart-like clusters (fig. 6) raised above the mucous membrane. The number of primary lobules in each varies, the most compound having as many as six lobules. These lobules are rounded externally and have converging apices, which, however, do not meet in the middle of the gland which is traversed transversely by a clear space covered with the epithelium of the osophagus. The apex of each presents a dark area. Under a power of 350 diameters each lobule is seen to be composed of a series of secondary lobules, all of which along with the primary lobules are enclosed in a fibrous capsule.

Stomach.-No organ in the body of whales seems to have given rise to so much controversy as the stomach, no two authors absolutely agreeing as to the number of cavities even in the same species. ${ }^{1}$. In the allied genus Globicephalus, the passage between what I term the 2nd and 3rd cavities has been regarded as a cavity, and again the duodenal expansion (Pl. XXVII, fig. 5, iv.) has been reckoned also as a gastric cavity. The number of chambers then would seem to depend on the mode of counting them rather than on their presence or absence in particular cases.

The stomach of Orcella (Pl. XXVII, fig. 5) consists of three cavities, and of an intervening narrow funnel-shaped channel between the second and third sacs. The first division is the largest. It is regularly pyriform in shape, with its base towards the left and its apex to the right side, but bent round

${ }^{1}$ Consult H. MI.-Edwards, Leẹons sur la Physiologie, \&c., t. vi., for the literature of this subject up to 1861 : also Flowers' Lectures, Medical Times and Gazette, vol, ii. 1872 : Turner, Trans. Roy. Soc. Edinr. 
somewhat to meet the oesophagus, the posterior wall of which is in the same plane with the dorsal wall of this cavity. The sac is much longer from left to right than it is broad antero-posteriorly, and it is placed transversely across the body. When the cesophagus is laid open posteriorly, one of the folds of that tube is observed to become enormously enlarged into a free flap which depends behind the opening into the second stomach so as completely to prevent the entrance of food into it, on its passage down the osophagus. The entrance to the second cavity occurs at the angle formed by the osophagus and the cavity in question, and is directed upwards and forwards, and towards the left side. The walls of the cavity are of great thickness. The mucous membrane is very rough and yellow, and covered all over with small, short, much convoluted ridges, with deep intervening sulci; the whole surface, in addition, being thrown into enormous folds which are arranged around the opening into the second cavity so as to close it completely.

The second stomach (fig. 5, ii.) has only about one-half the capacity of the first. It lies above and over the right third of the previous cavity at right angles to its long. axis, its base being dorsal or at the osophagus, and its apex opposite to that, on the ventral wall. It is oval in form, with its mucous membrane of a greyish tint and perfectly smooth, but thrown into large convoluted folds about one inch in thickness and diameter, and which radiate from the communication with the first stomach. This opening is placed on a line with the anterior wall of the œesophagus, and when contracted has a length of two inches. The rough yellow mucous membrane of the first stomach is visible around the opening common to the two cavities when the second is cut open. The orifice leading to the third stomach occurs about one inch below the last mentioned opening and it looks backwards. It is a narrow slit one-fifth of an inch in breadth, and the mucous membrane immediately around it is not convoluted. On laying the channel open it is found to dilate suddenly into a tube about half an inch in diameter, but at its lower third it expands even to about twice that dimension, again contracting to half an inch at its orifice leading to the third stomach. The third stomach (fig. 5, iii.) lies below the opening from the second stomach, being distant from it about two inches, viz., the length of the channel between these two cavities.

It assumes the form of a tube bent upon itself, and the convexity of the bend which is directed anteriorly is on a level with the upper opening of the funnel-like passage leading into it from the second stomach, while its left side lies parallel with the same passage. The pyloric orifice is on a level with the lower third of the first stomach, and about an inch below the base of the sacculation which marks the beginning of this cavity. There are some obscure folds in the latter locality, and a few similar folds at the bend. The mucous membrane is whitish, and presents two distinct characters. In the greater part of its extent it is covered with a fine mesh work of more or less transverse fibres enclosing: shallow depressions or pits, with a few isolated funnel-like orifices thus resembling the texture of a gravid Cetacean uterus. The remainder of the cavity is quite smooth, but with occasional funnel-shaped openings about 0 ".04 in diameter. The mucous 
membrane is not very thick. The third stomach is shut off from the duodenum by a broad flattened portion of the wall constituting a septum, in the centre of which is the pyloric opening, about $0 \cdot 12$ of an inch in diameter.

The duodenal sac $^{1}$ (fig. 5, iv.) is a capacious cavity which is rapidly contracted into a very narrow tube one inch before the opening of the common bile duct. The mucous membrane is smooth, but around the pyloric area, especially on the anterior wall of the sac, there are rough areas of the same character as those of the third stomach. A few pillar-like folds radiate from the pyloric septum which has a much greater expansion on this than on its other side, and a few deep funnel-shaped pits occur between the folds. A few solitary glands are scattered here and there, but there are no Peyer's patches. The gut-like portion of the duodenum (fig $5, d_{\text {.) }}$ ) available for observation, extends only to three inches. It is thrown into numerous longitudinal and transverse convoluted folds, approaching in character to valvulæ conniventes, and at its commencement it is covered by numerous deep pits.

Minute structure of the walls of the stomach.-As has been above stated, the superficial aspect of the mucous membrane of the gastric cavities differs even to the naked eye, so likewise when examined microscopically there are certain differences. It may be as well, however, before mentioning these, to state that both in the case of Orcella and of Platanista, a large series of microscopical preparations were made by myself and partly by Mr. A. Stirling of the University Anatomical Museum, Edinburgh, whose skill in microscopy and accuracy in manipulation are well known. The specimens were prepared from materials which had been preserved in alcohol; staining by re-agents in some cases being adopted where clear definition of textural character was desiräble. Various preservative media were used, but most of the specimens were of sufficient consistence to be mounted in Canada balsam. From their oily nature Cetacean tissues are well known to anatomists to retain their original characteristics intact and uninjured for a long period, and to be little affected or altered by their alcoholic preservation. Hence those sketches delineated in Plates XXXVI, XXXVII, and XXXVIII of dermal, visceral, placental, and other parts of the round-headed and Gangetic Dolphins (Orcella and Platanista), and most carefully drawn from the objects themselves under different microscopic powers will be found to convey clear impressions of their minute structural peculiarities. These will be described in detail, and will be considered, I trust, to have contributed somewhat towards the elucidation of the minute anatomy, physiology, and organic economy of at least two highly interesting genera of Cetacea. Those especially which relate to certain glandular structures or organs, and to placentation are, I conceive, highly important, in some cases corroborating and in others offering points of divergence from facts and opinions expressed by such authorities as Eschricht, Stannius, Ercolani, Flower, Turner, Alf. M.-Edwards, Murie, \&c.

To return to the stomach of Orcella: when sections are made, for example that shown in Plate XXXVI, fig. 14, viz., a vertical section of the wall of the first cavity, it is seen that this chamber, structurally, is but a passive recipient in the digestive

${ }^{1}$ Cuvier, Leęons d'Anat. Comp. Ire Edit. t. v. p. 345, p'• xxxviii, fig. 2; Flowers' Lectures, l. c., p. 427. 
process. In this respect, therefore, it is comparable to the paunch of ruminants, or it may be, to the gizzard of birds. Superficially, at $e$, there is relatively a considerable thickness of a somewhat coriaceous or horny epithelial layer, and which follows the sinuosities of the ridges and furrows. The epithelium is chiefly squamous and in horizontal compressed layers on the free surface, but, here and there, and deeply, groups of cylindrical epithelial cells are less or more aggregated together. These somewhat wavy horizontal layers, without any very marked line of demarcation, abut against and seem to constitute a series of vertical papillæ, similar to those of the skin, but their general appearance simulates the true gastric follicules of the succeeding stomach cavities. The series of columnar tubes $(c . g$.) descend in nearly parallel straight lines to the subjacent areolar tissue; their inferior differing from their upper extremities by terminating in clear and distinct, obtusely tapering or occasionally bulbous ends. These cylindroid columns are evidently of a solid consistence, and composed of epithelial cells varying in figure according as they are more loosely or more densely packed. The papillary interspaces are less than half the thickness of the columns and much more transparent; they have a somewhat fibroid character from the upright closely pressed position of elongate cells. Inferiorly this lineocellular character passes into the more distinct fibro-cellular tissue beneath. Here and there, muscular bands or cut ends of muscular fibres form an imperfect layer in the areolar tissue; the latter is wider-meshed and more fibrous below, and many minute blood-vessels $(v$.) traverse it in diverse directions.

A similar vertical section of the wall of the second stomach as seen somewhat more highly magnified (fig. 15) reveals the presence of a comparatively very thin and scarcely appreciable layer of free epithelium. The smoothish surface is everywhere perforated by orifices, the mouths of capacious gastric glands. These latter are long and tubular, mostly single, and straightish throughout or with wrinkled walls, although some either obscurely or more definitely point to saccular branching in their lower segments. The tubules are filled with the so-called peptic cells of the ordinary character. The sub-mucous, fibro-cellular and areolar tissue, with occasionally muscular fibrillæ; agrees to a certain extent with that of the first cavity of the stomach, but it differs in being more copiously supplied with bloodvessels, which are of great calibre and exceedingly thick-walled, and more shall be said of them presently. Indeed, as fig. 5, v, shows, their interior is reduced to a small hollow centre surrounded by a circular fibrous wall far exceeding the apparent necessities of the narrowed channel.

The third cavity of the stomach, and wherein possibly digestion is most actively carried on, has abundance of gastric glands, as in the preceding chamber, and, like it, many blood-vessels ramify within its musculo-serous coats.

Vascular channels of the stomach.-Under this head it is desirable to call attention to their general distribution along with certain other glandular structures in connection with them. In Professor Turner's account of the great Finner Whale stranded at Longniddry, ${ }^{1}$ he has given some interesting observations on a remarkable

\footnotetext{
${ }^{1}$ Trans. Roy. Soc. Edinb. 1870, rol. xxvi. pp. 231, \&c.
} 
"moniliform tube" in the mesentery of Balanoptera sibbaldii and other concurrent arrangements in the vascular system. Dr. Murie also, in researches on the Organization of the Ca'ing Whale ${ }^{1}$ (Globicephalus melas), has directed attention to peculiarities in the vascular and lymphatic system of that genus. The views propounded by these authors do not entirely coincide, though each admits a probable certain connection between the blood and the lymphatic systems. The fact of Orcella, and the possibility of other Cetaceans besides those mentioned, possessing structures modifying the more direct circulation of the blood among the viscera thus acquires additional importance, which future researches may render more clear and explain the physiological function performed by these modifying structures.

Owing to the heat of the weather and to other causes incident to the difficulties of dissecting in a tropical climate, I could not follow thoroughly the distribution of the coliac axis. I was, however, very soon struck by the fact that the arteries supplying the stomach were at intervals dilated into large sacs, from which small branches diverged which communicated with the main channels and their sacs by minute orifices, as is illustrated in fig. 8 .

Large vascular channels penetrated the walls of the stomach between the second and third cavities, and I shall presently more particularly allude to their connection with the glandular structure. The walls of the vessels were, as mentioned by Professor Turner, of great thickness, and this was the case not only in those of great calibre, but equally in the minute arterial twigs, given off not only to the stomach, but to the spleen, the pancreas, and the whole of the lymphatic glands. Indeed, when preserved in alcohol, they appeared as a vast ramification of hard cords penetrating everywhere gastric and surrounding tissues, and even carried onwards towards the mesentery. In most respects, therefore, they corresponded to Turner's description, and accorded with the character given of the "moniliform tube" (l.c. $)$.

Peculiar gland of stomach in Orcella.-Lying in the angle formed by the œsophagus and the second stomach, and hidden in its lower third by the third stomach, and covered above by the liver, is a large gland, which is closely related to the coronary artery and vein of the stomach. Its position is indicated by $g$. and pointer, fig. 5, Pl. XXVII. It is somewhat triangular in form, and measures 3 inches long and broad. Its base or hilus is placed towards the superior branch of the coronary artery, the anterior surface of which it wholly invests. Its lower third is also placed over the inferior branch of the coronary artery and vein. Its lower border is loosely adherent to the pancreas and its posterior surface to the right extremity of the first stomach, whilst its apex, where the vein and artery which traverse it quit the gland, is firmly adherent to the apex of the first stomach at its right side, where the œosophagus ends and the stomach begins. Its base is loosely adherent to the vena cava inferior, and the hepatic artery and portal vein enter the liver to the right of the gland. It is invested by a strong fibrous capsule, through which and between it and the cortical substance numerous blood-vessels

\footnotetext{
1 Trans. Zool. Soc. 1873, vol. viii. pp. 270, \&c.
} 
ramify. The fibrous capsule also sends outwards to the medullary substance strong fibrous bands, which unite with similar bands derived from the hilus. The cortical substance is about a quarter of an inch in thickness, and is of looser texture around its capsular than its medullary border which is fibrous in texture; the fibrous bands generally indicating the presence of arterial twigs provided with enormously thick coats. The gland is attached all along its under surface to either side of the inferior division of the coronary artery and vein, while its base, direeted upwards, is attached along the superior branch of that artery which it invests. At the beginning of the inferior division of the coronary artery two branches are given off for the supply of the gland, one passing into the inferior fifth of the gland, as a distinct branch, whilst the other, proceeding from the opposite side of the vessel, runs right through the, base of the gland, viz., parallel to the superior coronary artery and in front of and above the superior coronary vein, and inosculating with the superior coronary artery after it issues from the gland. These vessels, artery and vein, are embraced in the firm fibrous capsule, except below the vein where the fibrous character is lost.

As to the intimate structure of the above mentioned stomach gland, I have given its naked-eye appearance when sliced through in fig. 7, Pl. XXVII. Beneath its strong fibroid capsule, is firmish gland-like substance (g.) pierced here and there by thick-walled blood-vessels $(a$.$) of an arterial character, and wide,$ irregular, elliptical, or irregularly contoured venous channels $(v$.). In one part of it there is a much firmer, tougher, almost tendinous-like mass $(t$. $)$ and much less porous than the neighbouring tissue. The glandular substance itself in all essentials agrees with an ordinary lymphatic gland, with moreover a feature peculiarly its own, viz., an enormous number of good-sized, even large, vascular channels, besides a plentiful supply of tributary capillaries. See fig. 3, Pl. XXXVII, and also compare figs. 4 and 5 in same plate, being sections of a somewhat similar gland in the lung of Platanista and Orcella. Thin and partially transparent sections of these glands made in a variety of directions and examined under low and high microscopic powers show everywhere a vast number of capacious bloodchannels. These are by no means regular in calibre or direction, but branch hither and thither, and from them also proceed branches and branchlets of very irregular character. Very fine twigs seem to pass direct to those of larger calibre, and veins and arteries seem mingled promiscuously. This vascular plexus has not then the character of what is understood by rete mirabile, where the vessels maintain a nearly uniform calibre and run close together in parallel lines; but, on the contrary, it has a want of uniformity. Some of their walls are thin, as if alone bounded by a cellular layer; others are much thicker walled. Encompassing these vessels in every direction, and indeed simply allowing them to permeate it, is a trabecular frame-work of variable degrees of thickness and fineness and the meshes of which are of all sizes and shapes, though, where the intermediate more pulpy substance has been pressed out, the reticulation has a somewhat stellate configuration. This last is due to more condensed enlarged portions of the membrane giving off radii 
joining others, or to an increase of substance at certain points of junction. of the retiform connective tissue. Filling the interspaces is the more pulpy subtance composed of innumerable cells and granules, and occasionally aggregations of both, in some places thinner, in others thicker, as the case may be. These nucleated cells or globules correspond in size, shape, and general appearance to ordinary lymph corpuscles, which they doubtless are. The stellate appearance, above mentioned, in the fibrous net-work or trabecular frame-work is due in some instances to more closely adherent masses of these corpuscles, in others to the junction of spindle-shaped cells of the trabeculæ.

Scattered throughout the gland tissues may be observed some unequally shaped open spaces which presumably may be regarded as the so-called lymph sinuses. Lastly, it may be noticed, that although throughout the general glandular substance there does not clearly seem to be a true vascular rete mirabile, nevertheless there exists towards the surface of the gland a layer which assumes this character. This layer on cross-sections shows a congeries of vessels of a variety of sizes matted together and to some extent in intercommunication. These vessels are distributed through a mass of elastic fibres, and, here and there, linear, elongate but narrow, or large elliptical vacuities exist. These last may be the venous channels, but the exact relation and office of the lacunæ or vacuities it is difficult to make out satisfactorily.

While thus we have, not only in the stomach, but elsewhere, in this Cetacean, as I shall afterwards mention, large lymphatic glands, enclosed as it were in bloodchannels and doubtlessly in close physiological connection with them, the precise intercommunication of the lymph and blood in these organs, and whether it has any connection with or relation to the habitat and habits of Cetacea, are obscure problems yet to be solved. ${ }^{1}$

Relations of omentum to the viscera.-Tracing it from the angle of union of the first and second stomachs, it arches round to the lower curvature of the first mentioned of these two cavities until it reaches the notch at its left end; this marks the beginning of the third stomach along the lower curvature, where it passes and is continued for an inch on to the duodenum, Pl. XXVII, fig. 13. Leaving the duodenum it turns to the left and is attached along the lower border of the pancreas. But the gastro-duodenal artery, as it courses forwards behind the duodenum, carries with it a fold of omentum up to the septum of the third stomach, so that a small omental sac exists at that point where the artery reaches the third stomach, and another and much larger sac lies to the right and somewhat behind the former and is produced by the free forward arching of the artery. The omentum is prolonged along the left border of the pancreas a short way along its anterior margin, thence passes to the left to be attached to the apex of the first stomach, thus giving rise to a large sac, extending from the duodenum to the last mentioned locality, and thus enclosing the pancreas and the two small sacculations already

\footnotetext{
${ }^{1}$ See Turner and Murie's remarks and reflections on this subject in the Memoirs already quoted.
} 
described. From the apex of the first stomach it is prolonged along the upper border of the spleen for two-thirds of its extent, and leaving that gland courses upwards along the inferior border of the round gland splenule which is in such close relationship with the spleen and which is thus situated on the great sac of the omentum. It then is attached in a great curve along the anterior face of the first stomach up to the point at which we started.

Pancreas.-This gland, wholly hidden by the third cavity of the stomach, extends between the right extremity of the first stomach and the commencement of the duodenum. It is firmly attached to the portal vein which it almost wholly embraces, and also to the duodenal attachment of the gastro-duodenal artery. Its inferior extremity is immediately above the spleen, but separated from it by the intervening attachment of the omentum. Above the extremity of the first stomach, it lies side by side with the large gland of the first stomach. It does not reach the anterior surface, as already stated, but when the liver is cut away, it is observed surrounding the ducts and vessels of that gland, and a small process lies to the right of the duct in the angle formed by the third stomach and the duodenum, and another long portion to the right of the portal vein. It is placed obliquely from the left forwards to the right, and is nearly oblong in form, with a small offshoot to the wall of the gastro-duodenal artery. It is four inches long by one and a half inch in breadth. It opens into the ductus communis choledochus by two wide orifices, lying one before the other in front of the portal vein as it enters the liver. Each orifice is a quarter of an inch in diameter, and they are separated from one another by an interval of similar extent. The most anterior of the ducts arises from the anterior half of the gland, and is of sufficient capacity to admit a crow-quill for 3 inches of its extent, and the posterior duct has a similar diameter, and arises in the hinder half of the gland. The orifices of the ducts are thrown into thick folds, and when laid open the channels are seen to be covered with a smooth mucous membrane, which is thrown into pits and depressions defined by strands of the mucous membrane, minute orifices opening into the pits and depressions.

. Spleen.-This is attached to the lower border of the first stomach and lies immediately below the extremity of the second stomach, but separated from it by a wide interval (Pl. XXVII, figs. 11 and 13). Its length is 2.25 inches and its breadth $1 \mathrm{inch}$, and it is placed transversely. It is cordate in form, and the base of the heart-shaped body which is to the right, in one specimen is capped by a buttonshaped pedunculated portion of the gland. The body of the gland is attached along nearly the whole of its length, andrit is thus sessile. The spongy texture of the body of the gland is not continued directly into the button-like splenule, because the latter is contained in a distinct capsule of its own, but there is a fibrous thickening of the concavity of the base of the body of the gland, through which the vessels enter. In close relation to the left end of the spleen in the same specimen, there is a pedunculated laterally compressed rounded splenule $0^{\prime \prime} \cdot 70$ in diameter and 0.25 inch in thickness, but it is absent in another stomach. The trabecular substance is resolvable into two well-marked portions, an external and internal; the former con- 
stitutes a compact layer a quarter of an inch thick all round the sides of the gland, except at the union with the button-shaped splenule, and invests the internal portion which has the characteristic texture of the spleen.

Liver (Pl. XXVII, figs. 12 and 13).-In one old female, this organ, after thorough preservation in alcohol, measured about 12 inches in transverse and 9 inches in longitudinal or antero-posterior diameter. As in most of the whale tribe, it is thick, smooth, and free from lobular divisions. The umbilical eleft is, however, deepish, defining almost equal-sized dextral and sinistral moieties. A short shallow sulcus or merely superficial indentation on the posterior aspect of the left side was present in this specimen. The vena cava $(v, c$.) runs along the posterior border. The hepatic vessels $(h$.) enter about the middle of the gland, and they exhibit thick dense fibrous walls surrounded by what appears as subsidiary vascular tissue, a partial rete mirabile.

Ductus communis choledochus.-The liver opens by two orifices into this duct (Plate XXVII, fig. 9), and the pancreas by a similar number placed immediately below the openings of the bile canals. One of the hepatic ducts from the left lobe is situated anterior to that from the right, which is double, immediately before it enters the common duct. The duct is a great wide canal three-fourths of an inch in diameter, almost equalling the capacity of some portions of the small intestine when laid open, but it gradually diminishes in its course of five inches to the duodenum to a capacity of 0.06 inch at its opening into the intestinal canal. At its commencement, marked folds pass down from the orifices of the bile ducts, transverse to the long axis of the tube, but beyond the pancreatic ducts there is a limited area in which the folds are oblique. Throughout the rest of the duct the mucous membrane is thrown into strong wavy transverse folds, and at about its latter half these are traversed by three or four longitudinal furrows. To the naked eye the mucous surface is seen to be minutely pitted and transversely grooved, and in some parts this structure recalls the appearance presented by the mucous membrane of the gravid uterus of this species. When examined with a hand lens the pits are seen to be separated from each other by finely membranous septa and the grooves to be divided into compartments by similar septa. The pits and septa are of most frequent occurrence in the hollows between and crossing the transverse folds, but they occasionally occur on the folds themselves.

A microscopical examination of the walls of this common bile duct (Pl. XXXVI, fig. 16) disclosed a delicate layer of short columnar epithelium covering the free villous-like surface. Into this opened the mouths of many long branching lobular glands $\left(g_{0}\right)$, these latter being crammed with large nucleated cells. These glands, therefore, doubtless furnish a mucous or other secretion to be added to the biliary and pancreatic fluids. Beneath them, is a thick layer of elastic areolar tissue $(c$.$) ,$ and again, considerable strata of transverse and oblique, nucleated and unstriped muscular fibres $(m$.$) .$

Intestines.-I shall limit my remarks regarding the intestines to pointing out that the mucous folds of the duodenum do not form marked valvulæ conniventes as 
I shall have occasion afterwards to show in Platanista gangetica. In Orcella, the duodenal folds (Pl. XXVII, fig. 10), instead of forming regular lappets running quite across or around the cavity, have short rugæ directed partly longitudinally, partly obliquely, and partly transversely; and these enclose more or less lozengeshaped depressions. In this respect Orcella does also not agree with the allied genus Globicephalus as described by Dr. Murie.

Narial chamber and appurtenances.-In the description of the exterior of the animal, mention has been made of the crescentic blow-hole. The posterior nares, it may be observed, present much the same characters as in Platanista, afterwards to be fully treated, save that the large arched crypts that occur in the latter genus are exceedingly small and irregularly distributed in Orcella.

The spiracular sacs of several genera of the Delphinida have been described and figured, and their homology discussed by various writers, more particularly by John Hunter ${ }^{1}$ and Von Baer ${ }^{2}$ and Sibson, ${ }^{3}$ and more recently by Murie. ${ }^{4}$ The account and illustrations given of the sacs of Globicephalus melas by the last mentioned author are borne out in most respects by my examination of those of Orcella brevirostris. On each side of the blow-hole and within is a more or less irregular flask-shaped thinnish-walled bag, the so-called " maxillary sac:" behind these are tortuous narrow canals, as thick as a goose-quill, whose openings are into the common spiracular cavity, the so-termed "naso-facial" sacs or passages. Quite at the bottom of the blow-hole cavity, and resting on the front of the skull, are the large "premaxillary" bags, directed forwards and overlaid by the mass of fibrous tissue and blubber. The resemblances and differences between these accessory nasal organs and those of the Gangetic Dolphin (Platanista) shall be treated of further on.

Pharynx.-Beyond the presence of a wide glandular orifice situated near the base of the tube of the larynx and its longitudinal folds, the pharynx does not call for any special description. The gland is racemose and of the same nature as the glands investing the faucial region, and which are apparently identical with the secreting crypts opening by pores on the pharynx of Balcenoptera rostrata described by Carte and Macalister, ${ }^{5}$ and from which was expelled a quantity of viscid mucus. Similar glands have also been described by Turner ${ }^{6}$ in the pharynx of Balcenoptera sibbaldii and by Murie $^{6}$ on the fauces of Globicephalus melas. It is situated internal to the articulation of the arytenoids with the cricoid cartilage, and its position in this locality, on the supposition that it is a mucous gland, would seem to indicate that its special function was to lubricate this portion of the mucous membrane and so facilitate the movements of the two cartilages of the larynx on each other in the respiratory act.

1 "Observations on the structure and economy of Whales :" Phil. Trans. 1787, vol. xvi. p. 335.

2." Der nase der Cetaceen," Isis, 1826, p. 811.

3 Phil. Trans. 1848, p. 117.

4 Trans. Zool. Soc. vol. viii. p. 242; Camb. Journ. Anat. and Physiol. 1871, vol, v. p. 123 ; and Journ. Linu. Soc. Zool. vol. xi. p. 146.
5 L. c., p. 232.
${ }^{6} L . c$. 
Eustachian tube and guttural sacs. ${ }^{1}$ - The eustachian tube opens into the sae of the posterior nares on a line with the posterior margin of the soft palate, a very short way above the inner border of the thick constriction of the nasal orifice. I had an opportunity of examining these parts only in the foetus, in which the eustachian orifice is 0.2 inch above the part indicated. It is an oval slit from before forwards 0.02 inch in length, and it is situated in the centre of one of the thickened bands which surround the arched crypts. It leads into a short passage which runs up the wall of the sac for a little distance; then it bends upon itself, running outwards and slightly backwards as a passage $0 \cdot 10$ inch broad, which gives off small lateral passages protected by valvular folds, and which burrow in the textures surrounding the mucous wall of the posterior nares, in the same way as the similar passages in Platanista, but not to the same extent. It thus crosses the pharynx, but I have not had the opportunity to trace it to the internal ear. As it reaches the outer wall of the pharynx it gives off three sacs much smaller than in Platanistu, and which lie between the stylohyal and the anterior corner of the thyroid cartilage. These sacs lie one above the other, and the most superior is closely related to the thyroid cartilage ; all are directed downwards and backwards ; the most inferior burrowing downwards in the direction of the body of the thyroid cartilage. Each sac has the same structure as in Platanista, but I cannot detect any tendinous bands connected with folds like those that occur in that genus. It must be borne in mind also that the sacs are mere rudiments in this fotus compared with those of Platanista.

It will be observed that the cartilages of the larynx of the species are surrounded with little cavities, possessing much the same characters as the finer passages of the guttural sacs. It has occurred to me that if materials existed to trace out the ramifications of these structures, they would probably be found to have some communication with the curious sinuous passages which surround the larynx. If any connection should be proved to exist between them, it would seem as if these finer ramifications of the guttural sacs being filled with air must exercise some influence in depurating the blood in the vessels surrounding the larynx, and thus contribute to the functional activity of the complex mechanism of the orifice of the respiratory tube.

Larynx (Plate XXVIII, fig. 2).-The tube of the larynx of Orcella presents certain differences in its fotal and adult condition. It may be premised, however, that it has the general characters distinctive of the Cetacea, but differs from that of Platanista in its much greater length, although its opening is shorter, and in the narrow character of its aryteno-epiglottidean folds. In an adult, of about the same size as the Platanista from which the laryngeal measurements of that species were taken, the opening was only 0.80 inch long. In the fœtus the tube was projected 0.82 inch up the posterior nares. The epiglottis projected beyond the

\footnotetext{
${ }^{1}$ For remarks on the guttural pouch of Cetacea, see particularly Hunter's Memoir in Phil. Trans. and his essays and observations; also Eschricht on the Gangetic Dolphin, Danish Transactions, 5th ser. vol. ii. 1851, and translated ; Annals and Mag. Nat. Hist. 1852, vol. ix. p. 174; and Murie, op. cit.; Huxley's Anat. of Verteb. An. 1871, pp. 410, \&c.
} 
tips of the arytenoids which lay in two depressions on its upper surface $0 \cdot 15$ inch behind its free margin; whereas in the adult they completely overlay the epiglottis with their tips nearly on a line with its free margin. In the foetus they were also much more bent down upon the epiglottis than in the adult. The epiglottis too, instead of having its thick margin reverted and strongly projecting as is the case in the adult, in the fotus was flush with the rest of the tube. The epiglottis differs from that of Platanista gangetica in being relatively broader and in its external angles being much thicker and prolonged further into the free margin of the aryteno-epiglottidean membrane.

On opening into the larynx (fig. 2) a remarkable and beautiful structure was displayed, lining the lower part of the cartilage of the epiglottis and the arytenoepiglattidean membrane and the whole floor of the cavity, and part of the sides of the cricoid cartilage. A strong fold arising by three origins from the lower third of the cartilage of the epiglottis is attached along that cartilage to its base, where it gives off a series of short folds, three of which occur on the left and one on the right side. The most anterior of the former is attached to the base of the aryteno-epiglottidean membrane, and the two others to the main border of the base of the body of the arytenoid. The fold of the opposite side is attached to the same portion of the last mentioned cartilage of the right side, but it gives off four fine septal folds from its outside, which are prolonged up the sides of the cartilage of the epiglottis. These folds are connected together by transverse tendinous folds, which constitute little recesses by the generally arched lower border being free. Indeed this part of the structure has a close resemblance to the structure of the guttural eustachial pouch of Platanista. On the left side, only the most anterior fold gives off a tendinous fold, which runs up the side of the cartilage of the epiglottis, and has the same structure as already described on the right. The central fold is continued backwards between the base of the arytenoids as a thin sharp ridge-like fold, but behind that point it gradually expands, and about an inch behind the arytenoids divides into a number of tendinous-looking bands. Radiating from the posterior border and base of the arytenoids, and passing backwards along the sides and floor of the cavity, are numerous strong bands which die away posteriorly at the first ring of the trachea. These folds are connected together on the floor of the cavity by arched transverse folds and these again by secondary folds, so that a deeply honeycombed structure is produced, the space defined by the last mentioned folds constituting a series of deep pockets, pits or crypts. The folds when viewed with a hand lens are seen to be thrown into more or less exceedingly fine transverse rugæ. On making a vertical section through the larynx, it is demonstrated that none of the deep pits communicate with any air sac, nor is there any trace of such a structure. The floor of the larynx above the cricoid, from the base of the arytenoids backwards for some distance, presents a glandular structure, divided off into lobules presenting open orifices. Immediately below the base of the arytenoids, several orifices appear separated from each other by fine septa, and it is apparent that they form a complex series of 
tubes enveloping the larynx above, below, and on its sides, and however it may be bisected, these tubes are always brought into view. No other glandular body is visible in this larynx.

The foregoing peculiar deeply honey-combed structure of the basal portion of the inside of the larynx is apparently of rare occurrence among the Cetacea. It must not be confounded with the mesial laryngeal sac described by Eschricht and Reinhardt ${ }^{1}$ in the Greenland Right Whale (Balcena mysticetus), and by Knox ${ }^{2}$ in Physalus, Carte and Macalister ${ }^{3}$ in Balcenoptera rostrata, and by Murie ${ }^{4}$ in Risso's dolphin, Grampus griseus. The two first mentioned of these anatomists do not describe any peculiarity in the mucous surface lining inside of the laryngeal sac, neither do Carte and Macalister make mention of any glandular structure in connection with it in the Pike Whale. Murie, however, in his description of the larynx of Risso's dolphin, states that at the lower end of the perpendicular epiglottoarytenoid passage the longitudinal folds were here and there interrupted by shallow glandular pits and depressions, and that among these occurred the orifice into the laryngeal sac. These glandular pits and depressions alone seem to correspond to the honeycombed glandular structure figured on Plate XXVIII, fig. 2.

I made repeated microscopic examinations of the structure of the aforesaid glandular crypts. One specimen of a vertical section under a low power is shown in Pl. XXXVII, fig. 6. This exhibits a basework of trabecular fibro-elastic tissue, within the mesh-work of which are here and there dispersed variously sized and shaped spaces or closed follicular recesses $(f$. ) surrounded by patches of a glandular stroma $(g$.$) . At several points also the connective tissue has muscular packets (\mathrm{m}$. running through it, and traces of capillary vessels $(v$.) are met with. The free surface of the membrane is of a velvety, villous or rather papillary nature, studded with either elevated or depressed simple mucous glands $\left(g .{ }^{*}\right)$. Unless it be to afford a mucous lubrication to the laryngeal surface, it is difficult to assign any distinct office to the extensive glandular area under consideration.

Cartilages of the larynx (Pl. XXVIII, figs. 2, 8, and 9).-The cartilaginous framework of the larynx is also found to differ from that of Platanista, in the less development of some of its constituents, notably the cricoid cartilage; whereas it closely approximates to the form and structure of the same organ in Globicephalus.

The cricoid cartilage is nearly a facsimile of that of the last named genus and, like it, has an imperfect ring (fig. 8); the two ends of the cartilage being separated in the mesial line by a wide membranous interval.

The thyroid cartilage resembles that of Globicephalus and has no anteriorly projecting body as in the Susu, Platanista, and is not notched posteriorly. Like this genus it has a short anterior cornu, behind which the posterior cornu is expanded into a flat plate; this contracts, however, to a narrow rod as it approaches its cricoid attachment.

1 Recent Mem. Cet. Ray Soc. Publ. 1866, p. 102.

2 Cat. Prep. Whale, p. 11.

\footnotetext{
3. Phil. Trans., vol. 158, 1868, p. 238.

${ }^{4}$ Journ. Anat. and Phys., vol. v, 1871, p. 127.
} 
The body of the arytenoid cartilage of Orcella is a laterally compressed oval, with a sharp margin directed forwards and a rounded margin posteriorly, by the upper two-thirds of which it is articulated to the cricoid by a synovial capsulated joint. The inner surface is concave and the external flat. The anterior horn of the cartilage is a long, laterally compressed and pointed structure in the upper half of its extent, but in the lower half of its surface is thickened and convex from side to side. It is connected to the arytenoid body by fibrous tissue, so that it is freely moveable on it as is the case in Platanista. The posterior horn is a downward prolongation of the anterior, and is a rounded bar of cartilage and terminates abruptly in a flattened end at the lower portion of the penultimate sixth of the arytenoid body, where it is capped by two small cartilages applied to each other laterally, succeeded by another cartilage which is wedged in between them and the last sixth of the arytenoids and curving forwards overlies them. A great part of the attachment of the aryteno-epiglottidean ligament takes place from the outer border of these cartilages. Lying between this apical cartilage of the posterior horn and its fellow of the opposite side occurs a small elongated nodulated cartilage 0.5 inch long and 0.12 inch broad, which assists in filling up the gap that exists between the arytenoid and cricoid cartilages. It lies immediately below the mucous membrane of the cavity, and is crossed by the longitudinal fold of the larynx.

The cartilage of the epiglottis is shorter than the arytenoid horns, but of considerable breadth, so as to embrace these structures by its lateral margins. It is concave from side to side on its laryngeal face and strongly convex on its lingual surface, expanding above the origin of the hyo-epiglottic muscle, from before backwards, into a thick club-shaped head with a rather pointed end. Its upper half arches a little forwards, and its free end is rounded from side to side, and the margin, scroll-like, curving forwards and backwards, terminates laterally in two thick horn-like projections which turn backwards and support the anterior half of the free border of the membrane of the arytenoid and of the cartilage of the epiglottis.

When the mucous membrane is reflected from the side of the aryteno-epiglottidean membrane, it is seen to cover a complicated arrangement of valvular passages separated from each other by pillar-like septa, and ramifying along the sides of the base of the cartilage of the epiglottis. It is opposed to the honeycombed mucous membrane of the inside of the larynx, and appears to be continuous with channels which are displayed here and there surrounding the base of the larynx above and below when it is cut longitudinally. This arrangement doubtless stands in some relation to the glandular surface at the base of the larynx internally.

Trachea (Plate XXVIII, fig. 11).- This is much more capacious than in Platanista, and its first portion is more imperfect and membranous. Two small flat cartilages depend from the cricoid, one being placed anterior to its posterior inferior angle, lying between it and the free end. These are succeeded by two imperfect rings, each of which encircles about one-half of the tube, but they are separated anteriorly by a membranous interval, whilst they largely overlap each other behind where the lowermost one gives off a short offshoot to the right, from its upper border. The third 
encircles the tube, but its two ends do not meet. Posteriorly it gives off an offshoot which runs from right to left, appearing on the ventral surface of the left border of the trachea. The fourth is a short cartilage on the right side of the ventral aspect of the tube. The fifth encircles the trachea, though its ends do not unite, but overlap each other, and the anterior border of its dorsal portion gives off a short offshoot to the left. The next ring nearly twice encircles the trachea, above and below the point at which the right bronchus is given off. It commences in a free end on the left border, and after describing the course I have indicated unites with itself on the dorsal surface, where it gives off two short branches directed backwards and to the right. The right bronchus is attached to the projecting third of the fifth ring of the trachea, and it commences by a cartilage which twice encircles the tube, but describing its first round in a zigzag manner, leaves a vacuity at the inside of the tube which is opposed to the trachea. The method of division and distribution of the fifth cartilage is that which prevails on the main bronchial division. In the first part of the trachea the cartilages are round and cord-like, but as they are traced backwards they become relatively broader and flatter, yet thicker than those of Platanista, and are separated by rather wide intervals, so that the tube has considerable expansibility. The first bronchus is 4.50 inches long before it divides. The other division is as capacious as the left bronchus, and runs 3.75 inches before its division. The left bronchus is $2 \cdot 50$ inches from its division to its bifurcation.

Lungs (Plate XXIX, fig. 2).-In the adult the base of the right lung, instead of being pointed as in the left, is bevelled off obliquely from its outer to its inner margin. The anterior border in its upper third is hollowed out for the reception of the heart. Two small lappets above this portion overlie each auricle, and the apex is only 3 inches above the arch of the aorta. The extent of lung posterior to the apex of the heart measures 12.50 inches in length by 5.25 inches in breadth, while the total length of the organ is only 19 inches, so that the great mass is posterior to the heart. This portion is' concave anteriorly, and corresponds to the convex surface of the liver, over which it lies, but separated by the interposed diaphragm, and the dorsum of the lung is of course convex. The apex has two rounded angles separated by a concave interval, and its total breadth here is 5 inches; the posterior angle being twice as large as the anterior. Below the heart the two lungs appear to approach each other much more nearly than in reality, from the circumstance that the lower end of the cardial border of the lung is the seat of a large gland $(P g l$.$) which projects towards the middle line along the dia-$ phragmatic attachment of the pericardium.

In the fotus the apex of the lung is rounded without any angles; the base of the right lung is not bevelled off, but partially divided into two lobes.

Pulmonary glands ${ }^{1}$ (Pl. XXIX, fig. 2 Pgl., and Pl. XXXVII, fig. 5).--In the adult the pulmonary gland is largest on the left side. It is a triangular body $1^{\prime \prime} \cdot 50$

\footnotetext{
${ }_{1}$ Pulmonary glands, evidently of a kindred sort, have already been recorded by Hunter, as obtaining in Delphinus tursio; and in specimens of Globiceps inhabiting the Chinese, American, and British coasts, respectively, by Williams, Jackson, Gulliver, and Murie. In Risso's Grampus also they have been met with by the last-mentioned observer, who, moreover, has discussed their nature, and given figures of them, in position, in his Memoir on the organisation of the Ca'ing Whale already cited.
} 
long by $1^{\prime \prime}: 0$ in breadth at its base which is directed anteriorly. It is attached along the external border of the lung from below the pericardial attachment and from the anterior margin of its base. A process, 2 inches in length, is sent upwards along the pericardium, and another process passes inwards under the pericardium as far as the inferior vena cava on the right side. The said gland consists of two irregularly shaped masses, one of which is applied to the internal margin of the lung, and has a process prolonged upward from it along the pericardium as on the opposite side, and the other lies internal to the former mass, and reaches to the side of the vena cava. The portion of the gland which runs inwards towards the vena cava, and the process prolonged up the pericardium are traversed by an enormous vein, which when opened has a capacity of 0.9 inch throughout its course. The veins of the two sides open by a common orifice into the right side of the inferior vena cava immediately below where it reaches the heart. The left vein is thus twice as long as that of the right side, and it arches slightly upwards near its termination, so that its orifice is placed nearer the heart than that of the left side. The vessels, as they bend round the base of the gland of the left side and traverse the double glandular mass of the right lung, give off numerous fine branches to the glands, and, running about two inches along the pericardium, they are found to proceed from the walls of the chest, being projected off the sternal portion of the cavity on to the pericardium. At this point they are in close relation with the internal mammary artery (fig. $2, m$.), which leaves the pericardium from the thoracic wall at the point where they reach the latter structure. I never have had an opportunity of examining carefully the larger vascular plexuses which exist along the vertebral column of this dolphin and in its intercostal spaces, but the origin of this large venous trunk from the chest would render it probable that its chief function was to relieve the venous plexuses by affording their blood a short and direct channel to the heart, and thus a more frequent flow than they would possess had the blood to travel a greater distance. The object of this would seem to be to confer great functional activity on the respiratory structures of the chest, which it is necessary should perform their functions reliably, so to speak, and well.

Minute structure of pulmonary glands. - In treating of the pulmonary organs of Platanista gangetica, I shall have occasion to pass under review certain glandular structures analogous to those under consideration. In illustration of the tissues in question, I have figured on Plate XXXVII, fig. 5, a portion of the gland of Orcella, and at fig. 4 a part of that of Platanista. These sections drawn under a low microscopic power make obvious the resemblance of their intimate structure. The main substance of the tissue is composed of a retiform mesh-work $(r$.$) , in the interstices of which are closely packed cells (fig. 4, e.) of the$ diameter and appearance of lymph corpuscles. The finer threads of connective tissue in some places are as delicate as a spider's web, in others thicker, almost membranous in consistence; the two kinds forming a great variety in the dimensions and figure of the areolæ. Scattered about are much larger open spaces, quite irregular in contour and in thickness of walls. These evidently are transverse 
sections of vascular channels $(v$.$) . There are, however, others, chiefly round openings,$ of much smaller calibre and with remarkably thick walls as compared with their narrowed central channels. Besides these (best shown in fig. 4) are what may correspond partly to oblique or in some cases to the longitudinal sectional view of capacious blood-vessels, which apparently have a great number of tributaries piercing their fibrous walls (fig. $4,7 v$.).

Heart and blood-vessels. ${ }^{1}$-The heart of Orcella is of considerable size, but not so large proportionally to the animal as is the heart of Platanista, neither is it so markedly bifurcated at the apex, nor are the auricles so loculated as in the latter dolphin. The ventricular septum passes downwards slightly to the right side and the base of the organ is flattened, but its right half is lower and its right ventricle and auricle smaller than those of the left side; the former cavity is larger, but much narrower than its fellow. The left auricle, when the heart is distended, is closely applied over its base, and the right margin of this auricle touches the pulmonary artery; but the right auricle under similar circumstances projects upwards from the base of its ventricle, anteriorly exposing a considerable portion of it. The heart measures in the adult 5 inches across the base of the ventricles, and $3^{\prime \prime} \cdot 50$ from the origin of the pulmonary artery to the apex of the left ventricle; anteroposteriorly it is 3 inches through the thickest portion of the right ventricle, and across the auricles about $5 \cdot 75$ inches. (See Plate XXIX, fig. 2.)

At the point where the pulmonary artery has the pericardium reflected on to it, and occupying about the position of the ductus arteriosus, two pits occur, separated from each other by an interval of 0.25 inch. These are about 0.25 inch in diameter and the same in breadth, and the one to the left is a blind sac, defined on each side by tendinous or pillar-like folds of the pericardium prolonged on to the pulmonary artery. The other is protected at its upper border by a cord-like band that stretches across it transversely. To the left side it gives off a thinner and fibrous cord directed obliquely forwards. At the bottom of the pit there is a deep recess that admits a large probe, and passes dorsally obliquely outwards. Unfortunately the parts at the side of the left bronchus where the probe appears have been cut across, but the probe is seen to lie in a well-defined tube. There seems little doubt but that these invaginations of the pericardium mark the remains of the ductus arteriosus. occurs.

In the cavities and valves of the heart nothing specially worthy of note

I had the opportunity of examining the distribution of the vascular trunks and branches which spring from the aorta both in an adult and in a fotal specimen. A sketch of the former is given in Plate XXIX, fig. 2, in which figure, the numerous cervical and upper pectoral glands in relation with the vessels are also given.

\footnotetext{
${ }^{1}$ Besides Hunter, Carte and Macalister, Murie, \&c., Turner in his "Account of the Great Finner Whale," l. c., p. 227, gives a good description of the circulatory organs.
} 
In the adult animal, the aortic arch and great arteries somewhat correspond to the condition described and figured by Prof. Turner in the Pilot Whale. ${ }^{1}$ From near the summit of the arch of the aorta two main vessels of considerable capacity are given off. These evidently are right and left innominates, subclavians of Turner. Half an inch from its origin the so-called left innominate or brachio-cephalic throws forwards and sinistrally a large vessel equivalent to a left subclavian. From this at its upper bend there springs from right to left a small branch equivalent to a vertebral $\left(y_{\bullet}\right)$, and which bifurcates a quarter of an inch from its origin. To the left of this vertebral is a slightly larger branch which may correspond to a thyroid axis (it is Turner's transversalis colli), and at about an equal distance to the left is a yet larger branch, the axillary or brachial, while the continuation of the main stem into the chest constitutes the internal mammary artery $(m$.$) . The left innominate, about a quarter of an inch above its sub-$ clavian division, splits into two unequally sized trunks, the inner of which is the larger and may represent the carotid, the outer a trifle less in calibre.

The right or true innominate artery has a capacity little if at all greater than the left division. There springs half an inch from the aorta and behind it a moderately thick artery which passes upwards and to the right, and supplies the deep cervical and upper thoracic region of that side (de.). This evidently corresponds to the "thoracica posterior dextra" of Turner in Globicephalus. Derived from the right innominate close above the last, but more to the dextral than the posterior side, and passing beneath or deeper than what shall presently be referred to as the right subclavian, is a fairly-sized vessel, apparently the right axillary artery $\left(\alpha x .^{*}\right)$; and still higher than it, though almost overlapping it, is a thicker vessel which, judging from its position, may be termed the right subclavian ( $\left.s^{*}\right)$, although possibly objection may be found to this term, as the axillary branch is not continued from it. From this main right subclavian trunk, at half an inch distance from its origin, is what I take to be the right thyroid axis $\left(t h{ }^{*}\right)$-an artery springing from its upper border, and which almost immediately thereafter splits into two branches from which subsidiary branchlets are given off. To the right of this thyroidal axis, another smaller artery $(t c$.$) , which may be equivalent to a transversalis colli, comes$ off from the right subclavian stem, and it likewise splits into several branches. The continuation of the subclavian trunk meantime courses backwards into the chest forming the large internal mammary artery $\left(m .^{*}\right)$ of the right side. This same vessel, as likewise that of the opposite side of the chest, besides supplying blood to the sternal parts, pleuræ, etc., proceeds to the peculiar pulmonary glands already described, and each vessel, moreover, seems to join an anastomotic branch derived directly from the abdominal aorta behind the apex of the heart (see fig. $2, m *^{*}$ ).

In the fœtal specimen of $O$. brevirostris the arterial distribution in the main corresponds to what has been above described in the adult. There are in this

tCamb. Journ. Anat. and Physiol. vol. ii. p. 67; Knox, Cat. p. 18; Eschricht, Die Nordischen Wallthiere, p. 104; Malm, Anat. Balcenoptera carolince; CEfvers Vet.Ak Förhandl. 1868, and Barkor, Die Blutegefässe, etc., Breslau. 
example the double innominate trunks, and the left of these has a similar subclavian, and long parallel carotids. The outer carotid about its middle sends inwards or mesially a small pharyngeal branch and in the opposite direction a cervical branch, the main vessel itself passing below the hyoid arch. The inner of these parallel carotids, in its way towards the head and at unequal intervals, sends several branchlets towards the middle line of the neck, and itself passes above the hyoid. Besides a left vertebral artery and thyroid axis, a considerably sized and deeply situated branch appears to issue from the subclavian. This left deep cervical, post-thoracic, or superior intercostal, goes to form the rete mirabile lying on the inside of the chest. The chief differences on the right side of this fœtus as compared with the preceding adult are its wanting a separate axillary artery derived from the right innominate, the right being, like the left axillary, an offshoot from the subclavian, and the subclavian yielding at its root a branch apparently representing a superficial cervical.

Compared, therefore, with the vascular distribution in Globicephalus, the variations in Orcella seem to be as follows:-

(a). The proximity of the two main trunks arising from the aortic arch, these main vessels being wider apart in the Pilot Whale.

(b). No long "carotis facialis" (Turner) or median third carotid branch from the right subclavian.

(c). The deep cervical on the right springing from the innominate in Orcella, whereas it has a carotid origin in Globicephalus.

The brain: Its configuration.-Whilst the condition of the carcass of the full-grown animal permitted of many of the organs being fairly examined, such was not the case with the brain. It had become so softened, and its parts so fallen asunder, that it could not be properly examined. Its shape, however, was ascertained with tolerable exactitude by means of a cast of the cranial cavity in plaster of Paris. Plate XXX, figs. 4, 5, and 6, represent this cast from an upper, a lateral, and a basal view, half the diameter of the original.

The measurements of the brain or rather of the interior cranial cast are as undernoted :-

Greatest antero-posterior length (prominence of frontal lobe to post-cerebellar protuberance)
Inches.
Greatest breadth (viz., temporo-occipital region)
Diameter at the middle of frontal region in front of Sylvian depression
Greatest height (fronto-parietal region)
Extreme length of each cerebral hemisphere
Cerebellum in antero-posterior diameter, about .
Cerebellum extreme breadth, about .
Vertical beight of cerebellum .

Although the brain was somewhat disintegrated, I was able to determine that it was highly convoluted, like what we find in other Cetaceans.

Viewed from above (fig. 4), its breadth as compared with its length in the cerebral hemispheres is remarkable, this being in round numbers as 6 is to $4 \frac{1}{2}$. 
The longitudinal fissure is a deep and wide cleft, with both its margins rounded off, leaving a wide interval between the lips of the frontal and occipital corners. A very considerable surface of the cerebellum is thus exposed superiorly.

The anterior face of the brain presents a massive appearance, both breadth and depth being conspicuous. The supra-orbital region is specially prominent. What corresponds to the optic nerve tract presents a moderately marked vertical ridging situate about the middle. This front surface of the brain is relatively truncate and flattish as a whole.

The profile or lateral aspect (fig. 5) of this brain mould shows, not only the cerebellar exposure, but that the cerebellum is of a good height, and that the cerebrum is much deeper in the frontal than in the occipital region. The outline of the cerebral hemisphere from this point of view is kidney-shaped, the infraorbital region fullest, and the Sylvian fissure shallow and only noticeable low down. A rim of projection at the margin of the post infra-occipital sweep, and a semilunar ridge facing this, on the surface of the cerebellum, mark the depressions excavated in the bone for the large venous sinuses. The root of one of the branches of the 5th nerve stands well out, and the elevation of the orbital nerve (as alluded to on the anterior face) crops forward beyond the supra-frontal margin. If a vertical line be drawn giving the extreme limit of height of the cerebrum (which is in front of the Sylvian fissure), and another horizontally at right angles to this giving the extreme length of the cerebral hemisphere, these would show but a slight preponderance in favour of the latter. In other words, depth and breadth are characteristic features of this brain, but the latter, as shall hereafter be shown, is the distinguishing and most obvious difference between it and that of Platanista. The figures in Plate XXX, however, do not afford a fair comparison, as those of $P$. gangetica are representations of the brain itself, whilst those of Orcella are from the mould of the cranial cavity.

As in the upper surface, the base of the brain (fig. 6) is of great breadth, and the cerebellum is seen to cover a considerable area. This surface, moreover, taken as a whole, is remarkably flat, but especially so in the extensive figure-ofeight boundary formed by the infra-orbital regions, pons and cerebellum. A raised median, transversely oval portion, possibly indicative of a good-sized flocculus, is noticeable on each half of the cerebellum.

With regard to the nervous trunks, their great thickness, so far as this cast is concerned, is apparent rather than real, inasmuch as they give the capacity of the foramina and basi-cranial grooves; for, as is well known in Cetacea, the nerves are accompanied by accessory vascular plexuses and thick sheaths giving increment of bulk other than what is due to the nervous cords themselves. It may be remarked, however, that the 5th, 6th, 7th, and 8th pairs possess a magnitude corresponding to the functional importance of these nerves in the whale group.

Viewed from behind, the brain cast displays the occipital borders of the cerebrum obliquely pitched, and covering and overlapping outwardly the cerebellum, 
which in this aspect is a shade larger than either hinder extremity of the cerebral hemispheres. The medulla spinalis is relatively large, and set high in relation to the cerebellum.

From the foregoing description it would seem that Orcella has a delphinoid form of brain, comparatively massive, broad, and although in a general way flattish, yet by no means low set. The fronto-orbital lobes are unusually deep, and the anterior brain-facies altogether vertically abrupt in contour. The cerebellum is preponderantly large and in a great measure uncovered both laterally and above. Moreover, as the sequel will show, the brain of Orcella manifestly differs in several particulars from that of Platanista, while it strikingly follows the general shape of that of Globicephalus.

External organs of generation (Plates XXXIII and XXXIV).-The cleft of the vulva resembles that of other Cetaceans, the skin around being somewhat smooth and pale coloured. The most characteristic feature is the existence of the well marked perinæum (pe.) already mentioned, the raphe being about $1 \frac{1}{2}$ inches long, and in this particular, Orcella essentially differs from those whales which, being destitute of pelvic bones, have no perineal space.

The mammary slits (Plate XXXIII, fig. $1 \mathrm{~m}$ ) are each 0.70 inch long and situated 1.20 inch from the vulva, their hinder ends being $2 \cdot 20$ inches distant from the anus. The nipple is not prominent, being laterally compressed and placed at the base of the mammary furrow which is comparatively shallow, viz., $0 \cdot 20$ inch deep.

The mammary gland (mg.) has an enormous dilated lactiferous sac, 2 inches long, with a position immediately underneath the nipple. It runs horizontally forwards, and into it all the lactiferous ducts open. The other portion of the gland is very solid in character, flattened along the middle line, and in area has a length of 9.50 , a breadth of 3.25 , and 0.25 of an inch thick. It is invested by a strong fibrous capsule which is very firmly adherent to the gland substance, and is with difficulty removed from it. ${ }^{1}$

The vagina $(v)$ has the usual Cetacean characters, and has six os tinca. I did not observe in the vagina of the gravid female any of those remarkable glands which I shall have to describe in the gravid vagina of Platanista.

Gravid uterus. - The mouth of the true os is a little to one side, which also holds good with the lower os tinca, thus conferring a slightly spiral arrangement on the course of the canal. The true os, when viewed from the uterine aspect (Plate XXXIII, fig. 2), appears almost smooth, with only a few rudimentary folds, and in this respect it materially differs from the os uteri internum of Platanista (Plate XXXI, fig. 2), and the Narwhal. ${ }^{2}$ In the gravid female the foetus was developed in the left horn, and

\footnotetext{
${ }^{1}$ See Hunter, l. c. : Kuhn, Férussac, Bullet. des Sc. Nat. 1830, t. xxii. p. 322: Rapp, Meckel's Archiv. für. Anat. 1830, p. 358 : Die Cetaceen Zool. Anat. dargestellt, 1837, p. 178 : Trail. Edini. New Phil. Journ. 1834, Vol. xvii. pp. 117 et 363: Is-Geoff. St. Hilaire, Ann. des Sc. Nat. 2 Ser. Zool. t. 1. 1834, p. 174: Jacob, Brit. Assoc. Reports, 1835, p. 86: Astley Cooper, Anat. of Breast, 1839: H. Milne-Edwards, Leçons. sur la Physiol., t. ix. 1870, p. 124, and Turner, $l . c$.

2 Turner: Lectures on Placent. 1876, p. 50.
} 
it is worthy of remark that the majority of Cetacea hitherto observed in utero have been developed in the same horn. This fotus I removed with my own hands, and I am therefore in a position to say that its relations to the uterine wall were the same as those which obtained in Platanista, under which species the uterine and fotal relations will be fully described. The uterine walls, at the full period, are however, much thicker than those of Platanista (Plate XXXV, figs. 4 and 9), and the mucosa is much more spongy, and the crypts more numerous and much more regularly distributed than in that genus. Scattered among the crypts there are considerably larger infundibuliform orifices, and moreover the entire surface of the mucosa is not cryptose. A long narrow bare surface commences about 6 inches from the uterine orifice of the left Fallopian tube, and continues along the lower wall of the fecundated horn for about 3 inches beyond the point where the horn bends on itself at the septum. In one instance in Platanista this bare area occurred; whereas in another and more matured uterus it was absent; the nude surface of the chorion being present in both cases. I have not observed it in the Bactrian camel, and no trace of it is visible in the uterus of a Tapir, the fœtus of which was nearly fully mature, and the chorion of which had this area, free of villi, enormously developed. Besides this elongated tract free of villi, a very limited area occurs at each Fallopian pole of the two horns, and which has been figured at Plate XXXIII, fig. $3 \mathrm{f}$. This bare surface however, appears more properly to belong to the mucous surface of the Fallopian tube itself than to the uterine cavity.

The bare or non-cryptose areas which have been described,-namely, the smooth surface at the os uteri internum, the long tract free of villi following the course of the locality of opposition of the umbilical vessels after they divide on reaching the chorion, and the very limited bare surface of a doubtful nature at the Fallopian orifice of each horn,-would appear to differ structurally from the following bare surfaces.

Smooth spots.-The whole of the inner surface of the uterus, right and left horns;

* is irregularly studded over with smooth spots free of cryptose structure. The spots are of various shapes, but they generally have a more or less rounded appearance but are of different sizes, varying from 0.05 to 0.20 of an inch in diameter. They form denser groups in some places than in others. Even with the naked eye when a good light is allowed to fall at an angle on the uterine surface, I could detect what appeared to me to be an orifice in the centre of many of these smooth spots, and this I have also observed in Platanista and to a much more marked degree on the uterine surface of the Camel and Tapir, but only to a very limited extent on the uterine mucosa of Manis.

The surface of the fecundated horn is thrown more or less into rugose folds, which tend to radiate from the point where the horn bends on itself opposite the septum which divides the two horns, but they are not well marked except at the point indicated, and in the neighbourhood of the surface of the Fallopian tube from whence they radiate longitudinally. Rugose folds also occur in the long axis of the portion of the cavity immediately above the os uteri internum. In the unfecun- 
dated horn they are arranged more or less in transverse series of oblique folds, and are much more marked than in the greatly dilated left horn, and it is somewhat remarkable that the spongy texture becomes more pronounced, coarser and thicker as it approaches the right pole of this unfecundated horn, a feature also characteristic of the uterus of Platanista and to a more limited degree of the Tapir. These are the general facts connected with the appearance of the surface of the gravid uterine mucosa of Orcella. The whole inner surface of the uterus, left and right horns, from the os uteri internum to both Fallopian orifices was clothed by the chorion as in the case of diffuse placenta generally, but as its intimate relation to the uterine surface had been disturbed before I had an opportunity to remove the fotus, I did not observe the chorionic villi in situ among the cryptose tissue of the uterine mucosa There can be no doubt but that the smooth spots which stud its surface correspond, generally and even particularly in a large number of cases, to the bare spots on the uterine mucosa.

Microscopic structure of the foetal and the gravid uterus.-The recent interest taken in the histology of the unimpregnated and pregnant uterus and of the fœtal membranes generally, but especially in the case of the Cetacean group through the labours of Eschricht, ${ }^{1}$ Meigs, ${ }^{2}$ Rolleston, ${ }^{3}$ and more particularly the able memoirs of Prof. Turner, ${ }^{4}$ has induced me to record my observations on these structures in such rare forms as Orcella and Platanista.

Injections of parts were only made in a limited number of instances, but as the specimens had been preserved in alcohol, the injections did not reach the cryptose structure of the uterine mucosa, and only partially so into the chorion; however, the general characters of the tissues were elucidated.

In the parietes of the uterus of the almost mature fœtus as displayed under a low and a higher magnifying power (Plate XXXVIII, figs. 5 and 6 ), the free mucous membrane superficially is comparatively smooth, there are few rugæ or manifestations of mucous crypts, the membrane is wavy in outline, and any depressions that exist are shallow. The epithelial layer is thin, and the cells are apparently cylindrical. The subjacent or true uterine membrane, on the other hand, is relatively of considerable thickness, and, as usual, is composed of closely woven delicate connective tissue, everywhere studded with corpuscular bodies, similar to those described by Turner in the gravid uterus of Orca. These corpuscles, together with their nuclei, give it almost a granular appearance. The corpuscles are irregular in shape, subcircular, ovoid or elliptical. The involuntary muscular fibres with much fibro-areolar tissue intermixed, even in this very early condition, form a well marked layer, varying in thickness from a third to a fourth the depth of the preceding. A fibro-serous coat of about equal thickness to the last is in some places partially separated from it by largish blood-vessels which here often run between

1 " Delphini Phocænæ gravidi."

${ }^{2}$ Journ Acad. Nat. Sc. Philadelphia, 1849, vol. i. p. 267.

3 Trans. Zool. Soc. vol. v, p. 307.

${ }^{4}$ Trans. Roy. Soc. Edinb. vol. xxvi. and Lectures on the Comp. Anat. of Placenta, ete. 
these coats horizontally. Elsewhere the blood-vessels pass directly through with a moderate or relatively good-sized calibre, but as soon as they enter the proper tissue of the uterine wall they break up into numbers of small capillaries. These last as they proceed inwards and approach the interior mucous lining still further split up, and, in divaricating ramifications, form quite a rich but minute net-work or kind of capillary plexus, analogous to what Turner has observed in the gravid uterus of Orca.

The most interesting fact appertaining to this uterus is that I could nowhere detect the slightest traces of utricular glands; and in my search for these I passed in review a very considerable series of microscopic sections taken from different parts of the organ. Even where rudiments of uterine glands might be supposed likely to be found, as in the neighbourhood of mucous crypts and depressions, their absence was conspicuous, as is seen in Plate XXXVIII, fig. 7, representing a vertical section of the left wall of the cavity of the uterus under consideration.

As might be anticipated, in the case of the gravid uterus, a very different state of things obtained. The walls had vastly increased in thickness, the constituents of the muscular, the serous and the mucous layers in relative proportions, and there was a corresponding development of blood-vessels. The internal surface of the uterus was no longer smooth, but presented instead a highly spongiose character due to the existence of numerous minute recesses with occasional larger tubular orifices. The former appear as dots all over the surface of figure 4 of Plate XXXV, and in figure 5 they are seen to be divided and sub-divided into small secondary cryptlets. The minute recesses or crypts are produced by a highly reticulated anastomosing network of the fibres of the mucosa, generally outwardly radiating from a bare glistening spot as in the pig, tapir, ${ }^{1}$ camel, and Monodon, and as occurs also in Platanista. The strands of membrane so radiating ultimately blend with the outlying portions of other and neighbouring areas of radiation. The cryptlets contained in these

${ }^{1}$ In a gravid uterus of a Tapir, in which a fotus had attained a length of 4 inches, the surface of the chorion was quite destitute of villi, but when it was removed it was found to be covered by irregular fine wary folds. The uterine mucosa was perfectly free from a truly cryptose structure, but its surface was irregularly, but profusely and minutely, covered over with exceedingly wavy ridges and by smooth glistening spots which had a smoother surface than the rest of the mucosa. These spots when examined with a hand lens presented a central orifice. They also manifested a distinct tendency to an arrangement in long parallel lines in the long axis of each horn. In the uterus near the completion of pregnancy, the surface of the chorion, which wholly invested the inner surface of the uterus, was villous throughout, the villi consisting of two kinds, viz., very small villi with larger villi intermixed. The villi were separated from each other by minute round bare spots and by longitudinal and transverse lines corresponding to those of the uterus. There was a very extensive, perfectly nude, shining area along the course of the vessels from the cord, extending from the pole of the right (unfecundated) to that of the left (fecundated) horn, and having a breadth of 3 inches in some places. This area was of the same nature as that which occurs in Orcella, Platanista, and Manis. No bare area occurred at either of the poles, nor could I detect any on the surface opposed to the os uteri internum.

The uterine surface was very minutely, but profusely cryptose; the arrangement of the strands of membrane, however, producing the crypts was different from what I have observed in any other uterus. Coarse strands of membrane ran for considerable lengths side by side with a marked parallelism giving off branches anastomosing with each other, and from these finer branches defined innumerable minute crypts on either side of the coarser strands which were at a higher level than the intervening 
small recesses, and which exist for the reception of the divisions of a villous tuft of the chorion, are produced by deep anastomosing offshoots from the primary strands of membrane. The tubular orifices already mentioned, and some of which are shewn as larger black dots on figure 4, appear to me to result either from hypertrophy of the mucosa immediately around them, or from a contraction of the strands of radiating fibres, but both causes may originate them. I have generally found that when pressure was exercised on one of these orifices from without, by pressing the wall of the uterus inwards, that the uterine mucosa becoming stretched exposed a smooth spot at the base of the tubular recess. I have also frequently carefully slit them open under the microscope and found a similar smooth surface in their depths, but at the same time I have not unfrequently opened recesses and everted them by pressure to find them terminating in no smooth area. When a bare surface does occur at their bases, they are identical structurally not with the narrow bare tract opposed to the chorionic area of the umbilical vessels nor with the smooth surfaces of the os uteri internum and the Fallopian poles of the horns, but with the small bare spots distributed generally, over the surface of the gravid mucosa on which the orifices of utricular glands may be observed. I am therefore disposed to regard these tubular recessess as the equivalents of the "funnel-shaped crypts" of Prof. Turner" in Orca gladiator, and which he at first thought might probably be merely the widened mouths of utricular glands. They appear, as I have said, to be bare spots, the openings of glands, around. which the interglandular substance of the mucosa

areas which formed a series of furrows parallel to the former. Besides the minute crypts there were many infundibuliform recesses scattered over the mucosa. Many of the latter when pressure was exercised on them from the outside of the womb were everted, and displayed at their bottoms round bare spots, one to each recess, with strands of membrane radiating from its sides. In the furrows already mentioned, numerous glistening smooth spots were arranged in lines, a file of spots to each furrow, but others were irregularly scattered on the uterine surface, because the linear arrangement was not uniformly prevalent, although it was general. These bare spots, when the uterine mucosa was not stretched, assumed the form of shallow depressions, but when it was pulled out their smooth nature became more apparent, and in the centre of almost every spot a small orifice could be detected by the naked eye.

Besides these fine furrows and ridges parallel to the long axis of the horn, the uterine mucosa was traversed at irregular intervals by clear glistening fine lines at right angles to the former and separated from each other by intervals of about half an inch, while others were much more remote from one another. These transverse lines, when the uterine wall was stretched, were seen to be composed of a linear series of minute smooth spots, each having an opening in its centre, the mouth of an utricular gland. It is evident, therefore, that these bare spots, both in longitudinal and in transverse series, are the structural representatives of the bare spots in the uterus of the pig, the standard of comparison for diffuse placentæ. Besides the bare spots and fine lines the surface of the uterus had no bare areas at the poles of either horns, and more remarkable, there was no bare surface corresponding to the extensive branching nude surface of the chorion following the umbilical vessels which I have already described.

In a two-humped camel, at the full time, the uterus had a cryptose structure, as regular and beautiful as the cellular mass of a compound. Bryozoan, but irregularly covered over with numerous bare glistening spots, each perforated by a glandular orifice. There was no bare area at either pole of the uterus, but a portion of the mucous surface of the Fallopian tube, owing to the extension of the organ, appeared on its wall; there was, however, an irregular limited bare area on the dorsal surface of the uterus at the os internum. The chorion was finely villous all over equally at both poles, and there was no trace of the bare area of the chorion of Manis, Platanista, Orcella, and the Tapir, but it was studded over with bare spots corresponding to those of the uterus.

1 Trans. Roy. Soc. Edin. 1871. 
had become hypertrophied,-an alternative opinion also held by Prof. Turner. ${ }^{1}$ These spots on Orcella are undoubtedly the structural and physiological equivalents of the bare spots on the surface of the gravid uterus of the lemur, pig, tapir, and camel, and to the smooth intercryptal areas of the uterus of the mare described by Turner, ${ }^{2}$ and in part to the smooth surfaces distributed among the cryptose areas of the uterus of Manis. Orca, however as Prof. Turner ${ }^{3}$ has pointed out, differs in the free surfaces of its mucosa being more uniformly cryptose than in the pig, and more so, that there are no intermediate surfaces destitute of crypts on which the glands can open, whereas in the pig ${ }^{4}$ and mare, and I may add from personal observation in the tapir and camel, as well as in Orcella and Platanista, the crypts are collected into definite areas with distinct smooth surfaces intermediate to them. The distinction between the opening of the utricular glands of Orca and Orcella is structurally important, because it does not exist between Monodon monocerus as described by Turner ${ }^{5}$ and Platanista as described further on in this work. Orcella, Monodon, and Platanista, as Cetaceans, would thus appear to have one type of diffuse placentation, whereas Orca chiefly differs from them in the absence of "smooth areas encircling the mouths of the utricular glands.

As I have already stated, the injections of the uterine mucosa were unsuccessful, so that I cannot say anything regarding the distribution of the vessels in the walls of the crypts and cryptlets, but vessels were distinctly visible crossing the bare spots, (Plate XXXVII, fig. 9).

In microscopic sections of the mucosa, some of these recesses were slightly more open and empty than others, but these differences were probably produced by manipulation. In nearly all the spaces, mucous corpuscles, granules, and lymphy secretion, besides epithelium both of a cylindrical and tesselated character, were abundant, and oily globules were not unfrequently commingled.

Connective tissue and utricular glands.-The connective, nucleated, corpusculated uterine tissue. (Plate XXXVIII, figs. $6 c$ and 11), subjacent to the crypt-layer, was looser than in the non-gravid condition, and large vascular areas and channels, (Plate XXXVIII, figs. 3, $v$, and 10), were met with here and there. But its most pronounced character by far was the immense development of branching utricular glands, (Plate XXXVIII figs. 10 and 11, ug), equally in both horns. They formed a dense layer underlying the uterine mucosa, so dense that it could be dissected from off it as a sheet of glands. To demonstrate the openings of the glands on the uterine mucosa by actually tracing a gland tubule to its termination was a process attended with considerable difficulty. Cutting out a square piece of the uterine wall and fixing it slightly stretched on a leaded piece of cork under water with the uterine mucosa downwards, the serous and muscular coat could be easily removed from the glandular layer, and a gland tubule could be selected and traced to its

$$
{ }^{1} \text { Lect. p. } 48 . \quad \quad 2 \text { L. c., 40, fig. } 5 . \quad{ }^{3} \text { Ibid. p. } 48 .
$$

4 Turner, Trans. Roy. Soc. Edin. vol. xxxvi. p. 490; Ercolani, Mamm. dell' Acad. delle Sc. de Bologna, 1873 ; Turner, Lect. pp. 38-42.

5 Lect. p. 50 . 
termination. This was a tedious undertaking, as the ramifications of a single gland were very great, and some of the branches were so long that they were sometimes mistaken for the main tube and followed up, but to end in a blind sacculus. Tortuous sacculated branches were given off by the main stem close to its termination, (Plate XXXVII, fig. 9). As the end of the tubule was reached, it was found to run for some distance longitudinally below the mucosa, and from the circumstance that it was rather firmly attached to its under surface considering its delicate nature, the difficulty in tracing out the gland at this part of the research was great. After frequent similar observations conducted under the microscope, I was enabled to satisfy myself that the glands terminated on the surfaces at the base of the recesses and on the smooth spots scattered over the free surface of the mucosa. When the bare spots were examined with a hand lens, I had no difficulty in detecting the existence of an opening in the centre of many of them, associated in some instances (Plate XXXV, fig. 5) with a visible rounded linear eminence corresponding to the course of the termination of the gland tubule. In other instances, however, I failed to discover any very decided appearances of the glandular orifices, but I consider that these failures were due to a flaccid condition of the spots in which they could not be detected, and not to the absence of the openings. I had numerous sections made through bare spots to try and demonstrate the opening of a gland, but I failed, owing, I believe, to the circumstance that the glands' mouths open so obliquely on the surface. I would, however, again repeat that when the fresh uterine mucosa is examined under a low power and even with the naked eye, innumerable bare spots can be detected, each with an orifice generally near its centre, and that underneath these bare spots the tubules of the glands terminate, and also at the bases of the recesses; and the nature of these recesses I have already explained. Under a moderate power, the cylindrical epithelial lining of the glands is readily visible, and where a clean transverse section has been made (fig. 11), the clear interior with its layer of columnar epithelial cells is at once recognisable.

Chorion.-In a specimen preserved in spirit for some time the outer surface of the right horn is extremely rugose with some persistent lamellar folds radiating from the pole of the cavity. There is no trace of the uterine pouch that occurs in $P$. gangetica, although there is a slight dilatation in the corresponding portion. The most non-villous portion of the chorion is that which occupies the left horn and especially its two ends, the posterior surface being exceedingly rugose and in persistent folds as in P.gangetica. The right pole of the left horn and the left pole of the same cavity are more or less marked with lamellar folds. The left horn of the chorion (Plate XXXV, fig. 2), is covered with smooth spots of the same nature as in $P$. gangetica, but from the contracted condition of the right or non-gravid pole they are very difficult to detect on it, and are much less numerous than on the left pole. In transmitted light the villi are seen to be collected in small groups, but they are very minute on branched depressions which correspond to the course of the uterine blood-vessels. 
I could not detect a bare patch on the pole of the right horn nor on the portion of the chorion which is opposed to the os uteri, but as the chorion opposite the os was shrivelled, I am not prepared to accept the apparent absence of the bare area as conclusive evidence of its non-existence. But a well-defined patch of that nature occurs opposite the orifice of the left Fallopian tube and on the apical portion of the left horn, corresponding to the middle of the mesial septum, which spot is absent in Platanista, and no such spot is mentioned by Turner in Orca or in the Narwhal.

On the surface where the vessels enter the chorion, there is a linear bare patch (Plate XXXV, fig. 6), as in $P$. gangetica, but it is much more limited in its extent than in that genus, being only 6.50 inches long, with an average breadth of $0^{\prime \prime} \cdot 30$; and that notwithstanding the greater size of the membrane. This area is slightly dilated towards the left of the funis, but no cul de sac exists as in Platanista. It rapidly contracts on either side of this region, and about $1^{\nu} \cdot 50$ to the right of the funis a pedunculated corpuscle (fig. 6) occurs, as in Platanista. But it is unlike that of Platanista in being slightly swollen at the side of its base next the cord. From the base of the peduncle towards the left side, and traversing the patch throughout its extent, is a narrow linear fold continued to the right of the pedunculated body.

The bare area corresponding to the left Fallopian tube has a length of 0 ": 31 and a maximum breadth of $0^{\prime \prime} \cdot 18$. Only a very minute portion of its dilated part is perfectly smooth, and from it proceed small thickened folds, two pairs being opposite each other, the remainder of the area being covered with minute papillary folds. The area on the right extremity of the left pole of the chorion is pyramidal in form, and is perfectly smooth, with the exception of a few papillary folds near its apex, from which four larger smooth folds radiate downwards to its base. This pole of the left horn of the chorion is much more villous than the left pole, and hence the bare spots hardly exist in this locality.

The so-called smooth areas or spots of the chorion are only perfectly smooth in a very limited number of cases, although they may be destitute of villi properly so called, because the non-villous surface is thrown into fine wavy ridges which in some instances occupy the whole of the spot, passing across it in nearly parallel lines, or in others diving outwards from near its centre in which there is a ridge or fold larger than the radial folds. In other cases, however, the centre or a portion of the spot is perfectly smooth, but from its margin fine folds radiate outwards (Plate XXXV, figs. 4 and 5). The villi around these spots are somewhat longer than the others, and hence the chorion presents circular areas of enlarged villi (Plate XXXVII, fig. 14). Besides these areas, there are numerous other long linear dichotomously branched areas of varying extent, very sparsely covered with minute villi, that, to the unaided eye, appear almost smooth. These do not lie in the course of the chorionic blood-vessels but correspond to the course of the blood-vessels in the uterus. Round non-villous spots may occur along the course of these smooth branched areas. The long linear bare area (Plate XXXV, fig. 6) presents fine outwardly radiating folds 
from the central thickened area, and sparsely scattered, minute villi and folds like the bare spots of the chorion generally. The blood-vessels of the chorion branch dichotomously and do not show any of the tortuosities which characterise the chorion of the mare. A very few vessels, however, almost as fine as human hairs, distributed over the allantoid portion of the amnion, are somewhat tortuous, but in a moderate degree. I have traced these vessels into the arteries of the cord.

One of the dorsal surface bare spots situated 8 inches to the right of the funis is distinguished from all the other smooth spots of the chorion by bearing a shortly pedunculated solitary corpuscle. This spot has a diameter of 0.25 inch. The corpuscle does not occupy the centre of the spot, but is placed to its left side, (Plate XXXIV, fig. 4).

The membrana intermedia can be separated from the chorion and the amnion. The attachment of the allantois to the membrana intermedia, and through it to the chorion, differs from that of Platanista in this respect, that the allantois adheres more to the ventral and posterior surface of the chorion, whereas, in the former genus, it is attached from the posterior towards the dorsal surface. It differs also in form from that genus, the portion opposite the funis being pyramidal, and the continuation on either side of it being narrower and more tubular than in Platanista, but in its linear extent it resembles the latter.

The corpuscles of the amnion are very much larger than in $P$. gangetica, but have much the same distribution. Each corpuscle is white at its base, and many of them have short peduncles, while others appear to have fallen off, leaving their peduncles. Some of these bodies on the cord, in its last 3 inches, have peduncles an inch in length, but they do not exceed four to six in number, the majority being sessile. A few corpuscles also occur on the amnion, where it is reflected off the allantois, but close to the margin of the latter, to the right of the funis, and on the ventral aspect of the sac.

The allantois terminates 2 inches from the extremity of the right horn of the chorion, and it extends about 2 inches beyond the bare spot corresponding to the left Fallopian tube. It has thus a length of about 36 inches in the chorion contracted by preservation in spirit. At 7 inches from the left pole it has a breadth of 3 inches between the two points where it is reflected off the chorion, while opposite the funis the same interval has a breadth of about 7 inches.

Microscopic structure of the chorion.-In the partially injected chorion, its rough surface presents a villous vascular appearance somewhat resembling that of Platanista (Plate XXXVII, fig. 13), the villi, however, being shaggier and more unequal in size. In a vertical section of the chorion from the gravid horn of the uterus of Orcella, not injected (fig. 14), the inequality of the villous tufts is apparent. In some places they are bud-like, low and closely set, at other spots a portion of the membrane protrudes and throws forth long loops of arborescent vascular villi, thus giving rise to deep unequal intervals and to a pseudo-cotyledonary character. The chorionic villi are freely covered by squamous epithelium, though in some spots I could observe a modified cylindrical kind. The basement membrane is of the usual 
connective tissue, most delicate in nature, and with elongate and sub-circular nucleated corpuscular bodies distributed in profusion throughout it. Here and there, long linear rows of the fusiform cells appear, and predominate in encircling lines round the larger sized blood-vessels, being well marked where these are seen cut transversely. The opposite free allantoic surface of the chorion has a thin covering of large pavement or tessellated epithelium, each cell of which sits loosely to its neighbour, and all are abundantly granulated, or filled with refringent particles, simulating oil granules.

Umbilical cord.-This is about 13 inches long, and describes a series of curves. Besides the peduncular corpuscles which occur near its funis, the cord throughout its extent is studded over, both in the intervals between the vessels and on the latter themselves, with small glandular-like bodies which are covered by the investing membrane of the cord. These are of two kinds; one, elongated ovoid bodies, half white and half dark, or with almost black centres, and in this respect, as in their form and general characters, they resemble the pedunculated bodies of the amnion. The other bodies are much more numerous, and are either yellow globular masses or they consist of a number of such masses aggregated together. The yellow bodies are well-defined sacs (Plate XXXIV, fig. 8,y), with thick walls which do not collapse when cut across and are most numerous in the loose areas betwixt the vessels.

Lymphatics of cord.-Lying between the point of division of the umbilical vessels and the two veins there exists an oval, red, glandular body (Plate XXXIV, fig. $9 \mathrm{gl}$ ), almost a quarter of an inch in diameter. A fine reddish, wavy, moniliform tube (fig. $9, m$ ) enters this structure and leaves it at the opposite end. This red body is a sac filled with a grumous substance, which under the microscope consists of a multitude of very minute, variously sized round cells. These cells exhibit a black speck-like nucleus or centre, and along with them are larger cells and a mass of granules. The walls of the sac internally have a velvety appearance, from the fact that they are covered over by a multitude of fine villous processes. Situated $0^{\prime \prime} \cdot 75$ below the red glandular body, and lying over the left umbilical vein at the point where it reaches the chorion, a small sac occurs, $0^{\prime \prime} \cdot 35$ long. Its walls are very delicate, colourless, and transparent, and the upper half of its extent is divided off from the rest of the cavity by a very delicate septum, which has a slit in its centre, but I cannot be decided as to this, because it is possible I may have ruptured the septum in passing a needle into the larger cavity, before I became aware of the existence of the septum. The presence of the septum is externally indicated by a slight constriction of the sac, and the fotal end of the secondary cavity rapidly contracts and is prolonged upwards to the red glandular body as a fine tube, which is with difficulty distinguished, as it has the same colour as the general substance of the cord (fig. 9, lh). Another vessel of the same character passes out from the opposite end of the primary canal of the sac, but I failed to trace it to its end. A pedunculated structure (fig. 9, $p$ ), also evidently glandular, is closely associated with the glandular body just described. In near proximity to it is another moniliform tube the course of which I was not able to trace satisfactorily, but 
it had all the appearance of either terminating in the red glandular body or of being connected in some way to the moniliform tube proceeding from it. The course of this vessel in the opposite direction lay towards another transparent, but smaller sac (fig. $9 l h^{2}$ ), lying somewhat nearer the chorion than the first mentioned and larger sac.

The intimate relationship subsisting between all of these structures, glands, moniliform vessels, pedunculated glands and sacs, and their close connection with the vessels devoted to the nourishment of the fœtus, suggest the likelihood that they are important elements of a glandular system subservient to the vascular system of the chorion, and that the sacs are analogous to lymphatic hearts.

Besides the arteries and urachus which have their usual relations, there is another tubular cavity in the cord lying between the veins and the urachus, and when the cord is cut across close to the abdominal wall two or more orifices may be detected in the cut end leading into it. It has a length of about 5 inches, and is of considerable capacity, being in some parts fully half an inch in diameter. In some parts of its course it is divided into secondary channels by septa or folds extending from one wall to the other, and also from part to part of the same wall. The interspaces between the blood-vessels consist of a loose membrane, indeed so loose that a probe passes easily along the orifices as they become distended when the cord is cut across at intervals. Yellow glandular sacs are common on these areas, but are not numerous near the funis, and in fig. 9 they are seen in the upper part of the drawing chiefly in the mesial line and on one side.

The veins and also the arteries of the cord communicate with one another, and at about 10.25 inches in the case of the former and 10 inches in the latter, their respective internal calibres are as $0^{\prime \prime} \cdot 20$ to $0^{\prime \prime} \cdot 60$. In the artery, the communication is direct and is outwards from the smaller to the larger. But in the veins the channel is first towards the fotus and then |backwards ; the orifice in the first vein forming a kind of sac before the channel turns backwards to reach the other veins. In the case of the arteries, the channel passes below the urachus from artery to artery. Below this point, the larger artery presents a considerable dilatation of an elongated character, and a number of large branches are given off from it and very many small twigs. It is then continued on to the right side, branching in its course. The smaller artery does not show any dilatation, and passes to the left side of the chorion. Only very small twigs are given off from the arteries prior to their inosculation. The veins are dilated at intervals in their course prior to the inosculation of the main trunks, but not to the same extent as in Platanista. The vein from the right side of the chorion, also like the artery, presents a great dilatation at the point at which it lies alongside it, about an inch and a half below the anastomosis. But no such enlargement occurs in the vein to the left side of the chorion which does not receive so many branches as is the case with the vein of the right side.

Minute structure of the ovary.-In transverse transparent slices of the ovary of the footus of Orcella brevirostris I found the cortical layer surrounding the entire organ to be most numerously studded with ova (Plate XXXVII, fig. 10, o). 
Quite at the peripheral margin these Graafian vesicles were most abundant, causing the circumference to assume quite a granular cháracter even to the naked eye, and markedly so under a hand-lens.

In those parts of the section where it had not been made too thin, and where consequently the relations of the tissues were least disturbed, it seemed as if the follicles, just within the more uniform zonary margin, began to have a festooned appearance, the festooned groups being arranged somewhat irregularly into less or more wedge-shaped masses; these latter, occasionally composed of parallel lines, tending inwards in a wedge-shaped manner, some terminating in single narrow centrally directed lines, others joining and approaching archedly the angle of the neighbouring wedge. Thus the entire superficial surface of the ovary, with a diameter of over a quarter of an inch, has a surrounding ovigerous band about $0 " \cdot 08$ deep : the band thinning inwards with conical pillars sparsely connected by arching lines of scattered Graafian follicles.

The fibro-nucleate character of the attached border of the ovary is more pronounced than is the general stroma of the organ; the wavy nucleated nature of the connective tissue of the medullary stroma is notwithstanding very apparent, especially where encircling blood-vessels, and here and there it leaves open spaces.

On examination under higher powers of the microscope, the structure of the Graafian vesicles could be tolerably well made out in some places, much less so in others. In the best examples, the band of cells constituting the proligerous disc (tunica granulosa) was very clear and distinct, and it encompassed closely but loosely the much darker and denser vitellus, in the midst of which, but only in very few, a germinal resicle was appreciable, but whose germinal spot was by no means definitely made out.

I further investigated the ovary of the gravid female, one section of which, taken through the corpus luteum, I show in Plate XXXVII, fig. 11.

The stroma of this specimen $(s)$ was almost entirely composed of comparatively large-sized oval and hexagonal nucleated cells agglutinated together by delicate nucleo-granular and fibrillated connective tissue, fig. 11A. The stout outer fibrous true coat resolved itself very distinctly from these. Towards the periphery, immediately beneath the outer envelopes, but also more sparsely scattered through the medullary part of the ovary, were ova in various stages of development. Some of the Graafian vesicles were empty, the ova having escaped. In other ova present, cell proliferation, germinal vesicle, and nucleus were distinctly manifest.

Besides the cellular nature of the stroma, the most interesting features in this ovary, and shown in figure 11, were the remnant of a corpus luteum and the pale central bands. The follicle containing the corpus luteum ( $c l$ ) lay just within the tunica albuginea, and was about the size of a mustard-seed, of a triangular shape, the apex pointing inwards, and the vesicle retaining the lining cellular envelope (membrana granulosa). There was a narrow open space to one side, and the remainder of the cavity was occupied by the yellow body composed of corpuscular and 
granular substance, and what appeared to be fat or oil globules. Partly embracing the corpus luteum vesicle was a broad stripe of pale-coloured tissue (fig. 11, $p b$.), which ran towards the centre of the ovary, divaricating and thinning, and latterly terminating deeply in stellate areas. In this pale band, several cavities of different sizes and shapes existed, bearing a resemblance to empty Graafian follicles. The tissue forming this pale band differed in nature from the cellular stroma, being made up of a basis of homogenous structureless membrane, and imbedded in this was a multitude of elongate or oat-shaped nucleated fibre cells closely resembling the contractile fibre cells of unstriped muscular tissue. Other pale bands and streaks similar to what has been above described traversed the ovary at different points from its circumference centripetally, and some of the finer streaks joined others, forming a sort of irregular net-work of thin white lines distributed throughout the stroma generally.

The foetus of Orcella brevirostris (Plate XXXIII, fig. 1) : a female, is moderately elongated, with a roundish head and the body laterally compressed behind the dorsal flipper, the posterior margin of which is on a line with the anterior end of the vulva. From the margin of the upper lip the head is rounded off to the blow-hole, and there is no projection of the upper lip as in Globicephalus, but the tip of the lower lip is slightly anterior to that of the upper. The sides of the head anterior to the eye are flattened. The greatest swelling or rotundity of the head occurs over the eye. The mouth arches upwards, until at its angle it is in front of the eye, but at a lower level. On each side of the snout, $0^{\prime \prime} 50$ above the lip, there is a more or less longitudinal line of moustachial hairs $(h)$ on either side of the head, four on the right and six on the left, each hair being separated by an interval of about $0^{\prime \prime} \cdot 20$ to $0 " \cdot 28$, and being about $0^{\prime \prime} \cdot 50$ long and of a brown colour, and situated in a little pit. The most posterior hair is 1.75 inch from the angle of the mouth.

The eye is well developed and shows indications of eyelids, but there are no traces of eyelashes. From the inner canthus a depression curves upwards and forwards, and a deep pit occurs in the canthus corresponding to the opening of the lachrymal duct. A furrow also courses backwards from the posterior angle.

The external ear is a very small crescentic orifice, the convexity being directed forwards. It is nearly on the level of the angle of the mouth and 2.60 inches distant from it.

The blow-hole is a crescentic orifice placed transversely and slightly to the left side; the convexity of the crescent being backwards and a little anterior to the inner angle of the eye. In a straight line, its centre is distant 3 inches from the tip of the upper lip.

The pectoral flippers are moderately long and broad, but pointed, and about equalling in size a caudal flipper. Their free border is sinuous corresponding to the projections and intervals between the fingers, and the anterior margin is the outline of the half of an elongated oval. Their hinder border is very short, and concave to the depression at its origin. Behind the pectoral flippers the belly of course is 
indicated by a bulging of the inferior line as far back as the anus, and the back corresponding to this area is arched but somewhat flattened, and concave over the spinous processes. The dorsal flipper is somewhat falcate, its posterior margin being nearly vertical and its upper border rounded and arching backwards and upwards, but near its tip slightly downwards to the former. It lies between the umbilicus and the vent, its hinder margin being on a line or nearly so with the anterior margin of the vulva. It is also situated over the 27 th to the 32 nd vertebra, its posterior margin being on a line with the hinder margin of the last-mentioned vertebræ.

Behind the anus, the breadth of the body rapidly decreases and is much compressed from side to side, and it has a sharp dorsal and ventral margin which are prolonged between the caudal flippers to the notch. The upper third of this portion of the side is marked by a longitudinal furrow, which is prolonged forwards on to the trunk before the vent. The caudal flippers are rather pointed, and their outer margins curve somewhat inwards. The longitudinal breadth of the base of a flipper equals about half its length, and the distance between the tips is 6 inches.

The vulva is a slit $1^{\prime \prime} 50$ long, and on each side of it are the mammary slits distant $0 " 41$ from the opening, their posterior extremities being only $0^{\prime \prime} \cdot 41$ from the hinder end of the vulva. The slits are $0^{\prime \prime} \cdot 20$ long. The anus is separated from the vulva by a distinct perinæum $0^{\prime \prime} 41 \mathrm{l}$ long, which is the length of anal puckering.

The tail of the fœtus from the vent backwards was bent forwards against the left side of the belly, and the caudal flippers $(t)$ were coiled round on themselves; the right bending downwards below the body and appearing on the other side, its tip overlying the base of the left flipper. The latter was bent inwards and applied over the outside of the right flipper. The dorsal fin was bent downwards by its base and lay over the left side of the back.

The sides of the trunk from the pectoral flippers to the anus were thrown into six great folds separated by deep sulci. These latter did not extend on to the back nor on to the belly. Whatever explanation they may have, it is to be observed that these great folds are confined to the part of the body which is bent. The sulci were from $0^{\prime \prime} .50$ to $0^{\prime \prime} \cdot 75$ in depth. Besides these deep furrows the skin of the belly from a short distance before the pectorals backwards to the vent and extending on to the sides was thrown into long wavy convex ridges or folds about $0^{\prime \prime} \cdot 32$ in breadth, separated by very shallow depressions or sulci. On the sides they were shorter than on the belly, and higher up they were restricted to the intervals between the deep sulci. A few similar folds occur on the sides and back behind the vent, but they do not extend any distance. The back is crossed by similar shallow folds which are most pronounced behind the blow-hole and back of the head, but they do not reach the sides of the head.

The fotus with its membranes emptied of fluid, weighed $231 \mathrm{tbs}$.

The mammary gland of the fœtus is 3.50 inches long. 
The papilla of the skin are about $0^{\prime \prime} \cdot 04$ in length, and at their bases there is a deposit of dark pigment, but the layer at their ends is colourless. They appear to be generally distributed and not arranged in lines as in Platanista.

The fibrous layer of the skin is $0^{\prime \prime} \cdot 45$ in thickness.

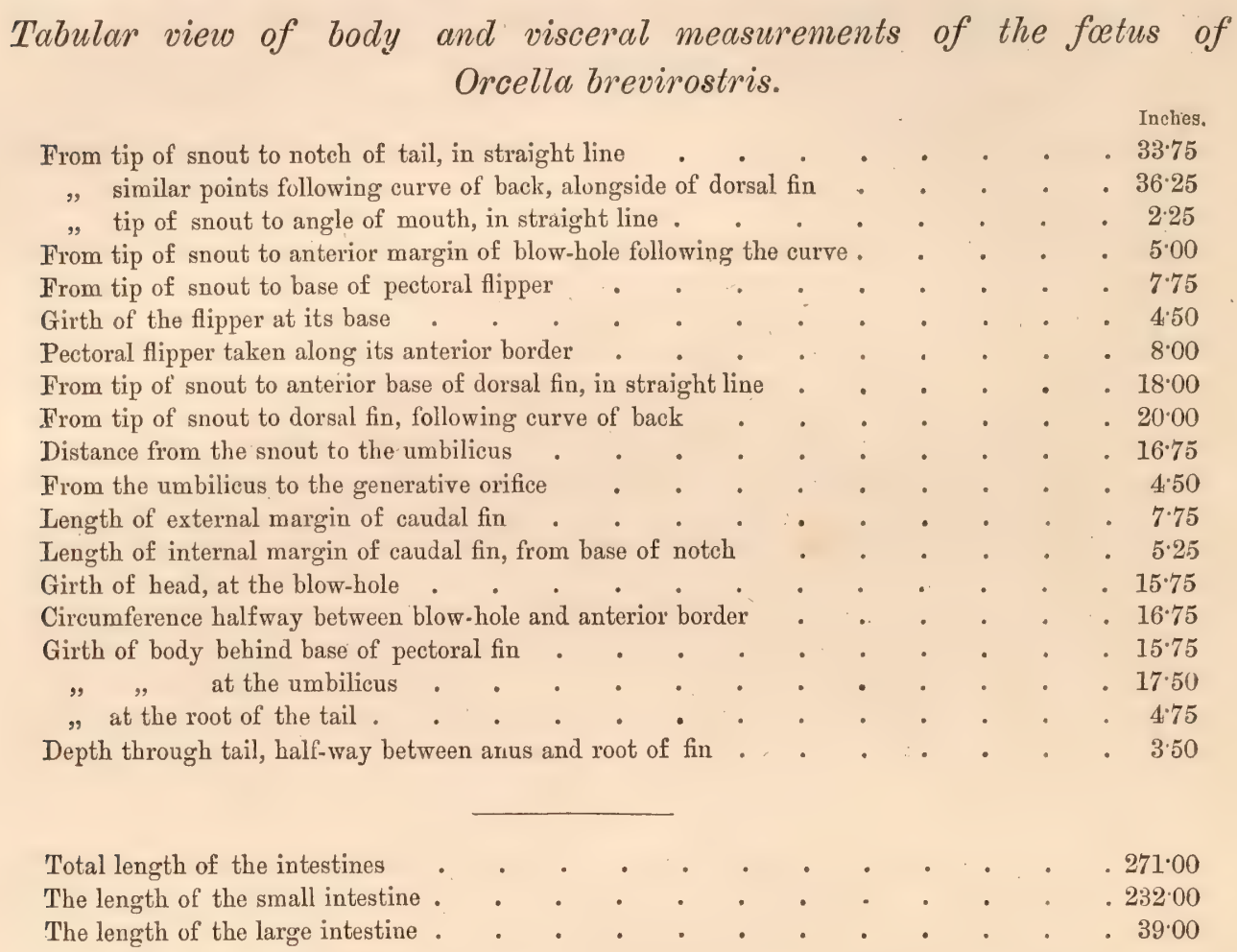

General remarks on the skeleton.-The number of vertebræ appears to be subject to little variation, 63 being the maximum in either species and 62 the minimum. The ribs attached to the vertebræ are generally 12 in number, but another pair may occur. In instances with the normal number of vertebral ribs, two pairs of floating ribs may be present, and in those animals with 13 true ribs one pair of floating ribs may be found.

In the foetus of $O$. brevirostris and in the adult male of $O$. fluminalis, the position of the pelvic bones was ascertained. In the former they lay between the 35th and 36 th vertebræ,-that is, between two vertebræ bearing well-developed chevron bones, and anterior to which was the 34th vertebra, with its chevron bones attached also to the 35th vertebra. In $O$. Auminalis, the greater part of the bones lay below the 36th vertebra, but their anterior ends were opposite to the hinder part of the body of the 35th. The chevron bones in this species also commenced between the 34th and 35th vertebræ. If the vertebræ opposite the pelvic bones are sacral, it is evident that in this genus, at least, the first chevron bones do not indicate the beginning of the caudal vertebræ properly so called. In Grampus rissoanus a similar relationship subsists between the pelvic and chevron bones, the latter occurring before the anterior ends of the former. If the two vertebræ lying above the 
pelvic bones are regarded as sacral, the vertebral formula of this genus is as follows: C. 7, D. 12 or D. 13, L. 14 or L. 13, S. 2, C. 27 or $28=62$ or 63.

In an adult male $O$. fluminalis, with 13 vertebral ribs, in which the vertebral segments had never been separated, these respective regions of the vertebral column had the following measurements : C. $3^{\prime \prime} \cdot 90$, D. $18^{\prime \prime} \cdot 80$, L. $16^{\prime \prime} \cdot 80$, S. $2^{\prime \prime} \cdot 50$, and C. $25^{\prime \prime} \cdot 75$ $=67^{\prime \prime} \cdot 75$, whilst in an adult gravid female of 0 . brevirostris with 12 ribs, but which had had the intervertebral substance removed, the different portions of the column were as follows : C. $3^{\prime \prime} \cdot 50$, D. $14^{\prime \prime} \cdot 75$, L. $16^{\prime \prime}: 50$, S. $2^{\prime \prime}$, and the caudal $26^{\prime \prime} \cdot 90=63^{\prime \prime} \cdot 65$. In the former of these specimens the total length of the skull was $12^{\prime \prime}$ and in the latter $11^{\prime \prime} \cdot 75$.

Vertebral column.-The first two cervical vertebræ of this genus are the only two segments which amalgamate with one another. Union takes place at an early age, but the amalgamation of the neural arches is never complete, as they are partially separated from each other by an incision which runs upwards for some distance from the upper margin of the intervertebral foramen. This incision is also prolonged downwards from the inferior border of the foramen, behind the posterior borders of the facet for the occipital, and is partially prolonged outwards, to the base of the transverse processes of the axis. The neural lamina of the 1st vertebra is broad and strong, but that of the 2nd vertebra is feeble. The arch between the posterior zygapophyses of the $2 \mathrm{nd}$ vertebra, as indicated by the incision, is of considerable breadth as compared with those behind it. The combined arches of the 1st and 2nd vertebræ send up a strong bifurcate spinous process, having behind it a short longitudinal ridge. The transverse process of the 1st vertebra is a large nodule directed somewhat backwards and separated by a deep notch from the longer, more pointed, and backwardly directed transverse process of the axis. The antero-posterior length of the bones inferiorly is about $1^{\prime \prime} \cdot 25$, whilst the longitudinal extension of all the other cervicals together does not exceed $2^{\prime \prime} \cdot 25$. The body of the 3rd vertebra has an antero-posterior thickness of $0^{\prime \prime} \cdot 35$, but those behind it manifest a slight increase to the 6th, whilst in the 7 th there is a more marked thickening.

The neural arches of the other cervical vertebræ are moderately high, and highest and most peaked in the $3 \mathrm{rd}, 4 \mathrm{th}$, and 5 th, the arches of the 6 th and 7 th being lower, but having more lateral expansion. The laminæ are somewhat feeble, and occasionally the lamina of one side does not unite with its fellow, and hence there is only the feeblest trace of a spinous process. In the gravid female the 3rd and 7 th cervical and 1st dorsal present this feature. The superior transverse process of the 3rd vertebra is well developed, dilated at its extremity and with a very slight backward tendency. In the 4 th cervical vertebra the process is much reduced in size, and a forwardly bent inferior process appears, which is much more strongly developed in the 5 th, and is elevated in position on the 6th, in which it can be merely traced. The upper transverse process is lost on the 5th vertebra, but on the 6th segment a small upper transverse process appears, and in the 7th it is prominent on the under surface of the bodies of the 4th and 5th vertebræ; there are two nodular hypapophyses and an azygos process on the 6 th and 7 th. From these facts it is evident 
that the chief peculiarities presented by the cervical vertebræ of this genus are confined to the united 1st and 2nd cervical vertebræ and to the imperfection of some of the neural arches. The measurements of united atlas and axis:-

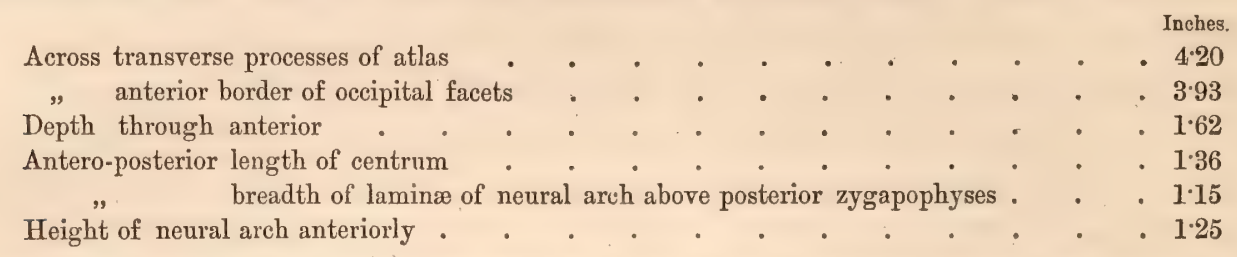

Viewing the remaining vertebræ as a whole, they do not present any very striking features. The spinous processes of the dorsal region are moderately developed and backwardly directed, but in the 1st dorsal, as I have pointed out, the neural laminæ are sometimes not united, and even in the $2 \mathrm{nd}$, 3rd, and 4th dorsal, the laminæ of opposite sides are posteriorly separated from each other by an incision, and this may be traced more or less to the 8th dorsal. The tips also of the spinous processes of the 4th to the 10th dorsal manifest a tendency to bifurcate. The body of the 1st dorsal is about one-third thicker than that of the last cervical, and the vertebræ behind it gradually increase in size to the 10th dorsal, the latter having an antero-posterior thickness of $1^{\prime \prime} \cdot 95$, which is the maximum length attained by the body of any vertebra. External to the anterior zygapophysis on the 5th dorsal there are distinct indications of a mammillary process, and its presence indicates the vertebra in which there is the first appearance of a tendency in the anterior and posterior zygapophyses to shift their position upwards along the neural laminæ to the base of the spinous processes. On the 7th dorsal the anterior and posterior zygapophyses have become wholly transferred to the base of the spinous process of that vertebra. The anterior zygapophyses diminish in length from the 10th dorsal. The transverse processes of the dorsal vertebræ have the usual Cetacean character.

In the lumbar vertebræ the neural canal rapidly diminishes in diameter from $0^{\prime \prime} \cdot 89$ to $0^{\prime \prime} \cdot 38$, and also in height, the height of the canal in the first of these vertebræ being $1^{\prime \prime} \cdot 16$ and in the last $0^{\prime \prime} \cdot 95$. The spinous processes are directed backwards, their anterior margins being concave and their posterior margins convex. They increase in length to the 8th, but diminish in length and in breadth from the 10th dorsal to the last caudal, with a trace of a spinous process, the diminution in the latter dimension being very gradual. In the 8th lumbar the tip of the spinous process is $1^{\prime \prime} \cdot 60$ above the level of the posterior ridge from the zygapophysis, and the latter point is $1^{\prime \prime} \cdot 40$ above the body of the vertebra. The processes are relatively considerably shorter than in Phocana. The anterior zygapophyses retain their conjoint bifurcate character as far as the 9th lumbar, clasping the posterior zygapophyses of the 8th segment, but in the 10th lumbar they suddenly become reduced in dimension to a rounded plate not touching the vertebra in front of it, and all trace of a mammillary process disappears on the last lumbar.

The transverse process of the first lumbar is about one-fourth longer than the transverse process of the last dorsal, and is much more backwardly directed. The processes gradually increase in length to the 5th lumbar, becoming more and more 
outwardly directed until they are nearly at right angles to the long axes of the bodies, but yet with a slight backward tendency. Measured from the centre of the body of the 5th vertebra posteriorly to its tip, the length of this process is only slightly in excess of the interval between the first mentioned point and the apex of the spinous process, which is exactly the reverse of the proportion between the transverse and spinous processes of Globicephalus, from which the skeleton of Orcella is remarkably different, in such details. In the 5th, 6th, and 7th lumbar vertebræ the lengths of the transverse processes and their proportions to the spinous processes are much the same as in the immediately preceding vertebræ, but in the 8 th the transverse process becomes slightly shorter, but hardly perceptibly so. In the 10th the diminution in length is more visible, and with this diminution the process tends to curve forwards. Decreasing in length, the processes increase in antero-posterior breadth towards their tips in the lumbar vertebræ.

In the two sacral vertebræ there is a considerable alteration in the character of the transverse processes as compared with the 8th lumbar, but the transition is gradual. In the sacral, the process is contracted at its base and expanded towards its tip, and the forward curve of the external half of the process is more marked than in the preceding vertebræ. The transverse process is nearly equal to the height of the spinous process measured from the centre of the body. The height of the neural canal is about one-third, and its greatest breadth is about one-eighth the height of the neural arch and its process combined.

The four succeding caudal vertebræ have much the same character as the sacral vertebræ, but they differ from them and the four preceding lumbar vertebræ in the greater development of the processes occupying the position of zygapophyses and in the appearance of a ridge which passes backwards from the front margins of the latter in the locality of a mammillary process. The length of the spinous and transverse processes gradually diminishes, and the breadth of the latter increases with their forward curve, and the spinous processes become nearly vertical.

In the succeeding caudals the bifurcate process in the position of a zygapophysis is even better marked, as it is traced to the 41st vertebra, in which the height of the spinous process measured from the middle of the body is less than the length of the transverse process taken from the same point. In the 40 th vertebra, the free end of the transverse process is obliquely shortened, the direction of the process being much forwards. These two last-mentioned characters become more pronounced in the next five vertebræ, associated at the same time with a reduction in the length of the transverse process which in the 44th vertebra is reduced to a hooklike process. The spinous process suffers considerable diminution in length with a gradual downward subsidence, towards the bodies of the vertebræ, of the processes in the position of the anterior zygapophyses, and the ridge connected with them becomes more marked as it is traced backwards. In the 46 th vertebra the transverse process becomes reduced to a lateral ridge on the front half of the body, but the spinous process is well marked, also the neural canal. The former of these processes disappears on the 47 th and the latter on the 51st segment. 
Chevron bones.-These structures begin between the 34th and the 35th vertebræ, and the first consists generally of two bones not united in the middle line, but articulating by two surfaces to the anterior and posterior borders of the 34th vertebra, and from the circumstance that it is so connected to the vertebra it would appear to consist of two pairs of bones united. In the next pair the bones of the opposite sides are also separate, but in all the succeeding bones, as far as the 19th, they are united, and each forms an arch across the vessels, but beyond that point they are again resolved into two. They attain their maximum development between the $43 \mathrm{rd}$ and the 44 th vertebræ.

Ribs.-The ribs are transferred to the transverse processes at the 8th dorsal, and in this respect Orcella differs from Globicephalus and ( $r c a$, in which the 7th rib is not attached to the body of the vertebræ, but is wholly transferred to the transverse process. The one or two pairs of free ribs lie in the muscles of the side at a considerable distance from the vertebral column. There are nine well ossified sternal ribs, and five of these on each side are applied to the side of the sternum. The first rib is articulated to the anterior external angle of the sternum. The ribs conform to the characters distinctive of the Delphinide.

Sternum.-This bone has the general features characteristic of the sternum of the Delphinida, with an emarginate anterior border, the bone attaining its greatest breadth behind the attachment of the first rib, where it outwardly dilates into two processes, most marked in O. Auminalis. The anterior border is notched in the latter species, but in $O$. brevirostris the primordial fissure has closed anteriorly, but enclosing a rounded imperfection of ossification distinctive of many Cetacean sterna. In the hinder end of the bone, the remains of the primordial fissure may either be indicated by a deep notch, as is generally the case in $O$. fluminalis, or by a groove in O. brevirostris. There are no traces of ossified mesosternal segments.

The sternum of the gravid female of O. brevirostris retained its original twofold nature, being mesially divided into two halves, and only two ribs were attached to it, and that unsymmetrically, the left being considerably anterior to the right rib.

Pectoral limb: Scapula.-This bone has more antero-posterior extension than in either Globicephalus, Orca, or Phocana, and is especially distinguished from the scapulæ of these genera by the broad sweep of the supra-scapular border and the downward arching of the coracoid and glenoid borders, which are of nearly equal length, their angles being nearly in the same plane. The acromion is long, narrow, and slightly downwardly curved.

Humerus, radius, and ulna.-These bones do not call for any special description, as their forms vary but little in the Cetacea, but it may be observed that the humerus is relatively longer than in Orca, having more the proportions that this bone bears to the other bones in Globicephalus. The same is also true of the radius and ulna.

Manus.-The second finger is the longest, and is relatively longer than the corresponding finger in Orca, and considerably relatively shorter to the rest of the 
limb than in Globicephalus, the proportions of the fingers to one another being much the same as in Orca, there being not that marked difference between the length of the 3rd and 4th finger that distinguishes Globicephalus. The whole length of the arm from the end of the humerus to the tip of the 2 nd finger in the dried limb of a female $O$. brevirostris is about one foot, of which the 2 nd finger measured from its carpal bone is 6 inches, the humerus being $3^{\prime \prime} \cdot 62$, the radius $3^{\prime \prime} \cdot 50$, the ulna 3 inches, and the carpus at its middle $1^{\prime \prime} \cdot 40$. The greatest breadth of the distal end of the humerus is $1^{\prime \prime} \cdot 70$, and the greatest breadth of the radius $1^{\prime \prime} \cdot 80$, the combined breadth of the forearm proximally is $3^{\prime \prime} \cdot 32$.

In the carpus four bones are in contact with the ends of the radius and ulna, two in opposition to the former and two to the latter, with another bone opposed to the metacarpal of the 2 nd finger. The small bone which is opposed to the outside of the most external of the ulnar bones is evidently the metacarpal of the 5th digit. The bone placed between the end of the radius and the metacarpal of the Ist digit is the scaphoid; the other bone touching the end of the radius and also a portion of the ulna is undoubtedly the intermedium, and the bone on the outside of the ulna the cuneiform or ulnare. Lying between the os intermedium and ulnare is another bone, which also touches the ulna, but which appears from its position to be the cuneiform, although it may probably be of a two-fold origin. There is a large space at the base of the 3rd metacarpal unoccupied by any bone, and which marks the position which the os magnum should have occupied. The bone applied to the extremity of the second metacarpal is the trapezoid. The manus has thus five bones in the carpus, three belonging undoubtedly to the first and two to the second row.

In the 1st finger there may be either one or two phalanges, the terminal phalanx being a mere ossicle; in the 2 nd finger there are five or six phalanges, which are as broad as long; in the 3rd there are three; in the 4th two, and in the 5th a phalanx may be represented by a single ossicle or by cartilage only. The metacarpals, five in number, vary considerably in form. That of the 1st finger is a squareshaped bone; that of the 2nd is a little longer than broad; that of the 3rd is twice as long as broad; that of the 4 th has its breadth equalling its length; while that of the 5th is quite as rudimentary as the first bone of the series.

The pelvic bones.-All the facts which I have been enabled to ascertain regarding the pelvic bones of this genus have been already stated under $O$. fluminalis and in the preceding pages, with the exception that the termination of the intestine lies between the posterior ends of the bones and is attached to them by a strong fascia. There are no accessory bones.

Skull.-The skull of 0 . brevirostris has been described by Prof. Owen ${ }^{1}$ in detail. The length of the palatal surface of the maxilla which represents the length of the back of the skull is very slightly shorter, or equal to the interval between the inferior border of the foramen magnum and the posterior borders of the palatal surfaces of the maxillaries. The osseous beak is slightly contracted a 
short way beyond its base, but immediately expands, and then gradually contracts, the outline of the premaxillaries having much the same contour as that of the maxillaries.

Teeth.-There are fewer teeth in the lower than in the upper jaw, there being always two to three less in the former, and the lower are larger than the upper teeth. The maximum number of teeth observed by me has been 17 in the upper jaw associated with 14 teeth in the lower jaw on each side, and the minimum number 14 in the upper and 12 in the lower jaw. The number of teeth on the two sides of the skull is liable to variation, 15 occurring on one side and perhaps 17 on the other, and the same may take place in the lower jaw, subject, apparently, to a maximum of 14 on both sides. In O. brevirostris the teeth vary from 15 to 17 in the upper jaw and from 12 to 14 in the lower jaw. One individual has $\frac{\text { R. } 17 \text { L. } 17}{R_{0} 14}$ L. 14 and another R. 16 L. 15

The premaxillaries have each one tooth near the external margin of their tips, and in this respect Orcella resembles Orca. In the fotus in which the teeth had their points still covered by the gums the diameter of a tooth did not exceed $0^{\prime \prime} \cdot 07$, whereas the same tooth in the mother had a diameter of $0^{\prime \prime} \cdot 20$. The teeth are rather sharply conical, and their crowns are slightly inclined inwards, but with use they become perfectly flat. In an adolescent $O$. brevirostris the teeth are unworn, but in an adult they are much worn away, especially the eight hindermost teeth, but the remaining portions of these teeth have much greater diameter than the corresponding portions of the same teeth in the adolescent.

The hyoid apparatus has the usual delphinoid character.

Conclusion.-The form of the skull of Orcella, the character of its teeth, the relation of its ribs to the vertebral column, the features of the latter generally, the well ossified sternal ribs, and the presence of a dorsal fin,-all indicate it to be a member of the family Delphinida. The sub-division of the Delphinide into natural groups, however, as has been remarked by Professor Flower ${ }^{1}$, is by no means easy, and we must either make as many sub-families as there are genera or group them together into one family. Professor Reinhardt ${ }^{2}$ also, in remarking on the systematic position of Pseudorca, contended that to regard Orca as a division among the toothed whales of more than generic worth, as a group or family by themselves, as had been suggested by Eschricht, was neither sound in itself nor indeed supported by any defensible reason, and what was true of Orca in this respect was equally applicable to Globicephalus, Grampus, Lagenorhynchus, Phoccena, \&c. Dr. Gray, however, followed an entirely different course, as he elevated Grampus, Globicephalus, and Orca into as many distinct families, and the Delphinide he sub-divided into five tribes, but as Professor Flower further remarks, the genera so blend one into the other that it is difficult neatly to define their distinguishing characters, and each new discovery of a Delphinoid Cetacean seems to lend more weight to these opinions.

1 Trans. Zool. Soc. 1869, vol. vi. p. 114.

2 Oversigt. over Kong. Danske, Vidensk. Selsk. Forhand. 1862 ; Transl. Ray Soc. 1866, p. 218. 
The present genus well illustrates the truth of these remarks, as it is at once apparent that it has certain undoubted resemblances to Globicephalus, Grampus, Orca and Pseudorca, whereas at the same time it so differs from each of them that the only course left is to refer the two species to a distinct genus. The term Orcella, however, is unfortunate, as in their external features they are not diminutive representatives of the killers, as they have neither high fins to their backs nor very broad pectorals.

This Cetacean type was originally regarded by Owen ${ }^{1}$ as a Phocena, but it has not the compressed teeth distinctive of that genus, from which it also widely differs in the characters of its vertebral column and in its external features generally. Dr. Gray at first considered it to be so nearly allied to Orca as only to merit subgeneric rank to the killers. It is, however, as I have just mentioned, remarkably distinct from these Cetaceans, as the dorsal fin, instead of being high and in the middle of the back, is low and placed behind the middle of the body. Orca is also distinguished by having extraordinarily large pectoral fins, nearly as broad as long, whereas, in Orcella, the pectoral flipper, although proportionally much broader than in Globicephalus, is only about half as broad as long. The pectoral limb, as a whole, is also proportionally considerably longer and narrower than in Orca. This is due to the greater length of the bones of the arm and those of the metacarpus and phalanges, which in Orca are relatively much less developed than in Orcella. In the manus also other differences present themselves, as the second and third fingers of Orcella are much longer than those of Orca, whereas the fourth and fifth are rather shorter. Orca also is distinguished from Orcella by its much more powerfully built skeleton with considerably fewer vertebræ, there being only a maximum of $53 \mathrm{in}$ it, to a maximum of 63 in Orcella. The cervical region of Orca, moreover, has generally four or five vertebræ anchylosed, whilst in the two species of Orcella the atlas and axis only amalgamate. Further, in the Killers and Ca'ing whales the ribs are transferred to the transverse processes at the 7th dorsal, whilst in Orcella the transference does not take place until the 8th. In its conical teeth, which are about the same number as in Orca, Orcella resembles the killers, and, as pointed out by Reinhardt, ${ }^{3}$ the breadth of the upper jaw in Orca is produced by the maxillaries and not by the premaxillaries, as in Globicephalus, and in this feature its skull resembles Orca.

Dr. Gray, in his last work on the Cetacea, ${ }^{4}$ separated Orcella from Orca, which he elevated into a distinct family, the Orcada; ; elevating Orcella to generic rank and placing it alongside Pseudorca, which he regarded as the type of a tribe of Delphinida. Pseudorca, however, has a much more depressed head than Orcella, which is intermediate in this respect between Orca and Globicephalus. The dorsal

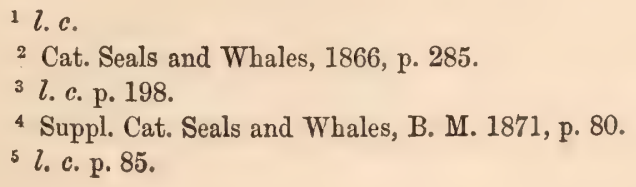


fin also of Pseudorca is placed about the middle of the back, but in its height it approaches more to the high dorsal of Orca than to the low dorsal of Globicephalus. Pseudorca also, in the fewer number of its vertebræ, 50, departs even more from this form than does Orca, and in its lower spinous processes and in the union of its first six cervical vertebræ, it differs considerably from this genus. The pectoral limb of Pseudorca is narrow like the anterior extremity of Globicephalus and Grampus, but is proportionally very much shorter and smaller. It is, however, very different from that of Orcella, which is situated further away from the head, and is considerably broader and more powerful. The scapula of Orcella in its great length and in the curvature of its glenoid and acromial borders approaches more to the scapula of Pseudorca than to the scapula of either Orca or Globicephalus, but it is distinct from any of them. Its humerus, radius, and ulna are much longer than in Pseudorca, and its manus is perfectly distinct from the narrow manus of the latter, in which the fingers, especially the second and third, are close together, giving rise to a narrow flipper, whereas in Orcella, they are along with the other fingers expanded and widely apart, producing a moderately broad fin. In Orcella the phalanges are broader than long, in Pseudorca longer than broad. The skulls also of these two forms differ as much from each other as they do from Globicephalus and Grampus respectively, and as do the two latter from each other; indeed the skull of Orcella, taken in all its features, has a closer resemblance to the skull of Grampus than to the skull of Pseudorca.

The skull is distinguished from that of Globicephalus by its much less laterally extended premaxillaries and its vertebral column, by the union of only two of its cervical vertebræ, an event which probably takes place after uterine life by anchylosis of two previously existing segments, whereas, in Globicephalus, all the cervical vertebræ are anchylosed or rather form one single bone as they originally formed one single cartilage. I have also referred to other structural differences that exist between the vertebral columns of Globicephalus and Orcella, more especially to the differences in proportion between the transverse and spinous processes.

From such considerations as these, and viewing the structure of Orcella as a whole contrasted with that of each of the already named genera, to each of which it presents certain features of resemblance, associated, however, with marked dissimilarities, it is evident that Orcella presents an assemblage of characters which remove it from any of these genera and entitle it to generic rank. These characters may be expressed as follows :-

Head globular; dorsal fin low, situated behind the middle of the body; pectoral fins oval, about one-sixth the length of the animal. Teeth conical, larger and fewer in the lower than in the upper jaw; 13 to 17 teeth in upper and 12 to 14 teeth in the lower jaw. Skull beaked; beak broad at the base, anteriorly pointed; premaxillary not much laterally dilated, bearing one tooth; vertebræ 62 to 63 ; first two cervical vertebræ anchylosed. Lumbar transverse processes moderately long; yertebral ribs 12 to 13, with one to two free ribs. Pelvic bones opposite 35th and 36th vertebræ. 
Genus Platanista, Cuvier.

Platanista gangetica, Lebeck. 'Plates XXV, \&c.

Delphinus gangeticus, Lebeck, Der Gesellschaft Naturf. Freunde zu Berlin, 1801, vol. iii., pp. 280-282, pl. 2; Roxburgh, Asiatic Res. vol. vii. 1801, pp. 170-174, pl. 5 ; Home, Phil. Trans. 1818, pp. 417-419, pl. 21.

Delphinus rostratus, Shaw, Genl. Zool., vol ii., pt. 2, 1801, p. 514; Blainville, Nouv. Dict. d'Hist. Nat. Appl. 1816-19, 2nd ed. Dauphin.

Delphinus shavensis, Blainville, Nouv. Dict. d’Hist. Nat. Appl. 1816-19, 2nd ed. Dauphin.

Platanista gangetica, Cuvier, Rech. Oss. Foss., nouv. éd., Paris, vol.v. pt. 1, pp. 279-280, and pl. 22, figs. 8 to 10, pl. 23, fig. 19; Lesson, Complé. Euv. Buffon, Cét. 1834, p. 215, Atlas pl. 3, fig. 3; Gray \& Hardw. Ill. Ind. Zool. 1830-34, pts. xv. \& xvi., pl. 4; Cuvier, Hist. Nat. Cét. 1836, pl. 8 fig. 2; Jardine, Nat. Lib. vol. vi. Mamm. 1837, pl. 28 ; M'Clelland, Cal. Journ. Nat. Hist. vol. i. 1841 , p. 425 ; Owen, Odont. $1840-45$, p. 449 ; Gray, Cat. B. M. Cet. 1850 , p. 137 ; Cat. Seals, Whales, 1866, p. 223 ; Eschricht, Danske Vid. Selsk. Skr., 5 te R. Bd. ii. 1851, pp. 347-387, 3 Pls.; Ann. and Mag. Nat. Hist. vol. ix. 1852, 2nd ser., pp. 161-188, pp. 279-293, pls. v. to vii.; Blyth, Cat. Mamm. As. Soc. Mus. 1863, p. 92 ; Flower, Trans. Zool. Soc. $(1866$, ) vol. vi. 1869, p. 87 , et seq.

Platanistina gangetica, Gray, Voy. Erebus and Terror, 1846, Mamm. pp. 45, 46, pl. 7, fig. 2.

Eschricht in his admirable memoir on the structure of this remarkable type of Cetacean fully summarised all that was known regarding it at the time he wrote. Since then, Professor Flower has described many of the important features of its osteology and greatly enlarged our knowledge regarding its affinities.

Eschricht considered that the figure of a female drawn under Reinhardt's direction was a faithful representation of the animal, and that "the skill of the draftsman, and, above all, the great experience of the naturalist, sufficiently guaranteed the correctness of the delineation." He has also stated that the accuracy of the drawing was still further corroborated by the close correspondence of its proportions with the skeleton of the self-same individual. There can be no doubt but that this drawing which was reproduced by Eschricht, was, as a whole, a considerable improvement on the representations of the animal given by Lebeck, Roxburgh, Lesson, F. Cuvier, Sir William Jardine, and Gray, but it cannot be overlooked that it erred in some important details. In Roxburgh's figure of a male, the artist has attempted to show the prominence of the head before the blow-hole, and he has given the approximate position of the pectorals, in both of which features Eschricht's figure is at fault. As, therefore, a faithful delineation was a desideratum, I have reproduced a photograph of a female dolphin (Plate XXV). A comparison of this plate with Eschricht's will show that the latter fails to represent the constriction of the neck, the undulating outlines of the back and belly, the bulging character of the head and the proper position of the pectoral fins. The constriction of the neck is a marked feature of this Cetacean, and was to be looked for from the character of the cervical vertebræ. Eschricht justly doubted the accuracy of Reinhardt's drawing on two points, viz., the positions of the eye and ear, which he considered were placed too far above the angle of the mouth. 
My attention was first called to this Cetacean genus while residing with my brother in the Royal Botanical Gardens, Calcutta. The residence ${ }^{1}$ of the Superintendent of these Gardens, from its proximity to the river bank, and from its commanding position, overlooking a long deep reach of the Hughli, afforded very favourable conditions for observing the habits and for obtaining specimens of this dolphin. The observations there instituted led me to doubt the conclusion which Eschricht had arrived at, viz., that the animal actually leaves the river during the cold weather and takes to the sea, and I therefore commenced a correspondence to render my inquiries complete, and also drew up a series of questions to elicit all the facts regarding its distribution and habits. This schedule of queries was printed and circulated by Government among the civil and other officials resident along the courses of the greater rivers of India and Burma, and among the members of the Pilot Service. Notwithstanding that the inquiry was of a novel and rather unusual character, the replies were most complete and full of interest, and, moreover, examples of the dolphin were sent to me from the Indus, Ganges, and Brahmaputra.

I gladly embrace this opportunity to express my indebtedness to all of those officers whose hearty co-operation in the research has greatly enabled me to settle the questions which are treated of in this contribution towards a history of this Cetacean. The following remarks on distribution are the result of a careful analysis of the reports received.

Distribution.-To illustrate the distribution of this Cetacean genus I have had the accompanying map prepared, in which its range is shown by a coloured line carried through those river systems of India in which it exists, and a glance will show that the information I have received does not establish its presence in the Nerbudda or Godavery, nor in the river systems of Burma.

The pilots stationed at the Sandheads, and who having so frequently to pass up and down the Hughli in which the dolphin abounds, are therefore familiar with it, unite with other Government Marine officials thoroughly acquainted with the sea-face of the delta of Bengal, in asserting that the long-snouted dolphin of the Ganges is never seen out at sea. I have never heard of an instance of its occurrence below Mud Point in Saugor Island, at the mouth of the Hughli, and from the reports submitted to me it would appear to have a similar limit to its seaward distribution in the other estuary streams of the Ganges and Brahmaputra, and I have satisfied myself of the correctness of these observations by personally going round a considerable portion of the sea-face of the Sunderbunds. Similar reports have reached me regarding the restriction of this genus to the fresh waters of the Indus. I have also to add the testimony of Blyth ${ }^{2}$ that it has never been observed out to sea.

Its distribution in the Ganges is recorded over an area comprised between the 77th and 89th degrees of east longitude. In the Brahmaputra it occurs through-

\footnotetext{
${ }^{1}$ Roxburgh, who, with Lebeck, shares the credit of having first described and named the dolphin of the Ganges, designed the house and lived in it.

: Journ. As. Soc., Bengal, vol, xxviii, 1859, p. 493.
} 
out all the main river, as far eastwards as longitude $95^{\circ}$ by latitude $27^{\circ} 30^{\prime}$ north, frequenting also all its larger streams. In the Indus it is found all the year round, from latitude $24^{\circ}$ to latitude $34^{\circ}$ north, being also distributed through the Jhelum, Chenab, Ravi, and Sutlej rivers up to their exits from the hills; the area over which it ranges in that part of India being included between the 68th and 77th degrees of longitude. It has thus a permanent distribution in these river systems over $12^{\circ}$ of latitude and $27^{\circ}$ of longitude; or, in other words, it has 800 miles of a northerly distribution from its lowest point of range, $22^{\circ}$ latitude, as it occurs in the Ganges, with 1,880 miles of lateral extension.

The upward range of this dolphin is apparently only limited by insufficiency of water, and by rocky barriers. As pointed out by Wallich, Hardwick's specimen was obtained 1,000 miles above Calcutta, and Cuvier remarks that it ascends the Ganges in great numbers as high as the river is navigable. Even in the month of May, when the Ganges is very low, it extends up the Jumna as far as Delhi, and also enters for a short way all the larger affluents of the main stream. In the Brahmaputra, at the same season of the year, it is found throughout the river as far north-east as Dibrugarh, and it probably extends beyond that point, for it is permanently present in such rivers as the Dihing, Dhansiri, Dikhu, and Disang. From the patrol of Kalabagh on the Indus, it is reported to be constantly present, which is also its habit in the Ravi and in the Sutlej, but it is said to have been found in the Indus, in April, as high up as Attock. The reports, however, all unite in confirming the natural anticipation that it has its widest range in the height of the rains, when the rivers are in flood, and that its distribution is most limited in the hot months when the rivers are low.

According to my own observations it is more frequently seen in the Hughli at Calcutta, and such distances from the sea in the cold weather, than during the height of summer and the rains, and this coincides with what was observed by Blyth and Cantor; but the latter conjectured that it migrated to the ocean at other seasons than in the cold weather. As I have stated, however, all the evidence negatives this conjecture. During the hot months I have rarely observed it in the Hughli, which it appears almost wholly to desert at that period. Its presence, however, as already stated, has been reported to me during all the year, but it is exceedingly rare from May to the end of June, so that it is to a certain extent migratory. The fishermen say that with the approach of the hot weather the dolphin ascends the river, returning with the rains. In July, and up to the end of September, its existence is demonstrated by its being frequently caught in the nets of the fishermen, but were it not for its capture, its presence could not then be determined. Iiving, as I have done, for three years overlooking the river, I have never observed a dolphin rise during the rains, although I have watched most carefully for them, and all the fishermen I have conversed with on the subject have told me that they never see them rise at that season. This fact may be accounted for on the supposition that the strength of the current is so great when the Hughli is full that the dolphin is prevented from rising to the surface in the marked manner it does during the 
cold weather when the current has slackened and there are comparatively quiet reaches in which it can disport. The disturbed state of the river when it is swollen doubtless renders the presence of the dolphin very difficult of detection, for at such times it will simply expose its blow-hole, too restricted a surface to be noticed on the troubled waters. In the cold weather its presence can easily be detected, without its being seen, by the blowing sound it makes when it rises to breathe; but during the rains, the rush of waters effectually drowns this means of becoming aware of its existence.

Habits and Food.- The Platanista, unlike the dolphin of the Irawady, is not gregarious, but more than one may be observed at the same time in a comparatively limited portion of a deep reach, but it is difficult to say whether the Gangetic dolphin confines itself to limited areas when there is no disturbing cause at work, such as the rains, leading it to disperse itself over other channels and branches of the river which are not accessible to it in the dry weather.

In rising to breathe, the Platanist may either simply expose the upper surface of its head, sufficiently to bring its blow-hole above water, or, what is more common, plunge out of the water upwards, forwards, and downwards, first exhibiting its long snout, followed by two-thirds of its back. At such times it emits a short, blowing sound, which doubtless has given rise to the term generally applied to it along the Ganges and Brahmaputra. During the cold months, in the quiet reaches, it even becomes at times extravagant in its movements, and will leap altogether out of the water with the tail curved downwards. As a rule, however, its respiratory visits to the surface are leisurely executed. I have had the rare opportunity of narrowly observing the respiratory movements of this dolphin from having had one alive for ten days in captivity." In its place of confinement this individual rose slowly to the surface, exposing the blow-hole and a portion of its back. The blowhole opened whenever it reached the surface of the water, the characteristic expiratory sound was produced, and so rapid was inspiration, that the blow-hole seemed to close immediately after the expiratory act, and then the animal slowly subsided. The respirations were tolerably frequent, occurring at intervals of about one-half or three-quarters of a minute, and the whole act did not take more than a few seconds for its fulfilment.

Some further observations on this captive might have led to the supposition that this Cetacean was exclusively a nocturnal feeder, because the fish given it during the day were untouched, but when counted on the following morning were materially diminished; every precaution having been taken to prevent their escape or removal from the tank in which the dolphin was confined. Careful and extended observation, however, of the animal in its natural state proves that it feeds during the day as well as during the night, because dolphins are frequently observed going through movements at the mouths of streams and close to the river bank, even among the

\footnotetext{
1 This dolphin, which measured 3 feet in length, was procured for me by the kind assistance of C. T. Buckland, Esq., C.S., who succeeded in interesting Captain Huey, of the India General Steam Navigation Company, running between Goalundo and Dacca. It was captured at Dacca, and was brought alive to Calcutta in a bath filled with water, being fed with fish by the way.
} 
shipping of Calcutta, which can only be accounted for on the supposition that they are engaged in a search for food, and like movements have also been noticed by night. The food of the Gangetic dolphin, as pointed out by Reinhardt, chiefly consists of fish and crustacea. The many fishermen whom I have interrogated on this subject have informed me that the dolphin seeks its food on the muddy bottom of the river. The only specimen I ever succeeded in harpooning was caught close to the half-sunken remains of a large ship, which was lying close to the river bank on the edge of a subaqueous alluvial cliff, over which it eventually fell into deep water. The outer margin of the wreck was a favourite resort of Palemon carcinus, and fishermen were daily in the habit of diving to its base in search of these prawns, which they there found very abundant. I have observed, while the fishermen were thus engaged, one or more dolphins plunging quite close to them, and it was on one of these occasions that I was so fortunate as to isolate and capture one. On opening its stomach, I found it filled with prawns, thus verifying the previous assertion of the fishermen that the dolphins so observed were in the pursuit of prawns, which they found in the mud at the bottom of the wreck. While the dolphins were thus feeding, I have frequently timed the duration of their stay at the bottom and found it generally to extend to about two minutes. It is probable that the dolphin is guided to its food by the tactile sensibility of its long snout, with which it grovels in the mud, because, as will be hereafter shown, the diminutive organ of vision, in this most anomalous Cetacean, is essentially rudimentary.

I have examined numerous other stomachs of this dolphin, and have found in them, besides Palamon carcinus, the unquestionable remains of Wallago attu, and Saccobranchus fossilis, both mud-frequenting fish. Besides these fish, however, Reinhardt found in the stomach of the specimen he examined Clupea telara, a species of Pimelodes and a large species of Pencus, and Roxburgh says that in the stomach of one individual he found only some grains of paddy (rice in the husk), a few fragments of shells, and many living active ascarides. ${ }^{1}$ Lebeck also observed rice in the stomach and mouth, and many living ascarides and grains of rice in the former. Mixed among the contents of stomachs examined by me, I have observed grains of paddy, seeds of the Kudoo grass, Paspalum scrobiculatum, and remains of beetles, while in the stomach of one there was a solitary undigested bee.

It is difficult to offer a quite satisfactory explanation of the presence of grain in the stomach of the dolphin. There can be little doubt but that it finds access adventitiously, and that it is in no way its food any more than beetles or bees. Two explanations suggest themselves: either that the rice had formed part of the contents of the stomachs of the fish swallowed by the dolphin, or that particles of rice had found their way into the stomach from the mud in which it grovels for its food. Large quantities of husked and unhusked rice are sold from boats at one of the ghâts in the port of Calcutta, and it is noticeable that at that spot

1. This ascaride, which is remarkably prevalent in the dolphin, has been identified by Dr. Cobbold as Ascaris simplex, Rud., P. Z. S. 1876, p. 297. 
dolphins are generally numerous, the explanation being that the fish are attracted by the rice that falls into the water, they in their turn drawing the dolphins to the place. In the stomach of $W$ allago attu rice has been frequently found; and, moreover, this fish has the reputation of being occasionally destructive to paddy crops. The remains of beetles and the presence of a bee in the stomach are probably also to be accounted for by their having first been swallowed by fish.

Gestation.-It appears to give birth usually to only one at a time, although it is stated that it sometimes produces twins: two gravid uteri opened by me in April each contained a single mature fœtus, and in two other instances, of which I have been informed, only one young in each was discovered. Some of my informants record that the period of gestation is from 8 to 9 months, and that the young are born between April and July, also that they are sometimes captured in the nets of the fishermen clinging to their mothers; and a correspondent at Dacea observes that they hold on by their mouths to the base of the mother's pectoral fin. I have observed the young following the mother in the months of November and December.

Native names.- This genus is known by different names along the Ganges, Indus, and Brahmaputra. Along the first-mentioned river, the term generally applied to it is sus, susu, or sunsar; along the Indus it is called, as a rule, bulhan, but the term sunsar appears to be occasionally applied to it; and along the Brahmaputra it is known to the Assamese as hihoo or sihoo, and in Cachar and Sylhet as huih, both $h$ 's being strongly aspirated. All these terms appear to be imitations of the sound made by the dolphin in respiration.

Capture and uses.-The Platanista is not unfrequently captured in the nets of the fishermen, but such an event is not considered a cast of fortune, for the animal, in its struggles to escape, seriously damages the nets, which are not adapted for entrapping such unwieldy and powerful mammals. A gravid female so caught in the Hughli, and measuring about 8 feet in length, was brought to me alive on the 4th March 1873. For about half an hour after her capture she had lain without shelter under the blazing heat of an almost tropical sun, only, however, to be transferred to the bullock cart in which, without any protection whatever from the scorching rays, she was driven a distance of more than three miles. Notwithstanding this barbarous treatment, she was, as I have said, alive, after having been more than four hours out of her native element, under circumstances most adverse to vitality. When I first saw her, she exhibited no movements but those of respiration, and even these were feeble. She respired about every minute or minute and a half. Thinking there was a prospect that I might preserve her alive and so observe her habits, I resolved to let her loose in a large sheet of water, close at hand. On reaching this, however, she appeared so exhausted that I took the precaution, in case I might lose her if she sank, to tie a light rope to her tail. No sooner did she touch the water than she floundered into it, and rolling about for a minute or so seemed to regain her strength and made off feebly for the middle of the tank, twice rising to the surface to breathe. After waiting 
some time in the hope that she would again show her vitality by coming up to the surface, my desire was disappointed, for her position was at length alone indicated by a profuse discharge of air bubbles over the spot where she was submerged. The rope now proved of use, for on gently pulling her out I found to my chagrin that all life had ceased.

When the dolphin is purposely sought for, which does not, however, appear to be a frequent occurrence in Bengal, it is transfixed by a harpoon, ${ }^{3}$ in the use of which, in catching Trionyx gangeticus, some of the fishermen are experts.

At Sukkur, on the Indus, the Dhopels are said to catch dolphins in shallow. water by the aid of trained otters.

The flesh and blubber are occasionally eaten by many of the low-caste Hindus of India, such as the Gurhwals, the Domes of Jessore and Dacca districts, the Harrees, Bourees, Bunos, Bunpurs, Tekas, Tollahas, the Domes of Burdwan and Bhagulpore, who compare it to venison; also by the Teewars and Machooas of Patna, the Mussahars of Shahabad, the Gourhs and Teers of Tirhoot, and the Mullahs of Sarun. In the North-West Provinces about Allahahad, the Chumars, Passees, Kooras, Khewuts or Mallahs, have rather a high estimate of the flesh, which they assert resembles turtle. The Koonths of Benares, Phunkeeas, Natehmurrahs, and Budhoas of Moradabad, and also such gipsy tribes as the Sainsees, Kunjars, and Hubbossahs in the neighbourhood of Meerut, do not despise it. In the Punjab we find the Choorahs, Dhapels, Sainsees, Budous, and Burars eating the flesh; and in Sind, the Kehuls. The Moras, a tribe of Mahomedan boatmen who lead a wandering life on the streams in the Punjab and in Sind, subsist on the dolphin when by good chance they catch one; this is also the case with the Cacharies and the Nágás of Assam. The Sansee women on the Indus eat the flesh under the idea that it makes them prolific.

All along the Ganges, Brahmaputra, and Indus the oil is universally considered as of great value as an embrocation in rheumatism and for giving much strength when rubbed on the back and loins. But many other animal oils, such as those of various species of turtle, the crocodile, and the pelican, have a similar reputation. It is said to be of a very penetrating nature, and owing to this property it is highly prized for preserving leather, such as harness, \&c. The illuminating powers of this oil are said to be very high. The Mooreahs of Assam, who work in brass, use it whenever they can, burning it in little earthen lamps, as the light it gives is more clear and brilliant than that to be obtained from fish or mustard oil. Also the natives along the banks of the Ganges and Indus value it much for its lighting

\footnotetext{
1 The harpoon consists of a long thin bamboo, varying in length from 6 to 9 feet, into the thick end of which an iron barb, fitted in a wooden socket, is let loosely. A strong cord is attached to the base of the iron barb, and its other end is tied round the socket end of the bamboo. The cord, which may be from 40 to 50 feet long, is then coiled round the bamboo from below upwards. This spear-harpoon is thrown with wonderful precision at the turtle or dolphin as it raises its head to breathe. When transfixed, the animal plunges into the deep water, carrying the barb away with it, whilst the line spins out from off the bamboo-shaft, which floats on the surface, or disappears to rise again, marking the position of the wounded animal.
} 
capabilities, and I am informed that there was once a factory for extracting the oil about four miles below Agra.

I am not aware that any use is made of the skin; yet, as this resembles the hide of other dolphins, it seems to be suitable for purposes where it is desirable to use leather of great toughness and durability.

Species.-Blyth not only informed Reinhardt ${ }^{1}$ that he distinguished two species of Platanista - one common in the Indus and but rarely found in the Ganges, the other entirely wanting in the Indus, - but he even went so far as to describe the Indus dolphin as a new species, and later, in $1863^{2}$ he was still inclined to believe that two species might be found to exist in the Ganges; and Eschricht ${ }^{3}$ also, in 1851, held a similar opinion.

Blyth's type of Platanista indi ${ }^{4}$ had lost the maxillary crests. It is the 'skull evidently of an adult individual, as the teeth are reduced to hard osseous cubes. Its total length from the inferior border of the foramen magnum to the tip of the snout, which is very partially broken, is 19.50 inches. The snout anteriorly has a slight downward curve. The sockets of the posterior teeth are obliterated above and below, so that it is impossible to count the teeth. This skull corresponds well with the skulls of ascertained males of the Gangetic dolphin, and the snout and teeth have the same characters.

Among Sir A. Burnes' drawings ${ }^{5}$ there is a figure of the Platanist of the Indus, and it represents an animal with all the characters of the Platanist of the Ganges, with the neck well defined and corresponding much to my Plate XXV. The drawing does not reveal any character specifically different from that of the Ganges Platanist. The specimen measures 7 feet long.

One of the characters assigned by Blyth to $P$. indi, and which would appear to have been the character to which he attached most importance, was the depth of the jaws with the teeth, which " measured in the middle of their length 3.25 inches to gangetica 1.75 inch." This depth of the jaw, however, is not distinctive of the Indus dolphin, because a mature female from the Hughli has a depth at the middle of the snout of 3.50 inches, and another and slightly larger skull, probably of the female sex, has a depth at the middle of the jaw of $4 \cdot 36$ inches. A male skull from the Hughli of the same size and age as the type of $P$. indi, which I consider to have belonged also to the male sex, has a depth at the middle of the jaw of 3.40 inches; so that this character selected by Blyth falls to the ground, and if the Indus dolphin is distinct, the features that distinguish it must lie in some other organ or part.

There is no 'information about the sex on Sir A. Burnes' drawing, or is the animal so posed as to display the external generative organs; but Blyth at that time believing that his specimens of the Gangetic Platanist were males, and

${ }^{1}$ Ann. and Mag., Nat. Hist., vol. ix (1852), p. 291.

${ }^{2}$ Cat. Mamm. As. Soc. Mus., 1863, p. 92, footnote.

3 Loc. cit.

${ }^{4}$ Journ. As. Soc., Bengal, vol. xxviii, 1859, p. 493; Cat. Mamm. As. Soc. Mus., 1863, p. 92. Jerdon : Mamm.

- Ind. 1867, p. 159. Gray : Cat. Seals and Whales, British Museum, 1866, Г. 221.

${ }^{5}$ Deposited in the As. Soc., Calcutta. 
that the males had longer snouts than the females, remarks that the rostrum is represented as short in proportion to the length of the animal, and that the specimen is evidently a female, whence the male should have a longer rostrum. He was of opinion that Sir A. Burnes' drawing was probably the identical individual that furnished the skull on which he founded his Platanista indi. This is, however, very doubtful, as the teeth are all represented as present in the representation of the animal, and are sharp-pointed, whereas in the type the backmost teeth had in all likelihood fallen out, and the teeth generally are much worn, and reduced almost to little squares. From the condition of the teeth as represented in the drawing, I would be disposed to regard the animal as an adolescent individual, and that it would attain to a greater size; but whether it would ever have reached the dimensions of the largest female from the Ganges is, of course, an open question.

A young Platanist from the Sutlej, presented to the Indian Museum by C. E. Wakefield, Esq., measures 49 inches in its total length, and has a gape of $10 \cdot 80$ inches. It is a female, and in its long snout it corresponds to the females generally of the Platanist of the Ganges. In the position of its dorsal fin and in the character of its pectoral and caudal flippers, I do not detect that it differs from the Gangetic individuals; but, of course, I am comparing a stuffed animal with a stuffed female from the Ganges, and I cannot say anything regarding the features of the Indus animal in the flesh beyond that Sir A. Burnes' drawing, which was, in all likelihood, made from a freshly caught specimen, does not reveal any external characters different from the dolphin of the Ganges. The only point in which the Sutlej young female differs from a Gangetic female of about her own age, is the somewhat greater length of her snout, and in possessing a few more teeth both above and below, but these variations are not more than have been observed among undoubted examples of Gangetic dolphins of one species. In the Sutlej female, the teeth are upper $\frac{\text { R. } 32}{\text { L. } 33}$, lower $\frac{\text { R. } 31}{\text { L. } 32}$, and in the Gangetic female upper $\frac{\text { R. } 28}{\mathrm{~L} .31}$, lower $\frac{\text { R. } 30}{\mathrm{~L} .30}$, both individuals indicating the existence of variation in the number of the teeth in both jaws, and, in so doing, leading us to anticipate variation in the length of the snout.

Professor Owen, ${ }^{1}$ in his "Osteological Catalogue of the Museum of the Royal College of Surgeons of England," distinguishes a skull from the Indus as P.gangetica var. minor, because, although it shows all the characteristics that have been pointed out by Baron Cuvier and Professor Eschricht, it is of small size, the total length not exceeding 12 inches, and the anterior teeth being much longer and more slender and acute. ".... All the facets of the occiput have coalesced, and not any of the sutural unions manifest any mark of immaturity. There are twenty-one teeth on the left side of the upper jaw and nineteen teeth on the right side; but the alveolar grooves extend further back, indicating the former existence of teeth, or germs of teeth which have been lost. There are twenty-six teeth on each side of the lower jaw, behind which is a short extent of an empty alveolar groove. The teeth, in place; 
are close together; the anterior ones in the lower jaw are an inch in length, slender, and sharp-pointed, with the points slightly incurved and projecting outside those of the upper jaw."

A skull of a Platanist from the Ganges measuring 12 inches in length and thus strictly comparable with the foregoing Indus skull, presents all the features described as characteristic of P.gangetica var. minor; all the occipital elements have almost wholly coalesced, complete union having taken place between the basioccipitals and exoccipitals, the only portion of a suture remaining unclosed being a very limited part between the exoccipitals and supra-occipitals; all the other sutures of the skull have very much the characters they have in adult life, but they want the well-defined ridges which appear with age. The skull, however, is undoubtedly the skull of a very young individual, as is fully verified by the condition of its vertebral column and limbs. The teeth of this specimen exactly correspond to the description given by Owen of $P$. gangetica var. minor. On the left side of the upper jaw only eighteen teeth had perforated the gums, and nineteen on the right side, but the piece of skin behind these teeth has dried off the jaws, carrying along with it the remaining teeth, and exposing the alveolar groove deprived of its teeth. In the lower jaw all the teeth are present, as the skin has not peeled off; they are close together, sharp and pointed, and the largest tooth is about one inch in length, and they gradually diminish in length from before backwards. I am, therefore, disposed to regard the characters which Owen considered as separating this Indus skull as a distinct variety as in no way remarkable in a young specimen of Platanist, and that the dental features of the skull in question and the open alveolar groove conclusively show it to have been the young of a large animal; but whether the Indus Platanist, which so closely resembles that of the Hughli, is specifically distinct from it has yet to be proved. In habits, however, the two would appear to be the same, as I gathered from replies to the queries on this point in my schedule of questions.

With reference to Plataniste from the Hughli, my experience has been the reverse of Mr. Blyth's, who, writing in 1863, states,- " I have never obtained a male" of this animal. I have obtained many, and of these have tabulated the measurements of nine skeletons and skulls, whereas the females observed by me have been comparatively few.

In the accompanying tables ( $\mathrm{I}$ to $\mathrm{IV}$ ) I have given detailed measurements of the skulls and skeletons of fifteen individuals, all of which were caught in the Hughli, with the exception of Nos. 2, 5, and 14. I have also given the external measurements of some of these animals (Table I), and in explanation of the seeming irregularity in the dimensions ascertained, I have to state that the individuals to be measured were invariably received unexpectedly, and generally partially decayed, so that they were always hurriedly measured and before reference could be made to previous notes. 
TABLE I. Table of external measurements, \&c., of a few Plataniste of different ages and of both sexes.

Tip of snout to notch of tail, in a straight line

" , over the curve of back and dorsal fin

" " to tip of dorsal fin, in a straight line

" " " to base of pectoral flipper in a straight

",$\quad$ to anterior margin of blow-hole, in

"straight line : ${ }^{\circ} \cdot{ }^{\circ}$.

" " to anterior margin of blow-hole, over

Blow-hole to highest point of dorsal ridge:

Tip of dorsal ridge to median notch of tail .

Umbilicus to anterior margin of genital orifice : HEAD-

Tip of snout to angle of mouth, in a straight line

Angle of mouth to eye

" $"$ ear

$" \quad$ shoulder

Eye to ear "

pectoral flipper

front of blow-hole : $:{ }^{\circ} \cdot$

Length of blow

Diameter of ",

Longitudinal diameter of eye, external ocular orifice

Vertical diameter of eye, external ocular orifice

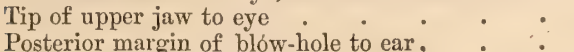

'Transverse breadth of '

Tip of lower jaw to lost tooth. GirTHS-

Round the head at the blow-hole . . .

At the neck, viz., halfway between blow-hole and

pectoral limb.

At the umbilicus

At the posterior margin of the generative orifice

At the root of the tail

LIMB -

Length along the anterior border of the pectoral flipper

" " $\quad$ posterior " free margin of the same " . .

Girth Distance between the flippers at their base, round

the under surface

DORSAI FIN-

Length

Depth or height

TAIL-

Length of the external margin of the caudal flipper

Tip to tip" of caudal flipper

Depth of the " notch . . .

tip of flipper

Genitatia-

Extreme length of genital orifice

I ength of each mam

Distance of mammary slits from genital orifice

VISCERAanus from posterior end of genital orifice

Length of small intestine .

cæcal appendage

\begin{tabular}{|c|c|c|c|c|c|c|c|}
\hline $\begin{array}{c}\text { No. I of } \\
\text { other } \\
\text { Tables } \\
\text { o } \\
\text { 2nd Marcl } \\
\text { 1872. }\end{array}$ & $\begin{array}{c}\text { क } \\
\text { Having } \\
\text { the foetus. }\end{array}$ & $\begin{array}{c}\text { Ò }^{1} \\
23 \text { rd June } \\
1867 .\end{array}$ & $\begin{array}{c}\text { ơ } \\
22 n d \mathrm{Jul} \\
1867 .\end{array}$ & $\begin{array}{c}\text { o jur. } \\
12 \text { thispril } \\
1872 .\end{array}$ & $\begin{array}{c}\text { No. VII } \\
\text { of other } \\
\text { Tables } \\
\delta \\
19 \text { th July } \\
1866 .\end{array}$ & $\begin{array}{l}\text { t juv. } \\
\text { 24th Feb- } \\
\text { ruary } 1869 .\end{array}$ & $\begin{array}{c}\text { Fœtus } \\
\precsim .\end{array}$ \\
\hline $99 \cdot 12$ & $93 \cdot 75$ & 89.00 & $82 \cdot 25$ & 59.00 & $83 \cdot 30$ & 56.00 & $27 \cdot 75$ \\
\hline 101.50 & $99 \cdot 75$ & $\ldots$ & $\ldots$ & $61 \cdot 25$ & $\ldots$ & & $\ldots$ \\
\hline$\ldots$ & $62 \cdot 25$ & $\ldots$ & ... & 38.00 & ... & 36.50 & \\
\hline$\cdots$ & $64: 00$ & $\cdots$ & $\cdots$ & $\cdots$ & $\ldots$ & $\ldots$ & 18.25 \\
\hline 35.75 & $33 \cdot 00$ & $\ldots$ & ... & $21 \cdot 00$ & $27 \cdot 50$ & 20.65 & 8.50 \\
\hline $19 \cdot 75$ & $17 \cdot 75$ & $17 \cdot 50$ & 16.65 & 12.50 & $12 \cdot 75$ & ... & $4: 37$ \\
\hline $21 \cdot 12$ & $\ldots$ & & & 13.25 & $\ldots$ & $\ldots$ & $\ldots$ \\
\hline $42 \cdot 00$ & $\ldots$ & 38.50 & $33 \cdot 70$ & $\ldots$ & & $\ldots$ & $\ldots$ \\
\hline$\ldots$ & & $30 \cdot 25$ & $28 \cdot 40$ & & $31 \cdot 60$ & $\ldots$ & \\
\hline$\ldots$ & $45 \cdot 50$ & $\ldots$ & $\ldots$ & $29 \cdot 00$ & $37 \cdot 12$ & $\ldots$ & 11.50 \\
\hline$\cdots$ & $16^{\circ} 75$ & $\cdots$ & $\ldots$ & 8.00 & $\ldots$ & $\ldots$ & 0.22 \\
\hline $20 \cdot 12$ & $18 \cdot 75$ & $14 \cdot 25$ & $16 \cdot 75$ & $12 \cdot 62$ & 13.50 & 8.00 & $4 \cdot 25$ \\
\hline $2 \cdot 36$ & 2.00 & $\ldots$ & ... & 1.50 & $2 \cdot 00$ & 1.50 & 0.80 \\
\hline 7.00 & $\ldots$ & & $\ldots$ & 3.80 & 6.35 & $\ldots$ & $\ldots$ \\
\hline$\ldots$ & $\cdots$ & $15 \cdot 25$ & 를 & $\ldots$ & 14.00 & $\ldots$ & $\cdots$ \\
\hline$\dddot{6} \cdot 25$ & $6 \cdot 13$ & $5 \cdot 50$ & $\begin{array}{r}5.22 \\
\end{array}$ & $\ddot{3.65}$ & $\begin{array}{r}14.00 \\
6.12\end{array}$ & 3775 & 1.81 \\
\hline$\ldots$ & & $6 \cdot 75$ & $\ldots$ & & $6 \cdot 60$ & & \\
\hline $2 \cdot 50$ & $3 \cdot 30$ & $2 \cdot 75$ & ... & $2 \cdot 25$ & $2 \cdot 25$ & $2 \cdot 12$ & 0.90 \\
\hline$\ldots$ & & $\ldots$ & $\ldots$ & 1.67 & $\ldots$ & & \\
\hline$\cdots$ & 0.25 & ... & ... & $\ldots$ & $\ldots$ & 0.15 & 0.12 \\
\hline & 0.22 & $\cdots$ & $\cdots$ & $\ldots$ & $\ldots$ & 0.15 & 0.02 \\
\hline 0.13 & 0.10 & ... & $\ldots$ & $\cdots$ & & $\ldots$ & 0.02 \\
\hline$\cdots$ & $\ldots$ & ... & $\ldots$ & $\ldots$ & $12 \cdot 25$ & $\ldots$ & $\ldots$ \\
\hline$\dddot{4} .25$ & ... & $\cdots$ & $\cdots$ & $\cdots$ & $7 \cdot 85$ & $\ldots$ & $\ldots$ \\
\hline 17.75 & $\cdots$ & $\cdots$ & 15.05 & $\cdots$ & $\cdots$ & $\cdots$ & $\ldots$ \\
\hline 20 & $\cdots$ & $\cdots$ & 1020 & - & $\cdots$ & $\cdots$ & $\cdots$ \\
\hline$\ldots$ & $29 \cdot 00$ & $28 \cdot 25$ & 26.50 & $\ldots$ & $24: 00$ & $25 \cdot 50$ & $11 \cdot 12$ \\
\hline $44: 75$ & $4.2 \cdot 75$ & 36.50 & $\ldots$ & $22 \cdot 50$ & $34: 85$ & ... & 13.62 \\
\hline 57.62 & 53.00 & $\ldots$ & $\ldots$ & $25 \cdot 85$ & & & 14.00 \\
\hline & $35 \cdot 25$ & $\ldots$ & $\ldots$ & & $36 \cdot 15$ & $30 \cdot 20$ & \\
\hline $14: 50$ & $13 \cdot 00$ & $\cdots$ & $\cdots$ & $7 \cdot 80$ & $11 \cdot 35$ & $\ldots$ & $3 \cdot 37$ \\
\hline 17.00 & 16.50 & 12.50 & $13 \cdot 25$ & $10 \cdot 50$ & 14.50 & $8 \cdot 85$ & $3 \cdot 62$ \\
\hline $10 \cdot 75$ & $9 \cdot 50$ & 8.75 & $8 \cdot 50$ & 6.85 & $9 \cdot 12$ & 6.40 & $2 \cdot 50$ \\
\hline 11.50 & $8 \cdot 92$ & $\ldots$ & $7 \cdot 40$ & $5 \cdot 25$ & $7 \cdot 75$ & $5 \cdot 12$ & 1.75 \\
\hline 3.50 & & $\ldots$ & & & $2 \cdot 80$ & & \\
\hline $8 \cdot 85$ & $8 \cdot 25$ & ... & 6.12 & 5.08 & ... & $4: 36$ & $2 \cdot 50$ \\
\hline$\cdots$ & $\cdots$ & 9.00 & $\ldots$ & $\cdots$ & $\cdots$ & $\cdots$ & $\cdots$ \\
\hline $14: 00$ & $12 \cdot 00$ & $\ldots$ & $7 \cdot 75$ & 5.00 & $7 \cdot 80$ & $\ldots$ & $2 \cdot 75$ \\
\hline 2.50 & 1.90 & ... & ... & $\ldots$ & $\ldots$ & ... & 0.50 \\
\hline $19 \cdot 3$ & $18 \cdot 00$ & $\ldots$ & 13.00 & $12 \cdot 25$ & 16.80 & $\ldots$ & 4.50 \\
\hline $15 \cdot 75$ & 13.00 & & $9 \cdot 00$ & $7 \cdot 86$ & $11 \cdot 75$ & $\ldots$ & 2.45 \\
\hline $26^{\circ} 00$ & & $19 \cdot 25$ & 14.50 & 13.00 & $19 \cdot 12$ & $\cdots$ & \\
\hline 1.75 & 0.95 & ... & ... & ... & $\cdots$ & ... & 0.30 \\
\hline$\cdots$ & $9 \cdot 20$ & $\ldots$ & $\ldots$ & $\ldots$ & 8.05 & ... & 1.87 \\
\hline $5 \cdot 85$ & $4: 25$ & $\ldots$ & 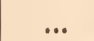 & & 4.00 & $1 \cdot 86$ & $\ldots$ \\
\hline 1.00 & 0.75 & $\ldots$ & $\ldots$ & 0.33 & ... & $\ldots$ & $\ldots$ \\
\hline$\ldots$ & $1 \cdot 35$ & ... & ... & $\ldots$ & & - & \\
\hline$\cdots$ & $\cdots$ & ... & $\cdots$ & $\therefore$ & $17 \cdot 12$ & $10 \cdot 65$ & $3 \cdot 00$ \\
\hline & $348 \cdot 00$ & $\cdots$ & $\cdots$ & $\cdots$ & $\cdots$ & $\cdots$ & 85.50 \\
\hline$\cdots$ & 38.50 & ... & ... & ... & ... & ... & $8 \cdot 00$ \\
\hline ... & 4.50 & .. & ... & $\ldots$ & $\ldots$ & $\cdots$ & $1 \cdot 00$ \\
\hline
\end{tabular}
1 With this exception all the other specimens of this Table were captured in the Hughii. It is the dolphin procured by Mr. Clay C.S., in the 


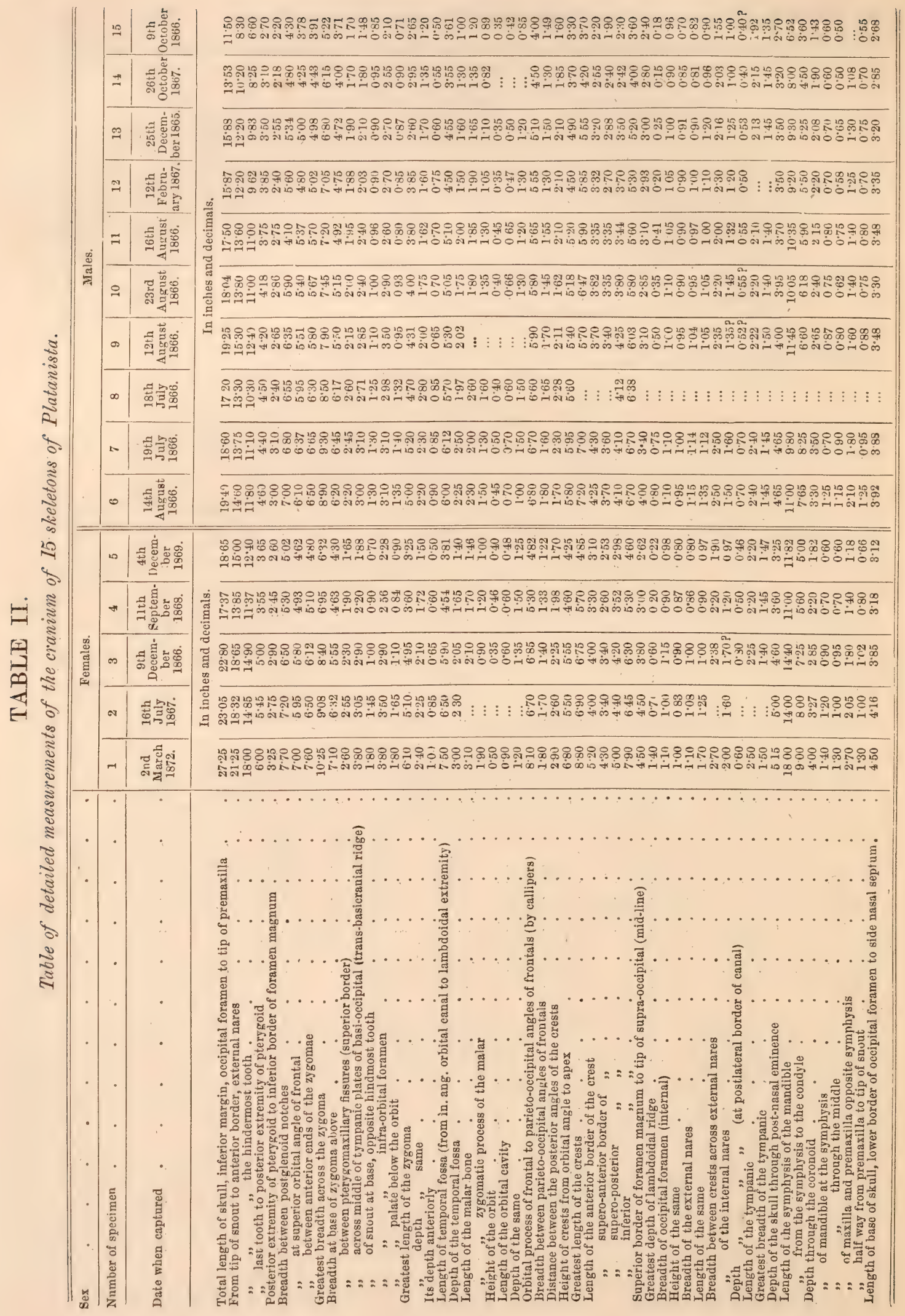


PLATANISTA.

429
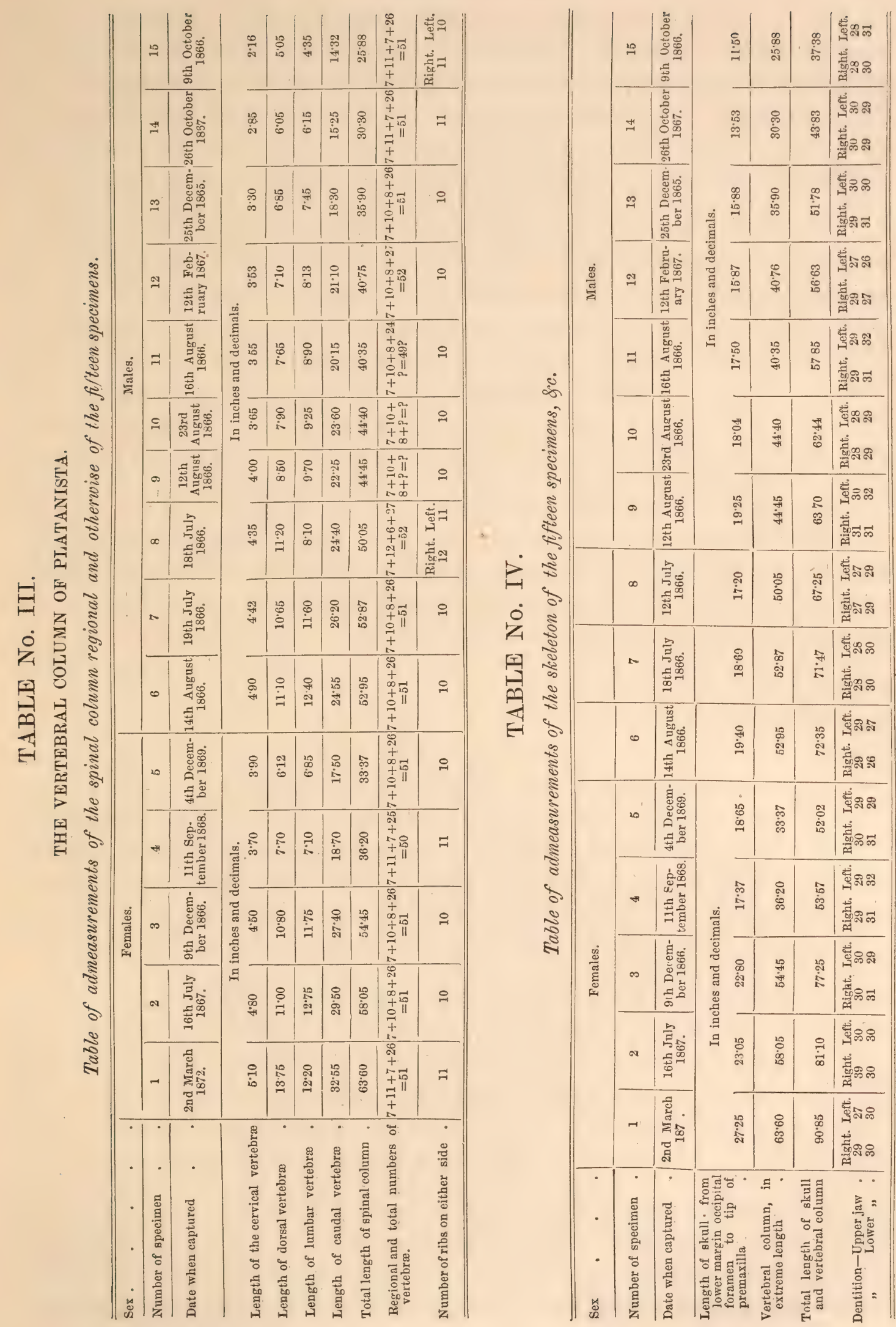
The sex of each animal was thoroughly ascertained; and in connection with the two sexes I have to point out that, although the males, 6, 7, and 8, from the Hughli, are fully adult, they are very much smaller in every. way than adult females from the same stream. The skeleton of the male No. 6 is 18.50 inches shorter than that of the female No. 1. The great difference that exists between the size of their skulls is well established by Plate XXXIX, in which fig. 1 is a representation of the male skull and fig. 2 is that of the female skull, the two having been photographed together. The skull of the female is 27.25 to 19.40 inches in the male, that is $7 \cdot 85$ inches longer. It will also be observed that the osseous snout of this female is proportionally longer than the rostrum of the male, but both are about the same depth at the middle, the depth of the conjoint jaws between the eighteenth and nineteeth teeth is in the male 3.20 to $3 \cdot 25$ inches in the female at the same point. The curvature of the snout is much the same in both, there being a considerable upturning of the extremity of the maxillaries and of the mandible. The trifling differences observable between the form of the maxillary crests of figs. 1 and 2 (Nos. 6 and 1 of tables) are of no importance, as these structures are variable; and the outline of the frontoparietal suture also differs considerably in different individuals of the same sex, and even on opposite sides of the same skull. In all their essential features, therefore, the male skulls, although much smaller, correspond to the female skulls, but their teeth, although proportionally smaller than in the females, preserve the same characters, their bases being much extended from before backwards and worn flat. The male dolphins which I have tabulated, beyond being smaller and having shorter snouts, show no other external features in which they differ from the females. The question, however, suggests itself, are these differences to be regarded as specific or merely as sexual? I am disposed to adopt the latter alternative, but at the same time, as still larger individuals are met with in the Ganges than any I have yet mentioned, and mature females occur smaller than No. 1 of the accompanying tables, my opinion on this point is not fully established. The skeletons Nos. 3 and 4 of these tables appear to be younger stages of the same specific form as No. 1, with long slender jaws and the sharply pointed teeth of adolescence, but a difficulty presents itself regarding the dolphin kindly forwarded to me by Mr. Clay, C.S., who took great interest in this enquiry. (See Table $I q^{1}$ ).

This specimen was harpooned on the 23rd June 1867, near Meerpore on the Suraj fork of the Bansi branch of the Ganges, about 10 miles north-west of Dacca, and Mr. Clay forwarded to me a sketch of the animal in the flesh with the measurements given in the accompanying table, along with the skeleton of the animal. Mr. Clay's drawing corresponds essentially to my Plate XXV, figure 1 of $P$. gangetica, but the teeth that remained in the jaw are represented as very large and much worn, indicating that the dolphin was considerably aged-a fact verified by the condition of the skull and skeleton. By the time the skeleton reached me all the teeth had fallen out of their sockets, the latter being well filled up with osseous deposit. The jaws, although having much the same form and relative length to the rest of the skull as in the female skull, Plate XXXIX, fig. 2, are much more feeble and have less depth, 
the entire animal being 10 inches shorter than the largest female from the Hughli, in which the condition of the teeth was that of a fully mature, but not aged animal. Another female from the Hughli with its teeth indicating adolescence, and having a long, attenuated, and not deep snout, has its skull only a quarter of an inch shorter than the skull of Mr. Clay's dolphin, and its adolescence is so pronounced that we may justly conclude that the animal would have attained to the dimensions of the largest recorded female from the same river. But the condition of the skull and skeleton of Mr. Clay's specimen leads to the conclusion that its period of growth was passed. Mr. Clay's specimen, it will be observed, was from the neighbourhood of Dacca, and as the differences that exist between it and the adult from the Hughli lie chiefly in size, it may be that there is a smaller race, for the skulls are so alike in all their essential features that the Dacca skull cannot be regarded as of a specific type. Moreover, I have had the opportunity to compare, side by side, in the flesh, two dolphins, one of the male and the other of the female sex, the former from the Hughli and the latter from Dacca, and after a most careful observation of these, in view of this question of the probability of the existence of more than one species of Platanista in the Gangetic and Brahmaputra systems, I have failed to detect any character by which they could be separated. However, if we take the condition of the alveolar sockets of Mr. Clay's specimen, as indicating that the animal was aged, which I believe we are entitled to do, then it follows that it is as old, if not older, than a skull of another specimen from the Ganges opposite to Chupra, in the Saran district, and which was caught in May 1870 and for which I am indebted to Mr. Garret, C.S. But this skull is 7 inches longer than the skull from Dacca, and is thus of great size. The few teeth that remain in the jaw are all flattened, and some of them are 0.68 inch in breadth. All the bottom of the alveolar groove is filled up as in Mr. Clay's dolphin, but the sockets are not so obliterated. With these facts in view it seems highly improbable that the latter could ever have attained to the dimensions of the large Chupra skull, which, in its features, has such a close resemblance to the largest females from the Hughli, that I am disposed to consider it of the same sex. Not having seen the Chupra specimen in the flesh, I can say nothing regarding its external characters. In its rostrum, however, it differs somewhat from large females from the Hughli in that the end of the snout, instead of being upwardly directed, is downwardly bent; but this character is probably the effect of age, as it occurs in other dolphins, and has been noticed by Professor Flower in Inia and Pontoporia, the former being nearly allied to Platanista. The lower jaws of both are alike. Some of the males from the Hughli conform more to the Chupra skull than to the skull of Mr. Clay's specimen, but that they could never have attained to the same size is conclusively proved by the complete ossification of their epiphyses.

The large skull of Mr. Garret's specimen measures 30 inches in extreme length, and is thus about 2.75 inches longer than the largest female skull from the Hughli, and $10 \cdot 60$ inches longer than the largest male skull from the same river, the male skull (No. 6) being fully adult, the teeth being very broad at their bases, but still more or 
less pointed. I am disposed to believe that this male skull (No. 6, and Plate XXXIX, fig. 1) is of the same species as the skull fig. 2 from the Hughli, which is only $2 \cdot 25$ inches shorter than the large skull from Chupra. By a comparison of the various measurements of the skulls Nos. 1 and 6, it will be observed that the great differences lie between the relative proportions of the snouts, which are decidedly longer in all of these female skulls than in the males. Of course, there is the other alternative that two or more species may exist, and that these males with small skulls may be the males of a species of which the females are yet unknown, and that I have never encountered the males of such large females as the specimen from Chupra. The evidence before me, however, does not sanction such a conclusion, and until further facts are adduced, there is no other course left but to regard the male as a considerably smaller animal and having a shorter snout than the female, and that individuals vary in size in different localities.

Respecting the probable size attained by this Cetacean genus, it would appear that the Chupra female had arrived at her limit of growth. In the largest female from the Hughli in the accompanying tables the epiphyses of the vertebral processes are firmly united with the vertebræ, and very many, but not all, of those of the bodies are completely anchylosed to the latter, so that she is fully adult. Taking the ascertained size in the flesh of this animal and the length of its skull as our guides, it seems probable that the aged Chupra female must have attained a length of nearly 9.50 feet from the tip of its rostrum to the fork of its tail, whereas the length of the largest male with quite as mature a skeleton and skull was scarcely 7 feet.

Microscopic structure of the skin.-The skin structurally differs little, if at all, from what obtains in the generality of the Whale tribe. The anomalous shape of the snout and the condition of the parts around the spout-hole, however, led me to examine the dermal constituents, and I here record my observations.

The thickness of the skin, as in land animals, varies according to region and other circumstances. Over the pectoral flippers, the skin is 5 millimetres thick, of which the epidermic layer forms two-thirds of a millimetre, and is dark bluish-black in section, the cutis being a clear white, of great consistence and sharply defined from the underlying oily layer, which is $8 \mathrm{~mm}$. thick and yellow in colour, and also strongly fibrous. On a level with the dorsal fin, the oil disappears out of this layer, which becomes like the one overlying it, only somewhat yellow. Over the vertebræ, in front of the dorsal fin, this fibrous layer is 1.50 inch in breadth from side to side and $2 \cdot 25$ inches in vertical thickness.

A piece of the cast-off, dried cuticle, when mounted in Canada-balsam and viewed by transmitted light, to the naked eye and with a hand-lens, appears as a yellowish or faintly brownish film, the darker tint marking fine parallel lines. Under a higher power the linear arrangement is seen to be wavy (Pl. XXXVI, fig. 1), the minute linear folds dove-tailing and running into one another, here and there. They; and likewise the lighter coloured intervening spaces, indeed the whole tissue, are speckled uniformly with minute dots, viz., scaly nucleated epithelial cells containing an abundance of dark pigment. 
Vertical sections through the dermal and subcutaneous tissues of part of the snout (Pl. XXXVI, figs. 2 and 3, and see also Pl. XXXI, fig. 1 h) demonstrate the usual constituents, save the absence of sudoriparous and sebaceous hair glands. The papillæ of the vertically descending epidermal layer are stout, and not quite uniform in length, the shorter ones being rather conical, the thicker slightly clubshaped, a few having bifid extremities. The corresponding ascending papillæ of the corium have a copious capillary supply derived from the rather numerous bloodvessels of the deeper tissues. Where the hair-like bristles have been cut through obliquely (fig. $2 h$, in the sections made from the foetal specimen of Platanista, their walls are thick, and surrounding them is a wide circular and dense fibrous area, the outermost wavy elastic fibres of which mingle with those of the neighbouring connective tissue. The superincumbent half of the fibro-vascular layer of the corium has but few traces of oil particles intermixed, but in its deeper half, the fatty particles and oil globules preponderate, and are both very numerous and characteristic, as large elliptical areas. In many of the larger-sized oil globules, bundles of needle-shaped and stellate crystals present themselves. In this snout-section, the fibres of the subcutaneous tissue, both strong and glistening, form often a lozengeshaped mesh-work, and deeply become stouter, as bundles of broader bands interlace freely and enclose in layers the fatty constituents above spoken of. Below the blubbery layer comes a layer of ordinary connective tissue, the masses of striated muscular fibres joining this again.

Mouth.-On opening the mouth of Platanista, its form is seen to be triangular, the base of the figure being placed posteriorly. The upper lips have a sharp edge and crescentic outline, the convexity looking inwards and downwards. The anterior end of the upper lip is prolonged forwards to the external margin of the alveolar line of the teeth of the snout, and its posterior end is under the eye. The upper lips are not supported by bone, but consist of the strong fibrous tissue that fills up the interspace between the maxillary laminæ, and the lower limit of which extends from the preorbital process of the frontal to the side of the dental portion of the superior maxilla opposite to the twenty-third tooth. The lower lips are round, fleshy, and concave from before backwards, and are overlapped by the sharp edge of the upper lips. The inner margin of the upper lip is devoid of pigment, but the under lip has more or less the colour of the external skin. The jaws are capable of great extension, opening at their tip, in a specimen nearly $6 \frac{1}{2}$ feet long, to 13 inches, the distance between the angles of the mouth being 4 inches, the anterior breadth being only 0.65 inch. The interior of the mouth and the palate are quite smooth in the half-grown individual, but, in the adult, the sides of the mouth from the angles are thrown into strong longitudinal folds which extend back to the fauces. In the same individual the faucial region measures $2: 50$ inches across and $\mathbf{1 . 7 5}$ inch in vertical capacity, which, however, is doubtless greatly increased when the tongue is drawn down.

Tongue.-In this fluviatile dolphin, the lingual organ is well developed. It is firmly attached at its tip by a fold which runs forward to the symphysis of the lower 
jaw, but its edges are free to a little way behind the angle of the mouth, and thus must have considerable mobility. In young specimens, 54 inches long, it is traversed by a raphe which is nearly co-extensive with the free margins, but directed from the mesial line at the tip to the right side. There is no trace of a foramen cæcum or of circumvallate papillæ; the tongue being remarkably smooth, only a few minute fungiform papillæ occurring on its sides, some distance beyond the angle of the mouth. In its free portion it is thickly clad with filiform papillæ. Below the free margin, immediately behind the tip, there are small glands which open by four orifices, generally arranged in a linear series with an azygos orifice above them. Behind the posterior half of the free border of the tongue and below it, there is a longitudinal row of large patulous orifices, generally three in number, with two or three more forming an arch above them. They increase in size from before backwards, the most posterior being divided by a vertical pillar into two openings. The orifices lead into sacs or recesses in the mucous membrane, into which one or more glands appear to open. In close connection with them, and above and behind them on the side of the free border of the tongue, there occurs a large patch of glandular orifices of various sizes, some of the more anterior openings being more or less surrounded by free folds of the mucous membrane, so that the surface appears rough and the orifices to be protected by valves. These orifices do not occur further back than the free margin, and are restricted always to the same spot. The lingual racemose glands are especially numerous on the root and sides of the tongue, and each gland appears to open by a distinct orifice, but the glands are not so long as in Orcella, although they have the same structure. In the adult, the root of the tongue is frequently corrugated, the corrugations simulating circumvallate papillæ, but in the young, as already stated, it is quite smooth. In the adult also the raphe cannot be distinguished.

Minute structure of its Papilla.-The filiform papillæ of the tongue microscopically manifest two distinct characters, each having a special distribution. On the front they are generally much more numerous than on the back part of the tongue, and on the former they are fully three times as large as on the latter locality. These anterior papillæ are more or less conical in form, but some are much broader and stouter than others, and their distinguishing feature is the division of their summits, and occasionally of their sides, into short non-divergent processes. These are very minute, and require a high power to demonstrate them satisfactorily. Some of them are almost vesicular, and others are oblong and pointed at their free ends, but all are short and very obscure. The papillæe clothing the back part of the tongue, or that portion on which the majority of the mucous glands open, are very minute flagilliform processes, situated generally on conical bases, while some are essentially whip-like, without any basal enlargement.

Racemose mucous glands. - Some of the orifices of those on the dorsum of the tongue have a pyriform body visible to the naked eye, projecting outwards from one side of the external termination of the duct. The base of this body is directed outwards, and its apex is prolonged downwards into the duct for a short way as a 
portion of its structure, which is quite distinct from that of the neighbouring substance of the tongue or of the papillæ, in that it has a cellulo-granular or glandular character. Projecting from the base there is what appears to me to be an orifice. If this is a glandular structure with an excretory duct, the position which it occupies as a kind of valve at the orifice of the excretory duct of the highly complex mucous gland, would render it probable that the two glands are intimately related to each other. The valvular gland, while performing its special functions in the economy of the oral cavity, may fulfil a secondary function, by closing the mucous gland, the secretion of which, it may be important, should not be excreted along with that of its plug.

Palate.-This presents two furrows internal to, and parallel with, the upper lips, and into which the lower lips are received when the mouth is closed. The anterior portion of these furrows is marked by five deep pit-like impressions corresponding to the five posterior teeth of the lower jaw. It would thus appear that the surfaces of the mouth are in very close apposition-a circumstance which is also verified by the fact that the tip of the tongue is generally marked by the impression of the two most posterior teeth of the upper jaw, and the postsymphysial space anterior to it is also marked by the impress of the teeth. The teeth of the two lines are not opposite to each other owing doubtless to the asymmetry of the skull, and as the lines are posteriorly divergent and approach each other at the front part of the palate, they are alternate in that region, and immediately external to them are the pits for the teeth of the lower jaw. There are seven teeth on the left and six on the right side. The palatal surface posterior to the teeth is slightly convex, but perfectly smooth. In this same individual, two orifices occur in the palate 6.50 inches posterior to the first tooth above, in the middle line, half an inch behind the posterior border of the pterygoids. These mucous crypts are placed transversely, and are separated from each other by an interval of about 0.25 inch. They are longitudinally oval orifices, 0.1 inch long, and each leads into a crypt in the mucous membrane, into which small mucous glands open. These orifices I have been unable to detect in an adult. The palate anterior to them and between and posterior to them, is nearly devoid of racemose glands, but these structures are numerous on the margin of the posterior portion of the palate and on the fauces. The soft palate is $\mathbf{1 . 7 5}$ inch long in the individual under consideration (54 inches), and its posterior margin is sharp without any indications of an uvula, anterior or posterior pillars, or tonsils.

Dentition and changes occurring with age.-Sir Everard Home ${ }^{1}$ remarks that the changes that take place in the form of the teeth as they wear away from long use are more remarkable than in most other teeth, for the perfect tooth has a tolerably sharp enamelled point, while the half-grown tooth has a concave, blunted cutting edge.

These changes in the form of the free ends of the teeth are also associated with a remarkable increase in the size of the teeth. In a young specimen differing in no 
way from the fully mature foetus of the female No. 1, except that its teeth are erupted, the thirteenth tooth on the left side of the upper jaw is 0.22 inch in antero-posterior breadth at its base, and 0.35 inch long, whereas in the female No. 1 and in the mother of the fotus the same tooth has a basal extension of not less than 0.87 inch and a length of $0.90 \mathrm{inch}$; in other words, the tooth grows from youth to age, but the nature of this growth will be seen hereafter. Eschricht described the arrangement and alternation of the teeth, the latter feature being occasionally carried to such a degree that the most anterior of the small conical teeth of the two sides, especially in the lower jaw, appear as if arranged in one line. Eschricht regarded the alternation of the teeth as a means seemingly to get room; but may it not rather be due to the, so to speak, natural tendency of the skull to asymmetry, because it is associated as a rule with an unequal number of teeth on either side of the jaw? Eschricht has also described the general characters of the teeth in youth; but it will be observed (Table IV) that the teeth in the lower jaw are not, invariably at least, equal to those in the upper, viz., twenty-nine on each side, as observed by Eschricht, because in Nos. 3, 6, 12, and 14, this rule does not hold good: the teeth, however, are generally more numerous in the lower than in the upper jaw. Notwithstanding the greater number of teeth in the lower jaw, the two or four posterior upper teeth extend behind them and have no teeth apposed to them below (see Pl. XXXIX), as observed by Eschricht.

The lower are much longer than the upper teeth, and when in position in youth they interlock between the latter, overlapping the sides of the upper jaw, the teeth of which also, to a more limited extent, are applied at their points to the outside of the mandible, and the teeth are in such close juxtaposition that the anterior teeth rub against each other, and these, as Professor Owen ${ }^{1}$ has observed, retain a prehensile structure contrary to the rule in Delphinide.

The first tooth of the lower jaw is placed anterior to the tooth of the upper jaw. The first two or three teeth are convex anteriorly and concave posteriorly, but the long teeth immediately succeeding these are flattened on their anterior and posterior surfaces, slightly upwardly and inwardly curved in the lower jaw, and the reverse in the upper, the external surface of the teeth being convex. The points in youth are very sharp. The long teeth diminish after the eighth rather rapidly.

In the young state the alveolar groove is not divided into compartments or sockets for the reception of the teeth, but is an uninterrupted furrow, from end to end, in which they are lodged. The inner margins of the groove, however, are wavy, and the little inward sinuosities indicate the commencement of osseous ridges, which increase with age and which ultimately, and while the skull is yet young, are converted by osseous growth into transverse partitions, which divide the alveolar groove into a number of well-defined sockets, in each of which is lodged a tooth. In the young state, the pulp cavity in the dried skull occupies the lower half of the tooth, but this cavity becomes closed at an early age and while the exposed portion of the tooth yet retains the characters of youth. The bases of the teeth while the 
pulp cavity is still open are laterally compressed, the longitudinal being about twice as long as the transverse diameter of the orifice; but when the cavity is closed, the base of the tooth longitudinally is so much laterally compressed as to assume the character of an osseous plate, carrying obliquely on its apex the portion of the tooth which originally appeared beyond the gum, and retaining all its youthful characters and with an unworn tip, but with its anterior border in the ease of the lower teeth deeply grooved by the friction of the upper tooth apposed to it, the latter teeth becoming similarly worn on their posterior borders. ${ }^{1}$ Associated with this closure of the pulp cavity occurs an increase in the dimensions of the base of the tooth.

Fig. 13.

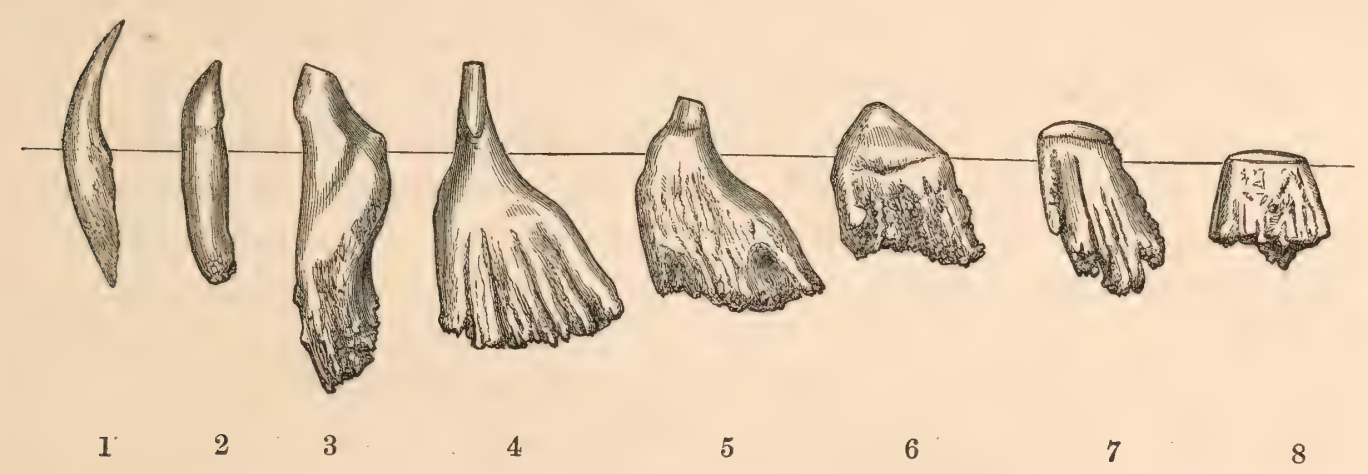

Series of teeth of Platanista gangetica, to illustrate their growth and wearage. All drawn of natural dimensions.

1-One of the long sharp front teeth of a young animal.

2-A tooth from the posterior end of the row of lower jaw of a young animal.

3-An adult tooth where wearage of crown is most irregular, and only a small piece of the enamel remains : pillars of cementum are produced at the fang.

4-Shows an adult tooth where great widening and flattening of the fang has taken place, the crown being still covered with enamel, and long and conical in shape.

5-Another adult tooth equally showing increased flattened root growth, but diminishing crown; a cap of enamel still exists, but the dentinal substance immediately below is highly polished on the outside, the pearly lustre simulating enamel.

6-An older more worn tooth, where the crown rubbed down to a low nipple shape is destitute of enamel, and even the dentine is altered into the so-called osteodentine.

7-A tooth now almost crownless, and the body a mere strip uniting the columnar superadded root of cementum.

8-A further stage where even absorption of the false root has proceeded, while the elements of the original tooth itself are not only rubbed down, but utterly gone: what remains is pure bony substance, substituted, but functionally answering for a dental organ.

In a more advanced stage the jaws are much deepened, and osseous deposits are observed to have taken place in the sockets, the jaw at the same time growing in all its dimensions, the bases of the teeth having noticeably increased in size, while the free original portion has become worn away on its sides and reduced in length by wear and breakage. At this stage, the teeth are not so deeply set in their sockets, a circumstance due to the fact that they seem to be outwardly pushed by the accumulation of osseous growths in the sockets themselves, and by their own enlargement.

With increasing age the portions of the teeth that originally pierced the gum are worn away entirely, until nothing but their enlarged bases remain, the free ends 
of the teeth having been worn to flat or rounded surfaces, having the same lateral and longitudinal dimensions as the enlarged bases.

At last the deposit of bone around the bases of the teeth proceeds to such an extent that the sockets disappear, and the teeth, if left in the mouth, are only in the fleshy gums ready to drop out. From these facts it is evident that important changes take place in the bases of the teeth after the early closure of the pulp cavity. In many of the teeth the bases are thrown into strongly marked ridges, which at their free ends may resemble so many short irregular fangs (see woodcut, fig. 13), which, as Professor Owen has observed, is an exceptional character in the existing carnivorous Cetacea.

In studying the foregoing changes in dentition, I had recourse to microscopic sections to substantiate in the development of the tissues that which was to a certain extent even patent to ordinary vision.

The earliest stage examined was that of the fotus, the same figured in the womb (Pl. XXXI). In this the teeth were not erupted, but the alveolar groove was almost open and the denticles easily felt by the finger. As I have noted later on, in the description of the exterior parts of this young animal, and which is shown in the above figure, a series of skin ridges on the outer labial margins corresponded outwardly to the non-erupted future teeth. The section, then, which I shall proceed to describe is taken transversely to one of these ridges, and is drawn on an enlarged scale (Pl. XXXVI, fig. 4). The fleshy gum on either side of the nascent tooth is of the dense fibroid character. A thin film of cylindrical epithelium lines the interior of the dental cavity, particularly its upper portion, or where it is least injured by the razor in the process of cutting. The tooth itself is of a spear-headed outline, the base on either side having a deep cleft, which, however, leaves a broad pedicle of attachment. The summit of the tooth bears a thick cap of enamel which thins downwards but reaches the very base, and even a thin lamina of enamel turns round the corner or angle of the lateral basal cleft. Calcification has not been completed in the rest of the tooth, but round the edges dentinal cells are discernible, and more internally the future lines of the tubuli can be distinguished, besides the larger vascular channels of the dentinal pulp.

No trace of cement or osteodentine is appreciable within the limits of the tooth substance proper. Below the root of the tooth, however, and in continuity with it, there are large open spaces, vascular and otherwise, and beyond and all around open spongy bone texture. The latter tissue is barely ossified, though large Haversian canals in process of formation are abundantly evident.

At a further advanced but still youthful stage, when the teeth are thoroughly calcified and erupted (Pl. XXXVI, fig. 5), not only the apex but the body of the tooth has a considerable coating of enamel. The dentine then composes the mass of the tooth, a modicum of cement occupying the lower portion of the fang.

In a perpendicular section of the adult tooth of Platanista, taken from the middle of the lower jaw (fig. 6), another stage in the chain of dental growth is met with; not only is the shape of the tooth altered, but the proportions of the 
tissues of the tooth are vastly changed. The enamel is limited to a thin tiny cap, and the dentine, with its central pulp cavity, is reduced to about a third or even less of its original proportions, according to the varying circumstances of age, position of tooth, \&c. The mass of the dental substance has now become osteodentine or cemental in nature. True bone lacunæ and canaliculi freely intermingle with what was before dental tubuli, and at the fang and the base of the body even quite supplant dentine.

In another tooth possibly older, but at all events one taken from the lower jaw behind its middle (Pl. XXXVI, fig. 7), apical enamel was barely perceptible, and the dentinal substance was still further reduced in dimension.

In yet another tooth from the posterior third of the lower jaw (fig. 8) the substitution of tissues had gone still further, no enamel being left, and pure dentinal structure was limited to little more than the apex. In fact, the tooth, save a very small portion, was converted into osteodentine.

In quite old worn-down teeth bony tissue alone remained, or only with diffculty could traces of dentine tubuli be recognised.

It is evident, then, that as the bases of the teeth in this genus increase in size, ${ }^{1}$ it is due to substitution of true osseous tissue for dentine, and that, associated with this, there is a gradual outward forcing of the teeth which leads to the complete disappearance in the adult of the elements of the tooth originally exposed above the gum, the place of which is taken by a tooth of bone, the product of a growing osseous base, and many times larger than the original tooth which was composed of all the structures that enter into the formation of Mammalian teeth generally.

The bases of the teeth of Globicephalus deductor appear also to undergo a considerable change in size from youth to age, and probably other Cetaceans will be found to illustrate similar changes.

Pharynx.-In the half-grown individual, the pharynx is defined behind the epiglottis by the presence of a more or less continuous transverse fold, the folds behind it being longitudinal; but no such separation between œsophagus and pharynx occurs in the adult, in which it is thrown into longitudinal folds continuous with those of the fauces, but much feebler, and prolonged into the oesophagus. In the semi-adult animal the pharynx has a transverse capacity of 2.50 inches, while in an adult it measures 5 inches in the same direction. The openings of racemose glands are numerous on the floor of the cavity and at the base of the epiglottis, but they are all but absent on its sides and roof.

The tube of the larynx has been twisted to the left side in all the individuals I have examined, and been firmly grasped by the sphincter of the posterior nares into which the tube is generally found projecting. In the foetus it is also found occupying a similar position, and has the same sinistral asymmetry which is extended to the tongue in the adult as well as in the young; this organ being more or less tilted up to the left side, so that the straight course to the œsophagus passes the right side of the epiglottis, which is doubtless the course followed by the food in the act of swallowing.

\footnotetext{
1 Owen, Odont., p. 352.
} 
Esophagus.-This is 1 foot in length, and 3.75 inches in breadth at the base of the epiglottis; 6 inches behind this, it contracts to 2.50 inches, dilating again at the orifice of the stomach to 3 inches. It is capable of great distension. The muscles consist of two layers. Posteriorly, the first or external layer passes from within outwards, the fibres in the middle being longitudinal, or nearly so; the lateral fibres are oblique, winding round the side of the tube to the ventral aspect, and are so crowded together at the side, that they produce the appearance as if this portion of the tube were provided with a special muscle. They terminate in a longitudinal line corresponding to the side of the trachea. Some of the external oblique fibres give off long loops which run across the œsophageal wall, in some eases at right angles. The second or internal layer on the posterior aspect is transverse, and appears to be continuous at the lower end of the œsophagus, with the obliquely transverse thin layers of the interval between the tracheal margins.

Microscopic structure.-The mucous membrane of the œsophagus near its lower end is of considerable thickness, and the papillæ are long and filiform; the epithelial cells being large and polygonal. I have not been able to detect any glands besides the ordinary mucous glands, which are most numerous near the anterior end of the tube.

Relations of stomach in the adult.-The left division of the stomach is almost wholly hidden by the liver, and lies slightly posterior to the right sac. When inflated, it is placed rather obliquely across the abdominal cavity in an antero-posterior direction, with its apex directed downwards to the right side, many inches anterior to its œsophageal orifice, which latter is slightly dorsally placed to the opening between the two stomachs. The right division lies obliquely across the abdomen hidden by the liver, except along its lower margin, which describes a curve of nearly half a circle. It rests on the left half of the first sac, and its apex is directed downwards to the right side, tending backwards and slightly upwards and then backwards, downwards and outwards to the left, to its junction with the third cavity. This latter lies behind, and is nearly covered by it. The oesophageal orifice is opposite the sixth rib, 7 inches from its distal extremity, and its apex is opposite and distant 2 inches from the distal end of the eighth rib. With the specimen placed on its back, this section of the stomach (second cavity) reaches the sternal attachment of the second rib, and, when fully inflated, it rises from 2.50 to 3 inches above the level of the œsophageal orifice. The third sac lies posterior to the second, and passes to the left nearly as far as the mesial line, where it is continuous with the duodenum which runs downwards and slightly to the left on a line with the lower margin of the mass of the stomach and posterior to the intestines.

Relations of stomach in the foetus.-The mass of the stomach lies to the left of the mesial line of the body, and the second or right cavity hides the left, which lies behind it. The apex of the first cavity is directed backwards, so that the sac is almost transverse to the longitudinal axis of the abdomen. The second sac occupies the greater part of the left half of the abdominal cavity, but extends slightly to the right of it. Its apex is bent upon itself, passing backwards and downwards to the 
left. The third cavity and duodenum pass to the left side behind the whole mass of the small intestine, where the jejunum rests at the left side on the large intestine, when it again bends abruptly round to the right side. The head of the large intestine abuts against the inferior wall of the second stomachic cavity on the left side, and the greatly enlarged cæcum lies below and in contact with the stomach transverse to the abdominal cavity; its apex resting against the umbilical vein, and its body being buried among the coils of the small intestine. The large intestine, which is quite as capacious a tube as the small gut, has a general upward direction from right to left. In this foetus, which is very near its full time, there is no trace of a transverse colon; indeed, the head of the large intestine is only in contact with the inferior wall of the left cavity of the stomach; the whole of the tube being as yet restricted to the left side of the body. The sigmoid flexure rests against the lower half of the inner wall of the left kidney, and is nearly concealed by the uterus.

Stomach.-This organ conforms to the general type in Cetacea. It consists chiefly of two large sacs, placed side by side, opening into each other by a common orifice at the termination of the osophagus. The first or left cavity is perfectly simple, but the second presents a sacculation in the right wall of its fundus; this leads into a short narrow passage or channel which conducts to the third cavity, this latter being about one-eighth the capacity of the others.

First cavity.-This (PI. XXV, fig. 1, I) must be regarded as simply a dilatation of the osophagus. It is slightly elongated, and more bulging on its left than on its right margin, with its anterior wall convex from before backwards. The œsophageal orifice is marked in some conditions by a series of strong folds which radiate downwards and outwards along the inner aspect of the walls of the sac, and assist in closing the orifice when it is contracted. The walls are very strong and muscular, and thicker than those of the second stomach, from which they also differ in structure. They have the palish-yellow tint of the osophagus, while those of the right cavity are pinkish-grey. Besides the folds already described, the walls in some instances are covered, at tolerably regular intervals, by an extensive series of transverse grooves, which, separating the foregoing folds, divide the inner aspect of this cavity into numerous rounded oblong areas, and produce an appearance resembling the convolutions of a mammalian brain, an effect which is heightened by the circumstance that many of the transverse grooves are not continuous throughout their length. The latter only appear about two inches below the osophageal opening, so that there is a broad area around it, marked only by longitudinal folds. In one adult stomach examined, a perfect cast of the inner surface of this cavity was noticed in the process of being thrown off as a layer of mucous membrane, about 0.02 inch thick, and rough to the touch. In this state it had a pale-yellowish colour, and the folds were divided crosswise, so that the membrane had a tessellated character, consisting of little raised oblongs, about half an inch broad and an inch long.

From the relative position of the two cavities already noticed, the common opening between them looks obliquely from left to right, the right margin of the 
opening being more dorsal than the left. The opening has a crescentic lower border, the concavity of which looks up the œesophagus, and at the opening a portion of the mucous membrane of each cavity is opposed to that of its fellow. The common orifice has a capacity, in an individual about 6 feet long, of about 2 inches in breadth, when moderately distended. The two cavities are united to each other only immediately below the common opening, and in the individual already mentioned the attachment is 1.60 inch in one direction and 1.50 in another.

Microscopic characters of the membrane of the first cavity.-A portion of the adult stomach, in which a layer of the mucous membrane was peeling off, showed this, under a low power of the microscope, as divided into two parts by a dark line corresponding to the line of desquamation, although the two were still connected together. The external there appears much more dense than the internal layer, and the former is of a uniform consistence, giving no indications of separation into thinner layers. It must be borne in mind that this desquamation of a surface layer of this eavity cannot be regarded as a post mortem phenomenon, for in the specimen in question the stomach was removed as soon as the animal died; even by that time the limit of effete mucosa had been already indicated at those points where the tissue had not become separated. The same condition I have observed in more stomachs than one.

This natural shedding of a superficial layer of the membrane of this first gastric cavity receives elucidation on a further study of the constituents of the entire wall of the organ being made. Consult Pl. XXXVI, figs. 12 and 13, and compare fig. 14 of a corresponding piece of the same gastric cavity of Orcella, already described. In that of Platanista under a low magnifying power (Fig. 12), the epithelial layers, desquamative and subjacent, are but of moderate thickness, relative to that of the entire wall of the stomach. The body of the connective and vascular tissue beneath these is on the contrary very thick, while the muscular and serous coats are of medium thickness. Under a much higher power, and thus greatly enlarged (Fig. 13) the characteristic features are easily resolved. The free internal surface is composed of a stratified mass of horny epithelial scales (ep) in different stages of - development. Layer after layer of these then must be given off as digestion proceeds, and the phenomenon of desquamation above mentioned must be, as inferred, a natural process of constant occurrence.

The second layer in close continuity with the first is analogous to the columnar cell-layer already described as existing in the first gastric cavity of Orcella (Fig. 14, $c g$ ). It is, indeed, only a continuation downwards of the epithelium, the cells assuming less of a horizontal, and more of a vertical, position. In Platanista, moreover, as contradistinguished to Orcella, the descending columns are far shorter, broader, and club-shaped. In fact, the columno-epithelial double layers of the former genus altogether are little more than half the depth of the latter. This coat of the first stomach in both animals may aptly be compared to the cuticular layer of the skin, the deeply placed prolongations being nothing more or less than a mucous or Malpighian layer. They are not, in any sense, true gastric secreting follicles, as in the 
ordinary mammalian digestive stomach, for they are solid compact masses of cells without exterior orifice, apparently do not secrete gastric juice, and only develope cylindrical epithelial cells, which latter are modified in figure, \&c., as they rise to the surface. In some respects they may be regarded in the light of mucous glands, the stratum homologically being equivalent to the gastric or peptic glands of the mammalian stomach generally. It would thus appear the latter sort are absent in this first gastric cavity, and instead, mucous glands, such as are found in quantity in the cardiac area of the stomach of the horse, alone are present. This condition of things recalls the coats of the gizzard of birds, where in some forms not only is there a thin partial desquamation of the superficial cells, but the entire horny layer is periodically shed and renewed. ${ }^{1}$

The submucous or alveolar layer (Fig. 13, c) of this first cavity in Platanista is, as usual, composed throughout of connective tissue, scattered through which are spindle-shaped cells, and blood vessels and capillaries in quantity.

The muscular layer (Fig. 13, $m$ ), in vertical section, presents fibres cut crosswise and lengthwise, corresponding therefore to the different direction of the fleshy. bundles, and the fibro-serous layer $(f s)$ is unusually thick.

Second or right cavity.-( $\mathrm{Pl}$. XXVI, fig. 1, II.) - This is irregularly pyriform, the stalk of the pear-like figure being the osophagus, the body being bent to the left side so that the right is much rounded and more extensive than the left, deeply concave margin. It does not reach to so low a level as the first cavity, than which it is less capacious. Its walls are not so firm as those of the left cavity, nor so thick, neither have I ever observed it to become similar to that of the oesophagus, however great may be the changes which the mucous membrane may undergo, for it is always more or less rugose. It is found generally thrown into very deep folds and is densely covered with fine rugæe, but nearly all the former are permanent, whilst the latter are transitory. Corresponding to the most concave portion of the left wall of the second cavity, a permanent fold is found encircling the inside of the sac obliquely from left to right, and below it there is a short strong crescentic fold stretching from the anterior on to and along the posterior wall, till on a level with the lower border of the cavity. The free margin of this almost valvular fold is directed ventrally and to the right side. A short way behind it, another and shorter fold stretches in the opposite direction from the posterior on to the anterior wall, and has its free margin directed dorsally and to the left side. These two folds are occasionally so strongly marked that they almost divide the apex or fundus of the second cavity into two distinct chambers, but, as they are not continuous around its walls, the division is very imperfect. In other states, although the folds are present, there is no appearance of division of this cavity into separate chambers.

In an active stomach the whole of the inner surface of the second cavity presents a uniform structure and character throughout its whole extent. A spirit specimen has a greyish-brownish tint, and the mucous membrane is thrown into an immense number of well-defined, finely convoluted rugæ. In this cavity, in an old female, the 
mucous membrane is greyish, and the only traces of rugre that can be detected are a few isolated patches of lobular processes of the membrane, which is generally smooth, but shows the persistent folds: In the last condition, the glandular surfaces are most easily detected. It is sparsely covered with a number of reddish spots of varied size and form, in which the mucous membrane is coarser than it is generally, but no special gland openings can be detected in these localities. A remarkable glandular area occurs on the anterior wall of the cavity almost facing the opening common

Fig. 14.

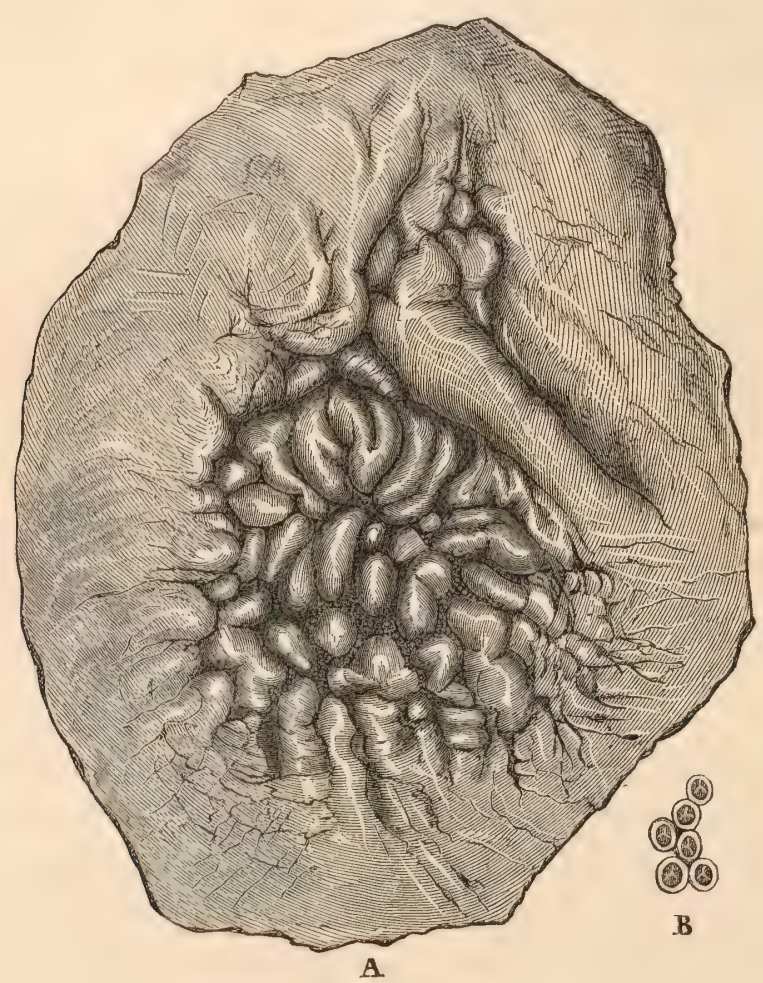

A sketch (natural size) of the surface of a portion of the second cavity of the stomach of Platanista at the part where the "cup-shaped bodies" are found. The subsidiary figure B shows a highly magnified view of a few of the cup-shaped bodies.

to it and the first cavity (Fig. 14). It is irregular in form and is at once discernible by its rough appearance; the rugosities, in the case of the young stomach with welldefined rugæ, occurring between these structures; and in the stomachs devoid of rugge, on the lobular processes, but chiefly between them. In a young dolphin the mucous membrane has raised rugged processes, some with rounded heads, and others with cup-shaped extremities, as if the distal half of the rounded head had been lost, or the cup had lost its lid. In two adults nothing but cup-shaped processes remained, and their stalks were short, and the majority of the processes small, and some were almost buried in the mucous membrane. They recall to mind, in their form and definite outline, the sucking dises of a Cephalopod. They have considerable tenacity and a slightly brownish colour, as if they were chitinous in their constitution. Such little cups,-and there must be some hundreds,- 
are 0.05 inch in diameter. The rim of the cup is not its greatest diameter, which is attained about the middle. These single cups in the adult are also connected to each other by strands of mucous membrane.

Microscopic characters of the second cavity.-This is clothed with cylindrical epithelium, and in its whole extent is densely clad with tubular glands, into which the cylindrical epithelium is prolonged. These glands form a layer about one-eighth of an inch in thickness, and they are so closely packed together at their open extremities that the interspaces between equal only half the breadth of a gland tubule. They are simple tubes in the first half of their extent, but they then divide into two branches, and in some instances bend suddenly before the division. These secondary branches rapidly diminish in capacity, and are soon reduced to narrow tortuous tubules which run vertically downwards, but more or less parallel to each other, and are lodged in a thick layer of corpusculated connective tissue. They appear also to give off other branches like themselves maintaining a similar course. The divisions can be undoubtedly observed, but they are not so numerous as one would expect. I am not, however, prepared to say that they are all racemose glands, but if simple ones occur, they would appear to be the exception and to differ only from the compound glands in being unbranched. It appears to me as if the glandular tubules depending from a common duct were bound up in one sheath, because I observed even as many as from two to four orifices, in oblique section, lying together as if in a cellular mass, external to which were the upward prolongations of the muscular mucosa. These cells around the tubules are large ovoid vesicles, with well-defined rounded nuclei, and, as they were unstained by hæmatoxylon, they are difficult to demonstrate. They are doubtless the peptic cells seen through the delicate membrana propria. The cylindrical cells lining the ducts and their chief branches, and occurring in the interspaces between the orifices of the ducts, have finely granular contents. In the hollows between the convolutions of this cavity, the peptic glands are larger tubes than on the convolutions, but shorter and more branched.

What I have termed cup-shaped bodies of this second gastric cavity I further examined by the microscope, both in vertical and horizontal section. They are altogether very peculiar and quite anomalous structures, and I have represented them in figs. 1 and 2, Pl. XXXVII. In the vertical section (Fig. 1) they partially occupy the glandular layer, but seem quite distinct and circumscribed from the adjoining tubular mucous glands. In the vertical section, they present a homogeneous or faintly granular egg-shaped outer area, and centrally a darker ovoid mass, also vertically placed. Whether by refraction of the light, or otherwise, in this view there seems to be a central band in the long direction of the inner object. In the transverse or horizontal sections (Fig. 2) these cup or egg-shaped bodies exhibit a thick circular outer wall, with an inner lining to the same. This latter is bent inwards chiefly in three, or occasionally in four, angular pieces projecting midway to the central open space. They, therefore, cause the interior to have a trifoil area, and where they almost meet divide the space into as many nearly circular 
compartments. Between the outer and inner coats of the walls, and at the bases where the inner lining is inbent, there further obtains a triangular space, three in all.

So far as I could observe and make out, the wall of the body was made up of a series of layers closely adherent to each other, and composed of a brittle granular, or indistinctly cellular material. The transverse sections bore a resemblance to the dense substance forming the wall of a large artery, but the constituents were not truly fibrous, but possibly, as I have already said, of a chitinous nature.

The exceeding regularity in the shape and composition of these cup-shaped bodies renders it very difficult to conceive what their true nature and function may be. They can hardly be glands or secretory organs. They are totally unlike any pathological product I know of, and have been observed always in the same position in many stomachs of this animal. Neither do they answer to inorganic, crystalline or any other deposit that I am aware of.

Passage between second and third cavities of stomach.-This passage is of variable length, depending on the condition of the stomach. In contracted.stomachs it hardly merits the name of a channel, being little more than an orifice; but in soft flaccid stomachs it is 1.50 inch long by 1.25 broad. It bends slightly to the left side in leaving the second cavity, and then turns abruptly to the right to reach the third. cavity. Its surface is quite smooth and does not present any glandular tracts. It opens into the third cavity close to its ventral wall, and nearly on the same level as its upper border.

Third gastric cavity. - The third and smallest cavity (Pl. XXVI, fig. 1, III) is either globulose or oval, according to its conditions, and the mucous membrane may present either a perfectly smooth or slightly rugose surface depending on its physiological condition at the time being. When contracted it presents a few longitudinal folds, radiating from the pyloric septum, and its surface is covered over with minute funnel-like orifices; but, in its distended and flaccid state, the folds disappear and the orifices are surrounded with pale areas of a different texture from the general mucous surface, which is grey. The orifices have the appearance as if the flaccid condition of the organ had permitted them to become expanded into colourless areas consisting almost entirely of their distended and everted tubes.

This third chamber of the compound stomach of Platanista, notwithstanding its small size as compared with the preceding first and second compartments, may nevertheless, from analogy and otherwise, be regarded as the true digestive sac. While its walls, to some extent, agree with the appearance of cavity number two, it nevertheless is more ruddy and vascular. Its mucous membrane contains abundance of large and simple tubular peptic glands, about $0 \cdot 10$ inch in length. These glands are parallel and clearly resemble in appearance and structure the simple glands of the pyloric end of the stomach of the pig.

In Plate XXVI, fig. 1, as in Plate XXVII, fig. 1, a fourth cavity is represented (IV), but this is not a true gastric chamber, but an enlargement of the upper part of the duodenum, of which more presently, in speaking of the intestines. 
Intestines. - The small intestine varies from 24 feet 1 inch to 22 feet 2 inches in specimens measuring from 6 to $5 \frac{1}{2}$ feet. Behind the pylorus, there is a welldefined sac (Pl. XXVI, fig. 1, IV), about 1.75 of an inch in length, formed by a thickened and constricted ring in the intestinal wall. The inside of this sac is marked by strong longitudinal folds with no trace of transverse ones. Another short sac (fig. 5, $i$ ), slightly smaller, succeeds, and has its inner wall thrown into a few longitudinal rugæ.

The ductus communis choledochus is situated at the termination of an oblong eminence on the upper wall of this sac. Near its orifice (Fig. 5,o) the duct preserves the character of the intestine, and is thrown into transverse folds like the valvulæ conniventes (which latter are so strongly developed in this Cetacean), but, beyond this, the mucous lining has a beautiful spongy texture (Figs. 6 and 7), like the mucosa of a gravid uterus.

The pancreatic duct opens into the ductus communis choledochus about the middle of its course on its anterior wall, and the spongy texture passes into it as well. I shall return to the consideration of it when we come to describe the pancreas.

The valvulæ conniventes (Pl. XXVI, fig. 4) begin to show themselves immediately after the ductus communis choledochus is passed, and they prevail so strongly and in such quantity that it is sometimes difficult to lay the canal open. These folds as in Hyperoodon obtain throughout the small gut, except on its last 4 or 5 feet, where occur short patches of longitudinal folds, about 2 inches long, alternating with long tracts of transverse folds; but in some conditions the last portion of the small intestine, about two or three feet, has been found perfectly smooth, so that valvulæ conniventes appear to be alone persistent. They commence as a few short feeble transverse folds, becoming more and more pronounced as they are traced backwards. They are placed somewhat obliquely across the tube, in transverse section; the extremities of alternate folds seeming mutually to overlap each other, so that the tract passed by the food is spiral. Some folds are much shorter than others, while a few are connecting folds passing obliquely from one alternate series to another. The folds are so deep that when the canal is cut across transversely the free margins of alternate folds are seen to overlap, thus dividing off the canal into a multitude of little chambers.

The small intestine (Fig. 11, $i$ ) is considerably contracted as it approaches the great intestine, and the two communicate by a very small orifice sufficient only to. admit the passage of a crowquill in an individual five feet long. At the point where the two join, there is a short diverticulum (Fig. 11, ca), from the large intestine prolonged upwards as a cæcum, 2 to 3.50 inches long, and having the same calibre as the great gut; and in this respect Platanista differs from all the toothed whales. ${ }^{1}$

The large intestine of the adult is two feet long, and it describes an abrupt turn to the right on a line with the lower third of the kidney, indicating the com-

${ }_{1}$ Cuvier: Leçons d’Anat. Comparée, 2me. edit., t. iv, 2me. Pt., p. 268. Flower: Medical Times and Gazette, 1872, vol. ii, p. 428. 
mencement of the rectal portion, the lower half of which is thrown intolongitudinal folds.

In the duodenal sac, there are two patches (Fig. 3) resembling groups of racemose glands. The whole of the smooth portion of the small intestine is covered, both over the mesenteric attachment and opposite to it, with small orifices marking the position of solitary follicular glands. Six inches from the vent the character of the mucous membrane entirely and suddenly changes, the line of separation being clearly indicated in the different character of the two membranes : the rectal portion is coarse and more yellow in color, and the pigment of the external skin is prolonged upwards except in the last 2 inches. It is also thrown into strong longitudinal folds, which are marked, here and there, by small openings leading into pits which run forwards along the mucous membrane of the tube. There are also three or four small circular openings which appear to be gland orifices.

In a young individual about $4 \frac{1}{2}$ feet, five glands (Fig. 5), each about the size of a small bean, lie over the course of the mesenteric artery and are in close contact with the pancreas and on a level with the intestinal orifice of the ductus communis choledochus. A gland (Fig. 11, g), somewhat globular in form, and with a diameter of 2 inches, occurs in close contact with the glands on the origin of the mesentery, and reaches also to the mesocæcum, and is closely attached to the end of the small intestine. It so occupies the origin of the mesentery that that membrane radiates from its lower margin, and nearly all the mesenteric veins converge to it and unite in its centre. It is also traversed by a branch of the mesenteric artery. The gland, however, consists of two well-marked portions; one traversed by the vessels, and another eccentric to them and lobulated. The first portion has a dark olivebrown colour, and is soft and of one consistence throughout, while the other has a pale pinkish yellow matrix through which a cartilaginous-like substance of a bluish tint is interspersed.

The stomach of the Platanista is so largely infested with the parasite determined by Cobbold ${ }^{1}$ to be Ascaris simplex that no sooner does the animal die than they crawl in numbers out of its mouth. They are chiefly confined to the stomach, but extend to the intestines.

The small intestine is the abode of another parasite, which Dr. Cobbold has named Distoma andersoni. ${ }^{2}$

Pancreas.-(Pl. XXVI, fig. 5.) - This gland lies in the bend formed by the third sac of the stomach and the duodenum, above the ductus communis choledochus, and at no great distance from the large gland (Fig. 11) that occurs at the union of the large and small intestines, and with which it is intimately connected, as the large vein traversing the latter passes directly through the upper division of the pancreas, and is so large that a probe, fully a quarter of an inch in diameter, can be passed along the vessel from one gland to the other in a young animal. In the same individual the gland measures 2.50 inches in length, with a maximum breadth of 2 inches and a thickness of about 0.50 inch. The general characters of the

$$
{ }^{1} \text { Proc. Zool. Soc., 1876, p. } 297 . \quad \text { 2 Journ. Linn. Soc., vol. xiii, p. 35, Pl. x, fig. } 3 .
$$


ductus communis choledochus which passes in front of the gland, I have already described.

Spleen.-(Pl. XXXVI, figs. 8 and 9.)-This gland in Platanista appears to be rather small, as in the adult it measured only 3.50 inches in extreme length by 2.25 inches in breadth. It is irregular in shape, and very unlike the well-formed spleen of Orcella. It is much compressed from side to side, and externally it is marked by a series of lobular projections. In the adult, the course of the vessels along the free border is remarkable, owing to the existence of large dilatations (Fig. 9) into which many crescentic orifices open, and another such sac occurred on the side of the gland. These sacs, or dilatations, were filled with a grumous substance in the fresh state which I had not the opportunity to examine microscopically. The walls of the sacs were lined with a serous membrane, and, in a few instances, short bands like corda tendinee stretched across from one wall to the other in connection with the orifices opening from the spleen into the sac. These orifices were of various sizes, some being as minute as a pin's point, while others were fully 0.12 inch in diameter. Their margins had a free fold of membrane almost valvular, and in some instances an orifice so protected was found at once to divide into smaller but similar ópenings. The largest sac had a capacity of 2 inches in length by 0.75 inch in breadth. Structurally both appear to be dilatations of the veins.

Liver.-Platanista agrees with other Cetacea in the simplicity of its hepatic organ; lobules and clefts being conspicuous by their absence. As the drawing shows (Pl. XXVI, fig. 10), it is almost transversely oval in figure, and very thick in proportion. The position of the umbilical fissure which is shallow, the median pit for the hepatic vessels, the inferior course of the wide vena cava, and the deficiency of a gall bladder, all simulate what obtains in the majority of Whales. An examination of the hepatic vessels showed no signs of a rete mirabile surrounding them, which, as I have noted, obtains in the short-headed dolphin Orcella. The hepatic tissue itself is firm; but otherwise presents no characteristic feature.

In the hepatic ducts of the Platanista are occasionally found immense numbers of a small brilliantly coloured fluke, Distoma campula, Cobbold. ${ }^{1}$

Blow-hole : its cavity, pads, and sacs.-The blow-hole (Pl. XXXII, fig. $4, b$ ) is a longitudinal slit, about 2 inches in length, usually a little to the left of the mesial line. In the longitudinal section of the skull, it is seen to be directed downwards and slightly backwards and outwards. At 1.20 inch from the surface it becomes funnel-shaped, with a quadrangular outline in transverse section. This portion at its base has a longitudinal diameter of 0.40 inch, and in this locality the orifice of each nostril is placed, and protected by rounded firm pads, which effectually close it.

In general appearance (PI. XXVII, fig. 1) it differs materially from the blow-hole in other Cetacea, inasmuch as the antero-posterior direction of the exterior orifice and the presence of the great lateral crests of the maxillary bones suggest a restriction of the aperture and passage. It is true that the spiracular cavity and nasal sacs are not capacious; nevertheless, their likeness to those of allied families is not 
essentially departed from, although slight variety obtains. Among the Delphinida and Globicephalida, with a transverse outer slit, a pair of oval pads rest against the hinder wall, and a small cartilage laterally approximates. The vertical passage descending to the two inner narial orifices sends forwards along the premaxillaries either a single one or a pair of elongated sacs. These thus bend round deeply below the facial blubber mass. From the spiracular cavity higher up, in some instances very superficial, a large thin-walled sac diverges outwards on either side. By an opening close by each of the latter; a narrow, often cord-like sac or tubular canal winds backwards and inwards, or sometimes even has a twist forwards. Thus, there are three pairs of sacs, differing in position and shape, all communicating with the spiracular cavity : a pair of pads or fibroid eminences, and a pair of rudimentary nasal cartilages, besides a medial septal cartilage.

Now, the same structures are obvious in Platanista. The longitudinal direction of the spout-hole produces therewith a very obliquely shelving anterior wall, and thus the boss roofing the elongated premaxillary sac appears to jut more upwards and backwards than in those Cetacea with a cross blow-hole. This boss, or anterior cushion, consists of very firm fibrous tissue, intermingled deeply with fleshy fibres, forming a premaxillary muscle. The latter again in front commingles with coarser reticulate fibroid tissue, between the meshes of which oily blubber is retained. Thus, the cupular eminence of the face, at the sides supported by the porous maxillary crest plates or arches, is composed of coarsely reticulate glistening fibroid tissue, with oily matter distributed in it. It is much firmer than in those Whales in which it assumes the constitution of true blubber. Below the mass in question is the premaxillary sac (wood-cut, Fig. 15, I) ; trending forwards, and connected therewith is a small outer recess. This latter (II), though much more deeply situated than in the Dolphins and Porpoises, evidently corresponds to their superficial lateral sac. Just behind and towards the inside corner of the bony narial aperture a small opening leads into a diminutive passage (III) curving outwards, and round a pad and gristle presently to be mentioned. The said pad $(p)$ is a nodular mass of solid fibrous tissue, overhanging the nasal passage. Immediately outside it, starting apparently from the frontonasal region, and following the course of the upper premaxillary process is a crescentic strip of cartilage $(c a)$. This is externally convex and internally concave, prominent behind and shooting downwards and forwards, outside the anterior boss already spoken of. The passage to the nares lying between them, but outside the cartilage, is a shallow crescentic depression subsidiary to the narial channel.

The cartilage is covered by fibrous tissue, and muscular fibres connect it outside and in front with the fleshy tissue distributed round the spiracular cavity generally.

The interior of the narial chamber, except the sacs, is lined with dark pigmental tissue, and in the more upright portion of the walls is thrown into narrowed wavy corrugations which doubtless are effaced on dilatation of the chamber. I may further call attention to a little glandular recess situated on the inner whorl of 
the nasal cartilage and below the postnodular pad. Mesially there is a strip of septal cartilage.

Fig. 15.

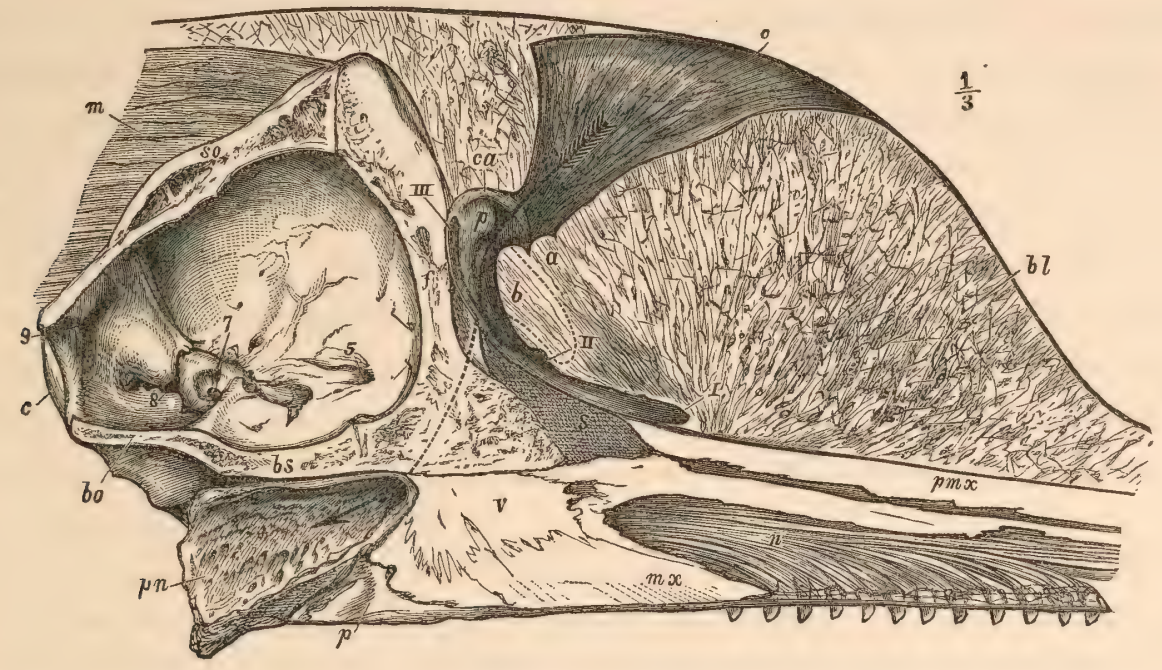

A vertical section through the head of Platanista gangetica, slightly to the right of the median line, designed to show the spiracular cavity and sacs, the fibrous blubber of the forehead, interior of brain cavity, and nerves supplying the teeth. The snout is curtailed, and the lower jaw, tongue, \&c., have been cut away. Drawn from nature and reduced about $\frac{1}{3}$ rd nat. size.

$o$, skin of the left side of the orifice of the blow-hole (an arrow is directed downwards through the spiracular cavity, and its point is shown passing into $(p n)$ the posterior nares); $b l$, the coarse fibrous tissue and blubber and fibrous material of the forehead, and which substance reaches quite to the top of the skull; $c a$, cartilaginous piece in the blow-hole; $p$, pad, immediately to the inside of the latter; $a \& b$, fibrous elevations or cushions in front wall of spout-hole, and here seen in section; I, lowermost nasal sac (premaxillary); II, orifice of lateral sac (maxillary), the dotted line signifies its position, otherwise it is hidden in the fleshy substance; III, narrowed spiral canal which passes partly round $(c \alpha)$ the nasal cartilage and constitutes the small third nasal sac (= nasofacial); $s$, cartilaginous septum nares; pmx, premaxillary bone ; mx, maxillary; $v$, vomer; $p$, pterygoid ; $f$, frontal; $b s$, basi-sphenoid; $b o$, basi-occipital ; $c$, occipital condyle ; so, supra-occipital ; 5 , sphenoidal fissure; 7 , internal auditory foramen ; 8 , fissure exit of eighth pair of nerves ; $g$, condyloid foramen; $m$, neck muscles; $n$, branches of superior dental nerve.

Posterior Nares.-(Woodcut, Fig. 15, pn; also Pl. XXVIII, fig. 3, pn.)-The internal nasal aperture is a longitudinally elongated oval opening, 2 inches in length, and one in breadth in the adult, and its margin is thick and fleshy. Its posterior border is slightly behind the posterior margin of the basi-occipital bone. It dilates between its margin and the posterior end of the pterygoid into a sac which fills up the downward and outwardly projecting plate of the basi-occipital and basisphenoid, and runs forward to the pterygoids. The sac thus fills up the triangular surface on the base of the skull, defined by these osseous parts, and in consequence is of considerable capacity, triangular in form, with the apex directed forwards to the osseous nasal septum; having a length of nearly 3 inches, and a breadth of $1: 50$ inch. The walls of this portion of the nasal canal originate external to the internal nares, so that they form a kind of imperfect floor to the sac, projecting internal to its walls for nearly an inch and a half anteriorly, but only about half an inch posteriorly. The front and sides of the opening are thick, while the posterior 
margin is thin. Two strong tendinous retractor muscles, two inches in length, are prolonged forwards and upwards from the anterior margin of the posterior nares along the floor of the sac and appear to be attached to the posterior palatine process of the pterygoids. They are separated by an interval anteriorly, but unite posteriorly and surround the margin of the orifice like a sphincter. The whole surface of this sac, from the orifice forwards to the narial septum, is richly covered with the orifices of small mucous glands (Pl. XXVIII, fig. 3). The surface also of the sac-like portion is thrown into strong tendinous bands or folds, resembling chorda tendinea. In all the specimens I have examined there are indications, more or less distinct, on the lateral walls of the sac of nearly longitudinal tendinous bands separated from each other by intervals varying from 0.25 inch to nearly an inch in extent, these interspaces being divided into long arched crypts varying in size and number and disposed more or less vertically. In one of these crypts the Eustachian tube (Fig. 3, $e u^{2}$ ) seems to open.

Eustachian Tube.-The opening to this tube $\left(e u^{2}\right)$ appears, as I have just said, to be situated in the posterior nares, - at least the only orifice communicating with the canal that I have been able to perceive is situated in that locality. The opening is placed on the lateral wall of the nares, 0.75 of an inch above the narial rima in an adult in which $\mathrm{I}$ had no difficulty in detecting the orifices and to the position of which I had been led by what I had observed in a semi-adult individual. I must state, however, that it was a matter of considerable difficulty to find the orifice in the last-mentioned specimen, but that its presence in the adult and in the position indicated was easily demonstrated. In looking into the postnarial pharyngeal sac or dilatation of the Eustachian tube in the semi-adult, a patulous diverticulum from the external wall of the sac, near its anterior end, was observed to pass outwards in the direction of the wall of the posterior nares : but on attempting to pass a probe along this, its progress was impeded by valvular folds of the walls of the passage. On directing my attention, however, to the external wall of the pose terior nares I found that the probe passed along one of the crypts $\left(e u^{2}\right)$ and ran upwards, and on introducing the probe again from the sac I found it appearing on the posterior nares through the crypt in question. In the adult I passed no probes, but observing an oval orifice in about the same position as the crypt, I slit open its upper margin and found it to constitute a canal $(d)$ which ran upwards and was about half an inch in length and a quarter in breadth, and, at the former distance from the opening, the outer wall of the passage abruptly stopped as a crescentic fold, the inner or narial wall being prolonged upwards for 0.40 inch beyond it, so that an elongated slit occurred in this position opening into a considerable cavity. This was found to result from the union of the Eustachian tube with its long posterior prolongation or guttural pouch, thus forming a cavity common to both, and which sends up valvular passages around the sac of the Eustachian orifice which is placed opposite to the end of its tube (Pl. XXVIII, fig. 3). The postnarial end $(p n)$ of the Eustachian tube and the commencement of the guttural pouch are each protected by thin folds of membrane which must act more or less 
as valves. The Eustachian tube, in the adult, at its termination has a diameter of 0.40 inch, and the guttural pouch is half an inch broad at its beginning. From the crescentic fold the direction of the guttural pouch is downwards, backwards, and inwards, and the postnarial passage lies on the commencement of the outer wall of the pouch, the two lying back to back; hence the difficulty of passing a probe from the guttural pouch into the posterior nares, for, when it reaches the orifice above the crescentic fold, it meets with the outer wall of the external passage, and a similar difficulty is encountered in tracing the Eustachian canal from its auditory end.

As these prolongations of the Eustachian tube are undoubtedly air receptacles, and in all probability subservient to audition, as seems to be the function of their homologues in the horse, we have an explanation of the position, direction, and valvular character of the external orifice in an animal which has to breathe by rising to the surface of water.

When the Eustachian tube reaches the outer wall of the posterior nares, it dilates into a tube of considerable capacity, being half an inch in diameter (in an individual $4 \frac{1}{2}$ feet long) at the point where it opens into the posterior nares, and immediately behind this, it suddenly expands into a large sac, lying internal to the stylohyoid, to which its outer wall is attached. Turning round that bone from behind forwards, this sac lies between it and the thyrohyal, and its internal wall lies against the outer wall of the back of the pharynx, while the roof of the sac lies below the exoccipital and basi-occipital bones. In the same individual, it has a length from before backwards of 1.75 inch, and a vertical height of 1.25 inch. The inner surface is white smooth glistening and tendinous in appearance, and its wall has numerous deep recesses of various dimensions formed by arching folds of the membrane constituting the walls of the sac; while other parts of it are covered by a tendinous meshwork, defining shallow crypts, of the same structure as those found on the walls of the posterior nares.

Some of the recesses lead into small secondary pouches, and from these into a labyrinth of smaller passages. A rather wide orifice, lying at the posterior margin of the stylohyoid, leads into a pouch divided into crypts and little pockets by valvular folds which turn round the outer margin of that bone, and lie along the cranial end of the thyrohyal. About the middle of the great sac from which this little pouch is given off, a strong valvular fold arches across it from the external to the internal walls, and serves to close a wide orifice leading into a second great sac hereafter to be considered. Behind this valve, and at the bottom of the sac, there are seven small orifices arranged in linear series, and each separated from its fellow by a pillarlike fold; and immediately above these occurs the opening leading into the secondary sac just described. These orifices, which, however, vary in number in different individuals, when traced out are found to lead into a third secondary sac, which passes downwards behind the thyrohyal. This orifice leading from the strong valvular fold just mentioned opens into the secondary sac, which is divided into compartments by large valves, and communicating with the sac behind the thyro- 
hyal by tortuous openings through valvular passages. This compound sac extends to the middle line, its first portion running along the inner surface of the stylohyal to its extremity, where its inner wall lies against the upper surface of the caratohyal. Thus, the sacs of opposite sides are here only separated from each other by a thin layer of connective tissue,-so thin, indeed, and the sacs presenting so many crypts that might communicate with their fellows of the opposite sac, that I had at first expected to have met with the anomaly of the Eustachian tubes communicating with each other at the base of the tongue. The second portion of the compound sac lies between the thyrohyal and the lower portion of the thyroid cartilage, and extends in front of the latter, and the sacs of opposite sides are here also only separated by a narrow interval of connective tissue. In the most anterior portion of the sac, that lying between the caratohyal and stylohyals, I have found small bones, and, strange to say, many crystalline lenses of fishes of apparently one size and probably of one species; and from one individual I removed two parasitic worms, Ascaris simplex, which is so prevalent in the stomach and intestines. The whole of this remarkable sac has its walls covered with valvular folds defining crypts and passages, and, at the commencement of the portion lying between the thyrohyal and thyroid cartilage, valvular folds are connected to each other by fine fibrous cords (PI. XXVIII, figs. 2 and 5).

The orifices in the posterior nares lie anterior to the epiglottis when in its normal position, and the downward direction of the external passage is to guard against the possibility of water finding access by them to the Eustachian system, and the valves subserve the same purpose. Still, nature, in avoiding one danger, has incurred another in the apparent tendency which the sacs have to become receptacles for foreign objects drawn up from the throat in the act of expiration, and which by their presence might prove the cause of inflammation and abscesses in the ramifications of the Eustachian system and at the root of the tongue. These foreign objects may doubtless find their way first into the posterior nares by the action of the muscles which grasp the epiglottis.

Microscopic structure of the walls of Eustachian sacs.-The very remarkable pouched character of the walls of the foregoing passage and their glutinous surface led me to investigate their minute structure (vide Pl. XXXVII, figs. 7 and 8). I find them to be throughout composed of loose folds of thick mucous membrane. Short irregular papillæ invest the surface, and everywhere, at scattered intervals, are small pits and the minute orifices of mucous glands. These glands are most of them superficially situated, but some are sunk deeper into the tissue, chiefly simple and tubular. Certain of them nevertheless are slightly racemose; and all contain cylindrical epithelium with often a central cavity. The elevated papillæ already mentioned are exceedingly vascular, indeed possess a thick network of fine capillaries, the parent vessels of which are both numerous and of considerable calibre. This tube, therefore, must at times be very turgid. The free surfaces of the papillæ are themselves quite shaggy under the microscope, being covered by a close-set layer of cylindrical fringed or ciliated epithelium. The deep connective tissue of the sub- 
mucous membrane is loose, strong-fibred, but very open, some fat cells and oily particles being mingled with the tissue, while elliptical-shaped great bundles of the striped muscular fibres course in different directions, right up almost to the glandular layer in some instances.

Parotid Gland.-I introduce in this place a short notice of a glandular structure met with in the neighbourhood of the jaw articulation. It has no immediate connection with the Eustachian apparatus, and only claims attention here from its proximity.

Lying immediately behind the attachment of the stylohyal, and 2.50 inches behind the articulation of the lower jaw, and on the same level, is a somewhat crescentic-shaped gland, 2 inches long and 0.75 of an inch broad, in the dolphin 51 inches long. This gland is doubtless the parotid, but I have been unable to detect any duct; my failure to do so is probably attributable to the condition of the specimen.

Larynx.-(Pl. XXVIII, figs. 6 and 7).--The opening to the larynx is a transverse slit, 1.25 inch in breadth when closed, and a longitudinally oblong orifice when open, 1.25 inch in length and a little more than 0.75 inch in breadth. The tube of the larynx projects forwards and upwards, generally towards the right side, and is 1.25 inch in length. There is nothing remarkable in its form, which coincides with that of other Cetaceans. The mucous membrane lining the base of the epiglottis and the inferior cornua and body of the arytenoids is covered sparsely, in the first locality, with small papillary processes, which are numerous over the two latter areas. A short fold of mucous membrane stretches backwards to opposite the posterior border of the body of the thyroid cartilage, having begun near the middle of the epiglottidean cartilage and opposite to the tip of the posterior horns of the arytenoids. On each side of the fold, there is a small orifice which I have been able to trace only a very short way, and it appears to be a blind sac, and I cannot detect any trace of a laryngeal pouch. A number of small closed cavities exist in some specimens, but not in others, and are situated over the body of the thyroid and before the ring of the cricoid and are most deceptive, for they simulate natural cavities to a wonderful degree, but the examination of the larynx in four individuals has satisfied me that they are purely adventitious.

The thyroid cartilage is remarkable for its great lateral expansion. It consists of a body with two wings or lateral bars of cartilage projecting outwards and backwards. The body is lingulate, and projects forwards anterior to the lateral bars, while its posterior border is notehed. From the hinder third of the lateral margin of the body, the bars of eartilage project outwards for 1.50 inch, nearly at right angles to the body, with a slightly backward inclination, and each wing projects outwards and dorsally to protect the anterior two-thirds of the cricoid. It then bends backwards and inwards to reach the cricoid. It presents no trace of an anterior horn. The thickness of the posterior portion of the cartilage does not exceed $0.10 \mathrm{inch}$, but it increases as it approaches the cricoid to more than double that thickness, and the anterior portion of the body is convex superiorly, and thicker than its posterior half; or than the lateral bars. The breadth of the latter structures is about $0.40 \mathrm{inch}$, but 
where they bend backwards is augmented to $0.72 \mathrm{inch}$. The cricoid cartilage is strong and compact, with a prominent dorsal ridge, which terminates anteriorly in a rounded projection, directed forwards and slightly upwards. The surfaces of the cartilage external to the ridge are concave, and, on looking at them from below, they are seen to have their margin somewhat everted. The margin anterior to the attachment of the arytenoid cartilages is concave, and the articulation for those structures to the cricoid, unlike that of the thyroid, is a capsular synovial joint, which Turner has also observed to be the case in the great Finner (Sibbaldius). The cricoid ring is thick, but there is a great hiatus between it and the posterior border of the body of the thyroid, due to the circumstance that the cricoid cartilage simply roofs in this portion of the cavity of the larynx. The passage through the cricoid ring is an inch broad, by 0.75 inch high. The body of the cartilage becomes much ossified in the adult.

Each arytenoid is a slightly oval laterally compressed cartilage, more pointed posteriorly than anteriorly, about 1 inch long by 0.70 inch in breadth. It presents three principal surfaces, an anterior, an external, and a posterior. The first is slightly concave in its centre, and its inner margin expands in its upper half into a triangular secondary surface, to which a downward process of the anterior horn is attached. At the upper end of this secondary surface is the narrow isthmus from which the anterior horn is projected. The limited nature of the structural union existing between the body of the arytenoid and its horn, permits the latter to have considerable mobility. The posterior surface of the body presents the elongated oval depression for articulation with the cricoid. The internal surface is broad above, pointed below and convex, and its posterior margin is continuous above with the upper border of the cricoid articular surface, anterior to which on the apex of the cartilage, and immediately behind the base of its anterior horn, is a small flattened secondary triangular area. The anterior horns are directed upwards and then forwards, so that their anterior borders are concave to rest against the epiglottidean cartilage. They are small laterally compressed structures, their inner surfaces being perfectly flat, so that the two cartilages can be closely opposed to each other. Their front and posterior margins are sharp, except in the basal half of the latter, which expands into a flat surface. At the point where the horn springs from the body, and depending from it, a short process rests against the inner margin of the first secondary surface of the body. This process or horn is prolonged backwards, as it were, by a variable number of small cartilages, usually three, closely applied to the inner margin of the anterior surface of the arytenoid, and are thus included in the aryteno-epiglottidean membrane. Anterior to the downwardly projecting process from the base of the anterior horn of the arytenoid, is another narrow rod, arching outwards and downwards, and occasionally divided at its extremity into two. In its position and relation this is the equivalent of the posterior horn of the arytenoid. It is sometimes, however, only connected to the arytenoid by fibrous tissue. Iying between it and the cuneiform cartilages already described, occur two or three other similar yellow cartilages, but varying in number and size. The largest is about $0 \cdot 25$ 
inch in length by $0 \cdot 10$ in breadth in some instances, but occasionally they are so small that they are liable to be overlooked. The epiglottidean when removed from the thyroid cartilage and its arytenoid surface placed flat, resembles a heel-less boot, the dorsum being the anterior border of the cartilage, and the sole corresponding to the concave portion, which latter is applied to the arytenoids. The toe, of course, is enormously expanded, with two small lateral horns, and is the apex of the cartilage. The back of the boot, the surface applied to the thyroid, is concave, but filled up in the recent state with the strong attachment of the thyro-epiglottidean ligament. The anterior angle of its thyroid surface, when denuded of membrane, is seen to be formed by a distinct cartilage triangular in form, and measuring nearly an inch in length and 0.25 inch in its greatest breadth. It occupies a position on the epiglottis in which some such arrangement would be expected, for it occurs opposite to that part of the cartilage which faces the body of the arytenoids and fills up a gap between them, the mobility eaused by the fibrous attachment of the two aiding the perfect apposition of the aryteno and epiglottidean mucous surfaces. This supernumerary cartilage is tipped at its rounded margin by one or two minute but distinct cartilages. The anterior margin of the cartilage at its extremity divides in two, and forms a notch through which passes the aryteno-epiglottidean ligament; this passes backwards to be attached along the dorsal aspect of the body of the thyroid, as far as the notch. The sides of the cartilage of the epiglottis are covered by numerous pits for the reception of glands.

Trachea-Before its division this is very short, the bronchus to the apex of the right lung being given off a couple or three inches from its commencement; the bronchi to the middle and base of the right lung and to the left lung respectively, being given off, as it were, by the conjoint bifurcation of the rest of the tube. On reaching the apex, the first bronchus divides into two principal branches, which follow the method of division of the trachea, $i$. e., divide each into three branches. The second bronchus when it reaches the lüng gives off three small branches, one after the other, to the external portion of the penultimate fourth of the organ, the main portion being directed to the middle of the lung, and dividing dichotomously. The third or left bronchus divides into two before it reaches the lung; the left branch being directed to the apex and the right to the rest of the lung.

The diameter of the trachea is greatest transversely. The cricoid cartilage is succeeded by a broad flattened ring of cartilage, varying according to the age of the individual from 0.25 inch to one inch in antero-posterior extent. On its side it is sometimes cut into by a fibrous band, so that it is quite possible that in some instances it may be much narrower by a separation of a portion of itself as a separate ring; and on its dorsal surface it shows a distinct tendency to break up into small plates. It is succeeded by a flattened band of cartilage which, commencing by a free end on the dorsal surface of the right margin of the trachea, passes round to the left, i.e., along the ventral surface till it reaches the left margin of the tube. There it suddenly bends on itself and passes behind its first portion, again to the right, along the ventral surface, so that it does in no way form the dorsal wall of the tube. But two 
portions are separated in the middle line by an intercalated little cartilage, or it may be described as beginning at the right border of the trachea by two free ends or pieces which enclose a cartilage at the middle and unite at the left wall of the tube. The first piece on the dorsal surface begins at the right margin of the tube by two free ends, lying side by side, and which unite about the middle of the tube, the single end just bending sufficiently round the left margin of the tube to form its wall. On the ventral surface, the first cartilage has two distinct cartilages behind it. The first is a small free cartilage opposed to its right third and terminating on the right wall of the tube, but not entering into the formation of the dorsal wall. The second lies against the two remaining thirds, but the cartilage passes right round the left margin to their dorsal surface, and running obliquely backwards to the right to the beginning of the first bronchus of that side. At its origin on the ventral surface, it has a short portion bent back before itself, but this piece does not reach to the left border of the tube (Pl. XXVIII, fig. 10). The first cartilage of the dorsal surface has two behind it, overlapping each other in the middle line, but confined to its own side of the trachea. The second cartilage of the ventral surface has two cartilages behind it similarly arranged with regard to each other. The third dorsal cartilage begins by a pointed end on the left wall of the tube, but soon divides into two halves, which lie parallel and are confined to the dorsal wall. The fourth ventral cartilage enters partially into the formation of the dorsal wall. Commencing at the right side of the tube, it can be traced describing four spiral lines, but never encircling the trachea, being almost exclusively confined to the ventral wall. It receives a process from the right of its commencement, and gives off two at the end of its first coil, which pass on to a portion of the dorsal surface, the anterior lying behind the dorsal prolongation of the second ventral cartilage; the posterior being prolonged beyond it to the angle of divergence of the first bronchus and trachea. The rest of the wall at the origin of the right bronchus is made up by small cartilaginous plates, and a similar arrangement holds good at the point where the last bronchus is given off; the ventral plates being generally bifurcated structures, only having a very limited dorsal surface and sometimes enclosing small plates between them. On the bronchi and their divisions, the cartilages are arranged in spiral rings, and on the larger bronchi I have counted as many as five distinct coils in one cartilage. The coils, however, are not simple, for secondary ones are given off, which are embraced in the primary ones as much shorter coils.

Lungs.-The pulmonary organs of Platanista as shown in Plate XXIX, fig. 1, are there thrown apart, the better to expose the heart and its surroundings. Each lung in the adult is 19.50 inches in length. When examined in the fresh condition, its substance, as in others of the Whale tribe, is particularly spongy and of a firmish texture. Both lungs are nearly similar in outline, and while they may be described as single, or without marked division into lobes, the upper segment in each is nevertheless marked by a shallow cleft, so as to warrant division into an anterior and posterior lobe. The former, especially the left lung, has a well-marked semilunar marginal excision, which produces a rounded lobular promontory quite 
in front; the after division of the semilune being narrow and pointed on the left side, and blunt and broad on the right side. The larger posterior lung division is more uniform in contour, its hinder end being unequally emarginate and produced on the right and left sides.

The entire inner borders of both lungs have irregular crenate edges; in this respect, in their partial segmentation, and in absence of lung bridge and superficial pulmonary glands, differing from what obtains in Orcella (compare Pl. XXIX, fig. 2).

Thoracic and Pulmonary Glands.-In mentioning the absence of superficial or sternal pulmonary glands in Platanista, it should be pointed out that glandular masses similar in kind are not altogether wanting, but only they are placed deeply at the root of the lungs, and at the base of the heart where they are attached to the pericardium.

Among these glandular masses may be included what evidently answers to the thyroid bodies. This pair of glands (Fig. 1,th) are of a bilobate figure and lie across the trachea at an obtuse angle, where the trachea divides into right and left bronchus. While joined mesially, each thyroid gland is egg-shaped, 1.75 inch long and just under 1 inch in greatest transverse mid-diameter. They are smoothsurfaced and dense in texture. Their intimate structure is of the usual vescicular and colloid character appertaining to the ordinary constitution of these bodies.

Less prominent and more deeply situated than the aforesaid is a patch of much smaller and quite irregularly sized and shaped glands $(g l . g l . g l$.$) . These dip between$ the bronchi, extend among the great vessels at the root of the heart, and one long narrow patch crosses the upper pericardial attachment, and sends finger-shaped prolongations between the vena cava and aorta. Partially covering these, and with the parts in natural position, somewhat overlying the thyroid bodies, there is also on each side a very large superficial gland; between 2 and 3 inches long, and of a kidney shape. Posterior to these and almost touching them is another rounder and flatter, but equally large pair of glands, of a similar appearance to the last. Yet nearer the apex of the heart and likewise attached to the pericardium in continuity with the last-that is, adherent by cellular tissue-is a great broad glandular mass of rounded outline. This dips both behind and in front of the heart almost from root quite to apex. Other scattered nodules of a glandular nature are dispersed promiscuously on the surface of the pulmonary and pericardial serous tissues.

It seemed to me that all these glands may, more or less, be regarded as coming under the denomination of modified lymphatic glands, whether bronchial or otherwise. In a great measure they agree with the analogous glandular material met with in Orcella (compare fig. 2, $g l . g l$., Pl. XXIX), and they also combine in part the nature of the so-called pulmonary glands $(p . g l$.$) of the latter animal. It is$ quite possible, nay probable, that portions of them may represent either remnants of, or be, permanent Thymus glands; but on this head I could not satisfy myself of their identity in composition with the well-known fotal Thymus bodies. 
Those that I examined microscopically led me to regard them as identical with the vasculo-lymphatic pulmonary glands already referred to in detail in Orcella.

Minute structure of Lung Gland.-If fig. 4, Pl. XXXVII, being a microscopic section of one of these glands from the lung of Platanista, be compared with figs. 3 and 5 in the same plate, respectively the stomach and pulmonary glands of Orcella, the identity of all three becomes manifest. In each there is a copious blood supply, the walls of the larger vessels, specially noticeable in fig. 4, being obliquely perforated with orifices for subsidiary capillary tubes. These ramify everywhere amidst the gland tissue. The basis of this latter is a fine retiform connective tissue, the minute fibrillæ in the meshwork of which radiate from points which, under a high power, appear to be nucleate corpuscular centres. In the meshes of the trabeculæ are masses of much larger cells, in all respects agreeing with lymph corpuscles (fig. $4, c$ ).

Lastly, there are irregularly shaped and differently sized spaces, which to all intents have the nature of lymph sinuses. The gland tissue proper or pulp is very unequally distributed, not only as respects quantity, near or further distant from the larger blood canals, but inter se a thickened patch appears surrounded by a space, this latter again joined by sparse retiform tissue being encompassed by a dense area of large corpuscular gland tissue. The aggregation of gland substance then is most variable, as are the open spaces or sinuses.

Heart.-When fully injected with plaster of Paris the heart of Platanista (Pl. XXIX, fig. 1) is a great broad relatively short organ. It then measures some 6.50 inches across from border to border at the base of the ventricles. The ventricles themselves are no more than 4.50 inches in length, but from the apex of the heart to the upper tip of the distended auricle is 6.50 inches. Roughly speaking, then, the heart is as broad as it is long. The ventricular apex exhibits a tendency to cleavage, or indistinctly shows a bifid extremity, the incision being very shallow, and the more lengthened left ventricle tending to the appearance of a double apex. The cavities and valves offer few points of interest. One which simulates a pathological character, though I believe it to be in this case normal, is the nature of the chordæ tendineæ. These generally have a peculiar knotted aspect due to the swellings of a number of ring-like cartilages, which produce an appearance that may be likened to the nodular character of the underground stem of the bamboo.

Arch of Aorta and great vessels.-Three distinct vessels spring from the transverse portion of the arch of the aorta, as in Man and many other mammals, namely, a right brachiocephalic, a left carotid, and a left subclavian; and from the descending thoracic aorta arises the left posterior thoracic artery, as is sometimes the case in the porpoise. ${ }^{1}$ The brachiocephalic artery is of considerable length and, above 2 inches from its origin, it gives off a small twig to the thyroid gland. A little in excess of this distance it divides into two large branches, the first the right carotid which passes forwards, and the second the right subclavian passing out-

\footnotetext{
1 Turner: Journ. Anat. and Phys., vol. ii, 1868, p. 68.
} 
wards; the former after its origin gives off a considerable branch from its right side to the thyroid gland, but after this it runs forwards unbranched for about four inches. A mass of vessels then arise, first a bundle from its left and then another from its right side, the two being in close relationship to each other. In these combined tufts I have counted as many as fifteen branchlets, each of which, immediately after its origin, broke up into numerous smaller vessels producing an intricate rete mirabile. About one inch beyond this, the carotid passes below the posterior angle of the root of the zygoma, and at this point again gives off another tuft of vessels likewise forming a rete mirabile. It then dips below the glenoid process of the squamous, and at the anterior extremity of the tympanic is again resolved into yet another and a similar bundle of vessels. Up to this point, in the whole course of the carotid, no prominent branch has sprung, and the calibre of the artery has been but little diminished, nor is there much reduction here where it terminates in this rete mirabile, among which, however, there are some twigs larger and longer than the others; but these I have not succeeded in tracing to any distance. It is evident that no large branch enters the interior of the skull, in which probably all the vessels assume the character of a rete mirabile.

The right subclavian divides at once into two branches, the internal mammary, and the continuation of the subclavian itself, the latter very much smaller than the former. From the anterior surface of the subclavian division a small artery passes inwards below the common carotid coursing forwards along the side of the trachea. The subclavian is continued outwards for a short distance and gives off a branch, the transversalis colli, and then breaks up into a plexus of small vessels constituting a rete mirabile, a continuation of which invests the brachial nerve, no distinct axillary artery existing, and the brachial being only represented by the foregoing plexus. The internal mammary is very large, but one inch from its origin it gives off the posterior thoracic artery which rapidly describes a sigmoid flexure and then passes forwards, itself also ultimately breaking up into a rete mirabile. The internal mammary does not divide into a plexus but it becomes small and can be traced a long way backwards. A twig springs from it and runs along the margin of the sternum internally.

The left common carotid has its origin from the arch of the aorta, about a half inch to the left of the brachiocephalic, and courses forwards for about five inches unbranched; after this point, it occasionally gives off branches to the thyroid, preserving in the rest of its distribution the same characters and divisions as in the right common carotid. The left subclavian arises close to the side of the left common carotid, separated from it by about 0.30 inch, and passes on undivided for almost an inch, when it breaks up into two, a small artery from the point of division proceeding to the thyroid. Of the two branches the posterior is the internal mammary, but where it leads backwards, a few twigs arise to form a plexus. Where the external mammary originates, a small artery runs backwards to the pericardium. The subclavian branch, after a course of an inch and quarter, sends forwards an 
artery along the neck somewhat superficially, and then continuing for another inch it terminates in a rete mirabile as on the left side, immediately external and anterior to the junction of the first sternal rib with the manubrium. There is no defined axillary, and therefore no brachial artery, properly so called; this latter vessel being represented by a rete mirabile following the nerve as on the right side. The left posterior thoracic artery arises about two inches and a quarter from the origin of the left subclavian artery.

The most remarkable feature of these vessels is the abrupt manner in which the branches are given off in dense tufts to form a rete mirabile; also the circumstance that the main arteries, themselves proceeding from the arch of the aorta, terminate abruptly in a similar rete mirabile.

The preceding description has been taken from a newly dead dolphin, the vessels of which were carefully injected immediately after death. The parts about the neck of this Cetacean are usually difficult to demonstrate, as they very rapidly decay. And even in specimens well preserved in alcohol, and to all appearance quite unimpaired, I have yet invariably found that decay had set in at the neck, doubtless from the amount of blood with which this region is surcharged.

Brain.-Those who have attempted to preserve and examine the cerebral substance in mass in a hot climate will appreciate the difficulties of so doing. I succeeded in extracting the brain of one animal, but the fluid in which it was necessary at once to preserve it so shrunk the organ as to destroy many of its prominent features (Pl. XXX, figs. 1, 2, and 3). I afterwards had recourse to taking an internal cast of the cranial cavity, which has supplied certain data defective in the preserved brain. In the following wood-cut (Fig. 16, p. 467) I have given the outlines of the casts of the brain cavities of Orcella and of Platanista, the former enclosing the latter, both having been drawn to one scale so as to bring out the differences in form and size of their brains, the two animals from which the casts were taken having been of similar length.

I shall first describe separately the brain itself with its convolutions, \&c., and then the plaster mould, and lastly draw attention to the distinctions between this latter and that of Orcella. It is to be borne in mind that what I state with regard to the dimensions, \&c., of the preserved brain requires to be modified by what obtains in the cast.

The brain taken from the alcohol had an antero-posterior measurement of 2.90 inches, a transverse diameter of $2 \cdot 65$ inches across the occipito-temporal regions, though only a width of $2 \cdot 20$ inches at the frontal regions, its greatest vertical height or depth being $2 \cdot 10$ inches. The cerebellum was a couple of inches broad, an inch and two-tenths long, and rather less than one inch deep. Not only had the preservation in spirit diminished its size as a whole, but the tendency was to give the brain a more irregular lob-sided appearance than it originally possessed, or than the mould warranted. Nevertheless, even in the fresh condition, there was an appreciable difference between the two sides, and, as will be shown, the convolutions of 
the right and left hemispheres materially differ. What inequality existed, and even the defects from unequal contraction, I have had represented, so that the figures 1, 2, and 3, Pl. XXX, faithfully pourtray the object.

The basal surface (Fig. 3) elicitates the peculiarities of the origin of the cranial nerves. The olfactory bulb does not appear to exist in that area, although the cast shows a protuberance. The optic commissure is relatively feebly represented, although its presence in the depression of the lamina cinerea is distinct. What is still more singular is the extraordinary diminutive pair of optic nerves (2) themselves. These are scarcely, if at all, thicker than an ordinary sewing thread. Indeed, it required a close searching observation to detect them, and the greatest care and skill in manipulation to trace them ; for in raising the membranes the chances of breaking them across were great. But I succeeded in following them up to the very minute perforations by which they entered and passed through in the skull. To the optic foramen I shall again refer in my description of the constituent bones of the cranium.

The pituitary body $(p)$ is of considerable size; even after having been preserved in spirit it retained a comparatively large magnitude. It is of an elliptical or transversely oval figure, 0.50 by 0.25 inch in its opposite diameters, and is of a firm consistence. Two united elevated bodies (a), immediately behind it, appear to be corpora albicantia. The precise conditions of these and their relations to the third pair of nerves I could not ascertain; for the membranes and large vascular plexus interfered with a correct interpretation of the parts; hence, as indistinctness prevailed, I have omitted in the figure (Fig. 3) the third and fourth pairs of nerves. In connection with this difficulty of demonstrating the existence of these nerves, it is interesting to bear in mind that I have ascertained the muscles of the eye-ball to be only rudimentary.

As to the trifacial or fifth pair of nerves (5), these are very conspicuous; both fasciculi constituting the roots being easily determinable, and their superficial origin, as usual, referable to the area of the crus of the cerebellum. The filaments composing the posterior root are stout coarse and very numerous. About half an inch or thereabouts from the superficial origin of the nerves is the broad flat and large Gasserian ganglion, but the branches from it and the further distribution of the nerves were not pursued.

Close behind the fifth, and therefore possibly a little more laterally than in the higher mammals, there is a good-sized cord of the sixth nerve $(6)$.

Judging from the origin and relative position, namely, almost abreast of the sixth nerve, and to the sides apparently joining the pons Varolii to the medulla oblongata, there springs laterally the enormously large nerve cords of the seventh pair (7). At the hinder border of each a much thinner nerve is closely applied, but not quite correctly shown in fig. 3 . If this interpretation be correct,- - and I have every reason to believe it so, seeing that Tiedemann and others admit there is a large acoustic nerve in the Dolphin (Delphinus delphis), - then Platanista agrees in this particular, and adds one more fact to the general proposition, that the 
internal organ of hearing in Cetacea is largely endowed with nervous supply, whatsoever otherwise may be the faculty of hearing in this aquatic group of the mammalia. The second smaller branch of the nerve will, of course, correspond to the facial.

The eighth pairs (8) (pneumogastric, glossopharyngeal, and spinal accessory), ninth pairs (hypoglossal), and the roots of the anterior spinal nerves, form a successive series of loose bundles of large roots, issuing in close succession along the lateral borders of the medulla and top of the cord. Their filaments are encased and interwoven with the thecal coverings of the cord and spinal vascular plexuses, but nevertheless their ganglia are pronounced. The nerve strands of the pneumogastric pair are apparently slightly the thickest; otherwise, it is difficult to distinguish between them.

I may here remark that in this preserved brain any division between the pons Varolii $(p v)$ and medulla oblongata $(m)$ is rather indefinite. The obscure line of demarcation, the want of transverse fibres at the upper part of the latter, and a kind of intermediate piece between them I presume to be Treviranus' so-called "trapezium." If so, it is thus quite appreciable in Platanista. Frederick Cuvier states, a "trapezium" is wanting in the dolphin (D. delphis), himself quoting Tiedemann; on the other hand, Huxley mentions of the porpoise (Phocaena), "the medulla oblongata has corpora trapezoidea."

The cerebral hemispheres are highly convoluted, though questionably if as much as in the porpoise, but, before referring to the convolutions, I shall point out the main fissures and certain of the primary or rather secondary sulci.

The longitudinal fissure is very deep posteriorly, but somewhat less so towards the frontal region, though nevertheless, on pressing aside the lips of the fissure, the corpus callosum is by no means near the surface. The Sylvian fissure $(s y)$ is also remarkably distinct, runs very much upwards on the lateral face of the cerebrum, or has a pronounced vertical direction, and in its course there is a widish deep valley partitioning the fronto-parietal from the temporo-parietal region. Even in the plaster of Paris cast of the cranial cavity, this median depression, or broad indentation of the parts opposite the lower end of the Sylvian fissure, is strikingly evident. It is this sunken area at the position in question which gives a marked feature to the brain of Platanista as compared with that of Orcella and such other brains of the Delphinida that have been figured. I could not satisfy myself of the presence of gyri forming the island of Reil in the Sylvian cleft, but they may be present.

On the right side, I could readily distinguish what may be regarded as corresponding to an antero-parietal sulcus. This commenced on the side of the frontal lobe and above the orbital region, and ran along the upper but outer cerebral face, in a winding manner, but with a tolerably arching curve, across the parietal region and towards the posterior border of the occipital lobe. It is highest just above the top end of the Sylvian fissure. Throughout its course various subsidiary short sulci join it at different points. 
With somewhat of a direction parallel to the former, is another even more highly contorted sulcus, which, beginning within the Sylvian fissure's anterior border, has its termination quite on the opposite side, or right round to the base of the temporal lobe $(I)$. It likewise has many subsidiary sulci or spurs. This corresponds with the fissure of Rolando or postparietal sulcus.

Here, not below, but on the fore face of the anterior lobe of the cerebrum are one or two sulci, which ascend and trend inwards towards the longitudinal fissure. These may be regarded as representatives of orbitofrontal sulci. Quite on the top of the brain and with parallel sinuosities, carried from frontoparietal to the postoccipital lobe are several sulci separating the gyri, of which more shall be said presently.

As to the convolutions on this right hemisphere, apparently three orbital exist and are, less or more, in continuity with the frontal gyri. An anteroparietal fold, with several loops, follows the course already assigned to the correspondingly named sulcus. Beneath this, and with the same kind of arched direction, is a long postparietal fold, which extends to behind the temporal lobe and outer postoccipital face. Besides these, there seems to be a marginal gyrus girding the fissure of Sylvius, and the loops and lobule of which, about the middle of the Sylvian cleft, may in part answer to the so-called central lobe or insula (island of Reil), although here certainly freely exposed. Of temporal gyri there are a few, those of the supratemporal region at least having, in the main, a perpendicular and not a horizontal direction.

On the vertex, besides a portion of the gyrus bounding the longitudinal fissure, that known as marginal, there are at least three broad elongated folds, placed parallel to each other and extending from the suprafrontal to the postoccipital lobe. Secondary longitudinal furrows occur within these, giving them an insular or looped character, wriggling of the folds being most frequent at the occipital region. When in the fresh condition, doubtless, subsidiary cross and oblique sulci give a more varied aspect to this area.

On the left hemisphere neither gyri nor sulci quite agree with what has been described as occurring on the right half. Those longitudinal parieto-occipital folds just spoken of present a modified pattern. The same holds good with the orbital frontal, antero and post parietal and other gyri mentioned. Still, the main features and general pattern have a certain likeness, the departures being in the secondary turns and indentations.

It is to be remembered that in the sketches, (Pl. XXX,) some of these last are not represented, and hence a smoother appearance is given than in reality the brain possessed.

I may sum up this much of the cerebral anatomy by stating that, so far as the convolutions and sulci are concerned, this species of dolphin has a brain of a considerably simpler type than in the porpoise or common dolphin, tending perhaps to some of the Carnivora, though in such a slight degree as still to impress it with all the attributes of the complex convoluted cerebrum of the Cetacea. 
I have hitherto said little respecting the lobes, these being, in fact, very much out of position compared with the mould of the brain. A frontal, parietal, occipital and temporal are undoubtedly present and well marked, but regarding the so-named middle or central lobe of Gratiolet I hesitate to affirm anything.

On making a median longitudinal section of the brain, and thus exposing the inner cerebral face, I noted among others the following points : the great and preponderant volume of the occipital lobe; the very considerable depth of cerebral substance above the corpus callosum, \&c.; an unusual arching of the corpus callosum of moderate thickness at its middle, but with greatly increased thickness of the anterior genu, and specially knob-like posterior spherical extremity; some depth of the fornix behind, but thinning forwards; the thalamus opticus of relatively small, or rather moderate dimension; and prominent corpora quadrigemina.

As to the convolutions and sulci of this inner face, the callosal gyrus makes one great sweep from behind forwards, broadening as it proceeds, and at its sharp turn in front being twice as wide as it is behind. It has no folds in its entire course. The calloso-marginal gyrus is like the last and surrounds it; having only one oblique antero-posterior indentation at the frontal region where it is, so to say, cleft.

The lateral ventricles are short. The termination of the anterior cornu is blunt and barely directed outwards, but, on the contrary, the cavity trends inwards and is deep; the corpus striatum being large, and markedly vertically directed. The posterior cornu likewise is abbreviated so far as its sweep back and inward bend extend, but it is nevertheless deep, and there is a rudimentary hippocampus minor, agreeing with the small calcarine gyrus of the inner cerebral face. The middle cornu also strikes very nearly straight downwards, and it possesses a distinct hippocampus major.

Views of the third and fourth ventricles were but imperfectly seen owing to the above sections destroying the relations of the parts.

The cerebellum is of considerable volume proportionally' to the cerebrum, although, all in all, less than obtains in Orcella. Its superior vermiform process is narrow, not very prominent, but distinct. Lateral lobes are well marked, but the flocculus is only of medium size.

The pons Varolii $(P v)$ is short in both diameters, but it is thickish. As previously stated, corpora trapezoidea are attached to the medulla oblongata; the latter has no very marked columns, but its smoothness inferiorly may have been produced by the spirituous medium in which it was preserved.

The grey matter both of the cerebrum and cerebellum is proportionately in a thick layer, and the sulci, as a rule, in both, are relatively deep.

Lastly, I would note that the vascular supply to the brain must be great if we judge by the membranes within and at its base.

All things considered, the brain of Platanista is wanting in the broad rotundity of the Whale group generally and so marked in Orcella. To a very limited 
degree it has Elephantine characters, viz., height and moderate breadth, though one cannot regard.it in any other light than that of a modified Cetacean form.

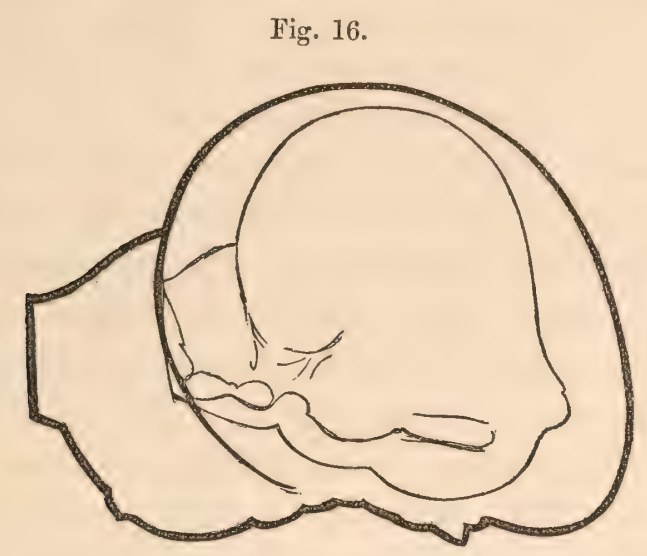

Outlines of the casts of the cranial cavities of Orcella and Platanista, the latter the internal, and the former tk external, outline: drawn to one scale.

Mould of cranial cavity.-The admeasurements of the mould of the cranial cavity of the adult are as follows:-

Greatest antero-posterior length (prominence of frontal lobe to postcerebellar prominence)
Inches.
Greatest breadth (viz., temporo-occipital region)
Diameter at the middle of frontal region, in front of Sylvian depression
Greatest height (fronto-parietal region)
Extreme length of each cerebral hemisphere
Cerebellum in antero-posterior diameter about

The top view of this cast shows at a glance what is even in some degree apparent in the shrunken brain, and which the second and third measurements above amply substantiate, viz., the marked difference in width between the fore and after parts of the cerebrum, that is to say that, while, as a whole, the brain of Platanista is broad to its length, the great preponderance of breadth is at the occipito-temporal lobes; whereas the frontal width is in reality moderate. From above, this cast also shows two nipple-like projections in the position of the olfactory lobes, but dependent rather on ethmoidal depressions than on absolute olfactory nervous expansion. The considerable exposure of the cerebellum is verified in this view of the cast; and the lofty hemispheres of the cerebrum, the deep valley of the longitudinal fissure and especially the open angle of the posterior and inner cerebral angles are all characteristic features.

In the anterior face, the orbito-frontal regions stand forward, whereas the suprafrontal areas retire. The lower latero-frontal eminences again are distinctly impressed, compared with the occipito-temporal prominences; these latter in this foreshortened view standing out almost like wings to the former.

The profile is exceedingly characteristic, for the exceeding loftiness of the cerebrum, compared to its length, strikes one as something most unusual. The very different sweep of the sharply rounded occipital border to the top of the brain, as 
compared with the shelving, almost concave frontal margin, to as far as the nipplelike projections, and the fulness of the infero-frontal or orbito-frontal.parts are also highly characteristic of the brain of Platanista. What is seen of the cerebellum in side view, along with the several large nervous trunks, coincides in producing the impression of height with vertical abruptness behind.

The occipital facies shows great steepness, or perpendicular shelving of the parietal region, and equally oblique inwardly trending borders to the lips of the longitudinal fissure, with a cutting away of the post-inner occipital lobes. The cerebellum is less expansive than might be anticipated, though the nerve and vascular channel impressions are apt to deceive in this respect.

Eye: its general appearance and structure-(Pl. XXXVI, figs. 9 and 10.)Certainly one of the strongest peculiarities of the Gangetic dolphin (Platanista) is the organ of vision. Frederick Cuvier remarks, "Les yeux sont fort petits, noirs, assez profondément enchâssés dans leur orbite, et situés à environ deux pouces au-dessus des coins de la bouche." Eschricht states that the eyes are extraordinarily small in diameter, only $1 \frac{1}{2}$ line. It may be called a blind Whale (according to him), for the perforations for the optic nerve in the skull are only rudimentary. In describing the young skull I shall afterwards refer to the optic foramen, (consult Pl. XL, fig. 1, op).

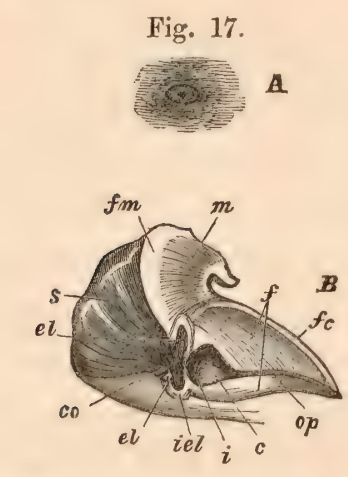

\footnotetext{
A, the eye of Platanista of natural size, seen from the outside.

$B$, a horizontal section through the right eyeball including orbital portion of skin, \&c., of natural size; $f$., fatty cushion surrounding the eye; $f c$, fibrous coat of same, with thin muscular layer below it; $m$, muscular fibres ; $f m$, fibrous membrane beneath; $s$, the skin; op, optic nerve; $c$, eye-chamber; $i$, iris; iel, internal eyelid; $e l$, el, external eyelids; co, cornea.
}

A careful examination of the eye removed from the animal immediately after death and repeated on three occasions on the eyes of different individuals, has established the remarkable fact that, in this Mammalian eye, no rudiment of a crystalline lens exists, although the aqueous and vitreous humours are present. Moreover, in the choroid there is only a trace of pigment, and the optic nerve is reduced to a thread. There is also this further imperfection, that the motor muscles of the eyeball are rudimentary and form a kind of compressor of the cushion of dense blubbery yellow fat, in which the eyeball is imbedded and which is immensely larger than it.

As fig. 10 shows, the upper and lower eyelids are relatively well defined, and in this specimen they approach but do not meet; the aperture being narrow, about 0.20 inch in the natural condition. The cutaneous papillæ of the palbebræ are large; but traces of Meibomian glands or of eyelashes are not discernible. Midst the fibrous fatty and connective tissues of the eyelids, bands of striated 
muscles $(m)$ are distinctly visible so that the lids must be somewhat moveable, though to what extent it is difficult to say.

Tracing the palpebral conjunctival membrane, its cylindrical marginal epithelium is readily followed into the re-entering angle of the eyelid, as it passes on to the cornea. In the angle, it has quite a papillary character, which is lost on the corneal surface. The corneal conjunctiva is nevertheless easily demonstrated, its free epithelial layer assuming a flattened compressed stratified scaly character. This outer layer is relatively of moderate thickness and passes insensibly into a deeper well-defined layer of spheroidal or vertically disposed oblong epithelium. This layer is further and notably distinguished by possessing a series of mucous glands which dip down on to the face of the cornea. These glands are simple and tubular, a few slightly racemose in character; most being long, but some intervening ones shorter. They are filled throughout with nucleated epithelial cells and granules. The submucous connective tissue between the glands and the more fibrous structure of the cornea itself, form papillæ which dip between the glands and in which, I believe, could be traced minute capillary and nervous twigs, and, in more than one instance, I observed an oval body possessing characters resembling the so-called "tactile corpuscles" of the human skin.

Indeed, the structural resemblances of the conjunctiva to the skin in Platanista are close, save the great quantity of dark pigmentary matter in the latter. If these observations be correct interpretations of the nature of the conjunctiva, they will go a considerable length towards the maintenance of the idea that the tactile nature of the front of the eyeball may, to a certain extent, supply the absence of power in the visual apparatus. Whether further investigations will support such a theory remains for future substantiation and more extensive examination.

The cornea proper equals in thickness the layers of conjunctiva above referred to. Throughout, it appears to consist of wavy elastic fibres, elongate or fusiform corpuscular cells, and ordinary connective tissue. The fibres are most dense internally and looser towards the conjunctiva. I feel by no means clear as to the presence of a posterior elastic lamina, the so-called membrane of Demours. At the junction with the iris, a film of transparent cells could be distinguished, but in none of my sections did this extend any distance beyond.

The eyeball, as a whole, has a pyriform shape, the blunt end being forwards. The very open condition at the entrance of the optic nerve suggests, of itself, imperfect development. The sclerotic coat is in close union with the choroid, and the former is tolerably uniform in its thickness, nowhere having any great depth. Its outer fibres mingle with the connective tissue of the surrounding cushion of large fat-cells, and its inner fibres, in commingling with the choroid, have patches of pigmental matter distributed amongst them.

The outer division of the choroid is thus somewhat indistinct from the sclerotic, though, in microscopic sections, the retinal border is as well defined as in the fresh eye. The pigment cells are sparse, except quite posteriorly, where they become more numerous; but a somewhat full vascular supply is evident, even by observation on 
the fresh eye, aided by the use of a hand-lens; but I may state that I did not manage to inject any specimens, being glad to preserve the eye by at once placing them in glycerine and alcohol.

The iris and its ciliary processes are conspicuous objects in the sectional views, inasmuch as the deposit of colouring matter renders them so.

With respect to the chambers and humours, $\mathrm{Pl}, \mathrm{XXXVI}$, fig. 9, shows their relations, \&c., tolerably clearly. The anterior chamber is about 0.08 inch in height, and less than half that in opposite diameter at its widest part, namely, in the middle. It has a crescentic shape, though, as represented in the figure, its walls are disturbed in position. The aqueous humour is thin, watery and clear, and the vitreous humour is of rather a jelly-like consistence with a faint bluish tint. The contour of the vitreous humour and chamber is decidedly pyriform.

A transverse section of the trunk of the optic nerve showed the nervous matter along with its fibrous sheath to be no thicker than the stem of an ordinarily sized pin; indeed, the latter had the advantage in diameter. The neurilemma in part, and also the surrounding thick fibrous envelope, have pigment corpuscles scattered through their tissue.

From the foregoing facts, which may be again briefly reiterated, viz., the rudimentary nature of the eye-rudimentary in the absence of a crystalline lens; the feeble development of the pigment of the choroid; the reduction of the motor muscles of the eye to a thin muscular sheath investing a mass of blubber; the deep imbedding of the visual portion of the eye; the glandular and tactile character of the conjunctival investment of the cornea; and the very feeble optic nerve; all lead to the conclusion that this mammalian eye can be of little more use than as a feeble receiver of impressions of light. Such a conclusion is not only rendered probable by structural conditions, but also by actual experiment. The young captive dolphin, to which I have already referred, when objects were rapidly passed in front of its eye, did not exhibit any manifestations of having perceived them; there was no startling, no marked turning aside to avoid them. Moreover, the animal did not appear to be able to ascertain the dimensions of the vessel in which it was confined, because it invariably struck its snout against the boundaries of the 'tank before it turned to describe the circuit of its limits; whilst, in contrast to this, the fish put in beside it for its food at once knew their bearings exactly. It, however, remains yet to be proved what are the powers, if any, of this eye under its natural conditions of a murky liquid surrounding. Doubtless, the cornea being obscured, so to speak, by the glandular structures which occur over it, must materially impede the entrance of the little light that reaches it through the minute external orifice.

But, again, there is the very remarkable feature of the tactile nature of the investing membrane of the eye; if this be fully verified, we should have an eye quite unique in its transitional character, and even more rudimentary than the eye of those burrowing rodents in which the organ is invested with a thin layer of skin. And, besides, there would be the great peculiarity that this is an eye disappearing 
under an aquatic life. According to our present knowledge, the only explanation to offer for the diminutive and modified character of this eye is on the theory of disuse arising from the absence of conditions favourable to vision; and to this may probably be added the action, to a limited degree, of natural selection.

There are difficulties, however, even in such an explanation, because there is not such a wide difference between the conditions of the Gangetic Platanist and those of the Irawady dolphin, or in anything connected with their respective river-systems as to easily account for the great degradation of the organ of vision in the one case, and the quite ordinarily sized eye in the other, as well developed as that of any marine Cetacean.

Urinary organs.-The kidney is a flattened, cake-like gland; in the adult 4 inches long by 3.50 inches in extreme breadth. The anterior end is rather pointed and turned towards the internal border. The posterior surface is made up of forty-seven, more or less, hexagonal lobules, flat, or slightly convex externally and packed closely together by their opposed faces. Laterally and internally, a few of the lobules become fused together. Nineteen of the marginal lobules of the dorsal surface are common to the two faces of the organ, while there are twenty-nine to thirty besides these visible on the anterior aspect, so that the kidney is made up of about eight lobules, visible externally. They vary from half an inch to one inch in superficial area, but are destitute of conical apices.

The cortical layer occupies the greater part of the lobules; some of the papillæ have as many as two or three mammilliform processes.

There are generally three calyces opening into a common dilatation (pelvis of lobule) of the duct at the base of the united lobules. In these cases generally one of the papillæ has its apex directed towards the periphery of the kidney.

Ureter.-The pelvis of the ureter is formed by the junction of six branches resulting from the union of the secondary and tertiary ducts of the renal lobules. The ureter altogether is 6 inches long. In the male, after leaving the kidney, it crosses behind the lower external corner of the testicle and beyond that point it passes behind a considerable portion of the abdominal venous plexus, which rests on it, and immediately below this it is posterior to the transverse coil of the vas deferens, and then a little further backwards and inwards it crosses over the descending coil of the generative duct to the bladder. It preserves the same general direction in the female, running downwards to the anterior wall of the vagina till on a level with the first great transverse fold of that channel. In the first part of its course it lies close behind the origin of the ovary.

The renal artery and vein enter the kidney at the upper extremity of the longitudinal groove. The artery is internal and dorsal to the vein. It is first placed in a deep sulcus, and the main trunk runs along the internal margin of the groove by the side of the branches of the ureter, and divides into numerous twigs, which reach the substance of the kidney by passing behind the ureter. The vein leaves the kidney external and anterior to the artery and lies along the outer margin of the groove. 
Urinary bladder.-This viscus is pyriform, 6 inches long in the male when contracted; its anterior wall 0.50 inch thick. In a female corresponding in dimensions to the above, the bladder is not more than 3 inches long. In both, the inner surface above the attachments of the ureters is densely rugose, while the area below them or trigone is perfectly smooth. Where the ureters are connected to the posterior wall, the position of each is marked internally by a deep pit-like puckering of the mucous lining, and their orifices are about 0.75 of an inch below and internal to this. Each opening is prolonged backwards and inwards for 0.9 inch as a groove; anteriorly they are separated by an interval of 0.5 inch, and below by little more than $0 \cdot 2$ inch.

Genital organs of male.-The orifice through which the penis is protruded is situated in the adult about 1 foot anterior to the anus. When retracted the organ describes two curves. Tracing it backwards for 11 inches we find it bent outwards and forwards upon itself for 4 inches, and then backwards and inwards for 3 inches more; so that the total length of the penis when straight is fully 18 inches. It is 1.50 inch in diameter at the base of the glans and 2 inches at its thickest part, immediately posterior to the second curve. The body is oval in transverse section, but the base of the long filiform extremity, where it springs from the bottom of the glans, presents a triangular cross section. It is interesting to observe that the urethra, in the greater part of its extent, is placed to the left of the mesial line, in this following the asymmetry that characterises the uterus and the cranial bones of both sexes. The filiform process (fig. 18 p, p. 495) originates at the base of the glans from which it is quite free. It is 5.25 inches in length and projects 3 inches beyond the glans. Its free extremity is 0.20 inch in diameter, while its root is one inch in thickness and is triangular in transverse section as far as it lies in connection with the glans; but beyond that point it is cylindrical and whip-shaped. Its surface, on which the lobes of the glans lie, is marked by a prominent longitudinal ridge which appears between the base of the lobes of the glans as a triangular fold of skin of the frænum. The under surface of the process is: continuous with, and on the same plane as, the neck of the penis. The bilobulate glans resembles the pointed ears of a dog. The lobes are 2.25 inches in length and $1^{\prime \prime} \cdot 25$ in diameter at their bases, and $1^{\prime \prime} \cdot 40$ in their greatest breadth which occurs about their middle. Their upper surface is smooth and continuous with the dorsum of the neck, but their under surface is divided longitudinally into three nearly equal divisions by two ridges, the more internal one corresponding to the ridge of the dorsum of the filiform process to which it is applied, and the other is closely opposed to its inferior lateral margin. The surface internal to the inner ridge lies against the corresponding surface of the other lobe, when the organ is retracted, but the lobes fall apart, when the penis is protruded. The area between the two ridges is in contact with the side of the filiform body. The portion external to the outer ridge is so deeply. longitudinally channelled that its free margin is in contact with the ridge. This arrangement admits of the glans being stored away in small compass and provides for great lateral expansion when the 
organ is active and distended with blood. The prepuce is attached about 2.40 inches behind the base of the glans, and the colour of the parts so far back is nearly the same as that of the body skin, but dependent on the shed cuticle of the opposed surface, which when scraped off exhibits a yellowish cutis below it. The prepuce as far as it covers the glans in the retracted state of the organ is smooth, but anterior to that the cutis is thrown into a dense mass of fine longitudinal folds or ridges, the margins of which have a finely serrated appearance due to the presence of minute papilliform processes, probably highly vascular. 'These become more strongly developed close to the point of union with the external skin, even to the entire loss of the supporting ridges. In this locality, they are laterally flattened processes placed side by side in their long diameters, forming regular wavy lines of filaments, about 0.04 inch in length. The lines are parallel to each other, but separated by regular intervals of not more than 0.01 inch; on the removal of the smooth covering of cuticle on the glans, a circumstance which frequently occurs in spirit specimens, the pale yellowish cutis is seen to be composed of irregular, transverse and longitudinal ridges composed of triangular papillæ of the same character as those which occur on the anterior portion of the prepuce, but only a little larger. These are distributed longitudinally on the back of the glans, but transversely on its sides.

Urethra.-The prostatic portion passes downwards and backwards till reaching the caput gallinaginis when the direction of the canal suddenly changes; then it runs directly forwards, forming an acute angle with the prostatic portion and preserving this course as far forwards as the anterior extremity of the membranous portion, where in the coiled state of the organ the first bend begins. Preserving its usual position on the inferior aspect of the penis till within 4 inches from the glans, it then crosses over to reach the dorsal aspect, where it enters the base of the filiform process. In the prostatic portion the canal narrows immediately opposite the rounded posterior extremity of the united cavernous bodies, but dilates on each side of the caput gallinaginis. In looking from above, into the lower part of this section of the urethra, the caput gallinaginis is seen in the distance projecting on the commencement of the membranous portion and to be nearly as large as the capacity of the canal opposite to the bulb of the spongy body. Viewing the crest from before, it is seen to be opposite to the end of the corpora cavernosa, and on making a vertical section of the canal and pulling aside its walls, a deep depression is seen on either side of the crest, with a few folds indicating that this portion of the canal is capable of considerable distension. The transverse breadth is about 0.90 inch, while the posterior extremity of the united corpora cavernosa is only 0.40 removed from the upper portion of the base of the crest. The membranous portion is 3 inches long, and in transverse section the tube is a vertical slit 0.25 inch in length, about 5 inches anterior to this the canal is reduced to an obliquely arched opening $0 \cdot 10$ inch in diameter. Three inches further forwards it is even still smaller, but preserving its obliquity. Immediately behind the prepuce, the section is nearly round, and its capacity slightly increased. Halfway between this and the base of the 
lobes of the glans, the canal has the outline of a small arch 0.06 inch across, and an inch further on it is a minute obliquely transverse slit 1.05 inch, and, an inch in advance of this, it is vertical and hardly distinguishable from the crypts of the spongy body. At the base of the lobes of the glans it is a transverse opening 0.12 inch across, and tracing the canal into the filiform process its capacity is increased to $0 \cdot 24$, in a specimen much shrunk by preservation in strong spirit. The mucous surface of the urethra is thrown into finer longitudinal folds throughout its whole length, from the membranous portion to the base of the glans; thus conferring on it a considerable capacity for distention.

The only lacunæ I detected occur opposite to the attachments of the retractor muscles and are elongately crescentic openings directed backwards.

In the female the urethra is 250 inches in length. Between the extremities of the grooves of the ureters, which run backwards for 0.90 inch, a longitudinal fold arises from a small eminence 0.25 inch long by 0.10 high and is prolonged along the whole extent of the vertical wall of the canal.

The prostate has not been demonstrated to my satisfaction, as the specimen under examination is not in good preservation. Four small pits arranged somewhat in a circle and situated to the side of the caput gallinaginis appear to be the openings of the ducts from this body. The caput gallinaginis will be considered in connection with the vasa deferentia.

Corpora cavernosa.-After separating from each other, each is prolonged backwards and outwards for 1.50 inch as a dense fibrous rod; this when bisected longitudinally is found to be filled with a soft spongy substance, contained in a special cavity shut off by a fibrous interval of three-quarters of an inch from the true cavernous substance of the penis.

The corpus spongiosum investing the hinder wall of the urethra divides into two crura; each prolonged into the centre of the bulbo-cavernosus muscle of its own side, and lodged in a strong fascia derived from the inner wall of the fibrous investment of the corpus cavernosum in the erector muscle. A vertical section shows this position of the spongy body extending $2 \cdot 25$ inches backwards from the urethra, around which it is prolonged forwards as a thin investment.

Relations of corpus cavernosum and corpus spongiosum.-Eight inches anterior to the membranous portion, a transverse section shows the corpus cavernosum with a rounded outline. Immediately behind the attachment of the prepuce the section is transversely oval, and about halfway between the latter locality and the base of the glans the organ preserves the same form. A section through the base of the lobes of the glans demonstrates the spongy body of nearly the same dimensions as the separated halves of the corpus cavernosum, between and rather above which it is placed. The corpora cavernosa either terminate here or are prolonged in their fibrous coverings into the lobes of the glans; while the spongy body, or more correctly the urethral continuation of it, is lengthened into the filiform process with the urethra at its upper extremity. The corpora cavernosa terminate in a rounded end 0.25 inch across, and external to their fibrous sheaths are 
surrounded by the spongy tissue just mentioned, which is of a highly erectile character, the lobes consisting exclusively of this tissue except when the corpora cavernosa are prolonged into them.

I have stated that the cavernous bodies may either pass into the lobes of the glans or stop short of them, an observation which I am enabled to make, having examined two organs in which this variation is shown. On the right side of one, the anterior crus passes for a full inch into the lobe directed forwards and outwards, while the other of the opposite side is projected into its lobe for only 0.50 inch ; but 0.36 inch anterior to its rounded termination there is an isolated piece of brown tissue of the same nature as its spongy substance, 0.36 inch in length and invested by a fibrous capsule. It is placed transversely and connected to the end of the crus by a line of fibrous tissue. In the other penis the corpus cavernosum is found extending 1 inch into the left lobe, but no trace of it can be detected on the right side in which its blunt end is observed at the base of the glans.

In the filiform process, the spongy body soon unites with the other erectile tissue which surrounds it, and the resultant structure is prolonged to the extremity of the process, becoming finer and finer and less dense as it nears the point.

The preputial sheath is 7 inches long and the circular fibres which form it appear to be derived from the panniculus carnosus muscle and extend backwards to behind the first bend.

The erector penis invests all the sides of the crus of the cavernous body except the inner face and the last half inch internally of its superior margin, which gives attachment to a bundle from the ejaculator seminis. It consists of fibres which arch downwards from the upper to the lower margin, where they terminate in a very strong glistening fascia adherent to the under surface of the crus.

Ejaculator seminis.-This muscle is very thick and encloses the spongy substance. It arises from the strong fascia attached to the inner wall of the fibrous covering of the corpora cavernosa, and the fibres stretch from before backwards and inwards, outwards and upwards to be fastened to the fascia in connection with the upper surface of the crura common to the two muscles. A few are also attached to the strong rectal fascia. Anterior fibres are directed downwards and backwards to meet the fellows of the opposite side in a strong fascia behind the bulb, and have the retractor muscle lying below them.

A strong muscle (levator ani) arises from the posterior extremity of the outwardly prolonged lamella of the fibrous investment of the crura, and expands towards the middle line over the hinder end of the ejaculator seminis, to become invested along the rectum by a wide surface and to mix with the sphincter ani.

Retractor muscles. - These are two long cord-like structures fixed posteriorly to the strong fascia covering the anterior surface of the ejaculator, and lying alongside of the rectum. Passing out between the two ejaculators they, of course, press against the bulb and rest on the line of union of these two muscles and the membranous portion of the urethra. The muscles are in close contact till they appear beyond the ejaculator muscles where they diverge to reach their respective sides of the penis. 
Testes.-These glands are situated external to the kidney, but do not reach quite so far as that organ and rest on the depressor muscles of the tail and on the transversalis abdominis. Their form appears to vary with age and functional activity. In one specimen caught on the 14th August the testicle presents three surfaces and is deepest from the dorsal to the ventral margin. The surface looking inwards towards the middle line is broad and slightly concave, and the one external to it is convex and narrowly crescentic and is directed ventrally, whilst the dorso-lateral surface is also broad but convex, and marked at its hinder end by a deep pit. It is 4 inches long, 3 broad across the concave face, and 2 inches in thickness from the ventral to the dorsal surface. In this specimen, the head of the epididymis covers the anterior and external surfaces of the upper extremity. The body and globus minor of the epididymis are dorso-lateral and external. In an individual captured on the 18th July, the testicle is a flattened oval, or nearly so, with only two surfaces, an inner and outer, and a continuous margin, its greatest thickness not exceeding 1 inch. The head of the epididymis is confined to the upper extremity, while the body is placed along the inner margin of the surface.

The epididymis, when dissected off the testicle in both, is seen to be made up of five distinct sections; first, the head with the vasa efferentia, the former consisting of two portions, one of which is smaller than, and overlays, the other; second, the body, which is thin and leaf-shaped; third, another thin but irregularly shaped part eccentric to the coil that connects it with the portions on either side of it, and with a short process projecting from its extremity and applied to the back of the testicle; fourth, a long, rather rounded oblong part connected by a pedicle to a short thick flattened trowel-like piece, which constitutes the fifth and last division or tail. The total length of the masses of the aggregated coils of the seminal tube is 16 inches, exclusive of the eccentric division, and it is probable that if the whole were uncoiled that it would extend to 30 or 40 feet.

Vasa efferentia.-These emerge on the internal surface of the testicle near its anterior end, and the orifices of thirteen tubes can be detected, when the structures are cut away close to the tunica albuginea. The vasa efferentia consist of four kinds : first, a simple convoluted tube; second, tubes with appended cæea; third, united divergently simple ducts with basal branched cæca; and fourthly, blind cæea or aberrant vasa efferentia. The first is about 3 inches in length and is much coiled; the second may have one or more small cæea at its base, either communicating with its canal or opening by separate orifices into the testicle. The third form consists of two portions, first two vasa efferentia, one with appended cæca, and the other simple and separate from the former at the point of divergence from the gland, but united beyond the cæca in a common tube; this afterwards forming two ducts. Two of the exca lie side by side with separate canals, but the one next the duct gives off a branch which enters it below the point, where it unites with its fellow. The fourth description comprises either simple or branched erca communicating with the testicle, each by an opening of its own. These 
are aberrant vasa efferentia, and the other unbranched cæca may be regarded in the same light.

Vas deferens.-This passes off from the epididymis at its outer and posterior extremity to reach the body, bending on itself to do so. It leaves the anterior extremity of the tail on a line with the lower end of the testicle along the free margin of the fold of the peritoneum, which stretches across the pelvic portion of the abdominal cavity and connecting the testes. It has the ureter behind it as it leaves the epididymis, and in the mesial line is in close contact with its fellow of the opposite side. Thence it suddenly turns backwards along the side of the contracted bladder and is crossed by the ureter immediately above the point of its attachment to that viscus. Beyond that locality it passes downwards and inwards and perforates the wall of the prostatic portion of the urethra about 0.75 inch above the caput gallinaginis to terminate on it as the seminal duct.

Caput gallinaginis. - This is situated on the back wall of the prostatic portion of the urethra, and the longitudinal ridge from the uvula vesciæ is continued with it. It depends on the floor of the urethra below it, and has a rather deep recess on either side of it, in which the ducts of the prostate are situated. It is 0.30 inch in length and in breadth, and 0.25 in height. Its extremity is surrounded by a fringe of mucous membrane which seems to assist in closing the two orifices of the seminal ducts, one of which is placed on either side of its free extremity with the sinus pocularis between and rather posterior to them. They are rounded orifices placed on either side of a thin partition, the free end of which expands from before backwards into a somewhat elongatedly rounded membrane with a rather tumid edge, and in the centre of which is the very shallow depression, the sinus pocularis. It is little more than 0.02 inch in depth, and when the two halves of the tumid edge are opposed like lips to the sinus, it cannot be detected.

Mammary organs.-In the male the mammæ are situated 0.30 inch in front of the vent, with an interval between them of 0.25 inch. The nipple is freely exposed on the surface, and is a short rugose cylindrical structure 0.25 inch in diameter, and 0.30 inch in height. Its tip is pale yellowish, perforated at the apex by a single orifice and more or less flattened and rugose. The gland is a small honeycombed structure, 0.30 inch long, and 1 inch in diameter, surrounded by a ring of fine muscular fibres derived from the superficial sphincter of the anus. The area around the anus is highly vascular; the orifice is transverse and the outer skin thrown into numerous cross folds.

In the female, the nipple is situated at the base of a deep pit, about an inch anterior and external to the anus (Pl. XXI, fig. $1, m), 0.45$ inch in depth, and 0.50 inch in longitudinal diameter. The nipple itself is a small conical structure compressed laterally, about 0.20 inch in height by 0.30 inch in its longitudinal length, and 0.15 broad in its transverse section. It is perforated at its apex by a single orifice that admits the passage of a probe. The canal in question is very short, not more than 0.20 inch in length, but it is very extensile. It commences at the posterior 
extremity of a wide chamber, $1 \cdot 10$ inch in length, the walls of which consist of a strong fibrous structure thrown into tendinous bands and marked by a few crypts, the openings of lacteal canals. The outer surface of the external half of this chamber is invested by a sphincter muscle for expelling its contents and keeping the orifice' leading to the canal closed. The chamber at its anterior end contracts to a moderately small orifice surrounded by a loose fold of the tendinous wall, that hangs so freely into the chamber as almost to resemble a valve. Placed immediately before it, is the capacious cavity into which all the larger ducts pour their secretion. This is 1.25 inch in length, by 0.50 in breadth, and its wall has the same tendinous character as the former. Anteriorly it is continued on into the gland as a duct, 0.20 inch in width. Numerous ducts open into this chamber from all directions, each orifice being marked by an arched fold; on compressing the mammary slit of a living gravid female a clear pale amber-coloured fluid, with a distinctly saltish taste, was squirted out with considerable force. It dried on the fingers like a varnish and was very sticky in drying. It consisted almost entirely of albumen.

The gland itself is fully 6 inches long with an average breadth of 1.50 inch, and it extends 3 inches anterior to the commencement of the duct at the head of the second chamber, and is placed parallel to the outline of the vulva, 1 inch below the surface. It is a pale yellowish structure of considerable consistence.

The extensile nature of the tissues surrounding the two chambers must admit of their being considerably distended with milk when the gland is active, and the probability is that the milk is squirted into the mouth of the young. The long snout of the young with its formidable array of teeth, and the circumstance that the skin is tightly drawn over it, and that the applied surfaces of the upper and lower jaws lie between the rows of teeth render it highly improbable that the young is fed through the extremity of the snout. The concave surface, however, at the base of the snout seems admirably adapted for application to the mammary region of the mother, and it seems likely that the young rises sideways to the nipple, so that the side of the mouth with its fleshy lips is brought over the mammary region, and that the milk by the pressure is squirted into it. In the living gravid female which came under my observation the slightest pressure exercised around the mammary slit caused the lacteal fluid as I have said, even before the birth of the fotus, to be squirted out to a considerable distance.

Vulva in young and adult stages.-In the virgin, measuring 57 inches, the vulva is 2.18 inches long, and in the gravid female $4: 36$ inches. In the former the mammary slits lie nearly in a line with the labia majora, but in the adult they become more external. The clitoris (Pl. XXXII, fig. 2, cl) is well developed, and in the virgin where its true form is best seen, it consists of a bilobular glans, beyond which projects a filiform process resembling the tubular termination of the male urethra, and in the virgin at the anterior margin of the base of the glans there is a mesial rounded eminence, which, however, in the adult has become shrivelled into folds. In the virgin the glans is half an inch in length by 0.36 inch in breadth, and the filiform process has the same length. The division between the lobes of the glans is very 
deep, and the two resultant structures resemble the cotyledons of a growing bean. The process arises between them posteriorly. A preputial fold springs from the base of the glans on either side of it, and the two passing forwards enclose it and the rounded eminence, terminating before the latter. Each fold arises from the glans as a double fold, the two portions of which rapidly unite, enclosing a depression. The labia minora are only faintly indicated. The urethral orifice lies to the right of the base of the filiform process, and is therefore eccentric in position to the mesial line of the body. The area around it and the corresponding surface on the opposite side are devoid of pigment.

In a female measuring 82.50 inches in length, the generative opening (Pl. XXXI, fig. 1) is a longitudinal slit about 3.50 inches long. The lips consist of a thick spongy mass, rich in oil. The internal skin is thrown into transverse wrinkles and is continued internal to the lips for about half an inch, preserving its colour and general character. Beyond this point its place is taken by the mucous membrane of the vagina, which is of a pale yellowish hue marked by greyish patches. On pulling the lips apart the sides of the general opening are seen to be thrown into. longitudinal folds.

Lying between the anus and the vulva in a transverse area, which is nearly devoid of pigment, are four small openings. Two occupy the middle line, and are placed so close together that they are only separated from each other by a thin septum, and their passages diverge outwards, each leading into a shallow sac. The other two orifices, placed on either side of the foregoing, are separated from them in an individual measuring 54 inches by an interval of about 2 millimetres, and are similarly constituted to the former. I can detect no glands in connection with these pits.

Characters of the virgin vagina and uterus.-In a female a little more than half grown, the vagina is 3.75 inches long (Pl. XXXII, fig. 1). It does not, however, occupy the mesial line, but tends to the right side of the body, so much so that the vaginal mouth of the os uteri is on a line with the right mammary slit, and, moreover, its ventral wall is directed outwards to the right side, whilst its dorsal wall is bent outwards to the left side, with the rectum placed over it to the left of the mesial line. Its transverse axis is thus placed obliquely from above downwards from right to left. Besides, however, being dextral in the course of its long axis, the latter presents three distinct curves. The first arches upwards and forwards, the convexity of the curve being directed upwards and backwards, which is followed by an anteriorly concave curve of the ventral wall, succeeded, behind the os uteri, by an upward and forward sweep. The canal dilates from behind forwards in the first three-fourths of its course, i. e., until it reaches the portion in which there are certain persistent cross folds in the wall, which resemble so many spurious uterine mouths. The external opening was so extremely small and puckered that the tip of the little finger could be introduced only with difficulty : there was no membrane resembling a hymen. It was thrown into two posterior and two anterior principal folds, the two former diverging to enclose the anus, being continued on to the dorsal wall of the vagina, only however for a very short 
way, while the two latter constituted broad folds, which were persistent in the enlarged vagina of the pregnant female. Besides these there are some other, but much smaller, folds around the opening. At the middle of the canal there is a strongly marked cross fold (Pl. XXXII, fig. 1, $f f$ ) on the ventral aspect, with some short oblique creases at its sides, and a short transverse fold before it. The first-mentioned limits anteriorly the longitudinal folds that arise at the opening of the vagina, and it can be detected in the vagina of the gravid female. The dorsal surface of the canal has only a few feeble longitudinal folds, and the area immediately before the transverse furrow of the ventral surface is perfectly smooth, but anteriorly to this occur the three or four great permanent folds, the os tince, characteristic of Cetacean vaginæ. The first two of these folds are quite smooth, but the third has generally its mucous membrane thrown into twenty to twenty-two thin secondary leaf-like folds, and in this respect it closely resembles the os uteri externum, which is covered with similar lamellæ more perfectly developed, and which are more or less continuous with others which occur on the os uteri internum itself. At the free margins of this the third fold and of the os uteri externum these lamellæ are bent upon themselves, and in the gravid uterus they are converted into very thin overlapping leaves. The appearance of the vaginal folds and the character and distribution of the lamellæ in the virgin are shown in fig. 1, Pl. XXXII, while at fig. 2, Pl. XXXII, is a representation of the inner orifice of the os uteri internum in the gravid female. The long axis of the entrance to the womb is directed obliquely forwards slightly to the left, but the uterine orifice is to the right of the middle line. The body of the uterus, which is 0.65 inch in length, is curved first to the left and then to the right side, so that the orifice of the left horn is brought into the same line with the os uteri internum, while the opening to the right horn lies external to it.

Owing to the oblique position of the vagina, and consequently of the uterus, the left horn also lies at a lower level than the right. These relations of the parts in such cases would seem to be conducive to the fertilization of the left horn in preference to that of the right, which is placed at a higher level and eccentric to the os uteri.

In the unimpregnated uterus (fig. 3), the horns bend backwards towards the organ, until they are on a level with the ovaries. The walls of the common cavity of the uterus (fig. 1, $u$ ) become thickened as they approach the horns, and the lamellæ of the mucous surface become swollen into rugæ. The mouths of the horns are large enough to admit a crowquill, and they are separated from each other at their commencement, for about 0.65 inch, by the common septum, the free margin of which constitutes their inner lip. Their inner surfaces $(f)$ are covered with from six to seven prominent longitudinal folds, usually terminating at their mouths in free ends, although they sometimes there unite. At the angle where each horn bends backwards on itself the mucous fold which passes over its induplication forms an angular projection inwards, and the rugæ or folds converge to the opening of the Fallopian tube, where they terminate. The right horn is 1.75 inch long, and the left 1.65 in length with a diameter of 0.36 inch. 
In the vagina of the virgin Platanista the mucous membrane has the general character of that structure in the sow.

Fallopian tubes.-These describe five distinct curves from the horns to the pavilion (Pl. XXXI, fig. 1), two of which are much greater than the others. The first of these occurs at the uterine end of the tube, and lies close to the attachment of the ovary, where its wall is quarter of an inch thick in the virgin. In the impregnated dolphin, it forms a well-defined prominence lying below the ovary on the left side, where its outer surface is finely corrugated (fig. $1, f$ ); below the right side there is no sush projection, although the corrugations are found marked over the area of the curve. In the virgin, this bend of the Fallopian tube, which is the narrowest part also in the mother, is visible externally as a small swelling (Pl. XXXII, fig. 3). The next curve is the better developed of the two. It lies a short way behind, where the tube begins to widen to the ostium abdominale, and is best seen in the virgin and on the right side of the mother. It is worthy of note that the right Fallopian tube of the impregnated dolphin has retained the characters of the convolutions of the virgin, while the left Fallopian tube has considerably departed from them ; therefore, may we not surmise that the virgin character of the right Fallopian tube would indicate that if this dolphin had ever before been a mother, she must have conceived as now in the left horn?. In the virgin the Fallopian tubes of both sides are of equal extent, 2.50 inches, while in the impregnated dolphin the right Fallopian canal is longer than the left, the latter being only 6.50 , while the former measures 7.50 inches in length. In the virgin, the tube has such a capacity that it can be slit open with moderate facility by a pair of ordinary dissecting scissors, and, of course, it is much wider in the impregnated female on both sides of the body. From its ostium uterinum the tube contracts as it passes through the first curve which has been described, and widens as it approaches the second, more rapidly dilating as it approaches the ostium abdominale, immediately before which it is somewhat again reduced in diameter. It is lined with fine permanent lamellar folds of different depths, which have an origin at the commencement of the tube, either distinct from the folds of the horn, or, as in the specimen before me, two of the folds of the left tube result from the division of one of the folds of the horn (Pl. XXXI, fig. 3) and immediately become so divergent as to embrace within them four other folds which have an independent origin of their own, only two or three other folds of separate origin being external to the embracing laminæ. The folds become slightly larger as they approach the ostium abdominale and much more numerous, and are connected together by oblique finer folds, which, in their turn, have cross fibres running between them, so that the appearance of a fibrous mesh work is produced around the ostium abdominale. The laminæ are prolonged outwards on to the pavilion in a radiate manner. In the impregnated female, the folds preserve the same characters as in the virgin, until they reach the dilated portions of the tube, and more especially around the ostium abdominale, where they form thin leaf-like overlapping folds like those which occur round the mouth of the uterus itself, and are prolonged on to the pavilion as thin radiating folds, some of which are an inch and a half in breadth. In the virgin the orifice of 
the pavilion on the right side is much more contracted than on the left (PI. XXXII, fig. 3), which is wide and patulous. They both look forwards. Springing from the superior external margin of the ovary is a prominent fimbria ovarica, which is prolonged outwards along the superior margin of the pavilion, on the inner aspect of which there is a deep pouch at its base. This pouch is formed by a broad transverse fold that passes between the ovarian attachments of the margin of the pavilion. In Orcella this fold is further removed from the ovary and constitutes a broad veil on the inside of the pavilion, dividing it into two chambers. In Platanista the margins of the pavilion are attached at the outer extremity to the margins of the ovary, but in Orcella in the impregnated female one border is continued as a delicate membrane along the Fallopian tube as far as the horns.

Minute structure of Fallopian tube.-This tube in P. gangetica consists of the most remarkably extensile tissue. A very small fragment, about one-half of an inch in length, when freed of its external peritoneal coat is capable of being extended to nearly one yard in length. The fibrous structure which manifests this remarkable property resembles the fibrous layer of the uterus. In both the virgin and maternal oviducts, the walls are thrown into well-marked longitudinal folds, which, however, are best seen in the former. The wall of the tube is lined with a well-defined coat of columnar epithelium overlying a richly corpusculated fibrous layer, resting on another layer of much longer wavy fibres, with fewer corpuscles, and to which the expansibility of the tube is chiefly due.

Utricular glands in the foetal and in the virgin uterus.-I have pointed out (ante, p. 397, Pl. XXXVIII, figs, 5, 6 and 7) that these structures are absent in the fœetal uterus of Orcella.

In Platanista, however, utricular glands are well developed in the foetal womb (Pl. XXXVIII, figs. 1 and 2), indeed almost to the same extent as in the unimpregnated uterus of the adult animal (fig. 4). This observation shows that it is unsafe to form an a priori judgment as to whether these glands should, or should not, exist in fœetal uteri, because Professor Turner, who is generally distinguished by great scientific caution, states that utricular "glands are not formed during intra-uterine life, and it is probable that they are not fully developed until the uterus reaches the stage of sexual maturity."

Under the microscope, each gland appears as a distinct system in the virgin (fig. 4), depending in a highly-branched manner. by a single tube from an orifice in the cylindrical epithelial surface-layer, situated in a slight depression of the mucosa. Together, the glands constitute a considerable mass, forming one-fourth or so of the total thickness of the walls, and are closely packed against each other, but very minute compared with the glands of the gravid uterus (fig. 8), than which also they have a much more decidedly vertical arrangement, the glands in the gravid uterus becoming stretched out by the extension of its walls. They would appear to be as numerous in the fotal and virgin as in the gravid uterus, 
their seeming greater abundance in the latter being due to increase in their dimensions.

The fibrous and corpusculated nature of the submucous tissue is well displayed in fig. 2.

Ovary of virgin.-The ovaries (Pl. XXXI, fig. 1, o, and Pl. XXXII, figs. 1 and $3, o$, ) are perfectly sessile, elongately oval bodies, about $0 \cdot 75$ inch in length and 0.47 in breadth. A broad fibrous fold, covered with peritoneum, and enclosing blood vessels in its margin extends from the inner end of each ovary to the dorsal wall, ceasing on a line with the inferior border of the kidneys, halfway between that point and the rectum. The ureters follow the dorsal attachment of this fold on either side, which forms a deep pouch thus (Pl. XXXII, fig. 3, Po, ) with the folds of peritoneum holding the Fallopian tubes in position, and which run outwards, and then forwards, to the kidneys.

On slitting off the left ovary I cut through a small sac at its base, apparently closed and lined with serous membrane thrown in folds.

Vagina in the gravid female.-From the anterior margin of its orifice to the os uteri externum, in the gravid female, the dimensions of which have been previously given, the vagina measures 8.25 inches, while from the former point to the anus it is only 1.50 inch, which is also the greatest diameter of the canal at its middle. The anterior wall of the lower two-thirds of its widest part is thrown into large folds, possessing distinct characters, whereas the dorsal wall is comparatively smooth, having only four rather feeble longitudinal folds, a circumstance which is probably attributable to the fact that extension of the canal is more limited in the latter than in the former direction, there being less space for expansion. The position of the folds in question is mapped out in the virgin vagina, in which the space, posterior to the permanent folds, is divided into two by the transverse line already described. The folds of the hinder division of this space, as they occur in the virgin, can still be clearly traced in the almost parturient vagina, but they are, of course, enormously enlarged in the latter and form a prominent oblong swelling, with a smooth space on either side of it. The anterior division of the space, which is perfectly smooth in the virgin, is raised in the gravid female into a convoluted mass of swollen folds, some of which join the lateral and mesial permanent folds of the posterior space. Between, and upon the longitudinal folds, an immense number of the minute orifices of glands open in linear series corresponding to the direction of the folds, with others scattered irregularly over the surface. The anterior portion of this part of the vagina is, moreover, encircled by five more or less well marked fine sharply defined furrows, which divide and subdivide between the ventral convolutions, each furrow being the tract in which are to be found the orifices of numerous glands. In one inch of a furrow as many as twenty glandular orifices can be detected.

The portion of the vagina lying between the foregoing region and the os uteri externum is marked first by three prominent tongue-like mucous folds, and anteriorly to these by two permanent constrictions or induplications of the vaginal 
wall, all of which are observed in the virgin, but now modified. Two of the tonguelike folds are opposed to each other in the middle line of the ventral wall, whereas the azygos fold occurs on the dorsal aspect of the canal and is long and pendulous, fitting in between the former two. On it are found three or four broad, but thin lamellar folds of the mucous membrane, while others, less strongly developed, and even assuming the character of fine rugæ clothe the anterior portion of this, and extend also on to the second fold, beyond which the lamellæ become more and more developed until on the constriction of the third fold they form a fringe of thin plates, most perfectly formed in the os uteri externum itself. These lamellæ in the virgin are confined to the third fold and to the os uteri. The third fold is so closely applied to the os uteri externum that it is very apt to be mistaken for it, but when it is cut into longitudinally it is found that its orifice anteriorly is not directly continuous with the os, but that it lies to the right of the latter, the two communicating through the interspace between them, and which in the specimen before me is filled with mucus. The wall of the vagina attains its greatest thickness at the first fold, where it is as much as one and a half inch, while its general thickness is not more than a quarter of an inch. The os is 0.75 inch long and is lined with seventeen broad lamellæ, those of opposite sides interlocking with each other. These lamellæ have a special course over the surfaces on which they occur, but their lengths are very various. In passing over the inwardly projecting folds and over the uterine opening of the os they attain their greatest breadth, and diminish greatly in the recesses between the folds. On the second induplication they are much thicker than in the os uteri externum, and their two surfaces are covered throughout with very narrow secondary lamellæ, which run parallel with their outlines. These secondary lamellæ are much finer and more numerous on the leaf-like folds of the third induplication and of the os uteri, on which they are not unfrequently connected to each other by tertiary cross lamellæ. In the uterus, the lamellar folds surrounding the os uteri run up the walls of the uterus, in some instances, for nearly an inch, where they are continuous with certain permanent folds which occur on its walls.

Minute structure of the vaginal glands.-These, as has been stated, are numerous, and, so far as the microscope reveals, they present a common character. The glands in great number descend into the submucous tissue as wavy, straight or branched tubules. A number of these tubules again combine and open into a kind of sac or glandular reservoir, which relatively large area or open space in certain aspects of the sections has a stellate configuration, the limbs being short closed diverticular appendages. The glandular tubules, reservoir, and diverticula are thickly lined with polygonal epithelium, and this reaches to the surface and is freely distributed on the vaginal wall (Pl. XXXVIII, figs. 9 and 12).

These tubular glands in some respects comport themselves to the disposition assumed by the true utricular glands of the uterine cavity, but they are straighter or less contorted than the latter, and are somewhat greater in calibre, and amidst their epithelium is pigmental matter sufficient to give the gland layer a dark brownish 
tint. They, moreover, are distinguished from the utricular glands in possessing the above-mentioned large open stellate areas or gląndular receptacles.

External appearance of the gravid uterus.-The left horn forms the bulk of the organ and is an oval sac lying obliquely across the abdomen with the left placed considerably posterior to the right pole. It measures 17.75 inches in transverse length, pole to pole, and its upper border is distant $19 \cdot 25$ inches from the anterior extremity of the vulva. The right horn depends as'a globular pouch from the anterior surface of the right third of the left horn, close to its posterior border, and the internal septum which separates the two horns is marked externally by a puckering of the serous covering. This horn measures 12 inches antero-posteriorly and has a breadth from right to left, when collapsed, of 7.50 inches.

Cavity of uterus.-The portion below the two horns is cup-shaped, and not more than 2.50 inches in length, measured from the os uteri internum to the dorsal origin of the mesial septum, which indicates the lowest limit of the left horn and the opening to the right horn, but its diameter from the free margin of the mesial septum to the left wall of the uterine cavity is 5.50 inches. The left horn and the common cavity of the uterus are thus continuous with one another. The right horn, however, occurs as a diverticulum from the right side of the common cavity of the uterus, and its entrance is guarded by two valvular folds of mucous membrane, one the external fold, which corresponds in position to the angle formed by the bending backwards of the horn upon itself, while the internal fold is the mesial septum. The former is a triangular fold with its broad free margin 5.50 inches in breadth and directed forwards and outwards. It lies between the ventral and dorsal walls of its cavity, and its apex is directed towards the os uteri internum. It has an extension of 3.50 inches. The mesial septum, which is much thinner than the former, is directed inwards and backwards, in which course it has a length of 5.75 inches, with a bold crescentic free border of 4.75 inches, arching from the anterior to the posterior walls of the termination of the common cavity of the uterus. Besides assisting in shutting off the right horn from the uterine cavity, the mesial septum forms the wall of the right pole of the left horn. Opposite to the mesial septum and continuous with the left wall of the common cavity of the uterus is another septum corresponding to the septum of the right horn, partially dividing the left horn into two. It has considerable dorsoventral extension, and its free margin, which is directed forwards and inwards, is slightly concave and measures 5.50 inches in extent. From its free margin to the os uteri internum is 5.75 inches, and on its left surface it measures 3.75 inches. The appearance of the cavities when laid open is shown in fig. 1, Pl. XXXIV, in which the impregnated left horn is seen to bend round at its right end between its own and the median septum, while the right horn is shut off by the valvular arrangement just described. The entrance into it is by a canal three inches long by the same in breadth, directed outwards and slightly forwards. The horn itself into which this broad passage leads, is a little more than 6 inches long by 4 inches in breadth a little above its middle. The anterior wall of the canal is very rugose, especially its aspect in the horn, and, as was to be expected, it is double the thickness of the walls 
of the true uterine cavity. The sides of the base of the horn are thrown into longitudinal mucous folds of no great strength.

Mucous surface of uterus of gravid female.-The extreme thinness and seeming smoothness of the walls of the left horn are what at first strike the observer. The left horn does not average more than 0.06 inch, and in this, as already remarked (page 395), it is in strong contrast to Orcella, but the wall of the common cavity of the uterus is twice as thick. The greatest thickness occurs in the two septa of the horns, in which it attains to 0.18 inch, but in the mesial septum it is somewhat less.

The mucous surface is marked by certain coarser and smoother areas, the latter predominating in the left horn and the former on the common cavity, and in the right horn. Both are of a spongy texture, and radiate from the Fallopian openings of these cavities along their long axes as in Orcella (antea, p. 395) and correspond, the first to the folds and the second to the intervening spaces between the folds of the virgin womb. It must not, however, be supposed that the distribution of these rugose areas of the left horn is at all prominent or well defined, but the course of the rugæ is, to a certain degree, discernible. Four can be observed radiating interruptedly towards the uterine orifice of the horn, but they are so little raised above the general surface of the mucous membrane that I hesitate to estimate to what extent they project beyond it. They occur as linear bands of variable diameter. The best marked runs from the Fallopian orifice along the upper third of the dorsal wall of the horn to the mesial septum, and another, much shorter and more indistinct, and separated from the former by an interval of about an inch and a quarter, has only a very limited distribution from its origin. Two other coarsely spongy bands run from the Fallopian opening along either side of the attached border of the horn, and extend to the origin of the left septum. In the right horn there are five of these folds radiating from the Fallopian orifice. They are slightly annulated folds of the mucous membrane, and they can be traced more or less continuously to the uterine orifice of the horn. At the beginning of their course they are raised above the surrounding mucous surface, even to a quarter of an inch, and are thus the most strongly pronounced folds in this uterus. The common cavity of the uterus does not present the fine spongy texture of the smoother parts of the horn, but is rough throughout its extent, the equivalents of the primitive folds of the virgin womb being more obliterated than in the right horn. Six, however, are discernible, radiating upwards from the os uteri internum as in Orcella, but they are little raised above the general surface. The septa are thrown into well-marked folds on both their surfaces, with the single exception of the left side of the mesial septum, which is not rugose. The folds run parallel to the free margins of the septa and anastomose more or less with each other.

The mucous membrane of the uterus between the coarser folds.-The areas which I have compared to the spaces that intervene between the folds of the virgin womb, exhibit a tendency, more or less, to have the fibres of their fine spongy texture arranged in lines transverse to the direction of the coarse folds, but beyond these, 
i.e., on those portions of the horns on which the folds have disappeared and where the wall of the uterus is very thin, the fibres of the mucosa do not exhibit any distinct system of general arrangement over large areas; indeed, this texture is so fine in many places, especially in the poles of the horns opposed to the Fallopian orifices in both horns, that the surface appears almost smooth. It is not, however, smooth in the true acceptation of the term when used with regard to the mucosa of gravid uteri, because the texture is essentially spongy, as in the uterine mucosa of the mare, tapir, Orcella, \&c., but it is so fine that it almost requires a hand-lens to demonstrate its appearance in some places, and it has none of the clear glistening character of the truly smooth spots of the mucosa, which are profusely scattered over it. The fibres comprising the meshwork are referable to two distinct groups. The most important group consists of a series of mucous ridgelets having a general course transverse to the long axes of uterine cavities, but on the areas of the primitive folds they become more or less parallel to their direction, and it is on these regions of the horns and uterine cavity that they are most developed, or, in other words, they are the structures which mark the position of the primitive folds of the virgin womb in the left horn, where the latter structures are all but obliterated by the vast extension of that cavity. The divisions and anastomoses of these ridgelets with each other are innumerable, and as they also give off transverse ridgelets they produce a most intricate network of larger and smaller strands, which define irregular sunken spaces for the reception of the villi of the chorion. These latter are again divided by minute threads of mucous membrane into little pits, which receive the branches of the chorionic villi.

On the mucosa of a very advanced uterus no trace of a bare area corresponding to the extensive bare area of the chorion to be hereafter described could be detected, but in another uterus less advanced a narrow branching nude area occurred in the same position as a similar area did in the uterus of Orcella, running up from the wall of the corpus uteri along the septum of the left horn. This bare tract, being irregular in its occurrence and very feebly developed, would appear to be of little or any physiological significance, but whether when it does exist it may be considered as indicating, of necessity, the existence of a corresponding bare tract in the chorion has yet to be ascertained.

The os uteri internum in two gravid uteri is thrown into a series of lamellar folds which overlap each other (Pl. XXXI, fig. 2) at their margins, but the area all around the mouth of the womb is finely cryptose with the exception of these points at which the smooth spots occur. The surfaces of the folds are covered with fine mucous ridgelets.

Around the Fallopian orifices (fig. 3) the uterine surface is cryptose, but the smooth lining membrane of the tube itself is somewhat projected, as it were, into the cavity of the womb as in Orcella, so that a limited bare area occurs within the crescentic fold that defines the orifice. There is no other bare area in this uterus.

Smooth spots.-The entire inner aspect of the womb from the os uteri to the uterine mouths of the Fallopian tubes is covered over with small circular perfectly 
smooth and glistening spots ( $\mathrm{Pl}$. XXXV, fig. 9) which, when bisected from the mucous to the muscular coats, give a convex profile towards the uterine cavity. They are nearly all on a level with the general mucous surface and occur either as larger or smaller spots involving a number of ridgelets, or are confined to one patch not surpassing the size of three or four of the pits or crypts. In the uterus before me, which is soft, and little, if anything, contracted by the spirit in which it has been preserved, the former predominate over the latter. In a square inch, taken at haphazard from the dorsal wall of the left horn, eighteen of these spots were counted, the largest being 0.19 inch in diameter and the smallest not more than 0.01 . They are irregularly distributed all over the mucous surface, but many are so minute that the uterine wall must be artificially stretched to exhibit them, and it is also important to note that when the uterus contracts many are hidden by the bringing together of the fine ridgelets of the mucosa, so that they are liable to be overlooked. The majority have a rounded form, and the ridgelets and fine threads of the mucosa radiate outwards from their circumference, but some have an elongated character, and others are irregular in shape.

In a uterus less mature than that from which the preceding description was taken the smooth spots appeared to be much more numerous, but this was doubtless due to the walls of the uterus being less expanded. It also showed the existence of larger bare spots than any hitherto described, but these, however, were not numerous and had no regular distribution, and, moreover, the largest was not more than about half an inch in extent and of most irregular outline.

When the bare spots of the ordinary character (Pl. XXXV, figs. 9 and 10) were examined with a hand-lens, the appearance as if a small orifice existed was distinctly visible in certain lights, fig. 10, occupying the centres of many of them and forcibly recalling one of the leading features in the structure of the gravid uterus of the sow. The mucosa over these nude areas is so delicate and transparent, that with the artificial aid just mentioned, the utricular glands underlying it were easily discernible. As the only tubular structures present in the wall of the uterus are blood vessels and utricular glands, and as these apparent openings are not the mouths of blood vessels, the conclusion is forced upon us, that if they are openings they are mouths of the utricular glands, holding the same relation to the walls of the uterus and to the bare spots in this Cetacean, as do the utricular glands in the uterus of the sow and in those of other uteri with a diffuse placentation that have been recently described by those masters in this field of anatomy, Ercolani and Turner.

Utricular glands.-When viewed under the microscope, a bare spot being selected for observation in horizontal section (Pl. XXXVIII, fig. 8) these structures are seen to be especially numerous all around it and are very tortuous and much branched, the branches being of various lengths, rather tending to convolute and to increase somewhat in diameter towards their blind extremities. They sometimes divide dichotomously, and sometimes three branches will be given off at one point, whilst in other instances a branch will give off only one short saccule from its 
side. The glands would appear to be not quite so numerous immediately below a spot, but the careful observation of their distribution and of their relations to the spots leads to the conclusion that, as in the sow and in the other Mammalian uteri, already referred to in this work, the smooth-spots of the gravid uterus of Platanista would seem to hold the same relations to the gland layer. Viewing the uterus with a hand-lens I have frequently seen what appeared to be unmistakable evidence of an opening of a gland, and in pursuing the plan of dissecting off the gland layer from the back of such a smooth-spot I have further convinced myself of the intimate relation of the glands to it and of their terminating in it, but under the microscope after the examination of a most extensive series of sections $I$ have never yet been able to demonstrate conclusively the opening of an utricular gland in such an area, not that we are to conclude that it is absent, but that the difficulty of demonstrating it is great.

Chorion.-The membranes (Pl. XXXIV, fig. 2) present three well-marked portions corresponding to the three divisions of the cavity of the womb. The first is the great sac moulded to the mucous surface of the left horn; the second is the sac filling the unfecundated right horn, and the third is what Professor Rolleston ${ }^{1}$ has called the cæcal extremity of the membranes from the two horns, projecting into the short corpus uteri. When the amnionic and allantoic fluids are drawn off, the chorion contracts into numerous rugose folds, which are very strongly marked in the right horn and on its uterine sac, but when the allantois is filled, and the membranes are placed in water for about half an hour, all these strong folds disappear, or slight traction demonstrates the fact that they are temporary. They radiate from the Fallopian poles of the chorion and from the apex of the uterine sac, but they are very feebly marked on the left horn, which has been greatly distended by the fœtus. In its distended state, however, the chorion is marked by certain persistent folds that are not removed by any amount of tension. When placed in water they form wavy fringes, and the most prominent run from the uterine pouch $(s p)$ to the angle of union of the two horns of the chorion. In passing on to the left horn their course is interrupted by a long linear bare patch hereafter to be described, but beyond this point they course round the right pole of the left horn to the dorsal aspect where they are lost. Each forms a wary fringe about half an inch in breadth in its broadest part. These folds radiate from the perfectly nude space as the apex of the sacculated portion of the membrane which depends into the corpus uteri (Pl. XXXIV fig. 2, sp. and 3,) and which corresponds to the lamellarly folded os uteri internum. This stellate bare patch (fig. 3) has a strong resemblance to the similar area in Orca and in the mare as described and figured by Turner. A few persistent folds occur at the two poles of the chorion and are doubtless adapted to the folds of the Fallopian orifices. Besides these, many fine rugose folds encircle the left horn of the chorion, and are especially numerous and best marked to the right of the umbilical region, where they correspond to the folds of the septum of the left horn, and in this region they spring from a linear bald

$$
1 \text { Trans. Zool. Soc., Vol. V, 1866, p. } 307 .
$$


area (Pl. XXXV, fig. 6) corresponding to the similar bare area in the chorion of Orcella, \&c. There may, or may not, be a corresponding bald area on the uterus, but if present it is very feebly developed. The villi of the chorion are much larger and more crowded together on the right than on the left horn, which is the exact opposite of what has been described by Turner in the chorion of the Narwhal. They are most numerous and attain their greatest size on its posterior or umbilical area, and are least developed on its anterior aspect. The whole surface is studded over with them with the exception of certain bare patches, and they have a distinct tendency to arrange themselves in wavy ridges on the more rugose portions and in rounded clusters on the areas where they are less developed.

Plate XXXVII, figures 12 and 13, uespectively show a vertical section through the chorion at a bare spot (b) with the partially injected villi on each side, and a surface view of the chorion also partially injected, the tufted villi in this case surrounding the middle bare spot.

Smooth spots of Chorion (Pl. XXXV, figs. 7 and 8).-The whole surface of the chorion is covered with small circular smooth spots (Pl. XXXV, fig. 7) and with others bearing very fine rugosities or folds, such patches being devoid of villi and varying in size, but corresponding to the smooth spots of the uterine mucous membrane (fig. 9) to which they would appear to be opposed. They are best seen on the anterior, ventral and dorsal walls of the left horn, i.e., where the villi are sparse. They vary in size from 0.06 to 0.25 inch in diameter, and are irregular in form. In a square inch of some regions, as many as eighteen to twenty such spots may be counted. A bare patch of a special character occurs on the left pole of the left horn of the chorion. It forms a crescentic linear bare area at the pole, the horns of the crescent having an interval of an inch between them, and from the concavity of the crescent a very narrow linear area extends towards the pole. This smooth area corresponds to the mouth of the Fallopian tube (Pl. XXXI, fig. 3): There is no other bare area on the pole of the right horn, its apex being covered with villi. But it must be borne in mind that this portion of the chorion (figs. 2 and 3) being neither distended with amnionic nor allantoic fluid lies comparatively loose in the Fallopian end of the right horn. The extremity, however, of the short uterine pouch (Pl. XXXIV, fig. 2 $s p$. and fig. 3) is perfectly devoid of villi as in Orca, ${ }^{1}$ for about an inch in extent, and this bare area corresponds to the os uteri internum (Pl. XXXI, fig. 2).

The most characteristic bare surface of this chorion (Pl. XXXV, fig. 1), however, is a long narrow linear area on that side of the funis which lies towards the dorsum of the mother. It stretches from within 5 inches of the left to within 17 inches of the right pole of the chorion, having thus an extension of 19.50 inches in a straight line and a serpentine course of $25 \cdot 75$ inches. Opposite the umbilical attachment it attains a breadth of about 0.50 inch, rapidly diminishing in diameter on either side of this to 0.06 inch. From the left it passes on to the right horn, running for some way along the dorsal wall of the latter and following the course of the larger vessels.

\footnotetext{
${ }^{1}$ Turner: Lectures on Placent., p. 43, fig. 7.
} 
In the umbilical expansion of this bare tract, there is a small cul de sac with a crescentic orifice (fig. 1, c). Moreover, near its termination on the right horn, a small pedunculated corpuscle (fig. $1, p$.) of the same character as the amnionic corpuscles of the cord and allantois occurs, with a small pear-shaped tubercle at its base. Facing towards the pole, and from the base of the peduncle of the corpuscle, there is a raised, somewhat moniliform and tubular-looking fold which can be traced along the middle of the bare tract to near its left termination.

As I did not succeed in injecting the villi of the chorion (Pl. XXXVII, fig. 12), I cannot give any idea of their true form when charged with blood, and I can say nothing regarding the arrangement of the blood vessels in them.

Membrana intermedia.-Even when the membranes are comparatively dry, a thin delicate membrane can be demonstrated to exist between the chorion and amnion, between the amnion and allantois, and between the allantois and chorion. But when they have been placed in water for about an hour, this structure in the right horn of the chorion swells up into a gelatinous mass, and it also assumes the same character, but in a more limited degree, between the chorion and amnion in the left horn. When the amnion is stripped off the chorion in the last mentioned locality, it has a gelatinous feeling on its outside, which is due to the presence of this membrane, which is also apt in every part of its extent to drag the vessels of the chorion along with it. Between the amnion and allantois the membrane does not tend to swell up on soaking, but preserves an extremely fine character.

Amnion.-This is entirely confined to the left horn of the chorion and can be easily separated from off the allantois over which it has only a limited distribution. It does not follow the allantois into the right horn of the chorion, nor does it invest the portion of the chorion depending into the cavity of the body of the uterus. It is closely related to the membrana intermedia. Towards the left pole its surface which covers the allantois is studded over with small corpuscles and evidently identical with the corpuscles of the amnion of Orca described by Turner ${ }^{1}$ and having the same relation to the amnion. Towards the left of the funis the same surface of this membrane has a broad transverse area devoid of these corpuscles, but further to the right and towards the middle of the allantoic surface these corpuscles are again numerous. Some of them are extremely minute and scarcely visible to the naked eye, and they are confined to the allantoic surface of the amnion. These corpusculated surfaces of the amnion are also studded over, in certain parts in great profusion, with minute sessile grey papilla-like structures, which give a rough feeling to the membrane. Corpuscle-like bodies, stalked and sessile, also occur on the amnion as it sheathes the cord (PI. XXXI, fig. 1, $c$ ).

The first mentioned bodies of the amnion, which vary in size from 0.04 inch to 0.70 inch, are nearly all pedunculated, and appear to be structurally identical with the long pedunculated and sessile bodies which stud the amnionic covering of the cord. The microscopic structure of these bodies I have not been able to satisfactorily determine, as all those which I have examined had been long preserved in

\footnotetext{
${ }_{1}^{1}$ Turner: Lectures on Placent., p. 23.
} 
alcohol, but they appeared to be filled with round nucleated cells. The peduncle is generally contracted at its base, after which it expands, again to contract at its junction with the body itself, which is usually pear-shaped and with walls of considerable strength invested by the amnion. Occasionally secondary bodies of the same nature are found attached by a peduncle to those of the amnion.

A small portion of the amnion with the grey bodies in question in situ is shown as a microscopic preparation in Pl. XXXVII, fig. 15. That which doubtless causes the gritty granular feel is a series of crystalline particles. Many of these are quite microscopic in size, but others, and in aggregated heaps, are quite visible to the naked eye and easily resolved by the aid of a hand-lens. The crystalline bodies, as a rule, are roundish, with a less or more amorphous centre, around which radiate needle or club-shaped (fig. 15A) spicules. Some of the globular crystalline objects are tolerably entire, but others are disintegrated, and their acicules are scattered about.

The basement tissue of the membrane is diaphanous, corpuscular and granular, the nucleated corpuscles here and there being drawn out, and fusiform and oil particles are freely dispersed throughout.

The allantoic portion of the amnion is also the seat of certain fine moniliform vessels which ramify among the corpuscles and which can be traced on to the sheath of the cord.

Allantois.-This extends to within 2 inches of the left pole of the chorion and to within 3 inches of its right pole, i.e., it is nearly coincident with the length of the chorion. When the amnion is reflected from off it, the allantois appears as an extremely thin, transparent membrane, but it must yet have considerable tenacity, as it does not rupture so readily as the chorion. This sac is entirely devoid of amnion after it leaves the left horn, but in the right horn it is separated from the chorion by the gelatinous membrana intermedia. This is also the case in its chorionic and amnionic relations in the left horn, where it is encased by that membrane in which the few very fine vessels which go to the amnion are partially imbedded. In peeling off the amnion from the allantois, it is observed that the corpuscles of the former have no relation to the latter sac. The allantoic fluid measured 8 quarts or 2 gallons.

Allantoic body.-A remarkable body was removed from the tubular portion of the allantois in the right horn of this almost mature uterus. It was discovered lying free in the cavity, having floated out when the sac was emptied. It resembled an almond in shape, and was 1.25 inch long and 0.66 broad (Pl. XXXVI, fig. 5). It showed no signs of having been attached to the allantoic wall. It precisely corresponded to the so-called "hippomanes" met with in the fotal membranes of the mare, \&c. Under the microscope it was seen (Pl. XXXVII, fig. 16) to be made up of a loose web of wide-meshed areolar-like substance. The meshes were by no means uniform in size or pattern, nor was the tissue of similar consistence. At one spot, the latter was a diaphanous, apparently textureless membrane; at another, more cellular-looking, fibrous and granular. Thus it did not agree with any simple organic tissue, seeming rather to be an albuminous secretion or plasma 
assuming areolar organization, with lymph corpuscles and oily particles intermixed. Its special feature, however, was the presence of a vast number of crystalline bodies, cubical, hexagonal, prismatic, needle-shaped and granular, probably related to glycogen or to dextrose. These were quite variable in size and freely scattered within the areas and amongst the substance of the membrane itself.

Relations of fatus to uterus (Pl. XXXI, fig. 1).-The fœtus was wholly confined to the left horn; the right pole of the amnion resting, through its interposed chorion, on the mesial septum (Pl. XXXIV, fig. 1, pa.) which separates the orifices of the two horns and form the wall of the right pole of the left horn. The head of the fœtus was turned away from the os uteri and lay in the left extremity of the left horn with the tip of its snout immediately above the orifice of the Fallopian tube of that side. The umbilicus was opposite the septum of the left horn, which septum lay between the extremity of the tail and of the pectoral flipper. The snout was at a considerably lower level than the tail. From behind the vent, the caudal portion was curved forwards and to the right side, and bent under the belly, so that the tip of the right caudal fin lay opposite the distal end of the right pectoral flipper, but separated from it by the umbilical cord. The caudal portion, so doubled on itself, was slightly below the level of the free margin of the septal fold, or external lip of the orifice to the left horn, but it did not reach to the common cavity of the uterus, because it was above the free border of the common septum which marks the upper limit of the body of the womb.

It will be observed (Pl. XXXIII, fig. 1) that the fotus of Orcella had the same relations to its uterine wall.

Umbilical cord.-As it leaves the membranes the cord is bent on itself and then runs for three inches to the right side of the space defined by the downward and forward bending of the tail of the embryo under its belly. It then describes three curves in rapid succession and, turning to the left, reaches the fotus in 2.50 inches. It is altogether 10 inches long when extended. Its point of union with the membranes is opposite to the septal fold of the left horn (Pl. XXXI, fig. 1,c).

I have already described various bodies superficially attached to the umbilical cord of Orcella (ante, p. 403) and also some peculiarities in the vessels which pass through it. In the cord of Platanista somewhat similar structural conditions are found.

On the surface of the cord here and there, but so numerous as to give a roughened dotted character to it, are small elevated bodies, some as large as, and others smaller than, a pin's head and distinct from the ordinary corpuscles of the cord and more akin to the grey bodies I have described on the amnion. They are more or less solid and,composed of a fibro-nucleated tissue arranged in a circle.

As regards the vessels, the arteries are dilated at rather regular intervals, into well marked sacs constricted off from each other, and communicating by narrow channels (Pl. XXXIV, fig. 6). 
These recall to mind the moniliform vessel of Orca and the sac-like dilatations of the arteries on the stomach of Orcella. In other instances the venous channels send off a diverticulum or side chamber (fig. 7), which occasionally is connected by a narrowed orifice with a subsidiary sac.

In a partially transparent transverse section of the umbilical cord (Pl. XXXVI, fig. 11), the arrangement of the two main arteries and two veins is shown, and besides, marginally and between the latter, a large vacuity, a probable remnant of the urachus. Both arteries and veins have relatively thick and dense walls. The urachus cavity is much thinner-walled, and interiorly I made out the remains of minute and short papillæ with an epithelial covering. Towards the peripheral margin of the cord the gelatine of Wharton is loose-meshed, and traversed by narrow ellipsoidal channels. Although these approach the superficial glandular bodies, they nevertheless do not seem to have any connection with them.

Fotus (Pl. XXXI, fig. 1, and Pl. XXXII, fig. 4).-The mouth of the fotus was only partially closed, but its openness was probably a post-mortem result, as the palatal surface had a longitudinal mucous ridge corresponding to a deep groove in the middle of the flat prelingual surface. The outer aspect of both jaws was raised into well-marked vertical ridges, and increasing in size from behind forwards and terminating in marginal papillary eminences, through which the sharp teeth could be felt; and on the right side there were eighteen such columns more or less visible on both jaws, and sixteen on the upper and eighteen on the lower on the left side. The angles of the mouth and the blow-hole were filled with a consistent grumous substance which appeared to be cast and disintegrated epithelium, as a few broken nucleated epithelial cells could be detected in it under the microscope. The pectoral flippers were laid backwards against the sides of the body, and the free margin of the right was slightly folded on itself. The dorsal fin was bent to the left side. The left caudal was folded inwards against the under surface of the right flipper, while its tip was bent over its own upper surface; the tip only of the right caudal flipper being folded in a manner similar to its fellow. In the two foetuses which have come under my observation the bodies have been marked by corresponding folds. Among the most prominent of these is a deep fold which marks the position of the neck, occurring half-way between the angle of the mouth and the pectoral flipper. It is deepest on the ventral surface and extends up the side to nearly on a level with the eye. Two other somewhat similar folds occur, one before and the other behind the anus, but as they are due to the downward and forward bending of the caudal portion of the animal they disappear shortly after birth. On the dorsal surface there are four large folds which have been alike in both fotuses: a shallow transverse fold shortly behind the blow-hole and corresponding in position to the gular fold; a second somewhat double fold stretching between the pectoral flippers; and another occurring at a third of the distance between the latter structures and the tip of the dorsal flipper; and a fourth half-way between the third fold and the dorsal fin. Behind the dorsal fin there are seven to eight short transverse folds across the rather sharp 
ridge of the back, and these remain a long time persistent. Besides these folds the skin generally is covered with wavy, transverse wrinkles, which however disappear in adult age in a healthy dolphin. The upper surface of the snout (Pl. XXXI, fig. 1, p.) is covered by scattered, rather strong, palish yellow bristles, and the under surface of the lower jaw with twenty-six similar hairs. I have not been able to detect hairs in any other part of the body and there is no whisker or

Fig. 18.

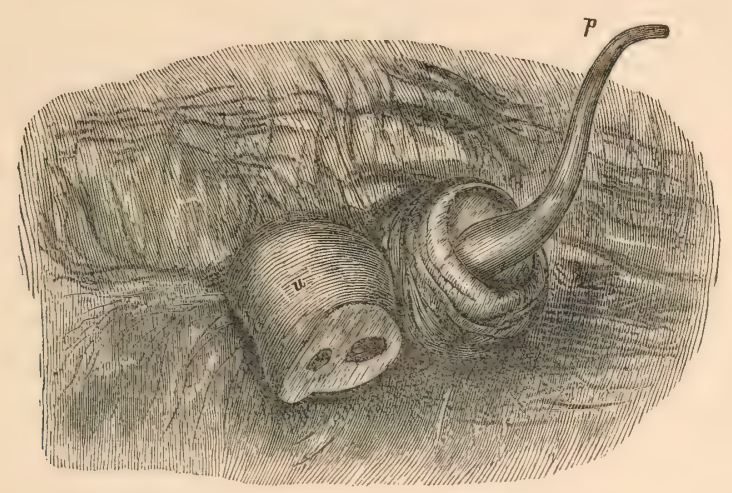

A sketch of the extended penis $(p)$ and cut umbilical cord $(u)$ of the fœtus of Platanista. Drawn of natural size.

moustache as occurs on the fœtus of Round-headed Dolphins. In the specimen specially under consideration, which is a male, the long tubular extremity of the urethral tube (fig. 18) is exserted, and the tip of the double glans is visible, the foreskin embracing these parts being bent with them to the left side!

Mechanism of Parturition.-The arrangement I have described, in whatever horn the fotus may be, although it is probable that conception generally takes place in the left horn, doubtless plays an important part in parturition. The parturient contractions of the septal fold of the left horn must be very powerful and by violently constricting the membranes in its neighbourhood it must hasten their rupture. This accomplished, its after contractions across the wedge-like posterior portion of the body of the fœtus force the latter to the left side of the left horn, a course which is rendered imperative owing to the septal fold being placed to the right of the pectoral fins which would be liable to be driven outwards at right angles to the body against the septal fold, and thus seriously retard birth. The common septum must also, from its oblique position, prevent the straightening of the caudal portion of the foetus, and moreover by its contractions it must assist in driving the foetus to the left, in the first instance. As the fœetus so passes, and as at each contraction it is held in the grasp of the septal fold of the left horn, the tail begins to straighten as the snout curves round to pass from left to right in the progress of the young animal out of the left horn towards the common cavity of the uterus. In this cavity strangulation of the snout in the orifice of the right horn is obviated by the close apposition of the folds which guard it. 


\section{The Skeleton of the Gangetic Dolphin.}

Cuvier $^{1}$ was the first anatomist to point out the great maxillary crests arching upwards and inwards over the blow-hole; the extraordinarily laterally compressed upper jaw ; the long symphysis of the lower jaw; the remarkable development of the temporal fossa ; the great size of the zygomatic process of the temporal; its application to the post-orbital process of the frontal; the small size of the orbits; the great thickness of the crests between the basilar and lateral parts of the occipital bone, which inwardly confine the vault under which the ear is situated; the union of the bulla tympani to the petrous, which latter is firmly wedged in between the temporal and surrounding parts of the occipital bone; the free character and great length for a Cetacean of the cervical vertebræ and the development in them of the lower transverse processes as in whale-bone whales; the large character of the scapula, the absence of a supra-spinous fossa, the presence of a large acromion and the rudiment of a coracoid. It was on such facts as these that Cuvier urged that the dolphin of the Ganges was a distinct genus remarkably different from any other dolphin, although he did not assign to it any distinct position among the toothed whales.

The next anatomist to throw a flood of light on its structure was Eschricht, in his well-known Memoir, in which he followed Cuvier's description step by step, adding to it and correcting some of Cuvier's observations. His most important contribution to the anatomy of the skull was his explanation of the structure of the temporal fossa and his indication of the probable site of the palatines in the nasal chamber, and his account of the pterygoids. The whole of his Memoir, however, is replete with information regarding the structure of the dolphin and is rich in comparisons of it with other Cetaceans, especially Hyperoodon, which he considered to be its nearest ally, although in some respects it was related to the Whitefish and to the allied great toothed whales, and in other regards to Inia, the fluviatile dolphin of the Amazon, whilst he held it to be quite isolated by other features of its structure.

By its maxillary crests the Gangetic dolphin in Eschricht's opinion was more closely allied to Hyperoodon than to Micropteron or any other fossil Cetacean. He admitted that the analogy in the structure of the cranium with the Hyperoodon, and partly with the cachalot, is altogether lost as regards the rest of the skeleton, in which there are striking differences between the two forms.

To the late Dr. Gray ${ }^{2}$ belongs the credit of being the first to bring out prominently the affinity manifested by Platanista to Inia; but although Eschricht allowed that this attempt by Dr. Gray to express the relationship of the animal was equally successful with that by Wagner who placed it between Inia and Micropteron, yet he held that d'Orbigny's incomplete account and figure of Inia did not reveal any of the peculiarities of the cranium of the Gangetic dolphin, and that

\footnotetext{
${ }^{1}$ Ossemens Fossiles, vol. viii, Pl. 1836, p. 88, et seq. et p. 128.

${ }^{2}$ Voyage, Erebus and Terror, 1846, p. 45.
} 
although no one could hesitate to separate it as a distinct genus and to regard it as probably not far removed from Inia, he considered that the two could hardly be placed under one common group, the Platanistina, under which Gray brought together the genera Platanista, Inia and Pontoporia, and which genera he has more recently ${ }^{1}$ elevated into as many families.

The osteological features, however, of Inia were very imperfectly known when Eschricht wrote, but now through the labours of Flower ${ }^{2}$ the structure of its skeleton has been well ascertained. Professor Gervais ${ }^{3}$ in 1855 grouped Platanista, Inia and Pontoporia to form one of the five tribes (Platanistins), into which he divided the Delphinida, the last but one of his four primary divisions of the Cetacea. ${ }^{4}$

Professor Flower has pointed out that Inia, Pontoporia and Platanista agree in the great development of the temporal fossa, which, however, is most marked in Platanista, and in this striking feature of the skull the last differs from all the other dolphins. In Platanista and Pontoporia the zygomatic process of the temporal abuts against the back of the orbital process of the frontal, so that there is no postorbital process, but in Inia this process is separated from the post-orbital process therein developed by a considerable interval. In all of these forms the zygomatic process of the temporal has a great family likeness, and is distinguished from the corresponding processes in other dolphins by its markedly stronger character, which relates to the great development of the temporal fossa. In the skull of Platanista which formed the subject of Professor Flower's observations, he mentions that it differed from that of Inia in the construction of the temporal fossa, namely, in this, that the frontal and squamous were not separated from each other by the pointed extremity of that portion of the parietal which forms the side of the fossa, whereas in Inia the squamosal was shut off from articulating with the frontal, and in Pontoporia the parietal prevents the union of the frontal and squamosal, and the pterygoid articulates with all of these bones. In Platanista, however, there would appear to be considerable individual diversity as to the extent to which the pterygoids separate the squamous from the frontal, which is certainly occasionally the case in the skulls which have come under my observation, although the arrangement described by Professor Flower is what is generally present. This variation is so modified in different individuals that it cannot be ascribed to any other cause than an inherent tendency in these bones slightly to alter their forms.

Professor Flower has supplemented Eschricht's observations on the construction of the hard palate and has proved the correctness of the latter's suggestion that the palatine would be found in the nasal tube, and that the bones appearing externally on the palate and entering into the temporal fossa were the pterygoids, and in these features Platanista is unique among the Cetacea. Inia itself, which

1 Cat. Seals and Whales, B. M., p. 87, et seq.

2 Trans. Zool. Soc., 1869, vol. vi.

3 Hist. Nat. des Mammif., 1855, p. 321.

It is a subject of regret to me that I have not had the privilege to consult the 13 Livr. of Van Beneden and Gervais' splendid work 'Ostéographie des Cétacés.' 
presents a close relationship to this form, differs widely from it in these details, as does also Pontoporia:

As pointed out by Cuvier, the petrotympanic is not merely suspended by means of fibrous tissue, but is locked into position by a process of the mastoid, whereas in Inia, Flower describes these bones as loosely attached to the cranium, and from their absence in the skull of Pontoporia he concludes that their attachment must be much the same as in Inia. In Platanista, on the other hand, the Eustachian extremity of the tympanic is long and tubular. In Inia this feature is much less pronounced, and the bone partakes more of the character that distinguishes it in Delphinus.

The resemblance of the lower jaw to that of the Cachalot has been forcibly pointed out by Cuvier, Eschricht and Flower; and the latter speaks of the lower jaw of Inia as a miniature representation of the same jaw, while the mandible of Pontoporia is intermediate between Platanista and Inia.

The teeth of this dolphin are very different from the firmly implanted short rugose-crowned teeth of Inia and are entirely destitute of any lobular character, and they are markedly distinct from the teeth of Pontoporia, as figured by Flower ${ }^{1}$ and Burmeister. ${ }^{2}$

Comparing the vertebral columns of Platanista, Inia and Pontoporia, great differences, besides the fewer vertebræ in the two latter as compared with the former, are found to obtain. The most marked feature of Platanista is the, so to speak, enormously developed oblique processes by means of which the individual vertebræ from the fifth dorsal backwards for a long way are interlocked with strongly forwardly directed spinous and well-developed transverse processes in the lumbar and anterior portion of the caudal region. In Inia there is only a faint trace of metapophyses, and all the interlocking so characteristic of Platanista is absent, but while in Pontoporia metapophyses are present in the dorsal, and partly in the lumbar region, its remarkably shaped transverse processes are very different from those of the Platanist.

As is well known, one of the most distinguishing characters of the vertebral column of the Platanist and by which it is separated from all Cetacea except Inia, is the unusual length of its neck, which is nearly as well developed as in many quadrupeds. The cervical vertebræ are marked by considerable transverse extension and by depression, and in these characters they differ from the vertebræ of Inia, while, however, as in Inia and Pontoporia, they are all free, but the neck of this last mentioned Cetacean is considerably shorter than in Inia.

In the atlas, as in Pontoporia, ${ }^{3}$ the spinous process is feebly marked, and there is only one long and strong transverse process, but in Inia there is a well-developed. spinous process and the rounded rudiments of two transverse processes, upper and lower. In the Susu the under surface of this bone has a long prominent bifid process

\footnotetext{
${ }^{1}$ Loc. eit.

2 Annales de Mus. Pub. de Buenos Aires, 1869, Pl. xxvii, figs. $2 a$ and $3 a$.

3 Burmeister: loc, cit.
} 
more strongly marked in Inia. A distinct odontoid occurs in Platanista, but the equivalent of this process is only feebly shown in Inia, and the spinous process is broad and bifid, while in the former it is powerful with considerable antero-posterior extension. In Platanista the union of the upper and lower transverse processes occasionally takes place, but it is usually confined to one side, and I have observed it in the fourth vertebra only, as this would appear to be the first segment in which the two processes first exist, and in which a perfect ring is sometimes formed, as in the third, fourth and fifth vertebræ of Pontoporia. ${ }^{1}$ This, however, would appear to be perfectly distinct from the adventitious perforation of the upper transverse process of the third vertebra noticed by Eschricht, but to be identical with the wellmarked canal occasionally formed in Inia and Pontoporia in the same vertebra by the union of the upper and lower transverse processes as described by Flower and Burmeister. Platanista differs from Inia in the great development of the lower transverse process of the sixth vertebra, and in the absence, as a rule, of this process in the seventh cervical, whereas in the latter vertebra it usually exists in Inia in a rudimentary condition, the spinous process of this vertebra being very feebly developed in Inia and Pontoporia, but strongly in Platanista.

In Platanista, the first dorsal has two facets on either side of the body for the articulation of the heads of the first and second ribs, but on the second and succeeding vertebræ to the sixth, only one facet occurs for the head of the rib, and it is situated on the posterior margin of the body obliquely behind the articulation on the transverse process for the tubercle of the rib anterior to it. There is a distinct approximation of the facet for the heads and the tubercles of the ribs, so much so that the facet for the head of the seventh rib on the sixth vertebra is nearly on the same level as the articulation for the tubercle of the same rib on the seventh vertebra. On the eighth the head and tubercle have practically coalesced, and it is this vertebra in the young animal in which the rib is first seen to be distinctly applied to the side of the body of the vertebra without the intervention of any process.

It will be seen from this description that the arrangement of the ribs is much the same as in Inia, and as in Pontoporia as described and figured by Burmeister. In Inia, the head of the rib is more attached to the intervertebral substance before its own vertebra, so that in the fourth and fifth vertebræ the articulation for the head of the rib instead of being on the posterior margin of the vertebra before its own is on the anterior margin of the segment to which the tubercle of the rib is attached. From the eighth vertebra backwards each rib in Platanista is only attached to its own vertebra, whereas in Inia this takes place in the sixth, the coalescence of the articular surfaces for the head and tubercle in Inia, as in Platanista, occurring on the eighth vertebra.

The difference between Hyperoodon and Physeter and Inia lies chiefly in the circumstance that in the two former the upper transverse processes appear suddenly to cease, and the rib retains its connection with the body only; but in the immature 
Platanist in which the ribs are attached direct to the bodies of the vertebræ in the sixth, seventh, eighth and ninth vertebræ, owing to the entire absence of any intervening process or projection from the bodies of these vertebræ, and owing perhaps to the imperfectly developed character of the transverse processes, the latter appear suddenly to cease, whereas in the adult the transverse processes appear gradually to subside on to the bodies of the vertebræ and to exist as tolerably well marked short processes even on the eighth and ninth vertebræ on which in the young there is no trace whatever of such a process, the structures afterwards developed in these as in the seventh also being only outgrowths of the bodies of the vertebræ. The process bearing the tenth rib is entirely different, and is a distinct structure developed quite independently from a centre of its own. These processes are apparently developed from behind forwards, as in a young skeleton those of the caudal and posterior portion of the lumbar region are firmly united to their vertebræ, while those bearing ribs and a few behind them are not so united to their segments.

Platanista in having eight lumbar vertebræ more resembles Pontoporia than Inia, as the former, according to Burmeister, has six or seven ${ }^{1}$ lumbar vertebræ, whereas Inia is stated by Flower to have only three or four, which is a marked difference from what prevails in the ordinary Delphinida, in which the lumbar region has great extension.

Professor Flower remarks that "nothing can be more dissimilar than the lumbocaudal region of the special column in Inia and Platanista," and from Burmeister's researches on the anatomy of Pontoporia we may add, between this dolphin and the Gangetic form.

In Platanista, as I point out hereafter, the sternal ribs, although cartilaginous in youth, become ossified with adult life, but always with a small portion of cartilage or 'intermediate rib,' as in the Monotremes, intervening between the end of the rib and the ossified sternal rib, whereas in Inia the sternal ribs are always cartilaginous. Flower in grouping Platanista, Inia and Pontoporia with Physeter, Hyperoodon and the Ziphioids did so under the impression that the absence of ossified sternal ribs was a character common to them as a group. But now, in addition to the sternal ribs of Platanista being known to be ossified in adult life, Burmeister ${ }^{2}$ has shown that the sternal ribs of Pontoporia are ossified, as in marine dolphins generally, to which it is allied.

Such facts have an important bearing, as Professor Flower who is facile princeps in this department of anatomy, when seeking for some starting-point or basis for a primary division of the toothed whales, Odontoceti, selected this presence or absence of ossified sternal ribs as "a character derived from a part of the organization apparently less liable to adaptive modifications than the teeth or fins." It would now appear, however, that this character has not that reliability which it was thought might be attached to it. The facts already adduced, and those yet to follow in this contribution to the anatomy of Platanista, seem to me to confirm the just appreciation which

\footnotetext{
1 Proc. Zool. Soc., 1867, p. 485.
}

${ }^{3}$ Loc. cit., p. 412. 
Cuvier, Eschricht and Flower had formed of its anomalous character, and to establish the position assigned to it by Dr. Gray as a distinct sub-family of the toothed whales, including the genus Inia, and through Pontoporia connected with the true Delphinida.

Supra-occipital (Pl. XL, fig. 2).-In the skull (10.75 inches long) of a young male caught in August, and therefore probably only a few months old, this bone is quite distinct from the exoccipital, but confluent at its upper angles with the parietals. The obscure external occipital crest is prolonged downwards, towards the margin of the foramen magnum, terminating in the incision or cleft (fig. 2, $c l$ ). There is a slight concavity on the sides of the upper half of the ridge, but the lower half of this surface of the bone is somewhat convex. The upper two-thirds of the internal surface are deeply concave, the lower third almost flat. The former portion is traversed by a prominent sharp vertical ridge, with no trace of a groove for the longitudinal sinus, but the transverse ridge shows indications of grooving for the lateral sinus. The sides of the ridge are marked by numerous nutrient foramina, and the fossæ themselves by long fine meningeal grooves. The cerebellar fossa is nearly flat in its upper half, but concave above the margin of the foramen magnum. The parietal margin of the bone equals the length of the exoccipital border.

In another and older male skull, measuring 14 inches in length, the parietal and frontal edges of the supra-occipital are slightly prolonged backwards, with an inward curve in the case of the former and backward curve in the case of the latter, below which there is a considerable concavity. The bone, however, is convex from the parietal to the margin of the foramen magnum, and the feebly-marked vertical ridge has a diminutive tuberosity. The incision at the foramen magnum is closed at the border of the orifice, but an elongated imperfection still exists above this. The foramen magnum preserves the same form as in the fœtal skull. The internal vertical ridge is very sharp.

In a male skull, adult or nearly so, the occipital region has undergone a remarkable change of form, which is also characteristic of the female. It is oblong and deeply concave between the parietals. This is due to the development of a prominent lambdoidal ridge, turning outwards and downwards in the position of the upper angle of the exoccipital to the base of the zygoma, and to an equally marked sagittal crest. In one adolescent adult, there is a rough nodular tuberosity but no ridge, while in a female of considerable adolescence, so to speak, the occipitointerparietal region is narrower and deeper than in males of apparently nearly the same age, and there is neither a trace of a tuberosity nor of a vertical ridge; yet, in another example, adult and of the same size, the tuberosity alone is developed. In adult skulls the incision at the foramen magnum disappears.

Exoccipitals.-In the foetal skull, the line of separation between these bones and the basi-occipital cannot be detected, the exoccipitals being only ossified on a line with the inferior extremities of the facets for the atlas, but anterior to that and between the facets there is a considerable cartilaginous area. Before the facets they are rather deeply concave, but their external surfaces are rather convex, especially 
where they bend forward to meet the squamous and parietals. The precondyloid foramen is large and well-developed, with the cartilaginous stylohyal rod firmly applied to it sideways and bending round the posterior extremity of the tympanic, from behind forwards, and between it and the paroccipital process to the periotic. The facial nerve is seen coming out through a foramen formed by a notch in the anterior margin of the exoccipital, immediately external to the cartilage aforementioned and the paroccipital process.

The exoccipitals ( $\mathrm{Pl}$. XL, figs. 3 and 4), in a young skull in which they are quite distinct, do not form the upper margin of the foramen magnum; but the condyles are almost entirely formed by them, only a fifth share being contributed by the basi-occipital. The anterior exoccipital face is concave internal to the transverse ridge and has the precondyloid notch immediately internal to the paroccipital process. The notch in the skull is converted into a foramen. The transverse ridge terminates above the inner border of the paroccipital process on a line with the anterior basi-occipital angle of the bone; the whole of the paroccipital process below that level is outside and deeply concave, especially at its lower margin, where a distinct pit is formed. A small but deep fossa occurs external to the lower end of the transverse ridge, separated by a fine ridge from the paroccipital concavity, into which the posterior superior external angle of the periotic abuts. The lower concavity faces the posterior surface of the periotic and pars mastoidea and the hinder aspect of the tympanic cavity, being separated from these bones by the stylohyal cartilage passing in behind the tympanic bone and posterior to the facial nerve, which is protected anteriorly by the paroccipital process.

In a skull measuring 12 inches long, in which the supra-occipital has not been amalgamated with the exoccipitals, the latter bones are completely united to the basi-occipital ; and in this skull there is an imperfection of ossification representing the posterior condyloid foramina, which are almost always present either on one or both sides associated with a thinning in this region where they do occur.

The paroccipital process becomes much thickened with age, and in an adult male its external margin below is grooved for the passage of the facial nerve, while its anterior aspect is much roughened; the concavity all but disappearing, the lower pit being occasionally converted into a short canal by a broad spiculum of bone arching over it.

The internal surface of the paroccipitals in the adult skull has the transverse ridges greatly developed and grooved for the lateral sinuses. Immediately external to the occipital protuberance, they are indented on their under surfaces by a rather deep pit, which is overhung above by their sharp edges. This pit is continuous with a broad and deep furrow that lodges the posterior occipital sinus. There is no trace of an internal occipital crest nor of a falx-cerebelli.

Basi-occipital (Pl. XL, fig. 5).- The supra-occipital would appear to unite with the exoccipitals about the same time that the basi-occipital amalgamates with the basisphenoid. In the very young skull it is perfectly flat on its under surface between the well-developed tympanic borders, with the exception of a thickened 
portion on its anterior fourth. This thickening becomes much intensified with age and deeply concave on its posterior aspect. The tympanic borders also become strongly developed as the animal increases in years, and it appears evident that, as the basisphenoid and the anterior thickened portion of the basi-occipital constitute the greater part of the upper wall of the posterior sinus, the increased thickness of this portion of the basicranial axis of the skull is for the protection of the brain against the pressure which it would sustain in the respiratory effort were its structure in this portion of a less solid nature.

The posterior three-fourths of the bone is very much thinner than in its anterior fourth. In the very young example captured in August, the bone is rather deeply concave in the mesial line for the reception of the medulla oblongata, with a concave depression on its sides for the reception of the lobes of the cerebellum. The concavity for the medulla is marked by two posteriorly divergent grooves, probably arterial. On the anterior extremity of this surface there is a small, well-marked depression, apparently for the reception of the pituitary body. In the fœtal skull the pituitary body is true to its position on the hinder end of the basisphenoid, as is demonstrated by the fact that a pin passed through the middle of the cartilage separating the two bones appears on the inner surface of the base of the skull posterior to the pituitary fossa. The remarkable change of position which overtakes this fossa is, however, inaugurated at a very early period. Passing outwards and backwards from the sides of the pituitary depression there is a faint ridge which terminates in a strong process of bone, which is transverse to the basicranial axis and defines on either side the anterior limit of the cerebellar lobe. This transverse process is separated by a transverse incision from another but less prominent process lying immediately below it. These two processes contribute to define the anterior border of the foramen lacerum posterius. With increasing age the uppermost process is prolonged inwards to near the median line of the skull, constituting two false, posterior clinoid processes, defining the hinder border of the pituitary fossa. In some skulls I have observed only one on the right side, which is the process usually most strongly marked. The anterior surface of the base of this process to the free margin of the basi-occipital external to the pituitary fossa, presents a rough triangular surface on which lies the posterior angle of the alisphenoid. With age these two united portions of the two basicranial bones become enormously thickened, projecting outwards and slightly backwards.

At the anterior angle of the exoccipital surface, there are two processes, a superior and inferior, the former contributing to form the anterior surface of the base of the process that defines the front border of the anterior condyloid foramen, the latter being the hinder termination of the downwardly and outwardly projecting plate against which the tympanic abuts. This plate terminates anteriorly in a process for the support of the basisphenoid, being applied to the inner surface of the base of the corresponding plate of that bone. The anterior surface presents a transversely elongated concave rough surface, which becomes united to 
the basisphenoid, and the posterior surface is crescentically concave before the inferior border of the foramen magnum. The tympanic plate is thin rough and slightly concave on its outer surface, and behind it is the elongated surface which unites with the exoccipital.

In the adult skull the line of union with the basisphenoid can sometimes be traced, but its union with the exoccipital cannot be detected. All the foregoing processes become greatly intensified in the adult, more especially the process external to the pituitary fossa; these project outwards beyond the cranial cavity as two strong buttresses on which the parietals rest, although they do not unite with these bones. Their extremities point to the internal auditory meatus, and their posterior sides define anteriorly a strongly marked groove for the seventh pair of cranial nerves ; immediately behind this there is another prominent groove for the eighth pair, which arch over the strong process defining the anterior wall of the precondyloid foramen and is so closely applied to the exoccipital that this foramen is all but perfect.

The basisphenoid (Pl. XL, fig. 11).-The alisphenoids are outwardly and upwardly curved, and their excephalic aspect much hollowed in the middle from before backwards, but convex from side to side, with a considerable concavity at the base of the wings for the reception of the lobes of the cerebrum. The wings may be referred to two portions, an anterior, by far the higher and larger, and a posterior, backwardly and upwardly projecting section, that lies on the rough surface of the basi-occipital external to the pituitary fossa. The cerebral hollow of the anterior portion of the wings is very thin and easily fractured, hence the imperfections in the figure (fig. 11), but its upper extremity is very thick and rough. Immediately below this latter portion there is a wide groove directed longitudinally forwards, leading to the sphenoidal fissure and prolonged backwards as a distinct process along which the two superior divisions of the fifth nerve pass. There is a large crescentic foramen just below the posterior process, a backward continuation of the groove for these divisions of the fifth nerve and through which the inferior maxillary division of the same nerve passes outwards through the alisphenoid and hence the foramen ovale. At the base of the posterior division of the alisphenoid there is another foramen (spinosum) which transmits a branch of the plexus at the base of the skull. The anterior division of the alisphenoid is applied by its front margin to the orbitosphenoid, while by its thickened superior rough surface it articulates with the inferior thickened rough angle of the parietal; it also rests on the external surface of the inferior posterior external angle of the parietal, i.e., being external to that process with the frontal process of the pterygoid external to it and excluding it from appearing in the outer wall of the skull, although in the temporal fossa it is close behind the superior border of the isolated portion of the pterygoid, that is wedged in between the frontal, parietal and squamosal. ${ }^{1}$ At this portion, the wall of the cranium consists of three layers of bone. These, from without inwards, are; first, the downward and forwardly

" ' See Flower's remarks on the structure of the temporal fossa of Platanista as compared with that of Inia, l. c. p. 90. 
projecting pterygoid process of the squamous which lies on the pterygoid; next, the pterygoid itself; and lastly, the anterior half of the alisphenoid. The anterior surface of the body has not united with the presphenoid in the specimen 14 inches long, and even in adult skulls this suture is always more or less distinct. The anterior portion of the under surface of the body is rod-like in the middle to permit of its fitting into the deep groove of the vomer, while the sides slope upwards and outwards and rest in the deep grooves on the posterior sphenoidal processes of the pterygoid, which continue forwards from the depending tympanic plates to the external margins of the internal nares; these plates thus extend from the exoccipital on to a line with the posterior margin of the vomer. The basisphenoid portion contributed to these plates is thus comparatively small, not extending forwards beyond the two posterior thirds of the bone. They are directed downwards, backwards and outwards, and although they become firmly amalgamated with the same processes of the basi-occipital, they are separate in the adult skull from the similar plates of the pterygoid which overlap them.

The posterior portion of the alisphenoid rests, as already stated, on the rough surface of the basisphenoid external to the pituitary fossa, and is perforated near its base by what appears to be the foramen spinosum. Its upper external angle has a marked depression on which the Gasserian ganglion lies. In young skulls this portion of the wing is very thin, and its outward angle abuts against the anterior margin of the internal auditory meatus; the periotic in youth projecting into the lateral wall of the skull, while the tympanic below it forms part of its floor. In adult life, this portion of the alisphenoid is enormously thickened and completely consolidated with the underlying process of the basi-occipital; the two simulating a periotic in form and consistence and in their position in supporting the Gasserian ganglion. By their after outward growth and by the inward thickening of the base of the parietal against which they abut, the true periotic and tympanic are entirely excluded from the inner wall of the cranium; and the imperfection at the base of the skull in this region, which in the young is nearly continuous from before backwards, is divided into two distinct sections, the foramen lacerum medium and the foramen lacerum posterius.

The upper margin of the posterior end of the body of the bone, although it does not form any part of the pituitary fossa, is so close to its posterior margin that it may almost be regarded as part of that border.

The orbitosphenoid.- This bone, which is quite distinct from the basisphenoid in youth and evidently for many years afterwards, unites apparently with the mesethmoid in uterine life. In the young, however, and even in the adult, the anterior limits of the bone in the interior of the skull can be detected, but its position undergoes a remarkable change from youth to age. In the former it constitutes part of the floor of the cranium, being in the same axis as the basisphenoid, but in the latter stage it is almost at right angles to that bone and forms the lower portion of the anterior wall of the cranial cavity. During these changes, what appears to be the anterior limit of the bone becomes more intensified than it is in youth, assuming 
the character of a pronounced sutural line. The bone is referable to two portions, a body and wings; the latter extend quite as far on to the side of the skull as do the alisphenoids. The wing-like portion presents two divisions, a posterior and anterior; the former constituting the front border of the sphenoidal fissure in the cavity of the skull, and the latter, above it, projecting into the base of the posterior angle of the frontal. There is apparently no mesethmoid spine, as that portion of the mesethmoid is let into the anterior end of the body of the orbitosphenoid. The ridge of the falx-cerebri can be traced on to the middle of the body in some young skulls, whereas in adults the body is either concave or pitted irregularly. Halfway between the extremity of the anterior division of the wing and the body of the bone, in what appears to be its mesethmoid border, there is usually, in young skulls, a considerable foramen for the passage of blood vessels; this may be either round or transversely elongated, but in adult skulls it becomes almost entirely obliterated.

The most remarkable feature, however, of the orbitosphenoid is the circumstance that it is traversed halfway between its anterior and posterior borders, and about halfway between its mesial line and the outer extremity of its wings, by an extremely small optic foramen; this is so minute and so like to the sentient foramina that occur scattered over the inner wall of the skull, that it is very apt to be passed over as one of these. Each optic foramen (Pl. XL, fig. 1, op ) is overhung by a fine bony plate, and a groove passes inwards and backwards in young skulls, but in adult crania it is all but obliterated. In youth the foramina are much more symmetrical in their position than in advanced life, and they always occur in the place I have assigned them; but in the latter period they are generally close to the anterior border of the basisphenoid and frequently at different elevations, one being usually higher than the other; in some skulls the left is higher than the right, and in others the right is on the higher level. The foramina are so minute that they only admit a fine bristle, and in adult skulls it is diffieult to pass even this through the whole length of the canal, which is of considerable extent. A hair that I inserted through the optic foramen of one skull again entered the interior of the skull by the sphenoidal fissure; but the cause of this will be apparent when the course of the optic canal through the frontal bone is considered.

The posterior division of the wing of the orbitosphenoid articulates by its extremity with the frontal anteriorly, and by its outer and under surface (which is broadly and deeply grooved for the branches of the fifth nerve passing out by the sphenoidal fissure) with the outer extremity of the alisphenoid; this is overlapped by the pterygoid and by the under surface of the base of the wings with the internal superior plate of the pterygoid; the body of the bone being supported by the vomer (consult PI. XI, fig. 1, \&c.)

Mesethmoid.-It is impossible, even in young skulls, to define the exact extent of this bone, as it unites in uterine life with the frontals (Pl. XL, fig. 1, me); but what appear to be its limits are best seen in the internal and nasal aspect of the cranium. It forms the upper portion of the posterior wall of the external nares 
below the level of their upper border, the external margin of which is formed by the premaxillæ. The anterior surface is divided in two by the low vertical ridge of the mesethmoidal cartilage, which is prolonged forwards and slightly downwards as a laterally compressed plate, received below into the groove of the vomer. In young skulls, the anterior surface of the mesethmoid is slightly concave, with the ridge that traverses it incompletely ossified; and it is perforated by two larger foramina for blood vessels, one on either of its halves, with generally two smaller foramina in its immediate neighbourhood. In adult life, the anterior surface has the appearance as if the wings of the vomer were upwardly expanded, becoming continuous superiorly with the upper portion of its vertical ridge; but it is open anteriorly for the downwardly thickened portion of the central plate, from which the septal cartilage springs, and is continued forwards. The wings of the vomer also appear, with age, to expand upwardly and outwardly over the foramina, and almost to invest them. The vertical ridge is thus strongly prominent in adult life, and the perforated sides of the bone are much more regular and concave than in youth.

On the internal surface of the skull, what appears to be the mesethmoid area undergoes remarkable changes from youth to age. In the former period, the internal frontal crest terminates in a vertical, rather long thick rounded ridge, which is even prolonged in some skulls on to the body of the orbitosphenoid. At the lower end of this ridge, there is a depression on either side of it, while immediately above, there are three small foramina, of which one is larger and more prominent than the others. In the adult skull, in which the orbitosphenoid and mesethmoidal areas are completely vertical, the two feeble depressions of the young skull are converted into deep pits, nearly half an inch in depth, separated from each other by a vertical plate, situated rather deeply in the common opening to the two pits; its upper half being thick, whilst its lower half forms a thin vertical plate: the bases of the pits are perforated by foramina. In the interior of these two pits we have thus the equivalent of the ethmoidal spine and cribriform plate. In such skulls, the internal frontal crest takes a curve to the right side, but, notwithstanding, the falx-cerebri is attached to the upper thickened half of the vertical plate between the two pits. On the lower extremity of the outer side of the mesethmoid anteriorly, the palatine bone lies between it and the frontal, the mesethmoid plate forming the upper posterior wall of the external nares.

Pterygoids (Pl. XL, figs. 13 and 14).-The true nature of these bones was first pointed out by Eschricht, ${ }^{1}$ in his " Memoir on Platanista" ; they form by far the greater part of the palate. The anterior half of the external plate is convex and the posterior half concave, especially near its hinder border. In the anterior two-thirds of the palatal surface, the bones of either side, in the fully adult skull, are separated from each other by the interposed vertical plates of the maxillaries, but behind this they are closely applied. The lateral concavity of their anterior halves confers

${ }^{1}$ Trans. Roy. Acad. Sci, Copenhagen, ii, 1851. Translated by Wallich, Ann. and Mag., Nat. Hist., 1852. 
a greater expansion on their palatal surfaces than occurs at their middle, which is contracted by the downward and forward prolongation of the concavity that occurs on their posterior halves. Behind the middle, the external plates are divergent, with their posterior inferior angles rounded off into the nasal surfaces of their internal plates; the inferior margins of which are folded forwards in an involute manner. From the central palatal contraction, backwards to the nasal plates, the two bones of either side form a mesial long anteriorly pointed triangular palatal surface, consisting of a fine network connecting the external and internal plates; their anterior extremities being also closed below by a similar structure. There are considerable imperfections of ossification also in the nasal plates. The opening into the sinus of the pterygoids exists internal and anterior to the posterior margin of the external plate within the posterior nares, and external to its outer wall, where that is formed by the internal plate. The orifice, in position, is oblong and is opposite and continuous with the anterior termination of the longitudinal fissure, along which the Eustachian tube runs backwards to the great cavity around the tympano-periotic. In looking through the orifice, it is seen to tend directly forward into the cavity that exists between the two plates of the maxilla; a goose quill passed through it shows that it is continuous with the large oval orifice and smaller foramina that exist on the anterior surface of the maxilla, external to the premaxilla and below the level of the external nares; some of which foramina transmit the infra-orbital nerve. The upper extremity of the anterior margin of the external plate is deeply notched, this notch with the posterior extremity of the superior maxillary constituting the pterygomaxillary fissure, which is continued below the sphenomaxillary fossa internally, and anteriorly terminating in three or four oval infra-orbital foramina. From the upper border of the pterygomaxillary fissure, the ridge dividing the temporal and zygomatic fossæ is prolonged backwards to the foramen ovale. The superior posterior half of the internal plate is applied over the alisphenoid, which is only grooved externally by the inferior maxillary; but a corresponding groove on the former completes the canal in which the nerve lies. The perfect overlapping of the alisphenoid by the pterygoid excludes the former from the outer wall of the cranium. It articulates with the frontal, parietal and squamous; the latter and its downwardly projecting pterygotympanic process, on the other hand, so overlapping this portion of the pterygoid that only a very small portion of it appears above the foramen ovale internal and anterior to the base of the zygoma. The superior anterior half of the internal plate of the pterygoid is also applied to the under surface of the orbitosphenoid. It completes the sphenoidal fissure and confluent foramen rotundum, and, by a thickened posteriorly concave sphenoidal process, overlaps the free auditory plates of the basisphenoid. A thin plate internal and anterior to this is applied to the under surface of the basisphenoid, its margin being wedged in between the expanded base of the vomer and the orbitosphenoid, thus constituting the roof and external wall of the internal nares. From the anterior extremity of the orbitosphenoidal portion of the inner plate, at the posterior margin of the pterygomaxillary fissure and immediately above the palatal, there are two 
plates as thin as tissue paper directed forwards and upwards, and enclosing a wide orifice that is downwardly and backwardly continuous with the posterior opening into the pterygoid sinus. These two plates are wedged in between the frontal, maxillary and palatal; the greater portion of the internal surface of the inner plate being applied to the palatal; its free, anterior margin forms the upper boundary of the large round infra-orbital canal of the maxillary and part of the roof of the pterygomaxillary fissure, and constitutes its posterior wall. The outer plate is opposed to the maxillary surface of the temporal plate of the frontal, where it forms the anterior superior boundary of the pterygomaxillary fissure. The alisphenoidal and orbitosphenoidal portions of the external plate project inwards and downwards over the nasal surface of the internal plate, which forms the greater part of the outer wall of the lower two-thirds of the nasal canals. From the anterior point of union of the internal and external plates, a long outwardly curved narrow thin spicular plate (op., figs. 13 and 14, Pl. XL), grooved on its inner surface, is projected forwards and appears in the inner wall of the apex of the orbital cavity. It is at first internal to and below the tract on the frontal traversed. by the nerves and vessels of the orbit, and afterwards forwards and outwards to assist with the maxillary in forming its inner and upper wall. In adult skulls, this process appears as a fragile spiculum in the upper wall of the orbit between the frontal and maxillary.

The posterior half of the internal plate of the pterygoid, anterior to its nasal surface, is applied to the outer surface of the lower portion of the palatine and by the anterior half to the sides of the vomer, and to the vertical plate of the maxillary. The anterior opening between it and the external plate is opposed to the posterior orifice of the sinus between the two infra-orbital plates of the maxilla, and is continuous with the imperfection of ossification that exists on the anterior surface of the maxilla, below the infra-orbital foramina. The pterygoid completely excludes the palatine from the palate, as first pointed out by Eschricht.

Parietal (Pl. XL, figs. 6 and 7).-The parietal when removed from the skull is more or less quadrangular, but in position it is separated above between the exoccipital, supra-occipital and frontal; narrowing to a point between the squamosal and the frontal, where its lower extremity is in contact with the pterygoid, which is applied over it. Its anterior bevelled border is applied over the posterior border of the temporal; the upper extremity of the margin of the bone presenting a thickened portion where it is wedged in between the external angle of the supra-occipital margin of the frontal and the supra-occipital. I have not been able to detect any interparietal. The supra-occipital border is directed downwards and backwards. In youth this margin simply overlaps the supra-occipital bending inwards, but in the adult skull it becomes much intensified and is bent outwards. The ex-occipital surface is short and overlaps the exoccipital, and anterior to it is the rough surface to which the squamosal is applied. The outer surface of the antero-inferior angle of the bone presents a smooth pit and a small sharp edge for articulation with the upper thickened border of the anterior division of the wings of 
the basisphenoid; a process from that border being applied to the external surface of the parietal. In youth, the petrous bone enters into the formation of the inner wall of the cranium, and has thus the greater portion of the lower border of the parietal applied to it. There is a small flattened process from the border of the parietal resting on the petrous over the internal auditory foramen, always present in young skulls. This process plays an important part in the economy of this region of the skull, as it expands with increasing years, and materially contributes to the after exclusion of the petrous from forming any portion of the inner wall of the skull; but in this it is much assisted by the growth of the false petrous process of the basisphenoid, by the outward growth of the basi-occipital and by the inward and anterior strengthening of the basicranial margins of the exoccipital. In adult life, this portion of the parietal is closely applied to the postauditory process of the basisphenoid, and anterior to that the border of the bone is bent downwards and articulated to the posterior division of the wings of the basisphenoid; forming the inner and upper wall of that portion of the great ear-chamber, which is prolonged forwards above the pterygoid process of the squamosal. By its inward growth it also contributes to the division of this fissure in the cranial walls into two parts: one the foramen lacerum anterius, defined anteriorly by the posterior division of the wings of the basisphenoid, externally by the basisphenoid, posteriorly by the false petrous portion of the basisphenoid by the shelving petrous processes of the parietal, and superiorly by the thickened, lower border of the parietal; the other the foramen lacerum posterius, behind the two last-mentioned processes which define its anterior border, its inner margin being formed by a deep concavity lying between the Glasserian process of the basisphenoid and the strong, outward projection of the basi-occipital which constitutes the anterior border of the precondyloid foramen of the occipital. The posterior wall is formed exclusively by the extremity of the downwardly, outwardly and forwardly projecting strong ridge of the exoccipital, along which the lateral sinus is placed and which also defines the posterior wall of the precondyloid foramen. Its upper wall is formed entirely by the thick, lower border of the parietal. The inner wall of the bone is deeply concave, marked by depressions for the cerebral convolutions and meningeal vessels, and by numerous nutrient foramina.

Frontal (Pl. XXXIX, figs. 1 and $2 f$, and Pl. XL, fig. 1).-This bone consists of a central, vertical or cerebro-nasal plate, the anterior surface of which, with the exception of a narrow strip down the middle of its anterior aspect and which forms the upper part of the hinder wall of the nares, is covered on either side by the ascending plates of the maxillaries and partially by the upper extremities of the premaxillaries. Projecting outwards, forwards and downwards like a pair of wings from the external borders of the vertical plate are the tempero-orbital plates, to the inner surface of which the ascending plates of the maxillaries are also applied. The orbit is placed on the under surface of the free extremity of the plate and has behind it the pit for the reception of the zygoma. The posterior surface of this plate constitutes the anterior wall of the temporal fossa. Project- 
ing backwards, outwards and slightly inwards from the base of the former there is another smaller plate, the temporal, which forms the internal surface of the temporal fossa.

The cerebro-nasal plate when viewed from the cerebral surface is almost quadrangular, and in young skulls the two original halves of the bone can be detected (Pl. XL, fig. 1). In that period of its history it is almost vertical, the most anterior portion of the cerebral lobes being lodged in two deep concavities in the upper two-thirds, separated from each other by a moderately developed, internal, vertical crest; but in aged skulls, the internal surface of the frontal has an upward and backward direction and the concavities for the cerebral lobes are perforated by numerous foramina. In two skulls, I noted a deep pit in the upper part of the left cerebral fossa close to the well-developed, vertical crest, and opposite to it on the other side of the crest a smaller pit. These pits are probably due to the presence on the surface of the brain of cystic parasites, which, pressing against the skull, produce absorption of its walls (?) In one brain the surface bore numerous cysts, which in some cases had corresponding depressions in the skull. In a nearly adult female skull of which I have made a vertical section through the posterior extremities of the frontals, a large well-defined sinus occurs on the left side; while the corresponding position of the opposite side is filled up with finely cancellated tissue; in young skulls, however, there are no traces of these sinuses.

The anterior surface of the vertical plate presents a prominent nodose-like ridge, bearing on the sides of its upper end the minute nasals. It is continuous with the nasal septum, but has a strong twist to the left, which confers on the right side of the plate a longer surface than on the left. The sides of this aspect of the plate are defined by the orbitotemporal wings, and below by the orbitosphenoid which is invested by the alar processes of the vomer. At the junction of the orbitosphenoid and parietals, in young skulls, there is an elongated fissure or imperfection of ossification internal to where the sphenoidal fissure opens on the anterior surface of the united bones. The orbitotemporal plates differ in form, the right having a straight anterior margin, while the left is outwardly curved in the upper first-half of its extent owing to the sinistral distortion of the skull. They are deeply concave from above downwards and forwards ; and their lower extremities, which are thin triangular plates directed downwards, forwards and slightly inwards, are traversed by the optic canals; a small portion of their posterior margin constituting a part of the upper boundary of the pterygomaxillary fissure. The inner surface of these parts of the orbitotemporal plates presents a rather broad but shallow furrow, which terminates in the orbit and along which the nerves and blood vessels pass; and below it are two small grooves, along which branches of the second or median branch of the trigeminal pass into the maxillary to appear on the front aspect of that bone. At the inner end of the first-mentioned fissure and on the inner wall of the canal-like continuation of the sphenoidal fissure, there is a minute orifice, the opening of the orbitosphenoid portion of the optic canal. So far the two inner branches of the fifth nerve lie in that canal, and at this point two nerves from the most external 
of the two branches are given off and pass along theinner aspect of the extremity of the orbitofrontal plate to the orbit. Where the optic canal opens into the sphenoidal canal the optic nerve is superior to the divisions of the fifth, which it crosses to reach the orbit. In passing a bristle through the canal it is frequently stopped in its progress by abutting against the outer wall of the sphenoidal canal opposite its own exit from the orbitosphenoid, and it is this which sometimes makes the bristle return into the skull by the sphenoidal fissure. In young, and even in some adult, skulls the optic canal shows an imperfection of ossification immediately above the pterygomaxillary fissure, its walls being thin and almost transparent.

The facial portion is the narrow elongated surface on which the external basal borders of the maxillary crests rest. It is directed downwards and forwards, narrowing towards its upper extremity, which is placed over the median line of the temporal fossa. The middle of its posterior border is marked by a deep notch, which is best defined on the right side in adult skulls.

The zygomatic process of the temporal ( $z$, fig. 2, Pl. XXXIX) is received into a pit on the hinder margin of the lower end of the facial portion, immediately behind or above the level of the superior border of the orbit, so that there is no post-orbital process. In adult skulls, the inner surface of the anterior end of the zygoma is sheathed by a thin plate of bone from the front wall of the temporal fossa. Anterior to the zygomatic pit is the crescentic upper margin of the orbit, which is a more or less triangular cavity, the apex of which is directed inwards and backwards. It has a depth of about 1:50 inch in adult skulls, with an anterior diameter of not more than one inch. The inner wall is chiefly formed by the thickened base of the malar, its roof being essentially frontal. Its floor is very narrow and is formed exclusively by the backwardly and outwardly projecting zygomatic process of the malar, which abuts against the zygomatic process of the squamosal; in this respect the orbit of this dolphin is more normal, so to speak, than the orbit of such forms as Globicephalus, Orcella and their allies. The malar vertical diameter of the orbit is little over half an inch. The malar floor does not project so far forwards as the upper frontal border of the orbit, but the deficiency is made up in life by a strong fibrous tissue which invests the eyeball and is external to the malar and to the frontal margin, so that the minute globe is almost external to its orbit.

The temporal, which is continuous with the orbitotemporal plate of the frontal, but directed downwards, backwards and outwards, is triangular and received between the parietal and pterygoids.

Squamosal (PI. XXXIX, figs. 1 and 2, and Pl. XI, figs. 8 and 9).-The distinguishing features of this bone are the great size and strength of its zygomatic arch, the remarkable postglenoid fossa and the strong downwardly and inwardly projecting process which embraces the petrous and is applied to the outer surface of the upper posterior extremity of the pterygoid and abuts against the anterior border of the tympanic. 
The squamous portion is nearly vertical, and the lower border of its rough inner surface projects downwards and inwards; its base or under surface below this border being deeply concave and marked with numerous foramina and forming a cavity into which the outer wall of the petrous bone is received. The hinder border of the squamous portion is marked by a fine ridge passing downwards, outwards and forwards to the posterior margin of the base of the zygoma. Behind this ridge, and projecting downwards and backwards from the squamous portion and forming one-half of the upper boundary in young skulls, and in adults the whole of the posterior wall of the external auditory meatus, is a nipple-shaped postauditory process simulating a mastoid. To the inside of this process the periotic and tympanic are firmly attached, and do not project behind its external margin, although the posterior border of the rough surface of the tympanic, which is attached to this process and the posterior fang of the periotic abut against the anterior border of the exoccipital; yet the fixedness of these two bones depends entirely on the attachment to this process. Internally this plate presents a nearly vertical pit into which the anterior fork of the mastoid is received and wholly invested. The outer surface of the posterior wall of this pit has the second fang-like process of the periotic applied to it. To the outside of the inner wall of the pit, the rough surface (vaginal) of the tympanic is applied; also investing the posterior fang of the mastoid and the styloid process. The posterior border of this process articulates with the exoccipital, to which it only becomes united in very old skulls. The lower border of the parietal surface of the squamosal, which is at a considerably higher level than the pit, projects inwards as a thin plate with the upper internal border of the pit, constituting a broad longitudinal furrow, in which lies the anterior division of the periotic.

The zygomatic process of this skull, as is well known, is remarkably large and has a considerable outward curve. It is very deep at its base, but its anterior extremity is narrowed to one-half of the vertical height of the former part and is applied to the frontal forming the posterior border of the orbit. The superior border is nearly longitudinal, with only a very slight upward tendency, while the lower convex border has a decided upward and forward curve. The external surface is markedly convex and the internal, deeply concave; so much so, that the powerful-looking bone has no commensurate thickness and is occasionally fractured. At its base above there is a groove for the temporal muscle. The posterior basal margin is concave, and at its upper end, in adults, it forms an arch over the external auditory meatus, springing from the anterior surface of the postauditory process; while, in young skulls, this process forms the whole of the upper external boundary of that opening. Its lower end is directed backwards and inwards, terminating in a rough postglenoid border, from which a thin, inwardly projecting plate is prolonged upwards and forwards in a curved manner to the anterior root of the petro-pterygo-tympanic plate. This glenoid plate constitutes part of the floor and of the external wall of the deep fossa that occurs on the inner surface of the base of the zygoma. On the inner wall of this fossa, between the periotic and 
tympanic, there is a small zig-zag fissure immediately external to the processus gracilis of the malleus, viz., Glasserian fissure. The articular surface for the mandible is an oval concavity looking forwards, inwards and downwards. The petropterygo-tympanic is a comparatively thin plate arising by two roots, contracted at its origin, but expanding at its extremity into three prongs in youngish specimens; whereas in adult skulls the extremity is more or less rounded with a central arched strong spine-like process, which in young skulls is the more anterior of the three prongs. The anterior root is situated at the upper border of the zygoma at its union with the parietal plate of the squamosal, but on its inner aspect it is continuous with the upward ridge from the glenoid. The posterior root, which is the largest, forms the roof of the postglenoid fossa, and lying longitudinally below the parietal surface of the squamosal has its posterior extremity slightly nodose, and on a line with the posterior margin of the base of the zygoma, and with a deep hollow behind it, into which the periotic is received. The inner surface of this pterygoperiotic plate is applied over the rough external surface of the pterygoid, and its terminal spine arches over the orifice through which the inferior maxillary nerve makes its exit from the cranium; being also applied to a small rough surface on the free margin of the external orifice of the foramen ovale, dividing that foramen, which is large, into two halves, a superior and inferior. The posterior surface of the plate closely invests the anterior and external borders of the periotic, and is applied more or less to the upper concave border of the long Eustachian process of the tympanic. Its upper border is applied against the pterygoid, which at this point overlaps the anterior division of the wing of the basisphenoid. The ridge I have described constitutes the lower boundary of the very large temporal fossa, and the surface of the plate below it is smooth but slightly concave.

Periotic (Pl. XI, fig. 9, pe).-In position it presents two surfaces and three borders; the former look upwards and downwards, and the latter are external, internal, and posterior. The internal border has a deep and wide notch before the cochlea, prolonged as a deep furrow on the under surface, thus resolving this aspect of the bone into two well-marked portions, an anterior and posterior. On the upper surface this notch is prolonged outwards and backwards along the anterior border of the cochlea, so that the anterior division of the bone in this aspect is more extensive than on the opposite face. The anterior portion is a powerful inwardly curved hook, convex from before backwards, presenting above on its inner border an upwardly projecting sharp conical, sometimes style-like process, that fits into a vacuity between the posterior and superior extremities of the internal and external plates of the pterygoid. The inner side of this process is marked by a groove which passes downwards and backwards to a very minute foramen on the inner border of the great notch at the anterior border of the cochlea; the commencement of a canal that opens into the aqueduct of Fallopius near. its termination and doubtless conveys the chorda tympanic nerve. Internal to this foramen on the outer surface of the periotic, there is another small foramen leading to a nutriment canal which 
runs close to the canal of the nerve. These canals can only be traced by fracturing the bone across at various intervals, and thus tracing them to their destinations. Into the deep notch in front of the cochlea is received the strong process of the tympanic before the malleus, and which is usually fractured off from the tympanic and left attached to the periotic, so firmly is it embraced by it. A round ossicle frequently intervenes between the anterior end of this section of the periotic and the petro-pterygo-tympanic process and the pterygoid, and appears to be a separated portion of the hook-like process.

The posterior division of the periotic forms by far the larger section and is thick and massive, being defined anteriorly, on the under surface, by the afore-mentioned notch and superiorly by the anterior border of the cochlea. Viewed from the upper surface, it is oblong, placed obliquely from without inwards and forwards on the under surface of the skull, its inner rounded extremity being the free border of the cochlea which projects into the hinder portion of the great chamber at the base of the skull. The meatus auditorius internus looks inwards and upwards with a slightly forward direction, and its external upper margin is thin and spicular, projecting considerably above the interval, which is also a thin raised ridge. The margin of the orifice as a whole gives rise to a slight tube, which points towards the opening at the base of the skull, through which the seventh pair of nerves pass out, and which corresponds to the deep furrow on the basi-occipital behind the powerful posterior wing of the basisphenoid; the periotic in the adult being entirely outside the cranial wall, while in young skulls the cochlear portion projects strongly into the cavity of the skull. The meatus auditorius internus is a deep circular pit, marked by a series of cribriform spirals with the opening of the aqueduct of Fallopius near the bottom of the pit, in its outer wall. Immediately external to the meatus auditorius internus and. nearly in a line with its hinder margin, there is a prominent well-defined pit, in the bottom of which occurs the minute aqueduct of the vestibule, the anterior wall of which usually bears a long spicule. It may be taken as a guide to the position of the semi-circular canals which occur in the petrous substance of the bone immediately anterior to it; the aqueduct of the vestibule opening internally, anterior to the inferior end of the superior or posterior semi-circular canal. Below this, on the posterior border of the bone, is the vertically, somewhat oval, and large fenestra rotunda, in the bottom of which are visible the two spiral laminæ of the modiolus and wall of the cochlea separated by a narrow intervening fissure. Between the fenestra rotunda and the internal auditory meatus is the short canal, the aqueduct of the cochlea. The under surface of this portion of the posterior division of the periotic presents two powerful, fang-like processes, the anterior of which fits into the deep pit on the postauditory process of the squamosal, the posterior being embraced by the exoccipital and the vaginal process of the tympanic. The deep notch between these two processes is completely occupied by the inner and posterior walls of the postauditory pit, which so grasp and embrace the anterior process that the periotic can only be removed by fracturing the walls of the pit. 
The opening for the aqueduct of Fallopius looks along the groove of the posterior process, and with the fenestra ovalis lies as usual in a hollow in which they are separated from each other by an interval of only 1.03 of an inch, the former being the most internal, looking outwards and downwards. Anterior and slightly external to these is the almost circular hollow for the head of the malleus.

Cochlea is flattened on the under or apical surface, somewhat globular in form and relatively of large size compared with the semi-circular canals, Pl. XL, figs. 1 and 2. Immediately posterior to the internal opening of the aqueduct of Fallopius, there is the orifice of the canal of the vestibule opening into the anterior wall of the vestibule, immediately above the external margin of the fenestra ovalis. In close relationship with the internal auditory meatus is the aqueduct of the cochlea, which is rather large with a wide internal orifice.

The aqueduct of Fallopius has a length of $0^{\prime \prime} \cdot 24$ and is curved from above downwards and backwards, near its termination having a slight inward curve. Near its lower end its anterior wall is marked by a depression perforated by the minute canal which probably transmits the large, superficial, petrosal nerve.

The fenestra ovalis is transversely oval, and within its outer and inner margins there is the rim on which the stapes rests. The vestibule is $0^{\prime \prime} \cdot 16$ in length and is curved upwards, backwards, inwards and downwards, but its two extremities are nearly on the same level. Its inner wall, immediately above the fenestra ovalis, is deeply concave, while the portion posterior to it is more contracted, the inner wall terminating in the commencement of the lamina spiralis which curves backwards and outwards. In the anterior extremity of its outer wall, there is a deep pit, in the bottom of which is the anterior end of the superior semi-circular canal, and in the floor of the vestibule immediately internal to the fenestra ovalis is another depression continuous with the former, but at a considerably lower level, and in which is the anterior extremity of the external semi-circular canal. In the roof of the anterior extremity of the vestibule the canal of the auditory nerve opens, being immediately posterior in position to the aqueduct of Fallopius. The vestibule is rather highly arched at the middle of its roof, into which opens the minute aqueduct of the vestibule, transversely to the long axis of the vestibule, protected below by an inwardlyprojecting shelf of bone. The posterior extremity of the vestibule bends downwards and inwards to the scala vestibuli as a narrow tube compressed from above downwards.

In the fenestra rotunda which has the position this opening occupies in Cetacea, the ridge corresponding to the canal described by John Hunter ${ }^{1}$ as peculiar to this group of mammals is distinctly visible, in addition to the ridge of the scala vestibuli which is the uppermost of the two. This secondary canal appears faintly as a ridge to the left of the canal of the cochlea in fig. 1, Pl. XLI, also in Globicephalus and Monodon, figs. 7 and 10, close to the protuberance corresponding 
to the fenestra rotunda. Tracing the extent of the cochlea from the somewhat oval apical chamber, it would appear to consist of a little more than one and a half turns. The canal of the cochlea, in transverse section, is seen in its first coil from the vestibule to be divided into the two distinct portions, the scala vestibuli and scala tympani, in a more marked manner than in other mammals, by the existence of a prominent osseous ridge, or almost lamina, along the inner wall of the periphery of the cochlea opposite to the lamina spiralis, the two being separated from each other by only a narrow space. This ridge begins at the fenestra rotunda, and is almost lost beyond the first turn of the canal. The lamina spiralis does not reach the apex of the cochlea, where there is a considerable chamber with perfectly smooth walls, and instead of terminating in a hamular process, it ends in a rounded extremity. It is much striated, indicating the tracts of the nerves; and along its under-surface, in close relation to the modiolus, runs a wide spiral cylindrical canal with very delicate walls, its outer and inner walls being pierced by many foramina, the remainder being smooth. Its upper wall is formed by the lamina spiralis itself, and its inner wall by the modiolus. It commences at the foramen rotundum, and the other canal, beginning at the fenestra rotunda, runs below the osseous ridge of the periphery of the cochlea, and is partly membranous, and it is lost about the end of the first turn. It will be observed (Pl. XLI, figs. 1 and 2) that the coils of the cochlea are separated from each other by a considerable osseous interspace.

Semicircular canals (Plate XLI, figs. 1 to 12).-The characters and position of the semicircular canals and their small size relatively to the cochlea, in the Cetacean genera Platanista, Orcella, Globicephalus and Monodon, are well brought out in the comparative series of ear-labyrinths figured, natural size, on Plate XLI, with the semicircular canals themselves magnified twice their natural size.

In connection with these figures, I have to mention that they are exact reproductions of a series of metal moulds made from the ear-labyrinths of these genera by my accomplished fellow-student and friend Professor Crum Brown, whose ingenious researches' into the relations and functions of the semicircular canals are now well known to every physiologist.

In the plate in question, it will be observed that this blind dolphin has semicircular canals greatly exceeding in size Globicephalus, an animal more than double its dimensions, and that the same holds good of these structures and the semicircular canals of Monodon, a whale which attains to $\mathbf{1 6}$ feet in length. These casts also bring out this circumstance that the semicircular canals of Orcella are very much smaller than those of this dolphin, although the animals are of nearly equal size; but whether other Cetacea of the same dimensions as Orcella have similarly-sized canals I am not in a position to say.

Although Orcella and Globicephalus are two forms allied to each other, it is important to note that the semicircular canals of the latter whale, an animal twice

1 Proc. Roy. Soc. Edin., 1874, p. 255; Jour. Anat. Phys., 1874, p. 327 ; see also Mach. Lehre v. d. Beweg. Empfind., 1875; Breuer, Wien. Med. Jahrb., 1874, p. 72; 1875, p. 87. 
the dimensions of the former, are only very slightly larger. It may be that this difference in size may have no structural or functional significance; but it should be borne in mind that the habits of the two forms are distinct, the smaller animal occurring near the coast and frequenting the muddy water of estuaries, and the larger whale living in the clear open sea. It will be further observed, however, that the canals of Monodon, although the animal is smaller than Globicephalus deductor, has slightly larger canals, and therefore still larger than those of Orcella, but, according to the proportional size of the animal, probably relatively smaller than those of Orcella.

I must again revert to the eye of Platanista, which I have shown to be rudimentary, and, in connection with this, call attention to the great development of the semicircular canals, as compared with other Cetacean genera possessing well developed eyes, because it has been pointed out by Crum Brown that, when a person is laid flat on a horizontal rotating table with the eyes closed, every muscle at perfect rest, and thus all the ordinary means of ascertaining the position of the body removed, the person is still able to form a tolerably accurate judgment as to the angle through which his body is moved, and, according to Crum Brown, ${ }^{1}$ he does this by means of the sensation instituted by the pressure on the ampullæ brought about by the movement of the body. He further supposes that the effect is different according as the flow is from the ampulla into the canal or from the canal into the ampulla, and that thus we are able to recognize the direction of the rotation, whether positive or negative, $e x . g r$., to the right or to the left, and so on. Hence the existence of six ampullæ, two for each of the three axes of rotation; and Crum Brown asserts that in man and all animals which he has examined, as in these Cetacean labyrinths, the two exterior canals of the two ears are very nearly in the same plane, and the superior canal of the one ear very nearly in the same plane as the posterior canal of the other. Platanista being practically blind, and having its semicircular canals largely developed, the supposition is permissible, in view of Crum Brown's theory, that the great development may somehow compensate for defective vision.

I must, however, further remark that this development of the canals does not appear to be associated with a keen sense of hearing (unless the animal on which I experimented was deaf), because I fired a pistol over it close to its ear, on two occasions, without its exhibiting any sign of having received any impression.

Tympanic (figs. 8, 9, and 10, Pl. XL).-It is a pointedly conical bullate bone lying below the periotic, with its sharp tubular apex directed forwards and inwards between the external and nasal plates of the pterygoid, impinging on the posterior nares in the angle formed by their external and posterior walls. From the Eustachian extremity, the bone is traversed longitudinally, in its outer half, by a wide and deep cavity, which terminates posteriorly in a semi-circular expansion of the 
outer half of the hinder margin, and which projects backwards beyond the inner half.

The superior border of the bone overlooking the cavity is much arched, rising from either extremity and culminating in a transverse bullate eminence, to the base of which posteriorly there is another and smaller bullate process separated by a deep rounded notch, the external auditory meatus, from a low pillar bearing the expanded rough surface to which the tympanic is attached to the post-auditory process. At the inner end of the large transverse bulla, the malleus is suspended by its neck from a firm anchylosis above the processus gracilis. Besides these attachments, a ridge runs outwards and forwards from a pit on the neck of the malleus above the processus gracilis, and seems to be the equivalent of the laxator tympani. Before the ridge and processus gracilis is a deep notch, the Glasserian fissure, anterior to which is a large thick downward and forwardly projecting process like an enormous malleus. Its outer surface forms an upwardly projecting portion of this margin of the tympanic, and is flattened externally with an irregular concavity at its base; its lower inner border nearly resting on the inner margin of the cavity of the tympanic; and as the tip of the malleus is close behind it, they define a vertical fissure, a continuation of the Glasserian fissure. Its internal surface is marked by two broad furrows and a central ridge which fit into the external surface of the anterior division of the periotic, the posterior margin of the external surface defining the anterior wall of the Glasserian fissure. In separating the tympanic, this process is usually left attached to the periotic. The two bones in adult skulls are slightly connected at the anterior margin of the external surface of the process, but so very minutely that I could only detect their presence by the aid of a lens. In young skulls there is no trace of anchylosis; but this process is so thoroughly wedged into the periotic, the mastoid so rooted like a tooth in the post-auditory process, and the vaginal process of the tympanic so locked in between the mastoid, exoccipital, and squamosal, that the bones never separate from the skull except by fracture.

The large and small bullæ require to be described in detail, as they are important structures in the economy of the ear. The former is compressed anteroposteriorly, and occupies the highest point of the upper border of the tympanic, being placed transversely to its longitudinal axis. It is closed anteriorly, but there is a small semi-circular opening into its eavity posteriorly, its hinder wall being incompletely closed; in the recent skull this opening is external to the tympanum; it is placed above the level of the posterior and smaller bulla, the cavity of which is internal to the tympanum. The inner extremity of the larger bulla is curved downwards and inwards, and has the malleus attached by its neck to its extremity. The external surface is curved downwards, forwards, and then backwards on the outer side of the tympanic as a prominent bullate band, its anterior border being the larger; but both it and its posterior border are defined by a deep furrow. Above, where it bends backwards, there is a slight concavity, but the remainder is convex. The posterior furrow is prolonged into the hinder opening before the smaller bulla, which is also an antero-posteriorly compressed transverse smooth 
rounded process, concave from behind forwards in its hinder surface which forms the anterior wall of the auditory meatus. In position it is considerably below the upper border of the larger bulla, which arches inwardly over it and into the cavity of which it projects, but leaving a fissure between its upper border and the arched posterior margin of that bulla, the fissure being continuous with the cavities of the larger bulla and tympanic. The cavity of the larger bulla is vertically oval and looks inwards, the greater part of the hinder wall and the floor being formed by the smaller bulla; this latter sends inwards forwards and upwards a curved ridge from its base, a ledge-like floor to the cavity which is much antero-posteriorly compressed and opening freely in the dried skull into the tympanic cavity. It does not occupy the whole of the bulla, for from the floor-ridge of the smaller bulla a fine ridge is prolonged upwards, defining its inner limit, internal to which there is a broad shallow groove running downwards behind its inner extremity where the malleus is attached, viz., transverse to the longitudinal axis of the tympanic and corresponding to the external bullate band. The inner surface of the cavity of the bulla in the recent skull is external to the tympanic membrane. This membrane is attached along the upper margin of the basal ridge (floor) of the smaller bulla, and the fine ridge prolonged onwards from it along the inner margin of the cavity, from the upper extremity of which it is reflected backwards to a ridge on the under surface of the rough post-auditory process of the tympanic. Thence it continues to the upper border of the tympanic, between that process and the smaller bulla, and across the base of the latter internally, back to its basal ridge, but above the opening into the cavity of this bulla, which latter is internal to the tympanic, and a short, blind canal with a moderately wide orifice into the tympanic cavity directed backwards. The inner surface of the cavity of the larger bulla consists of a fine network of delicate ridges, the majority of which are transverse, many of the intervening sulci being covered with very small pits. A minute canal occurs in the floor of the cavity, and traversing the external portion of the base of the smaller bulla, opens on the outside of the tympanic in the lower end of the furrow, defining the posterior external border of the bullate band.

I am indebted to Dr. Doran ${ }^{1}$ for the following account of the ossicles of the ear of Platanista: "In the Gangetic dolphin. (Platanista Gangetica) the head of the malleus is of the same form as in Delphinus, and the upper facet is larger than the lower; but the process in front is extremely elongated so as to be longer than the head itself, from which it is hardly more distinct than in Monodon, except that a faint groove, generally observed in the true dolphins, divides them above and internally. Instead of a rough and only slightly concave surface at the very extremity of the process, as is found in most Cetacea to mark the insertion of the tensor tympani, there is a very deep pit on the external aspect of the projection actually nearer its root than its point; this is highly characteristic. The point itself is sometimes slightly hooked, and from it to close under the articular surface, all along the inner aspect

+ From Doran, Trans. Linn. Soc., vol, i (2 ser.), Zoology, Part vii, 1878, not yet printed. 
of the process, runs a very distinct groove ending posteriorly in a faintly marked tubercle representing the manubrium. It seems as if the groove was homologous to

Fig. 18.

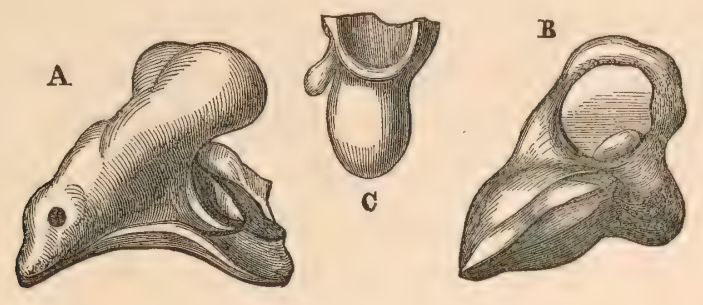

Magnified views of small ear bones of Platanista.

A, left malleus. B, right malleus from opposite side. C, the incus.

the outer surface of that process in other orders of the mammalia, the hooked or blunt point corresponding to the processus brevis. Many of the fibres of the fleshy prolongation of the membrana tympani to the malleus are attached to the bottom of that groove and are often seen still adherent in imperfectly dried specimens." In Monodon and the dolphins proper, some of the fibres are in the same manner inserted along the head of the malleus, as well as to the splinter-like, more definite homologue of the manubrium. ${ }^{1}$

The processus longus of the incus is as thick as in Monodon, and the articular surface for the head of the stapes is as small; the posterior crus is even less developed than in Delphinus. The stapes is of the same form as in the smaller dolphins, without a trace of any interneural aperture ${ }^{2}$; there is sometimes a large tubercle for the stapedius tendon on the inner aspect of the head.

Vomer (Pl. XL, fig. 1, vo).-This is directed downwards and forwards, but has a twist to the left side. It may be resolved into three portions: 1st, the expanded plates which invest the under surface of the orbito-sphenoid and a portion of the basisphenoid; 2nd, the thin nasal plate between them; 3rd, a division consisting of two wings, between which the mesethmoid cartilage (me) is received, the latter terminating below and anteriorly in a thin vertical plate wedged between the vertical plates of the maxillæ, the posterior extremities of which are applied to a lateral expansion on its posterior border.

The expanded plates are broad and form the posterior wall of the nasal canal. At the middle of their external margins there is a pointed process projecting downwards and outwards and which interposes between the palatine and pterygoid, and above this process the palatine is articulated to the rough surface on their thick external margins, and below it the nasal surface of the pterygoid is applied to the remaining portion of their external margins which bend inwards, terminating, in the adult, in a more or less truncated posterior margin. The upper borders of the

\footnotetext{
${ }^{1}$ In making a fresh dissection of the tympanum of this dolphin, I have found a strong band of fibres inserted into the groove, and the tensor tympani was inserted into the depression above described.

2 In the stapes of a young Susu there is a well-defined and rather large interneural aperture, but in tbree bones of adults there is, as Dr. Doran says, no trace of such an aperture.
} 
plates, directly above the nasal septum, are separated from each other by a rough groove continuous with the lower roughened surface of the mesethmoid ridge, to which the cartilage of that bone is attached and which is prolonged forwards chiefly between the premaxillæ to the extremity of the snout. The nasal plate is thin and slightly expanded from above downwards, ending below in a free sharp margin. A deep triangular anterior longitudinal notch separates the wings from the vertical plates, but both are closely applied to the premaxillæ and maxilla. At the upper margin of the wings, anterior to the nasal septum, they are separated by an oval nodose rough surface, which is prolonged downwards and forwards between the free extremities of the wings, and to it the mesethmoid cartilage is also attached.

Palatine (Pl. XL, fig. 12, and fig. 17 ). - The peculiar position of this bone in Platanista was first pointed out by Eschricht. It appears in the anterior and outer walls of the nasal cavities, and is placed so high in them that its upper extremity rises above the low anterior border of the external nares in the dried skull, the lower half of its nasal surface forming the anterior, and its upper half the external wall of the nasal cavity. The former completes the canal, but is seen with difficulty, owing to the backward projection of the pterygoids. When the maxilla is separated from the skull, the palatal is seen to invest the greater part of its posterior and external borders, below the frontal plate and the inferior border of the vomeric crest of the maxilla. It is nearly vertical, but has a slightly downward and forward course. Viewed from the outer side, it is seen to form the posterior boundary of a large round foramen in the maxilla, the inward and forward continuation of the pterygo-maxillary fissure. The lower border of this foramen is defined by a strong longitudinal lamellar process, the backward continuation of the external plate of the maxilla, which also forms the lower outer wall of the pterygo-maxillary fissure externally. This process terminates abruptly on a line with the posterior margin of the large foramen, and its root is so deeply grooved and so firmly embraced by a notch about the middle of the vertical height of the palatal (the two are clasped together like a hook and eye), that they can only be separated by fracture. The notch divides the palatal into two external surfaces, a superior and inferior; these form a very obtuse angle with each other, the former being directed upwards and inwards and the latter downwards and inwards, due to the spirally curved character of the nasal surface. The upper surface is also slightly bent from before backwards and inwards, and the inferior portion, which is concave from without inwards, has its posterior margin a little outwardly curved. The former has its upper extremity abruptly truncated and somewhat concave where it embraces the inferior extremity of the external surface of the frontal plate of the maxilla. The inferior portion has a pointed extremity which reaches close to the lower margin of the posterior angle of the vomerine crest of the maxilla, so that it is only excluded from appearing on the middle of the palatine surface by a few lines, and is directly below the pterygo-maxillary fissure. The whole of the lower and one-half of the superior surface are completely hidden by 
the pterygoid, the only portion which is not so invested being the upper half of the superior division of the external surface. The latter lies in a vacuity defined by the orbito-sphenoid, frontal, maxillary, palatine, and pterygoid, and corresponds to the spheno-maxillary fossa, because the sphenoidal fissure and optic foramen open into it. Close to its anterior margin, behind the large maxillary foramen already mentioned, there is a thin small outwardly-projecting plate, perforated on its upper surface by a minute foramen. A bristle passed downwards and forwards through this appears at the middle of the anterior border of its lower half; but when the pterygoid is in position, the tract in question is lengthened above and below by the opposition of the pterygoid to the outer surface of the bone. The canal is thus defined by the pterygoid, palatine and maxillary, and is the pterygo-palatine canal. An imperfection of ossification exists in the nasal surface of the bone and leads into the canal, doubtless transmitting a nerve to the mucous surface of the nasal canal. Immediately above this foramen there is another which leads directly into the nasal canal. The inner surface of the palatine, which is much more limited in its extent than the external, is applied by its upper half to a narrow surface on the hinder end of the maxilla below the frontal plate of that bone, fig. $17 n$, and its lower half to the outside of the vomerine crest of the maxilla. The centre is thin and marked by numerous imperfections of ossification, while its nasal borders are thickened and the external slightly expanded. A thin plate projects forwards from the upper portion of the anterior border of the bone at right angles to its long axis and corresponds to the anterior half of the concavely-truncated upper external border which embraces the base of the frontal plate of the maxilla. The lower half of the internal surface is smooth and slightly convex.

The nasal aspect of its posterior surface is smooth, but porous, being covered with numerous minute foramina. By far the greater portion of the upper half looks inwards, but a small part enters into the anterior wall of the nasal canal, while its lower half is directed inwards and backwards. In looking into the nasal cavity from below upwards, it is seen articulating by its inner or anterior margin with the side of the rough triangular expansion of the vomer, anterior to its nasal septum, and above this through the whole of its nasal course with the nasal surface of the posterior extremity of the maxilla. Its external or posterior border, on the other hand, is observed to lie along the anterior margin of the nasal surface of the pterygoids, at the upper end of which the external margin of the wing of the vomer is wedged in between it and the pterygoid, the remainder of the margin being applied to the former. Its upper margin is in contact with a transverse ridge on the anterior surface of the frontal immediately external to the mesethmoid, and its external angle articulates with that bone. In this portion of its course it lies between the mesethmoid and vomer, the frontal, maxillary, and pterygoid, and is above the level of the orbit, but far removed from it posteriorly.

Malar (Pl. XL., figs. 15 and 16).-This is a relatively small bone consisting, as in Cetacea generally, of two portions, a round thick knob-like anterior, and a styli- 
form posterior half. In adults the maxilla developes a thin plate below the origin of the zygomatic portion of the malar, and the orbital process of the maxilla so expands over it that the bone is firmly locked to the skull; while in younger skulls the malar is easily removed and indeed falls out. The round anterior extremity projects considerably downwards, defining a deep infra-orbital notch. The head of the bone anteriorly is also traversed by a longitudinal furrow from the lower margin of the orbit. The zygomatic portion in the adult is occasionally supported by a thin sheath derived from the frontal.

Maxilla (Pl. XXXIX, figs. 1 and 2, and Pl. XL, figs. 17 and 18).-The dental portion is a long laterally compressed rod, tapering towards its free extremity, and from the external and superior surfaces of its extremity springs an upwardly and backwardly projecting portion which overlaps the frontal between its naso-orbital processes, and which bears the crests which are so distinctive of this dolphin.

The external surface of the maxilla, behind the open end of the dental furrow, presents, in young skulls, two short parallel upwardly curved ridges; but these are confluent in adult skulls and continuous at their upper extremities with the margins or walls of an upwardly curved fossa which terminates immediately below the orbit. In young skulls, the fossa communicates by an anterior round slit, and posterior to this by a long narrow fissure, with the backward continuation of the dental cavity which forms the outer wall of the backward continuation of the true maxillary fossa or antrum; but it is marked by imperfections of ossification and by a permanent fissure which leads from the antrum to the fossa. The antrum has its margins usually connected by long spiculæ or bands, opening posteriorly by two orifices which are formed by the backwardly projecting process of the inner wall of the fossa. This latter is applied to the palatine and forms the lower border of the infra-orbital canal, into which the superior orifice leads directly, while the inferior opens posteriorly by an arched margin along the lower border of the inner plate of the maxilla (defining the outer wall of the fossa) and leads into the pterygoid sinus. The inner wall of this orifice is formed by the outer surface of the external plate of the maxilla in the fossa and by a portion of the palatal. Above the external imperfection of ossification, three to four small oval foramina open from the infra-orbital canal, and doubtless transmit branches of the infra-orbital vessels and nerves. The inner plate of the maxilla, from what has been said, thus apparently forms the outer wall of the fossa, but if the upward twisting of the bone is kept in view, and also its relations to the pterygoid and palatal bones, this portion may be regarded as the true palatine surface of the maxilla, as it supports the lateral, muscular extensors at this part of the palate. Such being the case, the palatal bone is not so abnormally situated as at first sight one would be led to suppose. When the palatine is removed from the posterior extremity of the maxilla, the commencement of the infra-orbital canal is enlarged, as that bone forms its posterior boundary defining it as a circular orifice, the floor of which is formed by the palatine ridge-like process of the maxilla, and to the under margin of which the 
pterygoid is applied. The palatine process of the maxilla terminates posteriorly in a hook and groove, the former embracing the palatine, and the latter receiving a curved sharp ridge of the same bone. Behind this, looking backwards, is the rough surface for the articulation of the palatine, above which is the small surface forming the boundary of the anterior wall of the external nares, posterior to the premaxilla. Above this is the expanded surface of the maxilla, which is applied to the frontal on either side of its nasal ridge or crest. This surface, which is the highest portion of the maxilla, looks backwards and downwards, and its extent varies on the two sides of the skull owing to its sinistral twisting, the left being by far the smaller. The right surface is concave in its lower two-thirds and convex above at its internal extremity, where it rests in a deep concavity on the anterior surface of the frontal, external to the nasal ridge. The frontal surface of the left maxilla is narrow and wholly concave, the corresponding maxillary surface of the frontal being convex. Anterior to the palatine surface of the maxilla and above the infra-orbital canal there is a broad, but thin flat surface marked by numerous imperfections of ossification in the young skull. This is defined above by a broadly arched free margin of the external plate of the maxillary crest, the arch leading into the cavity that exists between the two plates of the crests. This flattened surface is not applied to the frontal, so that a large space exists between the two bones; it is precluded from communicating with the nasal cavities by the palatine and is closed below by the pterygoids. Anteriorly it is continuous with the orbital cavity, so that the latter communicates in the dry skull with the interspace between the plates of the maxillary crests. Immediately above this arch, and below the whole length of the exposed portion of the maxillary crests, there is an elongated, slightly convex surface, to which the upper portion of the internal surface of the orbital process or wing of the frontal is applied. There is a ridge running downwards and forwards from the posterior angle of the crest to the posterior end of the free arched margin, leading into the cavity of the crest, and the ridge defines the posterior limit of the application of the orbital wing of the frontal to the maxilla, the surface of the maxilla posterior to it looking backwards and its orbito-frontal surface outwards. It also defines the posterior limits of the crest, and a line drawn from its lower extremity to the orbital process, which projects forwards over the upper end of the interspace (alveolar) between the plates of the maxilla, marks the lower limits of the maxillary crest. An irregular ridge defines the base of the external portion of the crest and corresponds to the upper free sharp wavy margin of the orbital wing of the frontal. The external surface of the crest in young skulls is more or less quadrangular, a form preserved in the adults, but becoming more constricted posteriorly. At all ages, the superior posterior angle is rounded. In youth, an external depression or constriction curves backwards, inwards and then forwards, terminating immediately behind the superior anterior angle in a well-marked depression; but with age the external surface of the crest becomes nearly flat, and the constriction is reduced to a depression at the base of the crest about its middle. In young skulls a number. of fine grooves radiate inwards in a curved 
manner from the external basal line of the crest, being most strongly marked in the constriction; but they disappear in the adult, in which the external surface is coarsely rugose. At all ages, the anterior two-thirds of the inner margins of the crest have a number of imperfections of ossification which communicate with the vacuity between the two plates; these also extend along the anterior border, but do not occur in the posterior third of the margin, as the internal plate is imperfect in that portion of the crest. A number of foramina open behind the anterior border. The anterior and middle thirds of the inner borders of the crests approach each other with age, but never touch; while their posterior thirds are strongly divergent from within outwards, defining a triangular space and constituting the osseous limits of the blow-hole. The right margin of this space is longer than the left, owing to the sinistral asymmetery of the skull.

The premaxillary surface is a very narrow area lying along the anterior base of the crest, above the posterior orifice or termination of the cavity of the dental portion of the jaw, and at its posterior half is internal to the fronto-nasal surface. It has an outward and inward curve from above downwards and is completely invested by the premaxilla. The outer margin of the premaxillary portion forms a rather prominent ridge. The fronto-nasal portion narrows from above downwards between the inner basal margin of the crest and premaxillary surface; on the right side, it is concave on its upper half, and slightly convex on its lower, while on the left side these characters are reversed. A little below the superior extremity of the premaxilla, and immediately external to its outer border, a foramen occurs in the upper half of the fronto-facial portion and leads nearly vertically downwards to a canal that opens below at the outer border of the palatine, but anterior to it in the upper portion of the spheno-maxillary fossa, defined by the palatine. This canal transmits a nasal branch of the fifth nerve.

The anterior aspect of the crest, looking inwards over the nares, consists, in its lower half, of a thin plate of bone corresponding to the flat perforated surface of the external aspect of the maxilla. In this surface, the two plates of the maxilla appear to be lost in each other, where they meet below the orbit, and the external plate of the crest thus appears to be quite distinct from either of them, these amalgamated plates forming the inner plate exclusively. This plate is very thin and is marked by a number of imperfections of ossification in its lower portion; but after passing over the lower half of the anterior or nasal surface of the crest, the imperfections of ossification become enormous, and the appearance is produced as if the plate stopped short at this point. But, from its anterior portion, a narrower surface is prolonged round the free margins of the crest to near its posterior superior angle; between this and the body of the plate pass numerous branched osseous spicules connecting the plate and its marginal portion together, the interspaces between the connecting bands being imperfections of ossification. In adults, the inner plate becomes much thickened and consolidated in its lower portion, and the narrow border, along the margin of the crest, also becomes much thickened and detached from the former, by absorption of the osseous connecting bands. 
Sexual differences displayed by maxillaries.-The characters which 'distinguish the snouts of the males and females are illustrated by the skulls represented in Plate XXXIX, and I have already pointed out what these characters are.

Changes by age in the alveoli and dentition.-The alveolar surfaces lie side by side throughout their extent, except posteriorly, where they are divergent at the fourth tooth from the last. In very young skulls the alveolar furrow posteriorly, as far forwards as the eighth or ninth tooth from the last, is continuous with the cavity of the maxilla, but about these teeth a narrow ridge appears on the inside of its external wall. This ridge soon re-unites with its inner wall, constituting a distinct roof perforated by foramina, which separate the furrow from the cavity of the jaw, throughout, however, only a very limited part of its extent, as this septum ceases about the twentieth tooth from the hindmost, the jaw cavity and furrow being merged in one. The formation of alveolar pits I have also previously described under Dentition.

Premaxilla (Pl. XXXIX, figs. 1 and 2, and Pl. XL, figs. 17 and 18).-This bone is nearly of the same length as the maxilla and consists of two portions, a facio-nasal plate, almost crescentic in form, constituting the outer border of the external nares, and a long thin compressed rod continued forward beyond the extremity of the maxilla. The former plate overlaps the facio-nasal portion of the maxilla, closing in the posterior termination of the cavity of the jaw and completing the anterior wall of the nasal canal. The remaining portion of the bone is nearly straight in youth, but, in adults, it partakes in the same marked curves that distinguish the maxilla. The outer surface of the premaxilla, about the beginning of the furrow lodging the infraorbital vessels and nerves, is marked by two or three imperfections of ossification in some skulls, but not in others. The premaxillary foramen occurs about one inch from the end of the snout in adult skulls, and is close to the upper border which is slightly divergent from its fellow, displaying the termination of the cartilaginous vomer. As already stated, the premaxilla appears to carry four teeth, as the line of suture can be traced along to the base of the fourth tooth; union, however, of the anterior extremity of the bone with the maxilla is an event of uterine life. The inner surface is divided into two portions, an upper deeply concave portion lodging the mesethmoid cartilage, and a thin plate below this, which gradually increases in depth from before backwards, applied to the inside of the vertical or palatine plate of the maxilla.

This bone also partakes of the general asymmetry of the skull, its left facionasal portion having a considerable sinistral twist, owing to the external nares being dragged to that side of the skull, a circumstance which also tends to reduce the upward extension of this part below the level of the bone of its right side.

Nasals.-These two small narrow bones lie in a depression on the lower end of the nasal ridge of the frontal, above where it is continuous with the mesethmoid portion of the ridge. The lower extremities form a very faint projection, marking the superior posterior termination of the nasal septum.

The Mandible and its dentition (Pl. XL, fig. 19, and Pl. XXXIX, figs. 1 and 2).-The distinguishing feature of the mandible, as is well known, is the very 
elongated character of the symphysis which, in adult females, forms nearly twothirds of the lower jaw, whereas in males it constitutes only a little more than onehalf of the total length of the mandible. The rami become united at the symphysis in utero... Only one tooth in the young cannot be said to be symphysial, whereas in adults with all their teeth intact the last tooth lies in debatable ground. In the young, the symphysial portion is slightly curved upwards and forwards as far as the twentythird tooth from the first, and then forwards and downwards, there being a faint upward curve at the base of the fourth tooth. The symphysial, or internal alveolar plate is but slightly curved in the young skull, thus agreeing with the nearly straight maxilla; but, as age advances and the curves become more intensely marked, it also partakes in the general curvature, which is adapted to the opposed curves of the maxilla. This curvature is a means, in addition to the interlocking of the teeth, by which the upper and lower halves of this long snout are held firmly in position when the mouth is closed.

The symphysial dental portion is strongly laterally compressed, the two alveolar lines being in close apposition. The external surface is slightly concave, and the middle of the symphysis is deeper than at the beginning of the ramus and much more so than at its own terminal upturned distal third. The coronoid is moderately high and arched, the depth of the jaw through it being less than onehalf of the distance between the condyle and the posterior end of the symphysis. It is concave at its base externally and flat internally, and its posterior margin slopes down to the condyle, which is vertically oval and directed backwards. The under surface of the coronoid portion of the ramus is broad, by the inward extension of the inner margin as a thin slightly outwardly curved plate, producing a concavity which is continuous with the fossa along the side of the lower border of the symphysis. A short sharp longitudinal ridge for the attachment of the external pterygoid muscle occurs in the concavity of the ramus before the condyle. The opening to the dental foramen, on the inner side of the jaw, is large and prolonged backwards into the lower angle of the condyle, from the outer surface of which it is only separated by the thickness of the condylar plate itself. In adult skulls, this becomes partially absorbed, so that the two communicate. The dental canal is very wide and infundibuliform.

The lower jaw partakes of the general asymmetry of the skull, the symphysial portion being twisted to the left side from its base forwards, and the free portion of the rami differing in their curves, the left being more externally curved than the right.

Hyoid (Pl. XL, fig. 20).-The basihyal (bh) is a somewhat transversely crescentic flattened bone with a convex anterior and a concave posterior border, and slightly concave on its upper and under surfaces, the two extremities of the crescent being abruptly truncated. It is not anchylosed to the thyrohyals $(t h)$ which are slightly curved, dilated at their basihyal ends, and contracted externally to that, with a prominent nodosity in adult life on their anterior surfaces defining the contraction. The ceratohyal is a long cartilaginous rod, nearly as long as the 
stylohyal $(s h)$, which is more or less cylindrical and twice curved on itself and somewhat compressed at its cranial end. In the fœtus, the basihyal is a minute ossicle, whereas the thyro and stylohyals are well ossified.

Vertebral column (Pl. XXXIX),-The vertebral formula is this: C 7, D 10 or 11, L 7 or 8 , C 26 or $27=51$ or 52 . I have examined twenty perfect skeletons and have never found less than fifty-one vertebræ.

Characters. - The vertebral column (figs. 3 and 4) describes two curves; the six anterior cervical vertebræ having a slight upward bend, while the dorsal vertebræ from the last to the seventh have an upward and forward curve, whereas from the latter to the first, the direction is downwards and forwards. The lumbar and caudal vertebræ are nearly in a straight line, the terminal seven vertebræ being slightly curved downwards. The cervical vertebræ are all distinct. The centra of the vertebræ are rather narrow antero-posteriorly, their breadth being considerably in excess of their length, in any portion of the column. The strongly developed spinous processes are directed backwards in the anterior vertebræ, up to the fifth dorsal; the process of the next vertebra is erect, whilst all the processes of the succeeding vertebræ are curved forwards in a marked degree, and the processes entirely disappear in the fortieth segment. The neural canal, which is capacious in the cervical and first part of the dorsal region, being much broader than high, rapidly diminishes in capacity, its breadth in the last dorsal vertebra being one-half of what it is in the first rib-bearing segment. In the lumbar region the height gradually exceeds the breadth. In the tenth caudal it is reduced to a tube about one line and a half in diameter. The strongly-developed metapophyses first appear in the fifth dorsal, and can be traced backwards as far as the fourteenth caudal, and are another marked feature of this dolphin. The last trace of zygapophyses occurs on the sixth lumbar vertebra. Transverse processes are present from the atlas to the fifteenth caudal in a more or less decided manner, but they are especially strongly developed in the lumbar and first five or six caudal vertebræ.

Special characters of individual vertebre.-The atlas is much broader than high, and has a strong transverse process, which is directed backwards and out wards. It springs from the pedicle external to the outer border of the posterior zygapophysis, and from between it and the anterior zygapophysis, i.e., above what would be the position of the neurocentral suture; it would thus appear to be serially homologous with the superior transverse process of the vertebræ immediately behind it. The inferior transverse process is most intensely developed in the sixth cervical vertebra, where it is directed forwards and outwards, and it can be distinctly traced forwards to the fourth cervical, here springing directly from the side of the centrum, but its superior root originating from the inferior root of the superior process. As there can be but little doubt that the transverse process of the axis is serially homologous with the superior transverse process behind it, the process of the atlas which occupies a relatively higher point on the neural arch, and which follows the direction common to the two superior transverse processes behind it, is also the homologue of these processes. The neural arch is lower and more 
flattened than in Inia, and it is marked by a pointed longitudinal ridge or spine, and it is rather deeply notched anteriorly at its base, for the suboccipital nerve and vertebral artery; and above the facet for the occipital condyle, a sharp process projects upwards and inwards from the inferior to the superior angle of the notch to such an extent that it is possible the notch in some individuals may become converted into a foramen. The inferior arch is very broad and strong, having a welldeveloped hypapophysial process for the support of the odontoid and a large concave facet on its upper surface for its reception. The posterior zygapophyses are unsymmetrical, the left being considerably larger than the right, and projecting inward beyond the inner wall of the neural eanal, which it also renders unsymmetrical. The base of the left facet and the right half of the odontoid facet are slightly raised above the level of the corresponding parts on the left side. The upper surface of the posterior facets are deeply grooved. The neural canal is broad above and narrow below.

The axis is distinguished by its very largely developed superior transverse process directed backwards and outwards. The odontoid is well developed and has a large articular facet on its under surface, and it is slightly twisted to the left. The neural canal is broader than high and arched with a broad flattened floor. The arch is broad, antero-posteriorly high, directed slightly backwards, and the spinous process is traversed by a well-marked ridge which terminates anteriorly in a free process, the apex of the spinous process being more or less bifid. The body of the axis is concave below and terminates in two posteriorly divergent, strong hypapophyses. The anterior zygapophyses, the upper extremities of which are on a level with the inferior border of the posterior zygapophyses, their inferior margins being on a line with the under surface of the odontoid, partake of the same want of symmetry that distinguishes the posterior surfaces of the atlas. Their surfaces are not continuous with the articular surface of the odontoid, so that the lateral movement of the head cannot be very great. The articular surface of the centrum is transversely oval, and the epiphysial surface markedly concave in the middle.

The third cervical has a very short centrum, a little broader than high. The neural canal is triangular, considerably broader than high, and with very narrow laminæ, directed slightly backwards, and presenting some very small processes at their point of union, but no further trace of a spinous process. The transverse process, occasionally perforated by a vascular foramen, has an antero-posteriorly thin, but deep base, which embraces two-thirds of the side of the centrum, sending forwards a small process from its inferior basal margin. Its upper border, below the zygapophyses, has a deep intervertebral notch, the inferior outward limit of which is defined by a small sharp process. The process lies immediately anterior and close to the transverse process of the axis, but has the superior transverse process of the fourth vertebra behind and above it. The zygapophyses are on the same level at the outer end of the laminæ, and the two of the right side are of about one size, but the posterior zygapophysis of the left side is very small. 
The fourth vertical has a thin, antero-posteriorly compressed centrum like the third, but it is relatively higher, its articular surfaces being as high as broad. The anterior surface is rendered deeply concave in its lower half by the forwardly projecting inferior transverse processes which are first strongly marked in this vertebra. The laminæ are very narrow and rod-like, with a very minute process at their union and a roughened surface external to it, there being no spinous process. The neural canal is broadly triangular and not so acutely arched as in the preceding vertebra. The zygapophyses become more removed from each other, the anterior being at a lower level than the posterior, and on the right side the two are separated from each other by a deep notch, while on the left they are closely applied to each other due to sinistral asymmetry, the left lamina of the neural arch being also dragged to the left side. The relative proportions also of the zygapophyses are reversed in this vertebra from that which prevails in the vertebra before it, the anterior being about half the size of the posterior zygapophyses. The invertebral notch is not so broad as in the third, but it is better marked, the equivalent of the process that defined its inferior outer limit in the latter vertebra is very strongly developed in this one; and, owing to the shortening of the superior transverse process, it occurs at its extremity, which is thus bifurcate. The superior transverse process is short and compressed from before backwards, concave on its superoposterior surface, bifurcate and directed outwards and slightly backwards, lying below the level of its fellow behind it and a little above its fellow before it. The base is prolonged down one-half of the side of the centrum, where it is separated by a semi-circular notch from the inferior transverse process. The latter has a broad base reaching from the superior process to the inferior border of the centrum, tapering to a point and directed forwards, its inferior surface more or less concave, and its superior surface flat, its anterior surface being grooved. It is considerably smaller on the left than on the right side. On the laminæ, halfway between the posterior zygapophyses and their line of union, a small, backwardly-projecting process simulating a hyperapophysis occurs.

The fifth resembles the fourth vertebra in its general form, but the neural arch is much stronger, and on its left side there is a stout but small backwardly projecting process like an hyperapophysis ; on the right side this structure is imperfectly developed. The neural canal is twice as broad as high, but its two halves are unequal, as the lamina of the right side is depressed. The zygapophyses of the two sides are unsymmetrical, those of the right having their articular surfaces on nearly the same plane, separated externally by a very small notch; while those of the left are widely apart from each other and smaller than those of the right side. The transverse process, bifurcate at its extremity, is larger than in the preceding vertebra, and separated by a wider notch from the anterior zygapophyses than in the fourth vertebra. This process is posterior and superior to the transverse process of the fourth vertebra, and lies on the same plane with the superior transverse process of the sixth. The inferior transverse processes are more strongly developed than in the fourth, but are considerably smaller than the superior processes. 
The sixth vertebra is distinguished from the foregoing by the very great development of the inferior transverse process, which is directed forwards and outwards with a slight upward curve. It is a rounded rod-like structure, separated by a deep oval notch from the superior transverse process, the length of which it equals. It arises from the lower half of the centrum, and the left is shorter than the right. The pedicles of the neural arch are better developed in this than in any of the preceding vertebræ. The zygapophyses of the left side, unlike those of the preceding vertebræ, are nearly on the same plane and are not separated by a notch, and the conjoint, antero-posterior expansion of the two is considerably in excess of that of the right zygapophyses, which are disunited externally by a small notch, almost converted into a canal by the approximation of the posterior and anterior extremities of the borders of the facets. The superior transverse process is also rod-like with a smaller extremity and one directed outwards and forwards. The neural canal partakes of the same asymmetry that distinguishes the preceding vertebræ, but even in a more marked degree, the left having considerably greater capacity than the right half. The arch is strong but backwardly twisted on the left side. There is a faint ridge in place of a spinous process, and a small process on the hinder border of the lamina. The centrum is thicker antero-posteriorly than in the three preceding vertebræ, but its articular surfaces are similar to those in the fourth and fifth.

The seventh cervical is distinguished by its well-developed pedicles, falcate spinous process, and well developed transverse processes. The body is thicker than in the sixth vertebra, and its articular surfaces are transversely oblong. Its under surface is marked by a longitudinal furrow perforated by a distinctly defined foramen. The neural canal is triangular, very slightly broader than high. The neural arch is twisted obliquely from side to side, the right being broader than the left half and anterior to it. The spinous process is as high as the length of one of the laminæ. It is directed backwards with a slight twist to the left. The zygapophyses are quite separate with the facets on the same plane. The transverse process arches outwards, slightly backwards, and is faintly curved downwards, especially at its extremity, above which it is marked by a roughened nodosity. At the base of the transverse process anteriorly occurs the irregular rough surface to which the head of the first rib is articulated.

Dorsal vertebra. - The first dorsal vertebra is distinguished by its sharp pointed almost falcate-like spinous process, whereas in all the other dorsal vertebræ this process is abruptly truncated at its extremity. The first four vertebræ differ from the rest of the dorsal segments, by having their transverse processes borne by the pedicles and by the absence of metapophyses. Their transverse processes decrease in size, and the vertebræ in lateral expansion, by the gradual shortening of the neural laminæ, and the processes are brought down nearer and nearer to the bodies. These latter, however, increase in transverse breadth and anteroposterior thickness from before backwards. The laminæ also become much reduced in transverse expansion from the first to the fourth dorsal, and in the latter the 
posterior zygapophyses are close to the base of the spinous process, their facets looking outwards and very slightly downwards. The spinous processes of the first are higher than any of the other dorsal vertebræ, and they have a considerable backward course and are closely opposed to each other. The third is generally distinguished by its anterior superior angle being projected forwards and upwards in a recurved manner. The transverse breadth of the bodies increases from the first to the fourth, the vertical height diminishing, so that the posterior articular surface of the fourth dorsal is transversely oval; whereas the anterior surface of the first is quadrangular, but a very little broader than high. The under surfaces of the body of the first three are marked by a more or less distinct longitudinal furrow as in the last cervical. On the second, third, and fourth there is a distinct tubercular swelling where the head of the rib rests on the posterior margin of the bodies of the vertebræ. The articular surfaces on the transverse processes are large and longitudinally elongate, and in the first distinctly concave.

The distinctive features of the six remaining dorsal vertebræ are the presence of strong metapophyses, short transverse processes, and broad spinous processes directed forwards, except in the case of the fifth and sixth, which have a slight backward course. In the fifth, the transverse process is so shortened that it appears merely as an elongated oval facet on the thickened external surface of the metapophysis, the thickening itself being the true transverse process which is obscured by the former. On the sixth, the transverse process attains its least development and appears as a small expanded ridge. There is a rough surface at its inferior margin to which the head of the rib is articulated, and a similar and larger surface on the external posterior margin of the body. From the seventh to the ninth vertebræ, the transverse processes increase very little in size, but become lower and lower in position. In the tenth vertebra, the rib is suddenly transferred to a transverse process as long as the centrum, but compressed from above downwards. The metapophyses become higher and higher in their position as they are traced backwards, and the zygapophyses in the last dorsal become placed at the base of the spinous process, the posterior pair having a more and more outward aspect and the anterior looking directly inwards. The metapophyses are thick powerful processes directed forwards, upwards, and outwards. The spinous processes increase in antero-posterior expansion from the seventh to the tenth, the last being much the broadest and higher than those before it. The last four dorsal vertebræ have their spinous processes curved forwards. The bodies are all broad and long with a transversely oval section, and on the under surface they are concave from before backwards but transversely curved between the transverse processes. The neural canal in the tenth is broader than high, but its capacity is less than one-half of the canal in the first dorsal.

Lumbar vertebra.- The seven or eight, as the case may be, are distinguished by their enormously developed transverse processes which attain their maximum in the third, fourth, and fifth, but at the same time these processes occur strongly developed along the first half of the caudal region. The zygapophyses wholly dis- 
appear on the seventh lumbar, in which also the metapophyses are suddenly diminished in breadth, being reduced to narrow pointed processes, embracing the bases of the spinous processes of the vertebræ. This change takes place gradually from the first lumbar in which the zygapophyses and metapophyses are as in the last dorsal. The spinous processes are more developed than in the dorsal region, and increase in size to the eighth lumbar, which has the highest process in the whole vertebral column. The bodies are much larger than those of the dorsal segments, and go on increasing to the last, which is about the largest in the column, with the exception of the first two or three caudals, which slightly exced it in size. They are all broader than long, and broader in their anterior than in their posterior surfaces. The articular surfaces are transversely oval. Their under surfaces in the first five have the same characters as the dorsals, but in the last three the under surface presents two hypapophysial ridges in its centre. The neural canal becomes much laterally compressed from the first to the last lumbar. In the former it is regularly triangular, whereas in the latter the height is nearly twice as much as the breadth, due to the pedicles gradually approaching each other by occupying a higher place on the bodies.

The ten dorsal, when in position, equal the length of seven lumbar vertebræ.

Caudal vertebre.-These are distinguished nearly throughout the whole of their extent by chevron bones, which are absent only in the last three intervertebral interspaces. ${ }^{1}$ The two halves of the first cherron bone do not usually unite inferiorly in the mesial line, and one-half occasionally amalgamates with its fellow behind it, the two halves of the two bones of the opposite side remaining distinct from each other. The third chevron has the most vertical extension, but it is anteroposteriorly narrower than those behind it as far as the twelfth. The chevron bones gradually diminish in size to the fourteenth, beyond which they rapidly decrease. The processes for their attachment are most prominent in the fifth caudal, but they can betraced backwards to the very last, bearing chevron bones, that is, if the two median ridges which define the outer margins of the depressions on the under surface of the bodies into which the foramina of the branches of the caudal artery open can be regarded as serially homologous with these processes; but if not, they occur unmistakably as far back as the fourteenth. On the side of the bodies of the fifth, sixth, and seventh caudals, below the transverse processes, a small process appears on the anterior side of the strongly marked oblique groove which passes forwards and downwards from the posterior border of the transverse processes, and along which the branches of the ventral vessels of the tail are transmitted. They become double in the seventh caudal, one being on either side of the groove, and they become more distinct and attain their greatest development in the tenth and eleventh caudal, beyond which they unite with each other and form a strong ridge near the lower border of the lateral surfaces of the twelfth to the fifteenth vertebræ. The lower

i Professor Flower says that chevron bones cease to be developed after the caudal vertebræ enter the laterally expanded portion of the tail, but in Orcella the chevron bones occur up to the very last vertebra, and in Platanista, with the exception of the terminal three, they are present in all. 
rounded. knobs that appear on the sides of the caudal vertebræ from the sixteenth to the twenty-second seem to be these processes greatly intensified.

The transverse process of the first caudal is nearly as strongly developed as in the last lumbar, but in the sixth it has become considerably reduced, and still more so in the seventh, eighth, and ninth, until in the tenth it is little more than a ridge pointing anteriorly. The three first transverse processes are directed backwards, but those succeeding are slightly curved forwards. On the eighth transverse process the groove for the branch of the caudal artery occurs on the side of the posterior end of the centrum, but, as it is traced backwards, it is seen to be moved more and more forwards until it cuts the transverse process near its middle, as a deep groove. In the fourteenth, the transverse process is reduced to a mere ridge, which is perforated by the arterial groove. In the vertebræ behind this, the transverse processes become enlarged and nodular, like the processes on the inferior aspect of the side already described and from which they are separated by a longitudinally oblique deep furrow. This enlargement begins to show itself in the fifteenth, but is more decidedly marked in the sixteenth, in which vertebra the arterial canal perforates both the processes at their common base. At the twenty-second vertebra the two processes are widely separate, but at the twenty-third there is only one nodular process perforated at its base, and in the twenty-fourth the groove has cut the process in two.

The oblique processes are long narrow rods in the first six vertebræ, but they become shorter and thicker in the seventh, their characters becoming intensified in the vertebræ succeeding it, till at last in the fourteenth they are reduced to an obscure eminence on the body of that segment. The processes of the first caudal embrace the base of the spinous process of the last lumbar, but in the second, third, fourth and sixth they only reach forward to on a line with the posterior margins of the spinous processes in front of them. All the remaining metapophyses stop short of the spinous processes in front of them.

The spinous processes of the caudal region are all forwardly curved, their hinder margins being convex, and their anterior margins concave, and they are of nearly equal breadth at their bases and extremities in the first five; but from the sixth backwards they rapidly and gradually diminish in length, their bases becoming narrowed and their extremities expanded. From the eighth backwards they simulate the form of the chevron bones, and in the ninth, tenth, eleventh, and twelfth a small process is developed at the hinder extremity of their superior margins. The fourteenth has the form and size of the fourteenth chevron, whereas the fifteenth and last is only one-fourth of its size. The neural canal in the last-mentioned vertebra is excessively small, and the process only occupies little more than one-half of the body, which is deeply grooved behind it by the arterial canal, so that this vertebra is intermediate in its characters between the vertebræ before it with strong spinous processes and those behind it in which these have disappeared. In the sixteenth vertebra; however, the remnants of the laminæ are unmistakably present 
but separated from each other by a groove, which can be detected in a similar position as far back as the nineteenth caudal vertebra.

The dorsal fin lies over the eighth lumbar and first caudal vertebræ, its apex being between the spinous processes of these vertebræ.

Ribs (Plate XLI, fig. 16) vary in number from ten to eleven. There are one presternal and three mesosternal. The first two are thick and nearly cylindrical, whilst the third is slightly compressed from without inwards, a character which becomes more intensified in the succeeding ribs, especially from the fourth to the eighth, in which the shafts have considerable antero-posterior expansion, though less marked in the remaining two. In the first, the part intervening between the tubercle and angle is compressed from before backwards, but with the tubercular portion much more strongly developed than in dolphins generally, and the neck, instead of being merely a flattened prolongation of the shaft, is narrow, compressed, and angular, with three surfaces, and diminishing in thickness from the base of the tubercle to the head. The outer surface of the angle is marked by a rough surface for muscular attachments. In the second rib, the anterior becomes the external surface in the lower third, as the shaft is twisted on itself, and the external surface between this and below the angle is almost ridgelike, the posterior surface being round. From the angle to the head, the rib is much antero-posteriorly compressed, and the outer aspect for an inch and a half below the angle is produced outwards into a prominent curved muscular ridge directed backwards and downwards, being continuous below with the rather sharp external border of the rib, while above, it is prolonged outwards and forwards beyond the angle as a laminar triangular process. This ridge can be traced as far back as the seventh rib, but gradually distally receding, its place in the eighth and ninth ribs being taken by a flattened smooth surface on the posterior border, but it re-appears in the ninth and tenth. The surfaces of the second rib are the same as in the first. The neck is short, there being only 0.42 inch between the tubercular and capitular surfaces. A well-marked process occurs on the lower border of the neck immediately external to the head; a rudiment of it may be detected in the first rib, whereas it is strongly developed in the third, but almost lost in the fourth rib. In the third and succeeding ribs to the eighth, the shafts are externally flattened, but strong and thick, the neck gradually diminishing in length till the tubercular portion and head are merged in one in the sixth and following ribs. The angle is very well marked in the third rib, as the triangular process is strongly developed, but in the following ribs it forms a more and more obtuse angle with the shaft. The tenth has occasionally a supplementary articular process on the posterior margin of the angle by which it is in contact with the transverse process of the eleventh vertebra (PI. XLI, fig. 15) to which it is bound by strong ligamentary bands. An eleventh rib is occasionally superadded, articulated to the eleventh and twelfth transverse process, and sometimes applied to the rough surface on the posterior border or angle of the tenth rib, which otherwise, so to speak, would have been itself applied to the 
eleventh transverse process. In some cases there are ten ribs on one side and eleven on the other, following the foregoing arrangement.

In a newly-born individual before me, there are only ten ribs on either side, and neither of its terminal ribs touches the eleventh transverse process, but in a fotal skeleton both of these are closely bound down to the eleventh process, from which a rather long piece of cartilage projects outwards and backwards.

Four pairs of ribs are articulated to the sternum, cartilaginous in the young but ossified in the adult condition, separated, however, from the vertebral ribs by an intermediate piece or cartilage, as already stated.

The scapula has its posterior border on a line with the posterior margin of the sixth rib, its hinder angle being on a level with the middle of the rib. The anterior angle of the scapula (process) is on a line with the anterior margin of the arch of the fourth cervical vertebræ, and its superior anterior angle is opposite to the arch of the fifth cervical, and the highest point of the bone is on a level with the spinous process of the first dorsal in a young individual.

The diaphragm is attached on a line with the inferior border of the sternum, running along the inferior margin of the cartilage of the fourth rib, from thence on to the apices consecutively of the free osseous ends of the fifth to the eighth rib inclusive. It then passes across the ninth rib a short distance above its apex, and from that crosses the tenth rib obliquely a still further distance above its apex, passing transversely across from side to side in an arch between the tenth and eleventh dorsal vertebræ.

Sternum (Pl. XXXIX, figs. 5, 6 \& 7).-The presternum is large and broad, generally more or less notched in front, with convergent or lateral borders and a transversely broad, abruptly truncated posterior extremity; it has a general resemblance to the presternum of Physeter macrocephalus, if the fontanelle and mesial suture of that presternum were filled up. It is subject, however, to great variations in its anterior border, depending on the degree to which the cartilaginous interval has filled up. In adolescents, it frequently forms a deep notch anteriorly. There is no trace of the process which in the dolphins and porpoises occurs behind the articulation for the first rib. The breadth of the presternum posteriorly equals one-half of its greatest breadth between the articulation of the two first ribs, and the mesial length is one and a half as long as the posterior breadth. It is slightly concave on its inner aspect and convex externally, and in an adult female there are distinct indications on the same aspect of the mesial sutural line of the two original elements. The facet for the first rib is borne on a slight projection of the anterior angles of the bone and looks backwards and outwards. The position of this rib, however, would appear to be variable, because in a young skeleton presented to the Medical College, Calcutta, by the late Dr. Falconer, the first rib on the right side is situated on the lateral border of the presternum, if anything, below its middle, far remote from the anterior angle, and on the left side it is also removed from the usual position, but anterior to the middle of the lateral border. There can be no error in this observation because the skeleton is a natural one, none of the attachments of the 
ribs to the sternum having ever been separated, and the perfect sternum being quite intact. It is significant that this sternum belongs to a skeleton with rib-like processes attached to the superior process of the seventh cervical vertebra, and it would thus appear that the presternum was involved in the same abnormality that produced this imperfect rib.

The first section of the mesosternum is about two-thirds of the length of the presternum, is shortly oblong in form, and much dorso-ventrally compressed, with concave but rounded lateral margins. It is perfectly flat internally, and very slightly concave from side to side externally, but somewhat concave from before backwards. Its anterior and posterior extremities are rather deeply notched in the middle line, the notch corresponding to the remains of a faint indication of the original suture between the two portions of which it is composed. The right half is considerably larger than the left.

The second rib generally articulates between the presternum and first section of the mesosternum, but in the youngest example before me, the attachment of the second rib is behind the ossicle of the first segment of the mesosternum; whereas in the mother of this specimen it is in the normal position. The hinder angles of the segment have each a hollow for the attachment of the third sternal rib. The presternum and mesosternum are separated from each other in the young by a considerable cartilaginous space, but they frequently unite even in adolescence. The second segment of the mesosternum consists of two distinct ossicles separated from each other and from the first section, in youth, by a wide cartilaginous interval which afterwards disappears, the two ossicles becoming thoroughly amalgamated, and in adults they nearly equal the length of the first section. The fourth rib is applied to the extremity of this ossicle. Only four ribs thus directly articulate with the sternum as a whole. The xiphoid cartilage is rather large and lingulate in the young, but never presents any trace of ossification.

Scapula (Pl. XLI, fig. 13).-This bone is fan-shaped and, as Cuvier remarks, "est beaucoup plus large qu'au dauphin." Its depth through its middle (glenoid) is three-fifths of its greatest length. The postscapular fossa is absent, the external surface being smooth and slightly convex. The suprascapular border is long and forms nearly the half of an elongated oval, defining a nearly triangular surface with the posterior border which is almost straight, the two meeting in a point. The anterior margin is divided into two deep notches by the large acromion which, in adults, developes a metacromial process directed upwards, the acromion pointing reversely downwards. The capacity of the upper or supra-metacromial notch is variable, even in the scapulæ of the same individual, which is also the case with the acromio-coracoid notch. The metacromial process is also variable in its intensity in the same individual, but there is no trace of it in very young dolphins; neither does the ossification of the coracoid show itself in early life. The latter is a mere rudiment, being little more than a small pointed nodule rising about half an inch above the glenoid articulation, which is more oval than round and in this very different from Pontoporia. The outer surface is marked by a ridge run- 
ning up from the coracoid to the suprascapular border, terminating in a faint notch, one inch posterior to the anterior angle of the suprascapular border, and indicating the position of the mesoscapula and defining a slight fossa in front of it. The pleural surface corresponding to this ridge is the most convex portion of the scapula. There is another slight ridge-like convexity prolonged upwards from on a line with the posterior glenoid border, but not continuous with it. The bone anterior to this is convex from before backwards, so that the interval between these ridges would seem to indicate the existence of a broad mesoscapula.

Humerus (Pl. XLI, fig. 14, $h$ ).-The length of this bone nearly equals the united extreme lengths of the antibrachium and carpus. The latter again are equivalent to the metacarpal bone and first phalanx of either of the first, second or third digits. The extreme breadth of the humerus at the radio-ulnar joint is twothirds of its own length. The narrowest part is immediately below the neck and is more than one-third of its length. The base is antero-posteriorly compressed from the neck to the radio-ulnar joint, where it expands into two nearly equal radial and ulnar surfaces, forming an obtuse angle with one another in the middle line, the external being sharp and longer than the internal margin, which is short thick and concave. The globular head is defined by a well-marked constriction, which, however, does not extend round the external surface, although there is little, if any, motion at the elbow joint. I have never observed the humerus to anchylose with the radius and ulna.

Radius.-This bone $(r)$ is much flattened and has a convex sharp external border, which is imperfectly ossified in young specimens. Its inner border is short and concave, corresponding to the short but elongately oval interspace that exists between the two bones of the antibrachium. By its distal extremity it articulates with three bones of the carpus, by the two nearly equal surfaces that meet in an obtuse angle.

Ulna.-This bone $(u)$ is flattened, broader than long at its distal extremity and slightly shorter than the radius, and has both of its lateral borders concave, its distal end expanding into two obliquely-placed surfaces, the proximal of which is much the smaller of the two and concave.

Bones of carpus (PI. XLI, fig. 14).-These are generally six in number, but they are subject to great variation even in the same individual, amalgamating with each other and with the ulna, and so being occasionally reduced to three. It does not appear that the fusion is the result of anchylosis dependent on old age, because it has as yet been observed only in comparatively young animals.

In carpi with six bones, there are three in the proximal row in contact with the radius,-in the distal row one at the extremity of the ulna and common to the fourth and fifth digits; the remaining two are at the base of the second and third digits. Sometimes the two bones on the pre-axial side of the radius ( $r d$ and $t m$ ) partially or wholly unite, the os intermedium (oi) amalgamates with the carpal ( $m g$ ) at the base of the third digit, and the bone (cu) supporting the fourth and fifth digits coalesces with the ulna. This condition gives only three carpal bones. Hence the 
digits have the appearance of being thus applied, viz., the first to a single bone on the pre-axial side of the radius; the third to a carpal wedged in between the radius and ulna; the fourth and fifth digits to the extremity of the ulna itself; whilst the second finger is applied to the single representative of the distal row of carpals.

In the case of a manus with six carpals, there can be little doubt that the bone wedged between the radius and ulna is the os intermedium or lunare, which has two bones lying, the one external to the other on its pre-axial side. As I have shown, these two bones are united in certain carpi, and we are, therefore, entitled to regard the one as the scaphoid or radiale, and the other as the trapezium, a view which appears to be fully borne out by their development. In the foetus, in which the carpus is like a piece of cartilaginous mosaic work, each carpal element having in its middle its little ossific centre and its limits defined by the septa of articulation, two such distinct carpal elements, placed one before the other, intervene between the radius and the base of the pollex. This arrangement in the fotal differs from what $I$ have described in the adult manus, in that these two pre-axial carpal elements are separated from each other by a transverse, instead of a longitudinal, articulation; and in that the external of the two is the more anterior, and is wholly excluded from touching the radius of itself, supporting the pollex as a true carpal in development and form; whereas in the adult it stretches from the metacarpal pollex to the radius with the other pre-axial carpal element wedged in between it and the os intermedium. As already mentioned, these two bones are occasionally fused into one in comparatively young mani, which entitles us to conclude that in the fotal manus they were represented only by one cartilage and ossific point. But it is when the two elements are distinct and divided transversely, and when in that condition the more distal of the two supports not only the pollex, but has also the metacarpal of the second finger applied to it, that the true nature of this distal element becomes apparent. Under these circumstances, it cannot well be regarded as a metacarpal. Furthermore, as the carpals for the support of the second and third fingers form two quadrangular bones at the bases of these digits, and as the os intermedium and os radiale or scaphoid are unmistakable, the conclusion seems unavoidable (in this aspect of things at least) that the distal element is a trapezium. If so, it follows that when it is elongated and reaches the radius it is also the same bone, and that the element internal to it is, of course, the scaphoid or radiale, facts which are supported by the history of their development, and further that a trapezio-scaphoid can only be said to exist in Platanista when these two elements are united in one, an abnormal occurrence in this dolphin.

The basal free bone of the pollex would thus appear to be a metacarpal, and as such in the six-carpaled manus is applied to the extremity of the trapezium, and touches the pre-axial side of the trapezoid.

The four remaining carpal bones are all nearly of one size and more or less quadrangular. The trapezoid projects slightly beyond the bones which support the third and fourth digits, and is in contact with the metacarpal of the pollex, the trapezium, the os radiale, os intermedium, os magnum, and outer edge of the third 
metacarpal. The third carpal lies wholly at the base of the third digit and only touches by its distal postaxial angle the base of the fourth metacarpal. It is surrounded by the second carpal, os intermedium, and the fourth carpal which supports the fourth and fifth digits, and has its distal and postaxial sides applied to the fourth and fifth metacarpals respectively, its proximal to the ulna, and its pre-axial to the third carpal. The os intermedium has the third carpal applied to its distal side and its preaxial and postaxial surfaces articulating with the os radiale and ulna respectively, while its proximal side is in contact with the radius, its postaxial and pre-axial angles touching the fourth carpal and also the os trapezoid.

The bone at the extremity of the ulna supporting the fourth and fifth digits would appear to represent the cuneiform and unciform, although it is developed from only one ossific centre. A similar uncertainty attaches to the morphology of the socalled os intermedium and os magnum, because it is possible that one or other may contain an os centrale, although there is nothing in the character of the fœtal manus to favor such an hypothesis, as each originates from a single ossific centre.

The phalanges are firmly fixed and divergent from each other, especially the fifth, so that considerable breadth is bestowed on the manus. The pollex is only little more than one-third of the length of the forefinger or second digit, which is slightly larger than the other three, these being almost equally long, the fifth, if anything, somewhat shorter than the fourth.

The metacarpals are more or less compressed from behind forwards, a character which is much more marked in the phalanges, the distal ones being flattened oval ossicles. The metacarpal of the pollex is short, but expanded at its base and contracted at its middle. It articulates with the variously modified trapezium and with a very restricted angle of the trapezoid. It is furnished with one well-ossified phalanx tipped with cartilage containing a small ossicle. The second metacarpal is supported by the trapezoid only, and is contracted in its shaft and expanded at its ends, being supported almost entirely by the third carpal, although it touches by the angles of its base the trapezoid and the fourth metacarpal. The latter in a similar manner is in contact with its fellows of the third and fifth digits, and has its base supported entirely by the probably complex cuneiform, which also carries by its postaxial side the fifth metacarpal, thus resting as well on the ulna.

The phalanges in the perfect manus are, $2,5,5,5,5$, and they are longer than broad, with their shafts contracted in the middle and expanded at their ends. The distal phalanges are generally small ossicles in the cartilaginous tips of the fingers.

Musculo-tendinous structures of the manus (Wood-cuts, figs. 19 and 20).-It is only within the last few years that representatives of flexors and extensors of the manus of Cetaceans have been demonstrated. This has been due chiefly to the dissections of Flower ${ }^{1}$, Carter and Macalister ${ }^{2}$, Perrin $^{3}$, and Struthers. ${ }^{4}$ Previous writers

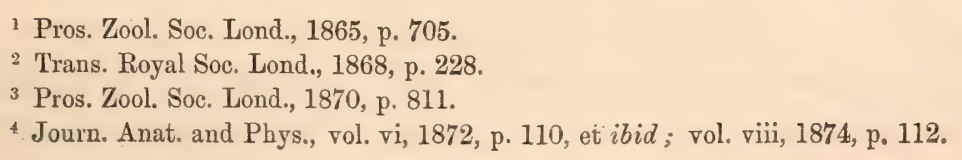


had noted a few diminutive muscular slips as alone extant between the scapula and humerus; the lower bony segments being supposed to be held together solely by aponeuroses, and therefore to be comparatively immobile. Platanista I have found to be another genus, wherein the manus is provided with tendons indicative of true flexor muscles.

Separate extensor tendons on the dorsal surface of the manus are by no means defined or clear. A comparatively aborted extensor communis digitorum muscle appears as a very thin, but broad layer of fleshy fibres which covers the ulna. At the cuneiform and os magnum, partly by their textural characteristics and longitudinal direction, three very thin and very much flattened tendons are observed to diverge and supply the third, fourth and fifth digits respectively, at least as far as their second phalanx. Both the pseudo-belly and tendons of this extensor are very considerably interwoven with the lateral and superincumbent fibrous tissue. The latter, moreover, is firmly adherent to, and with the greatest difficulty separated from, the skin itself.

Fig. 20.

Fig. 19.

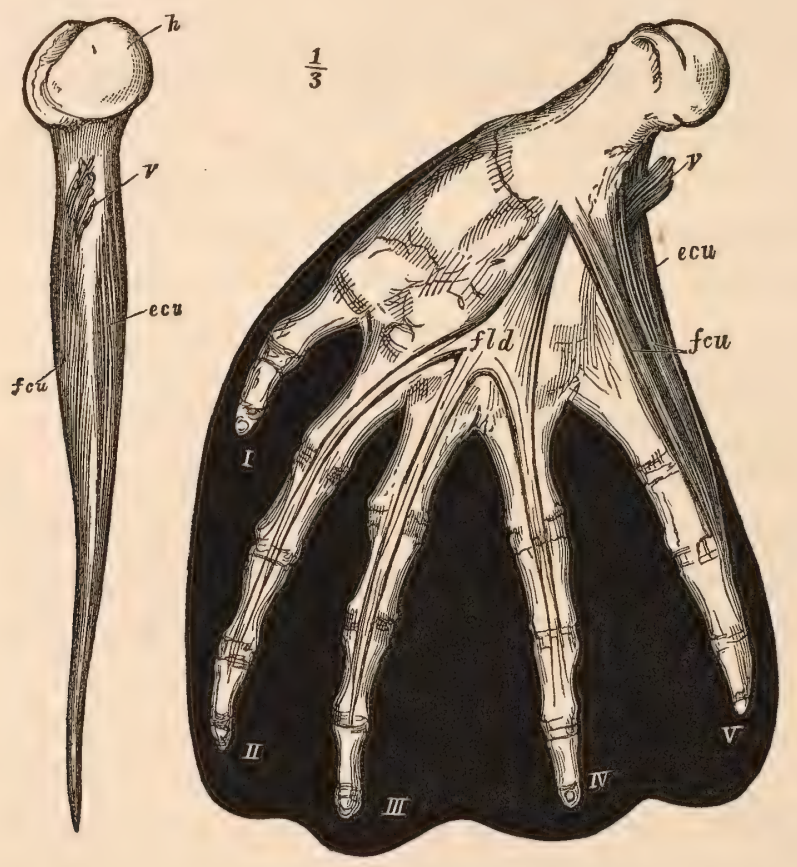

Fig. 19. -The right forearm of Platanista dissected on its inner surface to show musculo-tendinous parts as de. scribed in text. I, II, III, IV, V digits respectively; $f d$, flexor longus digitorum; fcu, flexor carpi ulnaris ; ecu, extensor carpi ulnaris; by, vessels supplying limb.

Fig. 20.-A view of the foreshortened narrow ulnar margin of limb, where the relations of ( $f c u$ ) flexor and (ecu) extensor carpi ulnaris are brought out.

Both figures from a fully adult animal are necessarily greatly reduced.

A flexor longus digitorum is still better marked, though by no means a prominent muscle. A longitudinal flat adpressed band of fleshy fibres a trifle narrower and thicker, is also adherent to the ulna. This becomes highly tendinous as the 
carpus broadens, and sends on three divergent flat tendons to the second, third, and fourth digits, as far as their distal phalanges. Threads of tendon running to the pollex and little finger can be distinguished, though their precise continuity with the above could not be satisfactorily made out. Indeed, in the case of the fifth digit it rather seemed to have a short flexor tendon of its own.

But that the Gangetic dolphin has considerable mobility of its manus and one of the digits is best shown by the presence of two very conspicuous fleshy elongate masses applied against the entire ulnar border, and indeed thereby widening the palm. That on the palmar aspect is attached to the shaft of the humerus and corresponding margin of the ulna, to the border of the fifth metacarpal, and the succeeding phalanges of the same digit. At its upper end it obliquely crosses to a slight extent the commencement of the flexor longus digitorum. Almost opposite the same spot, it is separated from that next to be described by the bunch of nerves and vessels passing to the palm.

The second muscle, more dorsally placed, has attachments precisely like the preceding, and, if anything, is the more bulky of the two. Both in their whole course are fleshy, the terminal tendons to the distal phalanges being scarcely appreciable.

Though spoken of as distinct, these muscles are in reality in close conjunction, overlapping the ulnar border of the fifth digit, and lying approximated together, like the leaves of a book. The brachial nerves and arterial rete mirabile, however, distinctly divide them above.

The attachment and position of these two muscles being somewhat anomalous, it is difficult to name them with certainty. That on the dorsal edge may either be an extensor carpi-ulnaris, an extension of the triceps, or even in part a continuation of that irregular brachial muscle, the so-called dorsi-epitrochlear. Possibly, it is an amalgamation of the two former. That on the palmar aspect may either be regarded as a single long flexor carpi-ulnaris, embracing and supplanting short digital flexors, or, united with it, may be a representative of the palmaris longus. A band of fibres towards the palmar side and which join the others at an oblique angle, besides certain connections with what may be considered a sparse palmar fascia, lead me to attribute the presence of the last-named muscle, here however fused with long ulnar flexors.

I think one may infer from the condition of the muscular structures of the manus of Platanista that this Cetacean possesses very considerable power over the annular or fifth digit. The amount of flexion and extension of the remaining digits must, however, be trivial as compared with other aquatic Mammals, the pollex at least being tolerably rigid.

Ossification of the vertebra, and their processes.-In a fœtus, the vertebral column of which measures 11.50 inches, the neural arch of the atlas is ossified from above the upper aspect of the articular surfaces, and on the inner angle of the anterior surface of the anterior pair of facets, the ossification is seen to extend into them; but all the remainder of this vertebra is cartilaginous, as well as a consider- 
able interspace between the dorsal extremities of the laminæ. The transverse process is situated between the upper extremities of the articular surfaces, external to the base of the ossified neural arch. In a disarticulated skeleton, the vertebral column of which is 19.50 inches in length, the atlas was found to be completely ossified, but its constituent elements, the neural arch and hypapophysis, were not united. The articulating surfaces are divided in their lower thirds by the suture corresponding to the neurocentral suture of the other vertebræ, and which, when the vertebra is in position with the axis, is seen to be continuous with the outer margin of the odontoid. The laminæ have almost united with each other. The transverse process, which is ossified, is thus placed high above the neurocentral suture, and corresponds to the superior processes of the cervical vertebræe as supposed by Eschricht. It is continuous with the neural ossification, of which it is an exogenous product. The lower arch is also fully ossified, and by the anterior surface of its upper extremity it contributes to form the lower third of the anterior articular surfaces of the atlas.

In the axis of the fotus, the pedicles, posterior zygapophyses, and laminæ are ossified, but an interspace between the laminæ above, and a considerable area external to the centrum and involving the transverse process, are cartilaginous. The transverse process is borne on the outside of the middle of the anterior articular surface immediately below the inferior ossified extremity of the pedicle. In another specimen, the process is seen to be entirely above the neurocentral suture and is imperforate, so that Eschricht's view of the double nature of this process is not supported by these facts. In the other fotus, there is no line of separation between the centrum and the odontoid, but, in the anterior extremity of the latter, there is a welldeveloped ossified mass. Anteriorly, the ossification of the neural arch is seen to be spreading downwards into the anterior zygapophysis. The older specimen displays a most instructive condition of the parts. The neural arch, articular facets, and transverse process are fully ossified, with the exception of the tip of the latter. The neurocentral suture is intact, cutting through the lower third of the anterior articular facets, with the transverse process wholly above it and defining the outer limit of the odontoid. This is fully ossified, but separated by a line of suture from the body of the axis; yet showing its double nature by a constriction in the middle of the posterior margin of its lower surface, the halves of the centrum being still distinct and bulging below to constitute the hypapophyses.

In the third cervical, the inferior extremity of the ossified neural arch is separated by a cartilaginous interval from the body of the vertebra; this interval being continuous externally with a cartilaginous process investing the side of the centrum. In the more matured specimen, a small foramen perforates the inferior extremity of the base of the right transverse process; but the neurocentral suture being intact, the whole of the process is seen to lie above it.

In the fourth cervical vertebra of the foetus, the lateral cartilaginous mass external to the centrum is divided into two portions. The superior, lying below the neural ossification, is broad and notched at its extremity, and is separated below by another 
notch from an inferior process, which, however, is continuous at its base with the foramen. In an older animal, the vertebra is ossified, but the neurocentral suture cuts through the notch which separates the superior from the inferior process, and the latter is seen to be an autogenous element developed at the inferior external angle of the centrum below the neurocentral suture, while the superior transverse process, as in the preceding vertebræ, is an exogenous product of the neural arch.

In the fifth and sixth vertebræ, a similar condition of things exists, only the inferior autogenous process becomes more strongly developed as it is traced to the sixth, where it occupies the same position as in the fourth vertebra.

In the seventh vertebræ of the fœetus, there is a cartilaginous interval between the neural laminæ; the transverse process is unossified, the pedicles are separated by a cartilaginous interspace from the centrum, and the position of the inferior transverse process on the side of the centrum in the previous vertebræ is occupied by the facet for the head of the rib. In the more mature skeleton before me, the neural laminæ have nearly united; the superior transverse process is fully ossified; and the neurocentral suture is at a higher level than in the preceding vertebræ and has a more outward course. A portion of the head of the first rib has been brought away. in separating the vertebra from the first dorsal, and is attached to the outer extremity of the neurocentral suture, between the external margin of the base of the pedicle and the lateral surface of the centrum, being chiefly applied to the latter and simulating the inferior transverse process of the sixth cervical vertebra.

There is this remarkable fact also connected with this same animal that the superior transverse process of each side bears at its extremity what must be regarded as the rudiment of the tubercular portion of a cervical rib, much more intensely developed on the right than on the left side. This condition of things is the very opposite of that which prevails in the last dorsal vertebra, in which the rib is borne on the extremity of the autogenous transverse process of the centrum of the tenth dorsal; which process is serially homologous with the autogenous transverse process of the lumbar region and with the similarly originated processes of the cervical vertebræ. It may be regarded as an enormously developed epiphysis of the superior transverse process simulating the portion of the rib distal to the tubercle; but it must be kept in mind that no other of the epiphyses of the vertebral process are developed.

The neurocentral suture in all the cervical vertebræ is intact, but in a still older skeleton the suture only exists in the seventh vertebra, having disappeared in all the others, and the inferior transverse processes are completely united with their respective centra.

In the dorsal region, the tubercles become more and more approximated to the heads of the ribs as they are traced backwards, till at last in the sixth, but more perfectly in the eighth, rib they are merged in one articular surface, which is exclusively applied to the transverse process of that vertebra which occurs on the side of the 
centrum. In the seventh cervical vertebra, it would appear as if the process were reversed and the head of the rib were merged in the tubercle.

From these facts, regarding the development of the transverse processes of the cervical region, it would appear that, as they occur in the atlas, axis, and third cervical, they are serially homologous with the superior transverse processes of the fourth, fifth, sixth and seventh cervical vertebræ. The transverse process of the third vertebra is occasionally, though rarely, perforated by a small foramen on one side, but its position is variable. Taking into account the foregoing observations relating to the development of the processes before us, it is evident that this perforation is adventitious and no guide to the ultimate nature of the process in question. It would appear also that the whole area of the articular surfaces of the atlas and anterior facets of the axis cannot be regarded as corresponding in position to the points of the attachments of the heads of the ribs in the thoracic vertebræ, but only to that very limited section which lies below the detached outer portion of the neurocentral suture; the superior aspect of those facets being apparently serially homologous. with the pedicles of the succeeding vertebral segments.

In the thoracic region, in the younger fotus, the interval between the laminæ above the spinous processes is cartilaginous. The transverse processes of the first, second, third, and fourth vertebræ are partially ossified at their bases, more especially so in the first, but by far the greatest part of them is cartilage; the succeeding transverse processes of the thoracic vertebræ being wholly cartilaginous, as are also the posterior zygapophyses. At the eighth vertebra, the pedicles become elevated from off the side of the centra, till in the eleventh vertebra a wide interval intervenes between the ossified base of the pedicle and the base of the transverse process. The first indication of the metapophysis appears on the fifth dorsal. The heads and tubercles of the ribs are only partially ossified.

In the older skeleton, the first, second, and third laminæ are not united, but all the remaining ones are. The zygapophyses are entirely ossified. The neurocentral suture is intact in all the vertebræ; in the first four the transverse process is above the suture, but in the fourth it occupies a much lower position than in the first, the articular surface from the tubercle of the rib being brought close to the neurocentral suture in all the dorsal vertebræ, the head of the rib being applied to the neurocentral suture, so that with the downward removal of the transverse process there is a corresponding confluence of the head and tubercle of the rib. In the fifth vertebra, the transverse process is still lower, and its rib facet is distinctly prolonged on to the neurocentral suture. In the sixth, the confluent tubercle and head of the rib is applied directly on the neurocentral suture, one-half to the inferior portion of the pedicle, the remaining half over the neurocentral suture, and portion of the body of the vertebra. In the seventh, eighth, and ninth, the articular surface from the rib lies below the neurocentral sutures, being farthest removed from it in the ninth. In the fifth vertebra, the transverse process is represented by a very slight expansion of the outer extremity of the lamina and pedicle external to the metapophyses and immediately above the neurocentral suture. In the sixth, it is still further reduced, 
and lying at a considerably lower level below the metapophyses than in the preceding vertebra and confined to a small surface, which is concave in the adult and situated on the outer basal border of the pedicle. The disappearance of the superior transverse process in the thoracic region is very gradual, and is completed in the seventh vertebra, where the rib-bearing process is wholly central. In the succeeding vertebræ, the process is very rudimentary, but it increases in lateral extension to the ninth. In all of these, it is an exogenous product of the centrum, and thus differs in its development from the superior transverse processes of the neck. When there are ten ribs the last is generally articulated to two transverse processes by its head to the autogenous transverse process of the tenth vertebra, and by its angle to the much larger similar transverse process of the first lumbar vertebra. In the third skeleton already referred to, the neurocentral suture is intact in all the dorsal vertebræ, save the last, in which, and in all the remaining neural arches, it has amalgamated with its centrum, although the remains of it can be traced in the last dorsal, in all the lumbar vertebræ, and in the first three caudals, its union with the centra being most complete in the terminal six caudal vertebri. The transverse processes of the lumbar region are also autogenous products, and in the younger skeleton they are all ossified, but quite distinct at their bases from the centra, and broadly tipped with cartilage. The neural arch is even at a still higher level on the bodies than in the last dorsal vertebra, and they are quite distinct from each other, none of them articulating by zygapophyses. The metapophyses are short and abruptly truncated, their tips being cartilaginous. The laminæe are also separated by a cartilaginous interspace. In the older foetus, the neurocentral suture is intact, as are also all the sutures at the bases of the transverse processes, which in the case of the first to the fourth lumbar disappear at a later period than all the others, and then the neurocentral, as illustrated by the condition of these parts in the third and oldest skeleton. In the former; or second skeleton, the metapophyses are strongly developed and overlap the vertebræ, and the zygapophyses are perfect.

In the caudal region, only the first transverse processes are ossified, but a small ossicle can be detected in the fourth and fifth; all the remaining processes are wholly cartilaginous. The third transverse process, on either side, has the remarkable character, that it is developed from two ossific centres, the one next the centrum being the larger and the distal one the smaller. In the right side, the ossicles are perfectly. distinct, whereas on the left, in which they are much more developed, they have partially united. This arrangement exactly simulates the condition of things found in the last dorsal vertebra, in which the rib is developed at the extremity of its autogenous transverse process. The ossicles of the chevron bones are developed as far back as the fourteenth in the youngest specimen, but in the third and oldest skeleton they can only be traced the same distance; it is evident, therefore, that all the remaining chevrons are developments of after-life, as the mother of the former specimen had twenty-two such structures. The ossicles occur as little round plates on the sides of the cartilaginous arches. The neural 
arches are ossified to the tenth caudal, and they becom 3 more and more faint as they are traced backwards. In the first five they consist of little more than flattened laminæ with a slight projection (metapophyses) on the middle of the anterior borders, while in the remaining five segments they are reduced to small round ossicles. In the older specimen the transverse processes have not united with the centra as far back as the sixth, their sutures being quite intact; but in the seventh and succeeding vertebræ the transverse processes are exogenous products of the centrum, occupying the position of the autogenous transverse processes, but chiefly developed from the anterior portion of the lateral surface of the centra. The neurocentral suture in the same skeleton is intact to the seventh caudal, but is completely anchylosed in the succeeding vertebræ.

In the cervical and dorsal regions of the youngest specimen, the epiphyses of the centra are partially developed, but in the second example they have nearly all attained their proportional size to their individual centra.

In a young male with a vertebral column 2 feet 4.70 inches in length, there are in all twenty-three chevron bones, of which ten are wholly and three partially ossified, the remaining ten being cartilaginous. The first two are in separate pieces, one on either side, and the most anterior pair are much smaller than those behind them, and are only partially ossified and unsymmetrical, the half of the right side being a mere ossicle imbedded in cartilage, while that of the left side is little developed. The second bone consists of two wholly ossified halves. The chevron bones from the third to the eighth inclusive form perfect arches, being united wholly by cartilage, and are perfectly ossified. The first chevron bone is placed between the twenty-sixth and twenty-seventh vertebræ, there being in all fifty-one vertebræ in the skeleton.

Ossification of sternum.-In the youngest specimen, the presternum consists of two large ossicles, perfect externally but separated from each other by a wide cartilaginous interspace, and behind the left ossicle there is another and much smaller ossicle, before the attachments of the second ribs of either side. In whatever way this abnormality may be viewed, it would appear that the two halves of the presternum may be occasionally formed, one or both, from more than one centre of ossification; because the little ossicle in question, being placed completely anterior to the second rib, would have, in all probability, united with the presternum. The anterior angle for the articulation of the first rib is cartilaginous. In the second specimen, the two halves all but meet in the middle line, but they are not united; and anterior and posterior to this point their inner borders diverge from each other, most so in the latter direction. Their anterior angles are perfectly ossified, but they do not bear the first rib, which is applied to their external lateral margins. In one individual not more than, if so much as, a month old, the two halves of the sternum are completely anchylosed, so that it is probable the presternal elements become almost, if not entirely, united in utero. This specimen has its anterior half relatively more expanded than in the adult, whereas the specimen with the first rib attached to its side would doubtless have in adult age a very much greater breadth at its middle than in a normal sternum. 
In the first specimen, no ossicles of the first segment of the mesosternum are developed, but in the second and third specimens, the ossicle on the left half is enormously larger than the minute ossicle that lies imbedded in the right half of the cartilage.

There are distinct indications, on the latter aspect of the mesial sutural line, of the two original elements. The facet for the first rib is borne on a slight projection on the anterior angles and looks backwards and outwards. It is subject, however, to considerable variation. In one specimen the anterior border is nearly straight instead of concave.

Conclusion.-In bringing this Memoir to a close, I shall briefly summarize the more prominent features of the animal of which it treats. The external characters may be re-iterated thus : a long compressed snout, with a formidable array of teeth; a vaulted compressed forehead; longitudinal blow-hole; scarcely perceptible eye; distinct neck; broad and abruptly truncated pectoral fins and small dorsal fin; and the male, a smaller but heavier-built animal than the female, with a shorter snout. To these may be added the remarkable changes which take place in the teeth and in the curvature of the snout between youth and age.

The most noteworthy peculiarities in the internal structure of this Cetacean appear to be, the great development of the Eustachian tube and of the large sacs connected with it, and which lie along the hyoid apparatus; the remarkable valvular and glandular structure of these sacs, and of their ramifications, only separated from each other in the mesial line by a thin membrane; the existence of a peculiar glandular area in the second cavity of the stomach, associated with enigmatical cup-shaped bodies; the apparent natural shedding of the superficial membrane of the first gastric cavity as in some birds ; the chambered character of the small intestine, due to the great development of valvulæ conniventes; the existence of a cæcum, with which is associated a large gland; remarkable dilatations in the vascular system of the spleen; the modifications of the spiracular sacs connected with the blow-hole; the fibrous blubber of the forehead; the modifications of the laryngeal cartilage; the broken-up character of the rings of the trachea; the broad bifid heart; the abrupt termination in rete mirabile of the branches of the great arteries towards the head, and the anterior extremities; the simply formed brain, distinguished by moderate breadth and considerable height; the excessively rudimentary character of the optic nerves; the possible absence of the third and fourth pairs of cranial nerves; the eye devoid of a crystalline lens and only a rudimentary choroid membrane present; the rudimentary development of the muscles of the eyeball; the glandular character of the conjunctival covering of the cornea; the presence of utricular-like glands in the vagina of the gravid female, and the existence of utricular glands in the uterus of the fœetus.

With regard to the skeleton, the great development of the maxillary crests; the anterior compression and elongation of the maxillaries with the premaxillaries; the prolonged mandible, with its extended symphysis; the position of the palatine in 
the nasal chamber; the peculiar relations of the pterygoids; the minute character of the optic foramina; the small orbit; the firm attachment of the periotic to the skull; the relatively large semicircular canals of the internal ear; the long cervical region; the large vertebral metapophyses, and ossified sternal ribs in adult life, along with other peculiarities described in this Memoir at some length, present an assemblage of characters as yet unknown in any other Cetacean. 
Genus BaL

\section{Balanoptera edeni, Andr., Plate XLIV.}

The first fragments of the Whale called Balcenoptera indica by Blyth were noticed in 1852 1 by their describer as follows:- "From Capt. T. P. Sparkes, Ramri. The left radius, two lumbar and one sacral vertebræ of an enormous Whale (Balanoptera?) and two lumbar vertebræ and the second (?) right rib of a smaller Whale. These, Capt. Sparkes, Assist. Commissioner, Ramri, supposed to have belonged to one individual, respecting which he contributes the following information: "The Whale was thrown up dead and in a horrid state of decomposition on Juggoo or Amherst Island during last rains (1851). I was unable to see it myself, but was told that the carcase measured 84 feet in length. The vertebræ and rib were all that I could recover on visiting the island just before I came up to Calcutta, with the exception of the two jaw bones, each about 14 feetlong, which the steamer was unable to bring up last trip, but which I will send you on her return this time from Arakan. This is the only instance I have heard of a Whale being stranded on the coast of Arakan.' Nevertheless, the bones sent are certainly those of two individuals, and probably species, differing materially in size; and we have a note of a Whale of the largest size having been stranded on the Chittagong coast, as recorded in the 'Friend of India' newspaper for September 15, 1842, and copied into most of the contemporary Indian journals, but no description was taken of it that would determine the genus."

When Blyth had received the jaws mentioned by Capt. Sparkes, he wrote in 1853: " "The two rami of the lower jaw of the Whale or Korqual (Balcenoptera), which was stranded last year upon Juggoo or Amherst Island (south of Ramri Island) as noticed in Vol. XXI, p. 359; but they prove to be larger by one-half than Capt. Sparkes had supposed, measuring 21 feet in length, minus an inch or two. This magnificent specimen is now fixed up in the Museum, as experience has shown that such bones cannot in this country be permanently exposed to the weather with impunity. The length of the left radius of this Rorqual measures 37 inches; the body of a sacral vertebra is 15 inches deep, by 16 inches broad, and nearly 14 inches in extremelength. A lumbar vertebra is somewhat smaller, with spinal apophyses measuring 27 inches: expanse of lateral apophyses from tip to tip 40 inches, and extreme height of the dorsal apophyses from the ground 37 or 38 inches." The proportional length of the radius, Blyth considered, indicated the animal to have been a Balcenoptera or Rorqual, while the remarkable slenderness of the lower jaw sufficed, he thought, to prove it a distinct species from any hitherto described Rorqual. He also regarded the medium length of the radius as marking it out as a very different species from the typical Megaptera or Hunchback Whale, and that it must indeed have been a Balcanoptera. Returning to the lower jaw, he again notices that, it is "remarkably

3 Jour. As. Soc., Bengal, vol. xxi, p. 358.

2 Jour. As, Soc., Bengal, vol xxii, p, 414. 
slender for a Balanoptera, being even more so than in Balana mysticetus as viewed laterally (vide Oss. Foss., Pl. XXVI, fig. 9), while the coronoid process is well developed, as in Gray's figure of the lower jaw of Balcenoptera rostrata (Zool. Voy. Erebus and Terror, Cetacea, p. 22 ); the base of the jaw, however, posterior to the process is not deeper, as in that figure, but the reverse, and the jaw is proportionally much longer anterior to the process. The entire length of each ramus is within less than two inches of twenty-one feet, showing the head to have been about onefourth of the total length. Vertical diameter three feet; in advance of summit of coronoid eighteen inches (measured by calipers); at three feet from tip, 13.50 inches; and where most contracted, posterior to the coronoid, fifteen inches only; extreme depth at coronoid process (inclusively) $26 \cdot 75$ inches. From middle of coronoid to summit of condyle posteriorly in a straight line, 37.50 inches. The shaft of the ramus is more approximately of the same thickness throughout than in Balana mysticetus, tapering quite evenly." Professor Flower ${ }^{1}$ has observed on these remarks by Blyth, that his description of the coronoid process of the lower jaw indicates that it did not belong to the genus Sibbaldius, but was probably a Physalus. The jaw, however, does not differ structurally from the jaw of the Whale found near the Sittang, and which I propose to designate B. edeni. It, moreover, agrees with Flower's description of the jaw of Balcenoptera: "Rami of lower jaw much curved and with a high pointed coronoid process." The radius is 35.60 inches long, and Blyth remarks it is "nearly similar in shape to, but more curved than, that of Megaptera poeskop (Rorqual du Cap, Cuvier, Oss. Foss., Pl. 227, fig. 22 e). The shape of this bone in Balana, as figured by Cuvier, is remarkably different."

The rib is proportionally small, measuring only 8 feet 2 inches round its curvature to superior articulation. It is probably the third of the series on the right side.

The five vertebræ which Blyth originally considered as belonging to two distinct Whales he afterwards, I believe, correctly regarded as having belonged to the same individual. Two are dorsal, according to Blyth, but they are undoubtedly the first and second lumbar vertebræ, if the animal had only ten ribs; however they have been much hacked and are mutilated of their processes. I differ also from him regarding the positions he assigned to the others.

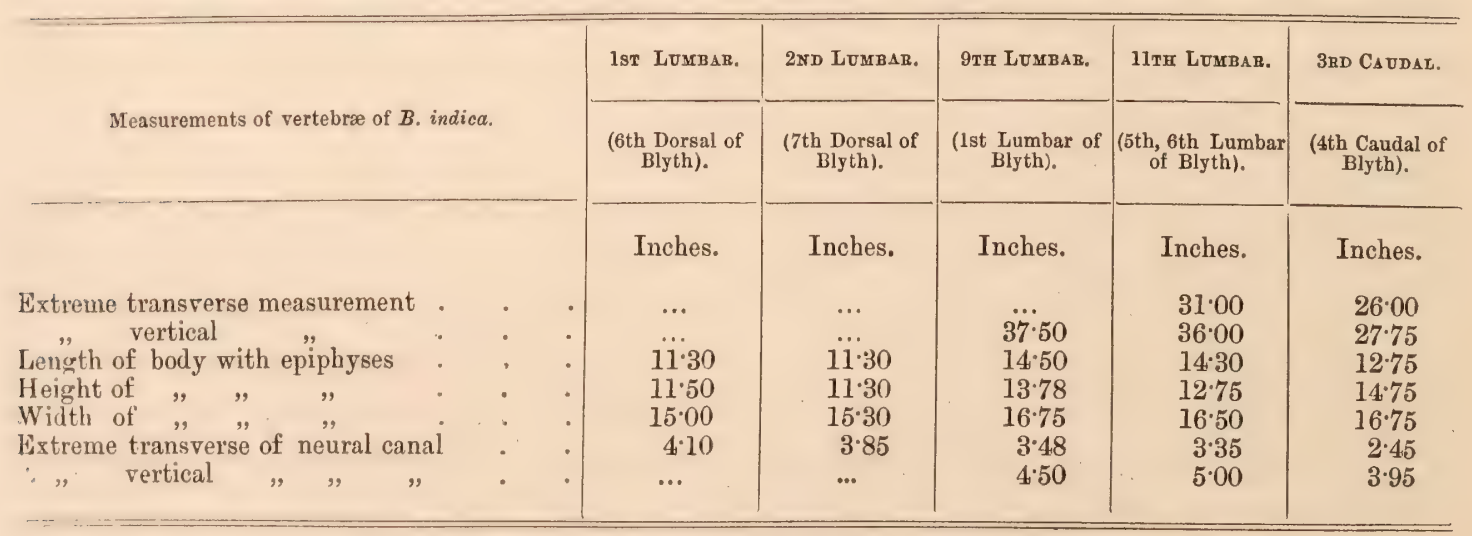

'Proc. Zool. Soc., 1864, p. 408, footnote. 
In the "Asiatic Researches," Vol. XV, App., p. xxxiv, a large jaw-bone of a Whale is recorded; but Blyth observes that it was only the basal portion of one, and that when he wrote, it was much injured by long exposure to the weather out-ofdoors; but it appeared, he considered, to have belonged to a rather smaller individual of the same species, which he thought he might safely venture on designating Balanoptera indica.

In the "Asiatic Researches," Vol. XVII, p. 624, and "Gleanings of Science," p. 711, the vertebræ and cranium of a Whale are recorded as having been presented to the Asiatic Society's Museum by G. Swinton, Esq. (1836). These, when Blyth wrote in 1859, were much damaged and mostly valueless from long exposure to all weathers, and, when I took over charge of the Museum for Government, these bones had fallen to pieces. The length of the Whale, Blyth mentions, was about 30 feet, of which the head was about one-fourth, and he was rather more inclined to consider this as the young of Balcenoptera indica than as another and smaller species. A fine skull of the same species, with the rami of the lower jaw measuring 10 feet, was obtained by the late Professor H. Walker from Arakan, and this specimen is deposited in the Zoological Museum of the Medical College, Calcutta, now under my charge. Blyth remarks of the first of these specimens that the bones of the lower jaw were mutilated, and that only the shafts remained, but that in the Medical College skull the coronoid, \&c., of the lower jaw accorded with those of the 21-feet jaw, which he considered as the type of Balcnoptera indica.

The question here suggests itself, - is it not possible that these comparatively small Whales are the young of the giant specimen, which measured 84 feet long, and the rami of the lower jaws of which, measuring close upon 21 feet in length, are now in the Indian Museum, along with other fragments? I think I can adduce evidence to prove conclusively that the two belong to distinct species, and that the skull of the specimen in the Calcutta Medical College must have been that of a nearly adult individual. This evidence is derived from the study of a Whale, which, owing to some cause or other, found its way into the Thaybyoo Choung, which runs into the Gulf of Martaban between the Sittang and Beeling rivers, and about equidistant from each, and now known as the Sittang Whale. The Whale ran up this creek for more than twenty miles and was stranded in a heavy squall on the 18th June 1871. It then exhausted itself by its furious struggles, during which it is said to have roared like an elephant and so loud as to be heard a very long way off; it died the same night, or on the morning of the following day.

Having seen a short paragraph in a Calcutta newspaper relating to the stranding of this Whale, I at once telegraphed to the Hon'ble A. Eden, then Chief Commissioner of British Burma, requesting him to be so good as to issue instructions for the preservation of the skeleton, and offering to send a competent person, if necessary, to assist in doing so. The Deputy Commissioner at Shwe Gyeen, Major A. G. Duff, was communicated with, and he sent me a reply, that assistance would be useless, as the place where the Whale had stranded was a wide tidal creek subject to the bore, and that all that remained of the creature had probably long ere this been broken to 
pieces by the tidal wave or been buried in deep sand, and that, beyond what had been already recovered, there was little probability of saving more. However, Major Duff had instructed one of his assistants, Mr. Duke, to proceed at once to the spot where the Whale was stranded, to obtain as much information as he could on the subject of its size, \&c., and to bring away whatever bones or other parts of the animal he could secure.

In a letter from Major Duff, dated 3rd August, I was informed that Mr. Duke had found the animal still almost intact and had been able to bring away some of the bones of the head, portions of the skin, and some "curious horny scales with fringed ends;" that he had measured the creature and ascertained its length to have been $24 \frac{1}{2}$ cubits ( 37 feet), and its girth as near as could be estimated 12 cubits or 18 feet. As the animal had been drifted about by the tide, and was unfortunately lying on its back, Mr. Duke was unable to determine whether or not it had a blowhole, a point regarding which, as also as to the set of the animal's tail, Major Duff had asked him to take particular notice, in order to satisfy himself as to its being really a Whale, because the natives in the neighbourhood had given most contradictory statements, 'some saying that it spouted and others that it did not.'

The animal was in a high state of decomposition, and it was with the utmost difficulty that Mr. Duke got people to assist him to recover the bones; moreover, the weather was extremely bad, and the wide inlet was by no means safe for boats. Notwithstanding the great difficulties of such an undertaking as this in a tropical climate, Mr. Duke was successful in preserving the skull of this Whale almost entire and of securing nearly all the vertebræ, a portion of one limb and some other bones now to be enumerated in detail, as also a few flakes of balene and a portion of the skin.

The skull (Pl. XLIV), the vertebræ, the bones of the extremity which have been preserved, the short balene with its fringed edge, all furnish evidence that this Whale was a Balcenoptera; but unfortunately there is nothing on record regarding the presence or absence of a dorsal fin.

The leading characteristics of the skull, PI. XLIV, as compared with the skulls of known Balcenoptera, are the great length of the maxillary portion and the little downward shelving of the upper surface of the maxillæ. In these points it is somewhat resembled by Balcenoptera rostrata, but the beak of this eastern Whale is relatively longer and more pointed than in the Whale of the North Sea, and the downward shelving of its maxillaries is much less. It is also distinguished from $B$. rostrata by the great length of its temporal fossa, in which feature it is approached by $B$. musculus, a Whale which, on the other hand, has a very much shorter and deeper beak, and in these respects resembles somewhat the skull of the Javan Whale B. schlegeli.

There can be no doubt about this Whale being closely allied to B. schlegeli, but I cannot reconcile the form of the skull with the figure of the skull of the type given by Professors Van Beneden and Gervais. I have reproduced three drawings taken from a photograph of the skull (Pl. XLIV, figs. 1, 2, 3), and it will be observed that although it bears a strong resemblance to the skull of 
$B$. schlegeli, it differs from it materially in the character of its beak, which is long and slender, and much more forwardly directed than the beak of B. schlegeli, and also in the absence of the curvature of the external margin of the maxilla which distinguishes B. schlegeli. The beak of the latter is also much more downwardly shelving at its base than is the maxillary of this form from the Bay of Bengal, and the skull has greater depth, as is shown by the circumstance that the orbital process of the maxilla in B. schlegeli is below the level of the base of the skull, whereas in this skull it is above it. The opening of the posterior nares also is much narrower than in $B$. schlegeli. The length of this skull compared with the type of $B$. schlegeli, is only about three inches longer, but notwithstanding the additional length it has less breadth and less occipital length associated with a shorter maxilla, less maxillary breadth, and a narrower beak. Its lower jaw also differs considerably in its length from that of $B$. schlegeli, being nearly 4 inches shorter, although its skull is longer than the skull of that type, which, according to Professor Flower's ${ }^{1}$ measurement, has the lower jaw longer than its skull, whereas in Van Beneden's and Gervais ${ }^{2}$ figure the lower jaw is represented as shorter than the skull. The lower jaw of B. schlegeli is much deeper and heavier than the jaw of this Whale, as is seen by the accompanying table of measurements, and the curve also differs materially, the latter being much more outwardly curved than the former.

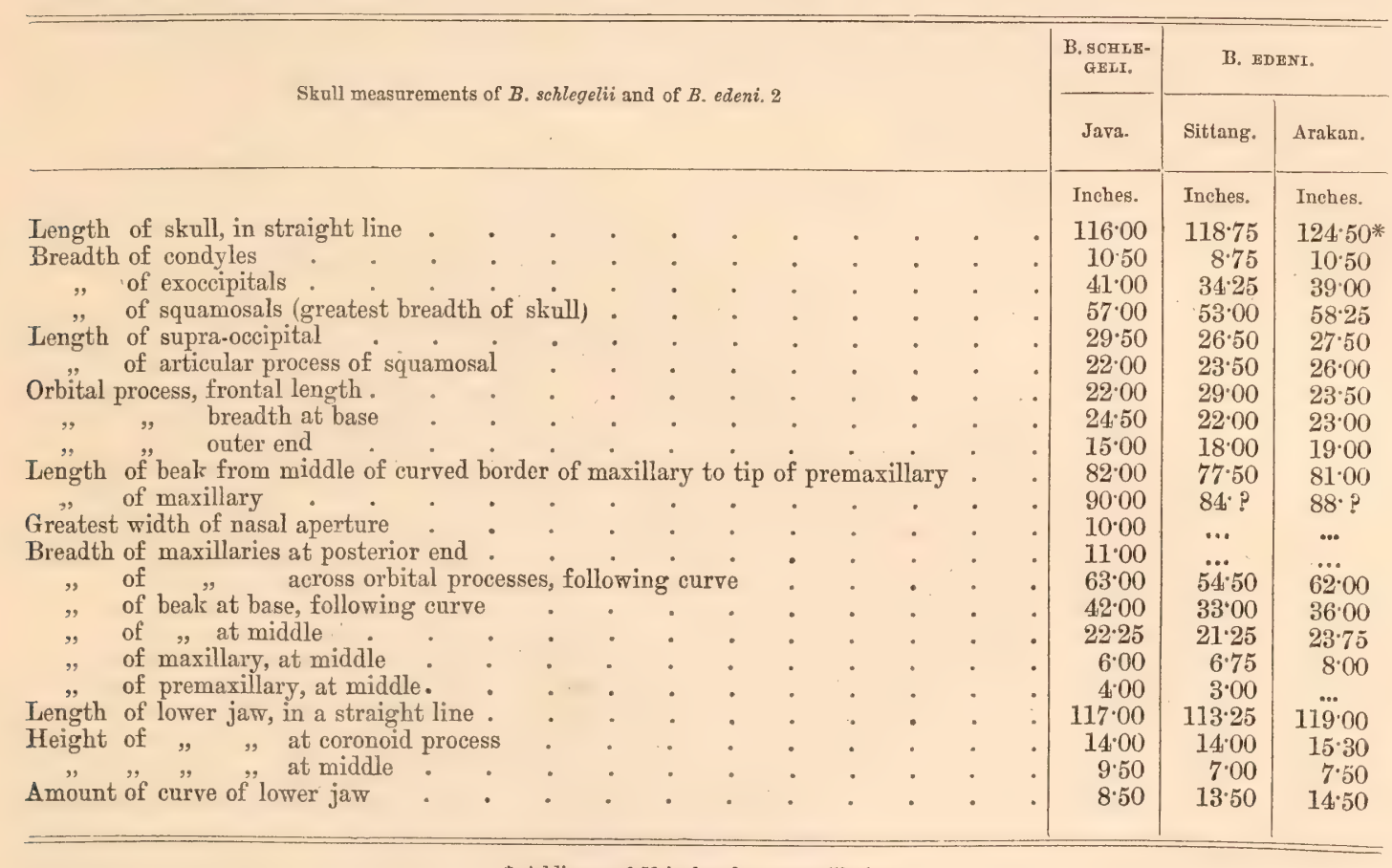

* Adding on 6"50 inches for premaxillaries.

The lower jaw of this Whale has all the characters of the jaw of the Whale described by Blyth as Balcenoptera indica, the rami having, as pointed out by him,

1 Proc. Zool. Soc., 1864, p. 410.

- I reproduce in this table the measurements given by Professor Flower of $B$. schlegeli and alongside of them those of $B$. edeni by myself. 
the distinctive characters of the genus Balanoptera. However, the former, as has already been noticed, is less than half the length of the latter.

The skull of the Whale referred to by Blyth as existing in the Museum of the Medical College, Calcutta, the measurements of which (Table No. 3) are placed alongside of those of the Sittang Whale (No. 2), appears to be specifically identical with it, the length being only 5.75 inches greater; and it is no more than 8.50 inches longer than the type of $B$. schlegeli (No. 1 ).

As the vertebral column of this Whale was saved, the condition of its epiphyses has enabled me approximately to determine its age. The epiphyses of the bodies of all the cervical and of the last fifteen caudal vertebre have completely amalgamated with their bodies; all the epiphyses of the bodies of the remaining vertebrre being in position, and more or less united to their bodies; the only epiphyses that have been lost are the posterior epiphyses of the second dorsal, the epiphyses of the fourth dorsal, and the anterior epiphyses of the fifth dorsal. The epiphyses of the spinous processes are all complete, and those of the humerus, radius and ulna are also amalgamated with the shafts of their bones. From these facts, therefore, it is apparent that this Whale is mature, and we may conclude that it never exceeds 38 to 40 feet, half the length of $B$. indica, but resembles in size the Whale of Java, named $B$. schlegeli. This conclusion is, of course, based on the supposition that the union of the epiphyses of the bones to their centra and shafts, indicates in the Cetacea, as in other Mammals, that an animal presenting such characters has attained its limit of growth.

Now, if we compare some of the few bones and vertebræ which are all that remain of the huge Balcnoptera with those in the Sittang Whale which correspond to them and are in the exactly same stage of growth, the immense difference in their relative proportions will be readily perceived.

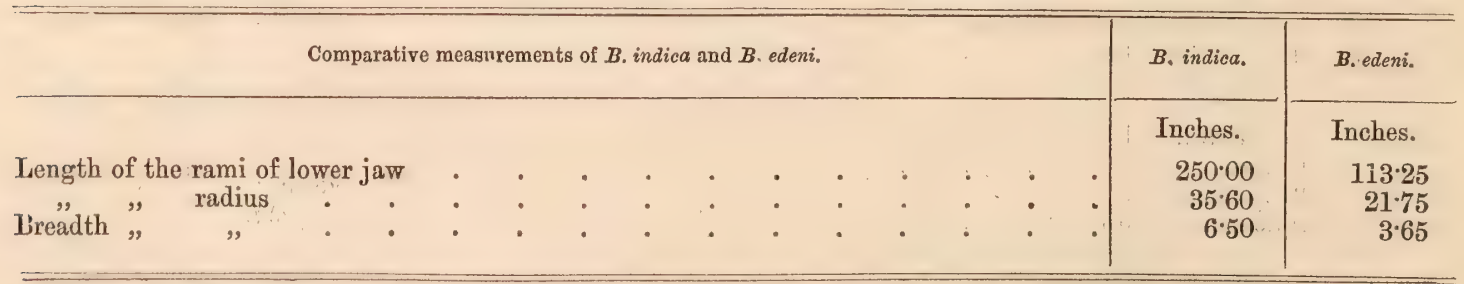

In the third caudal vertebra of the latter animal the amalgamation is quite as complete as in the large Whale, and the comparative measurements are-

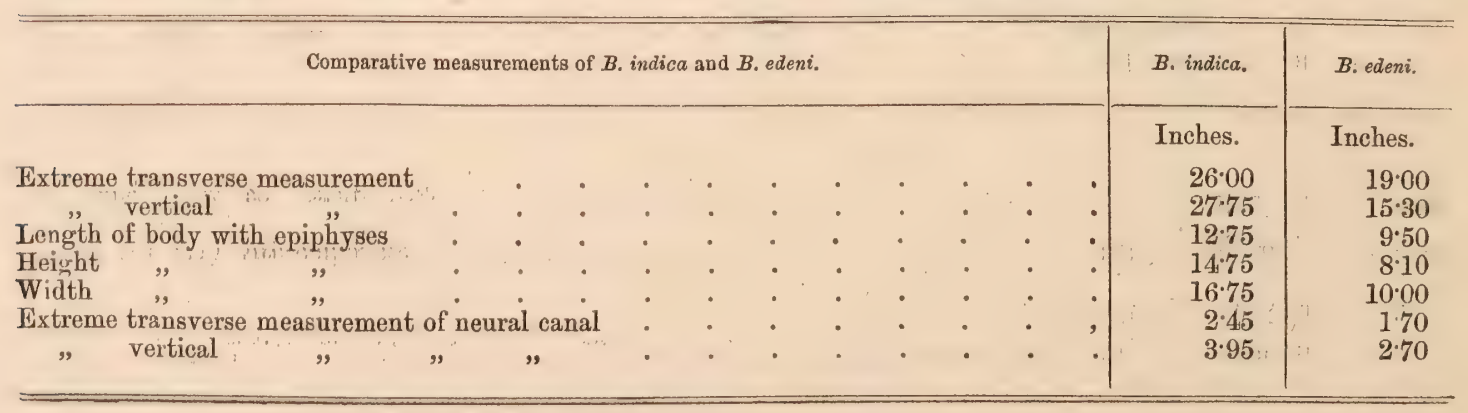


As these differences then in dimensions are not ascribable to age, they certainly indicate the existence of another Whale attaining to only half the size of Balcenoptera indica. And, as I have already said, the skull in the Medical College which Blyth regarded as the young of $B$. indica is not the skull of $B$. indica, but is specifically identical with the skull from Sittang.

The features which characterize the vertebral column of this smaller form, B. edeni, shall now be considered somewhat in detail. Forty-seven vertebræ have been preserved, and a careful observation of these in position does not reveal the absence of any of the principal vertebræ, with the exception of two probably after the forty-first vertebra, and, at the termination of the caudal portion, three appear to be wanting. Hence, the total number of segments would be fifty-two, only one vertebra less than in $B$. schlegeli. The vertebral formula of this Whale is as follows-C.7, D.10, L.14, C.21 =52. The caudal region has been determined by the first appearance of chevron bones.

The vertebral column measures, as it now is, 25 feet $\mathbf{5}$ inches, and if another foot is allowed for the missing vertebræ, we find that the skull has the proportion of one-fourth of the entire length of the animal, the proportion that generally prevails in the genus Balanoptera.

The bodies of the vertebræ increase in length up to the penultimate lumbar and also in depth, but beyond that point they gradually decrease in length, increasing, however, in depth to the third caudal, from which they again diminish in height; the caudal vertebræ, after the tenth, rapidly decrease in size, in this respect resembling the vertebral column of $B$. rostrata. The spinous processes generally are directed considerably backwards, and they all dilate more or less towards their ends, more especially in the last portion of the dorsal and in the lumbar region.

\begin{tabular}{|c|c|c|c|c|c|c|c|c|c|c|}
\hline \multirow{2}{*}{$\begin{array}{l}\text { Measurements of some vertebrr of the Sittang } \\
\text { Whale, Balcenoptera edeni. }\end{array}$} & \multicolumn{7}{|c|}{ Cerrical. } & \multirow{2}{*}{ DoRsAT. } & \multirow{2}{*}{$\frac{\text { LUMBAR, }}{12}$} & \multirow{2}{*}{$\frac{\text { CAUDAT. }}{6}$} \\
\hline & 1 & 2 & 3 & 4 & 5 & 6 & 7. & & & \\
\hline & In. & In. & In. & In. & In. & In. & In. & In. & In. & In. \\
\hline Extreme transverse measurement & $18 \cdot 00$ & $24: 75$ & $22 \cdot 61$ & $23 \cdot 00$ & $22 \cdot 00$ & $20 \cdot 25$ & $19 \cdot 75$ & $32 \cdot 00$ & $25 \cdot 00$ & $13 \cdot 75$ \\
\hline " $\quad$ transverse diameter of neural & $9 \cdot 75$ & $10 \cdot 25$ & $10: 00$ & $10 \cdot 50$ & 1075 & $11 \cdot 15$ & 1175 & $20 \cdot 50$ & $24: 00$ & 13.50 \\
\hline canal $\quad . \quad$. & $3 \cdot 00$ & $3 \cdot 80$ & $3 \cdot 75$ & $4: 00$ & $4: 17$ & $4: 23$ & $4: 55$ & $2 \cdot 60$ & $2 \cdot 20$ & $1 \cdot 05$ \\
\hline vertical $\cdot{ }^{\circ} \cdot$ & $5 \cdot 15$ & $3 \cdot 13$ & $3 \cdot 25$ & $3 \cdot 90$ & $3 \cdot 00$ & $3 \cdot 25$ & $3 \cdot 20$ & $3 \cdot 70$ & $3 \cdot 30$ & $1 \cdot 10$ \\
\hline " transverse diameter of body. & $\ldots$ & $7 \cdot 40$ & $6 \cdot 80$ & 6.75 & $6 \cdot 75$ & $6 \cdot 75$ & $7 \cdot 20$ & $7 \cdot 30$ & $8 \cdot 75$ & $10 \cdot 30$ \\
\hline Antero-posterior length of body and & ... & $5 \cdot 00$ & $5 \cdot 30$ & $6 \cdot 30$ & $5 \cdot 25$ & $5 \cdot 45$ & $5 \cdot 40$ & $5 \cdot 30$ & $6 \cdot 80$ & $8: 50$ \\
\hline epiphyses at inferior borders & $\ldots$ & $2 \cdot 50$ & $1 \cdot 50$ & $1 \cdot 75$ & $1 \cdot 85$ & $2 \cdot 20$ & 3.55 & 6.50 & $9 \cdot 30$ & 8.50 \\
\hline Transverse diameter of open space & ... & $2 \cdot 90$ & $5 \cdot 20$ & $5 \cdot 60$ & $5 \cdot 80$ & ... & ... & $\ldots$ & ... & $\cdots$ \\
\hline Vertical & ... & $1 \cdot 87$ & $4: 20$ & $4: 00$ & $3 \cdot 75$ & $\cdots$ & $\cdots$ & $\cdots$ & $\cdots$ & $\cdots$ \\
\hline
\end{tabular}

With regard to the special characters of the different regions of the vertebral column, all the cervical vertebræ are free from one another (Plate XLIV, fig. 6). Their spinous processes, with the exception of those of the first two, have much the characters of the spinous processes of $B$. schlegeli and of Fin-Whales generally; but the spinous process of the atlas (fig. 5) has greater antero-posterior breadth, 
and that of the axis has none of the pointed character that occurs in B. schlegeli, and it more resembles the spinous process of $B$. sibbaldi. The neural canal has considerable breadth ( 3 inches) and is much broader than high. The notch for the reception of the odontoid swelling of the axis lying below it is much contracted.' The transverse process of the atlas is well-defined, rather long, but basally shallow; very different from the deep wing-like twisted transverse process of $B$. schlegeli, as figured and described by Flower. ${ }^{1}$ The articular surfaces for the axis practically meet below, being separated from each other by 0.25 inch in the dried bone, and have thus no facet between them as in B. schlegeli. Two small facets, however, occur, one on either side of the pointed process that lies below the body of the axis. On the anterior surface of the lower portion of the neural arch which forms the front of the notch for the first nerve, there is an articular facet on the right side, measuring 1.25 inch in diameter, and on the opposite side there is a similar but smaller facet. Both articulate with the condylar facets of the skull and are adventitious. In other respects the atlas conforms to the general character of the bone in Fin-Whales.

The axis (woodcut, fig. 21, A) in its general form bears a strong resemblance to the

Fig. 21.
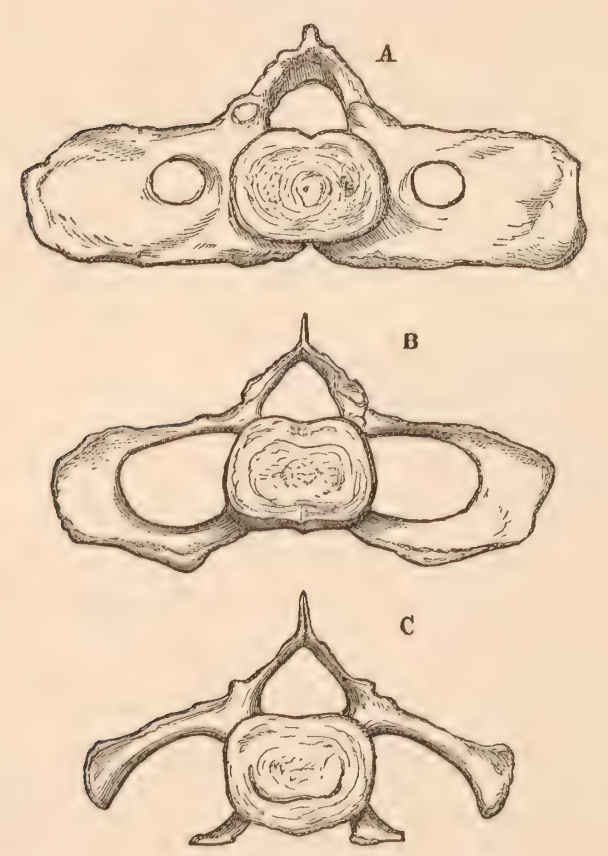

Posterior view of the cervical vertebræ of the $B$. edeni, $\frac{1}{16}$ th natural size. A, the second; B, the third; and C, the sixth cervical. axis of $B$. schlegeli. The lateral process is greatly expanded and is perforated by a small oval orifice close to its base, but somewhat above the middle of the process. The neural arch is strong, but the spinous process is low: the neural canal has a breadth of $3 \cdot 60$ inches to a height of $3 \cdot 10$ inches. The odontoid swelling is not very well marked. Two small facets occur close to the lower margin of the articular surfaces for the atlas and correspond to the articular surfaces on the pointed process which fits in between these facets.

The transverse processes, upper and lower, of the third as in the second cervical. vertebra (fig. 21, A \& B) are united, on either side enclosing a large open space, and the bodies of the two are somewhat quadrangular: the neural arches and spinous processes are feeble. In the fourth and fifth, the open space defined by the upper and lower transverse processes is much larger than in the previous vertebræ, and in the fifth, on the right side, the two transverse processes do not meet by half an inch, whereas on the opposite side they are broadly united. The neural arches are triangular and high. In the sixth (fig. 21, C), the transverse processes do not meet by an interval of 4.75 inches, the inferior process being short and stunted, and from the circumstance

\footnotetext{
1 Proc. Zool. Soc, 1864, p. 403, fig. 10.
} 
that the epiphyses of the vertebræ are completely amalgamated with the body and the spinous process, it shows no trace of having being capped with cartilage; this vertebra seems to have attained maturity, and, as in $B$. schlegeli, it has always the two transverse processes widely apart. The seventh cervical has a nodular rudiment of an inferior transverse process well-defined, and in this, this vertebra differs from the corresponding vertebra of $B$. schlegeli.

The spinous processes of the first two dorsal vertebræ correspond in character

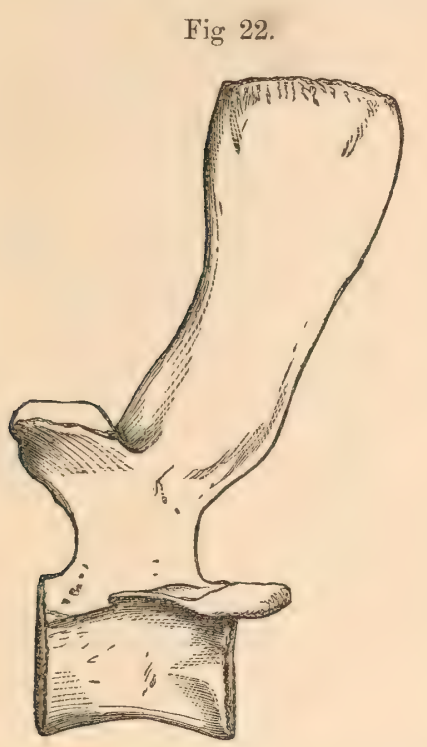
to the spinous processes of the cervical vertebræ, and in the third and fourth dorsals, they partake more of the characters of the cervical than of the dorsal vertebræ, but, in the fifth, the process suddenly assumes the broad expansion usual to a dorsal spinous process. The spinous processes are antero-posteriorly broad, and of considerable height (fig. 22), the maximum elevation being attained not until the eighth lumbar is reached. There is a slight anterior curvature of the spinous processes of the fourth and fifth dorsals, but in the succeeding dorsal vertebræ the backward direction of the processes become more and more pronounced to the eighth lumbar, behind which the processes gradually curve forwards and become more erect. One of the distinguishing features of these processes is the concavity of the anterior and posterior margins, associated with the expansion of their free Ninth dorsal vertebra, $\frac{2}{8}$ th natural size, ends and their considerable backward direction, which confers on the vertebræ a very different character from that of the vertebræ : of B. schlegeli, as figured by Van Beneden and Gervais in their magnificent work on the Cetacea.

In the caudal region, the spinous process in the first is but little concave

Fig. 23.

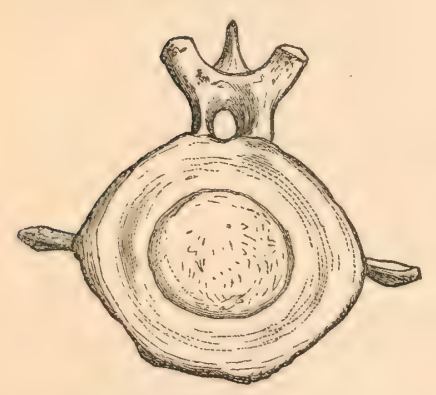

Posterior view of the sixth caudal vertebra, $\frac{1}{8}$ th natural size.
Fig. 24.

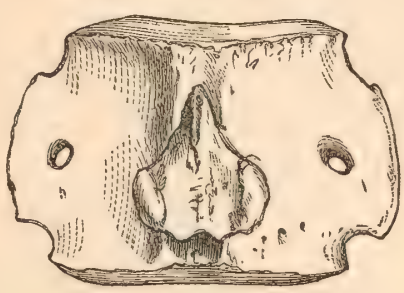

Upper aspect of the sixth caudal, $\frac{1}{8}$ th natural size. anteriorly ; still it has considerable length. As measured from its base anteriorly, it exceeds the antero-posterior length of the body of the vertebra by nearly a half the length of the latter. In the second caudal it is much reduced in height, and in the following vertebræ it so rapidly dwindles away in size that in the ninth it completely disappears. In the accompanying "woodcuts (figs. 23 and 24) I give the character of the caudals as seen in the sixth vertebra of the tail. 
The transverse processes of the dorsal region gradually increase in length and

Fig. 25.

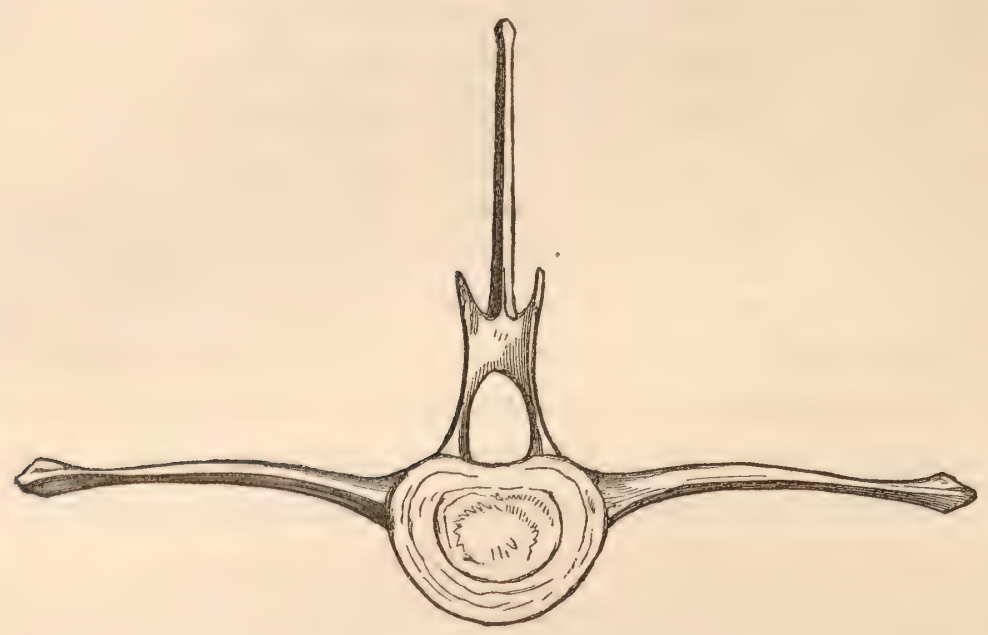

Ninth dorsal vertebræ seen from behind, reduced nearly $\frac{1}{8}$ th natural size. breadth to the fourth, the transverse process of the first dorsal being shorter than that of the last cervical, and all these processes, as usual, are much forwardly directed. A sudden change, however, is inaugurated in the fifth dorsal, in which the process is outwardly directed and considerably longer than in the fourth vertebra and much expanded at its free end.

From this point, the processes increase in length to the tenth dorsal which is the last, as there are only ten ribs, and they are gradually pushed somewhat backwards, and all are considerably contracted at their bases and middles. In the first lumbar, they markedly diminish in length and assume an entirely different character, being short and but little expanded at their ends. As they are traced backwards in the lumbar region, the diminution in their length is very gradual, and one of the chief features is the marked increase in their breadth, associated with a basal contraction. In the last lumbar, there is another change introduced as the process begins to decrease in size by a lessening of the dimensions of its anterior border which becomes bevelled off, and by a rapid reduction in the length of the process; so that in the seventh caudal, it becomes reduced to a lateral ridge. In the third caudal, it is perforated.

One chevron bone was forwarded to me along with the other bones. It is halbert-shaped and has a vertical depth of 7.75 inches, and a maximum breadth at its expanded portion of $6: 40$ inches.

Of the ribs, a fragment of the first rib of the left side was saved, and the entire sixth rib of the same side (fig. 26). The former is a portion of the shaft and of the

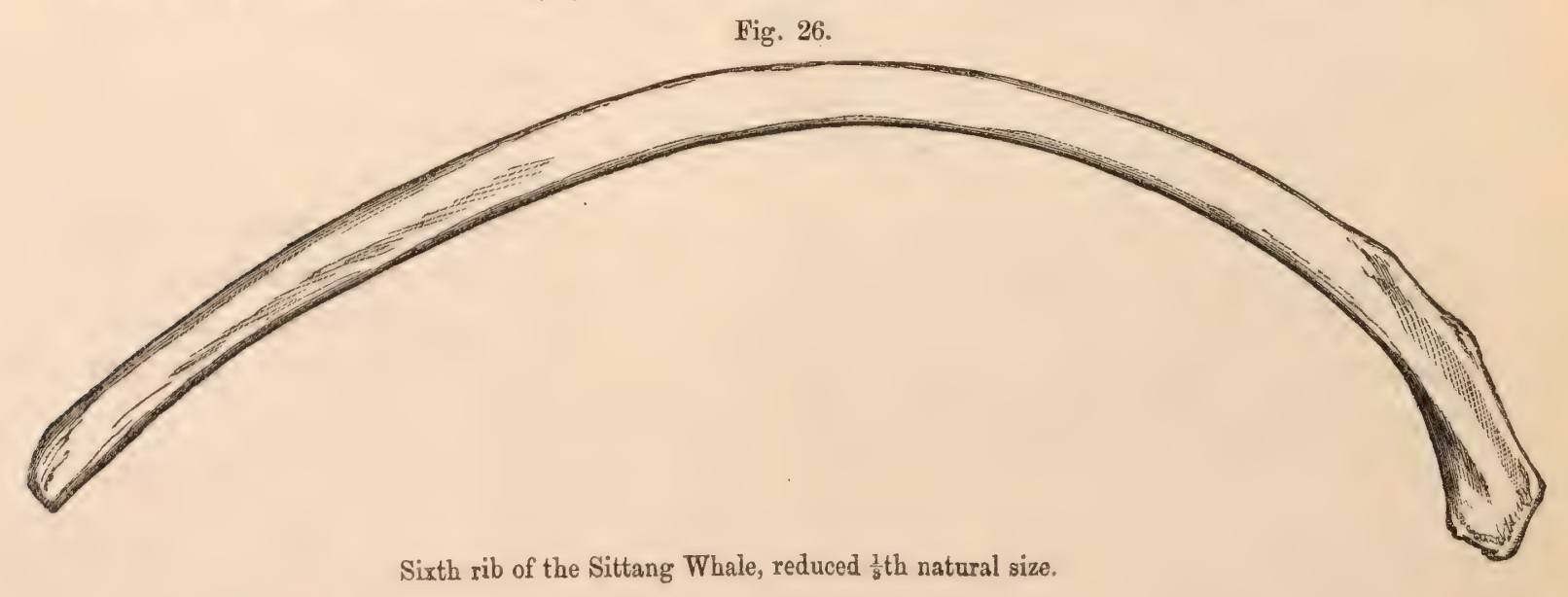


head and tubercle of the rib. It is single-headed, and the head and tubercle are welldeveloped, the distance from the outer margin of the latter to the inner border of the head being 6.25 inches. The breadth of this rib across the angle is 4.25 inches. The sixth rib is slender, but it has a well-defined angle, at which it attains a breadth of 2.60 inches. The length from the inner surface of the head to the free end is 51.50 inches, and it has a width at the lower end of 2.20 inches.

A humerus, radius, and ulna were saved. The first has much the same

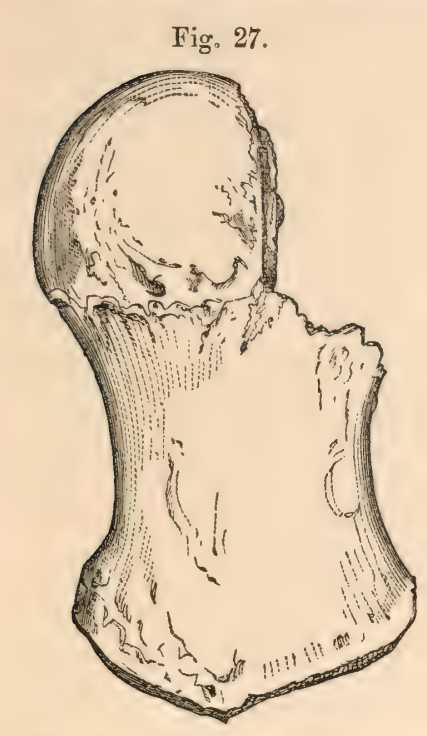
character as the same bone in $B$. schlegeli, but its lower end is more dilated. It measures in extreme length 12.25 inches, and at its middle is 4.60 broad, and at its inferior end 6.75 in breadth. The radius, at its upper end, is 4.90 inches broad by $2 \cdot 60$ in thickness, and, at its middle, 3.50 in breadth and 1.45 in thickness. It has a length of 21.75 inches, but a small portion of its lower end has been broken off, but not more, I should think, than half an inch. The ulna has the general characters presented by this bone in Balcenoptera, but, like the radius, a small portion of its distal end has been lost. Between the articular ends it measures $19 \cdot 25$ inches, and at its middle it has a breadth of 2 inches and a thickness of $1 \cdot 50$.

The aspect of the humerus, re. duced to $\frac{1}{5}$ th of its natural dimensions.

A metacarpal was also rescued, and it would indicate that the fingers had had the short characters of the manus of $B$. musculus.

Fig. 28.

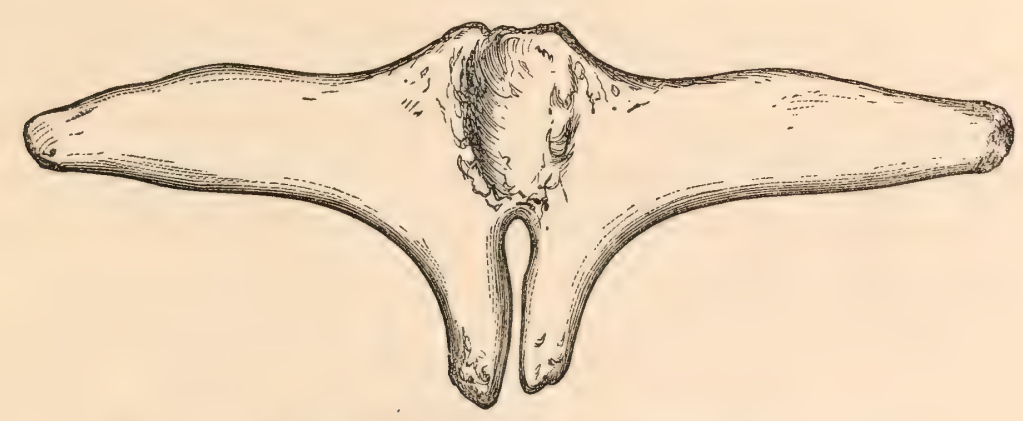

Hyoid bone of the Sittang Whale, reduced $\frac{1}{5}$ th its natural dimension.

The hyoid bone (fig. 28), having the usual constitution, has the lateral process long and narrow, and more resembling the processes of $B$. sibbaldi than those of the hyoid of $B$. schlegeli. The extreme breadth of the hyoid is 25 inches, with an antero-posterior length of 9.75 inches. The stylohyals are also larger and less expanded than in $B$. schlegeli: one measures 4.75 inches in extreme length, with a maximum breadth of $5 \cdot 25$. 
A small portion of the skin of this Whale was sent to me in a dried state, and the only observation I have to make regarding it is that it was extremely thin and deep black.

Six pieces of short balene accompanied the other remnants of this Whale; they were all of one size, or nearly so, with the exception of one small white piece, evidently only a portion of a flake, as, although it measures 5.25 inches in length, it has considerable basal thickness where it had been cut across. Its breadth is only 2.50 inches, and it is triangular in form, tapering to a point at its free end, which is broken up into a fringe of long fibres. The five remaining pieces are also triangular, with about 12 inches of length and a maximum breadth at the base of 6 inches. Their basal margins are uninjured, as the plates had evidently been drawn out of the decaying mucous membrane. The long curved free border is deeply fringed.

In November 1874, or about that period, a small balene Whale was cast ashore on the island of Sondip, lying at the mouth of the Brahmaputra, opposite to Chittagong. Some portions of the animal were saved by Babu Udaychand Dutt, Civil Medical Officer, Noákálí, and are now in the Indian Museum, Calcutta. ${ }^{1}$ They consist of the skull, less the maxillaries, premaxillaries, vomer, nasals, left palatine and the lower jaw. The right petrous and tympanic were preserved. The other bones saved are the atlas, one lumbar and two caudal vertebræ, the body without processes of a dorsal, one spinous and one transverse process, four epiphyses of vertebral centra, first rib of right side, eighth or ninth rib of same side, the right scapula, humerus, radius and ulna, a hyoid and a stylohyal. All of these bones indicate a very young animal, and the question occurs in connection with them,-may this be the young of the same species as Balcnoptera edeni, or can any opinion be pronounced on its relation to Balcenoptera indica?

The form of the portion of the skull which remains has a strong resemblance to the corresponding portion of the skull of the Medical College specimen, which skull differs from the Sittang skull in a few but what appear to me unimportant details, such as the much narrower character of the portion of the squamosal which enters into the formation of the temporal fossa, and in the less concave character of the upper part of the parietals in the same fossa. This Sondip skull has the narrow squamosal suture of the Medical College skull, but the concave parietal of the Sittang Whale. In other respects, it agrees with both those skulls, but as the maxillaries are not present in it, and as the skull of $B$. schlegeli is chiefly distinguished from those two skulls by the characters presented by these bones, it is possible, in view of the differences to be noted in the other bones of this young animal, that it may be specifically distinct from them and $B$. schlegeli, and therefore probably a hitherto-unknown Cetacean species. My greatest difficulty in reconciling this young Whale with Balcenoptera edeni lies in the characters presented by the lumbar vertebra, which appears to be the equivalent of the eighth lumbar of that Whale. This vertebra, as I have said, is in a very young stage; the epiphyses of the body are gone, and those of the spinous and transverse processes have evidently been cartilaginous;

${ }^{1}$ J. Wood-Mason : Proc. As. Soc., Bengal, 1874, Nov., p. 201. 
and yet, notwithstanding this, the body of this vertebra is considerably deeper and shorter than the corresponding vertebra of B. edeni, as is shown by the following measurements and has none of the depressed character, which is so distinctive of

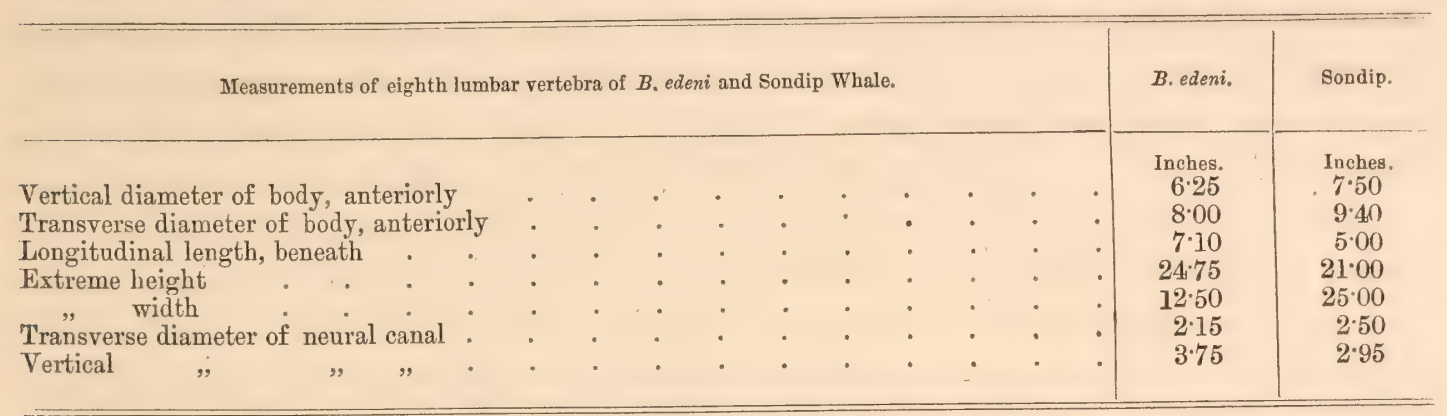

the dorsal and lumbar vertebræ of that animal. These differences are so marked that it is impossible to reconcile the character of this vertebra with any of the vertebræ of the Sittang Whale, and, moreover, the forward direction of the transverse processes is much more pronounced than in the corresponding vertebra of that animal, and the spinous process is more erect and of greater thickness in its last half, and not, like it, contracted at its middle.

In the Medical College, Calcutta, there are five vertebræ of a Whale, which, judging by the condition of their epiphyses, would appear to have belonged to an animal somewhat younger than the Sittang Whale, and yet they are considerably larger. I refer them to the tenth dorsal, sixth, seventh and eighth lumbars, and to the second caudal. I have not succeeded in tracing their history. They have the generic characters of the vertebræ of $B$. edeni in the form of their bodies, but the spinous processes are more erect. The following table will show to what degree they exceed in size the corresponding vertebræ of B. edeni:

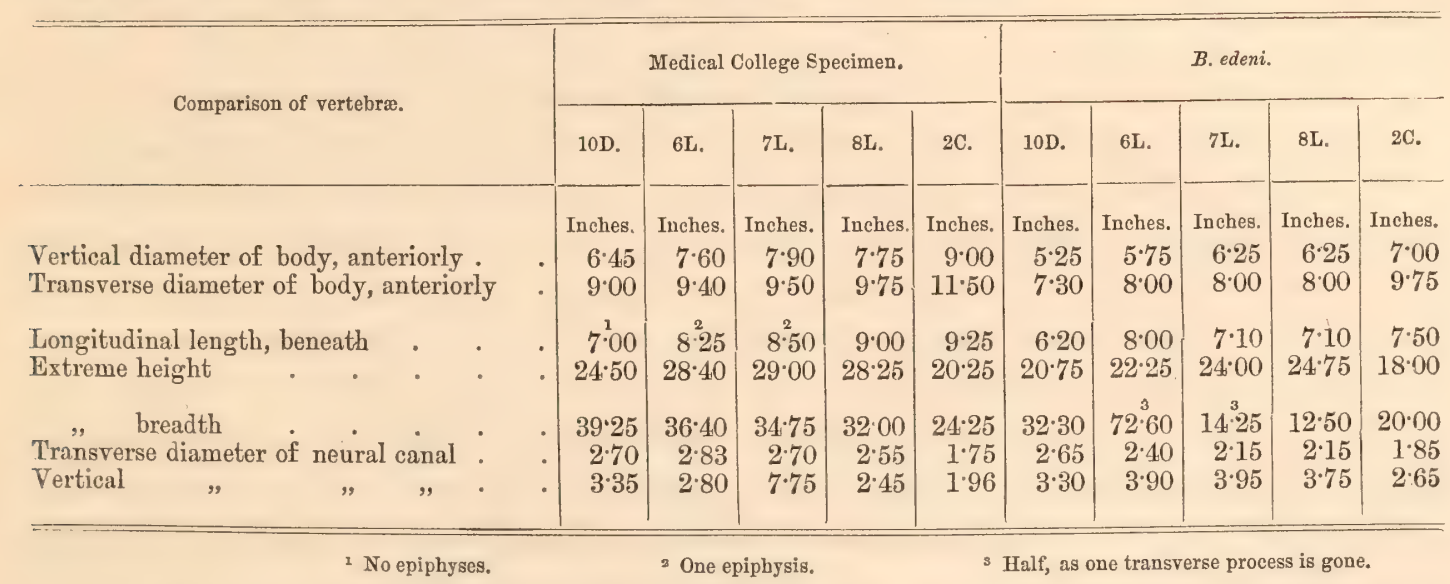

These vertebræ of the Medical College Whale, with the exception of the tenth dorsal and the second caudal, have lost some of the epiphyses of their bodies. In the first mentioned vertebra, the hinder epiphysis is intact, and, in the last, the epiphysis is partially united to the centrum around the margin in the Medical College specimen, whereas in $B$. edeni all trace of the distinction between the 
epiphysis and the body is entirely obliterated. It is evident from these facts that these vertebræ belonged to a species which attained to a considerably greater size than the mature $B$. edeni. Besides difference in size, there are characters manifested by the vertebræ which appear also to separate it specially from the Sittang Whale. In the tenth vertebra, the anterior zygapophyses are relatively much longer than in the latter, and much more forwardly directed, and the spinous process has much greater antero-posterior expansion. In the Sittang Whale the articulation for the ribs to the transverse processes is on their under surfaces, whereas in this other Whale, in the tenth dorsal the articulation is at the extremity of the process posteriorly. The zygapophysial characters indicated are perpetuated in the lumbar vertebræ. Although these vertebræ are relatively younger than those of the Sittang Whale, yet they are at such a stage of growth that it does not appear probable that the animal could ever have attained to the dimensions of $B$. indica; besides, they have none of the characters of $B$. schlegeli, as figured by Beneden and Gervais.

A rib of this Whale (Medical College) has been saved, the left first rib; and it is nearly entire, measuring in total length 47.50 inches from the tubercle. It is singleheaded, but it differs from the corresponding rib of the Sittang Whale in the greater length of the capitular portion, and in the less prominent character of the tubercle.

It seems to me improbable that the Sondip juvenile Whale is the young of B. edeni, because it apparently had yet such a capacity of growth that, had it lived, its vertebræ must have considerably surpassed the dimensions of the other. Indeed, I am inclined to regard the Sondip specimen as the young of an animal exceeding, in adult life, double the length of $B$. edeni and in all likelihood surpassing by 20 feet the Whale from which the vertebræ in the Medical College were derived. It may be the young of the giant $B$. indica, but there are not sufficient materials to determine this point.

The evidence which I have adduced would, therefore, go to render it probable that three species of Balanoptera exist in the Bay of Bengal, and, it may be, four, if the Sondip Whale prove to be distinct from B. indica. These Whales are of different sizes, one species being represented by the Sittang animal; not exceeding 40 feet, and for which I propose the name Balcenoptera edeni, in recognition of the Hon'ble Ashley Eden having been the means of saving this Whale to science; the second, a Whale, which its vertebræ prove to have been a Balanoptera reaching 60 feet in length, with which I would connect the name of that distinguished Indian naturalist, the late Edward Blyth, and designate it B. blythii; and a third attaining to the great size of 84 feet or more, and of which the Sondip Whale may represent the young, viz., Balcenoptera indica, Blyth. 


\section{A VES.}

LIST OF SPECIES

COLLECTED ON

THE TWO EXPEDITIONS

To

WESTERN Y U N A N 



\section{Order PSITTACI.}

Family-PSITTACID A

\section{Genus Pal}

\section{Pateornis eupatrius, Linn.}

La Perrucie de Gingi, Briss. Orn., t. iv, p. 343, pl. xxix, fig. 1, 1760.

La Grande Perruche à collier, Levaill., Perr., pl. xxx, 1805.

La Perruche à épanlettes ronges, id., l.c., pl. lxxiii, 1805.

Psittacus eupatrius, Linn., Syst. Nat., t. i, p. 140, 1766 ; Gmelin, Syst. Nat., t. i, p. 315,1788 ; Lath., Ind. Orn., p. 85, 1790.

Psittacus alexandri, Scop. (nec Linn.) Ann. i, Hist. Nat., p. 29, 1769 ; Lath., Ind. Orn., p. 97, 1790 ; Kuhl., Consp. Psitt., p. 30, 1820.

Palcornis alexandri, Vig., Zool. Journ., vol. ii, p. 49, 1825; Wagl., Mon. Psitt., p. 506, 1832 ; Selby, Nat. Libr., vol. x, p. 92, pl. ii, 1838; Jerdon, Madr. Journ., vol. xi, p. 208, 1840 ; Blyth, Ann. Nat. Hist., vol. xii, p. 90, 1843 ; Hodgson, Cat. Birds, Nep., p. 112, 1846 ; Blyth, Cat. Birds, Mus. As. Soc., Bengal, p. 4, 1849; Bonap. Consp., t. i, p. 2, 1850 ; Kelaart, Prod. Faun. Ceyl., p. 127, 1852 ; Layard, Ann. Nat., vol. xiii, p. 262, 1854; Horsfield \& Moore, Cat. Birds, Mus. E. I. Co., vol. ii, p. 610, 1856 ; Gray, List Psitt., p. 18, 1859 ; Adams., Proc. Zool. Soc., 1859, p. 173 ; Jerd., Birds of India, p. 256, 1862 ; Blyth, Ibis, 1863, p. ] ; Schleg., Mus. P.-B. Psitt., p. 76, 1864; Beavan, Ibis, 1865, p. 409; Blyth \& Walden, Journ. As. Soc., Bengal, vol. xliv, extra No., 1875, p. 54.

Conurus alexandri, Less., Tr. d'Orn., p. 214, 1831.

Palcornis cucullatus, Lea, Parrots, pl. xxxii, 1832.

Palaornis nipalensis, Hodgson, As. Res., vol. xix, pt. i, p. 177, 1836 ; Gray's Zool. Misc., p. 85, 1844. Palaornis eupatrius, Licht., Nomencl. Av., p. 71, 1854; Finsch, Papag., Bd. ii, p. 11, 1868 ; Gray,

Handl. B., vol. ii, p. 142, 1870 ; Hume, Stray Feathers, 1873, p. 170 ; id., t.c., p. 433 ; id., op. cit., 1874, p. 11 ; Ball, t.c., p. 389 ; Butler, op. cit., 1875, p. 457.

Palcornis sivalensis, Hume, Nests and Eggs, p. 115, 1875.

a. ㅇ Sawady, Upper Burma, 28th January 1875.

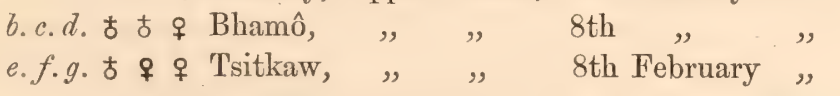

This Parrot was very abundant all around Bhamô, at Sawady and at Tsitkaw, but it seems not to extend to the eastwards across the Kakhyen hills.

\section{Pataornis torquatus, Bodd.}

La Perruche à collier, Briss., Orn., t. iv, p. 323, 1760.

La Perruche à collier couleur de rose, Pl. Enl., 551, 1770 ; Buffon, Hist. Nat. Ois., t. vi, p. 152, 1778. 
La Perruche à collier rose, Levaill., Perr., pls. xxii, xxiii, 1805.

Psittacus torquatus, Bodd., Tabl. Pl. Enl., p. 32, 1783 ; Kuhl., Consp. Psitt., p. 30, 1820.

Psittacus manillensis, Bechst., Stubenvög, p. 612 ; Hahn., Orn. Atl. Papag., pl. vi, 1834.

Psittacus frenatus, Licht., Doubl. Cat., p. 6, 1823.

Palcoornis torquatus, Vigors, Zool. Journ., vol. ii, p. 50, 1825 ; Sykes, Proc. Zool. Soc., 1832, p. 96 ; Jerdon, Madr. Journ., vol.xi, 1840, p. 207; Blyth, Ann. Nat. Hist., vol. xii, p. 90, 1843; Hodgson, in Gray's Zool. Misc., 1844, p. 85 ; Gray, Gen. B., vol. ii, p. 409, 1846 ; Gray, Cat. B. Nep. Hodgs. Coll., p. 118, 1846 ; Blyth, Cat. B. Mus., As. Soc., Bengal, p. 4, 1849; Kelaart, Prodr. Faun. Ceylon, p. 127, 1852; Layard, Ann. Nat. Hist., vol. xiii, p. 262, 1854 ; Burgess, Proc. Zool. Soc., 1854, p. 256 ; Horsfield \& Moore, Cat. B. E. I. Co., vol. ii, p. 611, 1856; Philipps, Proc. Zool. Soc., 1857, p. 99; Adams., Proc. Zool. Soc., 1859, p. 173 ; Gray, List Psitt., p. 19, 1859 ; Jerdon, B. Ind., vol. i, p. 257, 1862 ; Blyth, Ibis, 1863, p. 2 ; Schlegel, Mus. P.-B. Psitt., p. 80, 1864 ; Beavan, Ibis, 1865, p. 404 ; Finsch, Papag., Bd. ii, p. 17, 1868 ; Gray, Handl. B., vol. ii, p. 142, 1870; Godwin-Austen, Journ. As. Soc., Bengal, vol. xxxix, p. 266, 1870 ; Hume, Stray Feathers, 1873, p. 170; Hutton, t. c., p. 338 ; Adam., t. c., p. 372 ; Hume, op. cit., 1874, p. 13 ; id., t. c., pp. 177, 470 ; Ball, t. c., p. 389 ; Hume, t. c., p. 470 ; id., op. cit., 1875, p. 56 ; id., Nests and Eggs, Ind. B., p. 116, 1875; Blyth \& Walden, Journ. As. Soc., Bengal, vol. xliv, extra No., 1875, p. 55 .

Conurus torquatus, Less., Tr. d’Orn., p. 215, 1831.

Palcoornis inornatus, Vigors, Zool. Journ., vol. v, p. 274, 1832.

Palcornis bitorquatus, Blyth, Cat. B. Mus., As. Soc., Bengal, p. 4, 1849.

Palcoornis layardi, Blyth, l.c., p. 341, 1849; Gray, List Psitt., p. 19, 1859.

a.b. t $q$ Mandalay, Upper Burma, 20th September 1868.

$\begin{array}{llrl}c . & \text { + Mengoon, " } & \text { 14th January } & \text { " } \\ \text { d. } & \text { t Yaylaymaw, " } & \text { 5th January } & 1875 .\end{array}$

\section{Palmornis cyanocephalus, Linn.}

La Perruche à tête bleue, Briss. Orn., t. iv, p. 359, pl. xix, fig. 2, 1760.

Psittacus cyanocephalus, Linn., Syst. Nat., t. i, p. 141, 1766, (ex Briss.)

Palcoornis rosa, Swinhoe, Proc. Zool. Soc., 1863, p. 259, et 1871, p. 391.

Palcornis bengalensis, Hume, Stray Feathers, 1874, p. 16; id., 1875, p. 57; Blyth \& Walden, Journ. As. Soc., Bengal, vol. xliv, extra No., 1875, p. 55.

Palaornis cyanoceplialus, Gouid, Birds of Asia, pt. xxvi, 1st August 1874.

a. b. \& Thingadaw, 16th January 1868.

c. $\quad$ t Bhamô, 16th January 1868.

d.e. $\delta$ t juv. Momien, Yunnan, lst and 10th July 1868.

\section{Paldernis melanorhynchus, Wagler.}

Palceornis melanorhynchus, Wagl., Mon. Psitt., p. 511, 1832 ; Gray, Gen. B., vol. ii, p. 410, 1846 ; Licht., Nomencl. Av., p. 72, 1854 ; Gray, List Psitt. B. M., 1859, p. 24; Finsch, Parrots, Bd. ii, p. 70, 1868; Gray, Handl. B., vol. ii, p. 143, 1870 ; Blyth \& Walden, Journ. As. Soc., Bengal, vol. xliv, extra No., 1875, p. 57.

Palcoornis nigrirostris, Hodgson, in Gray's Zool. Misc., p. 85, 1844.

Palcornis derbianus, Fraser, Proc. Zool. Soc., 1850, p. 245, pl. xxv ; Gould, B. Asia, pt. x, 1858 ; Gray, List Psitt., 1859, p. 25.

Belurus melanorhynchus, Bonap., Rev. Zool., 1854, p. 153. 
Palcornis vibrisca, Schlegel, Mus. P.-B. Psitt., p. 85, 1864.

Palaorn is pondicerianus, Brehm, Thierleb., p. 70, 1865.

$$
\text { a. b. f \& Pudeepyoo, Upper Burma, 1st January } 1875 .
$$

These birds were shot on the same day, and the male had a red and the female a black bill. The latter had also a slight shade of blue on the head.

\section{Order ACCIPITRES.}

$$
\text { Family-FALCONID A. }
$$

Genus Falco, Linn.

\section{Falco subbuteo, Linn.}

The Hobby, Albin, Nat. Hist. Birds, vol. i, p. 6, pl. vi, 1738.

Le Hobreau, Briss. Orn., t. i, p. 375, 1760.

Falco subbuteo, Linn., Syst. Nat., t. i, p. 127, 1766; Temm., Man. d’Orn., t. i, p. 25, 1820 ; Naum., Vög. Deutschl., Bd. i, p. 296, pl. xxvi, 1822; Werner, Atlas Ois. d’Eur. Rapaces, pl. ix, 1827; Gould, B. Eur., vol. i, pl. xxii, 1837; Yarr., Hist. B. Birds, vol. i, p. 40, 1843 ; Schlegel, u. Susem, Vög. Eur., taf. x, fig. 1, 1845 ; Kjærb.; Orn. Dan. Afb., Bd. iii, fig. 1, 1851; Schlegel, Vög. Nederl., pl. viii, 1854; Strickland, Orn. Syn., p. 85, 1855; Hewits., Eggs, B. Birds, vol. i, p. 26, pl. ix, fig. 1, 1856 ; Fritsch, Vög. Eur., tab. iii, figs. 1, 2, 1858 ; Radde, Reise Sibir., Bd. ii, p. 100, 1863 ; Blyth, Ibis, 1863, p. 9 ; Moore, Ibis, 1865, p. 9; Gould, Birds of Great Britain, pt. viii, 1865 ; Farman, Ibis, 1868, p. 412 ; Sundev., Sv. Fogl., p. 215, pl. xxvi, fig. 4, 1869 ; Heugl., Orn. N. O.-Af., p. 33, 1869; Salvad, Faun. Ital. Ucc., p. 20, 1871 ; Swinhoe, Proc. Zool. Soc., 1871, p. 340 ; Saunders, Ibis, 1871 , p. 59 ; Sharpe \& Dresser, B. Eur., pt. iv, 1871 ; Godman, Ibis, 1871, p. 165 ; Schlegel, Rev. Accipitr., p. 38, 1873 ; Sharpe, Cat. B., vol. i, p. 395, 1874; Layard, B. S. Afr.; David, Journ. de Voy. en Chine, t. ii, 1875, p. 39.

Falco barletta, Daud. Traité d’Orn., t. ii, p. 129, 1800.

Hypotriorclis subbuteo, Boie, Isis, 1826, p. 976 ; Gray, Gen. B., vol. i, p. 20, 1844; Kaup., Contr. Orn., 1852, p. 54 ; Bonap. Consp., t. i, p. 25, 1850 ; Jerdon, Birds of India, vol. i, p. 33, 1862; Tristr., Ibis, 1865, p. 258; Degl. \& Gerbe, Orn. Eur., Bd. i, p. 85, 1867 ; Layard, B. South Africa, p. 21, 1867 ; Hume, Rough Notes, pt. i, p. 85, 186? ; Gray, Handl. B., vol. i, p. 20, 1869; Gurney in Anderss. B. Dam. Ld., p. 14, 1872.

Falco hirundinum, Brehm, Vög. Deutsch., p. 65, 1831 .

Dendrofalco subbuteo, Gray, List Gen. B., p. 3, 1840.

Dendrofalco hirundinum, Brehm, Naum., 1855, p. 269.

Dendrofalco arboreus, Brehm, ut suprá.

Hypotriorchis cuvieri, Gray, Handl. B., vol. i, p. 20, 1869.

a. Momien, Yunnan, June 1868.

I obtained one young specimen at Momien and kept it alive for several months. The feathers of the back in the young are deep brown, and nearly all are edged with a rusty margin. The central tail feathers are uniform slaty with rufous tips, and the others are barred with rufous on the inner webs, and all, with the exception of the external feathers, have a fragmentary bar on the outer webs. The under surface, from the chin to the vent, including the tail-coverts, has a rufous tinge, and 
the breast and belly and leg-coverts have black streaks, fainter on the thighs. The cheek stripe is not very distinct.

\section{Falco saturatus, Blyth.}

Tinnunculus alaudarius, Blyth, Cat. Birds, As. Soc. Mus., p. 15, No. 69 I, 1849.

Tinn unculus saturatus, Blyth, Journ. As. Soc., Bengal, vol. xxviii, 1859, p. 277 ; Ibis, 1866, p. 238; Hume, Rough Notes, 1869, p. 100 ; Stray Feathers, vol. v, 1877, p. 129; Blyth \& Walden, Journ. As. Soc., Bengal, vol. xliv, extra No., 1875, p. 59.

? Tinnunculus atratus, Blyth, G. R. Gray, H. L. Birds, Brit. Mus., 1869, p. 23 ; Walden, Journ. As. Soc., vol. xliv, extra No., p. 59; Sharpe, Cat. Accip., Brit. Mus., 1874, p. 426; Hume, Stray Feathers, 1877, vol. v, p. 129.

$$
\text { a. む juv. Momien, June } 1868 .
$$

I shot this Kestrel on the 'grassy hills about Momien. It is remarkable for the especially very dark and rich colour of the upper plumage, and on which the reddishbrown areas, instead of assuming the form of transverse bars, are converted into round spots by the dark blackish-brown of the feathers being prolonged along the shafts and along the margins, and to that degree that the latter colour is more pronounced than the former. I have never observed this plumage in true $F$. tinnunculus. A bird, however, from Tenasserim approaches the Yunnan bird in this respect, but with this difference that the reddish-brown is not reduced to spots, but while retaining its barred character is equalled, if not eclipsed, by the dark-brown bars. The bird presenting these colours is an adult female of the species named F. saturatus by Blyth. On the under surface, the Yunnan bird has the feathers suffused with a pale reddish, as also occurs somewhat in F. tinnunculus, but it is darker, and the centre of each feather is also longitudinaliy marked with a broad black band, as in F. tinnunculus. In the type of F. saturatus, this rufous colouring of the under parts is absent, but it was an adult.

The type of F. saturatus is a female. Two females of what I believe to be this race or species exist in the Indian Museum, but one of them bears in Blyth's handwriting the name " $T$. fuscatus" and the locality of Tenasserim and the Revd. J. Barbe as the donor, which are the particulars of the specimen referred to by Blyth in his Catalogue, p. 15, No. 69 I, and mentioned as being probably the female of a distinct race remarkable for the great development of the dark markings of its plumage.

Comparing these specimens with a Calcutta female, $F$. tinnunculus, of the same age, the striking features are the much greater prevalence of the dark markings and the broader black banding of the tail, also the broader dark markings on the breast. In a young male from Tenasserim received from the late Mr. W. S. Atkinson, the back is richer reddish than in $F$. tinnunculus, and the black spots are much larger, the head also is darker slaty-black, and the breast spots are long and linear, and the round black spots on the belly fewer, but larger than those of F. tinnunculus. The grey tail of this specimen is darker than the tail of $F$. tinnunculus, and the barring on the inner webs is stronger, and the bars, it seems to me, are more numerous, but the 
materials at my disposal are not sufficient to determine whether this is merely a local race.

In the Indian Museum, Calcutta, besides the Tenasserim and Yunnan specimen referable to $F$. saturatus, there is another example from Samaguting, Assam.

\section{Genus Microhiterax, Sharpe.}

\section{Microhierax cæerUlescens, Linn.}

Fraico carulescens, Linn., Syst. Nat., t. i, p. 126, 1766.

Harpagus carulescens, Swain., Classif. B., vol. ii, p. 213, 1837.

Hierax bengalensis, Blyth, Journ. As. Soc., Bengal, vol. xi, p. 780, 1842.

Hierax eutolmus, vel bengalensis, Hodgson, in Gray's Zool. Misc., p. 81, 1842.

Hierax carulescens, Gray, Gen. B., vol. i, p. 21, 1844.

Hierax eutolmus, Gray, l.c., p. 21, 1844; Jerdon, Birds Ind., vol. i, 1862, p. 42 ; Blanford, Ibis, 1870 , p. 464.

Falco cerulescens bengalensis, Schl., Mus. P.-B. Falc., p. 33, 1862.

Microhierax carulescens, Sharpe, Cat. B., vol. i, p. 366, 1874.

a.b. \& Sawady, Upper Burma, 30th January 1875.

c. t. The left bank of Tapeng River, Tsitkaw, 11th February 1875.

The following are the measurements of a pair :-

\begin{tabular}{|c|c|c|c|c|}
\hline $\mathrm{T}$ & $\begin{array}{c}\text { Total length. } \\
6 \cdot 2\end{array}$ & $\begin{array}{l}\text { Wing. } \\
3.9\end{array}$ & $\begin{array}{l}\text { Tail. } \\
2 \cdot 7\end{array}$ & $\begin{array}{r}\text { Tarsus. } \\
0.80\end{array}$ \\
\hline Sawady & $6 \cdot 5$ & $4 \cdot 3$ & $2 \cdot 6$ & $0 \cdot 85$ \\
\hline
\end{tabular}

I observed this bird on only two occasions, in the centre of a dense forest, perched in pairs on the summits of high trees, nearly denuded of their leaves. From the great altitude at which they were, it was extremely difficult to shoot them, but so little were they accustomed to fire-arms and unscared by the noise that they actually refused to move, as shot succeded shot. This bird has a peculiar short metallic call.

\section{Genus Pernis, Cuvier.}

\section{Pernis Ptilorhynchus, Temminck.}

Falco ptilorhynchus, Temminck, Pl. Col., t. i, pl. xliv, 1823.

Pernis ptilonorhynchus, Steph., Gen. Zool., vol. xiii, pl. xxxv, 1826.

Pernis cristata, Cuvier, Régne An., t. i, p. 335, 1829.

Pernis torquata, Less., Traité d'Ornith., p. 76, 1831.

Pernis ruficollis, Less., l.c., p. 77, 1831.

Pernis albigularis, Less., l. c., p. 77, 1831.

Pernis maculosa, Less., in Bélang. Voy. Ind., p. 223, 1834.

Pernis ellioti, James, Trans. Wern. Soc., vol. vii, p. 493, 1836.

Pernis bharatensis, Hodgson, in Gray's Zool. Misc., p. 81, 1844.

Pernis apivorus, Temm. et Schlegel, Faun. Jap. Aves, p. 24, 1850.

Pernis brachypterus, Hume, Stray Feathers; vol, iii, p. 36, 1875; id., op. cit., p. 36 ; Fairbank, $t . c$, p. 253.

a. Bhamô, February 1868. 
The measurements of the above specimen are as follows:-

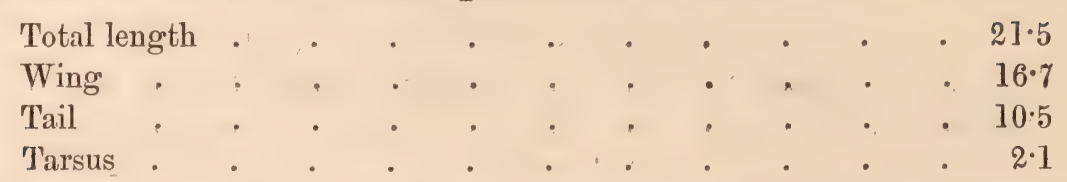

The bird in question is in the plumage which Mr. Sharpe describes $(l . c$.$) as$ the intermediate stage; certainly it is not adult and has no crest to speak of. Mr. Hume $(l . c$.$) does not speak very positively as to the specific distinctness$ of the Burmese Honey Buzzard, and it is probable that the bird from these countries is intermediate between the ordinary Indian species and the large crested form which inhabits Java.

Genus Elands, Savigny.

\section{Elanus ceruleus, Desf.}

La petite Buse criarde, Sonn., Voy. Ind., t. ii, p. 184, 1782.

Falco caruleus, Desf., Mém. Acad. R. des Sciences, 1787, p. 503, pl. xv.

Criard Falcon, Lath., Gen. Syn. Suppl., vol. i, p. 38, 1787.

Falco vociferus, Lath., Ind. Orn., vol.i, p. 46, 1790.

Le Blac, Levaill., Ois. d’Afr., t. i, p. 147, pls. xxxvi, xxxvii, 1799.

Falco melanopterus, Daud., Traité d’Orn., t. ii, p. 152, 1800.

Falco clamosus, Shaw, Gen. Zool., vol. vii, p. 200, 1809.

Elanus casius, Savigny, Syst. Ois. d'Egypte, p. 274, 1809.

Elanus melanopterus; Leach, Zool. Misc., p. 5, pl. 122, 1817; Jerdon, B. Ind., vol. i, p. 112, 1862 ;

Hume, Rough Notes, vol. ii, p. 21, 1870 ; Blyth \& Walden, Journ. As. Soc., Bengal, vol. xliv,

1875, ex. No., p. 60 ; David, Journ. Voy. en Chine, 1875, t. i, p. 30.

Elanoides casius, Bonn. et Vieill., Enc. Méth., t. iii, p. 1206, 1823.

Buteo vociferus, Bonn. et Vieill., Enc. Méth., t. iii, p. 1220, 1823.

Elanus minor, Bonap. Consp., t. i, p. 22, 1850.

Elanus caruleus, Strickland, Orn. Syn., p. 137, 1855 ; Sharpe, Cat. B., vol. i, p. 336, 1874.

a. to Momien, 6th June 1868.

This specimen approaches Elanus hypoleucus in appearance, as it shows a little white near the base of the inner webs of the primaries. My specimen measures as follows:-

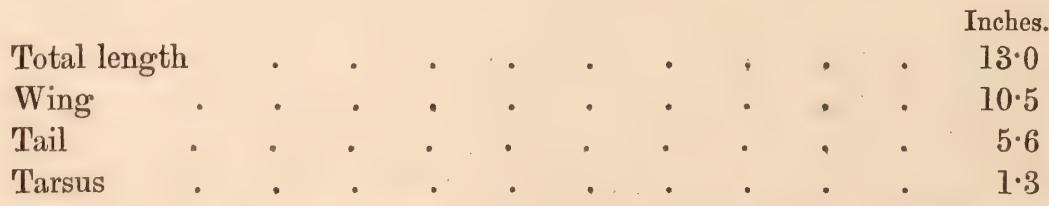

These dimensions agree, very fairly, with those given by Mr. Sharpe in his Catalogue.

\section{Genus Crrcus, Lacepède.}

10. Cincus melanoleucus, Forster. Pls. XLV \& XLVI.

Falco melanoleucus, Forster, Indisch. Zool., p. 12, pl. xi, 1781.

Faucon à collier des Indes, Sonn., Voy. Ind., t. ii, p. 182, 1782. 
Black-and-IThite Falcon, Penn., Ind. Zool., p. 33, pl. ii, 1790.

Tchoug, Levaill., Ois. d'Afr., t. i, p. 133, pl. xxxii, 1799 ; Sund., Crit. om Levaill., p. 27, 1857.

Circus melanoleucus, Vieill., Nouv. Dict. d’Hist. Nat., t, iv, p. 465, 1816 ; Less., Traité d’Orn., p. 87, 1831 ; Gray, Gen. B., vol. i, p. 32, 1845 ; Strickland, Orn. Syn., p. 154, 1855; Jerdon, Birds of India, vol. i, p. 98, 1862 ; Schlegel, Mus. P.-B. Circi, p. 8, 1862 ; Gurney, Ibis, 1868, p. 356 ; Gray, Handl. B., vol. i, p. 37, 1869; Hume, Rough Notes, pt. ii, 1870, p. 307 ; Stray Feathers, vol. iii, 1875, p. 34; Swinhoe, Proc. Zool. Soc., 1871, p. 34; Ibis, 1874, p. 266 ; Holdsworth, Proc. Zool. Soc., 1872, p. 414; Sharpe, Cat. Birds, Brit. Mus., vol. i, 1874, p. 61 ; Gurney, Ibis, 1875, p. 226 ; Godwin-Austen, Journ. As. Soc., Bengal, vol. xlv, 1876, p. 67; A. Anderson, Proc. Zool. Soc., 1876, p. 315 ; Hume, Stray Feathers, 1877, p. 11.

Strigiceps melanolelicus, Kaup., Mus. Shenck., t, iii, 1845, p. 258; Bonap. Consp., t. i, 1850, p. 35.

a. 우 Tsitkaw, 12th February 1875 .

b. juv. Muangla, Sanda Valley, Yunnan, May 1868.

The sex of this adult female (Pl. XLVI) was accurately ascertained, and I take the opportunity to figure alongside of it the young specimen shot at Muangla; also the male bird (Pl. XLV).

I observed this bird only at Tsitkaw and at Muangla. In the former locality it was observed hunting over the level marshy expanse behind the village, and at Muangla, over the rice-fields between the hills and the 'Tahô river.

\section{Genus Astur, Lacepède.}

\section{Astur poliopsis, Hume.}

Micronisus badius, Sclater, Ibis, 1864, p. 246; Swinhoe, Ibis, 1870, p. 84; Proc.Zool. Soc., 1871, p. 411. Micronisus poliopsis, Hume, Stray Feathers, 1874, vol. ii, p. 325 ; id., t. c., p. 468, and id., op. cit., 1877, vol. v, p. 9 .

Astur poliopsis, Sharpe, Cat. Accip. Birds, B. M., 1874, p. 110 ; Bingham, Stray Feathers, 1877, p. 81.

\section{a.b. \& $\&$ Tsagain, Upper Burma, 29th December 1874. \\ c. Bhamô, 9th February 1868.}

The female is very much darker than the male, and not nearly so blue: the vinous cross-bars below are much broader and not so clear. The above-mentioned. pair give the following measurements :-

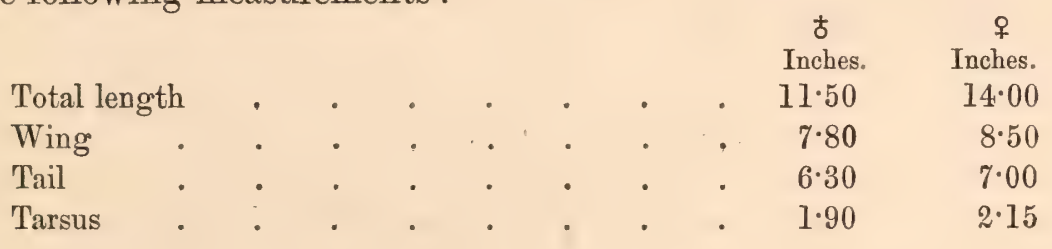

\section{Genus Haliaetus, Savigny.}

\section{Haliaetus leucoryphus, Pallas.}

Aquila lencorypha, Pall., Reise Russ. Reichs., t. i, p. 454, 1771.

White-crowned Eagle, Lath., Gen. Syn. B., vol. i, p. 42, 1781. 
Falco leucoryphus, Gm., Syst. Nat., t. i, p. 259, 1788; Schl. und Susem., Vög. Eur., taf. 27a, 1839.

Falco fulviventer, Vieill., N. Dict. d'Hist. Nat., t. xxviii, p. 283, 1819.

Falco macei, Temm., Pl. Col. 8, 223, 1824.

Haliaëtus macei, Vigors, Zool. Journ., vol. i, p. 336, 1824; Gray, Gen. B., vol. i, p. 17, 1845; Bonap. Consp. Av., t. i, p. 15, 1850 ; Strickl., Orn. Syn., p. 52, 1855 ; Gray, Handl. B., vol. i, p. 17, 1869 ; Hume, Stray Feathers, vol. i, p. 159, 1873 ; id., Nests and Eggs, Ind. B., p. 45, 1874; Scully, Stray Feathers, vol. iv, 1876, p. 124.

Aquila macei, Less., Man. d'Orn., t. i, p. 84, 1828.

Haliaëtus unicolor, Gray \& Hardw., Ill. Ind. Zool., pl. xix, 1832 ; Jerdon, Ibis, 1871, p. 236.

Haliaëtus albipes, Hodgs., Journ. As. Soc., Bengal, vol. v, p. 228, 1836.

Cuncuma albipes, Hodgs., op. cit., vol. vi, p. 367, 1837.

Haliaëtus leucoryphus, Keys. \& Blas., Wirb. Eur., p. xxx, 1840 ; Strickl., Orn. Syn., p. 52, 1855 ; Fritzsch., Vög. Eur., tab. 8, figs. 5, 6, 1858 ; Schl., Mus. P.-B. Aquilæ, p. 590, 1862 ; Degl. \& Gerbe, Orn. Eur., Bd. i, p. 45, 1867; Gray, Handl. B., vol. i, p. 17, 1869 ; Hume, Rough Notes, pt. ii, p. 242, 1870; id. et Henders., Lahore to Yarkand, p. 173, 1873 ; Severtzoff,

Turkest. Jevotn., p. 63, 1873 ; Sharpe, Cat. B., vol. i, p. 308, 1874.

Ichthyatus leucoryphus, Blyth, Ann. and Nat. Hist., vol. xiv, p. 37, 1844.

Haliaètus lanceatus, Hodgs., in Gray's Zool. Misc., p. 81, 1844.

Pontoaetus macei, Kaup., Isis, 1847, p. 280.

Cuncuma macei, Gray, List Accipitr., B. M., p. 23, 1848.

Pontoaetus leucoryphus, Gray, Gen. B., vol. iii, app. p. 2, 1849.

Aquila deserticola, Eversm., Bull. Soc. Imp. Mosc., t. xxv, p. 545, tab. 8, 1852.

Haliaëtus fulviventer, Jerdon, B. Ind., vol. i, p. 82, 1862.

\section{a. t Banks of the Tapeng, 3rd February 1875.}

In my course up the river from Mandalay to Bhamô, and from the latter town to Tsitkaw, this Eagle was frequently observed in pairs generally occupying the most prominent tree in the landscape, prominent both by its height, leaflessness, and by the circumstance of its position. The trees they selected to build on were usually close to the river-bank, and from their altitude above the surrounding forest, the birds must have commanded the view of a wide range of country. Their nests were always on the highest fork either of a leafless Bombax malabaricum or on some old and gaunt Dipterocarpus. As Tickell remarks, this Eagle never makes the slightest attempt to defend its nest, and, when fired at, it generally soars aloft for a few minutes and again alights, clanging forth its peculiar and harsh cry.

\section{Genus Milvus, Cuvier.}

\section{Milvus Melanotis, Temminck \& Schlegel.}

Milvus melanotis, Temm. und Schl., Faun. Japon., Aves, p. 14, pls. v et v B. (? 1845) ; Swinhoe, Ibis, 1873, p. 228; Sharpe, Cat. Accip. Birds, B. M., 1874, p. 324; A. Anderson, Stray Feathers, vol. iii, 1875, p. 387; Scully, op. cit., vol. iv, 1876, p. 90, et. seq.; Ball, op. cit., vol. v, 1877, p. 412 ; David, Journ. de Voy. en Chine, t. i, 1875, p. 32, et. t. ii, p. 39.

Milvus niger, var. melanotis, Schrenck, Reise Amurl. Vög., 1860, p. 234.

Milvus niger, Radde, Reise Sibir. Voy., 1863, p. 135, taf. 1, fig. 1. 
Milvus major, Hume, Rough Notes, 1870, ii, p. 326 ; Stray Feathers, vol. ii, 1874, p. 160 ; Ball, l.c., p. 381 .

Milvus govinda, Swinhoe, Proc. Zool. Soc., 1871, p. 341.

a. के immature, Momien, 7th July 1868.

b. む juv. Momien, 23rd June 1868.

Both these birds have the white patch very conspicuously developed on the lower surface of the wing, and they are, therefore, referred to $\boldsymbol{M}$. melanotis. The female has the wing $18 \cdot 8$ inches in length; the male $19 \cdot 7$.

I shot them in a clump of fir trees, around a ruined monastery, immediately outside the walls of Momien. Unlike the kite of India and Burma, I observed that they did not subsist on the refuse of the bazaar, but hunted for their food over the grassy hillsides.

\section{Genus Pandron, Savigny.}

\section{Pandion haliaetus, Linn.}

Falco haliaetus, Linn., Syst. Nat., t. i, p. 129, 1766 ; Naum., Vög. D., Bd. i, p. 241, pl. xvi, 1822 ; Werner, Atlas, Rapaces, pl. xix, 1827; Schl. u. Susem. Vög. Eur., taf. 24, 1839.

Falco arundinaceus, Gm., Syst. Nat., t. i, p. 263, 1788.

Falco carolinensis, Gm., l. c., p. 263, 1788.

Falco cayennensis, Gm., l.c., p. 263, 1788.

Aquila americana, Vieill., Ois. Am. Sept., t. i, p. 31, 1807.

Aquila piscatrix, Vieill., l. c., t. i, p. 29, pl. iv, 1807.

Pandion fluvialis, Savigny, Deser. Egypte, Ois., p. 272, 1809.

Aquila haliatus, Meyer, in Meyer und Wolf, Taschenb., Bd. i, p. 23, 1810.

Accipiter haliatus, Pall., Zoogr. Rosso. Asiat., t. i, p. 355, 1811.

Triorches fuvialis, Leach, Syst. Cat. Mamm. \&c., B. M., p. 10, 1816.

Aquila balbusardus, Dumont, Dict. Sci. Nat., t. i, p. 351, 1816.

Pandion americanus, Vieill. et Oud. Gal. Ois., pl. xi, 1825.

Balbusardus haliatus, Fleming, Brit. An., p. 51, 1828.

Pandion haliatus, Less., Man. d’Orn., t. i, p. 86, 1828 ; Sw. \& Rich., Faun. Bor.-Am. Birds, p. 20, 1831; Gould, B. Eur., pl. xii, 1837; Gray, Gen. B., vol. i, p. 17, pl. vii, fig. 5, 1845; Bonap. Consp., t. i, p. 16, 1850 ; Strickl., Orn. Syn., p. 63, 1855; Hartl., Orn. W. Africa, p. 7, 1857 ; Schrenk, Reise Amurl. Zool., p. 227,1859 ; Jerdon, B. Ind., vol. i, p. 80, 1862 ; Schl., Mus. P.-B. Aquilæ, p. 22, 1862 ; Radde, Reise Sibir. Ois., p. 97, 1863; Newt., Ooth. Wolley, p. 58, 1864 ; Degl. \& Gerbe, Orn. Eur., Bd.i, p. 47, 1867 ; Layard, B. S. Afr., p. 16, 1867; Hume, Rough Notes, pt. i, p. 234, 1869; Gray, Handl. B., vol. i, p. 15, 1869; Heugl., Orn. N.-Ost. Afr., Bd.i, p. 54, 1869; Gould, B. Gt. Br., pt. xvii, 1870 ; Finsch. und Hartl., Vög. Ostafr., p. 40, 1870 ; Newt. ed. Yarr., Brit. B., vol. i, p. 30, 1871; Pelz., Orn. Bras., p. 4, 1871 ; Swinhoe, Proc. Zool. Soc., 1871, p. 340 ; Coues, Key N. Am. B., p. 219, 1872 ; Holdsw., Proc. Zool. Soc., 1872, p. 412 ; Salvad., Faun. Ital. Ucc., p. 9, 1872; Shelley, B. Egypt, p. 203, 1872 ; Hume, Stray Feathers, vol. i, 1873, p. 159; op. cit., vol. ii, 1874, p. 468; Schl., Mus. P.-B. Revue Accipitr., p. 123, 1873; Salvad. et Antin., Ucc. Bogos., p. 21, 1873; Stoliczka, Stray Feathers, vol. ii, 1874, p. 461; Salvad., Uce. Born., p. 7, 187 t; Sharpe, Cat. B., vol. i, p. 449, 1874; Layard, B. S. Afr., p. 68, 1875 ; Coues, B. N. West., p. 367 , 1874; Blyth \& Walden, Journ. As. Soc., Bengal, vol. xliv, 1875, extra No., p. 63 ; A. Anderson, Proc. Zool. Soc., 1876, p. 313; David, Journ. de Voy. en Chine, t. ii, 1875, p. 39.

Pandion alticeps, Brehm, Vög. Deutschl., p. 33, 1831.

Pandion planiceps, Brehm, l. c., p. 33, 1831. 
Pandion carolinensis, Audub., B. N. Am;, pl. Ixxxi; Orn. Biogr., t. i, p. 415, 1831; Bonap. List

B. Eur. As. and Am., p. 3, 1838; id. Consp., t. i, p. 16, 1850 ; Cass, in B. Calif. and Texas, p. 112, 1855 ; Strickl., Orn. Syn., p. 64, 1855 ; Cass. in Baird’s B. N. Am., p. 45, 1860; Gray; Handl. B., vol. i, p. 15, 1869 ; Baird, in Cooper, B. Calif., p. 454, 1870.

Pandion indicus, Hodgs., in Gray's Zool. Misc., p. 81, 1844.

Pandion albigularis, Brehm, Naum., 1855, p. 268.

Pandion minor, Brehm, l.c., p. 268.

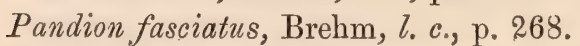

Pandion haliatus, var. carolinensis, Ridgway, N. Am. B., vol. iii, p. 182, 1874.

a. む Tsitkaw, Upper Burma, 10th February 1875.

The Osprey does not appear to be common in Upper Burma.

\section{Order STRIGES.}

$$
\text { Family-BUBONIDAR. }
$$

Genus Buво, Cuvier.

\section{Bubo Ignavus, Forster.}

Strix bubo, Linn., Syst. Nat., t. i, p. 131, 1766.

Bubo microcephalus, Leach, Syst. Cat. Mamm. \&c., Brit. Mus., p. 11, 1816.

Bubo ignavus, Forster, Syn. Cat. Brit. B., p. 3, 1817; Sharpe, Cat. Striges, vol. ii, B. M., 1875, p. 1 .

Bubo maximus, Fleming, Brit. An., p. 57, 1828.

Bubo germanicus, Brehm, Vög. Deutschl., p. 119, 1831.

Bubo septentrionalis, Brehm, Vög. Deutschl., p. 120, 1831.

Bubo europaus, Less., Traité, p. 115, pl. xvii, fig. 1, 1831.

Asianus bubo, Swainson, Classií. B., vol. ii, p. 217, 1837.

Bubo atheniensis, Bp. Consp., t. i, p. 48, 1850.

Bubo grandis, Brehm, J. f. O., 1853, p. 346.

Bubo bubo, Licht., Nomencl. Av., p. 7, 1854.

Bubo melanotus, Brehm, Naum., 1855, p. 270.

ㅇ Momien, 1st July 1868.

I have three European examples (Norwegian) of this species before me, and I cannot detect that this Yunnan bird differs from them, except that its toes are not nearly so well plumed. Its total length is 25 inches; the wing $18 \cdot 0$; the tail $11 \cdot 0$; and the tarsus $3 \cdot 2$.

This fine female was snared in one of the ruined towns about Momien, and was brought to me alive, and the natives asserted that it is not uncommon.

\section{Genus Carine, Kaup.}

16. Carine pUlchra, Hume.

Athene pulchra, Hume, Stray Feathers, 1873, p. 469 ; id., op. cit., 1875, p. 39.

Carine pulchra, Sharpe, Ibis, 1875, p. 258 ; id., Cat. Birds, B. M., vol. ii, 1875, p. 140.

a. \& 6. Tsingoo, Upper Burma, 2nd and 7th October 1868. 
This form would appear, from the reasons stated by Mr. Hume and which also suggested themselves to me when I first shot this bird in 1868, to be specifically distinct from $C$. brama of India.

I found both of these individuals roosting, in early morning after the sun was up, among the dense foliage of a Banyan tree.

\section{Genus Ninox, Hodgson.}

\section{Ninox LUGUBRIs, Tickell.}

Strix lugubris, Tickell, Journ. As. Soc., Bengal, vol. ii, p. 573, 1833; Sharpe, B. Cat. B. M., vol. ii, p. 154, 1875.

Ninox nipalensis, Hodgson, Madr. Journ. Lit. \& Sc., vol. v, p. 24, pl. xiv, 1837.

Otus lugubris, Jerdon, Madr. Journ. Lit. \& Se., vol. x, p. 87, 1839.

Ninox lugubris, Blyth, Ann. \& Mag. Nat. Hist., vol. xii, p. 98, 1843 ; Sharpe, Ibis, 1875, p. 258 ;

Cat. Birds, vol. ii, 1875, p. 154; Hartl., Vögel, Madagascar, 1877, p. 50.

Ninox jeridius, Hodgson, Gray's Zool. Mise., p. 82, 1844.

Ninox scutellatus, Blyth, Journ. As. Soc., Bengal, vol. xvi, 1847, p. 521 ; Jerdon, Birds of India, vol. i, p. 147, 1862 ; and Ibis, 1872 ; Hume, Rough Notes, pt. ii, p. 420; Blyth \& Walden, Journ.

As. Soc., Bengal, vol. xliv, 1875, extra No., p. 67.

Athene hirsuta, Bonap. Consp., t. i, p. 41, 1850.

Ninox madagascariensis, Bonap., Rev. et Mag. de Zool., 1854, p. 543 ; Hartl., Faun. Madag., 1861, p. 22 ; Gurney, Ibis, 1869, p. 453.

Noctua hirsuta, Schleg., Mus. Pays-Bas, Striges, 1862, p. 25.

Athene lugubris, Gray, Handl., vol. i, 1869, p. 41.

Athene madagascariensis, Gray, Handl., l.c., p. 42.

a. ‡ Bhamô, February 1868.

This Owl agrees in every respect with specimens from Central India and Bengal.

\section{Order-PICARIE.}

\section{Family - BUCEROTID AR.}

\section{Genus HrDrocissa, Bonaparte.}

\section{Hydrocissa ALBIRostris, Shaw.}

Buceros malabaricus, Gmelin, Syst. Nat., t. i, p. 359, 1788, ex. Edwards, pl. 281, fig. D.; Latham, Ind. Orn., vol. i, p. 143, 1790; Mc'Clelland, Proc. Zool. Soc., 1839, p. 164; Schl. und Müll., Verhandl. der Nederl. Aves, pp. 22, 25, 28, 1839-44.

Buceros albirostris, Shaw, Gen. Zool., vol. viii, p. 13, 1811; Blyth, Journ. As. Soc., Bengal, vol. xii, p. 995, 1843; Gray, Cat. B. Nep., p. 112, 1846; Blyth, Journ. As. Soc,, Bengal, vol. xvi, p. 994, 1847; vol. xviii, p. 803, 1849; id., Cat. B. Mus., As. Soc., Bengal, p. 43, 1849 ; Schl., Mus. P.-B., Buceros, p. 6, 1862 ; Gray, Handl., vol. ii, p. 128, 1870 .

Buceros leucogaster, Blyth, Journ. As. Soc., Bengal, vol. x, p. 922, 1841; vol. xii, p. 177, 1843.

Buceros nigralbus, Hodgson, in Gray's Zool. Misc., p. 85, 1844. 
Buceros pica, Gray, Gen. B., vol. ii, p. 399, 1847.

Buceros affinis, Hutton, Blyth, Journ. As. Soc., Bengal, vol. xviii, p. 802, 1849; Blyth, Cat. B. Mus., As. Soc., Bengal, p. 43, 1849.

Hydrocissa pica, Bonap., Consp. Gen. Av., t. i., p. 90, 1850.

Hydrocissa albirostris, Horsfield \& Moore, Cat. B. Mus. E. Ind. Co., vol. ii, p. 589, 1856-58; Cab. \& Heine. Mus. Hein., th. ii, p. 171, 1860; Jerdon, Birds of India, vol. i, p. 247, 1862 ; Ibis, 1872, p. 5; Blyth, Ibis, 1866, p. 351; Salv., Uce. Born., p. 82, 1874; Hume, Stray Feathers, 1874, p. 470; op. cit., 1875, p. 55; op. cit., 1876, p. 20 ; Blyth \& Walden, Journ. As. Soc., Bengal, vol. xliv, extra No., 1875, p. 68 ; Bingham, Stray Feathers, 1876, p. 84 .

Hydrocissa coronata, Godwin-Austen, Journ. As. Soc., Bengal, vol. xxxix, 1870, p. 95.

a. \& b. Shienpagah, Upper Burma, 15th January 1868.

As these two birds were of one flock there can be no doubt of their specific identity, even although they differ much in size and in the form of their casques. One corresponds to $B$. albirostris, Shaw, and the other to B. affinis, Hutton. Jerdon has also recorded that in the Dehra Doon he had killed one or two individuals of the supposed species (H. affinis) of much smaller size, nearly corresponding with the dimensions of H. albirostris, and he pointed out that the Cachar birds referred by Major Godwin-Austen to $H$. coronata agreed in their measurements with H. affinis, Hutton.

With regard to $H$. intermedia, Blyth, which resembles $H$. albirostris, except that its outer tail feathers are wholly white, it is noteworthy that birds of this species occur with some of their tail feathers wholly white, a circumstance that suggests a very close affinity between it and $H$. coronata, and $H$. convexa.

Family-UPUPID A.

Genus UPUPA, Linn.

\section{UPUPA INDICA, Bonap.}

Upupa minor, Sykes, Proc. Zool. Soc., 1832, p. 97 (nec Shaw).

Upupa senegalensis, Blyth, Journ. As. Soc., Bengal, vol. xiv, p. 189 (1845) ; Cat. B. Mus., As. Soc., Bengal, p. 46, 1849.

Upupa indica, Bonap., Aten. Ital., 1854, p. I2 ; Reich. Handb. Scans., p. 320, taf. D. xevi, fig. 4037, 1853 ; Finsch. \& Hartl., Vög. Ostafr., p. 198, 1870 ; Sharpe \& Dresser, Hist., B. Europe, pt. vii, October 1871, p. 5.

Upupa ceylonensis, Reich. ut supra, p. 320, taf. D. xcv, fig. 4036, 1853.

Upupa epops, Burgess, Proc. Zool. Soc., 1855, p. 27 (nec Linn.)

Upupa nigripennis, Horsf. \& Moore, Cat. B. Mus. E. Ind. Co., vol. ii, p. 725, 1856-58, (ex Gould Ms.) ; Gray, Handl., vol. i, p. 102, 1869.

Upupa longirostris, Jerdon, B. Ind., vol. i, p. 393, 1862 ; Sharpe \& Dresser, ut supra, p. 6 ; Hume,

Stray Feathers, 1875, p. 89.
a. b. Upper Burma, 20th September 1868 (culmen 2:2-2.5).
c. Bhamô, 27th January 1868 (culmen 2*0).
d. Bhamô, 6th February 1868 (culmen 2·15).
e. Bhamô, 22nd February 1868 (culmen 2:0). 
In the account of the Hoopoes given in the 'Birds of Europe' the length of bill in Indian examples of $U$. nigripennis is said to vary from $2 \cdot 0$ inches to $2 \cdot 35$, while, in Burmese examples, the bill varies from 2.0 to 2.5 inches, which agrees with the measurements of my five specimens. Mr. Hume, in some remarks on this species, observes that whereas a Pegu bird had a bill measuring 2.5 inches, he had never known an Indian bird to have one exceeding 2.1 inches. Independently, howerer, of the birds mentioned in the article on Hoopoes in the Birds of Europe, there is a bird in the British Museum measuring $2 \cdot 2$ inches in the bill. Although the majority of the Burmese specimens may have a longer bill than others from India, there are some which do not exceed the latter, and therefore I cannot see any grounds for separating $U$. longirostris as a distinct species.

\section{Family-ALCEDINID $A$.}

\section{Genus Halcyon, Swainson.}

\section{HaLCyon SMYrNensis, Linn.}

Martin-pêcheur de la côte de Malabar, Buff., Pl. Enl., p. 894.

Alcedo smyrnensis, Linn., Syst. Nat., t. i, p. 181, 1766; Me'Clell., Proc. Zool. Soc., 1839, p. 156.

Alcedo fusca, Bodd., Tabl. PI. Enl., p. 54 (1783, ex Buff.) ; Martens, Journ. f. Orn., 1866, p. 18.

Halcyon smyrnensis, Steph., Gen. Zool., vol. xiii, p. 99, 1826 ; Sykes, Proc. Zool. Soc., 1831, p. 84; Gray, Gen. B., vol. i, p. 79, 1846; id., Cat. Fissir. Brit. Mus., p. 55, 1848; Blyth, Cat. B. Mus., As. Soc., Bengal, p. 47, 1849; Bonap. Consp., t. i, p. 155, 1850 ; Cass., Cat. Halcyon, Philad. Mus., p. 6, 1852 ; Moore, Proc. Zool. Soc., 1854, p. 268; Horsf. \& Moore, Cat. B. Mus. E. Ind. Co., vol. i, p. 125, 1856-58; Blyth, Ibis, 1866, p. 348; Tristr., t.c., p. 86 ; Sharpe, Monogr. Alced., pl. lix, 1870 ; Hume, Stray Feathers, 1873, p. 168; Adam., t. c., p. 372; Ball, op. cit., 1874, p. 387 ; Hume, t.c., p. 470; id., Nests and Eggs, Ind. B., p. 105, 1875; Dresser, B. Eur., pt. xlii, 1875; Hume, Stray Feathers, 1875, p. 51 ; Armstrong, op. cit., 1876, p. 306 ; Hume, t. c., p. 388; op. cit., 1877, p. 19; t. c., Oates, p. 143; Fairbank, op. cit., 1876, p. 394.

Dacelo smyyrnensis, Less., Traité d’Orn., p. 246, 1831.

Halcyon fusca, Gray, Gen. B., vol. i, p. 79, 1846; id., Cat. Fissir. Brit. Mus., p. 55, 1848 ; Bonap. Consp., t. i, p. 155, 1850 ; Cass., Cat. Halcyon, Philad. Mus., p. 6, 1852 ; Horsf. \& Moore, Cat. B. Mus. E. Ind. Co., vol. i, p. 125, 1856-58; Jerdon, B. Ind., vol. i, p. 224, 1862 ; Pelz., Reise Novara, Vögel., p. 49, 1865; Stoliczka, Journ. As. Soc., Bengal, vol. xxxviii, 1868, p. 19; Walden, Ibis, 1871, p. 165 ; Jerdon, op. cit., 1872, p. 4.

Entomothera smyrnensis, Reich., Handb. Alced., p. 13, 1851.

Entomothera fusca, Reich., l. c., p. 12, t. ccccix, figs. 3088-89, 1851.

Entomobia smymensis, Cab. \& Heine, Mus. Hein., th. ii, p. 155, note, 1860.

Entomobia fisca, id., l. c., p. 155, 1860.

Dacelo fusca, Schl., Mus. P.-B. Alcedines, p. 28, 1863; Heugl., Orn. n. o. Afr., 188, 1869.

a. Mengoon, 14th January 1868.

b. c. d. Bhamô, February 1868.

Prevalent in Upper Burma. 
Genus Al CEDo, Linn.

\section{Alcedo bengalensis, Gmelin.}

Alcedo bengalensis, Gm., Syst. Nat., t. i, p. 450, 1788 ; Blyth, Cat. B. Mus., As. Soc., Bengal, p. 49, 1849 ; Jerdon, B. Ind., vol. i, p. 231, 1862 ; Sharpe, Monogr. Alced., pl. ii, 1870.

Alcedo minor, Schl., Mus. Pays-Bas. Alced., p. 7, 1863.

Alcedo ispida minor, Heugl., Orn. n. o. Afr., p. 178, 1869.

Alcedo bengalensis, var. sondaica, Reich., Handb. Alced., p. 3, 1851.

Alcedo sondaica, Cab. \& Heine, Mus. Hein., th. ii, p. 3, 1851.

Alcedo japonica, Bonap. Consp., vol. Anis., p. 10, 1854.

Alcedo moluccensis, Wallace, Proc. Zool. Soc., 1863, p. 484 (nec Blyth).

a. Mandalay, 26th September 1868.

๖. Bhamô, 6th February 1868.

c. Muangla, Sanda Valley, 18th May 1868.

These two Burmese specimens seem to me to agree with Indian examples, but the one from Yunnan is rather different, having the ear-coverts and under surface rather pale rufous, the blue of the back very bright, and the blue spots on the wing-coverts very slightly developed.

This Kingfisher is not uncommon in Upper Burma, and I traced it along the Tapeng river to Sanda.

\section{Genus Ceryle, Boie.}

\section{Ceryle RUdis, Linn.}

Martin-pêcheur noir et blanc de Senegal, Buff., Pl. Enl. 62.

Martin-pêcheur huppè du Cap de Bon Esperance, Buff., Pl, Enl. 716.

Alcedo rudis, Linn., Syst. Nat., t. i, p. 181, 1766.

Ceryle rudis, Boie, Isis, 1828, p. 316 ; Sharpe, Monogr. Alced., pl. xix, 1871.

Ispida rudis, Jerdon, Madr. Journ, 1840, p. 232.

Ceryle varia, Strickl., Ann. Nat. Hist., vol. vi, p. 418, 1841.

Ispida bitorquata, Swainson, Classif. of B., p. 336, 1837.

Ispida bicincta, Swainson, B. of W. Afr., vol. ii, p. 95, 1837.

Ceryle bicincta, Reich., Handb. Alced., p. 20, ccceviii, fig. 3098, 1851.

Ceryle leucomelaneura, Reich., Handb. Alced., p. 21, t. cccix, fig. 3488, 1851.

a. Bhamô, 6th February 1868. ${ }^{3}$

๖. t Tapeng River, 2nd February 1875.

The male bird above mentioned has the whole of the throat and fore-neck thickly blotched with black, with which colour all the feathers are broadly tipped to an unusual degree, although markings on the throat are not uncommon, even in very adult birds, as the present example undoubtedly is. 


\section{Family-CORACIID A}

\section{Genus Coracias, Linn.}

\section{Coracias affinis, Me'Clelland.}

Coracias affinis, Mc'Clell., Proc. Zool. Soc., 1839, p. 164; Horsf. \& Moore, Cat. B. Mus. E. Ind. Co., vol. ii, 1856-58, p. 574; Jerdon, B. Ind., vol. i, 1862, p. 217 ; Schl., Mus. P.-B. Coraces, p. 136 ; Gould, B. Asia, xx; Hume, Stray Feathers, vol. iii, 1876, p. 50 ; op. cit., vol. iv, 1877, p. 18; Oates, t. c., p. 143 ; Armstrong, t.c., p. 305.

a. Mandalay, 26th September 1868.

๖. c. Bhamô, 6th and 15th February 1868.

d. Manwyne, Sanda Valley, 12th May 1868.

e.f. Muangla, Sanda Valley, 22nd May 1868.

The two specimens killed at Muangla have the black tips to the tail feathers much less pronounced than in the other examples. This bird is not at all uncommon in the valley of Sanda, especially in the neighbourhood of the towns and villages, which are generally embosomed in gigantic bamboos and fine trees. I did not observe it beyond Muangla.

\section{Family-MEROPIDAR.}

\section{Genus Merops, Linn.}

\section{Merops PHILIppinensis, Linn.}

Le Grand Guêpier des Philippines, Briss. Orn., t. iv, p. 560, pl. xliii, fig. 1, 1760 ; D'Aubent., Pl. Enl., pl. lvii, 1783.

Merops philippinus, Linn., Syst. Nat., t. xiii, p. 183, (1767, ex Briss.) ; Gray, List Fissirostres, p. 59, 1843 ; Blyth, Cat. B. Mus., As. Soc., Bengal, p. 52, 1849 ; Moore, Proc. Zool. Soc., 1854, p. 263 ; Horsf. \& Moore, Cat. B. Mus. E. Ind. Co., vol. i, p. 86, 1856-58; Phillips, Proc. Zool. Soc., 1857, p. 87 ; Cab. \& Heine, Mus. Hein., th. ii, p. 139, 1860 ; Gould, Proc. Zool. Soc., 1859, p. 149; Irby, Ibis, 1861, p. 228; Jerdon, B. Ind., vol. i, p. 207, 1862 ; Schleg., Mus. P.-B. Merops, p. 2, 1863 ; Swinhoe, Ibis, 1866, p. 129; Beav., Ibis, 1867, p. 318 ; Gray, Handl. B., vol. i, p. 99, 1869 ; Wald., Tr. Zool. Soc., vol. viii, p. 42, 1872 ; Holdsw., Proc. Zool. Soc., 1872, p. 422 ; Wald., Tr. Zool. Soc., vol. ix, p. 149, 1875 ; Hume, Nests and Eggs, p. 101, 1875 ; Blyth \& Walden, Journ. As. Soc., Bengal, vol. xliv, extra No., p. 72, 1875 ; Hume, Stray Feathers, 1875, pp. 324-456; Legge, t. c., p. 281. Fairbank, op. cit., 1876, p. 254; Hume, op. cit., 1877, p. 18 ; Oates, t. c., p. 143 ; Fairbank, t. c., p. 294.

Le Guépier vert à queue d’azur, Montb., Hist. Nat. Ois., t. vi, p. 504, 1783.

Le Guêpier daudin, Levaill., Hist. Nat. Guêp., p. 49, pl. xiv, 1806.

Merops javanicus, Horsf., Tr. Linn. Soc., vol. xiii, p. 171, 1821; Raffles, op. cit., p. 294, 1822 ; Bonap. Consp., vol. i, p. 160, 1850 ; Reich., Handb. Meropidæ, p. 66, taf. ccccxliv, figs. 3227-28, 1852 ; Wald., Proc. Zool. Soc., 1863, p. 484.

Merops savignyi, Kittl. in Luthé's Voy. (Postels), vol, iii, p. 327.

Merops cyanorrhos, Temm., MS. in Mus. Brit.

Merops daudini, Cuv., Règne Anim., vol. i, p. 442, 1829; Gray, Handl. B., vol. i, p. 99, 1869; Swinhoe, Proc. Zool. Soc., 1871, p. 348; Hume, Stray Feathers, 1874, p. 162 ; op. cit., 1875, p. 49 ; Armstrong, op. cit., 1876, p. 304 .

Merops typicus, Hodgs., in Gray's Zool, Misc., p. 82, 1844. 
AVES.

Merops philippinensis, Swinhoe, Ibis, 1865, pp. 230, 348; Marshall, Tbis, 1872, p. 203 ; Ball, Stray Feathers, 1873, p. 57, 1874, p. 386 ; Legge, op. cit., 1874, p. 13; Holdsw., p. 125 ; Ball, op. cit., 1877, p. 413.

a. Mandalay, 26th September 1868.

I did not observe this species either at Bhamô or beyond.

\section{Merops viridis, Linn.}

Merops viridis, Linn., Syst. Nat., vol. i, p. 182, 1766 ; Less., Traité d’Orn., p. 238, 1831 ; Sykes, Proc. Zool. Soc., 1832, p. 82 ; Gray, Gen. B., vol. i, p. 86, 1846; id., Cat. Fissir. Brit. Mus., p. 69, 1848 ; Blyth, Cat. B. Mus., As. Soc., Bengal, p. 53, 1849; Bonap. Consp., t. i, p. 84, 1850 ; Reich., Handb. Merops., p. 67, taf. cecexlv, figs. 3231-32, 1852 ; Horsf. \& Moore, Cat. B. Mus. E. Ind. Co., vol. i, p. 84, 1856-58; Gould, B. Asia, pt. vii, 1855 ; Jerdon, B. Ind., vol. i, p. 20̌, 1862 ; Gray, Handb. B., vol.i, p. 99, 1869 ; Stoliczka, Journ. As. Soc., Bengal, vol. xli, 1872, p. 232 ; Adam., Stray Feathers, 1873, p. 371 ; Hume, t. c., p. 167; id., op. cit., 1874, p. 469 ; Ball, op. cit., 1874, p. 886 ; Hume, op. cit., 1875, p. 49; id., Nests and Eggs, Ind. B., p. 99, 1875 ; Fairbank, Stray Feathers, vol. iv, 1876, p. 254; Armstrong, t. c. p. 304; Godwin-Austen, Journ. As. Soc., Bengal, vol. xlv, 1876, p. 69.

Guêpier à collier de Madagascar, Buff., Pl. Enl., p. 740.

Guêpier Lamarck, ou à gorge bleu, Levaill., Promer. and Guêp., vol. ii, p. 39, pl.x, 1807.

Merops lamarckii, Cuvier, Règne Anim., 1829, p. 442.

Merops indicus, Jerdon, Madr. Journ., vol. xi, p. 227, 1840 ; Blyth, Ann. Nat. Hist., xii, p. 93, 1843.

Merops torquatus, Hodgs., in Gray's Zool. Misc., p. 82, 1844.

Merops ferrugeiceps, id., l. c., p. 82, 1844.

Phloshrus viridis, Cab. \& Heine, Mus. Hein., th. ii, p. 136, 1859.
a. b. Mandalay, Upper Burma, 25th and 26th September $] 868$.
c. Mengoon, " , 14th January 1868.
d. Shienpagah, " "
e. Sanda, Yunnan, 5th May 1868.

This species is prevalent in the Sanda valley. All the birds from Upper Burma and Sanda belong to Hodgson's variety $M$. ferrugeiceps, which has the head and neck much redder than in the Indian birds, and the chin and throat more grassy green.

\section{Merops leschenaditi, Vieill.}

Le Guêpier Laichenot, Levaill,, Guêpiers, p. 51, pl. xviii (1807).

Merops leschenaulti, Vieill., N. Dict. d’Hist. Nat., t. xiv, p. 17 (1817); Blyth, Cat. B. Mus., As. Soc., Bengal, p. 53, 1849 ; Blyth \& Walden, Journ. As. Soc., Bengal, vol. xliv, 1875 ; Fairbank, Stray Feathers, vol. v, 1877, p. 394.

Merops quinticolor, Gray, List Fissirostres, p. 70, 1843; id., List B., Nepal, Hodgs. Coll., p. 57, 1846 ; Moore, Proc. Zool. Soc., 1854, p. 264; Jerdon, B. Ind., vol. i, p. 208, 1862 ; Gray, Handl, B., vol. i, p. 100, 1869 ; Legge, Ibis, 1871, p. 13; Holdsw., Proc. Zool. Soc., 1872, p. 423; Wald., Ibis, 1873, p. 301.

Merops erythroceplalus, Swinhoe, Proc. Zool. Soc., 1871, p. 348.

Merops swinhoei, Hume, Stray Feathers, 1874, p. 163; id., op. cit., 1875, p. 50 ; id., Nests and Eggs, Ind. B., 1873, p. 102 ; Fairbank, Stray Feathers, 1876, p. 254; Armstrong, t. c., p. 303.

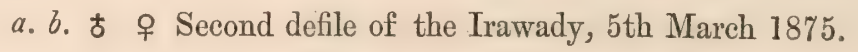


On the left bank of the Irawady at the above mentioned locality this species is very common.

\section{Genus Nyctiornis, Swainson.}

\section{Nyctiornis athertoni, Jardine \& Selby.}

Merops athertoni, Jard. \& Selby, Ill. Orn., vol. ii, pl. Iviii, 1825-43.

Bucia nipalensis, Hodgson, Journ. As. Soc., Bengal, vol. v, p. 361, 1836.

Nyctiornis caruleus, Swainson, Classif. B., vol. ii, p. 333, 1837.

Nyctionis amherstiana, Royle, Himal. Botany, vol. i, p. 76, 1839.

Nyctionis athertoni, Mc'Clell., Proc. Zool. Soc., 1839, p. 155; Gray, Gen. B., vol. i, p. 87, 1840 ; id., Cat. Mamm., \&c., Nepal, Coll. Hodgs., p. 58, 1846 ; Bonap. Consp., t. i, p. 164, 1850 ; Gould, B. Asia, ii, pt. ii ; Reich., Handl. Merop., p. 81, pl. ccccliii, figs. 3262, 3263, 1852; Horsf. \& Moore, Cat. B. Mus. E. Ind. Co., vol. i, p. 89, 1854; Cab. \& Heine, Mus. Hein., th. ii, p. 132, 1860 ; Jerdon, B. Ind., vol. i, p. 211, 1862 ; Gray, Handl. B., vol. i, p. 98, 1869 ; Hume, Stray Feathers, 1874, p. 469; id., Nests and Eggs, Ind. B., p. 103, 1874; id., Stray Feathers, 1877, p. 18; Fairbank, t. c., p. 394.

Merops cyanogularis, Jerdon, Madr. Journ., vol. xi, p. 229, 1840.

Bucia athertoni, Blyth, Journ. As. Soc., Bengal, vol. x, p. 922, 1841.

Napophila athertoni, Blyth, Journ. As. Soc., Bengal, vol. xi, p. 104, 1842.

Alcemerops paleazureus, Less., Rev. Zool., 1842, p. 262.

Napoptiila meropina, Hodgs., Gray's Zool. Misc., p. 82, 1844.

Alcemerops athertoni, Blyth, Cat. B. Mus., As. Soc., Bengal, p. 52, 1849.

$$
\text { a. b. c. Bhamô, 24th and 29th February } 1868 .
$$

I shot two of these birds at early morning, perched side by side on the branch of a tree about 20 feet above a foot-path which ran along a patch of low treejungle.

\section{Family-CAPITONID AE.}

\section{Genus Megal ema, Gray.}

\section{Megalema hodgsoni, Bonap.}

Bucco caniceps, Hodgs., in Gray's Zool. Misc., p. 85, 1844.

Bucco lineatus, Blyth, Journ. As. Soc., Beñgal, vol. xv, p. 12, 1846.

Megalama lineata, Blyth, Cat. B. Mus., As. Soc., Bengal, p. 66, 1849 ; Horsf. \& Moore, Cat. B. Mus. E. Ind. Co., p. 636, 1856 ; Jerdon, B. Ind., vol. i, p. 309, 1862.

Megalcema hodgsoni, Bonap. Consp., t. i, p. 144, 1850 ; Goff., Mus. P.-B. Buccones, p. 34, 1862;

Gray, Cat. Capitonidæ, B. Mus., p. 12, 1868 ; Marshall, Monogr. Capitonidæ, pl. xxxvi; Hume, Stray Feathers, vol. v, 1877, p. 27; Godwin-Austen, Journ. As. Soc., Bengal, vol. v, 1876, p. 70 .

Megalama Mc'Clellandi, Horsf. \& Moore, Cat. B. Mus. E. Ind. Co., p. 637, 1856; Gray, Cat. Capitonidæ, B. Mus., p. 12, 1868.

\footnotetext{
a.-e. Shuaygoo, Upper Burma, 21st January 1868.

f. Bhamô, 29th January 1868.

g. Bhamô, February 1868.

h. Bhamô, 7th September 1868 .
} 
If Megalema hodgsoni is really distinct from $\mathbb{M}$. lineata, then all my specimens appear to belong to the former species. The Messrs. Marshall, in their valuable Monograph of this group, give the wing of $M$. lineata as 4.5 inches : the measurements of $\boldsymbol{M}$. hodgsoni are not given, but it is stated to be a larger bird. My specimens measure from 5 to $5 \cdot 3$ inches.

This species is a very prevalent form in Upper Burma, and I have seen as many as 40 to 50 in one tree. It is very common about Bhamô, but I did not observe it in the hills, or in the high country beyond.

\section{Megatima astatica, Latham.}

Trogon asiaticus, Lath., Ind. Orn., vol. i, p. 201, 1790.

Le Barbu à gorge blen, Levaill., Barbus, p. 57, pls. xxi, xxii, 1806.

Bucco caruleus, Dum., Dict. Sci. Nat., t. iv, p. 48, 1806.

Capito cyanicollis, Vieill., N. Dict. d'Hist. Nat., t. iv, p. 498, 1816.

Bucco cyanops, Cuv., Règne Anim., t. i, p. 428, $181 \%$.

Bucco cyanicollis, Temm., Pl. Col. texte, 1831.

Bucco ceruleigula, Hodg., in. Gray's Zool. Misc., p. 85, 1844.

Megalaima asiatica, Gray, Gen. B., vol. ii, p. 426, 1846 ; Bonap. Consp., t. i, 1850, p. 143; Goff.,

M. P.-B. Buccones, p. 16, 1863; Gray, Cat. Capitonidæ B. Mus., p. 8, 1868; Hume,SStray

Feathers, 1877, vol. v, p. 27 ; W. Ramsay, Ibis, 1877, p. 457.

Bucco asiatica, Blyth, Ann. Nat. Hist., 1847, p. 385.

Megalama asiatica, Blyth, Cat. B. Mus., As. Soc., Bengal, p. 67, 1849 ; Marshall, Monogr. Capitonidæ, pl. xxix, 1871.

Cyanops asiatica, Bonap. Consp., Vol. Zygod., p. 12, 1854; Horsf. \& Moore, Cat. B. Mus. E. Ind.

Co., p. 641, 1856 ; Jerdon, B. Ind., vol. i, p. 313, 1862 ; Blyth, Ibis, 1867, p. 297.

Bucco voigti, Kreling, Emdener, Jahresber., 1851, p. 20.

a. Ponsee, Kakhyen hills, Yunnan, March 1868.

b.c. ᄒ Kakhyen hills, 12th February 1875.

This species is not uncommon in the Kakhyen hills, up which it extends even to the height of 4,500 feet, but I did not observe it to the eastward, in the higher but well-wooded mountains surrounding the Hotha and Sanda valleys.

\section{Family-PICID $A$.}

\section{Genus Chrysocolaptes, Blyth.}

\section{Chrisocolaptes sultaneus, Hodgson.}

Picus sultaneus, Hodgs., Journ. As. Soc., Bengal, vol. vi, p. 105, 1837; id. in Gray's Zool. Misc., 1844, p. 85 ; Blyth, Journ. As. Soc., Bengal, vol. xi, p. 105, 1842.

Chrysocolaptes sultaneus, Gray, Gen. B., vol. ii, p. 436, 1845; Gray, Cat. Mamm., \&c., Nepal, Coll. Hodgs., p. 116, 1846 ; Blyth, Cat. B. Mus., As. Soc., Bengal, p. 55, 1849 ; Bonap. Consp., t. i, p. 121, 1850; Horsfield \& Moore, Cat. B. Mus. E. Ind. Co., vol. ii, p. 653, 1856-58; Gray, Handl. B., vol. ii, p. 189, 1870; Godwin-Austen, Journ. As. Soc., Bengal, vol. xxxix, p. 97, 1870 ; Ball, Stray Feathers, 1874, p. 291; Hume, t.c., p. 471; Armstrong, op. cit., 1876, pp. 310-311; Hume, op. cit., 1877, p. 26. 
Picus strenuus, Mc'Clell., Proc. Zool. Soc., 1839, p. 165.

Picus guttacristatus, Tickell, Journ. As. Soc., Bengal, vol. ii, p. 578, 1833.

Picus strictus, Jerdon, Madr. Journ., vol. xi, p. 210, 1840 ; Blyth, Journ. As. Soc., Bengal, vol. xi, p. 970,1842 .

Chrysocolaptes strictus, Blyth, Journ. As. Soc., Bengal, vol. xii, p. 1004, 1843; vol. xiv, p. 191, 1845.

$$
\begin{aligned}
& \text { a. Bhamô, 10th January } 1868 . \\
& \text { b. Bhamô, 6th February } 1868 .
\end{aligned}
$$

Shot within the stockade which encircles the town.

\section{Genus Gecinus, Boie.}

\section{Gecinds striolatus, Blyth.}

Picus squamatus, apud Jerd., Madr. Journ., vol. xi, p. 213, 1840.

Picus striolatus, Blyth, Journ. As. Soc., Bengal, vol. xii, p. 1000, 1843; Jerdon, Madr. Journ., vol. xiii, pt. 2, p. 133, 1844; Sundev., Consp. Av. Pic., p. 60, 1866.

Brachylophus zanthopygaus, Hodgs., in Gray's Zool. Mise., 1844, p. 85.

Gecinus striolatus, Gray, Gen. B., vol. ii, p. 439, 1846 ; Hodgs., Cat. B., Nepal, p. 117, 1846 ; Horsfield \& Moore, Cat. B. Mus. E. Ind. Co., p. 660, 1856-58; Jerdon, B. Ind., vol. i, p. 287, 1862; Gray, Handl. B., vol. ii, p. 192, 1870; Legge, Stray Feathers, 1873, p. 488; Ball, op. cit., 1874, p. 391 ; Hume, op. cit., 1875, p. 68 ; Blyth \& Walden, Journ. As. Soc., Bengal, vol. xliv, p. 76, 1875; Butler, Stray Feathers, vol. iv, 1876, p. 37; Fairbank, t.c., p. 267; Hume, op. cit., 1877, p. 26 ; Fairbank, t. c., p. 395 ; Ball, t. c., p. 413; Godwin-Austen, Journ. As. Soc., Bengal, vol. xlv, p. 70, 1876.

Gecinus xanthophygaus, Bonap. Consp. G. Av., vol. i, p. 127, 1850.

Chloropicus striolatus, Malh., Monogr. Picidæ, vol. ii, pl. lxxvii, p. 134, 1862.

a. \& b. t Momien, 17th June 1868.

This is the common Woodpecker of the elevated region to the east of the Kakhyen hills.

\section{Genus YungIPICUs, Bonaparte.}

\section{Yungipicus Rubricatus, Blyth.}

Picus pygmans (ᄒ ad.), Blyth, Journ. As. Soc., Bengal, vol, xiv, p. 197, 1845, nec Vigors.

Picus rubricatus, Blyth, Journ. As. Soc., Bengal, vol. xviii, p. 804, 1849 ; id., Cat. B. Mus., As. Soc., Bengal, p. 63, 1849 ; Sundev., Consp. Av. Pic., p. 114, 1866.

Bcopipo semicoronata (pt.), Cab. \& Heine, Mus. Hein., th. v, p. 54, 1863.

Yungipicus rubricatus, Jerdon, B. Ind., vol. i, p. 276, 1863; Godwin-Austen, Journ. As. Soc., Bengal, vol. xxxix, 1870, p. 97 ; Hume, Stray Feathers, vol. iii, p. 60, 1875.

a. Sanda, Yunnan, 15th May 1868.

I procured only one specimen of this bird, which has hitherto been received only from the South-Eastern Himalayas. 


\section{Genus Chrisonotus, Swainson.}

\section{Chrysonotus shorei, Vigors.}

Picus shorei, Vigors, Journ. Zool. Soc., 1831, p. 175 ; Gould, Cent. Him. B., pl. xlix, 1832; Jerdon, Madr. Journ., vol. xiii, p. 139, 1844.

Brachypterus shorei, Hodgs., in Gray's Zool. Mise., p. 85, 1844.

Tiga shorei, Blyth, Journ. As. Soc., Bengal, vol. xiv, p. 193, 1845; Gray, Gen. B., vol. ii, p. 44l, 1846 ; Hodgs., Cat. B., Nep., p. 117, 1846 ; Gray, Handl. B., vol. ii, p. 196, 1870 ; Hume, Stray Feathers, 1875 , p. 73 ; id., 1877 , p. 497.

Chrysonotus shorei, Horsfield \& Moore, Cat. B. Mus. E. Ind. Co., vol. ii, p. 658, 1856-58; Jerdon, B. Ind., vol. i, p. 298, 1862.

Chrysonotus biddulphi, Tickell, Walden, Ibis, 1876, p. 344.

a. ‡ Bhamô, 16th January 1868.

Hitherto this bird has only been found in the Himalaya and the Malabar ghâts.

Family-CUCULIDA.

\section{Genus Cuculus, Linnæus.}

\section{Cuculus canorus, Linn.}

Te Coucou, Montb., Pl. Enl., t. vi, pl. 811.

Cuculus canorus, Linn., Syst. Nat., t. i, p. 168, 1766 ; Lath., Ind. Orn., vol. i, p. 207, 1790 ; Temm., Man. d’Orn., t. i, p. 381, 1820 ; Roux, Orn. Prov., pls. lxv, lxvi, 1825 ; Ménétr., Cat. Rais. Ois. Coucas., p. 46, 1831; Sykes, Proc. Zool. Soc., 1832, p. 98 ; Selby, Ill. Orn., vol. i, p. 397, 1833; Gould, B. Eur., pl. 240, 1837 ; Macgill, Brit. B., vol. iii, p. 109, 1840 ; Blyth, Journ. As. Soc., Bengal, vol. xi, p. 901, 1842 ; Yarrell, Brit. B., vol. ii, p. 179, 1843; Gray, Cat. M. and B., Nepal, Hodgs. Coll., p. 119, 1846 ; id., Gen. B., vol. ii, p. 463, 1847; Blyth, Cat. B. Mus., As. Soc., Bengal, p. 71, 1849 ; Bonap. Consp., t. i, 1850, p. 102 ; Middend., Sibir. Reise, p. 131, 1851 ; Brehm, Naum., 1855, p. 271; Jaub. \& Lap., Rich. Orn., p. 336, 1856 ; Horsfield \& Moore, Cat. B. Mus. E. Ind. Co., p. 702, 1858; Schrenck, Sibir. Reise, p. ¿56, 1859 ; Linderm., Vög. Griechenl., p. 39, 1860 ; Jerdon, B. Ind., vol. i, p. 322, 1862 ; Radde, Sibir. Reise, p. 133, 1863 ; Filippi, Viagg. Pers., p. 350, 1865; Loche, Expl. Sci. Algér. Ois., t. ii, p. 76, 1867 ; Sundev., Svensk. Fogl., pl. xxi, fig. 4, 1867 ; Degl. \& Gerbe, Orn. Eur., vol. i, p. 161, 1867; Doderl. Avif. Sicil., p. 53, 1869; Blanf., Geol. and Zool. Abyss., p. 312, 1870 ; Gray, Handl. B., vol. ii, p. 215, 1870 ; Godwin-Austen, Journ. As. Soc., Bengal, vol. xxxix, p. 267, 1870 ; Swinhoe, Proc. Zool. Soc., 1871, p. 395 ; David, N. Arch., vol. vii, Bull., p. 4, 1871 ; Hume, Lahore to Yarkand, p. 180 ; Holdsw., Proc. Zool. Soc., 1872, p. 430 ; Salvad., Faun. Ital. Uec., p. 41, 1872 ; Wald., Tr. Zool. Soc., vol. viii, p. 115, 1872; Gould, B. Brit., vol. iii, pl. lxvii, 1873 ; Cock. \& Marsh., Stray Feathers, 1873, p. 351 ; Adam., t. c., p. 373 ; Ball, op. cit., 1874, p. 393 ; Shelley, B. Egypt, p. 162 ; Blyth \& Walden, Journ. As. Soe., Bengal, vol. xliv, extra No., 1875, p. 79; Hume, Nests and Egggs, Ind. B., p. 133, 1873; id., Stray Feathers, 1875, p. 78 ; Blanf., Zool. Pers., p. 119, 1876; Butler, Stray Feathers, 1876, p. 37; Scully, t. c., pp. 90, 134; Hume, t.c., pp. 279 et 288 ; op. cit., 1877, vol. v, p. 27; Butler, t.c., p. 227; Wharton, Ibis, 1876, p. 26; Seebohm \& Brown, op. cit., 1877, p. 112 ; Dresser, t. c., p. 320 ; Finsch., t.c., pp. 50, 51 ; Ayres, l. c., p. 342; W. Ramsay, t. c., p. 458.

Cuculus hepaticus, Sparm., Mus. Carls., pl, lv, 1788 ; Lath., Ind. Orn., vol. i, p. 215, 1790.

Cuculus rufus, Bechst., Orn. Taseh., th. i, p. 84, 1802. 
Le Coucou vulgaire d' Europe, Levaill., Ois. d'Afr., t. v, pls. 202, 203, 1806.

Cucuhus borealis, Pall., Zoogr. Ross. Asiat., t. i, p. 442, 1831.

$$
\text { a. } \text { t Ponsee, 21st April } 1868 .
$$

I have two specimens before me from England, with which my Yunnan bird agrees in every particular. Dr. Jerdon has remarked that the under tail-coverts of C. canorus have distinct arrow-shaped markings, but in the specimen before me, they are barred, but more widely so than on the breast, \&c.

We first heard the Cuckoo at Ponsee, about the end of March, and its wellknown notes were usually traced to some patch of low tree-jungle on old paddy clearings, on the hillsides overlooking our camp.

\section{Cuculus sonnerati, Latham.}

Le petit Coucou des Indes, Sonn., Voy. Ind., t. ii, p. 211, 1782.

Sonnerat's Cuckow, Latham, Gen. Syn. Suppl., p. 102, 1787.

Cuculus sonnerati, Latham, Ind. Orn., vol. i, p. 215, 1790 ; Strickl., Proc. Zool. Soc., 184.6, p. 104; Gray, Gen. B., vol. ii, p. 463, 1847 ; Blyth, Journ. As. Soc., Bengal, vol. xiv, p. 204, 1847; id., Cat. B. Mus., As. Soc., Bengal, p. 72, 1849 ; Layard, Ann. Nat. Hist. (2), vol. xiii, p. 452, 1854; Jerdon, B. Ind., vol. i, p. 325, 1862 ; Gray, Handl. B., vol. ii, p. 217, 1870; Holdsworth, Proc. Zool. Soc., 1872, p. 430; Hume, Stray Feathers, 1874, p. 472; Blyth \& Walden, Journ. As. Soc., Bengal, vol. xliv, extra No., p. 80, 1875 ; Fairbank, Stray Feathers, vol. iv, $1876, \mathrm{pp} .255$ et 265 .

Cuculus himalayanus, Jerdon, Madr. Journ., vol. xi, p. 220, 1840.

Cuculus venustus, Jerdon, Madr. Journ., vol. xiii, p. 141, 1844.

a. む Sawady, Upper Burma, 27th January 1875.

Genus Cacomantis, Müller.

36. Cacomantis Rufiventris, Jerdon.

Polyphasia tenuirostris, Godwin-Austen, Journ. As. Soc., Bengal, vol. xxxix, p. 98, 1870.

Polyphasia rufiventris, Jerdon, Ibis, 1872, p. 15.

Olylagon tenuirostris, Hume, Stray Feathers, 1875, p. 80.

Cacomantis passerinus, Blyth \& Walden, Journ. As. Soc., Bengal, vol. xliv, extra No., 1875, p. 80, (nec. Vahl.)

Cacomantis rufiventra, Armstrong, Stray Feathers, 1876, p. 312.

a. Ponsee, 20th April 1868.

I have observed specimens of C. rufiventris, in which the rufous passes as far forwards as the chin, and others in which the ashy of the breast spreads back on to the iufous of the abdomen.

\section{Genus Surniculus, Lesson.}

\section{Surniculus LUGUbris, Hodgson.}

Cuculus lugubris, Hodgson, Trans. Linn. Soc., vol. xiii, p. 175, 1821 ; id., Zool. Res., Java, pl. lviii, 1824; Muill., Verhandl., p. 178, ]839-44; Low, Sarawak, p. 411, 1848; Schlegel, Mus. P.-B. Cuculi, p. 28, 1864; ; Pelz., Novar. Reise, Vög., pp. 104, 162, 1865. 
Cuculus albopunctatus, Drap., Dict. Class. d'Hist. Nat., t. iv, p. 570, 1823.

Pseudornis dicruroides, Hodgson, Journ. As. Soc., Bengal, vol. viii, 1839, p. 136, plate.

Surniculus lugubris, Bonap. Consp., t. i, p. 105, 1850 ; Sclater, Proc. Zool. Soc., 1863, p. 209 ;

Walden, Ibis, 1872, p. 368; Sharpe, Ibis, 1877, p. 8 ; Salvad., Ann. Mus. Civ. Gen,, t. v,

1874, p. 63 ; Sharpe, Ibis, 1877, p. 8 ; Tweedale, t. c., p. 287.

Cacangelus lugubris, Cab. \& Heine Mus. Hein., th. iv, p. 17, 1862.

a. Mandalay, 20th September 1868.

b. Ponsee, 21st April 1868.

The specimen obtained in the hills at an altitude of 3,000 feet is larger than the other from the plains. They differ in no other respect.

Family-CAPRIMULGID E.

Genus Caprimdigus, Linnæus.

38. Caprimulgus jotaka, Temminck und Schlegel.

Caprimulgus jotaka, Temminck und Schlegel, Faun. Japon., p. 37, pls. xii, xiii, c. 1845 ; Gray, Gen. B., vol. i, p. 47, 1847 ; Bonap. Consp., vol.i, p. 60, 1850 ; Gray, Handl. B., vol. i, p. 57, 1809 ; David, N. Arch, Mus., t. vii, Bull., p. 4, 1871 ; Finsch., Verh. z. b. Wien, Bd. xxiii, p. 346, 1873 ; Blyth \& Walden, Journ. As. Soc., Bengal, vol. xliv, extra No., 1875 ; Godwin-Austen, op. cit., vol. xlv, 1876, pp. 68, 83 ; Swinhoe, Ibis, 1876, p. 331 ; Rowley's Orn. Misc., vol, vi, p. 157,1877 .

a. o Ponsee, 19th April 1868.

I shot this bird on an old paddy field, and had correctly named it before it was verified by comparison with birds in Europe.

\section{Caprimulgus macrurus, Horsfield.}

Caprimulgus macruris, Horsfd., Trans. Linn. Soc., vol. xiii, p. 142, 1821; Gould, B. Austr., vol. ii, pl. ix, 1848; Gray, Gen. B., iii, App. p. 3, 1849 ; Blyth, Cat. B. Mus., As. Soc., Bengal, p. 83, 1849 ; Reich., Vög. Neuboll, p. 185, 1850 ; Bonap. Consp., p. 60, 1850 ; Cass., Cat. Capr. Phil. Mus., p. 5, 1851; Horsfd. \& Moore, Cat. B. Mus. E. Ind. Co., vol. i, p. 112, 1854; Cab. \& Heine, Mus. Hein., th. iii, p. 59, 1860 ; Bernst., Journ. f. Orn., 1859, p. 182 ; Gray, Proc. Zool. Soc., 1861, p. 433 ; Jerdon, Birds of India, vol. i, p. 195, 1862; Wall., Proc. Zool. Soc., 1863, pp. 22, 484; Rosenb., Journ. f. Orn., 1864, p. 117; Gould, Handb. B., Austr., vol. i, p. 100, 1865; Schleg., N. T. D., t. iii, p. 340, 1866 ; Blyth, Ibis, 1866, p. 341 ; Ramsay, Proc. Zool. Soc., 1868, p. 383 ; Beavan, Ibis, 1869, p. 406 ; Gray, Handl. B., vol, i, p. 57, 1869 ; Hume, Stray Feathers, vol. i, 1874, p. 469, et 1875, p. 46 ; Salvad., Ucc. Born., p. 117, 1874; Blyth \& Walden, Journ. As. Soc., Bengal, vol. xliv, 1875, extra No., p. 83.

a. ठ Bhamô, January 1868.

This species extends from North Australia, through Java, the Malayan Peninsula and Burma to Lower Bengal, but it is very rare in the last locality. 


\section{Order PASSERES.}

Family-CORVID AR.

\section{Genus Corvus, Linnæus.}

\section{Convus insolens, Hume.}

Corvus culminatus, Schomb., Ibis, 1864, p. 252 (nec Sykes).

Corvus insolens, Hume, Stray Feathers, 1874, p. 480; 1875, p. 144.

Corvus impudicus, Hume, Stray Feathers, 1875, p. 142.

Corvus splendens, Blyth \& Walden, Journ. As. Soc., Bengal, vol. xliv, extra No., p. 86, 1875;

W. Ramsay, Ibis, 1877, p. 459 .

a. \& b. Katha, Upper Burma, 20th January 1868.

The voice of this Crow is markedly distinct from that of C. splendens, and as its characteristic coloration is apparently persistent, Mr. Hume has separated it specifically from the Indian form, to which, however, it is closely allied.

It extends northwards from Rangoon to Bhamô, and at the latter place I found it associated with C. levaillanti, but less numerous. It does not, however, reach the high country to the east, and I did not observe it in the Kakhyen hills.

\section{Corvus levalillanti, Lesson.}

Corvus levaillanti, Less., Traité d’Orn., p. 328, 1831 ; Pucher. R. Z., 1853, p. 547 ; Holdsw., Proc. Zool. Soc., 1872, p. 460 ; Hume, Stray Feathers, 1874, pp. 243, 479; Ball, l. c., p. 418 ; Hume, op. cit., 1875, p. 143; id., Nests and Eggs, Ind. B., p. 411, 1875 ; Fairbank, Stray Feathers, 1876, p. 260.

Corvus culminatus, Sykes, Prö. Zool. Soc., 1832, p. 96 ; Gray, Cat. Mamm., \&c., Nepal, Coll. Hodgs., p. 102, 1846 ; Blyth, Journ. As. Soc., Bengal, vol. xv, p. 24, 1846; vol. xvi, p. 727, 1847 ; id., Cat. B. Mus., As. Soc., Bengal, p. 89, 1849 ; id., Journ. As. Soc., Bengal, vol. xxiv, p. 479, 1855 ; Hutton, op. cit., vol. xvii, p. 9, 1848 ; Bonap. Consp., t. i, p. 385, 1850; Layard, Ann. Nat. Hist. (2), vol. xiii, p. 213, 1854; Burgess, Proc. Zool. Soc., 1854, p. 144; Horsfd. \& Moore, Cat. B. Mus. E. Ind. Co., vol. ii, p. 553, 1856-58; Jerdon, B. Ind., vol. ii, p. 295, 1863; Gray, Cat. Mamm., \&c., Nepal, Coll. Hodgs., p. 55, 1863 ; Schleg., M. P.-B. Coraces, p. 16, 1S67; Blyth, Ibis, 1867, p. 34, 1868, p. 132 ; Gray, Handl. B., vol.ii, p. 11, 1870 ; GodwinAusten, Journ. As. Soc., Bengal, vol. xliii, 1874, p. 170 ; id., op. cit., vol. xlv, 1876, p. 83.

Corvus corax, Royle, Ill. Him. Bot., p. 77, 1839.

Corvus enca, Sundev., Ann. Nat. Hist., vol. xviii, p. 306, 1846.

Corvus macrorhynchus, Gray \& Hardw., Ill. Ind. Zool., vol. ii, pl. xxxvi, fig. 2, 1832 ; Jerdon, Madr.

Journ,, vol. xi, p. 18, 1840 ; Hodgs., in Gray's Zool. Mise., p. 84, 1844.

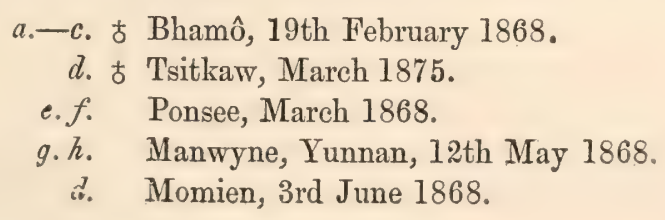


This species is very common at Bhamô in the villages outside the stockade. It arrived at the village of Ponsee about the end of March and established a colony in some high trees near our camp. It is the common Crow in the Sanda valley, confining itself, however, as a rule, to the outskirts of the villages and towns. It is less numerous at Momien, where Magpies (Pica rustica) and Mynas (Sturnopastor nigricollis) abound. In fact, one of the characteristic features of the valleys beyond the Kakhyen hills is the prevalence of these three species of birds.

\section{Genus PicA, Brisson.}

\section{Pica Rustica, Scop.}

La Pie, Briss. Orn., t. ii, p. 35, 1760; Montb., Pl. Enl., t. iii, pl. 488, 1773.

Corvus pica, Linn., Syst. Nat., t. i, p. 157, 1766 ; Wils., Am. Orn., vol. iv, p. 75, pl. xxxv, fig. 2,

1811; Temm., Man. d’Orn., t. i, p. 113, 1820 ; Naum., Vög. Deutschl., Bd. ii, taf. 56, fig. 2,

1822 ; Werner, Atlas, Omnivores, pl. vii, 1827 ; Audub., Orn. Biogr., t. iv, p. 408, pl. ccelvii,

1831 ; Nordm. Demid. Voy. Russ. Merid., t. iii, p. 116, 1844; Schleg. u. Susemihl, Vög.

Eur., Bd. ii, taf. 4, fig. 2, 1839; Schleg., Vög. Nederl., pl. 141, 1854.

Corvus rusticus, Scop., Ann., t. i, p. 38, 1769.

Pica melanoleuca, Vieill., N. Dict. d'Hist. Nat., t. xxvi, p. 12], 1818 ; Wagl., Syst. Av. Pica, sp. 1, 1829 ; Audub., B. Amer., roy. 8vo., vol. iv, p. 99, pl. cexxvii, 1842 ; Macgill, Br. B., vol. i, p. 562, 1837.

Corvus hudsonius, Sabine, App. Narr. Frankl. Journ., p. 671, 1823.

Pica albiventris, Vieill., Faun. Franc., p. 119, 1828.

Pica europaa, Boie, Isis, I826, p. 551 ; Sundev., Sv. Fogl., pl. xix, fig. 3, 1860.

Pica germanica, Brehm, Vög. Deutschl., p. 177, 1831.

Pica septentrionalis, Brehm, l. c., p. 178.

Pica hiemalis, Brehm, l. c., p. 178.

Garrulus picus, Temm., Man. d’Orn., t. iii, p. 63, 1835; Drummond, Ann. Nat. Hist., vol. xii, p. 414, 1842.

Pica hudsonica, Bonap., Comp. List B. Eur. and N. Amer., p. 27, 1838; Gray, Gen. B., vol. ii, p. 314, 1845 ; Bonap. Consp., t. i, p. 383, 1850 ; Baird, B. N. Amer., p. 576, pl. xxv, 1858; Dall \& Bann., Tr. Chic. Acad., vol. i, p. 286, 1869; Gray, Handl. B., vol. ii, p. 10, 1870.

Pica caudata, Keys. u. Blas. Wirb. Eur., p. 45, 1840 ; Gould, B. Eur., vol. iii, pl. 216, 1840; Yarr., Br. B., vol. ii, p. 107, 1843; Gray, Gen. B., vol. ii, p. 314, 1845; Blyth, Journ. As. Soc., Bengal, vol. xv, p. 26, 1846 ; id., Cat. B. Mus., As. Soc., Bengal, p. 9, 1849; Hutton, Journ. As. Soc., Bengal, vol. xvi, p. 778, 1847 ; Bonap. Consp., t. i, p. 382, 1850 ; Midd., Sibir. Reise Zool., p. 158, 1851; Jaub. et Barth., Lapomm. Rich. Orn., p. 101, 1858; Fritsch, Vög. Eur., taf. 27, fig. 6, 1858; Schrenck, Reise Amurl. Vög., p. 322, 1859; Linderm., Vög. Griechenl., p. 69, 1860 ; Filippi, Viagg. Pers., p. 350, 1865 ; Radde, Reise Sibir. Vög., p. 206, 1862 ; Gould, B. Gt. Br., vol. iii, pl. 216, 1863; Bettoni, Ucc. Lomb., pl. 101, 1869; Doderl., Avif. Sicil., p. 66, 1869; Gray, Handl. B., vol. ii, p. 10, 1870 ; Salvad., Faun. Ital. Uec., p. 175, 1871; Shelley, B. Egypt, p. 160, 1872.

Pica bottanensis, Deless., Rev. Zool., t. ii, p. 100, 1840; Gray, Gen. B., vol. ii, p. 314, 1845; Blyth, Cat. B. Mus., As. Soc., Bengal, p. 91, 1849; Horsf. \& Moore, Cat. B. Mus. E. Ind. Co., vol. ii, p. 551, 1856-58; Jerdon, B. Ind., vol. ii, p. 305, 1863 ; Gould, B. Asia, pt. xv, 1862 ; Gray, Handl. B., vol. ii, p. 10, 1870.

Pica megaloptera, Blyth, Journ. As. Soc., Bengal, vol. xi, p. 193, 1840.

Pica media, Blyth, Journ. As. Soc., Bengal, vol. xiii, p. 393, 1842; id., Cat. B. Mus., As. Soc., Bengal, p. 91, App. p. 19, 1849 ; Horsf. \& Moore, Cat. B. Mus. E. Ind. Co., vol. ii, 
p. 554, 1856-58; Gray, Handl., vol. ii, p. 10, 1870; David, N. Arch. Mus., t. vii, Bull., p. 9, 1871 ; Sivinhoe, Proc. Zool. Soc., 1871, p. 382 ; David, Journ. de Voy. en Chine, t. ii, 1875, p. 40.

Pica varia, Schleg., Rev. Crit., p. 54, 1844; id., Dier. Nederl,, pl. xiii, figs. 7, $7 a, 1861$ : id., Mus. P.-B. Coraces, p. 39, 1867 ; Kjārb., Orn. Dan., pl. xii, fig. 2, 1852.

Pica sericea, Gould, Proc. Zool. Soc., 1845, p. 2; Gray, Gen. B., vol. ii, p. 314, 1845 ; Bonap. Consp., t. i, p. 383, 1850.

Cleptes hudsonicus, Gambel, Journ. Acad. N. Sir. Philad., 1847, p. 47.

Pica tibetana, Hodgs., Ann. Nat. Hist., vol. iii, p. 203, 1849.

Pica varia japonica, Schleg., Faun. Jap. Aves, p. 81, 1850.

Pica japonica, Bonap. Consp., vol. i, p. 383, 1850; Gray, Handl. B., vol. ii, p. 10, 1870.

Pica butanensis, Bonap. Consp., t. i, p. 383, 1850.

Cleptes pica, Cab., Mus. Hein., th. i, p. 229, 1850.

Pica vulgaris, Brehm, Journ. f. Orn., 1858, p. 173.

Pica leucoptera, Gould, B. Asia, pt. xiv, 1862; Gray, Handl. B., vol. ii, p. 10, 1870.

Pica rustica, Dresser, B. Eur., pt. xxii, 1873; Irby, B. Gibr., p. 129, 1875 ; Dresser, Ibis, 1875 , p. 238 ; Blanf., E. Persia, p. 264, 1876.

Pica melanoleuca, var. hudsonica, Cones, Key N. Amer. B., p. 164, 1872.

Picu caudata, var. Zactriana, Severtz. Turkest. Jevotn., p. 64, 1873.

Pica caudata, var. hudsonica, Baird, Brewer \& Ridgw., N. Amer. B., p. 266, 1874.

Pica pica, Sharpe, Cat. B. B. M., vol. iii, p. 62, 1877.

$$
\begin{array}{ll}
\text { a. e. t \& } & \text { Bhamô, 20th January } 1875 . \\
f . g . \text { t } & \text { Ponsee, 5th May } 1868 .
\end{array}
$$

As a rule, the European birds have brighter coloured central tail-feathers than the Asiatic ones, but I have a Bhamô specimen with a tail almost as bright as in any European bird. The extent of the white on the wing varies very slightly. My first specimens were procured at Bhamô, where it is not very common. When the Kakhyen hills were reached it became more numerous, but not to the great extent which characterised it in the country to the east, where it may be said to take the place of Crows, near villages. It is so prevalent that one of the first observations a traveller makes on entering the country is that it is a land of Magpies. The Yunnan birds have all the habits of those described by Swinhoe of roosting in company and sallying out for food and returning at night, cackling and curveting with sundry antics. The Magpies appeared at our camp at Ponsee about the beginning of April and were breeding in a high tree, close to a small rookery of Corvus levaillanti. Swinhoe mentions that he has skins of $P$. rustica from Amoy, in which the white band on the rump is scarcely visible, which is a character of the rump-band of the so-called $P$. bottanensis, Desh.

\section{Genus Dendrocitta, Gould.}

\section{Dendrocitta rufa, Scopoli.}

La Pie ronsse de la Chine, Sonn. Voy. Ind., t. ii, p. 186, pl. 106, 1782.

Rufous Crow, Lath., Gen. Syn. Suppl., p. 84, 1790.

Grey-tailed Roller, Lath., Gen. Syn. Suppl., p. 86, 1787.

Lanius rufus, Scop., Del. Faun. et Flor. Insubr., t. ii, p. 86, 1786. 
Corvus rufus, Lath., Ind. Orn., vol. i, p. 16, 1790.

Coracias vagabunda, Lath., Ind. Orn., vol. i, p. 171, 1790.

La Pie rousse, Levaill., Ois. d'Afr., t. ii, p. 31, pl. lix, 1801.

Pica. rufa, Vieill., N. Dict. d'Hist. Nat., t. xxvi, p. 130, 1808 ; Steph., Gen. Zool., vol. xiv, p. 64, 1826 ; Wagl., Isis, 1829, p. 750 ; Sundev., Ann. Nat. Hist., vol. xviii, p. 168, 1846.

Pica vagabunda, Vieill., N. Dict., t. xxvi, p. 121, 1818; Wagl., Syst. An. Pica, sp. 5, 1827; Gould, Cent. Himal. B., pl. xlii, 1832 ; Gray in Hardw., Ill. Ind. Zool., vol. i, pl. xxv.

Dendrocitta vagabunda, Gould, Proc. Zool. Soc., 1833, p. 57 ; et Trans. Zool. Soc., vol. i, p. 89, 1833 ; Gray, Cat. Hodgs. Coll., Nepal, p. 101, 1846 ; Bonap. Consp., t. i, p. 369, 1850.

Crypsirhina vagabunda, Swainson, Classif. B., vol. ii, p. 266, 1837; Jerdon, Madr. Journ., vol. xi, p. 19, 1840 ; Blyth, Journ. As. Soc., Bengal, vol. xii, p. 932, 1843 ; vol. xiii, p. 389, 1844; Hodgs. in Gray's Zool. Misc., p. 84, 1844.

Crypsirtina rufa, Swainson, Classif. B., vol. ii, p. 266, 1837 ; Blyth, Journ. As. Soc., Bengal, $\mathrm{xv}$, p. $30,1846$.

Dendrocitta rufa, Hartl., Syst. Verz., 1844, p. 60, 1844; Blyth, Cat. B. Mus., As. Soc., Bengal, p. 92, 1849 ; Cab., Mus. Hein., th. i, p. 216, 1850 ; Horsf. \& Moore, Cat. B. Mus. E. Ind. Co., vol. ii, p. 565, 1854; Jerdon, B. Ind., vol. ii, p. 314, 1863; Gray, Handl. B., vol. ii, p. 8, 1870 ; Godwin-Austen, Journ. As. Soc., Bengal, vol. xxxix, 1870, p. 110; Hume, Stray Feathers, 1873, p. 206 ; Adam., t. c., p. 386 ; Hume, op. cit., 1874, p. 480 ; id., Nests and Eggs, Ind. B., p. 421, 1873; Blyth \& Walden, Journ. As. Soc., Bengal, vol. xliv, 1875 ; Butler, Stray Feathers, 1877, p. 35; Fairbank, t. c., p. 260 ; Armstrong, t. c., p. 331; Sharpe, Cat. Birds, B. M., vol. iii, 1877, p. 76.

Temmerus rufus, Gray, Gen. B., vol. ii, p. 310, 1845.

Temmerus vagabundus, Gray, l. c., p. 310, 1845.

Crypsirhina pallida, Blyth, Journ. As. Soc., Bengal, vol. xv, p. 30, 1846.

Dendrocitta pallida, Blyth, Cat. B. Mus., As. Soc., Bengal, p. 336, 1849; Horsf. \& Moore, Cat.

B. Mus. E. Ind. Co., vol. ii, p. 568, 1s54; Jerdon, B. Ind., vol. ii, p. 315, 1863 ; Gray, Handl.

B., vol. ii, p. 8, 1870.

Vagabunda rufa, Kaup., Journ. f. Orn., 1854, p. lv; Ball, Stray Feathers, 1874, p. 418.

Glaucopis rufa, Schleg., Mus. P.-B. Coraces, p. 77, 1867.

a. Katha, 20th January 1868.

I procured only one specimen of this species which does not appear to be common in Upper Burma.

\section{Genus Unocissa, Cabanis.}

\section{Urocissa magnirostris, Blyth.}

Psilorhinus magnirostris, Blyth, Journ. As. Soc., Bengal, vol. xv, p. 27, 1846 ; id., Cat. B. Mus., As. Soc., Bengal, p. 93, 1849.

Calocitta magnirostris, Bonap. Consp., t. i, p. 381, 1850.

Urocissa magnirostris, Cab., Mus. Hein., th. i, p. 87, note, 1850 ; Gould, B. Asia, pt. xiii, 1861 ; Jerdon, B. Ind., vol. ii, p. 311, 1862 ; Godwin-Austen, Journ. As. Soc., Bengal, vol. xlii, 1874, p. 170 ; Hume, Stray Feathers, 1874, p. 480, 1875, p. 145; Blyth \& Walden, Journ. As. Soc., vol. xliv, 1875, p. 88 ; W. Ramsay, Ibis, 1877, p. 460 ; Sharpe, Cat. H. B. M., vol. iii, 1877, p. 71.

Cissa magnirostris, Gray, Handl. B., vol. ii, p. 7, 1870.

a. Upper Burma, 2nd and 16th June 1868.

6. Hotha valley, Yunnan, 8th August 1868. 
The evidence which has already been adduced regarding the character assigned by Blyth to this supposed species seems all to tend in the direction of proving it to be only a local race distinguished by a somewhat longer bill.

A large series of birds will in all probability show that even the large bill is not a stable character.

Having examined the type, I am disposed to think that the great naked space described by Blyth as surrounding the eye is chiefly due to the accidental loss of feathers, and that the area does not differ in its dimensions from the corresponding area in $U$. occipitalis, and Mr. Hume distinctly states that there is no naked space surrounding the eyes. Captain Wardlaw Ramsay has recently remarked that the colouring of the wings is not more bright than in $U$. occipitalis.

A number of adults of this species appeared at Ponsee, shortly before our departure, along with Pica rustica and C. levaillanti, and were daily seen near our camp which was close to the village. Mr. Oates, as quoted by Hume, remarks that "it likes the neighbourhood of villages in forest country," and Hume calls attention to the difference in this respect between $U$. magnirostris and $U$. occipitalis, the latter having never been observed by him in the immediate vicinity of villages. None of these birds were observed at Ponsee during the first month of our detention, and as Pica rustica began immediately with the Crows to build their nests on their arrival, I conclude that $U$. magnirostris arrived for a similar purpose. In connection with these facts it is as well to point out that the country to the east is singularly denuded of forest.

$$
\text { Family-STURNIDA. }
$$

\section{Genus Acridotheres, Vieillot.}

\section{ACRIDOtheres tristis, Linn.}

Paradisea tristis, Linn., Syst. Nat., t. i, p. 167, 1766 ; Buff., Pl. Enl., 219, 1783.

Gracula gryllivora, Daud., Traité d’Orn., t. ii, p. 285, 1800.

Acridotheres tristis, Vieill., Analyse, p. , 1816; Pears., Journ. As. Soc., Bengal, p. 648, 1841 ; Blyth, Journ. As. Soc., Bengal, vol. xiii, p. 361, 1844; vol. xv, p. 314, 1846; id., Ann. Nat. Hist., vol. xx, p. 384, 1847; Gray, Gen. B., vol. ii, p. 335, 1847; Tickell, Journ. As. Soc., Bengal, vol. xvii, p. 304, 1848; Hutton, t. c., p. 8 ; Bonap. Consp., t. i, p. 419, 1850 ; Cab., Mus. Hein., th. i, p. 205, 1850 ; Layard, Ann. Nat. Hist. (2), vol. xiii, p. 218, 1854; Tytler, t. c., p. 368, 1854; Theob., Journ. As. Soc., Bengal, vol. xxiii, p. 597, 1855; Horsf. \& Moore, Cat. B. Mus. E. Ind. Co., vol. ii, p. 532, 1856; Jerdon, B. Ind., vol. ii, p. 325, 1863; Gray, Handl. B., vol. ii, p. 19, 1870 ; Godwin-Austen, Journ. As. Soc., Bengal, vol. xxxix, 1870, p. 110 ; Holdsw., Proc. Zool. Soc., 1872, p. 462 ; Hume, Stray Feathers, 1873, pp. 207, 440; Adam., t. c., p. 386; Ball, op. cit., 1874, p. 419; Hume, t. c., pp. 246, 480; id., op. cit., 1875, p. 146; id., Nests and Eggs, Ind. B., p. 428, 1873; Blyth \& Walden, Journ. As. Soc., Bengal, vol. xliv, ex. No., p. 90, 1875; W. T. Blanford, op. cit., vol. xlv, 1876, p. 91 ; Butler, Stray Feathers, 1877, p. 35 ; Fairbank, t. c., p. 260 ; Hume, t.c., p. 279 ; id., p. 456, 1877, p. 38 ; Oates, t.c., p. 160 ; Gammie, t. c., p. 384 ; Fairbank, t. c., pp. 391, 407 .

Gracula tristis, Lath., Gen. Hist., vol. iii, p. 147, 1822 ; Sundev., Ann. Nat. Hist., vol. xviii, p. $303,1846$. 
Pastor tristis, Wagler, Syst. Av. Pastor, sp. 5, 1827 ; Sykes, Proc. Zool. Soc., 1832, p. 95 ; Maclell., Proc. Zool. Soc., 1839, p. 163; Jerdon, Madr. Journ., vol. xi, p. 20, 1840; Blyth, Ann. Nat. Hist., vol. xii, p. 96, 1843 ; Hodgs., in Gray's Zool. Misc., p. 84, 1844; Gray, Cat. Mamm., \&c., Nepal, Coll. Hodgs., p. 104, 1846.

Maina tristoides, Hodgs., Journ. As. Soc., Bengal, vol. v, p. 771, 1836.
a. $b$. Katha, 20th January 1868.
c. Bhamô, 11th September 1868.
d. Manwyne, 12th May 1868.

Common in Upper Burma and extending across the Kakhyen hills.

\section{ACRIDOTHERES FUSCUS, Wagler.}

Pastor fuscus, Wagler, Syst. Av. Pastor, p. 6, 1827; Blyth, Journ. As. Soc., Bengal, vol. xi, p. 885.

Maina cristatelloides, Hodgson, Journ. As. Soc., Bengal, vol. v, p. 771, 1836.

Gracula cristatella, Sundev., Ann. Nat. Hist., vol. xviii, p. 304, 1846.

Acridotheres fuscus, Blyth, Journ. As. Soc., Bengal, vol. xiii, p. 362, 1844; Bonap., Consp. Gen. Av., t. i, p. 420, 1850; Horsfield \& Moore, Cat. B. Mus. E. Ind. Co., vol. ii, p. 537, 1856 ; Jerdon, Birds of India, vol. ii, p. 327; Blyth \& Walden, Journ. As. Soc., Bengal, vol. xliv, 1875, extra No., p. 90, 1863; Hume, Nests and Eggs, Indian Birds, p. 431, 1873; Gray, Handl., vol. ii, p. 19, 1870 .

Acridotheres cristatellus, Blyth, Journ. As. Soc., Bengal, vol. xiii, p. 362, 1842 ; Hodgson, in Gray's Zool. Misc., p. 84, 1844.

Acridotheres griseus, Blyth, Journ. As. Soc., Bengal, vol. xv, p. 32, 1846 ; id., Cat. B. Mus., As. Soc., Bengal, p. 108, 1849.

Acridotheres cristatelloides, Cab., Mus. Hein., th. i, p. 206, 1850.

Heterornis fusca, Gray, Gen. B., vol. ii, p. 335, 1847.

a. Mandalay, 26th September 1868 .

\section{Common in Upper Burma.}

\section{Acridotheres siamensis, Swinhoe.}

Acridotheres siamensis, Swinhoe, Proc. Zool. Soc., 1863, p. 303 ; Gray, Handl. B., vol. ii, p. 20 , 1870 ; Finsch., Abhandl. Bremen, vol. , p. ; Blyth \& Walden, Journ. As. Soc., Bengal, vol. xliv, 1875, extra No., p. 90 ; W. Ramsay, Ibis, 1877, p. 460.

a. b. Muangla, Yunnan, 18th and 19th May 1868.

c. Tsaykaw, Upper Burma, 14th February 1875.

It is to be observed that this species occurs both in the valley of the Irawady at Bhamô and in the high valleys to the east, where it is not at all uncommon.

\section{Genus Sturnopastor, Hodgson.}

48. StURNOPAstor CONTRA, Linn., var. sUPerciliaris, Blyth.

Sturnopastor supercitiaris, Blyth, Journ. As. Soc., Bengal, vol. xxxii, p. 77, 1863 ; Gray, Handl., vol. ii, p. 22, 1870; Hume, Stray Feathers, 1874, p. 480 ; id., Nests and Éggs, Indian Birds, p. 427, 1875; id., op. cit., 1875, p. 149; Armstrong, op. cit., 1876, p. 331. 
Stwrnopastor contra, Blyth \& Walden, Journ. As. Soc., Bengal, vol. xliv, 1875, extra No., p. 90 , 1875; Tweedale, Ibis, 1877 (pars.), p. 319.
a. Katha, 20th January 1868.
b. Bhamô, February 1868.

This race is very prevalent in Upper Burma, but it does not extend across the Kakhyen hills to the east, as far as my observations go, where it appears to be replaced by Sturnopastor nigricollis. In specimens of S. contra, from Bengal, I find a few white feathers over the eye in all, so that it is only the relatively greater development of the white on that region, in the Burmese birds, that entitles this race to the name Blyth has given it. The white on the forehead and the browner back appear to be more characteristic of the race than the white supercilium. In the specimens from the above localities, the black on the breast is uniformly of less extent than either in $S$. contra or in the types of the variety.

There is a skin in the Calcutta Museum of another variety of $S$. contra from Malacea. It is a larger bird with a longer tail than any of the other specimens of this species. Another peculiarity is the greater development of the white on the rump and the rather intense metallic blue lustre of the brownish-black of the back. Each of the feathers on the flanks has a large deep brown spot, edged with pale ashy or white. It is possible that it may turn out to be the $P$. jilla, Horsfield, of Java, the diagnosis of which is not sufficiently detailed to enable me to determine it.

Specimens of $S$. contra, Linn., from Central India have the belly markedly greyish ashy, and the black feathers on the upper part of the chest are narrowly margined with a grey, similar to that on the belly, and the feathers on the shoulder and side of neck and upper back are streaked with the same colour. In true S. contra, Linn., there is, as a rule, always more or less grey streaking of the feathers on the side and base of the back of the neck, the prolonging back, as it were, of the superior posterior angle of the white patch on the ear-coverts, and this is seen most intensified in one of Blyth's specimens of S. superciliaris, in which the grey streaking has become a white collar, the downward and backward prolongation, around the neck, of the white of the ear-coverts.

\section{Sturnopastor nigricollis, Payk.}

Gracula nigricollis, Payk., Nova Acta Stockh., t. xxviii, pl. ix, 1807.

Pastor temporalis, G. R. Gray, in Griffith, An. Kingd., vol. vi, p. 422, 1829; id., Gen. B., vol. ii, p. 334, 1847; Blyth, Journ. As. Soc., Bengal, vol. xiii, p. 366, 1844.

Gracupica melanoleuca, Less., Tr. d’Orn., p. 40, 1831.

Pastor bicolor, J. E. Gray, Zool. Misc., p. 1, 1844.

Sturnopastor temporalis, Blyth, Journ. As. Soc., Bengal, vol. xv, p. 36, 1846; Bonap. Consp., t. i, p. $421,1850$.

Sturnopastor melanoleucus, Gray, Gen. B., vol. ii, p. 336, 1847.

Acridotheres nigricollis, Gray, Gen. B., vol. ii, p. 335, 1847; id., Handl. B., vol. ii, p. 20, 1870.

Sturnus temporalis, Blyth, Cat. B. Mus., As. Soc., Bengal, p. 109, 1849.

Gracupica nigricollis, Horsf. \& Moore, Cat. B. Mus. E. Ind. Co., p. 528, 1856; Swinhoe, Proc. Zool. Soc., 1871, p. 384. 
Sturnopastor nigricollis, Blyth \& Walden, Journ. As. Soc., Bengal, vol. xliv, 1875, extra No., p. 90,1875 .

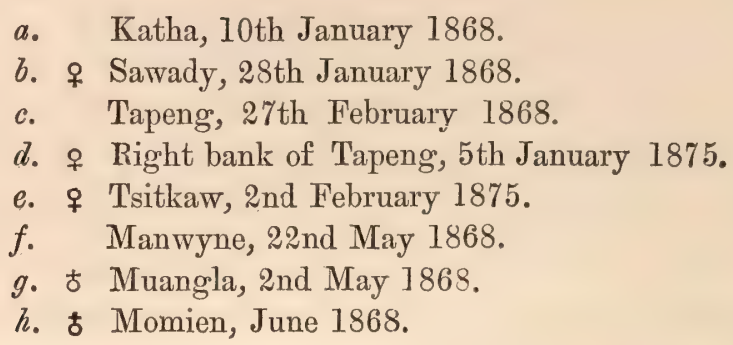

This species is not so common in Upper Burma as in the high country to the east of Bhamô. I have a specimen of the species from the extreme east of China before me, and these Burmese and Yunnan birds differ in no respect from it.

It has much the same habits as $S$. contra, var. superciliaris. I found it breeding in the month of May in one of the few clumps of trees at Muangla.

\section{Genus Temenuchus, Cabanis.}

50. Temendchus burmanicus, Jerdon.

Sturnia burmanica, Jerdon, Tbis, 1862, p. 21.

Temenuchus burmanicus, Gray, Handl. B., vol. ii, p. 20, 1870 ; Hume, Stray Feathers, 1875, p. 149; Blyth \& Walden, Journ. As. Soc., Bengal, vol. xliv, 1875, extra No., p. 90 ; Armstrong, Stray Feathers, vol. iv, 1876, p. 332.
a. Yaylaymaw, Upper Burma, 6th January 1875.
b. Bhamô, 24th January 1868.
c. " 29th ", ",
d. ", 22nd February ",

This species appears to be widely distributed over Burma, but I did not observe it on the Chinese side of the range of hills to the east of Bhamô.

The head, cheeks, and throat are very liable to vary in the intensity of their colouring. In eight specimens before me only two have these parts white; in all the others they are greyish-white, but in these cases when the feathers are drawn aside they are seen to be pure white below.

\section{Temendchus maiabaricus, Blyth.}

Le Martin vieillard de la côte de Malabar, Sonn., Voy. Ind., t. ii, p. 195, 1782.

Malabar Thrush, Lath., Gen. Syn., vol. ii, pt. 1, p. 30, 1783.

Turdus malabaricus, Gm., Syst. Nat., t. i, pt. II, p. 816, 1788.

Acridotheres malabaricus, Bonn. et. Vieill., Enc. Méth., p. 691, 1823 ; Pears., Journ. As. Soc., Bengal, vol. x, p. 649, 1841.

Pastor pagodarum, Wagler, Syst. Av. Pastor, sp. 8, 1827; Mc'Clell., Proc. Zool. Soc., 1839, p. 163.

Maina affinis, Hodgs., Journ. As. Soc., Bengal, vol. v, p. 771, 1836.

Pastor cinereus, Jerdon, Madr. Journ., vol, xi, p. 23, 1840. 
Pastor malabaricus, Jerdon, Madr. Journ., vol. xiii, p. 138, 1844.

Sturnia malabarica, Blyth, Journ. As. Soc., Bengal, vol. xiii, p. 363, 1844 ; id., Cat. Mus., As. Soc., Bengal, p. 110, 1850 ; Blyth \& Walden, Journ. As. Soc., Bengal, vol. xliv, 1875, extra No., p. 90.

Pastor caniceps, Hodgs., in Gray's Zool. Misc., 1844, p. 84; Blyth, Ann. Nat. Hist., vol. xii, p. 97.

Pastor blythii, Gray, Cat. B. Nep., Coll. Hodgs., p. 104, 1846.

Hetarornis malabaricus, Gray, Gen. B., vol. ii, p. 335, 1847 ; Bonap. Consp., t. i, p. 419, 1850.

Temenuchus malabaricus, Cab., Mus. Hein., th. i, p. 204, 1850 ; Horsf. \& Moore, Cat. B. Mus.

E. Ind. Co., vol. ii, p. 530, 1856 ; Jerdon, B. Ind., vol. ii, p. 330, 1864 ; Gray, Handl. B., vol. ii, p. 20, 1870; Ball, Stray Feathers, 1874, p. 419 ; Hume, t. c., p. 480 ; id., Nests and Eggs, Ind. B., p. 433, 1873; id., Stray Feathers, 1875, p. 323 ; Butler, t. c., p. 494; Armstrong, op. cit., 1876, p. 332 ; Hume, t.c., p. 402; id., op. cit., 1877, p. 38 ; Butler, t. c., 1877, p. 230 ; Godwin-Austen, Journ. As. Soc., Bengal, vol. xlv, 1876, p. 83.

a.b. ซ Muangla, 12th May 1868.

These birds are paler on the belly and head than Bengal specimens of this species. It is common in the Sanda valley, but I did not notice it in the Nantin or Momien valleys farther to the east.

\section{Family $-P L O C E I D A$.}

\section{Genus Ploceus, Cuvier.}

\section{Ploceus baya, Blyth.}

Ploceus philippinensis, Sykes, Proc. Zool. Soc., 1832, p. 94; Jerdon, Madr. Journ., vol. xi, p. 25, 1840 ; Blyth, Journ. As. Soc., Bengal, vol. xi,pp. 871, 889, 1842; Strickl., Journ. As. Soc., Bengal, vol. xiv, p. 553, 1845 ; Tickell, Journ. As. Soc., Bengal, vol. xvii, p. 299, 1848 ; Blyth, Cat. B. Mus., As. Soc., Bengal, p. 115, 1849; Burgess, Proc. Zool. Soc., 1852, p. 88; Layard, Ann. Nat. Hist., vol. xiii, 2nd Ser., p. 257, 1854; Tytler, l. c., p. 368.

Ploceus baya, Journ. As. Soc., Bengal, vol. xiii, p. 945, 1844; Bonap. Consp., t. i., p. 442, 1850 ; Cab. \& Heine, Mus. Hein., th. i, p. 180, 1851 ; Horsf. \& Moore, Cat. B. Mus. E. Ind. Co., p. 515, 1856-58 ; Jerdon, B. Ind., vol. ii, p. 343, 1863; Gray, Handl. B., vol. ii, p. 44, 1870 ; Godwin-Austen, Journ. As. Soc., Bengal, vol. xxxix, p. 110, 1870 ; Holdsw., Proc. Zool. Soc., 1872, p. 463; Adam., Stray Feathers, 1873, p. 387; Hume, op. cit., 1874, p. 481 ; Ball, t.c., p. 420 ; Hume, Nests and Eggs, Ind. B., p. 436, 1873; id., Stray Feathers, 1875, p. 153 ; Blyth \& Walden, Journ. As. Soc., Bengal, vol. xliv, 1875, extra No., p. 92; Butler, Stray Feathers, 1876, p. 39 ; Fairbank, t.c., p. 260 ; Hume, op. cit., 1877, p. 323.

Ploceus atrigula, Hodgs., in Gray's Zool. Misc., p. 84, 1844.

Ploceus passerinus, Hodgs., in Gray's Zool. Misc., p. 84, 1844.

Euplectes baya, Jerdon, Madr. Journ., vol. xiii, p. 134, 1844.

Fringilla bengalensis, Sundev., Ann. Nat. Hist., vol. xviii, p. 260, 1846.

Euplectes flaviceps, Hodgs., Cat. B., Nep., p. 105, 1846.

Bhamô, 3rd February 1868.

Very common, building in bushes in long grass. On my return to Bhamô in September I found many nests of this bird on partially submerged bushes at considerable distances from the land.

I did not observe it on the Chinese side of the Kakhyen hills. 


\section{Ploceus manyar, Horsfield.}

Fringilla manyar, Horsf., Trans. Linn. Soc., vol. xiii, p. 160, 1822.

Ploceus flaviceps, Less., Tr. d’Orn., p. 435, 1831 (ex. Cuv. MS.) ; Bonap. Consp., t. i, p. 443, 1850.

Euplectes flaviceps, Swains., An. in Menag., p. 310, $183 \%$.

Euplectes bengalensis, Jerdon, Madr. Journ., vol. xi, p. 25, 1840.

Euplectes striatus, Blyth, Journ. As. Soc., Bengal, vol. xi, p. 873, 1842, vol. xii, p. 181 bis., 1843; id., Ann. Nat. Hist., vol. xii, p. 166, 1843.

Ploceus manyar, Strickl., Proc. Zool. Soc., 1839, p. 163; Blyth, Journ. As. Soc., Bengal, vol. xiii, p. 945, 1844 ; id., Cat. B. Mus., As. Soc., Bengal, p. 115, 1849; Gray, Gen. B., vol. ii, p. 352, 1849 ; Layard, Ann. Nat. Hist. (2), vol. xiii, p. 257, 1854; Horsf. \& Moore, Cat. B. Mus. E. Ind. Co., vol. ii, p. 514, 1856-58; Jerdon, B. Ind., vol. ii, p. 348, 1863; Gray, Handl. B., vol. ii, p. 44, 1870 ; Hume, Stray Feathers, 1873, p. 208; id., Nests and Eggs, Ind. B., p. 440, 1873 ; id., Stray Feathers, 1875 , p. 154; Blyth \& Walden, Journ. As. Soc., Bengal, vol. xliv, 1875, extra No., p. 92, 1875 ; Butler, Stray Feathers, p. 876, p. 39 ; Hume, $t . c$., p. .224; Ball, t. c., p. 235 .

a. b. c. Bhamô, 23rd February 1868.

Prevalent in Upper Burma.

\section{Genus Munia, Hodgson.}

\section{Munia atricapilla, Vieill.}

Loxia atricapilla, Vieill., Ois. Chant., p. 84, pl. liii, 1805.

Coccothraustes atricapilla, Vieill., N. Dict. d'Hist. Nat., t. xiii, p. 534, 1817.

Munia rubronigra, Hodgs., Asiat. Researches, vol. xix, p. 153, 1830; Blyth, Cat. B. Mus., As. Soc., Bengal, p. 116, 1849 ; id., Journ. As. Soc., Bengal, vol. xxvi, p. 412, 1851 ; Horsf. \& Moore, Cat. B. Mus. E. Ind. Co., vol. ii, p. 507, 1856 ; Gray, Cat. Mamm., \&c., Nepal, Coll. Hodgs., p. 56, 1863 ; Jerdon, B. Ind., vol. ii, p. 353, 1863 ; Godwin-Austen, Journ. As. Soc., Bengal, vol. xxxix, p. 110, 1870 ; Walden, Ibis, 1876, p. 177; Holdsw., Proc. Zool. Soc., 1872, p. 464; Blyth \& Walden, Journ. As. Soc., Bengal, vol. xliv, 1875, extra No., p. 92.

Lonchura melanocephala, Mc'Clell., Proc. Zool. Soc., 1839, p. 163.

Spermestes melanocephala, Hodgs., in Gray's Zool. Misc., p. 84, 1844; Blyth, Ann. Nat. Hist., vol. xii, p. 166, 1843. Munia malacea, (nec L.), Gray, Cat. Mamm, \&c., Nepal, Coll. Hodgs:, p. 106, 1846 ; Bp. Consp.,
t. i, p. 452, 1850 .

Amadina malacca, Gray, Gen. B., vol. ii, p. 370, 1849.

Munia sinensis, (nec L.), Reichenb., Handb. Singvögel, p. 39, tab. 14, figs. 123-24; Moore, Proc. Zool. Soc., 1859, p. 444.

Amadina sinensis, Mottley and Dillw., Contr. Nat. Hist., Labuan, p. 25, pl. vi, 1855.

Donacola atricapilla, Blyth, Ibis, 1870, p. 171.

Amadina atricapilla, Gray, Handl., B., vol. ii, p. 64, 1870.

Munia atricapilla, Salvad., Ucc. Born., p. 265, 1874; Hume, Stray Feathers, 1874, p. 481; id., op. cil., 1875, p. 155 ; id., Nests and Eggs, Ind. B., p. 444, 1875 ; Sharpe, Ibis, 1876, p. 50.
a. Mandalay, 26th September 1868.
b. c. d. t Muangla, 17th July 1868.
e. $f$.
y
, 
At Mandalay I found this species in small parties in the long grass, by the side of the large swamp behind the city, and at Muangla in flocks by the hedgerows.

\section{Munta punctularta, Linn.}

Le Grasbee tachelé de Java, Briss. Orn., t. iii, p. 239, pl. xiii, fig. 2, 1760.

Loxia punctularia, Linn., Syst. Nat., t. i, p. 302, 1766 ; Lath., Gen. Hist. B., vol. v, p. 247, 1822. Fringilla punctularia, Horsf., Trans. Linn. Soc., vol. xiii, p. 16, 1822.

Fringilla nisoria, Temm., Pl. Col., t. iii, pl. 500, fig. 2, 1825.

Amadina punctulata, Hay, Journ. As. Soc., Bengal, vol. xiv, p. 554, 1845 ; Gray, Gen. B., vol. ii, p. 370,1849 ; id., Handl. B., vol. ii, p. 56, 1870.

Munia punctularic, Blyth, Cat. B. Mus., As. Soc., Bengal, p. 117, 1849; Bonap. Consp., t. i, p. 452, 1850 ; Horsf. \& Moore, Cat. B. Mus. E. Ind. Co., vol. ii, p. 605, 1858; Jerdon, B. Ind., vol. ii, p. 1355, 1833; Blyth \& Walden, Journ. As. Soc., Bengal, vol. xliv, 1875, extra No., p. 93.

Oxycerca nisoria, Gray, Gen. B., vol. iii, App. p. 10, 1849.

Uroloncha punctularia, Cab., Mus. Hein., th. i, p. 174, 1850.

Munia punctulata, Hume, Stray Feathers, 1874, p. 481; id., Nests and Eggs, Ind. B., p. 444, 1875. Lonchura punctulata, Adam., Stray Feathers, 1873, p. 387 ; Ball, op. cit., 1874, p. 420; Hume, op. cit., 1875, p. 156.
a. t Bhamô, 9th September 1868.
c. \& Bhamô, 22nd February 1868.
d. t Momien, 1st June 1868.

In small flocks among the shrubby jungle outside Bhamô, but not common. I obtained only one specimen of this bird at Momien, among some low shrubs.

These birds would appear to present some slight differences on the ordinary race of birds from India. The margins and centres of the thoracic and abdominal feathers are reddish-brown and also larger and more elongately oval. They have the greyish slightly mottled rump, but the tail-coverts are almost greenish-gamboge, and the central tail feathers, which are rather ovately pointed, marked with the same colour. In two of the specimens of $M$. punctularia in the Indian Museum however, there is a faint indication of this. The shafts of all the feathers, with the exception of those of the wings, tail, lores, cheek, ear-coverts and throat, are pale coloured, giving the bird a markedly striated appearance, also strongly marked in other Museum specimens of this species. The markings differ from those of the next species, $M$. undulata, in a very marked way. In the latter, the outline of the feather is defined by a brownish-black line, with a white external margin, and two irregular transverse bands of the same colour divide the feather into two white spots. These transverse bands are sometimes confined to one-half of the feather, and they occasionally disappear or extend along each side of the shaft as a dark line. In $M$. punctularia, on the other hand, the marginal dark line is pale reddish-brown, and, as a rule, there is another of the same kind internal to it, and preserving the outline of the feather. It is interesting to observe that while this may be regarded as the general character of these feathers, those on the flanks and a few on the breast show a decided tendency to cross-barring. The transition from the dark 
internal outline band to the typical cross-bars of $M$. undulata can be traced on the flanks of this species.

\section{Munia undulata, Latham.}

The Cowry Bird, Edwards, Birds, vol.i, pl. xl, 1743.

Eastern Grosbeak, Latham, Gen. Syn. Suppl., p. 155, 1787.

Loxia undulata, Latham, Ind. Orn., vol i, p. 386, 1790.

Lonchura nisoria, Sykes, Proc. Zool. Soc., 1832, p. 94.

Munia lineoventer, Hodgson, Asiatic Researches, vol. xix, p. 154, 1836; id., in Gray's Zool. Misc., p. 84, 1844 .

Spermestes nisoria, Jerdon, Madr. Journ., vol. xi, p. 26, 1840.

Loxia punctularia, Pearson, Journ. As. Soc., Bengal, vol.x, p. 647, 1841.

Amadina punctularia, Blyth, Journ. As. Soc., Bengal, vol. xiii, p. 949, 1844; Strickl., Ann. Nat. Hist., vol. xiii, p. 38, 1844.

Munia punctularia, Gray, Cat. Mamm., \&c., Nepal, Coll. Hodgs., p. 106, 1846.

Amadina undulata, Blyth, Journ. As. Soc., Bengal, vol. xv, p. 37, 1846; Gray, Gen. B., vol. ii, p. 372,1849 ; id., Handl. B., vol. ii, p. 56, 1870.

Munia undulata, Blyth, Cat. B. Mus., As. Soc., Bengal, p. 116, 1849; Horsfield \& Moore, Cat. B., vol. ii, p. 506, 1856 ; Jerdon, B. Ind., vol. ii, p. 354, 1863 ; Holdsw., Proc. Zool. Soc., 1872, p. 464; Godwin-Austen, Journ. As. Soc., Bengal, vol. xxxix, p. 110, 1870.

Munia similaris, Stoliczka, Journ. As. Soc., Bengal, vol. xxxvii, 1868, p. 56 ; Walden, Ibis, 1869, p. 211.

a. ‡ Bhamô, 22nd February 1868.

The birds in Upper Burma appear to belong to this species, but Major GodwinAusten remarks that the Munipur birds agree with those from Burma in the possession of the Marquis of Tweedale, and he has separated these as M. subundulata. ${ }^{2}$ He considers the species to be allied to $M$. nisoria of Java.

\section{Genus Estrildda, Swainson.}

\section{Estrildda fLAVIdiventris, Wallace.}

Estrilda flavidiventris, Wallace, Proc. Zool. Soc., 1863, pp. 486, 495; W. Ramsay, Ibis, 1877, p. 461 .

Estrilda flavidiventris, Gray, Handl. B., vol. ii, 1870, p. 51.

Estrilda burmanica, Hume, Stray Feathers, vol. iv, 1876, p. 484; Oates, op.cil., 1877, p. 163.

a. Bhamô, 7th February 1868.

b. t Tsitkaw, 7th February 1875 .

c. Muangla, 8th May 1868.

d. e.f. Sanda, 29th July 1868.

g. h. o Momien, June 1868, 1st July 1868.

These specimens are perfectly undistinguishable from the types in the British Museum with which they have been compared.

It is not uncommon, but local about Tsitkaw at the foot of the Kakhyen hills in the valley of the Irawady. It extends into the high country to the east as far 
as Momien. At Bhamô and at Tsitkaw it occurred in considerable flocks, in dense shrubby jungle with long grass, and it was common at Sanda and Muangla in thick hedgerows outside these towns, being rare on the grassy hill sides surrounding Momien.

\section{Family-FRINGILLID $A$.}

\section{Genus Passe R, Linnæus.}

\section{Passer montanus, Linn.}

Mountain Sparrow, Edw., Glean. Nat. Hist., vol. ii, p. 124, pl. 269, 1760.

Le Moineau de montagne, Briss. Orn., t. iii, p. 79, 1760.

Le Moinean de campagne, Briss., l. c., p. 82.

Le Bouorenil de Hamboury, Briss., l. c., p. 314.

Fringilla montana, Linn., Syst. Nat., t. i, p. 324, 1766 ; Temm., Man. d’ Orn., t. i, p. 3ə̌4, 1820 ; Werner, Atlas Granivores, pl. xlii ; Yarrell, Br. B., vol. i, p. 469, 1843; Kjärb., Orn. Dan., pl. xxxvi, fig. 5, 1854; Sundev., Sv. Fogl., pl. v, fig. 7, 1856.

Le Friquet, Montb., Pl. Enl., t. iv, pl. 767, fig. 1, 1775.

Loxia hamburgia, Gm., Syst. Nat., t. i, p. 854, 1788.

Fringilla campestris, Schrank, Fauna Boica, th. i, p. 181, 1798-1803 ; Demid. Voy., Bd. iii, p. 180, 1840.

Passer montanina, Pall., Zoogr. Ross. As., t. ii, p. 30, 1811.

Passer montanus, Koch., Baier. Zool., Bd. i, p. 219, 1816 ; Steph., Gen. Zool., vol. xiv, p. 40, 1826 ; Selby, Ill. Br. Orn., vol.i, p. 300, 1833 ; Macgill, Br. B., vol. i, p. 351, 1837; Keys. \& Blas., Wirbelth. Eur., p. 157, 1840 ; Blyth, Journ. As. Soc., Bengal, vol. xiii, p. 947, 1844; vol. xiv, p. 553, 1845 ; id., Cat. B. Mus., As. Soc., Bengal, p. 120, 1849 ; Gray, Gen. B., vol. ii, p. 372, 1849 ; Bonap. Consp., t. i, p. 508, 1850 ; Cab., Mus. Hein., p. 156, 1851 ; Brehm, Naum., 1855, p. 277 ; Schleg., Vög. Nederl., vol. i, p. 162, 1858 ; Horsfield \& Moore, Cat. B. Mus. E. Ind. Co., p. 500, 1858 ; Schrenck, Reise, Amurl., p. 289, 1859 ; Jaub. \& Lapomm., Rich. Orn., p. 131, 1859 ; Linderm., Vög. Griechenl., p. 56, 1860; Jerd., B. Ind., vol. ii, p. 366, 1863; Radde, Reise, Sibir., p. 181, 1863; Degl. \& Gerbe, Orn. Eur., vol. i, p. 246, 1867; Doderl., Avif. Sicil., p. 75, 1869 ; Gray, Handl. B., vol. ii, p. 86, 1870 ; Fritsch., Vög. Eur., pl. xx, fig. 12, 1871 ; Heugl., Orn. N. O. Afr., vol. ii, p. 632, 1871 ; David, N. Arch. Mus., t. vii, Bull., p. 14, 1871 ; Swinhoe, Proc. Zool. Soc., 1871, p. 386 ; Salvad., Faun. Ital. Ucc., p. 146, 1872 ; Shelley, B. Egypt, p. 150, 1872 ; Gould, B. Brit., vol. iii, pl. xxxiii; Severtz., Turkest. Jevotn., p. 64, 1873; Hume, Lahore to Yarkand, p. 254, 1873; Stoliczka, Stray Feathers, 1874, p. 464; Hume, t. c., p. 481; Godwin-Austen, Journ. As. Soc., Bengal, vol. xliii, p. 171, 1874; Seebohm \& Brown, Ibis, 1876, p. 114; Scully, Stray Feathers, 1876, p. 165; Hume, t. c., p. 499; Schalow, Journ. für Ornith., 1876, r. 123; Taczanowski, t. c., p. 199; Oates, Stray Feathers, 1877, p. 163; Swinhoe, Ibis, 1877, p. 145; Hume, Nests and Eggs, Ind. Birds, p. 460, 1873; id., Stray Feathers, 1875, p. 157; Blyth \& Walden, Journ. As. Soc., Bengal, vol. xliv, 1875, extra No., p. 94, 1875 ; Dresser, B. Eur., pt. xlvi, 1875; Blanford, E. Persia, p. 255, 1876.

Pyrgita montana, Cuv., Règne Anim., t. i, p. 385, 1817 ; Boie, Isis, 1822, p. 554; Gould, B. Eur., vol. iii, pl. 184, fig. 2, 1837 ; Hodgs., in Gray's Zool. Misc., p. 84, 1844; Gray, Mamm. and B. Nepal, Coll. Hodgs., p. 107, 1846 ; Bettoni, Uce. Lomb., tav. 9, 1865 ; Filippi, Viagg. Pers., p. 349, 1865 ; Loche, Expl. Sci. Algér. Ois., t. i, p. 136, 1867; Walden, Tr. Zool. Soc., vol. ix, p. 206,1875 .

Pyrgita campestris, Brehm, Vög. Deutschl., p. 267, 1831.

Pyrgita septentrionalis, Brehm, l. c., p. 268. 
Passer arboreus, Blyth, Rennie's Field Naturalist, vol. i, p. 467, 1833.

$$
\begin{aligned}
& \text { a. t Bhamô, 6th February } 1868 . \\
& \text { b. } \delta \text { Ponsee, 26th March } 1868 . \\
& \text { c. d. } \quad \text {, 26th May } 1868 . \\
& \text { e. ठ Manwyne, 12th May } 1868 . \\
& \text { f.g. h. \& Momien, 3rd July } 1868 . \\
& i \text {. } \quad \text { 3rd July } 1868 .
\end{aligned}
$$

This is the common sparrow in the Kakhyen hills and in the country to the east, building under the thatch of the Kakhyen roofs and under the eaves of the Chinese houses, and in all these localities it is as abundant as sparrows generally are around human habitations in Asia and Europe.

\section{Passer flaveoulus, Blyth.}

Passer flaveolus, Blyth, Journ. As. Soc., Bengal, vol. xiii, p. 946, 1844; Bonap. Consp., Gen. Av., p. 508, 1850 ; id., Journ. As. Soc., Bengal, vol. xxxi, p. 344, 1862 ; Gray, Handl. B., vol. ii, p. 86, 1870; Hume, Stray Feathers, 1874, p. 481; id., Nests and Eggs, Indian Birds, p. 460, 1873; id., Stray Heathers, 1875, p. 156; Blyth \& Walden, Journ. As. Soc., Bengal, vol. xliv, extra No., 1875, p. 94.

a. Mengoon, 16th January 1868.

This bird is apparently not common in Upper Burna, but it is more prevalent to the south, Mr. Oates recording it at Thayetmyo to be nearly as common as $P$. indicus.

\section{Passer cinnamomeus, Gould.}

Pyrgita cinnamomea, Gould, Proc. Zool. Soc., 1835, p. 185.

Passer cinnamomeus, Blyth, Journ. As. Soc., Bengal, vol. xi, p. 108, 1842 ; vol. xiii, p. 947, 1844; id., Cat. B. Mus., As. Soc., Bengal, p. 119, 1849 ; Gray, Gen. B., vol. ii, p. 373, 1849; Bonap. Consp., t. i, p. 508, 1850 ; Horsf. \& Moore, Cat. B. Mus. E. Ind. Co., vol. ii, p. 500, 1854; Jerdon, B. Ind., vol. ii, p. 265, 1863 ; Stoliczka, Journ. As. Soc., Bengal, vol. xxxvii, 1868, p. 57 ; Gray, Handl. B., vol. ii, p. 86, 1870 ; Hume \& Hender., Lahore to Yarkand, p. 252, pl. xxv, 1873; Cock. \& Marsh., Stray Feathers, 1873, p. 357; Brooks, op. cit., 1875, p. 254; Hume, Nests and Eggs, Ind. Birds, p. 459, 1875.

a. b. c. d. t Momien, 31st May 1868, 1st and 6th June 1868.

$$
\text { e.f. } \quad, \quad 30 \text { th May 1868, 2nd June } 1868 .
$$

Common in the fields outside the city, in long grass and hedgerows.

\section{Genus EmbERIZA, Linnæus.}

\section{Emberiza aureola, Pallas.}

Emberiza aureola, Pall., Reis. Russ. Reichs., p. 711, 1773; id., Zoogr. Ross.-As., t. ii, p. 52, 1811 ; Gould, B. Eur., vol. iii, pl. 174, 1837; Fritsch., Vög. Eur., tab. 20, fig. 1; Schrenk, Reis. Amurl., p. 277, 1859; Jaub. \& Barth., Lap. Rich. Orn., p. 153, pl. x, 1859; 
Radde, Reis. Ost. Sibir., p. 157, taf. iv, figs. a-h, 1863 ; Bree, B. Eur., vol. iii, p. 60, 1866 ; Sharpe \& Dresser, B. Eur., pt. iv, 1871 ; Finsch., Ibis, 1877, pp. 54, 55.

Passerina aureola, Vieill., Nat. Dict., t. xxv, p. 6, 1817; Degl. \& Gerbe, Orn. Eur., Bd. i, p. 301, 1867; Salvad., Faun. Ital. Ucc., p. 137, 1871.

Passerina collaris, Vieill., N. Dict., t. xxv, p. 6, $181 \%$.

Emberiza selysi, Verany, Atti. del Congres. Scient. Ital. Napoli., 1848.

Mirafra flavicollis, Mc'Clell., Proc. Zool. Soc., 1839, p. 163; Gray, Gen. B., vol. ii, p. 383, 1844.

Euspiza aureola, Gray, Gen. B., vol. ii, p. 376, 1844; Hodgs., in Gray's Zool. Misc., p. 84, 1844; Bonap. Consp., t. i, p. 468, 1850 ; Blyth, Journ. As. Soc., Bengal, vol. xxiii, p. 732, 1854; Gray, Cat. Mamm. \&c., Nepal, Coll. Hodgs., p. 108, 1856 ; Horsf. \& Moore, Cat. B. Mus. E. Ind. Co., vol. ii, p. 487, 1856 ; Jerdon, B. Ind., vol. ii, p. 380, 1863 ; Gray, Handl. B., vol. ii, p. 112, 1870 ; Swinhoe, Proc. Zool. Soc., 1871, p. 3£7; Hume, Stray Feathers, 1874, pp. 250, 481 ; Blyth \& Walden, Journ. As. Soc., Bengal, vol. xliv, 1875, extra No., p. 94; Hume, Stray Feathers, 1875, p. 159 ; Godwin-Austen, Journ. As. Soc., vol. xlv, 1876, p. 83.

Emberiza dolichonia, Bonap., Atti della sett. Adun. Sci. Ital., 1845, p. 715.

Euspiza Alavogularis, Blyth, Journ. As. Soc., Bengal, vol. xviii, pp. 86, 811, 1849 ; id., Cat.'B. Mus., As. Soc., Bengal, p. 129, 1849 ; Bonap. Consp., t. i, p. 468, 1850.

Hypocentor aureolus, Cab., Mus. Hein., t. i, p. 131, 1850.

a. む b. c. Bhamô, February 1868.

I observed this species only on two occasions, about the middle of February, in large flocks, in long grass, in the immediate neighbourhood of recently reaped rice-fields.

\section{Emberiza fucata, Pallas.}

Emberiza fucata, Pall., Reis. Prov. Russ. Reich., th. iii, p. 698, 1776; id., Zoogr. Rosso.-As., t. ii, p. 52, 1811; Blyth, Journ. As. Soc., Bengal, vol. xi, p. 601, 1842; vol. xiii, p. 957, 1844; Gray, Gen. B., vol. ii, p. 377, 1844; Temm. \& Schl., Faun. Jap. Aves, pl. Ivii, 1850; Bonap. Consp., t. i, p. 464, 1850 ; Fritsch., Vög. Eur., taf. 20, fig. 6, 1860 ; Jerdon, B. Ind., vol. ii, p. 375, 1863; Swinhoe, Proc. Zool. Soc., 1871, p. 388; Godwin-Austen, Journ. As. Soc., Bengal, 1874, p. 171 ; Stoliczka, Journ. As. Soc., Bengal, vol. xxxvii, 1848, p. 58 ; Hume, Stray Feathers, 1876, p. 224 ; Taczanowski, Journ. für Ornith., Bd. xxiv, 1876, p. 198.

Emberiza lesbia, Gould, B. Eur., vol. iii, pl. 178, 1837.

Euspiza fucata, Blyth, Cat. B. Mus., As. Soc., Bengal, p. 129, 1849; Journ. As. Soc., Bengal, vol. xxiii, p. 215, 1854; Horsf. \& Moore, Cat. B. Mus. E. Ind. Co., vol. ii, p. 488, 1854; Blyth \& Walden, Journ. As. Soc., Bengal, vol. xliv, 1875, extra No., p. 95.

Hypocentor fucatus, Cab., Mus. Hein., Bd. i, p. 181, note, 1850.

Onychospina fucata, Bp., C. R., vol. xxxvii, 1853, p. 919 ; Rev. Mag. Zool., 1857, vol. ix, p. 162.

Citrinella fucata, Gray, Handl. B., vol. ii, p. 113, 1870 ; Hume, Stray Feathers, 1875, p. 157 ; id., Nests and Eggs, Ind. B., p. 465, 1873.

$$
\text { a. b. ᄒ Momien, 3rd June } 1868 .
$$

In small flocks by the hedgerows, on the grassy hill sides; not common.

\section{Emberiza pusilla, Pallas.}

Emberiza pusilla, Pall., Reis. Russ. Reichs., p. 697, 1773 ; Gray, Gen. B., vol. ii, p. 377, 1844; Blyth, Cat. B. Mus., As. Soc., Bengal, p. 130, 1849 ; Bonap. Consp., t. i, p. 464, 1850; 
Midd., Sibir. Reis., p. 148, taf. xiii, fig. 4, 1851 ; Schl., Vög. Nederl., pl. 147, 1854; Jaub. \& Barth., Lap. Rich. Orn., p. 163, pl. , 1859; Sehrenk, Reis. Amurl., p. 289, 1859; Fritsch., Vög. Eur., tab. 20, fig. 3 ; Sundev., Sv. Fogl., pl. lxv, fig. 5 ; Schl., Dier. Nederl. Vög., pl. xv, fig. 9, 1.861 ; Radde, Reis, Ost.-Sibir. Orn., p. 171, 186.3 ; Jerdon, B. Ind., vol. ii, p. 376, 1863 ; Stoliczka, Journ. As. Soc., Bengal, vol. xxxvii, 1868, p. 59 ; Swinhoe, Proc. Zool. Soc., 1871, p. 389 ; Hume, Stray Feathers, 1874, pp. 490, 497 ; id., 1876, pp. 279, 291 ; Seebohm \& Brown, Ibis, 1876, p. 116; Gätke, Journ. für Ornith., vol. xxiv, 1876, p. 99; Ibis, 1876, p. 128; Finsch., Ibis, 1877, pp. 57, 62, 64; Seebohm, t. c., p. 157; W. Ramsay, t. c., p. 462 .

Emberiza durazzi, Bonap., Taun. Ital. Ucc., pl. xxxvi, fig. 1, 1832-41.

Ocyris oinopus, Hodgs., in Gray's Zool. Misc., p. 84, 1844; id., Proc. Zool. Soc., 1845, p. 35 ; Horsf. \& Moore, Cat. B. Mus. E. Ind. Co., vol. ii, p. 488, 1856 ; Gray, Cat. Mamm., \&c., Nepal, Coll. Hodgs., p. 58, 1863.

Emberiza sordida, Hodgs., Journ. As. Soc., Bengal, vol. xiii, p. 958, 1844.

Emberiza oinopus, Gray, Cat. Mamm., \&c., Hodgs., 1856, p. 108.

Buscarla pusilla, Bonap., Rev. et Mag. de Zool., 1857, p. 163, pl. ix.

Cynchramus pusillus, Degl. \& Gerbe, Orn. Eur., Bd. i, p. 327, 1867.

Citrinella pusilla, Gray, Handl. B., vol. ii, p. 115, 1870.

Euspiza pusilla, Blyth \& Walden, Journ. As. Soc., Bengal, vol. xliv, 1875, extra No., p. 95, 1875.

a. है Ponsee, 16th March 1868.

b.,$\quad$ April 1868.

This species was not uncommon on the terraces of paddy cultivation and in the bush-jungle surrounding these and the village of Ponsee, the only locality where it was obtained.

\section{Genus MeL o PH Us, Swainson.}

\section{Melophus melanicterus, Gmelin.}

Mainean de Macao, Buffon, Hist. Nat. des Oiseaux, t. iv, 1777, pl. 224, fig. I.

Fringilla melanictera, Gm., Syst. Nat., t. i, p. 910, 1788, ex Buff.

Emberiza erythroptera, Jard. \& Selby, Ill. Orn., pl. 132, 1825-39.

Emberiza cristata, Vig., Proc. Zool. Soc., 1831, p. 35; Sykes, Proc. Zool. Soc., 1832, p. 93; Blyth, Journ. As. Soc., Bengal, vol. xi, p. 602, 1842.

E:nberiza lathami, J. E. Gray, Zool. Misc., p. 2, 1831.

Emberiza subcristata, Sykes, Proc. Zool. Soc., 1832, p. 93.

Emberiza nipalensis, Hodgs., As. Res., voll. xix, p. 157, 1836 ; id., in Gray’s Zool. Misc., p. 84, 1844.

Melophus erythropterus, Swainson, Classif. B., vol. ii, p. 290, 1837.

Euspiza lathami, Gray, Gen. B., vol. ii, p. 376, 1844; Blyth, Journ. As. Soc., Bengal, vol. xiii, p. 957, 1844; id., Cat. B. Mus., As. Soc., Bengal, p. 129, 1849 ; Gray, Cat. Mamm., \&c., Nepal, Coll. Hodgs., p. 107, 1846; id., Handl. B., vul. ii, p. 112, 1870.

Melophus melanicterus, Bonap. Consp., t. i, p. 470, 1850; Horsf. \& Moore, Cat. B. Mus. E. Ind. Co., vol. ii, p. 489, 1856 ; Jerdon, B. Ind., vol. ii, p. 381, 1863 ; G. King, Journ. As. Soc., Bengal, vol. xxxvii, 1868, p. 216 ; Swinhoe, Proc. Zool. Soc., 1871, p. 387; Hume, Stray Feathers, 1873, p. 47; Cock. \& Marsh., t. c., p. 357; Hume, t. c., p. 388; Brooks, op. cit., 1875, p. 254; Butler, t. c., p. 498 ; Godwin-Austen, Journ. As. Soc., Bengal, 1874, p. 171 ; Blyth \& Walden, Journ. As. Soc., Bengal, vol. xliv, 1875, extra No., p. 95 ; Butler, 
Stray Feathers, 1876, p. 37; Hume, Stray Feathers, 1876, p. 224; Fairbank, l. c., p. 261; W. Ramsay, Ibis, 1877, p. 462.

a. Bhamô, 22nd February 1868.

b. c. d. Ponsee, 2nd April 1868, 19th April 1868, 25th April 1868.

e. Sanda, 26th July 1868 .

This bird occurs rarely at Bhamô, but at Ponsee it is not uncommon in small parties of four or seven. It fed regularly on the old rice terraces below our camp, and when disturbed used to betake itself to the low shrubs close by. At Sanda, I found it in and about low shrubby patches, on the grassy hill sides behind the town.

Family-ALAUDID $A E$.

\section{Genus A l A U D A, Linnæus.}

\section{Alauda gulgula, Franklin.}

Alauda gulgula, Frankl., Proc. Zool. Soc., 1831, p. 119; Jerdon, Madr. Journ., xi, p. 30, 1840 ; Blyth, Journ. As. Soc., Bengal, vol. xi, p. 201, 1842, vol. xiii, p. 96, 1844; id., Cat. B. Mus., As. Soc., Bengal, p. 132, 1849; Bonap. Consp., t. i, p. 245, 1850 ; Layard, Ann. Nat. Hist., (2), vol. xiii, p. 27, 1854; Jerdon, B. Ind., vol. ii, p. 434, 1863 ; Stoliczka, Journ. As. Soc., Bengal, vol. xxxvii, 1868, p. 64; G. King, t. c., p. 216 ; Gray, Handl. B., vol. ii, p. 117, 1870; Holdsw., Proc. Zool. Soc., 1872, p. 465; Henderson \& Hume, Lahore to Yarkand, p. 269, pl. xxix, 1873; Adam., Stray Feathers, 1873, p. 389; Hume, t.c., p. 420 ; Brooks, t. c., p. 484; Ball, Stray Feathers, 1874, p. 440; Stoliczka, t. c., p. 463; Hume, Nests and Eggs, Ind. B., p. 486, 1875 ; Blyth \& Walden, Journ. As. Soc., Bengal, vol. xliv, 1875, extra No., p. 95, 1875 ; Butler, Stray Feathers, 1876, pp. 2, 39 ; Hume, Stray Feathers, 1876, p. 224; Armstrong, t.c., p. 337; Godwin-Austen, Journ. As. Soc., Bengal, vol. xlv, 1876, p. 83 ; Dresser, 1bis, 1876, p. 181 ; Oates, Stray Feathers, 1877, p. 163 ; Blanford, $t$. c., p. 247 ; Hume, t. c., p. 329.

Alauda gracilis, Blyth, Journ. As. Soc., Bengal, vol. xi, p. 20, 1842 ; id., Ann. Nat. Hist., vol. xii, p. 166, 1843.

Alauda gangetica, Blyth, Journ. As. Soc., Bengal, vol. xii, p. 181, 1843 ; id., Ann. Nat. Hist., vol. xii, p. 165, 1843.

Alauda leiopus, vel orientalis, Hodgs., in Gray's Zool. Misc., p. 84, 1844; Gray, Cat. Mamm., \&e., Nepal, Coll. Hodgs., p. 108, 1856.

Alauda arvensis, Sundev., Ann. Nat. Hist., vol. xviii, p. 259, 1846.

Alauda leiopus, Blyth, Journ. As. Soc., Bengal, vol. xxiii, p. 215, 1854.

Alanda malabarica, Horsf. \& Moore, Cat. B., vol. ii, p. 467, 1856, (nec Sykes).

Alauda celivox, Swinhoe, As. Soc. Journ., North China Br., 1859, Zool. 1859, p. 6793 ; Ibis, 1860, p. 62 ; et p. 132 ,p. 429 ; 1861, p. 46 ; 1867, p. 227 ; 1870, p. 354; Proc. Zool. Soc., 1863, p. 89 , p. 272 ; 1871, p. 389 ; Severtzoff, Stray Feathers, 1875, p. 424.

Alauda inconspicua, Severtzoff, Turkest. Jevotn., 1873, pp. 67, 142.

Alauda peguensis, Oates, Stray Feathers, 1875, p. 343.

a. b. c. Sanda and Momien, May and June 1868.

This is the common lark in the high country to the east of the Kakhyen hills. 


\section{Genus Alatdula, Horsfd. \& Moore.}

66. Alaudula raytal, Blyth.

Alauda raytal, Blyth, Journ. As. Soc., Bengal, vol. xiii, p. 962, (1844, ex Buch. Ham. MSS.); id., Journ. As. Soc., Bengal, vol. xv, p. 40, 1846 ; Gray, Handl. B., vol. ii, p. 119, 1870.

Calandrella raytal, Blyth, Cat. B. Mus., As. Soc., Bengal, p. 132, 1849.

Mirafra raytal, Gray, Gen. B., vol. iii, App. p. 18, 1844.

Alauda pispoletta, Bonap. Consp., t. i, p. 244, (1850, nec Pall.).

Alaudala raytal, Horsf. \& Moore, Cat. B. Mus. E. Ind. Co., vol. ii, p. 471, 1856 ; Jerdon, B. Ind., vol. ii, p. 428, 1863; Stoliczka, Journ. As. Soc., Bengal, vol. xxxvii, 1868, p. 64; Godwvin-Austen, Journ. As. Soc., Bengal, vol. xliii, 1874, p. 171; Hume, Stray Feathers, 1875, p. 159; id., Nests and Eggs, Ind. B., p. 481, 1873 ; Blyth \& Walden, Journ. As. Soc., Bengal, vol. xliv, 1875, extra No., p. 95, 1875; Hume, Stray Feathers, 1877, p. 327, footnote.

a.b. 하 오 Yaylaymaw, January 1875 .

\section{Genus Mrrafra, Horsfield.}

\section{Mirafra assamica, Me'Clelland.}

Mirafra assamica, Mc'Clell., Proc. Zool. Soc., 1839, p. 162 ; Blyth, Journ. As. Soc., Bengal, vol. xi, p. 199, 1842 ; vol. xiii, F. 958, 1844; Gray, Gen. B., vol. ii, p. 383, 1844; Bonap. Consp., t. i, p. 243, 1850; Blyth, Journ. As. Soc., Bengal, vol. xxiv, p. 259, 1855; Horsf. \& Moore, Cat. B. Mus. E. Ind. Co., vol. ii, p. 476, 1856 ; Jerdon, B. Ind., vol. ii, p. 416, 1863 ; Gray, Handl. B., vol. ii, p. 121, 1870 ; Godwin-Austen, Journ. As. Soc., Bengal, vol. xxxix, 1870, p. 272 ; id., vol. xlv, 1876, p. 83; Ball, Stray Feathers, 1874, p. 421; Hume, Nests and Eggs, Ind. Birds, p. 473, 1873; Blyth \& Walden, Journ. As. Soc., Bengal, vol. xliv, 187.5, ex. No., p. 75.

Mirafra assamensis, Blyth, Ann. Nat. Hist., vol. xii, p. 166, 1843; id., Cat. B. Mus., As. Soc., Bengal, p. 134, 1849.

Plocealauda typica, Hodgs., in Gray's Zool. Misc., p. 84, 1844.

irafra javanica, Gray, Cat. Mamm., \&c., Nepal, Coll. Hodgs., p. 109, 1856.

a. 우 b. ㅎ Bhamô, July 1868 .

This lark is not uncommon about Bhamô.

Family-MOTACILLID 2 .

Genus Corydalia, Vigors.

68. Corydalia richardi, Vieillot.

Anthus richardi, Vieill., Nat. Dict. d'Hist. Nat., t. xxvi, p. 492, 1818 ; Temm.; Man. d'Orn., p. 263, 1820 ; id., Pl. Coll., vol. iii, p. 101, 1824; Vigors, Zool. Journ., vol. i, p. 4ill, pl. xiv, 1825; Roux, Orn. Provenc., pls. 189, 190, 1825 ; Werner, Atlas, Insectivores, pl. lxxxiii, 1827 ; Gould, B. Eur., vol. ii, pl. 135, 1837 ; Macgill, Brit. B., vol. ii, p. 199, 1839; Demidoff, Voy. Russ. Mérid., vol. iii, p. 358, 1840 ; Gray, Cat. Mamm., \&c., Hodgs., Nepal, p. 46, 1846 ; id., Gen. B., vol. i, p. 206, 1847 ; Blyth, Cat. B. Mus., As. Soc., Bengal, p. 135, 1849; - Schl., Vög. Nederl., pl. xciii, 1854; Sundev., Sv. Fogl., p. 42, pl. xlvi, fig. 5, 1858 ; Fritsch., Vög. Eur., 
tab. 16, fig. 4, 1860 ; Blas., Nactr. Naum. Vög. Deutschl., vol. xiii, p. 94, pl. 371, figs. 3, 4, 1860 ; Doderl., Avif. Sicil., p. 97, 1869 ; Droste, Vög. Bork., p. 104, 1869; Borggr., Vogel-f. Norddeutschl., p. 86, 1869 ; Gray, Handl. B., vol. i, p. 252, 1869 ; Salvad., Faun. Ital., p. 128, 1871 ; Gould, B. Gt. Br., vol. iii, pl. viii, 1872 ; Hastings, Handb. Br. B., p. 24, 1874; Dresser, B. Eur., pt. 26, 1874; Newt. ed. Yarrell, Br. B., vol. i, p. 206, 187 t.

Anthus longipes, Hollandre, Faune de la Moselle, p. 84, 1825.

Corydalla richardi, Vig., Zool. Journ., vol. ii, p. 397, 1826 ; Bonap. Consp., t. i, p. 24.7, 1850 ; Cab., Mus. Hein., th. i, p. 15, 1850 ; Jaub. et Barth., Lap. Rich. Orn., p. 287, 1858; Jerdon, B. Ind., vol. ii, p. 231, 1863; Degl. \& Gerbe, Orn. Eur., Bd. i, p. 363, 1867; Loche, Expl.-sci. Alger., ii, p. 11, 1867 ; Swinhoe, Proc. Zool. Soc., 1871, p. 366 ; Holdsw., Proc. Zool. Soc., 1872, p. 458; Brooks, Stray Feathers, 1873, p. 358; Hume, op. cit., 1874, pp. 239, 497 ; Ball, t. c., p. 417; Blyth \& Walden, Journ. As. Soc., Bengal, vol. xliv, ex. No., p. 95, 1875; Scully, op. cit., 1876, p. 152; Armstrong, t.c., p. 330 ; Prejew., in Rowley's Orn. Misc., pt. vi, p. 195, 1877.

Anthus ricardi, Yarr., Br. B., vol. i, p. 398 ; Stephenson, B. Norf., p. 168.

Anthus macronyx, Gloger, Handb. Vög. Eur., p. 269, 1834.

Anthus rupestris, Ménétr., Cat. Rais. Cauc., p. 37, 1839.

Cichlops monticolus, Hodgs., in Gray's Zool. Misc., p. 83, 1844.

Corydalla sinensis, Bonap. Consp., t. i, p. 247, 1850.

Corydalla orientalis, Brehm, Naum., 1856, p. 463.

Corydalla russelti, Brehm, l. c., p. 463.

Agrodroma richardi, Doderl., Avif. Sicil., p. 333, 1869.

Corydalla chinensis, Swinhoe, Proc. Zool. Soc., 1871, p. 366.

a. Muangla, 2nd May 1868.

b. 오 Momien, 2nd June 1868.

Common on the grassy hills behind Muangla and around Momien.

\section{Corydalla ubiquitaria, Hodgson.}

Anthus agilis, Jerdon, Madr. Journ., vol. xi, p. 33, (1840, nec Sykes.)

Anthus malayensis, Blyth, Journ. As. Soc., Bengal, vol. xi, pp. 797, 885, 1842, (nec Eyton.)

Cichlops ubiquitarius, Hodgs., in Gray's Zool. Misc., p. 83, 1844.

Cichlops fortipes, Hodgs., l. c., p. 83, 1844.

Anthus ubiquitarius, Gray, Cat. Mamm., \&c., Nepal, Hodgs., p. 77, 1846.

Anthus fortipes, Gray, l. c., p. 77, 1846.

Anthus rufulus, Blyth, Cat. B. Mus., As. Soc., Bengal, p. 135, 1849 ; (nec. V.) Bonap. Consp., t. ii, p. 248, 1850 ; Horsf. \& Moore, Cat. B. Mus. E. Ind. Co., vol. i, p. 357, 1854; Gray, Handl. B., vol. i, p. 252, 1869.

Corydalla rufula, Jerdon, B. Ind., vol. ii, p. 233, 1863; Stoliczka, Journ. As. Soc., Bengal, vol. xxxvii, 1868, p. 48 ; Holdsw., Proc. Zool. Soc., 1872, p. 458; Brooks, Stray Feathers, 1873, p. 359; Adam., t. c., p. 384; Ball, op. cit., 1874, p. 416 ; Hume, t. c., p. 497; id., op. cit., 1875, p. 142; Brooks, t. c., pp. 252, 278 ; Butler, t. c., p. 490 ; Blyth \& Walden, Journ. As. Soc., Bengal, vol. xliv, 1875, ex. No., p. 96 ; Hume, Nests and Eggs, Ind. Birds, p. 384, 1873 ; Fairbank, Stray Feathers, 1876 ; Butler, t. c., pp. 221, 260, 401; Armstrong, t. c., p. 330 ; Hume, t.c., pp. 341, 458.

a. Mandalay, 26th September 1868.

b. c. Bhamô, July 1868 and 31st December 1875, on Sand Flats,

d. Muangla, 21st May 1868.

Common in all these localities, 
Genus Pipastes, Kaup.

\section{Pipastes maculatus, Hodgson.}

Anthus arboreus (nec Bechst.), Jerdon, Madr. Journ., vol. xi, p. 11, 1840 ; Gray, Cat. Mamm., \&c., Nepal, Hodgs., p. 76, 1846 ; Midd., Sibir. Reis., t. ii, p. 153, 1853 ; Schrenk, Reis. Amurl., p. 335,1860 ; Radde, Reis. Sibir., t. ii, p. 223, 1862.

Anthus maculatus, Hodgs., in Gray's Zool. Misc., p. 83, 1844; Cab., Mus. Hein., th. i, p. 15, 1850 ; Bonap. Consp., t. i, p. 248, 1850 ; Ball, Stray Feathers, 1874, p. 416; A. Anders., op. cit., 1875 , p. 353 ; Brooks, op. cit., 1876, p. 278.

Anthus brevirostris, Hodgs.; in Gray's Zool. Misc., p. 83, 1844.

Anthus trivialis, Blyth, Journ. As. Soc., Bengal, vol. xvi, p. 432, 1847 (nec. L.)

Dendronanthus maculatus, Blyth, Cat. B. Mus., As. Soc., Bengal, p. $135,1849$.

Anthus agilis, Horsf. \& Moore, Cat. B. Mus. E. Ind. Co., vol. i, p. 354, 1854; Gray, Handl. B., vol. i, p. 251, 1869.

Pipastes agilis, Jerdon, B. Ind., vol. ii, p. 228, 1863 ; Grould, B. Asia, pt. 18, 1865 ; Swinhoe, Proc. Zool. Soc., 1871, p. 360 ; Adam., Stray Feathers, 1873, p. 384; Hume, Lahore to Yarkand, p. 226, 1873 ; id., Stray Feathers, 1874, p. 479 ; 1875, p. 142 ; id., Nests and Eggs, Ind. B., p. 382, 1873 ; Fairbank, Stray Feathers, 1876, p. 260 ; Taczan., Bull. Soc. Zool., France, t. i, p. 159, 1876 ; Prejew., in Rowley's Orn. Misc., pl. vi, p. 195, 1877.

Pipastes maculatus, Brooks, Stray Feathers, 1875, pp. 250, 277 ; Butler, t. c., p. 490 ; Blyth \& Walden, Journ. As. Soc., Bengal, vol. xliv, 1875, ex. No., p. 96; Armstrong, Stray Feathers, 1876, p. 338 ; Butler, op. cit., 1877, p. 230 ; Ball, t.c., p. 417.

a. b. Mengoon,14th January 1868.

c. d. Bhamô, 19th and 22nd February 1868.

e.f.g. h. Ponsee, 12th, 18th, and 25th March 1868, 20th April 1868.

i. t Right bank of Tapeng, 5th February 1875.

$k$. ㅇ On the way to Ponline, Kakhyen hills, 17th February 1875.

\section{Genus Budrtes, Cuvier.}

\section{Budytes. viridis, Bonap.}

The Green Wagtail, Brown, Ill. Zool., p. 86, pl. xxxiii, fig. 2, 1876.

Motacilla viridis, Gm., Syst. Nat., t. i, p. 962, 1788, ex Brown ; Gray, Gen. B., vol. i, p. 203, 1847; id., Handl. B., vol. i, p. 247 ; Dresser, B. Eur., pt. xl, 1875.

Motacilla flava, Roux, Orn. Prov., pl. 196, 1825.

Motacilla cinereocapilla, Savi, Nuovo Giorn. delle Lett., p. 190 ; id., Orn. Tosc., 1. iii, p. 216, 1831 ; Kjärb., Orn. Dan., pl. xix, fig 4, 1854.

Budytes cinereocapilla, Bonap., Comp. B. Eur. \& N. Amer., p. 19, 1838 ; Fritsch., Vög. Eur., taf. 17, fig. 16, 1860 ; Gould, B. Gt. Br., vol. iii, pl. v ; Swinhoe, Proc. Zool. Soc., 1871, p. 364; Shelley, B. Egypt, p. 129, 1872; Hume, Stray Feathers, 1876, p. 260.

Motacilla flava, var. borealis, Sundev., K. Vet. Akad. Forh. Stockh., 1840, p. 53; id., Sv. Fogl., pl. ix, fig. 6, 1858.

Motacilla flava cinereocapilla, Schl., Rev. Crit., p. xxxviii, 1844; Heugl., Orn. N. O. Afr., p. $321,1870$.

Budytes nigricapilla (pt.), Bonap. Consp. Av., t. i, p. 249, 1850.

Budytes viridis, Bonap. Consp., t. i, p. 250, 1850 ; Horsf. \& Moore, Cat. B. Mus. E. Ind. Co., vol. i, p. 350, 1854; Jerdon, B. Ind., ii, p. 222, 1863 ; Stoliczka, Journ. As. Soc., Bengal, 
vol. xxxvii, 1868, p. 48 ; Godwin-Austen, Journ. As. Soc., Bengal, xxxix, p. 271, 1870 ; Adam, Stray Feathers, p. 384; Salvad., Uec. Born., p. 260, 1874; Blyth \& Walden, Journ. As. Soc., Bengal, vol. xliv, 1875, ex. No., p. 96 ; Dresser, Ibis, 1878, p. 178; Godwin-Austen, Journ. As. Soc., Bengal, vol. xlv, 1876, p. 81; Fairbank, Stray Feathers, 1876, p. 260; Brooks, Ibis, 1877, p. 208.

Budytes atricapillus, Brehm, Vogelf., p. 141, 1855.

Budytes flava, $\beta$ cinereocapilla, Severtzoff, Turkest. Jevotn., 1873, p. 67.

$$
\begin{aligned}
& \text { a. b. t Bhamô, 2lst January } 1868 \text { and 8th February } 1868 . \\
& \text { c. } \quad \text { Ponsee, 1lth March } 1868 .
\end{aligned}
$$

In a male shot on the 21st January 1868, the head to the shoulders and the sides of the face and neck are greenish cinereous, with an olive tinge on the crown and side of the neck; the rest of the upper plumage is greenish-olive. 'The lores are darker than the rest of the head, and the supercilium is white, most distinctly marked behind the eye. The chin, throat and neck white, tinged with bright yellow, and the breast albescent, with faint greyish cinereous and bright yellow. All the remaining under parts bright yellow. Thigh coverts dusky, tinged with yellow.

\section{Budytes calcaratus, Hodgson.}

Budytes calcarata, Hodgs., Asiat. Researches, vol. xix, p. 190, 1836 ; Gray, Cat. Mamm., \&c., Nepal, Coll. Hodgs., p. 76, 1846; Hume, Stray Feathers, 1874, p. 479; Blyth \& Walden, Journ. As. Soc., Bengal, vol. xliv, 1875, ex. No., p. 96 ; Hume, Nests and Eggs, Ind. B., p. 382, 1873 ; Fairbank, Stray Feathers, 1876, p. 260.

Budytes citreoloides, Hodgs., in Gray's Zool. Misc., p. 83, 1844; Gould, B. Asia, pt. 18, 1865 ;

Stoliczka, Journ. As. Soc., Bengal, vol. xxxix, 1868, p. 48; Hume \& Henders., Lahore to

Yarkand, p. 224, 1873; Hume, Stray Feathers, 1873, p. 202 ; Adam., t. c., p. 384; Butler, op. cit., 1875, p. 490 ; 1876, p. 39.

Budytes citreola, Jerdon, B. Ind., vol. ii, p. 225, 1863 ; Gray, Cat. Hodgs. Coll., 1863, p. 39.

Motacilla citreoloides, Gray, Handl. B., vol. i, p. 247, 1869; Dresser, Ibis, 1876, p. 178.

Budytes atreola, var. melanota, Severtzoff, Turkest. Jevotn., 1873, p. 67.

a. b. t $q$ Bhamô, February 1868.

c. d. t o Tsitkaw, 6th February 1875.

\section{Genus Motacilla, Linnæus.}

\section{Motacilla Luzonensis, Scop.}

La Bergonette à collier de l’ isle de Lucon, Sonn., Voy. N. Guin., p. 61, pl. xxix, 1776.

Motacilla luzonensis, Scop., Del. Flor. et Faun. Insubr., t. ii, p. 95, 1786 ; Gray, Gen. B., vol. i, p. 203, 1847 ; id., Cat. Mamm., \&c., Nepal, Coll. Hodgs., p. 75, 1846 ; Blyth, Journ. As. Soc., Bengal, vol. xvi, p. 429, 1847 ; id., Cat. B. Mus., As. Soc., Bengal, p. 137, 1849 ; Bonap. Consp., t. i, p. 250, 1850 ; Horsf. \& Moore, Cat. B. Mus. E. Ind. Co,, vol. i, p. 348, 1854; Jerdon, B. Ind., vol. ii, p. 218, 1863; Gray, Handl. B., vol. i, p. 246, 1869; Godwin-Austen, Journ. As. Soc.; Bengal, vol. xxxix, p. 108, 1870 ; Henders. \& Hume, Lahore to Yarkand, p. 223, 1873 ; Ball, Stray Feathers, 1873, p. 73 ; 1874, p. 415; Hume, op. cit., 1874, p. 237; 1875, p. 142 ; 1876, p. 291 ; id., Nests and Eggs, Ind. B., p. 380, 1873 ; Blyth \& Walden, Journ. As. Soc., Bengal, vol. xliv, 1875, ex. No., p. 96 ; W. Ramsay, Ibis, 1877, p. 462. 
Motacilla alboides, Hodgs., Asiatic Researches, vol. xix, p. 191, 1836.

Motacilla leucopsis, Gould, Proc. Zool. Soc., 1837, p. 78 ; Swinhoe, Proc. Zool. Soc., 1870, p. 121. Motacilla felix, Swinhoe, Proc. Zool. Soc., 1870, p. 121.

Motacilla alboides, var. 1, felix, Swinhoe, Proc. Zool. Soc., 1871, p. 363.

Motacilla alboides, var. 2, schuenensis, Swinhoe, l.c., p. 363.

\section{a. 。 우 Bhamô, January and February 1868.}

Common at Bhamô, but I did not observe it between Ponsee, Momien and Hotha.

\section{Motacilla maderaspatensis, Gmelin.}

La Bergeronnette de Madras, Briss. Orn., t. iii, p. 478 ; Buff., Pl. Enl., t. vi, 1783, p. 158.

Motacilla maderaspatensis, Gm., Syst. Nat., t. i, p. 961, 1788; Jerdon, Madr. Journ., vol. xi, p. 10, 1840 ; Gray, Gen. B., vol. i, p. 203, 1847 ; Gould, B. Asia, pt. 5, 1853.

Motacilla variegata, Steph., Gen. Zool., vol. xiii, pt. 2, p. 234; Sykes, Proc. Zool. Soc., ]832, p. 91 ; McClell., Proc. Zool. Soc., 1839, p. 161.

Motacilla picata, Frankl., Proc. Zool. Soc., 1831, p. 119.

Motacilla maderaspatana, Blyth, Journ. As. Soc., Bengal, xvi, p. 428, 1846 ; Cab., Mus. Hein., th. i, p. 137, 1850 ; Bonap. Consp., t. i, p. 251, 1850 ; Layard, Ann. Nat. Hist., 1853, p. 268; Horsf. \& Moore, Cat. B. Mus. E. Ind. Co., i, p. 347 ; Jerdon, B. Ind., vol. ii, 1863, p. 217 ; Stoliczka, Journ. As. Soc., Bengal, vol. xxxix, 1868, p. 48 ; Gray, Handl. B., vol. i, p. 246 ; Ball, Stray Feathers, 1873 ; Severtzoff, Turkest. Jevotn., 1873, pp. 66, 415 ; Godwin-Austen, Journ. As. Snc., Bengal, xliii, p. 168, 1874; ; Hume, Stray Feathers, 1874, p. 26 ; id., t. c., p. 47 ; Brooks, op. cit., 1875, p. 246 ; Butler, t.c., p. 489 ; Fairbank, op. cit., 1876, p. 260 ; Dresser, Ibis, 1876, p. 177.
a. Tapeng, 29th February 1868.
b. Sanda, 15th May 1868.
c. ㅇ Momien, 3rd May 1868.
d. ᄒ, 30 th May 1868.

The young female is greyish cinereous on the back with a dash of olive-green. The black is appearing on the rump and forehead and over the white supercilium: and the chin, throat, and breast are dusky. The rest of the under surface is white. The quills are dusky black, and the central tail feathers are dull black: The male is younger than the female, and shows no black on the upper parts. The quills and central tail feathers are the same as in the female.

This was the common wagtail in the Sanda and Momien valleys.

\section{Family-HENICURID在.}

\section{Genus Henicu R Us, Agassiz.}

\section{Henicurus immaculatus, Hodg.}

Enicurus immaculatus, Hodgs., Asiat. Res., vol. xix, p. 190, 1836 ; id., Gray’s Zool. Miscell., p. 83, 1844; Gray, Cat. Mamm., \&c., Nepal., Coll. Hodgs., p. 76, 1846 ; Blyth, Journ. As. Soc., Bengal, vol. xvi, p. 157, 1847; id., Cat. B. Mus., As. Soc., Bengal, p. 159, 1849; Bonap. Consp., t. i, p. 251, 1850; Horsf. \& Moore, Cat. B. Mus. E. Ind. Co., vol. i, p. 346, 1854; Jerdon, 
B. Ind., vol. ii, p. 213, 1863; Godwin-Austen, Journ. As. Soc., Bengal, vol. xxxix, 1870, p. 107 ; id., op. cit., vol. xlv, 1876, p. 80 ; Hume, Stray Feathers, 1875, p. 141 ; id., op. cit., 1877, p. 37.

Henicurus immaculatus, Elwes, Ibis, 1872, p. 254.

\section{a. Bhamô, February 1868.}

The Calcutta Museum possesses specimens of this species from Cachar and Arakan. Hodgson first discovered it in Nepal. Elwes has observed it in Sikhim, and Godwin-Austen in the Khási and Dafla hills; and Hume records it from Upper Pegu and Cachar.

\section{Family-TURDIDA.}

\section{Genus Monticola, Boie.}

\section{Monticola cyanea, Linn.}

Le Merle blen, Briss. Orn., t. ii, p. $298,1760$.

Turdus cyanus, Linn., Syst. Nat., t. i, p. 296, 1766; Werner, Atlas Insectivores, pl. xx ; Crespon, Orn. du Gard., p. 106, 1840; Gray, Gen. B., vol. i, p. 219, 1847; Bailly, Orn. Savoie, t. ii, p. 225, 1853; Gray, Handl. B., vol. i, p. 260, 1869.

Le Merle solitaire, Montb., Pl. Enl., t. iv, pl. 250, 1785.

Turdus solitarius, Lath., Ind. Orn., vol. i, p. 345, 1790.

Monticola cyana, Boie, Isis, 1822, p. 552 ; Heugl., N. O. Afr., i, p. 371, 1869 ; Shelley, B. Egypt, p. 70, 1872 ; Salvad., Faun. Ital. Ucc., p. 85, 1872 ; Blanf., E. Persia, p. 155, 1876.

Sylvia solitaria, Savi, Orn. Tose., t. i, p. 217, 1827.

Petrocossyphus cyaneus, Boie, Isis, 1828, p. 319 ; Bonap. Consp. List, B. Eur. and N. Amer., p. 16, 1838 ; id., Consp. Gen. Av., i, p. 297, 1850 ; Brehm, Naum., 1855, p. 281 ; Jerdon, B. Ind., vol. i, p. 511, 1863 ; Bettoni, Ucc. Lomb., t. i, pl. 1, 1865 ; Loche, Expl. Sci. Algér. Ois., t. i, p. 194, 1867; Stoliczka, Journ. As. Soc., Bengal, vol. xxxvii, 1868, p. 34; Godwin-Austen, Journ. As. Soc., Bengal, vol. xxxix, p. 102, 1870 ; Sharpe \& Dresser, B. Eur., pt. viii, 1871; Hume, Lahore to Yarkand, p. 190, 1873; Irby, B. Gibr., p. 74, 1873 ; Hume, Stray Feathers, 1873, p. 48 ; Ball, t. c., p. 69 ; Hume, t. c., p. 179; Cock. \& Marsh., t. c., p. 353 ; Adam., t. c., p. 377 ; Gould, B. Brit., ii, pl. xliii, 1873 ; Brooks, Stray Feathers, 1875, p. 236 ; Blyth \& Walden, Journ. As. Soc., Bengal, vol. xliv, 1875, ex. No., p. 99 ; Dresser, Ibis, 1875, p. 335 ; Legge, Stray Feathers, 1876, p. 249 ; Fairbank, t. c., p. 257 ; id., t.c., p. 398 ; Wharton, Ibis, 18i6, p. 23; W. Ramsay, op. cit., 1877, p. 462.

Petrocincla cyanea, Gould, B. Eur., vol. ii, pl. lxxxvii, 1837 ; Jaub. \& Lapomm., Rich. Orn., p. 220, 1859; Doderl., Avif. Sicil., p. 109 ; Bree, B. Eur., vol. i, p. 199, 1866 ; Degl. \& Gerbe, Orn. Eur., t. i, p. 447, 1867; Blanf., Geol. \& Zool. Abyss., p. 357, 1870 ; David, N. Arch. Mus., t. vii, Bull., p. 6, 1871; Swinhoe, Proc. Zool. Soc., 1871, p. 368 ; David, Journ. Voy. en Chin., 1875 , t. ii, p. 68 .

Petrocichla cyana, Keys. \& Blas., Wirbelth, Eur., p. 176, 1840 ; Linderm., Vög. Griechenl., p. 83, 1860.

Turdus azureus, Crespon, Faun. Mérid., p. 179, 1844.

Petrocincla longirostris, Blyth, Journ. As. Soc., Bengal, vol. xvi, p. 150, 1847.

Petrocichla cyane, Severtzoff, Turkest. Jevotn., p. 65, 1873.

Cyanocincla cyana, Hume, Stray Feathers, 1874, p. 220 ; Ball, t.c., p. 407 ; Butler, op. cit., 1875, p. 470 ; Hume, Nests and Eggs, Ind. B., p. 226, 1873 ; Butler, Stray Feathers, 1876, p. 34 ; id., op. cit., 1877, p. 220 ; Hume, t. c., p. 420.

a. ซ b. 오 Bhamô, February 1868. 
I shot these two specimens in the low shrubby jungle outside the town of Bhamô. The male is not fully grown, and the blue feathers of the head, chin, and neck are tipped with pale rufous. The blue is duller than in a full-grown example of this species from Italy. In another and adult male from Cachar, with a slightly shorter bill than the European bird, there is hardly any perceptible difference of colour between them, but if anything, the blue of the Cachar bird is slightly deeper than that of the European bird. In another young male from Cachar the blue is decidedly duller than in the adult, and the tips of the feathers of the under-surface and back are faintly banded dark-brown and pale-grey, or even white on the under tail coverts; and, in another and still younger male from the same locality, the black bands on the forehead and lores are rounded spots, with rufous margins, occupying the whole of the exposed portion of the feather. On drawing the feathers aside they are seen to be quite as blue as in the adult male, but without the iridescence. On the chin and throat the exposed portions of the feathers are finely banded pale rufous, tipped with dark-brown. There is a faint indication of a pale mesial line on the chin and upper part of the throat, which is well defined in the female. The bills of these two are shorter than the bill of the European bird. In a male from Nágpur, Central Prôvinces of India, the bill is the same length as in Cachar birds, and the feathers of the under-surface are banded dark-brown and white at their tips, and faintly so on the middle of the back; the feathers of the forehead and crown are broadly tipped with brown.

In an adult male from Leh, the bill is long, like the European bird, but hardly perceptibly longer than that of a female from Nágpur, the bill of which is longer than that of a male from the same locality. The blue of the Leh bird is quite as pale as the European one. The colors of the female are as variable as those of the male. All the Western Himalayan birds I have seen are lighter coloured and longer billed than the eastern forms, but I have pointed out the existence of long-billed birds as far south as Nágpur. The birds from Bengal to the Irawady are short-billed, and, as a rule, duller than those to the west, although I have indicated that light-coloured birds also occur in Cachar. Blyth's $M$. longirostris, which he now regards as merely a variety of $M$, cyaneus, has a very long, but not a deep, bill. It seems to me that $M$. manillensis is distinct from $M$. cyaneus, although Blyth regarded them as the same. The former is paler than the latter, and, in young birds, the terminal three banding of the feathers is very marked both dorsally and ventrally, and the head and neck to the shoulders are so broadly banded that nearly all the blue is hidden. On the breast, there are only two bands, a white and a terminal brown one, the former being the most prominent. There is a slight intermixture of blue. On the abdomen, the blue is replaced by rich chestnut, banded at the tip with a broad band of white, succeeded by a narrower brown line. The under tail coverts are rich chestnut, tipped narrowly with white. 
Genus Copsrchus, Wagler.

\section{Copsychus saularis, Wagler.}

Dial Bird, Albin, N. H. Birds, vol. iii, pl. xvii, 1740.

Little Indian Pye, Edwards, N. H. Birds, vol. iv, pl. 181, 1751.

Gracula saularis, Linn., Syst. Nat., t. i, p. 165, 1766.

Le Cadrau, Levaill., Ois. d’Afr., t. iii, p. 50, pl. 109, 1800 ; Sundev., Cirt. Orn. Levaill., p. 36, 1856.

Copsychus saularis, Wagler, Syst. Av. nov. gen. Gracula, 1827; Blyth, Journ. As. Soc., Bengal, vol. xi, p. 889, 1842 ; Gray, Gen. B., vol. i, p. 177, 1846 ; Blyth, Cat. Brit. Mus., As. Soc., Bengal, p. 166, 1849 ; Bonap. Consp., t. i, p. 267, 1850 ; Horsf. \& Moore, Cat. B. Mus. E. Ind. Co., vol. i, p. 275, 1854; Selby, Proc. Zool. Soc., 1861, p. 186 ; Jerdon, B. Ind., vol. ii, p. 114, 1863; Gould, B. Asia, pt. xvii, 1868; Stoliczka, Journ. As. Soc., Bengal, vol. xxxvii, 1868, p. 40 ; King, t. c., p. 215; Gray, Handl. B., i, p. 266, 1869; Swinhoe, Proc. Zool. Soc., 1871, p. 359 ; Hume, Nests and Eggs, Ind. B., p. 303, 1874; id., Stray Feathers, 1874, pp. 230, 477; 1875, p. 133 ; Butler, t.c., 1876, p. 38 ; Fairbank, t.c., p. 259; Armstrong, t.c., p. 327; Hume, op. cit., 1877, pp.415, 458, p. 35 ; Oates, t.c., p. 157 ; Butler, p. 229 ; t. c., p. 322 ; Hume, t. c., p. 329 ; Fairbank, t.c., p. 406 ; David, Journ. Voy. en Chin., t. ii, 1875, p. 143.

Turdus saularis, Sykes, Proc. Zool. Soc., 1832, p. 87.

Gryllivora saularis, Swains., Zool. Illustr., vol, ii, pl. lxi.

Gryllivora intermedia, Swains., Ann. in Menag., p. 291, 1837; Jerdon, Madr. Journ., vol. x, p. $263,1839$.

Gryllivora magnirostris, Swains., l. c., p. 291, 1837.

Gryllivora rosea, Swains, l. c., p. 342.

Dahila docitis, Hodgs., As. Res., xix, p. 186, 1836.

Kittacincla melanolenca, Less., Rev. Zool., 1840, p. 354.

Polypeira docilis, Hodgs., Journ. As. Soc., Bengal, vol. x, p. 28, 1841.

Copsychus mindanensis (nee. Gm.), Blyth, Journ. As. Soc., Bengal, vol. xvi, p. 139, 1843; id., Cat. B. Mus., As. Soc., Bengal, p. 166, 1849 ; Bonap. Consp., t. i, p. 267, 1850 ; Horsf. \& Moore, Cat. B. Mus. E. Ind. Co., vol. i, p. 27., 1854; Gould, B. Asia, pl. xvii; Selby, Proc. Zool. Soc., 1861, p. 186 ; Gray, Handl. B., vol. i, p. 265, 1869; Hume, Stray Feathers, 1873, p. 459.

Copsychus ceylonensis, Selby, Proc. Zool. Soc., 1861, p. 186 ; Gray, Handl. B., vol. i, p. 266, 1869; Holdsw., Proc. Zool. Soc., 1872, p. .

Copsychus roseus, Gray, Handl. B., vol. i, p. 177, 1869.

a. o Upper Burma, 2lst January 1868.

b. t Muangla, Sanda Valley, 18th May 1868.

This is not a very common bird, although by no means rare. I observed it in the Kakhyen hills and to the eastward, as far as Sanda.

\section{Genus Chimarrhornis, Agassiz.}

78. Chimarrhornis leucocephata, Vigors.

Phonicura lencocephala, Vigors, Proc. Zool. Soc., 1830, p. 35 ; Gould, Cent. Himal, B., pl. xxvi, fig. 1, 1832.

Ruticilla leucocephala, Less., Rev. Zool., 1840, p. 265 ; Gray, Cat. Mamm., \&c., Nepal, Hodgs., p. 34, 1846 ; id., Gen. B., vol. i, p. 180, 1846 ; Blyth, Journ. As. Soc., Bengal, vol. xvi, p. 134, 
1847 ; id., Cat. B. Mus., As. Soc., Bengal, p. 169, 1849 ; Bonap. Consp., t. i, p. 296 , 1850 ; Moore, Proc. Zool. Soc., 1854, p. 30 ; Horsf. \& Moore, Cat. B. Mus. E. Ind. Co., vol. i, p. 309, 1854; Gray, Handl. B., vol. i, p. 220, 1869.

Chomarrhornis leucocephalus, Hodgs., in Gray's Zool. Misc., p. 82, 1844; Jerdon, B. Ind., vol. ii, p. 143, 1863; Stoliczka, Journ. As. Soc., Bengal, vol. xxxvii, 1868, p. 44; Godwin-Austen, Journ. As. Soc., Bengal, 1870, p. 106 ; Swinhoe, Proc Zool. Soc., 1871, p. 358 ; Henders. \& Hume, Lahore to Yarkand, p. 214, 1873 ; Blyth \& Walden, Journ. As. Soc., Bengal, vol. xliv, 1875, extra No., p. 101; Brooks, Stray Feathers, 1875, pp. 226, 240; A. Anderson, $t$. c., p. 355 ; Godwin-Austen, Journ. As. Soc., Bengal, vol. xlv, 1876, p. 79.

a. b. t Second defile of the Irawady, 5th March 1875. Burma.

The foregoing is the only locality in which I observed this species in Upper

Genus Cranedula, Brehm.

\section{Cyanecula suecica, Latham.}

La Gorge-bleu, Briss. Orn., t. iii, p. 413, 1760 ; D’Aub., Pl. Enl., t. vi, pl. 610, fig. 2, 1783.

Motacilla suecica, Linn., Syst. Nat., t. i, p. 336, 1766.

Sylvia suecica, Lath., Ind. Orn., vol. ii, p. 521, 1790 ; Demid., Voy. Russ. Mérid., p. 135, 1840 ;

Kjärb., Orn. Dan., pl. xxii B., fig. 5, 1851.

Sylvia cyanecula, Wolf, Taschenb. Deutsch. Vög. i, p. 240, 1810, pt. .

Motacilla carulecula, Pall., Zoogr. Rosso-As., t. i, p. 480, 1811.

Saxicola suecica, Koch, Baier. Zool., t. i, p. 189, 1816, pt.

Ficedula suecica, Boie, Isis, 1822, p. 553.

Curruea suecica, Selby, Tr. Nat. Hist. Soc., Northumb., p. 255, 1831.

Cyanecula suecica, Brehm, Vög. Deutschl., p. 350, 1831 ; Gray, Gen. B., vol. i, p. 182, 1846; Blyth, Cat. B. Mus., As. Soc., Bengal, p. 167, 1849; Bonap. Consp., t. i, p. 296, 1850 ; Cab., Mus. Hein., th. i, p. i, 1850 ; Horsf. \& Moore, Cat. B. Mus. E. Ind. Co., vol. i, p. 311, 1854; Jaub. et Barth., Lap. Rich. Orn., p. 235, 1858 ; Fritsch., Vög. Eur., tab. xxiii, figs. 6, 9, 1858; Jerdon, B. Ind., vol. ii, p. 152, 1863; Degl. et Gerbe, Orn. Eur., i, p. 4'34, 1867 ; Loche, Expl. Sci. Alger. Ois., t. i, p. 322, 1867 ; Stoliczka, Journ. As. Soc., Bengal, vol. xxxvii, 1868, p. 45 ; Doderl., Avif. Sicil., pp. 116, 338, 1869; Gray, Handl. B., vol. i, p. 223, 1869 ; Heugl., Orn. N. O. Afr., t. i, p. 336, 1869 ; Salvad., Faun. Ital. Ucc., p. 93, 1871 ; Holdsw., Proc. Zool. Soc., 1872, p. 454; Gould, B. Gt. Br., ii, pl. xliv, 1872 ; Harting, Handl. Br. B., p. 104, 1872 ; Shelley, B. Egypt, p. 85, 1870 ; Hume \& Henders., Lahore to Yarkand, p. 214, 1873; Dresser, B. Eur., pt. 26, 1874; Blyth \& Walden, Journ. As. Soc., Bengal, vol. xliv, 1875, ex. No. p. 101 ; Ball, Stray Feathers, 1875, p. 293 ; Oates, t. c., p. 337 ; Butler, p. 478 ; id., op. cit., 1876, p. 35 ; Scully, t. c., p. 145 ; Ball, p. 233 ; Fairbank, t. c., pp. 259, 266 ; Nehrkorn, Journ. für Ornith., 1876, p. 156 ; Seebohm \& Brown, Ibis, 1876, p. 125 ; Finsch., op. cit., 1877, p. 49; W. Ramsay, t. c., 1877, p. 463; Butler, Stray Feathers, 1877, p. 229.

Cyanecula orientalis, Brehm, Vög. Deutschl., p. 351, 1831.

Phanicura suecica, Sykes, Proc. Zool. Soc., 1832, p. 92 ; Selby, Ill. Brit. Orn., i, p. 195, 1833; Gould, B. Eur., vol. ii, pl. xevii, 1837 ; Jerdon, Madr. Journ., vol. x, p. 267, 1839; Stephenson, B. Norfolk, p. 96, 1866.

Pandicilla suecica, Blyth, Field Nat., vol. i, p. 291, 1833.

Ruticilla cyanecula, Macgill, Br. B., vol. ii, p. 300, 1839.

Lasciola suecica, Keys. \& Blas., Wirb. Eur., p. lviii, 1840 ; Schl., Vög. Nederl. Ind., pl. Ixxxvi, fig. 2, pl. Ixxxvii, 1854.

Lusciola (Cyanecula) orientalis, Schl., Rev. Crit., p. 32, 1844.

Calliope suecoides, Hodgson, in Gray's Zool. Misc., p. 83, 1844. 
Cyanecula suecoides, Hodgson, $t$. c., p. 83, 1844.

Erythacus suecica, Degl., T. Orn. Eur., i, p. 543, 1849.

Cyanecula carulecula, Cab., Mus. Hein., th. i, p. 1, 1850 ; Gray, Handl. B., vol. i, p. 223, 1869 ;

Swinhoe, Proc. Zool. Soc., 1871, p. 359; Tacz., Bull. Soc. Zool., France, t. i, p. 143, 1876 ;

Przew., in Rowley's Orn. Misc., pt. vi, p. 180, 1877.

Cyanecula dichrosterna, Cab., Mus. Hein., th. i, p. 1, 1850.

Sylvia suecica, var. carulecula, Midd., Sibir. Reis., Bd. ii, p. 177, 1853.

Cyanecula cyane, Bonap., Cat. Parz., p. 5, 1856.

Luscinia suecica, Sundev., Sv. Fogl., pl. xii, figs. 6, 7, 1858.

Insciola suecica, var. carulecula, Radde, Reis. Sibir., p. 253, 1863.

Sylvia carulecula, Bree, B. Eur., vol. ii, p. 10, 1867.

Ruticilla suecica, Newb. et. Yarr., Br. B., i, p. 321, 1873.

a. ㅇ. Tsitkaw, 14th February 1875 .

\section{Genus Calltope, Gould.}

\section{Calliope kamschatkensis, Gmelin.}

Motacilla calliope, Pall., Reis. Russ. Reichs., t. iii, p. 697, 1776.

Kamtschatka Thrush, Lath., Gen. Syn., p. 28, 1783, et Suppl., vol. ii, frontsp., 1787.

Turdus camtschatkensis, Gm., Syst. Nat., t. i, p. 817, 1788, ex Lath.

Accensor calliope, Temm., Man. d'Orn., t. iii, p. 174, 1835.

Melodes calliope, Keys. \& Blas., Wirb. Eur., p. lviii, 1840.

Calliope lathami, Gould, B. Eur., vol. ii, pl. xiv, 1837; Blyth, Journ. As. Soc., Bengal, vol. xi, p. 112, 1842.

Cyanecula calliope, Gray, Gen. B., vol. i, p. 152, 1846.

Calliope camtschatkensis, Blyth, Journ. As. Soc., Bengal, vol. xvi, p. 134, 1847 ; id., Cat. B. Mus., As. Soc., Bengal, p. 169, 1849 ; Bonap. Consp., t. i, p. 295, 1850 ; Horsf. \& Moore, Cat. B. Mus. E. Ind. Co., vol. i, p. 313, 1854; Jaub. \& Barth., Lap. Rich. Orn., t. 236, 1859 ; Jerdon, B. Ind., vol. ii, p. 150, 1863; Degl. \& Gerbe, Orn. Eur., t. i, p. 464, 1867 ; Homeyer, Journ. f. Orn., 1868, p. 161 ; Swinhoe, Proc. Zool. Soc., 1871, p. 359 ; Ball, Stray Feathers, 1873, p. 413 ; Hume, op. cit., 1874, p. 478; id., t.c., 1875, p. 135; t.c., 1876, p. 135; Walden, Trans. Zool. Soc., vol. ix, p. 194; Ball, t. c., 1877, p. 233 ; Taczanowski, Journ. für Orn., 1876, p. 192 ; Dresser, Ibis, p. 76, 1878.

Erythacus calliope, Degl., Orn. Eur., i, p. 514, 1849.

Sylvia calliope, Midd., Sibir. Reis. Zool., p. 174, pl. xv, fig. 2, 1851.

Lusciola calliope, Schrenk, Reis. Amurl., p. 359, 1859; Radde, Reis. Sibir. Orn., p. 248, 1863.

Cyanecula cantschatkensis, Gray, Handl. B., vol. i, p. 224, 1869.

$$
\text { a. Bhamô, February } 1868 .
$$

In thick shrubby jungle outside the town.

\section{Calltope pectoralis, Gould.}

Calliope pectoralis, Gould, Icones Avium, pl. iv; Blyth, Journ. As. Soc., Bengal, vol. xii, p. 934, 1843 ; vol. xvi, p. 135, 1847 ; id., Cat. B. Mus., As. Soc., Bengal, p. 169 ; Bonap. Consp., t. i, p. 295, 1850 ; Horsfield \& Moore, Cat. B. Mus. E. Ind. Co., vol. i, p. 313, 1854; Jerdon, B. Ind., vol. ii, p. 151, 1863; Stoliczka, Journ. As. Soc., Bengal, vol. xxxvii, 1868, p. 45 ; Blanford, Journ. As. Soc., Bengal, vol. xli, p. 52, 1872; Brooks, t. c., p. 77 ; id., Stray Feathers, 
1875, p. 241 ; Hume, Nests and Eggs, Ind. Birds, p. 325, 1873; Severtzoff, Stray Feathers, 1875 ; p. 429 ; Godwin-Austen, Journ. As. Soc., Bengal, vol. xlv, 1876, p. 79 ; Dresser, Ibis, 1876, p. 78.

Bradybates pectoralis, Gray, Gen. B., vol. i, p. 181, 1846.

Cyanecula pectoralis, Gray, Handl. B., vol. i, p. 224, 1869.

Calliope ballioni, Severtzoff, Turkest. Jevotn., 1873, pp. 65, 122; Stray Feathers, 1875, p. 429;

Dresser, Ibis, 1876, p. 78.

a. † Bhamô, Upper Burma, 27th February 1868.

b. \& Ponsee, 13th March 1868.

The male is in full winter plumage. The female, however, does not present any trace of white on the base of the tail, but in every other respect it agrees with the females of this species.

Severtzoff obtained this species in Turkestan, Jerdon records it from Kashmir and Sikhim, and in the Calcutta Museum it is represented from Cachar. It has recently been observed by Godwin-Austen in the Dafla hills, Assam, and these specimens extend its distribution to the valley of the Upper Irawady and to the frontier of Yunnan.

\section{Genus Pratincola, Koch.}

82. Pratincola Jerdoni, Blyth.

Rhodophila melanoleuca, Jerdon, B. Ind., vol, ii, pp. 128, 872 ; Gould, B. Asia, pt. xviii. Oreicola jerdoni, Blyth, Ibis, 1867, p. 14 .

Saxicola jerdoni, Gray, Handl. B., vol. i, p. 227.

a. b. c. d. ‡ Bhamô, 23rd January 1868, 1st and 6th February 1868.

e. t Bhamô, 20th January 1875.

$f \cdot g$. of Tsitkaw (Tapeng), 6th February 1875.

Not uncommon at Bhamô. It has much the habits of a Pratincola, and I usually found it perched on long grass on the outskirts of some open space.

I have carefully measured the length of the bill of this species, and find that it is no longer than the bills of some Pratincole, if so long as some, such as P. caprata and $P$. ferrea. The nostrils of Pratincole, such as $P$. caprata and others, appear to me to be quite as much entitled to be called longitudinal as that of Rhodophila, and I fail to detect that the nostrils are more impeded by narial tufts than Pratincola. The slight rounding of the tail over that which prevails in Pratincola cannot of itself be regarded as a generic character. There is the same difference between the sexes as prevails in Pratincola. The female is uniform rufous-brown above, the rufous more marked on the lower back and upper tail coverts. Wing coverts, quills and tail brown, the two secondaries and coverts margined with rufous. A faint hardly perceptible greyish supercilium. Chin and throat white. Breast pale rufouscinereous, passing into pale rufous on the flanks and the thigh coverts and round the vent. Under tail coverts dirty white. 


\section{Pratincola ferrea, Hodgson.}

Rubecula ferrea, Hodgs., in Gray's Zool. Misc., p. 83, 1844.

Saxicola ferrea, Gray, Cat. Mamm., \&c., Coll. Hodgs., p. 71, 1846; id., Gen. B., vol. iii, App.p. 8, 1849.

Pratincola ferrea, Blyth, Journ. As. Soc., Bengal, vol. xvi, p. 129, 1847 ; id., Cat. B. Mus., As. Soc., Bengal, p. 170, 1849 ; Bonap. Consp., t. i, p. 305, 1850; Horsfield \& Moore, Cat. B. Mus. E. Ind. Co., i, p. 286, 1854; Jerdon, B. Ind., vol. ii, p. 127, 1863; Stoliczka, Journ. As. Soc., vol. xxxvii, 1868, p. 41; Gray, Handl. B., vol. i, p. 228, 1869 ; Henders. \& Hume, Lahore to Yarkand, p. 205, pl. xii, 1873 ; Hume, Stray Feathers, 1874, p. 478 ; id., op. cit., 1875, p. 135 ; op. cit., 1876, p. 36 ; id., Nests and Eggs, Ind. Birds, p. 318, 1873 ; Brooks, Stray Feathers, 1875, p. 239.

a.-c. t d. ㅇ Ponsee, 1st and 3rd May 1868.

I observed this Pratincola only on the Ponsee hills, where it is far from being common. These specimens agree in every way with undoubted examples of this species; but I have two specimens from Simla identified by Dr. Stoliczka, in which the black centres are very feebly developed, and the feathers of the head, neck, back and wing coverts are tipped with earthy brown. This is more marked in one specimen than in the other, and the former has a number of white feathers on the forehead. All the tail quills of the first specimen are more or less tipped with rufous.

\section{Pratincola caprata, Horsfield.}

Le Traquet de l’isle de Luçon, Briss. Orn., t. iii, p. 442, pl. xxiv, figs. 2, 3, 1760.

Motacilla caprata, Linn., Syst. Nat., i, p. 335, 1766, ex Briss.

Saxicola fruticola, Horsfield, Tr. Linn. Soc., vol. xiii, p. 157, 1820.

Saxicola bicolor, Sykes, Proc. Zool. Soc., p. 92, 1832.

Saxicola erythropygia, Sykes, Proc. Zool. Soc., p. 92, 1832.

Motacilla sylvatica, Tickell, Journ. As. Soc., Bengal, ii, p. 575, 1833.

Saxicola caprata, Jerdon, Madr. Journ., vol. x, p. 265, 1839; Gray, Gen. B., vol. i, p. 179, 1846 ; id., Cat. Mamm., \&c., Nepal, p. 71, 1846.

Pratincola caprata, Blyth, Journ. As. Soc., Bengal, vol. xvi, p. 129, 1847; id., Cat. B. Mus., As. Soc., Bengal, p. 169, 1849; Bonap. Consp., t. i, p. 305, 1850; Horsfield \& Moore, Cat. B. Mus. E. Ind. Co., vol. i, p. 284, 1854; Jerdon, B. Ind., vol. ii, p. 124, 1863 ; Stoliczka, Journ. As. Soc., Bengal, vol. xxxvii, 1868, p. 407; Gray, Handl. B., vol. i, p. 228, 1869; Elwes, Ibis, 1870, p. 527 ; Walden, Proc. Zool. Soc., vol. viii, p. 63, 1871 ; Salvad., Ucc. Born., p. 252, 1874; Ball, Stray Feathers, 1874, p. 413; Hume, t.c., p. 477; id., op. cit., 1875, p. 134; id., Nests and Eggs, Ind. B., p. 314, 1873 ; Walden, Proc. Zool. Soc., vol. ix, p. 193, 1875 ; Butler, Stray Feathers, 1876, p. 39 ; Fairbank, t. c., p. 259 ; Butler, op. cit., 1877, p. 229.

Saxicola melaleuca, Hodgs., in Gray's Zool. Misc., p. 183, 1844.

Pratincola atrata, Blyth, Journ. As. Soc., Bengal, vol. x, p. 177; Jerdon, B. Ind., vol. ii, p. 124, 1863 ; Gray, Handl. B., vol. i, p. 228, 1869.

Pratincola bicolor, Hume, Nests and Eggs, Ind. B., p. 314, 1875.

$$
\begin{array}{ll}
\text { a.c. t d.e. } & \text { o Upper Burma. } \\
f . g . h . & \text { t Bhamô, 18th to 23rd February } 1868 . \\
i . & \text { क Yaylaymaw, 7th January } 1875 . \\
\text { i. } & \text { क Momien, June } 1868 .
\end{array}
$$


Very common on the outskirts of long grass, or on shrubs in the open. I did not observe it on the Kakhyen hills, although it is very common at Tsikkaw at their base, on the Burmese side, and it appears to extend to the valleys on the Chinese face of those hills, as I shot a female at Momien.

The Calcutta Museum possesses a young female of this species from the north of Simla. The general colour is a light cinereous brown vinaceous, rufescent on the breast, passing into pale rufescent buff on the abdomen. The head, neck, back, chin, throat and breast are spotted with white, the spots small on the upper parts, and large on the hinder surface. It is smaller than the general average of Indian birds.

\section{Fratincola indica, Blyth.}

Saxicola rubicola, Sykes, Proc. Zool. Soc., p. 91, 1832.

Saxicola saturatior, Hodgs., in Gray's Zool. Misc., p. 83, 1844.

Pratincola indica, Blyth, Journ. As. Soc., Bengal, vol. xvi, p. 129, 1847 ; id., Cat. B. Mus., As. Soc., Bengal, p. 170, 1849 ; Bonap. Consp., p. 305, 1850; Gould., B. Asia, pt. xv, pl. xii, 1863 ; Jerdon, B. Ind., vol. ii, p. '124, 1863 ; Beavan, Ibis, 1867, p. 446 ; Gray, Handl. B., i, p. 228, 1869 ; Blanford, Ibis, 1870, p. 466; Godwin-Austen, Journ. As. Soc., Bengal, vol. xxxix, p. 106, 1870 ; Swinhoe, Proc. Zool. Soc., 1871, p. 360 ; Cock. \& Marsh., Stray Feathers, 1873, p. 355; Stol., op. cit., 1874, p. 464; Ball, t.c., p. 413; Butler, op. cit., 1875, p. 475; Blyth \& Walden, Journ. As. Soc., Bengal, vol. xliv, 1875, extra No., p. 102, 1875; Butler, Stray Feathers, 1876, p. 35 ; Scully, t. c., p. 142; Fairbank, t. c., p. 259; Brooks, t. c., p. 274; Armstrong, t. c., p. 327 ; Taczanowski, Journ. für Ornith., 1876, p. 194; Hume, Stray Feathers, 1877, p. 36 ; Butler, t. c., p. 229; Hume, t.c., pp. 241 and 242, et seq.

Pratincola saturatior, Horsfield \& Moore, Cat. B., p. 285, 1854.

Pratincola robusta, Tristram, Ibis, 1870, p. 497; Hume, Stray Feathers, 1877, p. 131.

Pratincola rubicola, Hume, Stray Feathers, 1873, p. 183; id., Lahore to Yarkand, p. 204, 1873; id., Stray Feathers, 1874, p. 233 ; op. cit., 1875, p. 134; id., Nests and Eggs, p. 316, 1873.

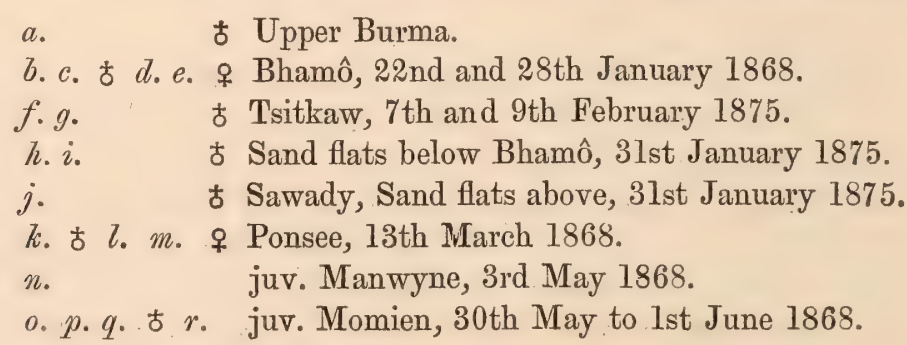

A male shot at Bhamô on 22nd January has the head, neck, and back black, but the feathers of the nape are finely edged with rufous, and those on the back, wing coverts and rump, broadly so. In one, shot on 13th March, only a very few feathers on the middle of the back are tipped with rufous, and in another, shot on 31st May 1868, there is no trace of rufous on any of the feathers on the upper surface. The only difference I can detect in females shot at the same intervals of time is a tendency in the rufous of the under parts to become darker. Two young birds shot on 3rd and 30th May are dark-brown above, with a central rufous streak on the head feathers, and a broad rufous spot with a brown tip on each of the feathers of the back. The wing coverts are broadly edged with rufous, and the 
secondaries are the same. The tail has a rufous tip. All the under surface is rich rufous; the feathers on the chin, throat and breast being tipped with dark-brown.

This was a very common bird all along our route from Bhamô, as far as Momien, where I shot it in the month of June, and where I am inclined to believe it breeds. It was usually found near long grass, or low shrubs.

Family-MUSCICAPID 2 .

Genus Muscicapula, Blyth.

86. Muscicapula sapphira, Blyth.

Muscicapula sapphira, Blyth, Journ. As. Soc., Bengal, vol. xii, p. 939, 1843 ; ex Tickell MS.; Jerdon, Ill. Ind. Orn., pl. xxxii, 1849; Blyth, Cat. B. Mus., As. Soc., Bengal, p. 173, 1849 ; Bonap. Consp., t. i, p. 316, 1850; Horsfield \& Moore, Cat. B. Mus., As. Soc., Bengal, vol. i, p. 295, 1856 ; Jerdon, B. Ind., vol. i, p. 471, 1862 ; Godwin-Austen, Journ. As. Soc., Bengal, 1872, vol. xli, p. 172.

Muscicapa sapphira, Gray, Gen. B., vol. i, p. 263, 1846; id., Handl. B., vol. i, p. 322, 1869.

a. t Ponsee, 19th April 1868.

This specimen differs only in one respect from Tickell's description, but the difference is so trifling that I cannot regard it as giving the bird any higher position than that of a local variety. It is this-there is no broad median ferruginous line, properly so called, on the ventral aspect. This band of colour is broken up by the blue of the side of the neck and breast into two areas, one on the chin and anterior part of the throat, bounded below by a gorget of blue, mixed with some ferruginous feathers, and succeeded by a small ferruginous area on the commencement of the breast, bounded below and on the sides by a broad blue area, in which a number of white feathers occur. The abdomen and under tail coverts are white. Jerdon states that the feet are brown, whereas Tickell describes these as black, the colour I found them to be.

\section{Genus Cyornis, Blyth.}

\section{Cyornis RUbeCuloIDes, Vigors.}

Phoenicura rubeculoides, Vigors, Proc. Zool. Soc., 1831, p. 35; Gould, Cent. Himal. B., pl. xxv, fig. 1, 1832.

Niltava brevipes, Hodgs., Ind. Rev., vol. i, p. 650, 1837.

Muscicapa rubecula, Swains., Monogr. Flycatch., p. 221, pl. xxvii c, 1838.

Cyornis rubeculoides, Blyth, Journ. As. Soc., Bengal, vol. xii, p. 941, 1842 ; id., Cat. B. Mus., As. Soc., Bengal, p. 173, 1849 ; Bonap. Consp., i, p. 320, 1850 ; Horsfield \& Moore, Cat. B. Mus. E. Ind. Co., vol. ii, p. 289, 1854; Jerdon, B. Ind., vol.i, p.466, 1862 ; Blyth, Ibis, 1866, p. 371 ; Blanford, Ibis, 1870, p. 468; Holdsw., Proc. Zool. Soc., 1872, p. 442 ; Rlyth \& Walden, Journ. As. Soc., Bengal, vol. xliv, 1875, ex. No., p. 103, 1875 ; Hume, Stray Feathers, 1875, p. 105; Brooks, t. c., p. 235; Walden, Ibis, 1876, p. 353; Hume, Stray Feathers, 1877, p. 339; W. T. Blanford, t. c., p. 484 . 
Chaitaris rubeculoides, Hodgs., in Gray's Zool. Misc., p. 84, 1844.

Niltava rubeculoides, Gray, Gen. B., vol. i, p. 264, 1846 ; id., Cat. Mamm., \&c., Nepal, Hodgs., p. 90 , 1846 ; id., Handl. B., vol. i, p. 325, 1869.

Erythrosterna rubecula, Bonap. Consp., t. i, p. 318, 1850.

\author{
a. क Kabyuet, 10th January 1875. \\ b. o Upper Burma, 16th March 1868. \\ c. q Bhamô, 6th February 1868. \\ d. t Tapeng river, 21st March 1868. \\ e.-f. g. \& Ponsee, 2nd May 1868, 15th March 1868, 28rd April 1868, and \\ 15th March 1868.
}

This bird is generally distributed over Upper Burma and the Kakhyen hills.

\title{
88. Cyornis Tickelim, Blyth.
}

Muscicapa hyacintha, Tickell, Journ. As. Soc., Bengal, vol. ii, p. 574, 1833.

Muscicapa banyumas, Jerdon, Madr. Journ., vol. xi, p. 15, 1840.

Cyornis banyumas, (nee. Horsf.), Blyth, Journ. As. Soc., Bengal, vol. xii, p. 941, 1842 ; id., Cat. B.

Mus., As. Soc., Bengal, p. 173, 1849; Jerdon, B. Ind., vol. i, p. 466, 1862.

Cyornis tickellice, Blyth, Journ. As. Soc., Bengal, vol. xii, p. 941, 1843; Jerdon, B. Ind., vol. i, p. 467, 1862 ; Gray, Cat. Hodgs. Drawings, 1863, p. 48 ; Blanford, Journ. As. Soc., Bengal, vol. xxxviii, 1869, p.174; Blyth, Ibis, 1870, p. 166 ; Lloyd, op. cit., 1872, p. 197; Hume, Stray

Feathers, 1873, p. 436 ; Ball, op. cit., 1874, p. 405 ; Butler \& Hume, op. cit., 1875, p. 468 ;

Butler, op. cit., 1876, p. 37; Blyth \& Walden, Journ. As. Soc., Bengal, vol. xliv, 1875, ex

No.; Fairbank, Stray Feathers, 1876, p. 257 ; id., op. cit., 1877, p. 402.

Cyornis elegans, Blyth, Cat. B. Mus., As. Soc., Bengal, p. 173 (nee Temm.)

Cyornis jerdoni, Blyth, Ibịs, I866, p. 371 ; Holdsw., Proc. Zool. Soc., 1872, p. 442.

Niltava jerdoni, Gray, Handl. i, p. 325.

Niltava tickellia, Gray, Gen. B., i, p. 264; id., Handl. B., i, p. 325.

a. 워 Upper Burma, 16th January 1868.

b. c. t Ponsee, 15th March and 23rd April 1868.

Some of the males are slightly darker above than Calcutta and Singbhoom specimens, and the ferruginous of the chin, throat and breast is more intense, while others are almost quite as pale. The ear-coverts are the same colour as the back, dark indigo-blue. In one specimen which was ascertained to be a female of this species, there is a pale pinkish pale metallic lustre on the forehead and over the eye.

In thick low jungle outside Bhamâ and at an elevation of 3,300 feet on the Kakhyen hills.

\section{Genus S IP H IA, Hodgson.}

\section{Siphia strophiata, Hodgson,}

Siphia strophiata, Hodgs., Ind. Rev., vol. i, p. 651, 1857 ; Gray, Cat. Mamm., \&e., Coll. Hodgs., p. 92 , 1846; Blyth, Journ. As. Soc., Bengal, vol. xvi, p. 125, 1847 ; id., Cat. B. Mus., As. Soc., Bengal, p. 171, 1849; Horsfield \& Moore, Cat. B. Mus., vol. i, p. 293, 1854; Jerdon, B. Ind., vol. i, 1863, p. 316; Stoliczka, Journ. As. Soc., Bengal, vol. xxxvii, 1868, p. 32; Pelz., Ibis, 
1868, p. 316 ; Godwin-Austen, Journ. As. Soc., Bengal, vol. xxxix, 1870, p. 101 ; id., op. cit., vol. xlv, 1876, p. 72 .

Dimorpha strophiata, Hodgs., Proc. Zool. Soc., 1845, p. 26 ; Bonap. Consp., t. i, p. 319, 1850.

Niltava strophiata, Gray, Gen. B., vol. i, p. 264, 1846 ; id., Handl. B., vol. i, p. 326.

a. Ponsee, 28th March 1868.

I have carefully compared this bird with Darjeeling specimens with the bright ferruginous breast spot. It wants this mark, but it agrees with these birds in every other particular, and I think there can be no doubt that the rufous of the breast is either subject to seasonal change, or is late in appearing, as in Erythrosterna. ${ }^{1}$ I found it at an elevation of 3,000 feet on the Kakhyen hills, and Jerdon states that on the Eastern Himalaya it ranges as high as 8,000 feet and upwards. This is one among many instances of how the Himalayan fauna stretches across the north of Assam to the mountain ranges to the east of Burma.

\section{Genus Erythrosterna, Bonaparte.}

\section{Erythrosterna albicilila, Pallas.}

Muscicapa albicilla, Pall., Zoogr. Rosso. Asiat., t. i, p. 462, Aves, tab. i, 1811. Saxicola rubeculoides, Sykes, Proc. Zool. Soc., 1832, p. 92.

Muscicapa leucura, Swains., Nat. Hist. Flyc., p. 253, c. 1837; Gray, Handl. B., vol. i, p. 322, 1869. Synornis leucura, Hodgs., in Gray's Zool. Misc., p. 83, 1844.

Synornis joulaimus, Hodgs., t. c., p. 83 ; id., Proc. Zool. Soc., 1845, p. 26.

Erythrosterna leucura, Blyth, Cat. B. Mus., As. Soc., Bengal, p. 171; Bonap. Consp., t. i, p. 318 ;

Horsfield \& Moore, Cat. B. Mus. E. Ind. Co., vol. i, p. 297 ; Jerdon, B. Ind., vol. i, 1865, p. 481 ;

Swinhoe, Ibis, 1860, p. 357, 1863, p. 92 ; Blyth, Ibis, 1866, p. 572 ; Swinhoe, Ibis, 1870, p. 247 ;

Blanford, id., 1870, p. 468 ; id., Proc. Zool. Soc., 1863, p. 290 ; Dybowski, Journ. f. Orn., 1872, p. 448; Blyth \& Walden, Journ. As. Soc., Bengal, vol, xliv, 1875, ex, No., p. 103; Hume, Stray Feathers, 1875, p. 105 ; Tacz., Bull. Soc. Zool. Fr., t. i, p. 169; Armstrong, Stray Feathers, 1876, p. 323; Godwin-Austen, Journ. As. Soc., Bengal, vol. xlv, 1876, p. 72 ; Brooks, Stray Feathers, 1877, p. 451 ; Blanford, t. c., p. 484.

Thamnobia niveiventris, Swinhoe, Ibis, 1860, p. 54.

Erythrosterna mugimaki, Swinhoe, Ibis, 1861, p. 330.

Erythrosterna albicilla, Swinhoe, Proc. Zool. Soc, 1862, p. 317; id., Proc. Zool, Soc., 1871, p. 380.

a. t Katha, 19th January 1868.

b. Sawady, 27th January 1875.

c. † Bhamô, 23rd January 1868.

The Katha bird is shewing the ferruginous on the lores, chin and throat, while the Bhamô one, shot a few days later, has only a small patch on the chin. In the latter, the throat is white and the breast ashy. In specimens of $E$. parva from Jubbulpore, Central India, killed in December, I find the chin, throat and breast deep ferruginous.

${ }^{1}$ I have seen a specimen of this bird from Darjeeling shot in August, in which there is only a faint trace of rufous on the breast. 


\section{Genus Eumyias, Cabanis.}

\section{Eumyias melanops, Vigors.}

Mruscicapa melanops, Vigors, Proc. Zool. Soc., 1831, p. 171 ; Gould, Cent. Himal. B., pl. vi, 1832; Sykes, Proc. Zool. Soc., 1832, p. 85; Jerdon, Madr. Journ., vol. xi, p. 15, 1840. Muscicapa lapis, Less., Rev. Zool., p. 104, 1839.

Hypothymis melanops, Gray, Cat. Coll. Mamm., \&c., Nepal, Hodgson, p. 48, 1846 ; Bonap. Consp., t. i, p. 320, 1850; Horsfield \& Moore, Cat. B. Mus. E. Ind. Co., vol. i, p. 292, 1854.

Niltava melanops, Gray, Gen. B., i, p. 264, 1846 ; id., Handl. B., vol. i, p. 325, 1869.

Stoparola melanops, Blyth, Journ. As. Soc., Bengal, vol. xvi, p. 125, 1847; Hutton, Journ. As. Soc., Bengal, vol. xvii, p. 686, 1848; Blyth, Cat. B. Mus., As. Soc., Bengal, p. 174, 1849; Layard, Ann. Nat. Hist., 1854, p. 127; Swinhoe, Proc. Zool. Soc., 1871, p. 381 ; Adams., Stray Feathers, 1874, p. 338; Ball, t.c., p. 405; Hume, t.c., p. 475; Brooks, op. cit., 1876, p. 467; Butler, op. cit., 1877, p. 228.

Glancomyias melanops, Cat. Mus. Hein., th. i, p. 53, 1850.

Eumyias melanops, Horsfield \& Moore, Cat. B. Mus. E. Ind. Co., vol. i, p. 422, 1857; Jerdon, B. Ind., vol. i, p. 463, 1862; Swinhoe, Proc. Zool. Soc., 1863, p. 289; Stoliczka, Journ. As. Soc., Bengal, vol. xxxvii, 1868, p. 29; Blanford, Ibis, 1870, p. 468; Cock. \& Marsh., Stray Feathers, 1873, p. 352 ; Brooks, op. cit., 1875, p. 235; Fairbank, op. cit., 1876, pp. 257, 396 ; Armstrong, t. c., p. 323 ; Godwin-Austen, Journ. As. Soc., Bengal, vol. xlv, 1876, p. 71.

$$
\begin{aligned}
& \text { a. t B Bhamô, 2nd February } 1868 . \\
& \text { b.c. * } \quad \text { \& Ponsee, 13th and 25th March } 1868 . \\
& \text { d. } \text { o juv. Sanda, 26th July } 1868 . \\
& \text { e. } q \text { \& } f \text {. juv. Momien, 5th June } 1868 .
\end{aligned}
$$

The young of this species has the lores and all the under surface from the chin to the vent covered with round pale and rufous spots.

It will be observed that this species extends as far eastwards as Momien, where it alone occurs in the patches of forest which here and there rarely clothe the hill sides.

Family—SYLVIIDA.

\section{Genus Acrocephalus, Naumann.}

\section{Acrocephalus Dumetorum, Blyth.}

Sylvia montana, Sykes, Proc. Zool. Soc., 1832, p. 89 (nec Horsf.)

Sylvia arundinacea, Eversm., Add. Pall. Zoogr. Rosso Asiat., t. iii, p. 11, 1842.

Acrocephalus montanus, Blyth, Journ. As. Soc., Bengal, vol. xv, p. 594, 1845, (nec. Horsf.)

Acrocephatus dumetorum, Blyth, Journ. As. Soc., Bengal, vol. xviii, p. 815, 1849; Jerdon, B. Ind., vol. ii, p. 155, 1863 ; A. Anders., Stray Feathers, vol. iii, p. 351, 1875; Butler, t. c., p. 479; Dresser, B. Eur., pt. liii, 1876 ; id., Ibis, 1876, p. 84.

Sylvia (Salicaria) magnirostris, Lillj., Oefv. K. Vet. Akad. Förh., 1850, p. 274, pl. xix.

Calamoherpe magnirostris, Meves, Oefv. K. Akad. Förh., 1871, p. 752.

Calamodyta dumetorum, Meves, Journ. f. Orn., 1871, p. 431.

Salicaria sphenur a, Severtz., Turkest. Jevotn., pp. 66, 128, 1873 ; Dresser, Ibis, 1876, p. 86 ; Seebohm, Ibis, 1877, p. 154. 
Salicaria eurhyncha, Severtz., Turkest. Jevotn., pp. 66, 128, 1873 ; Dresser, Ibis, 1876, p. 85 ; Seebohm, Ibis, 1877, p. 85.

Salicaria magnirostris, Severtz., Turkest. Jevotn., p. 127, 1873; Seebohm, Ibis, 1877, p. 158.

Salicaria concolor, Severtz., Turkest. Jevotn., pp. 66, 130, 1873 ; Dresser, Ibis, 1876, p. 88; Seebohm, Ibis, 1877, p. 156.

Salicaria arundinacea, Severtz., Turkest. Jevotn., p. 65, 1873; Seebohm, Ibis, 1877, p. 151.

Acrocephalus streperus, Dresser, Ibis, 1876, p. 83.

a. t Tsitkaw, 6th February 1875.

\section{Genus Neornis, Hodgson.}

\section{Neornis BRevicaudatus, Blyth.}

Drymoeca brevicaudata, Blyth, Journ. As. Soc., Bengal, vol. xvi, p. 459, 1847.

Horornis assimilis, Gray, Cat. Mamm., \&c., Nepal, Coll. Hodgs., p. 30, 1856 ; Blyth, Ibis, 1867, p. 220; Hume, Stray Feathers, 1873, p. 494.

Neornis assimitis, Blyth, Ibis, 1867, p. 22; Godwin-Austen, Journ. As. Soc., Bengal, vol. xliii, 1874, p. 167 ; Hume, Nests and Eggs, Ind. B., p. 360, 1875 ; Blyth \& Walden, Journ. As.

Soc., Bengal, vol. xliv, 1875, extra No., p. 105.

Sylvia assimilis, Gray, Handl. B., vol. i, p. 217, 1869.

a. む Ponsee, 19th April 1868.

\section{Genus PhyLloscopús, Boie.}

\section{Phylloscopus fuscatus, Blyth.}

Phyllopneuste fuscata, Blyth, Journ. As. Soc., Bengal, vol. xi, p. 113, 1842 ; xii, p. 965, 1843 ; Bonap. Consp., t. i, p. 290, 1850; Swinhoe, Proc. Zool. Soc., 1871, p. 356 ; Hume, Stray Feathers, 1874, p. 236 ; 1875, p. 138 ; Blyth \& Walden, Journ. As. Soc., Bengal, vol. xliv, 1875, extra No., p. 105.

Phylloscopus brunneus, Blyth, Journ. As. Soc., Bengal, vol. xiv, p. 591, 1845 ; id., Cat. B. Mus., As. Soc., Bengal, p. 185, 1849.

Horornis fulviventris, Hodgson, Proc. Zool. Soc., 1845, p. 31; Bonap. Consp., t. i, p. 290, 1850 ; Horsfield \& Moore, Cat. B. Mus. E. Ind. Co., vol. i, p. 335, 1854; Gray, Cat. Mamm., \&c., Nepal, Coll. Hodgs., 1854, p. 64, et. ed., 1863, p. 30.

Horornis fulviventer, Blyth, Ibis, 1867, p. 21.

Regulus fulviventris, Gray, Gen. B., vol. i, p. 175, 1848.

Plylloscopus fuscatus, Blyth, Cat. B. Mus., As. Soc., Bengal, p. 185, 1849; Jerdon, B. Ind., : vol. ii, p. 191, 1863; Blyth, Ibis, 1867, p. 25 ; Hume, Stray Feathers, 1874, p. 478; Armstrong, op. cit., 1876, p. 329; Godwin-Austen, Journ. As. Soc., vol. xlv, 1876, p. 80; Seebohm, Ibis, 1877, p. 85.

Sylvia (Phyllopneuste) sibirica, Midd., Sibir. Reis., t. ii, p. 180, tab. 16, figs. 4-6, 1851 ; Radde, Reis. Ost. Sibir., p. 260, 1863.

Phyllopneuste sibirica, Schrenk, Reis. Amurl. Vög., p. 362, 1859.

Abromis armandii, A.-M. Edw., N. Arehiv. Mus., t. i, 1865, p. 22.

Sylvia fuscata, Gray, Handl. B., vol. i, p. 215, 1869.

Oreopmeuste davidii, Swinhoe, Proc. Zool. Soc., 1871, p. 355.

Phyllopneuste maacki, Trist., Ibis, 1871, p. 110. 
? Horeites brunnescens, Hume, Ibis, 1872, p. 109; Stray Feathers, vol. iii, 1875, p. 410 ; op. cit., vol. iv, 1876 , p. 497.

a. 9 Kabyuet, 9th January 1875 .

b. t Ponsee, 19th April 1868.

In low shrubby jungle in the above localities.

\section{Phylioscopus Lugubris, Blyth.}

Phylloscopus lugubris, Blyth, Journ. As. Soc., Bengal, vol. xii, p. 968, 1843 ; id., Ann. Nat. Hist., vol. xii, p. 98, 1843 ; id., Journ. As. Soc., Bengal, vol. xiv, p. 591, 1845 ; id., Cat. B. Mus., As. Soc., Bengal, p. 185, 1849 ; Jerdon, B. Ind., vol. ii, p. 192, 1863; Hume, Stray Feathers, 1874, p. 478; Blyth \& Walden, Journ. As. Soc., Bengal, vol, xliv, 1875, ex. No., p. 105; Seebohm, Ibis, 1877, p. 78 ; Armstrong, Stray Feathers, 1876, p. 329.

Abrornis xanthogaster, Hodgson, in Gray's Zool. Misc., p. 82, 1844; Gray, Cat. Mamm., \&c., Nepal, Hodgs., p. 66, 1846.

Phyllopneuste flaveolus, Gray, Cat. Mamm., \&c., Nepal, App. p. 152, 1846.

Regulus lugubris, Gray, Gen. B., vol. i, p. 175, 1848.

Regulus flaveolus, Gray, t. c., p. 175, 1848.

Abrornis lugubris, Bonap. Consp., t. i, p. 290, 1850.

Abrornis flaveolus, Bonap., t. c., p. 290, 1850.

Sylvia hugubris, Gray, Handl. B., vol. i, p. 215, 1869.

a. b. c. Bhamô, 4th February 1868.

\section{Phylloscopus viridanus, Blyth.}

Phyllopneuste rufa, Blyth, Journ. As. Soc., Bengal, vol. xi, p. 191, 1842.

Phylloscopis viridanus, Blyth, Journ. As. Soc., Bengal, vol. xii, p. 967, 1843; id., op. cit., vol, xiv, p. 591, 1845 ; id., Cat. B. Mus., As. Soc., Bengal, p. 185, 1849; Gray, Cat. Mamm., \&c., Nepal, Coll. Hodgs., p. 31, 1863; Jerdon, B. Ind., vol. ii, p. 193, 1863 ; Stoliczka, Journ. As. Soc., Bengal, vol. xxxvii, 1868, p. 46; Holdsw., Proc. Zool. Soc., 1872, p. 457; Henders. \& Hume, Lahore to Yarkand, p. 220, pl. xix, 1873 ; Stoliczka, Stray Feathers, 1874, p. 462 ; Hume, t. c., p. 478; Brooks, op. cit., 1875, pp. 243, 244, p. 279; Scully, op. cit., 1876, p. 148; Brooks, t. c., p. 499; Dresser, Ibis, 1876, p. 81; Seebohm, op. cit., 1877, p. 73.

Abrornis tenuiceps, Hodgson, in Gray's Zool. Misc., p. 82, 1844; ; Gray, Cat. Mamm., \&c., Nepal, Coll. Hodgs., p. 66, 1846.

Phyllopneuste viridana, Gray, Cat. Mamm., \&c., Nepal, Hodgs., App. p. 152, 1846 ; Ball, Stray

Feathers, 1874, p. 440 ; Blyth \& Walden, Journ. As. Soc., Bengal, vol. xliv, 1875, ex. No., p. 105.

Regulus viridanus, Gray, Gen. B., vol. i, p. 175, 1848.

Abrornis viridana, Bonap. Consp., t. i, p. 290, 1850 ; Adam., Stray Feathers, 1873, p. 382.

Sylvia viridana, Gray, Handl. B., vol. i, p. 217, 1869.

Phyllopneuste viridanus, Fairbank, Stray Feathers, 1876, p. 259.

Phyllopneuste intermedia, Severtzoff., Turkest. Jevotn., 1873, p. 125.

a. b. Bhamô, 4th February 1868. 


\section{Phylloscopus affinis, Tickell.}

Motacilla affinis, Tickell, Journ. As. Soc., Bengal, vol. ii, p. 570, 1833.

Phyllopneuste affinis, Gray, Cat. Mamm., \&c., Nepal, Coll. Hodgs., 1866, p. 65; id., ed.1863, p. 31 ; Ball, Stray Feathers, 1874,p. 462; Stoliczka, t. c., p. 462; Hume, t. c., p. 478; id., op. cit., 1876, p. 139.

Phylloscopus affinis, Blyth, Journ. As. Soc., Bengal, vol. xvi, p. 442, 1847 ; id., Cat. B. Mus., As. Soc., Bengal, p. 185, 1849 ; Jerdon, B. Ind., vol. ii, p. 194, 1863 ; Stoliczka, Journ. As. Soc., Bengal, vol. xxxvii, 1868, p. 46; Godwin-Austen, Journ. As. Soc., Bengal, vol. xxxix, 1870, p. 107 ; Seebohm, Ibis (pars.), 1877, p. 100.

Regulus affinis, Gray, Gen. B., vol. i, p. 175, 1848.

Abrornis affinis, Bonap. Consp., t. i, p. 290, 1850 ; Moore, Proc. Zool. Soc., 1854, p. 106.

Sylvia affinis, Gray, Handl. B., vol. i, p. 213, 1869.

a. 우 Momien, 2nd June 1868.

\section{Phylloscopus superciliosus, Gmelin.}

Yellow-browed warbler, Lath., Gen. Syn., vol. ii, p. 409.

Motacilla superciliosa, Gm., Syst. Nat., t. i, p. 975, 1788, ex. Lath.

Sylvia superciliosa, Lath., Ind. Orn., vol. ii, p. 526, 1790 ; Gray, Handl. B., vol. i, p. 216, 1869.

Regulus modestus, Hancock (nec Gould), Ann. Nat. Hist., vol. ii, p. 310, 1839; Yarr., Brit. B., vol. i, p. 316, 1843 ; Cab., Naum., t. ii, p. 5, 1852 ; Gaetke, Journ. f. Orn., i, p. 91, 1853 ; Regulus inornatus, Blyth, Journ. As. Soc., Bengal., vol. xi, p. 191, 1842.

Phylloscopus modestus, Blyth, Journ. As. Soc., Bengal, vol. xii, p. 963, 1843.

Phyllopneuste modestus, Blyth, Ann. Nat. Hist., vol. xii, p. 98, 1843.

Phyllopneuste reguloides, Hodgson, in Gray's Zool. Misc., p. 82, 1844; id., Journ. As. Soc., Bengal, vol. xxiv, p. 575, 1855.

Reguloides modestus, Blyth, Journ. As. Soc., Bengal, vol. xvi, p. 442, 1847.

Phyllobasileus superciliosus, Cab., Journ. f. Orn., 1853, p. 81.

Sylvia proregulus, Middend. (nec Pall.) Sibir. Reise., Bd. ii, pt. 2, p. 183, 1853.

Ficedula proregulus, Schleg., Vog. von Nederl., pp. 130, 241, 1854-58.

Reguloides proregulus, Horsfield \& Moore, Cat. B. Mus. E. Ind. Co., vol. i, p. 342, 1854; Swinhoe, Ibis, 1860, p. 54; id., op. cit., 1861, p. 330 ; id., op. cit.; 1863, p. 307 ; Jerdon, B. Ind., vol. ii, p. 197, 1863.

Phyllopneuste proregulus, Blasius, Naum., t. viii, p. 311, 1858.

Sylvia bifasciata, Gaetke, Naum., t. viii, p. 4119, 1858.

Reguloides superciliosus, Swinhoe, Ibis, 1863, p. 307 ; Brooks, Ibis, 1869, p. 354; Swinhoe, op. cit., 1870, p. 345 ; Brooks, op. cit., 1872, p. 26 ; Swinhoe, op.cit., 1874, p. 441 ; Hume, Stray Feathers, 1874, p. 478 ; id., 1875, p. 140 ; Blyth \&\& Walden, Journ. As. Soc., Bengal, vol. xliv, 1875 , ex. No., p. 106.

Phylloscopus superciliosus, Newton ed. Yarr., Brit. B., vol. i, p. 443, 1873 ; Dresser, B. Eur., pt. xxx, 1874 ; Cordeaux, Ibis, 1875, p. 180 ; Dresser, Ibis, 1876, p. 81 ; Seebohm, op. cit., 1877, p. 102.

Ficedula superciliosa, Severtzoff, Turkest. Jevotn., p. 65, 1873.

a. t Yaylaymaw, 7th January 1875.

b. ‡ Bhamô, 5th February 1878.

c. Ponsee, 24th April 1868.

d.e. 하 우 Nampoung, 19th February 1875.

$f$.

Among high forest trees and numerous in the last mentioned locality in February. 


\section{Phylloscopts viridipennis, Blyth.}

Phylloscopus viridipennis, Blyth, Journ. As. Soc., Bengal, vol. xxiv, 1855, p. 275.

Reguloides viridipennis, Hume, Stray Feathers, 1874, p. 479 ; Blyth \& Walden, Journ. As. Soc.,

Bengal, vol. xliv, 1875, extra No., p. 106 ; Hume, Stray Feathers, 1877, p. 330; t. c., p. 504;

Davison, $t . c .$, p. 458 .

$$
\text { a. Ponsee, 27th April } 1868 .
$$

Hume has clearly pointed out wherein this bird differs from the Indian form which he has named $P$. (R.) flavo-olivaceus (loc. cit., p. 504), and which would appear to be only a race of $P$. trochiloides.

\section{Phylloscopds occipitalis, Jerdon.}

Phyllopneuste occipitalis, Jerdon, Journ. As. Soc., Bengal, vol. xiv, p. 593, 1845; Blyth, Cat. B. Mus., As. Soc., Bengal, p. 183, 1849.

Reguloides occipitalis, Jerdon, B. Ind., vol. ii, p. 196, 1863; Blyth, Ibis, 1867, p. 25; Godwin-

Austen, Journ. As. Soc., Bengal, vol. xxxix, 1870, p. 107 ; Dresser, Proc. Zool. Soc., 1872,

p. 25; Brooks, Ibis, 1872, p. 24; Cock. \& Marsh., Stray Feathers, 1873, p. 355 ; Hume, t.c., p. 197 ; id., op. cit., 1875, p. 323 ; id., Nests and Eggs, Ind. B., p. 362, 1875 ; Hume,

Stray Feathers, 1876, p. 41 ; Fairbank, t. c., p. 260 ; Brooks, t. c., p. 275.

Sylvia occipitalis, Gray, Handl. B., vol. i, p. 217, 1869.

Phylloscopus occipitalis, Seebohm, Ibis, 1877, p. 80 .

a. b. ঠ Nampoung, 19th February 1875.

Among high forest trees.

$$
\text { c. } 7, \quad, \quad,
$$

\section{Genus Abrornis, Hodgson.}

\section{Abrornis superciliaris, Tickell.}

Abrornis supercitiaris, Tickell, Journ. As. Soc., Bengal, vol. xxviii, 1859, p. 414; Hume, Stray Feathers, 1874, p. 479; op. cit., 1875, p. 140; Blyth \& Walden, Journ. As. Soc., Bengal, vol. xliv, 1875, extra No., p. 106.

Abrornis albigularis, Jerdon, Blyth, Proc. Zool. Soc., Lond., 1861, p. 200.

Abrornis flaviventris, Jerdon, Birds of India, vol. ii, pt. 1, p. 203, 1863.

Sylvia superciliaris, Gray, Handl. B., B. M., vol. i, 1869, p. 217.

a. Ponsee, 20th March 1868.

\section{Genus Culicipeta, Blyth.}

\section{Culicipeta tephrocephala, Andr. Plate L.}

Culicipeta tephrocephalus, Anders., Proc. Zool. Soc., 1871, p. 213 ; Hume, Stray Feathers, 1874, p. 479 id., op. cit., 1875, p. 140 ; Blyth \& Walden, Journ. As. Soc., Bengal, extra No., 1875, p. 107. Cryptolopha tephrocephala, Hume, Stray Feathers, 187\%, p. 113. 
This species resembles $C$. burkii, but has the head and nape cinereous, with a black band along their lateral margin, as in C. burkii. The latter is slightly duller green.

Mr. Hume states that the bill of the single specimen sent to him from Upper Pegu by Mr. Oates has a much smaller bill than C. burkii.

$$
\text { Family-MERULID AR. }
$$

\section{Genus Garrulax, Lesson.}

\section{Garrulax monitiger, Hodgson.}

Cinclosoma moniliger, Hodgs., As. Res., vol. xix, p. 147, 1836.

Ianthocincla pectoralis, McClell., Proc. Zool. Soc., 1839, p. 160.

Crateropus moniligerus, Blyth, Journ. As. Soc., Bengal, vol. xi, p. 179, 1842.

Garrulax moniliger, Blyth, Journ. As. Soc., Bengal, vol. xii, p. 949, 1843 ; vol. xiv, p. 598, 1845 ;

Gray, Gen. B., vol. i, p. 225, 1846 ; Hodgs., Cat. B. Nep., p. 82, 1846 ; Blyth, Cat. B. Mus.,

As. Soc., Bengal, p. 96, 1849 ; Bonap. Consp., Gen. Av., p. 371, 1850 ; Horsfield \& Moore, Cat.

B. Mus. E. Ind. Co., p. 204, 1854; Gray, Handl. B., i, p. 281, 1869 ; Blanford, Ibis, 1870,

p. 467 ; Godwin-Austen, Journ. As. Soc., Bengal, vol. xxxix ; id., op. cit., xlv, 1876, p. 76,

1870, p. 104; Hume, Stray Feathers, 1874, p. 476; 1875, p. 123; Blyth \& Walden, Journ.

As. Soc., Bengal, vol. xliv, 1875, extra No., p. 108; Oates, Stray Feathers, 1877, p. 156.

Garrulax McClellandii, Blyth, Journ. As. Soc., Bengal, vol. xii, p. 949, 1843 ; xvi, p. 451, 1847.

a. Bhamô, 7th February 1868.

I first observed this bird at Yenanyoung; Blanford records it from Ava.

\section{Garrulax sannio, Swinhoe.}

Garrulax sannio, Swinhoe, Ibis, 1867, p. 403 ; id., Proc. Zool. Soc., 1871, p. 371 ; Godwin-Austen, Ann. and Mag. Nat. Hist., vol. xvii, 1876, p. 34; Stray Feathers, 1876, p. 502.

Garrulax albosuperciliaris, Godwin-Austen, Proc. Zool. Soc., 1874, p. 45 ; id., Journ. As. Soc.,

Bengal, vol. xliii, p. 161, pl. vi, 1874; id., Stray Feathers, 1875, p. 393 ; id., Ann. and Mag.

Nat. Hist., vol. xvii, 1876, p. 34 .

$$
\begin{aligned}
& \text { a. b. Muangla, July } 1868 . \\
& \text { c. d. Nantin, 24th May } 1868 \text {. } \\
& \text { e.f.g. Hotha, 16th August } 1868 \text {. }
\end{aligned}
$$

I first met with this species at Muangla in the shrubby thickets about the town, and afterwards at Nantin and Hotha, where it does not appear to be rare.

This species ranges westwards to the Munipur valley.

\section{Genus Actinodura, Gould.}

105. ACtinodura nipalensis, Hodgson.

Cinclosoma nipalensis, Hodgs., As. Res., vol. xix, p. 145, 1836.

Ixops nipalensis, Hodgs., in Gray's Zool. Misc., 1844, p. 84. 
Actinodura nipalensis, Hodgs., Cat. Birds, Nep.,p. 84, 1846 ; G. R. Gray, Gen. B., i, p. 226, 1846 ; Filythit, Cat. B. Mus., As. Soc., Bengal, p. 98, 1849 ; Jerdon, B. Ind., vol. ii, p. 53, 1863; Gould, B. Asia, pt. xviii, 1866 ; Gray, Handl. B., vol. i, p. 283, 1869; Jerdon, Ibis, 1872, p. 308.

a. Ponsee, 20th March 1868.

\section{ACtiNODURA Egertoni, Gould.}

Actinodura egertoni, Gould, Proc. Zool. Soc., 1836, p. 18 ; Gray, Cat. B., Nep., p. 84, 1846 ; id., Gen. B., vol. i, p. 226, 1846 ; Fraser, Zool. Typ., pl, xl, 1849 ; Blyth, Cat. B. Mus., As. Soe, Bengal, p. 98, 1849 ; Bonap. Consp. Av., p. 373, 1850 ; Horsfield \& Moore, Cat. B. Mus. E. Ind. Co., p. 212, 1856-58; Jerdon, B. Ind., vol. ii, p. 52, 1863 ; Gould, B. Asia, pt. xviii, 1866 ; Gray, Handl. B., vol. i, p. 283, 1869; Hume, Nests and Eggs, Ind. B., p. 266, 1873. Leiocincla plumosa, Blyth, Journ. As. Soc., Bengal, vol, xii, p. 953, 1843, vol. xiv, p. 600, 1845. Alcurus nipalensis, Hodgs., in Gray's Zool. Misc., p. 83, 1844.

Actinura egertoni, Godwin-Austen, Journ. As. Soc., Bengal, vol. xlv, 1876, p. 76.

a. Ponsee, 17th March 1868,

This is the only specimen I observed,

Genus Pteruthids, Swainson.

\section{Pteruthius exalatus, Tickell. Pl. XLVII.}

Pteruthius aralatus, Tickell, Journ. As. Soc., Bengal, 1855, p. 267 ; Blyth, Ibis, 1867, p. 32 ; Gray, Handl. B., i, 314, 1869 ; Blyth \& Walden, Journ. As. Soc., Bengal, vol. xliv, 1875, ex. No., p. 109 ; Gould, B. Asia, 1st July 1876, part xxviii.

Allotrius aralatus, Hume, Stray Feathers, 1874, p. 479 ; op. cit., 1877, p. 114.

a. के Ponsee, 20th March 1868.

b. 오 Sanda, 27th July 1868 ,

This species is quite similar to Pt. erythropterus of the Himalaya, as pointed out by Blyth, except in that the latter has constantly the tertiaries wholly ferruginous in both sexes. In the former the female has the tertiaries greenish golden yellow, like the secondaries, with merely a tinge of ferruginous upon the shaft and on the inner web only of each; and the male differs from that of the Himalayan bird by having nearly the whole outer webs of the tertiaries bright golden yellow, the first having also a black tip and inner edge; the next a black tip to the outer web only; the third and longest, an oblique and elongated black tip to the outer web, and the feather succeeding this has also a mark on its outer web, of mingled ferruginous and golden yellow.

Blyth further observes that he could not detect in the type specimen any trace of the carneous tinge seen particularly on the flanks posteriorly of $P$. erythropterus; these specimens, however, show this distinctly, but more in the direction of the vent than the flanks. The female has the under parts, with the exception of the white throat only, much more fulvescent than the under parts of the female $P$. erythropterus. 
The only difference between these Kakhyen hill specimens and Tickell's is, that the body beneath, instead of being nearly white, is markedly cinereous. I do not, however, attach any importance to this, for a tendency to cinereous is also distinctly visible on the under parts of $P$. erythropterus, which $P$. cralatus also resembles in this respect; Hume observes that this species is intermediate between $P$. erythropterus and $P$. flavicapis, having the grey back of $P$. erythropterus and the yellow wing of $P$. flavicapis.

Total length $6 " 40$; wing $3 \cdot 7$; tail $2 \cdot 50$; tarsus 0.75 ; bill (gape) 0.53 .

I obtained two specimens of this species, one at Ponsee and the other at Sanda, and the latter I have figured.

\section{Family-LEIOTHRICHID A.}

Genus Leiothrix, Swainson.

\section{Leiothrix CALLIPYGa, Hodgson.}

Bahila callipyga, Hodgs., Ind. Rev., vol. ii, p. 88, 1838.

Callipyga furcata, Hodgs., Journ. As. Soc., Bengal, vol. x, p. 29, 1841.

Leiothrix callipyga, Hodgs., Journ. As. Soc., Bengal, vol. xiii, p. 934, 1844; Gray, Cat. Mamm., \&c., Nepal, Hodgs., p. 84, 1844; Gray, Handl. B., vol. i, p. 313, 1869; Hume, Nests and Eggg, Ind. B., p. 390, 1874; Gammie, Stray Feathers, 1875, p. 266.

Leiothrix furcatus, Hodgs., in Gray's Zool. Misc., p. 84, 1844.

Leiothrix luteus, Blyth, Journ. As.. Soc., Bengal, vol. xiv, p. 552, 1845; id., Cat. B. Mus., As. Soc., Bengal., p. 99, 1849; Gould, B. Asia, pt. iii, 1851 ; Horsfield, \& Moore, Cat. B. Mus. E. Ind. Co., vol. i, p. 364, 1854; Jerdon, B. Ind., vol. ii, p. 250, 1863.

$$
\begin{aligned}
& \text { a.b.c. क Ponsee, March } 1868 . \\
& \text { d.e.f. " " }
\end{aligned}
$$

There is a good deal of variation in the intensity of the yellow tint on the head and neck, in the rich orange yellow of the neck and breast, in the yellow of the lores, and in the depth of tint on the ear coverts. In females these parts, as a rule, are not so brilliant as in the males, but I have males (young ?) as dull coloured as females. The head and neck, in some males, are almost orange yellow-olive, and dull green to yellow-olive in others. In the birds with dull coloured heads, the orange of the breast is light, the ear coverts are almost ashy-olive, and the lores are dirty white, and the dark line from the lower mandible is hardly discernible.

In the orange olive-green-headed birds, the lores are always tinged with yellow, the ear coverts are much lighter, the mandible streak is well defined, and the breast is rich orange-red. In Gould's figure, the orange of the breast is represented much further back than in my specimens, but this character is very variable. In one very brightly coloured bird the chin and throat alone are brilliant yellow, the neck and upper part of the breast are reddish orange-yellow, well marked off from the throat, but fading below into ashy olive-green on the sides and pale yellow on the centre of the abdomen. 
Common in low bush jungle under-forest on the Kakhyen hills about Ponsee.

Not having had authentic Chinese specimens of $L$. luteus wherewith to compare my Burmese examples, I cannot speak with certainty respecting the specific differences of the two birds. Mr. G. R. Gray, however, in the 'Handlist' separates them, and $I$ adopt his conclusion with regard to the name of $L$. callipyga for the Indian bird, which indisputably belongs to it.

\section{Leiothrix argentadris, Hodgson.}

Mesia argentauris, Hodgs., Ind. Rev., vol. ii, p. 88, 1838.

Plilocalyx argentauris, Hodgs., Journ. As. Soc., Bengal, vol. x, p. 29, 1841.

Fringilloparus argentauris, Hodgs., Journ, As. Soc., Bengal, vol. xiii, p. 935, 1844; id., Gray's Zool. Misc., p. 84, 1844.

Leiothrix argentauris, Gray, Gen. B., vol. i, p. 269, 1846 ; Blyth, Cat. B. Mus., As. Soc., Bengal, p. 99, 1849 ; Bonap. Consp., t. i, p. 332, 1850 ; Horsfield \& Moore, Cat. B. Mus. E. Ind. Co., vol. i, p. 365, 1854; Jerdon, B. Ind.; vol. ii, p. 251, 1863 ; Gray, Handl. B., vol. i, p. 313, 1869 ; Godwin-Austen, Journ. As. Soc., Bengal, vol. xxxix, 1870, p. 109 ; Blyth \& Walden, Journ. As. Soc., Bengal, vol. xliv, 1875, ex. No., p. 109 ; W. Ramsay, Ibis, 1877, p. 464.

a. Ponsee, 23rd April 1868

b. Shitee Mt., Kakhyen range, 20th February 1875.

Rare, as compared with $L$. callipyga, but associated with it at Ponsee.

\section{Leiothrix cYanuropterus, Hodgson.}

Siva cyanouroptera, Hodgs., Ind. Rev., ] 838, p. 88; Gray, Cat. Mamm., \&c., Nepal, p. 95, 1846 ; Gould, B. Asia, pt. xiv, 1862 ; Jerdon, B. Ind., vol. ii, p. 253, 1863 ; Hume, Nests and Eggs, Ind. B., p. 393, 1874.

Leiothrix lepida, McClell., Proc. Zool. Soc., 1839, p. 162.

Hemiparus cyanouropterus, Hodgs., Journ. As. Soc., Bengal, vol. x, p. 29, 1841.

Ioropus cyanouropterus, Hodgs., Journ. As. Soc., Bengal, vol. xiii, p. 937, 1844; id., in Gray's Zool. Misc., p. 84, 1844.

Leiothrix cyanuroptera, Gray, Gen. B., vol. i, p. 269, 1845 ; Blyth, Cat. B. Mus., As. Soc., Bengal, p. 99, 1849 ; Bonap. Consp., t. i, p. 332, 1850 ; Horsfield \& Moore, Cat. B. Mus. E. Ind. Co., vol. i, p. 366, 1854; Gray, Handl. B., i, p. 313, 1869 ; Godwin-Austen, Journ. As. Soc., vol. xlv, 1876, p. 82.

a. 우 Ponsee, March 1868.

\section{Genus Herpornis, Agassiz.}

\section{Herpornis xantholeuca, Hodgson.}

Erpornis xantholeuca, Hodgs., Journ. As. Soc., Bengal, vol. xiii, p. 380 (1844) ; Blyth, Cat. B. Mus., As. Soc., Bengal, p. 101 (1849) ; Horsfield \& Moore, Cat. B. Mus. E. Ind. Co., vol. i, p. 232, 1854; Jerdon, B. Ind., vol. ii, p. 264, 1862 ; Hume, Stray Feathers, 1874, p. 479, 1875, p. 142. Erpornis xanthochlora, Hodgs., Proc. Zool. Soc., 1845, p. 23; Bonap. Consp., t. i, p. 259, 1850 ; Gray, Handl. B., vol. i, p. 315, 1869.

Timalia xanthochlora, Hodgs., Cat. Birds, Nepal, p. 85; Gray, Gen. B., vol. iii, App. p. 10, 1849. 
Herpornis xantholeuca, Godwin-Austen, Journ. As. Soc., Bengal, vol. xlv, 1876, p. 83; Sharpe, Ibis, 1876, p. 41 .

a. t Nampoung, 19th February 1875.

b. \& Shitee Mt., Kakhyen hills, 20th February 1875.

\section{Family-ZOST'EROPIDAE.}

Genus Zosterops, Vigors.

112. Zosterops Palpebrosa, Temminck.

Sylvia palpebrosa, Temm., Pl. Col., 293, fig. 3, 1824.

Zosterops maderaspatensis, Jerdon, Madr. Journ., xi, p. 7, 1840.

Zosterops palpebrosus, Blyth, Journ. As. Soc., Bengal, vol. xv, p. 44, 1846 ; Hutton, Journ. As. Soc., Bengal, vol. xvii, p, 690, 1848; Gray, Gen. B., i, p. 198, 1848; Blyth, Cat. B. Mus., As. Soc., Bengal, p. 220, 1849 ; Bonap. Consp. G. Av., p. 398, 1850 ; Jerdon, B. Ind., vol. ii, p. 265 1863 ; Horsfield \& Moore, Cat. B. Mus. E. Ind. Co., p. 263, 1854; Hartl., Journ. f. Orn., 1865, p. 14; Stoliczka, Journ. As. Soc., Bengal, vol. xxxvii, 1868, p. 51 ; Gray, Handl. B., vol. i, p. 162, 1869; Godwin-Austen, Journ. As. Soc., Bengal, vol. xxxix, 1870, p. 109 ; Holdsw., Proc. Zool. Soc., 1872, p. 458, pl. xx, fig. 1; Adam., Stray Feathers, 1873, p. 384; Ball, t. c., p. 74; Cock. \& Marsh., t. c., p. 356 ; Ball, op. cit., 1874, p. 417; Hume, t.c., p. 479; id., op. cit., 1875, p. 143; Brooks, t. c., p. 252 ; Blyth \& Walden, Journ. As. Soc., Bengal, vol. xliv, 1875, ex. No., p. 110 ; Hume, Stray Feathers, 1876, p. 37 ; pp. 291, 463 ; Fairbank, t.c., p. 266 ; Fairbank, op. cit., 1877, p. 401.

a. \& Momien, July 1868 .

In bushes on the grassy hill sides.

Jerdon describes the belly as bluish-white, which it is in some specimens, but in others it has a decided buff tinge. The centre of the belly is always paler than the sides. The black lores are always more or less developed, but in Temminck's figure there is only a faint trace of black in that region. A bird from Central India agrees exactly with Temminck's figure, but it is a young male, while in others, apparently adults, from the same locality, the lores are prominently black. In a bird from Ootacamund on the Nilgiris, with a longer and every way larger bill than the ordinary run of Indian birds, the lores are jet black, and better defined than in any of the others. The sides of the body and flanks are ashy-grey, and the middle of the belly albescent; but I have seen small-billed specimens, undoubted Z. palpebrosus, with the same colour on the abdomen; indeed the tints vary much on these parts. This long-billed individual can be connected to true Z. palpebrosus by a gradation, not only of bill measurements, but also of dorsal and loreal tints.

\section{Zosterops SIMPLex, Swinhoe.}

Zosterops simplex, Swinhoe, Proc. Zool. Soc., 1862, p. 317, 1863, p. 203 ; id., Ibis, 1863, p. 294, 1866 , p. 171, 1870, p. 348 ; Gray, Handl. B., i, p. 163, 1869; Swinhoe, Proc. Zool. Soc., 1871 , p. 349 ; Gould, B. Asia, pt. xxiii, 1871. 
This bird differs chiefly from $Z$. palpebrosa in being a little darker and in having the bill a little longer than Indian birds.

\section{Family-PARID AR.}

\section{Genus MeLanochloria, Lesson.}

\section{Melanochlora sultanea, Hodgson.}

Parus sultaneus, Hodgs., Ind. Rev., 1836, p. 31 ; id., in Gray's Zool. Misc., p. 83, 1844; Gray, Gen. B., vol. i, p. 192, 1847; Horsfield \& Moore, Cat. B. Mus. E. Ind. Co., vol. i, p. 369, 1856 ; Gray, Handl. B., vol. i, p. 234, 1869.

Parus cristatus, Lafr., Rev. et Mag. de Zool., 1837, pl. Ixxx; Mc'Clell., Proc. Zool. Soc., 1839, p. 162 ; Blyth, Journ. As. Soc., Bengal, vol. xi, p. 184, vol. xii, p. 955, 1843 ; id., Cat. B. Mus., As. Soc., Bengal, p. 102, 1849; Strickl., Proc. Zool. Soc., 1846, p. 100 ; Gray, Handl. B., vol. i, p. 234, 1869.

Melanochlora sumatrana, Less., Rev. Zool., 1839, p. 42.

Crataionyx flava, Eyton, Proc. Zool. Soc., 1839, p. 104.

Crataionyx ater, Eyton, Proc. Zool. Soc., 1839, p. 104.

Parus sumatranus, Blyth, Journ. As. Soc., Bengal, vol. xi, p. 792 ; Gray, Gen. B., vol. i, p. 192, 1847. Melanochlora sultanea, Bonap. Consp., t. i, p. 333, 1850; Jerdon, B. Ind., vol. i, p. 282, 1862 ;

Walden, Proc. Zool. Soc., 1866, p. 551 ; Gould, B. Asia, pt. xx, 1868; Hume, Stray Feathers, 1874, p. 479,1875 , p. 143.

Meĩanocỉiora flavocristatus, Bonap. Consp., t. i, p. 333, 1850.

a. t Kakhyen hills, March 1875.

Genus Parus, Linnæus.

\section{Parus commixtus.}

Parus commixtus, Swinhoe, Ibis, 1868, p. 63; id., Proc. Zool. Soc., 1871, p. 361 ; Hume, Stray Feathers, 1874, p. 479 ; Blyth \& Walden, Journ. As. Soc., vol. xliv, ex. No., 1875, p. 111.

Parus commixus, Gray, Handl. B., vol. i, p. 231, 1869.

a. Adult, Ponsee, 3rd May 1868.

b. c. $d$. juv. Muangla, 21st January and 19th March 1868. serim.

This species has been found to the south in Karenee and in Northern Tenas-

\section{Parus nipalensis, Hodgson.}

Parus nipalensis, Hodgs., Ind. Rev., 1838, p. 31 ; Blyth, Journ. As. Soc., Bengal, vol. xi, p. 459, 1842 ; id., op. cit., vol. xii, p. 182, 1843; Godwin-Austen, Journ. As. Soc., Bengal, vol. xlv, 1876, p. 83; Gray, Cat. Mamm., \&c., Nepal, p. 72, 1846; Blyth \& Walden, Journ. As, Soc., Bengal, vol. xliv, 1875, ex. No., p. 112.

Parus schistinotus, Hodgs., in Gray's Zool. Misc., p. 83, 1844.

Parus atriceps (nec Horsf.), Sykes, Proc. Zool. Soc., 1832, p. 92; Mce'Clell., Proc. Zool. Soc., 1839, p. 162 ; Jerdon, Madr. Journ., xi, p. 7, 1840 ; Blyth, Journ. As. Soc., Bengal, vol. xiii, p. 943,1844 . 
Parus cincreus (nec Vieill.), Blyth, Cat. B. Mus., As. Soc., Bengal, p. 103, 1849 ; Bonap. Consp., t. i, p. 229, 1850; Blyth, Contr. Orn., 1852, p. 49; Layard, Ann. Nat. Hist., vol. xii, 1853, p. 267; Horsfield \& Moore, Cat. B. Mus. E. Ind. Co., vol. i, p. 370, (pt.) 1854; Jerdon, B. Ind., vol. ii, p. 278, 1863 ; Gray, Handl. B., vol. i, p. 231 ; Holdsw., Proc. Zool. Soc., 1872, p. 460 ; Adams., Stray Feathers, 1873, p. 384; Ball, op. cit., 1874, p. 417.

Parus casius, Swinhoe, Proc. Zool. Soc., 1871, p. 361 ; Hume, Nests and Eggs, 1873, p. 405; id., Stray Feathers, p. 143, 1875.

a. \& Mengoon, 14th January 1868.

Family-SITIID A.

Genus Dendrophila, Swainson.

117. Dendrophila corallina, Hodgson.

Sitta frontalis (nec Horsf.), Tickell, Journ. As. Soc., Bengal, vol. ii, p. 579, 1833; MeClell., Proc. Zool. Soc., 1839, p. 165; Gray, Cat. B., Nepal, Hodgs., p. 62, 1846.

Sitta corallina, Hodgs., Journ. As. Soc., Bengal, vol. v, p. 779, 1836.

Dendrophila frontalis, Jerdon, Madr. Journ., vol. xi, p. 48, 1840; Blyth, Journ. As. Soc., Bengal, vol. xiv, p. 580, 1845; id., Cat. B. Mus., As. Soc., Bengal, p. 190, 1849; Jerdon, B. Ind., vol. i, p. 388, 1862 ; Beavan, Proc. Zool. Soc., 1866, p. 3; et Ibis, 1869, p. 425 ; Blanford, Ibis, 1870, p. 466 ; Holdsw., Proc. Zool. Soc., 1872, p. 435; Fairbank, Stray Feathers, 1876, p. 265 ; Fairbank, op. cit., 1876, p. 393 ; op. cit., 1877, p. 399 ; Godwin-Austen, Journ. As. Soc., Bengal, vol. xlv, 1876, p. 71.

Dendrophila corallina, Bonap. Consp., t. i, 1850, p. 226 ; Gray, Hand List, B. M., ii, 1864, p. 182 ; Hume, Stray Feathers, 1874, p. 473 ; 1875, p. 89 ; Sharpe, $t_{.} c_{.}, 1875$, p. 436.

a. t Ponsee, 14th April 1868.

b. ㅇ Right bank of Tapeng, 5th February 1875 .

The Marquis of Tweedale has recently stated ${ }^{1}$ that he is disposed to regard the Javan bird as identical with the Himalayan form, but as the identity of the two forms has not been satisfactorily proved, I have followed Sharpe in separating them.

Family-TIMALIID A.

Genus Pomatorhinus, Horsfield.

118. Pomatorhinus Ruficollis, Hodgson.

Pomatorlinus ruficollis, Hodgs., As. Res., vol. xix, p. 182, 1836 ; Blyth, Journ. As. Soc., Bengal, vol. xi, p. 175, 1842 ; vol. xii, p. 946, 1843 ; Hodgs., Cat. B., Nepal, p. 86, 1846 ; Gray, Gen. B., vol. i, p. 229, 1846 ; Blyth, Cat. B. Mus., As. Soc., Bengal, p. 147, 1849; Bonap. Consp., Gen. Av., p. 220, 1850 ; Horsfield \& Moore, Cat. B. Mus. E. Ind. Co., vol. i, p. 236, 1854; Jerdon, B. Ind., vol. ii, p. 29 ; Beavan, Ibis, 1867, p. 433 ; Gray, Handl. B., vol. i, p. 278, 1869; Godwin-Austen, Journ. As. Soc., Bengal, vol. xliii, 1874, p. 160 ; op. cit., 1876, vol. xlv, p. 75.

a. Momien, 29th May 1868.

${ }^{2}$ Ibis, 1876, p. 346. 
The rusty colour is most intense immediately behind the black ear-coverts. The tarsus is $1^{\prime \prime} \cdot 25$. This species is closely allied to the $P$. musicus, Swinhoe, which has the breast spots dark-brown instead of pale rusty-olive, and the belly marked with bright rusty-red. The differences between the Formosan and Momien specimens, both of which are before me, are not greater than those which exist between it and undoubted specimens of $P$. erythrogenys, Gould. The tail, as in the generality of the species of this genus, is faintly barred.

I found this bird solitary, in a hedgerow enclosing a potatoe field near Momien.

\section{Pomatorhinus erythrogenys, Vigors.}

Pomatorhinus erythrogenys, Vigors, Proc. Zool. Soc., 1831, p. 173 ; Gould, Cent. Himal. Birds, pl. Iv, 1832 ; Blyth, Journ. As. Soc., Bengal, vol. xi, p. 175, 1842 ; vol. xii, p. 946, 1843 ; G. R. Gray, Gen. Birds, vol. i, p. 229, 1846; Blyth, Cat. B. Mus., As. Soc., Bengal, p. 146, 1849 ; Bonap. Consp., t. i, p. 220, 1850 ; Horsfield \& Moore, Cat. B. Mus. E. Ind. Co., p. 235, 1854; Jerdon, B. Ind., vol. ii, p. 31, 1863; Gray, Handl. B., vol. i, p. 277, 1869; Jerdon, Ibis, 1872, p. 301 ; Hume, Stray Feathers, 1874, p. 476 ; Brooks, op. cit., 1875 , p. 237 ; Blyth \& Walden, Journ. As. Soc., Bengal, vol. xliv, 1875, ex. No., p. 113.

Pomatorhinus ferrugilatus, Hodgs., As. Res., vol. xix, p. 100, 1836.

a. Momien, 3rd June 1868.

This specimen agrees in every respect with one from Simla, except that the breast is dashed with dark-brown instead of dusky, of the same intensity as in $P$. erythrocnemis, Gould, to which it has a wonderful resemblance in many ways; but the bright rusty of the knees and vent are not darker than the rusty on the sides of the abdomen and body generally. This specimen was found in the same locality as the previous bird (P. ruficollis).

\section{Genus Timalia, Horsfield.}

\section{Timalia pileata, Horsfd.}

Timalia pileata, Horsfield, Trans. Linn. Soc., vol. xiii, 1821, p. 151 ; Zool. Research., Java ; Gray, Cat. Mamm., \&c., Nepal, Hodgs., 1846, p. 85; Jerdon, Birds of India, vol. ii, 1862, p. 24; Hume, Stray Feathers, 1873, p. 476 ; op. cit., 1875, p. 118 ; Armstrong, op. cit., 1876, p. 323; Oates, op. cit., 1877, p. 152.

Napodes pileata, Cabanis, Mus. Heine., th. i, p. 77, 1860.

Timalia jerdoni, Walden, Ann. and Mag. Nat. Hist., 1872, vol. x, p. 61 ; Blyth \& Walden, Journ. As. Soc., Bengal, vol. xliv, 1875, extra No., p. 114.

Timalia bengalensis, Godwin-Austen, Journ. As. Soc., Bengal, vol. xli, 1872, p. 143 ; op.cit., vol. xlv, ] 876, p. 75 .

a. Yaylaymaw, 5th January 1875.

b. \& Bhamô, 4th February 1868.

The top of the head of this species would be more accurately described as rich chestnut, instead of bright rusty-red. I count as many as fourteen dark-brown bars on the tail. They are so prominent as to attract attention. The line of union of 
the chestnut of the head with the white frontal band is marked by a faint black line which is present in all the specimens I have examined. The Bhamô bird has the white frontal band narrower than in Indian ones, and the ear-coverts, instead of being white, have a faint rufous tinge, which also occurs on the chin; the abdomen is dark olivaceous ferruginous.

\section{Genus Mixornis, Hodgson.}

\section{Mixornis Rubricapilla, Tickell.}

Motacilla rubricapilla, Tickell, Journ. As. Soc., Bengal, vol. ii, 1833, p. 576.

Iora chloris, Blyth, Journ. As. Soc., Bengal, vol. xi, p. 794, 1842.

Mixornis ruficeps, Hodgs., Proc. Zool. Soc., 1845, p. 23.

Timalia gularis, Gray, Cat. Mamm., \&c., Nepal, Hodgs., p. 85, 1846.

Mixornis chloris, Bonap. Consp. Av., t. i, p. 217, 1850.

Timalia chloris, Bonap., Comptes Rendus, t. xxxviii, p. 59, 1854.

Mixornis mbricapilla, Horsf. \& Moore, Cat. B. Mus. E. Ind. Co., vol. i, p. 229, 1854; Jerdon, B. Ind., vol. ii, p. 23, 1863; Walden, Proc. Zool. Soc., 1866, p. 547; Blyth, Ibis, 1867, p. 3; Beavan, t. c., p. 432 ; Blanford, Ibis, 1870, p. 467; Godwin-Austen, Journ. As. Soc., Bengal, vol. xxxix, 1870, p. 103; Blyth, Ibis; 1870, p. 170 ; Walden, Ibis, 1872, p. 376 ; Hume, Stray Feathers, 1873, p. 118 ; 1875, p. 118; Ball, op. cit., 1874; Hume, t. c., p. 476 ; id., Nests and Eggs, Ind. B., p. 245, 1873; Godwin-Austen, Journ. As. Soc., Bengal, vol. xlv, 1876, pp. 75, 409.

Timalia rubricapilla, Gray, Handl. B., vol. i, p. 316, 1869.

\section{a. t Bhamô, September 1868.}

My specimen, when compared with Nepalese examples, is more distinctly streaked on the throat, the latter being of a more vivid yellow. It has also a reddish tinge on the back, which makes it appear very like the Malayan species. From this, however, it is distinguished by its pale rufous wings like the Himalayan bird.

\section{Genus AlCIPpe, Blyth.}

\section{Alctppe Phayrei, Blyth. Pl. XLVIII.}

Alcippe phayrei, Blyth, Journ. As. Soc., Bengal, vol. xiv, p. 601, 1845; Hume \& Oates, Stray Feathers, 1875, vol. ix, pp. 116, 117.

Malacopteron phayrei, Gray, Handl. B., vol. i, p. 317, 1869.

Alcippe magnirostris, 'Walden, Journ. As. Soc., Bengal, vol. xlv, extra No., 1875, p. 115 ; Ibis, 1877 , p. 487; Hume, Stray Feathers, vol. v, 1877, pp. 56, 60.

$$
\begin{aligned}
& \text { a. b. ¿ Bhamô, 20th September } 1868 . \\
& \text { c. e. o Sawady, 25th to 30th January } 1875 . \\
& f \text {. } \quad \text { t Right bank of Tapeng river, 5th February } 1875 . \\
& \text { g. } \quad \text { + Nampoung, 19th February } 1875
\end{aligned}
$$

Little or no difference exists in the sexes of this species, but the two specimens killed in September seem to be rather duller coloured and to have browner bills, and the black stripe does not exist in the same intensity. 
Mr. Hume (Stray Feathers, iii, p. 116) records this species from Upper Pegu, and speaks of it as being less rufescent than $A$. poiocephala. The only specimen of the latter species which I have been able to compare is a Kattywar example presented by Major Hayes Lloyd to the British Museum. This is perhaps not quite typical, but it is certain that all my birds are very much more rufescent than it. The other distinctions mentioned by Mr. Hume hold good.

\section{Genus StachrRIs, Hodgson.}

\section{Stachyris Nigriceps, Hodgson.}

Stachyris nigriceps, Hodgs., Journ. As. Soc., Bengal, vol. xiii, p. 378, 1844; id., Proc. Zool. Soc., 1845, p. 22 ; id., Ann. Nat. Hist., vol. xvi, p. 193, 1846 ; Gray, Cat. B., \&c., Nepal, Hodgs., p. 74, 1846 ; Blyth, Cat. B. Mus., As. Soc., Bengal, p. 150, 1849 ; Bonap. Consp., Gen. Av., p. 332, 1850 ; Horsf. \& Moore, Cat. B. Mus. E. Ind. Co., p. 231, 1856-58; Jerdon, B. Ind., vol. ii, p. 21, 1863; Godwin-Austen, Journ. As. Soc., Bengal, xxxix, p. 103, 1870 ; Hume, Nests and Eggs, Ind. B., p. 242, 1873; id., Stray Feathers, 1875, p. 117; Blyth \& Walden, Journ. As. Soc., Bengal, vol. xliv, 1875, extra No., p. 116; Hume, Stray Feathers, 1875, pp. 13, 117, 322; Godwin-Austen, Journ. As. Soc., Bengal, vol. xlv, 1876, p. 75; Oates, Stray Feathers, 1877, p. 152.

Timalia nigriceps, Gray, Gen. B., vol. iii, App. p. 10, 1849; id., Handl. B., vol. i, p. 315, 1869.

$$
\begin{aligned}
& \text { a. む Ponsee, 26th March } 1868 . \\
& \text { b. ซ , April } 1868 . \\
& \text { c. }, \quad,
\end{aligned}
$$

This no way differs from specimens from Darjeeling and Arakan in the Calcutta Museum. Neither Blyth nor Jerdon mention in their descriptions that there are two rather obscure black white-edged bands on either side of the back of the neck, the backward prolongations of a black, white-margined band which runs over the eye and some distance behind the ear-coverts. The feathers between these two bands are more brown than black posteriorly, but on the forehead they are darker. The white margins of the head feathers arranged symmetrically in long lines alternate with the dark ones. A dark-brown line from the lores passes below the eye to its posterior angle, and another to the throat enclosing a large white spot, at the angle of the mouth; on the throat it joins its fellow from the opposite side, and they expand to form a dark-brown patch on the centre of the throat and chin.

The specimens are all from the low shrubby jungle about Ponsee.

\section{Stachyris chrysea, Hodgson.}

Stachyris chrysca, Hodgs., Journ. As. Soc., Bengal, vol. xiii, p. 379, 1844; Proc. Zool. Soc., 1845, p. 23 ; Ann. Nat. Hist., vol. xvi, p. 193, 1845 ; Cat. B., Nep., p. 75, 1846 ; Blyth, Cat. B. Mus., As. Soc., Bengal, p. 150, 1849; Bonap. Consp., G. Av., p. 332, 1850 ; Jerdon, B. Ind., vol. ii, p. 22, 1863; Gray, Handl. B., vol. i, p. 315, 1869; Godwin-Austen, Journ. As. Soc., 
Bengal, vol. xxxix, p. 103, 1870 ; Hume, Nests and Eggs, Ind. B., p. 245, 1873; Blyth \& Walden, Journ. As. Soc., Bengal, vol. xliv, 1875, extra No., p. 116; Godwin-Austen, Journ. As. Soc., Bengal, vol. xlv, 1876, p. 75.

Timalia chrysaa, Gray, Gen. B., vol. iii, App. p. 10, 1849.

$$
\text { a. Ponsee, 30th April } 1868 .
$$

I procured only one young example of this species, and it is very immature; at the same time, the identification has been ascertained by comparison with undoubted individuals of the species of different ages.

It is improbable that it ranges to the eastward beyond the Kakhyen hills, as the character of the fauna changes and becomes more and more Chinese.

\section{Genus Pyсто Rhis, Hodgson.}

\section{Pyctorits sinensis, Gmelin.}

Chinese Titmouse, Lath., Syn., vol, ii, 2, p. 555, 1783.

Parus sinensis, Gm., Syst. Nat., t. i, p. 1012, 1788.

Timalia hypoleuca, Frankl., Proc. Zool. Soc., 1831, p. 118; id., Journ. As. Soc., Bengal, vol. i, p. 313, 1832 ; Jerdon, Madr. Journ., vol. x, p. 260, 1839 ; Blyth, Ann. Nat. Hist., xii, p. 97, 1843 ; Journ. As. Soc., Bengal, vol. xi, p. 795, 1842 ; xii, p. 181, 1843 ; Gray, Gen. B., vol. i, p. 228, 1846.

Timalia bicolor, Lafresn., Mag. de Zool., 1835, Ois., pl. xxxix.

Timalia horsfieldii, Jerdon \& Selby, Ill. Orn., pl. 119 ; Blyth, Journ. As. Soc., Bengal, vol. xi, p. 199, 1842 ; Gray, Cat. Mamm., \&c., Nepal, Coll. Hodgs., p. 86, 1846.

Pyctorhis hypoleuca, Hodgs., Gray's Zool. Misc., 1844, p. 83.

Chrysomma hypotencos, Blyth, Journ. As. Soc., Bengal, vol. xlv, p. 602, 1845.

Pyctortis rufifrons, Hodgs., Proc. Zool. Soc., 1845, p. 24.

Chrysomma sinense, Blyth, Journ. As. Soc., Bengal, vol. xvi, p. 454, 1847; id., Cat. B. Mus., As. Soc., Bengal, p. 150, 1849; Bonap. Consp., p. 216, 1850 ; Horsf. \& Moore, Cat. B. Mus. F. Ind. Co., vol. i, p. $230,1854$.

Pyctorhis sinensis, Jerdon, B. Ind., vol. ii, p. 15, 1863 ; Stoliczka, Journ. As. Soc., Bengal, vol. xxxvii, 1868, p. 36; King, t. c., p. 214; Gray, Handl. B., vol. i, p. 316, 1869; Hume, Nests and Eggs, Ind. B., p. 237, 1873 ; id., Stray Feathers, 1873, p. 179; Adam., t. c., p. 378 ; Ball, op. cit., 1874, p. 408 ; Hume, t. c., p. 475 ; id., op. cit., 1875, p. 115; id., op. cit., 1876, p. 34; Fairbank, t. c., p. 265; Blyth \& Walden, Journ. As. Soc., Bengal, vol. xliv, 1875, ex. No., p. 117 ; Godwin-Austen, ib., vol. xlv, 1876, p. 74; Oates, Stray Feathers, 1877, p. 151.

\section{a. ๖ Bhamô, February 1868.}

This specimen differs from the Indian birds in the upper parts being slightly darker, and the under parts pale cinereous white, on the chin, throat and breast, the belly being of a darker tint of the same colour, slightly tinged with rufous. Jerdon describes all the lower plumage of the species as white, whereas nearly every bird has a well marked rufous tinge on the abdomen. There is also always a pale supercilium, which is prolonged behind the eye.

This is not a common bird about Bhamô. 


\section{Genus Chueuasicus, Blyth.}

\section{Chleuasicus RuficePs, Blyth. ${ }^{1}$ Plate XLVII.}

Chlenasicus ruficeps, Blyth, Journ. As. Soc., Bengal, vol. xlv, p. 578, 1845 ; Jerdon, B. Ind., vol. ii, p. 7, 1863 ; Hume, Stray Feathers, vol. v, 1877, p. 499.

Suthora ruficeps, Blyth, Cat. B. Mus., As. Soc., Bengal, p. 102, 1849 ; Gray, Handl. B., vol. ii, p. $235,1870$.

Chlenasicus muficeps atro-superciliaris, var., Godwin-Austen, Proc. As. Soc., Bengal, 1877, p. 147.

Chleuasicus atro-superciliaris, Godwin-Austen, Proc. As. Soc., Bengal, 1877, p. 102 ; Journ. As. Soc., Bengal, vol. xxvi, 1877, p. 44; Stray Feathers, 1877, p. 499.

\section{a. Ponsee, 22nd April 1868.}

I shot this rare bird among tall grass at an elevation of about 4,500 feet, near the summit of the ridge above Ponsee. It was flitting amongst the grass from stem to stem with its mate.

This specimen which I have figured has a narrow black band from the bill to the anterior angle of the eye, passing over the eye as a narrow supercilium, expanding somewhat behind it over the ear-coverts, and in this respect it corresponds to the bird described by Lieutenant-Colonel Godwin-Austen as a variety from India or Upper Assam, and which Mr. Hume believes to be the male bird.

Genus SuthorA, Hodgson.

127. Suthora Brunnea, Andr. Plate XLIX.

Suthora brunnea, Anderson, P. Z. S., 1871, p. 211 ; Swinh., t.c., p. 373 ; Gould, B. A., pt. xxviii, 1876. Suthora suffusa, Swinhoe, Proc. Zool. Soc., London, 1871, p. 372.

a. b. c. \& d. Momien, 5th June 1868.

Total length $5^{\prime \prime} \cdot 20$; wing $2^{\prime \prime} \cdot 15$; tail $2^{\prime \prime} \cdot 74$; bill $0^{\prime \prime} \cdot 35$; tarsus $0^{\prime \prime} \cdot 84$.

Above brownish-olive, head and nape rich reddish ferruginous; chin and throat as well as the breast suffused with rosy, and faintly striated with brown; middle of abdomen buff; sides of abdomen and under tail-coverts dusky olive-brown; wings and tail brown; primaries and tail-feathers narrowly and faintly margined with yellowish-olive.

The characters which Swinhoe assigned to S. suffusa are those by which I distinguished between S. bulomachus, Swinhoe, and this species, viz., the much richer character of the red of the head and neck in $S$. brunnea, and the absence of red on the wing; the centre of the abdomen being buff. Besides S. webbiana there are the recently discovered species by M.l'Abbé David, S. conspicillata, S. cyanophrys, and $S$. gularis, the latter allied to the beautiful little golden-headed species S. daflaensis, discovered by Lieutenant-Colonel Godwin-Austen in the Dafla hills.

${ }_{1}^{1}$ Through an oversight on the part of those entrusted with the preparation of the plates in London, I regret that an orthographical error has been allowed to pass in the naming of this plate. 
I found this bird in the low shrubby jungle near. Momien, at 4,500 feet, and always in large flocks, some thirty. or forty together, which made short, rapid and low flights from bush to bush, uttering a sharp and constantly repeated chirp.

$$
\text { Family-MEGALURIDA. }
$$

Genus Chatarrhea, Blyth.

128. Chatarrhata gularis, Blyth. Plate XlVIII.

Chatarrhaea gularis, Blyth, Journ. As. Soc., Bengal, vol. xxiv, p. 478, 1855; Blanf., Ibis, 1870, p. 460 ; Hume, Stray Feathers, 1875, p. 124.

Malacocercus gularis, Gray, Handl. B., vol. i, p. 279, 1869.

Crateropus gularis, Blanf., Ibis, 1874, p. 76 ; id., Stray Feathers, 1874, p. 329 ; Blyth, Journ. As. Soc., Bengal, vol. xliv, 1875, ex. No., p. 117.

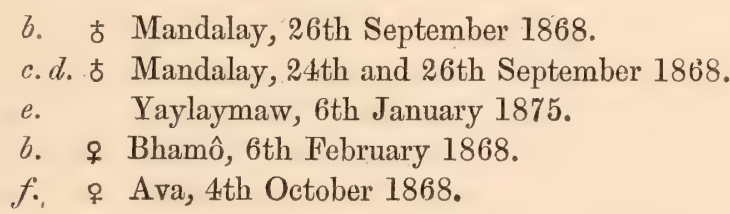

This species is common at Bhamô among the long tall rank grass of the swamps behind the town. It is also abundant in similar localities to the east of Mandalay.

\section{Genus Megalurus, Horsfield.}

\section{Megalurus palustris.}

Megalurus palustris, Horsf., Tr. Linn. Soc., vol. xiii, p. 159, 1820 ; Gray, Gen. B., vol. i, p. 169, 1845 ; Blyth, Cat. B. Mus., As. Soc., Bengal, p. 139, 1849; Bonap. Consp., t. i, p. 279, 1850; Cab., Mus. Hein., th. i, p. 45, 1850 ; Horsf. \& Moore, Cat. B. Mus., As. Soc., Bengal, vol. i, p. 330, 1854; Jerdon, B. Ind., vol. ii, p. 70, 1863 ; Blyth, Ibis, 1865, p. 30 ; Gray, Handl B., i, p. 206, 1869 ; Blanf., Ibis, 1869, p. 467 ; Hume, Nests and Eggs, Ind. B., i, p. 276 , 1873 ; Hume, Stray Feathers, 1874, p. 476, 1875, p. 124; Walden, Tr. Zool. Soc., ix, p. 189, 1875 ; Blyth \& Walden, Journ. As. Soc., Bengal, vol. xliv, 1875, ex. No., p. 118; Ball, Stray Feathers, 1876, p. 233; Godwin-Austen, Journ. As. Soc., Bengal, vol. xlv, 1876, p. 78; Oates, Stray Feathers, 1877, p. 156.

Mahurus marginalis, Temm., Pl. Col., tom. iii, pl. lxv, fig. 2, 1823 (ex Review, MS.) ; Kittl., Voy. Lütke (Postels), Bd. iii, p. 326.

$$
\begin{aligned}
& \text { a.b.c. d. t } q \text { Bhamô, 23rd and 24th February } 1868 \text {. } \\
& \text { e. } \delta \text { Tsitkaw, 6th February } 1875 .
\end{aligned}
$$

Common throughout Upper Burma. 


\section{Genus Drymoipus, Bonaparte.}

\section{Drymoipus inornatus, Sykes.}

Prinia macrura, Frankl., Proc. Zool. Soc., 1831, p. 118; Jerdon, Madr. Journ., vol. xi, p. 4, 1846. Prinia inornata, Sykes, Proc. Zoo!. Soc., 1832, p. 89; Jerdon, Madr. Journ, vol. xi, p. 4, 1840; Blyth, Journ. As. Soc., Bengal, vol. xiii, p. 376, 1844, vol, xviii, p. 812, 1849 ; Fraser, Zool. Typ., pl. xliv, 1848-49 ; Layard, Ann. Nat. Hist., 1853, p. 263 ; Gray, Handl. B., vol. i, p. 197, 1869.

Sylvia longicaudata, Tickell, Journ. As. Soc., Bengal, vol. ii, p. 576, 1833.

Prinia franklinii, Blyth, Journ. As. Soc., Bengal, vol. xiii, p. 376, 1844.

Prinia fusca, Hodgs., in Gray's Zool. Misc., p. 82, 1844; id., Proc. Zool. Soc., 1845, p. 29 ; Gray, Cat. Mamm., \&c., Nepal, Coll. Hodgs., p. 63, 1846.

Drymoica fusca, Blyth, Journ. As. Soc., Bengal, vol. xvi, p. 460, 1847.

Drymoica inornata, Blyth, t.c., p. 459, 1847 ; id., Cat. B. Mus., As. Soc., Bengal, p. 142, 1849 ; Gray, Gen. B., vol. i, p. 164, 1848; Horsf. \& Moore, Cat. B. Mus. E. Ind. Co., vol. i, p. 328, 1854; Gray, Cat. Mamm., \&c., Nepal., Coll. Hodgs., 1863, p. 29.

Suya inornata, Bonap. Consp., t. i, p. 281, 1850.

Drymoipus inornatus, Jerdon, B. Ind., vol. ii, p. 198, 1863 ; Godwin-Austen, Journ. As. Soc., Bengal, vol. xxxix, 1870, p. 107; Holdsw., Proc. Zool. Soc., 1872, p. 456; Henders. \& Hume, Luahore to Yarkand, p. 215, pl.xvii, fig. 1, 1873 ; Hume, Stray Feathers, 1873, pp. 439, 494; Ball, op. cit., 1874, p. 440; Hume, Nests and Eggs, Ind. B., p. 346, 1873 ; Brooks, Stray Feathers, 1875, p. 295.

Drymoipus longicaudatus, Jerdon, B. Ind., vol. ii, p. 180, 1863; Henders. \& Hume, Lahore to Yarkand, p. 215, pl. xvii, fig. 2, 1873 ; Hume, Stray Feathers, 1873, p. 194; Hume, op. cit., 1876 , pp. 39, 407; op. cit., 1877, p. 92 ; Adams., op. cit., 1873, p. 382 ; Hume, Nests and Eggs, Ind. B., p. 350, 1873 ; Brooks, Stray Feathers, 1875, p. 295; Brooks, op. cit., 1876, pp. 229, 274 ; Butler, op. cit., 1875, p. 483; id., op. cit., 1877, p. 286 ; Fairbank, op. cit., 1876, p. 259.

Prinia longicauda, Gray, Handl. B., vol. i, p. 197, 1869.

Drymoipus terricolor, Hume, Stray Feathers, 1873, p. 382, 1876, p. 407 ; id., Nests and Eggs, Ind. B., p. 349, 1873.

Drymoipus longicauda, Ball, Stray Feathers, 1874, p. 414.

Drymoipus fuscus, Hume, Nests and Eggs, Ind. B., p. 348, 1873.

Drymoca longicaudata, Blyth \& Walden, Journ. As. Soc., Bengal, vol. xliv, 1875, ex. No., p. 118.

Drymopus longicaudatus, Godwin-Austen, Journ. As. Soc., Bengal, vol. xlv, 1876, p. 80.

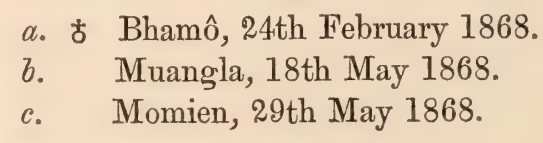

In bushes and hedgerows. Uncommon.

\section{Genus Prinia, Horsfield.}

\section{Prinia rufescens, Blyth.}

Prinia rufescens, Blyth, Journ. As. Soc., Bengal, vol. xvi, p. 456, 1847 ; Gray, Gen. B., p. 162, 1848 ; Blyth, Cat. B. Mus., As. Soc., Bengal, p. 143, 1849 ; Bonap. Consp., t. i, p. 284, 1850 ; Jerdon, B. Ind., vol. ii, p. 173, 1863; Gray, Handl. B., vol. i, p. 196, 1869; Blyth \& Walden, Journ. As. Soc., Bengal, vol. xliv, 1875, ex. No., p. 119.

$$
\text { a. b. c. Bhamô, 23rd, 27th, and 29th January } 1868 .
$$


Rufescent, dark olive-brown above, rufous more intense on the lower back. Quills edged with bright ferruginous. Chin and throat white, slightly ashy on the breast. Abdomen rufescent white. Tail-hair brown. Bill black. Legs fleshy coloured.

The species is very near $P$. gracilis, which I also obtained at Bhamô, but it has a shorter wing. The only differences between the specimens and the type are that the tail is not so rufescent in the birds from Bhamô and the breast is faintly cinereous.

\section{Prinia gracilis, Franklin.}

Prinia gracilis, Frankl., Proc. Zool. Soc., 1836, p. 119 ; Gray, Gen. B., vol. i, p. 162, 1848; Blyth, Cat. B. Mus., As. Soc., Bengal, p. 143, 1849; Jerdon, B. Ind., vol. ii, p. 172, 1863; G. King, Journ. As. Soc., Bengal, vol. xxxvii, 1868, p. 215 ; Gray, Handl. B., vol. i, p. 196, 1869 ; Ball, Stray Feathers, 1873, p. 414; Hume, t.c., p. 478; id., op. cit., 1875, p. 136 ; id., Nests and Eggs, Ind. B., p. 341, 1873 ; Blyth \& Walden, Journ. As. Soc., Bengal, vol. xliv, 1875, ex. No., p. 119 ; Butler, Stray Feathers, 1876, p. 480.

a. t Bhamô, 28th January 1868.

133. Prinia hodgsoni, Blyth.

Prinia gracilis, Jerdon, Madr. Journ., vol. xi, p. 3, 1840.

Prinia hodgsoni, Blyth, Journ. As. Soc., Bengal, vol. xiii, p. 376, 1844; id., op. cit., vol. xvi, p. 456, 1847 ; Gray, Cat. Mamm., \&c., Nepal, Coll. Hodgs., p. 63, 1846 ; id., Gen. B., vol. i, p. 162, 1848 ; Blyth, Cat. B. Mus, As. Soc., Bengal, p. 143, 1849; Bonap. Consp., t. i, p. 284, 1850; Horsf. \& Moore, Cat. B. Mus. E. Ind. Co., vol. i, p. 322, 1854; Jerdon, B. Ind., vol. ii, p. 173, 1863; Gray, Cat. Mamm., \&c., Nepal, Coll. Hodgs., p. 28, 1863; Gray, Handl. B., vol. i, p. 196, 1869; Hume, Stray Feathers, 1873, p. 136; id., op. cit., 1876, p. 37 ; Ball, t. c., p. 234; Fairbank, t. c., pp. 259 and 265 ; Hume, t.c., p. 40 ; id., Nests and Eggs, Ind. B., p. 342, 1873 ; Blyth \& Walden, Journ. As. Soc., Bengal, vol. xliv, 1875, ex. No., p. 119; W. Ramsay, Ibis, 1877, p. 466.

Prinia albigularis, Walden, Ann. Nat. Hist. (4), vol. v, p. 219, 1870; Blyth, Ibis, 1871, p. 112.

$$
\begin{gathered}
\text { a. b. } \text { ' Muangla, 19th May } 1868 . \\
\text { c. Sanda, 26th July } 1868 .
\end{gathered}
$$

I have compared these specimens with Blyth's types, from which they in no way differ.

\section{Genus Cisticola, Kaup.}

\section{Cisticola melanocephala, Andr.}

Cisticola melanocephala, Anders., Proc. Zool. Soc., 1871, p. 212 ; Godwin-Austen, Journ. As. Soc., Bengal, vol. xliii, 1874, p. 165, pl. ix, fig. 2; id., op. cit., vol. xlv, 1875, p. 30.

Cisticola ruficollis, Walden, Ann. Nat. Hist. (4), vol. vii, p. 241, 1871; Stray Feathers, 1875, p. 283 ; op. cit., 1877, p. 90 ; Hume, t. c., pp. 93, 140.

a. b. Sanda, July 1868.

Total length $4^{\prime \prime} \cdot 35$; wing $1^{\prime \prime} \cdot 70$; tail $2^{\prime \prime}$; tarsus $0^{\prime \prime} \cdot 72$; bill $0^{\prime \prime} \cdot 52$. 
Head black, feathers obscurely margined with rufous; lores and supercilium pale rufous, faintly striated with-brown; back and rump black, feathers margined with rufous cinereous; tail brown above, obscurely banded; cinereous below, o bscurely banded, black-spotted near the apex and tipped with pale rufous cinereo us; under tail-coverts ferruginous; wing-coverts brown, faintly margined with rufous; quills brown, edged with rufous; below ferruginous albescent.

Mr. Hume is disposed to regard this form as specifically identical with $C$. tytleri, Blyth, but the evidence as yet adduced by him is not conclusive.

Genus SurA, Hodgson.

135. Suya crinigera, Hodgson.

Suya crinigera, Hodgs., Asiat. Researches, vol. xix, p. 183, '1836 ; Blyth, Journ. As. Soc., Bengal, vol. xiii, p. 375, 1844; ; Bonap. Consp., t. i, p. 281, 1850; Horsf. \& Moore, Cat. B. Mus. E. Ind. Co., vol. i, p. 325, 1854; Jerdon, B. Ind., vol. ii, p. 283, 1863; Stoliczka, Journ. As. Soc., vol. xxxvii, 1868, p. 45 ; Cock. \& Marsh., Stray Feathers, 1873, p. 355; Hume, Nests and Eggs, Ind. B., p. 353, 1873 ; Hume, Stray Feathers, 1875, p. 138; Ball, t. c., p. 207 ; Brooks, t. c., p. 243.

Decurus criniger, Hodgs., in Gray's Zool. Misc., p. 82, 1844.

Decurus caudata, id., loc. cit., p. 82, 1844.

Prinia criniger, Gray, Cat. Mamm., \&c., Nepal, p. 63, 1846.

Drymoica criniger, Blyth, Journ. As. Soc., Bengal, vol. xvi, p. 458, 1847; id., Cat. B. Mus., As. Soc., Bengal, p. 142, 1849; Gray, Gen. B., vol. i, p. 164, 1848; Hutton, Journ. As. Soc., Bengal, vol. xvii, pt. 2, p، 692, 1848.

a. b. c. ㅇ d. t Momien, May, June, and July 1868.

In bushes and hedgerows, among the ruined towns, and not uncommon.

136. Suta superciliaris, Andr. Plate LI.

Suya superciliaris, Anders., Proc. Zool. Soc., 1871, p. 212.

a.b. t Momien, 2nd June 1868.

Total length $7^{\prime \prime}$; wing $1^{\prime \prime} \cdot 87$; tail $4^{\prime \prime}$; tarsus $0^{\prime \prime} \cdot 85$; bill $0^{\prime \prime} \cdot 44$.

The bright supercilium and the faintly black-spotted breast are the distinguishing characters of this species.

Olive-brown above, the head and nape faintly washed with black; supercilium white; lores black; chin, throat, and breast white, tinged with rufous; breast indistinctly spotted with black; abdomen and under tail-coverts reddish-brown; wings and tail brown, margined with rufous; shafts of the tail-feathers black.

\section{Genus Ortнотомиs, Horsfield.}

137. Овтнотомus sutorius, Forster.

Le petit Figuier á longue queue de la Chine, Sonn., Voy. Ind., t. ii, p. 205, 1782. 
Motacilla sutoria, R. S. Forster, Penn. Ind. Zool., 1781, p. 17, pl. viii ; Gmel., Syst. Nat., t. i, p. 997,1788 .

Long-tailed warbler, Lath., Gen. Syn., vol, ii, pt. 2, p. 501, 1782.

Tailor warbler, Lath., t. c., p. 515, 1782.

Motacilla longicauda, Gm., Syst. Nat., t. i, p. 954, 1788.

Sylvia longicauda, Lath., Ind. Orn., vol, ii, p. 545, 1791.

Sylvia sutoria, Lath., t. c., p. 551, 1791.

Sylvia guzurata, Lath., loc. cit., p. 554, 1791.

Malurus longicaudus, Pears., Journ. As. Soc., Bengal, x, p. 644, 1841.

Orthotomus bennetti, Sykes, Proc. Zool. Soc., 1832, p. 90 ; Lafresn., Mag. de Zool., 1836, pl. lii; Jerdon, Madr. Journ., vol. xi, p. 1, 1840 ; Gray, Cat. Mamm., \&c., Nepal, Hodgs., p. 63, 1846.

Orthotomus lingoo, Sykes, Proc. Zool. Soc., 1832, p. 90 ; Lafresn., Mag. de Zool., 1836, pl. liii.

Orthotomus ruficapilla, Hutton, Journ. As. Soc., Bengal, vol. ii, p. 501, 1833.

Orthotomus sphenurus, Swains., An. in Menag., p. 343, 1837.

Orthotomns longicaudus, Strickl., Ann. Nat. Hist., vol. xiii, p. 35, 1844; Blyth, Journ. As. Soc., Bengal, vol. xiii, p. 377, 1844; vol. xliv, 1875, extra No., p. 120; id., Cat. B. Mus., As. Soc., Bengal, p. 144, 1849; Gray, Gen. B., vol. i, p. 162 ; Tickell, Journ. As. Soc., Bengal, vol. xvii, p. 298, 1848; Hutton, Journ. As. Soc., Bengal, vol. xvii, pt. ii, p. 691, 1848 ; Bonap. Consp., t. i, p. 281, 1850 ; Layard, Ann. Nat. Hist., 1853, p. 262 ; Moore, Proc. Zool. Soc., 1854, p. 81 ; Horsf. \& Moore, Cat. B. Mus. E. Ind. Co., vol. i, p. 317, 1858; Jerdon, B. Ind., vol. ii, p. 164; Gray, Handl. B., vol. i, p. 195, 1869; Godwin-Austen, Journ. As. Soc., Bengal, vol. xxxix, 1870, p. 271 ; Blanford, op. cit., 1871, p. 273; Swinhoe, Proc. Zool. Soc., 1871, p. 351; Adam., Stray Feathers, 1873, p. 381 ; Hume, t. c., p. 194; Ball, op. cit., 1874, p. 414; Hume, t. c., p. 478; id., op. cit., 1875, p. 136; id., Nests and Eggs, Ind. B., p. 331 ; Butler, Stray Feathers, 1875, p. 479 ; Fairbank, op. cit., 1876, p. 259; Austen, Journ. As. Soc., Bengal, vol. xlv, 1875, p. 79.

Orthotomus sutorius, Hodgs., in Gray's Zool. Misc., p. 82, 1844; Walden \& Blyth, Journ. As. Soc., Bengal, vol. xliv, 1875, extra No., p. 120, note; Sharpe, Ibis, 1877, p. 109.

Orthotomus ruficapillus, Hodgs., t. c., p. 82.

Orthotomus sphenurus, id., t. c., p. 82.

Orthotomus sutoria, id., Proc. Zool. Soc., 1845, p. 29.

Orthotomus patia, id., t. c., p. 29.

Sutoria agilis, Nichols., Proc. Zool. Soc., 1851, p. 195.

Orthotomus phyllorhapheus, Swinhoe, Ibis, 1860, p. 49 ; Gray, Handl. B., i, p. 195, 1869.

a. $\delta$ Right bank of the Tapeng, 5th February 1875 .

b. Bhamô, September 1868.

This species does not appear to extend beyond the hills to the east of Bhamô.

Family-LANIID 27 .

\section{Genus Lanids, Linnæus.}

\section{LaniUs tePhronotus, Vigors.}

Collurio tephronotus, Vigors, Proc. Zool. Soc., 1831, p. 43 ; Gray, Handl. B., vol. i, p. 392, 1869 ; Hume, Nests and Eggs, Ind. B., p. 171, 1873.

Lanius nipalensis, Hodgs., Ind. Rev., vol. i, p. 445, 1837.

Lanius tephronotus, Gray, Gen. B., vol. i, p. 290, 1846 ; Blyth, Cat. B. Mus., As. Soc., Bengal, p. 151, 1849; Bonap. Consp., t. i, p. 364, 1850; Horsf. \& Moore, Cat. B. Mus. E. Ind. 
Co., vol. i, p. 166, 1854; Jerdon, B. Ind., vol. i, p. 403; 1862 ; Stoliczka, Journ. As. Soc., Bengal, vol. xxxvii, 1868, p. 26 ; G. King, t.c., p. 215 ; Swinhoe, Proc. Zool. Soc., 1871, p. 375; Hume, Stray Feathers, vol. ii, p. 473, 1874; Godwin-Austen, Journ. As. Soc., vol. xlv, 1876, p. 71 ; Hume, Stray Feathers, 1877, p. 29.

Collurio obscurior, Hodgs., in Gray's Zool. Misc., p. 84, 1849.

a. t Katha, 19th January 1868.

b. I Shuaygoomyo, 21st January 1868.

c. \& Sawady, 28th February 1875.

The dark cinereous of the back has a slightly olive tinge above the rufous area of its lower part and the upper tail-coverts. In a young male there is no black streak in front of the eyes, and the lores are rather whitish, and there is a pale streak over and behind the eye. The ear-coverts are reddish-brown. The cinereous of the upper surface has a faint olive tinge throughout, and the rufous of the lower back and tail-coverts spreads further upwards. The central tail feathers are reddish-brown, and the lateral ones are of a paler tint. They are all faintly and finely barred, and the two longest feathers have pale rufous tips. The wings are dull brown, and a few of the secondaries have rufous margins. The chin and throat are dirty white, and the sides of the throat and neck and the breast are white, with a tinge of rufous with narrow, wavy, dull brown transverse bands. The rufous is brightest on the sides of the chest and the abdomen. The abdomen, flanks and lower tail-coverts are rufous white, the rufous being strongest on the flanks.

\section{LANIUS NIGRICEPS, Franklin.}

Collurio nigriceps, Frankl., Proc. Zool. Soc., 1831, p. 117; Gray, Handl. B., vol. i, p. 392, 1869; Hume, Nests and Eggs, Ind. B., p. 172.

Lanius nigriceps, Jerdon, Madr. Journ., vol. x, p. 236, 1839 ; id., Ill. Ind. Orn., pl. xvii, 1847 ; Gray, Gen. B., vol. i, p. 290, t. 71, 1847 ; Blyth, Cat. B. Mus., As. Soc., Bengal, 1849, p. 151; Ibis, 1870, p. 164; Horsf. \& Moore, Cat. B. Mus. E. Ind. Co., vol. i, p. 166, 1854; Jerdon, B. Ind., vol. i, p. 404, 1862 ; Beavan, Ibis, 1870, p. 311 ; Hume, Stray Feathers, p. 4773, 1874, p. 29.

a. t Bhamô, 6th February 1868.

b. t Bhamô, 20th January 1875.

c. d. Bhamô, 10th and 20th February 1868.

e. ¿ Kamoonee, left bank of Tapeng river, 11th February 1875.

f.g.h. o P Ponsee, 11th and 16th March 1868.

i. t Sanda, 28th July 1868.

These birds and others from Cachar in the Indian Museum, Calcutta, have the black extending a little further down the back than is usual in Bengal specimens, and in an adult from the latter locality, the ashy band bordering the black of the nape is present only in the faintest trace. The backs of freshly killed Bengal adult specimens are more chestnut than rufous, but these Burmese and Yunnan birds are slightly paler, and the ashy band in nearly all fades into the black. 
This is a common species about Bhamô, but it becomes less abundant, as we ascend the Kakhyen hills and reach the long elevated valley of Sanda, to the east of which, I did not observe it. In the Irawady valley, I always found it in the neighbourhood of long grass, in marshy unfrequented places; and on the hills, in grassy hollows surrounded by the jungle, and through which some stream ran. I did not observe it below Bhamô.

\section{Lanius CRIstatus, Linnæus.}

The Crested Red or Russet Butcher-Bird, Edwards, N. H. Birds, ii, p. 54, pl. liv, 1747.

La Pie-Griesche rousse de Bengale, Briss. Orn., ii, p. 173, 1760.

Lanius cristatus, Linn., Syst. Nat., t. i, p. 134, 1766; Gray, Cat. Mamm., \&c., Nepal, Hodgs., p. 100, 1846 ; Jerdon, B. Ind., vol. i, p. 406, 1862 ; Beavan, Ibis, 1865, p. 418 ; id., op. cit., 1870, p. 312 ; Walden, Ibis, 1867, p. 212 ; Gray, Handl. B., vol. i, p. 393, 1869 ; Swinhoe, Proc. Zool. Soc., 1871, p. 375 ; Holdsw., Proc. Zool. Soc., 1872, p. 436 ; Hume \& Henders., Lahore to Yarkand, p. 182, 1873 ; Hume, Nests and Eggs, Ind. B., p. 175, 1873; Blyth \& Walden, Journ. As. Soc., Bengal, vol. xliv, 1875, ex. No., p. 121 ; Ball, Stray Feathers, 1873, p. 65 ; Hume, op. cit., 1874, p. 198; Ball, t.c., p. 399 ; Hume, t.c., p. 473; Hume, op. cit., 1875, p. 91 ; Butler, t. c., p. 464; Fairbank, op. cit., 1876, p. 256 ; Armstrong, t. c., p. 316 ; Hume, op. cit., 1877, p. 29 ; Butler, t. c., p. 228.

Lanius phonicurus, Pall. Reis., Bd. iii, p. 693, 1776 ; Gm., Syst. Nat., t. i, p. 309, 1788; Sundev., K. Vet. Akad., Stockhl., 1840, p. 36 ; Midd., Sibir. Reis., Bd. ii, p. 188, 1851; Blasius, Naum., 1858, p. 310 ; id., Ibis, 1862, p. 66 ; Schrenk, Amur-Reis., Bd. i, p. 384, 1860 ; Radde, Reis. Ost-Sibir., Bd. ii, p. 277, 1863 ; Walden, Ibis, 1867, p. 216, pl. v, fig. 2; Gray, Handl. B., i, p. 393 ; Przew., in Rowley's Orn. Misc., part vi, p. 274.

Crested Red Shrike, Lath., Gen. Syn., vol. i, pt. i, pp. 170, 178.

Lanius melanotis, Valenc., Dict. Sci. Nat., xl, p. 227, 1826 ; Pucher. Arch. Mus., t. vii, p. 424.

Lanius ferrugiceps, Hodgs., Ind. Review, 1837, p. 446.

Colluris ferrugiceps, Hodgs., in Gray's Zool. Misc., p. 84, 1844.

Enneoctonus lucionensis, Gray, Gen. B., vol. i, p. 291, 1847 ; Swinhoe, Ibis, 1804, p. 420.

Enneoctonus phonicurus, Gray, Gen. B., vol. i, p. 291, 1847; Bonap. Consp., t. i, p. 362, 1850 ; Cab., Mus. Hein., th. i, p. 72, 1850.

Enneoctonus cristatus, Bonap. Consp., t. i, p. 362, 1850 ; Cab., Mus. Hein., th. i, p. 72, 1850 ; Horsf. \& Moore, Cat. B. Mus. E. Ind. Co., vol. i, p. 167, 1854.

Otomela phoenicura, Bonap., Rev. et Mag. de Zool., 1853, p. 436.

Otomela cristatus, Bonap., t.c., p. 437 ; Schalow, Journ. f. Orn., 1875, p. 130.

\section{a. 。 Ponsee, May 1868.}

Among nineteen specimens of $L$. cristatus from the same locality, the rufous is not alike in two, and in one specimen the head and the back of the neck are marked off distinctly from the rufous olive of the back. I think there can be little doubt that this amount of variation depends greatly on the age of the specimens. In two specimens from Amoy referred by Swinhoe to $L$. lucionensis, but of different ages, the light slaty frontal area in one extends further back than in the other which has the top of the head darker.

This bird was not uncommon about the village of Ponsee. 


\section{Lanius collurioides, Lesson.}

Lanius collurioides, Less., Belang. Voy. Ind., p. 250, 1834; Walden, Ibis, 1867, p. 220 ; Armstrong, Stray Feathers, 1876, p. 316.

Lanins hypolencus, Blyth, Journ. As. Soc., Bengal, vol. xvii, p. 249, 1845; id., Cat. B. Mus., As. Soc., Bengal, p. 152, 1849 ; Blanf., Ibis, 1870, p. 468; Hume, Stray Feathers, iii, p. 90, 1875. Collyrio hypolencus, Gray, Handl., vol. i, p. 392, 1869.

a. o Mandalay, 26th September 1868.

$$
\text { b.c.d. " " " } \quad "
$$

One of these specimens, sexed a male, has the lores and a narrow frontlet white: an appearance of this white is just visible in a Burmese specimen in the British Museum, and is strongly marked in another in the same collection. In a bird collected by Mr. Blanford at Ava, the forehead and lores are black like the crown, as they are also in these three other specimens.

The sides of the abdomen in all these specimens are more or less tinged with rufous, and in one they are nearly as dark as in $L$. hardwicki. This is a common species about Mandalay, where I found it on trees in the neighbourhood of the large swamp outside the city.

\section{Genus TePH ROD ornis, Swainson.}

\section{Tephrodornis pondiceriana, Gmelin,}

Gobe mouche de Pondichéry, Sonn., Voy. Ind., 2, p. 198, 1782.

Muscicapa pondiceriana, Gm., Syst. Nat., t. ii, p. 939, 1788.

Lanius muscicapoides, Frankl., Proc. Zool. Soc., 1831, p. 117; Journ. As. Soc., Bengal, vol. i, p. 265, 183\%.

Tanius griseus, Tick., Journ. As. Soc., Bengal, vol. ii, p. 573, 1833.

Keroula indica, Gray, in Hardw. Ill. Ind. Zool., vol, ii, pl. xxxiii, figs. 1, 2, 1833-34.

Tenthaca leucurus, Hodgs., Ind. Rev., i, p. 447, 1837.

Tephrodornis superciliosus, Swains., Jerd. Madr. Journ., vol. x, p. 237, 1839 ; Blyth, Journ. As. Soc., Bengal, vol. xi, p. 799, 1842.

Tephrodornis indica, Hodgs., Cat. B., Nepal, p. 99, 1846; Gray, Gen. B., vol. i, p. 290, 1847.

Tephrodornis pondiceriana, Blyth, Journ. As. Soc., Bengal, vol. xv, p. 305, 1846 ; Cat. B. Mus., As. Soc., Bengal, p. 153, 1849; Bonap. Consp. G. Av., p. 358, 1850; Horsfield \& Moore, Cat. B. Mus. E. Ind. Co., p. 169, 1854; Jerdon, B. Ind., vol. i, p. 410, 1862 ; Gray, Handl. B., vol, i, p. 394, 1869; Beavan, Ibis, 1876, p. 312; Blanford, op. cit., p. 468; Hume, Nests and Eggs, Ind. B., p. 176, 1873; Hume, Stray Feathers, 1873, p. 177; Adam., t. c., p. 276; Hume, op. cit., 1875, p. 92; Blyth \& Walden, Journ. As. Soc., Bengal, vol. xliv, 1875, ex. No., p. 122; Legge, Stray Feathers, 1876, p. 243; Fairbank, $t . c_{.}$, p. 256; Hume, $t$. $c_{\text {., }}$ pp.456, 458; Fairbank \& Hume, op. cit, 1877, p. 400 ; Sharpe, Cat. Birds, B. M., vol, iii, 1877, p. 275.

\section{a. Bhamô, 6th February 1868.}

This was the only specimen of this species I abtained. 


\section{Genus Hemipus, Hodgson.}

\section{Hemipus capitalis, Mc'Clelland.}

Muscicapa capitalis, Mc'Clelland, Proc. Zool. Soc., 1839, p. 157.

Hemipus piccecolor, Hodgs., Proc. Zool. Soc., 1845, p. 33.

Hemipus picatus (nec Sykes), Gray, Cat. Mamm., \&c., Nepal, Hodgs., p. 93, 1846 ; Blyth, Cat. B. Mus., As. Soc., Bengal, p. 154, 1849 ; Horsfield \& Moore, Cat. B. Mus. E. Ind. Co., vol. i, p. 136 (pars.), 1854; Gray, Handl. B., vol. i, p. 323.

Hemipus capitalis, Blyth, Cat. B., As. Soc. Mus., 1849, p. 154; Bonap. Consp., t. i, p. 319, 1850 ; Godwin-Austen, Journ. As. Soc., Bengal, vol. xxxix, 1870, p. 99 ; Jerdon, Ibis, 1872, p. 116 ; Sharpe, Cat. Birds, B. M., vol. iii, 1877, p. 306.
a. है Ponsee, 2nd May 1868.
b. ᄒ , 18th March 1868.
c. ঠ Nampoung, 19th February 1875.

Head and back of neck black; back and rump brown; a brownish-black terminal cross line margined with white on the rump; tail black, the lateral feathers broadly tipped with white, most markedly on the external one; upper tail-coverts black; chin white; throat, breast, and belly brownish cinereous; under tail-coverts white; wing-coverts brownish-black; wing band white.

I first met with this bird in a clump of oaks and other temperate trees, at an elevation of 3,500 feet, on the Kakhyen hills, and afterwards, 1875, at a height of not more than 1,200 feet in the glen of the Nampoung.

$$
\text { Family-GRAUCALID } \mathbb{E} \text {. }
$$

\section{Genus Graucalus, Hartlaub.}

\section{Gradcalus macei, Lesson.}

Graucalus macei, Less., Tr. d’Orn., p. 349, 1831; Blyth, Cat. B. Mus., As. Soc., Bengal, p. 190, 1849 ; Bonap. Consp. Gen. Av., p. 354, 1850; Horsfield \& Moore, Cat. B. Mus. E. Ind. Co., p. 173, 1854; Beavan, Ibis, 1870, p. 313 ; Blanford, op. cit.; p. 468; Godwin-Austen, Journ. As. Soc., Bengal, vol. xxxix, p. 99, 1870 ; op. cit., 1876, vol. xlv, p. 71 ; Hume, Nests and Eggs, Ind. B., p. 181, 1873; Ball, Stray Feathers, 1873, p. 65 ; Hume, op. cit., 1874, p. 204; Adam., t. c., 1874, p. 400; Blyth \& Walden, Journ. As. Soc., Bengal, vol. xliv, 1875, extra No., p. 123; Hume, Stray Feathers, 1875, p. 94, 1877, p. 21 ; Fairbank, t. c., p. 400. Graucalus nipalensis, Hodgs., Ind. Rev., vol. i, p. 327, 1837.

Campephaga macei, Gray, Gen. B., vol. i, p. 283, 1846 ; Handl. B., vol. i, p. 336, 1869.

$$
\begin{aligned}
& \text { a. ㅇ Tsagain, 29th December } 1874 . \\
& \text { ๖.c. } 0 \text {, } 27 \text { th }
\end{aligned}
$$




\section{Genus Pericrocotus, Boie.}

\section{Pericrocotus elegans, Mc'Clelland.}

Phonicornis elegans, Mc'Clell., Proc. Zool. Soc., 1839, p. 156.

Pericrocotus elegans, Gray, Gen. B., i, p. 282, 1846; Hume, Stray Feathers, 1875, p. 95 ; $t$ : c., p. 320 (note); id., op. cit., 1877, p. 194.

Pericrocotus rutilus, Gray, Handl. B., vol. i, p. 335, 1869.

Pericrocotus speciosus, Sharpe, Stray Feathers, 1876, p. 206 (pars.)

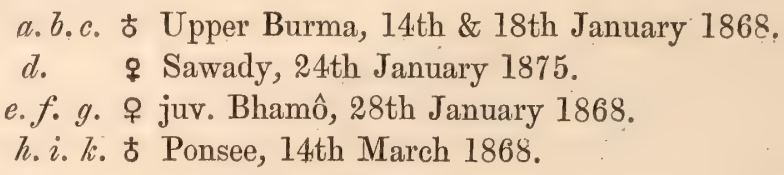

All these specimens belong to the small-billed form, which Mr. Hume has doubtless rightly identified as the $P$. elegans of Me'Clelland. It can scarcely be reckoned anything but a race of the Himalayan P. speciosus, and in all probability $P$. fraterculus of Swinhoe (Ibis, 1870, p, 244) and P. andamanensis, Tytler (Ibis, 1867, p. 322,) should be united to it.

This species is common in the month of March in the Kakhyen hills, and on one occasion, during that month, I shot three out of a flock. The birds were flying in and out of a high oak, Quercus fenestrata, which was then blossoming and attracting insects.

\section{Pericrocotus brevirostris, Vigors.}

Muscipeta brevirostris, Vigors, Proc. Zool. Soc., 1831, p. 43.

Phanicornis brevirostris, Gould, Cent. B., pl. viii, 1832; Jerdon, Madr. Journ., x, p. 243, 1839.

Phanicornis affinis, Me'Clell., Proc. Zool. Soc., 1839, p. 156 (ᄒ).

Pericrocotus brevirostris, Gray, Gen. B., vol. i, p. 282, 1846; Blyth, Journ. As. Soc., Bengal, vol. xi, pp. 184, 192, vol. xv, p. 309, 1846 ; id., Cat. B. Mus., As. Soc., Bengal, p. 193, 1849 ; Bonap. Consp. At., t. i, p. 357, 1850 ; Horsf. \& Moore, Cat. B. Mus. E. Ind. Co., vol. i, p. 141, 1854; Jerdon, B. Ind., vol. i, p. 421, 1862 ; Gray, Handl. B., vol. i, p. 334, 1869 ; Swinhoe, Proc. Zool. Soc., 1871, p. 379; Henders. \& Hume, Lahore to Yarkand, p. 184, 1873 ; Hume, Nests and Eggs, Ind. B., p. 183, 1873 ; Brooks, Stray Feathers, 1875, p. 234; Butler \& Hume, t. c., p. 465 ; Scully, t. c., p. 209 ; Ball, t. c., p. 232 ; Godwin-Austen, Journ. As. Soc., Bengal, vol, xlv, 1876, p. 71; Hume, Stray Feathers, 1877, pp. 29, 187 ; Butler, t. c., p. 228 .

Pericrocotus affinis, Gray, Gen. B., p. 282, 1846.

a. क Sawady, 30th January 1875.

b.c. 우 Right bank of Tapeng River, 5th February 1875,

d. 古 Nampoung, ]9th February 1875.

e. o Ponsee, 27th March 1868.

f. o juv. Hotha, 13th August 1868.

Flocks of from thirty to forty birds were not uncommon in the Kakhyen hills in February, in the midst of a fine forest with little or no undergrowth. They 
frequented the summits of the trees, alighting for a few minutes, moving rapidly through the branches, flying outwards and back again, and then making off to another tree, and being ever constantly on the move. It is not at all common in the higher regions of the hills, but it is interesting to observe that I obtained a young male in August at an elevation of 4,800 feet.

\section{Pericrocotus roseus, Vieill.}

Muscicapa rosea, Vieill., N. Dict. d’Hist. Nat., xvi, p. 486, 1818.

Phonicornis affinis, Mc'Clell., Proc. Zool. Soc., 1839, p. 157.

Pericrocotus roseus, Gray, Gen. B., vol. i, p. 282, 1846; Blyth, Journ. As. Soc., Bengal, vol. xv, p. 310, 1846 ; id., Cat. B. Mus., As. Soc., Bengal, p. 193, 1849; Bonap. Consp. Av., t. i, p. 356, 1850 ; Horsf. \& Moore, Cat. B. Mus. E. Ind. Co., vol. i, p. 141, 1854; Gould, B. Asia, pt. ix, 1857; Jerdon, B. Ind., vol. i, p. 422, 1862; Hume, Nests and Eggs, Ind. B., p. 184, 1874 .

Phonicornis roseus, Jerdon, Ill. Ind. Orn., text to pl. xi, 1849.

$$
\text { a. b. t Muangla, Sanda valley, May } 1868 .
$$

I shot this species in an isolated thickly-wooded hill behind the town of Muangla in the Province of Yunnan. All the hills around are grassy and free of trees, with the exception of a few small pines (Pinus khasayanus), and the lower portions of the high ranges of mountain that define the valley have been cleared of forest, so that the number of species occurring in the valley is small.

\section{Family $-H I R U N D I N I D A$.}

\section{Genus HIRUND 0, Linnæus.}

148. HIRUNdo RUSTICA, Linn.

L'Hirondelle des Chéminées, Briss. Orn., t. ii, p. 486, 1760 ; Montb., Pl. Enl., t. vii, pl. 543, fig. 1, 1783.

Hirundo rustica, Linn., Syst. Nat, t. i, p. 343, 1766 ; Lath., Ind. Orn., vol. ii, p. 572, 1790 ; Temm., Man. d’Orn., t. i, p. 427, 1820 ; Menétr., Cat. Rais. Zool. Caucas., p. 45, 1832; Selby, Ill. Orn., vol. i, p. 120, 1833; Gould, B. Eur., vol. ii, pl. liv, 1837 ; Macgill, Brit. B., vol. iii, p. 558, 1840 ; Demid. Voy., t. iii, p. 201, 1840 ; Yarrell, Brit. B., vol. ii, p. 213, 1843 ; Gray, Gen. B., vol. i, p. 57, 1845 ; Bonap. Consp. Gen. Av., t. i, p. 338, 1850 ; Kjärb., Orn. Dan., taf. xiv, fig. 1, 1851 ; Middend, Sibir. Reis., p. 188, 1851 ; Sundev., Svensk. Fogl., ẋvii, fig. 5, 1856 ; Schleg., Vög. Nederl., pl. lvii, 1858; Jaub. \& Lapomm., p. 307, 1859; Linderm., Vög. Griechenl., p. 117, 1860 ; Jerdon, B. Ind., vol. i, p. 157, 1862 ; Degl. \& Gerbe, Orn. Eur. Filippi, Viagg. Pers, p. 346, 1865 ; p. 587, 1867 ; Loche, Expl. Sci., Alger. Ois., vol. ii, p. 64, 1867 ; Stoliczka, Journ. As. Soc., Bengal, vol. xxxvii, 1868, p. 17; King, op. cit., p. 214; Gray, Handl. B., vol. i, p. 68, 1869; Doderl., Avif. Sicil., p. 143, 1869 ; GodwinAusten, Journ. As. Soc., Bengal, vol. xxxix, p. 94, 1870; Blanford, Geol. Zool. Abyss., p. 347, 1870 ; Finsch. \& Hartl., Vög. Ost. Afr., p. 134, 1870 ; Fritsch., Vög. Deutschl., taf. 23, fig. 4, 1871 ; Holdsw., Proc. Zool. Soc., 1872, p. 418; Salvad., Faun. Ital. Ucc., p. 51, 1872 ; Shelley, B. Egypt, p. 120, 1872 ; Severtzoff, Turk. Jevotn., 1873, p. 67 ; Ball, Stray Feathers, 1873, p. 55 ; Hume, t. c., p. 164; Adam., t. c., p. 370; Hume, Lahore to 
Yarkand, p. 176, 1873 ; Heugl., Orn. N. O. Afr., p. 150, 1873; Gould, B. Brit., ii, pl. v, 1873 ; Hume, Nests and Eggs, Ind. B., p. 72, 1873; id., Stray Feathers, 1874, p. 154; Ball, t. c., p. 383; Stoliczka, t. c., p. 464; Hume, .c., p. 469; id., Stray Feathers, 1875, p. 41 ; Irby, B. Gibr., p. 103, 1875 ; Blyth \& Walden, Journ. As. Soc., Bengal, vol. xliv, extra No., p. 126, 1875 ; Dresser, B. Eur., pt. xxxvii, 1875 ; Blanford, East. Pers. Zoo., vol. ii, p. 215, 1876; Hume, Stray Feathers, 1876, p. 39, 1877, p. 17 ; Scully, t. c., p. 131 ; Fairbank, t. c., p. 254 ; Armstrong, t. c., p. 303; Schalow, Journ. für Ornith., 1876, p. 176 ; Dresser, Ibis, 1876, p. 188.

Cecropis rustica, Boie, Isis, 1826, p. 971 ; Brehm, Naum., 1855, p. 271.

Cecropis pagorum, Brehm, Vög. Deutschl., p. 138, 1831.

$$
\begin{array}{cl}
\text { a. Shienpayah, 15th January } 1868 . \\
\text { b. } . \quad \text { Bhamô, 2nd June } 1868 . \\
\text { d. } \text {. Momien, 24th January } 1868 .
\end{array}
$$

\section{Hirundo filifera, Steph.}

Hirundo filifera, Steph., Gen. Zool., vol. xiii, p. 78, 1826 ; Gray, Gen. B., vol. i, p. 58, 1845; Blyth, Cat. B. Mus., As. Soc., Bengal, p. 197, 1849 ; Bonap. Consp., t. i, p. 338, 1850; Cab., M. H., Bd. i, p. 46, 1850 ; Horsf. \& Moore, Cat. B. Mus. E. Ind. Co., vol. i, p. 93, 1854; Jerdon, B. Ind., vol. i, p. 159, 1862 ; Kirk, Ibis, 1864, p. 320 ; Gould, B. Asia, pt. xviii, 1866 ; Stoliczka, Journ. As. Soc., Bengal, vol. xxxvii, p. 17, 1868; King, t. c., p. 214; Heugl., Orn. N. O. Afr., p. 155, 1869; Sharpe, Proc. Zool. Soc., 1870, p. 312; Finsch. \& Hartl., Vög. Ostafr., p. 141, 1870; Blyth \& Walden, Journ. As. Soc., Bengal, vol. xliv, 1875, p. 127 ; Aitken, Stray Feathers, 1875, p. 212 ; Butler \& Hume, op. cit., 1876, p. 451 ; W. Ramsay, Ibis, 1877, p. 466.

Hirundo smithi, Cranch, App. Tuckey Exped. Zaire, p. 467, 1818; Hartl., Orn. W. Afr., p. 26, 1857 ; id., Journ. f. Orn., 1861, p. 103.

Hirundo ruficeps, Licht., Verz. Doubl., p. 68, 1823 ; Ferr. et Galin., Voy. Abyss. Zool., t. iii, p. 242, 1847 ; Blanf., Geol. \& Zool. Abyss., p. 34.8, 1870.

Hirundo filicandata, Frankl., Proc. Zool. Soc., 1831, p. 115 ; Rüpp., Syst. Uebers., p. 22, 1845 ;

Heugl., Syst. Uebers., p. 14, 1856 ; Autin., Cat. Ucc., p. 26, 1865.

Cecropis filicauda, Brehm, Journ. f. Orn., 1853, p. 452.

Hirundo filicanda, Müll., Journ. f. Orn., 1855, p. 5.

Ubromitrus filifera, A. Brehm, Reis. Habesch., p. 209, 1863.

Hirundo anchiete, Bocage, Jorn. Lisboa., 1867, pp. 150, 331.

Hirundo velocissima, Pz., Würt. MS. teste Heuglin.

Hirundo fuscicapilla, Heugl., Orn. N. O. Afr., p. 154, 1869.

Uromitris filifera, Hume, Nests and Eggs, Ind. B., p. 75, 1873; Ball, Stray Feathers, 1875, p. 289. a. Bhamô, 21st January 1868.

As the testimony of naturalists generally tends to unite the African and Indian wire-tailed Swallows, I regard them as one and the same species. Indian specimens, however, are generally rather larger and have finer and longer tails.

\section{Hirundo ERTthropygia, Sykes.}

Hirundo erythropygia, Sykes, Proc. Zool. Soc., 1832, p. 83; Jerdon, Madr. Journ., vol. xi, p. 237, 1840 ; Blyth, Ibis, 1866, p. 337 ; Stoliczka, Journ. As. Soc., Bengal, vol. xxxvii, 1868, p. 17; King, t. c., p. 214; Gray, Handl. B., vol, i, p. 69, 1869; Cock. \& Marsh., Stray Feathers, 
1873, p. 350 ; Adam.; t. c., p. 370 ; Hume, op. cit., 1874, p. 122; Aitken, op. cit., 1875, p. 212 ; Brooks, t.c., p. 230 ; Hume, t. c., p. 318 ; Butler, t. c., p. 451 ; Godwin-Austen, Journ. As. Soc., Bengal, vol. xlv, 1876, p. 68 ; Butler, Stray Feathers, 1877, p. 226.

Hirundo daurica, Gray, Cat. Mamm., \&c., Nepal, Hodgs., p. 54, 1846 ; Blyth, Cat. B. Mus., As. Soc., Bengal, p. 198, 1849 ; Bonap. Consp., t. i, p. 339, 1850 ; Horsf. \& Moore, Cat. B. Mus. E. Ind. Co., vol. ii, p. 92, 1856 ; Jerdon, B. Ind., vol. i, p. 160, 1862.

Cecropis erythropygia, Gould, B. Asia, pt. xx, 1868; Blyth \& Walden, Journ. As. Soc., Bengal, vol. xliv, extra No., p. 127, 1875; Fairbank, Stray Feathers, 1876, p. 254.

Lillia erythropygia, Hume, Nests and Eggs, Ind. B., p. 76, 1873; id., Stray Feathers, 1877, p. 255.

a. * Yaylaymaw, 7th January 1875.

This Swallow was common at the above locality.

\section{Genus Cotyue, Boie.}

\section{1. Сотyle sinensis, J. E. Gray.}

Hirundo sinensis, J. E. Gray, in Hardw. Ill. Ind. Zool., vol. i, pl. xxxv, fig. 3, 1830 ; Blyth, Journ. As. Soc., Bengal, vol. xvi, p. 119, 1847; id., Cat. B. Mus., As. Soc., Bengal, p. 199, 1849. Hirundo brevicaudata, Mc'Clell., Proc. Zool. Soc., 1839, p. 156 ; Gray, Gen. B., i, p. 58, 1845. Hirundo subsoccata, Hodgs., in Gray's Zool. Misc., p. 82, 1844.

Hirundo minuta, Hodgs., in Gray's Zool. Misc., p. 82, 1844.

Cotyle subsoccata, Hume, Nests and Eggs, Ind. B., p. 82, 1873.

Cotyle sinensis, J. E. Gray, Cat. B. Brit. Mus. Fissir, p. 30, 1848; Bonap. Consp., t. i, p. 342, 1850 ; Horsf. \& Moore, Cat. B. Mus. E. Ind. Co., vol. i, p. 96, 1854; Jerdon, B. Ind., vol. i, p. 164, 1862 ; Gray, Handl. B., vol. i, p. 73, 1869; Godwin-Austen, Journ. As. Soc., Bengal, vol. xxxix, 1870, p. 266 ; Swinhoe, Proc. Zool. Soc., 1871, p. 347; Adam., Stray Feathers, 1873, p. 370 ; Hume, op. cit., 1874, p. 469, 1875, p. 42 ; id., Nests and Eggs, Ind. B., p. 82, 1873 ; Blyth \& Walden, Journ. As. Soc., Bengal, vol. xliv, ex. No., p. 127, 1875 ; Hume, Stray Feathers, 1875, p. 42 ; Butler \& Hume, t. c., p. 452; Fairbank, t. c., p. 254; Butler, t. c., p. 227 .

\section{a. 6. S Second defile of the Irawady, 5th March 1875 .}

I shot this species on a little sandy promontory in the second defile of the Irawady, at which spot it was very numerous, flying at the height of a few feet above the sand, and constantly alighting for a few moments. I did not elsewhere observe it, and I procured only two females.

\section{Family-DICRURID A.}

\section{Genus Снibia, Hodgson.}

\section{2. С нibia hоттеnтota, Linnæus.}

Le choucas du Cap de Bonne Espérance, Briss. Orn., t. ii, p. 33, pl. ii, fig. 2, 1760.

Corvus hottentotus, Linn., Syst. Nat., i, p. 155, 1766 ; Lath., Hist. B., vol. iii, p. 50, 1821.

Criniger splendens, Tickell, Journ. As. Soc., Bengal, vol. ii, p. 574, 1833. 
Edolius crishna, Gould, Proc. Zool. Soc., 1836, p. 5; Blyth, Journ. As. Soc., Bengal, vol. xi, pp. 169, 799, 1842.

Chibia casia, Hodgs., Ind. Rev., vol. i, p. 324, 1837.

Chibia hottentota, Strickl., Ann. Nat. Hist., vol. xiii, p. 36, 1844; Gray, Gen. B., vol. i, p. 287, 1845 ; Blyth, Journ. As. Soc., Bengal, vol. xv, p. 294, 1846 ; Gray, Cat. Birds, Nepal, Hodg., p. 99, 1846 ; Blyth, Cat. B. Mus., As. Soc., Bengal, p. 200, 1849 ; Bonap. Consp. G. Av., p. 350, 1850 ; Jerdon, B. Ind., vol. i, p. 439, 1862 ; Gray, Handl., vol. i, p. 287, 1869 ; Godwin-Austen, Journ. As. Soc., Bengal, vol. xliii, p. 157, 1874; Ball, Stray Feathers, 1874, p. 403; Hume, t. c., p. 474; id., op. cit., 1875, p. 101 ; Ball, t. c., p. 291 ; Blyth \& Walden, Journ. As. Soc., Bengal, vol. xliv, ex. No., p. 128, 1875 ; Armstrong, Stray Feathers, pp. 876, 321; Godwin-Austen, Journ. As. Soc., Bengal, vol. xlv, 1876, p. 71; Sharpe, Cat. Birds, B. M., vol. iii, 1877, p. 235.

Edolius barbatus, Gray, Zool. Misc., p. , 1844.

Cometes crishna, Hodgs., Gray's Zool. Misc., p. 84, 1844.

Trichometopus hottentotus, Cab., Mus. Hein., i, p. 112, 1850.

Dicrurus (Chibia) hottentota, Horsfd. \& Moore, Cat. B. East Ind. Co's. Mus., vol. i, 1854, p. 157.

a. + Tsagain, 29th December 1874.

\section{Genus BHRINGA; Hodgson.}

153. Bhringa remifer, Temminck.

Edolius remifer, Temm., Pl. Coll., t. iii, pl. 178, 1823; Blyth, Journ. As. Soc., Bengal, vol. xi, pp. 169, 800, 1842.

Bhringa tectirostris, Hodgs., Ind. Rev., vol. i, p. 325, 1837; Hume, Stray Feathers, 1874, p. 474; id., Nests and Eggs, Ind. B., p. 193, 1873 ; id., Stray Feathers, 1875, p. 101; Armstrong, op. cit, 1876, p. 320.

Bhringa remifer, Gray, Gen. B., vol. i, p. 288, 1845 ; Blyth, Journ. As. Soc., Bengal, vol. xv, p. 294, 1846 ; id., Cat. B. Mus., As. Soc., Bengal, p. 200, 1849; Bonap. Consp. Gen. Av., p. 350, 1850 ; Jerdon, B. Ind., vol. i, p. 434, 1862; Gray, Handl. B., vol. i, p. 287, 1869; Godwin-Austen, Journ. As. Soc., Bengal, vol. xxxix, p. 268, 1870; Blyth \& Walden, op. cit., vol. xliv, ex. No., p. 128, 1875; Sharpe, Cat. Birds, B. M., 1877, vol. iii, p. 257.

Dicrurus (Bhringa) remifer, Horsf. \& Moore, Cat., vol. i, p. 159, 1854.

$$
\text { a. t Ponsee, April } 1868 .
$$

I shot only one specimen of this handsome bird at the above elevation.

\section{Genus СнартіA, Hodgson.}

\section{Chaptia enea, Vieill.}

Le Drongo bronzé, Levaillant, Ois. d'Afr., iv, p. 75, pl. 176, 1805.

Dicrurus aneus, Vieill., N. Dict. d'Hist. Nat., vol. ix, p. 586, 1817, ex Levaill.; Jerdon, Madr. Journ., vol. x, p. 240, 1839; Horsf. \& Moore, Cat. B. Mus. E. Ind. Co., vol. i, p. 159, 1854.

Dicrurus aeratus, Steph. Zool., vol. xiii, pt. 2, p. 138, 1825.

Chaptia muscipetoides, Hodgs., Ind. Rev., vol. i, p. 327, 1837.

Edolius aratus, Blyth, Journ. As. Soc., Bengal, vol. xi, p. 801, 1842.

Chaptia anea, Gray, Gen. B., vol. i, p. 288, 1845; Blyth, Journ. As. Soc., Bengal, vol. xv, p. 294; 1846 ; id., Cat. B. Mus., As. Soc., Bengal, p. 200, 1849; Bonap. Consp., p. 3501850 ; Gray, Handl. B., vol. i, p. 287, 1869; Brooks, Stray Feathers, 1873, p. 234; Hume, op. cit., 
p. 100, 1874, p. 474; ; id., Nests and Eggs, Ind. B., p. 192, 1873 ; Blyth \& Walden, Journ. As. Soc., Bengal, vol. xliv, ex. No., p. 128, 1875 ; Fairbank, Stray Feathers, 1876, pp. 257, 265 ; Armstrong, t.c., p. 320 ; Hume, t. c., p. 395 ; Godwin-Austen, Journ. As. Soc., Bengal, vol, xlv, 1876, p. 71 ; Sharpe, Cat. Birds, B. M., vol. iii, 1877, p. 243.

$$
\text { a. Ponsee, 13th March } 1868 .
$$

\section{Genus BUCHAN GA, Hodgson.}

\section{BuchaNga ATRA, Hermann.}

Le Drongolon, Levaillant, Ois. d'Afr., t. iii, pl. 174, 1802.

Muscicapa atra, Hermann, Obs. Zool., p. 208, 1804.

Dicrurus macrocercus, Vieill., N. Dict., t. ix, p. 588, 1817 ; Jerd., Madr. Journ., vol. xiii, pt. 2, p. 121, 1847 ; Blyth, Journ. As. Soc., Bengal, vol. xv, p. 298, 1846 ; Gray, Gen. B., vol. i, p. 286, 1845 ; id., Cat. Mamm., \&c., Nepal, Coll. Hodgs., p. 98, 1846 ; Bonap. Consp., t. i, p. 351, 1850 ; Jerdon, B. Ind., vol. i, p. 427, 1862 ; Gray, Handl. B., vol. i, p. 286, 1869.

Edolius forficatus, Horsf., Tr. Linn. Soc., vol. xiii, p. 144, 1821.

Muscicapa biloba, Licht., Verz. Doubl., p. 52, 1823.

Dicrurus indicus, Steph., Gen. Zool., vol. xiii, p. 139, ex. Levaill., 1826 ; Hodgs., As. Res., vol. xviii, p. 21, fig., 1820.

Dicrurus balicassius, (nec. L.), Sykes, Proc. Zool. Soc., 1832, p. 86 ; Jerdon, Madr. Journ., vol. x, p. 238, 1839 ; Mc'Clelland, Proc. Zool. Soc., 1839, p. 158; Blyth, Journ. As. Soc., Bengal, vol. xi, p. 175, 1842.

Buchanga albirictus, Hodgs., Ind. Rev., vol. i, p. 326, 1837 ; Hume, Stray Feathers, 1873, p. 178 ; Adam., t.c., p. 377; Ball, op. cit., 1874, p. 402 ; Hume, t.c., p. 474; Armstrong \& Hume, op. cit., 1876, p. 318, 1877, p. 29; Fairbank, t. c., p. 401.

Dicrurus minor, Blyth, Ann. \& Mag. Nat. Hist., vol. xiii, p. 129, 1844; id., Cat. B. Mus., As. Soc., Bengal, p. xxii, 1849 ; id., Ibis, 1867, p. 305.

Dicrurus fingah, Hodgs., in Gray's Zool. Misc., p. 84, 1844.

Edolius fingah, Blyth, Journ. As. Soc., Bengal, vol. xv, p. 800, 1846.

Dicrurus longus, Bonap. Consp., t. i, p. 352, 1850; Horsf. \& Moore, Cat. B. Mus. E. Ind. Co., vol. i, p. 152, 1854.

Dicrurus himalayensis, Tytler, Ibis, 1868, p. 200 (descr. nulla) ; Gray, Handl. B., vol. i, p. 286, 1869. Dicrurus albirictus, Gray, Handl. B., vol. i, p. 285, 1869 ; Hume, Stray Feathers, 1875, p. 97.

Dicrurus cathrecus, Swinhoe, Proc. Zool. Soc., 1871, p. 377 ; Godwin-Austen, Journ. As. Soc, Bengal, vol. xlv, 1876, p. 71.

Buchanga minor, Holdsw., Proc. Zool. Soc., 1872, p. 438.

Buchanga cathocca, Walden, Journ. As. Soc., Bengal, vol. xliv, ex. No., p. 130, 1875.

Buchanga atra, Sharpe, Cat. Birds, B. Mus., vol. iii, p. 246, 1877.
a. ‡ Bhamô, Upper Burma, 9th September 1868.
b. f Sanda, 15th May 1868.
c. \& Muangla, 22nd May 1868 .

This species is not uncommon at Bhamô, and I traced it along our route as far east as the middle of the Sanda valley, 2,500 feet, beyond which, however, I failed to observe it. The Bhamô specimens were shot in September, and are moulting their primaries.

I did not observe it in the sequestered Hotha valley, which is separated from the Sanda one by a high range of mountains, and is at a higher elevation. 
156. Buchanga longicaddata, Hay.

Dicrurus macrocercus (nec. V.), Jerdon, Madr. Journ., vol. x, p. 240, 1839; Blyth, Ann. \& Mag. Nat. Hist., vol. iv, p. 46, 1844.

Dicrurus longicandatus, A. Hay, Jerdon, Madr. Jovrn., vol. xiii, t. 2, p. 121, 1844; Blyth, Journ. As. Soc., Bengal, vol. xv, p. 298, 1846 ; id,, Cat. B. Mus., As. Soc., Bengal, p. 202, 1849 ; Bonap. Consp., t. i, p. 351, 1850 ; Horsf. \& Moore, Cat. B. Mus. E. Ind. Co., vol. i, p. 152, 1854; Jerdon, B. Ind., vol. i, p. 430, 1862 ; Gray, Handl. B., vol. i, p. 285, 1869 ; Hume, Stray Feathers, 1875 , p. 97.

Buchanga longicaudata, Walden, Ibis, 1868, p. 316 ; Beavan, t. c., p. 497; Holdsw., Proc. Zool. Soc., 1872, p. 438 ; Fairbank, Stray Feathers, 1876, p. 257 ; Hume, t.c., pp. 394, 415 ; Sharpe, Cat. Birds, B. M., vol. iii, 1877, p. 249.

Buchanga waldeni, Beavan, Ibis, 1868, p. 497, (nee Schl.).

Buchanga longicauda, Hume, Stray Feathers, 1874, p. 474.

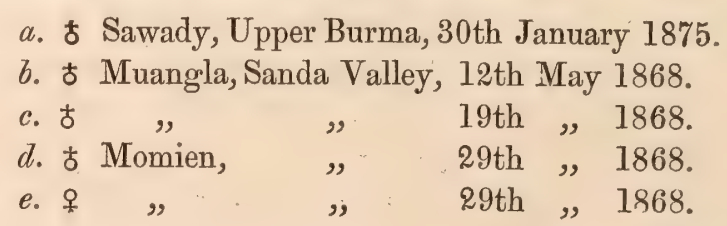

This is much more common in the valleys of Western Yunnan than the preceding species; however, it becomes rare in the elevated valley of Momien, which may be due in part to the absence of forest, as well as to the almost temperate character of the climate.

Family-TCHITREADA.

Genus Terpsiphone, Gloger.

157. Terpsiphone afFinis, Blyth.

Tchitrea affinis, Blyth, Journ. As. Soc., Bengal, vol. xv, p. 292, 1846, ex Lord A. Hay, M. S., et. vol. xvi, p. 1179, 1849 ; id., Cat. B. Mus., As. Soc., Bengal, p. 203, 1849 ; Gray, Gen. B., vol. iii, App. p. 12, 1849 ; Horsf. \& Moore, Cat. B. Mus. E. Ind. Co., vol. i, p. 134, 1854; Moore, Proc. Zool. Soc., 1854, p. 270 ; Jerdon, B. Ind., vol, i, p. 448, 1862 ; Sclater, Proc. Zool. Soc., 1863, p. 217 ; Schl., N. T. D., t. iii, p. 85, 1866; Gray, Handl. B., vol. i, p. 332, 1869 ; Walden, Ibis, 1872, p. 373 ; Hume, Stray Feathers, 1874, pp. 216, 474; Blyth \& Walden, Journ. As. Soc., Bengal, vol. xliv, ex. No., p. 131, 1875; Hume, Stray Feathers, 1875, p. 324; Godwin-Austen, Journ. As. Soc., Bengal, vol. xlv, 1876, p. 71.

Muscipeta affinis, Bonap. Consp., t. i, p. 325, 1850.

Tchitrea paradisi, Schl., Dierkd., fig. 10, p. 147, 1857-58.

Muscipeta affinis, var., Wall., Proc. Zool. Soc., 1863, p. 485.

Terpsiphone affinis, Salvad, Ucc. Born., p. 137, 1874.

a. Bhamô, 20th September 1868.

Dr. Jerdon observes that the chestnut birds can always be recognised by the absence of the rich glossy black neck and throat of $T$. paradisi, but this is not invariably the case, for I have specimens of that species before me from the Botanical Garden, Calcutta, and Chanda, Central India, in which the neck, instead of being glossy black, is dark-ashy, as in T. affinis. 


\section{Genus Нтротнумгs, Boie.}

\section{Hүротнyмis AZURea, Bodd.}

Gobe-mouche bleu des Philippines, Buff., Pl. Enl., t. v, pl. 666, fig. 1.

Muscicapa azurea, Bodd., Tabl. Pl. Enl., p. 41 (1783, ex Buff.).

Muscicapa carulea, Gm., Syst. N., i, p. 943, 1788, ex Buff.; Kittl., Küpf. Vög., p. 7, pl. ix, fig. 1, 1832.

Muscicapa occipitalis, Vigors, Proc. Zool. Soc., 1831, p. 97.

Muscicapa ceruleocephala, Sykes, Proc. Zool. Soc., 1832, p. 85.

Myragia azurea, Gray, Gen. B., vol. i, p. 261, 1846 ; Horsf. \& Moore, Cat. B. Mus. E. Ind. Co., vol. i, p. 138, 1854; Jerdon, B. Ind., vol. i, p. 450, 1862; Godwin-Austen, Journ. As. Soc., Bengal, vol. xxxix, 1870, p. 100 ; Gray, Handl. B., vol. i, p. 328, 1869 ; Swinhoe, Proc. Zool. Soc., 1871, p. 381 ; Holdsw., Proc. Zool. Soc., 1872, p. 440; Ball, Stray Feathers, 1873, p. 68 ; id., op. cit, 1874, p. 404; Hume, op. cit., p. 217, 1875 ; id., t. c., p. 103 ; id., Nests and Eggs, Ind. B., p. 198, 1873 ; Fairbank, Stray Feathers, 1876, p. 257; Armstrong, t. c., p. 322 ; Hume, $t . c .$, pp. 395,424 .

Myagra carulea, Blyth, Cat. B. Mus., As. Soc., Bengal, p. 204, 1849 ; Gray, Cat. Mamm., \&c., Coll. Hodgs., p. 93, 1856.

Hypothymis carulea, Bonap. Consp., t. i, p. 320, 1850 ; Cab., Mus. Hein., th. i, p. 56, 1850.

Muscicapa anadensis, Bonap. Consp., t. i, p. 320, 1850 (nec. Quoy et Gaim.).

Hypothymis azurea, Walden, Ibis, 1872, p. 102 ; Salvad, Ucc. Born., p. 133, 1874; Walden, Proc. Zool. Soc., vol. ix, p. 182, 1875 ; Blyth \& Walden, Journ. As. Soc., Bengal, vol. xliv, ex. No., p. 131, 1875; Sharpe, Ibis, 1877, p. 18; Tweedale, t. c., p. 316.

a. Mandalay, 20th September 1868.

6. Second defile of Irawady, 6th May 1875.

\section{Genus R Hipid u R A, Vigors \& Horsfield.}

\section{Rhipidura aLbofrontata, Franklin.}

Rhipidura albofrontata, Frankl., Proc. Zool. Soc., 1831, p. 116 ; id., Journ. As. Soc., Bengal, vol. i, p. 264, 1832 ; Sykes, Proc. Zool. Soc., 1832, p. 85 ; Blyth; Journ. As. Soc., Bengal, vol. xii, p. 935, 1843 ; Gray, Gen. B., vol. i, p. 258, 1846 ; Horsfield \& Moore, Cat. B. Mus. E. Ind. Co., p. 145, 1856 ; Gray, Handl. B., vol. i, p. 331, 1869.

Rhipidura aureola, Less., Tr. d'Orn., p. 390, 1831.

Leucocerca albofrontata, Jerdon, Madr. Journ., vol. xi, p. 12, 1840 ; id., Ill. Ind. Orn., pl. ii, 1847; Blyth, Cat. B. Mus., As. Soc., Bengal, p. 206, 1849 ; Bonap. Consp. G. Av., p. 324, 1850 ; Jerdon, B. Ind., vol. i, p. 452, 1862 ; Blanford, Journ. As. Soc., Bengal, vol. xxxii, p. 79, 1863 ; Stoliczka, op. cit., vol. xxxvii, 1868, p. 28; Ball, Stray Feathers, 1874, p. 404; Hume, Nests and Eggs, Ind. B., p. 201, 1873; Blyth \& Walden, Journ. As. Soc., Bengal, vol. xliv, ex. No., p. 132, 1875 ; Hume, Stray Feathers, 1876, p. 34; Fairbank, t. c., p. 257.

Lencocerca aureola, Holdsw., Proc. Zool. Soc., 1872, p. 440; Hume, Stray Feathers, 1873, p. 178; Cock. \& Marsh., t. c., p. 352 ; Adam., t. c., p. 377 ; Hume, t. c., p. 436 ; id., op. cit., 1875, p. 104.

\footnotetext{
a. Mengoon, 14th January 1868.

๖. t Upper defile of the Irawady, March 1875.

c. Katha, 20th January 1868.

d. Ponsee, March 1868.
} 
The general colour of the upper surface of these specimens is lighter than in Indian birds, and the head and neck, instead of being deep black, are dusky brown. The wings are of a lighter tint, and the spots on the wing-coverts are indistinct in some and fainter in all, than in Indian birds. In one specimen a central tail feather is tipped with white.

\section{RHIPIDURA ALBICOLLIS, Vieill.}

Platyrhynchus albicollis, Vieill., Nouv. Dict. d'Hist. Nat., vol. xxvii, p. 13; Pucheran, Archiv. du Mus., vol. vii, 1854-55, p. 358, pl. xx, fig. 1; Hartl., Journ. für Ornith., vol. iii, 1855, p. 426 ; Salvad., Ibis, 1877, p. 143.

Rhipidura fuscoventris, Frankl., Proc. Zool. Soc., 1831, p. 117; Sykes, Proc. Zool. Soc., 1832, p. 85 ; Blyth, Journ. As. Soc., Bengal, vol. xii, p. 935, 1843 ; Gray, Gen. B., vol. i, p. 259 , 1846 ; id., Cat. Mamm., \&c., Nepal, Hodgs., p. 93, 1846 ; Horsfield \& Moore, Cat. B. Mus. E. Ind. Co., p. 145, 1854; Pucher., Archiv. du Mus., vol. vii, 1854-55, p. 358; Hartl., Journ. für Ornith., 1855, p. 426 ; Gray, Handl. B., vol. i, p. 331, 1869 ; Salvad., Ibis, 1877, p. 143 ; Giebel, Ibis, Ornith., 1877, vol. iii, p. 222.

Rhipidura albigula, Hodgs., in Gray's Zool. Misc., p. 84, 1844.

Leucocerca fuscoventris, Blyth, Journ. As. Soc., Bengal, vol. xv, p. 290, 1846; id., Cat. B. Mus. As. Soc., Bengal, p. 206, 1849; Jerdon, Ill. Ind. Orn., p. 11, 1849; Bonap. Consp., t. i, p. 324, 1850 ; Jerdon, B. Ind., vol. i, p. 451, 1862 ; Godwin-Austen, Journ. As. Soc., Bengal, vol. xxxix, 1870, p. 100 ; Cock. \& Marsh., Stray Feathers, 1873, p. 352 ; Hume, Nests and Eggs, Ind. B., p. 200, 1873; Ball, Stray Feathers, 1874, p. 404.

Leucocerca albicollis, Hume, Stray Feathers, 1875, p. 103; Godwin-Austen, Journ. As. Soc., Bengal, vol. $x l v, 1876$, p. 71 .

$$
\begin{aligned}
& \text { a. ‡ Bhamô, 1st February } 1868 . \\
& \text { b. } \quad \text { " 31st January } 1875 . \\
& \text { c. ‡ Ponsee, 28th March } 1868 . \\
& \text { d. t }, 25 \text { th April } 1868 . \\
& \text { e. ㅇ " 3rd May } 1868 .
\end{aligned}
$$

These specimens agree in every particular with Bengal birds, but the wingcoverts are finely and very obscurely tipped with rufous, and those of the under surface are the same. The female from Bhamô has a minute rufous spot on two of the feathers of the great wing-coverts, and there are faint traces of rufous on the abdomen. These spots occupy the same position as the white spots of $R$. albifrontata, but they are so obscure that they are liable to be overlooked.

The habits of this bird are well described by Dr. Jerdon. I procured the Bhamô specimens within the stockade, in a dense clump of jack trees, and the Ponsee birds in a thicket on an old clearing at 3,500 feet.

\section{Family-BRACHYPODIIDAE.}

\section{Genus Hipsipetes, Vigors.}

161. Hypstpetes yUnnanensis, n. s. Plate L.

Hypsipetes yunnanensis, Anderson, Proc. Zool. Soc., 1871, p. 213 ; Swinhoe, t. c., p. 369. 
Length $10^{\prime \prime}$; wing $5^{\prime \prime}$; tail $4^{\prime \prime} \cdot 50$; tarsus $0^{\prime \prime} \cdot 70$; bill (gape) $1^{\prime \prime} \cdot 16$.

Black; head, neck, and interscapular region metallic black; middle of back and rump dusky black, tinged with cinereous; the feathers margined with cinereous; upper tail-coverts brownish-black, feebly tinged with cinereous; below dark cinereous spotted with brownish-black; sides of the abdomen slaty cinereous; under tail-coverts ashy, margined with white; wing-coverts brownish-black; wings and tail blackish-brown, the primaries narrowly margined with cinereous; bill, legs and feet coral red; claws dusky; irides bright reddish-brown.

This bird is intermediate between $H$. psaroides and H. ganeesa, but is most closely allied to the latter. It is also nearly allied to $H$. nigerrima, Gould, with which I have compared it. It is a larger bird than any of the foregoing species. It is also a much greyer bird generally than the $H$. perniger, Swinhoe, and considerably larger.

Blyth's $H$. concolor is so imperfect in every way that I do not attempt to supplement his meagre description.

I procured only one specimen of this species on the hill-side at Ponsee on old forest clearings.

\section{Genus HEMrixu, Hodgson.}

\section{Hemixus flavala, Hodgson.}

Hemixos flavala, Hodgs., in Gray's Zool. Misc., p. 83, 1844; id., Journ. As. Soc., Bengal, vol. xiv, p. 572, 1845 ; Blyth, Cat. B. Mus. As. Soc., Bengal, p. 207, 1849 ; Bonap. Consp., vol. i, p. 261, 1850; Horsfield \& Moore; Cat. B. Mus. E. Ind. Co., vol. i, p. 250, 1854; Jerdon, B. Ind., vol. ii, p. 80, 1863 ; Blyth, Ibis, 1867, p. 7 ; Bulger, Ibis, 1869, p. 165 ; GodwinAusten, Journ. As. Soc., Bengal, 1870, p. 106 ; Oates, Stray Feathers, 1875, p. 337 ; GodwinAusten, Journ. As. Soc., Bengal, vol. xlv, 1876, p. 78.

Hemipus flavala, Gray, Cat. Mamm., \&c., Nepal, p. 90, 1846.

Pycnonotus flavala, Gray, Gen. B., i, p. 237, pl. lix, 1847; id., Handl. B., vol. i, p. 270, 1869.

a. ๖. t Ponsee, 3rd April 1868.

This bird was living in communities on high trees in the outskirts of the village along with Otocompsa emeria and Pycnonotus nigripileus.

\section{Genus Отосомтsa, Cabanis.}

163. ОтоCOMPSA EMERTA, Linnæus.

Le petit merle hupé de la Chine, Briss. Orn., t. ii, p. 255, pl. xxi, fig. 2, 1760.

Lanius jocosus, Linn., Syst. Nat., t. i, p. 138, 1766; (ex Briss.)

Ixus jocosus, Sykes, Proc. Zool. Soc., 1832, p. 88 ; Pears., Journ. As. Soc., Bengal, vol. x, p. 640, 1846 ; Bonap. Consp. Av., t. i, p. 265, 1850 ; Swinhoe, Proc. Zool. Soc., 1871, p. 370.

Pycnonotus jocosus, Blyth, Journ. As. Soc., Bengal, vol. xiv, p. 566, 1845 ; id., vol. xv, p. 286, 1846 ; Gray, Gen. B., vol. i, p. 237, 1847; Blyth, Cat. B. Mus. As. Soc., Bengal, p. 208, (pars), 1849 ; Horsfield \& Moore, Cat. B. Mus. E. Ind. Co., vol. i, p. 238, 1854; Gray, Handl. B., vol. i, p. 271, 1869 . 
Otocompsa jocosa, Cab., Mus. Hein., th. i, p. 109, 1850 ; Jerdon, B. Ind., vol. ii, p. 92, 1863 ; Beavan, Ibis, 1867, p. 440 ; Godwin-Austen, Journ. As. Soc., Bengal, vol. xxxix, 1870, p. 106 ; Ball, Stray Feathers, 1873, p. 70.

Ixus erythrotis, Horsfield \& Moore, Cat. B. Mus. E. Ind. Co., vol. i, p. 421, 1854.

Ixus monticolus, Mc'Clelland, Proc. Zool. Soc., 1839, p. 160 ; Shaw, Ibis, 1867, p. 8.

Otocompsa emeria, Hume, Stray Feathers, vol. i, p. 309, 1873; vol. iv, pp. 225, 477, 1874; vol. iii, p. 126, 1875; 1877, p. 35; Armstrong, 1876, p. 325; Oates, t. c., 1877, p. $15 \%$.

Otocompsa monticola, Blyth \& Walden, Journ. As. Soc., Bengal, vol. xliv, extra No., 1875, p. 135.

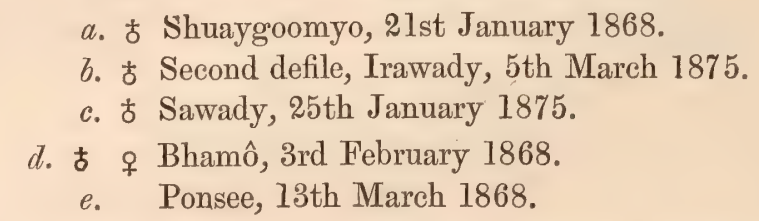

The race in Burma resembles the Indian form in every respect, except that the hair-like crimson feathers below and behind the eye are darker and shorter than in the Bengal race, and the white ear-patch is a little larger. I did not observe this bird beyond; in the Sanda valley to the eastward its place appears to be taken by Pycnonotus xanthorrhous, Andr.

\section{Genus Prcnonotus, Kuhl.}

\section{Prononotus nigripileus, Blyth.}

Pycnonotus nigropileus, Blyth, Journ. As. Soc., Bengal, vol. xvi, p. 472, 1847 ; id., Cat. B. Mus. As. Soc., Bengal, p. 209, 1849 ; Ibis, 1867, p. 9 ; Beavan, Ibis, 1867, p. 441 ; Blanford, . c., 1870, p. 467; Walden, Proc. Zool. Soc., Lond., 1866, p. 549; Blyth \& Walden, Journ. As.

Soc., Bengal, vol. xliv, extra No., p. 135, 1875.

Ixus nigripileus, Bonap. Consp. Av., t. i, p. 265, 1850.

Molpostes nigropileus, Hume, Stray Feathers, 1870, p. 378, 1874, p. 477.

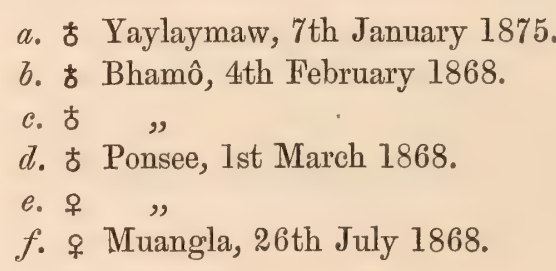

This species is common at Bhamô, and in the Kakhyen hills, but I did not observe it beyond the Sanda valley.

The young has the head deep brown, and the tail feathers brown, with distinct indications of barring, with deep brown when held in certain lights.

\section{Pycnonotus xanthorrhods, Andr. Plate II.}

Pycnonotus xanthorrhous, Andr., Proc. As. Soc., Bengal, 1869, p. 265 ; Proc. Zool. Soc., Lond., 1871, p. 214; Blyth, Journ. As. Soc., Bengal, vol. xliv, extra No., 1875, p. 135, note.

Ixus andersoni, Swinhoe, Ann. and Mag. Nat. Hist., vol. v, ser. 4, 1870, p. 175. 
Ixus xanthorrhous, Swinhoe, Proc. Zool. Soc., 1871, p. 369 ; David, Journ. de Voy. Explor. en Chine, vol. i, 1875, p. 30, et vol. ii, p. 40.

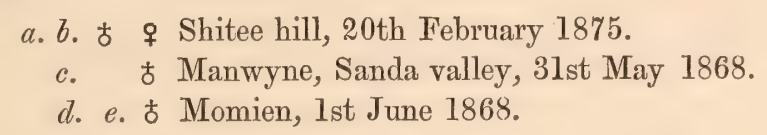

Length $7^{\prime \prime} \cdot 70$; wing $3^{\prime \prime} \cdot 65$; tail $3^{\prime \prime} \cdot 60$; bill (gape) $0 " 77$; tarsus $0^{\prime \prime} \cdot 70$.

This species is nearly allied to O. jocosa in the general style of its colouring, but differs from it in its yellow under tail-coverts, and in its ear-coverts being pale brown. It has the square tail and the well developed rictal bristles of a Pycnonotus.

Held in certain lights, the under surface of the tail shows indistinct dark brown bars.

\section{Prcnonotus Blanfordi, Jerdon.}

Pycinonotus blanfordi, Jerdon, Ibis, 1๖62, p. 20.

Pycnonotus familiaris, Blyth, Journ. As. Soc., Bengal, vol. xxxi, 1862, p. 243.

Microscelis blanfordi, Gray, Handl. B., vol. i, p. 268, 1869.

Microtarsus blanfordi, Hume, Stray Feathers, 1875, p. 125:

Ixos blanfordi, Blyth \& Walden, Journ. As. Soc., Bengal, vol. xliv, extra No., p. 134, 1875; Oates,

Stray Feathers, 1877, p. 156.

a. Mandalay, 26th September 1868.

b. ㅇ. Bhamô, 19th February 1868.

c. ㅇ , , , ,

This is a very common species above Mandalay, but it does not extend to the hills, as far as my observations go. It approaches very closely to P.plumosus, Blyth, from which it differs in having much whiter ear-coverts, and in the quills and tail being not so green and in the lower parts being lighter.

\section{Pycnonotus flavescens, Blyth.}

Pycnonotus flavescens, Blyth, Journ. As. Soc., Bengal, vol. xiv, p. 563, 1845.

Ixus flavescens, Hume, Stray Feathers, 1874, p. 477; Blyth \& Walden, Journ. As. Soc., Bengal, vol. xliv, extra No., p. 134, 1875.

\section{a. Ponsee, 27th March 1868.}

Blyth's description is as follows: "Colour dull greenish-olive above, the crown darker with broader and more rounded coronal feathers than in $P$. finlaysoni; alars margined with brighter yellowish-green and caudals less decidedly; under parts paler, mingled with dull yellow, imparting a streaky appearance; the vent and lower tail-coverts bright yellow, paling off on the belly; lores blackish, surrounded with yellowish-white. Bill and feet dark. Length about 7 inches and 0.75 . Wing 3.25. Tail 4 inches. Gape 0.88. Tarsus 0.75. It is said to be rare in Arracan. It differs from $P$. finlaysoni in wanting the yellow stripe on the throat, with yellowish colour of the crown and in having its tail feathers more graduated." 


\section{Genus Phyllornis, Boie.}

\section{Phylloris aurifrons, Temminck.}

Phyllomis aurifrons, Temm., Pl. Col., 484, fig. 1, 1829; Gray, Gen. B., vol. i, p. 124, 1846 ; id., Cat. Mamm., \&c., Nepal, Hodgs., p. 61, 1846 ; Blyth, Cat. B. Mus., As. Soc., Bengal, p. 212, 1849 ; Bonap. Consp., t. i, p. 396, 1850 ; Cab. \& Heine, Mus. Hein., th. i, p. 114, 1850 ; Horsf. \& Moore, Cat. B. Mus. E. Ind. Co., vol. i, p. 258, 1854; Jerdon, B. Ind., vol. ii, p. 99, 1863 ; Gray, Handl. B., vol. i, p. 277, 1869; Godwin-Austen, Journ. As. Soc., Bengal, 1870, vol. xxxix, p. 106 ; Ball, Stray Feathers, 1874, p. 411; Hume, t. c., p. 477 ; id., Stray Feathers, 1875, p. 129.

Chloropsis malabaricus, Jerdon \& Selby, Ill. Orn., pl. v, and text to pl. 100.

Chloropsis aurifrons, Jerdon \& Selby, text to p. 100 ; Blyth, Journ. As. Soc., Bengal, vol. xi, p. 458, 1842, vol. xii, p. 956, 1843; Jerdon, Madr. Journ., vol. xiii, p. 123, 1844.

Phyllornis malabaricus, Fairbank, Stray Feathers, 1876, pp. 258, 265; Hume \& Fairbank, ibid., p. 400 .

a. b. c. o Sawady, 25th and 30th January 1875.

d. Bhamô, 13th September 1868.

e. $\quad$, 19th February 1868.

The only difference observable in my specimens is that the black of the neck does not extend quite so far down as in Temminck's drawing, and in specimens of this species from Singbhoom, Midnapore, and Dehra Doon. I did not observe it on the Kakhyen hills nor in the valleys beyond.

\section{Genus IorA, Horsfield.}

169. IORA TYPHIA, Linnæus.

Motacilla typlia, Linn., Syst. Nat., vol. i, 1766, p. 331.

Iora typhia, Hume, Stray Feathers, 1877, p. 428.

$$
\text { a. b. t Bhamô, 8th September } 1868 .
$$

In no way different from Indian birds.

Common throughout Upper Burma, but does not extend into the valleys beyond Muangla.

$$
\text { Family-ORIOLID ER. }
$$

\section{Genus OrIolds, Linnæus.}

\section{Oriolus melanocephalus, Linnæus.}

The black-headed Indian Icterus, Edwards, Birds, pl. Ixxvii, 1747.

Le Loriot de Bengale, Briss. Orn., ii, p. 329, 1760.

Oriolus melanocephalus, Linn., Syst. Nat., vol. i, p. 160 ; Jerdon, Madr. Journ., x, p. 262, 1839; Gray,

Gen. B., vol. i, p. 232, 1845; Blyth, Cat. B. Mus, As. Soc., Bengal, p. 215, 1849; Bonap.

Consp., t. i, p. 346, 1850 ; Horsf. \& Moore, Cat. B. Mus. E. Ind. Co., vol. i, p. 269, 1854;

Jerdon, B. Ind., vol. ii, p. 110, 1862; Schl., Mus. P.-B. Coraces, p. 106, 1867 ; Gray, Handl. 
B., vol. i, p. 292, 1869 ; Ball, Stray Feathers, 1873, p. 71; 1874, p. 412; Hume, Stray Feathers, 1873, p. $230 ; 1874$, p. 477; 1875, p. 133; id., Nests and Eggs, Ind. B., p. 301, 1874; Armstrong, Stray Feathers, 1877, p. 327 ; Sharpe, Cat. B., B. M., vol. iii, 1877, p. 215. Oriolus maderaspatanus, Frankl., Proc. Zool. Soc., 1831, p. 118.

Oriolus M'Coshii, Tickell, Journ. As. Soc., Bengal, ii, p. 577, 1833.

Oriolus hodgsonii, Swains., An. in. Menag., p. 290, 1837 ; Blyth, Journ. As. Soc., Bengal, vol. xi, p. 460, 1842 ; Hodgss., in Gray's Zool. Misc., p. 83, 1844; Gray, Gen. B., vol. i, p. 232, 1845. Oriolus strigipectus, Hodgs., in Gray's Zool. Misc., p. 83, 1844.

Oriolus ceylonensis, Bonap. Consp., t. i, p. 347, 1850 ; Jerdon, B. Ind., vol. ii, p. 111, 1862 ; Schl., Mus. P.-B. Coraces, p. 107, 1867; Gray, Handl. B., vol. i, p. 292, 1869 ; Holdsw., Proc. Zool. Soc., 1872, p. 453 ; Hume, Stray Feathers, 1873, p. 439 ; Sharpe, Cat. B., B. M., vol, iii, j877, p. 216.

a. t Sawady, 28th January 1875.

b. c. Bhamô, 28th January and February 1868.

The black does not extend quite so far down the breast as in Indian birds.

It does not appear to be common about Bhamô, and I did not observe it in the Kakhyen hills nor in the country beyond.

Family-NECTARINIDA

Genus Arachemerthra, Cabanis.

171. Arachnechthra edeni, n. s. Plate XLTX.

Arachnechthra asiatica, Hume, Stray Feathers, 1874, p. 473, et 1875, p. 87; Blyth \& Walden, Journ. As. Soc., Bengal, vol. xliv, extra No., p. 141.

a. ‡ Six miles below Bhamô, 31st January 1875.

Mr. Hume, in his account of the birds of Upper Pegu, mentions that all the specimens which he has seen from Thayet-myo "have been remarkable by the entire absence of any greenish gloss in any light." This I find to be the case with my Bhamô bird, which I have compared with a large series of Indian skins, and there can be no doubt that Mr. Hume's observations are quite to the point, and that the absence of green shade separates the Burmese from the Indian birds. Although $A$. cunucaria, vel asiatica appears purplish above, the shade is very different from the violet lustre of $A$.edeni, and in the latter this violet colour of the back is continued on to the sides of the neck and cheeks, the purplish throat being margined on each side with violet instead of with green, as is so evident in all specimens of $A$. asiatica. The Bhamô example measures : total length 4.2 inches; culmen $0 \cdot 75$; wing $2 \cdot 1$; tail 1.5 ; tarsus 0.55 .

\section{Genus Етнорт А, Cabanis.}

172. ÆTHOPYGA MILES, Hodgson.

Goulpourah creeper, Lath., Gen. Hist. B., iv, p. 222, pl. lxxiv, 1822.

Nectarinia seheria, Tickell, Journ. As. Soc., Bengal, vol. ii, p. 577, 1833. 
Cinnyris miles, Hodgs., Ind. Rev., vol. ii, p. 273, 1837.

Cinnyris labecula, Mc'Clell., Proc. Zool. Soc., 1839, p. 167.

Certhia goalpariensis, Royle, Ill. Himal. Bot., vol. ii, pl. vii, fig. 1.

Nectarinia goalpariensis, Jerdon, Nat. Sibr., vol. v, pp. 230, 267, pl. xxvi; Gray, Gen. B., vol. i; p. 98 ; id., Cat. Mamm., \&c., Nepal, Coll. Hodgs., p. 59 ; Blyth, Cat. B. Mus. As. Soc., Bengal, p. 223 ; Tytler, Ann. Nat. Hist., ( 2), vol. xiv, p. 175, 1854.

Nectarinia labecula, Blyth, Journ. As. Soc., Bengal, vol. xii, p. 973 ; Gray, Gen. B., vol. i, p. 98.

Nectarinia goalpariensis, Bonap. Consp., t. i, p. 405, 1850; Gould, B. Asia, pt. ii, 1850.

Atthopyga goalpariensis, Cab., Mus. Hein., th. i, p. 103, 1850 ; Hume, Nests and Eggs, Ind. B., p. 146, 1873.

AEthopyga miles, Cab., Mus. Hein., th. i, p. 103 ; Horsf. \& Moore, Cat. B. Mus. E. Ind. Co., vol. ii, p. 732 ; Jerdon, B. Ind., vol. i, p. 362 ; Walden, Ibis, 1870, p. 32 ; Grodwin-Austen, Journ. As. Soc., Bengal, vol. xxxix, p. 98 ; Hume, Stray Feathers, 1873, p. 413 ; Ball, Stray Feathers, 1874, p. 396 ; Blyth \& Walden, Journ. As. Soc., Bengal, vol. xliv, extra No., 1875. p. 141; Brooks, Stray Feathers, 1875, p. 233.

Promerops goalpariensis, Gray, Handl. B., vol. i, p. 110.

a. e. t Sawady, 25th to 30th January 1875 .

$f$. $\quad$ ठ Bhamô, 29th January 1868.

Not uncommon about Bhamô.

\section{3. ЕтноруgA DABRyi, Verr.}

Nectarinia dabryi, Verr., Rev. et Mag. de Zool., 186\%, p. 173, pl. xv.

Promerops dabrii, Gray, Handl. B., vol. i, p. 110, 1869.

Atthopyga abrii, Swinhoe, Proc. Zool. Soc., 1871, p. 349; David, N. Arch. Mus., vii, Bull., p. 8, 1871 ; Hume, Stray Feathers, 1877, pp. 52, 72, pp. 271, 272
a. オ Bhamô, 19th January 1875.
b. ᄒ Shitee Meru, 20th February 1875.
c. t Ponsee, 28th March 1868; alt. 3,300 feet.

This species which was first obtained from the north of China is closely allied to Nectarinia nipalensis, Hodgson. M. J. Verreaux in his description says: "Mais le caractére qui le distingue de tous les autres, et qui lui est particulier, c'est le blanchâtre qui borde les rectrices externes." Four specimens of $N$. nipalensis, however, from Darjeeling in the Calcutta Museum have the external rectrices with whitish tips of the very same shade as those of $N$. dabryi, although not quite so broad. In the female $N$. nipalensis the white tips are very marked.

\section{Genus Cha l coparia, Cabanis.}

174. Chalcoparia cingalensis, Gmelin.

Green warbler, Brown, Ill. Zool., pl. xxxii, fig. 2, 1776.

Cingalese warbler, Lath., Gen. Syn., iv, p. 474, 1783.

Motacilla cingalensis, Gm., Syst. Nat., vol. i, p. 964, 1788.

Sylvia cingalensis, ex Lath., Ind. Orn., vol. ii, p. 533, 1790.

Le sonimanga à bec droit, Audeb. \& Vieill. Ois. Dor., pl. lxxv, 1802. 
Nectarinia phonicotis, Temm., Pl. Col., 108, fig. 1, 388, fig. 2, 1824; Blyth, Cat. B. Mus. As. Soc., Bengal, p. 225, 1849 ; Sel., Proc. Zool. Soc., 1863, p. 220.

Anthreptes phanicotis, Blyth, Journ. As. Soc., Bengal, vol. xii, p. 979, 1843.

Cinnyris phoenicotis, Bonap. Consp.; t. i, p. 408, 1850.

Nectarinia cingalensis, Gray, Gen. B., vol. i, p. 99, 1847 ; Mottl. \& Dillw., Nat. Hist., Labuan, p. 16, 1855.

Chalcoparia cingalensis, Cab., Mus. Hein., p. 103, 1850; Reich., Handb. Scansoria, p. 304, pl. dlxxxvii, figs. 3987-88, 1853; Walden, Ibis, 1870, p. 48; Salvad., Uce. Born., p. 180, 1874; Hume, Stray Feathers, 1874, p. 473; 1875, p. 86.

Chalcoparia phcenicotis, Horsf. \& Moore, Cat. B. Mus. E. Ind. Co., vol. ii, p. 747; Moore, Proc. Zool. Soc., 1859, p. 463.

Anthreptes cingalensis, Walden, Proc. Zool. Soc., 1866, p. 543.

Promerops cingalensis, Gray, Handl. B., i, p. 111, 1869.

a. t Sawady, 27th January 1875.

\section{Genus Drcжu M, Cuvier.}

\section{Dic.eum cruentatum, Linnæus.}

The little black, white and red Indian Creeper, Edwards, Birds, vol. ii, p. 81, pl. lxxxi, 1747 .

Le Grimpereau de Bengale, Briss. Orn., t. iii, p. 663, 1760.

Certhia cruentata, Linn., Syst. Nat., vol. i, p. 187, 1766, ex Edwards.

Le petit Grimpereau à dos roux de la Chine, Sonn., Voy. Ind., t. ii, p. 209, pl. 117, fig. 1, 1782.

Certhia coccinea, Scop., Del. Flor. et Faun. Insubr., t. ii, p. 91, 1786, ex Scop.

Certhia erythronotos, Lath., Ind. Orn., t. i, p. 290, 1790, ex Sonn.

Le sonimanga à dos rouge, Audeb. \& Vieill., Ois. Dor., t. ii, pl. xxxv, 1802.

Diccum erythronotum, Cuvier, Règne An., t. i, p. 410, 1817 ; Mc'Clell., Proc. Zool. Soc., 1839, p. 167 ; Blyth, Journ. As. Soc., Bengal, vol. xii, p. 983, 1843, vol. xiv, p. 558, 1848.

Dicaum rubricapillum, Less., Traite, p. 303, 1831.

Dicaum cruentatum, Strickl., Ann. Nat. Hist., vol. xiii, p. 38, 1846 ; Blyth, Cat. B. Mus. As. Soc., Bengal, p. 226, 1849; Bonap. Consp., t. i, p. 402, 1850; Cab., Mus. Hein., th. i, p. 98, 1850; Gould, B. Asia, pt. vi, 1854; Tytler, Ann. Nat. Hist., vol. xiii, p. 373, 1854; Gray, Handl. B., vol. i, p. 114, 1869 ; Blanford, Ibis, 1870, p. 467; Swinhoe, Proc. Zool. Soc., 1871, p. 349; Hume, Nests and Eggs, Ind. B., p. 155, 1873; id., Stray Feathers, 1874, p. 473 ; 1875, p. 87 ; Blyth \& Walden, Journ. As. Soc., Bengal, vol. xliv, 1875, extra No., p. 142; Armstrong, Stray Feathers, 1876, p. 315.

Nectarinia ignita, Begbie, Ann. Nat. Hist., vol. xvii, p. 408, 1846.

Dicaum coccineum, Gray, Gen. B., vol. i, p. 100, 1847; Horsf. \& Moore, Cat. B. Mus. E. Ind. Co., vol. i, p. 747, 1856 ; Jerdon, B. Ind., vol. i, p. 373, 1862; Godwin-Austen, Journ. As. Soc., Bengal, vol. xxxix, 1870, p. 99.

a. Bhamô, 4th January 1868.

This solitary individual was shot among the high trees within the stockade at Bhamô.

176. Dic ÆUM CHRYSORRH必UM, Temminck.

Dicaum chrysorrhaum, Temm., Pl. Col., 478, fig. 1, 1829 ; Strickl., Proc. Zool. Soc., 1846, p. 100 ; Gray, Gen. B., vol. i, p. 100, 1847; Blyth, Cat. B. Mus. As. Soc., Bengal, p. 227, 1849; Bonap. Consp., t. i, p. 403, 1850 ; Horsf. \& Moore, Cat. B. Mus. E. Ind. Co., vol. ii, p. 751, 
1854; Gray, Handl. B., vol. i, p. 114, 1869; Hume, Stray Feathers, 1874, p. 473; Blanford, Ibis, 1870, p. 467 ; Salvadori, Cat. sist. degli Uce. di. Borneo, 1874, p. 168; Godwin-Austen, Journ. As. Soc., Bengal, vol. xliii, 1874, p. 156 ; Blyth \& Walden, Journ. As. Soc., Bengal, vol. xliv, extra No., p. 142, 1875; Sharpe, Ibis, 1877, p. 17.

Dicaum chrysochlore, Blyth, Journ. As. Soc., Bengal, vol. xii, p. 1009, 1843.

\section{a. * Nampoung, 19th February 1875 .}

The Nampoung is a fine mountain stream running through a deep glen and defining the eastward limit of the Chinese frontier. A level flat on its banks is covered with magnificent forest trees, with a clear undergrowth, in strong contrast to the tangled mass of regetation in the mountain forests above. This spot was the resort of a diversity of small birds, most numerous among which were Reguloides and Pericrocotus, and associated with these was this species of Diccum.

\section{Order GEMITORES.}

Family-TRERONID $A$

\section{Genus Crocopus, Bonaparte.}

\section{Crocopus viridifrons, Blyth.}

Treron viridifrons, Blyth, Journ. As. Soc., Bengal, vol. xiv, p. 849, 1845 ; id., Cat. B. Mus. As. Soc., Bengal, p. 228, 1849; Godwin-Austen, Journ. As. Soc., Bengal, vol. xxxix, 1870, p. 111 ; Gray, Handl. B., vol. ii, p. 222, 1870.

Crocopus viridifrons, Bonap. Consp., t. ii, p. 11, 1857; Reich., Handb. Columb., p. 106, taf. cxlix, fig. 1344; Hume, Stray Feathers, 1874, p. 481; 1875, p. 161; Blyth \& Walden, Journ. As. Soc., Bengal, vol. xliv, extra No., p. 143, 1875 ; Godwin-Austen, Journ. As. Soc., Bengal, vol. xliv, 1876, p. 83 ; W. Ramsay, Ibis, 1877, p. 456 ; Oates, Stray Feathers, 1877, p. 163.

a. 우 Tsagine, 29th December 1874 .

b. ㅇ Yaylaymaw, 5th January 1875 .

c. of Tamilone, 6th February 1868.

This species has a very close resemblance to C. phcenicopterus, Lath., especially when the yellow-green is well developed on the forehead of that species, in which, however, it is never so bright as in the present bird. It is distinguished from C. phcnicopterus by its brighter greenish-yellow caudal band, by its generally grey upper tail-coverts, and by the purer grey of the abdominal region, but it tends to blend with $C$. phoenicopterus, in the same way that the latter does with C. chlorigaster, and it is probable that an extensive series of specimens of the three species, taken from the centres and extreme limits of their areas of distribution, would show that they all lead into one another. 


\section{Family-COLUMBID $A$.}

\section{Genus Turtur, Selby.}

178. Turtur tigrina, Temminck.

Columba tigrina (t)., Temminck, Knip's Pig. t. i, p. 94, pl. xliii, 1811; Horsf., Trans. Linn. Soc., vol. xiii, p. 183, 1821; Schleg., Handl. Dierk., t. i, p. 404, $185 \%$.

Turtur chinensis (pt.), Bonap. Consp., t. ii, p. 63, 1854; Gray, List, Spec., B. M., vol. iv, Col., p. 42, 1856 ; Gray, Handl., vol. ii, p. 238, 1870.

Turtur tigrina, Rchb., Columb., p. 62, pl. 246, figs. 1361-62, ca. 1861; Scl., Proc. Zool. Soc., 1863, p. 221 ; Wall, Proc. Zool. Soc., 1863, p. 486 ; id., Ibis, 1865, p. 391 ; Walden, Trans. Zool. Soc., vol. viii, p. 85, 1872 ; id., Ibis, 1872, p. 381 ; Ball, Stray Feathers, 1873, p. 80 ; Hume, t. c., p. 461 ; Schleg., M. P.-B. Col., p. 127, 1873; Hume, Nests and Eggs, p. 506, 1873 ; Hume, Stray. Feathers, 1874, p. 269 ; id., t. c., p. 481 ; Blanford \& Walden, Journ. As. Soc., Bengal, vol. xliv, extra No.; p. 145, 1875 ; Brüggem., Abh. Ver., Brem., V, p., 1876 ; Armstrong, Stray Feathers, 1876, p. 337 ; Oates, t. c., 1877, p. 164.

Spilopelia tigrina, Sund., Meth. Nat. Av. Disp. Tent., p. 100, 1873 ; Salv., Ucc. Born., p. 296, 1874; ; id., Ann. Mus. Civ. Gen.

a. g. Upper Burma, 14th and 21st January 1868, 28th July, and 7th October 1868.

h. $i$. Ava, 4th October 1868.

j. Yaylaymaw, 5th January 1875.

k. Katha, 19th January 1868.

2. r. Bhamô, February and September 1868 .

s. Tapeng, Ist March 1868.

t. v. Ponsee, 14th, 15th, and 16th March 1868.

w. Momien, Yunnan, 5th June 1868.

Very common along the Irawady to Bhamô, less so on the Kakhyen hills, but very plentiful in the Sanda valley. I did not observe a single dove in the treeless Nantin valley, but a few are found at Momien, in the gardens inside the city and in those attached to the Chinese monasteries outside the walls. Blyth has clearly indicated the differences which exist between this species and $T$. suratensis and T. chinensis. "It wants the pale vinaceous spots on the scapularies and wings of $T$. suratensis, whilst it retains the black mesial streaks which are wanting in $T$. chinensis. There is much less ash on the wings than in T. suratensis, but it is of the same size as the latter, or much smaller than $T$. chinensis, Scop., which last has also deep ash-coloured lower tail-coverts." Many of my specimens, however, are quite as large as two specimens of $T$. chinensis in the Indian Museum. The average of 21 measurements of the wings, tarsi, \&c., of T. tigrina are as follows :-

Wing $6^{\prime \prime}$; tail $6^{\prime \prime}$; tarsus $0^{\prime \prime} \cdot 83$; gape $0^{\prime \prime} \cdot 83$.

\section{Turtur meena, Sykes.}

Columba meena, Sykes, Proc. Zool. Soc., 1832, p. 14 \%.

Turtur meena, Bonap. Consp., G. Av., t. ii, p. 60, 1857 ; Jerdon, B. Ind., vol. iii, p. 467, 1864; Godwin-Austen, Journ. As. Soc., Bengal, vol. xxxix, p. 272, 1870; Hume, Nests and Eggs, 
Ind. B., p. 501, 1873; Stray Feathers, 1874, p. 481; id., .. c., 1875, p. 163; Blyth \& Walden, Journ. As. Soc., Bengal, vol. xliv, extra No., p. 146, 1875; Hume, Stray Feathers, 1877, p. 40.

Turtur rupicolus, Gray, Handl., vol ii, p. 238, 1870.

a. ㅇ Katha, 19th January 1868.

b. \& Tsitkaw, 9th February 1875 .

c. $d$. t Ponsee, 11th March 1868.

\section{TuRTUR RISORIUS, Linn.}

La tourterelle à collier, Briss. Orn., t. i, p. 95, 1760.

Columba risoria, Linn., Syst. Nat., vol. i, p. 285, 1766 ; Temm., Hist. Pigeons., t. i, p. 323, 1813 ; Alléon, Rev. Zool., 1865, p. 5.

Collared turtle, Lath., Gen. Syn., vol. ii, pt. 2, p. 648, 1783.

Colombe blonde, Temm., Pigeons, pl. xliv, 1807.

Turtur risorius, Selby, Nat. Hist., Pigeons, pl. xvii, c. 1835 ; Gray, Cat. Gall., \&c., B. Mus., p. 12, 1844; ; Blyth, Cat. B. Mus. As. Soc., Bengal, p. 235, 1849 ; Gray, Cat. Columba, p. 44, 1856 ; Jerdon, B. Ind., vol. ii, p. 481, 1862 ; Brehm, Habesch., p. 222, 1863; Gray, Handl. B, vol. ii, p. 239, 1870 ; Swinhoe, Proc. Zool. Soc., 1871, p. 397; Hume, Stray Feathers, 1873, p. 218; Adam., t.c., p. 390 ; Ball, Stray Feathers, 1974, p. 425; Blyth \& Walden, Journ. As. Soc., Bengal, vol. xliv, extra No., p. 146, 1875 ; Hume, Nests and Eggs, Ind. B., p. 506, 1873 ; id., Stray Feathers, 1875, p. 165 ; Brooks, t. c., p. 256 ; Blanford, East. Pers., vol. ii, p. 270, 1876 ; Taczan., Bull. Soc. Zool., France, t. i, p. 241, 1876 ; Butler, Stray Feathers, 1876, p. 3 ; Fairbank, t. c., p. 262 ; l. e., 1817, 409.

Turtur douraca, Hodgs., in Gray's Zool. Misc., p. 85, 1844; Schleg., Mus. P.-B. Columba, p. 123, 1873.

Turtur ridens, Brehm, Naum., 1856, p. 286.

Peristera risorea, Brehm, Vogelf., p. 257, 1856.

Streptopelia risorea, Bonap. Consp., vol. ii, p. 65, 1857 ; Reichenb., vollstdt., die Nat. Tauben, pp. 74, 175, taf. clii, fig. 1365, 1862 .

a. Upper defile, Irawady, September 1868.

I shot the bird about forty miles below Bhamô. The colour generally is darker and more vivid than in Indian specimens of the species, and the collar is larger and more crescentic than in ordinary T. risorius, and if Jerdon's measurements are founded on fresh specimens this bird is decidedly larger. He gives 13 inches as the extreme length, but my specimen measures 14 inches, its wing 7 inches, and its tail 6.

\section{TURTur orientaits, Latham.}

La tourterelle brune de la Chine, Sonn., Voy. Ind. Orient., t. ii, p. 177, 1782.

Columba orientalis, Lath., Ind. Orn., vol. ii, p. 606, 1790.

Columba rupicola, Pall., Zoogr. Ross. Asiat., vol. i, p. 566, 1811.

Columba pulchrata, Hodgs., in Gray's Zool. Misc., p. 85, 1831.

Columba meena, Sykes, Proc. Zool. Soc., 1832, p. 149.

Columba agricola, Tickell, Journ. As. Soc., Bengal, vol. î, p. 581, 1833.

Columba gelastes, Temm., Nouv. Rec., Pl. Col., pl. 550, 1838; Temm. \& Knip, Hist. Nat.,

Pigeons, t. ii, pl. xxvii ; Middend., Reis. Sibir., p. 189, 1851. 
Columba ferrago, Eversm., Add. ad Zoogr. Ross. As., vol. iii, p. 17, 1842.

Turtur meena, Gray, Gen. B., vol. ii, p. 472, 1844; Bonap. Consp., t. ii, p. 60, 1854; Jerdon, B. Ind., vol. iii, p. 476, 1864; Blyth \& Walden, Journ. As. Soc., Bengal, vol. xliv, extra No., p. 14.6, 1875 ; Hume, Stray Feathers, 1875, p. 165.

Turtur orientalis, Blyth, Cat. B. Mus. As. Soc., Bengal, p. 236, 1849 ; Swinhoe, Ibis, 1860, p. 63; Schleg., Mus. P.-B. Columba, p. 118, 1873; Dresser, B. Eur., pt. lv, 1876.

Columba (Turtur) gelastes, Temm. \& Schleg., Faun. Japon., p. 100, pl. 1x, B. 1854.

Turtur rupicola, Bonap. Coup d'œil sur l'ordre des Pigeons, p. 29, 1855; Gray, List Spec. B., vol, iv, Columba, p. 41, 1856 ; id., Handl. B., vol. ii, p. 238, 1870; Swinhoe, Proc. Zool. Soc., 1871, p. 397 ; Holdsw., Proc. Zool. Soc., 1872, p. 467.

C'olumba.(Viticollis) major, Temm., fide Bonap. Consp., t. ii, p. 60, 1850.

Columba (Vitticollis) minor, Temm., fide Bonap. ut supra, 1857.

Columba (Peristera) turtur, L. var. gelastes, Schrenck, Reis. Amurl., p. 389, 1859.

Turtur viticollis, Hume, in Henderson's Lahore to Yarkand, p. 274, 187.3.

$$
\begin{aligned}
& \text { a. t Katha, 20th January } 1868 . \\
& \text { b. Tsitkaw, 6th February } 1875 . \\
& \text { c. d. Ponsee, April } 1878 .
\end{aligned}
$$

I obtained this species first at Katha and afterwards at Tsitkaw, where it is numerous, and also at Ponsee. It differs from T. meena in several particulars; 1 st, the anterior half of the body has not the rufescent tinge of $T$. meena, which is most marked on the occiput, hind neck, and upper back of that bird; 2 nd, the rufous margins of the wing feathers are not so intense or broad as in T. meena; 3rd, the abdomen is vinaceous-brown, the same as on the lower half of the breast, and about the vent is bluish-ashy; $4 t h$, the sides of the body, under the wing, are more uniformly bluish-ashy than in the $T$. meena, and the under tail-coverts are slightly darker. The nape, till on a line with the collar, is rufescent vinaceous, and the neck spot, instead of being abruptly defined, as in T. meena, has a bluish-ashy tint on all its sides, except the upper one, and it is altogether longer. The back is brownish, marked with slightly vinous rufescent, and the feathers are very faintly margined with rufescent brownish; the lower back and rump deep bluish-grey, the feathers very faintly washed with rufescent at their tips. Under surface vinaceous-brown, deepest on the breast.

\section{Genus Chalcорнатs, Gould.}

\section{Chalcophaps indica, Linn.}

The Green-winged Dove, Edwards, Birds, vol. i, pl. xiv, 1743.

Columba indica, Linn., Syst. Nat., i, p. 299, 1766, ex Edwards.

Touterelle de Java, Montb., Pl. Enl., t. iii, pl. 177.

Columba javanensis, Müll., Syst. Nat. Suppl., p. 133, 1776.

İe Pigeon vert à tête grise d’ Antigue ou de l’isle Panay, Sonn., Voy. N. Guin., p. 112, pl. Ixvi, 1776.

Columba pileata, Scop., Del. Flor. et Faun. Insubr., t. ii, p. 94, 1786, ex Sonn.

Coluneba albicapilla, Gm., Syst. Nat., vol. i, p. 775, 1788, ex Sonn.

Columba javanica, Gm., Syst. Nat., vol. i, p. 781, 1788; Horsf., Trans. Linn. Soc., vol. xiii, p. 183, 1821 ; Raffl., t.c., p. 317, 1822.

Columba griseocapillata, Bonn. et Vieill., Enc. Méth., p. 238, 1823, ex Sonn. 
Columba superciliaris, Wagler, Syst. Av. Columba, p. 256, 1827, ex Edwards.

Monornis perpulchra, Hodgs., in Gray's Zool. Misc., p. 85, 1844.

Chalcophaps indica, Gray, List, Galline, \&c., B. M., p. 18, 1844; id., Gen. B., vol, ii, p. 477, 1846; Bonap. Consp., t. ii, p. 91, 1854; Gray, Cat. Columba, B. M., p. 59, 1856 ; Jerdon, B. Ind., vol. iii, p. 484, 1864; Pelz., Reis. Nov. Vög., p. 109, 1805 ; Schl., N. T. D., t. iii, p. 265, 1866 ; Gray, Handl. B., vol. ii, p. 244, 1870 ; Swinhoe, Proc. Zool. Soc., ]871, p. 397 ; Walden, Trans. Zool. Soc., vol. viii, p. 86, 1872 ; Schl., Mus. P.-B. Columbæ, p. 145, 1873; Ball, Stray Feathers, 1873, p. 80 ; Hume, Stray Feathers, 1874, pp. 269, 481; Nests and Eggs, Ind. B., p. 509, 1873; Ball, l. c., p. 425; Salvad., Uce. Born, p. 299, 1874; Hume, Stray Feathers, 1875 , p. 165 ; id., Blyth \& Walden, Journ. As. Soc., Bengal, vol. xliv, ex. No., p. 147, 1875; Hume, Stray Feathers, 1876,p. 404; Tweedale, Ibis, 1877, p. 322.

Peristera bornensis, Müller, MS. in Mus. Ludg.

Chalcophaps bornensis, Bonap., C. R., xliii, pp. 947, 949, 1856; Wall., Ibis, 1868, p. 393.

Chalcophaps javanica, Bonap., C. R., xlii, p. 949, 1856.

Chalcophaps javanensis, Gray, Handl. B., vol. ii, p. 245, 1870.

Chalcophaps formosana, Swinhoe, Ibis, 1865, p. 357.

Chalcophaps pileata, Gray, Handl., vol. ii, p. 245, 1870.

a. ‡ Katha, 19th January 1868.

\section{Order GALIIN 2 .}

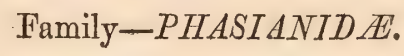

Genus Pavo, Linn.

183. Pato muticus, Linn.

Le Paon de Japon, Briss. Orn., t. i, p. 289, 1760.

Le Spicifere, Buff., Hist. Nat. Ois., t. ii, p. 366, 1771.

Pavo muticus, Linn., Syst. Nat., vol. i, p. 268, 1766 ; Vig., Mem. Raffles, p. 676, 1830 ; Gray,

Gen. B., vol. iii, p. 494, 1845 ; Blyth, Cat. B. Mus. As. Soc., Bengal, p. 239, 1849 ; Sclater,

Proc. Zool. Soc., 1863, p. 123 ; Gray, List Gall., B. M. Coll., p. 22, 1867 ; id., Handl. B., vol. ii, p. 256, 1870 ; Elliot, Monogr. Phas, vol. i, pl. v, 1872.

Pavo spicifer, Shaw \& Nodd., Nat. Misc., pl, 641, 1804; Gray, List B. Brit. Mus., vol. iii, p. 22, 1844 .

Pavo aldrovandi, Wils. Ill. Zool., pls. xiv, xv, 1831.

Pavo spiciferus, Vieill., Gall. Ois., t. x, p. 14, pl. 202, 1834.

spiciferus muticus, Bonap., C. R., xlii, p. 878, 1856.

a. 屯 Upper defile of Irawady, February 1868 .

This peafowl is common in Upper Burma, wherever there is forest and water. It is very partial to the sides of streams, and in early morning, and evening, its loud call is a familiar sound on the banks of the Irawady for many miles below and above Bhamô. It is found along the wooded banks of the Tapeng as far as the base of the hills.

These birds spend the greater part of the day in the trees, but, at early morning and in the evening, betake themselves to the river banks and to open spots in the 
forest to feed. In the neighbourhood of Bhamô they may be found at these times on some strip of well-watered paddy land, a little way into the forest to the south-east of the town. Before sun-rise, I have observed them on the high trees, feathering themselves and waking the forest with their call. They are very wary; and when disturbed, they do not, as a rule, fly far, but make for some lofty tree close at hand.

\section{Genus Gallus, Linn.}

\section{Gatlus ferrugineus, Gmelin.}

Le grand Caille de la Chine, Sonn., Voy. Ind., t. ii, p. 171, 1782.

Hackled partridge, Lath., Syn., vol. ii, pt. 2, p. 766, pl. lxvi, 1783.

T'etrao ferrugineus, Gm., Syst. Nat., vol. i, p. 761, 1788.

Phasianus gallus, Gm., Syst. Nat., vol. i, p. 737, 1788.

Perdix ferruginea, Lath., Ind. Orn., vol. ii, p. 651, 1790.

Gallus bankiva, Temm., Pigeons et Gallin., t. iii, p. 654, 1815; Jerdon \& Selb., Ill. Orn., pl. 139, 1830 ; Less., Tr. d’Orn., p. 491, 1831 ; Hodgs., in Gray's Zool. Misc., p. 85, 1844; Cass., U. S. Expl. Exp. Orn., p. 289, 1858 ; Scl., Proc. Zool. Soc., 1863, p. 122; Wallace, t. c., p. 486 .

Gallus ferrugineus, Blyth, Ann. Nat. Hist. (2), vol. i, p. 455, 1848 ; id., Cat. B. Mus. As. Soc., Bengal, p. 242, 1849 ; Bonap., C. R., xlii, p. 879, 1856 ; Adams., Proc. Zool. Soc., 1859, p. 185 ; Irby, Ibis, 1861, p. 234; Jerdon, B. Ind., vol. iii, p. 536, 1864; Gray, List, B. Brit. Mus., p. 37, 1867 ; Blyth, Ibis, 1867, p. 154; Beavan, Ibis, 1868, p. 381 ; Gray, Handl. B., vol. ii, p. 261, 1870; Godwin-Austen, Journ. As. 'Soc., Bengal, vol. xxxix, p. 272, 1870; Hume, Nests and Eggs, Ind. B., p. 528, 1873; Ball, Stray Feathers, 1874, p. 426; Hume, t. c., p. 482 ; Elliot, Monogr. Phasianida, vol. ii, pl. xxxii ; Hume, Stray Feathers, 1875, p. 171 ; Blyth \& Walden, Journ. As. Soc., Bengal, vol. xliv, extra No., p. 148, 1875; Hume, Stray Feathers, 1875, p. 171; Armstrong, op. cit., p. 876, p. 338; Godwin-Austen, Journ. As. Soc., vol. xlv, 1876, p. 83; Dresser, Ibis, 1876, p. 324; W. Ramsay, Ibis, 1877, p. 468; Hume, Stray Feathers, 1877, p. 44; Oates, op. cit., p. 164. Gallus (Bankiva) domesticus, Severtzoff, Jevotn. Turkest., 1873, p. 68.

$$
\begin{aligned}
& \text { a.d. t 우 Bhamô, February } 1868 . \\
& \text { e. t Ponsee, 13th March } 1868 .
\end{aligned}
$$

As stated by Blyth, the Indian birds are slightly paler than those from Assam and the countries to the south and east, but in no other respect do they appear to differ from one another. This species extends to the east of the Kakhyen hills, and is very plentiful in Upper Burma. On one occasion near Bhamô I saw a solitary cock with more than one hen and a number of young birds.

\section{Genus Euplocamus, Temminck.}

\section{Euplocamus lineatus, Vigors.}

Phasianus leucomelanos, Lath., Ind. Orn., vol. ii, p. 633, 1790.

Monaulus melanion, Vieill., Tabl. Enc. Méth. Orn., t. i, p. 66, 1820.

Lophophorus cuvieri, Temm., Pl. Col., t. v, pl. i (1820 hybrid). 
Phasianus lineatus, Vig., Proc. Zool. Soc., 1831, p. 24 (ex Lath. MS.); Beavan, Ibis, 1868, p. 381 .

Genneus lineatus, Wagl., Isis, 1832, v. 1228.

Phasianus fasciatus, Mc'Clell., Cal. Journ., Nat. Hist., vol. ii, p. 146, pl. iii, 1832.

Phasianus reynaudii, Less., Voy. Bélang. Zool., p. 276, pls. viii, ix, 1834.

Lophophorus leucomelas, Gray, List Gen. B., p. 60, 1840 (hybrid).

Euplocamus lineatus, Gray, List Gen. B., p. 78, 1841 ; Blyth, Cat. B. Mus. As. Soc., Bengal, p. 244, 1849 ; Sclater, Proc. Zool. Soc., 1863, p. 120 ; Sclater, in Wolf's Zool. Sketches, ii ser., p. 38, 1867 ; Gray, List B. Brit. Mus. Gall., p. 34, 1867 ; id., Handl. B., vol. ii, p. 260, 1870 ; Elliot, Monogr. Phas., vol. ii, pl. xxiii, 1872; Gould, B. Asia, pt. xxviii, 1875 ; Hume, Stray Feathers, 1875, pp. 16, 165; Oates, Stray Feathers, 1877, p. 164.

Alectrophasis leucomelanos, Gray, List Gen. B., p. 78, 1841 (hybrid).

Gallophasis lineatus, Gray, Gen. B., vol. iii, p. 498, 1845.

Gallophasis fasciatus, id., l. c.

Grammatoptilus lineatus, Bonap., C. R., xlii, p. 879, 1856.

Euplocamus cuvieri, Oates, Stray Feathers, 1875, p. 342.

a. ᄒ Mengoon, Upper Burma, February 1868.

This bird was shot by one of our party on the right bank of the Irawady, a short way above Mandalay.

186. Euplocamus andersoni, Elliot. PI. LIII.

Euplocamus andersoni, Elliot, Proc. Zool. Soc., 1874, p. 137 ; id., Monogr., Phasianida, ii, pl. xxii, 1872.

Nycthemerus andersoni, Blyth \& Walden, Journ. As. Soc., Bengal, vol. xliv, ex. No., p. 149, 1875.

a. $\delta$ Kakhyen hills to the east of Bhamô.

b. 0 , , , ,

I first became acquainted with this bird through its tail feathers which I rem ceived as a present from a hill chief. They were sufficient to indicate the existence of a hitherto unknown species of silver pheasant which I mentioned in my notes at the time under a distinct name. However I soon afterwards was fortunate enough to obtain a living specimen which was kept alive in Calcutta for some time until it was in full plumage. It was then figured, and the drawing was submitted to Mr. Elliott, who confirmed the opinion I had formed regarding the marked distinctness of the bird from the common lineated pheasant of Burma and its affinity to the silver pheasant of China. I placed the drawing at his disposal, and he described the bird in the Proceedings of the Zoological Society.

On the second expedition of 1875 I procured another male somewhat younger than the type, but agreeing with it in all its essential details, and this specimen is now in the British Museum.

Again, since then, I have succeeded, through the kind assistance of Captain Cooke, Assistant Political Resident, Upper Burma, in obtaining another male which has now been alive in the Zoological Garden, Calcutta, for more than a year. It agrees exactly with the type. I have never succeded in obtaining a female. 
Dr. Sclater' has recently suggested that the female of this species is the bird which Mr. Gould has reproduced in his Birds of Asia as the female of C.pralatus. Mr. Gould's figure is founded on a drawing of a female pheasant which was obtained by Crawfurd on his mission to Ava, and on which drawing Dr. J. E. Gray established the species $P$. crawfurdi described in Griffith's Cuvier's Animal Kingdom. ${ }^{2}$ The evidence, however, of the identity of $P$. crawfurdi with $E$. andersoni is not so complete as to entitle us to accept the name $P$. crawfurdi which is applicable only to a drawing.

\section{Genus Thaumalea, Wagler.}

187. Thaumalea amherstize, Leadb.

Phasianus amherstice, Leadb., Trans. Linn. Soc., vol. xvi, p. 129, Pl. 15, 1829 ; Temm., Pl. Col., 82nd. livr., 1830.

Thaumalea amherstice, Wagl., Isis, 1832, p. 1228 ; Gray, List B., Brit. Mus., vol. iii, p. 24, 1844; Blyth, Cat. B. Mus. As. Soc., Bengal, p. 246, 1849 ; Bonap., C. R., xlii, p. 879, 1856; Sclater; Proc. Zool. Soc., 1863, p. 117 ; Swinhoe, Proc. Zool. Soc., 1871, p. 307 ; Elliot, Monogr. Phas., ii, pl. xiv, 1872 ; Gould, B. Asia, pt. xviii, 1866.

Epomia amherstii, Hodgs., in Gray's Zool. Misc., p. 85, 1844.

Chrysolophus anherstia, Gray, List Gall., p. 29, 1867 ; id., Handl. B., vol. ii, p. 258, 1870.

$$
\begin{aligned}
& \text { a. t Muangla, May } 1868 . \\
& \text { b. 오 Momien, June } 1868 .
\end{aligned}
$$

This splendid bird occurs on the hills between Sanda and Momien, and in the country to the north and west. The tail feathers are largely used as plumes for the war hats of the Panthay Officers, and it is a well known bird to the hillmen generally. I obtained the cock at Muangla, and the hen at Momien, and since the expedition of 1868 a living male was sent down to Bhamô, from whence it was forwarded to the Chief Commissioner, the Hon'ble A. Eden.

\section{Genus Phasiands, Linn.}

188. Phasianus sladeni, Andr. Plate LII.

Phasianus sladeni, M.S. Anderson, Elliot, Proc. Zool. Soc., June, 1870, pp. 404, 408; Anderson, op. cit., 1871, p. 214 (pars).

$$
\text { a. \& b. t c. \& d. \& Momien, June 1868. (5,000 ft.). }
$$

The forehead, head, nape, chin, and throat deep metallic green; the sides and lower part of the neck and the throat intense metallic purple; ear-coverts brownish-black, with faint green reflexions; the region of the eye and the sides of the face naked, reddish scarlet; the shafts of the interscapulars and dorsal feathers yellowish; all the dorsal feathers black at the base; interscapulars and humerals

\footnotetext{
${ }^{1}$ Proc. Zool. Soc., 1876, p. 274.

${ }^{2}$ l. c., vol. viii, p. 27, 1829.
} 
pale golden-red and lurid red and golden; a triangular black spot at the tips of the feathers, and the margins fringed with black; the upper back reddish-chestnut, obscurely margined with lurid golden with yellowish-red and violet reflexions; the shafts of the feathers white; the breast intense steel-blue, with brilliant green and violet reflexions; the lower breast obscurely spotted with reddish scarlet; the sides of the body pale golden chestnut or reddish-brown, broadly subfasciated and narrowly and distantly lined with black, with lurid golden reflexions; the middle of the abdomen shining bluish-green; the wing-coverts brown and very broadly margined with cinereous, with violet reflexions; the quills brown, banded with fulvous. The specimens were brought to me without their tails.

Above brownish-black, the feathers margined with brownish-yellow; the interscapulars reddish margined with pale brown; the chin and throat white; below greyish-brown; the belly faintly lined with brown; the sides of the abdomen with large dart-shaped brownish-black markings; the quills brown, spotted and banded with blackish-brown and washed with rufous.

Common on the grassy hills around Momien.

I have another hen pheasant from the same locality, but differing from the female of this species in the following particulars, viz., the under parts are tawny, and the breast and sides of the abdomen are only feebly spotted with reddish-brown.

The two males in my possession are alike in every particular.

It appears to be closely allied to $P$. versicolor and $P$. torquatus. It is affined to the former species by its colourless neck, pale tipped rump, and greyish wingcoverts, and deeply coloured breast and belly, but differs from it in having the lower breast obscurely spotted with reddish scarlet, and the sides of its abdomen richly but broadly semifasciated. The rump, breast, interscapulars and sides have a strong resemblance to $P$. torquatus.

It differs from $P$. elegans, with which I was at first disposed to think it as identical, by the dark metallic bluish-green being continued much further down the back of the neck, in the darker colour of the rump, which has less green in it, and in the absence of black and white concentric wavy lines in the centres of the feathers of the wing-coverts, and in this respect it is allied to $P$. shawi and to $P$. insignis.

Family-TETRAONIDA

Genu's Francolinus, Stephens.

189. Francolinus periatus, Gm.

La perdrise porlée de la Chine, Buff., Hist. Nat. des Ois., t. ii, 1772, p. 452.

Pearled partridge, Lath., Syn., vol. ii, 1781, p. 648; Genl. Hist. B., vol. viii, 1823, p. 276.

Tetrao sinensis, Osbeck., Voy. en Chine, 1771, p. 326.

Tetrao perlatus, Gm., Linn. Syst. Nat., vol. i, pt. ii, p. 758, 13th ed., 1788.

Perdix sinensis, Brisson, Ornith., vol. i, 1790, p. 234, pl. xxviiiA, fig. 1.

Perdix perlata, Temm., Pig. and Gall, vol. iii, 1815, p. 326 ; Vieillot, Galerie des Oiseaux, tome ii, 1825, p. 41, tab. cexiii. 
Francolinus perlatus, Stephens, Genl. Zool., vol. xi, pt. ii, 1819, p. 325 ; Swinhoe, ibid., 1860, p. 63 ; id., op. cit., 1861, p. 50 ; 1862, p. 259 ; 1867, p. 406.

Francolinus phayrei, Blyth, Journ. As. Soc., vol. xii, 1843, p. 1011; id., op. cit., vol. xxiv, 1855, p. 480 ; Blyth \& Walden, op. cit., vol. xliv, extra No., 1875, p. 149.

Irancolinus maculatus, Gray, Zool. Mise., 1844, p.2.

Francolinus sinensis, Blyth, Cat. B. Mus. As. Soc., Bengal, 1849, p. 251 ; Swinhoe, Proc. Zool. Soc., 1863, p. 307; op. cit., ]871, p.' 400 ; Ibis, 1870, p. 359; Oates, Stray Feathers, 1877, p. 164; W. Ramsay, Ibis, 1877, p. 468.

Francolinis chinensis, Hume, Nests and Eggs, 1873, p. 539 ; id., Stray Feathers, 1875, p. 171.

a. to Bhamô, and February 1875. partridge.

There can be no doubt regarding the identity of $F$. phayrei with the Chinese

\section{Genus Arboricola, Hodgson.}

\section{Arboricola atrogularis, Blyth.}

Arboricola atrogularis, Blyth, Journ. As. Soc., Bengal, vol. xviii, p. 819, 1849 ; id., Cat. B., Mus. As. Soc., Bengal, p. 253, 1849 ; Jerdon, B. Ind., vol. iii, p. 579, 1864.

Perdix atrogularis, Gray, Handl. B., vol. ii, p. 267, 1871.

Arborophila atrogularis, Hume, Stray Feathers, 1874, p. 449 ; op. cit., 1877, p. 44.

a. t Kakhyen hills, 18th February 1875 .

\section{Genus Bambusicola, Gould.}

\section{Bambusicola fytchir, n. s. Plate LIV.}

Bambusicola fytchii, Anders., Proc. Zool. Soc., 1871, p. 214, pl. xi ; Blyth \& Walden, Journ. As. Soc., Bengal, vol. xliv, 1875, extra No., p. 152 ; Hume, Stray Feathers, 1877, vol. v, p. 493.

Bambusicola hopkinsoni, Godwin-Austen, Journ. As. Soc., Bengal, vol. xliii, pt. ii, 1874, p. 172 ; Hume, Stray Feathers, iii, 1875, p. 399.

$$
\text { a.b. to \& Ponsee, 12th March } 1868 .
$$

This bird occurred on the old rice clearings on the hill sides at Ponsee.

The species extends to the Khasi hills (Shillong), where it was first obtained by Major Godwin-Austen and afterwards by Mr. Cockburn collecting for Mr. Hume.

I have compared the types of $B$. fytchii with the type of $B$. hopkinsoni, and find that the two are specifically identical, as was pointed out by $\mathrm{Mr}$. Hume.

$$
\text { Family-TURNICID AE. }
$$

\section{Genus Turnix, Bonnat.}

\section{TURNIX plumbipes, Hodgson.}

Hemipodius plumbipes, Hodgs., Bengal Sport. Mag., 1837, p. 346.

Turnix atrogularis, Eyton, Proc. Zool. Soc., 1839, p. 107.

Hemipodius taigoor, Eyton, t. c., p. 107.

Turnix taigoor, Gray, Cat. Mamm., \&c., Nepal, Coll. Hodgs., p. 128, 1846. 
Turnix ocellatus, Jerdon, B. Ind., vol. iii, p. 597, 1864; Gould, Anat. Journ. As. Soc., vol. xxxix, 1870 , p. 174 .

Turnix pugnax, Gray, Cat. Gall. Brit. Mus., p. 69, 1867; id., Handl. B., vol. ii, p. 271, 1870.

Turnix plumbipes, Blyth \& Walden, Journ. As. Soc., Bengal, vol. xliv, 1875, extra No., p. 152;

Hume, Nests and Eggs, Ind. B., p. 554, 1873; Hume, Stray Feathers, 1875, p. 178 ; Oates,

Stray Feathers, 1877, p. 164 .

Turnix ocellata, Blanford, Ibis, 1870, p. 470.

a. Muangla, 16th July 1868.

This is the larger Himalayan race which appears to be distinct from T. taigoor, Sykes.

\section{Order GRALLATORES.}

Family-CHARADRIDA.

Genus Edicnemus, Temminck.

193. Edicnemus CRepitans, Temminck.

Le Grand Pluvier, Briss. Orn., t. v, p. 76, 1760 ; Buff., Pl. Enl., t. ix, pl. 919.

Charadrius adicnemus, Linn., Syst. Nat., t. i, p. 255, 1766 ; Wagler, Syst. Av. Charadirus, sp. 1.

Otis adicnemus, Lath., Ind. Orn., vol. ii, p. 661, 1790 ; Yarr., Br. B., vol. ii, p. 380, 1843.

Edicnemus crepitans, Temm., Man. d’Orn., 1815, p. 322 ; Naum., Vög. Deutschl., pl.; Werner, Atlas, pl., 1827; Ménétr., Cat. Rais. Zool. Caucase, p. 54, 1832; Gould, B. Eur., vol. iv, pl. 288, 1837; Nordin. in Demid. Voy. Russ. Mèrid., Bd. iii, p. 230, 1840; Grày, Gen. B., vol. iii, p. 535, 1844; Macgill., Br. B., vol. iv, p. 77, 1852 ; Schl., Vog. Nederl., pls. 209, 210, 1858; Jaub. \& Barth., Lapomm. Rich. Orn., p. 441, 1859 ; Linderm., Vög. Griechenl., p. 132, 1860 ; Jerdon, B. Ind., vol. iii, p. 654, 1863; Schl., Mus. P.-B. Cursores, p. 20, 1865 ; Degl. \& Gerbe, Orn. Eur., Bd. ii, p. 115, 1867 ; Loche, Expl. Sci. Alger. Ois., t. ii, p. 258, 1867; Bettoni, Ucc. Lomb., t. ii, pl. 102, 1868 ; Doderl., Avif. Sicil., p. 349, 1869; Finsch. \& Hartl., Vög. Ostafr., p. 619, 1870 ; Salvad., Faun. Ital. Uce., p. 199, 1871 ; Gray, Handl. B., vol. iii, p. 9, 1871 ; Holdsw., Proc. Zool. Soc., 1872, p. 472 ; Gould, B. Gt. Br., iv, pl. xxxv, 1872; Shelley, B. Egypt, p. 230, 1872 ; Heugl., Orn. N. O. Afr., p. 985, 1873 ; Hume, Stray Feathers, 1873, p. 232; Adam., t. c., p. 395 ; Severtzoff, Turkist. Jevotn., 1872, p. 69 ; Hume, Stray Feathers, 1875, p. 182; Blyth \& Walden, Journ. As. Soc., Bengal, vol. xliv, extra No., p. 152, 1875 ; Butler \& Hume, Stray Feathers, 1876 , p. 14; Dresser, Ibis, 1876, p. 326.

Fedoa odicnemus, Leach, Syst. Cat. Mamm., \&c., B. M., p. 28, 1816.

Edicnemus griseus, Koch., Syst. Baier. Zool., Bd. i, p. 266, 1816.

Edicnemus europous, Vieill., N. Dict. d'Hist. Nat., t. xxiii, p. 230, 1818; Roux, Orn. Prov., pl. 266,1825 .

Edicnemus belloni, Fleming, Brit. An., p. 114, 1828.

Edicnemus desertorum, Brehm, Vogelf., p. 280, 1855.

Edicnemis arenarius, Brehm, Vogelf., p. 280, 1855.

Edicnemus desertorum, Brehm, t. c., p. $280,1855$.

Edicnemus affinis, Brehm, Reis. Habesch., pp. 400, 441, 1863.

Qidicnemus indicus, Salvad., Atti Soc. Ital. Sci. Milano, t. viii, p. 370, 1866 ; Ball, Stray Feathers, 1874, p. 430 ; Hume, Nests and Eggs, Ind. B., p. 581, 1873 ; Blanford, East. Persia, p. 288, 1876. a. Upper Thigyain, Upper Burma, 18th January 1868.

Not uncommon in Upper Burma. 


\section{Genus Lobivaneluds, Strickland.}

194. Lobivanelius atrondchalis, Blyth.

Sarcogramma atronuchalis, Blyth, Journ. As. Soc., Bengal, vol. xxxi, p. 345, note; Blyth \& Walden, op. cit., vol. xliv, ex. No., p. 152, 1875.

Chettusia atronuchalis, Gray, Handl. B., vol. iii, p. 11, 1871.

Lobivanellus atronuchalis, Hume, Stray Feathers, 1875, p. 181.

a. Tapeng river, 27th February 1868.

b. Bhamô, 19th February 1868.

This differs from the Indian race in the greater extent of the black on the sides and back of the neck, extending from the latter nearly on to the back, and having a well marked white band separating it from the olive-brown of the back, which is glossed with green and very faint purple. The white band behind the eye is, of course, enclosed by the black of the neck. This species is common at Bhamô and in the Sanda valley.

\section{Genus Hoplopterus, Bonaparte.}

\section{Hoplopterus ventratis, Wagler.}

Char:adrius ventratis, Wagler, Syst. Av. Charadrius, sp., 1829.

Charadrius duvauceli, Less., Compl. Buff. Ois., t. iii, p. 408, 1837.

Phitomachus ventralis, vel. spinosus, Hodgs., in Gray's Zool. Misc., p. 86, 1844.

Hoplopterus spinosus, Gray, Gen. B., vol. iii, p. 542, 1847.

Hoplopterus ventralis, Gray, List, Gralle, \&c., B., M. p. 64 (1844); id., Cat. Mamm., \&c., Nepal, Hodgs., p. 132, 1846 ; Blyth, Cat. B., Mus. As. Soc., Bengal, p. 260, 1849 ; Bonap., C. R., xiii, p. 418, 1856 ; Jerdon, B. Ind., vol. iii, p. 650, 1864; Gray, Handl. B., vol. iii, p. 12, 1871; Swinhoe, Proc. Zool. Soc., 1871, p. 403 ; Hume, Stray Feathers, 1874, p. 482; 1875, p. 181 ; id., Nests and Eggs, Ind. B., p. 578, 1873 ; Blyth \& Walden, Journ. As. Soc., Bengal, vol. xliv, ex. No., p. 153, 1875; Ball, Stray Feathers, 1876, p. 234; Hume, loc. cit., 1877, p. 46.

Tarillus ventralis, Schl., M. P.-B. Cursores, p. 61, 1865.

a. \& Tsitkaw, 2nd February 1875.

b. Muangla, 21st May 1868.

\section{Genus Cha radrius, Linn.}

196. Charadrius fulvus, Gmelin.

Fulvous plover, Lath., Gen. Syn., vol. iii, p. 211, 1785.

Charadrius fulvus, Gm., Syst. Nat., i, p. 687, 1788, ex Lath.; Wagler, Syst. Av. Charadrius, sp. 37, 1827 ; Gray, List, Gallina, p. 67, 1844; id., B. Trop. Isl. Pacif. Ocean, p. 47, 1858 ; Schl., Mus. P.-B., Cursores, p. 50, 1865 ; Fritsch. \& Hartl., Faun. Central Polyn., p. 188, 1867 ; Sharpe \& Dresser, B. Eur., pt. ix, 1871 ; Salvad., Faun. Ital. Uec., p. 204, 1871; Gray, Handl. B., vol. iii, p. 14, 1871; Finsch., Journ. für Ornith., 1872, p. 168; 1874, p. 193 ; Butler, B., N. Zeal., p. 212, 1873 ; Hume, Stray Feathers, 1873, p. 228 ; 1874, pp. 287, 
482 ; Ball, op. cit., p. 429 ; Hume, op. cit., 1875, p. 179 ; Salvad., Ucc. Born., p. 314, 1874; Sharpe, Voy. Ereb. \& Terr. Aves, App. p. 29, 1875; Walden, Tr. Zool. Soc., vol. ix, p. 226, 1875 ; Blyth \& Walden, Journ. As. Soc., Bengal, vol. xliv, ex. No., p. 153, 1875 ; Tacz., Bull. Soc. Zool., France, t. i, p. 247, 1876; Butler \& Hume, Stray Feathers, 1876, p. 11 ; Fairbank, l. c., p. 262 ; Armstrong, l. c., p. 339 ; Hume, l. c., pp. 433, 459, 463 ; Cockburn, l. c.s p. 54, vol. ii ; Sharpe, Ibis, 1876, p. 51 ; Layard, l. cit., p. 393 ; Tweedale, Ibis, 1877, p. 322; W. Ramsay, l. c., p. 468 ; Butler, Stray Feathers, 1877, p. 232 ; Ball, l. c., p. 419 .

Charadrius pluvialis (nec. L.), Pall., Zoogr. Rosso-Asiat., p. 141, 1811 ; Horsf., Tr. Linn. Soc., vol. xiii, p. 187, 1822; Middend., Sibir. Reise., p. 210, 1851 ; Radde, Reise. Sibir., p. 322, 1863 ; Pelz., Reise. Novara. Vög., p. 115, 1865.

Charadrius xanthocheilus, Wagler, Syst. Av. Charadrius, sp. 36, 1827; Gould, B., Austr., vol. vi, pl. xiii, 1848 ; Reichenb., Vög. Neuholl., p. 208, 1850 ; id., Handl. Gralla, pl. 100, fig. 693, 1851 ; Cass., U. S. Expl. Exp., p. 325, 1858.

Charadrius taitensis, Less., Man. d’Orn., t. ii, p. 321, 1828.

Charadrius virginianus, Jard. \& Selby, Ill. Orn., vol. ii, pl. Ixxxv, c. 1830; Gray, Voy. Erebus \& Terror, Birds, p. 11, 1846.

Eudromias xanthocheilus, Gray, List Gralle, \&c., B. M., p. 68, 1844.

Charadrius glaucopis, Forster, Descr. Anim., p. 176, 1844.

Charadrius virginicus, Blyth, Cat. Birds, Mus. As. Soc., Bengal, p. 262, 1849 (nec. Borkh.); Swinhoe, Ibis, 1861, p. 51 .

Charadrius (Pluvialis) orientalis, Schl., Faun. Jap., p. 106, pl. 1xii, 1850.

Pluviatis longipes, Bonap., C. R., x, 1856, p. 407.

Pluvialis xanthocheilus, Bonap., t.c.

Pluvialis taitensis, Bonap., $t$. $c$.

Pluvialis fulvus, Bonap., t.c.

Charadrius (Arnatus) longipes, Schl., Vog. Ned, p. 411, 1858.

Charadrius longipes, Blasius, Naum., 1858, p. 316 ; Gray, B. Trop. Isl., p. 47, 1858 ; Blas. \& Bald., Nachtr. Naum. Vög. Deutschl., t. xiii, p. 225, 1860 ; Jerdon, B. Ind., vol. iii, p. 636 ; Wright, Ibis, 1864, p. 1411 ; Gray, Handl. B., iii, p. 14, 1871.

Charadrius auratus, Schrenk, Reis. Amurl. Vög., p. 416, 1860.

Charadrius orientalis, Gould, B., Austr., vol. ii, p. 225, 1865.

a. + t Tapeng, 28th February 1868 .

b. c. d.e. Tsitkaw, 3rd February 1875 .

Common in Upper Burma and the Shan States.

\section{Genus Egralitis, Boie.}

\section{Egralitis dubia, Scop.}

Petit pluvier à collier de l’isle de Luçon, Sonn., Voy. Nouv. Guin., p. 84, pl. xlvi, p. 46, 1876.

Le petit pluvier à collier, Buff., Hist. Nat. Ois., t. viii, p. 90, 1781.

Charadrius dubius, Scop., Del. Flor. et Faune Insubr., p. 93, 1786.

Charadrius, sp. nov., Beseke, Schr. Berl. Naturf. Gesellsch., Bd. vii, p. 463, 1787.

Charadrins alexandrinus, var. d., Gm., Syst. Nat., t. i, p. 684, 1788.

Charadrius curonicus, Gm., Syst. Nat., t. i, p. 692, 1788; Gray, Gen. B., vol. iii, p. 544, 1847 ; Jaub. et Barth., Lap. Rich. Orn., p. 447, 1850 ; Fritsch., Vög. Eur., tab. xxxiii, figs. 3, 4, 1808 ; Schrenk, Reis. Amurl., p. 412, 1E60; Radde, Sibir. Reis., p. 325, 1803 ; Loche, Expl. Sci. Alger. Ois., t. ii, p. 268, 1867.

Charadrius philippinus, Lath., Ind. Orn., vol. ii, p. 745, 1790; Schl., Mus. P.-B. Cursores, p. 28, 1865. 
Charadrius minor, Wolf. \& Meyer, Vög. Deutschl., heft 15, 1805; Roux, Orn. Prov., pl. 276, 1825; Werner, Atlas, pl., 1827 ; Naum., Vög. Deutschl., t. vii, p. 225, taf. 177, 1834; Gould, B. Eur., vol. iv, pl. 297, 1837; Yarrell, Hist. Br. B., vol. ii, p. 409, 1843 ; Kjärb., Orn. Dan., pl. xxx, fig. 1, 1851 ; Macgill., Br. B., iv, p. 128, 1852 ; Schl., Vög. Nederl., pl. 218, 1854; Sundev., Sv. F'ogl., pl. xxxvii, fig. 4, 1858.

Charadrius fluviatilis, Bechst., Gemein. Nat. Deutschl., Bd. iv, p. 422, 1809; Heugl., Orn. N. O. Afr., Bd. ii, p. 1029, 1871.

Charadrius hiaticula, Pall., Zoogr. Rosso.-Asiat., vol. ii, p. 144, 1811.

Charadrius minutus, Pall., t. c., p. 145, 1811.

Charadrins pusillus, Horsf., Tr. Linn. Soc., vol. xiii, p. 187, 1822.

Asgialitis minor, Boie, Isis, 1822, p. 558; Brehm, Vög. Deutschl., p. 549, 1831; Shelley, B. Egypt, p. 242, 1878 ; Gould, B. Gt. Br., iv, pl, xlii, 1873 ; Dybowski, Journ. für Ornith., 1868, p. 337.

Agialitis fluvialitis, Brehm, Vög. Deutschl., p. 549, 1831; Hume, Stray Feathers, 1873, p. 230; Adam., t. c., p. 394; Hume, Stray Feathers, 1874, pp. 289, 482 ; id., Nests and Eggs, Ind. B., p. 572, 1873; Irby, Orn. Gibr., p. 162, 1875 ; Scully, Stray Feathers, 1876, p. 185; Ball, t. c., p. 236 ; Tacz., Bull. Soc. Zool., France, t. i, p. 248, 1876.

Charadrius hiaticuloides, Frankl., Proc. Zool. Soc., 1831, p. 125.

Charadrius zonatus, Swains., B. W. Afr., vol. ii, p. 235, pl. xxv, 1837.

Aigialitis curonicus, Keys. \& Blas., Wirb. Eur., p. lxxi, 1840 ; Doderl., Avif. Sicil., p. 176, 1869 ; Salvad., Faun. Ital. Ucc., p. 205, 1871 ; Ball, Stray Feathers, 1874, p. 429 ; Blyth \& Walden, Journ. As. Soc., Bengal, vol. xliv, 1875, ex. No., p. 154; Butler, Stray Feathers, 1876, p. 12 ; Armstrong, t.c., p. 340 ; Dresser, B. Eur., pt. lii, 1876.

Hiaticula curonica, Gray, Cat. Gralla, \&c., p. 68, 1844; Licht., Nomencl. Av., p. 94, 1854.

Hiaticula philippina, Blyth, Cat. B. Mus. As. Soc., Bengal, p. 264, 1849.

Charadrius gracilis, Brehm, Naum., 1855, p. 288.

Charadrius pygmaus, Brehm, Naum., 1855, p. 289.

Egialitis pygmaa, Brehm, Vogelf., p. 282, 1855.

Agialitis gracilis, Brehm, t.c., p. 282, 1855.

Aigialitis zonarius, Hartl., Orn. W. Afr., p. 216, 1857.

Egialitis pusillus, Swinhoe, Ibis, 1860, p. 63.

Egialitis minutus, Jerdon, B. Ind., vol. ii, p. 641, 1863.

Pluviatilis fluviatilis, Droste, Vogeler.-Bork., p. 153, 1869.

Agialitis intermedius, Swinhoe, Ibis, 1870, p. 361.

Agialztrs dubia, Swinhoe, Proc. Zool. Soc., 1871, p. 414; Walden, Tr. Zool. Soc., vol. viii, p. 89, 1872 ; Holdsw., Proc. Zool. Soc., 1872, p. 471 ; Salvad., Ucc. Born., p. 316, 1874; Walden, Tr. Zool. Soc., vol. ix, p. 227, 1875; Blyth \& Walden, Journ. As. Soc., Bengal, vol, xliv, 1875, ex. No., p. 153, 1875 .

Agialitis philippinus, Hume, Stray Feathers, 1875, p. 180.

AEialitis minutus, Legge, Stray Feathers, 1875, p. 372.

a. b. Bhamô, 28th January 1868.

c. d. e. Muangla, 22nd May 1868.

Family $\rightarrow$ SCOLOPACID $A$.

Genus Totands, Bechstein.

198. Totanus canescens, Gmelin.

La Barge grise, Briss. Orn., t. v, p. 267, 1760.

Cinereous Godwoit, Lath., Syn., vol. iii, p. 145, 1785. 
Scolopax glottis, Linn., Syst. Nat., t. i, p. 245, 1766 ; Lath., 'Ind. Orn., vol. ii, p. 720, 1790 ; Bechst., Naturg. Deutschl., Bd. iii, p. 130, 1793 ; Yarrell, Brit. B., vol. ii, p. 549, 1843.

Scolopax canescens, Gm., Syst. Nat., t. i, p. 668, 1788.

Totanus griseus, Bechst., Naturg. Deutschl., iv, p. 249, 1809.

Totanus fistulans, id., t. c., p. 241.

Totanus glottis, Bechst., Naturg. Deutschl., Bd. iv, p. 249, 1809; Temm., Man. d’Orn., t. ii, p. 659, 1820 ; Flem., Brit. Anim., p. 104, 1828; Selby, Ill. B. Orn., p. 86, 1833 ; Gould, B. Eur., vol. iv, pl. 312, 1837; Demid. Voy., Bd. iii, p. 245, 1840; Gray, Gen. B., vol. iii, p. 573, 1846 ; Middend., Sibir. Reis., p. 213, 1851; Kjärb., Orn. Dan., pl. xxxvi, fig. 3, 1854; Sundev., Svensk. Fogl., xl, fig. 5, 1856 ; Schleg., Vög. Nederl., pl. 242, 1858; Schrenck, Reise Sibir., p. 414, 1859; Jaub. \& Lapomm., Rich. Orn., p. 456, 1859 ; Linderm., Vög. Griechenl., p. 137, 1860 ; Schleg., Mus. P.-B. Scolopaces, p. 6, 1862 ; Radde, Reise, p. 327, 1863 ; Jerdon, B. Ind., vol. iii, p. 700, 1863 ; Layard, B. S. Afr., p. 325, 1867 ; Godwin-Austen, Journ. As. Soc., Bengal, vol. xxxix, p. 274, 1870; Gray, Handl. B., vol. iii, p. 45, 1871; David, N. Arch. Mus., t. vii, Bull., p. 12, 1871 ; Swinhoe, Proc. Zool. Soc., 1871, p. 4:05 ; Holdsw., Proc. Zool. Soc., 1872, p. 475 ; Walden, Trans. Zool. Soc., vol. viii, p. 96, 1872 ; Heugl., Orn. N. O. Afr., p. 1169, 1873 ; Hume, Lahore to Yarkand, p. 290, 1873; Ball, Stray Feathers, 1873, p. 85 ; Salvad., Uce. Born., p. 327, 1874; Walden, Tr. Zool. Soc., 1875, p. 234; Blyth \& Walden, Journ. As. Soc., Bengal, vol. xliv, ex. No., p. 155, 1875.

Totanus chloropus, Meyer \& Wolf., Taschenb., Bd. ii, p. 37, 1810 ; Meyer, Vög. Liv. und Esthl., p. 199.

Limosa glottis, Pall., Zoogr., vol. ii, p. 179, 1811.

Limosa totanus, id., t. c., p. 183, 1811.

Limicula glottis, Leach, Cat. M. and B., Brit. Mus., p. 32, 1816.

Glottis natans, Koch., Baier. Zool., p. 305, 1876.

Glottis chloropus, Nills., Orn. Suec., t. ii, p. 57, 1817.

Glottis grisea, Brehm, Vög. Deutschl., p. 631, 1831.

Glottis fistulans, Brehm, t. c., taf. xxxiii, fig. 2.

Iotanus glottoides, Vigors, Proc. Zool. Soc., 1831, p. 173.

Limosa glottoides, Sykes, Proc. Zool. Soc., 1832, p. 163.

Glottis floridanus, Bonap., Comp. List, B. Eur. \& N. Amer., p. 51, 1838.

Glottis vigorsii, Gray, Cat. Brit. Mus. Gralla, p. 99, 1844.

Glottis horsfieldii, id., t. c., p. 99.

Glottis canescens, Ed., t.c., p. 99 ; Bonap., C. R., t. xliii, p. 596, 1856 ; Adams., Proc. Zool. Soc., 185 , p. 189; Loche, Expl. Sci. Alger., t. ii, p. 316, 1867; Fritsch., Vög. Eur., taf. 38, figs. 13, 14, 1871 ; Gould, B. Brit., vol. iv, pl. liii, 1873.

Glottis glottoides, Gould, B. Austr., fol. vi, pl. xxxvi; id., Handb., vol. ii, p. 265, 1865.

Totanus canesces, Sharpe \& Dresser, B. Eur., pt. v, 1871; Salvad., Faun., Ital., p. 221,1872

Shelley, B. Egypt, p. 256 ; Hume, Stray Feathers, 1873, p. 247; Adam., t.c., p. 397; Hume, Stray Feathers, 1874, pp. 229, 482 ; Irby, B. Gibr., p. 165, 1875 ; Scully, Stray Feathers, 1876 , p. 189 ; Fairbank, $t$. cit., p. 263 ; Armstrong, t. cit., p. 344; Hume, t. cit., p. 465.

a. Bhamô, 27th January 1868.

\section{Totanus grareola, Gmelin.}

Wood sandpiper, Penn., Arctic Zool., vol. ii, p. 482.

Tringa glareola, Linn., Syst. Nat., t. i, p. 250, 1766, ex Penn.; Lath., Ind. Orn., vol, ii, p. 730, 1790 ; Yarrell, Brit. B., ji, p. 534, I843.

Totanus glareola, Temm., Man, d’Orn., p. 421, 1815 ; Kaup., Nat. Syst., p. 140, 1829 ; Selby, 11 . Orn., vol. ii, p. 77, 1833 ; Gould, B. Eur., iv, pl. 315, 1837; Bonap., Comp. List., B. Eur. and 
N. Amer., p. 51, 1838 ; Demid. Voy., Bd. iii, p. 243, 1840 ; Gray, Gen. B., vol. iii, p. 573, 1846 ; Middend., Reis. Sibir., p. 215, 1815 ; Kjärb., Orn. Dan., taf. xxxv, 1851 ; Macgill., Brit. B., vol. iv, p. 346, 1852 ; Brehm, Naum., 1855, p. 292 ; Schleg., Vog. Nederl., pl. 246, 1858; Schrenck, Hartl. Orn., W. Afr., p. 204, 1857 ; Reise Amurl., p. 416, 1859 ; Linderm., Vög. Griechenl., p. 139, 1860 ; Layard, B.S. Afr., p. 326, 1867 ; Jaub. \& Lapomm., Rich. Orn., p. 460, 1859 ; Sundev., Svensk. Fogl., pl. xli, 1860 ; Radde, Sibir. Reise, p. 329, 1863; Degl. \& Gerbe, Orn. Eur., ii, p. 223, 1867; Doderl., Avif. Sicil., p. 185, 1869; Filippi, Viagg. Pers., p. 351, 1865; Gray, Handl., vol. iii, p. 44, 1869; Finsch. \& Hartl., Vög. Ost. Afr., p. 750, 1870 ; Fritsch., Vög. Eur., pl. xxxviii, 1871 ; Swinhoe, Proc. Zool. Soc., 1871, p. 406 ; David, N. Arch. Mus., t. vii, Bull., p. 12, 1871 ; Shelley, B. Egypt, p. 259, 1871 ; Gurney, in Anderson B. Damar. L., p. 302, 1872 ; Salvad., Faun. Ital. Ucc., p. 219, 1872 ; Heugl., Orn., N. O. Afr., p. 1163, 1873; Gould, B. Brit., pt. iv, pl. Ivii, 1873 ; James, Stray Feathers, 1873,

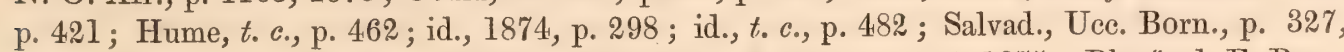
1874; H Hume, Stray Feathers, 1875, p. 183 ; Irby, B. Gibr., p. 167, 1875 ; Blanford, E. Pers., p. 285, 1876 ; Seebohm \& Brown, Ibis, 1876, p. 291 ; Dresser, t. cit., p. 412.

Totanus affnis, Horsf., Trans. Linn. Soc., vol. xiii, p. 191, 1821 ; Gray \& Hardw., Ill. Ind. Zool., pl. li, fig. 2.

Totanus grallatores, Steph., in Shaw's Gen. Zool., vol. xii, pt. 1, p. 148, 1824.

Totanus sylvestris, et palustris, Brehm, Vög. Deutschl., pp. 638, 639, 1831 ; Ball, Stray Feathers, 1874, p. 431.

Rhynchophilus glareola, Bonap., C. R., xliii, p. 587, 1556; Loche, Expl. Sci. Alger., t. ii, p. 325, 1867 ; Ball, Stray Feathers, 1874, p. 431 ; Walden, Tr. Zool. Soc., ix, p. 233, 1875 ; Hume, Stray Feathers, 1877, p. 46.

Actitis glareola, Jerdon, B. Ind., iii, p. 696, 1863 ; Godwin-Austen, Journ. As. Soc. Bengal, xxxix, p. 272, 1872 ; Holdsw., Proc. Zool. Soc., 1872, p. 474; Walden, Trans. Zool. Soc., vol. viii, p. 96, 1872 ; Ball, Stray Feathers, 1873, p. 85 ; Blyth \& Walden, Journ. As. Soc., Bengal, vol. xliv, ex. No., p. 155, 1875 ; Fairbank, Stray Feathers, 1876, p. 263 ; Armstrong, t. cit., p. 344; Tweedale, op. cit., 1877, p. 322; Ayres, t. cit., p. 351.
a. b. ㅇ K Kabyuet, 9th January 1875.
c. d. t Bhamô, 18th February 1868.
e. t Tsitkaw, 6th February 1875.

Common in Upper Burma and in the Shan States.

\section{Totanus ochropus, Temminck.}

Le. Becasseau appelé vulgairement Cul-blanc, Briss. Orn., t. v, p. 177, pl. xvi, fig. i, 1760.

Tringa ochropus, Linn., Syst. Nat., t. i, p. 250,1766 ; Lath., Ind. Orn., t. ii, p. 342, 1790 ; Yarr., Br. B., ii, p. $528,184.3$.

Le Becassean, Buff., Pl. Enl., t. viii, pl. 843.

Totanis ochropus, Temm., Man.d' Orn., p. 420, 1815 ; Werner, Atlas, Gralles, pl. xxi ; Kaup., N. S., p. 144, 1829; Ménétr., Cat. Bris. Caucas, p. 51, 1832 ; Selby, Ill. Br. Orn., vol. ii, p. 75, 1833 ; Naum., Vög. Deutschl., viii, pl. 197, 1836 ; Gould, B. Eur., iv, pl. 315, 1837 ; Demid., Voy. Russ. Merid., Bd. iii, p. 243, 1840 ; Gray, Gen. B., vol. iii, p. 573, 1846 ; Midd., Sibir. Reis., p. 215, 185 I ; Kjärb., Orn. Dan., pl. xxxvi, fig. 6, 1851 ; Macgill., Br. B., vol. iv, p. 342, 1852 ; Schl., Vög. Nederl., pl. 245, 1858; Schrenk, Reise Amurl., p. 416, 1859; Jaub. et Barth., Lap. Rich. Orn., p. 459, 1859; Sundev., Sv. Fogl., pl. xli, fig. 1, 1860 ; Linderm., Vög. Griechenl., p. 139, 1860; Radde, Sibir. Reis. Vog., p. 330, 1863; Schl., Mus. P.-B. Scolopaces, p. 70, 1864; Filippi, Viagg. Pers., p. 351, 1865; Degl. \& Gerbe, Orn. Eur., Bd. ii, p. 225, 1867; Doderl., Avif. Sicil., p. 186, 1869 ; Gray, Handl. B., vol. iii, p. 44, 1871; Swinhoe, Proc. Zool. Soc., 1871, p. 406 ; Fritsch., Vög. Eur., tab. xxxviii, fig. 2, 1871; David, N. Arch. 
Mus., vii, Bull., p. 12, 1871 ; Salvad., Faun. Ital. Ucc., p. 218, 1872 ; Shelley, B. Egpyt, p. 258, 1872 ; Heugl., Orn. N. O. Afr., Bd. iii, p. 1161, 1873 ; Gould, B. Gt. Br., iv, pl. lvi, 1873 ; Hume, Stray Feathers, 1873, p. 247; Adam., t.c., p. 396 ; Hume, Stray Feathers, 1875 , p. 183; Irby, B. Gibr., p. 167, 1875 ; Dresser, B. Eur., pt. liii, 1876 ; Blanford, E. Persia, ii, p. 285, 1876; Wharton, Ibis, 1876, p. 27 ; Dresser, t. c., p. 412.

Helodromas ochropus, Kaup., Naturl. Syst., p. 144, 1829 ; Bonap., C. R., xliii, p. 597, 1856 ; Loche, Expl. Sci. Alger. Ois., t. ii, p. 326, 1867; Ball, Stray Feathers, 1874, p. 4 isl.

Totanus rivalis, Brehm, Vog. Deutschl., p. 642, 1831.

Totanus leucourus, id., t.c., p. 643, 1831.

Actitis ochropus, Jerdon, B. Ind., vol. iii, p. 698, 1863 ; Godwin-Austen, Journ. As. Soc., Bengal, vol. xxxix, p. 273, 1870 ; Blanford, Geol. \& Zool. Abyss., p. 433, 1870; Holdsw., Proc. Zool. Soc., 1872, p. 474; Henders. \& Hume, Lahore to Yarkand, p. 289, 1873; Stoliczka, Stray Feathers, 1875, p. 220; Blyth \& Walden, Journ. As. Soc., Bengal, vol. xliv, ex. No., p. 155, 1875; Scully, Stray Feathers, 1876, p. 188; Fairbank, t. cit., p. 263 ; Butler, op. cit., 1877, p. 233.

a. 우 Tsitkaw, 6th February 1868 .

b. Tapeng, 1st March 1868.

\section{Genus Tringa, Naumann.}

\section{Tringa temmincki, Leissl.}

Tringa pusilla, Lath., Ind. Orn., vol. ii, p. 737, 1790 ; Flem., Brit. Anim., p. 112, 1828; Yarrell, Brit. B., vol. ii, p. $647,1843$.

Tringa temminckii, Leissl., Nachtr. zu Bechst. Naturg. Deutschl., Bd. ii, p. 75, 1811; Temm., Pl. Col,, t. v, pl. v, fig. 1, 1823; Naum., Vög. Deutschl., vii, pl. 189, 1834; Gould, B. Eur., vol. iv, pl. 333, 1837; Demid. Voy., Bd. iii, p. 241, 1840; Gray, Gen. B., vol. iii, p. 579, 1845 ; Blyth, Cat. B., Mus. As. Soc., Bengal, p. 270, 1849; Kjürb., Orn. Dan., taf. xxxv, fig. 2, 1851 ; Middend., Sibir. Reise, p. 221, 1857 ; Sundev., Svensk. Fogl., pl. xliii, fig. 5, 1856 ; Schleg., Vög. Nederl., pl. 234, 1858; Schrenck, Reis. Amurl., p. 422, 1859; Jaub. \& Lapomm., Rich. Orn., p. 469, 1859 ; Linderm., Vög. Griechenl., p. 143, 1860; Radde, Sibir. Reis., p. 332, 1863 ; Schleg., Mus. P.-B. Scolopaces, p. 47, 1864; Jerdon, B. Ind., vol.iii, p. 691, 1864; Godwin-Austen, Journ. As. Soc., Bengal, vol. xxxix, p. 273, 1870; Gray, Handl. B., vol. iii, p. 50, 1871; Sharpe \& Dresser, B. Eur., pt. vii, 1871 ; David, N. Arch. Mus., t. vii, Bull., p. 12, 1871 ; Swinhoe, Proc. Zool. Soc., 1871, p. 409-; Shelley, B. Egypt, p. 252, 1872; Heugl., Orn. N. O. Afr., p. 1192, 1873; Hume, Stray Feathers, 1873, p. 244; Liegge, t. c., p. 4.91 ; Hume, Stray Feathers, 1874, p. 482 ; id., Lahore to Yarkand, p. 289, 1875 ; id., Stray Feathers, 1875, p. 183; Blyth \& Walden, B. Burm., p. 156, 1875; Irby, B. Gibr., p. 73 , 1875 ; Butler, Stray Feathers, 1876, p. 17; Fairbank, t. cit., p. 263; Seebohm \& Brown,' Ibis, 1876, p. 368; Dresser, t. cit., p. 44; Butler, Stray Feathers, 1877, p. 233.

Pelidna temminckii, Boie, Isis, 1826, p. 979 ; Brehm, Naum., 1855, p. 293 ; Fritsch., Vög. Deutschl., taf. $38,1871$.

Leimonites temminckii, Kaup., Naturl. Syst., p. 37, 1829 ; Gould, B. Brit., vol. iv, pl. lxxiii, 1873.

Actodromas temminckii, Bonap., C. R., xliii, p. 596, 1856 ; Loche, Expl. Sci. Alger. Ois., t. ii, p. 314, 1867 ; Salvad., Faun. Ital. Ucc., p. 214 , 1872; id., Uce. Born., p. 324, 1874.

Tringa (Actodromas) temminckii, Blass., List, B. Eur., p. 19, 1862.

a. Bhamô, 5th February 1868.

b.c. " 7 th , , , 
Genus Actitis, Illiger.

\section{ACTitis HYPOLEUCUS, Linn.}

La Guinette, Briss. Orn., v, p. 183, 1760.

La petite alonette de Mer, Buff., Pl. Enl., t. viii, pl. 850, 1783.

Tringa hypoleucos, Linn., Syst. Nat., t. i, p. 250, 1766 ; Lath., Ind. Orn., vol, ii, p. 734, 1790 ; Yarrell, Br. B., ii, p. 539, 1843.

Trynga leucoptera, Pall. Zoogr., vol. ii, p. 196, 1811.

Totanus hypoleucos, Temm., Man. d'Orn., p. 424, 1815; Steph., Gen. Zool., xii, p. 142, 1824; Roux, Orn. Prov., pl. 297, 1825 ; Selby, Ill. Orn., vol. ii, p. 81, 1833; Gould, B. Eur., vol. iv, pl. 316, 1837; Gray, Gen. B., vol. iii, p. 574, 1846 ; Jaub. \& Lapomm., p. 461, 1859; Kjärb., Orn. Dan., pl. xxxvi, 1851; David, N. Arch. Mus., t. vii, Bull., p. 12, 1871 ; Irby, B. Gibr., p. 168, 1875.

Totanus guinettu, Leach, Syst. Cat. M. \& B. Brit. Mus., p. 30, 1816; Brehm, Vög. Deutschl., p. $649,1831$.

Actitis hypoleucos, Bonap., Comp. List, B. Eur. and N. Amer., p. 51, 1838; Demid. Voy., Bd. iii, p. 243, 1840 ; Middend., Sibir. Reis., p. 215, 1851 ; Macgill., Brit. B., iv, p. 351, 1852 ; Brehm, Naum., 1855, p. 292 ; Sundev., Svensk. Fogl., pl. xli, fig. 3, 1856 ; Bonap., C. R., xliii, p. 597, 1856 ; Schleg., Vög. Nederl., pl. 240, 1858 ; Schrenck, Reis. Amurl., p. 417, 1859 ; Linderm., Vog. Griechenl., p. 140, 1860 ; Radde, Reis. Sibir., p. 380, 1863 ; Jerdon, B. Ind., vol. iii, p. 699, 1863 ; Degl. \& Gerbe, Orn. Eur., Bd. ii, p. 227, 1867; Loche, Expl. Sci. Alger., t. ii, p. 326, 1867 ; Bettoni, Ucc. Lomb., ii, pl. lxxxix, 1868 ; Doderl., Avif. Sicil., p. 186, 1869 ; Finsch. \& Hartl., Vög. O. Afr., p. 752, 1870 ; Blanf., Zool. \& Geol. Abyss., p. 433, 1870; Godwin-Austen, Journ. As. Soc., Bengal, vol. xxxix, p. 273, 1870; Walden, Trans. Zool. Soc., vol. viii, p. 96, 1872 ; Salvad., Faun. Ital. Ucc., p. 216, 1872 ; Gould, B. Brit., iv, pl. 1viii, 1873; Hume, Lahore to Yarkand, p. 289, 1873; Ball, Stray Feathers, 1873, p. 85 ; id., 1874, p. 4.31; Hume, t. c., p. 483; Brooks, Stray Feathers, 1875, p. 257 ; Blyth \& Walden, Journ. As. Soc., Bengal, vol. xliv, ex. No., p. 155, 1875; Butler, Stray Feathers, 1876, p. 18 ; Scully, t. cit., p. 188 ; Fairbank, t. c., p. 263 ; Schalow, Journ. für. Ornith., 1876, p. 21 ; Nehrkorn, t. c., p. 160 ; Wharton, Ibis, 1876, p. 27 ; Seebohm \& Brown, t. c., p. 292 ; Butler, Stray Feathers, 1877, p. 233.

Tringoides hypoleuca, Gray, List Gen. B., 1841, p. 88 (?) ; Swinhoe, Proc. Zool. Soc., 1871, p. 406 ; Gray, Handl. B., iii, p. 4.6, 1871 ; Holdsw., Proc. Zool. Soc., 1872, p. 474; Hume, Stray Feathers, 1873, p. 247 ; Adam., t. c., p. 397 ; Salvad., Ucc. Born., p. 326, 1874; Hume, Stray Feathers, 1874, p. 299 ; id., 1875, p. 183 ; id., Nests and Eggs, Ind. B., p. 588, 1873 ; Walden, Tr. Zool. Soc., 1875, p. 234 ; Blanf., East. Pers., p. 285 ; Armstrong; Stray Feathers, 1876, p. 344; Hume, t. c., p. 465.

a. Mandalay, Sand Flats, January 1868.

b. 우 Second defile of Irawady, 5th February 1875.

\section{Genus Scolopax, Linn.}

\section{Scolopax gaLitnago, Linn.}

La Becassine, Briss. Orn, v, p. 298, 1760 ; Buff., Pl. Enl., t. viii, pl. 883, 1783.

Scolopax gallinago, Linn., Syst. Nat., t. i, p. 244, 1766; Scop., Ann. Hist. Nat., p. 97, 1769 ; Lath., Ind. Orn., vol. ii, p. 714, 1790; Bechst., Naturg. Deutschl., Bd. iii, p. 110, 1793; Pall., Zoogr. Ross. As., vol. ii, p. 174, 1811 ; Vieill., N. Dict. d'Hist. Nat., t. iii, p. 356, 1816; Wern., Atl. Gralles, pl. xxix, 1820; Temm., Man. d’Orn., t. ii, p. 676, 1820; Bonn. 
\& Vieill., Enc. Orn., p. 1158, 1823; Selby, Ill. Orn., vol. ii, p. 121, 1833; Naum., Vög. Deutschl., Bd. iii, pl. 209, 1836 ; Gould, B. Eur., vol. iv, pl. 321, 1837; Demid. Voy., t. iii, p. 251, 1840 ; Yarrell, Brit. B., vol. ii, p. 603, 1843 ; Temm. \& Schleg., Faun. Japon., p. 112, 1850 ; Thomps., B. Trel., vol. ii, p. 262, 1850 ; Middend., Sibir. Reis., p. 224, 1857; Kjœrb., Orn. Dan., pl. xxxvii, 1851; Macgill., Brit. B., p. 368, 1852 ; Sundev., Svensk. Fogl., pl. xlix, fig. 4, 1856 ; Schleg., Vög. Nederl., pl. 222, 1858; Radde, Reise Sibir., p. 337, 1863; Severtz., Turkest. Jevotn., p. 69, 1872; Blanford, Geol. \& Zool. Abyss., p. 432, 1870 ; Dresser, Ibis, 1876, p. 330.

Scolopax grallinaria, Gm., Syst. Nat., t. i, p. 662, 1788.

Gallinago media, Leach, Syst. Cat. M. \& B., Brit. Mus., p. 31, 1816; Gray, Gen. B., vol. iii, p. 583,1845 ; Baird, Ibis, 1867 , p. 282.

Scolopax brehmi, Kaup., Isis, 1823, p. 1147; Jard., Contr. Orn., 1849, p. 134; id., 1850, p. 17.

Telmatias gallinago, Boie, Isis, 1826, p. 979; Brehm, Vogelf., 1855, p. 306.

Pelorlynnchus brehmi, Kaup., Naturl. Syst., p. 119, 1829.

Telmatias peregrina, Brehm, Vög. Deutschl., p. 621, 1831 ; id., Vogelf., 1855, p. 306.

Gallinago brehmi, Bonap., Icon. della Faun. Ital., t. i, pl. xliii, 1832-41 ; id., Comp. List, B. Eur. \&

N. Amer., p. 52, 1838 ; Gray, Gen. B., vol. iii, p. 583, 1845 ; Brehm, Naum., 1855, p. 291.

Scolopax delamottei et pygmaa, Baillon, Mèm. Soc. d’Em. d’Abbev., 1834, p. 71.

Gallinago scolopacinus, Bonap., Comp. List, B. Eur. \& N. Amer., p. 52, 1838; Bonap., C. R., xliii, p. 1023, 1856 ; Jaub. \& Lapomm., Rich. Orn., p. 481, 1859; Schleg., Mus. P.-B. Scolopaces, p. 4, 1864; Jerdon, B. Ind., vol. iii, p. 674, 1864; Filippi, Viagg. Pers., p. 351, 1865 ; Loche, Expl. Sci. Alger. Ois., t. ii, p. 296, 1867; Degl. \& Gerbe, Orn. Eur., Bd. ii, p. 183, 1867 ; Doderl., Avif. Sicil., p. 195, 1869; Godwin-Austen, Journ. As. Soc., Bengal, vol. xxxix, p. 273, 1870 ; Finsch. \& Hartl., Orn. Ost-Afr., p. 771, 1870 ; Swinhoe, Proc. Zool. Soc., 1871, p. 407; David, N. Arch. Mus., t. vii, Bull., p. 12, 1871; Gray, Handl. B., vol. iii, p. 52, 1871 ; Salvad., Faun. Ital. Uce., p. 227, 1871; Holdsw., Proc. Zool. Soc., 1872, p. 473 ; Ball, Stray Feathers, 1873, p. 85; Hume, t. c., p. 235; Adam., t. c., p. 395; Walden, Tr. Zool. Soc., 1873, p. 235 ; Gould, B. Brit., iv, pl. lxxix, 1873 ; Ball, Stray Feathers, 1874, p. 431; Stoliczka, t. c., p.465 ; Hume, t.c., p. 482 ; id., Stray Feathers, 1875, p. 182 ; Stoliezka, t.c., p. 220 ; Le Messurier, t. c., p. 380 ; Blyth \& Walden, Journ. As. Soc.; Bengal, vol. xl, extra No., p. 156, 1875 ; Hume, Nests and Eggs, Ind. B., p. 586, 1873 ; Blanford, East. Pers., p. 282, 1876.

Scolopax peregrina, Temm., Man. d’Orn., iv, p. 435, 1840.

Ascolopax gallinago, Keys. \& Brehm, Wirbelth. Eur., p. 77, I840 ; Linderm., Vóg. Griechenl., p. $145,1860$.

Telmatias salicaria, brehmi, petenyi, septentrionulis, stagnatilis, faroensis, lacustris et brachypus, Brehm, Vogelf., 1855, p. 306.

Gallinago petenyi, septentrionalis, faroensis, lacustris, peregrina brachypus, Brehm, Naum., 1855, p. 291.

Gallinago atripennis, Bonap., C. R., xliii, p. 579, 1856 ; Hartl., Vög. W. Afr., p. 239, 1857.

Gallinago japonicus, Bonap., C. R., xliii, p. 1123, 1856.

Gallinago burka, Bonap., C. R., xliii, p. 759, 1856.

a. 古 Kabyuet, 9th January 1875.

b. c. Bhamô, 7th February 1868.

Abundant in suitable localities. 


\section{Genus Rнтмснжа, Cuvier.}

\section{Rhynchan Bengalensis, Linn.}

The Bengal Water Rail, Albin, Birds, t. iii, p. 85, pl. xc, 1736.

Le chevalier de Bengale, Briss. Orn., t. v, p. 209, 1760.

Rallus benghalensis, Linn., Syst. Nat., t. i, p. 263, 1766.

Beccassine de la Chine, Buff., Pl. Enl., 881.

Scolopax chinensis, Bodd., Tabl. Pl. Enl., p. 53, 1783.

Scolopax sinensis, Lath., Ind. Orn., vol. ii, p. 717, 1790.

Scolopax capensis, Raff., Tr. Linn. Soc., vol. xiii, p. 327, 1821.

Rhynchcea orientalis, Horsf., t. c., p. 193, 1821.

Rhynchcea variegata, Vieill. et Oud., Gal. Ois., t. ii, p. 109, pl. 240, 1825 ; Schl., Mus. P.-B. Scolopaces, p. 16, 1864.

Rhynchaa australis, Gould, Proc. Zool. Soc., 1837, p. 155 ; Gray, Gen. B., vol. iii, p. 585, 1846 ; Gould, B. Austr., vi, pl. xli, 1848 ; id., Handl. B. Austr., vol. ii, p. 274, 1865.

Rhynchaa bengalensis, Gray, List of Gralla, \&c., B. M., p. 108, 1844; Jerdon, B. Ind., vol. iii, p. 677, 1864; Swinhoe, Proc. Zool. Soc., 1871, p. 408; Gray, Handl. B., iii, p. 336, 1871; Hume, Stray Feathers, 1873, p. 235; Adam., t. c., p. 396 ; Ball, Stray Feathers, 1874, p. 431 ; Salvad., Ucc. Born., p. 336, 1874; Hume, Nests and Eggs, Ind. B., p. 586, 1873; Blyth \& Walden, Journ. As. Soc., Bengal, vol. xliv, extra No., p. 157, 1875 ; Butler, Stray Feathers, 1876, p. 15; Fairbank, t. c., p. 263; Swinhoe, Ibis, 1877, p. 146; W. Ramsay, t.c., p. 469 ; Hume, Stray Feathers, 1877, p. 46 ; Butler, t. c., p. 223.

Rhynchca chinensis, Gray, Gen. B., vol. iii, p. 585, 1846.

$$
\text { a. } \text { ¿ Momien, 4th June } 1868 .
$$

This is the only specimen of this species observed by me.

$$
\text { Family-PARRIDAR. }
$$

\section{Genus Metopidius, Wagler.}

\section{Metopidius indicus, Latham.}

Indian jacana, Lath., Syn. Suppl., p. 257, 1787.

Parra indica, Lath., Ind. Orn., t. ii, p. 765, 1790 ; Hartl., Contr. Orn., 1849, p. 26; Schl., M. P.-B., Ralli, p. 67, 1865 ; Pelz., Reis. Nov. Vög., p. 132, 1865 ; Gray, Handl. B., vol. iii, p. 70, 1871 ; Salvad., Uce. Born., p. 343, 1874.

Parra cuprea, Vahl., Shrift. Naturh. Selsk., Bd. ii, p. 51, 1793.

Le grand jacana, verd à crète, Temm., Syst. Cat. Cab. d’Orn., p. 265, 1807

Parra cristata, Vieill., N. Dict. d'Hist. Nat., xvi, p. 450 (1817, ex Temm.); Bonn. et Vieill., Enc. Méth., t. iii, p. 1056, 1823.

Parra aenea, Cuv., Règne, An., t. i, p. 498, 1817.

Parra superciliosa, Horsf., Trans. Linn. Soc., vol. xiii, p. 194, 1821; id., Zool. Researches in Java, pl. lxiv, 1824.

Parra melanochloris, Vieill. et Oud., Gal. Ois., 1st ed., ii, pl. 264, 1820-26.

Metopidius aeneus, Wagl., Isis, 1832, p. 279.

Hydralector cristatus, Wagl., t. c., p. 280.

Parra arata, Tickell, Journ. As. Soc., Bengal, vol. ii, p. 582, 1833.

Parra melanoviridis, Vieill., Gall. Ois., 2nd ed., ii, p. 164, 1834. 
Metopidius indicus, Blyth, Cat. B. Mus. As. Soc., Bengal, p. 273, 1849; Jerdon, B. Ind., vol. iii, p. 708, 1864; Ball, Stray Feathers, 1874, p. 431; Hume, t.c., p. 483; id., Stray Feathers, 1875, p. 183 ; id., Nests and Eggs, p. 591, 1873 ; Blyth \& Walden, Journ. As. Soc., Bengal, vol. xliv, extra No., p. 157, 1875; Fairbank, Stray Feathers, 1876, p. 263 ; Armstrong, t. c., p. 348 ; Butler, op. cit., p. 212.

$$
\begin{aligned}
\text { a. b. c. d. } & \text { Bhamô, February } 1868 . \\
\text { e. } & \text { Tsitkaw, Upper Burma, 7th February } 1875 .
\end{aligned}
$$

Common around Bhamô.

Family-GRUID $R$.

Genus Grus, Linn.

206. Grus antigone, Pallas.

Ardea antigone, Linn., Syst. Nat., t. i, 1766, p. 235 ; Gmelin, op. cit., 1788, p. 622.

Grus antigone, Pallas, Zoog. Rosso-Asiat., vol. ii, 1831, p. 102.

Grus torquata, Vieillot, Gal. Ois., t. ii, th. 256, 1825.

Grus orientalis, Franklin, Proc. Zool. Soc., 1831.

Antigone torquata, Bonap. Consp., vol. ii, p. 100, 1850.

a. b. Tsitkaw, March 1868 and March 1875.

This crane is distributed over Upper Burma and the high country beyond.

From our camp at Ponsee, at an elevation of 3,300 feet, I observed, in the beginning of March, great numbers of this bird passing in the direction of the Burmese valley, and flying in $\mathrm{V}$-shaped flocks. My attention was first attracted to them by their loud call overhead, for the birds were so distant as to appear mere specks. When the flock in advance was right over the summit of the high mountain, on the slope of which our camp was pitched, the birds flew round in a great circle and continued doing so, until nine other flocks came up, and each circling round commingled with the others. They then marshalled off into two great bands, which broke up again into $V$-shaped flocks, as they continued their flight. I counted about sixty in a flock, and as the flocks were nearly of uniform strength, there could not have been fewer than 600 birds.

$$
\text { Family-IBIDID } A \text {. }
$$

Genus Falcinelius, Bechst.

\section{Falcinellus rufus, Scop.}

Le Courly verd, Briss. Orn., t. v, p. 326, pl. xxvii, fig. 2, 1760.

Le Courly marron, Briss., t. c., p. 329, 1760.

Le Courly brun d'Amérique, Briss., t. c., p. 330, 1760.

Le Courly varié de Mexique, Briss., t. c., p. 333, 1760.

I'antalus falcinellus, Linn., Syst. Nat., t. i, p. 241, 1766 ; Yarr., Br. B., vol. ii, p. 505, 1843; Jaub. \& Barth., Lap. Rich. Orn., p. 368, 1858.

Scolopax rufa, Scop., Ann., i, p. 93, 1769. 
Numenius igneus, Gm., Nov. Comm. Acad. Petr., t. xv, p. 460, 1771.

Numenius viridis, Gm., t. c., p. 462, 1771.

Bay Ibis, Lath., t.c., p. 113, 1783.

Green Ibis, Lath., Gen. Syn., vol. iii, p. 114, 1783.

Glossy Ibis, Lath., t. c., p. 115, 1783.

Courlis d'Italie, Daubent., Pl. Enl., 819.

Tantalus igneus, Gm., Syst. Nat., t. i, p. 649, 1788.

Tantalus viridis, Gm., t. c., p. 648, 1788.

Tantalus niger, Gm., t. c., p. 650.

Tantalus mexicanus, Gm., t. c., p. 652.

Numenius falcinellus, Pall., Zoogr. Rosso-Asiat., t. ii, p. 165, 1811.

Ibis sacra, Temm., Man. d'Orn., p. 315, 1815.

Ibis noir, Savign., Hist. Nat. Myth. de l'Ibis, p. 35, fig. 4.

Numenius chilii, Vieill., N. Dict. d'Hist. Nat., t. viii, p. 303, 1817.

Ibis falcinellus, Vieill., N. Dict., xvi, p. 23, 1817; Temm., Man. d’Orn., t. ii, p. 598, 1820 ; Roux, Orn. Prov., pl. 309, 1825; Wagl., Syst. Av. Ibis, sp., 1827 ; Werner, Atlas, pl. , 1827 ; Less., Traité, p. 566, 1831; Gould, B. Eur., iv, pl. 301, 1837; Audub., B. Amer., vol. v1, p. 50, pl. 358, 1842 ; Gray, Gen. B., iii, p. 566, 1847; Kjærb., Orn. Dan., tab. 33a, fig. 3, 1851 ; Macgill., Br. B., vol. i, p. 493, 185?; Schl., Vög. Nederl., pl. xx, 1854; Hartl., Orn. W. Afr., p. 230, 1857 ; Schl., Mus. P.-B., Ibis, p. 2, 1863; Pelz., Reis. Novara, Vög., pp. 125-127, 1865; Layard, B. S.-Afr., p. 319, 1867 ; Schl. \& Poll., Faun. Madag., p. 128, 1868 ; Finsch \& Hartl., Vög. Ostafr., p. 730, 1870 ; Gray, Handl. B., vol. iii, p. 39, 1871 ; Heugl., Orn. N. O. Afr., p. 1132, 1871; Swinhoe, Proc. Zool. Soc., 1871, p. 411 ; Shelley, B. Egypt, p. 262, 1872 ; Severtz., Faun. Turkest., p. 68, 1873 ; Irby, Orn. Gibr., p. 191, 1875.

Plegadis falcinellus, Kaup., Naturl. Syst., p. 82, 1829; Salvad., Faun. Ital. Ucc., p. 247, 1871.

Tantalides falcinellus, Wagler, Isis, 1832, p. 1231.

Ibis erythrorhyncha, Gould, Proc. Zool. Soc., 1837, p. 127.

Ibis ordii, Bonap., Comp. List, B. Eur. \& N. Amer., p. 49, 1838 ; Baird, B. N. Amer., p. 685, 1860.

Falcinellus igneus, Gray, List, Gen. B., p. 84, 1814; id., List, Gralla, Brit. Mus., p. 92, 1844 ; Gould, B. Austr., vi, pl. xlvii, 1848; Blyth, Cat. B., Mus. As. Soc., Bengal, p. 274, 1849 ; Bonap. Consp., t. ii, p. 158, 1857 ; Fritsch., Vög. Eur., tab. 43, fig. 1, 1858 ; Jerdon, B. Ind., vol. ii, p. 770, 1864; Gould, Handl., B. Austr., vol. ii, p. 286, 1865; Loche, Expl. Sci. Alger., t. ii, p. 155, 1867 ; Degl. \& Gerbe, Orn., Eur., Bd. ii, p. 329, 1867 ; Holdsw., Proc. Zool. Soc., 1872, p. 479 ; Gould, B. Gt. Br., iv, pl. xlvii, 1873; Salvad., Ucc. Born., p. 360, 1874; Hume, Nests and Eggs, Ind. B., p. 635, 1874; Butler \& Hume, Stray Feathers, 1876, p. 25 ; Butler, op. cit., 1877, p. 233 ; Elliot, Proc. Zool. Soc,, 1875, p. 503 ; Butler \& Hume, Stray Feathers, 1876, p. 25.

Ibis brevirostris, Peale, U. S. Expl. Exp., vol. viii, p. 219, 1848; Hartl., Arch. f. Naturg., Bd. xviii, p. 118, 1848.

Tantalus bengalensis, Bonap. Consp., t. ii, p. 158, 1857.

Ibis peregrina, Bonap., t. c., p. 159, 18 s.7.

Eudocimus erythrorhynchus, Bonap., t. c., p. 159, 1857.

Plegadis bengalensis, Bonap., C. R., xl, p. 725 .

Plegadis peregrinus, Bonap., $t$. c., p. 725.

Plegadis ordii, Bonap., t. c., p. 725.

Plegadis erythrorhyncha, Bonap., t. c., p. 725.

Falcinellus ordii, Cones, Pr. Philad. Acad., 1866, p. 96 ; Tacz., Proc. Zool. Soc., 1874, p. 562.

Palcinellus autumnalis, Doderl., Avif. Sicil., p. 220, 1869.

Falcinellus erythrorhynchus, Gundl., Journ. für Ornith., 1871, p. 285. 
Ibis falcinellus, Gray, Handl. B., vol, iii, p. 39, 1871.

Jbis ordii, Gray, t.c., p. 39, 1871.

Ibis erythrorhynchus, Gray, t. c., p. 39, 1871.

Ibis falcinellus, var. ordii, Cones, Birds, N. West, p. 517, 1874.

Endocimus faleinellus, Bocage., Journ. für Ornith., 1876, p. 300.

Falcinellus rufus, Reichen., Journ. für Ornith., 1877, p. 146.

\section{a. ㅎ b. ㅇ Tsitkaw, March 1868.}

Observed at intervals along the Irawady from Mandalay to the foot of the Kakhyen hills, and not uncommon about Tsitkaw.

Family-ARDEID $A$.

Genus A RDEA, Linn.

208. Ardea cinnamomea, Gmelin.

Ardea cinnamomea, Gmel., Syst. Nat., t. i, p. 643, 1788; Wagler, Syst. Av., Ardea, sp. 39, 1827;

Gray \& Hardw., Ill. Ind. Orn., pl. lxvi, 1830-34; Schleg., Mus. P.-B., Ardea, p. 40, 1863;

Mart., Journ. für Ornith., 1866, p. 354.

Ardea nebulosa, Horsf., Tr. Linn. Soc., vol. xiii, p. 190, 1822.

Ardetta cinnamomea, Gray, List, B. Brit. Mus., 1844, p. 83 ; Blyth, Cat. B., Mus. As. Soc.,

Bengal, p. 282, 1849 ; Sclater, Proc. Zool. Soc., 1863, p. 223 ; Jerdon, B. Ind., vol. iii, p. 755,

1864; Godwin-Austen, Journ. As. Soc., Bengal, vol. xxxix, p. 274, 1870; Swinhoe, Proe.

Zool. Soc., 1871, p. 413 ; Holdsw., Proc. Zool. Soc., 1872, p. 478 ; Salvad., Ucc. Born., p. 354,

1874; Hume, Stray Feathers, 1874, p. 311 ; Ball, t. c., p. 435 ; Hume, t.c., p. 483; Blyth \&

Walden, Journ. As. Soc., Bengal, vol. xl, ex. No., p. 160, 1875 ; Fairbank, Stray Feathers,

1876, pp. 263, 266; Hume, op. cit., 1877, p. 47; Oates, t. c., p. 168.

Ardeola cinnamomea, Bonap. Consp., t. ii, p. 132, 1855.

a. Sanda, 28th July 1868.

This is the only example of this species obtained by me, and it will be observed that it is not from Burma, but from the high country to the eastward.

\section{ARDEA PURPUREA, Linn.}

The Héron pourpré, Briss. Orn., t. v, p. 420, 1760.

Le Héron pourpré hupé, Briss. Orn., t. i, p. 424, pl. xxxvi, fig. 2, 1760; Daubent., Pl. Enl., 788.

Le Grand Butor, Briss., t. c., p. 455, 1760.

Ardea purpurea, Linn., Syst. Nat., t. i, p. 236, 1766 ; Gm., Syst. Nat., t. i, p. 626, 1788; Temm:, Man. d’Orn., t. ii, p. 570, 1820 ; Licht., Verz. Doubl., p. 77, 1823; Wagler, Syst. Av. Ardea, sp. 6, 1827; Naum., Vög. Deutschl., ix, p. 63, pl. 221, 1838; Keys. \& Blas., Wirbelth. Eur., p. Ixxix, 1840 ; Gray, List, Gralla, \&c., p. 76, 1844; id., Gen. B., vol. iii, p. 555, 1847 ; Rüpp., Syst. Uebers., p. 120, 1847 ; Blyth, Cat., p. 278, 1849; Macgill., Br. B., vol. iv, p. 463, 1852 ; Schleg., Vög. Nederl., pls. 188, 189, c. 1854; Bonap. Consp., t. ii, p. 113, 1856 ; Hartl., Vög. West Afr., p. 220, 1857 ; Jaub. \& Lapomm., Orn. Prov., p. 359, 1858; Sundev., Svenska Fogl., pl. lxxvii, fig. 1, c. 1860 ; Hartl., Madag., p. 73, 1862 ; Jerdon, B. Ind., vol. iii, p. 74.3, 1863 ; Schleg., Mus. P.-B. Ardeae, p. 8; 1863 ; Layard, B. S. Afr., p. 306, 1867 ; Fristch., Vög. Eur., tab. 43, fig. 1, 1867 ; Degl. \& Gerbe, Orn. Eur., p. 290, 1867 ; Schleg. \& Poll., Fauna, Madag., p. 163, 1868 ; Doderlein, Avif. Sicil., p. 210, 1869; 
Aubin. \& Salvad., Viagg. Bogos., p. 147, 1871; Gray, Handl. B., vol. iii, p. 27, 1871; Swinhoe, Proc. Zool. Soc., 1871, p. 411; Salvad., Faun. Ital., p. 241, 1872; Shelley, B. Egypt, p. 266, 1872; Gould, Gt. Brit., vol. iv, pl. xxi, 1873 ; Severtzoff, Turkest. Jevotn., 1873, p. 68 ; Heugl., Orn. N. O. Afr., p. 1051, elxxxiv, 1873 ; Hume, Nests and Eggs, Ind. B., 1873, p. 611 ; Ball, Stray Feathers, 1873, p. 86 ; Hume, t. c., p. 253 ; id., op. cit., 1874, p. 303 ; id., p. 483 ; Ball, $t$. c., p. 434; Walden, Ibis, 1874, p. 148 ; Durnford, t. c., p. 390 ; Legge, op. cit., 1875, p. 403 ; Danford \& Brown, $t$. cit., p. 424; Hume, Stray Feathers, 1875, p. 190 ; Butler, op.cit., 1876, p. 23 ; Fairbank, t. c., p. 263 ; Schalow, Journ. für Ornith., 1876, p. 17 ; B. du Bocage, t.c., p. 303; Barret, Ibis, 1876, p. 210 ; Dresser, $t . c$. , p. 325 ; Sharpe, t. c., p. 24; Tweedale, t. c., p. 323; Hume, Stray Feathers, 1877, p. 46 ; Oates, t.c., p. 167 ; Irby, B. G. P., p. 182, 1875; Blyth \& Walden, Journ. As. Soc., Bengal, vol. xliv, ex. No., p. 159, 1875.

Ardea rufa, Scop. Ann., t. i, p. 87, 1768 ; Gmel., Syst. Nat., p. 642, 1788.

Ardea variegata, Scop. Ann., t. i, p. 88, 1768.

Ardea caspia, Gmelin, Reis. d. Russld. Bd. ii, p. 193, pl. xxiv, 1774; Brehm, Vogelf., p. 293, 1855.

African Heron, Lath. Suppl., p. 237.

Greater Bittern, Lath., Gen. Synopsis, vol. iii, pt. 1, p. 58, 1785.

Crested Purple Heron, id., t. c., p. 95.

Purple Heron, id., t. c., p. 96.

Rufous Heron, id., t. c., p. 99.

Ardea purpurea, Gm., Syst. Nat., p. 641, 1788.

Ardea botaurus, id., t.c., p. 636.

Ardea monticola, Vieill., N. Dict., xiv, p. 416, 1817.

Ardea purpurea, var. manillensis, Meyer, Acta Acad. Caes.-Leop. Carol., Bd. xvi, p. 102, 1834.

Ardea purpurescens, Brehm, Vogelf., p. 293, 1855.

Ardea pharaonica, Bonap. Consp., t. ii, p. 113, 1856.

Ardea (Pyrrherodia) purpurea, Finsch.\& Hartl., Vög. Ostafr., p. 67, 1870.

a. o Sawady, 25th June 1875.

b. c. Bhamô, 15th February 1868.

Distributed over Upper Burma, but not numerous.

\section{Genus Herodias, Boie.}

\section{Herodias INTermedia, Wagler.}

Ardea intermedia, Wagler, Isis, 1829, p. 659 ; Pelz., Reis. Novara, Vög., p. 118, 1865 ; Finseh, \& Hartl., Vög. Ostafr., p. 686, 1870; Gray, Handl. B., vol. iii, p. 28, 1871 ; Hume, Nests and Eggs, Ind. B., p. 615, 1873.

Ardea melanopus, Wagler, Isis, 1829, p. 659.

Ardea putea, Frankl., Proc. Zool. Soc., 1830, p. 124.

Ardea nigrirostris, Gray \& Hardw., Ill. Ind. Orn. Zool., ii, pl. xlix, fig. 2, 1834, Gray, Gen. B., vol. iii, p. $555,1847$.

Ardea egrettoides, Temm., Man. d’Orn., t. iv, p. 374, 1840 ; Gray, Gen. B., vol. iii, p. 555, 1847 ; Temm. \& Schl., Faun. Jap. Aves, p. 115, pl. 1xix, 1850.

Herodias plumifera, Gould, Proc. Zool. Soc., 1847, p. 221.

Ardea plumifera, Gould, B. Austr., vi, pl. lvii, 1848.

Herodias intermedia, Blyth, Cat. B. Mus. As. Soc., Bengal, p. 279, 1849 ; Hume, Stray Feathers, 1873, p. 233 ; Adam., t. c., p. 399; Hume, Stray Feathers, 1874, p. 303 ; Ball; t. c., p. 434; Walden, Trans. Zool. Soc., vol. ix, p. 237, 1875; Blyth \& Walden, B. Burm., p. 159, 1875 ; Oates, Stray Feathers, 1875, p. 190; Butler, Stray Feathers, 1876, p. 23. 
Ardiea nivea, Pucher., Rev. et Mag. de Zool., 1851, p. 576.

Egretta plumifera, Bonap., Compt, rend., xl, p. 722, 1855 ; id., Consp., t. ii, p. 115, 1857.

Egretta egrettoides, Bonap., t.c.; id., Consp., t. ii, p. 115, 1857.

Egretta nigrirostris, Bonap., $t . c$.

Egretta intermedia, Bonap., t. c.; id., Consp., t. ii, p. 116, 1857.

Egretta melanopus, Bonap., t. c.; id., Consp., t. ii, p. 116, 1857.

Herodias egrettoides, Swinhoe, Ibis, 1861, p. 267 ; Gould, Handb., B. Austr., vol. ii, p. 393, 1865;

Jerdon, B. of Ind., vol. iii, p. 745, 1864.

Ardea alba, Schl., Mus. P.-B. Ardece, p. 19, 1863.

Herodias alba, Jerdon, B. Ind., vol. iii, p. 745, 1864.

Herodias egretta, Ball, Stray Feathers, 1877, p. 347.

a. Tapeng river, February 1868.

\section{Herodias garzetta, Linn.}

Ardea garzetta, Linn., Syst. Nat., t. i, p. 237, 1766 ; Lath., Ind. Orn., vol. ii, p. 694, 1790; Steph., in Shaw's Gen. Zool., vol. xi, p. 545, pl. xli, 1819; Temm., Man. d’Orn., p. 574, 1820; Wagl., Syst. Av., sp. 10, 1827; Selby, Ill. Orn., vol. ii, p. 21, 1833; Flem., Brit. Anim., p. 96 ; Jen., Brit. Anim., p. 187, 1835; Gould, B. Eur., vol. iv, pl. 277, 1837; Demid., Voy. Siberie, Bd. iii, p. 260, 1840 ; Yarrell, Brit. B., ii, p. 458, 1843; Gray, Gen. B., vol. iii, p. 555, 1847 ; Schleg., Vög. Nederl., pl. 191, 1858; Linderm., Vög. Griechenl., p. 150, 1860 ; Schlegel, Mus. P.-B. Ardea, April 1863, p. 12; Gray, Handl., vol. iii, p. 28, 1871; Hume, Stray Feathers, 1873, p. 462; id., Nests and Eggs, Ind. B., p. 616, 1873; Blanford, East. Pers., p. 296, 1876.

Egretta garzetta, Bonap., Comp. List, B. Eur. and N. Amer., p. 47, 1838; Macgill., Brit. B., iv, p. 471, 1852 ; Brehm, Naum., 1855, p. 290 ; Jaub. \& Lapomm., Rich. Orn., p. 361, 1859; Filippi, Viagg. Pers., p. 351, 1865 ; Salvad., Faun. Ital. Ucc., p. 241, 1872.

Garzetta egretta, Bonap. Consp., t. ii, p. 118 ; Loche, Expl. Sci. Alger. Ois., t. ii, p. 133, 1867 ; Swinhoe, Proc. Zool. Soc., 1871, p. 412.

Herodias garzetta, Boie, Oken's Isis, 1822, p. 560 ; Jerdon, B. Ind., vol. iii, p. 746, 1868; Doderl., Avif. Sicil., p. 213, 1869 ; David, N. Arch. Mus., t. vii, Bull., p. 12, 1871 ; Holdsw., Proc. Zool. Soc., 1872, p. 477 ; Blanford, Geol. \& Zool. Abyss., p. 435; Gould, B. Brit., vol. iv, pl. xxiii, 1873 ; Shelley, B. Egypt, p. 268 ; Ball, Stray Feathers, 1873, p. 87 ; Hume, t. c., p. 253 ; Adam., t. c., p. 399 ; Hume, 1874, p. 304; Ball, t.c., p. 434; Hume, 1875, p. 190 ; Blyth \& Walden, Journ. As. Soc., Bengal, vol. xliv, extra No. 1, p. 159, 1875 ; Irby, B. Gibr., p. 184, 1875 ; Walden, Tr. Zool. Soc., 1875, p. 237 ; Butler, Stray Feathers, 1876 , p. 23; Fairbank, t. c., p. 263; Bocage, Journ. für Ornith., 1876, p. 303 ; Hume, Stray Feathers, 1877 , p. 46.

\section{a. b. Bhamô, February 1868.}

c. † Tapeng river, February 1875 .

\section{Common throughout Upper Burma.}

\section{Genus BuPHus, Boie.}

\section{Buphus coromandus, Bodd.}

Le Crabier de Coromandel, Daub., Pl. Enl., 910, 1784.

Cancroma coromanda, Bodd., Tabl. Pl. Enl., p. 54, 1783.

Ardea r'uficapilla, Vieill., N. Dict. d'Hist. Nat., xiv, p. 409, 1817. 
Arlea bicolor, Vieill., t. c., p. 409, 1817.

Ardea coromandeliensis, Steph., Gen. Zool., xi, p. 577, 1819.

Ardea russata (pt.), Temm., Man. d’Orn., ii, p. 566, 1820.

Ardea affinis, Horsf., Tr. Linn. Soc., xiii, p. 189, 1822.

Ardea russata, Wagl., Syst. Av. drdea, sp. 12, 1827.

Aidea caboga, Frankl., Proc. Zool. Soc., 1830, p. 124.

Ardea bubulcus (pt.), Gray, Cat. Gralla, p. 82, 1844.

Ardea coromanda, Gray, Gen. B., vol. iii, p. 556, 1847; Schl., Mus. P.-B. Ardea, p. 30, 1863 ; Hume, Nests and Eggs, p. 618, 1873.

Herodias bubulccis (pt.), Blyth, Cat. B., Mus. As. Soc., Bengal, p. 280, 1849.

Bubulcus coromandus, Bonap., C. R., xl, p. 722, 1855 ; Bonap. Consp., t. ii, p. 125, 1857 ; Swinhoe, Proc. Zool. Soc., 1871, p. 412 ; Hume, Stray Feathers, 1873, pp. 256, 462 ; Adam., t. c., p. 399; Hume, Stray Feathers, 1874, pp. 309, 483 ; Ball, t. c., p. 434; Salvad., Ucc. Born., p. 350, 1874; Walden, Trans. Zool. Soc., ix, p. 237, 1875; Armstrong, Stray Feathers, 1876, p. 349 ; David \& Oust., Ois. Chine, p. 441, 1877.

Bubulcus coromandeliensis, Bonap., Consp. Av., t. ii, p. 125, 1857.

Herodias coromanda, Wall, Proc. Zool. Soc, 1863, p. 487.

Buphus coromandus, Jerdon, B. Ind., vol. iii, p. 74.9 ; Blyth \& Walden, Journ. As. Soc., Bengal, vol. xliv, extra No., p. 160, 1875; Butler, Stray Feathers, 1876, p. 23 ; Fairbank, t. c., p. 263 ; op. cit., 1877, p. 410.

a. Upper Burma, 7th October 1868.

b. Mandalay, 29th September 1868.

c. d.e. Muangla, 18th, 19th, and 22nd May 1868.

Very common throughout Upper Burma and in the Shan States of Yunnan.

Genus Ardeola, Boie.

213. Ardeola prasinosceles, Swinhoe.

Ardeola prasinosceles, Swinhoe, Ibis, 1860, p. 64; 1861, p. 52; 1863, p. 421; 1870, p. 365

Proc. Zool. Soc., 1863, p. 320; 1871, p. 413.

Ardea prasinosceles, Gray, Handl., vol. iii, p. 30, 1871.

a. Bhamô, 23rd February 1868.

\section{Genus Buto Rides, Blyth.}

\section{Butorides Javanica, Horsfield.}

Ardea javanica, Horsf., Tr. Linn. Soc., vol. xiii, p. 190, 1822 ; Less. Man., t. ii, p. 240, 1828 ; Gray, Gen. B., vol. iii, p. 556, -1847; Schl., Mus. P.-B. Ardece, p. 43, 1863 ; Pelz., Reis. Novara, Vög., p. 124, 1865; Gray, Handl. B., vol. iii, p. 31, 1871 ; Finsch \& Hartl.,

Beitr. Faun. Centralpolyn., p. 1867.

drdea chloriceps vel virescens, Hodgs., in Gray's Zool. Misc., p. 86, 1844.

didetta stagnatilis, Gould, Proc. Zool. Soc., 1847, p. 221 ; id., B. Austr., vol. vi, pl. 1xvii, 1848 ;

Reichenb., Vög. Neuholl., p. 201, 1850; id., Handb., Gralla, taf. 74, figs. 2667-68.

Ardetta macrorhyncha, Gould, Proc. Zool. Soc., 1848, p. 39 ; id., B. Austr., vol. vi, pl. lxvi, 1848 ;

Reich., Vög. Neuholl., p. 538, 1850 ; id., Handb. Gralla, taf. 75, figs. 2669-70.

Ardea 1atruetis, Peale, N. S. Expl. Exp., p. 216, 1848; Hartl., in Wiegm. Arch., 1852, p. 118. 
Ardea stagnalis, Gray, Gen. B., vol. iii, App. p. 25, 1849 ; Cass., U. S. Expl. Exp., p. 297, 1858 ; Gray, List, B. Trop. Isl., Pacific Ocean, p. 49, 1859 ; Pelz., Voy., Novara, Vög., p. 124, 1865.

Ardea macrorhyncha, Gray, Gen. B., vol. iii, App. p. 25, 1849 ; Schl., Mus. P.-B. Ardea, p. 44, 1863.

Butorides javanica, Blyth, Cat. B., Mus. As. Soc., Bengal, p. 281, 1849; Bonap. Consp., t. ii, p. 130, 1857; Jerdon, B. Ind., vol. iii, p. 752, 1862 ; Swinhoe, Ibis, 1863, p. 420 ; Gould, Handb., B. Austr., vol. ii, p. 316, 1865; Godwin-Austen, Journ. As. Soc., Bengal, vol. xxxix, p. 274, 1870; Swinhoe, Proc. Zool. Soc., 1871, p. 413; Holdsw., Proc. Zool. Soc., 1872, p. 478 ; Ball, Stray Feathers, 187., p. 85; Hume, t. c., pp. 256, 450; Adam., t. c., p. 399 ; Hume, Stray Feathers, 1874, pp. 310, 483; Ball, t. c., p. 435; Hume, Stray Feathers, 1875 , p. 191 ; id., Nests and Eggs, Ind. B., p. 620, 1873 ; Salvad., Ucc. Born., p. 351, 1874; Blyth \& Walden, Journ. As. Soc., Bengal, vol. xliv, extra No., p. 160, 1875 ; Butler, Stray Feathers, 1876, pp. 24, 35 ; t. c., Fairbank, p. 263 ; Hume, t. c., p. 405 ; id., p. 467; Sharpe, Ibis, 1876, p. 52; Tweedale, op. cit., 1877, p. 323; Walden, Trans. Zool. Soc., vol. viii, p. 100, 1874; id., op. cit., ix, p. 237, 1875.

Ardea scapularis, Schl., Faun. Japon. Aves, p. 116, 1850.

Ardetta thalassina, Kelaart, Prodr. Faun. Zeyl., p. 133, 1852.

Herodias javanica, Licht., Nomencl. Av., p. 89, 1854.

Butorides chloriceps, Bonap., Consp. Av., t. ii, p. 129, 1857.

Butorides patruelis, Bonap., t. c., p. 130.

Butorides staynatilis, Bonap., t.c., p. 130.

Butorides macrorliyncha, Bonap., t. c., p. 131, 1857 ; Gould, Handb., B. Austr., p. 317, 1865.

Ardea (Butorides) virescens, var. scapularis, Schrenk, Reis. Amurl. Vög., p. 437, 1859.

Ardeola patruelis, Schmeltz., Cat. Godeffr., t. iii, p. 3.

Buteroides javanicus, Godwin-Austen, Journ. As. Soc., Bengal, vol. xlv, 1876, p. 85; Hume, Stray Feathers, 1877 , p. 47.

a. む Sawady, 30th January 1875 .

b. ठ Bhamô, 4ith March 1875.

Common about Bhamô.

\section{Genus Nycticorax, Stephens.}

\section{Nycticorax Griseus, Linn.}

Ardea grisea, Linn., Syst. Nat., t. i, p. 239, 1766.

Ardea nycticorax, Linn., Syst. Nat., t. i, p. 235, 1766 ; Lath., Ind. Orn., ii, p. 678, 1790 ; Wils., Amer. Orn., vii, p. 101, pl. lxi, fig. 2, 1813; Temm., Man. d’Orn., p. 577, 1820; Wagl., Syst. Av., sp. 31, 1827 ; Ménétr., Cat. Rais. Zool. Caucas., p. 50, 1832 ; Naum., Vögel., t. 225, 1838 ; Demid. Voy., Bd. iii, p. 262, 1840; Yarrell, Brit. B., vol. ii, p. 485, 1843; Sundev., Svensk. Fogl., pl. lxxv, fig. 4, 1856 ; Schleg., Vög. Nederl., pl. 103, 1858; Linderm., Vög., Griechenl., p. 153, 1860.

Te Bilıreaux, Buff., Pl. Enl., t. viii, pls. 758, 759, 1783 ; Briss. Orn., t. v, p. 493, 1790 ; Stephens, Gen. Zool., vol. xi, p. 609, pl. xlvii, 1819.

Nycticorax europaus, Selby, Ill. Orn., ii, p. 39, 1833 ; Gould, B. Eur., vol.iv, pl. 279, 1837.

Nycticorax gardeni, Bonap., Comp. List., B. Eur. \& N. Amer.; p. 48, 1838 ; Macgill., Brit. B., vol.iv, p. 433, 1852.

Nycticorax griseus, Gray, Gen. B., vol. iii, p.557, 1847 ; Blyth, Cat. B., Mus. As. Soc., Bengal, p. 281, 1849 ; Brehm, Naum., 1855, p. $2: 0$; Bonap. Consp., t. ii, p. 140, 1857 ; Jaub. \& Lapomm., Rich. Orn., p. 366, 1859 ; Jerdon, B. Ind., vol. iii, p. 758, 1863 ; Loche, Expl. Sci. Alger., t. ii, p. 143, 1867; Doderl., Avif. Sicil., p. 217, 1869; David, N. Arch. Mus., t. vii, Bull., 
p. 12, 1871 ; Holdsw., Proc. Zool. Soc., 1872, p. 478; Salvad., Faun. Ital., p. 245, 1872 ; Walden, Tr. Zool. Soc., vol. viii, p. 23, 1872 ; Shelley, B. Egypt, p. 270, 1872 ; Ball, Stray Feathers, 1873, p. 88; Hume, Lahore to Yarkand, p. 296, 1873 ; Gould, B. Brit., iv, pl. xxvi, 1873 ; Ball., Stray Feathers, 1874, p. 435 ; Salvad., Ucc. Born., p. 356, 1874; Blyth \& Walden, Journ. As. Soc., Bengal, vol. xliv, ex. No., p. 161, 1875; Irby, B. Gibr., p. 187, 1875 ; Walden, Tr. Zool. Soc., vol. ix, p. 238, 1875 ; Blanford, E. Pers., p. 296, 1876.

Nyctiardea nycticorax, Swinhoe, Proc. Zool. Soc., 1871, p. 413; Gray, Handl., iii, p. 33, 1871; Hume, Nests and Eggs, Ind. B., p. 624, 1873; id., Stray Feathers, 1873, p. 256 ; id., 1875, p. 192.

$$
\text { a. b. Bhamô, 23rd February } 1868 .
$$

This bird was building on a large tree on the high bank of the river outside the Bhamô stockade. There must have been as many as fifty birds in the heronry.

\section{Family-RALLID $A$.}

\section{Genus Erчtнга, Reichenbach.}

\section{Erythra phønicura, Forster.}

Rallus phonicurus, Forster, Zool. Ind. Selc., p. 19, 1781 ; Gm., Syst. Nat., t. i, p. 340, 1788.

Fulica chinensis, Bodd., Tabl. Pl. Enl., p. 54, 1783, ex Buff. Pl. Enl., 896.

Gällinula phonicura, Lath., Ind. Orn., vol. ii, p. 770, 1790; Less., Tr. d’Orn., p. 534, 1831 ;

Mottl. \& Dilw., Contr. Nat. Hist., Lab., p. 60, 1855 ; Jerdon, B. Ind., vol. iii, p. 720, 1864 ;

Schl., M. P.-B. Ralli, p. 41, 1865 ; Pelz., Reis. Nov. Vög., p. 162, 1865 ; Gray, Handl.

B., iii, p. 67, 1871; Swinhoe, Proc. Zool. Soc., 1871, p. 414; Ball, Stray Feathers, 1874,

p. 432 ; Hume, Nests and Eggs, Ind. B., p. 599, 1873; Stray Feathers, 1873, p. 462 ; 1874, p. $300 ; 1875$, p. 187.

Gallinula erythrina, Bechst., Kurze Uebersicht, Vög., p. 471, 1811.

Porpyhyrio phonicurus, Vieill., N. Dict. d'Hist. Nat., xxviii, p. 29, 1819.

Gallinula javanicx, Horsf., Tr. Linn. Soc., vol. xiii, p. 136, 1821.

Porzana phonicura, Blyth, Cat. B., Mus. As. Soc., Bengal, p. 284, 1849 ; Sclater, Proc. Zool.

Soc., 1863, p. 223; Hume, Stray Feathers, 1873, p. 251 ; 1874, p. 483; Blyth \& Walden, Journ. As. Soc., Bengal, vol. xliv, ex No., p. 16, 1875 ; Butler, Stray Feathers, 1876, pp. 31, 35 ; Fairbank, t. c., p. 263.

Erythra phonicura, Reich., Av. Syst. Nat., p. xxi, 1852 ; Bonap., C. R., xliii, p. 600, 1856 ; Gray, Cat. Hodgs., Nepal, Coll., p. 76, I863; Walden, Tr. Zool. Soc., viii, p. 94, 1872; Salvad., Ucc. Born., p. 341, 1874; Sharpe, Proc. Zool. Soc., 1875, p. 111 ; Waiden, Tr. Zool. Soc., vol. ix, p. 229, 1875.

$$
\text { a. Bhamô, February } 1868 .
$$

Common in Upper Burma.

\section{Genus Ralitina, Reichenbach.}

\section{Ratuina fusca, Linn.}

Le Raste brun des Philippines, Briss. Orn., t. v, p. 173, pl. xv, fig. 2, 1760.

Rallus fuscus, Linn., Syst. Nat., t. i, p. 262, 1766, ex Briss.

Gallinula rubiginosa, Temm., Pl. Col., t. v, pl. 357, 1825. 
Porzana fusca, Blyth, Cat. B., Mus. As. Soc., Bengal, p. 285, 1849 ; Jerdon, B. Ind., vol. iii, p. 724, 1864; Stoliczka, Stray Feathers, 1874, p. 461 ; Blyth \& Walden, Journ. As. Soc.,

Bengal, vol. xliv, ex. No., p. 161, 1875; Walden, Tr. Zool. Soc., ix, p. 230, 1875.

Euryzona rubiginosa, Bonap., C. R., xliii, p. 599, 1856.

Rallina fusca, Schl., M. P.-B. Ralli, p. 20, 1866; Gray, Handl. B., vol. iii, p. 58, 1871; Hume,

Nests and Eggs, Ind. B., p. 604, 1873; id., Stray Feathers, 1875, p. 183.

Limnobanus fuscus, Sundev., Av. Méth. Tent., p. 131, 1873.

a. $\quad$ t Sanda valley, 26th June 1868.

b. c. o Momien, June 1868.

This is a rather common bird in the marshes, especially in those around Momien.

\section{Genus Нуротеidia, Reichenbach.}

\section{Hrpotenidia striata, Linn.}

Le Rasle rayè des Philippines, Briss. Orn., t. v, p. 167, pì. xiv, fig. 2, 1760.

Rallus striatus, Linn., Syst. Nat., t. i, p. 262, 1766, ex Briss ; Less., Traité, p. 536, 1831 ; Blyth,

Cat. B., Mus. As. Soc., Bengal, p. 285, 1849 ; Jerdon, B. Ind., vol. iii, p. 726, 1864;

Ball, Stray Feathers, 1873, p. 86.

Rallus gularis, Horsf., Tr. Linn. Soc., vol. xiii, p. 599, 1821 ; Raffles, t. c., p. 328 ; Bernst., 'Journ. für Ornith., 1861, p. 190 ; Sclater, Proc. Zool. Soc., 1863, p. 223.

Rallus indicus, Reich., Handb. Rasores, pl. 201, figs. 2575-76, 1853, ex Ven. MLS.

Hypotenidia striata, Bonap., C. R., xliii, p. 599, 1856 ; Schl., M. P.-B. Ralli, p. 24, 1865 ; Swinhoe, Proc. Zool. Soc., 1871, p. 415; Walden, Ibis, 1872, p. 382 ; id., Tr. Zool. Soc., vol. viii, p. 95, 1872 ; Hume, Stray Feathers, 1874, pp. 302, 483 ; 1875, p. 189 ; id., Nests and Eggs, Ind. B., p. 605, 1874; Walden, Tr. Zool. Soc., vol. iv, p. 232, 1875; Blyth \& Walden, Journ. As. Soc., Bengal, vol. xliv, ex. No., p. 161, 1875; Hume, Stray Feathers, 1876, p. 294; Armstrong, t.c., p. 349; W. Ramsay, Ibis, 1877, p. 471 ; Oates, op. cit., 1877, p. 165.

Eulabeornis striatus, Gray, Handl. B., vol. iii, p. 57, 1871.

$$
\text { a. Momien, June } 1868 .
$$

Common in Upper Burma and in the Sanda valley of Western Yunnan.

\section{Genus Gallinula, Brisson.}

\section{Gallindla chloropus, Linn.}

La Poule d'ean, Briss. Orn., vi, p. 3, 1760 ; Daubent., Pl. Enl., 877, 1783.

Fulica chloropus, Linn., Syst. Nat., t. i, p. 258, 1766.

Fillica albiventris, Scop. Ann., t. i, p. 105, 1768.

Fulica fusca, Gm., Syst. Nat., i, p. 697, 1788.

Frulica maculata, Gm., t. c., p. 697, 1788.

Fulica flavipes, Gm., t.c., p. 701, 1788.

Fulica fistulans, Gm., t. c., p. 702, 1788.

Gallinula chloropus, Lath., Ind. Orn., t. ii, p. 770, 1790 ; Roux, Orn. Prov., pl. 334, 1825; Werner, Atlas, Gralla, pl. i, 1827; Gould, B. Eur., vol. iv, pl. 342, 1837/; Naum., Vög. Deutschl., ix, p. 587, pl. 240, 1838; Yarr., Br. B., vol. iii, p. 28, 1843; Gray, Cat. Grallee, \&c., Brit. Mus., p. 122, 1844; id., Gen. B., vol. iii, p. 599, 1845; Blyth, Cat. B., Mus. 
As. Soc., Bengal, p. 286, 1849 ; Kjærb., Orn. Dan., tab. 38, fig. 6, 1851 ; Macgill., Br. B., iv, p. 547, 1852; Schl., Vög. Nederl., pl. 252, 1862; Hartl., Orn., Western Afr., p. 244, 1857 ; Jaub. et Barth., Lap. Rich. Orn., p. 491, 185\&; Sundev., Sv. Fogl., pl. xlv, fig. 4, 1858; Fritsch., Vög. Eur., pl. xxxv, figs. 1, 2, 1858; Jerdon, B. Ind., vol. iii, p. 718, 1864; Schl., Mus. P.-B. Ralli, p. 45, 1865 ; Layard, B. S. Afr., p. 341, 1867; Loche, Expl. Sci. Alger. Ois., t. ii, p. 347, 1867 ; Degl. et Gerbe, Orn. Eur., Bd. ii, p. 262, 1867 ; Schl. \& Poll., Faun. Madag., p. 136, 1868; Doderl., Avif. Sicil., p. 201, 1869; Finsch. \& Hartl., Vög. Ostafr., p. 787, 1870 ; Swinhoe, Proc. Zool. Soc., 1871, p. 414 ; Gray, Handl., vol. iii, p. 66, 1871 ; Salvad., Faun. Ital. Ucc., p. 232, 1871 ; Heugl., Orn., N. O. Afr., p. 1224, 1871 ; Shelley, B. Egypt, p. 275, 1872 ; Anders., B. Dam. Ld., p. 323, 1872 ; Holdsw., Proc. Zool. Soc., 1872, p. 475; Hume \& Henders., Lahore to Yarkand, p. 293, 1873 ; Severtzoff, Turkest. Jevotn., 1873, p. 69 ; Gould, B. Gt. Br., vol. iv, pl. Ixxxvi, 1873 ; Hume, Stray Feathers, 1873, p. 250 ; Adam., t. c., p. 398 ; Ball, Stray Feathers, 1874, p. 432; Stoliczka, t. c., p. 461 ; Hume, t. c., p. 483, 1875, p. 187 ; Walden, Tr. Zool. Soc., ix, p. 229, 1875 ; Blyth \& Walden, Journ. As. Soc., Bengal, vol. xliv, ex. No., p. 162, 1875 ; Hume, Nests and Eggs, Ind. B.; p. 597, 1874; Irby, Orn. Gibr., p. 144, 1875; Butler, Stray Feathers, 1876, p. 20 ; Hume, t. c., p. 192; Tacz., Bull. Soc. Zool., France, i, p. 260, 1876; Oates \& Hume, Stray Feathers, 1876, pp. 20, 35; Scully, t.c., p. 192; Godwin-Austen, Journ. As. Soc., vol. xlv, 1876, p. 84; Schalow, Journ. für Ornith., 1876, pp. 157, 188 ; Palmén, t.c., p. 51 ; Nehrkorn, t.c., p. 160 ; Bocage, t.c., p. 298 ; Wharton, Ibis, 1876 p. 27 ; Burnett, t.c., p. 213 ; Swinhoe, t.c., p. 335 ; Dresser, t. c., p. 413 ; Hartl., Vög. Madag., p. 347, 1877 ; Hume, Stray Feathers, 1877, p. 46 ; Oates, $t . c .$, p. 165 ; Butler, $t . c$. , pp. 224, 233.

Crex chloropus, Licht., Verz. Doubl., p. 79, 1823.

Rallus chloropus, Savi, Orn. Fosc., t. ii, p. 382, 1829.

Stagnicola septentrionalis, Brehm, Vög. Deutschl., p. 704, 1831.

Stagnicola chloropus, Brehm, t.c., p. 706, 1831.

Slagnicola minor, Brehm, Vogelf., p. 331, 185̋̈.

Stagnicola parvifrons, Brehm, l. c.

Stagnicola meridionalis, Brehm, l.c.

Stagnicola brachyptera, Brehm, l. c.

$$
\begin{aligned}
& \text { a. } \text { t } \text { Bhamô, 3rd February } 1868 . \\
& \text { b. 오 Muangla, 19th May } 1868 . \\
& \text { c. d. e. }
\end{aligned}
$$

Common in Upper Burma and in Western Yunnan.

$$
\text { Family-LARID } \mathbb{R} \text {. }
$$

Genus Sterna, Linn.

\section{Sterna Seena, Sykes.}

Sterna seena, Sykes, Proc. Zool. Soc., 1832, p. 171; Gray, Handl. B., vol. iii, p. 121, 1871; Ball, Stray Feathers, 1874, p. 440; Hume, Stray Feathers, 1875, p. 193; id., Nests and Eggs, Ind. B., p. 650, 1874; id., Stray Feathers, 1875, p. 193; Butler, op. cit., 1876, p. 32; Fairbank, t. c., p. 264; Hume, op. cit., 1877, p. 47.

Sterna aurantia, J. E. Gray \& Hardw., Ill. Ind. Zool., vol. ii, pl. lxix, fig. 2, 1834; G. R. Gray, Gen. B., vol. iii, p. 659, 1846; Hume, Stray Feathers, 1873, p. 281; Oates, op. cit., 1875, p. 348.

Sterna brevirostris, J. E. Gray \& Hardw., Ill. Ind. Orn., pl. lxix, fig. 1, 1834. 
Sterna roseata, Hodgs., in J. E. Gray's Zool. Misc., p. 86, 1844.

Sylochelidon seena, G. R. Gray, Cat. Anseres, B. M., p. 175, 1844 ; id., Cat. Mamm., \&c., Nepal, coll. Hogs., p. 148, 1856.

Seena aurantia, Blyth, Cat. B., Mus. As. Soc., Bengal, p. 291, 1849 ; Bonap., C. R., xliii, p. 772, 1856 ; Jerdon, B. Ind., vol. iii, p. 838, 1864; Blasius, Journ. für Ornith., 1866, p. 73; Godwin-Austen, Journ. As. Soc., Bengal, 1870, p. 275 ; Holdsw., Proc. Zool. Soc., 1872, p. 483 ; Blyth \& Walden, Journ. As. Soc., Bengal, vol. xliv, ex. No., p. 163, 1875.

Seena seena, Hume, Stray Feathers, 1874, p. 484.

$$
\begin{aligned}
& \text { a.b. ‡ Bhamô, 20th January } 1875 .
\end{aligned}
$$

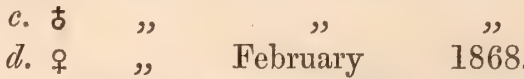

$$
\begin{aligned}
& \text { e. } \text { t Tapeng river, 3rd February } 1875 .
\end{aligned}
$$

Common about Bhamô in old river-courses.

\section{Sterna Javanica, Horsfield.}

Sterna javanica, Horsf., Tr. Linn. Soc., vol. xiii, p. 198, 1821 ; Blyth, Cat. B., Mus. As. Soc., Bengal, p. 292, 1849 ; Jerdon, B. Ind., vol. iii, p. 840, 1864; Hume, Nests and Eggss, 1873, p. 652; Adam, Stray Feathers, 1874, p. 339; Hume, Stray Feathers, 1875, p. 282 ; Oates, Stray Feathers, 1877, p. 169

Sterna melanogaster, Temm., Pl. Col., 434, 1827 ; Horsf., Cat. Java Birds in Zool. Res. in Java, 1824:1 Gray, Cat. Anseres, B. M., p. 179, 1844; Burgess, Proc. Zool. Soc., 1855, p. 184; Gould, B. Asia, pt. xix, 1867; Holdsw., Proc. Zool. Soc., 1872, p. 481 ; Blyth \& Walden, Journ. As. Soc., Bengal, vol. xliv, ex. No., p. 163, 1875 ; Hume, Stray Feathers, 1876, p. 40 ; id., p. 224; Godwin-Austen, Journ. As. Soc., Bengal, vol. xlv, p. 85.

Stema acuticauda, Gray \& Hardw., Ill. Ind. Zool., pl. lxx, fig. 3, 1834.

Hydrochelidon melanogaster, Gray, Gen. B., vol. iii, p. 660, 1846 ; Bonap., C. R., xlii, p. 773, 1856. Sterna melanogastra, Schl., M. P.-B. Sterna, p. 21, 1863 ; Salvad., Uec. Born., p. 378, 1874. Sternula melanogastra, Blasius, Journ. für Ornith., 1866, p. 74.

Hydrochelidon javanica, Gray, Gen. B., iii, p. 660, 1846 ; id., Handl. B., iii, p. 122, 1872. Pelodes javanica, Ball, Stray Feathers, 1874, p. 440 ; Hume, Stray Feathers, 1875, p. 193.

$$
\begin{array}{ccc}
\text { a. b. } \text { 广 ; c. ㅇ Bhamô, 20th January } 1875 . \\
\text { d. 우 } \\
\text { e. }
\end{array}
$$

\section{Genus HYDROCHELID ON, Boie.}

\section{Hydrocheltidon hybrida, Pallas.}

Sterna hybrida, Pall., Zoogr. Rosso.-Asiat., vol. ii, p. 338, 1811 ; Schl., M. P.-B., Sterna, p. 32, 1863 ; Oates, Stray Feathers, 1875, p. 348.

Sterna leucopareia, Temm., Man. d'Orn., ii, p. 746, 1820, ex Natt. M. S.; Werner, Atlas, Palmipides, pl. vii, 1827; Müll., Naturl. Gesch. Land. en Volkenk., p. 125, 1839-44, Naum., Vög. Deutschl., Bd. x, pl. 255, 1840 ; Yarr., Br. B., vol. iii, p. 404, 1843; Gould, B. Eur., vol. v, pl. 424, 1848.

Sterna grisea, Horsf., Trans. Linn. Soc., vol. xiii, p. 199, 1821.

Sterna delamottei, Bonn. et Vieill., Enc. Méth., t. i, p. 350, 1823.

\footnotetext{
1 On this date and its coincidence, cf. Salvadori, l.c.
} 
Tiralva indica, Steph., Gen. Zool., xiii, p. 109, 1826.

Pelodes leucopareia, Kaup., Natuirl. Syst., p. 107, 1829.

Sterna similis, Gray \& Hardw., I1l. Ind. Zool., pl. lxx, fig. 2, 1834.

Hydrochelidon fuviatilis, Gould, Proc. Zool. Soc., 1842, p. 140 ; id., B. Austr., vol. vii, pl. xxxi, 1848; Gray, Handl, B., vol. iii, p. 122, 1871.

Hydrochelidon grisea, Gray, List Anseres, B. M., p. 180, 1844; id., Gen. B., vol. iii, p. 660, 1846.

Hydrochelidon indica, Gray, List Anseres, B. M., p. 180, 1844; id., Gen. B., iii, p. 660, 1846; Blyth, Cat. B., Mus. As. Soc., Bengal, p. 290, 1849 ; Bonap., C. R., xlii, p. 773, 1856 ; Jerdon, B. Ind., vol. iii, p. 837, 1864; Gray, Handl. B., iii, p. 121, 1871 ; Ball, Stray Feathers, 1875, p. 294; Hume, Nests and Eggs, Ind. B., p. 648, 1874; Blyth \& Walden, Journ. As. Soc., Bengal, vol. xliv, ex. No., p. 163, 1875 ; Butler, Stray Feathers, 1876, p. 32 ; Hume, $t . c$, p. 224.

Hydrochelidon similis, Gray, Gen. B., vol. iii, p. 660, 1846.

Hydrockelidon hybrida, Gray, Gen. B., vol. iii, p. 660, 1846; Bonap.; C. R., xlii, p. 773, 1856 ; Jaub. \& Barth., Lap. Rich. Orn., p. 398, 1859 ; Fritsch., Vög. Eur., pl. liv, fig. 10, 1866 ; Blas., Journ. für Ornith., 1866, p. 82 ; Degl. \& Gerbe, Orn. Eur., Bd. ii, p. 468, 1867 ; Doderl., Avif. Sicil., p. 253, 1869 ; Gray, Handl. B., vol. iii, p. 121, 1871 ; Swinhoe, Proc. Zool. Soc., 1871, p. 421 ; Salvad., Faun. Ital. Ucc., p. 283, 1872 ; id., Ucc. Born., p. 372, 1874 ; Dresser, Ibis, 1876, p. 416 ; Oates, Stray Feathers, 1877, p. 235 ; Heugl., Orn., N. O. Afr., Bd. iii, p. 1449, 1874; Cones, B. N. W., p. 784, note, 1874; Irby, B. Gibr., p. 211, 1875.

Hydrochelidon leucopareia, Macgill., Br. B., vol. v, p. 663, 1852 ; Gould, B. Gt. Br., v, pl. Ixxvii ; id., Handb., B. Austr., vol. ii, p. 400, 1865 ; Shelley, B. Egypt, p. 301, 1872 ; Holdsw., Proc. Zool. Soc., 1872, p. 480 ; Walden, Trans. Zool. Soc., vol. viii, p. 103, 1872, et ix, p. 244, 1875 .

Hydrochetidon leucogenys, Brehm, Naum., 1855, p. 295.

Hydrochelidon delalandii, Bonap., C. R., xlii, p. 773, 1856 ; Gray, Handl. B., vol. iii, p. 122.

Pelodes hybrida, Gurney in Anderss. B. Dam. Ld., p. 362, 1872.

Hydrochelidon leucopareius, Severtzoff, Turkest. Jevotn., 1873, p. 70.

a \&. b. Bhamô, February 1863.

Common at Bhamô in February.

\section{Order NATATORES.}

Family-PELECANIDA.

Genus Pelecanus, Linn.

223. Pelechanus philippinensis, Gmelin.

Le Pélican des Philippines, Briss. Orn., t. vi, p. 527, pl. xlvi, 1760 ; Buff., Pl. Enl., 965, 1783.

Le Pélican brun de l'isle de Luçon, Sonn., Voy. N. Guin., pl. liii, 1776.

Je Pélican rose de l’isle de Luçon, Sonn., Voy. N. Guin., pl. liv, 1776.

Rose-coloured Pelican, Lath., Gen. Syn., vol. iii, p. 579, 1785.

Pelecanus roseus, Gm., Syst. Nat., t. i, p. 570, ex 1788, ex Sonn., pl. liv; Salvad., Ucc. Born., p. $363,18 \pi 4$.

Pelecanus manillensis, Gm., Syst. Nat., i, p. 571, 1788, ex Sonn., pl. liii.

Felecanus philippinus, Gm., Syst. Nat., t. i, p. 571, 1788, ex Briss. ; Gray, Gen. B., iii, p. 668, 1845 ; Blyth, Cat. B., Mus. As. Soc., Bengal, p. 297, 1849 ; Gray, Cat. Mamm., \&c., Nepal, Hodgs., p. 148, 1856; Bonap. Consp., ii, p. 162, 1857 ; Schl., M. P.-B. Pelecani, p. 33, 1863 ; Jerdon, 
B. Ind., vol: iii, p. 858, 1864; Sclater, Proc. Zool. Soc., 1868, p. 268, et 1871, p. 633 ; Swinhoe, l. c., p. 420 ; Bocage, Journ. Lisb., 1871, p. 174; Hume, Stray Feathers, 1873, p. 288 ; 1874, p. 324; 1875, p. 194; Blyth \& Walden, Journ. As. Soc., Bengal, vol. xliv, ex. No., p. 164, 1875; Hume, Nests and Eggs, p. 658, 1875 ; Butler \& Hume, Stray Feathers, 1876, p. 33; Hume, t.c., p. 224; t.c., p. 279 ; Hume, op. cit., 1877, p. 169 ; Oates, t. c., p. 235. Pelecanus rufescens (pt.), Elliot, Proc. Zool. Soc., 1869, p. 584.

$$
\begin{aligned}
& \text { a. \&. b. Bhamô, 12th September } 1868 . \\
& \text { c. \& } d \text {. Molay river, 7th September } 1868 .
\end{aligned}
$$

I shot four specimens of this species on the Upper Irawady, where they were very abundant in the month of September. I had passed over the same ground on the previous February without seeing any, but in September, in favourite haunts, they were gathered in large flocks. At the mouth of the Molay river, a few miles above Bhamô, there was in September a pelicanry occupying about four or five large, but not very high trees, which were white with these birds.

Among the above birds there is but one adult.

Family-GRACULID AR.

\section{Genus Phatacrocorax, Brisson.}

\section{Phalacrocorax carbo, Linn.}

The Cormoran, Briss. Orn., t. vi, p. 511, 1760 ; Buff., Pl. Enl., ix; pl. 927.

Pelecanus carbo, Linn., Syst. Nat., t. i, p. 216, 1766.

Carbo cormoranus, Meyer \& Wolf, Tasch. Deutschl., Bd. ii, p. 576, 1810; Ménétr., Cat. Rais. Zool. Caucase, p. 55, 1832.

Phalacrocorax carbo, Leach, Syst. Cat. Mamm., \&c., B. M., p. 34, 1816; Steph. Gen. Zool., vol. xiii, p. 76, 1826 ; Gould, B. Eur., vol. v, pl. 407, 1837; Audub., B. Amer., t. vii, p. 123, pl. 4i15, 1842 ; Bonap. Consp., t. ii, p. 168, 1857; Hartl., Orn., W. Afr., p. 259, 1857; Schrenk, Reis. Amurl., p. 488, 1859 ; Radde, Reis. Sibir., p. 379, 1863 ; Degl. \& Gerbe, Orn., Eur., vol. ii, p. 352, 1867 ; Doderl., Avif. Sicil., p. 224, 1869 ; Swinhoe, Proc. Zool. Soc., 1871, p. 420; Shelley, B. Egypt, p. 295, 1872; Gould, B. Brit., v, pl. lii, 1873 ; Sharpe, Voy. Erebus \& Terror, Birds, p. 37 ; Dresser, Ibis, 1876, p. 414; Schalow, Journ. für Ornith., 1876, p. 5.

Hydrocorax carbo, Vieill., N. Dict. d'Hist. Nat., t. viii, p. 83, 1817.

Pelecanus sinensis, Shaw \& Nodder., Nat. Misc., vol. xiii, pl. 529 (c. 1820).

Phalacrocorax nova-hollandia, Steph. Gen. Zool., vol. xiii, p. 93, 1826; Bonap. Consp., t. ii, p. 169, 1857 ; Buller, B., N. Zeal., p. 325, 1873.

Carbo leucogaster, Meyer, N. Act. N. Cuv., 1833, pl. xxii.

Cormoranus crassirostris, Baillon, Mém. Soc. Abbev., 1834, p. 77.

Phalacrocorax carboides, Gould, Proc: Zool. Soc., 1837, p. 156 ; id., B. Austr., vol. vii, pl. Ixvi, 184.8.

Phalacrocorax medius, Nilss., Skand. Faun., t. ii, p. 478, 1835.

Haliaus cormoranus, Naum., Vög. Deutschl., Bd. xi, p. 52, 1842.

Graculus carbo, Gray, Gen. B., vol. iii, p. 667, 1845; Reichenb., Handb. Natat., figs. 362-65, 1855 ; Baird, B. N. Amer., p. 876, 1858; Jerdon, B. Ind., vol. iii, p. 867, 1863 ; Schl., Mus. P.-B. Pelecani, p. 6, 1863; Layard, B. S. Afr., p. 380, 1867 ; Godwin-Austen, Journ. As. Soc., Bengal, xxxix, p. 275, 1870 ; Gray, Handl. B., iii, p. 127, 1871; David, N. Arch. Mus., vii, Bull., p. 14, 1871 ; Hume, Stray Feathers, 1873, p. 289; Adam., t. c., p. 403 ; 
Ball, Stray Feathers, 1874, p. 440; Stoliczka, t.c., p. 465; Hume, t. c., p. 484; Stoliczka, Stray Feathers, 1875, p. 220 ; Brooks, t.c., p. 257 ; Oates, t. c., p. 349 ; Hume, Nests and Eggs, Ind. B., p. 659, 1874; Blyth \& Walden, Journ. As. Soc., Bengal, vol. xliv, extra No., p. 164, 1875 ; Blanford, East. Persia, p. 298, 1876; Butler \& Hume, Stray Feathers, 1876, p. 33 ; Scully, t. c., p. 204; Hume, t. c., p. 224; Oates, op. cit., 1877, p. 169; Butler, l. c., pp. 225, 235.

Carbo graculus, Pucher., Rev. Zool., 1850, p. 631.

Carbo filamentosus, Temm. \& Schl., F. J. Aves, p. 129, 1850.

Carbo capillatus, Temm. \& Schl., F. J. Aves, pls. lxxxiii, lxxxiv, 1853.

Phalacrocorax capillatus, Bonap., Consp. Av., t. ii, p. 168, 1857.

Phalacrocorax macrorhynchus, Bonap., t. c., p. 169, 1857.

Phalacrocorax sinensis, Bonap., t. c., p. 169, 1857.

Graculus sinersis, Jerdon, B. Ind., vol. iii, p. 862, 1863; Butler, Stray Feathers, 1876, p. 33 .

Carbo phalacrocorax var. continentalis, Severtzoff, Turkest. Jevotn., 1873, p. 414.

\section{a. Bhamô, July 1868.}

This species is comparatively rare in Upper Burma, as compared with the smaller cormorant.

\section{Phatacrocorax pygmeus, Pallas.}

Pelecanus pygmaus, Pall., Reis., t. ii, Anhang., p. 712, 1773.

Phalacrocorax pygmaus, Pall., Zoogr. Rosso-Asiat., vol.ii, p. 300, pl.1xxiv, 1811 ; Gould, B. Eur., v, pl. 409, 1837; Demid., Voy. Russ. Mérid., iii, p. 303, 1840 ; Brehm, Naum., 1855, p. 296 ; Linderm., Vög. Griechenl., p. 167, 1860; Filippi, Viagg. Pers., p. 352, 1865 ; Degl. et Gerbe, Orn. Eur., Bd. ii, p. 356, 1867; Doderl., Avif. Sicil., p. 227, 1869; Shelley, B. Egypt, p. 295, 1872 ; Dresser, B. Eur., pt. lii, 1877.

Carbo pygmaus, Temm., Man. d’Orn., 1815, p. 591.

Hydrocorax pygmaus, Vieill., N. Dict. d'Hist. Nat., p. 88, 1817.

Hydrocorax niger, Vieill., t. c., p. 88, 1817.

Carbo javanicus, Horsf., Tr. Linn. Soc., vol. xiii, p. 197, 1822.

Carbo melanognathus, Brandt, Bull. Acad. Sci., St. Petersb., Bd. iii, p. 57, 1838.

Halicus pygmæus, Naum., Vög. Deutschl., xi, p. 112, taf. 281, 1842; Bonap. Consp., t. ii, p. 179, 1857; Loche, Expl. Sci. Alger., t. ii, p. 166, 1867.

Graculus pygmaus, Gray, Gen. B., vol. iii, p. 667, 1849 ; Blyth, Cat. B., Mus. As. Soc., Bengal, p. 298, 1849; Gray, Handl. B., vol. iii, p. 129, 1871; Blyth \& Walden, Journ. As. Soc., Bengal, vol. xliv, extra No., p. 164, 1875; Blanford, East. Pers., p. 298, 1876 ; Fairbank, Stray Feathers, 1876, p. 264; Hume, Stray Feathers, 1877, p. 47 ; Oates, t. c., p. 170.

Carbo niepcii, Malh., Faun. Orn. Alger., p. 38, 1855.

Microcarbo pygmaus, Bonap., Cat. Parzud., p. 10, 1856 ; Salvad., Ucc. Born., p. 366, 1874.

Halicus melanognathus, Bonap. Consp., t. ii, p. 179, 1857.

Haliaus algeriensis, Bonap., t. c., p. 179, 1857.

Hatiaus javanicus, Bonap., t. c., p. 179, 1857.

Haliaus niger, Bonap., $t$. c., p. 179, 1857.

Graculus javanicus, Jerdon, B. Ind., vol. iii, p. 863, 1864; Godwin-Austen, Journ. As. Soc., Bengal, vol. xxxix, p. 275, 1870; Holdsw., Proc. Zool. Soc, 1872, p. 483; Butler \& Hume, Stray Feathers, 1876, p. 34.

Graculus melanognathos, Hume, Stray Feathers, 1873, p. 289 ; Adam., t. c., p. 403 ; Hume, 1874, p. 484; id., Nests and Eggs, Ind. B., p. 660, 1874; id., Stray Feathers, 1875, p. 194.

a. Tapeng, 1st March 1868.

๖. c. Muangla, 22nd May 1868. 
At the latter locality this species was occupying a large tree along with H. garzetta and H. egrettoides. It is very common in the Sanda valley, but I did not observe it at Momien.

\section{Family - PLOTID AE.}

Genus Plotus, Iinn.

\section{Plotus melanogaster, Forster.}

Anhinga melanogaster, Forst., Ind. Zool., p. 22, pl. xii, 1781.

Plotus melanogaster, Gm., Syst. Nat., t. i, p. 580, 1788; Lath., Ind. Ornith., vol. ii, p. 865, 1790 ; Horsf., Tr. Zool. Soc., vol. xiii, p. 198, 1821 ; Raffles, t. c., p. 330 ; Gray, List, Gralla, \&c., B. M., p. 181, 1846 ; id., Gen. B., iii, p. 66,1848 ; Blyth, Cat. B., Mus. As. Soc., Bengal, p. 299, 1849 ; Bonap. Consp., t. ii, p. 181, 1855 ; Schl., M. P.-B., Pelecani, p. 26, 1863 ; Jerdon, B. Ind., vol. iii, p. 865, 1864; Gray, Handl. B., vol. iii, p. 125, 1871 ; Walden, Tr. Zool. Soc., vol. viii, p. 106, 1872 ; Hume, Stray Feathers, 1873, p. 289 ; Adam., t. c., p. 403; Ball, Stray Feathers, 1874, p. 440 ; Hume, t. c., p. 484; Salvad., Ucc. Born., p. 367, 1874; Hume, Nests and Eggs, Ind. B., p. 661, 1874; id., Stray Feathers, 1875, p. 194; Blyth \& Walden, Journ. As. Soc., Bengal, ex. No., p. 165, 1875 ; Walden, Trans. Zool. Soc., vol. ix, p. 247, 1875 ; Butler \& Hume, Stray Feathers, 1876, pp. 34, 35; Fairbank, t. c., p. 264; Hartl., Ibis, 1877, p. 335 ; Oates, Stray Feathers, 1877, p. 170.

Plotus nova-hollandice, Gould, Proc. Zool. Soc., 1847, p. 34; id., B. Austr., vii, pl. 1xxv, 1848; Gray, Gen. B., vol. iii, p. 664, pl. 184, 1848 ; Bonap., Consp. Av., t. ii, p. 181, 1855 ; Gould, Handb. B., Austr., vol. ii, p. 496, 1865; Pelz., Reis. Nov. Vög., p. 156, 1865 ; Gray, Handl. B., vol. iii, p. 125, 1871.

a. Bhamô, 6th February 1868.

In February I observed a large flock of this bird roosting on a high tree overlooking the Irawady. At other times I observed many isolated birds.

\section{Family-ANATID AE.}

\section{Genus Anser, Linn.}

\section{Anser Indicus, Lath.}

Barred-headed Goose, Lath., Gen. Syn. Suppl., p. 277, 1787.

Anas indica, Lath., Ind. Orn., vol. ii, p. 839, 1790.

Anser undulatus, Bonn. et. Vieill., Enc. Méth., t. iii, p. 114, 1823.

Anser indicus, Steph. Gen. Zool, volt xii, pl. ii, p. 36, 1824; Gould, Cent. Himal. B., pl. Ixxx, 1832 ; Eyton, Monogr. Anat., p. 90, 1838 ; Jerdon, B. Ind., vol. iii, p. 782, 1864; Schl.,

Mus. P.-B. Anseres, p. 114, 1866 ; Gray, Handl. B., vol. iii, p. 75, 1871 ; Hume, Stray

Feathers, 1873, p. 260 ; Adam., t.c., p. 401 ; Hume, Nests and Eggs, Ind. B., p. 636, 1873 ;

Hume, Stray Feathers, 1876, pp. 27, 40 ; id., p. 499; Dresser, Ibis, 1876, p. 419.

Anser skorniakovi, Severtzoff, Turkest. Jevotn., 1873, p. 419.

Eulabeia indicus, Ball, Stray Feathers, 1874, p. 436.

\section{a. T Tsitkaw, March 1868 .}


Occasionally large flocks of this bird were observed at various parts of the Irawady above Mandalay, and on the sand banks in the Tapeng and on the old rice flats behind the village.

\author{
Genus Anas, Linn.
}

\title{
228. ANAS PECILORHYNCHA, Forster.
}

Anas precitorhyncha, Forst., Indische Zool., p. 23, pl. xiii, 1781; Eyton, Monogr. Anat., p. 138, 1838 ; Blyth, Cat. B. Mus., As. Soc., Bengal, p. 304, 1849 ; Jerdon, B. Ind., vol. iii, p. 799, 1863 ; Schl., Mus. P.-B. Anseres, p. 43, 1866 ; Holdsw., Proc. Zool. Soc., 1872, p. 479 ; Hume, Stray Feathers, 1873, p. 261 ; Adam., t. cit., p. 402; Hume, Nests and Eggs, Ind. B., p. 643, 1873; Blyth \& Walden, Journ. As. Soc., Bengal, vol. xliv, ex. No., p. 165, 1875 .

Spotted-billed Duck, Lath., Gen. Syn., vol. iii, pt. 2, p. 487, 1785.

Anas pakilorlyncha, Gm., Syst. Nat., t. i, p. 535, 1788, ex Lath.; Gray, Handl. B., vol. iii, p. 82, 1871 .

Mareca pœcilorhyncha, Steph. Gen. Zool., vol. xii, p. 134, 1824.

a. t Bhamô, 20th February 1868.

b. t Tamilone, Tapeng river, 4th February 1875.

This duck does not appear to be uncommon in Upper Burma, but it is not so numerous as in the North-West Provinces of India.

\section{Genus Tadorna, Leach.}

\section{Tadorna casarca, Linn.}

Anas casarca, Linn., Syst. Nat., t. iii, App. p. 224, 1768.

Anas rutila, Pall., N. Comm. Petrop., t. xiv, p. 579, 1770 ; Temm. Man., t. iii, p: 832, 1822 ; Werner, Atlas, Palimpides, pl. xxx, 1827; Nordm., in Demid. Voy. Russ. Merid., p. 286, 1840; Naum., Vög. Deutschl., pl. 299, 1842; Yarr., Brit. B., vol. iii, p. 137, 1843; Kjœrb. Orn. Dar., pl. xlviii, 1854; Sund., Sv. Fogl., pl. 1xxxiii, fig. 1, 1856 ; Radde, Reis. Sibir., p. 361, 1863 ; Severtzoff, Turkest. Jevotn., 1873, p. 70 ; Palmén, Journ. für Ornith., 1876, p. 56.

Anas casarca, Gm., Reise., t. ii, p. 182, 1774; Savign., Descr. de l'Egypte, pl. x, fig. 2 ; Schl., Mus. P.-B. Anseres, p. 66, 1866.

Anser casarca, Vieill., N. Dict. d'Hist. Nat., xxiii, p. 341, 1818.

Podorna mutila, Boie, Isis, 1822, p. 563 ; Gould, B. Eur., v, pl. 358, 1837; Shelley, B. Egypt p. 282, 1872 ; Harting, Handb., Brit. B., p. 157, 1873 ; Gray, B. West Scotl., p. 361, 1873 ; Irby, Orn. Gibr., p. 197, 1875 : Dresser, Ibis, 1876, p. 419.

Casarka rutila, Bonap., Comp. List. B. Eur. \& N. Am., p. 56, 1838; Eyton, Monogr. Anat., p. 106, 1838 ; Blyth, Cat. B., Mus. As. Soc., Bengal, p. 303, 1849; Salvin, Ibis, 1859, p. 362 ; Jerdon, B. Ind., vol. iii, p. 791, 1864; Loche, Expl. Sci. Alger., t. ii, p. 366, 1867 ; Layard, B. S. Afr., p. 350, 1867 ; Fritsch., Vög. Eur., pl. xlvii, fig. 9, 1878; Gray, Handl. B., vol. iii, p. 80, 1871 ; Swinhoe, Proc. Zool. Soc., 1871, p. 418; Salvad., Faun. Ital. Ucc., p. 256, 1872 ; Heugl., Orn. N. O. Afr., p. 1306, 1874; Hume, Stray Feathers, 1873, p. 261 ; Adam., t. c., p. 401; Ball, Stray Feathers, 1874, p. 437; Hume, Stray Feathers, 1875, p. 193 ; Blyth \& Walden, Journ. As. Soc., Bengal, vol. xliv, extra No., p. 165, 1875 ; Oates \& Butler, Stray Feathers, 1877, p. 234; Hume, Stray Feathers, 1876, p. 28 ; Scully, t. c., p. 198 ; Fairbank, t. c., p. 264 .

Tulpanser rutila, Keys. \& Blas., Wirb. Eur., p. 84, 1840. 
Tadorna casarca, Macg., Brit. B., vol. ii, p. 163, 1842 ; Degl. \& Gerbe, Orn. Eur., t. ii, p. 501, 1867; Doderl., Avif. Sicil., p. 257, 1869 ; Dresser, B. Eur., pt. xlii, 1875.

Anas aurantia, Marsil., Danub., v, pl. liv (teste von Heuglin).

a. b. to ㅇ Sand banks of Tapeng river, 4th February 1875.

Common about Bhamô and in the Sanda valley.

Genus Spatula, Boie.

230. Spatula clypeata, Linn.

Le souchet, Buff., Pl. Enl., 971, 972, 1786.

Anas clypeata, Linn., Syst. Nat., t. i, p. 200, 1766 ; Gm., Syst. Nat., t. i, p. 518, 1788 ; Ménétr., Cat. Rais. Zool. Caucas., p. 57, 1832 ; Demid. Voy., Bd. iii, p. 289, 1840 ; Yarrell, Brit. B., vol. iii, p. 147, 1843 ; Middend., Reis., p. 233, 1851 ; Sundev., Svensk. Fogl., Iviii, p. 6, 1856 ; Schleg., Vög. Nederl., pl. 295, 1858; Schrenck, Reis., p. 481, 1859 ; Radde, p. 373, 1863; David, N. Archives Mus., t. vii, p. 13, 1871; Severtzoff, Turkest. Jevotn., 1873, p. 70; Palmén, Journ. für Ornith., 1876, p. 56.

Rhynchaspis clypeata, Steph., in Shaw's Gen. Zool., vol. xii, pt. 2, p. 115, 1824; Gould, B. Eur., pl. 360, 1837 ; Macgill., B. Brit., vol. v, p. 74, 1852 ; Brehm, Naum., 1855, p. 298; Linderm., Vög. Griech., p. 162, 1860; Loche, Explor. Sci. Alger., t. ii, p. 374, 1867 ; Shelley, B. Egypt, p. 285, 1872.

Spatula clypeata, Flem., Brit. Anim., p. 123, 1828; Gray, Gen. B., vol. iii, p. 615, 1845; Blyth, Cat. B., Mus. As. Soc., Bengal, p. 303, 1849 ; Jerdon, B. Ind., vol. iii, p. 796, 1864; Degl. \& Gerbe, Orn. Eur., Bd. ii, p. 503, 1867 ; Doderl., Avifi. Sicil., p. 257, 1869; Godwin-Austen, Journ. As. Soc., Bengal, vol. xxxix, p. 275, 1870 ; Gray, Handl. B., vol. iui, p. 85, 1871 ; Swinhoe, Proc. Zool. Soc., 1871, p. 418 ; Salvad., Faun. Ital., p. 257, 1871 ; Holdsw., Proc. Zool. Soc., 1872, p. 479 ; Hume, Stray Feathers, 1873, p. 260 ; Adam., t.c., p. 402 ; Gould, B. Brit., vol. v, pl. xiv, 1873 ; Heugl., Orn., N. O. Afr., p. 1331, 1873 ; Ball, Stray Feathers, 1874, p. 437 ; Stoliczka, t. c., p. 465 ; id., 1875, p. 220 ; Irby, B. Gibr., p. 197, 1875 ; Blanford, East. Pers., p. 301, 1876; Butler \& Hume, Stray Feathers, 1876, p. 28 ; Scully, t. c., p. 199; Fairbank, t. c., p. 264; Dresser, Ibis, 1876, p. 420 ; Butler, Stray Feathers, 1877, p. 234 .

Clypeata macrorhynchus, platyrhynchus, pomarina et brachyrhynchus, Brehm, Handb. Nat. Vög. Deutschl., pp. 876 and 879, 1831.

$$
\begin{aligned}
& \text { a. 古 Bhamô, January } 1868 . \\
& \text { b. \& Banks of Tapeng river, 3rd February } 1875 \text {. }
\end{aligned}
$$

Not uneommon in suitable localities.

\section{Genus Querquedula, Stephens.}

\section{Querquedula CReCCA, Linn.}

La petite Sarcelle, Briss. Orn., t. vi, p. 436, 1760 ; Buff., Pl. Enl., x, pl. xciv.

Anas crecca, Linn., Syst. Nat., t. i, p. 204, 1766 ; Ménétr., Cat. Rais. Zool. Caucase, p. 57, 1832 ; Nordm., in Demid. Voy. Brissee Mer., Bd. iii, p. 290, 1840 ; Yarrell, Br. B., vol. iii, p. 185, 1843; Middend., Sibir. Reis., p. 238, 1851 ; Schl. \& Susem., Vög. Eur., pt. xii, taf. 1, 1854; Sundev., Sv. Fogl., pl. lix, fig. 5, 1856 ; Schl., Vög. Nederl., pl. 296, 1858; Jaub. et Barth., Lapomm. Rich. Orn., p. 515, 1859 ; Schrenk, Reis. Amurl., p. 474, 1839 ; Linderm., Vög. 
Griechenl., p. 161, 1860; Radde, Reis. Sibir., Bd. ii, p. 367, 1863; Severtzoff, Turkest. Jevotn., 1873, p. 70 ; Blyth \& Walden, Journ. As. Soc., Bengal, vol. xliv, extra No., p. 166, 1875 ; Schalow, Journ. für Ornith., 1876, p. 13 ; Palmén, $\ell$. c., p. 57.

Querquedula crecca, Steph. Gen. Zool., vol. xii, p. 146, 1826; Gould, B. Eur., vol. v, pl. 362, 1837; Gray, Gen. B., vol. iii, p. 616, 1845 ; Blyth, Cat. B. Mus., As. Soc., Bengal, p. 305, 1849 ; Macgill., Br. B., v, p. 48, 1852 ; Jerdon, B. Ind., vol. iii, p. 806, 1864; Loche, Expl. Sci. Alger., t. ii, p. 378, 1867; Degl. et Gerbe, Orn. Eur., Bd. ii, p. 521, 1867 ; Doderl., Avif. Sicil., p. 263, 1869; Godwin-Austen, Journ. As. Soc., Bengal, vol. xxxix, p. 275, 1870 ; Blanford, Geol. \& Zool. Abyss., p. 438, 1870; Gray, Handl. B., vol. iii, p. 83, 1871; Swinhoe, Proc. Zool. Soc., 1871, p. 418; Sharpe \& Dresser, B. Eur., pt. 1, 1871 ; Holdsw., Proc. Zool. Soc., 1872, p. 479 ; Shelley, B. Egypt, p. 286, 1872 ; Salvad., Faun. Ital., p. 262, 1872 ; Henders. \& Hume, Lahore to Yarkand, p. 297, 1873; Gould, B. Gt. Br., vol. v, p. 16, 1873; Hume, Stray Feathers, 1873, p. 262 ; Adam., t. c., p. 402; Ball, Stray Feathers, 1874, p. 438; Stoliczka, t. c., p. 465 ; Irby, B. Gibr., p. 201, 1875 ; Hume, Stray Feathers, 1875, p. 193 ; Blanford, East. Pers., p. 301, 1876; Wharton, Ibis, 1876, p. 28 ;

Dresser, t.c., p. 419 ; Hume, Stray Feathers, 1877, p. 47 ; Butler, t. c., p. 234.

Nettion crecca, Kaup., Natürl. Syst., p. 95, 1829.

Querquedula subcrecca, Brehm, Vög. Eur., p. 885, 1831.

Querquedula creccoides, id., t. c., p. 885, 1831.

\section{a. Bhamô, 6th February 1868.}

b. Tamilone, 3rd February 1875.

Common in the old river-courses about Bhamô, and along the Tapeng, and in the Sanda valley.

\section{Querquedula falcata, Pallas.}

Anas falcata, Pallas (Georgi), Reise. Russ. Reichs., p. 167, 1775 ; Brandt, Descr. et 1cones, Anim. Ross. Nov. Aves, fasc. i, pl. iii, 1836 ; Bree, B. Eur., iv, p. 150, 1866 ; Schl., Mus. P.-B. Anseres, p. 72, 1866 ; Midd., Sibir. Reise, p. 231, taf. xxi, fig. 2, 1867.

Anas falcaria, Pall., Reise. Russ. Reichs., t. iii, p. 701, 1776.

Querquedula falcaria, Eyton, Monogr. Anat., p. 126, 1838.

Querquedula falcata, Bonap., Rev. Crit. Orn., Eur. Degl., p. 193, 1850; Degl. \& Gerbe, Orn., Eur., Bd. ii, p. 526, 1867; Sharpe \& Dresser, B. Eur., pt. ii, 1871 ; Gray, Handl. B., vol. iii, p. 84, 1871 ; Hume, Stray Feathers, 1876, p. 225.

Eunetta falcata, Bonap., Compt. Rend., xliii, p. 650, 1856 ; Swinhoe, Proc. Zool. Soe., 1871, p. 419.

Anas (Querquedula) falcata, Schrenck, Reise. Amurl., p. 476, 1859 ; Radde, Reise. Ost., Sib., p. $369,1863$.

Querquedula multicolor, Swinhoe, Ibis, 1860, p. 67.

a. b. 우 Tamilone, Tapeng, 4th February 1875.

After careful examination of the ducks in the British Museum, the falcated Teal was the only one with which the above specimen seemed to agree. 
Family-PODICEPID $A$.

\section{Genus Podiceps, Latham.}

\section{Podiceps phintppensis, Bonn. \& Vieill.}

Le Castagneux des Philippines, Daubent., Pl. Enl., ix, pl. 945, 1784.

Colymbus auritus, Bodd., Tabl. Pl. Enl., p. 56, 1783.

Colymbus minor, var. b., Gm., Syst. Nat., t. i, p. 591, 1788.

Colymbus phitippensis, Born. et Vielll., Enc. Méth., i, p. 58, pl. xlvi, fig. 3, 1823.

Podiceps philippensis, Blyth, Cat. B., Mus. As. Soc., Bengal, p. 311, 1849; Jerdon, B. Ind., จol. iii, p. 822, 1864; Gray, Handl. B., vol. iii, p. 94, 1871 ; Swinhoe, Proc. Zool. Soc., 1871, p. 415 ; Ball, Stray Feathers, 1874, p. 439; Walden, Tr. Zool. Soc., vol. ix, p. 245, 1875 ; Blyth \& Walden, Journ. As. Soc., Bengal, vol. xliv, ex. No., p. 166, 1875 ; David \& Oustal., Ois. Chine, p. 572, 1877 ; Butler, Stray Feathers, 1876, p. 31; Fairbank, t.c., p. 264.

T'achybaptus philippensis, Bonap., C. R., xlii, p. 775, 1856.

Podiceps minor, Hume \& Henders., Lahore to Yarkand, p. 298, 1873; Hume, Nests and Eggs, Ind. B., p. 646, 1873; id., Stray Feathers, 1873, p. 268 ; Adam., t.c., p. 402 ; Adams., Stray Feathers, 1874, p. 341 ; Hume, Stray Feathers, 1874, p. 193 ; id., 1876, p. 203.

a.b. t Tapeng, 29th February 1868.

c. ซ $d$. ㅇ Momien, 5th June 1868.

Common about Tsitkaw, at the foot of the Kakhyen hills, and at Momien. 


\section{REPTILIA \\ COLLBCTED ON THE \\ TWO EXPEDITIONS \\ To}

WESTERN YUNNAN. 



\section{CHELONTA.}

Family-TESTUDINID A2.

\section{Genus Testudo, Auctorum.}

As far as I have been able to observe the structure of the osseous parts of the Chelonian species properly referable to the Genus Testudo, and the form of the bones and constituent parts of the shells of such small species as T. elongata, there do not appear to be any characters entitling them to be separated generically, and this remark is applicable to the tortoise described by Gray under the name of Manouria, and to the shell and bones of the animal referred by him to the genus Scapia. There are various modifications in the form of the anterior elements of the constituents of the plastron, and especially of the so-called clavicles or epiplastral pieces, but these cannot be regarded as having any generic significance.

A study of the figures of the skulls of the animals described by Günther in his admirable Monograph of the gigantic land tortoises, reveals, also, no generic differences, but a general uniformity in the skull and in the relations of its parts, viz., a palatal region conforming more or less to one type, characterized by length, openness and concavity; the presence of a median ridge, the posterior portion of the palatal surface, being, as a rule, defined by ridges from the pterygoid; the premaxillaries generally concave on the under surface; the alveolar surface of the maxillaries with a longitudinal, sometimes dentated ridge interior to its outer border, the inner margin of the alveolar surface somewhat thickened and also ridge-like; and the point of union of the premaxillaries and maxillæ, and the line of union of the former bones with each other marked, more or less, by an eminence sometimes pointed, sometimes: rounded. Now, in all these characters the skulls of the small radiated tortoises resemble the Genus Testudo; Dr. Gray, however, considering that the mesial alveolar ridge on their maxillaries was indistinct, separated them under the generic term Peltastes. But the lower jaw, also, of these so-called Peltastes, conforms to the Testurlo type of structure. Dr. Gray has further separated the African species of the radiated forms on the strength of the maxilla and premaxilla not presenting any tooth-like eminences. The absence or presence, however, of such structures in the skulls of the gigantic tortoises would never be considered as of generic significance; and there is nothing to sanction its being regarded as such in

1 All the Reptilia described in this section were either observed or obtained on one or other of the Expeditions to Yunnan, with the exception of a few species of Chelonia indicated by a +. 
those small, but intimately allied forms, and, moreover, the character does not appear to hold good even among the African species.

Great stress has been laid on the separation of the pectoral plates of Manouria, but as I have elsewhere shown, ${ }^{1}$ this character is not persistently present in animals undoubtedly specifically identical and referable to the so-called Manouria emys, in which the division of the epidermic caudal plate was considered sufficient evidence of this land tortoise being an Emyde. Since I pointed out the variability in the pectoral plates of Testudo emys, I have met with two instances in Testudo elegans of the separation from one another of the pectoral plates, so that my view that this phenomenon is ascribable to variation, and is not indicative of generic difference in structure, is strengthened. I have never met with a divided caudal in any other land tortoise than Testudo emys, and I have on no occasion found it united in that species. I have here shown, however, that the nuchal plate of $T$. elongata is occasionally absent, although in the great majority of specimens it is well developed, so that it would also appear that too much importance should not be attached to this shield. The absence or presence of a nuchal, the division of a caudal plate, or the separation of the pectoral plates from one another, has each in itself about the same structural significance as the absence of a claw in the fore foot of a Batagur, or the division or non-division of the anal plate of an Ophidian. Underlying these epidermic modifications, we find a perfectly stable osseous frame-work, true to a generic type, common to all those forms I have indicated among land tortoises.

Testudo elongata, Blyth.

Testudo elongata, Blyth, Journ. As. Soc., Bengal, vol. xxii, pp. 639-40, 1853; id., op. cit., vol. xxiv, p. 712, 1855; id., op. cit., vol. xxv, p. 448, 1856 ; id., op. cit., vol. xxxii, 1863, p. 83, footnote; Gray, Proc. Zool. Soc., 1856, p. 181, pl. ix; id., op. cit., 1861, p. 139 ; id., Ann. and Mag. Nat. Hist., vol. vi, 3rd ser., 1860, p. 218 ; Günther, Rept., Brit. Ind., 1864, p. 8; Strauch, Vertheil. Schildkr., 1865, p. 27 ; Theobald, Cat. Rept. Journ. As. Soc., Bengal; vol. xxxvii, ex. No., 1868, p. 9; Journ. Linn. Soc. Zool., vol. x, 1868, p. 6; Descr. Cat. Rept., B. Ind., p. 3, 1876.

Peltastes elongatus, Gray, Suppl. Cat. Sh. Rept. B. M., 1870, pp. 9, 10 ; App. Cat. Sh. Rept., p. 15, 1873 ; id., Hand-List and Sh. Rept., 1876, p. 6.

Testudo elongata, Gray, Strauch, Chelon. Stud., 1862, p. 22.

The male is elongately oval, with straight sides, very slightly expanded at the seventh and eighth marginals, the upper surface of the shell being flat. The anterior surface of the shell is concave over the first and second, partially over the third marginals, and the caudal plate is produced downwards, slightly below the level of the anals, there being also a flattening of the sides of the last vertebral. The depth of the male through the third vertebral is one-third the length of the carapace. The anal notch is broad, and its margins divergent. The tail of the male is broad at the base, and long.

${ }^{3}$ Proc. Zool. Soc., Lond., 1872, p. 132. 
The females, in 86 living specimens, were all smaller than the males, ${ }^{1}$ not so elongated, deeper, with round backs and sides, and with the caudal plate not prolonged so far downwards as in the male. There is also, generally, a nodose-like ridge on the first vertebral, and the anal notch is more crescentic in form than in the male, in which its margins are straight. The tail of the female is much shorter than that of the male.

The young is more rounded than the female, the posterior margin of the shell is serrated, and the first and second marginals have their posterior external angles terminating as outwardly and backwardly projecting spines, similar to those on the posterior margin of the shell.

The nuchal ${ }^{2}$ plate is occasionally absent, and is very variable in size and form. In some it is triangular, almost ungulate, and as broad as long, while from this extreme on the one hand, it dwindles down through examples of every intermediate grade into a narrow linear shield, hardly perceptible in some instances. The first vertebral is as long as broad. In some, its lateral margins are straight and divergent, so that it is broader anteriorly than posteriorly, while in others they are slightly externally convex and the shield is as broad in front as behind. The first marginal borders are anteriorly convergent, and the posterior margin is straight and broad. The second and third vertebrals are alike in form, and much broader than long; the breadth exceeding the length by one-half. The costal margins are nearly equal in length, and the anterior and posterior borders are transversely straight, the anterior border of the second being considerably narrower than the corresponding margins of the third and fourth shields. The latter plate is not so much broader than long, as contrasted with the former shields, and its hinder margin is only a little more than half the breadth of its anterior margin. The fifth is less than one-half of its length, broader than long, and all its margins are straight, the fourth costal equalling the caudal margin in its extent.

In the young, a distinct ridge occurs along the marginals between the axilla and groin, and, in adult females, it exists interruptedly, while all trace of it is lost in the male. In the young, the gular plates project slightly beyond the postgulars as two rather nodose prominences. These shields are generally unsymmetrical, one being larger than the other, and their relative length to the postgulars is variable, as they sometimes equal the length of these shields, and at others exceed them. ${ }^{3}$ The pectorals exceed the postgulars, but their breadth is subject to variation, and the plates are occasionally unsymmetrical, one being considerably broader than the other. The pectoral is the largest shield, and nearly equals the postgular and gular. The preanal equals the gular and one-half of the postgular suture. The anal suture is very short, about one-fourth of the length of the gulars, and it is so reduced in adult males as almost to be absent. The anal notch in the young is

1 Hutton (Journ. As. Soc., Bengal, vol. vi, p. 689, 1837), in his observation on $T$. actinodes, states that the female of that species considerably exceeds the male in size.

2 In 86 living individuals of both sexes, the nuchal was absent only in four cases.

${ }^{3}$ In an adult male they exceed the postgular by more than one-half of its length. 
much arched in some, but in others the margins are divergent, which is the case in adult males, the width of the notch exceeding the length of the pectorals and postgulars. In both sexes, the pectoral exceeds the inguinal breadth.

The areola of the nuchal occurs in its anterior extremity, and in the marginals the areolar area is situated at the posterior external angle, and is thus below the centre of the plates. In the vertebrals, it is central and transverse, and central in the costals, but above the middle of the plates. The shields of the carapace are marked by strong lines, concentric to the areolæ. The areolæ of the gulars occur on the nodosities close to the anterior ends of the shields. They are almost central on the postgulars, pectorals and abdominals, but externally eccentric on the preanals. In youth the sternal plates are also marked with areolar concentric lines. In the adult male the areolæ all but disappear, but in the female they are well marked on the carapace.

The head in the male is flat above between the eyes, but downwardly curved in the female, with a nearly vertical snout, and a longitudinal gape. The pre-ocular portion is moderately long and pointed, with the nostrils above its middle and directed forwards and outwards, a groove running down from each to the interspace between the three dentations at the anterior extremity of the upper jaw. The young have the upper surface of the head considerably arched, instead of being flat. A pair of large oblong plates on the upper surface from the nostrils to the middle of the orbits. A portion is occasionally separated off, or partially so, from each plate in front of the eye. Behind these plates, there is sometimes a central triangular plate, with its base anterior, and a plate on either of its sides, but occasionally the triangular plate is divided in two longitudinally. External to these plates, there are three consecutive rows of shields, occasionally divided transversely, and the most external the smallest and separated from the tympanum by a line of two large supra-tympanic shields which are sometimes united into one. The most anterior of these supra-tympanic shields is separated from the eye by a large post-orbital plate. There is a line of six small supra-orbitals, and below the post-orbital there is a group of five pre-tympanics. In the adult male especially, the portion of the maxillary plate between the nostrils is frequently rubbed off, and the circumorbital region is fleshy and almost warty. The occipital region is covered with small irregularly-shaped plates. The tympanum in the adult is fleshy. There is a series of small plates behind the symphysial plate of the lower jaw. The skin of the neck is very loose, and covered with smooth, flat, almost fleshy, minute scales. The scales of the anterior surface of the forelimb are flattened, and but little projecting or imbricate; a few enlarged scales on the posterior surface of the limb, some of which are generally larger than the others and projecting. The scales on the heel are enlarged; those of the hind limb generally small, flat and smooth, and arranged more or less in transverse or oblique rows. The scales on the upper surface of the tail are considerably larger, also those over the hip-joint. The tail of the male terminates in a large, strong, horny claw-like point, while that of the female is only

\footnotetext{
I The specimens are not sufficiently young to show the areolæ of the anals,
} 
capped at its extremity by a small horny scale. The claws, five on the fore, and four on the hind feet, are short, strong and stout.

The upper surface and sides of the head are pale-yellowish, but in adults there is a pale-pinkish tinge about the nostrils, eye and tympanum. In very old males, where the skin about the nostrils has been rubbed off, the skin is very pink, and in these individuals the warty skin about the eye and the skin of the tympanum are also very pink. The skin of the neck and of the limbs is greyish, and the scales of the limbs are yellow and black, the larger scales being chiefly yellow. The claws are yellow. In the young, the head has a greenish tinge, the nostril is faintly pink, but there is no trace of red around the eye nor on the tympanum. The iris is deepbrown, almost black, and the eye is clear and lustrous.

The shell has a greenish-yellow tinge in youth, the centres of the plates being occupied with large black spots, which are, however, subject to great variation as to size. In some instances, even in the young, they are broken up into small spots, while in the adult male in which the shell loses all trace of green and is light reddish-brown, they all but disappear, while some shells are nearly black above. In the adult female, the greenish tinge remains, and the spots are more persistent. The under surface is greenish-yellow in youth, yellowish in the adult female, reddish- brown in the old male. The plates are covered with large black spots or blotches, which are as variable in form and size as those on the carapace, but they tend to disappear with age.

Measurements of shell of Testudo elongata, Blyth.

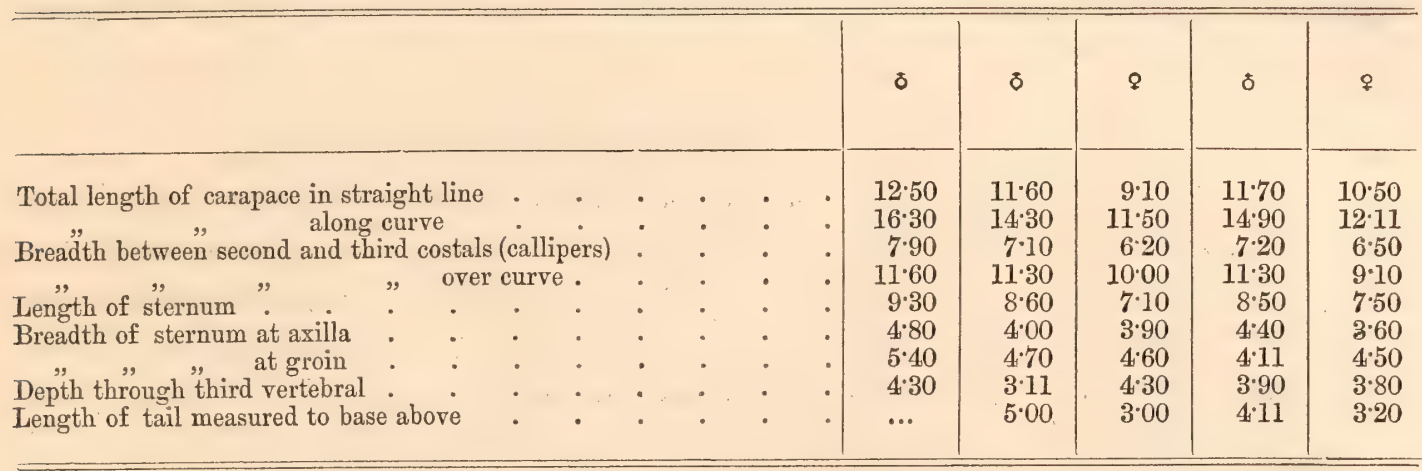

From these measurements it is evident that the specimens mentioned by Theobald ${ }^{2}$ as adults were only adolescents, as measurements of his largest male along the curve of the back gave only $11^{\prime \prime} \cdot 75$ compared with $16^{\prime \prime} \cdot 3$, the corresponding measurement of the largest specimen in the above table.

The female skull is considerably smaller than that of the male. The zygomatic and post-orbital arches are thin and narrow. The three dentations of the upper jaw anteriorly are well developed. The alveolar surface of the jaw is marked on its posterior half by a short median ridge, with a furrow on its inner side. There is a shallow pit on the posterior aspect of the premaxillaries. The internal nasal fossa is long, and very broad and deep, and is marked by three sharp

\footnotetext{
1 Journ. Linn. Soc., Lond., 1868, vol. х, p. 7.
} 
longitudinal vomerine ridges. The premaxillaries have considerable backward expansion to meet the vomer, and are perforated by two round foramina. The anterior extremity of the maxillary furrow is occasionally perforated by a prominent round foramen. The palatine foramen is longitudinally oval, large, and sometimes two or four small foramina occur near it. The base of the skull has considerable lateral expansion, and is flat. The symphysis of the lower jaw is erect, not deep, and culminates in a feeble hook. The posterior two-thirds of the alveolar edge is rather deeply grooved. The coronoid is neither prominent nor high.

The vertebral bodies in T. elongata are placed close to the neural plates, but in T. platynota at a considerable distance from them, and the bodies in T. elongata are broad, but in $T$. platynota much laterally compressed. However far removed, or however near to the neural plates the bodies of the vertebræ may be, they ultimately become connected, throughout their length, with the neural plates by the growth of a delicate osseous partition which originates at the extremities of the bodies and grows from the neural plates and from the neural arch of the bodies as well; the line of suture, however, between the neural plates being preserved in this partition.

The number of vertebræ which by means of transverse processes and ribs support the pelvis, would seem to be variable. In this species, I have observed as many as five distinct vertebra brought into connection with the ilium, the first two having the distal ends of their processes abutting against the eighth costal plate on a broad surface applied to the ilium, with the rib of the next vertebra broad and large, and the succeeding rib more feeble, and the next still more so, the penultimate being anchylosed to the body of its vertebra; whilst in $T$. platynota I have observed only three sacral ribs. Generally only two or three sacral ribs are applied to the ilia in the other genera, such as Batagur, Emys, Cyclemys, \&c. ${ }^{1}$

In this species, transverse processes occur on the third vertebra after the last sacral, and are strongly developed, far within the limits of the pelvis, but this is a very different condition of things to what prevails in T. platynota, in which all the caudal vertebræ are provided with lateral autogenous processes, which are quite distinct from the centres of the vertebræ, in a female in which all the costal plates have grown up to the marginals. The terminal caudal vertebræ which in the male bear the claw-like scale, oceasionally become firmly united with one another.

The difference in the length of the tail of the sexes is due to the much larger and longer vertebræ of the male, which is the case also in the fresh-water tortoises, and indeed in Chelonia generally.

The stomach has the general character of the group. The small intestine is 21.50 inches in length in a male, the carapace of which is $11^{\prime \prime} \cdot 7$, and the large intestine in the same individual is 12 inches. There is a sacculated-like portion or rudimentary cæcum on the sides of the large intestine at its beginning.

\footnotetext{
1. In an adult Chelonia virgata I observe that complete amalgamation of the sacral ribs with the vertebræ takes place, although some anatomists have stated that anchylosis never occurs. The series of skeletons of Chelonia in the Indian Museum would seem to make it probable that anchylosis in the adult state is not unfrequent.
} 
The liver is very large, and, unlike the Batagurs and their allies, is devoid of a gall bladder. The bile duct is about 3 inches long and opens into the intestine about the same distance from the pylorus. At its origin in the liver it is somewhat dilated, but it does not constitute a bladder. The kidneys are compact, and have somewhat the form of the mammalian gland. They are one inch and a quarter in length by $0^{\prime \prime} 63$ breadth at the hilum, by $0^{\prime \prime} .75$ across the part anterior to that. The allantoic bladder is of considerable size. The peritoneal canal is prolonged in the female as far as the sides of the glans, where it terminates as a closed tube. The glans clitoris consists of three transverse folds, placed one before the other, but intimately united to each other. The proximal fold consists of three parts, two lateral and one internal; the first part is triangular and pointed, and the other is a median ridge expanding into an oval extremity. The second fold is simple, while the third forms a rather long pointed process. The oviduct, in an adult, measured 25 inches in length, and was much thickened and distended in its last three inches.

On one occasion, I was attracted by a peculiar cry to a spot where some of this species were. There I found a solitary pair, and that the cry was produced by the male, evidently under great sexual excitement, as his mouth was open, a rare circumstance in a Chelonian, except in the act of eating, and his tongue was protruding. He was holding on to the back of the female with his front legs, and, with outstretched neck, was trying to lay hold of her head. I watched them for some time, and observed that he occasionally came to the ground and violently butted his companion from behind by the front part of his shell, rushing at her, and rapidly withdrawing his head at each stroke. This curious scene went on for some time, when I at last removed them, and found that the under surface of the posterior portion of both shells, and the ground beneath them, was smeared with a clear gelatinous fluid.

Hutton, in his interesting account of $T$. actinodes, refers to this habit which these tortoises have of butting, but he did not connect it with the sexual act. He, however, plausibly, but improbably, suggests that the hollow nature of the plastron of the male may be a sexual differentiation to permit of the successful accomplishment of the sexual act by enabling the male to retain his hold on the female during the act, but in females referable to $T$. platynota, Blyth, the plastron is somewhat concave.

A number of this species which I let loose in a garden eat freely of plantains, but, on one occasion, I observed one specimen, a female, eating greedily of dead prawns and fish which had been procured to feed Trionyces. They were generally restless at night, but whether they are nocturnal in their natural state, I do not know.

This species is active in its movements, and the males do not evince any timidity whatever; the females generally withdraw themselves at once into their shells when handled, in this contrasting with the confiding male, which will eat from the one hand, while it is held in the other. 
In eating, the head is held downwards, and the animal appears to be incapable of feeding when the head is raised. The front legs are much used to push the food into the mouth.

This species is very prevalent in Lower Burma, and it ranges southwards through Tenasserim, eastwards to Cambodja, and northwards to Arracan, and there is this curious fact connected with its distribution, that it occurs also at Chybassa, in Singhbhum, on the table land of India, in the district of Chota Nagpur, from whence I procured specimens from Colonel Dalton.

It may probably extend from Burma through Assam and along the Terai region to the west, as Major Kinloch informs me that on one occasion he found a tortoise alive in the Terai at Julpaigorie, and which he identified with a drawing of this species which I showed him. In Upper Burma its place is taken by T. platynota.

This species is known to the Burmese as the Laik Nakhonga, or red-nosed tortoise, and in Arracan it is called the hill tortoise.

\section{Testudo platrnota, Blyth.}

Testudo platynotus, Blyth, Journ. As. Soc., Bengal, vol. xxxii, 1863, p. 83; Theobald, Journ. Linn.

Soc., vol. x, 1868, p. 7 ; Journ. As. Soc., Bengal, ex. No., vol. xxxvii, 1868, p. 9 ; Descr. Cat. Rept., Brit. Ind., 1876, p. 2.

Testudo elegans, Günth., var. Rept., Brit. Ind., 1864, p. 5.

Peltastes platynotus, Gray, Suppl. Cat. Shd. Rept., 1870, p. 8 ; id., Proc. Zool. Soc., Lond., 1870, p. 655, plate xxxiii; id., App. Cat. Shd. Rept., p. 5, 1872.

This species is closely allied to the land tortoise of Southern India and Ceylon, T. actinodes, and which it resembles in having no nuchal plate. It is distinguished from $T$. elongata by the absence of the nuchal, by its less elongated and more rounded form and relatively smaller feet, especially the front feet, which are the same as in $T$. actinodes.

The vertebral plates are the same as in $T$. actinodes, but the areolæ of the plates, as a rule, are not so high as in that species, especially as in those found in Sindh. It is, however, strongly resembled in this respect by Ceylon examples.

The Burmese land tortoise, which Blyth described under the name of T. platynota, was based on three carapaces, which he found in use in the Rangoon bazaar for baling out oil from earthen vessels. He remarks that the shells in question were conspicuously distinguished by being. quite flat on the back, and that the carapace was much broader, but not so high as in $T$. stellata and T. geometrica, and he considered that the species was more obviously distinct from the two latter than these are from each other. He mentions that he had not seen the plastron, but yet Dr. Gray remarked that Blyth did not describe the plain underside which he had found in all the specimens he had examined.

The specimens referred to this supposed species were all characterized, as in T. actinodes, by the absence of a nuchal, and from our knowledge of the form. 
generally assumed by the females of this small group of radiated land tortoises, it is probable that the rounded form of the types is to be ascribed to their being examples of the female. There can be no doubt but that the plates are more flattened than in $T$. actinodes, but I cannot avoid thinking that the shells in question had been purposely selected on account of their little nodose character which made them more suited for the baling of oil. This would appear to be a legitimate supposition, as I have observed tortoises of the $T$. actinodes group at Bhamô, and have since received them from other parts of Burma, with the nodes raised as in some examples of the Indian species.

The areolar nodes and the lines of growth are the subjects of considerable variation as regards the extent to which they are developed in the allied species, T. actinodes, as some shells are almost smooth, and without marked nodes or lines, while in others both are well developed. It would appear that when both, or one or other, are present to a marked degree, the characteristic colouring prevails. In the types of $T$ :platynota, although the areolar nodes are low, not rising above the level of the shell, the lines are strongly present, also the anastomosing yellow lines on the dark-brown back-ground. I have, however, as I have already stated, observed land tortoises referable to T. platynota, Blyth, which have distinct nodes on the upper surface of the shell, but at the same time not to the marked extent that occurs in the majority of examples referable to $T$. actinodes, although there are examples of the latter quite as little raised at the nodes as the most nodular specimens of $T$. platynota.

Dr. Gray has remarked that the leading character of this species is to be found in the smooth plastron, but I have observed the sternum of $T$. actinodes not unfrequently perfectly smooth.

Theobald, who was inclined to regard it as a local race of $T$. actinodes (T. elegans), states that it is uniformly larger than the Indian species, but I have examples of $T$. actinodes as large as it. Tortoises have such a capacity of growth, that difference in size, unless very marked, is of little significance as regards species.

Young male.-Shell elongated; sides at middle almost straight, highly arched; moderately flat above over the vertebrals. No reversion of the posterior marginals as in T. actinodes. Plastron concave; nuchal absent. The front vertebral shield is shorter and broader than in T. actinodes, whereas the second, third and fourth vertebrals are broader, and the caudal plate is broader and much less pointed than in T. actinodes. The gulars are small and very slightly divergent, and the external margin of the postgulars is less bulging: the pectorals appear to be somewhat relatively narrower. The areolæ of the preanals do not project as in T. actinodes. The anal notch is much the same as in T. actinodes. The tail is long, with a small claw at its extremity.

The female has a slightly concave plastron, and her shell is not so elongated as in the male, and is more roundedly arched from side to side, and there is a slight expansion at the posterior marginals. The tail is short, with a smaller claw than in the male. 
In both male and female, the areolar nodosities are well indicated, but in the costals, the areolæ do not rise up into eminences embracing the rest of the plate, as generally occurs in T.actinodes, and on the under surface the areolæ are not perceptible, but as this sometimes occurs in Ceylon land tortoises referable to T. actinodes, or to a variety of that species, much importance cannot be attached to this character.

The head has much the general form as in T. actinodes, and the jaws are crenated in the same way and with three feeble teeth not so marked as in T. elongata. The feet are smaller than in $T$. elongata, and are about the same relative size as in $T$. actinodes, but the fore limb is covered with fewer and more rounded scales. In $T$. actinodes many of the larger scales are leaf-shaped, while in T. platynota they are all rounded. ${ }^{1}$ The rounded scales on the soles of $T$. platynota are larger than in $T$. actinodes, but the heel wants the sharp scales that mark it in $T$. actinodes. The nails of the fore feet of $T$. platynota are shorter and broader than in $T$. actinodes, while those on the hind feet of the latter are scarcely so large and broad. The large conical scales, on the posterior portion of the thigh, are very much smaller than in $T$. actinodes, and not at all prominent as in that species. The head is covered generally by a large vertical plate and by two pairs of large plates in front of it, one before the other, separated in the mesial line by a small intercalated plate, but the upper surface of the head of T. actinodes is covered rather irregularly with largish plates, and the tympanum is smaller than in the latter species.

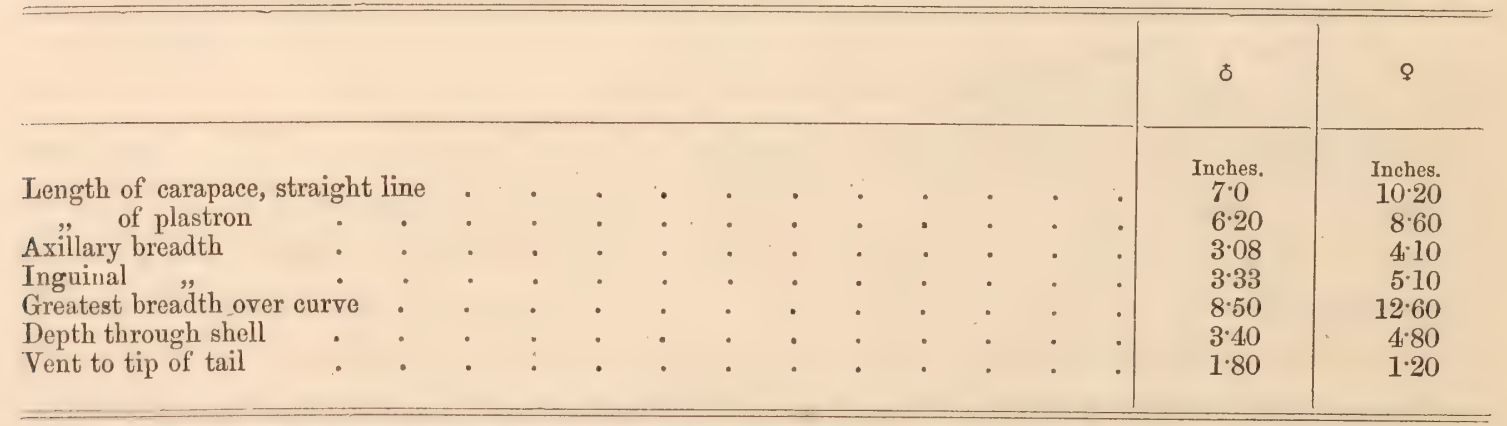

The skull is shorter and broader than the skull of $T$. actinodes, and anteriorly there is greater breadth between the inner margin of the alveolar plates of the skull than in T. actinodes, and hence the alveolar plates are more narrowed anteriorly. The vomerine ridge is prolonged further backward in the skull of T. platynota, and the pterygoid region is not so concave as in $T$. actinodes, and is transversely narrower. The tympanic orifice is smaller, and the squamous region is not so deep as in T. actinodes, and the basi-occipital region is considerably broader in $T$. platynota compared with $T$. actinodes. The supra-ocular region of the skull is broad as in the last mentioned species, but shorter and not so produced forwards over the nostrils. The temporal fossa, at its greatest breadth, is considerably broader than in $T$. actinodes. The symphysis of the lower jaw is narrower than in the

\footnotetext{
1 In Ceylon examples of $T$. actinodes, the scales are round in young animals.
} 


\section{CHELONIA.}

latter, and the lateral indications of a tooth are less marked, and the alveolar furrow is not so broad.

As in $T$. actinodes, the dorsal portion of the vertebral column is much compressed as contrasted with $T$. elongata, and more removed from the neural plates. The sacral vertebræ are two in number; and all the caudal vertebræ (22 in number) to the extremity of the tail, bear caudal ribs perfectly distinct from the vertebræ. In the first caudal, the rib nearly touches the pelvis, but in the second the rib is suddenly smaller, and still more so in the third, but in the fourth there is a sudden increase in size, and the ribs increase in length to the eighth, after which they gradually decrease in size.

The individual elements of the manus and pes are feeble compared with those of T. elongata.

The sternum presents the same type as the sternum of $T$. actinodes, having a comparatively narrow xiphiplastron compared with $T$. elongata; and the form of the entoplastron agrees with that of $T$. actinodes, but is smaller and not so quadrangular as in T. elongata.

The eyes have the sclerotic bones so prevalent in the land tortoises and Emydes.

The colour of the shell is variable. In the types it is covered with broad yellow lines radiating from the yellow areolæ, with intervening dark-brown areas, as in $T$. actinodes, but much broader than in that species, only three arising from each side of the second and third vertebrals, and all being directed outwards; the antero-posterior lines from the anterior and posterior margins of these areolæ and from the anterior border of the fourth areola being absent, and the interspace in the mesial line between these vertebral plates being a transversely lozenge-shaped brown figure. Four yellow lines diverge from the posterior border of the areola of the fourth vertebral, two from the anterior aspect of the fifth, and six from its posterior border. Two lines proceed from the sides of the first vertebral areola and join the two most anterior yellow lines from the second vertebral, and two lateral yellow lines pass out from the sides of the first vertebral areola. The areolæ of the costals are connected above by a longitudinal yellow line joined at its middle by the mesial lateral yellow line of the vertebrals, and three to four divergent yellow lines pass down from the costal areolæ to the marginals, from the areolæ of which two yellow lines are upwardly divergent; but there are no other transverse lines as in $T$. actinodes, and the area between the downwardly divergent lines is dark-brown in its upper half and yellow in its lower half.

This coloration, which is very regular and distinct in the types, is much obscured in some individuals which are yellow, with brown radiating lines, the general colour of the shell being yellowish. The absence of yellow lines between the vertebrals in the mesial line, and the dark-brown character of that area, and the brown and yellow area between the costal areolæ and the downward lines; are the characteristic colour-features of this species. The under surface of the sternum in these yellowish individuals is yellow, with only some brown patches along the margins of the shields. I have never seen the plastron of a brightly coloured individual. 
The head and limbs are dull brownish-yellow, the naked skin about the nostrils is bluish. The scales on the limbs are bright yellow, also the claws. The iris is pinkish-brown and the tympanum brownish. The egg is a largish oval with rather rounded ends, and measures $2 " \cdot 10$ in length by $1^{\prime \prime} \cdot 50$ in breadth. The eggs are deposited in the end of February, but if oftener than once a year, I cannot say. An egg of Testudo actinodes from Cutch, also laid in the month of February, is more rounded than the egg of T. platynota, and smaller, measuring $1^{\prime \prime} \cdot 80 \mathrm{by} \mathbf{1}^{\prime \prime} \cdot 40 \mathrm{broad}$.

This species is generally distributed over Upper Burma, and I observed the shells used, even at Momien, in the oil-shops; it occurs also in the hilly region about Akyab.

$$
\text { Family-EMYDID } 2 \text {. }
$$

\section{Genus Geoemyda, Gray.}

Dr. Gray, in his Catalogue of the Tortoises, Crocodiles, \&c., published in 1844, ${ }^{1}$ founded the genus Geoemyda, distinguishing it from Emys by the following comparative statement: Geoemyda.-Head covered with a thin skin, toes 5, 4, free, short. Emys.-Head covered with a thin hard skin, toes 5, 4, webbed. ${ }^{2}$ He gave it rank as the first genus in the family Emydida.

The first species mentioned under Geoemyda was the South African Emyde, Emys spengleri, Schweigger, ${ }^{3}$ and associated with it was another form from Sumatra, Emys speciosa, Bell, ${ }^{4}$ (Duméril and Bibron, ${ }^{5}$ ) with which Dr. Gray was disposed at that time to identify the Testudo emys, Müll. and Schleg. ${ }^{6}$

In the Catalogue of Shield Reptiles published in 1855, ${ }^{7}$ we find the genus Manouria established on two shells from Penang collected by Dr. Cantor, who had identified them with Emys speciosa, doubtless misled by Dr. Gray having referred to Emys speciosa, Bell, the tortoise described by Müller and Schlegel as Testudo emys, the figure of which, like Dr. Gray's figure of Manouria fusca, showed that the pectoral plates were far apart in these specimens collected by Cantor. Although Dr. Gray's figure of Manouria fusca corresponded with Müller and Schlegel's plate, yet no reference was made to it; the Testudo emys, M. and S., still appearing as a synonym of Geoemyda speciosa. In the work under revision, the latter species was separated from Emys spengleri, and was then the sole representative of the genus Geoemyda, from which the doubtful species Emys spengleri was separated under the new generic term Nicoria, as Dr. Gray had ascertained that its toes were united by a scaly web, but to the species Nicoria spengleri were referred Emydes from China and Africa.

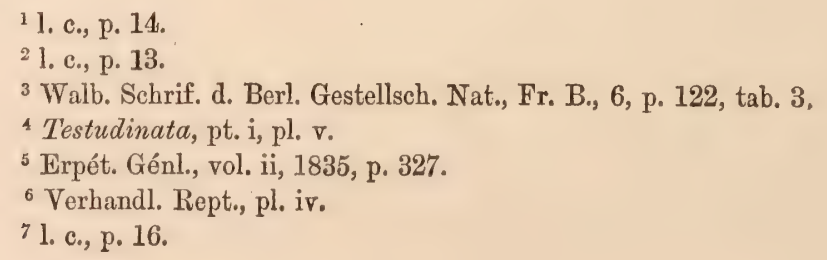


In the Supplement to the foregoing work ${ }^{1}$ the characters of Geoemyda were altered, and the toes were stated to be short, expanded, strong, united to the claws or slightly webbed; and the important observation was made that the zygomatic arch was absent. Two other species were referred to the genus, one described by Dr. Gray from Cambodja under the name of Geoemyda grandis, and a species from Central India, G. tricarinata, Blyth.

In the Appendix to the same work ${ }^{2}$ we at last find the Testudo emys, M. and S., referred to as synonymous. with Manouria fusca, and this name changed to Manouria emys; and it is also stated that the animal had been erroneously confounded with Geoemyda speciosa, Dr. Günther having been the author who first corrected the error into which Dr. Gray had fallen in describing the Testudo emys, Müll. and Schleg., under the new specific name fusca.

Dr. Günther, in his Reptiles of British India, ${ }^{3}$ in his definition of the genus, mentions that the toes are very distinct and the hind toes moderately webbed, and that the two species, G. spinosa and G. grandis, appear to be intermediate forms between Testudo and Emys. He also referred to G. tricarinata, Blyth, but apparently with doubt regarding its generic position.

Theobald, in his Catalogue of Reptiles, ${ }^{4}$ and in his Account of the Reptiles of Pegu, ${ }^{5}$ separated the four genera, Manouria, Geoemyda, Cuor $a$, and Cyclemys, from the Emydida under the family name of Geoemydide, considering them as Emydida (and therefore properly as a tribe of that family,) characterized by a concave sternum in the male, which he considered indicated more terrestrial habits than the typical Emydide which he distinguished from the Geoemydidae by the males having a flat sternum. Such a character, however, seems not of sufficient importance to constitute a family, more especially as there can be no doubt but that the sternum of certain species of true Emydes is more or less concave. These remarks apply to Geoemyda, which has all the osteological and internal anatomy of an Emyde, whereas the so-called genus Manouria is structurally distinct from these two forms.

Theobald ${ }^{6}$ has described under the name of Chaibassia a new sub-genus, of the habit of Geoemyda, taking as his type the Geoemyda tricarinata, Blyth, ${ }^{7}$ already mentioned, distinguishing the new sub-genus by its complete zygomatic arch. The type of G. tricarinata, Blyth, was from Chybassa, in the District of Singhbhum, Chota Nagpur, Bengal, but when Theobald described his new sub-genus, he had before him, besides one of Blyth's types, three living tortoises which he identified with G. tricarinata, and which he stated were from the Naga Hills. I am, however, informed by Lieutenant-Colonel Godwin-Austen, who collected these specimens, that they did not come from the Naga Hills, but were from the Bishnath

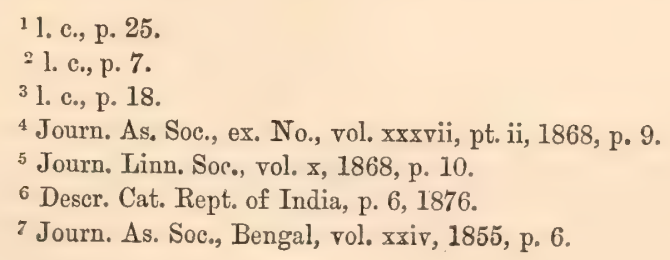


Plain, near Tezpur, in Assam, close to the Brahmaputra; but any way, the generic term Chaibassia selected by Theobald is an unfortunate one.

Theobald referred this new sub-genus and Geoemyda to the family Testudinida, from which, however, their structure markedly separates them; the structure of Geoemyda, also that of Chaibassia, being essentially that of an Emyde.

An inspection of the specimens from the Bishnath Plain in Assam, and a comparison of them with Blyth's types of G.tricarinata, conclusively prove that the two are perfectly distinct species, but generically identical. ${ }^{1}$

In 1875, I described a tortoise from Arracan, which I referred to the Genus Geoemyda and named G. depressa. ${ }^{2} \mathrm{Mr}$. Theobald afterwards ${ }^{3}$ re-described the same species under the name of Geoemyda araliana, from specimens in the Indian Museum, Calcutta.

I propose now to consider wherein these species of Geoemyda differ from one another and from Emys, to which they are closely allied, and what the characters are of Chaibassia. I regret that I have no example of $G$. spinosa to compare with these forms.

1 The animals from the Bishnath Plain are distinguished from Chaibassia tricarinata, Blyth, by the very much larger and anteriorly broader first vertebral, the lateral margins of which are widely anteriorly divergent, the posterior border straight and equalling one-half the breadth of the anterior border: the fourth and fifth vertebrals are not so large as in C.tricarinata. In the latter, the gulars are triangular, while, in the Assam species, the external lateral margins of the gulars are rounded. The anal plates of $C$. tricarinata are decidedly larger than in the Bishnath species, in which the anal notch is smaller. The form of the shells of the two species is practically the sane, viz, elongately oval, relatively highly arched, downwardly shelving at the sides, and very slightly broader posteriorly than anteriorly. The female is somewhat contracted in the Assam form at the fifth, sixth and seventh marginals, with no reversion of the marginals, which are very feebly denticulated. A nuchal plate in both species, and three raised ridges, the vertebral the longest, involving all the vertebral plates; the lateral ridge on the costals more feeble. The colour of the Assam shell is black above, almost orange-yellow on the under surface; the dorsal ridges, and the under surface and the margins of the shell bright yellow. The head black, with a broad reddish band from above each nostril, increasing in breadth as it passes over the eye and over the tympanum, where it ceases; a narrow similar band below the angle of the mouth, along the inferior margin of the lower jaw. Skin of throat and neck pale blackish-brown, also the granulated skin of the limbs, hind quarters and tail. Fore-limb, below the elbow, covered externally with large black scales ; a few large black scales also behind the outer side of the wrist; no large scales on outer surface of hind limb, except at the outer margin of the foot, and on the hinder half of the sole; toes free; hind foot rather club-shaped; claws large,
sharp and black. The colours of $C$. tricarinata are unknown.

The head of the Assam form is more pointed than in C. tricarinata, and the facial portion longer. These characters are pronounced in the skull, and the frontal region is much longer and narrower than the corresponding region in $C$. tricarinata, and the palatine, but more especially the pterygoid region, is distinguished from the latter by its great breadth. The following are the measurements of the two sexes, from which it would appear, as both are adults, that the male is the smaller of the two:-

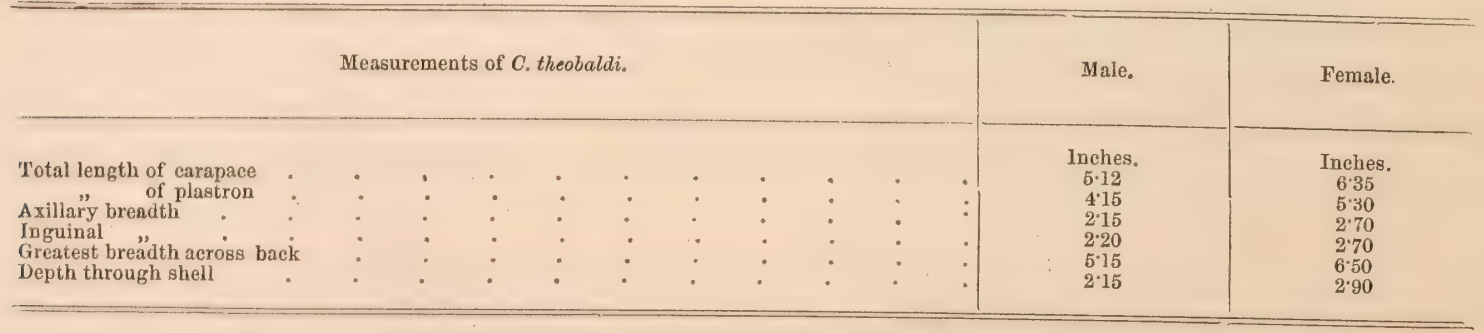

I have much pleasure in connecting Mr. Theobald's name with this species.

${ }^{2}$ Ann. and Mag. Nat. Hist., 4th Ser., vol. xvi, p. 284, Oct., 1875 ; no proof of this paper having been sent me to correct, it is full of blunders.

${ }^{3}$ Descr. Cat. Rept., Brit. Ind., Calcutta, 1876, Errata et add., p. vii. 
The only difference between the shells of $G$. grandis and Emys trijuga is this, that the shell of the former is perhaps slightly more elongated, and that each osseous marginal plate is notched at the middle of its free border, and the xiphiplastron is somewhat larger than in Emys trijuga. The skull, while conforming to the general characters of the posterior nares, palate, alveolar ledge of the maxilla, open palatine foramen and broad pterygoid region of Emys, is, at the same time, a shorter and broader skull destitute of a quadrato-jugal, with a very broad frontal and nasal surface.

The shell of Geoemyda depressa presents the same characters as G. grandis, only, as its specific name implies, it is considerably depressed from above downwards. The vertebral column, however, is much more flattened than in G. grandis, in which the individual segments are much laterally compressed as in the small radiated land tortoises, and Emys in the form of its vertebræ is intermediate between G. depressa and G.grandis. The skull also of G. depressa, Pl. $\mathrm{lxxv}$ B, figs. 1 to 5 , in all its characters is a miniature representation of the skull of $G$. grandis, although it is specifically distinguishable from it in a few of its details. There is also no difference between the lower jaws of Geoemyda and Emys. The bones of the feet of G. grandis and of $G$. depressa have all the characters of the feet of Emys, but the bones are relatively stronger, the 5th digit of the hind foot in Geoemyda and Emys being provided with only one phalanx beyond the metacarpal element. The form of the limb bones and of the carpal and tarsal constituents are the same in both, and their respective pelves conform to one type.

The osteological differences therefore lie only in the skulls. The examination, however, of the skulls of many examples of Emydes shows that the quadrato-jugal bone is frequently very feebly developed, indeed so much so that it is apt to be overlooked, and if the muscular substance is roughly removed, the bone is liable to be detached with it. The jugal also, in some species, is reduced to a very thin rod. In both of these species, $G$. grandis and in $G$. depressa, the jugal is not strong, except in very old individuals.

In C. tricarinata the shell has the elongated character of $G$. grandis, but the caudal is the only marginal element notched, and the vertebræ are broad, as in $G$. depressa. The feet have much the same osteological features as in the foregoing species, but the 3rd and 4th toes of the fore foot, but especially the 5th, are feebler than in G. grandis, G. depressa, and in Emydes generally. The 5th toe of the hind foot has the same characters as in G. grandis, G. depressa, and Emys trijuga. The pelvis and other bones agree with Emys and with these two species of Geoemyda.

The skulls of $C$. tricarinata and $C$. theobaldi are intermediate between the skulls of G. grandis and G. depressa, and of such Emydes as E.trijuga, in which the zygomatic arch is not imperfect as stated by Gray. They have the same characters as regards the posterior nares, alveolar ledge, flattened area between the palatine foramina, and large palatine foramen, but the last is relatively smaller than in Emys trijuga. The fronto-nasal region of the skulls of $C$. tricarinata and C. theobaldi 
conforms more to the Emys type than to that of Geoemyda, and the skulls, in the presence of a quadrato-jugal, agree with Emys.

There is nothing in the features of the internal anatomy of these forms that would entitle us to separate them from the Emydes. They are all provided with cloacal bladders, but to a varying degree. In $G$.grandis the bladders are very large, and the whole of their inner surfaces are covered with dendritic papillæ. In $G$. depressa they are small, and also in $C$ theobaldi, but I am unable to speak of these structures in C. tricarinata, having never had the opportunity to examine a fresh example of that species. In the genus Emys they are large and generally smooth.

The presence of cloacal bladders indicates that all of these animals have one habit, and in this respect they must be regarded as belonging to the Emydida, and the males, as in the Emydes, have a more or less concave sternum, but these structures are not present in the so-called genus Manouria nor in the Testudinide generally.

In Geoemyda grandis the toes of the fore feet are webbed to the base of the claws, but not broadly so, and the hind toes are hardly perceptibly webbed, while in $G$. depressa the web, at the base of the toes, in the hind foot, is still more obscure. In Emys both feet are webbed, but the even partial webbing in these two forms referred to Geoemyda, serves to connect them with Emys.

In Chaibassia tricarinata the toes seem to have been in much the same condition as in $C$. theobaldi, in which no web can be said to exist.

As there can hardly now be any doubt regarding the natural family to which these four species rightly belong, the question arises what value is to be attached to the absence in the skulls of $G$. grandis and $G$. depressa of a quadrato-jugal bone. Besides this feature, which separates the latter from the true Emydes, their skulls, although conforming in their alveolar palatine characters and large palatine foramina to the Emyde type, differ from it in the great breadth of the fronto-nasal region. But viewing their structure as a whole, they appear to me to be entitled to generic rank among the Emydide.

The Emyde which Mr. Theobald has placed in the new sub-genus Chaibassia subordinate to Geoemyda should, by the structure of its skull, be more properly considered as sub-generic to the genus Emys, because its whole form above and below, its more elongated character generally, and the presence of a quadrato-jugal, show it to be closely allied to Emys, indeed so much so, that, judging by the skull alone, one would not be justified in separating it generically from Emys. There is, however, a feature observable in Blyth's type of C. tricarinata, and in another of the same species which I procured from Chota Nagpur, through the valued assistance of Colonel Dalton, C.S.I.; which would seem to indicate a tendency in this form to diverge towards the members of the family Cistudinida. It is this, that the process from the hyposternal piece which springs upward and abuts against the first costal and third marginal plates, does not become firmly attached to the latter, but is movable on it, and this false joint involves apparently the side of the hyposternal, but does not extend forward to the hyosternal. This is observable in the male type of 
C. tricarinata, Blyth, and in a female of the same species from Chota Nagpur, and it is distinctly visible in the alcoholic female type of Chaibassia theobaldi, but no trace of it is visible in the male example in alcohol. Had this character been persistent in both sexes of $C$. theobaldi, I should not have had any hesitation in regarding Chaibassia as a distinct generic form, occupying a position intermediate between the box tortoises and the Emydes. It is an Emyde in all its other features, except its feet, which being unwebbed, and the hind foot rather club-shaped indicate an affinity towards the land tortoises, with which, however, it has no alliance by its skull, nor by its cloacal bladders, nor indeed by the characters of its visceral cavity and soft parts, which are also those of an Emyde. It must therefore remain with the Emydes, but it is entitled among them to generic rank on account of its divers affinities.

It is interesting to observe that $C$. theobaldi in its shell and in the type of its colouring considerably resembles Cuora. It is also worthy of remark that although the transverse suture between the hyo- and hyposternal pieces is not mobile, it is yet very prominently seen through the epidermic plates.

+ Geoemyda depressa, Andr. Plates LV, LVI, and LXXV B, figs. 1 to 5.

Geoemyda depressa, Andr., Ann. and Mag. Nat. Hist., 4th ser., vol. xvi, Oct. 1875, p. 284.

Geoemyda arakana, Theobald, Deser. Cat. Rept., Brit. Ind., 1876, p. 7.

Shell elongated, much depressed, the depression increasing from before backwards, the shell being somewhat expanded across the inguinal region; vertebral region (2 and 3) nearly flat. Anterior border broad and slightly concave; posterior border, behind inguinal area, expanded, and with a strongly serrated margin; vertebrals with a low ridge in adults. Interval between the first costal and anterior marginals concave, also the interval between the fourth costal and its marginals which are reverted. The sides of the middle of the shell, (second and third costals, considerably convex; anal notch moderately deep; nuchal and gulars well developed; anterior border transverse.

Shell above light brown, with a blackish tinge on the external border of the marginals. Sternum rather clear yellow, the interval between the axillary and inguinal notches deep black; the outer halves of the pectoral and anal plates being blackish-brown, with a partial reticulation extending across the plates; the gulars, postgulars, and anals have also a tendency to be coarsely and irregularly reticulated with the same colour.

Head of animal rather small; upper and lower jaws deep, and area below the nostrils slightly convex. Limbs large, especially the hind legs; claws strong and webs not well developed. The anterior aspect of the lower part of the fore leg covered with large imbricate scales, and smaller scales on the dorsum of the foot, a large scale being at the base of each claw. Hind limb covered with small scales, but with a line of enlarged scales along its posterior margin. Tail moderately long and covered with rounded scales. The neck-skin loose and covered with minute 
scales. Head, in life, leaden; iris brown; neck and skin of limbs pale yellowishbrown. Large scales on the limbs blackish, with brownish margins.

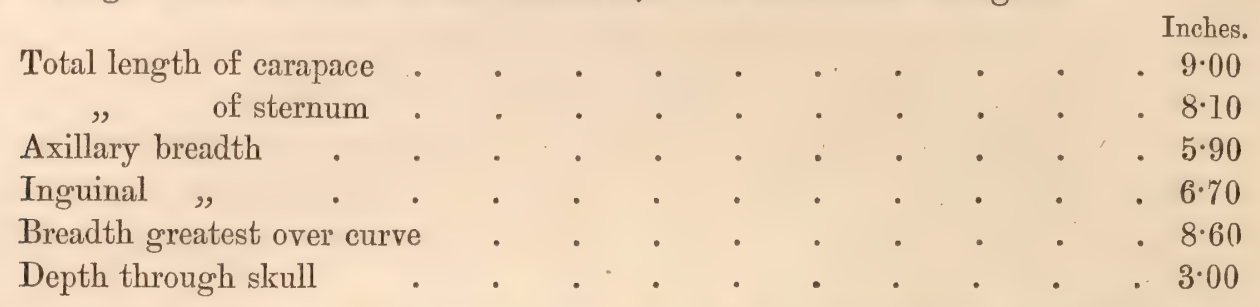

The only locality from whence I have obtained examples of this interesting species was the hilly region in the neighbourhood of Akyab in Arracan.

\section{Genus Emrs, Curier.}

It is being gradually discovered as naturalists look to the structure of the animals which have been referred to the genus Emys, that it includes many forms which cannot be regarded as generically identical. So little, however, is yet known of the structure and real affinities of the animals comprising it, and of their relations to each other, that any attempt to group the animals into genera, based on present knowledge, must be essentially tentative. Dr. Gray, who has contributed much to our knowledge of the Chelonia, in describing the species in the British $\mathrm{Mu}$ seum in 1855, referred 33 species to the genus Emys; but in 1870, after a consideration of more ample materials, and chiefly of the skull characters, referred the 33 species to no less than 12 distinct genera, some of which are undoubtedly well marked generic types of structure, the features of which are especially pronounced in the modifications which take place in the skull, more particularly in the character of the fronto-nasal region, the zygomatic arch, and the alveolar surface of the jaws and palate. Such modifications are generally found extending to a number of species, but the differential features are occasionally masked by similarity in the outward form. On the other hand, species which by external appearance would be thought widely apart are found, on close examination and on reference to the internal structure of the shell and skull, to be very closely allied, e.g., the two sub-genera Morenia and Hardella among the Batagurida. These two subgenera, however, are placed by Strauch widely apart, Morenia ocellata being grouped next to Pangshura smithi, and Hardella thurgi close to Emys trijuga, with which it has no more affinity than Morenia ocellata has with Pangshura smithi. The forms referred to Emys, by Strauch, also present a remarkable diversity of structure, as is seen in the two species Pyxidea mouhotti and Cyclemys orbiculata, Bell, the latter of which possesses cloacal bladders and a broad palate like Geoemyda, whereas Pyxidea mouhotti has no cloacal bladders, and has a narrow palate like Emys, with a feeble zygomatic arch, a character which also occurs in the skull of Cyclemys, and in some of the North American forms referred to Cistudo.

Dr. Gray referred ${ }^{1}$ the Emydida to three types of structure, the Geoemydina, Emydina, and Belliana, the first typified by the genus Geoemyda, the second by the 
genus Melanochelys, and the third by the genus Bellia. The first two of these, according to Gray, contained forms with imperfect, or perfect zygomatic arches. The first, he stated, had never webbed feet, the second had webbed feet, and the third tribe, Belliana, resembled the Emydina. The only one genus, however, among the 15 genera referred to those tribes that possesses an imperfect zygomatic arch is the genus Geoemyda. Although Gray stated that Melanochelys had an imperfect and weak zygomatic arch, this was an error, as the species $E$. trijuga, on which the genus is founded, has been satisfactorily proved by my personal observation of many skulls from Ceylon, Southern India, Madras, Central India, and Burma, to have a perfect zygomatic arch, so that the genera of the second and third groups are all distinguished by a perfect arch. It is doubtful whether several of the nine genera, referred to the Emydina, may not have ultimately to be united with the genus Emys, which I temporarily accept in the sense adopted by Gray, with the above correction.

\section{Enys triJdGa, D. \& B., var. burmana. Plate LVII \& LVIII.}

Emys trijuga, Theobald, Journ. Linn. Soc., vol. x, p. 13, 1868 (pars).

Emys edeniana, Theobald, Deser. Cat. Rept., Brit. Ind., 1876, p. 12.

Shell not so elongately oval as in Indian examples of the species, moderately high and broad, and broader in females than males, anterior margin slightly posteriorly concave. Lateral margin acutely revolute in the young, reduced to a ridge in nearly adult specimens. In the young slightly expanded at the eighth marginal, the posterior marginal shields being involute, more so in some than in others, and feebly in the adult. The posterior margin is slightly serrated in some young specimens and undulating in adults; caudal notch hardly developed. Three dorsal ridges, the vertebral ridge the most prominent; the costal areolar ridges very feebly developed, passing through the areolæ which have sometimes a tendency to nodosity, and not extending on to the last costal and scarcely on to the first, in which, however, the areolæ. are well marked. The costal ridges nearly disappear with age, but the vertebral is always distinct, and most prominent on the three last, and on the first vertebral. The nuchal is narrow and almost linear broader behind than in front. The vertebrals are generally broader than long, the second and third being as long as broad. There are frequent exceptions to this, especially in the case of the first vertebral which is often much longer than broad, and in such cases the other vertebrals partake of its elongated character. All the vertebrals, with the exception of the first and last, are almost as broad in front as behind, and the costal margins of the second, third and fourth are all about one length, the anterior costal margin of each being more or less convex, and the posterior concave. The first vertebral is pentagonal, either broader than long, as long as broad, or considerably longer than broad. Its lateral margins are more or less concave in the middle, but divergent anteriorly. The posterior margin is transverse, notched for the vertebral ridge. The second vertebral is generally a little broader in front than 
behind, but in others it is of equal -width at both ends. In the former case, the first costal margin is convex and the second sinuous or concave. The posterior margin is usually notched. The third shield resembles the second, but is usually a little shorter and broader. Both these shields, however, are subject to elongation. The fourth is almost invariably considerably broader than long, with the same costal margins as in the third, with its posterior margin equalling the third costal margin. The fifth is contracted near its anterior extremity, and the breadth of its anterior margin almost equals one-half of its length. It is generally in contact with a caudal and marginal, but sometimes with two of the latter.

The sternum of the female is quite flat, but that of the male is very slightly concave. The inguinal exceeds the sternal breadth in both sexes. In the young, there is a slight lateral ridge, formed chiefly by the areolæ disappearing with age. The gulars are abruptly terminated, their anterior breadth nearly equalling the united length of the gulars and postgulars, these plates being of almost equal length, the gulars sometimes being the longest. The pectorals and abdominals are of equal length, their sutures having a backward direction, which is most marked in adults, especially in the abdominals. The pre-anals and anals are of equal length, the pre-ano-abdominal suture being concave from before backwards and the pre-ano-anal convex from behind forwards. The anal notch is widely triangular in adults, and deeply arched in young specimens.

Measurements of shells.

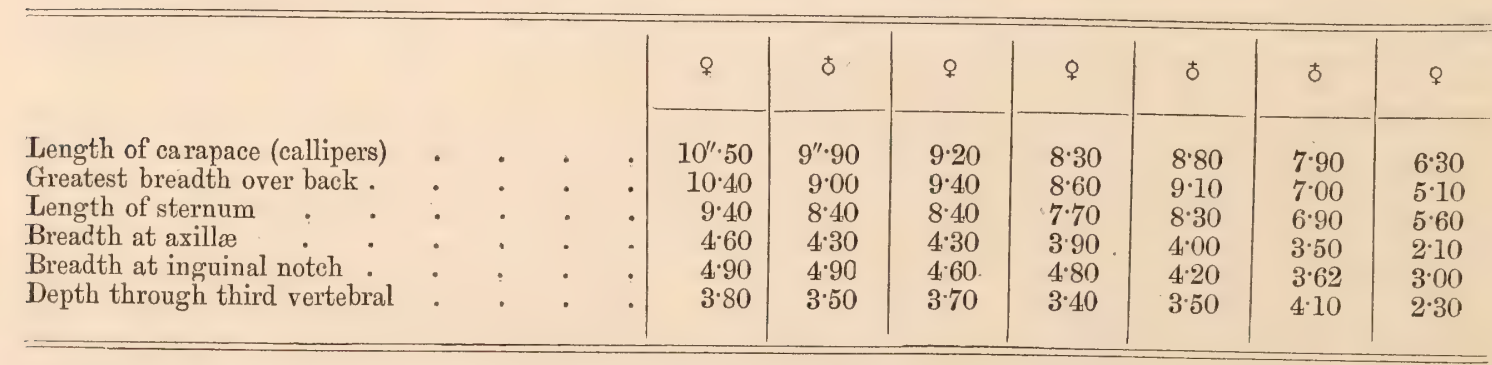

The snout is moderately long, triangular above, and rather pointed, the breadth between the anterior angles of the eyes exceeding its length. The breadth at the angle of the jaws, below the tympanum, equals the distance from the tip of the snout to the posterior margin of the tympanum. The breadth between the posterior angles of the eyes is a little in excess of the distance from the tip of the snout to the posterior canthus of the eye, measured along the side of the face. The height of the muzzle, measured from the bottom of the premaxillary notch to its upper border, equals the interval between its tip and the anterior angle of the eye. The maxillary plate is acutely notched in front with a well-marked denticulation on either side of it; the maxillary margin is curved and not serrated. The sides of the face are nearly vertical, and the eye is moderately large and about the size of the tympanum. The upper surface of the head is covered with a smooth skin, but there are a few small plates behind the eye and above the tympanum, and a granular area between the 
eye and the angle of the mouth and the tympanum, the latter being covered with smooth skin. The skin of the neck is granular, and there are a few whitish papillx on the mental region and about the orifices of the chin glands. The scales on the lower half of the leg are arranged the same as in Indian examples, but they are narrower and more transverse and not quite so numerous. Those along the inner margin of the limb are also considerably longer than in the Indian form, the scales not gradually but suddenly decreasing as they reach that border. The upper surface of the foot of the female is also more covered by smaller scales than in specimens from the Madras Coast. The toes are short and broad and nearly fully webbed, and they are covered above with four large transverse scales. A row of seven large scales along the outer margin of the limb and a transverse row of four very large scales on the posterior aspect about the carpal joint with an imperfect smaller row above it, as in the Madras form. Occasionally, a series of enlarged scales on the knee. Five large scales along the inner border of the tibia. Upper surface of hind leg granular, with smaller and more numerous granules than in the Indian form. A series of enlarged scales over the 5th toe and four enlarged scales over each of the other toes. A few enlarged scales on the inner margin of the heel, and the sole covered with moderately sized flat scales. A small plate at the base of each claw on the fore and hind feet. Claws 5, 4, moderately long and curved. Tail of male longer than that of female, covered below, behind the vent, with a double row of small scales. The rest of the skin above and below granular, the granules above generally capped by minute black horny spines, the others usually terminating in white papillæ.

The colour of the adult shell is deep black, darker than in the Madras form, with a yellowish-horny narrow interrupted line along the margin of the sternum, but in the young the shell has a brownish tinge on the dorsal ridges and along the outer margins of the costals, with a rather better-defined yellow margin to the sternum, and with a few dull yellowish patches on the under surface of the preaxillary and post-inguinal marginals.

The head of the male above is nearly uniform brown, darkest on the upper surface over the nose, and is destitute of any markings. The horny plates of the jaws in the male are leaden-grey, with a vertical black streak between the notch and the nostrils, which are in a black area; the margin of the jaw is blackish, and there is an obscure pale elongated spot on the side of the mandible, below the anterior angle of the eye. In some females, the upper surface of the head is reticulated with olive-brown and orange-yellow. The tip of the nose is deep blackish-brown, and behind this, to the commencement of the parieto-occipital crest the middle is occupied with much finer and more obscure reticulations than those above the eye and on the temporal region. The maxillary and mandibular plates are reticulated with pale greenish-horny and orange-yellow, and the former has the dark vertical premaxillary streak of the male, and the dark lower margins. An orange spot on the mandible below the angle of the mouth, leading interruptedly to the tympanum. The skin of the neck is grey; the fine granular scales of the upper surface black, those of the under surface being the same colour as the skin. 
In the female, these parts have an olive tinge, especially on the chin and throat, and the former is spotted with orange. The skin of the axillary region, and the base of the neck and the inner surface of the limbs, and the corresponding part of the hind limbs and hind quarters are pale greyish in the male, with a decided yellowish tinge in the female; the scales on the lower division of the upper and under surface of the limbs of both sexes being wholly black. In the female, the insides of the limbs are yellowish, involving the large rows of scales that occur on these parts, which in the male are concolorous with the grey under surfaces. The claws are jet black. The iris is dark brown, almost black.

The skull differs somewhat from the skull of the Indian examples of the species in the stronger denticulation of the jaws, but this character is variable throughout the varieties. In other respects the skulls of all the varieties are, I find, specifically identical, after a careful consideration of them and an attempt to discover specific characters by which to separate them.

Dr. Gray on two occasions figured skulls which he referred to this species. Of his first figure he remarked:- "Skull figured as Emys trijuga, Gray, Cat. Sh. Rept., B. M., t. 37, f. 2 ("E. subtrijuga, figure not good, zygomatic arch too broad and extending to the ear bone"). $\quad$ As Dr. Gray did not state from whence the skull was obtained, and as he acknowledged the inaccuracy of the figure, it is impossible to say what species it may represent. He gave the source of his second figure as Dr. Oldham, but does not mention whence Dr. Oldham obtained it, but as Dr. Oldham presented specimens of natural history to the British Museum both from India and from Burma, the skull may be from one or other of those widely different regions. This second figure does not agree any more than the former with the skulls which I have removed from the bodies of Madras and Ceylon examples of Emys trijuga, and no more does it agree with the skull of this Burmese variety. One of the faults Dr. Gray found with his first figure was that the zygomatic arch was represented as reaching to the 'ear bone,' but the same feature occurs also in Dr. Gray's second figure.

The skull of the female is slightly narrower in its anterior half than the male skull. The upper surface of the adult skull is perfectly flat, and the nasal portion is not depressed, but in young specimens there is a slight swelling over the pre-frontals, and the extremities of these bones are slightly arched from side to side. The orbits are large, oval, dilated anteriorly, and rather pointed posteriorly. The naso-orbital region is narrow, but below that, the orbital surface of the maxilla is triangular. The infra-orbital area is shallow. The jugal is very narrow and spicular, and the post-frontal is of moderate breadth, and nearly twice as broad as the quadrato-jugal, which is so small that it is apt to be lost. The nasal cavity is truncatedly triangular, broad above, narrow below. The premaxillaries are very narrow, and flattened in the mesial line, as they are partially separated by a shallow notch with a feeble denticulation external to it in the young skulls, but which in the adult becomes reduced to a slight, hardly perceptible swelling. The maxillary

\footnotetext{
${ }^{1}$ Suppl. Cat. Sh. Rept., 1871, p. 34.
} 
margin is very slightly curved inwards, being nearly vertical in its posterior half, but more downwardly shelving anteriorly. The premaxillary pit is shallow, and the premaxillary foramina are situated at the anterior end of the inner margin of the alveolar plate. The latter is slightly grooved externally and convex internally, and its breadth is less than one-half of the least breadth of the pterygoid. The nasal canals are obliquely oval at their palatine termination, and are continued backwards as far as the anterior end of the large oval palatine foramen. The palatine and pterygoids are slightly concave, the breadth of the pterygoid contraction is equal to one-half of the interval between the anterior external processes of the pterygoid. The distance between the mandibular facets of the quadrates equals the length from the occipital facet to the end of the basisphenoid, which is rather elongated and reaches to the middle of the pterygoid contraction. The depression on the under surface of the basi-occipital is well defined anteriorly. The occipital spine is long and nearly straight, and the temporal area externally is rather narrow from above downwards, somewhat posteriorly elongated and slightly upward bent at its hinder end. The mandible has an upwardly pointed symphysis; the symphysial breadth is moderate, being nearly equal to the height of the posterior end of the coronoid. The outside of the ramus to the coronoid is concavely bevelled off. The alveolar surfaces are narrow and present one groove, each rising up posteriorly to the coronoid. The latter is less than twice the height of the narrowest portion of the ramus.

The vertebral centres are rather strong and short, and there are 3 sacral and 22 caudal vertebræ, the tail vertebræ of the male being considerably larger and longer than in the female. The first caudal transverse process is directed backwards close to the ilium and behind the third, but it does not reach the pelvis. In the second cervical vertebra there are occasionally two small ossicles developed at the posterior extremity, one on either side of the dorsal spine.

In females, $6^{\prime \prime} \cdot 2$ in length of carapace, the pubis and ischium are thoroughly amalgamated, not even a transverse suture being visible, and the longitudinal puboischial suture is all but lost. In males of the same size, the pelvis is similarly advanced, but the divergent anterior extremities of the pubis, which in the female are separated by cartilages, are entirely united. The pubic region of the male is narrower and more pointed than in the female, and the ischial border of the latter is broader and less downwardly curved than in the former, and the iliac orifice is broader in the female than in the male.

The manus is broad, with short digits, and a distinct intermedium. The interspace between the radius and ulna is wide and crescentic. The 5th toe of the hind foot has two phalanges, of which the last is very small.

The tongue is densely covered with filiform papillæ. The free fold external to the laryngeal orifice, defines a broad triangular surface. Immediately behind the hyoid arch, the œsophagus is marked by a small area of numerous wavy rugæ, the anterior termination and convergence of the well-marked longitudinal folds of the œsophagus. There is notrace of papilliform appendages. The stomach presents 
a considerable dilatation on the small intestine, but the anterior division of the left lobe of the liver is large and widely invests it. The posterior section of the gland fills up the lesser curvature posteriorly. The small intestine of a male, measuring 6 inches, was $29^{\prime \prime} \cdot 25$ in length. The large intestine began by a decided and sudden enlargement, and was 6 inches long. The liver is olive-brown and minutely punctulated with black. The free lobule of the cystic division is occasionally unconnected with the process that projects to the right from the inferior angle of the left division of the liver, but the two are generally connected by a delicate band of liver substance. The gall bladder usually perforates the outer side of the liver, but is sometimes invested by it. The pancreas is narrow, band-like, compact but thin, extending from close to the pyloric extremity to a little to the left of the termination of the gall duct. The spleen is a reddish gland, in the usual Chelonian position, 7 lines in length by 3 in width. The thymus is small, round and yellowish, 4. lines in diameter, slightly compressed from above downwards, situated anterior to the base of the heart and lying below the origin of the great vessels. It is divided into minute hexagonal lobules, which have almost completely degenerated into fat. There are numerous lymphatics of a deep almost blackish colour, all about the cardiac area, especially at the apex of the lungs and along the mesial line of the neck. There is a very extensive cluster of large black inguinal glands closely applied over the cloacal bladders, immediately external to the kidney and the extremity of the lung which overlaps the anterior end of the kidney. The lungs are simple, being very litle lobulated, the dorsal margin presenting a flat surface where it is applied to the sides of the vertebral column, but without any lobulating; a partial bilobing of the apex; a projecting outer margin, contracting anteriorly and posteriorly; and a simple terminal sac-like lobule. The lungs are not very capacious. The glans-penis and the clitoreal area are jet black; the urethral folds are very distinct. The glans is pointed, with the rosette consisting of three pairs of lobes on either side of the termination of the urethral groove, the distal pair being connected together by a transverse septum, the distal surface of which is traversed by the end of the urethral groove. The mesial pair of lobes are very small. The clitoris consists of two lobes forming a triangle with a distal apex, their extremities free proximally, a transverse fold connecting them with a pit below it, the ends of the lobules having each a small filamentous process behind it, in reality the termination of the urethral fold of either side. The cloacal bladders are large, without any villi, the walls being perfectly smooth when expanded, but rugose when contracted. From their orifices a smooth tract runs along the cloaca to terminate externally.

This variety differs but slightly from the Indian form, but sufficiently to entitle it to be indicated as a local race. In its habits also it appears to me to be less active.

Like the Indian form, this Burmese variety is exclusively a vegetable-feeder, and I observed that among other aquatic weeds it eat the common Vallisneria, and, in confinement, plantains with avidity. It lays a number of oval eggs at one time, burying them a little way underground. 
I obtained this species at Bhamô, and have received specimens from Moulmein and from Khyouk-Phyoo in Arracan. It is prevalent throughout the Irawady, and doubtless extends down the Malayan peninsula. It is closely allied to $G$. nigricans. There appear to be four distinct varieties of this species; the Burmese form; the Madras form which extends northwards as far as Chota Nagpur and across India to Goa, and to the north-west as far as the Jumna Canal, from whence it has been recorded by Theobald, thus having a distribution much the same as Emyda vittata, Peters; and a variety in the southern extremity of India (Travancore); and another in Ceylon. The shells are most variable in form, and the differences lie chiefly in colour.

The Madras variety, E. trijuga var. maderaspatana, is generally brown, with a paler margin to the shell, and the females are paler than the males. The head is dark brownish-olive. In the Southern India variety (Travancore) var. coronata, the shell is entirely black above and below, with no pale band on the sternum between the axilla and groin. The upper surface of the head from the tip of the snout between the eyes to the commencement of the occipital spine, and the upper surface and one-half of the sides of the first two-thirds of the neck, black. A vertical black line from between the nostrils to the border of the lip. A yellow band from the orbit over the tympanum, and temporal area golden-yellow, but of variable extent. The Ceylon variety, Emys sebr, Gray, is wholly black, except a narrow yellowish line down the vertebral ridges and along the margin of the shell, but the margins of the plastron are broadly light yellow, and the inner aspects of the marginals are yellowish. In the adult, the head is almost uniformly black, but in the young it is brightly spotted all over with orange.

I have never observed an Emyde of this nature in the Calcutta tanks, nor indeed in Bengal, and on examining the types of $E$. trijuga, D. and B., in the Paris Museum, I found they corresponded to the Madras pale-brown variety. The specimen said to have been procured at Calcutta is very young, and is certainly not D. hamiltoni, as has been suggested by Blyth, but it has the spotted head of the Emydes found in Ceylon; however it is too young for any one satisfactorily to determine what it really is.

The type of $E$. belangeri, Lesson, I could not find in the Paris Museum, after having searched for it.

$$
\text { Family-BATAGURIDAR. }
$$

\section{Genus BAta GuR, Gray.}

Shell solid; ridged or unridged on the dorsal surface; vertebral plates generally broad posteriorly; the fourth, in some, anteriorly pointed; posterior margin of shell denticulated in the young state, denticles disappearing with age. Sternum flat in both sexes. Process from hyoplastron sending up a strong lamellar process to the first costal plate, greatly constricting the axillary entrance to the visceral section of the shell; hypoplastron sending up a similar process to the fifth and sixth costal 
plates, and narrowing the inguinal end of the visceral section of the shell. Skull with the jugal and quadrato-jugal bones strongly developed; a broad and long alveolar plate to the upper jaw, with one or more ridges, and with its outer margin denticulated; posterior nares somewhat constricted and deep; palate narrow, concave; palatine foramina minute; pterygoid region not broad, constricted at the middle, nearly flat. Membrane bones in the eye. Feet with five toes anteriorly and posteriorly, only four in the hind foot appearing externally beyond the skin; claws 4-4 or 5-4. Toes broadly webbed. One or two sigmoid flexures to the large intestine. Cloacal bladders. Two processes of the lung free in the visceral cavity. Eggs oval. Males generally smaller than females, and with the caudal vertebræ elongated.

\section{Batagur trivitiata, Dum. \& Bib. Plates LXII \& LXIII.}

Emys trivittata, D. \& B., Erpét. Génl., vol. ii, 1835, p. 351 ; Cantor, Journ. As. Soc., Bengal, vol. xv, 1847, p. 610 ; Duméril, Cat. Méthod. des Rept., 1851, p. 14; Gray, Cat. Tort., \&c., B.M., 1844, p. 17.

Batagur trivittata, Theobald, Journ. Linn. Soc., vol. x, 1858, p. 14 (t only); id., Journ. As. Soc., ex. No., vol. xxxviii, p. 13, 1868 (ᄒ only).

Batagur dhongoka, Blyth, Journ. As. Soc., Bengal, vol. xxxii, p. 84, 1863, pars.

Clemmys dhongoka, Strauch, Vertheil. Schildkr., p. 88, 1865, pars.

Kachuga peguensis, Gray, Proc. Zool. Soc., 1869, p. 201, fig. 12 (skull) ; id., Suppl. Cat. Shd. Rept., 1870, p. 55, fig. 20 ; Theobald, Proc. Zool. Soc., 1870, p. 676.

Kachuga trilineata, Gray, Append. Cat. Sh. Rept., p. 18, 1873, pars.

Batagur trivittata, Theobald, Descr. Cat. Rept., B. Ind., 1876, p. 21 (t only).

I have personally examined the types of E. trivittata in the Paris Museum, which are stated to have been obtained by Reynaud, who was the Surgeon attached to the Expedition of the Chevrette to the East Indies. The males which I have here described, and of which I procured three from the Irawady and one from Bhamô, agree exactly with the types in the Paris Museum, so that there can be no doubt of the specific identity of these males with $E$. trivittata. There is a difficulty, however, regarding the supposed females.

Dr. Gray ${ }^{2}$ described a species of fresh-water tortoise from a skull said to have been procured in India, and assigned to it the name of Kachuga trilineata, Theobald, which was evidently a misprint for trivittata, the name under which Theobald ${ }^{2}$ had described the male and female of this species. On the same occasion Dr. Gray described another skull to which the habitat of India was assigned, under the inappropriate name of $K$. peguensis, if India were the proper habitat of the animal.

In 1870, Mr. Theobald ${ }^{3}$ pointed out that he had never described a freshwater tortoise under the name of $B$. trilineata, and had never taken to England the skull of a three-streaked Batagur from India, although he had taken to London

\footnotetext{
1 Proc. Zool. Soc., Lond., 1869, p. 200.

2 Journ. Linn. Soc., vol. x, 1868, p. 14.

3 Proc. Zool. Soc., 1870, p. 676.
} 
skulls of such a species from Pegu, and he again correctly identified the threestreaked Burmese Batagur with $B$. trivittata, and directed attention to the skull of what he believed to be an adult female collected by himself in Pegu and which was at that time in the British Museum. Mr. Theobald also stated that this female skull was very different from the skull of the male, which was a smaller and more finely coloured animal, and that he considered it probable that the skull of the female was the skull on which Dr. Gray had established the species B. trilineata. He was further under the impression that the $K$. peguensis of Gray had been founded on a skull (possibly aberrant) of either Tetraonyx lessoni or B. trivittata. ${ }^{1}$

In 1870 Dr. Gray ${ }^{2}$ accepted Mr. Theobald's term B. trivittata as the equivalent of his $K$. trilineata, which he at that time acknowledged as his own, but he did not recognize the identity of the three-streaked Batagur of the Trawady with the Emys trivittata of Duméril and Bibron, and described it under a term which had first been erroneously applied by himself under the impression that the term had originated with another naturalist. ${ }^{3}$

In the Supplement in which the Irawady three-streaked Batagur appears as $K$. trilineata, Dr. Gray gave as the habitats of the species, Nepal and Pegu, and mentioned that the Nepal specimen was the one figured originally under the name of Emys lineata, but which is undoubtedly $B$. lineata or $K$. lineata of page 56 of the same Supplement. Moreover, under $K$. fusca at page 56, a female from Nepal is mentioned, presented by Hodgson, and undoubtedly an example of $K$. lineata, as I have satisfied myself by actual examination of the specimen; the other specimen of $K$. fusca having been obtained from Theobald, and, being a female, was doubtless regarded by him as the female of B. trivittata. Dr. Gray, in describing $K$. trilineata, adopted Theobald's conclusions regarding the differences that subsist between the sexes, and he stated that on re-examination he was inclined to regard the differences between the skulls as merely sexual, or individual. Dr. Gray, however, did not go so far as to include the term $K$. peguensis as a synonym of $K$. trilineata, and in speaking of the skull of $B$. peguensis he said that it might prove to be the skull of one of the species described in his Cataiogue, thus conveying the impression that he did not regard the evidence of the specific identity of the skulls as conclusive. A comparison of the figures of the two skulls reproduced by Dr. Gray in his Supplement is sufficient to convince any one familiar with the variations that may occur in skulls, that the two forms are very closely allied, whatever explanation may be offered of the slight observable differences occurring between them. In the Appendix to the Catalogue of Shield Reptiles, Dr. Gray correctly pointed out that Theobald was in error in suggesting that $K$. peguensis was possibly founded on a skull, probably aberrant, of Tetraony $x$, as the skull of $B$. baska is at once distinguished from the skulls of all known

1. Theobald, Proc. Zool. Soc. 1870, p. 676.

2 Suppl. Cat. Shd. Rept., 1870, p. 54.

3 I state these facts, as they are absolutely necessary to a clear understanding of the specific terms which have been apulied to this form. 
Batagurs by the presence of two strong palatal ridges, the inner, however, being much smaller than the outer ridge.

The female referred by Theobald to $B$. trivittata had no trace of black bands on the shell, which, instead of being greenish above, as in the male, and yellow below, was uniform brown, above and below. Now, in Batagur duvaucelli, which is a very nearly allied form, and the sexes of which are well known, and which has its shell with three black dorsal streaks, as in the males referred by Theobald to E. trivittata, there is no such difference in the colour of the shells of the two sexes, which are both black-streaked. There is this to be said, however, that these males referable to the species $B$. trivittata differ from the males of $B$. duvancelli in attaining to a much greater size; the males of $B$. duvaucelli, as far as my observations go, seldom exceeding 9 inches in length, whilst some females are 16 inches long; the largest male, B.trivittata, from the Irawady attained to $17^{\prime \prime} \cdot 90$. Besides these differences in size subsisting between the sexes of $B$. duvaucelli, there can be no doubt but that among some species, at least of Batagur, the male, as in birds, is a much more brilliantly coloured animal than the female, if not at all times, at least during the breeding season. This is the case in the species known as $B$. lineata, in which the head and neck of the male are brilliantly coloured, black, scarlet and yellow, and it also holds good in B.baska, in which the male has the area around the nostrils waxy-blue, the anterior portion of the head, behind this, deep black, followed by brilliant scarlet, extending over the neck even to the fore limbs.

The male of $B$. lineata is a small animal compared with the female, but in $B$. baska there is no great disproportion between the sexes. In another sub-genus, (Hardella) there does not appear, as far as my experience goes, to be any difference in colour between the males and females of this very common river tortoise $B$. (Hardella) thurgi, but the largest female of it which I have measured was $19^{\prime \prime} \cdot 10 \mathrm{com}$. pared to $6^{\prime \prime} \cdot 20$, the length of an adult male; and a proportion between the sexes somewhat similar to this prevails among the so-called Pangshures, and a great disproportion also occurs between the sexes of the sub-genus Morenia, all of these forms presenting more or less one type of structure. In the Pangshures, in which the males are small, the lineation of the shell, if it occurs in one sex, is always present in the other, and in Hardella the shells of both sexes are more or less lineated, and, in MIorenia, the shells of the males and females are alike ocellated. There are, however, such great differences between the colours of the soft parts of the sexes in such species as $B$. lineata, in which the head and neck are brilliantly streaked red and black, these parts in the female being dull olive, that the difference of colour subsisting between the males and females referred by Theobald to $B$. trivittata, even in view of the conformity of colouring in the male and female of $B$. duvaucelli and the other forms mentioned, should not have deterred me in unreservedly accepting Mr. Theobald's conclusion regarding the specific identity of these males and females had there been a strong similarity in the form of the shells, and had I not received from the Irawady a young male tortoise (Pl. lxiv), resembling the females in question, and to that degree that it may ultimately prove to be the male of the 
females referred to $B$. trivittata by Theobald, because its shell much more resembles the shells of the females than the shells of the black-striped males. Moreover, although a little younger than the male (Pl. lxii), its characters are such that it seems highly improbable that it could ever attain to the characters presented by that species, and which is unquestionably $B$. trivittata, D. and B. Besides, I have obtained from the Irawady young females nearly of the size as this young male, and agreeing with it in every particular of shell form. These young females correspond in all essential particulars to the adult females considered by Theobald to be females of B.trivittata. As the young brown male cannot be reconciled as specifically identical with the black-banded males; and as moreover it does not exhibit any capacity whatever, ever to change by growth into the form and colour of the males of undoubted $B$. trivittata, it would appear that there are two species of Batagur in the Irawady closely allied by the characters of their vertebral plates and skulls, but differing from each other in the general form of their shells and in their coloration; the females of $B$. trivittata, according to this view, being unknown, whilst both sexes of the other are known, the females constituting in part the species first described by Dr. Gray under the name of B. fusca. This latter term, however, is open to objection, as Dr. Gray included in it two species; therefore, I propose to distinguish the species represented by these females and young male as B. iravadica.

However, I separate these tortoises specifically with some hesitation, because the skulls of the adult males and females referred by Theobald to $B$. trivittata are so alike to one another, and so resembled by the skull even of the uniformly coloured male, that I cannot seize on any cranial character which would separate them specifically, unless it be the greater upturning of the nasals in the latter. Looking, however, at the young male (Pl. lxiv) as a whole, and comparing it with the young male of $B$. trivittata, (Pl. 1xii), the external features are very different, viz., the shorter and relatively higher shell of the former, the inward projection of the second costal between the second and third vertebrals, the more serrated jaws, as in the female (Pl. lxviii), and the uniformly brown shell compared with the green thrice black-banded shell of $B$. trivittata. The short rounded head and the spinous nodosities of the vertebrals are youthful characters.

The shell of an adult male of $B$. trivittata, the sex of which was accurately determined by me, presents the following characters :-

The shell is oval, somewhat expanded posteriorly, with slightly reverted marginals. It is highly and roundedly arched anteriorly, and therefore deep, but the posterior half of the shell is somewhat depressed. The young male, however, figured (Pls. lxii and lxiii) is not so highly arched over the first and second vertebrals; and the dorsal ridge, which is absent in the adult, is strongly marked. The plastron has the general form in the genus, and in the adult is devoid of the lateral ridge which exists in the young. In the full-grown male, the nuchal is large, triangular, broad posteriorly and narrow anteriorly, which is its general form. The first and second vertebrals are of equal breadth, with their lateral margins slightly sinuous, the shields 
being broader than long, and the second longer than broad, but only to a slight degree. In the young male (Pls. Ixii and Ixiii), the posterior two-thirds of the lateral margins of the first vertebral are slightly convergent, and the remaining anterior third suddenly divergent. The third vertebral has the same breadth in its anterior half as the two shields anterior to it, but the sides of its posterior half are convergent,its posterior border being slightly concave. The anterior border is nearly straight, whereas the anterior border of the second shield is slightly convex. The breadth of the third vertebral exceeds its length about one and a half times. The fourth vertebral is considerably longer than broad, and its greatest breadth is attained at its middle, both its ends are of nearly the same breadth, and its anterior border is slightly convex, and its posterior border concave.

The anterior border of the gulars is transverse, and the form of the combined shields is a broad triangular figure; their common suture equals one-half of the length of the preanals. The postgular suture with the pectorals is posteriorly convex, and the length of the postgular plates is considerably less than the length of the pectorals. The pectoro-abdominal suture is also posteriorly convex, but not so much as in the previous suture. The abdominal plates equal the length of the preanals and one-half the length of the anals. The anals are about half the length of the abdominals. The anal notch is wide, but not deep. The lateral ridge in adolescents assumes the form of an elongated eminence on the side of the pectorals, and on the posterior ends of the abdominals.

The portion of the head anterior to the eyes is slightly upturned, the nasosymphyseal line is moderately oblique and the head moderately broad. The margins of the jaws are denticulated. The limbs are well developed, and the hind feet rather broad and the toes are well webbed. Claws 5-4. The limbs sparsely covered, as in the species generally, by small isolated scales which become large along the outer margins of the limb and over the toes. The tail is long.

The shell is pale dull greyish-green, strongly marked by three broad black bands tending to unite posteriorly. The vertebral band begins on the nuchal and extends on to the caudals; the lateral bands begin on the posterior portion of the first costal and generally unite behind with the vertebral band. Trregular black parallel streaks or spots occur on the fourth marginal backwards, paling and diminishing posteriorly. The under surface of the plastron pinkish yellow, with greenish areas occupying the sides of each plate, separated by yellow intervals.

Head of the animal rich green, with a yellowish tint along the lips. A narrow black band runs from the nostrils along the mesial line of the upper surface of the head, somewhat expanded between the eyes, and passes on to the upper surface of the neck. A narrow black dotted line from the nostrils to the eye. The iris is greenish, with a pinkish conjunctiva. The green of the head passes into yellowish on the neck. The tail and the outer surfaces of the limbs are greenish, with a yellowish external margin; claws pinkish yellow ; the inner surfaces of the limbs are pale fleshy.

Theobald described the head of the male of the animal he referred to $B$. trivittata as having the head of a deep flesh-red, or carnation tint, apparently as in B. baska, 
in the adult state, which is very different from the waxy-green of the Bhamô male just described from the living but only adolescent animal, the difference in head colouring being the result of sexual maturity, either permanent or seasonal.

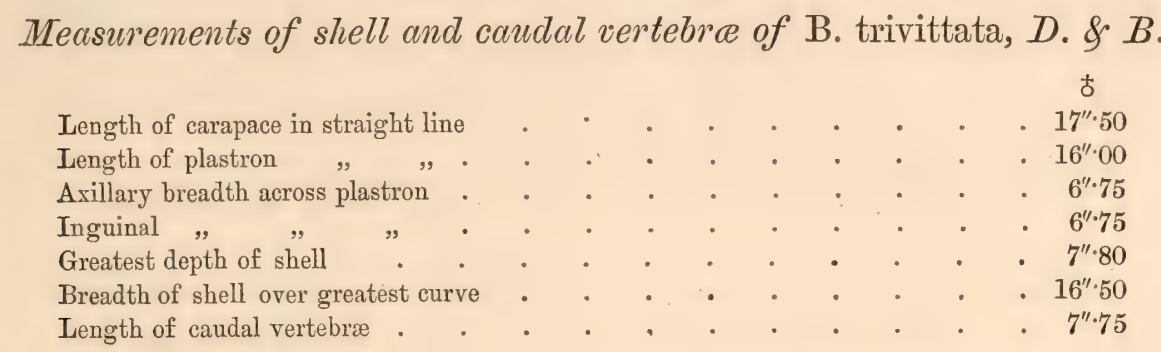

The skull is very closely allied to the skull of $B$. lineata, the two species having the same form of palate, but the posterior plate of the palate in $B$. lineata is much broader than in $B$. trivittata, and the posterior nares of the former are narrower than in the latter; also the pterygoid portion of the skull of $B$. trivittata is broader than in $B$. lineata. The nose of the latter is less upturned than in $B$. trivittata, and the muzzle of the latter is narrower, longer, and more pointed; and the margins of the jaws not so strongly serrated. In general form, it also closely resembles the skull of $B$. duvaucelli, and in the upturning of its nose is almost exactly like that species, but its posterior nares are much more open and the palatal region is separated from that of $B$. duvaucelli by the narrow character of the posterior plate.

I have figured the skull of the young male ( $\mathrm{Pl} . \operatorname{lxxv}^{\mathrm{A}}$, figs. 1 to 5 ).

The small tongue is marked by a slight median groove, on each side of which are a few blackish oval fleshy processes, the most posterior being divided into finger-like points, and external to this there is, on each side of the base of the tongue, a bunch of these finger-like processes separate from the others. The larynx forms a flattened triangular eminence, with a longitudinal crenated slit in its centre, the external margins of the eminence being surrounded by a fringe of processes, like those occurring on the tongue. Behind the larynx, the first part of the œsophagus is covered to a limited degree with papillary eminences, as in $B$. baska, $B$. thurgi, and in $B$. duvaucelli. These become flattened and lamellar in some instances, and close behind the larynx form two short lines, which, losing their lamellar and papillary character, rapidly increase in number and assume the form of fine wary longitudinal mucous pidges, prolonged into the first part of the stomach as much thicker longitudinal folds, twelve to fifteen in number, which disappear shortly after entering the stomach. The stomach is considerably dilated up to the left border of the liver, and from the longitudinal folds, to this point, is smooth. Its transverse portion, to below the narrow mesial isthmus of the liver, is funnel-like and with very thick walls, with muscular coats nearly a quarter of an inch in thickness. At its extremity this portion of the stomach rapidly contracts into a small pyloric-like orifice, and its inner surface is marked with about eight somewhat wavy thick longitudinal 
folds. The intestine preserves the character of the true Batagurs, such as $B$. lineata, $B$. duvaucelli, and $B$. baska, in having a simple sigmoid turn after the transverse colon. The cæcum also is rudimentary, as in the foregoing species, and not so developed as in B. (Hardella) thurgi. The large intestine, in the largest male, measured from its lower internal end to its junction with the small intestine, 2 feet $4 " \cdot 75$; and the small intestine, with its walls much contracted on themselves, was 5 feet $2^{\prime \prime} \cdot 75$. The cloacal bladders are well developed, also the allantoic bladder itself. It has large inguinal glands.

The liver has the general characters of this organ in Batagur (Morenia) ocellata.

There are no osteological features to entitle this animal to be separated generically from $B$. lineata or $B$. duvaucelli, nor is there anything in its soft anatomy to justify such a sub-division of the species.

It occurs throughout the Irawady, from the estuary streams up to Bhamô, where it is not uncommon. Theobald records it from the Moulmein river and the Salween. It does not occur in Bengal, as far as I am aware, where it is represented by $B$. duvancelli.

Batagur Iravadica, n. s. Pls. LXIV, LXV, LXVIII, \& LXIX.

Batagur trivittata, Theobald, Journ. Linn. Soc., vol. x, 1868, p. 14 ( $q$ only); Journ. As. Soc., Bengal, ex. No., vol. xxxvii, 1868, p. 13 ( $q$ only).

Kachuga trilineata, Theobald, apud Gray, Proc. Zool. Soc., 1869, p. 200 (skull, fig. 13); Gray,

Suppl. Cat. Shd. Rept., 1870, p. 54, pars. fig. 19 (not Nepal specimen); id., App. Cat. Shd.

Rept., 1873, p. 18, pars.; Theobald, Proc. Zool. Soc., Lond., 1870, p. 676.

Kachuga fusca, Gray, pars. Suppl. Cat. Sh. Rept., 1870, p. 56.

Batagur trivittata, Theobald, Deser. Cat. Rept., B. Ind., 1876, p. 21 ( + only).

Adult $q$. The shell anteriorly is less full than in old males of $B$. trivittata, and not so roundedly arched from side to side, and it is more downwardly arched anteriorly. The vertebral ridge is feebly marked. The posterior portion of the shell is expanded, and the marginals about the 7th, 8th, and 9th slightly reverted. The lateral ridge on the plastron is not persistent in the adult.

The nuchal is large and triangular, with its base placed posteriorly. The vertebral shields have much the same form and arrangement as in B. lineata and B. trivittata, but the three first vertebral plates in adult females are not so broadlas in the males of the latter species, and their lateral margins are more convex, but in other respects these plates and those that follow much resemble the corresponding plates of the males of $B$.trivittata. There are, however, certain differences between the two which would seem to be persistent in the adults. In the adult male of $B$. trivittate the lateral margins of the first vertebral are nearly straight, whereas in adult females of $B$. iravadica the lateral margins are markedly concave towards the mesial line, and the same holds good of the second vertebral, which in this respect differs from the nearly straight-sided corresponding shield of the $B$. trivittata. The anterior section of the plastron is not so broad as in the males of 
B. trivittata, and its sides are straighter, but the form of the plates is much the same in both species.

The adult female is dark uniform brown above and below, with no black bands on the back, as in B. trivittata, but the brown on the under surface is made up as it were of dark rods of colour, lying closely side by side on a brown back-ground, and radiating more or less from the position of the areolæ of the plates. In the adolescent (Pl. lxix), the plastron is almost wholly yellow, only a faint brown radiation presenting itself from the areolæ of the gulars, postgulars and pectorals.

The head is olive, also the internal surface of the limbs and the tail. The horny sheaths of the jaws are yellowish and the under surface of the neck; the greater part of the upper surface of the neck being brownish. The iris is brown and the claws yellow. The plates on the limbs are distributed much in the same way as in other species of Batagur.

The largest female measured is No. 1 of the following table:-

\begin{tabular}{|c|c|c|c|c|c|c|c|c|c|c|c|c|c|}
\hline & & & & & & & & & & & $\begin{array}{c}\text { No. } 1 . \\
\text { \& }\end{array}$ & $\begin{array}{c}\text { No. } 2 . \\
\text { q. } \\
\text { Juv. }\end{array}$ & $\begin{array}{c}\text { No. } 3 . \\
\text { J } \\
\text { Juv. }\end{array}$ \\
\hline Length of carapace in straight liue & - & - & - & . & - & . & . & - & . & . & $17 \cdot 20$ & $8 \cdot 10$ & $7 \cdot 15$ \\
\hline , of plastron & - & - & . & - & . & - & . & : & . & • & $15 \cdot 90$ & $7 \cdot 40$ & 6.36 \\
\hline Axillary breadth of plastron & . & - & - & . & . & 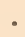 & . & . & . & • & $6 \cdot 60$ & $2 \cdot 80$ & $2 \cdot 65$ \\
\hline Inguinal $", \quad$ • & • & - & - & . & • & . & . & 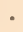 & . & . & 6.75 & $3 \cdot 20$ & $2 \cdot 63$ \\
\hline Greatest depth of shell & $\cdot$ & - & - & - & . & - & • & . & . & • & $7 \cdot 90$ & $3 \cdot 50$ & $3 \cdot 40$ \\
\hline " breadth of shell over curve & : & - & - & - & • & : & • & - & - & - & $15 \cdot 70$ & $8 \cdot 52$ & $7 \cdot 50$ \\
\hline Length of caudal vertebræ & - & - & - & . & . & - & . & . & . & . & $5 \cdot 60$ & $0 \cdot 00$ & 0.00 \\
\hline
\end{tabular}

Juv. o Shell oval, highly arched, denticulated posteriorly, and costals rather flat. Dorsal ridge well developed from the first vertebral to the caudals, least marked on the first vertebral. Marginals expanded, not reverted. Nuchal broad posteriorly, anteriorly pointed, large and triangular. Form of the vertebrals much as in B. trivittata, but the fourth vertebral shorter. The lateral margins of the first vertebral are first strongly convergent for a short way from the marginals, and then divergent, the anterior margin slightly convex and the posterior margin concave, the length of the shield being slightly exceeded by its breadth. The second vertebral has its lateral margins slightly concave behind its articulation with the first costal. It is broader than long, and its anterior border is convex, and its posterior border concave. The third shield is hexagonal, the sutures with the second and third costals being somewhat sinuous, but of equal length. The anterior border is slightly concave and the posterior border convex. This shield is nearly twice as broad as long. The fourth vertebral is an elongated hexagon, its greatest breadth is between the third and fourth costal sutures, and the shield is nearly as broad as long. This plate has much the same form as in B. lineata, and its third costal suture is the longest. The fifth has the general form of this shield in Batagur. The vertebral ridge rises into a kind of nodosity at the posterior margins of the second, third and fourth vertebrals. The anterior portion of the plastron is rather rounded; broader than the post-inguinal portion. The lateral ridge is confined to the posterior portion of the pectorals and abdominals. Anal notch feeble, open; gulars triangular, a little 
more than half the length of the postgulars; the latter nearly equalling the length of the pectorals, which equal the preanals in length, and are considerably shorter than the abdominals. The anals are one-fourth shorter than the preanals.

In the young animal ( $\delta$ ) Pls. lxiv and $1 \mathrm{xv}$, somewhat younger than the preceding, the general character of the shields, as described in the female, are preserved, but the dorsal ridge is more marked, and sharply pointed at the ends of the second, third and fourth vertebrals. The posterior portion of the shell is also more denticulated. The plastron has the same form as in the female, but the lateral ridge is strongly marked along each side, becoming intensified near the hinder border of each shield, and the gulars are somewhat broader, and the inguinal breadth less.

The general colour of each of the female shells is brown above with a faintly darker area over the areola of each costal, and the margin of the shell is paler, and its under surface is wholly brown. In the male, the upper surface is entirely brown with a yellow margin and darker on the areolæ, but neither in this specimen nor in the females is there any tendency to develope the black bands, as in B. trivittata. The under surface is yellow, but all the areolar centres of the plates are covered more or less with a blackish pigment, which seems scaling off, and is not represented sufficiently dark in the plate.

In alcoholic specimens of these young males and females, the colour of the head and neck is pale brownish tinged with pinkish, without any trace of a black band on the vertex; the jaws are yellowish, and the axillary and inguinal regions and the sides of the tail are pale greyish-brown. The claws and the margins of the limbs are yellowish.

The skulls of two adult females, which agree with one another in all their essential features, present certain differences the one on the other. In one specimen the basisphenoid is very much broader than in the other, in which the posterior nares are somewhat narrower than in the former. The breadth also across the mesial portion of the base of the skull, defined by the ridges of the pterygoids, is narrower in the skull with the broad basisphenoid than in the other. There are also minute differences in the forms of the bones entering into the temporal fossa. The frontal also, in the two adult and in one adolescent skull, enters into the upper margin of the orbit, narrowly in one, broadly in the others; whilst in the young male it is wholly excluded from the orbit. These adult female skulls agree with the skull figured by Gray as Kachuga trilineata, the original of which was obtained from Theobald, who at first regarded it as a female skull, although in $1876{ }^{1}$ he states that the species B.trilineata, Gray, was based on the head of a male animal. This differs from the male skulls referred to $B$. trivittata, in the same details that the skulls figs. 19 and $20^{2}$ differ from one another, viz., in the greater breadth of the female skull (? fig. 19) at the posterior angle of the upper jaw, although the skull fig. 19 is a shorter skull than fig. 20. The prefrontals also are less upturned in these females than in the males, which is also a feature of difference between figs. 19 and 20. I am therefore disposed to think that Mr. Theobald's first

12 Descr. Cat., p. 21.

${ }^{2}$ Suppl, Cat. Shd. Rept., pp. 54, 55. 
statement regarding the sex of these skulls was probably correct. The aural orifice also of the female skulls is not so round as in the male skull. These are the only differences which suggest themselves after a very careful examination of the adults.

In the young male (Pl. $1 \times x v^{\mathrm{B}}$, figs. 16 to 20$)$ the upper surface of the skull is nearly flat, but its other features are the same as in the females.

The skull closely resembles the skull of $B$. lineata, from which, however, it is at once separated by its deeper premaxillary notch; the feebler serration of the maxillary; the much more concave character of its under surface; the much less downward arching of its palate, and especially by the antero-posteriorly broad plate behind the single palatal ridge. Superiorly the skulls are very much alike.

As stated in the definition of the genus, the eyes of this as of other species are strengthened, as in birds, by a ring of bones in the sclerotic.

The viscera of the large female were compared carefully with those of the adult male of $B$. trivittata, and the only notable differences were, 1 st, the much shorter small intestine measuring only $46^{\prime \prime} \cdot 50$, and the large intestine 30 inches, although the intestinal tube, in the individual examined, was very soft and flaceid compared with the contracted gut of the specimen of B.trivittata; and 2 nd, the much smaller ear-shaped processes of the lung, lying free in the visceral cavity, compared with the large processes of $B$. trivittata. The cloacal bladders had much the same character as in $B$. trivittata.

I have received examples of this species from Pegu and from Bhamô in Upper Burma, so that it appears to be generally distributed throughout the Irawady.

I propose here to consider two other allied species which do not belong to the fauna of the Irawady and its affluents, but which from their close relation to this and the foregoing species, and the little that is known regarding them, are worthy of being here considered.

\section{+ Batagur dutaucelli, D. \& B.}

Emys dhongoka, Gray, Ill. Ind. Zool., vol. ii, 1834, Tab. 60, fig. 2 (not described) ; Blyth, Journ. As. Soc., vol. xxiii, p. 210, 1854.

Emys duvancelli, Dum. \& Bib. Erpèt. Gén., vol. ii, 1835, p. 335 ; Gray, Cat. Tort. B. M., 1844, p. 15 ; Duméril, Cat. Méth. Rept., 1851, p. 14.

Batagur dhongoka, Gray, Cat. Sh. Rept., 1855, p. 36, Tab. xviii, figs. 1 to 3, juv.; Günther, Proc. Zool. Soc., 1861, p. 214 ; id., Rept., Brit. Ind., 1864, p.42 ; Blyth, Journ. As. Soc., Bengal, vol. sxxii, p. 84, 1863, pars; Theobald, Cat. Rept. Journ. As. Soc., Bengal, vol. xxxvii, ex. No., 1868, p. 12 ; id., Des. Cat., 1876, p. 22.

Kachuga hardwickii, Gray, Proc. Zool. Soc., Lond., 1869, p. 202.

Clemmys dhongoka, Strauch, Chelon. Stud., 1862, p. 33 ; id., Verth. der Schildkr., 1865, p. 88, pars. Dhongoka hardwickii, Gray, Suppl. Cat. Sh. Rept. B. M., 1870, p. 57, pars; App. Cat. Sh. Rept., 1872, p. 18, pars.

Dhongoka hardwickii, Gray, Hand-List, Sh. Rept., 1873, p. 52.

The shell is oval and more pointed posteriorly than anteriorly, attaining its greatest expansion about the seventh marginal, with its posterior portion depressed, with a depression sometimes over the region of the fourth vertebral, or continued 
across between the third and fourth costals. A vertebral ridge in the young rising into two prominent nodosities on the posterior margin of the second and third vertebrals. In adults, the ridge all but disappears, but the nodosities are visible; or the ridge is most marked on the first and last vertebrals and caudal. Caudal notch well defined in the adult females, but apparently less so in the males. Nuchal small and triangular, pointed in front and broad behind. The first vertebral is more elongated than in the young, and in some it has a distinct hour-glass form, but in others the anterior half of the hour-glass is much more contracted than the posterior half. In this form it strongly resembles the first vertebral of $B$. thurgi. Its shape varies considerably, as it is sometimes only as broad as long, while in others it is much longer than broad. The suture between the first and second vertebrals is always transverse. One of the most characteristic features of the vertebrals is the pointed posterior extremity of the second plate, which projects inwards into the third plate with a central nodosity. This plate is broader anteriorly than posteriorly, and its breadth may equal its length, or it may be broader than long. The character of this plate in the adult (in some young examples the backwardly pointed form of the second vertebral is not so well defined), enables the species at once to be distinguished from the other two species of black-lined Batagurs, B. trivittata and $B$. thurgi, in both of which the sutures between the first and second, and second and third vertebrals are transverse. There are many other features by which they can be separated, but these shield characters suffice to distinguish $B$. dwvancelli. The third vertebral is deeply emarginate on its anterior border, and its greatest length equals its breadth. The fourth vertebral is long, with a transverse suture between it and the plate before and behind it, and it is generally a little narrower anteriorly than posteriorly, and in this is like B. lineata. In the character of its second vertebral, it is closely approached by the so-called genus Pangshura. The greatest breadth of this plate falls short of its length, and its general character is to be dilated at its middle, and slightly contracted at its ends. In $B$. thurgi, this plate is short and broad, while in $B$. trivittata it is long as in $B$. duvaucelli, and in $B$. iravadica it is also somewhat long, as in $B$. lineata, its Western representative. The fifth vertebral is broader than long, with a somewhat rounded anterior margin, equalling about one-half the length of the plate, and with a nearly straight, sinuous, or posteriorly concave fourth costal border. It is in contact with a small portion of the tenth marginal.

In the young, the posterior margin of the shell is strongly serrated from the eighth to the twelfth marginal, but this serration entirely disappears in the adult.

The carapace of the male is considerably more depressed, and not so deep as the carapace of the female.

The sternum of the male is narrower and more elongated anteriorly than in females of the same size, and has a less axillary and inguinal breadth. The sternal ridge is well developed in the young, but disappears with age, and is obsolete in females measuring $7^{\prime \prime} \cdot 11$, with a faint trace of it in males a little larger than this. 
The gulars are abruptly truncated anteriorly, their free marginal breadth equalling, or nearly equalling, twice their length. The length of the postgulars is onefifth less than the length of the pectorals, and the latter are about one-third shorter than the abdominals which equal the pectorals and two-thirds of the postgulars. The preanals are about the same length as the pectorals, and the anals are two-thirds as long as the preanals. The anal notch is broadly crescentic. In the young, the proportions are different; the gulars are as long as the postgulars, the preanals as long as the pectorals and nearly one-half of the postgulars; the abdominal nearly equalling the pectoral and postgulars together.

The muzzle is short, moderately broad and upturned, with a feeble concavity between the anterior angle of the eyes; the breadth between the eyes, anteriorly and above, considerably exceeding the distance between their anterior angles and the tip of the muzzle. The nostrils are close together, round, and directed forwards, upwards and outwards. The eye is of moderate size. The jaw is serrated, with two somewhat larger anterior teeth; the margin of the upper jaw is downwardly convex, and slightly upwardly curved posteriorly. A large quadrangular plate behind the eye, with one narrow elongated plate below it, partially broken up into smaller plates, between it and the gape. A large plate above the tympanum, with some smaller transverse plates above it; the plates of the opposite side nearly separated from each other by the posterior extremity of the great plate of the vertex. Skin of the neck very finely granular, which is the character of the skin generally, with the following exceptions : on the inner half of the lower portion of the fore limb there are a series of separate, moderately-sized narrow transverse raised plates, with five large flat plates on the membranous posterior margin of this portion of the limb, with two to four obscure small plates on the dorsum of each toe, on both pairs of limbs. On the hind leg there is a small group of enlarged transverse separate plates on, and near the hind margin. A transverse row of three small plates on the under surface of the wrist, with a small patch of raised sharp plates on the inner surface of the heel. The tail is more granular than the rest of the skin, and is set with spiniferous granules. The tail of the male is considerably longer than that of the females and projects much beyond the carapace. The claws, five anteriorly and four posteriorly, are moderately long, and the webs of the toes are broad and full.

There is an indistinct pale-yellowish, almost white band, between the eyes over the nostril, continued more or less over the superior posterior angle of the orbit, and from behind the orbit, over the tympanum. The upper jaw is yellowish, tinged with green about the nostrils. A broad leaden band through the eye, in the young, to the angle of the mouth and embracing the tympanum, very obscure or absent in the adult. A feeble greenish band from the chin along the throat in the young, disappearing or becoming feeble with age. The upper surface of the head and neck is olive-brown, with a more olive hue on the neck, which is also the colour of the upper surface of the limbs. The sides of the neck have a few obscure palish spots, and the under jaw and chin, throat, and neck are pale yellowish. The under surface of all the remain. 
ing parts is yellowish, with a faint bluish tinge. The upper surface of the shell is a pale olive-brown, almost olive-grey, with a broad black line along the vertebral ridge and another along the upper margin of the costals, the margin of the shell being also black. The under surface is yellowish, with a greenish hue. The iris is a very pale pink, with an inner bright golden margin, but there is no spot. The claws are brownish at the base and yellowish horny at the tips.

I have not observed any difference in colouring between the males and females.

This species does not appear to attain to the size of the other species of Batagur, the largest male and female I have observed measuring as follows :-

\begin{tabular}{|c|c|c|c|c|c|c|c|c|c|c|c|c|}
\hline \multicolumn{11}{|c|}{ Measurements of B. duvaucelli, D. \& $B$. } & \multirow{2}{*}{\begin{tabular}{c}
\multicolumn{1}{c}{} \\
Inches. \\
16.00 \\
13.90 \\
14.25 \\
5.80 \\
5.55 \\
5.75
\end{tabular}} & $\begin{array}{c}\$ \\
\text { Inches. } \\
8 \cdot 6 \\
7 \cdot 0\end{array}$ \\
\hline $\begin{array}{l}\text { Length of carapace in straight line } \\
\text { "re of plastron in ", } \\
\text { Greatest breadth across shell } \\
\text { Axillary breadth } \\
\text { Inguinal ": } \\
\text { Depth through second vertebral }\end{array}$ & $\dot{:}$ & : & $\begin{array}{l}\dot{ } \\
\dot{ } \\
\dot{ }\end{array}$ & $\begin{array}{l}\dot{ } \\
: \\
\dot{ } \\
\dot{ }\end{array}$ & : & $\begin{array}{l}\dot{ } \\
\dot{ } \\
\dot{ }\end{array}$ & $\begin{array}{l}\dot{\bullet} \\
\dot{ } \\
\dot{ } \\
\dot{ } \\
\dot{ }\end{array}$ & $\begin{array}{l}\dot{\cdot} \\
\cdot \\
\cdot \\
\dot{ } \\
\text {. }\end{array}$ & . & • & & $\begin{array}{c}\text { Inches. } \\
\begin{array}{c}8 \cdot 6 \\
7 \cdot 0 \\
7 \cdot 3 \\
2 \cdot 50 \\
2 \cdot 90 \\
3 \cdot 3\end{array}\end{array}$ \\
\hline
\end{tabular}

All the males that I have observed have been small, and distinguishable from the females by the great length of their tails, dependent, as in other Batagurs, not on a variation in the number of the vertebræ, but in the elongation of the bodies of the vertebræ, the tail performing in them the important function of making room for, and supporting, the external organ of generation. Whether they are persistently smaller than the females, I am not in a position to say, although the evidence would seem to point in the direction of their being always smaller, as the males of the subgeneric form Pangshura certainly are; but that the males of this large Batagur have the same disproportionate size to the females as prevails among the Pangshures, I have not sufficient materials to determine. So little is known regarding the laws which regulate the growth of the shell of the Chelonia, it would be premature to hazard any decided opinion as to whether or not the closure of the costal and other fontanelles indicates cessation of growth. I am disposed to think that growth does not cease with closure of the fontanelles.

Dr. Gray has elevated this form to generic rank under the name Dhongoka, distinguishing it from his new genus Kachuga by a single dermic character, viz., the elongated and contracted form of the first vertebral, which shield is nearly square in Kachuga, but there is not a single feature in the internal anatomy, nor in the structure of the skull of Batagur lineata (which may be taken as a typical example of that author's genus Kachuga), by which to separate it generically from the very closely allied species Batagur duvancelli. Dr. Gray retains the genus Batagur for the single species, $B$. baska, which is distinguished by having four claws on both fore and hind feet, and by the osseous ridges of the palate and mandible being more strongly developed than in either $B$. lineata or $B$. duvancelli. But it would seem that these skull differences only merit sub-generic importance, for the skull of $B$. lineata shows distinct indications of the second and hinder 
palatal ridge, while in the lower jaw there is a broad concave surface behind its ridge, only differing from the posterior groove of $B$. baska in its posterior wall being less defined, and the sides of the longitudinal groove less developed. In $B$. baska this central groove is prolonged to the symphysis, owing to the ridge of either side meeting at that point; but in $B$. lineata the two ridges join behind the symphysis, to which they are connected by a sharp central ridge, but this is only a modification of the type of structure which is common to both skulls, and which would hardly seem to merit the importance Dr. Gray has attached to it. Moreover, in $B$. duvaucelli (not the skull figured by Dr. Gray under that name, which appears to be $B$. lineata), there is a still further modification of the mandible, while the palatal surface is nearly the same as in B. lineata. In $B$. duvancelli there is no groove behind the ridge, which is broad and flat without any trace of a longitudinal groove, but the ridges, meeting as in $B$. lineata, are prolonged by a central ridge on to the symphysis. We have thus in B. lineata, a form intermediate in these skull characters between $B$. baska on the one hand, in which they have their highest expression, and $B$. duvaucelli on the other, in which they are least marked. Were it not that $B$. baska is so closely related in its internal anatomy and the structure of its skull to $B$. lineata and $B$. duvaucelli, more importance might be attached to the absence of a fifth claw on its fore foot, but this is little more than a dermic character, and not at all comparable to the absence of a digit, which, when it does occur, is generally considered as of generic importance.

The skull is closely allied to the skull of $B$. lineata, being much broader and flatter in the frontal region and between the orbits than in $B$. baska, but less so than in B. lineata, with a much shorter and broader snout, with the pre-frontals only slightly upturned. It is distinguished from the skull of $B$. lineata by the much greater breadth of the pterygoid region of the skull. The vomer also is much nearer the anterior end of the basisphenoid than in $B$. lineata. The internal nares are oblong in $B$. lineata, with the palatine margin slightly, if anything, inwardly convex, whereas in $B$. dwoucelli these margins are outwardly convex, which gives an oval contour to the conjoint openings. The palate also wants the third ridge which is only indicated in $B$. lineata, and the longitudinal broad eminence that occurs between the traces of the third ridge. But the most distinguishing feature is the total absence of the broad concavity and the longitudinal furrow that occur in $B$. lineata, posterior to the first alveolar ridge of the mandible. In $B$. duvaucelli, the first alveolar ridge is broad and flat on its summit, without any furrow behind it.

The stomach of a female measuring 8 ".25 in the length of its carapace has an extent of 5.25 inches along the lower curve. The small intestine, which is of about one-fourth the capacity of the large intestine, measures 35.75 inches in length. The latter begins by a sudden enlargement which projects more on one side than the other. It has a length of $17 \cdot 50$ inches.

The dorsal division of the left lobe of the liver does not overlap the stomach, but is wholly enclosed in the bend, and the ventral division only partially overlaps 
it. There is a narrow fissure in the anterior margin of the latter, and internal to this another, and, from the lower end of its inner margin, a narrow band is given off which joins with a corresponding narrow band from the quadrate lobule, and as the two sides of the liver have also the usual connection, there are thus two connecting bands, as in Pangshura. Where the true connecting band joins the right division, a long broad bifurcate process passes downwards to receive the vena cava, reaching down a long. way below the spleen which rests to the right of its bifurcation. The cystic lobe is conical and expanded below, and slightly bifurcate on its posterior lower margin. The cystic bladder is remarkable for its great length, $1^{\prime \prime} \cdot 75$, and for the circumstance that its anterior (ventral) third is quite free from the liver and projecting out a long way from its margin. It is very narrow and tubular, somewhat contracted when it reaches the margin of the liver, and slightly distended beyond that. It is placed transverse to the longitudinal axis of the body. The head of the pancreas is close to the pyloric extremity of the stomach. The gland is closely adherent to the posterior wall of the duodenum, and is narrow and band-like, contracting in extent from left to right, and having a length of 3.50 inches. The anterior extremity is the broadest portion of the lung and is rather deeply divided into two lobes. The posterior end of the lung also terminates in a deep incision, the internal lobe being moderately large and sac-like. The cloacal bladders are well developed and richly clad with villous processes. The allantoic bladder is large, very delicate, and partially divided, as is the case generally with the Emydida. After the animal has been kept for some time out of water and is then immersed, the allantoic bladder becomes rapidly distended to a great size, with a clear, very pale, watery fluid. The clitoris is a compact rosette of three pairs of external lobes, with a minute pair internal to the most proximal pair and a small azygos eminence distal to the former, with a deep pit beyond it, between the two terminal pairs of external lobes. There is a small papilla on either side of the termination of the urinal groove, proximal and external to the first pair of lateral lobes. The area of the clitoris is suffused with a dark purplish-black pigment.

Twenty specimens of this species have passed under my observation, and the majority alive. One from the Brahmaputra, four from Dacca in Eastern Bengal, and the others from the Nerbudda and the Ganges at Allahabad and Fatehgarh. All these last specimens are young, while two of the Dacca examples are adults, and one adolescent. The species probably ranges up the Ganges to the base of the Himalaya, and it has a wide distribution through the Brahmaputra. ${ }^{1} \quad$ I have not received it from Burma, or Arracan, where it is represented by B. trivittata. The Batagur referred to by Blyth under the name of $E$. dhongoka, as coming from these localities, and also by Gray, was doubtless B. trivittata.

I kept two specimens alive in water for some time, and found that the younger example (6 inches long) to which my observations were by force of circumstances restricted, used to breathe every seven minutes. Its nostrils were simply protruded above the surface of the water, and retained in that position for about 
half a minute, during which it made a long expiration, followed by a deep inspiration, the creature then slowly subsiding, tail backwards, to the bottom. The animals, unless they were much irritated, never attempted to bite, but when so treated, they sluggishly seized any object put in their way holding it between their jaws with considerable tenacity, at the same time withdrawing the head into the shell. They moved about on the ground with considerable agility, supporting their heavy bodies erect on their legs, like a land tortoise.

There seems to be little doubt that this species is a vegetable-feeder, as I placed in the vessel in which the specimens were kept quantities of the common pond weeds of Calcutta, which they eat freely, and which I removed from their intestines in large dark green masses, whilst the fish and prawns that were supplied to them were never eaten.

\section{+ Batagur lineata, Gray.}

Emys dhor, Gray (pars), Syn. Rept., 1831, p. 20.

Emys dentata, Gray, Syn. Rept., 1831, (vide errata), plates viii and ix, juv.; Ill. Ind. Zool., vol. ii, 1834, tab. 58, fig. 1 only.

Emys lineata, Gray, Syn. Rept., 1831, p. 23 ; Cat. Tort., B. M., 1844, p. 16; Dum. \& Bib., Erpét. Génl., t. ii, 1835, p. 335 (pars) ; Duméril, Cat. Méthod. Col. Rept., 1851, p. 15, pars.

Emys kachuga, Gray, Ill. Ind. Zool., vol. i, 1832, tab. 74.

Batagur baska, Gray (pars), Cat. Shd. Rept., 1853, p. 35.

Batagur lineata, Gray, Cat. Sh. Rept., 1853, p. 33, pl. xvii ; Günther, Proc. Zool. Soc., 1861, p. 214; Theobald, Journ. As. Soc., Bengal, vol. xxxvii, 1868, ex. No., p. 12.

Batagur dhongoka, Gray, Cat. Sh. Rept., 1855, p. 36 (pars), plate xxxvi, skull only.

Batagur tentoria, Gray (pars), Cat. Sh. Rept., 1855, p. 37 (specimen c.)

Batagur ellioti, Gray, Proc. Zool. Soc., 1862, p. 264; id., Ann. and Mag. Nat. Hist., 1863, vol. xii, p. 75 ; Günther, Rept. of Brit. Ind., 1863, p. 40, pl. iii, figs. A, Al.

Clemmys lineata, Strauch, Verth. der Schildkr., 1865, p. 87.

Clemmys ellioti, Strauch, Verth. der Schildkr., 1865, p. 88.

Kachuga hardwickii, Gray, Proc. Zool. Soc., 1869, p. 202.

Kachuga lineata, Gray, Suppl. Cat. Sh. Rept., 1870, p. 56.

Kachuga dentata, Gray, Suppl. Cat. Sh. Rept., 1870, p. 56.

Batagur trilineata, Gray (pars), Suppl. Cat. Sh. Rept., 1870, p. 55.

Dhongoka hardwickii, Gray, Suppl. Cat. Sh. Rept., 1870, p. 57 (pars); App. Cat. Sh. Rept., 187\%, p. 18, pars.

Batagur kachuga, Theobald, Descr. Cat. Rept., B. Ind., 1876, p. 19, pars.

Dr. Gray, in his work entitled Synopsis Reptilium, published January 1831, described this species under the name of Emys dhor (p. 20), and referred to the Ill. Ind. Zool. for a figure of the species. On looking over this last mentioned work; it will be found that no Chelonian is figured under such a name. The explanation, however, is to be found in the list of errata appended to the first mentioned work before the Index, in which we read, "p. 20, lines 31 and 36, for dhor read dentata." Bearing this in mind, and turning to the list of Plates in the Syn. Rept., we find two figures given of the species (Tables viii and ix) under its corrected name Emys dentata. Referring again to the Ill. Ind. Zool., ${ }^{1}$ we find three figures and

\footnotetext{
1 Vol. II, 1834, t. 58
} 
the head of a tortoise all placed under one name, Emys dentata, said to have come from Fatehgarh in the North-West Provinces of India. It is evident, however, that two distinct generic types are represented under the one generic and specific name, and that the uppermost figure is a representation of the species first figured in the Synopsis Reptilium, under the name of Emys dentata, and that the other animal of which there are two figures, and one of its head, is a Cyclemys, with its plastron separated from the carapace by a soft pliable interval as in that genus.

Another tortoise was described ${ }^{1}$ under the name of Emys lineata, and again the III. Ind. Zool. was referred to, but no species is there figured under such a name, but in the Catalogue of Tortoises, ${ }^{2}$ the information was supplied with regard to this reference, and Emys lineata is found figured ${ }^{3}$ under the name of Emys kachuga.

In the first Catalogue of Tortoises, ${ }^{4}$ one species named The Dhor, was included under the genus Cyclemys, and the specific term E. dhor or E. dentata applied to it, and the two figures in the Syn. Rept., to which I have already referred, were quoted with the description, as applicable to the species, and the figures of the two generic types in the Ill. Ind. Zool., were still considered as representing one and the same animal. A specimen from Java presented by Mr. Bell is mentioned, and this is probably one of the specimens figured at Tab. 58, Vol. II of the Ill. Ind. Zool. In the Syn. Rept., p. 20, it is stated that Emys dhor, afterwards corrected, as I have said, to $E$. dentata, was "only known from three young specimens," one of which Dr. Gray received from Mr. Bell. It is not stated in the last mentioned work from whence this young specimen was obtained, but in the Catalogue referred to above, this information is supplied, and Java is given as the habitat of the species, whereas, on the plate in the Ill. Ind. Zool., Fatehgarh, in the North-Western Provinces of India, is said to have been the source of the specimens there figured.

I have received from Mr. Andrew Anderson a specimen the exact equivalent of fig. 1 of the 58 Tab., Vol. II, Ill. Ind. Zool., from the very same locality, Fatehgarh, and which agrees also in every particular with the tortoise first figured under the name of $E$. dentata in the Synopsis Reptilium. It is therefore evident that the term $E$. dentata is applicable to the Fatehgarh tortoise, and to the Cyclemys from Java which was afterwards figured along with it.

A further complication, however, arises, because the upper figure on Tab. 58 was afterwards regarded ${ }^{5}$ as the young of Batagur baska, but. more recently Dr. Gray pointed out that the Emys dentata of his Syn. Rept., and of the Ill. Ind, Zool., is not the young of $E$. baska, but is the same as was afterwards described as $E$. ellioti from the Kistna river.

\footnotetext{
1 Syn. Rept, p. 23.

2 Cat. Tort., B.M., 1844, p. 16.

3 Ill. Ind. Zool., vol. i, 1832, Tab. 74

4 l. c., p. 32.

5 Cat. Shd. Rept., 1855, p. 35.

${ }^{6}$ Suppl. Cat. Shd. Rept, 1870 ,
} 
Now, with regard to $E$. lineata, this species was at first "established on the drawings of a nearly adult animal of this genus in Hardwicke's collection in the British Museum ${ }^{1}$, which is of uniform pale olive colour." The crown of the head is brown, and the upper part of the neck is pale brown, with seven red-brown streaks, the sides of the face and temple are bluish, and the chin with two yellow spots on the sides near the glandular orifices. Dr. Gray states that the same species is evidently figured by Dr. Hamilton under the name of Emys kachuga, but the stripes on the sides of the neck are much brighter red-brown. A copy of his drawing is published in the Ill. Ind. Zool. as Batagur kachuga, Gray. In the Cat. of Shd. Rept., 1855, p. 35, four specimens are referred to this species, and a specimen from Nepal is figured at Plate xvii.

This specimen shows no lineation on the neck, and from its general characters I am disposed to regard it as a female. I have received from Purneah a male tortoise exactly resembling this figure of Emys kachuga in all its details, and for which I am indebted to Mr. G. W. Shillingford. The form of the vertebral plates is the same as those of the tortoise figured in the Shd. Rept., Plate xvii. Moreover, I have received, as I have already said from Fatehgarh, about 200 miles to the northwest of Purneah, a tortoise of the same size, and presenting all the characters of the specimen first figured from the same locality by Gray, but considerably smaller and very much younger than the Purneah animal.

The form of the shell and plates, and the characters of the upper surface of the palate, and the coloration of the neck, seem to me, all to point to the Fatehgarh Batagur, described along with a Cyclemys under the name $E$. dentata, as being the young of Emys lineata. I have also from the Godavery the shell of a young Batagur, 6 inches long, agreeing with Günther's ${ }^{2}$ figure of $B$. ellioti, and the resemblances of this shell to the shell of the Fatehgarh specimen are so great that I cannot but consider the two as identical, or that the Godavery form is only a subspecies. Dr. Gray, however, while at last ${ }^{3}$ allowing that the term Emys dentata was applicable to this Batagur and not to a Cyclemys, separated between Kachuga lineata and $K$. dentata, restricting the former term, $E$. lineata, to the animal depicted by General Hardwicke's drawing and figured from Buchanan Hamilton's drawings as Emys kachuga, and limiting the latter term to the upper figure on Tab. 58, Vol. II, of the Ill. Ind. Zool., with which he regarded E. ellioti to be identical, and to the specimen $d$ which he had referred ${ }^{4}$ to $B$. lineata. I have, however, carefully examined this specimen $d$, and I cannot see that it differs from B. lineata.

In connection with $B$. lineata, I may mention that under Kachuga fusca two specimens were referred by Dr. Gray to this latter species, one from Burma, collected by Theobald, and the other from Nepal, collected by Hodgson. The latter

\footnotetext{
${ }^{1}$ Gray, Suppl. Cat. Shd. Rept., 1870, p. 56.

= Rept., Brit. Ind., Pl. III, figs. A, Al.

3 Suppl. to the Cat. of Shd. Rept., 1870, p. 56.

* Cat. of Shd. Rept., 1855, p. 36.
} 
appears to be an example of $B$. lineata, and the former appears to be the specimen referred by Theobald ${ }^{1}$ to $B$. lineata, but which is distinct and probably $B$. iravadica.

The following are the characters of the female of this species:-

Snout short, and not upturned as in $B$. baska, concave from before backwards between the eyes. Eyes rather prominent and directed outwards; iris dark or lightbrown, without any speck. Head broad between the eyes and across the ear, much broader behind than $B$. baska. Upper surface of the head, behind the eyes and over the ear, covered with moderately sized shields. A large shield below the angle of the mouth, with some small scales behind it. Ear rather large. Skin of the neck and limbs finely granular. The toes are broadly webbed, and the anterior surface of the fore foot covered with narrow long separated scales or shields, those on the middle and inner side of the limb being the largest, with three or four large round scales on the flap above the fifth toe of the front foot. The upper surface of the toes with large transverse scales. The sole with small round separate scales, with three long narrow transverse plates behind these, and succeeded by smaller scales of a similar nature. A patch of enlarged transverse scales along the upper and under surfaces of the margin of the hind limb, with enlarged transverse scales on the upper surface of the toes, and rounded small scales on the sole; claws rather short, brown at the base and yellow at the tips. The tail consists of 23 vertebræ, and extends a short distance beyond the carapace. The skin is granular, and there is a lateral line on either side of its upper surface, of almost spiny granules larger than the others. The under surface of the tail, behind the vent, bears two lines of rather large flat tubercles.

The shell has a vertebral ridge, and is a rather long oval, its margin slightly expanding from the sixth to the seventh marginals, but rounded off from the hinder margin of the last plate, with the margins in this region very slightly upturned. It is a much narrower oval than $B$. baska, and the margins are much less reverted, and the shell is much less expanded posteriorly. There is also an absence of the same fullness over the first vertebral that distinguishes $B$. bask $a$, but, in the rounding and fullness of the anterior portion of the carapace, there is considerable variation due to individual peculiarities, and not to sex. The sides of the carapace over the first and second costals are occasionally almost flat, while in others they are distinctly convex. The shell slopes gradually downwards and backwards from the hinder margin of the second vertebral, and the costal region in that portion of the shell is very feebly curved. The nuchal is triangular, with a broad posterior base in young and adolescent individuals, but, in the adult before me, it is considerably narrowed posteriorly and is broader in front than behind. The first vertebral has divergent lateral margins as in B. baska, whilst in $B$. duvaucelli the margins are more or less contracted in the middle. It is hexagonal, with a concave posterior margin, the concavity being directed backwards. Its nuchal border, in some, slightly exceeds the length of its first marginal border, while in others this proportion is reversed. The first marginal border is sometimes about one-half the extent of the first costal suture and at other times longer.

' Journ. Linn. Soc., vol. x, 1868, p. 16. 
The second vertebral suture is shorter than the costal border, in some, longer than in others. The second vertebral is sometimes slightly longer than broad, and in others as broad, if not broader than long. Its distinguishing feature is its forwardly arched anterior half, corresponding to the first vertebral and first costals, and its posteriorly contracted half, corresponding to the second costals which project into the concave lateral margin of this portion of the shield which has a straight posterior border. In the centre line, near the hinder end, the plate is marked by a distinct somewhat backwardly projecting nodosity. The third vertebral is broader than long; its costal margin is concave from behind forwards, and nearly equalling in breadth two-thirds of the length of the plate. The plate is also marked near its hinder border by a low spinous nodosity. The fourth rertebral is elongated, being considerably longer than broad in some; but the length of this plate is subject to variation. The middle of the third costal margin is concave from without inwards, and its posterior half convex from within outwards. The vertebral margin of the fourth costal is convex, straight, or sinuous. The posterior border is concave, or straight, and about one-third less than the breadth of the anterior border, while in others it equals it. The third has a low spinous nodosity near its end. These nodosities all but disappear in the adult. The fifth is triangular, the apex more or less rounded, and the base broad, articulating with two marginals. It shows distinct indications in adolescents, and even in adults, of a central ridge. The length of the gular is one-half that of the postgular suture, which in its turn nearly equals the length of the pectoral, which is about the same length as the abdominal suture. The preanal is a little longer than the postgular suture. The anal is a little more than two-thirds the length of the preanal suture, and is equivalent to the united posterior breadth of the preanals. The gulars are longer than in $B$. baska, equalling nearly half of the length of the postgular suture, which is either as long as, or shorter than, the pectoral suture. The abdominal suture equals or nearly so the united gular and postgular length; the preanal is shorter than, or little exceeds the length of, the pectorals. The anals are little longer than their greatest breadth, and the anal notch is shallow and broad. The ridge on the sides of the sternum disappears in adolescents.

The head is light greenish-olive, darker above, yellowish above the tympanum to the upper margin of the orbit, greenish-yellow from the nose to the angle of the mouth, dark purple about the nostrils from which a faint dark-greenish broad band passes to the eye, and increasing in breadth behind the orbit dips down to the angle of the mouth and stretches through the tympanum, re-appearing behind it. The occiput is occasionally dark olive-brownish or even blackish. The renaainder of the animal is yellowish-olive, more yellowish on the enlarged scales of the limbs.

The shell above is dark-brown, almost black in some, while in others it is almost a pale olive-brown. The under surface is yellowish, the shields being more or less obscurely radiated, in the dark individuals, with brown from the areolæ. The postinguinal marginals have a greenish-yellow tinge, clouded with brownish. Notwithstanding the general similarity, at first sight, of the shell of this tortoise to $B$. 
baska, the broader head, much shorter snout and one-ridged palate of the animal at once serve to distinguish it from $B$. baska.

The male of $B$. lineata is known to me only from two specimens, one a perfect animal in the flesh which I had alive, and the other a shell procured at Allahabad by Mr. John Cockburn, who informs me that he has noticed the remarkable difference in size between the sexes of this and other species of fresh water tortoises.

The male is not adult, but its shell is in the same stage of growth as a female having a shell 16 inches long, and yet this male is only 9 inches long, about half the size of the female.

Measurements of male and female examples of $B$. lineata.

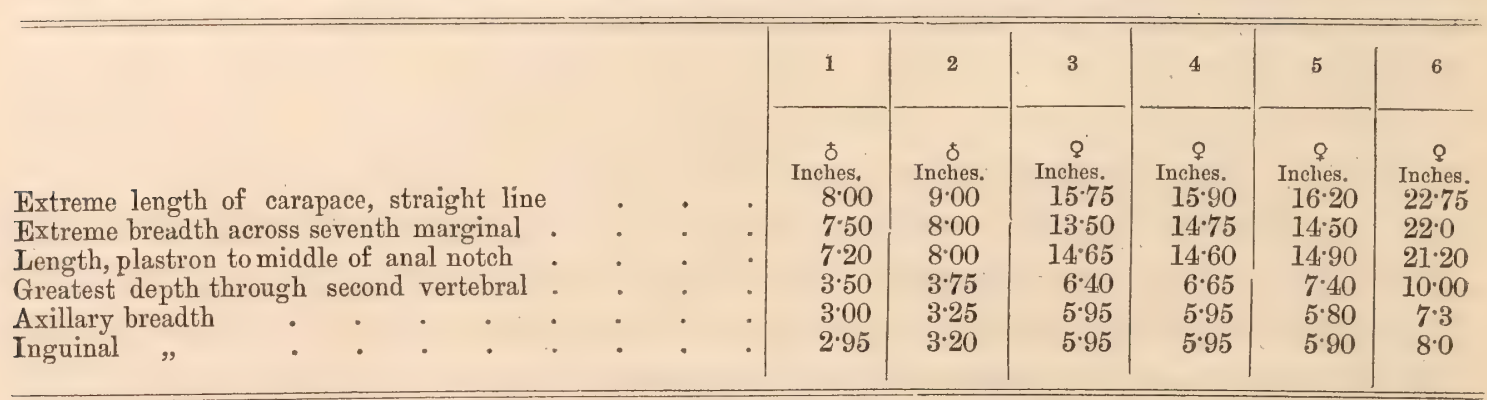

The vertebral plates of the two males are exactly alike, and have the exact form of the same plates of those females with the broader vertebrals. The vertebral ridge can be traced along the back, culminating in the hinder end of the second and third plates as a more prominent ridge not continuous along the two plates and not so highly prolonged on to the fourth vertebral. The ridges along the sides of the plastron are yet distinctly visible. The shell is a moderately long, rather regularly oval, and the posterior margins are slightly reflected, and the caudal notch is small, but distinct, and the dentation of the hinder margin of the shell is still decidedly present. In life, the shell was a dark olive, with a slightly rufescent tinge over the anterior portion of the dorsal surface, the under surface being rosy-red, the margins on the same surface being suffused with bluish. The limbs were of the colour of the upper surface of the shell, but the large plates running along the external margin of each limb were bright red. The upper surface of the head, from the nostrils backwards between the eyes, to near the occiput, was brilliant red, and from the hinder margin of this area, four broad similarly coloured lines ran backward, two on either side of the mesial line, diminishing in intensity and size from before backwards. A broad deep black band arose from the posterior half of the upper and posterior borders of the eye, disappearing a little behind the head on the side of the neck. From the broadest part of this black band, another red band proceeded along the side of the neck to the shell. A yellow band occurred immediately below the black band and ran a short way along the side of the head, with a narrow black band below it, under which was a still narrower yellow line from the angle of the mouth, with a broad bluish-black area below it again, tending to become linear posteriorly. The front of the nose, below the nostrils, was red, and the rest of the 
horny covering of the upper jaws was bright yelluw, with a blackish-green line along its side to the angle of the mouth. The horny covering of the lower jaw was yellow, suffused with greenish-black, with a symmetrical greenish spot on its inner margin. A few red lines occurred behind the yellow and black lines below the eye, and the throat, internal to the lower jaw, was marked by two brilliantly red oblong marks, placed opposite each other. On the upper surface of the neck, the ground colour was whitish; the rest of the skin of the neck, around the fore limbs and hind limbs, and along and around the tail, were suffused with red.

In a young specimen which agrees exactly with the figure in the Syn. Rept. and with the upper figure of Ill. Ind. Zool., the vertebral plates are rather equally broad throughout, but this is a character of nearly all Batagurs in youth, although, at the same time, the characters and features of the plates are preserved. The ridge culminates on the second and third vertebrals in two almost prominent spines. The posterior external angles of the marginals, from the seventh backwards, form a kind of toothed line, and the caudal notch is small, but very distinct. The ridges along the plastron are well defined. The neck is marked exactly as the specimen last described, and considering it in all its details, there can be no doubt but that the Batagur described as Emys dentata, Gray, is the young of Emys kachuga, Gray.

This small specimen measured-

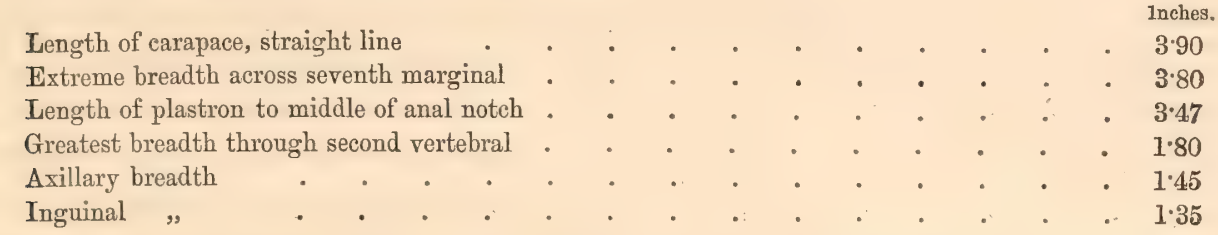

Its palate has the same character as that of the previously described female and male.

A shell from the Godavery river obtained by $\mathrm{Mr}$. W. T. Blanford, appears to me to be a young female, the only very young example of the sex that has come under my observation.

\section{It measures-}

\begin{tabular}{|c|c|c|c|c|c|c|c|c|c|}
\hline Len & & & & & & & & & $\begin{array}{c}\text { Inches. } \\
5.80\end{array}$ \\
\hline adth across seventh marginal & & 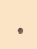 & & & & & & & $5 \cdot 85$ \\
\hline astron to middle of anal notch & ${ }^{\circ}$ & . & & 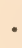 & . & & & & $5 \cdot 15$ \\
\hline t breadth through second vertebral & . & - & & & 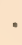 & & & & $2 \cdot 50$ \\
\hline Axillary breadth . & 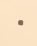 & - & & & & & & & $2 \cdot 25$ \\
\hline nguinal & & & & & & & & & $2 \cdot 10$ \\
\hline
\end{tabular}

This shell has all the characters of the preceding young shell, and the vertebrals are so alike the vertebrals of adult $B$. lineata that this specimen must be regarded as an example of the species. It is more rounded than the male shell, and in this presents the character of a female, which I believe it to have been. The denticulation of the hinder part of the shell is still marked.

I have removed the skulls from the three smaller female specimens of the table of measurements p. 750, and they agree in every particular with the skull 
figured by Dr. Gray as the skull of $B$. dhongok $a,{ }^{1}$ and afterwards referred with doubt by the same observer to this species. ${ }^{2}$ The figure of the body of this species given by Dr. Gray was taken from a young specimen obtained in Nepal, and I have before me three specimens which I procured alive from the Calcutta turtlebrokers, the other being the large adult in the Indian Museum with no history attached to it, but probably procured by Mr. Blyth in Calcutta. These four specimens agree in their general form and the shape of their shields with Dr. Gray's figure of this species.

The skull is at once distinguished from the skull of $B$. baska by its having only one ridge on the palate, and by its more truncated snout which is not upturned to the same extent as in $B$. baska, nor so compressed as in that species. The upper surface of the snout is nearly flat, with only a very faint upturning at its extremity. The external nares are broader, as is the snout generally, than in $B . b a s k a$, and the interorbital area is also quite flat and broad, as is also the inter-zygomatic. As already said, the palatal surface is marked, on each side, by only one distinct and prominent oblique serrated ridge internal to the alveolar border of the maxilla, although there are indications internal to each of the strong second ridge that occurs in $B$. $b a s k a$ in that position; and in the adult the longitudinal ridge which separates the last mentioned ridges in $B$. baska is broad and rounded, while in the younger specimens it is much as in that species. From the anterior extremity of this ridge, a furrow runs forwards, as in $B, b a s k a$, to the premaxillary pit. There are only two lateral palatal furrows and not three, as in $B$. baska. The posterior nares are more expanded from behind forwards in $B$. baska, than in the present species, in which the lateral borders are nearly parallel. The pterygoid contraction of the base of the skull is also much narrower in B. lineata than in B. baska. The lower jaw has the same structure as $B . b a s k a$, only the hinder furrow which is so strongly marked in that species, is very shallow and hardly merits the name of a furrow, being more a concavity. The serration of the alveolar margins is stronger than in $B$. baska. There does not appear to be any character yielded by these skulls, as there is none in the internal structure of the animals that would entitle us to separate them wholly generically.

This is a considerably larger species than $B$. duvaucelli, and the absence of any black lines in either sex suffices to distinguish it at once. It is, however, more difficult to point out wherein the skulls differ, because my experience is that the skulls of the allied species of Batagur do not differ much from one another, but the chief feature in external configuration which serves to separate the two is the relative greater breadth and shortness of the skull of B. lineata as compared with B. duvancelli. Certain characters, however, ean generally be detected, and, as a rule, the most reliable one is to be found in the palatal region. Iike $B$. duvancelli, $B$. lineata has only one palatal ridge, but in the latter there is always present a longitudinal eminence or ridge in the mesial line behind and between the lateral ridges; and proceeding from either side of this longitudinal ridge, there is in $B$. lineata the 
distinct tendency to form a second palatal ridge, as in $B$. baska, but it is very feebly developed.

There is also a character furnished by the lower jaws by which $B$. lineata can be separated from $B$. duvaucelli. In the latter, there is a narrow simple surface behind the ridge corresponding to the ridge of the upper jaw; but in B. lineata this surface is distinctly broader anteriorly, and is marked by two short longitudinal ridges at its anterior part.

There are twenty-three caudal vertebræ, in the first three of which the transverse processes are only rudimentary, but appear suddenly in the fourth, attaining their maximum in the sixth, and disappearing in the fourteenth.

The tongue, small and triangular, is grooved by a longitudinal sulcus. The sides of the laryngeal orifice are protected by a serrated ridge of mucous membrane, and the two ridges meeting behind are prolonged backwards as a serrated ridge for about one inch and a half. Behind the tongue, the oesophagus, for about three inches, is thrown into longitudinal folds of rather large flattened papillæ. The stomach is narrow and tubular, 10 inches in length along the convexity of the curve. Its lower end, for about three inches above the pylorus, is very thick and strong, while that above it, is thin and with a distended sac-like portion behind the termination of the osophagus. The small intestine, in a female measuring 16 inches in the length of its carapace, was 57:50 inches long, while the large intestine, which is marked at its commencement by a sacular dilatation, was 26 inches long:

The liver is large compared with that of Batagur baska, and differs from it in several structural details which either indicate that the species are not so nearly allied as their external appearances would lead one to believe, or imply that the liver is very variable in its form. The ventral section of the right lobe of the liver completely overlaps the longitudinal section of the stomach; its outer margin, which is rather thin and circular, projecting considerably to the left of the stomach. The anterior angle is thick, and there is attached to it dorsally a very restricted portion of peritoneum. The inferior border passes obliquely upwards to the right over the stomach, and between this and the anterior angle, there is first a notch, on a line with the lower border of the transverse connecting lobe, by which the left vena cava enters, and the anterior margin of the notch is formed by a leaf-like lobule which passes upwards to the anterior angle, and along which the peritoneum is attached from the notch. The posterior or dorsal lobe of the right section of the liver is lingulate, and lying behind the bend of the stomach fills up only a restricted portion of the interspace between the two bends of the stomach. From the notch in front, a thin band-like process of liver substance depends in the peritoneal attachment. The cystic or right lobe consists of three well-marked portions, the section containing the gall bladder lying between the other two and against the side of the shell. The most ventral section, which is not separated from the cystic by any deep fissure, is quadrangular in its outer aspect, with a long process passing off from its anterior end, while internally there is a smaller triangular process at the base of the former. The whole of the inner margin of the ventral section and anterior border 
of the quadrangular section have peritoneal attachments. The cystic portion is the largest, concave internally, convex on its outer side, and almost flat ventrally. It has a pointed conical anterior end, posterior to which, on its inner side, it is joined by the most anterior portion of the transverse lobe. The gall bladder is situated in the lower third of the concavity, and is placed dorso-ventrally, its apex appearing on the ventral aspect. The cystic lobe is attached over the lung, all along its external border, with the exception of about two inches in its lower portion, and the attachment runs round its conical anterior end, and is continuous with the peritoneal fold of the transverse lobe. The third division is more or less quadrangular, and is the most dorsal of the divisions, and is connected to the dorsal surface of the apex of the cystic lobe, where it is also united to the transverse lobe. All its margins are attached, and it sends down a long narrow ribband of liver substance along the vena cava. The gall duct is rather long and narrow, and after a course of $3 \cdot 75$ inches it reaches the intestinal wall, along which the duct runs for 1.75 inch before it opens internally. There is no perceptible thickening of the mucous coat of the wall of the intestine where the duct joins it, as in B. thurgi. The bile is a very dark blackish-green.

The allantoic bladder has the attachments common to this viscus, its sides and fundus being quite free. It is partially divided, and is capacious, but not so much so as the bladder of $B$. baska, which is attached to the liver on both sides. The cloacal bladders are large, but with very delicate walls, devoid of the villous processes of $B . b a s k a$, the mucous membrane being thrown into a fine mesh work of loose delicate folds. The internal lobes of the clitoris are blackish-purple, and closely resemble those of $B . b a s k a$. The peritoneal canal is wide, and terminates external to the lobes of the clitoris according to my observations. ${ }^{1}$ The inner side of its wall is marked by fine fibrous transverse short bands, with intervening spaces. The ovaries are yellowish, and about five inches long in one female, which, although so large, was apparently a virgin. The oviduct was eight inches long and had never been dilated.

The lung is much longer than the lung of $B$. baska, from which it is also distinguished by the most anterior external lobe being deeply divided from the one behind, and longer than in $B . b a s k a$. The posterior sac of the inner border is also much longer than in that species, the two terminal lobes of the two borders being long saes.

This species, as will be observed from the foregoing tables, attains to a considerable size, nearly equalling in dimensions the allied form $B$. baska. It is, however, apparently comparatively rare in the Sunderbunds of Bengal, whence it is brought to Calcutta along with Batagur thurgi and B. baska to be sold as food to low caste Hindoos. It is more plentiful in the north-western portion of the Gangetic system, extending into Nepal, and it is probably the large species found in the Nerbudda, and is doubtless one of the forms occurring in the Godavery. Like $B$. baska, it has none of the fierce snapping habits of the Trionycida, although it occasionally

1 Journ. Linn. Soc., Vol. xir, p. 441. 
snaps, making a peculiar barking noise owing to the friction of its hard serrated jaws against each other. It appears to be a vegetable-feeder like the other species of Batagur, but it invariably declines to eat in confinement, perhaps owing to our ignorance of its natural food.

It has a remarkable power of sustaining long fasts, as I had a specimen in my possession which did not eat any food over a period of four months.

\section{Sub-Genus Morenia, Gray.}

Apertures of shell only slightly contracted; alveolar surface of skull very broad antero-posteriorly, and transversely rugulose ; tubercular, with a ridge internal to the external alveolar margin, but conforming in distribution to the outline of the latter, from which it is removed to some distance. A deep depression on the alveolar surface of the premaxillaries. Posterior nares about the middle of the base of the skull, covered by the shelving alveolar plate.

\section{Batagur (Morenta) Ocellata, Dum. and Bib. Plates lx and lxi.}

Emys ocellata, D. \& B., Erpét. Génl., vol. ii, p. 329, 1835, pl. xv, fig. 1; Duméril, Cat. Méthod. Rept., p. 14, 1851; Gray, Cat. Tort. B.-M. 1844, p. 18; Blyth, Journ. As. Soc., Bengal, vol. xxii, 1853, p. 645; id., l. c., vol. xxiv, 1855, pp. 481, pp. 712 ; Günther, Rept., Brit. Ind., 1864, p. 22.

Eatagur ocellata, Gray, Proc. Zool. Soc., 1856, p. 182, pls. x and xa; id., Ann. and Mag. Nat. Hist., vol. xix, p. 348, $185 \%$.

Emys berdmorei, Blyth, Journ. As. Soc., Bengal, vol. xxvii, p. 281, 1858; id., l. c., vol. xxxii, p. 82. Kachuga berdmorei, Gray, Proc. Zool. Soc., 1869, p. 204; Theobald, Proc. Zool. Soc., 1870, p. 676. Clemmys ocellata, Strauch. Chelon, Stud., 1862, p. 33 ; id., Vertheil. Schildkr., 1865. p. 89, pars:

Batagur berdmorei, Theobald, Journ. Linn. Soc., vol. x, p. 16, 1868 ; Journ. As. Soc., Bengal, vol. xxxvii, ex. No., 1868, p. 12, pl. , figs. 2.

Morenia berdmorei, Gray, Suppl. Cat. Shd. Rept., B.-M., 1870, p. 62 ; id., Hand List, Shd. Rept. B. M., 1873, p. 55; Theobald, Descr. Cat. Rept. Ind., 1876, p. 17.

The adult female shell is a moderately long oval about 8.25 inches in extreme length in a straight line, and is high, and well arched transversely. It is concave on either side of the first vertebral, and similarly so above the eighth, ninth and tenth marginals. The margins are not reverted, nor are they serrated. The sternum is broad, flat, and keeled from the axilla to the groin. There are distinctindications of a vertebral ridge on all the vertebrals, and on the third and fourth plates the ridge becomes nodose. The nuchal is much longer than broad, and is generally linear, with the point anterior, although some may be observed with the posterior end narrower than the anterior. The vertebrals are generally much broader than long, although in some the length equals the breadth. The first vertebral has its first marginal borders meeting at an obtuse angle, the lateral margins are generally convex on the posterior two-thirds, but concave on the anterior third, the breadth, however, between the anterior angles being little greater than that of the posterior diameter. 
There are specimens, however, in which the proportion is reversed, and there are examples with first vertebrals with straight lateral margins divergent from behind forwards, and in these cases the shield is usually as long as broad: the posterior margin is sinuous. The longitudinal axis of the plate is occupied by a distinct ridge. The second, third and fourth vertebrals are nearly quadrangular and almost of equal breadth, the first-mentioned being the narrowest. Their lateral margins are all more or less parallel but sinuous, and the posterior margins concave from behind forwards. The fifth forms a broad suture with the fourth, and its lateral margins are slightly contracted in their anterior fourths, and the length of this shield varies considerably. One marginal is in contact with the first vertebral, four with the first costal, and three touch the second, third and fourth; the fifth vertebral only being very narrowly in contact with the tenth marginal. The caudals, in some specimens, project backwards slightly, as if compressed, but the caudal notch is absent.

The gulars project beyond the post-gulars, but are truncated in front, and their suture exceeds that of the post-gulars. The postero-post-gular suture is nearly transverse in some, but in others forms a posteriorly obtuse angle. The pectorals are a little longer than the abdominals, and the postero-abdominal suture is directed backwards. The abdominals are the next longest shields equalling the post-gular and half of the gulars, and standing in the same proportion to the preanals and anals: The preanals are very little longer than the pectorals, and the anals equal the pectorals and nearly one-half of the gulars. The anal notch is broad. The axillary breadth equals one-half of the length of the sternum, and exceeds the breadth of the sternum at the groin.

In younger females, the shell is more rounded, and in very young specimens about 3.25 inches long, the shell is nearly round, and the first and second marginals slightly reverted, the vertebral ridge being well developed, almost as in Pangshura, forming a prominent truncated spine on the third vertebral and all but absent on the fifth shield. The sternal ridge is strongly marked. The gulars nearly equal the post-gulars in length; the pectorals, the abdominals, and the preanals equal nearly the anals; the two last pairs of shields being only a little longer than the first.

On carefully examining about 100 living examples of this species, I found that there were two distinct forms of shell, one a large, full and globose shell, and the other a more depressed and more elongated oval; the animals of the former characterized by short tails, and those of the latter with long tails, but that with these exceptions the animals of the two forms of shell were identical. On dissecting a number of examples of each type, it was found that the deep and shortly oval shells with the short-tailed animals were females, and the longer ovals and more depressed shells with long-tailed animals were males.

The adult male is a narrower and more elongated oval than the female and considerably smaller, measuring 6 inches in a straight line. It differs also in form by the less arched character of the shell, both antero-posteriorly and trans- 
versely. It has also the anterior margin of the shell slightly reverted and the caudal region more produced downwards. The dorsal ridge is also more marked. The interval between the margin of the carapace and the sternum is less than in the female, and instead of being convex, as in the latter, it is irregularly flat and concave, the sternal ridge being much more developed than in the opposite sex, and the sternum slightly contracted at its middle and always more or less concave, with the margins tending to reversion. The anal notch is also deeper than in the female. The plates of the carapace and sternum are much the same as in the female, and they are very thin in both sexes, and are very easily rubbed off.

Shells of $B$. (MT.) ocellata, D. \& B.

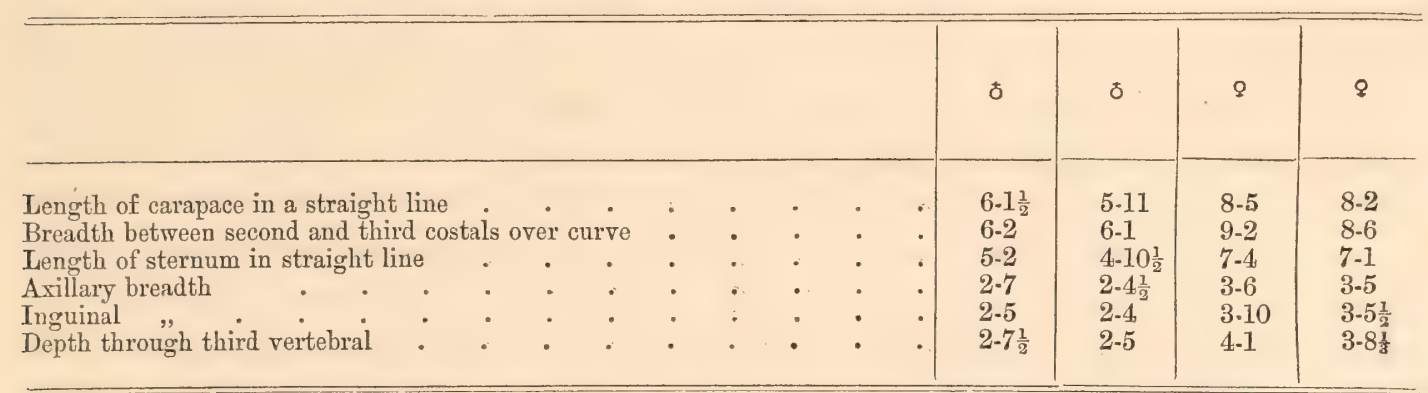

In males, measuring as above, the carapace is wholly ossified, while in females of the same size there is a considerable unossified area between all the costals and marginals, which would appear to be conclusive proof of the smaller size of the male.

The snout is short and rather pointed, and the nostrils close together, round, and directed forwards. The margins of the jaw are finely serrated, and there is a notch in the front of the upper jaw, with a tooth on either side of it between which the symphysial hook of the lower jaw is received. The upper surface of the head is flat, and covered by one plate; and there is a large plate behind the eye. The plate of the mandible is backwardly convex on the chin, and there is a small plate below its extremities and below the angle of the mouth. A series of very small scales behind the angle of the mouth; the mental glands each open by two orifices in the usual position. Skin of tympanum nearly smooth. Neck moderately long; the skin on its upper surface nearly smooth, with scattered minute round blackish papillæ; the skin on the sides and under surface somewhat scaly and papillar.' The base of the neck is smooth, as is also the skin on the groin. The fore feet are broad and powerful; the toes broad, and the five claws strong. The toes are covered with from five to six transverse plates, and the upper surface of the free portion of the limb with separate transverse plates. The sole is covered with rounded plates, above which there is a transverse naked area, succeeded by a transverse row of three large plates. The outer margin is fringed with five to six largish plates. The upper surface is nearly free of transverse scales, except on the sides, and there are a few scattered minute papillæ on the bare portions. The tail is short, but it projects one-half of its length beyond the carapace. The latter half of its under surface has a double row of enlarged scales. Its sides and upper surface are covered with sharp conical tubercles, among which some larger ones occur on the sides. 
The carapace is olive-brown of various shades, sometimes very dark and at others very light. Each plate of the carapace is very finely reticulated with black lines, and is occupied by a large blackish-brown rounded spot surrounded by a pale yellowish-brown zone, the outer margin of which is blackish-brown. The central black spots on the vertebrals occur on the ridge-nodosities, and on the first four shields they are linear; on the fifth the spot has the shape of the shield. The black spots become relatively smaller with age and more feebly marked. The margin of the shell is yellowish, and the whole under surface yellowish; the osseous sutures shining through the plates as lighter yellow lines. I have a specimen before me (a male) with the sternal plates brownish, but this appears to have been produced by some salt of iron.

The general colour of the head is dark greyish-brown, browner on the upper surface. The large vertical plate is olive greyish, with two indistinct dark longitudinal parallel lines on it, below the eye; sometimes a small yellowish spot before the eye, the tip of the snout below the nostrils being obscurely marked with yellowish. A pale greenish-yellow narrow line along the upper margin of the snout, over the eye, continued on to the neck, and margined with blackish. A similarly coloured line from behind the eye over the tympanum, on to the neck, also margined with blackish. A like, but more indistinct line on the under surface of the rami of the mandible, slightly inwardly convergent and dilated posteriorly, terminating before the angle of the mouth. Skin of the neck pale brownish, passing into light grey. Limbs pale brownish-leaden with a tinge of olive. Tail dark brown above, with obscure yellowish longitudinal lines.

After a comparison of the specimens on which these observations rest with the types of $E$. ocellata, in the Paris Museum, I do not hesitate to regard them as examples of O. ocellata, D. \& B., although the types of this species were said by Duméril and Bibron, and by M. M. Duméril to have been obtained by Belanger in Bengal.

Having forwarded specimens of the ocellated Batagurs of Bengal and of Burma to Prof. Peters, he wrote to me saying that he considered the Burmese species to be the true $B$. ocellata, D. \& B. As I was in Paris at the time Prof. Peters made this suggestion, I compared the types of $B$. ocellata with the accurate drawings of the Burmese and Bengal species reproduced in this work, and arrived at the conclusion that Prof. Peters' identification was correct.

I have collected on a large scale in Eastern Bengal, but on no occasion have I obtained a living animal corresponding to the ocellated tortoise of Burma, and only on four occasions have I succeeded in obtaining living examples of the new form, with which I have great pleasure in connecting Professor Peters' name. I am therefore disposed to consider that some mistake arose regarding the locality from which Belanger's specimens were obtained, as they certainly correspond to the Burmese species and not to that rare and beautiful form $B$. petersi.

The tongue is small, and grooved longitudinally on its hinder part, and it is separated from the larynx by a deep furrow, convex from behind forwards; the 
laryngeal orifice, passing forwards and downwards into the furrow, is opposite the longitudinal lingual fold. One-half of the orifice thus looks forwards, and the half posterior to it upwards. Besides its fine thickened border, the posterior half of the orifice has a rounded ridge of mucous membrane on either side, as in B. thurgi; the two, being in contact behind and anteriorly divergent, form a triangle with the base anteriorly. The anterior fourth of the osophagus, from behind the larynx, is very smooth, although a few minute papillæ may be detected; but behind this a few large papillæ appear arranged more or less in longitudinal lines, and increase in numbers as they are traced backwards, becoming more villous and more numerous, suddenly ceasing on the latter portion of the œesophagus where they are thrown into very fine free folds, and in this respect it also resembles $B$. thurgi. The stomach is partially overlapped by the ventral portion of the right hepatic lobe; but much less so by the dorsal portion. The stomach contracts much towards the pylorus, the duodenum presenting a dilatation immediately behind the pylorus. The stomach, in an adult female, measured six inches, the small intestine 31 inches, and the large intestine 14 inches. The gall duct opened four inches from the pylorus.

The first two inches of the duodenum have the mucous coat thrown into fine anastomosing lamellar-like folds, containing finer folds within them; but the portion intervening between this and the orifice of the gall duct has the folds more longitudinal and distinct, but before the latter orifice they are distinct longitudinal lamellar folds, with finer intervening folds extending over the whole length of the small intestine.

The large intestine commences by a sudden dilatation, which is more capacious on one side than the other, indicating a cæcum. The first six inches are doubled on each other, as in Hardella. The inside of the large intestine is smooth, the folds of the small intestine abruptly terminating at its commencement.

The transverse connecting portion of the liver is much deeper from before backwards than in any other Batagur I have examined, and is transversely narrower. The two veins from the right and left divisions are thus very near each other, and the compact appearance of the gland is heightened by the absence of any of the long processes or appendages that distinguish the liver of $B$. thurgi. The dorsal division of the left lobe has its left border completely overlapping itself, and its right lower border terminates in two short processes. The notch of the ligament is deep and crescentic, and situated at the right extremity of the lower border of the ventral division of this lobe. The lower border of the connecting lobe is notched in its centre, and this, along with the notch of the ligament, and another notch where the connecting lobe joins the right division of the gland, present two marginal processes between the two lateral notches. At the commencement of the upper posterior border of the right lobe there is a short process. The right and transverse lobes are flat on their under surfaces, and the gall bladder lies along the inner border of the former lobe, close to the division between it and the latter. It is on the same plane as the under surface, and does not project beyond the liver substance as in other allied tortoises. 
The allantoic bladder is very large, and perhaps more free than in the true Batagurs. It consists of two halves with a narrow isthmus, the left half always the larger. When dilated, it equals in size the whole of the other viscera put together, and its walls are very delicate. The cloacal bladders are small and globose, and covered internally with numerous villi. There are large glandular structures in the inguinal region.

The apex of the lung is partially divided in two, and below this it is externally contracted; the portion below this, again, consists of three lobes one before the other, the terminal, or most inferior, being moderately long and fine, with the kidneys behind and along its inner border. In a male, with the carapace 6 inches long, the lung measured when distended 3.50 inches long, with a breadth at the apex of $1^{\prime \prime} \cdot 97$.

The iris is of a pale sparkling metallic yellowish-white, much mottled with black, especially anteriorly and posteriorly, producing in some the appearance as if a black band passed through the iris.

The axillary and inguinal septa are but little developed, and the vertebral formula in the female is C. 9 , D. 8, S. 3 , C. 19 , or 20 . In some males, there are a fewer number of caudal vertebræ than in the female, although the tail is considerably longer in the former than in the latter sex. But the greater length is brought about as in other species by the much longer and larger vertebræ of the male. The transverse processes in the caudal vertebræ begin to show themselves strongly on the seventh, and increase to the thirteenth, beyond which they diminish, disappearing on the last three.

By its skull this genus is closely allied to B. thurgi, having a similarly formed palate and internal nares, the former, however, being less pitted than in $H$. thurgi. The grooving and ridging of the mandible are also the same, or nearly so, as in that species, only the palate has a proportionally greater antero-posterior expansion, and the coronoid process does not rise above the level of the post-coronoid portion of the ramus, being outwardly directed and sessile. The sub-genera, Hardella and Morenia, if there were no other characters but those derived from the skull to separate them, might with propriety be united; but the different structure of their shells, and the remarkably elongated lung of Hardella, suffice to distinguish them as two subgeneric modifications of Batagur.

The skull is remarkably distinct from the skull of $B$. (M.) petersi, Andr., differing from that species in being much broader, and more especially in its having a much shorter and broader muzzle.

This appears to be one of the most prevalent species in Arracan and Burma. It is thoroughly aquatic in its habits, but has nevertheless the power of living out of water for a lengthened period, doubtless by reason of its large allantoic bladder. It is very gentle in its habits, and does not attempt to bite, but when suddenly handled emits a kind of hissing noise, retracting itself into its shell. It lives on the bulbous roots of aquatic plants like its near congener, Batagur thurgi. 


\section{+ Batagur (Morenia) Petersi, Andr. Plate LiX.}

Emys ocellata, Blyth., Journ. As. Soc., Bengal, vol. xxvii, p. 281, 1854; id., l. c., vol. xxxii, p. 82, 1859 ; Theobald, Cat. Rept. Journ. As. Soc., Bengal, vol. xxxvii, ex No., 1868, p. 13, plate. Morenia ocellata, Gray, Suppl. Cat. Sh. Rept., B. M., 1870, p. 63.

The adult female is slightly smaller, and more elongately and narrowly oval than the female of $B$. (M.) ocellata. The shell is more arched, with much greater fullness over the fourth and fifth vertebrals than in $B$. $(M$. $)$ ocellata, and like the latter it has a vertebral ridge. The post-inguinal portion of the plastron also is much broader than in the last mentioned species. The nuchal is long, due to the circumstance that the anterior margin of the shell is hardly, if at all, emarginate, the nuchal thus having more the appearance of a narrow marginal, than of a nuchal plate. The proportions between the anterior and lateral margins are the exact opposite of what prevails in $B$. ocellata, because the first marginal has much greater antero-posterior breadth than the sixth marginal; this plate in $B$. ocellata being much broader than any of the other marginal plates. The length of the nuchal itself equals the breadth of the sixth marginal, whereas in $B$. ocellata, the length of the nuchal is less than one-half the breadth of the sixth marginal. The lateral marginals also are not so outwardly directed as in B. ocellata, and in this they follow the more arched character of the shell, but the anterior marginals are more upwardly reverted than in $B$. ocellata. The fourth marginal in $B$. ocellata is applied to the whole of the outer surface of the axillary plate, with the exception of a small surface, anteriorly to which the third marginal touches, but in $B$. petersi the fourth marginal is only applied to the anterior half of the outer surface of the axillary, and the third only touches the anterior angle of the axillary. This character is persistent throughout a large series in $B$. ocellata in which the fifth marginal is always largely excluded from articulating with the axillary by the fourth marginal, whereas in B.petersi the fourth and fifth marginals are nearly equally divided between the axillary. The vertebrals are of nearly equal breadth; the first is longer than broad, with a posterior concave margin and its anterior margin convex. The second, third and fourth shields are broader than long, the length diminishing as they are traced backwards; the fifth shield has a broad anterior border like the other vertebrals. The ridge terminates on the posterior border of the second, third, and partially on the fourth vertebral, in an abrupt eminence. The outer margins of the post-gulars and of the preanals are somewhat expanded; the gulars, anteriorly as in B. ocellata, form a nearly straight line, and each plate is triangular. The post-gular suture is relatively longer than in B. ocellata, and the mesial preanal suture is very much shorter than in that species (see Duméril and Bibron's figure of type); the suture in $B$. petersi equalling less than one-half of the mesial anal suture, while in $B$. ocellata the preanal suture nearly equals the length of the anal suture. The pectorals also of $B$. petersi are relatively larger than in B.ocellata. In B. ocellata the inguinal plate forms a suture with the sixth 
marginal, whereas in B.petersi (see figure of the type of $B$. ocellata) the sixth marginal is completely excluded from touching the inguinal, with which the seventh marginal forms a very broad suture, with nearly the anterior half of the outer margin of the inguinal having the eighth marginal forming the suture along its latter half, the eighth marginal being all but excluded from touching the inguinal. The under surface of the plastron of B.ocellata is somewhat more concave than in B. petersi.

The two males which I have observed are full grown, but considerably smaller than the female which was also adult, and the relative proportion between the sexes is given in the following table. The male differs only from the female in its smaller size and slightly less elevated and narrower shell :-

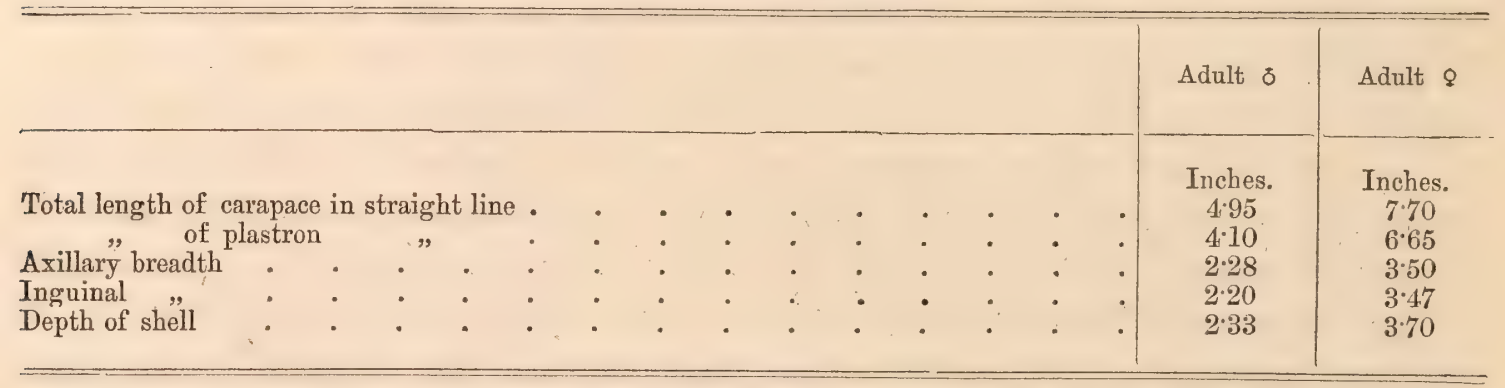

The head is much more pointed than in $B$. ocellata, the muzzle is relatively longer, and the portion below the nostrils much more backwardly sloped than in $B$. ocellata. The skin of the neck is covered with granules, much in the same way as in $B$. ocellata, and the limbs with small scales, as in Batagurs generally, but $B$. petersi has three rather large yellow scales, a little above the base of the first toe.

The coloration of the two species is markedly distinct; the shell of B. ocellata is brown-olive, with a large dark-brown round spot in the centre of each of the costals, surrounded by a pale areola, with a dark external border; the centre of each vertebral is also occupied by an elongated dark-brown spot with a paleareola around it, and each marginal also shows a tendency to form a brown spot like the foregoing. $B$. petersi, on the upper surface, is blackish, with a pale narrow greenish-yellow line along the margins of the vertebrals, and a light yellow line along the margins of the costals, with a bright yellow margin, as in B. thurgi, along the outer edge of the marginals. Each costal is occupied by a narrow pale greenish ring, the centre of which is the dark black of the upper surface of the shell generally; a narrow greenish-yellow line passes outwards through the middle of each marginal, and these marginal lines tend to join with each other above, external to the yellow costal rings, and to form marginal rings, but they are imperfect at the margin, due to the broad yellow border of the marginals. There is also a distinct tendency, in yellow lines given off from the vertebral aspect of the costal rings, to the formation of another series of costo-vertebral rings, but these rings are generally broken and become imperfect as they touch the vertebrals. A yellow line runs through the nuchal and vertebrals almost to the last vertebral, and from the posterior end of each shield, at the ridge, a greenish line 
runs forwards from each of its sides to form a triangular figure, the two lines not joining each other at the anterior end of the shield, but these yellow lines correspond to the well-defined rings of the costals and the imperfect rings of the marginals.

The plastron is rich orange-yellow, but the axillary and the sixth and seventh marginals below are occupied by a dusky central area. The front, sides, and top of head, and the anterior portion of the neck above, are rich olive-black, fading on the posterior portion of the neck above to olive-brown, the rest of the neck being of this colour. A narrow yellow line on the upper surface of the head runs from between the eyes backwards. A yellow line stretches from the upper margin of the nostrils backwards, along the upper margin of the orbit; a narrow line from behind the eye over the upper margin of the ear, fades away on the side of the neck; a narrow yellow line, from below the nostril along the side of the face, extends to the angle of the mouth, and slightly backwards; the line of the opposite side begins as a separate line by itself, but occasionally imperfect at its beginning. A yellow line runs along the lower margin of the under jaw; the divergent yellow lines on the throat commence posterior to the orifices of the mental glands. The eye is black. The limbs above are covered with blackish scales, the inner and outer margin of each limb having a pale narrow yellow line, and two yellow lines down the upper surface of the limb; claws blackish.

The skull is very much narrower and much more pointed than in $B$. (MI.) ocellata, and this character comes out also in the lower jaw; and in this narrow character it is very different from the head of the types of $D$. ocellata in Paris. Like $B$. ocellata it has all the palatal and mandibular characters of $B$. thurgi.

The structure of the soft parts is much the same as in B. ocellata. In the large dilatation which marks the beginning of the large intestine, after which the intestine again contracts to a small size, I found a great multitude of an Ascaroid worm.

There are some osteological differences between the two species; the neck of $B$. petersi being somewhat proportionately longer than the neck of $B$. ocellata, the bodies of the cervical vertebræ of the former being the longer of the two. The nuchal plate, in an adult female of $B$. ocellata, is nearly twice as broad anteriorly as in $B$. petersi, and the outer anterior portion of the plastron is very much larger in $B$. petersi than in $B$. ocellata, and the hyoplastral elements are considerably longer in the mesial line than in B. ocellata, the post-inguinal area of the plastron of $B$. petersi being considerably broader than that of B. ocellata.

Blyth was the first to discover this species in Bengal. In 1859 he obtained two living specimens in the Calcutta bazaar, and being misled doubtless by the circumstance that the types of B. ocellata were stated by Duméril and Bibron to have been obtained in Bengal, he re-named the Burmese species $E$. berdmorei. The evidence I have adduced regarding the structure and disposition of the plates of the species, and which can be tested with the drawing of the type, and which have been verified by actual inspection of the types in Paris, establishes, as I have already said, that the true $E$. ocellata was the Burmese form, and therefore that Belanger's specimens were not from Bengal, where $E$. ocellata is unknown. 
The form $B$. petersi appears not to be common, and although Blyth obtained his specimens in Calcutta, there is no evidence that they were found near Calcutta. According to my experience, most of the Chelonia that find their way to the Calcutta market come from considerable distances. The specimens I have obtained are four in number; one female obtained by Mr. G. Nevill at Huzurapur in the Jessore District, two males from Furreedpore, and one male from Dacca.

\section{Sub-Genus Hardelda, Gray.}

Axillary and inguinal septa of the shell strongly developed as in the ordinary species of Batagur. Alveolar surface of the upper jaw very wide, and anteroposteriorly long, as in Morenia. An oblique raised dentated ridge in its middle, on either side, separated anteriorly by a deep pit over the premaxillaries. Margins of the upper and lower jaws strongly dentated. A deep premaxillary notch with a prominent tooth on either side of it, the high smyphysial tooth of the lower jaw fitting into the notch. The lower jaw with a ridge on each side separated anteriorly by a longitudinal groove.

\section{+ Batagur (Hardella) thurgi, Gray.}

Emys thurjii, Gray, Syn. Rept., p. 22, 1831 ; Dum. \& Bibr., Erpét. Génl., vol. ii, 1835, p. 318; Duméril., Cat. Méthod Rept., 1851, p. 14.

Emys thurgii, Gray, Cat. Tort. B. M., 1844, p. 17 ; id., Cat. Shd. Rept., B. M., 1855, p. 21 ; Blyth, Journ. As. Soc., Bengal, vol. xxii, p. 63, 1855; id., l. c., vol. xxxii, p. 81, 1863.

Emys thuji, Gray, Ill. Ind. Zool., vol. i, tab. 73, 1832.

Emys Aavonigra, Lesson, Bull. de Sc. Nat., t. xxv, p. 12; Voy. de Belanger, Zool., p. 293, 1834.

Clemmys thurgi, Strauch, Chelon. Stud., p. 32, 1862; id., Vertheil. Schildkr., p. 71, 1865.

Emys thurgi, Günth., Rept. of Brit. Ind., p. 24, 1864.

Kachuga oldhanii, Gray, Proc. Zool. Soc., Lond., 1869, p. 200, fig. xiv, skull.

Batagur thurgi, Gray, Proc. Zool. Soc., Lond., 1870, p. 708 ; Theobald, Journ. As. Soc., Bengal, vol. xxxvii, ex. No., 1868, p. 12 ; Descr. Cat. Rept., Brit. Ind., p. 23, 1876.

Hardella thurgi, Gray, Suppl. Cat. Sh. Rept., B. M., p. 58, fig. xxi, 1870; id., App. Cat. Shd. Rept., B. M., p. 18, 1873 ; Theobald, Proc. As. Soc., Bengal, 1872, p. 84; Hand List, Sh. Rept., 1878, p. 52.

Hardella indi, Gray, Suppl. Cat. Shd. Rept., 1870, p. 58; id., Hand List, Sh. Rept., p. 52, 1873.

The shell of the female is an elongated oval, narrower in front than behind, attaining its greatest breadth at the sixth and seventh marginals. The border from the eighth to the twelfth marginals is sinuous, but not serrated in the adult, although it is so in the young. The posterior margins are slightly upwardly convergent, forming a very obtuse angle with the sternal portion of the margin of the shell. There is a faint concavity over the anterior angle of the first costal and the hinder half of the first and second marginals, also over the ninth, tenth and eleventh marginals, and between the fourth and fifth vertebrals in the adult. The caudal notch is well developed. The costals are well arched in the female but flatter in the male. In the young and the male, an areolar nodosity occurs near to the 
centre of the superior border of the first and second costals, and close to the superior posterior angle of the third costal. In the fourth costal, the upper is more convex than the lower half, but there is no distinct nodosity. In the adult, these nodosities are distinctly visible as swellings in these portions of these shields; and as the second, third and fourth vertebrals are rather concave than otherwise, although they are markedly convex in the young and in males, these nodosities almost simulate a costal ridge in the adult, as they constitute an obscure longitudinal eminence which is separated from the vertebral ridge by an intervening shallow concavity. In the young, the vertebral ridge is most pronounced at the hinder border of the areolæ which are strongly transversely developed, slightly posterior to the centres of the plates, the outlines of which they retain, their surfaces being finely roughened, and the areolæ surrounded by lines concentric to their forms.

The ridge is most defined in the first vertebral, and in the young embraces the nuchal. In the male, and young females of the size of the ascertained males, the ridge terminates rather abruptly close to the posterior margin of each plate in a kind of nodosity; but in the large adult females these entirely disappear, and the ridge is rather depressed at the junction of the plates. In the young, the vertebral plates are relatively much broader than in the adults, the breadth of the second vertebral plate, which is about the same breadth as the third, equalling the distance between its external angle and the margin of the shell, while, in the adult female, the breadth of that plate is less than one-half of that distance, whilst in the males it is considerably more. In the young, the nuchal is triangular and broader at its base than long, while in the adult that shield preserves the same form. In the former stage, the first vertebral is almost quadrangular in some, while in others it is narrower in front than behind, with the margins nearly straight, and is considerably broader than long. In the adult, this shield is sometimes as broad as long, while in others it is longer than broad. Its lateral margins are sometimes nearly parallel, whilst in others they converge anteriorly as straight lines, while occasionally their anterior halves are concave and their posterior halves convex, so that the shield is nearly bell-shaped. In the majority of adults, the second, third, and fourth vertebrals are longer than broad, with rectangular borders, the costal margins of the third and fourth plates being more or less sinuous, while other individuals have the first and second vertebrals broader than long, and the third and fourth as long as broad, besides other intermediate individual variations. The general characters, however, of the first, second, third and fourth vertebrals are, that they are more or less quadrangular or oblong, generally longer than broad, with nearly rectangular margins and of nearly equal breadth anteriorly and posteriorly, with the exception of the posterior margin of the fourth vertebral, which is less than two-thirds the breadth of its anterior border. In the young, the first, fourth and fifth vertebrals are of nearly equal breadth, but, in the adult, the last mentioned shield is by far the broadest. It is contracted at its anterior extremity, and its costal margin is convex, and it articulates broadly with the eleventh marginal. 
The sternum has the gular transversely truncated, the post-gular considerably broader than the preanal portion of the young female, and the anal notch broad and its margins obtuse. The sternal ridges, which are posteriorly convergent, are marked by an areolar nodosity on the posterior margin of the pectorals and abdominals. In the adult female, the post-gular region is narrower than the preanal, and the axillary and inguinal diameters are nearly equal. In the male, the characters of the young female prevail, and the axillary is broader than the inguinal breadth. The ridge all but disappears in the adult female, and in the male it is feeble. The gulars are generally shorter than the post-gulars which are always less than the pectorals. The abdominals are the largest of all the sternal shields, and the preanals are invariably larger than the post-gulars, and occasionally as long, or longer, than the pectorals. In young specimens, the anal suture is sometimes not so long as the posterior margin of an anal, while, in the adult, it is longer than the breadth of the anal notch.

In some individuals the sternum is projected more forwards than in others, being nearly in a line with the anterior margin of the carapace, while in others it is much further back.

The following table gives the measurements of the carapace and sternum in eleven females and three males, the sexes of which were ascertained by dissection :-

Measurements of living specimens of Batagur thurgi.

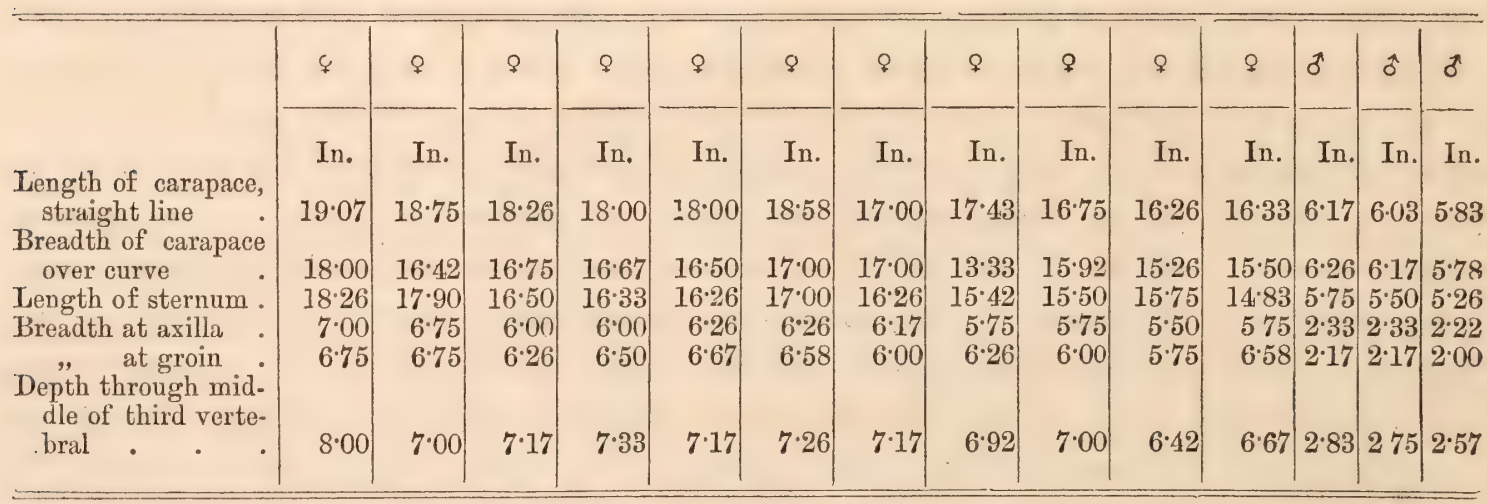

Out of thirty living,examples of this species, of all ages and sizes, only three were males, the largest being only $6^{\prime \prime} \cdot 17$ in the length of its carapace, whilst the largest female measured as much as 19.07 inches, in a straight line. I cannot say whether the remarkable discrepancy between the sizes of the two sexes indicated in this table is persistent, but this I can state, that the shells of these small males are fully consolidated, and that the penis was so enormously developed that it measured one-half of the length of the carapace. The males are distinguished by the more elongately oval character of their shells, which are not so high as those of the female, and by their longer tails, and these three characters serve at once to distinguish them from the opposite sex. The rarity of the male sex is also worthy of note. 
A few small yellowish tubercles on the upper surfaces of the toes of the fore foot, with the exception of the first; and a triangular scaly surface crossing the limb from the outer margin of the elbow to the dorsum of the first toe; the hinder margin of the limb, having a row of six or seven large membranous plates. On the under surface of the limb, a patch of medium-sized scales occurs in the fold of the ankle joint, and smaller scales on the sole of the foot. A few enlarged scales on the upper surface of the hind toes, and along the hinder margin of the limb, on which they confer a serrated border. The tail is covered above with rather spiny tubercles.

Shell dark brown above, with an orange margin, a black vertebral line and a dark spot over the areolæ of the three first costals, sometimes a continuous line. Under surface yellow, each plate occupied with a dark brown centre, so that the yellow is almost marginal. Head dark brown. An orange band above the snout, between the eyes and through the eyelid. A narrower orange-yellow band from the posterior angle of the eye and over the tympanum on to the sides of the neck, where it fades. A yellow band from the anterior angle of the eye forwards, below the nostrils, to the opposite side, the band being. separated from the one above it by a narrow dark brown band passing through the nostrils. A yellow spot below the eye. A yellow band from the exterior of the base of the symphysial hook of the lower jaw along the ramus of the latter and below the tympanum, to the sides of the neck. A dark band internal to this, the under surface of the throat being mottled with dark brownish and yellowish. A very obscure yellowish band from the anterior margin of the tympanum backwards. Limbs olive brownish above, margined with yellowish. Claws dark brown. Tail with a yellow dorsal line. In the adult, the bright colours are fainter than in the young. In some males there is an orange line along the lower margins of the second, third and fourth costals, and which I have not observed in the females.

The leading characters by which this skull is separated from other Batagurs are the absence of any upturning of the nose; the deep notch on the alveolar margins of the premaxillaries, external to which is a strong triangular serrated toothlike process ; the strong dentation of the alveolar border of the maxillary ; and still stronger toothed character of the lower jaw, which has a large symphysial sharp tooth, fitting in to the notch in the upper jaw and the absence of a coronoid.' The internal nares are broad, and shorter than in other Batagurs, but this character would be of no sub-generic value were it not associated with a differently formed external wall. In true Batagurs, the palatine and pterygoid form an expanded surface at the posterior angle of the maxillary palate, producing a well-defined external wall to the internal nares by the sharp border of the palatine. The latter is pierced by the palatine canal, on the same plane with the general surface of the palate, whereas, in B. thurgi, there is no expanded pterygo-palatine surface, the pterygoid arching outwards and anteriorly to the posterior angle of the maxillary palate, there being no ridge-like border to the palatine, which is wholly concave and pierced in the outer wall of the nares by its canal. 
In the general form of the skull, the so-called $B$. (Hardella) thurgi is very closely approached by $B$. (Morenia) ocellata and $B$. (M.) petersi, but the different extent to which the axillary and inguinal septa of the shells of Hardella and Morenia are developed is so great, that it appears to me that the two should have each sub-generic rank to Batagur.

When the mandible of Hardella is compared with the mandible of $B$. lineata, $B$. baska, $B$. iravadica, and $B$. trivittata, it will be observed that in these species it is characterised by a well developed process, which even projects above the upturned posterior extremity of the serrated alveolar border of the upper jaw, and at a considerable altitude above the alveolar line of the lower jaw. In B. thurgi, and in $B$. ocellata and $B$. petersi, there is no upturning of the alveolar line of the upper jaw, and the so-called coronoid process does not exist. The lower jaw, also, of $B$. thurgi is a magnified repetition of the jaws of the two species $B$. ocellata and $B$. petersi, and this is very well seen when the skull of an adult $B$. ocellata is compared with the small male skull of $B$. thurgi. In such a comparison, the skulls are so similar, that the generic identity of the two, apart from other considerations, would be probably maintained. There is the same shaped palatine region with a corresponding number of ridges and depressions, and similarly formed external nares, only in Morenia the palatine foramen is more posterior and placed out of the nares than in Hardella; but there is also a similar mandible, flattened, denticulated continuously and with an expanded posterior surface. The viscera also, in both the subgeneric forms, are much alike.

In the female, there are 21 caudal vertebræ. The first has an outwardly directed, well-marked transverse process which disappears in the second and third, but in the fourth it is strongly developed and curved forwards, this forward curve existing in a less degree in the two succeeding vertebræ, in which the process is more strongly developed, but it decreases in strength in the seventh with a backward direction, and gradually decreases in size to the seventeenth vertebra, disappearing on the eighteenth. The shell has the well-marked septa of Batagur baska and B. lineata.

The tongue is small, triangular, and marked by a longitudinal furrow, about two inches behind the laryngeal orifice; the œsophagus is covered with more or less longitudinal lines of rather large flattened processes of the mucous membrane, and behind this again for about three inches, these structures become lengthened into conical papillæ $0^{\prime \prime} \cdot 21$ in length, simulating, to a certain extent, the remarkable mucous stylet-like appendages of the œesophagus of Chelonia virgata. The remainder of the osophagus is thrown into numerous sharp longitudinal folds which are continuous with the folds of the stomach, which disappear at the bend where the viscus becomes transverse, reappearing again about four inches from the pylorus; the interspace free of folds being sacculated and with smooth walls. The left half of the stomach literally lies in a groove of the liver, between the ventral and dorsal lobes, the longitudinal portion being wholly hidden by the free margin of the ventral lobe. With the exception of the slight distension 
to the right of the bend of the stomach, the viscus is tubular, as in allied tortoises. Its walls in the latter situation are thin, but in all the remaining portion to the right they are $0^{\prime \prime} \cdot 35$ thick. The small intestine preserves one calibre throughout, and its mucous coat is thrown into longitudinal folds, finer but of the same general character as those on the œsophagus, with three or four very fine wavy folds between each. It measures seven feet three inches in the largest adult, the measurements of which I have given, and is considerably longer than in $B$. baska, $B$. lineata, \&c. There is a distinct pyriform cæcum about two inches long when contracted, and about one inch in diameter. The large intestine is three feet long, and it is very different from the large intestine of $B . b a s k a, B$. lineata, and $B$. duvancelli, in describing two sigmoid curves instead of one. The liver invests the stomach to a much greater extent than in either $B$. baska or B. lineata. The gall bladder, which is of considerable size, lies in a concavity on the left side of the gland, and is transverse to the body from the dorsal to the ventral surface, bent slightly to the right, its apex appearing through the liver substance from the right side of the cavity in which the viscus is placed. The gall duct is eight inches long before it reaches the intestine, and, at this distance, its presence is indicated, in the mucous coat of the intestine, by an almost cartilaginous process of the wall, and beyond this it runs under the mucous coat for $1^{\prime \prime} \cdot 40$ and then opens by a minute orifice, although the tube has considerable capacity. The bile has a rather rich dark-green colour, and the liver is much lighter-coloured than in other tortoises I have examined.

The clitoris of this species consists of an outer rosette of four lobes in pairs, with a terminal pointed lobe, the inner rosette being small, consisting of one pair of lobes and an azygos terminal lobe traversed by the urinal canal, $i . e$, the same type as in $B$. basloa and $B$. lineata. The peritoneal canal having the same length as in these species and apparently opening near the base of the glans.

The cloacal bladders are large and covered internally with long villi, which, however, do not extend on to the cloacal walls, as in $B$. baska. The longitudinal folds guarding the ovario-urinary chamber are full and broad, and when drawn asunder are seen to be connected by a transverse constriction, or short fold, below which there is a small pit. The ureters open immediately below the orifice of the oviducts, at the extremity of a short downward prolongation of the folded border of this orifice. The ureter is short ( 1.50 inch), but of considerable calibre, and its narrow orifice is defined by a crescentic fold on its upper margin which prevents regurgitation of the fluid.

The oviduct is capacious, and, in the individual before me, the ovary was 18 inches long, and had numerous ova; the contents of the larger ova were a bright yellow grumous substance. The oviduct measured 3 feet 4 inches. The first foot from the cloacal opening had its inner surface of a decided pinkish hue, and was thrown into numerous transverse, but interrupted fine folds, while all the remaining portion of the tube was of a pale greyish, almost faint bluish-white tint. The peritoneal attachments of the tube were well defined internally and gave rise to its 
division into an anterior and posterior wall, each of which were covered with fine folds placed obliquely across each wall, but parallel to each other.

The allantoic bladder is small compared with that of $B$. lineata, and presents two halves that are thrown into numerous fine folds, on their red inner aspects.

The lung is very different from either the lung of $B$. baska or $B$. lineata, and is chiefly distinguished by the large flask-shaped lower lobe which depends over the oviduct and abuts against the cloacal bladder, distending the inguinal region at every deep inspiration, pushing before it the cloacal bladders and the enormous masses of yellow consistent fat that occur in that region. It nearly equals the length of the body of the lung, which is narrow and rather elongate, partially divided at its anterior extremity, with a sinuous external margin, terminated below by a small flask-like lobe. The anterior portion of the lung is nearly twice as broad as the lower end, before the flask-like lobes are given off. The lateral length of the lung is 11.50 inches; its greatest breadth anteriorly 3.75 inches, and posterior $2^{\prime \prime} \cdot 16$. The length of the large flask-like lobe is 4.50 inches.

Hardella thurgi is a thoroughly aquatic species, frequenting deep slow-flowing nullahs, and the long land-locked reaches of deep water that occur, for example, in the district of Purneah, old channels of the Cossy river, which has travelled about ten miles to the westward, during a comparatively short space of years. These slow-flowing and stagnant waters are generally well stocked with aquatic weeds of various kinds but little known, and generally teem with fish, and are thus the favourite resort of crocodiles. The H.thurgi lives in these muddy bottoms where it scrapes up the bulbous roots of the aquatic plants, occasionally rising to the surface to breathe, but not so frequently as the Pangshures and Trionyces, by reason of its capacious lung. The stomachs and intestines I have opened have invariably been filled with dark-green vegetable matter, but with no trace of an animal diet. This water tortoise is eaten by Crocodilus palustris, and I have been informed by a reliable authority that he has seen a crocodile trying to swallow a large $H$. thurgi, and that he has found the stomach of C. palustris, packed full of fragments of the shells of tortoises.

It is not at all of a fierce disposition, and when unmolested seldom attempts to bite, and even when much irritated it only slowly opens its mouth, and withdrawing its head, emits a blowing hissing sound.

Although thoroughly aquatic, I have kept it during the hot weather out of water, and without food, for more than two months, and with no evil effects as far as I could judge; after it is returned to the water, having been previously for long deprived of it, the allantoic bladder becomes rapidly distended, as in other and allied species, with a clear watery fluid, which, when the animal is frightened, is ejected with considerable force.

This species appears to be widely distributed through the Gangetic system of rivers, extending up the Brahmaputra, but not occurring in Arracan and Burma. 
During the cold weather months, many hundreds are brought to Calcutta and purchased by a low caste of Hindus ${ }^{1}$, who keep them alive in tanks and sell them to the Mugh population and to the Chamars for food, also eating them themselves.

In the Purneah district, I have had an opportunity of observing at Kolassy, a tribe of Sontals who have been settled in the district for some generations, dive for this species in deep water, and perform the much more astonishing feat of capturing in the same way the very fierce $T$. gangeticus and $T$. hurum. Ten of these men, all but naked, collected together, and I was-surprised to see each man provided with a large bundle of green marsh grass, neatly tied up as a cylinder, about 2 feet long by 9 inches in diameter, cut cleanly across at the ends. As they went into the water each thrust his green bundle before him which I soon perceived to be a float, on which each rested his chest, as he got beyond his depth. Then, one after another, pushing away their floats, dived and re-appeared generally with an example of Hardella thurgi obtained in the mud at the bottom. Having caught a tortoise the diver rests on his float to recover his breath, and coming slowly to shore lands his captive which he carries in two hands, propelling himself slowly by his feet. In this way they caught, in a very short time, about fifteen tortoises of the following species, viz., P. tecta, E. granosa, and H. thurgi.

\section{Sub-Genus Tetraon $\mathrm{YX}$, Lesson.}

\section{Batagur (Tetraonyx) baska, Gray. Pl. LXVI, LXVII, juv.}

Emys batagur, Gray, Syn. Rept., p. 24, 1831 ; id. Ill. Ind. Zool., vol. ii, 1834, t. 59.

Emys baska, Gray, Ill. Ind. Zool., vol. i, p. 32, tab. 75.

1rionyx cuvieri, Gray, Syn. Rept., p. 50, 1831.

Tetraonyx batagur, Gray, Cat. Tort. B. M., 1844, p. 29.

Batagur baska, Gray, Cat. Sh. Rept., B. M., p. 35, pl. xvi, 1855 pars; id. Ann. \& Mag. Nat. Hist., 1857, vol. xix, p. 343 ; id. Suppl. Cat. Sh. Rept. B. M., p. 52, fig. skull, 1870; Günther, Rept.,

Brit. Ind., p. 37, pl. iii, figs. B B ; Blyth, Journ. As. Soc., Bengal, vol. xxxii, 1863, p. 84.

T'etraonyx baska, Gray, Proc. Zool. Soc., 1869, p. 200, fig. ii, skull.

I'etraonyx longicollis, Lesson, Belanger, Voy. aux Ind. Rept., p. 297, 1834.

Tetraonyx lessoni, D. \& B., Erpét. Gén. vol. ii, p. 338, pl. xvi, fig. 1, 1835, M. M. Duméril. Cat. Méth. Rept., p. 15, 1851; Blyth, As. Soc. Journ., vol. xxii, p. 645, 1853; Theobald, Linn. Soc.

Journ., vol. x, Zool. p. 17, 1868; id., Cat. Rept. Journ. As. Soc. vol. xxxvii, ex. No., p. 11, 1868. Ietraonyx baska, D. \& B., Erpét. Génl. vol. ii, 1835, p. 341.

${ }^{1}$ There is a colony of these Hindu brokers on the eastern outskirts of Calcutta, on the high road to a great fish mart to which many fish that find their way to the city bazaars, and even to those of its suburbs, are first brought alive, in boats half filled with water, and sold to the highest bidders. These Bengalee Chelonian brokers live in wretched thatched mud huts around a tank, the banks of which are literally paved with the shells of this species, and with the granulated shields of Chitra, Trionyx and Emyda, which are also highly esteemed as food. On visiting this curious spot, I was first shewn a fer huge specimens of $T$; gangeticus lying in the shallow water at the side of the tank, moored to its bank by a cord passed through the webs of the fore and hind feet of one side; and secured to a wooden peg driven into the bank. On the opposite side of the tank, a large enclosure had been staked off in deep water, and I was informed that it was flled with Hardella thurgi which is always penned up in this way to prevent its escaping, for it is a good walker on dry land. Close to this tank was another and much smaller pond, but so shallow that the backs of the turtles and tortoises appeared as low mounds above its green surface, coated with a thick pellicle of confervæ. Here, again, there was a central circular pen filled with Hardella thurgi, and, round about it, were many specimens of $T$. gangeticus disabled and pegged as just described. 
Tetraonyx affinis, Cantor, Journ. As. Soc., Bengal, vol. xv, 1847, p. 612 (pars).

Tetraonyx baska, Duméril, Cat. Méth. Rep., p. 15, 1851.

Clemmys longicollis, Strauch, Chelon. Stud., 1862, p. 33 ; id. Vertheil. der Schildkr. 1865 p. 87.

Snout pointed and turned upwards, the upper surface concave between the anterior half of the orbits, convex behind this. The facial portion is much more pointed, up-turned and narrower than in $B$. lineata, and the nostrils are more tubular. An elongated shield between the orbit and the anterior upper half of the tympanum, with a very narrow elongated shield below it and the aural border. Tympanum covered with rather small scales, arranged somewhat in concentric circles. The skin granular on the neck and on other parts of the body as in $B$. Tineata, with similarly defined scales. The jaw is feebly serrated and slightly notched anteriorly.

The general colour of the upper surface of the head and neck in the female is olive-green, with the horny covering of the jaws yellow, the under surface of the neck being also more yellow than the upper surface; the limbs and tail being dark olivegreen. The claws yellow. The upper surface of the shell is a uniform olive-brown, the under surface yellow.

The shell has no ridge in adult life, but the young has a rather pronounced vertebral ridge. The shell is not so elongately oval as in $B$. lineata and is more expanded posteriorly and has more reverted marginals. It is also generally more arched from side to side in its anterior half; broader before and much fuller over the region of the first and second vertebrals and first costals, than in the generality of shells of $B$. lineata. It attains its greatest depth between the second and third vertebrals. It is distinguished from $B$. lineata by the more quadrangular form of its vertebrals, but more especially by the absence of the fourth elongated vertebral of that species.

The nuchal is not so broad posteriorly as in specimens of the same size of B. lineata. Like that species, the first vertebral has divergent lateral margins, but the hinder margin, if it is at all concave, is not so much so as in $B$. lineata, and it is occasionally quite straight. It is broader than long, its greatest breadth being between the costo-marginal angles, and its posterior breadth also either exceeds or equals the length. The shield is marked by a feeble longitudinal swelling. The second vertebral is also broader than long. Its first costal margin is directed backwards and outwards and is nearly straight, the second costal border being directed inwards and backwards from the former, with a sinuous outline. The posterior border is very faintly concave from behind forwards. The greatest breadth of the shield is attained between the two costals, the breadth of the posterior border scarcely equalling the length of the shield. The third vertebral is also a little broader than long, and only slightly broader in its anterior than in its posterior margin which is backwardly concave. Its greatest breadth is attained between the second and third costals, and if its slight outward projection at that point is omitted, the two sides of the third plate are nearly parallel, but a little posteriorly convergent. The fourth is considerably broader than long, and the front margin 
broader than the hinder suture. The third costal sutures are sinuous and posteriorly divergent, while the fourth costal margins are the reverse, and nearly straight. The second and third vertebrals are nearly of equal breadth, and the fourth is only a little narrower than the last. The fifth is much broader than long, with a straight truncated anterior margin, half as broad as its posterior margin. The caudal notch is hardly perceptible.

The gular suture is shorter than in B. lineata, equalling about one-third or onefourth of the post-gular suture. The latter almost equals the pectoral suture, which is less than the two former sutures by about one-half of the gular suture. The abdominal is the longest suture, but the preanal suture is shorter than the conjoint gular sutures. The anal suture is less than the greatest breadth of one of its shields.

I have not observed any very great disproportion between the males and females of this species, but the largest specimen that has passed under my observation was a female from Kyouk Phyoo on the coast of Arracan, which greatly exceeded the dimensions of any male, but still not to that degree that seems to prevail in B. thurgi, B. duvaucelli and some other species.

The only structural difference that I can detect between the two sexes, is the much greater length of the tail in the male, as compared with the female, which is brought out in the accompanying table:

Measurements of shells of B. baska, Gray.

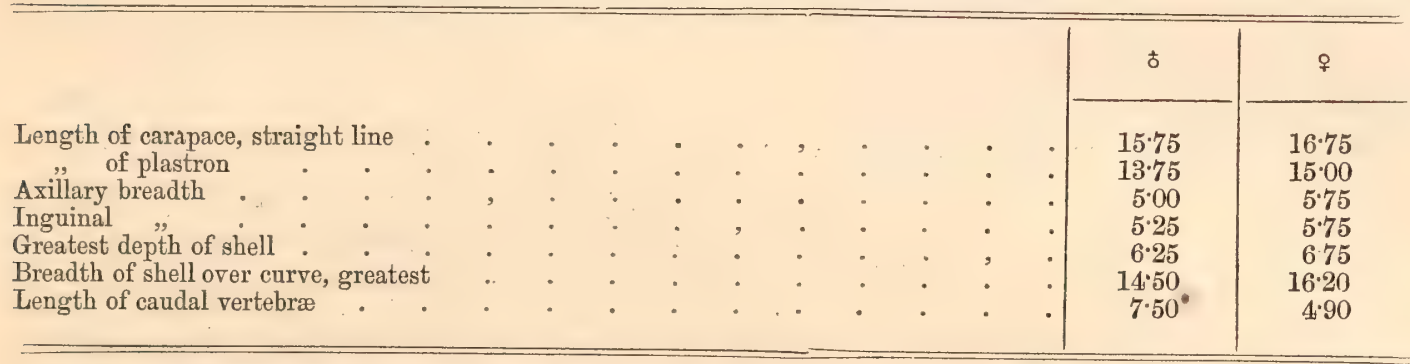

In adolescence, the nasal portion of the skull of the male is perhaps more pointed and upturned than in the female at the same period. In youth, however, the skull of the male is almost flat (see Pl. $\mathrm{Xxxv}^{\mathrm{A}}$ figs. 6 to 10) as is shown in a specimen from the Irawady which has all the skull characters of this species, and regarding the specific identity of which there can be no doubt. Unless the specific characters of the adult are well ascertained, the young of such species as $B$. baska and of other species of Batagur, owing to the great changes in form that take place between youth and age in the shell characters, are very liable to be mistaken for distinct species. I may also add that unless the characters which distinguish the sexes are well known, similar errors are liable to arise regarding them, and, moreover, the sexes can only be satisfactorily determined by a direct appeal to the organs of generation.

The male, however, is distinguishable from the female by the remarkably brilliant colouring of the front part of the body, but this is not always present, and may perhaps depend on sexual periods. 
The general colour of the upper surface of the shell, in the bright-coloured phase of the male, is rich brown, somewhat marbled with darker in the form of lines, the under surface having a rosy yellow tint. The area around the nostrils is pale bluish, but all the rest of the head, and the under surface of the neck are deep black, passing into a rich crimson on the base of the neck, the whole of the fore-limb being brilliant rosy carmine. The hind limb is dull reddish purple, and the tail and hinder parts are of the same colour, only darker. The eye is a pale greenish yellow. The alveolar or palatal surface of the plates of the jaws is always almost black in both sexes, but darker in the male.

The skull is distinguished by the contraction of the facial portion, which begins at the posterior margin of the prefrontals; the region posterior to this being narrow and concave on its upper surface, with the prefrontals in the adult upturned to a greater extent than in any other Batagur. Internal to the sharp finely serrated margin of the maxillaries, there are two parallel strongly serrated ridges on either side of the palate. The anterior ridges are separated from each other in front by a deep mesial groove, continuous with the furrow internal to each, and which is prolonged forwards into the premaxillary depression; the internal ridges are also separated from each other by a sharp longitudinal ridge; this ridge expands anteriorly between them, but they are separated from it by the furrow internal to each, sending a narrow prolongation round the anterior extremity of each ridge into the anterior furrow. The hinder border of the palate is slightly reverted, forming the posterior wall of the second furrow. The posterior nares have their lateral margins slightly anteriorly divergent and not prolonged so far forwards as in B. lineata; they are thus broader than in that species. The post-palatal portion of the base of the skull, around the nares, is broader and more expanded than in $B$. lineata, and $B$. duvancelli resembles $B$. baska in this respect, rather than $B$. lineata. The,pterygoid constriction of the base of the skull is also much broader than B. lineata, and in this character B. duvancelli also resembles it. It equals half of the space between the pterygoid angles of the post-palatal surface, a proportion which also prevails in $B$. duvaucelli, while in $B$. lineata it is less than one-third of that interspace. The base of the skull, in this region, does not project so far downwards as in $B$. lineata. The area between the articular facets for the mandible is only marked by two very shallow concavities on the pterygoids, while in $B$. lineata there is a deep crescentic concavity, and external to it a deep furrow running downwards and forwards. In $B$. duvancelli, this concavity and furrow are merged in one, defined by the ridge that runs inwards forwards and upwards from the inner margin of the facet for the mandible. The concavity on the under surface of the occipital is much larger than in B. lineata, which is the case also with $B$. duvancelli, although the superior lateral concavities of the basioccipital are larger and more backwardly projecting in the former species. The parietal region of the skull is also much more flattened than in B. lineata, as it is also in $B$. duvancelli, although, in its general form, the skull of the latter is more nearly allied to this species than to the former. The eye, as in other species, is strengthened by a ring of sclerotic 
bones, ten to twelve in number, Pl. $1 \times x v$, fig. 11, which constitute a strong supporting ring to the sclerotic. The temporal fossa has a rather acutely pointed anterior superior border, while in $B$. lineata and $B$. duvancelli the same border is obliquely transverse and broad.

As in $B$. lineata, the lower jaw has a longitudinal groove between the posterior symphysial margin and the post-alveolar ridge, but instead of stopping short where it meets the angle of junction of the ridges of the opposite sides, it is prolonged forward between them, terminating on the symphysis, while in B. lineata the ridges unite; a sharp but short ridge occurring at the angle of union, which is the case also in $B$. duvaucelli, only in that species there is no groove posterior to the post-alveolar, which has only a single narrow surface behind it nearly on its own level. The groove behind the inner ridge of the lower jaw has a well-defined inner border in $B$. baska, whereas, in $B$. lineata, this border is not upraised, and there is consequently no true posterior groove, but only a broad shelf of bone.

In this species and $B$. lineata, there is a concavity on the outer surface below the alveolar border corresponding to the surface on which the superior maxillary rests, but in $B$. duvaucelli no such concavity exists.

The skull of the large individual from Khyouk Phyoo measuring $5 " \cdot 45$ in extreme length and $3^{\prime \prime} \cdot 10$ in width below the ear is fully adult, as the sutures on the anterior portion of the upper surface of the head are disappearing; and since the skeleton presents every appearance of full maturity, the dimensions given under that specimen may be regarded as indicating the limit of growth of the female.

The first vertebra after the eighth dorsal is applied by its transverse process in the same way to the eighth costal plate as occurs in $B$. lineata, but the nodosity so formed is applied to the ilium before the transverse processes of the first of the true sacral vertebræ, of which there are only two with distinct transverse processes. The transverse processes appear in the fifth and disappear in the fifteenth caudal vetebra. In a female there are 27 tail vetebræ. The axillary and inguinal septa are developed almost to the same extent as in B. baska.

The tongue is very small, not more than half an inch in length, and is marked by a longitudinal furrow, as in Baturgida generally, leading to the laryngeal orifice which is almost exactly below the posterior nares. The larynx is thus placed much anteriorly. The surface of the mouth, and the œsophagus for three inches behind the larynx, are covered with large and numerous rounded villiform processes. The tubular intestiniform stomach is stretched across from side to side between the anterior septa of the shell. Entering the visceral cavity, at the upper end of the left septum, it passes a short way backwards and then stretches across to the posterior margin of the right septum, from which it is separated by the narrow transverse lobe of the liver. It then turns backwards, and, when opposite the gall bladder, it is covered anteriorly by the right division of the liver, which arches over it, and from that point its backward curve is inwards. The left lobe of the liver embraces anteriorly the csophageal portion of the stomach and lies in ${ }^{5}$ the lesser curvature. The total length of the greater curvature in one 
individual was 11:50 inches and of the lesser curvature 7.80 inches, with a maximum diameter of $1^{\prime \prime} \cdot 10$. The total length of the small intestine was $45^{\prime \prime} \cdot 60$, and of the large intestine $15^{\prime \prime} \cdot 60$. There is a small conical dilatation of the large intestine on the beginning of its left wall. The first five inches of the small intestine are considerably dilated and the mucous coat is smooth, but beyond that, to the large intestine, there are long tracts in which it is thrown into long continuous wavy parallel rugæ of different calibre, but of marked regularity. The liver is rather small compared with $B$. lineata, and its right and left lobes lie immediately behind the septa, its right being but little larger than its left lobe. The latter has a lingulate anterior surface directed backwards and inwards, from left to right, with the tip recurved outwards, the peritoneal sac being alone attached along the upper border. Its outer half lies across the oesophageal portion of the stomach, the recurved inner end resting in the depth of the smaller curvature. This lobe has two small lobules at its base, dorsal to the attachment of the gastro-hepatic omentum, and they also lie in the smaller curvature, the smaller lobule being bent anteriorly over the root of the other, and fitting into the lesser curvature. The other lobule contracts rapidly and in the middle line is not more than 0.75 of an inch in breadth antero-posteriorly, while its transverse width is three inches. The two vence cava run along the anterior surface of this connecting lobe (lobulus caudatus), the heart resting on it about its middle. The right section of the liver is deeply concave, chiefly by the inward projection of the ventral half of the right lobe which is broadly bifurcate at its extremity, and to which the allantoic bladder is attached, and by the dorsal half of this lobe meeting the lobulus quadratus at right angles. The lobulus quadratus sends down a long filamentary process from its inner margin, behind the gall duct, and along it the vena cava passes. The gall bladder which is large is so deeply imbedded in the right lobe that its fundus appears on the external surface of the liver as a round projection close to the margin between the two divisions of the right lobe. The bile duct has a course of about six inches, and opens into the intestine, six inches from the pylorus. The bile is a very dark-green, almost approaching to black.

The pericardium was full of a very clear fluid which measured about 2 ounces. The right auricle was beating vigoronsly for about two hours after all external signs of life had ceased, but the other cavities exhibited hardly, if any, perceptible movements, any motions that they did make appeared more to be due to the blood propelled by the right auricle and to its movements. The right auricle has thin, almost transparent puckered walls and is considerably larger than the left auricle. Its apex is directed inward, and slightly forward. The pulmonary artery divides at 0.68 inch from its base, and the brachial arteries arise one inch from the base of the ascending carotid. The right descending aorta, lying between the pulmonary artery and ascending carotid, bends over to the right nearly in a transverse direction, crossing the left carotid, left and right bronchi, and bending round about the middle of the left bronchus reaches the back. The right aorta gives off at 0.75 of an inch from its base, a common trunk, a quarter of an inch in length, which divides into the 
carotids and brachial arteries and then crosses the pulmonary artery and the right bronchus. It is about six inches long from the point it bends dorsally to the bronchus, and it gives off no branches in its course to its junction with the left aorta. The latter, which is also six inches long in its dorsal course before it branches, $0 \cdot{ }^{\prime 2} 25$ above its junction with the right aorta, gives off two branches. One long branch passes forwards to the left over the transverse colon to the concavity of the lesser curvature of the stomach, and enters the left lobe of the liver, but gives off no branches until it reaches the stomach. The other branch passes forwards to the right, crosses the dorsal aspect of the pyloric end of the stomach and then runs along the gastro-hepatic omentum to the right, and backwards to the right of the quadrate lobe of the liver, to supply the liver pancreas and also the pyloric end of the stomach and duodenal portion of the intestine, sending a few branches to the commencement of the large intestine. The mesenteric branches of the colic axis arise by a short common tube about two lines in length, from which they radiate. Commencing from above, the first branch is small and proceeds to the transverse colon; the next in order to the right, two in number, viewing the animal from above, are directed outwards to the duodenum, spleen, and pancreas. The next branch passes to the ileum, while the two remaining and most posterior branches are directed to the jejunum and to the last part of the great intestine. All these mesenteric arteries thus pass off, anteriorly to the right, and posteriorly to the union of the two aortæ. The supra-renal arteries are distant $3 \cdot 75$ inches from the point of union of the right and left aortæ, and the renal arteries are 0.58 below them, but anterior to the supra-renals; backwards to the renal arteries nine small renal branches pass off from each side of the aorta to the kidneys. The division of the aorta into its iliac branches occurs two lines below the renal branch.

The ovaries in the virgin are narrow bands $0^{\prime \prime} \cdot 16$ broad by $2^{\prime \prime} \cdot 25$ in length, their lower ends curved forwards. On the right side, as well as on the left, two large processes of the lung lie in front of the ovaries, as in Batagurs generally, and on the former side, the last part of the duodenum is closely attached to the side of the upper part of the rectum and to the lung. The omental fold from this portion of the small intestine invests the pendent portion of the lung. From the oviduct to the rectal attachment of the ligament of the ovary, a delicate fold of peritoneum stretches and is attached along the under surface of the ligament, and can be traced along the abdominal wall as far forwards as on a line with the lower margin of the liver, and which gives attachment to the oviduct, which is $6^{\prime \prime} \cdot 25$ in length by little more than $0^{\prime \prime} .05$ in breadth. The trumpet-like mouth of the ovary dilates at its free extremity to $0^{\prime \prime} \cdot 25$ in breadth.

The intestine terminates about half an inch above the arched membrane that passes forwards and downwards from its orifice on to the lateral walls of the cloaca, when contracted closing in the arched membrane that protects the orifices of the ureters and bladder from the fæces. The former arch of membrane when closed only allows of a passage to and from the lateral cloacal bladders. The intestinal recess of the cloaca is thrown into longitudinal folds, while the urinary recess is 
comparatively smooth with the orifices of the ureters situated well in on its sides, with rather patulous orifices directed inwards and downwards. The orifices of the cloacal bladders are very wide, as in all Batagurs, and distensible, easily dilating to two inches and a half in extent. The whole of the inner walls of the bladders are covered with villiform processes, as in Pangshura, very sparse near their apices but especially plentiful at their orifices, and on the sides of the cloacal canal nearly as far forwards as the clitoris. The latter organ has two lateral lobes on either side, with a common, somewhat pointed anterior lobe, with a small central lobe resembling the last, and grooved for the termination of the urinary canal. The urinary canal is three inches in length, and it dilates in its anterior third as it approaches the orifice of the ureters. The allantoic bladder is very large, and the fundus of its right division is attached as far forward as the liver by a narrow mesentery. A specimen which had lived for two months without water beyond an occasional douche, but which had not been near water for three weeks before its death, except on the previous day when it was immersed, the bladder was found distended to a great size with a clear fluid, and so large as to invest the whole of the intestines, reaching to both lobes of the liver.

The trachea divides at 6.75 inches from the laryngeal slit and is to the left of the mesial line. The right and left bronchi are 7.50 inches long, and in their length and convolutions resemble the coiled air-tubes of some birds. The left bronchus is completely curved upon itself at the apex of the left lung, anterior to which it lies along the anterior border of the osophagus till it reaches the apex of the lung where it describes the foregoing curve, and then crosses the dorsal aspect of the csophagus to enter the lung about two inches below its apex and one inch internal to the inner border of the lung. The right bronchus enters its lung at about the same position, but does not curve on itself like the left tube, but in its course from the trachea describes a number of small curves.

The lung is six inches in extreme length, by three inches in breadth. It is broad anteriorly and narrower behind. Its external margin is marked by six divisions, the most anterior being the largest, and forming the outer half of the broad anterior end of the lung and is partially divided into three secondary lobules. The posterior division is not very long, but is divergent from the lobe before it. The inner border terminates in a moderately long dilatation, projecting backwards across the ovaries and separated from the last lobe of the outer border by a wide notch.

Batagur baska, Gray.

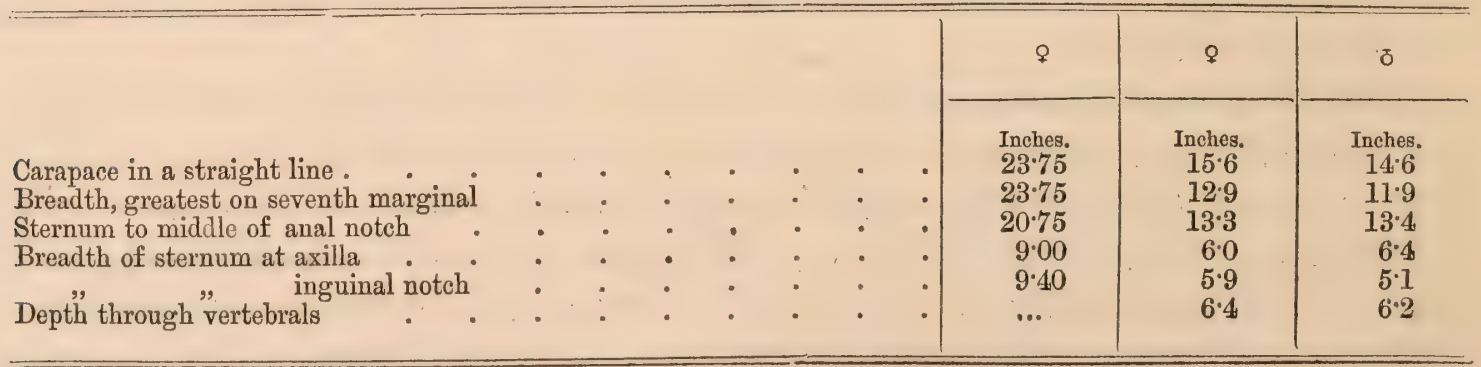


This species occurs in the Sunderbunds to the east of Calcutta, and is more common than $B$. lineata. How far it extends to the westward I cannot say, but it appears probable that its place is taken in the north-west by $B$. lineata and B. duvaucelli, and that it is more essentially a Malayan than an Indian form. I have received it from the coast of Arracan, and it is generally distributed. throughout the Irawady.

I have carefully examined the type of $T$. longicollis, and do not find any character by which it can be separated from $B$. baska.

\section{TRIONYCID正.}

Genus EmYDA, Gray.

Emyda scutata, Peters. Plates LXXIV, LXXV, \& Plate LXXVA.

Emyda granosa, Theobald ( pars), Journ. Linn. Soc., vol. x, p. 18, 1868.

Emyda scutata, Peters, Monatsbr. Preuss. Akad., 1868, p. 449 ; Gray, Suppl. Cat. Shd. Rept., B. M., p. 107, 1870 ; Theobald, Descr. Cat. Rept. Brit. Ind., 1870, p. 32.

This is a shorter and more rounded oval than any of the other species of the genus, and if the nuchal valve is excluded, the anterior and posterior margins of the shell are rounded nearly to the same extent. The nuchal is very small and suspended in a cartilaginous flap. The anterior vertebral swelling is better defined in the male than in the female. The first costal area in the female is markedly concave. The marginals in the adult are nearly all of one size, whereas, in the other forms, the first marginal is always much larger than the rest. The plastron is known by its very much smaller epiplastra, hyoplastra, and hypoplastra, and by its very large entoplastron, characters which separate it from all the other species; also, by its closely approximated xiphiplastra, broad anteriorly and narrow posteriorly, their inner margins forming a straight line, with no divergence either anteriorly or posteriorly.

The sexes are distinguished by well marked characters. The males are smaller than the females, and the callosities of the plastron in the male are relatively larger than in the female. In a fully grown male measuring $7^{\prime \prime} \cdot 50$, the epiplastra are triangular with a long anterior border. The inner margin is slightly convex, but nearly straight, while the posterior margin is nearly transverse, being directed slightly backwarus, these two margins each equalling two-thirds of the length of the anterior margin. The callosities are rather widely separated by an interval, equalling nearly one-half of the length of the internal margin, but being broader anteriorly and posteriorly, owing to the convexity of the inner margins. Each epiplastron is much smaller than the entoplastron, the extreme length of one of these being less than the transverse breadth of the entoplastron, but exceeding its longitudinal breadth, the greatest breadth of an epiplastral callosity being little more than three-fourths of the latter measurement of the entoplastron. The entoplastron is transversely oval, the posterior side being somewhat swollen; its 
breadth considerably exceeds the length of a xiphiplastron, and even the conjoint breadth of two. The conjoint hyoplastron and hypoplastron have a rounded internal margin, the entoplastral border being marked by a deep notch. These elements are separated by an interval of only one line from the entoplastron, internal to the notch. The xiphiplastra form a suture in the middle line, the internal being the largest of all the margins, the external border being five-sixth of its length. The external borders are anteriorly divergent, so that the plates are broad anteriorly and narrow posteriorly. The anterior margin is slightly convex and notched at its outer angle; the posterior equals one-third or so of the external border, and it forms an oblique angle with its fellow, varying in degree. The umbilical interspace, and the area around the entoplastron are much more restricted in this than in any of the other species.

In the female the epiplastra are narrower and more elongated than in the male, the entoplastron is considerably smaller and more rounded, and the abdominals are proportionally smaller and separated by a wide interval. The xiphiplastra also are relatively smaller, and their anterior margins are transverse and further apart from the abdominals. These characters are persistent at all ages.

In youth (specimens $5^{\prime \prime} \cdot 65$ ) the entoplastron of the male is round, while that of some females is transversely oval. The xiphiplastra in the male are in apposition in the middle line, but their anterior margins are divergent, whereas in these females they are separated, and both anterior and posterior margins are divergent.

From the base of the snout to the vertex, behind the eyes, appears to be slightly more arched in the males than in the females. The head is moderately broad behind the vertex, being flat or slightly concave, and has much the same breadth as in E. vittata, Peters. The upper lip is full and pendulous. The eye is moderately large, considerably smaller than the tympanic area. The first claw of both the fore and hind foot is relatively stronger than in the Gangetic species, E. punctata, Gray. The toes are not so broadly webbed as in the last mentioned form, and in $E$. vittata and $E$. granosa (Madras); the web between the fourth and fifth toes of the hind foot, and the membrane: along the base of the fifth toe, are especially narrow. The skin on the snout and upper surface of the head between the eyes in the males is covered with very fine granules.

The general colour of the upper surface of the shell in the adults is a dark olive-brown with an obscure black reticulation, or spotted; the cartilaginous marginal surface being a paler brown. The spots are occasionally reduced to irregular rings, while in others they form dark reticulations all over the shell. The sternum is yellowish-white, the callosities and marginals being pale fleshy. The upper surface of the head and neck and limbs, and under surface of feet are paler olive-brown than the shell, and, in adult females, the head and neck are occasionally yellowish-olive. An obscure variable dark longitudinal band or spot between the eyes; a dark line from the posterior margin of the eye over the tympanum. Two obscure black spots on the vertex, occasionally absent, and some smaller spots on the beginning of the neck. The lips are more or less yellowish 
on the under surface, and in the pale coloured females are orange; the angle of the upper lips on the side being yellowish-orange, which does not occur in dark-coloured males, but only to a very faint degree. The yellowish-orange, however, extends behind the angle of the mouth involving the tympanum. The hyoid region has a yellowish tinge, while the rest of the under surface of the neck is pinkish-white; the under surface of the limbs is the same colour with a purplish blush. The claws are yellow, dark olive at the base, or wholly yellow in pale varieties. The iris is various shades of pale yellow, in some, nearly white.

The skull (Plate LXXVA, figs. 12 to 16,) is closely allied by its form to the skull of $E$. vittata, but its zygomatic arch is more bulging and the orbital portion of the skull relatively shorter, the surface antero-posteriorly of the temporal fossa being also shorter than in $E$. vittata. The shorter character of the skull as compared with the skull of $E$. vittata also shows itself in the palatal and pterygoid regions, which are shorter than in the foregoing species, while its posterior nares are somewhat broader. The lower jaw is markedly distinct from that of $E$. vittata, in its weaker symphysis, less lateral depth, and less divergent coronoids. The skull of $E$. vittata is much less pointed than the skull of $E$. punctata, which has an elongated facial portion even more pointed than in E. ceylonensis. Although these differences exist between the skulls of $E$. scutata and E. vittata, they are undoubtedly more nearly related to each other by their skulls than to any of the other species.

E. scutata, Peters.

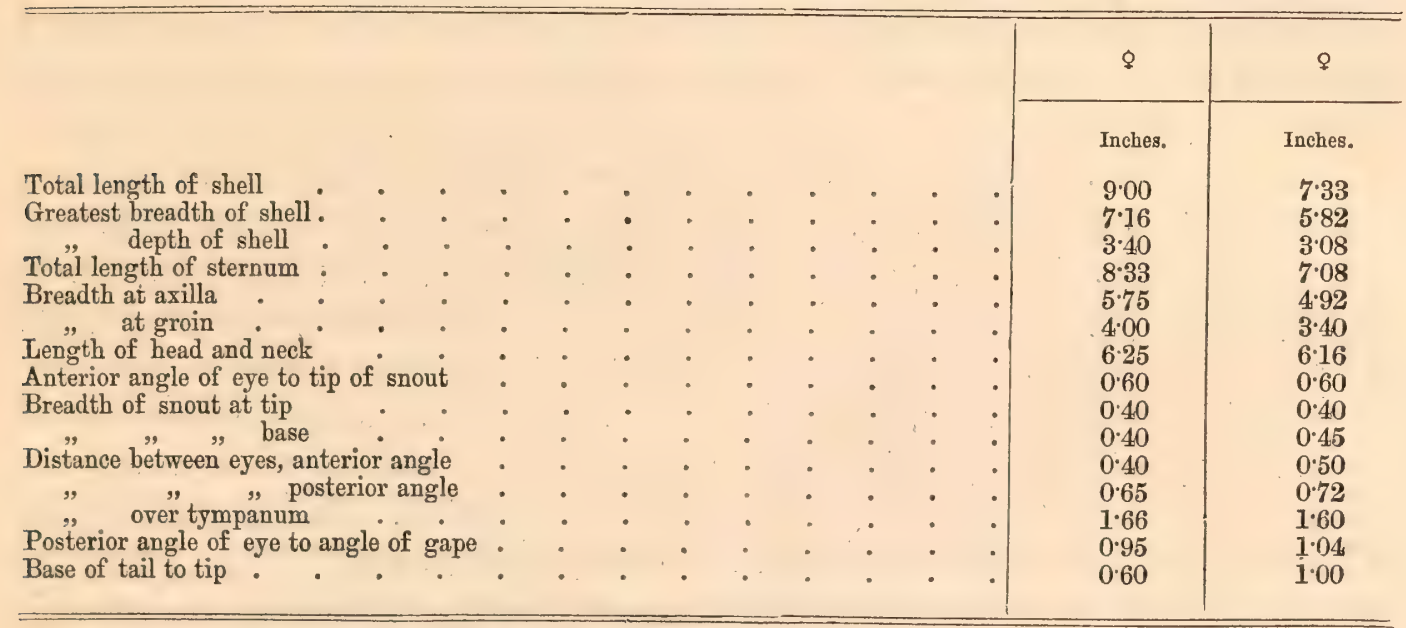

This species is distinguished by the small size of its epiplastral plates and the relatively great size of its entoplastral callosity and by its nearly triangularshaped xiphiplastra and by its comparatively short hyo- and hypoplastra and small marginals. The epiplastra have the posterior contraction hardly, if at all, marked, and they taper considerably to their posterior ends. The rami of the entoplastron are about as divergent as in $E$. punctata, and the plate is almost spherical, but broader generally in its posterior than its anterior half. The portion of the hyoplastral plate lying between the external and the entoplastral process 
does not appear to attain the development that distinguishes it in the other species, and, unlike any of the other species, the external process is directed rather outwards and backwards than outwards and forwards. The anterior conjoint margin of the xiphiplastrals is transverse and twice as broad as the conjoint posterior margins, the two halves of which form an obtuse angle much the same as in adult $E$. punctata. These plates, as already stated, are proportionally large for the species which appears to be the smallest of all.

The stomach in this genus is not more dilated than the osophagus, or than the small intestine at its beginning, and it is not so wide as the large intestine. The first third is directed obliquely across the abdomen from right to left, lying, however, on the left side of the mesial line. Its middle third is nearly longitudinal, and its latter third is almost transverse, and the pyloric end, which is slightly contracted and thickened, appears in the visceral cavity well to the left of the mesial line. In opening the abdomen, the coils of the intestine are seen arranged in three concentric circles with the transverse portion of the large intestine appearing between the duodenal fold and first part of the second circle. On removing the intestines entire from off the vertebral column and carapace, and turning to the back, two other concentric complete circular folds are observed, the innermost fold beginning at the left side with the others external to it, the transverse colon terminating on the left side, to the right of the pylorus. There is no cæcum, and the total length of the small intestine measures 3 feet 3 inches, and the large intestine $6 \frac{1}{2}$ inches, in an animal $8^{\prime \prime} \cdot 75$ in length.

Two inches behind the larynx, the œsophagus is covered for about an inch with rather long triangular flat villi, the surface of the pharynx anterior to that locality, and the tongue and roof of the mouth being covered with similar but much smaller structures. The rest of the cesophagus, the pyloric third of the stomach, and the most contracted portion of the small intestine are marked with fine longitudinal folds. The remainder of the digestive tract, with the exception of the large intestine, is smooth and of nearly equal breadth throughout, and were it not for the narrow pylorus, there would be no indication either of stomach, œsophagus or small intestine, but merely a continuous tube. The right lobes of the liver are proportionally much larger than in Batagur, and the bile duct is large, but I have not been able to detect its opening in the intestine. The lung is stronger, but quite as large as in the Batagurida. There are two bronchi, one to each side. The lung is more or less oblong and thick on its external two-thirds, but very thin internally, its lower border being in close contact with the testicle and kidney.

The penis, which lies in the post-caudal dilatation of the cloaca, is large, compressed from above downwards, the glans consisting of two equal semi-ovals, placed in apposition, like a bilobate leaf, the tip being slightly pointed. It is deeply concave on its under surface, which carries two rather long conical filamentary processes, one before the other, the anterior pair of which are the longest, and situated at the distal end of the proximal or basal third of the glans. These two processes are widely separated from each other, and opposite to them the urinary 
groove divides into two, one groove proceeding to each process. The groove which passes first slightly posterior to the base of the process, then courses back in a spiral manner on the process, till it reaches the anterior aspect of its tip. The other grooves, passing backwards to the posterior or distal processes, are straightly divergent, each terminating internally, but slightly posteriorly on the tip of its process. The urinary groove of the body of the penis, as well as the grooves of the glans, are very deep, and must form nearly a perfect canal when their edges are in apposition. The groove is not continuous with the orifice of the bladder, but below where the ureters open, the cloaca is marked by fine longitudinal rugæ. The peritoneal canals commencing slightly below and external to the neck of the bladder appear to terminate in the bases of the proximal pair of filamentary processes and in the spongy substance of which the glans is made up. There are no lateral cloacal bladders. The allantoic bladder is a moderately sized pyriform sac marked by strong rugæ on its fundus; the remainder of its wall being smooth.

In females measuring $5^{\prime \prime} \cdot 35$ in length of carapace, the clitoris which is like a miniature penis, is $0^{\prime \prime} \cdot 20$ in extreme length. The division between the lobes is more deeply marked than in the penis, and the filaments are more continuous with the lobes, one pair being directed forwards and the other backwards, while in the penis these structures form nearly a right-angle with the longitudinal axis of the glans. From the base of the proximal pair of processes, a fold of skin passes upwards and outwards, terminating externally in a little wart-like papilla that marks the position of the ending of the peritoneal canal. The urethral groove is shorter in the females and only extends about half the distance that intervenes between the clitoris and ureters, the intermediate surface being densely covered with transverse folds.

The females are distinguished from the males by their apparently greater size; their proportionally much shorter and narrower tails; by the more rounded character of the shell, and its greater fulness behind the inguinal region and greater depth through the middle line. In both sexes, the tail is generally so bent on itself in the cloacal region, that when the animal is retracted and the vent closed, the bend of the caudal vertebræ projects downwards, so as to abut against the anal fold of the sternum posterior to the penis and cloaca, with the anal fold and caudal contraction of the carapace effectually closing the entrance to the cloaca. The upper surface of the tail in $E$. granosa is marked by a smooth ungulate surface of a darker colour than the rest of the skin, and at first sight resembling a scale.

There is a minute papilla at the anterior extremity of the floor of the nasal passage with a short fold passing backwards from it in the direction of the nasal septum and acting as a valve.

In specimens of this genus only an inch and a quarter in length, the plastron presents no trace of the callous plates that afterwards become developed on its constituent bones. In a specimen $1_{4}^{\frac{3}{4}}$ inch in length, however, the epiplastral plates are indicated by a puckering of the skin over the anterior end of the bones, and over the hyo- and hypoplastra at the point where they have already united immediately 
before the anterior extremity of the inguinal valves. The bones of the posterior pairs are thickened over the point from which their median transverse connecting rod diverges inwards. There is a considerable deposit of pigment in these localities, in very young specimens, the whole of the area in the neighbourhood of the second, third, and last pair of the plastral bones being deep black, this colour becoming fainter with age; but it is still present in specimens measuring 4 inches in length.

In animals 3 inches long, the anterior roughened surfaces are $0^{\prime \prime} \cdot 35$ long. They first make their appearance near the anterior extremities of the epiplastra, and grow outwards as distinct plates beyond the external margins of the epiplastra, their internal borders corresponding to the same border of the bones. The azygos callosity appears on the arch of the entoplastron towards its posterior margin. The lateral callosities first appear on the broad surface formed by the union of the hyo- and hypoplastra, and extends as these bones grow on to the posterior rami of the hypoplastra, above the division, but less so on to their external rami, and hardly reaching their internal rami. The hinder callosities, $0^{\prime \prime} \cdot 35$ long in this female, appear on the surface from which the three arms of each xiphiplastron diverge, and gradually extend on to the first and hinder arms, but more so on to the former than on to the latter. These callosities do not extend on to the transverse rami of the hypoplastral bones.

In examples 4 inches long, the plates of the epiplastra are more or less quadrangular, separated from each other by two-thirds of their own diameters, while the entoplastral plate is a minute rough crescentic area. The hyo- and hypoplastral rough surfaces have a straight anterior margin, two concave internal margins, one before the other, and one external concave border. The xiphiplastra are rather elongated ovals, separated from each other in their posterior halves by one-half of their own diameters, their anterior halves being strongly divergent. In the fresh state all these callosities are invested with a thin skin.

In the adult, the skin is thick and fleshy, the granules are round and pearly, and on the inside of the sternum the callous plates are seen to invest the bones with the exception of a short basal portion which permits the epiplastra to move freely on the entoplastron. The development in the epiplastra is most extensive on their posterior ends, the bony plate in that direction being more than twice the size of the anterior section. The entoplastral plate is developed downwards between the two halves of the bone, the ends fit into the lateral plates before their anterior processes and produce a notch in $E$. punctata. The processes of the hyo- and hypoplastra are wholly and broadly invested by the rough plates, only the extremities of their internal processes remaining free in $E$. punctata. In adults, the xiphiplastral plates embrace all their bones except their extremities anteriorly and posteriorly, while three of the transverse processes fit into each other side by side, the tip of each abutting against the opposite bony plate when the two halves of the plastron are bent upwards and inwards, so that this motion is very limited, while motion in the opposite direction is very free. 
The outline of all the original bones and their processes can be detected in the bony plates, so that it would appear that growth commencing in the parts indicated in the young extends gradually in all directions, till at last this secondary osseous structure embraces all the constituent bones, leaving only their articular processes free, the bones themselves preserving their outlines.

Variation, however, is not confined to the plastral plates, but occurs also in the shells, independently of differences ascribable to age. In youth, the shell is of a more rounded form than in after life, when it is a more elongated oval. In some specimens the anterior margin of the shell and the anterior vertebral swelling are fuller than in others; the vertebral line is raised in a few, while in others it is rounded off at the sides.

In fresh healthy specimens, the upper shell is always entirely covered with skin so thick as to obscure the granular surface under it, but in adults it sometimes becomes abraded, exposing the almost white granular shell below it.

These curious mud turtles when left to themselves will slowly and cautiously extend their necks, but as soon as they are approached they do not attempt to escape, but withdraw with great rapidity into their shells and firmly close them. I have never observed them snap at objects, in the same way as Trionyx, and the much more formidable Chitra, which darts out its long neck with a rapidity unparalleled among animal motions.

When the head is retracted it is completely hidden so that the anterior margins of the carapace and sternum meet. The skin on the long retracted neck forms two folds; the innermost but highest fold is so formed that its upper border, which is slightly longer than the snout, and so, doubtless for the protection of that sensitive part, overhangs it; but at the sides of the mouth it slopes downwards and backwards, the free margin in that position of the fold lying along the chin, so that by this arrangement the mouth is not covered by this fold. The most external fold which is formed by the skin at the base of the neck, covers the whole of the inner fold against which it lies, and all that part of the mouth left uncovered by it, leaving only the nostrils unprotected.

The neck when retracted is so doubled on itself, that the base of the cervical vertebræ, at the anterior extremity of the carapace, is on the same line with the tip of the snout, the posterior bend being opposite the inguinal notch of the sternum, and pushing backwards before it the coils of the intestines which partially embrace it on either side.

This, like the other members of the genus, frequents muddy bottoms, and, when jheels dry, it buries itself in the mud, at no great depth below the surface.

The female in laying her eggs, which are round and about an inch in diameter, scrapes a shallow hole for them in the mud and then covers them up.

They are exclusively vegetable and grain-feeders.

This species appears to be generally distributed throughout Burma, extending along the various rivers that debouch into the main stream, from Lower Pegu up to Bhamô, where I obtained examples, and it doubtless ranges still higher. 


\section{Genus Trionyx, Geoff.}

Trionyx Peguensis, Gray. Plates LXX, - LXXIII,

Trionyx peguensis, Gray, Suppl. Cat. Shd. Rept., 1870, p. 99, Theobald, Descr. Cat. Rept., Brit. Ind. (Calcutta), 1876, p. 31.

Isola peguensis, Gray, Proc. Zool. Soc., 1873, p. 31.

The specimens of Trionyx collected by Mr. Theobald in Pegu and Arracan, and which found their way to the British Museum, were three in number, as far as I have been able to make out by an inspection of the registers in which they are entered and of the specimens themselves. There is a young Trionyx in alcohol, the type of $T$. formosus, and the skull of which was afterwards extracted; the skull of the type of $T$. phayrei, the shell of which was presented by Theobald to the Bristol Museum; ${ }^{3}$ and the head of an adult in spirit, ${ }^{4}$ the type of $T$. peguensis, and the skull of which was afterwards figured under the name of Isola peguensis.

Theobald mentions that only two skulls of Trionyx (exclusive of young animals in spirit) passed from his hands into the British Museum, either by gift or purchase, "a head of T. stellatus," and second, "the skull of my type of T. phayrei." This is confirmed by the Hand List of Shield Reptiles.

The history of these specimens is noteworthy. The young animal in alcohol was described in 1869 as T. formosus, ${ }^{5}$ and in 1872 as Nilsonia formosa, ${ }^{6}$ but at this latter date Dr. Gray contrasts the skull of the young animal which had been removed from the specimen, with an adult skull which he received from C. Falconer, Esq., ${ }^{7}$ one of the executors of the late Dr. Hugh Falconer. This adult skull has been since figured, ${ }^{8}$ and we are thus enabled to judge of its true nature. After a careful consideration of the figure, I do not hesitate to pronounce it to be the skull of a Gangetic species, viz., T. hurum, ${ }^{9}$ distinguished from T. Gangeticus by its antero-posteriorly long symphysis without a median ridge, and to be the skull of the fresh-water turtle which has been described under the names of $T$. sewaare, $T$. ocellatus, ${ }^{11}$ and $T$. buchanani, ${ }^{12}$ all of which yield similar skulls, quite distinct from the young skull of $T$. formosus. The skull of $T$. phayrei was first apparently

1 Hand List Shd. Rept., B. M., 1873 p. 77.

2 1. c., p. 80.

3 Obs, on Ind. and Burm. Trionyx, Theobald, Cal. 1873, p. 8.

${ }^{4}$ Hand List Shd. Rept., p. 80.

5 Proc. Zool. Soc., 1869, p. 217, Plate xv, fig. 1; Suppl. Cat. Shd. Rept., 1870, p. 99.

6 Ann. and Mag. Nat. Hist., vol. x, p. 332, 4th Ser., 1872.

7 1. c., p. 332.

8 Proc. Zool. Soc., 1873, p. 46, fig. 2.

9 Syn. Rept., 1831, p. 47, Tab. x; Ill. Ind. Zool. vol. ii, 1833, t. 16. 10 Gray, Ann. and Mag. Nat. Hist., vol. x, 1872, p. 336 ; Proc. Zool. Soc., 1873, p. 50 ; Theobald, Proc. As. Soc.,
Berigal, 1875, p. 172 .

11 Ann. and Mag. Nat. Hist., vol. x. 1872, p. 337 ; Proc. Zool. Soc., 1873, p. 51 ; Theobald, Proc. As. Soc., Bengal, 1875 , p. 174.

12 Proc. As. Soc., Bengal, 1874, p. 78. 
referred by Gray to $T$. formosus, ${ }^{1}$ as he states under $T$. formosus that "this may be the species indicated as a Trionyx phayrei," but afterwards ${ }^{2}$ he identified the skull of $T$. phayrei with $T$. hurum of his Synopsis Reptilium, but with which T. phayrei has no affinity. In $1871^{3} \mathrm{I}$ identified a skull, recognized by Theobald to be the skull of his T. phayrei, with the type skull, $T$. jeudi, and I stated that after a comparison of the two, I could not detect any characters by which to separate them, but Dr. Gray considered that I had erred, and that the turtle I described as $T$. phayrei was distinct from $T$. jeudi and referable to his $T$. perocellatus. But, as we have seen, Dr. Gray after this still identified T. phayrei with T. hurum. But in the Hand List my view of the identity of T.phayrei and T. jeudi was ultimately accepted, but the species was erroneously referred to the $T$. sewaare, which is identical with the T. hurum of the Syn. Reptilium.

The head in alcohol which was the only specimen of the kind in the British Museum obtained from Theobald has a peculiar history. In the Suppl. to the Cat. Shield Rept. ${ }^{5}$ the head of an adult animal in spirit is stated, under Trionyx jeudi, to have been obtained from Mr. Theobald, who procured it in Pegu, but it is remarked that the symphysial ridge of the lower jaw is only slightly raised and very different from the type of $T$. jeudi. On the following page, a head in spirit from Mr. Theobald is again mentioned, and described as the type of $T$. peguensis. There can be no doubt but that this also is the head referred to under T. jeudi. The skull of this head was ultimately removed and figured by Dr. Gray, ${ }^{6}$ and the prepared skull shows a large injury which is explained by Theobald, who states that the two Trionyces he collected in Pegu were shot by his revolver.? The specimen which constituted the type of $T$. peguensis, Theobald mentions ${ }^{8}$ was taken by a fish hook from the Sittang river at Tonghoo, but as both specimens were shot by him, we conclude that this example was shot after it had been landed by the hook.

I shall now consider these specimens in detail, and some other Trionyces which have since been figured and described by Theobald, ${ }^{9}$ in order to arrive at an understanding of their relations to the species figured in this work. I have not seen the shell of the type of $T$. phayrei which was obtained by Theobald in a mountain stream in the Arracan range, west of Pegu, but it was remarkable owing to the circumstance that the roughened surfaces which generally occur on the elements of the plastron of Trionyces were almost absent, the granulations being only slightly developed. Theobald did not describe the coloration of his type, beyond stating that the colour during life was dark dull brown, handsomely lined as in Pelochelys cantori;

1 Proc. Zool. Soc., 1869, p. 219, et. Suppl. Cat. Sh. Rept., 1870, p. 98.

2 Ann. and Mag. Nat. Hist., $x, 1872$, p. 336.

3 Proc. Zool. Soc., 1871, p. 154.

${ }_{4}$ l. c., p. 80.

5 l. c., p. 98.

6 Proc. Zool. Soc., 1873, p. 52, fig. 5.

7 Proc. As. Soc., Bengal, 1874, p. 85.

$s$ Obs. on Ind. and Burm. Trionyces, Cal., 1873, p. 7 :

${ }^{9}$ l. c., Proc. As. Soc., Bengal, 1874; l.c., 1875. 
the under surface yellowish-white. Since then, however, Theobald ${ }^{1}$ has figured and described under the name of $T$. careniferus, Gray, (?) and also under the name of T. phayrei, Theob., without any expression of doubt, the head and shell of a fresh water turtle from Pegu. Mr. Theobald was so good as to allow me to make a coloured drawing from the same specimen, and I have compared the heads of a series of eight turtles from Moulmein, Myanyoung, and Bhamô on the Irawady, with it, and all of them exactly agree with the animal which he in 1873 considered to be his T. phayrei. At the same time $\mathrm{Mr}^{2}$. Theobald figured from a specimen obtained at Moulmein another species which he regarded as Trionyx stellatus, Geoff.

The head of the specimen referred to $T$. phayrei, is reticulated on its upper surface with black elongated irregularly formed spots, which extend partially on to the upper half of the thick upper lip, but not on to its lower half, nor on to the under surface of the head. The head is moderately broad.

The head of the turtle from Moulmein referred to T. stellatus, Geoff., is narrower and more pointed than the former, and the head is covered more densely, and is reticulated by broken black spots or markings which are more open on the sides of the head. They extend, however, over the upper lip and on all the under surface of the head, and the marking, although generally the same in both, is specifically distinct from the first mentioned head.

Mr. Theobald has figured ${ }^{3}$ one-half of the carapace and one-half of the plastron of each species. The pitted reticular structure of the carapace of $T$. careniferus, Gray (?) $=T$. phayrei, is represented as being coarse, but not nearly so much so as in the carapace of T. stellatus, Geoff.

The under surface of the plastron of $T$. careniferus, Gray $(?)=T$. phayrei, Theob., is figured perfectly smooth, with no trace of granulations, but the figure is so small as not to show a slight tendency to granulation, visible in the specimen figured, and which is shown in the drawing I had made, of life size, from the specimen.

This plastron has a very strong resemblance to the plastron of the Trionyx figured by Gray as T. subplanus. A specimen in the British Museum named Dogania subplana appears to be the specimen figured. The characteristic features of this plastron, as of the plastron figured by Theobald, is the heavy entoplastron and the smooth surface of the other elements. There is no evidence, however, that this Trionyx is the T. subplanus, Geoff., as that species was founded on a carapace only, which Geoffroy considered might have appertained either to the Trionyx of Georgia or of the Euphrates. I have never met in the Gangetic system with a tortoise like Gray's specimen referred to T. subplanus and figured as such, and as coming from the Ganges; but General Hardwicke apparently received the specimen

\footnotetext{
1 Obs. on Ind, and Burm. Trionyx, 1873, p. 7, pl. ii, et Proc. As. Soc., Bengal, 1874, p. 75, pls. iii \& iv.

${ }^{2}$ l. $c ., \mathrm{p}, 6, \mathrm{pl}$. i.

${ }^{3} l . c .$, pls. $\mathrm{i}$ and ii, et $l . c .$, pls. iii \& iv.

4 Illust. Ind. Zool., vol. i, 1832, pl, lxxix.
} 
from Singapore, and it may be it is identical with species of Trionyx from Burma which Theobald has described as having a smooth carapace. The figure shows the remains of what appears to have been a dark reticulation of the upper surface of the head.

The plastron of $T$. stellatus is represented as having its hyoplastron and hypoplastron and xiphiplastron covered with granulations as in Trionyx generally, and with a light entoplastron. The specimens here figured (Plates lxx to lxxiii) under the name of Trionyx peguensis, have heads exactly agreeing with Theobald's figure, Plate ii, $l . c$., referred by him to $T$. careniferus, Gray (?) $=T$. phayrei, Theob. The eight specimens from Moulmein and the Irawady are all alike in these particulars, viz., that their heads have one coloration and one form so closely corresponding in all their details to Theobald's figure that they must in this respect be regarded as specifically identical with the head figured on Plate ii and Plate iii, l.c. The heads of these animals exactly agree with the head in the British Museum named by Gray T. peguensis. There is, however, this remarkable difference between their plastra and the plastron figured under the name of $T$. phayrei, that animals of the same size as that figured by Theobald have their plastra covered with granulations as in the plastron of $T$. stellatus, figured by Theobald on Plate i and Plate iii $(l, c$.

I have never seen a Triony $x$ from the Irawady with a head like that of $T$. stellatus, Geoff., apud Theobald.

The skull of the adult figured on Plate lxxii and lxxiii of this work, and which I here reproduce, natural size, Figs. 29, 30 and 31, agrees with the skull of the head of the type of $T$. peguensis. The skull has a rather long symphysis marked by a

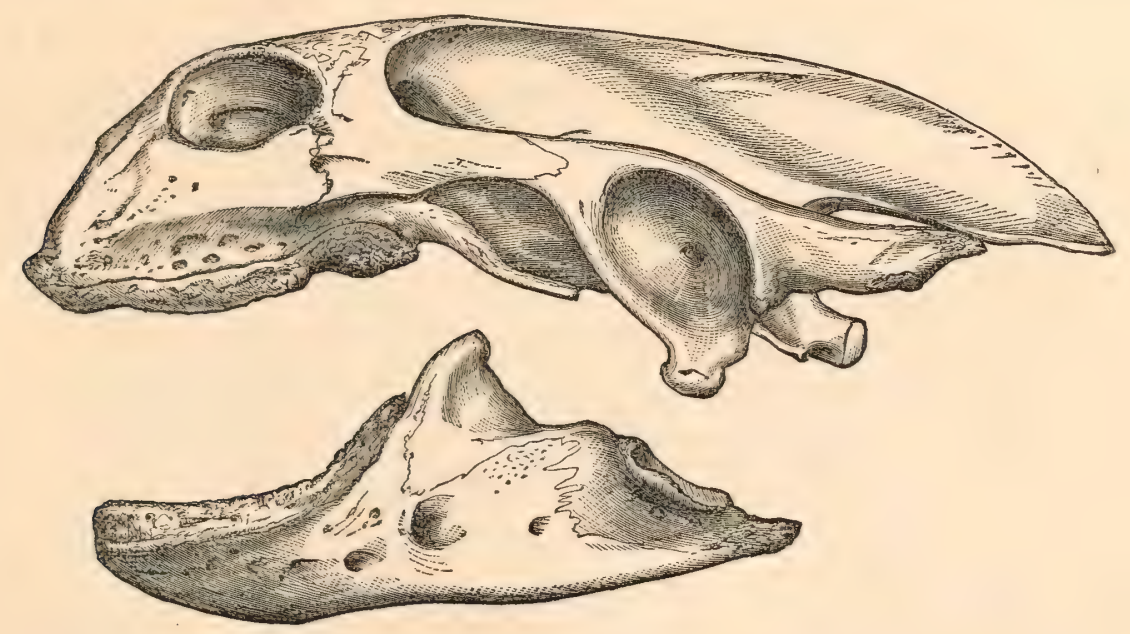

Fig. 29.

Skull of Trionyx peguensis, Gray.

longitudinal ridge, and in the former character it resembles the skull of $T$. hurum, which, however, has no ridge, but rather a mesial groove. 
Mr. Theobald ${ }^{1}$ has recently described a turtle from Thayet Myo on the Irawady, with a plastron covered with granulations, as in the plastron referred by him to T. stel-

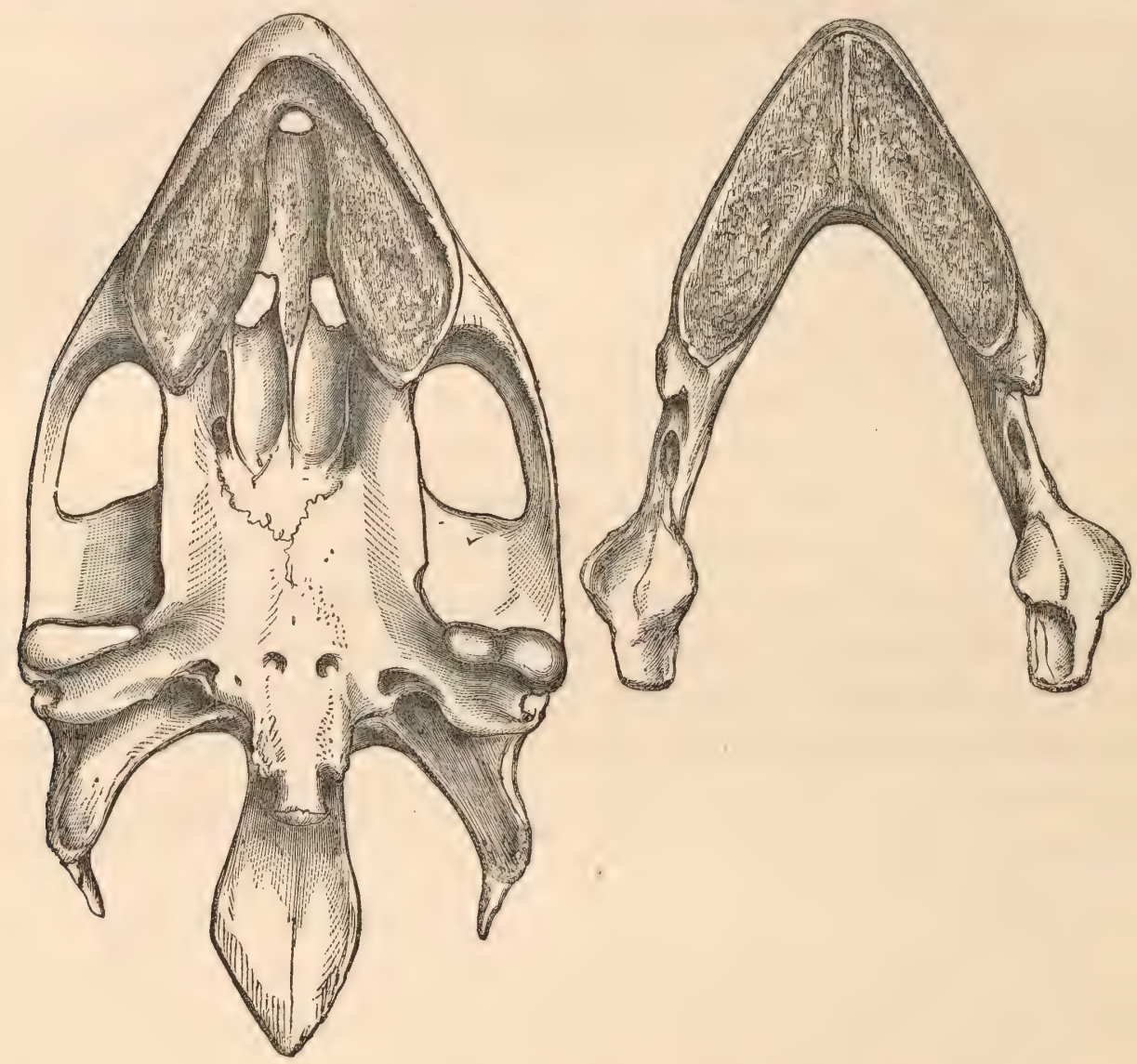

Fig. 30 .

Fig. 31.

Skull of Trionyx peguensis, Gray.

latus; and the skull of this specimen, it is important to observe, corresponds to the skull of $T$. peguensis. Theobald recognized this, but remarks ${ }^{2}$ that the plastral characters indicated a totally different animal, and that the style of the coloration of the head was so different from that of $T$. peguensis that it clearly belonged to some other species. In connection with these remarks, however, by Mr. Theobald, it must be borne in mind that he regarded the turtle figured by him under the name of $T$. stellatus as the equivalent of $T$. peguensis - a view of the question I cannot adopt, after reading Dr. Gray's first description of $T$. peguensis, and after having compared the specimen I have figured under this name with the type of $T$. peguensis.

It is further stated by Mr. Theobald that the dried head of the specimen which served as his type of $T$. grayi when moistened with water closely resembled the coloration of the head he has figured under the name of $T$. phayrei, and which he also names T. careniferus, Gray (?), from which, however, he was prevented identifying it, as the plastron of $T$. grayi was covered with granulations. The skull of

1 Proc. As. Soc., Bengal, 1875, p. 176, pl, iii.

2 1. c., p. 176. 
T. grayi is undoubtedly identical with the skull of the turtle figured in this work, and with the skull of the type of $T$. peguensis. The skull of the turtle figured by Theobald as T. stellatus is, as far as I am aware, unknown. The shape of the head does not indicate a skull like the skull of $T$. peguensis.

Mr. Theobald has described and figured ${ }^{1}$ a young turtle from Tenasserim under the name of $T$. ephippium, and it will be observed on a reference to the figure of the head that in its elongated form and in the dark reticulations spreading over the under surface of the head, it corresponds much to the head figured as T. stellatus, Geoff. There is also this noticeable feature of this supposed species, that its plastron is perfectly smooth like the plastron figured as the plastron of T.careniferus, Gray (?) = T. phayrei, Theobald. The head, however, of the latter corresponds to the heads of eight turtles from the Irawady in the Indian Museum, Calcutta, which have their plastra covered with coarse granulations, and which in the form of their entoplastron piece exactly correspond to the plastron referred to $T$. stellatus and to the plastron of T. grayi. The granular surfaces or callosities on these eight plastra exactly correspond to the granulations figured on the plastron referred to T. stellatus and T. grayi. The plastron of T. ephippium, on the other hand-a species which has a head the equivalent in form and markings with the head figured as T. stellatus-has a smooth plastron, with a heavy entoplastron like that of the smooth plastron referred to $T$. careniferus, which is in Theobald's plate associated with a head specifically distinct from that of T. ephippium and T. stellatus.

I have pointed out that the adult or adolescent skull referred by Gray to $T$. formosus corresponds to the skull of $T$. hurum. The skull $(68,4,3,142)$ removed from the type is so small, that its specific characters are not sufficiently marked to enable it to be decided wherein it differs from the skull of T. hurum, but it does not appear to be that species which is confined to the Gangetic rivers. I am disposed to consider it as the young of $T$. peguensis.

From these facts it is apparent that considerable difficulty has been experienced in determining the one species of Trionyx from the Irawady described in this work. I have no hesitation, however, in identifying it with the Trionyx which has been described by Gray as T. peguensis, and were it not that the plastron of the Trionyx figured by Theobald under the name of T. careniferus, Gray, and T. phayrei, Theobald, is described as smooth, and that its entoplastron is differently formed from the entoplastron of the specimens before me, I should have considered this species, from the specific identity of its head with the head of the latter, as an example of the same species.

The smooth character of the plastron figured by Theobald might perhaps be accounted for on the supposition that it was abnormal, but even were this so, such an explanation would not explain away the difference between its entoplastron and the entoplastra of the eight Trionyces which I have examined from Moulmein and from the Irawady. 
The T. careniferus, Gray, was founded on a turtle from the Moluccas received from the Leyden Museum. The type is now much bleached, and as the skull has not been removed, it is impossible to say whether it is specifically the same as T. javanicus, with which Gray ${ }^{1}$ has regarded it as identical. The head is broader than in $T$. perocellatus, Cantor, like which the carapace is covered with large pointed tubercles, which is also a character of $T$. javanicus, to which, in form, and in the shape of its head, it has a strong resemblance. It appears to attain to a larger size than $T$. perocellatus, Cantor; and in specimens of larger size than the largest $T$. perocellatus, it is observable that the plates of the plastron are considerably smaller, and that the rugosities are apparently not developed. The entoplastral piece is not so outwardly expanded as in $T$. perocellatus, and the xiphiplastra are much more elongated. The epiplastra are widely apart over the entoplastron, as in specimens referable to $T$. stellatus. It would seem in all its characters to be most closely allied to T. javanicus, if not identical with it.

In describing the Burmese species, Theobald refers, as I have said, the T. peguensis, Gray, to the T. stellatus, var. japon., Geoff. This variety from Japan, however, was not indicated by Geoffroy, but by Temminck and Schlegel. Moreover, there are apparently two species of Trionyx found in Japan, one corresponding to the supposed foregoing variety of T. stellatus, Geoff., but which is identical with $T$. perocellatus, which is the T. sinensis, Wiegm., ${ }^{2}$ and which appears to have been more recently re-described by Brandt ${ }^{3}$ under the name of T. schlegeli; the T. stellatus, Geoff., and T. javanicus, Geoffroy, being seemingly synonymous terms and refering to the same animal as T. careniferus, Gray. I have examined animals referable to T. stellatus or to T. javanicus, and I cannot allow that the T. peguensis, Gray, has any affinity with them.

The other Trionyx found in Japan besides T. sinensis, Wiegm., is a form allied to T. javanicus, Geoff., and which Gray first referred to D. subplana, and which has been figured by Schlegel ${ }^{4}$ under the name of $T$. japonicus. It appears to me to be distinct from the so-called D. subplana, Gray, and from $T$. javanicus.

I give two figures of this. Irawady Trionyx-one of an adult, and the other of a moderately young individual still in the ocellated stage; and I would observe that in its ocelli and general characters, this species may almost be regarded as the representative in Burma of the Gangetic species T. hurum, with its young stage T. ocellatus, the skull having the symphysis of the lower jaw long antero-posteriorly, as in T. hurum, but with a mesial ridge instead of a furrow. I retain Gray's name for the species, viz., T. peguensis, as its use is not likely to be productive of error.

Head moderately broad and pointed. Greatest breadth across the tympanic region, not broad before the eyes. Tubular portion of nostrils rather long; upper lip full. Rather abruptly depressed from between the eyes downwards to the

${ }^{1}$ Hand List, Shd. Rept., 1873, p. 85.

2 Nova. Acta. Leop. Carol., vol. xvii, p. 189.

3 Bull. Phys. Math. de l' Acad. Imp. des Sc., St. Petersb., vol. xvi, No. 67, p. 111, 6th June 1857.

${ }^{4}$ Abild. neucr Amph., pl, xxxi, 1837-44. 
tubular nostrils. Toes broadly webbed. Claws moderately strong. Tail not long, projecting in both, sexes beyond the fleshy carapace, but longest in the male. Carapace an elongated oval, with a vertebral ridge more or less prominent, with the carapace external to this marked on either side, with two to three raised wavy lines or rudimentary ridges, the line next the vertebral ridge being the longest, the others external to it more interrupted. A swelling over the hinder portion of the nuchal and inner portion of first costals. The nuchal flap of the cartilaginous carapace covered with transverse series of elongated eminences placed side by side; the broad hinder portion of the fleshy carapace covered with about thirteen longitudinal rows of little somewhat backwardly pointed fleshy knobs, one longitudinal series being continuous with the vertebral ridge and others with the finer wavy lines already described. These knob-like eminences are continued more or less over all the cartilaginous area and osseous carapace, in longitudinal parallel lines. The sculpturing of the carapace is somewhat coarse, and the raised reticulating lines tend to enclose circular depressions. The cartilaginous area of the plastron has the general characters in Trionyx. The callosities are well developed, but in the female figured, it will be observed that a considerable area was still open in the centre. The epiplastra are rather long and slender; they do not meet below on the entoplastron, which has moderately divergent rami, and is characterized by being somewhat feeble and does not show any trace of the growth of a sculptured surface. The other plates are broadly covered with the callous growths, and the sculpturing adheres to the same type as on the carapace, consisting of a rather coarse reticulation of raised lines enclosing spaces, the lines tending on the hyo- and hypoplastral pieces to follow the outline of the inner and outer margins of these plates, ${ }^{1}$ and the outlines of the xiphiplastron. The latter plates tend to meet in the mesial line anteriorly, but they are slightly divergent posteriorly.

In the young, the vertebral ridge on the carapace is well pronounced, and tends to become double and to have a finely nodose appearance. The lines or fine ridges also are more regular and parallel, and each consists chiefly of a longitudinal aggregation of little fleshy eminences which on the hinder portion of the cartilaginous carapace are larger and more apart and somewhat spinose on their hinder margins. The swelling of the nuchal and costals is present. In the young figured, the sculptured callosities of the plastron have not yet appeared.

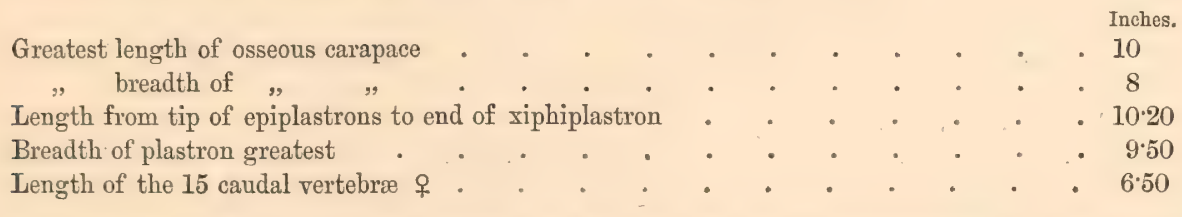

The upper surface of the head and neck yellow, reticulated on the head, with broad black interrupted lines not extending on to the under surface, nor passing below the upper half of the upper lip. The portion behind the occiput, and the upper surface of the neck black-spotted, in the adult more or less finely reticulated.

\footnotetext{
1 They are represented too concentric in the plate.
} 
The upper surface of the limbs and tail greenish-olive. The under surface of the head, neck, limbs, and tail white, suffused with bluish. In the young, there is a yellow spot behind the angle of the mouth, with a dark area behind it prolonged over the tympanum, and along the under surface of the throat, from side to side, with dark margins. A broad irregular yellow spot behind this, running up on to the surface of the head, behind the tympanum, and across the under surface of the neck. The rest of the under surface of the neck purplish, also the under surface of the plastron, as in young Asiatic Trionyces generally. ${ }^{1}$ The upper surface of the carapace is dark olive-grey, densely punctulated with small black spots, the two sides of the carapace anteriorly and posteriorly being occupied by a large obscure dark round area, densely punctulated in its centre with deep black. These black areas are the last traces of the brilliant dorsal ocelli of the young. Under surface of plastron pale fleshy yellowish, marked with the courses of numerous bloodvessels, and the callous areas pinkish.

In the young, the upper surface of the carapace is dark olive-grey, with two pairs of ocelli. The centre of each ocellus is a round black spot, with a pale reddish margin encircled by a broad dark area, nearly black. These ocelli are encircled again by a broad dark line, portion of a broad reticulation of the shell, with similar lines most crowded near the margin, where there is still a much finer black reticulation, as on the head. The margin of the young shell is yellow, and its under surface blackish, internal to the yellow margin, especially on the hinder half of the posterior surface, and over the bones more or less. The plastron itself being yellowish, suffused here and there with dusky. The upper surface of the limbs is dark olive, spotted with yellow.

In the young specimen figured, the yellow spots on the cheek have almost disappeared.

The skull (figs. 29-31, p. 790-91) has the facial portion moderately pointed in the adult, but in the young it is proportionally somewhat shorter. The alveolar ledge of each side is separated from the posterior nares to the premaxillary foramen by a moderately deep and broad groove. The pterygoid region is broad, concave from side to side, with the lateral margins somewhat convex. The posterior nares are moderately long, with a ridge running backwards and inwards from the palatine to the postpalatine foramen. The facial portion of the skull is directed considerably forwards and downwards, and the external nasal opening is quadrangular. The symphysis of the lower jaw is antero-posteriorly elongated, somewhat spatulate with a prominent longitudinal ridge.

I have obtained specimens of this species from Moulmein through the assistance of Colonel Sladen, and from Myanyoung and other parts of the Irawady through the invaluable aid accorded to the Indian Museum by Sir Ashley Eden, during the period he was Chief Commissioner of British Burma. I have also received it from Bhamô. The type of the species, as already stated, was from Tonghoo, on the Sittang, where it was obtained by Mr. Theobald.

' This is the stage apparently corresponding to T. formosus and probably to T. grayi. 


\section{SAURIA.}

Family-VARANID A

\section{Genus Hydrosaurus. Wagler.}

\section{Hydrosaurus salvator, Laur.}

Stellio salvator, Laur., Syn. Rept., p. 56, 1768.

Hydrosaurus salvator, Gray, Cat. Lizards, B. M., 1845, p. 13; Günther, Rept. Brit. Ind., 1864, p. 67 ; Theobald, Descr. Cat. Rept. Brit. Ind., 1876; p. 39 ; Ferguson, Rept. Fauna, Ceylon, 1877 ; p. 9.

This species is common throughout Burma, and I obtained one example at Bhamô.

Family-ZONURID AR.

\section{Genus Pseudopus, Merr. \\ Pseudopus gracilis, Gray.}

Psendopus gracilis, Gray, Cat. Lizards, p. 56, 1845 ; Günther, Rept. Brit. Ind., 1864, p. 75 ; Theobald, Journ. Linn. Soc., Lond., vol. x, 1868, p. 24; Cat. Rept. \& Mus. As. Soc., Bengal, Journ. As. Soc., Bengal, 1868, vol. xxxvii, p. 22 ; Jerdon, Proc. As. Soc., Bengal, 1870, p. 74; Anderson, Proc. Zool. Soc., Lond., 1871, p. 156 ; Theobald, Descr., Cat. Brit. Ind. 1876, p. 47. Dopasia gracilis, Gray, Ann. \& Mag. Nat. Hist., vol. xii, 1853, p. 389 ; Günther, Proc. Zool. Soc., Lond., 1860, p. 172, note.

Ophiseps tessellatus, Blyth, Journ. As. Soc., Bengal, vol. xxii, 1854, p. 655.

I obtained this species at Muangla in the Sanda valley. The specimens, like those from the Kashia Hills in the British Museum, have sixteen longitudinal rows of scales from fold to fold, whilst Blyth's Rangoon example of the species has only fourteen such rows, and eight on the ventral surface, while the specimens from Muangla and the Kashia Hills have ten rows of ventral scales. These specimens, and those in the British Museum, have palatine teeth, but Blyth states that the Rangoon lizard had none. Eight of the dorsal rows of the Muangla lizard are strongly and continuously keeled, but the others are smooth. There are from 110 to 115 transverse rows from the chin to the anus. The shields of the head, with the exception of the vertical, the three occipitals, and the row of supra-orbitals, are variable in number. Among eight specimens in the Indian Museum, Calcutta, no two are alike in respect of these shields, 
and the same remark applies to their colouring. In the Yunnan examples, the upper surface is light brown, darker on the head; the under aspect is pale yellow. The lateral fold begins one inch behind the gape, and its ventral margin has a dark edge, and, a scale's breadth below it, there is a faint dark lateral line, and, at the same distance above it, a dark broad, almost black line running from an inch behind the gape to the tip of the tail. There is a ventral series of black spots on the anterior two-thirds of the body. In some specimens these spots are bright blue; in others they extend across the back as transverse blue bands with dilated lateral portions, forming an interrupted band along the side.

Family-SCINCII) At.

Genus Tropidopнorus, D.\& B.

Tropidophorus Berdyorer, Blyth. Plate LXXVI, Fig. 3.

Aspris berdmorei, Blyth, Journ. As. Soc., Bengal, vol. xxii, 1853, p. 650 ; Günther, Rept. B. Ind., 1864, p. 77.

Tropidophorus berdmorei, Theobald, Cat. Rept. As. Soc. Mus. Journ. As. Soc., Bengal, Ex. No., vol. xxxvii, 1868, p. 23 ; Journ. Linn. Soc., vol. x, 1868, p. 24; Descr., Cat. Rept. Brit. Ind., 1876, p. 48.

I obtained specimens of this species in the Hotha valley, Yunnan.

Lower eyelid scaly. No supranasals. The prefrontal forms a suture with the rostral, and meets in a point with the vertical and postfrontal. The vertical has narrow hinder margins and is transversely truncated. A pair of small anterior and of large posterior occipitals separated by a narrow wedge-like azygos shield. Four superciliaries. Two loreals and one prefrontal. Six upper labials. A pair of large anal scales. Sub-caudals large. Thirty-four rows of scales round the body. Forty-five transverse rows between the axilla and groin. The fore limbs feeble, reaching only to the angle of the mouth. The hind leg, when laid forwards, stretches half-way between the groin and axilla. Total length $6{ }^{\prime \prime} \cdot 75$; tail $3 \cdot 50$.

Upper surface dark brown, with light brown margins. Back and tail with a series of large yellowish-brown transverse blotches, with black margins. They extend on to the sides of the back, and each has two or three white spots at its lateral margins. They become very indistinct on the tail. Side of the body and tail with small white spots. Under surface yellowish; chin, neck and under surface of tail marbled with brown.

The remarkable circumstance connected with these Yunnan specimens of this species is that the scales are quite smooth, whereas in the types from Mergui described by Blyth, and also in other specimens in the British Museum presented by Mr. Theobald from Pegu, the scales of the back are strongly keeled. My specimens are adult, and with this enigmatical exception of the entire absence of keeling, agree in every other particular with Blyth's types, with which I have compared them. The identity is so perfect that no course is left but to regard these keeled 
and non-keeled lizards as belonging to one and the same species. There is this also to be kept in view, that in specimens in the British Museum, two of which are half-grown, while the other is an adult female, the keeling in the former is much more distinct than in the latter.

Tropidophorus microlepis, Günther, is nearly allied to T. cochinchinensis. It has the posterior frontals forming a wide suture together. In T. microlepis there is a distinct tendency to the formation of keels in the ventral scales, more especially visible in those of the under surface of the neck, near the chest. The posterior nares are situated further back than in T. berdmorei, and occupy about the same position as in $T$. grayi. In $T$. cochinchinensis the posterior nares occupy about the same position as in $T$. berdmorei, and the scales on the under surface, except on the throat, are smooth. On the latter locality they are somewhat keeled. The under surface of T. grayi is keeled.

The coloration of $T$. cochinchinensis, T. microlepis, and T. berdmorei is much the same in all.

Theobald's specimens were captured among wet gravel in the stony beds of streams. I found it among rubble on the banks of the Namsa, in the Hotha valley, at an elevation of 4,500 feet.

The types were obtained in Mergui, and Theobald observed it on the Pegu range, forty miles from Rangoon. The other species T. cochinchinensis and T. microlepis are from Cochin China and Siam respectively, and T. grayi inhabits the Philippines.

\section{Genus MocoA, Gray.}

\section{MOCOA EXIGUA, n. s.}

The small lizard which I describe under this name was obtained at Momien.

The eye has à transparent disc. No supranasal. Ear without denticles or lobules. The prefrontal single, in contact with the rostral, and broadly so with the vertical. Four superciliary shields. A pair of anterior occipitals; the azygos shield separating them from the posterior occipitals rather large. The posterior occipitals broad and large. A pair of very large anals with a small shield on either side of them. Twenty-eight rows of scales round body. Forty-five rows between the axilla and groin. Limbs feeble, the fore legs reach to the eye, the hind legs to half-way between the axilla and groin. A dark brown band from the snout along the back to the tail, on which it disappears near the root. A pale greenishyellow band from above the posterior angle of the eye, along the side of the back to the base of the tail, in the colour of which it is lost. A broad brown band from the side of the snout through the eye and ear and above the fore limbs along the side, disappearing, a short way beyond the hind limbs. The under surface pale yellowish-brown. Tail uniform olive, with a dorsal and lateral series of minute black dots, corresponding to the dark body-bands. Limbs spotted brown and olive. 
Family,-GECKOTIDAR.

Genus GEcKo, Gray.

Gecko guttatus, Daudin.

Lacerta gecko, Linn., Mus. Adolph. Frid., vol. i, 1754, p. 46 ; Syst. Nat., xii ed., vol.i, 1766, p. 365 ;

Gmelin, Linn. Syst. Nat., ed. xiii, 1788, p. 1068 ; Shaw, Genl. Zool., vol. iii, 1802, p. 264, pl. lxxvii.

Gekko teres, Laur., Synops. Rept., 1768, p. 44.

Gekko verticellatus, Laur., Synops. Rept., 1768, p. 44.

Gecko guttatus, Daudin, Hist. Nat. Rept., vol. iv, 1802, p. 122, pl. xlix ; Gray, Griffith’s An. Kingd., vol. ix, 1831, p. 48 ; Günther, Rept. Brit. Ind., 1864, p. 102 ; Theobald, Journ. Linn. Soc., vol. x, 1868, p. 28 ; Descr. Cat. Rept., Brit. Ind., 1876, p. 71, Stoliczka, Journ. As. Soc., Bengal, vol. xli, 1872. p. 92.

Lacerta guttatus, Hermann, Obs. Zool. (Opus. Posth.), 1804, p. 256.

Gekko verus, Merrem, Tent. Syst. Amph., 1820, p. 42; Gray, Zool. Journ., vol. iii, 1827, p. 223.

Gecko annulatus, Kuhl., Beitr. Zool., 1820, p. 132.

Gecko revesii, Gray, Griffith's An. Kingd., vol. ix, 1831, p. 48 ; Cat. Lizards, B.M., 1845, p. 161.

Platydactylus guttatus, Dum. \& Bibr., Erpét. Génl., vol. iii, 1836, p. 328, pl. xxviii, fig. 4; Guérin,

Iconogr. Reg. An., 1834, pl. xiii, Dumẻril, Cat. Méthod. Rept., 1851, p. 36.

Platydactylus revesii, Duméril, Cat. Méthod. des Rept., 1851, p. 37.

Gekkeo indicus, Gerard, U. S. Explor. Exped. Herpet., 1858, p. 290, pl. xvi, figs. 9, 16.

Specimens of this species are not unfrequent with as few as eighteen preanal pores; but in the examples which I obtained in Upper Burma, there are twentytwo in a slightly angular series. The young have occasionally pale yellow transverse bands on the back, and the tail is broadly banded dark brown and white.

The eggs of this species are strongly compressed ovals, with a long diameter of 0.83 inches and are joined together in a mass of sixteen to twenty eggs.

This is an essentially Malayan form, occurring throughout Burma and the Andamans, and spreading westwards to the neighbourhood of Calcutta and into Assam.

\section{Genus Hemidactruds, Cuvier.}

SubrGenus Peripia, Gray.

Hemidactylus (Peripia) meyeri, Bleeker.

Platydactylus lugubris, Cantor, Journ. As. Soc. Bengal, vol. xvi, 1847, p. 622. Hemidactylus meyeri, Bleeker, Nat. Tijdschr. Ned. Ind., vol. xvi, 1859, p. 47.

Peripia cantoris, Günther, Rept. Brit. Ind., 1864, p. 110 ; Theobald, Journ. As. Soc., Bengal, ex. No. 1868, p. 30 ; Descr. Cat. Rept. Brit. Ind., 1876, p. 80, Stoliczka, Journ. As. Soc., Bengal, vol. xxxix, 1870, p. 163; id. op. cit., vol. xli, 1872, p. 103, Ferguson, Rept. Faun. Ceylon, p. $12,1877$.

Gecko harrieti, Tytler, Journ. As. Soc., Bengal, vol. xxxiii, 1864, p. 548.

Peripia meyeri, Günther, Proc. Zool. Soc., 1872, p. 594.

I have compared this specimen with the type of $P$. cantoris, Günther, from Penang, with which it agrees, except in that it has twenty-four femoral pores, 
continued across the preanal region as in H. (Peripia) mutilatus. The tail is imperfect, but what remains of it has no enlarged sub-caudals.

I obtained only one example of this rare Gecko at Ponsee, at an elevation of 3,300 feet on the Kakhyen Hills.

\section{Hemidactylus (Peripta) mutmatus, Weigm.}

Heimidactylus (Peropus) mutilatus, Weigm., Nov. Act. Leop., vol. xvii, 1835, p. 238 ; Fitzinger, Syst. Rept., 184:3, p. 103.

Peropus mutilatus, Gray, Cat. Lizards, B.M., 1845, p. 159 ; Gerard, United States Explor. Herpet., 1858, p. 277 ; Cope, Proc. Acad. Nat. Sc., Philad., 1868, p. 319 ; Günther, Proc. Zool. Soc., 1873, p. 168.

Hemidactylus mutilatus, Dum. \& Bibr., Erpét. Génl., vol. iii, 1836, p. 354; Dum., Cat. Méthod. des Rept., 1851, p. 38.

Hemidactylus peronii, Dum. \& Bibr., Erpét. Génl., vol. iii, 1836, p. 352, pl. xxx, fig. 1; Cantor, Journ. As. Soc., Bengal, vol. xvi, 1847, p. 628.

Peripia peronii, Gray, Cat. Lizards, B.M., 1845, p. 158 ; Kelaart, Prod. Fauna Zeylan. 1852,p. 187 ; Günther, Rept. Brit. Ind., 1864; $i d$. Ann. and Mag. Nat. Hist., vol. x, p. 422 ; 1872 ; id. "Brenchley's Cruise of Curacoa," 1872, p. 407; p. 110; Peters, Berlin Monatsber. 1867, p. 14; Theobald, Journ. Linn. Soc., 1868, vol. x, p. 29 ; Descr. Cat. Rept. Brit. Ind. 1876, p. 79 ; Stoliczka, Journ. As. Soc., Bengal, vol. xxxix, 1870, p. 140, p. 163; id. op. cit., 1872, vol. xli, p. 103 ; Ferguson, Rept. Fauna, Ceylon, p. 12, 1877.

Gecko pardus, Tytler, Journ. As. Soc., Bengal, 1864, vol. xxxiii, p. 547.

Peripia mutilata, Stoliczka, Journ. As. Soc., Bengal, vol. xlii, 1873, p. 113.

Peropus packardii, Cope, Proc. Acad. Nat. Sc., Philad., 1868, p. 319.

This is a common Tree-Gecko at Bhamô, where in the months of February and March I found it on trees; but it occurs also in the houses which are all built of bamboo and teak.

Young specimens are brown, marked with small blackish-brown spots, and with smaller interspersed whitish spots. The adults are pale olive greyish-brown, with hardly any trace of spots, but all the scales of the upper surface, as in the young, are minutely punctulated with brownish. The colour of this lizard tends to conform to the surface on which it lives, while at the same time the young are more deeply coloured than the adult. I have compared these specimens with examples of the species in the British Museum, both from the Isle of France and Ceylon, with which they structurally agree. They have all the enlarged chin shields, and the preanal pores vary from thirty-six to thirty-eight in these individuals, but Theobald has observed as many as forty-two in Rangoon specimens.

The edge of the tail is minutely serrated in all, depressed and rather flattened on the under surface, with a mesial line of enlarged sub-caudals raised above the level of the small imbricate scales external to it, and which are arranged in oblique rows numbering about six scales to each row, on either side, at the base of the tail. The numbers of these scales diminish from before backwards, so that at the middle of the tail, and throughout the rest of its extent, they become reduced to two or three in each row, the under surface of the tail being thus, in its distal half, wholly occupied by the enlarged sub-caudals. In its latter half, the tail tapers rather rapidly to a 
fine point which tends to curl. Günther ${ }^{1}$ records that in a Penang specimen in which the tail had been reproduced, this member terminated in a dilated flap, and Stoliczka ${ }^{2}$ mentions an apparently similar case.

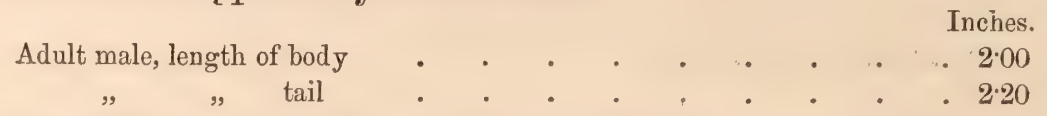

These specimens fully verify Stoliczka's observation that the ungual phalanx of the thumb is distinctly present in a rudimentary form, and that the ungual phalanx of the inner toe, so far from being absent, is provided with a very minute claw, even in the adults. Stoliczka, however, was unable to detect its presence in some old specimens. The existence of the ungual phalanges in both of these toes removes any necessity for separating this lizard generically from Hemidactylus, as the mere absence of a claw on the thumb, considering the rudimentary nature of this structure in some Hemidactyli, cannot well be regarded as of structural importance. The circumstance, however, that the other species $H$. meyeri is also devoid of a claw on the thumb, would seem to indicate that these two forms may with advantage be grouped under the sub-generic term Peripia, more especially as they are also distinguished by a fold of skin along the back of the thigh, and between the thigh and lower leg. ${ }^{3}$ The genus Spathodactylus ${ }^{4}$ has still more rudimentary thumbs and first toes, and the plates are less developed than in Hemidactylus and its sub-division Peripia, but the characters, which separate Spathodactylus from Peripia do not appear to be more than sub-generic. The toes of $H$. $(P$.$) mutilatus are distinctly webbed at the base,$ and Cope remarks that $P$. packardii agrees with Günther's description of $P$. peronii, except that the former has all the toes strongly palmate at the base. P.packardii, was obtained at Penang, and is apparently identical with this species.

\section{Hemidactiylus maculatus, D. \& Bibr.}

Hemidactylus maculatus, D. \& Bibr., Erpét. Génl., vol. iii, 1836, p. 368 (pars.); Gray, Cat. Lizards, B. M. (pars.), p. 153, 1845 ; Duméril, Cat. Méthod. Rept., 1852, p. 39 (pars.) ; Kelaart, Fauna Zeylanica, (nec., H. Syzesii), 1852, vol. i, p. 158; Jerdon, Journ. As. Soc., Bengal. vol. xxii, 1853, p. 467 ; Günther, Rept., Brit. India, 1864, p. 107 (pars.) ; Theobald, Journ. Linn. Soc., 1868, vol. x, p. 32 ; Stoliczka, Journ. As. Soc., Bengal, vol. xxxix, 1870, p. 164; id. op. cit, vol. xli, 1872, p. 94; Blanford, op. cit., vol. xxxix, 1870, p. 361 ; Zool. Persia, 1876, p. $3 \pm 2$; Peters, Von Der Decken's Reisen, vol. iii, pt. 1, 1869, p. 14; Anderson, Proc.

Zool. Soc., 1871, p. 160 ; Ferguson, Rept., Fauna, Ceylon, p. 11. 1877. Nubitia argentii, Gray, Cat. Lizards, B. M., 1845, p. 273.

Gecko tytleri, Tytler, Journ. As. Soc., Bengal, vol. xxxiii, 1864, p. 547.

Hemidactylus fasciatus, Theobald, Journ. As. Soc., Bengal, vol. xxxvii, 1868, p. 30.

The two Geckos which I refer to this species were obtained at Tsagain in Upper Burma. The sides and upper surface of the body, nape, sides of neck, upper surface

${ }^{1}$ 1. c.

1. c., p. 163.

${ }^{3}$ Stoliczka, observing that some of the posterior plates on the toes are only angularly bent and not divided, even went so far as to hold that the species included under Peripia should, strictly speaking, form only a section of the genus Gecko.

${ }^{4}$ Giinther, Proc. Zool. Soc., 1872, p. 594. 
of limbs and tail are covered with numerous enlarged tubercles, none of which are as large as the ear. On the back, they are considerably smaller than on the sides and are trihedral in form, while in the latter region they are rounded. They are very small on the nape, and gradually cease between the eyes posteriorly. On the trunk, they form about eighteen irregular longitudinal rows. On the upper surface of the limbs, they are large and somewhat conical. On the tail, they are spinose, and considerably larger than on the back, and are arranged in transverse rows of six to seven in number, the most external assuming the form of spines and being the largest. They are not distributed throughout the length of the tail, but are confined to its proximal two-thirds, and form about 13 rows, the remainder of the tail being covered with flattened moderately sized, but non-imbricate scales. The remainder of the body-skin is very finely granular. The preanal scales are somewhat enlarged, and the mesial line of the proximal two-thirds of the under surface of the tail is occupied by a series of large plates, with two to three rows of moderately sized imbricate scales external to them. There are eleven longitudinal rows of small scales between the vent and the commencement of these sub-caudal plates which invest the whole of the under surface of the latter third of the tail. The thumb and inner toe are well developed. Two pairs of enlarged plates behind the mental. The throat seales are very small, and almost granular in appearance, but imbricate. Eleven to twelve upper, and eight to nine lower labials. The femoral pores in these two males are only seven on either limb, and in both they do not meet in the middle line, but are separated by an interval of six moderately sized scales, larger than those of the middle of the belly. Beyond these there are no other enlarged preanals.

From the foregoing description it is apparent that the only respect in which these lizards differ from the generality of the examples of this species is in the comparatively small number of the femoral pores.

In the reproduced tail the sub-caudal plates are broader than in the normal member, and the spinous tubercles of the upper surface and sides of the tail are not reproduced.

\begin{tabular}{|c|}
\hline ength of body (male) \\
\hline
\end{tabular}

The coloration of these specimens is uniform olive greyish-brown above, with obscure indications of moderately sized dark spots. There is a dark band through the eye to the ear. Under surface pale yellowish.

\section{Hemidac'trlus frenatus, Schlegel.}

Hemidactylus frenatus, Schlegel, D. \& Bib., Erpét. Génl., vol. iii, 1836, p. 366 ; Cat. Méthod., Reptiles, 1851, p. 39 ; Kelaart, Prod. Faunæ Zeylan., vol. i, 1852, p. 161 ; Cantor, Journ. As. Soc., vol. xvi, 1847, p. 630 ; Günther, Rept. Brit. Ind., 1864, p. 108 ; Peters, Von der Decken's Reisen in Ost-Afrika, vol. iii, Erste Abth. p. 14, 1869; Stoliczka, Journ. As. Soc., vol. xxxix, 1870, p. 164; id., op. cit., vol. xli, 1872, p. 96 ; Theobald, Journ. Linn. Soc., vol. x, 1868, p. 31 ; Descr. Cat. Rept. Brit. Ind., 1876, p. 78.

Gecko chaus, Tytler, Journ. As. Soc., Bengal, vol. xxxiii, 1864, p. 547. 
Gecko caracal, Tytler, $l$. c., p. $54 \%$.

Hemidactylus sublavis, Theobald, Journ. As. Soc., Bengal, vol. xxxvii, ex. No., p. 80.

? Hemidactylus punctatus, Jerdon, Journ. As. Soc., Bengal, vol. xxii, 1853, p. 467.

Three females and two males, all from Bhamô, have the sacral region, sides, and upper surface of the tail with a few scattered flattened enlarged tubercles, more numerous in the two first regions in some specimens, than in others. The upper surface of the tail is marked by a number of verticils, each of which bears about six of these tubercles, the most external of which is somewhat spinose. In the reproduced tail, this verticillate arrangement more or less disappears, and it is smooth laterally and superiorly. The under surface is clad with enlarged plates, and the tail is somewhat depressed and tapers to a very fine point. All the upper parts are finely granular. Forty to forty-three longitudinal rows of scales on the belly. The femoral pores number 32, interrupted in the mesial line by a small scale in one specimen, but continuous in the other male. A mesial patch of enlarged preanal scales. The thumb and inner toe small, especially the latter, on which the small claw is distinctly present in all the specimens. The upper labials vary from 11 to 12 , and the lower, from 8 to 9 . The two pairs of enlarged shields behind the mental are very persistent. The coloration is variable, as some are uniformly coloured olive-grey above, and in these there is no band through the eye; whilst others are much darker and marbled with blackish, and in these the band through the eye is present.

The intestine of the species is provided with a distinct cacal enlargement, at the commencement of the large intestine, which is less than one-third the length of the small intestine which equals the distance between the snout and vent. The stomach of one male was filled with the elytra of a small beetle.

This species I found only on trees, and usually huddled together in little groups of three or four of different ages in crevices of the bark.

The distribution of this species is very extensive, as it has been recorded from Ceylon, Bengal, Assam, Burma, the Andamans and Nicobars, the Malayan Peninsula and Archipelago, Siam and Cochin China; and Peters records it from the Seychelles.

AGAMID A.

Genus Dra co, Linn.

Draco maculatus, Gray.

Dracunculus maculatus, Gray, Cat. Lizards, B. M., 1845, p. 236.

Draco maculatus, Cantor, Journ. As. Soc., Bengal, 1847, vol, xvi, p. 645 ; Günther, Rept., Brit. Ind., 1864, p. 125, pl. xiii, c.; Theobald, Journ. As. Soc., Bengal, 1868, vol. xxxyii, Suppl. No. p. 34; Journ. Linn. Soc., vol. x, 1868, p. 33 ; Deser. Cat. Rept. Brit. Ind., 1876, p. 97.

- Two examples of this species were caught at Ponsee, one of them in an insect net, while in the act of springing from tree to tree, across a thickly wooded hill tract.

The specimens which I have examined from Pegu are smaller than Assam and Yunnan individuals, but I do not observe that they differ in any other respect from the types with which I have compared the latter. 
This flying lizard has a hidden tympanum, and is thus referable to Dracunculus, Weigmann, but such a slight modification of the peripheral characters is not sufficient to constitute a sub-genus.

This species has also been found in Assam, Pegu, and Siam, and through Tenasserim to Penang.

Genus J A PALura, Gray.

Japalura yunnanensis, n. s. Plate LXXVI, fig.. 2.

A rather large, conically spinose tubercle behind the superciliary ridge, with a more or less developed ridge passing obliquely backwards on the occiput to the origin of the nuchal crest. A prominent ridge of three to four large conical tubercles behind the eye and over the hidden tympanum. Scales rather small, keeled and imbricate, with a number of large scales scattered singly and in groups over the side and back; the tips of all directed obliquely backwards and upwards. Scales of the under surface keeled, those of the throat small. Scales of under surface of toes keeled. Those of the tail keeled; the sub-caudals the laigest. Nuchal crest feebly developed, consisting of triangular lobes; it is prolonged along the back as an obscurely serrated ridge, disappearing on the base of the tail. A fold across the neck. In females (males not known) a longitudinal ridge of skin in the position of the gular sack. About 45 scales in a longitudinal row from limb to limb. Dentition in two females (1) $\frac{1}{10}+\frac{14}{10}=\frac{2}{2} \frac{8}{0}$ and (2) $\frac{1}{1} \frac{4}{5}+\frac{14}{15}=\frac{2}{3} \frac{8}{0}$. The first female is old and has lost some of the teeth of the lower jaw. Two eanines in each jaw. Hind leg extends in one specimen to near the eye, in another it does not reach the mouth. General colour olive, with a tinge of brown. A well marked black band with a yellow anterior margin from the posterior margin of eye to the angle of mouth. Five black transverse bands, somewhat irregular on the back, narrow and distinct on the neck, but broad on the body, and separated from each other by narrow olive-yellow bands. The large scales are chiefly distributed on these light-coloured bands. Tail faintly banded brown and olive. Under surface uniform olive yellow.

The two specimens which have served for the foregoing description are both females from the neighbourhood of (Momien) Teng-yue-chow. They measured about the same size: total length $10^{\prime \prime}$; tail 7 inches.

Measurements of the different species of Japalura.

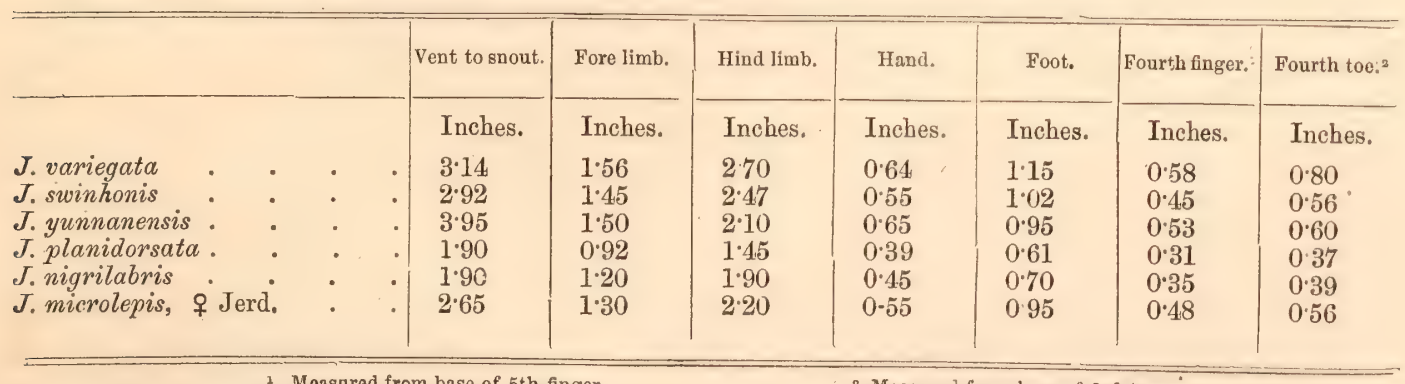

1 Measured from base of 5 th finger.

2 Measured from base of $3 \mathrm{rd}$ toe. 
J. yunnanensis differs from J. variegata in the larger size of its scales generally, a character which is especially discernible in the scales on "the throat. It is also distinguished from that species by its proportionally shorter toes, and from $J$. swinhonis by its much shorter legs (see table), to which, however, it approaches in the large character of its scales. In $J$. variegata the sublingual scales are nearly smooth, while in this species they are strongly keeled.

The small $J$.planidorsata is distinguished by the numerous enlarged spiny scales on the side of the head, and by the presence of from six to seven V-shaped enlarged spiny scales, crossing the back from the upper portion of the side and connected together at their free ends by a more or less interrupted longitudinal line of enlarged scales. The first transverse line occurs on the nape, but the last is reduced to a large spiny scale. The scales of the dorsal transverse bands are in a single row. The scales on the middle of the body are smaller than those on the dorsal surface and not so spiny. The planidorsate character is due to the transverse and longitudinal lines of enlarged scales. I was at first ${ }^{1}$ inclined to regard $J$. planidorsata as the young of $J$. variegata, but the foregoing description of its characters, which is drawn up from the type, conclusively proves that the two species are distinct, and that the late Dr. Stoliczka, ${ }^{2}$ was correct in questioning the accuracy of my first determination.

J. nigrilabris, Peters, from Borneo is a nearly allied species to J. planidorsata, but devoid of the transverse bands of enlarged scales, but with the same form of crest and the same hirsute appearance.

Since I expressed the opinion some years ago that the $J$. microlepis of Jerdon was probably the female of $J$. variegata, Gray, I have examined not only the type in the British Museum, but have myself procured the species alive in the Botanical Gardens, Calcutta, where it may have been introduced from Darjeeling or elsewhere, either in the egg, or alive in the cases of orchids and other plants that are yearly received at these Gardens. The Calcutta specimen I have compared with the type of T. microlepis, with which it perfectly agrees.

I was for some time under the impression that this lizard from Calcutta might prove to be the Otocryptis (Ptyctolamus) gularis, Peters ${ }^{3}$, which was purchased as coming from Calcutta. I therefore forwarded the Calcutta specimen to Professor Peters, who kindly compared it with $O$. gularis, and pronounced it distinct, remarking that $O$. gularis has no gular fold, but on each side three arched furrows just before that place where $J$. microlepis has the gular fold, and that the latter is nearly related to J. nigrilabris, Peters, from Borneo, yet distinct.

1 Proc. As. Soc., Bengal, 1870, p. 76.

2 Journ. As. Soc., Bengal, vol. xli, pt. 2, 1872, p. 106.

${ }^{3}$ Monatsher Acad. Wiss. Berl. 1864, p. 386. 


\section{Genus Calotes, Cuvier.}

Calotes versicolor, Daudin.

Agama versicolor, Daudin, Hist. Rept., vol. iii, 1810, p. 395, pl. xliv; Kuhl., Beitr. Zool., 1820, p. 114; Merrem, Syst. Amph., 1820, p. 51.

Agama vultuosa, Harlan, Journ. Acad. Nat. Se., Philad., vol. iv, 1825, p. 296, pl. xix.

Agama indica, Gray, Zool. Journ., vol. iii, 1828, p. 217.

Calotes tiedemanni, Gray, Rept. Griffith's An. Kingd., vol. ix, 1831, p. 55.

Calotes versicolor, Dum. \& Bibr., Erpét. Génl., vol. iv, 1837, p. 4.05 ; Gray, Cat. Lizards, B. M., 1845, p. 243 ; Kelaart, Prod. Fauna Zeylan., 1852, p. 170 ; Blyth, Journ. As. Soc., Bengal, vol. xxii, 1852, p. 170 ; Jerdon, l. c., p. 470 ; Günther, Rept. Brit. Ind., 1864, p. 140 ; Steind., Reise der Frig. Novara, Rept., 1867, p. 27 ; Theobald, Journ. As. Soc., Bengal, 1868, vol. xxxvii, p. 35 ; Journ. Lin. Soc., vol. x, 1868, p. 33 ; id., Deser., Cat. Rept. Brit. Ind., 1876, p. 109 ; Anderson, Proc. Zool. Soc., 1872, p. 381 ; W. T. Blanford, Zool., Persia, 1876, p. 313.

Calotes cristatus, Jacquemont, Voy. dans l'Inde, Atlas, Rept. pl. ii, 1844.

Calotes viridis, Gray, Ann. and Mag. Nat. Hist., 1846, vol. xviii, p. 429.

This common tree-lizard is prevalent at Mandalay and Bhamô, but I did not observe it in the hills to the east of the latter locality, where its place appears to be taken by C. emma, but at Mandalay it is associated with C. mystaceus. One specimen from the last-mentioned locality had a bright yellow broad band from the snout passing backwards to the shoulder, involving the cheeks, lower lips, one-half of the eye and the tympanum; and behind and in a line with it a series of bright, rusty-red spots at regular intervals, the scales of the intervening spaces being whitish. In another, the pale lateral band was carried along the sides, contracting at regular intervals to a mere line, with the rusty spots in the centres of the dilatations. In these respects the colouration approaches to C. maria and C. jerdoni, but it is not peculiar to Burmese individuals, because I have observed it, but in a more modified degree, in Indian examples of the species.

This species appears to be generally distributed over Burma, for it has now been observed at Bhamô, Mandalay, Pegu, and also in Tenasserim; it has likewise been recorded from China. Its western range is not so well ascertained, but Blanford records it from Bilúchistán. It appears to be generally spread over the greater part of India from the Himalaya to Ceylon, and it is found in these mountains up to elevations of 10,000 feet.

\section{Calotes mystaceus, Dum. \& Bib.}

Calotes mystaceus, Dum. \& Bib., Erpét. Génl., vol. iv, 1837, p. 408; Gray, Cat. Lizards, B. M., 1845, p. 245 ; Duméril, Cat. Méthod. Rept., 1851, p. 87 ; Blyth, Journ. As. Soc., Bengal, 1852, vol. xxi, p. 754; id., op. cit., 1853, vol. xxii, p. 647; Günther, Rept. Brit. Ind., 1864, p. 141 ; Steindachner, Reise Frig. Novara, Rept., 1867, p. 28 ; Theobald, Journ. Linn. Soc., vol. x, 1868, p. 33 ; id., Journ. As. Soc., Bengal, vol. xxxvii, 1868, ex. No. p. 36, (pars); id., Descr., Cat. Rept., Brit. Ind., ]876, p. 106 ; Stoliczka, op. cit., vol. xxxix, 1870, p. 138 ; Anderson, op. cit., vol. xl, 1871, p. 32. 
This is a common species in the neighbourhood of Mandalay. It appears to be an essentially Malayan form, spreading from Siam westwards to the Garo Hills and occurring also in the Nicobars. Its existence in Ceylon is doubtful : but Kelaart forwarded what he believed to be a specimen to the Indian Museum, Calcutta. I have, however, not been able to identify it. Ferguson includes this species in his recent work, "The Reptile Fauna of Ceylon," but mentions that he has never been able to procure a specimen.

\section{Calotes maria, Gray.}

Calotes maria, Gray, Cat. Lizards, B. M., 1845, p. 243 ; Günther, Rept. Brit. Ind., 1864, p. 144; id., Proc. Zool. Soc., 1870, p. 778, pl. xlv, fig. B. ; Jerdon, Proc. As. Soc., Bengal, 1870, p. 77; Theobald, Deser., Cat. Rept. Brit. Ind., 1876, p. 108.

Calotes platyceps, Blyth, Journ. As. Soc., Bengal, vol. xxi, 1852, p. 354; id., op. cit., vol. xxii, 1853, p. 650 ; Blyth, Kelaart, Prod. Faunæ Zeylan., 1852, app. p. 43 ; Günther, Rept. Brit. Ind., 1843, p. 143, nota.

These specimens conform to the types of the species with which they have been compared.

The occurrence of this lizard, in the district of Teng-yue-chow (Momien) which is remarkably deficient in trees, would seem to indicate that the species is not so arboreal as its allies $C$. versicolor and $C$. emma.

\section{Calotes emma, Gray.}

Calotes emma, Gray, Cat. Liz., 1845, p. 244; Blyth, Journ. As. Soc., Bengal, vol. xxii, 1853, p. 413, App. p. 647; Günth., Rept. B. Ind., 1864, p. 144; Theobald, Journ. As. Soc., Bengal, 1868, vol. xxxvii, extra No., p. 36 ; Journ. Linn. Soc., vol. x, 1868, p. 33 ; Descr., Cat. Rept. Brit. Ind., 1876, p. 108 ; Jerdon, Proc. As. Soc., Bengal, 1870, p. 77.

In the specimens of this species, which were obtained by me, the spines on the head are not so strongly developed as in the type, but all the other characters are well marked.

Length of body 4.75 , length of tail $10 \cdot 25$.

This species has been recorded from the Khasia Hills, Assam, Pegu, Mergui, and Tenasserim, and the subjects of this notice were caught at an elevation of 3,000 feet, on the Kakhyen Hills.

\section{OrIOCALOTES, Günther.}

Oriocalotes Kakhienensis, n. s. Plate LXXVI, fig. 1.

This essentially arboreal lizard was captured at Ponsee.

The head is covered with obtusely keeled scales of different sizes, a few large scales occurring near the front of the snout, and on the superciliary ridges and occiput. No spines on the head as in O. minor. An obscure rounded ridge runs 
from the eye to the tympanum. The canthus rostralis and superciliary ridge are not well defined. Scales of the body of moderate size, imbricate, keeled; those on the side of the back directed upwards and backwards, and those below downwards and backwards. A few large keeled scales scattered over the sides. A fold of almost granular scales over the shoulder. Scales of the neck keeled. About seven longitudinal rows of large smooth scales at the angle of the lower jaw, diminishing in number as they approach the chin. Scales on the tail nearly as broad as long. Base of tail compressed, but thick and somewhat rounded. Scales of chest and belly of moderate size and strongly keeled. Fifty transverse rows from limb to limb, and from sixty to sixty-four irregular rows round the body. The fore leg extends to the tip of the snout, the hind one to the angle of the jaw. A slight fold above and in front of the shoulder. General colour, olive on the upper surface of the body, irregularly variegated with brown and yellow, these colours having a tendency to arrange themselves in cross bands. The lighter spots mark the enlarged scales. The scales of the head are irregularly coloured brown and yellow. The slightly enlarged base of the tail is yellow; the rest, uniform olive-green. Under surface olive-green. A broad black band from the posterior margin of the eye to the tympanum; two narrow black bands below the eye; also one in front and three above. The sutures of the labials are black. The nuchal crest is composed of six to eight triangular spines, disappearing a short way behind the shoulder. The third and fourth toes are of nearly equal length.

$O$. minor which is the species most closely allied to $O$. discolor, has a prominent spine on the posterior end of the superciliary eminence and another above the ear, and still another behind these two. It is a short-bodied stout lizard with a short head and prominent eyes. Its dorsal crest is low, and consists of enlarged spinous scales. The enlarged scales on the side are variable in number, but the ordinary scales which clothe the sides and back have the arrangement and general character of the scales of Calotes, whereas in Oriotiaris the scales generally have the character which they present in Japalura, from which it differs in its naked tympanum.

$O$. discolor is a very much larger lizard than 0 . minor, from which it is distinguished by the entire absence of spines behind the eye and even the ear, and by its much less strongly keeled scales.

The only character in which this species differs from the definition of the genus Oriocalotes, as drawn up by Günther from the characters of one species, is the absence of the superciliary spine. The latter structure, however, is so little developed in $O$. minor, that its absence in another lizard, presenting all the other essential characters of the genus, is in no way remarkable. It may be, however, that further research will tend to unite Oriocalotes to Calotes, and Oriotiaris to Japalura.

O. minor has hitherto been found only in the Khasia Hills, and this species would appear to represent it in the high region on the opposite side of the Irawady valley. 


\section{OPHIDIA.}

\section{TORTRICID $\approx$.}

\section{Genus Cyimdrophis, Wagler. \\ Crlindrophis Rufus, Laur.}

Russell, Ind. Serp., 1801, vol. ii, p. 32, pl. xxvii, \& pl. xxviii.

Anguis rufa, Laurenti, Synops. Rept., 1768, p. 71 ; Shaw. Gen. Zool. vol. iii, 1802, p. 586.

Anguis rufus, Gmel., Syst. Nat., 1788, vol. iii, p. 1123; Schneid., Hist. Amph., 1801, vol. ii, p. 333. Eiry rufa, Daud. Hist. Rept. 1803, vol. vii, p. 263.

Tortrix rufa, Merr., Tent. Syst. Amph. 1820, p. 84; Schinz, Nat. Abbild. Rept., 1834-35, p. 131, pl. 48, fig. 2 ; Schleg., Phys. Serp., 1837, vol. i, p. 128, vol. ii, p. 2, pl. i, figs. 1 to 3.

I'ortrix rufus, Gray, Griff., An. Kingd., 1831, vol. ix. p. 74.

Ilysia rufa, Licht. Verz. Doublett. Mus. Berl., 1823, p. 104.

Ilysia rufa, Fitz. Neue Class. Rept., 1826, p. 54.

Cylindrophis resplendens, Wagler, Syst. Amph., 1830, p. 195 ; id. Icon. Descr., 1833, pl. v, fig. 1.

Cylindrophis rufa, Gray, Zool. Misc., 1842, p. 46; Cat. Snakes, B. M., 1849, p. 111; Dum. \& Bibr., Erpét. Générale, vol. vi, 1844, p. 595 ; Cantor, Journ. As. Soc., Bengal, vol.xvi, 1847, p. 900 ; MM. Duméril, Cat. Méthod. des Rept., 1851, p. 222 ; Günth., Rept. Brit. India, 1864, p. 179 ; Jan. \& Sord. Icon. Gén. Oph., No. ix, 1865, pl. iv, figs. 1 and 2, var. melanota. Cylindrophis rufus, Steind. Reise Novara, Rept. 1867, p. 56 ; Theobald, Journ. Linn. Soc., 1868, p. 39; id., Descr. Cat. Rept. Brit. Ind., 1876, p. 127; Stol., Journ. As. Soc., Bengal, vol. xxxix, 1870, pp. 14.0, 183; id., op. cit., vol. xlii, 1873, p. 114.

I collected only two specimens of this species, one at Prome on the Irawady, and the other at Ava on the same river, in Independent Burma.

The measurements of the Ava specimen are as follows: Length 7 inches. Head $0 \cdot 17$; gape 0.17 ; tail $0 \cdot 25$.

It has 216 ventrals and 7 sub-caudals. The scales are ranged in nineteen longitudinal series; the ventrals are nearly twice as large as those on the vertebral line. The vertical is much longer than broad and smaller than the superciliary. The occipitals are a little smaller than the vertical and are rounded behind. The nasals are more than half the size of the frontals. There are six upper labials, the third and fourth entering the orbit. Temporals $1+2+2$.

In colour it is uniformly irridescent bluish-black, with pale yellow bands across the back, but not extending on to the belly and frequently interrupted on the back. Another series of smaller and more indistinct yellow bands along the sides of the belly, alternating with the dorsal bands and not prolonged on to the sides of 
the back. The first dorsal band is a little distance behind the angle of the mouth. The chin-shields are black, but those below and behind the gape have broad white margins, and from the latter region an obscure whitish lateral line can be traced on the anterior half of the body. It is produced by the broad white margins of one or more longitudinal lateral lines of scales.

The specimen from Prome, only somewhat larger, being 8.92 inches long, resembles the former in every respect having the same number of ventrals and sub-caudals. There is only a slight variation to note in the colour of the head, viz., that the lateral band is prolonged along the upper lip to the front of the eye, where it turns up to reach the lower half of the frontal.

\section{OLIGODONTID A.}

Genus Simotes, D. \& Bib.

Stmotes theobald, Günther.

Simotes theobaldi, Gthr., Ann. \& Mag., Nat. Hist. 1868 (June), p. 417; Theobald, Descr. Cat. Rept. Brit. Ind., 1876, p. 152.

One specimen of this species was found at Mandalay. I have compared it with the type, with which it perfectly agrees.

\section{COLUBRIDR.}

Genus Ablabes, Günther.

Ablabes BICOLOR, Blyth.

Calamaria bicolor, Blyth, Journ. As. Soc., Bengal, vol. xxiii, 1854, p. 289.

Allabes bicolor, Gthr., Rept. Brit. Ind., 1864, p. 226.

Grotea bicolor, Theob., Journ. As. Soc., Bengal, vol. xxxvii, 1868, ex. No., p. 45; id., Descr. Cat. Rept. Brit. Ind., 1876, p. 145.

I captured one specimen of this species at Muangla, and have compared it with the type of the species, and with the specimen in the British Museum, which served Günther for the description in his work on the Reptiles of India. The latter specimen, as Günther remarks, is not in a good state of preservation; and after an examination of it I have failed to satisfy myself whether or no the nostril is in one or between two shields, but Günther states that the nostril is between two small plates. It would appear, however, from the Yunnan specimen, and from the type also of Calamaria bicolor, that the nasal plates tend to unite; and from the extent to which this tendency is developed in the latter, Theobald was led to regard the nostril as pierced in the centre of a large shield. But I observe in the type of $C$. bicolor that the nasal slit is crescentic, and that two nasal plates are indicated by a distinct groove which passes in front of the nostril, and that its labial 
end is marked by a distinct notch. In the Muangla specimen, the two-fold character of the nasals is also indicated by the epidermis peeling off along a similar groove. I am therefore inclined to regard the normal condition of the nostril to be that described by Günther, although in the Yunnan snake the nasals are united into a large shield.

In the type of $A$. bicolor there is only one preocular, but in a specimen from the Khasia Hills in the British Museum, and in this snake from Yunnan, there are two pre-oculars; but it appears that the lowermost of these plates in these two specimens must be regarded either as a separated portion of the third labial or of the uppermost preocular, and that the number of the preoculars is thus a variable character, because the type of $C$. bicolor, Blyth, and the British Museum specimen referred to, agree in other respects. The Muangla specimen further indicates that the number of postoculars is also a variable character, for the number of these plates, unlike the former examples, is three, the most inferior resting on the third and fourth labials over their suture, and thus excluding all the upper labials from entering the orbit, this supplementary shield being apparently a separated portion of the fourth upper labial.

This Yunnan snake is one foot ten inches in length, but a small portion of the tail is absent. The ventrals are 195, and the existing sub-caudals number 57. The anal is bifid, and there are 17 rows of scales on the body.

The colour is uniform dark olive-brown above, and orange-buff below. Each scale has a dark-brown lateral margin and an obscure faint yellow tip, and all are finely speckled with brown. The confluence, or continuity of the dark lateral margins of the scales gives rise to an obscure, but finely longitudinally banded appearance.

This species has hitherto been found only in Assam and the Khasia Hills, but its occurrence in Western Yunnan is in no way remarkable, because there is a similarity between the fauna of the Khasia Hills and that of Yunnan.

\section{Ablabes COLLARIs, Gray.}

Psammophis collaris, Gray, Ann. Mag. Nat. Hist., 1853, vol. xii, p. 390.

Ablabes collaris, Günth., Cat. Col. Snakes, 1858, p. 28 ; Rept. B. Ind., 1864, p. 228 ; Stol., Journ. As. Soc., Bengal, 1870, pp. 140 and 184; id., op. cit., 1871, p. 430 ; Anders., Proc. Zool. Soc., 1871, p. 171 ; id., Journ. As. Soc., Bengal, 1871, p. 33; Strauch. Mém. Petersb., vol xxi, 1873-74, p. 41, pl. i, fig. 2 ; Theobald, Deser. Cat. Rept. Brit. Ind., 1876, p. 156.

Only one specimen of this species was obtained by me in Yunnan, in the Hotha valley. I have compared it with the type in the British Museum, with which it agrees in all its essential characters. Ventrals 173 . Tail imperfect. Head $0^{\prime \prime} \cdot 50$; gape $0^{\prime \prime} \cdot 38$. Scales, 17 series. The teeth are of equal size, small, numerous and crowded, 36 in each upper maxillary and 86 in the lower jaw, with 40 palatine teeth on each side.

Loreal square, or slightly elongated vertically. The lower angle of the anterior nasal shield is on a level with the margin of the upper lip, and it excludes 
the first labial from contact with the rostral. Both pairs of frontals are transversely elongated: the vertical is rather lower than the supereiliary. The occipitals are large and obliquely truncated behind, and only in contact with the upper postocular. One preocular reaching the upper surface of the head: two postoculars in contact, with an elongated temporal, behind which there is another elongated shield alongside the occipital, and below it, and over the ninth and tenth labials, there are two smaller temporal shields. There are ten upper labials, the fourth, fifth and sixth entering the orbit; the eighth and tenth the largest; and two pairs of chin-shields, the anterior in contact with four labials.

It is uniformly reddish-brown above; olive-yellow below. A broad black collar, with a yellow border behind, is continued along the upper lip. A black curved band passes over the posterior ends of the occipitals; and another over the hinder margin of the superciliaries and vertical, faint-black, and marbled on the other shields of the head. A short dark indistinct vertebral line on the neck; and a black dot on the angle of each ventral and sub-caudal; the anterior eighth of the body has an additional spot internal to the black dot.

The whole under surface of the lower jaw is minutely speckled, and there is a black spot on the margin of each upper labial.

This species appears to be a hill form, as it has hitherto been found only in the Himalaya, Khasia, Jaintiá and Yunnan mountains at considerable elevations. Its most western known limit is the valley of the Sutlej.

\section{Ablabes Bistrigatus, Günther.}

Ablabes bistrigatus, Günther, Ann. and Mag. Nat. Hist., 1868, June, p. 417; Theobald, Journ.

Linn. Soc., 1868, p. 42 ; Deser. Cat. Rept. Brit. Ind. 1876, p. 155.

The first example of the species was obtained in Pegu by Mr. Theobald, and is now in the British Museum, and the second specimen which I found at Prome perfectly agrees with it.

The Prome specimen measures 10.50 inches, of which the head is 0.25 , the gape $0 \cdot 16$, and the tail 3 inches. There are 185 ventrals and 77 sub-caudals. The scales are in 17 series, and the anal is bifid. The loreal is longer than high, and the vertical is rather large, but much smaller than the occipitals, which are rounded, and in contact with the postoculars behind. One preocular and two postoculars; one temporal in contact with the lower postocular, and another elongated shield behind it and below the occipital. 'Two other temporal shields between the eighth, ninth and tenth labials and the occipito-temporal shield; ten upper labials; the fourth, fifth and sixth shields entering the orbit. The eighth shield excluded from the labial margin by the seventh and ninth shields. Two chin-shields subequal in size, the first in contact with fourth labials. About 30 crowded small teeth of nearly equal size in each division of the upper jaw. Colour uniform olivebrown. Upper surface of the head black; a yellow band from the eye to the neck, and another from the occipitals; the former crossed by two black bands, one 
over the neck broad, and another, a narrow one, over the base of the occipitals. The black included between these two yellow lines has the form and shape of the head, and as each posterior frontal has a crescentic yellow spot at its inner and posterior margin, the marked appearance of the head is produced. The black collar does not pass on to the ventral shields, but a narrow black well-defined lateral band runs backwards over the fourth row of scales to the end of the tail. There are three longitudinal rows of minute black dots on the scales below this line which defines the olive-brown of the back from the yellow of the hinder parts. The most ventral line of dots runs along the angles of the ventral shields. A vertebral series of black dots, each dot separated by an interval of two or three scales. They become very minute on the hinder part of the trunk and on the tail.

\section{Genus Colvber, Günther.}

\section{Coluber porphyraceus, Cantor.}

Coluber porphyracens, Cantor, Proc. Zool. Soc., 1839, p. 51; Günth., Rept. B. Ind., 1864, p. 239, pl. xx, fig. 1; Anders., Proc. Zool. Soc., 1871, p. 172 ; Theobald, Deser. Cat. Rept. Brit. Ind., 1876, p. 163.

Psammophis nigrofasciatus, Cantor, Proc. Zool. Soc., 1839, p. 53, juv.

Coronella callicephalus, Gray, Ann. and Mag. Nat. Hist., 1853, vol. xii, p. 390 ; Blyth, Journ. As. Soc., Bengal, vol. xxiii, 1855, p. 289.

Coluber callicephalus, Günth., Cat. Col. Snakes; 1858, p. 92.

Two of the three specimens brought from Western China were procured at Momien and show scarcely any difference except in size, the one being twice the length of the other. They have the rostral twice as broad as high; the anterior frontals rounded in front, broader than long and half the size of the posterior pair. Lateral margins convergent, hinder ones meeting at an acute angle. Occipitals large, transversely truncated behind. Nostril between two nasals. Loreal rather small and elongate. One preocular just reaching on to the upper surface of the head, touching the vertical on one side, but not on the other. Two postoculars, the upper about four times larger than the lower, which is over the suture of the fifth and sixth labials. Temporals $1+2$. The anterior in contact with upper postocular anteriorly, and with two oblong temporals behind. The occipital in contact with upper postocular nearly throughout its whole length. Upper labials eight; the fourth and fifth entering the orbit. The first lower labials form a suture behind. the mental. Two pairs of chin-shields; the anterior pair in contact with four labials and about twice the size of the posterior pair. Dentition: 16 upper, 16 lower jaw.

$$
\begin{gathered}
\text { Length of larger specimen } 23.50 \text {; head } 0.57 \text {; tail } 3.66 \text { inches. } \\
\text { " lesser " } 11 \text { " } 0.46 ; " 1.57 \text { " }
\end{gathered}
$$

The ventrals are 195 and the sub-caudals 55 in the larger, and there are 197 ventrals and 57 sub-caudals in the lesser specimen.

The scales in both are ranged in 19 rows. 
Coloration: olive-brown above, with broad, dark-brown, black-edged transverse bands, each margined externally by a pale yellowish-brown line; 20 in the larger and 17 in the lesser example. These bands do not pass on to the ventral or sub-caudal shields. A black line through the centre of the frontals, vertical and occipitals; a black line from the eye to the first transverse band. Two narrow black longitudinal dorsal lines connecting the last eleven bands. Some of the transverse bands near the end of the body and those on the tail are resolved into large lateral spots with the same distribution of colour as in the bands.

The specimen obtained at Hotha presents a few variations from the preceding. The vertical is somewhat longer; the superciliary margin being only one-fifth less than the greatest breadth. The loreal is small and elongated. The preocular is broadly separated from the vertical. Two postoculars on one side and only one on the other; in the latter case the occipital takes the place of the upper postocular. The temporal is in contact with the inferior postocular only. Seven upper labials on one side, six on the other, the former on the side where there is only one postocular; the third and fourth labials enter the eye on this side; and on the other, only the elongated third labial forms the lower margin of the orbit. The coloration the same as the type.

This example measures, total length 28 inches; head 0.95 ; gape 0.33 ; tail $4 \cdot 25$. Ventrals 192; sub-caudals 54. Scales in 19 rows. Dentition $16+16=32$ and $16+16=32$.

This species which has as yet been recorded only from the Khasia Hills, from Assam, and from Darjeeling, and now from the high country of Yunnan, would appear to be exclusively a hill form.

Genus Elaphis, Dum. \& Bib.

ELAPHIS YUNNANENSIS, $n$. $s$.

This snake, of which I captured three individuals at Momien, is closely allied to E. taniurus, Cope, but from the circumstances that my specimens have only 23 rows of scales on the body and as many as from 252 to 258 ventral shields, and that the coloration of the trunk differs from that of E.taniurus, I am constrained to separate it from that species rather than to indicate it as a variety. If any of these specimens had approximated to the lesser number of ventral shields in E. tceniurus, and to the greater number of body scales, and had the verticals had the same form, I certainly would not have separated them.

The anal shield in one of these specimens is entire, thus conforming to one of the characters of the genus Compsosoma, and indeed so strong are some of the resemblances of these snakes to that genus, that the consideration suggests itself whether valid grounds exist for separating Elaphis and Compsosoma.

Head distinct from neck; elongated, narrow, and somewhat pointed. Eye moderately large, with a round pupil. Rostral broader than high. Anterior frontals 
about one-third the size of the post-frontals, rounded in front and broader than long. Vertical large, equalling the distance between its anterior margin and the tip of the snout, with posteriorly convergent lateral margins as long as the breadth of the anterior border of the shield; posterior margins forming nearly a right angle. Superciliaries posteriorly expanded and as long as the vertical. Posterior margins of occipital divergent, the shield in contact with superior postocular. Nasal plates large. Loreal twice as long as high with its posterior extremity pointed. Two preoculars, the lower very small and in the line of the labials; the upper large and broad, reaching to the upper surface of the head, but not in contact with the vertical. Two or three postoculars in contact with two temporals. Two elongated anterior temporals side by side, those behind them irregular. Eight or nine upper labials, the fourth and fifth, or the fifth and sixth, entering the orbit.

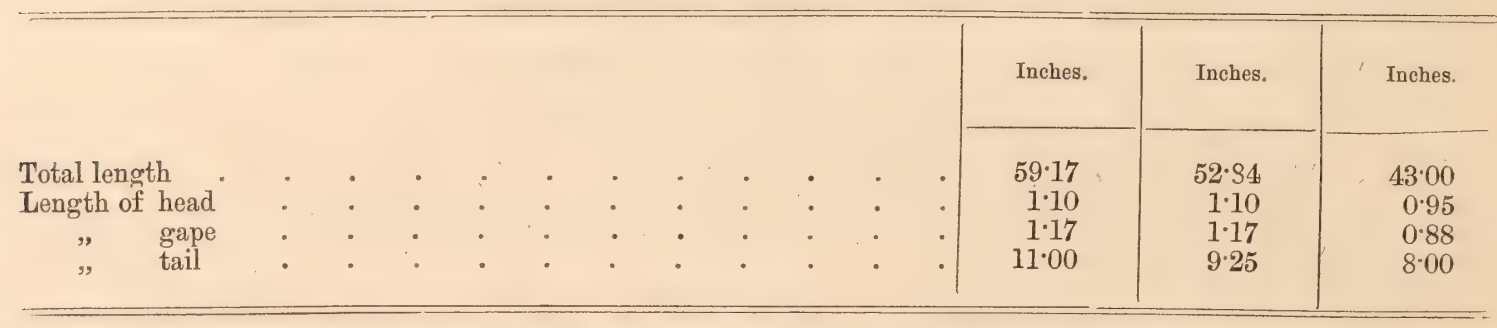

Ventrals 252-258; Sub-caudals 90-101; Scales on the body 93.

Ground colour bright olive-yellow, darker on the upper surface of the head. A narrow black band from behind the eye to the neck. A series of large elongated irregular black spots on each side of the vertebral line, on the anterior half of the trunk connected by a narrow intervening black area, many of these spots assuming the form of black rings with yellow centres. On the hinder half of the body, the connecting black lines disappear, and a broad yellow band runs along the vertebral line to the tip of the tail. About the position of the twenty-fifth ventral, a lateral series of elongately oval black rings with yellow centres begins, each ring occupying about six rows of scales and separated from its fellows by about four rows of scales. There are from 12 to 14 of these rings, but they are displaced in the middle of the body by large oblong dark-brown spots occupying the sides of the body, each spot being separated from its fellow by a narrow transverse yellow line continuous above with the yellow dorsal area. On the sides of the tail, these large brown spots become confluent, and constitute a well-defined brown lateral line. A bright yellow line along the angles of the ventrals, in the last sixth of the trunk, and prolonged to the angles of the sub-caudals. The lateral margins of alternate groups of the ventrals, on the anterior part of the trunk, below the rings, are margined with black, and there is a narrow interrupted band along the line of the feeble keel. The ventrals and sub-caudals are yellow, but the former are obscurely spotted with black. 


\section{Genus Compsosoma, Dum. \& Bib.}

\section{Compsosoma radiatum, Boie.}

Russell, Ind. Serp., vol. ii, 1801, p. 44, pl. 42.

Coluber radiatus, Boie, Isis, 1827, p. 536 ; Schleg., Phys. Serp., 1837, rol. ii, p. 135, pl. v, figs. 5 and 6 ; Cantor, Journ. As. Soc., Bengal, 1847, p. 920.

Coluber quadrifasicatus, Cantor, Proc. Zool. Soc., 1839, p. 51.

Tropidonotus quinque, Cantor, Proc. Zool. Soc., 1839, p. 54.

Colognathus radiatus, Fitz. Syst, Rept., 1843, p. 26.

Compsosoma radiatum, Dum. \& Bibr., Erpét. Gén., vol. vii, 1854, p. 292 ; Günth. Rept. B. Ind., 1864, p. 243 ; Steind., Reise Novara, 1867, p. 64; Theobald, Journ. Linn. Soc., 1868, p. 45; Stol. Journ. As. Soc., Bengal, 1870, pp. 141, 187 ; id.op. cit., 1871, p. 430 : id. op. cit., 1873, p. 114; Theobald, Descr. Cat. Rept. Brit. Ind., 1876, p. 165.

Spilotes radiatus, Günth. Cat. Col. Snakes, 1858, p. 96.

One specimen differs from the type in having only eight upper labials, the fourth and fifth entering the orbit. The dentition appears to be, upper jaw $16+16=32$; lower jaw $16+16=32$. Length 45 inches; head 0.95 ; tail 9.25. Ventrals 236 ; sub-caudals 99 ; scales in 19 rows.

In another specimen of this variety, with eight upper labials, the third, fourth and fifth enter the orbit, and both anterior temporals are in contact with the postoculars.

These specimens, however, agree in every other respect with $C$. radiatum. They were obtained at Mandalay.

\section{Genus Ptyas, Fitzinger.}

\section{Ptras mucosus, Linn.}

Russel's Ind. Serp., vol. ii, 1801, p. 20, pl. xviii, fig. 2.

Coluber mucosus, Linn., Mus. Adolph. Frid., 1754, p. 37, pl. xiii, fig. 2, pl. cexxiii, fig. 2; Russell. Ind' Serp., vol. i, 1796, p. 40, pl. xxxiv ; Lacep. Quadr. Ovip. 1789, vol. ii, p. 238, pl. xxxiv, Latr. Rept., vol. iv, 1800, p. 156 ; Daud. Rept., vol. vi, 1804, p. 355.

Coluber blumenbachii, Merr., Tentam, 1820, p. 119; Schlegel, Ess. Yhys. Serp., vol. ii, 1837, p. 137, pl. v, figs. 7 and 8.

Coluber dhumna, Cantor, Proc. Zool. Soc., 1839, p. 51; Journ. As. Soc., Bengal, vol. xvi, 1874, p. 74.

Coryphodon blumenbachii, Dum. \& Bibr., Erpét. Génl., vol. vii, 1854; p. 184, Günther, Cat. Cal. Snakes, 1858, p. 111.

Leptophis trifrenatus, Hollow, Proc. Acad. Philad., 1860, p. 503.

Ptyas mucosus, Cope, Proc. Acad. Philad., 1860, p. 563 ; Günther, Rept. Brit. Ind., 1864, p. 249 ; Steind., Novara, Rept., 1867; p. 64; Theobald, Journ. Linn. Soc., vol. x, 1868, p. 46 ; id., Descr. Cat. Rept. Brit. Ind. 1876, p. 169; Stoliczka, Journ. As. Soc., 1870, vol. xxxix, pp. 137, 141, 185; Blanford (W. T.) loc. cit., p. 372 ; Anderson, op. cit., vol. xl, 1871, p. 34; Ferguson, Rept. Fauna, Ceylon, 1877, p. 19.

This widely distributed and common species occurs at Mandalay, and at Momien, nearly 5,000 feet above the sea. In the example from the latter locality 
there are four loreals on the right side, the supplementary shield being evidently a separated portion of the uppermost loreal. This specimen measures 51.50 inches in length, of which the tail is 14 inches, and it has 196 ventrals and 127 subcaudals.

In the Mandalay snake there are nine upper labials, the fifth and sixth entering the orbit. In all other particulars, these specimens agree with Indian examples of the species.

Ptyas korRos, Reinwardt.

Coluber korros (Reinw.) Schleg., Phys. Serp., 1837, vol. ii, p. 139; id., Abbild., 1837, pls. xxvii and xxviii, figs. 1-6 ; Cantor, Journ. As. Soc., Bengal, vol. xvi, 1847, p. 921.

Corryphodon korros, Dum. \& Bibr. Erpét. Génl., vol. vii, 1854, p. 186 ; Günth., Cat. Col. Sn., 1858, p. 110.

Ptyas korros, Cope, Proc: As. Philad., 1860, p. 563 ; Günth., Rept. B. Ind., 1864, p. 250 ; Steind., Reise Novara. 1867, p. 65; Jan. \& Sord, Icon. Gén. Oph., 1867, pl. iii ; Theobald, Journ. Linn. Soc., 1868, p. 46 ; id., Deser. Cat. Rept. Brit. Ind., 1876, p. 169 ; Stol., Journ. As. Soc., Bengal, vol, xl, 1871, p. 34; vol. xlii, 1873, p. 114 .

The following specimens from the parallel valleys of Sanda and Hotha in Yunnan agree with the generality of the examples of this snake which have come under my observation, except in the greater number of the ventral and sub-caudal shields, but even the highest number of the ventral shields in these Yunnan snakes is exceeded by a specimen of the species from Darjeeling in which they are as many as 187.

Length-total 52.25 inches; tail 19 inches; ventrals 183 ; sub-caudals 145.

" 60 inches " imperfect. " 179 ?

This species ranges eastwards from the Sikkim Himalaya through Assam to Upper Burma, Western Yunnan, and Southern China and Siam, and through Arracan and the Malayan Peninsula to Sumatra and Java.

The snake from Ceylon referred by. Blyth to this specimen is apparently an example of $P$. mucosus, and Ferguson states that $P$. korros is never found in that island.

\section{Genus Tropidonotus, Kühl. \\ Tropidonotus stolatus, Linn.}

Russell, Ind. Serp., vol. i, 1796, pls. x \& xi ; id., op. cit., vol. ii, 1801, pl. xv, juv.

Stolated Snake, Shaw. Gen. Zool., 1802, vol. iii, p. 542.

Coluber stolatus, Linn., Mus. Adolph. Frid., 1754, p. 26, pl. xxii, fig. 1; Syst. Nat., 12th ed., 1766, vol. i, p. 379 ; Laurenti, Syst. Rept., 1768, p. 95 ; Gmel., Syst. Nat., 1788, vol. i, part iii, p. 1098.

Coluber cervinus, Gmel., Syst. Nat., 1788, vol. i, part iii, p. 1114; Lacép., Quadr. Ovip., vol. ii, 1789, p. 107 ; Latr., Rept., 1801, vol. iv, p. 80 ; Daud., Rept. 1803, vol. vii, p. 161.

Natrix stolatus, Merr., Tent. Syst. Rept., 1820, p. 123.

Tropidonotus stolatus, Boie, Isis, 1827, p. 535 ; Schleg., Phys. Serp., 1837, vol. ii, p. 317; Cantor, Journ. As. Soc., Bengal, vol. xvi, 1847, p..937; Jerdon, Journ. As. Soc., Bengal, vol. xxii, 
1853, p. 530 ; Günth., Cat. Col. Sn.; 1858, p. 68; Rept. B. Ind., 1864, p. 266 ; Theobald Journ. Linn. Soc., 1868, p. 47 ; id., Deser. Cat. Rept. Brit. Ind., 1876, p. 177 ; Stol., Journ As. Soc., Bengal, vol. xxxix, 1870, pp. 141, :991; Anders., Journ. As. Soc., Bengal, vol. xl, 1871, p. 34; Ferguson, Rept., Fauna, Ceylon, 1876, p. 20.

Amphiesma stolatum, Dum. \& Bibr., Esp., Gen., 1854, vol. vii, p. 727; Jan, Canestr. Arch. Zool. vol. iii, 1864, p. 233.

This specimen agrees in every respect with Indian examples of the species, with the exception that the light-coloured longitudinal bands are olive-brown instead of white or yellow, but becoming white spots on the transverse black bands.

Ventrals 147.

No other specimen came under my notice besides this one which was obtained at Bhamô. On the high land beyond that town its place seems to be taken by the next species.

\section{Tropidonotus Modes'rus, Günther.}

Tropidonotis modestus, Günther, Proc. Zool. Soc. 1875, March 16th, p. 232.

A comparison of a large series of this species from Cherra Poonjee, Khasia Hills, and examples from Western Yunnan, with the types in the British Museum, enables me somewhat to extend the original characters given by Günther.

Head narrow, distinct from neck, rather anteriorly tapering and flat above; snout of moderate length, rather pointedly rounded. Eyes moderate. Scales very feebly keeled on the sides in the females, but more pronouncedly on the back; scales of the male generally strongly keeled, the tips of the scales near the end of the trunk, and on the tail, being somewhat divided. Scales in 19 rows. Prefrontal subtriangular, somewhat pointed or rounded anteriorly. Postfrontals transversely elongated. Vertical of moderate size, lateral margins nearly parallel in some, and rather strongly convergent in others. Hinder portion generally acutely pointed.

Occipitals as long as the vertical and postfrontals, obliquely or transversely truncated behind in some, rounded in others. Loreal oblong or nearly square. One or two preoculars, the upper reaching to the surface of the head, but not touching the vertical. Two or three postoculars. Temporals $1+2+2$ or $2+2+1$. The anterior in contact with the postoculars. Nine upper labials, the 4th, 5th and 6th entering the orbit. Two pairs of elongated chin-shields, the hinder pair the longest and divergent. The anterior pair in contact with five labials. Twelve closely set teeth on each side of the upper jaw, increasing in size from before backwards; the last tooth large, and at a slightly longer interval from the preceding tooth than the latter is from the tooth before it. Ventrals 154 to 168 . Sub-caudals 82 to 122. In the only male examined, all the sub-caudals were entire without exhibiting any tendency to division, and they were reduced in number to 82 , whereas in the females the lowest number of these plates was 96 . The non-division of the sub-caudals, although a remarkable circumstance, can only be regarded in the light of an accidental variation, for there can be no doubt of the specific identity of this male with the females, although it differs from them in having strongly keeled scales which, on 
the hinder part of the body and tail, tend to bifurcate or divide at their free extremities. Stoliczka' has recorded that the male of S. platyceps, Blyth, is also distinguished from its female by the stronger keeling of the scales. This male of S. modestus was captured in the Khasia Hills by the late Lieutenant Bourne in the very same locality in which he obtained the females which have been compared with the types of the species. Its sex was determined not by any fancied external characters distinctive of the sexes, but by actual dissection. Comparing this specimen with a female of nearly the same dimensions of body, the tail in the latter is 8 inches to 6.20 inches in the male; but the comparison of a large series of females reveals the fact that the tail in them is, at the same time, liable to vary slightly in its length.

The Yunnan specimens, two in number, have 8 and 10 ventrals less than the smallest number of ventrals in the Cherra Poonjee snakes, viz., 162, whereas their sub-caudals are respectively 122 and 110 ; the largest number of sub-caudals that I have met with in specimens from the Khasia Hills being 108.

In the Yunnan snakes, the colour is uniform dark olive-brown above, the ground colour of the under surface being yellow, but each ventral has a black spot on its angle, these spots becoming confluent on the hinder part of the body, and prolonged on to the sub-caudals as a black line. A narrow pale-olive yellow lateral band runs along the body above the spots, disappearing on the posterior half of the body. There is an obscure short pale-yellow band from the gape on to the side of the nape, followed by a lateral series of pale spots separated from each other by an interval of two scales. On the posterior half of the trunk, these spots become confluent, and are prolonged on to the tail as an obscure yellowish band. All the labials have blackish posterior margins, and their surfaces, and those of the chin-shields and the sub-caudals, are more or less speckled with dusky-brown.

In the examples from the Khasia Hills the coloration somewhat differs from the foregoing. The colour of the upper surface is dark olive-blackish, the pale band on the sides of the nape is hardly visible, and the pale lateral spots and band are very obscure, and are almost lost. The dark colour of the upper parts passes on to the sides of the ventrals, and meets from either side nearly in the mesial line on the anterior part of the body, and wholly so posteriorly, and on the sub-caudals; but a narrow yellow area is generally left along the free margin of each plate, and is the representative of the yellow lateral line of the Yunnan snakes. The labials, chinshields and throat are speckled or clouded with dusky. In the male from Cherra Poonjee, the pale lateral spots are very distinct, and the pale line along the angles of the ventrals is observable, also the two rows of dark or black spots, one above, and the other below the pale lateral spots. In this specimen, as in some Cherra Poonjee females, the pale narrow line from the gape, along the side of the nape, is also observable.

The types of this species were in all probability from the Khasia Hills. It is closely allied to T. platyceps, Blyth. 


\section{Tropidonotus DIPSAs, Blyth.}

Tropidonotus dipsas, Blyth, Journ. As. Soc., Bengal, vol. xxiii, 1854, p. 297.

Tropidonotus junceus, Stoliczlka, Journ. As. Soc., Bengal, vol. xl, 1871, p. 434; Theobald, Deser.

Cat. Rept., Brit. Ind., 1876, p. 176.

Twelve specimens were collected of this snake; a young one from Ponsee, another example from Sanda, and the remainder from the secluded valley of Hotha. The species is very prevalent around the village of Hotha, where it is the common grass-snake. There is a certain similarity in its colouring to $T$. stolatus, which it appears to replace in Western China. T. stolatus is found but sparingly at Bhamô, and seemingly does not extend its range to the Kakhyen hills, which form the natural boundary between the low-lying valley of the Irawady and the elevated country of Yunnan.

Head distinct from the neck, moderately long and broad, slightly depressed. Snout rather rounded at the point; scales in 19 rows, strongly keeled. Rostral twice as broad as high. Anterior frontals sub-triangular, transversely truncated in front and more than half as large as the posterior frontals. Vertical nearly as long as the occipitals. Lateral margins convergent, slightly concave in some, convex in others; hinder margins meeting at a right angle, occipitals rounded behind. In young specimens they are narrower than in adults and more elongated. Eight or seven upper labials, the third, fourth, and fifth, or third and fourth, entering the orbit; the latter when two of the labials are confluent. Loreal square. One to three preoculars, the upper reaching the surface of the head. Three postoculars. Temporals irregular, $2+1+3$, or 2 or $1+1+2$. One or two temporals in contact with one to three postoculars. Anterior pair of chin shields much shorter than the hinder pair, in contact with five lower labials. Eighteen teeth in each jaw, with two longer behind, scarcely separated by an interval. General colour dark olive-brown, with a black lateral band from behind the eye to the angle of the mouth and along the side of the body to the end of the tail with a lighter olive-brown band below it; the lateral margins of the ventrals being edged with black: a light olive-yellow band above the black one, commencing a little way behind the eye and extending to the tip of the tail. Under surface gamboge-yellow.

The following table will illustrate the amount of variation to which this species is subject.

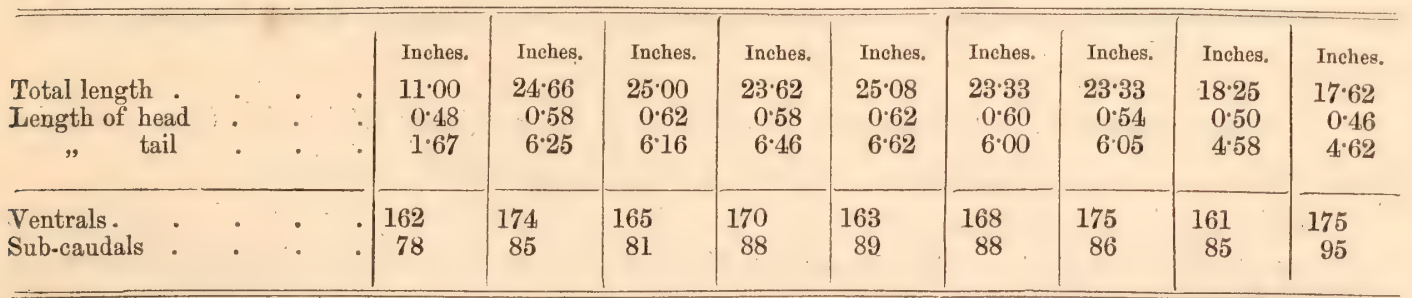

Nineteen rows of scales in all the specimens, save No. 3, which has only 18 on the middle of the trunk, and a little farther back only 17 rows of scales. 
REPTILTA.

Variations in the head-shields of nine specimens.

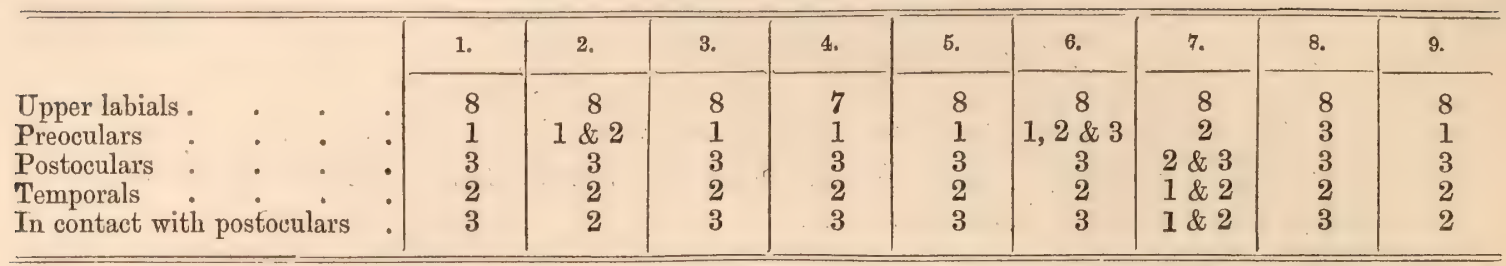

1. The first variety is one in which the loreal is prolonged into the orbit and is surmounted by one preocular which reaches the head. Its temporals are $2+1$ +2 ; the anterior shields are in contact with three postoculars. The occipitals are rather more elongated than in some other specimens; eight upper labials; third, fourth and fifth orbital.

2. One preocular, but the shield on one side is nearly divided in two. Temporals $2+1+3$; the anterior shields in contact with the two lower postoculars; third, fourth and fifth orbital. Vertical with the lateral margins straight convergent.

3. One preocular. Temporals $2+2+1$ in contact with three postoculars. Lateral margins of vertical slightly concave; eight upper labials; third, fourth and fifth orbital.

4. One preocular. Temporals $2+1+2$ in contact with three postoculars. Upper labials 7; the third and fourth orbital. The seven labials are evidently produced by the fusion of the third, fourth and fifth labials. The vertical is rather shorter than in the others, and its form is more sharply defined, its lateral margins being very straight and convergent; eight upper labials; third, fourth and fifth orbital.

5. One preocular. Temporals $2+1+2$ in contact with the postoculars. Vertical with its lateral margins slightly convex and three posterior angles rounded.

6. Two preoculars on one side, three on the other. Temporals and vertical as in No. 4 ; eight upper labials; third, fourth and fifth orbital.

7. Two preoculars. Postoculars two on one side and three on the other ; temporals on one side $1+1+2$, on the other $2+1+3$. In the former case, in contact with lower, in the latter, with the two upper postoculars. Lateral margins of vertical as in No. 3 ; upper labials eight; third, fourth and fifth orbital. In this specimen it is evident that the superior of the two anterior temporals is a separated portion of the occipital.

8. Three preoculars. Temporals irregular. One small plate wedged between the two lowest postoculars. The sixth labial with an elongated temporal behind it and another above it, touching the middle and superior postocular. Vertical slightly elongated with the posterior angles (lateral margin) rounded. Labials eight; third, fourth and fifth orbital.

9. One preocular. Temporals $2+1+2$ in contact with the two superior postoculars. Vertical labials and orbital as in the preceding specimen.

This species ranges to Assam, the Khasia Hills and Sikkim; but it appears to have a greater numerical development to the east than towards the west, and from the circumstance that it is rare in the valley of the Irawady, it may be considered to be a mountain form. 
The Tropidonotus junceus, Cantor, from Penang, the type of which is in the British Museum, has one preocular reaching the upper surface of the head, and the rostral prolonged backwards. It is quite distinct from this species.

\section{Tropidonotus quincunciatus, Schleg.}

Russell, Ind. Serp., vol. i, 1796, pl. xx, pl. xxviii \& pl. xxxiii ; vol, ii, 1801, pl. iii, fug. 1, juv., \& pls. xiv \& xva juv.

Hydrus piscator, Sehneid., Hist. Nat. Amph., 1792, vol. i, p. 247.

Hydrus palustris, Schneid., ibid., p. 249.

Enhydrus piscator, Latr. Rept., 1801, vol. iv, p. 203.

Enhydrus palustris, Latr. Rept., 1801, vol. iv, p. 205.

Marsh-Hydrus, Shaw, Gen. Zool., 1802, vol. iii, p. 569.

Coluber anastomosatus, Daud., Rept., 1803, vol. vii, p. 140.

Coluber braminus, Daud., Rept., 1803, vol. vii, p. 176.

Coluber umbratus, Daud., Rept., 1803, vol. vii, p. 144.

Coluber brunneus, Hermann, Obs. Zool., 1804, p. 283.

Coluber atratus, Hermann, Obs. Zool. 1804, p. 283.

Natrix umbrata, Merr. Tentam, p. 119, 1820.

Natrix lugubris, Merr. Tentam, p. 133, 1820.

Natrix piscator, Merr. Tentam, 1820, p. 122.

Natrix palustris, Merr. Tentam, 1826, p. 124.

Coluber rectangulus, Gray, Ill. Ind. Zool., vol. ii, 1830, plate lxxxv, figs. 4-7.

Coluber hippus, Reuss, Mus. Senck., 1834, p. 150, pl. ix, fig. 2.

Coluber quincunciatus, Schleg., Phys. Serp., 1837, vol. i, p. 167; vol. ii, p. 307, pl. xii, figs. 4 and 5 . Tropidonotus quincunciatus, Dum. \& Bibr., Erpét. Gén., 1854, vol. vii, p. 592 ; Günth., Cat. Colubr. Sn. B. M., 1858, p. 64; id., Rept. B. Ind., 1864, p. 260 ; Steind., Reise Novara, 1867, p. 65; Jan \& Sord., Icon. Gén. des Ophid., 1868, No. xxvii, pl. i, fig. i; Theobald, Journ. Linn. Soc., 1868, p. 46 ; id., Descr. Cat. Rept. B. Ind., 1876, p. 175 ; Stol., Journ. As. Soc., Bengal, vol. xxxix, 1870, pp. 137, 141 and 190 ; id., op. cit., vol. xl, 1871, p. 431, pl. xxvi, fig. 1, var.; id., op. cit., vol. xlii, pp. 114 and 162; Blanfd., Journ. As. Soc., Bengal, vol. xxxix, 1870, p. 371.

Tropidonotus tytleri, Blyth, Journ. As. Soc., Bengal, vol. xxxii, 1863, p. 88.

Tropidonotus striolatus, Theobald, Journ. As. Soc., Bengal, vol. xxxvii, 1868, pp. 53 and 55.

Tropidonotus piscator, Jerd., Journ. As. Soc., Bengal, vol. xxii, 1853, p. 530.

The larger specimen has spots arranged as in var. A. Günth., but they become obsolete about the posterior half of the body, which is uniform light olive-brown. The angles of the ventrals have blackish margins. The lateral dots instead of being scarlet are light yellow. The lesser example belongs to the same type of colouring, but the black spots are indistinct and the yellow ones rather prominent, The lateral margins of the sub-caudals are black.

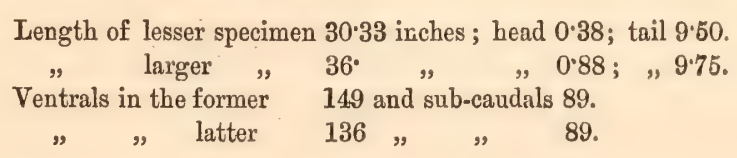

They both possess nineteen rows of scales.

These specimens were obtained at Mandalay and Bhamô. 


\section{Tropidonotus subminiatus, Boie.}

Tropidonotus subminiatus, (Reinw.) Boie, Isis, 1827, p. 535 ; Schleg., Ess. Phys. Serp., 1837, vol. ii, p. 313 ; Blyth, Journ. As. Soc., Bengal, vol. xxiii, 1854, p. 296 ; Günth., Cat. Col. Sn., B. M., 1858, p. 69 ; Rept. B. Ind., 1864, p. 265 ; Theobald, Journ. Linn. Soc., 1868, p. 47 ; Stol., Journ.

As. Soc., Bengal, vol. xl, 1871, p. 434, pl. xxvi, fig. 3 ; Anders., Proc. Zool. Soc., 1871, p. 177. Rhabdophis subminiatus, Fitz., Syst. Rept., 1843, p. 27.

Amphiesma subminiatum, Dum. \& Bibr., Erpét. Gén., 1854, vol. vii, p. 734; Jan, Canestr. Arch. Zool., vol. iii, 1865, p. 234; Jan \& Sord., Icon. Gén., Oph. No. xxix, 1865, pl. i.

Iropidonotus (Amphiesma) subminiatus, Steind., Rept. Reise Novara, 1867, p. 66.

The colour is uniform olive-green above with a few black and reddish spots on the front of the body. In young specimens which have a blackish colour on the neck, the scales for some distance behind it have their margins tinged with coral-red. Under-surface yellow with an irregular line of black dots on the angles of the ventrals and a black triangular spot below the eye.

Of the Muangla specimens only one has the labials regular, viz., eight upper labials, the third, fourth and fifth entering the orbit. Its postoculars are regular, but the temporals are in contact only with the two lowest. Two other specimens have eight labials on the one side and nine on the other, and in both cases the third, fourth and fifth enter the orbit. However, the one has three postoculars on the side with nine labials, and on the other side the lowest of the postoculars is nearly divided in two. The other specimen has four postoculars on the side with eight labials all in contact with the temporals; on the opposite side, there are only three, the two lowest alone being touched by the temporals. Another example has only seven labials on the one side and eight on the other, the third and fourth entering the orbit on the side with seven, and the third, fourth and fifth on the side with eight: on the side with seven the fifth labial is excluded by the lower postocular, and a portion of the third labial is detached as a lower preocular. The accompanying tables will illustrate the variations of the specimens, all of which have nineteen rows of scales.

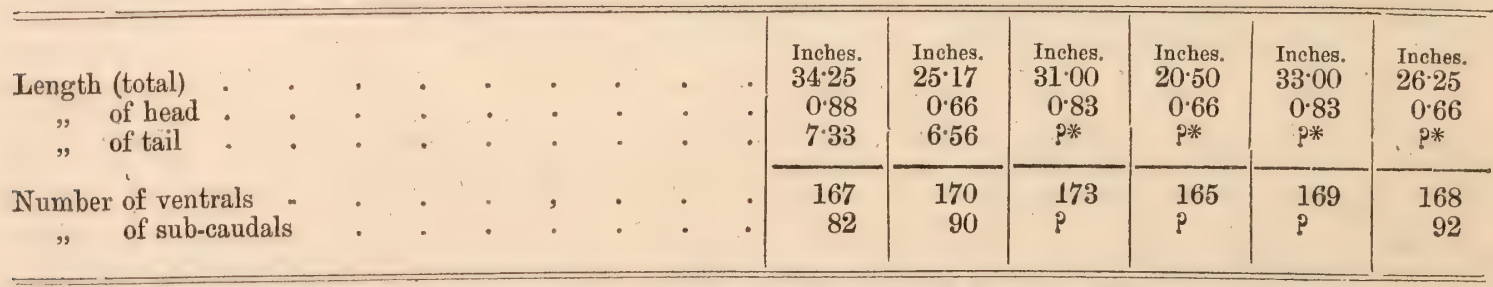

This species is not uncommon in the valleys of Sanda, Nantin, Momien and Hotha.

\section{Genus Atretium, Cope.}

Atretium schistosum, Daud., var. yunnanensis.

Chittee, Russell, Ind. Serp., vol. ii, 1801, plate iv.

Coluber schiștosus, Daud., Rept., vol. vii, 1803, p. 132 ; Merr. Tentam Erpét., 1820, p. 103.

\footnotetext{
* Tail imperfect.
} 
Tropidonotus schistosus, Schleg., Ess. Phys. Serp., vol. i, 1837, p. 168; vol. ii, p. 319 ; Cantor, Journ. As. Soc., Bengal, 1847, vol. xxi, p. 938; Dum. \& Bib., Erpét. Génl., vol. vii, 1854, p. 596.

Tropidonotus moestus, Cantor, Proc. Zool. Soc., 1839, p. 54.

Tropidonotus surgens, Cantor, Proc. Zool. Soc., 1839, p. 54.

Atretium schistosum, Cope, Proc. Acad., Philad., 1861, p. 299; Günther, Rept. Brit. Ind., 1864, p. 273 ; Steind., Reise Novara, Rept., 1867, p. 67; Anderson, Journ. As. Soc., vol. xl, 1871, p. 34 ; Theobald, Descr. Cat, Rept., Brit. Ind., 1876, p. 179 ; Ferguson, Rept. Fauna, Ceylon, 1877 , p. 20.

Helicops schistosus, Jan, Canestr., Arch. Zool., vol. iii, 1865, p. 245, p. 250 ; Icon. Génl. Ohp., No. sxviii, 1868, pl. ii, fig. 3.

The head is of moderate size; snout rather pointed. Body of moderate thickness. The anterior frontals are triangular and form $a$ very short suture with the rostral, but in two cases out of three before me, they are excluded from the rostral by a small azygos shield which is also wedged between them. The posterior frontals are broader than long, and about the same breadth as the anterior frontals. In one out of two, they are united with a notch behind, corresponding to their line of union. In the two, they are divided into three and four pieces. The vertical is long and constricted in the middle, the posterior half tongue-shaped. Occipitals longer than the vertical, rounded behind, sometimes with a portion separated from their hinder extremities. Loreal sub-quadrangular, higher than broad.

One preocular reaching to the upper surface of the head. Three postoculars, the lowest in contact with three labials. Temporals $2+3$; two elongate shields in contact with three postoculars. Nine upper labials, the fourth and fifth orbital. Twenty-three maxillary teeth, increasing in length posteriorly.

Measurements of three specimens.

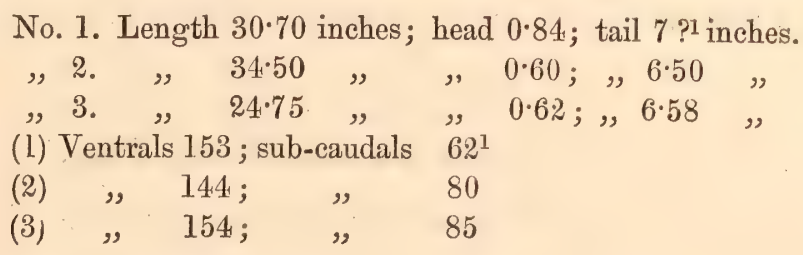

All have nineteen rows of keeled scales.

Colour uniform dark olive-brown above; yellow beneath.

These Yunnan specimens differ from the generality of Indian examples in the narrow suture between the anterior frontals and rostral; in the divided posterior frontals; in the presence of nine upper labials, and in having slightly larger preoculars, verticals and occipitals, but these features are not sufficiently important to entitle them to specific rank.

Specimens were obtained at Muangla and Hotha at elevations of 2,000 and 4,500 feet.

It has been generally supposed that this species is more characteristic of the Indian than of the Indo-Chinese, or Malayan fauna. Its occurrence, therefore, in the foregoing slightly modified condition, in the elevated region of Western Yunnan, is a fact of considerable interest. 


\section{DENDROPHID丑.}

\section{Genus Gonyosoma, Wagler.}

\section{Gonyosoma Gramineum, Gthr.}

Gonyosoma gramineum, Günther, Rept. B. Ind., 1864, p. 294, pl. 293, fig. D; Theobald, Descr. Cat. Rept., Brit. Ind., 1876, p. 191.

Upper surface grass-green, a yellow line along the keel of the ventrals and sub-caudals; beneath, pale yellow-green. Upper labial shields and those of the lower jaw, pale yellowish-green.

Length 37 inches; head 0.80 ; tail 9.25 .

Ventrals (keeled) 193. Sub-caudals 99. Anal bifid. Nineteen rows of fully keeled scales. Head flat, moderately large with an obtusely rounded snout. Rostral nearly twice as high as broad. Prefrontals sub-triangular, rounded in front, nearly half as large as the postfrontals. Postfrontals much broader than long, bent down on the side of the head to the low loreal. Vertical moderately sized. Lateral margins equal, the anterior margins are strongly convergent and slightly concave; hinder margins meet at a right angle. Occipitals rounded behind, their suture equals the length of the vertical. Nostril rather prominent, between two almost united nasals. Loreal rather low, oblong. One preocular reaching to the upper surface of the head. Temporals $2+2$ in contact with postoculars, Nine upper labials, fourth, fifth and sixth orbital. Seventeen rows of maxillary teeth of nearly equal size.

One specimen which has been compared with the type was found at Bhamô.

\section{Genus DeNDROPHIS, Boie.}

Dendrophis PICtA, Gmelin.

Seba, Thes., 1734, vol. i, pl. xcix, No. 3.

Coluber filiformis, Linn., Mus. Adolph. Frid., 1754, pl. xvli, fig. 2, juv.; Russ., Ind. Serp., vol. ii, 1801, pls. xxv \& xxvi.

Coluber caruleus, Bonnat., Ophiol. Encycl. Méthod., 1784, p. 30.

Coluber pictus, Gmel., Syst. Nat., 1788, p. 1116.

Coluber decorus, Shaw., Gen. Zool., 1802, vol. iii, p. 538 ; Merr. Tent., 1820, p. 128.

Leptophis maniar, Bell, Zool. Journ., vol, ii, 1825, p. 329.

Ahatulla decora, Gray, Ann. Phil., 1825, p. 16.

Dipsas schokari, Kuhl, Beiträge, 1826, p. 80.

Dendrophis pictus, Boie, Isis., 1827, p. 530 ; Jan \& Sord., Icon. Ophid., No. xxxii, 1869, pl. i; Theob., Journ. Linn. Soc., vol. xi, 1868, p. 52 ; id., Journ. As. Soc., Bengal, vol. xxxvii, ex. No., 1868, p. 59 ; Stol., Journ. As. Soc., Bengal, vol. xlii, 1873, p. 162.

Dendrophis picta, Wagler, Syst. Rept., 1830, p. 183 ; Schleg., Phys. Serp., 1837, vol. i, p. 157, and vol. ii, p. 228, pl. ix, figs. 5-7; Dum. \& Bibr., Erpét. Gén., vol. vii, 1854, p. 197 ; Günth., Cat. Col. Sn., 1858, p. 148; Rept., B. Ind., 1864, p. 297 ; Stol., Journ. As. Soc., Bengal, vol. xxxix, 1870, pp. 137, 138, 141 ; id., op.cit., vol. xlii, 1873, p. 114; Anders., Journ. As. Soc., Bengal, vol. xl, 1871, 35; var. andamanensis; id., Proc. Zool. Soc., 1871, p. 184; Theobald, 
Descr. Cat. Rept., Brit. Ind., 1876, p. 190 ; Ferguson, Rept. Fauna, Ceylon, 1877, p. 20. Ahcetulla bellii, Gray, Ill. Ind. Zool., vol. i, 1834, pl. lxxx, fig. 2.

Dendrophis boii, Cantor, Proc. Zool. Soc., 1839, p. 53.

Leptophis pictus, Cantor, Journ. As. Soc., Bengal, vol. xvi, 1847 ; Cat., p. 930.

This species is prevalent at Bhamô.

The labials in the three specimens under consideration are variable. In one example there are 9 upper labials on one side and 10 on the other, and the tenth labial resulting from the division of the ninth: on both sides, the fourth, fifth and sixth are orbital. In the other two specimens there are only 8 upper labials, the fifth and sixth being united; the fifth alone entering the orbit.

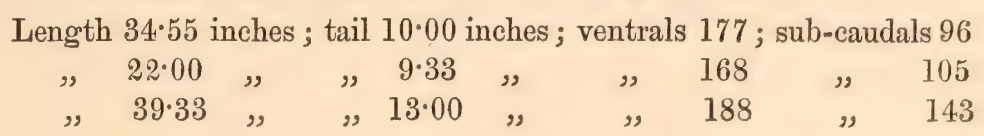

\section{Genus Chrysopelea, Boie.}

Chrysopelea ornata, Shaw.

Russell, Ind. Serp., vol. i, 1796, pl. ii.

Coluber ibiboboca, Latr. Rept., vol. iv, 1800, p.'131 ; Daud., Rept., vol. vi, 1803, p. 327.

Coluber ornatus, Shaw, Genl. Zool., vol. iii, 1802, p. 477.

Natrix ornata, Merr. Tentam, 1820, p. 109.

Tyria ornata, Fitz., New Class. Rept., 1826, p. 60.

Chrysopelea ornata, Boie, Isis., 1827, pp. 546, 547; Wagler, Amph., 1830, p. 188 ; Dum. \& Bibr., Erpét. Génl., vol. vii, 1854, p. 1042 ; Günther, Cat. Col. Snakes, 1858, p. 146 ; Rept. Brit. Ind., 1864, p. 298; Steind., Reise Novara Rept., 1867, p. 71 ; Jan \& Sord., Icon. Génl., No. xxxiii, 1869, pl. i, fig. 1 ; Stoliczka, Journ. As. Soc., vol. xxxix, 1870, pp. 141, 194; id., op. cit., vol. xliii, 1873, p. 114; Anderson, op. cit., vol. xl, 1871, p. 35; Theobald, Descr. Cat. Rept. Brit. Ind., 1876, p. 121 ; Ferguson, Rept. Fauna, Ceylon, 1877, p. 20.

Chrysopelea paradisi, Boie, Isis., 1827, p. 547; Wagler, Amph., 1836, p. 188.

Dendrophis ornata, Schlegel, Ess. Phys. Serpt., 1837, p. 234, pl. ix, figs. 8, 10 ; id., Abbild., 1837-44, pl. vi, figs. 1-10 ; Filippi, Cat. Mus., Pavia, 1840.

Leptophis ornata, Cantor, Journ. As. Soc., Bengal, vol. xvi, 1847, p. 934; Blyth, Journ. As. Soc., 1854, vol. xxiii, p. 293.

Dendrophis paradisi, Motley \& Dillwyn, Contrib. Nat. Hist., Labuan \& Borneo, 1855, p. 460, fig.

Ventrals 219. Sub-caudals imperfect. Anal bifid; 17 rows of seales. Five narrow gamboge-yellow cross-bands on the head, alternating with four broad black ones. The third black band is crescentic and the breadth of the diameter of the eye. It fills the intra-orbital space, and has a transverse line of three yellow spots. The fourth black band covers the occipitals, and has a transverse row of 12 yellow spots, with an odd one on either side. All the black bands are connected by another lateral one above the upper labials which are yellow. The back is crossed by black bands, the lateral margins of which are broken up into oblique black and yellow bars : these dorsal bands narrow posteriorly. All the scales are gamboge-yellow with a longitudinal black line through their centres, the hinder margin being tipped with black. The longitudinal black lines are continuous, and the dusky hinder margins form. fine oblique lines, and the two together constitute a fine black network on a rich 
yellow ground. A black spot on the keel of each ventral. This type of coloration agrees with snakes from the Khasia hills and Siam.

The foregoing specimen was captured at Mandalay in Upper Burma.

\section{DRYIOPHIDE.}

Genus Passerita, Gray.

Passeritia mycterizans, Linn.

Coluber mycterizans, Linn., Mus. Adolph. Frid., 1754, p. 28 ; Bonnat, Ophiol. Encycl. Méthod., 1784, pl. xxx, fig. 62 ; Russell, Ind. Serp., vol. ii, 1801, pls. xii and xiii ; Daud. Rept., 1803, vol. vii, p. 9, pl. lxxx, fig. 1.

Dryinus nasutus, Merr. Tentam, 1820, p. 136 (nec Bell) ; Dum. \& Bibr., Erpét. Gén., 1854, vol. vii, p. 809.

Dryinus oxyrhynchus, Bell, Zool. Journ., 1821, p. 325

Passerita mycterizans, Gray, Ann. Phil., 1825, vol. x, p. 208; Günth., Cat. Col. Sn., 1858, p. 160 ; id., Rept., B. Ind., 1864, p. 305 ; Proc. Zool. Soc., 1869, p. 502 ; Steind., Reise Novara, 1867, p. 73 ; Theobald, Journ. Linn. Soc., 1868, vol. x, p. 53 ; Jan \& Sord., Iconogr. Gén. Ophid. 1869, No. 32, pl. v ; Blanf., Journ. As. Soc., Bengal, 1870, p. 373 ; Theobald, Descr. Cat. Rept., Brit. Ind., 1876, p. 193 ; Ferguson, Rept. Fauna, Ceylon, 1877, p. 21.

Dryophis nasutus, Boie, Isis, 1827, p. 520; Guérin, Iconogr. Rept. Cuv. Reg. An., 1830, p. 22, fig. 2; Jan \& Sord., Iconogr. Gén. Oph., No. xxxii, pl. v, fig. 2.

Tragops nasutus, Wagler, Icon. Amphib., 1830, p. 184.

Dryiophis nasuta, Schleg., Phys. Serp., 1837, pl. x, fig. 1.

Herpetotragus nasutus, Fitz., Syst. Rept., 1843, p. 27.

This snake appears to be sparingly but generally distributed over Burma. Theobald has recorded it from Pegu, Prome, Thayetmyo and Tonghu, and I have now to extend its distribution to Bhamô. I did not meet with it in the high, region to the east of the last-mentioned locality.

\section{LYCODONTID王.}

\section{Genus Lrcodon, D. \& B.}

\section{LyCODON AULICUS, Linn.}

Rusșel, Ind. Serp., vol. ii, 1801, p. 42, pl. xxxix, var. A.

Coluber aulicus, Linn., Mus. Adolph. Frid, .1754, vol, i, p. 29, pl. xii, fig. 2 ; id., Syst. Nat., 12th ed., 1766, vol. i, p. 381.

Iycodon auticus, Boie, Isis, 1826, vol. xix, p. 981 ; Cantor, Journ. As. Soc., Bengal, vol. xvi, pt. 2, 1847, p. 915 ; Jerd., Journ. As. Soc., Bengal, vol, xxii, 1853, p. 528; Dum. \& Bibr., Erpét. Gén., vol. vii, 1854, p. 369; Günth., Cat. Col. Sn., 1858, p. 201 ; Rept. B. Ind., 1864, p. 316 ; Blyth, Journ. As. Soc., Bengal, vol, xxix, 1860, p. 110 ; Steind., Reise Novara, 1867, p. 74; Stol., Journ. As, Soc., Bengal, 1870, pp. 137, 141, 201; id., op. oit., 1873, pp. 115, 162 ; Jan \& Sord., Icon. Gén. Oph., No, xxxvi, 1870, pl. iv, fig. 1 ; Theobald, Descr. Cat. Rept., Brit. Ind., 1876, p. 199 ; Ferguson, Rept. Fauna, Ceylon, 1877, p. 21.

Lycodon hebe, Schleg., Phys. Serp., 1837, vol. ii, f. 106, pl. iv, figs. 1-3 (nec C. hebe, Daud.)

Tytleria hypsirhinoides, Theob., Journ. As, Soc, Bengal, vol, xxxvii, 1869, ex. No, p, 66; Journ. Linn. Soc, 1868, vol, x, p. 49, 
The following specimens from Bhamô and Ponsee agree in coloration with the variety $\gamma$ of Günther's Reptiles of India. In both examples the anal is bifid.

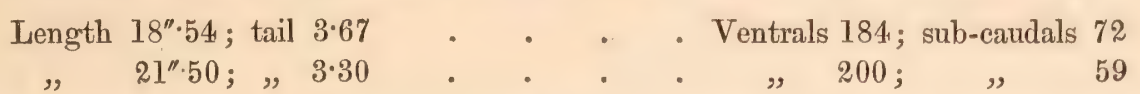

This species has now been received from Amoy, Ponsee, Bhamô, Assam and Agra. It extends also throughout the Peninsula of India to Ceylon, through Burma and the Malayan Peninsula to the Andamans, Nicobars, Java, Philippines and Timor.

\section{Genus Ophites, Wagler.}

\section{Ophites fasciatus, n. s. Plate LXXVIII.}

Head flat and rather spatulate, distinct from the neck. Anterior frontals rather broader than long; posterior frontals much more so ; vertical of moderate size nearly as broad as long; occipitals narrow and elongate; nostril between two nasals, the anterior frontal and the first labial. The loreal long and tapering to a point posteriorly and entering the orbit. One preocular reaching to the upper surface of the head. Two postoculars. Temporals $2+3+2$; two in contact with the postoculars. Eight upper labials, the third, fourth and fifth entering the orbit. The posterior chin-shields narrow and much longer than the anterior shields, which are in contact with five labials. The second and third teeth are elongated, followed, after a considerable interval, by two small teeth, the most posterior being the longer. These are succeeded by two much longer, almost fang-like teeth. The palatine teeth are numerous and sub-equal in size. The mandible has an anterior fang. Seventeen rows of feebly keeled scales, the keels becoming more pronounced posteriorly. Ventrals 213. Suboculars 90. The anal entire.

Total length 21 inches; tail $4: 34$.

Body encircled by fifty-five broad purplish-black bands separated by reddish intervals about half their breadth. Upper surface of the head dark-brown. Upper labials yellowish with dusky sutures. The first black band does not encircle the neck.

I captured this specimen at Ponsee.

This species differs from $O$. subscinctus in having a preocular along with the loreal entering the orbit, and in having two anterior temporals instead of one. The young of $O$. subscinctus has the body and tail embraced by only 13 broad black bands which, unlike $O$. fasciatus, do not extend on to the ventrals. O. albofuscus like $O$. fasciatus has a loreal and preocular, but the loreal does not enter the orbit, and the vertical is much broader anteriorly than in O. fasciatus and is slightly broader than long, which is the reverse of what occurs in the latter snake. The body of $O$. albofuscus is dorsally marked by 53 dark bands, but they do not pass on to the ventrals as in $O$. fasciatus, which is also the case with $O$. septentrionalis in which the shields of the posterior pair are shorter than the anterior, which is the opposite of what occurs in this species. In O. albofuscus there are 256 ventrals, but there are only 213 in this species. 


\section{ELAPID丑。}

\section{Genus NAJA, Laur.}

\section{NAJA TRIPUdians, Merr.}

Naja tripudians, Merr. Tentam. Syst. Amph, 1820, p. 147.

Both specimens are uniform brownish above, yellow beneath, with three broad blackish bands across the neck and forepart of the abdomen of the one, and two across the neck of the other. The under surface of the former is blotched here and there with brown, that of the latter is immaculate yellow. The inferior anterior temporal rests on the 5th and 6th labials.

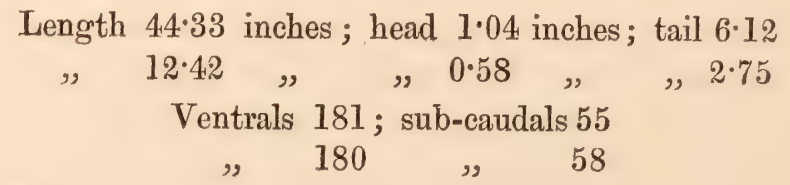

Mandalay and Momien.

\section{Genus Bungarus, Daud.}

\section{Bungarus fasciatus, Schneider.}

Russell, Ind. Serpt., vol. i, 1796, p. 3, pl. 3.

Psendoboa fasciata, Schneider, Hist. Amph., 1799-1800, p. 283.

Bungarus annularis, Daud., Rept., vol. v, 1811, p. 265, pl. lxv, figs. 1 \& 2 ; Schlegel, Phys. Serpt., vol. ii, 1837, p. 457, pl. 16, fig. 21 ; Abbild. 1837-44, pl. 18, figs. 1-5.

Aspidoclonion annulare, Wagler, Syst. Amph., 1830, p. 193.

Bungarus fasciatus, Cantor, Journ. As. Soc., Bengal, vol. xvi, 1847, p. 1034; Jerdon, Journ. As.

Soc., Bengal, 1853, vol. xxii, p. 522; Günther, Rept. Brit. Ind., 1864, p. 343 ; Theobald, Journ.

As. Soc., Bengal, vol. xxxvii, 1868, p. 73 ; id., Journ. Linn. Soc., 1868, p. 62 ; id., Descr.

Cat. Rept. B. Ind., 1876, p. 216 ; Fayrer, Thanatoph. India, 1872, pl. 9.

Only one example of this species passed under my observation in Upper Burma, having been captured at Tsagain on the right bank of the Irawady.

\section{CROTALID A}

\section{Genus Trimeresurus, Günther.}

\section{Trimeresurus gramineus, Shaw.}

Russell, Ind. Serpt., vol. i, 1796, p. 13, pl. ix.

Coluber gramineus, Shaw., Genl. Zool., 1802, vol. iii, p. 420.

Vipera viridis, Daud., Rept., vol. vi, 1803, p. 112.

Cophias viridis, Merrem, Tentam, 1820, p. 155.

Trigonocephalus viridis, Schlegel, Ess. Phys. Serp., 1837, p. 544, pl. 19, figs. 12, 13.

Irigonocephalus gramineus, Cantor, Journ. As. Soc., Bengal, vol. xvi, 1847, p. 1040.

Trimeresurus viridis, Gray, Zool. Miscell., 1842, p. 48; Ann. \& Mag. Nat. Hist., 1853, vol. xii, p. 391 ; Cat, Snakes, B. M., 1849, p. 7. 
Trimeresurus elegans, Gray, Ann. \& Mag. Nat. Hist., vol. xii, 1853, p. 391.

Botkrops viridis, Dum. \& Bibr., Erpét. Génl., vol, vii, 1854, p. 1513.

Trineresurus gramineus, Günth., Rept. Brit. Ind., 1864, p. 385; Theobald, Journ. As. Soc., Bengal, vol. xxxvii, ex No., p. 75 ; id., Journ. Linn. Soc., Lond., vol. xi, 1868, p. 64; id., Descr. Cat. Rept. B. Ind., 1876, p. 219 ; Stoliczka, Journ. As. Soc., Bengal, vol. xxxix, 1870, pp. 141, 216; Anderson, op. cit., vol. xl, 1871, p. 37 ; id., Proc. Zool. Soc., 1871, p. 194.

A specimen from Ponsee measures 14 inches, of which the tail forms 1.92 inches. The ventrals are 174, and the sub-caudals 58. The only particular in which this snake differs from the hitherto known examples of this species is in the presence of 23 instead of 21 rows of scales. The supranasals are separated from each other and from the rostral by an azygos plate nearly equalling a supranasal in size. The scales of the upper surface of the head are imbricate and smooth. The superciliary is long and undivided. General colour grass-green, lighter on the sides and pale yellowish-green on the under surface. The upper lips pale-green.

I have compared this specimen with the snakes referred by Günther to this species, and with Cantor's $T$. gramineus and with the types of $T$. viridis and T. elegans, Gray, from which it is in no way specifically separable.

In the snake from the Himalaya, collected by Dr. Hooker and referred by Dr. Gray to $T$. viridis, two shields intervene between the supranasals; the first labial is distinct from the nasal, but two shields exist between the supranasals and the loreal, one of these on the right side being confluent with the supranasal. It is interesting to observe that this latter asymmetrical detail is exactly reproduced in another snake, also obtained by Hooker in the Himalaya, and regarded by Gray as the type of a new species, $T$. elegans. The latter differs from the former, among other subordinate details, in having only one shield between the supranasals. In one of Cantor's specimens from Bintal, referred to this species, I observe that the first labial and nasal are united except behind the nostril, and that a similar arrange ment exists in a Rangoon specimen, but in other Penang snakes of this species these two plates are distinct. It is extremely difficult, however, in many instances to distinguish between examples of $T$. bicolor, Gray, and T. gramineus, but the former would appear to be recognizable from the latter by its smaller head. scales, the stronger carination of its supraorbitals and temporals, and in the more elongated character of its body scales, in all of which respects it differs also from T. albolabris, which is in no way separable from T. erythrurus, Cantor. I make these remarks because it does seem that T. carinatus, Gray, to which T. bicolor, Gray, has been relegated as a synonym, is specifically distinct, whereas some doubt does exist as to the specific distinctness of $T$. carinatus, Gray, and T. purpureus, Gray. The type of $T$. carinatus ${ }^{1}$ is a dark brownish-purple snake, but with a greenish tinge on the side, and with a pale lateral streak, and with dusky undere parts, and with narrower ventrals than the green snakes ( $T$. bicolor) which have 
been referred to it. Its ventrals are 163 and its sub-caudals 76 , and it has 25 rows of strongly keeled scales. The scales on the upper surface of the head are small and tubercular, the scales on the temporal region being only feebly keeled. The two supranasals are separated from each other by two shields and by a small granule in front of the left shield, but such an arrangement is evidence itself of variability in this region. Two plates between the loreal and supranasals. The first labial is confluent with the nasal. Compare with this the following characters of the type of $T$. purpureus, Gray. The colour is uniform reddish-brown above, with a tinge of purple on the side of the head and indications of a pale lateral line along the body; the ventrals dusky, numbering 164, and the sub-caudals 61 ; the rows of scales 28. The upper surface of the head is covered with rather small tubercular scales; the scales of the body being moderately keeled. No azygos shield, but two small shields, one behind the other, between the supranasals. In Cantor's specimens of $T$. puniceus there is an azygos shield and the superciliaries are sometimes divided, and there is a long subocular which are some of the characters assigned by Stoliczka to T. mutabilis. 'The first labial in the type and in T. puniceus is united to the nasal, as in $T$. mutabilis. In the types of $T$. puniceus there are, as in T. carinatus and as occasionally in T. mutabilis, 3 rows of scales between the infraoculars and labials. The coloration of $T$. mutabilis is much the same as in $T$. puniceus. In the type of the former species, I have counted 25 rows of scales, so that the scales are thus only two rows in excess of the snake from the same area described by Steindachner as $T$. labialis, and which agrees in other respects with $T$. purpureus, from which $T$. cantoris, Blyth, does not appear to be separable.

This snake was found in the forest surrounding Ponsee, at an elevation of 3,500 feet, and it has been found on the east coast of China.

\section{Trimeresurus erythurus, Cantor.}

Russell, Ind. Serpt., vol. ii, 1801, pl. 20,

I'rigonocephalus erythurus, Cantor, Proc., Zool. Soc., 1839, p. 31.

Trimeresurus albolabris, Gray, Zool. Miscell., 1842, p. 48.

Trimeresurus erytturus, Gray, Cat. Snakes, B. M., 1848, App., p. 115 ; Günther, Rept. Brit. Ind., 1864, p. 386 ; Steindach., Reise Novara Rept., 1867, p. 86 ; Theobald, Journ. Linn. Soc., vol. $x_{\text {, }}$ 1868, p. 64; id., Dum., Cat. Rept. B. Ind., pars, 1876, p. 220 ; Fayrer, Thanatophidia, 1872, pl. 14; Stoliczka, Journ. As. Soc., Bengal, vol. xxxix, 1870, p. 217; id., op. cit., vol. xlii, 1873, p. 115 ; Anderson, id., op. cit., vol. xl, p. 37.

The head in front of the angle of the mouth broad, nearly twice the breadth of the space between the anterior angle of the eyes. Snout rather pointedly arched. Two pairs of shields on the upper part of the snout, the anterior pair in contact behind the rostral. A small azygos shield sometimes intercalated between them and the rostral, but not separating them entirely from that shield. These two pairs of shields, and the small azygos one, when it occurs, evidently result from the breaking up of one original pair. Superciliaries elongated and not divided. The second labial forms the front of the facial pit. The nasal is united to the first 
labial by a narrow isthmus in front of the nostril ; twenty-one rows of keeled scales. Dark gamboge-green on the back, brilliant yellow-green on the sides above the ventrals, pale-green on the under surface, a bright brick-red line along the upper surface of the tail. The side of the head in adults, pale bluish-green. The ventrals with yellow posterior margins. In a young specimen, there is a pale yellowish-green line from the nostril, below the eye, to the neck; but along the sides of the body it is prolonged as a white line. A few very obscure reticulated deep-blue lines on the sides of the face and chin in both young and old.

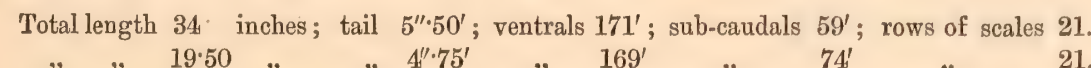

I am indebted to Professor Rolleston of Oxford for the opportunity to examine the type of this species which is preserved in the Museum of that University, and which he forwarded to me in London, in order that I might compare it with the type of $T$. albolabris in the British Museum and with the specimens from Upper Burma, on which these remarks are based.

In the type, as in the latter specimens, the scales on the upper surface of the head are moderately large, slightly imbricate, smooth on the vertex, but slightly keeled on the temporal region and nape, and below the eye, where one row of scales intervenes between the infraocular and the labials. The superciliary, as in the specimens from Upper Burma, is long and narrow, but only two large shields occur behind the rostral. That little specific importance, howerer, can be attached to this character, is proved by a consideration of the various accepted species of Trimeresuri, for in all of them these shields, when they exist, are occasionally liable to be broken up. The first labial in the type is united to the nasal, but this is also a variable character, for in some individuals no such union takes place. It has also twenty-one rows of feebly keeled scales, which is the prevalent number in the majority of the examples of this species which have passed under my observation. The colour of the upper parts is grass-green, paler on the sides, and that of the lower surface is greenishyellow. The lips are pale yellow, and there is no temporal band. The pale labial band is well developed, and the tail is brownish and transversely reticulated with blackish. Stoliczka was disposed to consider that the usual number of the rows of scales round the body in the adult is 23 , and that the number 21 is distinctive of the young. His remarks, however, seem to apply only to examples of the species from Moulmein.

\begin{tabular}{|c|c|c|c|c|c|c|}
\hline Type of $T$. albolabris, & $\begin{array}{l}\text { Body. } \\
18 \cdot 00\end{array}$ & celes, & $\begin{array}{l}\text { Tail. } \\
2 \cdot 75\end{array}$ & $\begin{array}{c}\text { Ventrals. } \\
153\end{array}$ & $\begin{array}{c}\text { Sub-caudals. } \\
49\end{array}$ & $\begin{array}{c}\text { Rows of scale } \\
21\end{array}$ \\
\hline,$\quad$, & $14: 75$ & , & $3 \cdot 50$ & 156 & 59 & 21 \\
\hline Formosa & $17 \cdot 40$ & , & $4 \cdot 50$ & 155 & 66 & 21 \\
\hline ,; & $15 \cdot 75$ & , & $\because \cdot 75$ & 150 & 63 & 21 \\
\hline Hong-Kong & $19 \cdot 50$ & , & $3 \cdot 00$ & 164 & 53 & 21 \\
\hline Siam & $12 \cdot 13$ & , & $1 \cdot 75$ & 159 & 44 & 21 \\
\hline Pachebone & $24: 25$ & , & $4 \cdot 25$ & 168 & 54 & 21 \\
\hline Java & $28 \cdot 25$ & , & $4: 75$ & 160 & 60 & 21 \\
\hline ? India & $19 \cdot 25$ & , & $5^{\circ} 00$ & 161 & 75 & 21 \\
\hline Moulmein (Stoliczka), & $20^{\circ}$ & ", & $5 \cdot 00$ & 157 & 63 & 23 \\
\hline , & 8 & $y$ & 250 & 167 & 63 & 21 \\
\hline
\end{tabular}


As in T. monticola, the sub-caudals of this species have some of their number entire.

This species does not appear to be so arboreal in its habits as some of the others. Stoliczka obtained it on the limestone hills near Moulmein, and Theobald records that he found a single specimen in the caves near the same locality. The larger of the two specimens I procured, I encountered on the limestone rocks, below the Yethaycoo pagoda, in the second defile of the Irawady, lying coiled up on the ground, ready to strike.

Trimeresurus monticola, Günther. Plate LXXVI, figs. 4 \& 5.

Parias maculata, Gray, Ann. and Mag. Nat. Hist., vol. xii, 1853, p. 392.

Trimeresurus monticola, Günther, Rept. Brit. Ind., 1864, p. 388, pl. xxiv, B.; Theobald, Journ. As. Soc., Bengal, vol. xxxvii, 1868, ex No., p. 76 ; id., Deser. Cat. Rept., Brit. Ind., 1876, p. 220 ; Anderson, Proc. Zool. Soc., 1871, p. 194; Fayrer, Thanat. of India, 1872, pl. xv.

In the valley of Hotha, this species is not at all uncommon, and I obtained four examples of different ages. Two of these specimens, unlike the types of the species and the other examples from Western Yunnan, have the second labial distinct from the plate in front of the facial pit. In the T. mutabilis, Stoliczka, the second upper labial may either form the front of the facial pit, or it may occasionally be divided in two. A similar variation occurs in the Trimeresurus referred by Stoliczka to $T$. andersoni. This variation, however, as far as my observations go, would appear to be a rare occurrence, because in the extensive series of Trimeresuri in the British Museum, I have failed to detect a single instance in which the second labial when it forms the front of the facial pit is completely divided, or an example in which the second labial, when it does not enter into the facial pit, unites with the shield that does. In one individual, however, of $T$. anamallensis, the second labial shows a tendency to division on one side. The occasional division, however, of the second labial into a facial pit-shield in T. monticola and in T. mutabilis introduces another element of difficulty in determining what are really reliable specific characters, so far as the Trimeresuri are concerned; for those characters, which, in other snakes, are generally guides to the species by reason of their stability, are obscured in the Trimeresuri by their variability.

The scales in these Yunnan specimens which are all from one locality, viz., the outskirts of the small town of Hotha, vary from 23 to 25, but in Himalayan examples of the species there are occasionally 26 rows of scales. The ventrals in the two specimens in which the second labial does not enter into the facial pit number 151 and 156 each, with 41 and 57 sub-caudals respectively with the anal 
in both entire. To illustrate the variations which occur in the ventrals and sub-caudals of this species I give the following table.

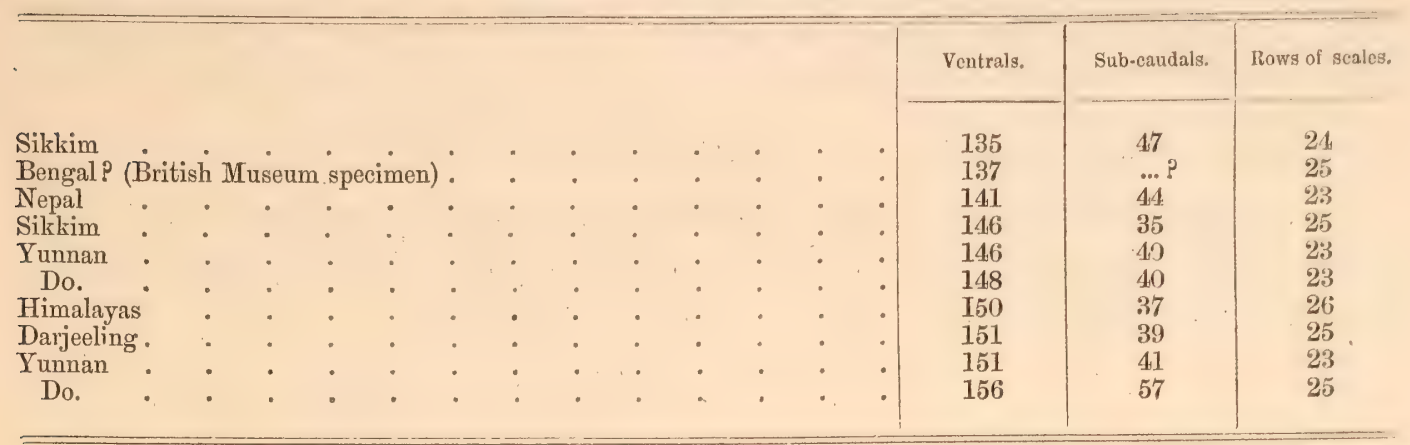

In one of these Yunnan specimens with the divided second labial, many of the sub-caudals are simple.

There is thus in this species a variation in the ventral and sub-caudal shields of 21 to 32 respectively, and the preceding table would seem to indicate that when there is a diminution in the number of the ventrals, there is not of necessity any corresponding reduction of the sub-caudals, and vice versa $\vec{a}$. I have recorded elsewhere, ${ }^{1}$ that variations in the number of head-shields are inaugurated in utero, and $I$ have observed that the number of the ventrals and sub-caudals vary in the individuals of a brood.

The snields or scales between the supranasals, as is in other species of Trimeresuri, are variable and do not offer any specific characters. They may either be absent or be represented by one or by a pair of small scales or shields.

An adult female measures 30 inches', of which the tail is 4.50 inches, and a male $6 \cdot 12$ inches and its tail $3 \cdot 35$ inches.

A closely allied, if separable form, is the young snake from Penang described by Stoliczka as $T$. convictus ${ }^{2}$ and which he long hesitated to separate from this species.

\section{VIPERID $Æ$.}

\section{Genus Daboia, Gray. \\ Dabota RUSSEllit, Shaw.}

Coluber russellii, Shaw, Gen. Zool., 1802, vol. iii, p. 418.

Vipera daboia, Daud., Rept., 1802, vol. vi, p. 119; Wagl., Syst., 1830, p. 177.

Vipera elegans, Daud., Rept., vol. vi, p. 124, pl. lxxiii ; Wagl., Syst., 1830, p. 177; Schleg., Phys. Serp., 1837, vol. ii, p. 588, pl. xxi, figs. 4 and 5.

Coluber triseriatus, Hermann, Obs. Zool., 1804, vol. i, p. 278.

Echidna elegans, Merr. Tentam., 1820, p. 153 ; Dum. \& Bibr., 1854, vol. vii, p. 1435.

Daboia pulchella, Gray, Zool. Misc., 1842, p. 69.

Daboia russellii, Gray, Zool. Misc., 1842, p. 69 ; Cat. Snakes, 1849, p. 24; Günth., Rept. B. Ind., 1864, p. 396 ; Theobald, Descr. Cat. Rept., Brit. Ind., 1876, p. 217 ; Stol., Journ. As. Soc.,

${ }^{1}$ Proc. Zool. Soc., 1871, p. 180, p. 195.

2 Journ. As. Soc, Bengal, 1870, vol, xxxix, p. 224. 
Bengal, vol. xxxix, 1870, pp. 142 and 226; Blanfd., Journ. As. Soc., Bengal, 1870, p. 374; Anders., Journ. As. Soc., Bengal, vol. xl, 1871, p. 37; Fayrer, Thanatoph., 1872, pl. xi; Ferguson, Rept. Fauna, Ceylon, 1877, p. 25.

Echidna russellii, Steind., Reise Novara, 1867, p. 88.

Daboia elegans, Theob., Journ. Linn. Soc., vol. x, 1868, p. 64; Journ. As. Soc., Bengal, vol. xxxvii, 1868, p. 77.

Tipera russellii, Strauch., Mém. St. Pétersbourg, vol. xiv, 1870, p. 85.

I captured one example of this species at Pagan in Upper Burma, but quite young, measuring only 25 inches. The ventrals are 164 , and the sub-caudals 45 , and there are 29 rows of scales. 


\section{A M P H I BI A}

COLIECTED ON THB

TW0 EXPEDITIONS

ro

WESTERN YUNNAN. 



\title{
AMPHIBIA.
}

\author{
ANURA.
}

RANIDE.

\section{Genus Rana, Auct.}

Rana tigrina, Daud.

Rana tigrina, Daud., Hist. Rept., 1803, vol. viii, p. 125; Hist. des Rainettes, \&c., 1803, p. 64, pl. xx; Merrem. Tent. Syst. Amph., 1820, p. 174; Dum. \& Bibr., Erpét. Génl., vol. viii, 1841, p. 375 ; Cantor, Journ. As. Soc., Bengal, 1847, vol. xvi, p. 1060 ; Kelaart, Prod. Journ. Zool., 1852, p. 192; Jerdon, Journ. As. Soc., Bengal, vol. xxii, 1853, p, 531 ; Günther, Cat. Batr. Sal., 1858, p. 9 ; Rept. Brit. Ind., 1864, p. 407 ; Peters, Monats. Berl. Akad., 1863, p. 77 ; Steind., Rept. Reise Novara, 1867, p. 18, pl. i, figs. 14-17; Theobald, Journ. As. Soc., Bengal, vol. xxxvii, 1868, p. 79 ; Stoliczka, Proc. As. Soc., Bengal, 1872, pp. 85-102; Journ. As. Soc., Bengal, 1873, vol. xlii, p. 112 ; Ferguson, Rept. Fauna, Ceylon, 1877, p. 26.

Rana mugiens, Daud., Rainettes, \&c., 1803, pl. xxiii (not descr.) ; Latr. Rept., 1801, vol. ii, p. 153 (in part).

Rana picta, Gravenh., Delic. Mus. Zool. Vratislav. (Batr.), 1829, p. 39.

Rana cancrivora, Gravenh., Delic. Mus. Zool. Vratislav. (Batr.), 1829, p. 41 ; Tschudi, Classif. Batr. Mém. Soc. Sc. Nat. Neuchat., vol. ii, 1839, p. 79.

Rana brama, Lesson, Zool. du Voy. de Bélanger, Rept., 1834, p. 329, pl. vi.

Rana munlosa, Weigm., Nov. Act. Acad. C. Leop., vol. xvii, 1835, p. 255, pl. xxi, fig. 1.

Rana vittigera, Weigm., Nov. Act. Acad. C. Leop., vol. xvii, 1835, p. 258, pl. xxi, fig. 2.

The specimens of this frog which were collected in Hotha have the limbs slightly shorter than the length of the body, which is in reverse proportion to what prevails in Indian individuals. But in all other characters they conform.

The males during the breeding season are pale greenish-yellow with dark spots and a pale vertebral streak, and are smaller than the females which are greyish-olive with dark spots.

This species has a very wide distribution, extending from China and the Malayan Peninsula through Burma, India, Ceylon and the lower or outlying ranges of the Himalayas as far west as the Indus.

\section{RANA FUSCA, Blyth.}

Rana fusca, Blyth, Journ. As. Soc., Bengal, vol. xxxiv, pp. 719-720; Günther, Rept. Brit. Ind., 1864, p. 403; Theobald, Cat. Rept. As. Soc. Mus., 1868, p. 79 ; Günther, Proc. Zool. Soc., 1868, p. 478; Anderson, Proc. Zool. Soc., 1871, p. 197; Stoliczka, Journ. As. Soc., Bengal, vol. xlii (1873), p. 115. 
This species approaches $R$. hexadactyla and $R$. cyanophlyctis, but it is distinguished from the former by its distinct and smaller tympanum, larger vomerine teeth, by the absence of the transverse fold between the orbits, by its emarginate interdigital membrane, and by the character of its coloration; and from the latter by its distinct and smaller tympanum, prominent vomerine teeth and by the metatarsus being destitute of a fold. On the other hand, it is more allied to $R$. tigrina in the character of its vomerine ridges, and still more so to $R$. kuhlii in its fang-like processes in the lower jaw, the character of its tympanum and metatarsal tubercle.

It occurs at Mandalay, but I did not observe it in the neighbourhood of Bhamô, below which town, however, I obtained one example of $R$. kuhlii, which is the common frog in the Kakhyen hills and in the high valley of Hotha.

\section{RANA KUHLII, Schlegel.}

Rana kuhlii, Schlegel, Mus. Ludg. Batav. ; Dum. \& Bib., Erpét. Génl, vol. viii, 1841, p. 384; Günther Cat. Batr. Sal. B. M., 1858, p. 8 ; Rept. Brit. Ind., 1864, p. 404, pl. xxvi, A. B. ; Theobald, Journ. As. Soc., Bengal, vol. xxxvii, 1868, p. 80 ; Anderson, Proc. Zool. Soc., 1871, p. 197 ; Journ. As. Soc., 1871, p. 37 ; Stoliczka, Proc. As. Soc., Bengal, 1872, p. 145 ; Ferguson, Rept. Fauna, Ceylon, 1877, p. 26.

Rana.corrugata, Peters, Monatsber. Berl. Akad., 1863, p. 412.

Rana conspicillata, Günther, Proc. Zool. Soc., 187\%, p. 597, pl. lx, fig. A.

I obtained one example of this species in the second defile of the Irawady on the left bank of the river, and numerous specimens of all ages at Ponsee in the Kakhyen hills and from the still higher elevation of Hotha further to the east.

In all of these examples, the skin of the head and back, and of the upper surface of the thighs, is perfectly smooth, but in the young there are a few obscure tubercles on the sides of the body. All the specimens, however, with the exception of an adult male, have the inner aspect of the tarsus, the undersurface of the metatarsus, and the upper surface of the lower half of the calf of the leg roughly tubercular, the tubercles being especially large on the latter region. The metatarsal fold and the fringe of the toes are also roughly granular. The toes are completely webbed, but the membrane is more or less emarginate.

The young are light greenish-brown marbled with darker, but the adults are generally so dark that the marbling cannot be traced. There is a black band between the eyes in young specimens, and a pale yellow band from the snout through the eye to the tympanum. The under surface also is quite smooth, and is yellowish mottled with dark-brown on the throat and chest, the sides of the abdomen and on the under surface of the limbs. Some of the young specimens show indistinct dorsal folds. Only one out of the 33 collected shows a yellowish dorsal line. The fang-like apophyses of the lower jaw are well developed.

These specimens resemble the types in the Leyden Museum in having the sides of the body slightly tubercular, but, unlike them, they have the skin of the surface of the body thrown into fine folds, marked by small eminences with pore. 
like depressions, - a character which is also observed in examples of the species from Ningpo.

The Yunnan specimens more closely resemble the frogs from Borneo, which were described by Günther as $R$. conspicillata, but which he now allows to be one of the many varieties of this widely distributed species.

In the British Museum, there is a frog from Ningpo distinctly referable to this species, and which is characterised by the same fine transverse, almost concentric and wary, glandular ridges which have been observed in Ceylon examples of the species. It is a circumstance worthy of note that this specimen shows no trace of vomerine teeth, and yet the body alone measures 2.10 inches, and has strongly developed apophyses on the lower jaw.

\section{Rana yUnnanensis, n. s., Plate LXXVIII.}

Head broader than long; the snout rounded and somewhat pointed; nostril nearer the snout than the eye ; canthus rostralis feeble; tympanum visible, but indistinct, half the size of the eye; a glandular fold from the eye over the tympanum to the shoulder ; vomerine teeth but little developed and in two short oblique ridges, on the inner side of the choanæ, convergent behind, but separated from each other by a wide interval. Openings of the internal nostrils small, round, those of the eustachian tubes very small. Tongue free, cordate, deeply notched. A feeble fold along the metatarsus and along the first toe enclosing a small but strong laterally compressed sharp-edged crescentic tubercle. A fold along the fifth toe. Fingers tapering, tips not enlarged; the first, second, and fourth subequal in size, the third slightly longer than the second, a few minute horny spines on the upper surface of the thumb. Toes incompletely webbed, the membrane emarginate, reaching to the extremities of all the toes but the fourth: fourth toe, one-third longer than the third. Upper surface densely covered with round warty tubercles, each surmounted by a small black horny granule. Smooth beneath. Uniform greenish olive-brown, with obscure dark bands from the orbit to the lip and on the upper surface of the limbs; under surface brownish-yellow, reticulately spotted with deep brown. From the vent to the metatarsal tubercle is rather more than the length of the body. Length of body $2^{\prime \prime}: 08$ : vent to metatarsal tubercle $2 " \cdot 16$. The two specimens were procured at Hotha, 5,000 feet above the sea.

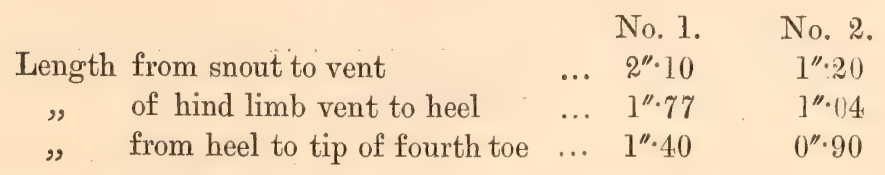

From the obscure nature of the vomerine teeth in this species, and its general resemblance to Dicroglossus adolfi, I was at first disposed to refer it to the genus Dicroglossus, but the unquestionable presence of vomerine teeth proved it to be a Ranu. The types of Dicroglossus adolfi possess posteriorly convergent eminences from the inner margins of the choanæ, which feel rugose when a fine instrument is drawn 
across them, thus suggesting the presence of vomerine teeth. They are small frogs, the largest measuring only $1 " 56$ from the tip of the snout to the vent.

R. yunnanensis differs from $D$. adolfi in having a broader snout; its nostrils placed further apart; not so broadly webbed toes; and the membrane of the fourth toe stopping short at the distal end of the second phalanx, while in $D$. adol $f$ it reaches to the extremity of that toe. The metatarsal tubercle of the latter species is, unlike that of $R$.yunnanensis, rather free and pointed; and a small tubercle exists at the base of the fifth toe, which does not occur in $R$. yunnanensis, and the folds along the inmost and outermost toes are much broader than in the last-mentioned species.

It is distinguished from $R$. kuhlii by its shorter and more rounded snout, and by its nostrils being placed more superiorly and nearer to the eye than in that species, and more on the upper surface of the head; the canthus rostralis being but little developed. Other features by which it is recognizable from $R$. kuhlii are its visible tympanum, complete absence of apophyses on the lower jaw, and by its widely separated vomerine ridges.

It is closely allied to R. verrucosa, Günther, from Malabar, but differs from it in its broader snout, and in its laterally compressed sharp-edged metatarsal tubercle, but this structure has none of the pronounced character which is assumed by the metatarsal tubercle of Pyxicephalus.

\section{RANA GRACILIS, Wiegm.}

Rana gracitis, Wiegm., Nov. Acad. Leop. Carol., 1835, vol. xvii, p. 257 ; Peters, Monatsber., Berl. Akad., 1863, p. 78; Günther, Rept. Brit. Ind., 1864, p. 409 ; Steind., Reise Novara Rept., 1867, p. 18; Stoliczka, Journ. As. Soc., Bengal, 1870, pp. 136, 139, 142 ; Blanford, Journ. As. Soc., Bengal, 1870, p. 374; Anderson, Proc. Zool. Soc., Lond., 1871, p. 200.

Rana vittigera, Günther, Cat. Sal. Batr., 1858, p. 9 (not Wiegm.) ; Theobald, Journ. As. Soc., Bengal, 1868, p. 80.

Rana limnocharis, Stoliczka, Proc. As. Soc., Bengal, 1872, p. 102.

In the specimens from Ponsee and Hotha the snout is pointed, and in a few there are distinct traces of a metatarsal fold. In some cases it can be detected on one leg and not on the other. The cutaneous fold along the fifth toe is well developed. In the males, a large black patch involves the anterior half of the rocal sacs.

This is a very common species in the Hotha valley, but the adults are not so large as specimens in the valley of the Irawady. 
ENGYSTOMATIDA.

Genus Diplopelma, Günther.

Diplopelma carnaticum, Jerdon.

? Engystoma carnaticum, Jerdon, Journ. As. Soc., Bengal, 1853, vol, xxii, p. 534.

Diplopelma carnaticum, Jerdon, Proc. As. Soc., Bengal, 1870, p. 85 ; Stoliczka, Journ. As. Soc., Bengal, 1870, vol. xxxix, p. 154, pl. ix, fig. 5.

The specimens from Lower Burma and from Tsitkaw, in Upper Burma, agree with the frogs which Stoliczka referred to under this name, on the authority of Dr. Jerdon.

I obtained this frog under logs of wood near the banks of the Tapeng, during the month of February.

\section{Genus Calluia, Gray. \\ CALLULA PULCHRA, Gray.}

Kaloula pulchra, Gray, Zool. Miscell., 1842, p. 38 ; Günther, Cat. Batr. Sal., 1858, p. 123.

Hyladactylus bivittatus, Cantor, Journ. As. Soc., Bengal, vol. xvi, 1847, p. 1064; Theobald, ibid., vol. xxxvii, 1868, p. 86.

Callula pulchra, Günther, Rept. Brit. Ind., 1864, p. 437 ; Stoliczka, Journ. As. Soc., Bengal, 1870, vol. xxxix, p. 139, p. 155 ; ibid., 1873, vol. xli, p. 114; W. T. Blanford, ibid., 1870, vol. xxxix, p. 375 ; Anderson, Proc. Zool. Soc., 1871, p. 211.

I obtained this beautiful frog in the month of October along with Bufo melanostictus under fallen brick-work of the ruins of Ava. Stoliczka has observed that it appears after sunset about the same time as B. melanostictus, and that it feeds on white ants. The remarks on the systematic position of this frog by that accomplished Zoologist are characterized by the usual sagacity which distinguished his reflections on the affinities of animals, and it is probable that the genus Callula, as pointed out by him, is closely allied to Diplopelma, and should be ranked alongside of it.

The frog does not appear to be abundant, and it was not observed in the neighbourhood of Bhamô, nor in the Kakhyen hills.

\section{BUFONID丑.}

Genus Bठfo, Auct.

Bufo melanostictus, Schneid.

Bufo melanostictus, Schneid., Amph. Fascic. i, 1799, p. 216 ; Gravenh., Delic. Mus. Vratislav., 1829, p. 57 ; Cantor, Journ. As. Soc., Bengal, vol. xvi, 1847, p. 1063; Günther, Cat. Batr. Sal., 1858, p. 61 ; Rept. Brit. Ind., 1864, p. 422 ; Steind., Reise Novara, 1867, p. 42 ; Theobald, Journ. As. Soc., vol. xxxvii, 1868, p. 83 ; Stoliczka, Journ. As. Soc., Bengal, vol. xxxix, 1870, pp. 136, 140, 156; vol. xlii, 1873, pp. 112 and 163. 
Bufo scaber, Daud., Hist. Rept., vol. viii, 1803, p. 194; Hist. Rain., 1803, p. 94, pl. xxxiv, fig. 1 ; Latr., Hist. Rept., vol. ii, 1825, p. 134; Schleg., Abbild., 1837-44, p. 63, pl. xx, fig. 2 ; Tschudi, Mém. Soc., Neuchat., 1839, vol. ii, p. 88; Dum. \& Bib., vol. viii, 1841, p. 699.

Bufo bengalensis, Daud., Hist. Rain., 1803, p. 96, pl. xxv; fig. 1; Hist. Rept., vol. viii, 1803, p. 197 ; Less. Voy. Bélanger, Rept., 1834, p. 334.

Bufo carinatus, Gray, Ill. Ind. Zool., 1832, vol. i, p. 83, fig. 1.

Bufo dubia (Shaw) Gray, Ill. Ind. Zool., 1832, vol. i, p. 83, fig. 2.

Two specimens are from Prome, five from Ava, six from Ponsee, two from Momien, and one from Hotha. In the two adults from Prome, a number of the tubercles between the two prominent metatarsal tubercles have united, evidently by pressure, to form a flat black horny-like disc. The gradual formation of this disc can be traced in the other specimens. In young individuals from Ponsee and Momien, small tubercles occur far forwards on the top of the snout. The vertebral series of large tubercles ean hardly be distinguished from others in that region. The head of the large adult from Hotha is more triangular than in the Prome specimens. In very young ones from Ava, the warts and all the tubercles on the head defining the position of the future ridges are bright pink. They have also a faint interocular band.

In travelling down the Irawady to Mandalay my attention was attracted one evening, after my boat had been moored for the night, by a loud croaking, only a few yards off, close by the margin of the river. The sound was so loud that I resolved to ascertain what species produced it, and accordingly I had a torch lit and proceeded in the direction of the sound, and soon came upon a pair of toads, seated upon a floating bamboo, with up-lifted heads and dilated throats. They ceased immediately the light approached, but began again after a few seconds, when I secured both, and found that they were examples of this species. I was quite unprepared to find that the very loud sound was produced by this species, as Cantor has described its call as a plaintive chirping sound.

This toad is prevalent in Upper Burma and in the high country to the east as far as Momien, where it is interesting to observe that it is associated with the newt Tylototriton.

\section{POLYPEDATID无.}

\section{Genus Polypedates, Dum. \& Bib.}

\section{Polypedates marmoratus, Blyth.}

Polypedates marmoratus, Blyth, Journ. As. Soc., Bengal, 1856, vol. xxiv, p. 188; Theobald, Cat. Rept. Mus. As. Soc., Bengal, Journ. As. Soc., Bengal, Ext. No. 1868, vol. xxxvii, p. 85; Anderson, Proc. Zool. Soc., 1871, p. 209 ; Journ. As. Soc., Bengal, vol. xl, p. 38 ; Stoliczka, Proc. As. Soc. Bengal, 1872, p. 108.

Polypedates afghana, Günther, Cat. Brit. Sal., 1858, p. 81 ; Rept. Brit. Ind., 1864, p. 432.

Polypedates (?) marmoratus, Günther, Rept. Brit. Ind., 1864, p. 428.

Amolops afghanus, Cope, Nat. Hist. Rev., 1865, p. 117.

Blyth's example of this species was from Pegu; but the species has since been obtained in Sikkim, at an elevation of 3,000 feet, and also in the Khasia hills. 
The Yunnan specimens were found at Ponsee in the Kakhyen hills at an elevation of 3,500 feet.

These last-mentioned examples of the species exactly agree with the type of $P$. afghana, Guinther, in the British Museum, and with the specimens in Calcutta which yielded the $P$. marmoratus, Blyth, with the exception that the latter is somewhat granular on the upper surface.

The type of $P$. afghana has the skin perfectly smooth; but the side, lower front of the belly and around the vent are slightly glandular. The Yunnan specimens entirely agree with it in these respects and in its coloration, which above is brown, being finely marbled or spotted with pale yellowish-brown, but so minutely that at a distance the general colour appears to be brown. The under surface is pale yellowish and unspotted.

In the British Museum there is a specimen from Darjeeling corresponding to $P$. marmoratus, Blyth, and which, like it, has the upper surface very finely glandularly granular, and the sides of the belly more coarsely so. The under surface of this specimen is also immaculate. In another and still larger example conforming in its colouring of its upper parts to the type $P$. afghana, the head and anterior portion of the back are smooth; but the hinder part is finely glandularly tubercular, and the sides, belly, and backs of the thighs likewise. This specimen has the chin and throat brown spotted, as in the Yunnan examples.

\section{Polypedates yunnanensis, n. s., Plate LXXVIII.}

Head flat; eyes prominent; snout rather pointed. Canthus rostralis rounded. Loreal region concave. Tympanum more than one-half the diameter of the eye. Nostril below canthus rostralis, slightly nearer the end of the snout than the eye. Vomerine teeth on two oblique ridges convergent, but widely separated. Tongue large, elongately cordate, markedly notched. First and second fingers nearly equal in length, the fourth about one-fifth shorter than the third; the second nearly onehalf shorter than the third. Thumb much swollen in the male. Toes long, the fourth equalling one-fourth the length of the body, webbed to the disks, the membrane being deeply emarginate on either side of the fourth toe, and less so between the others. Disks of fingers and toes feebly developed. A tubercle at the base of the first toe narrow and elongate, and a fringe along the digit, and another along the distal half of the fifth toe; no second tubercle. A glandular fold from the eye over the tympanum. A few large wart-like glands behind the angle of the mouth, and an interrupted series over the shoulder and along the sides in the position of the fold in Hylarana, with numerous wart-like glands below it. Small, yellow, pustularlike tubercles on the wart-like glands of the side, and on the sacral region, and still smaller ones on the upper lip, tympanic region, and on the outside of the limbs, but absent in some of the specimens. The belly in the adult male, as far as the line between the shoulders, is minutely granular, and at and beyond this point tho 
granules are grouped into a central band, which expands on the chest into a circular granular area, on a line between the angle of the mouth and the shoulders. From the vent to the heel equals the length of the body, or slightly more or less.

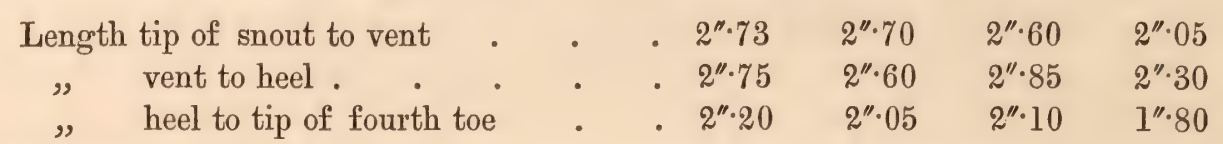

These measurements would seem to indicate that the limbs are proportionally larger in the young than in the adult.

The upper surface and sides are dark greenish-brown, marked with large round blackish-brown spots with ragged edges, and sometimes with light centres. Broad blackish-brown interrupted bars occur on the limbs and feet, and black spots on the upper and lower jaws. The under parts are yellow with faint brown spots on the fore part of the belly and throat, while in others those parts are immaculate. In the young, the markings are finer, and the bars on the legs more numerous, while the under surface is in no way granular, as in the adult.

This species is allied to $P$. marmoratus, but distinguished from it by its small disks and more emarginate interdactyle membrane. This frog, in the tendency which it exhibits to form a glandular fold along the side, serves to link together the two genera Hylarana and Polypedates. Hotha.

This species I only met with at an elevation of 4,500 feet in the valley of

Genus Ixal U,s, Dum. \& Bib.

Ixalus lateralis, Andr., Plate LXXVIII.

Ixalus lateralis, Anderson, Journ. As. Soc., Bengal, vol. xl, 1871, p. 29.

These specimens were found under stones in a partially dried water-course on the left bank of the Irawady, about 30 miles below Bhamô. They agree in all their essential particulars with the type, the habitat of which was unknown, but which, from the circumstance that it is a specimen in the Calcutta Museum, we may conclude was obtained from some portion of the surrounding region, as the collection of frogs in that Institution is exclusively Indian and Malayan. The only points in which I can detect that these Burmese specimens differ from the type are, that in some, the back is slightly tubercular; in some, there is a large, triangular, dusky olive spot, the base of which extends across, between and upon the eyelids, while its apex is directed backwards; in others, there are two or more irregular, similarly coloured spots on the back; these and the interorbital spot being narrowly margined with yellowish.

The web of the foot is prolonged along the toes as a kind of fringe or mem. branous border. This character had become so obscure in the type, from its being preserved in spirit, that it was overlooked.

In life, the colours are olive above, with a tinge of greenish, and the under parts pale yellowish, marbled with brown. 


\section{Ixalus KakHIENensis, n. sp., Plate LXXVIII.}

Head rather broad; snout short and moderately pointed. The canthus rostralis rounded; the area before the eye rather deeply concave. The tympanum less than one-half the size of the eye. Limbs moderately elongated, and the disks rather large. The toes fully webbed, with the exception of the fourth toe, in which the membrane does not reach its extremity. The fore limb when laid forwards has the wrist nearly reaching the snout, and the hind limb has the heel slightly beyond the snout. The upper surface of the body and the sides of the head are dark olive black, paling on the upper surface of the limbs to olive brown, obscurely transversely banded with blackish-brown. Chin, throat, and chest and sides of body marbled with brown and whitish. The belly yellowish, and obscurely brown spotted. The under surface of the limbs yellowish, and finely brown speckled; finger and toes yellowish and brown banded, the disks being blackish.

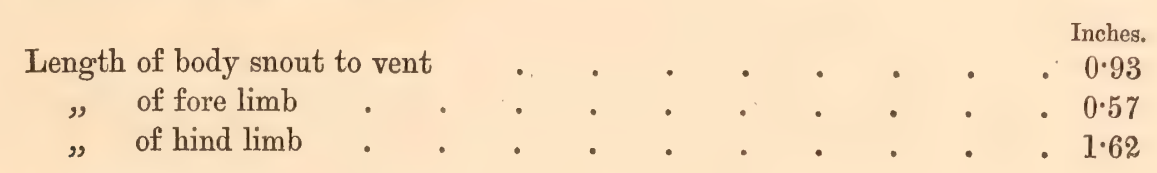

In fields, in the Nampoung valley, 1,000 feet.

\section{Ixalus tuberculatus, n. sp., Plate LXXVIII.}

Snout short and rather broad and very slightly concave before the eyes. Canthus rostralis feebly developed and rounded. Nostril but little below the canthus rostralis, small, but with a rather swollen margin, and much nearer the end of the snout than the eye, which is rather large, and the eyelids finely tubercular. The tympanum is about one-fourth the dimensions of the eye. The fore limb when laid forwards has the wrist, and the hind limb the heel, at the tip of the snout. The disks of the fingers are considerably dilated and larger than those on the toes. The latter are very feebly webbed, the web reaching only to the end of the first phalanx. Small scattered isolated tubercles on the upper surface and on the sides of the body, the belly and the inner aspect of the upper third of the thighs being finely granular. General colour of the upper parts is uniform dark olive. All the small tubercles, as a rule, white. In some specimens, a transverse pale yellowish band between the eyes and two similar bands behind them. A large black irregular spot on the groin, extending halfway up the side with two yellow spots, the thigh broadly but obscurely banded with dark brown and yellow, one broad band across the middle of the thigh and lower leg. The humeral portion of the arm brownish, marbled with yellowish; elbow yellow; limb below marked with dark olive and paler yellowish spotted. Sides of snout and upper lip marked with yellowish and olive, and lower lip and chin with brown and yellow. Chest and belly yellowish, but this colour is 
nearly obscured by very fine brown punctulations, which do not usually extend on to the granules of the belly, which are yellowish.

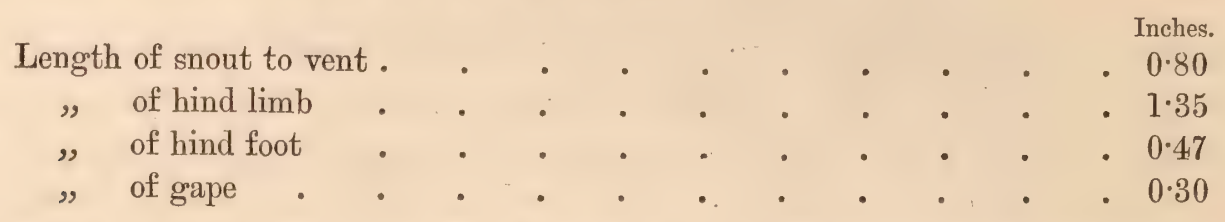

On level marshy flats on the banks of the Nampoung in the centre of the Kakhyen hills.

Genus Hyuarana, Tschudi.

Fruarana ertihrma, Schlegel.

Hyla erythrcea, Schleg., Abbild. 1837-44, p. 27, tab. 9, fig. 3.

Hylarana erythrea, Tschudi., Classif. Batr. Mém. Soc., Sc. Nat. Neuchat., 1838, vol. ii, p. 37 et 78 ; Günther, Rept. Brit. Ind., 1864, p. 425; Stoliczka, Proc. As. Soc., Bengal, 1872, p. 104.

Limnodytes erythraus, Dum. \& Bibr., Erpét. Génl., vol. viii, p. 841, p. 511, pl. lxxxviii, fig. 1; Can-

tor, Journ. As. Soc., Bengal, 1847, vol. xvi, p. 1062.

This is not an uncommon species at Shuay-goo-myo, Upper Burma, where I obtained it in the month of March under logs of timber near the river bank.

These specimens from Upper Burma agree in all their details with individuals from Siam; and, like all the examples of $H$. erythrea that have come under my observation, they have no tubercle at the base of the fourth toe. It was the existence of this tubercle, and the very prominent character of the tubercle at the base of the first toe of H. tytleri, Theobald, that led Stoliczka to consider the Lower Bengal form as distinct from $\mathbb{H}$. erythrea. In all other respects, however, the two forms are so closely allied that it seems extremely doubtful that they are distinct; but as the materials are not yet sufficient to settle the question, I have hesitated to include H. tytleri as a synonym of H. erythraa.

\section{Hrlarana margariana, n. s., Plate LXXVIIt.}

Body slender. Head of moderate breadth and rather flat, but slightly arched from behind forwards and of little vertical depth. The breadth across the tympana equals the distance between the hinder border of one tympanum and the tip of the snout. The transverse interval between the nostrils is four-fifths of that between the tympana. The canthus rostralis is rounded, with the loreal region deeply concave, with the nostril thus close to the end of the snout. The tympanum is large, nearly equalling the size of the eye. The vomerine teeth are very feebly developed on two obscure ridges directed obliquely backwards from the anterior inner angle of the choanæ, but widely separated from each other in the mesial line. The tongue is elongately circular and broadly notched behind. The limbs are long and slender; the fore limb from the head of the humerus to the tip of the third finger equals the distance between the vent and the front border of the tympanum. The 
length of the body from the vent to the snout almost equals the distance between the vent and the heel. The rudiment of a web occurs at the base of the fingers. The toes are not broadly webbed, but the membrane, although emarginate, reaches to the disks in all the toes with the exception of the fourth, where it ceases at the distal end of the second phalanx. A small elongated tubercle at the base of the first toe. Disks of the fingers very feebly developed, but those of the toes more strongly so, but not prominent, both fingers and toes being very slender. The first finger slightly exceeds the length of the second, but is slightly shorter than the fourth, considerably shorter than the third. The fifth toe is very slightly longer than the third, while the fourth is one-third of its length longer than the fifth.

$\begin{array}{clllll}\text { Length, tip of snout to vent } & \ldots & \ldots & \ldots & 1.71 & 1.65 \\ " \quad \text { of vent to heel } \ldots & \ldots & \ldots & \ldots & 1.81 & 1.75 \\ " \quad \text { of heel to top of fourth toe } & \ldots & \ldots & \ldots & 1.38 & 1.35\end{array}$

A narrow glandular fold from behind the eye along the side of the body. Skin perfectly smooth.

The colour of all the upper parts is dark olive-brown, with a dark, almost blackish band from the snout through the eye, along the sides to the groin, and a narrow pale-yellowish line from below the eye to the shoulder. A narrow, obscure greenish-yellow line along the glandular fold. The fore and hind limbs obscurely banded with brown, but on the hind limbs the colour is much better defined, dark-brown bands with pale margins occurring at regular intervals. The throat and chest are almost black from the profuse fine punctulation of the skin with a darkbrown pigment which is more sparsely distributed on the under surface of the limbs and on the belly, the latter being yellowish. The membrane of the fingers is similarly punctulated.

This species was found under stones in a hill stream debouching into the Irawady, in the second defile.

I have associated the name of the lamented Margary with this species. He took a lively interest in the scientific objects of the Expedition of 1875, but was ruthlessly murdered by the Chinese at Manwyne.

\section{HYLID AE.}

Genus H H L A, Dum. \& Bib.

HrLa Chinensis, Günther.

Hyla arborea, var. Cantor, Ann. and Mag. Nat. Hist., vol. ix, 1842, p. 483. Hyla arborea, var. chinensis, Günther, Cat. Brit. Soc., 1858, p. 10\%, pl. 9, c. Hyla clinensis, Günther, Rept. Brit. Ind., 1864, p. 436 ; Steind., Amph. Reise Novara, 1867, p. 59.

These specimens agree in all their details with the types with which they have been compared.

In the month of July I found a few bushes about Momien covered with this frog. 


\section{URODELA.}

\section{Salamandrida Mecodonta.}

Genus Tylototriton; Andr. ${ }^{1}$

Skull flat, depressed, very short and broad, and surrounded in both sexes by a prominent rounded porous ridge running from the temporals on the outer margins of the frontals, prefronto-lachrymals, premaxillaries and nasals, the ridges of the two sides being continuous anteriorly. A short osseous porous ridge along the parietals. Temporals and frontals united into a complete arch; pterygoids applied to the maxillaries. Teeth in both jaws; palato-vomerine teeth mecodont. ${ }^{2}$ Paratoids large, auricular, flattened from above downwards. A line along the sides of the body of rounded isolated porous glandular knobs, terminating on the root of the tail. A broad porous vertebral ridge. The extremities of the spinous processes of the vertebræ dilated transversely into a flattened porous ridge for the support of the glandular area of the back. An obscure line of pores from the axilla to the groin. A permanent gular fold from paratoid to paratoid along the under surface of the neck and passing more or less over the nape. Tail long, laterally compressed, limbs well developed. Tongue of moderate size, suborbicular, adherent, slightly free at the lateral sides. Vertebræ 46, ribs 16 : 13 dorsal, 1 sacral, and 2 caudal ribs, supporting lateral glandular knobs. Skin tubercular. Toes unwebbed, 4, 5 . Cloaca slightly produced.

Tylototriton verrucosus, Andr., Plate LXXVI, fig. 6.

Tylototriton verrucosus, Andr., Proc. Zool. Soc., 1871, p. 423 ; J. Wood-Mason, Proc. As. Soc., Bengal, 1877, p. 53.

The lateral cranial ridge is subtriangular, and the median ridge runs backwards from inside the apex of the triangle, but not so far as the former, the extremities of which curve inwards like a scroll in front of the paratoids. The paratoids are slightly concave above and auricular in form. The nostrils are placed close to the extremity of the rounded snout, but with a considerable interval between them, and are semicircular with a small valvular flap of skin. The eye is of moderate size;

1 Proc. Zool. Soc., Lond., 1871.

${ }^{2}$ Strauch, Mém, de l'Acad. Imp. des Sc. St. Pétersb., Sér. vii, t. xvi, 1871. 
the upper eyelid is large and glandular. Sixteen knob-like glands occur along the side of the body, the first a short distance behind and above the axilla and on a level with the paratoids. The last three are behind the leg when it is extended at right angles to the body. The vertebral glandular ridge begins on a line with the scroll-like extremities of the cranial crest and terminates at the root of the tail. An obscure line of pores, larger than those of the rest of the body, from the groin along the side to the under surface below the axilla. ${ }^{1}$ A series of pores behind the angle of the mouth along the lateral, cranial ridge to the tip of the snout, on the loreal region, behind the eye, along the mandible and internal to it. The chin and throat are thickly covered with small smooth porous glandular tubercles of nearly uniform size. The sides and upper parts of the body and tail are densely covered with glandular tubercles (porous) of various sizes, irregularly distributed. The ventral surface is transversely wrinkled and covered with very minute porous glands, which scarcely project above the level of the skin. The upper margin of the tail is sharp, commencing on a line with the last lateral knob; the under surface is rounded. There are numerous folds on the inner margin of the orifice of the vent. The forearm extends the length of the fingers beyond the snout; the leg reaches half-way to the axilla. Colour uniform blackish-brown; paler on the lips, snout, chin, throat, and under surface of the limbs, all of which have a brownish-olive tinge. Under surface of the tail dull orange-yellow, fading into lightish brown on the sides.

The following are the measurements of eight specimens, males and females :-

\begin{tabular}{|c|c|c|c|c|c|c|c|c|c|c|}
\hline \multicolumn{5}{|c|}{ Length from tip of snout to vent 4} & Males. & \multicolumn{5}{|c|}{ vent to tip of tail 3.75 inches. } \\
\hline " & " & , & " & 3.58 & , & , & و & , & $3 \cdot 33$ & , \\
\hline " & , & " & " & $3 \cdot 00$ & " & " & " & , & $3 \cdot 00$ & , \\
\hline " & $"$ & $"$ & $"$ & $\begin{array}{r}2 \cdot 25 \\
1\end{array}$ & Females. & $"$ & " & " & $2 \cdot 80$ & s" \\
\hline$"$ & $"$ & " & " & $3 \cdot 00$ & inches & " & $"$ & " & $3 \cdot 00$ & aches. \\
\hline " & " & " & " & 3.00 & " & $"$ & ", & ， & $3 \cdot 00$ & " \\
\hline " & " & $"$ & " & $3 \cdot 00$ & , & " & " & , & 2.58 & " \\
\hline " & " & ", & ", & $2 \cdot 92$ & ", & " & ", & , & $2 \cdot 66$ & , \\
\hline
\end{tabular}

This species is common in the high country of Yunnan, and since its discovery there it has been found in the Darjeeling Hills by Colonel Mainwaring. ${ }^{2}$

Vertebral column.-It is not very flexible, and it tapers so much to a point at the tail that the last vertebra can be distinguished from the one before it only by the aid of a hand lens. Throughout the trunk, the vertebræ, as in Urodela generally, are opisthocœlous, but in some of the dorsal vertebræ the arrangement is procolian, and in the 15th caudal vertebra there was a ball at either end, the procolian arrangement occurring in the 16 th and prevailing throughout the remainder of the tail. In another individual the 25 th caudal had a ball at either extremity of the centrum, whilst the remaining vertebræ were procœlian. 1 In certain conditions of the skin, these pores are very difficult to detect, but in other states they are gaping
and easily seen.

Proc. As. Soc. Beng., 1877, p. 53. 
The 1st vertebra has the usual two lateral facets, Plate LXXVIII, fig. 1 a a, for articulation with the occipital condyles with an odontoid-like process $(b)$, similar to that figured by Mivart ${ }^{1}$ in Amphiuma, fitting into an articular surface between the occipital condyles. In one specimen, the parasphenoid sent up a small nodule between the posterior margins of the exoccipitals and entered into the middle of the anterior margin of the cavity. In this instance, fig. 2 , the intercondyloid process of the atlas was divided into two rounded articular facets $b$, which corresponded to two median articular surfaces, fig. $25 \mathrm{~s}$, internal to the facets of the condyles. I have observed this arrangement in two eases. In specimens in which the odontoid-like process is not very long, either one or both of the lateral facets of the 1st vertebra are confluent with it, but, when it is of moderate size, each surface is sharply defined. The spinous process of the 1st vertebra, fig. $3 c$, has its extremity dilated and covered with a broad rough porous plate $(h)$ or crest corresponding to the porous glandular layer of the back, and a sharp anterior edge $(d)$ and a deeply concave posterior surface $(e)$ for the reception of the spinous process of the 2nd vertebra. In the succeeding vertebræ, figs. 6 to 15 , the spinous process becomes much laterally compressed, and the lateral margins of the posterior concavity, figs. $8 g$ and $12 g$, become distinct plates, from which the posterior zygapophyses $(f)$ depend.

The most peculiar feature of the vertebræ is the existence on the summit of the spinous process of the dorsal, sacral, and first two or three caudal vertebræ of the rough osseous expansion or crest, already referred to, and conforming to the outline of each process, and which appears to be peculiar to this newt. It is pointed anteriorly and bifurcate posteriorly for the reception of the anterior extremity of the process immediately behind it. The anterior and posterior zygapophysial facets have the general characters of these structures in the Urodela. There are no hypapophysial ridges in the trunk vertebræ. Transverse processes are not indicated in the 1st vertebra (fig. 6), but a process of this nature bearing a rib ( $m$ and $p$ ), figs. 7 to 14, is developed in each of the vertebræ from the 2 nd to the 2 nd caudal. In the rest of the caudal vertebræ, the transverse processes, figs. 15 and $16 l$, also assume the general character distinctive of the Urodela. In the dorsal region the two transverse processes, superior and inferior, are placed side by side in the usual manner and united by their edges, each terminating in an articular surface for the head and tubercle of the rib. The base of each process is deeply concave posteriorly, and is perforated by a vascular canal, as in many other genera of Urodela. $^{2}$ In the caudal region, figs. 15 to 18, the transverse processes are short, their vertical plates having a somewhat wavy margin connected to the anterior and posterior articular processes by a long longitudinal lamella and by a ridge to the posterior inferior margin of the hypaxial arch. There is so great a similarity at first sight between the dorsal and ventral arches, that when a single caudal vertebra is taken up, one hesitates at first to decide between the arches. In the

1 Proc. Zool. Soc., 1870, fig. 19, p. 277.

2 Mivart, $l$. c., p. 271. 
3rd caudal, the transverse process becomes flattened from before backwards, and the hypapophyses spring from it and from the centrum as a common base in a much more perfect manner than occurs in the 1st caudal vertebra of Siren, as described by Mivart.

The hypaxial arch, figs. 15 to $18 m$ and $n$, consists of a broad flat plate, with two diverging processes posteriorly. In the 4 th caudal vertebra, a prominent ridge is developed on the anterior face of the plate, which is curved with its convexity forwards; and this modification becomes more and more intensified, until at last, in the middle of the tail, fig. $16 \mathrm{~m}$, the ridge is converted into a broad thin lamina, with two divergent plates, which serve to embrace the ridges of the arch behind.

The ribs.-There are sixteen ribs, thirteen in the dorsal, one in the sacral, and two in the caudal region. Each rib is supported on a double-headed transverse process, and is capable of a certain amount of mobility. As the ribs are traced backwards, the tubercular and eapitular portions are less distinctly marked, as is also the division of the transverse processes into dorsal and ventral sections. The ribs are well developed in the five anterior vertebræ, and are moderately curved, but the succeeding ribs are nearly straight. The proximal ends of the ribs, figs. 19, 20, are flattened from before backwards, and each consists of a capitular and tubercular process, separated from each other by a narrow interval, except in those in which these parts tend to become confluent. A considerable process (figs. 19, 20, \&c., p) is developed on the posterior margin of each of the first five ribs. All of these rib processes, with the exception of the first, terminate in the knob-like glands of the side, and the free extremities of the remaining ribs end in the same structures. The first rib lies under the scapula, and has no gland opposite to it. The sacral rib, figs. 11 and $12 \mathrm{~m}$, has such a strong resemblance to its transverse process that it might be mistaken for such, and from its nature has of course no relations with the lateral glands.

Scapular arch.-The scapular arch lies over the 1st rib and on the anterior fourth of the 2 nd between the 2 nd and 3rd vertebræ. All the constituent bones are completely united with one another. The coracoid element is a semicircular flattened rather thick plate (fig. 4i1), separated from its fellow by the semi-osseous epicoracoid flaps which overlap each other. The glenoid cavity is behind the line of the scapula on the posterior and superior margin of the coracoid, and looks upwards, backwards and outwards, and is triangular with its base upwards. It has two protuberant walls; but the upper and posterior margins are continuous with the posterior margin of the coracoid, and scooped out into a deep wide notch, closed in the recent state by a strong membrane. The lateral margins are separated from each other anteriorly by a narrow notch for the reception of the articulating ridge of the humerus. There is a nerve foramen in the usual position in front of the glenoid cavity and a deep notch at the base of the anterior angle of the scapula and coracoid. The scapular element is slightly concave externally, and expanded from below upwards terminates in a broad semi-osseous or cartilaginous suprascapula without any notch on its anterior angle. 
The humerus (figs. 4.2 and $42 a$ ).-The head of the humerus is slightly oval and continuous with a prominent anterior ridge, along which the articulating surface is prolonged for one-half of its length. This ridge fits into the anterior notch of the glenoid cavity. There is a very prominent process behind for the attachment of muscles to the hinder margin of the coracoid, behind and below the glenoid cavity. Viewing the humerus in front, the upper half is seen to be flattened laterally and the lower half antero-posteriorly. The result is, that the largest axis of the head is in the last-mentioned direction. There is a deep pit on the radial condyle immediately above the capitellum, and an olecranon fossa on the back of the bone above the trochlear articulation. Regarding the humerus in profile from the inner side, it is observed that the radial articular surface projects prominently forwards, while viewed anteriorly it is longitudinally oval. The trochlear surface is narrower in front than behind. The external and internal supracondyloid prominences are well marked.

The radius (fig. 43) lies obliquely across the arm, with the ulna posterior and external to it. It is a short bone with a broad carpal extremity, articulating with two carpal bones ( $c$ and $d$ ) and the ulna. The head is rounded with a cupshaped articular facet, which forms a large sigmoid articular cavity along with a concave articular surface on the head of the ulna.

The ulna (fig. 43). - The humeral articulation of the ulna is slightly concave, and the radial facet is immediately below it. The inner side of the former is folded over as it were on its inner side to form a small articular surface corresponding to the trochlear facet.

The carpus (fig. 43) $)^{1}$ consists of seven bones, of which only two are in contact with the radius and ulna. The bone in contact with the ulna appears to be a united os ulnare and os intermedium. A large, almost round, os centrale occupies as usual the centre of the carpus, in contact with all the bones of the carpus.

The pelvic arch (fig. 44) is attached by the sacral rib in the usual manner. The ilium is directed downwards and forwards, and is narrowed and slightly contracted in its middle, with either end feebly expanded. Its lower extremity forming the upper border of the acetabulum has a prominent tubercle on its outer and anterior margin, immediately above the acetabulum, facing a rather large process on its ischial side. The ilium, below the tubercle, forms part of the acetabulum, which has only two borders, an upper belonging to the ilium, and a lower to the ischio-pubis. The anterior and posterior borders are closed in by strong membranes. The ischial process of the acetabulum is separated from the upper posterior angle of the ischium by a deep depression in the position of the lesser siatic notch bounded behind by a prominent process. The free margin of the pubis is bevelled off and very thick, and there is the obturator foramen near its internal angle. Two ypsiloid cartilages are found in the usual position.

\footnotetext{
1 This plate, I regret to say, has not had the original drawings which were made by myself with the greatest care reversed, so that what is right on the plate is left in nature. The figures also, especially of the skull and carpus, have not that distinctness which could have been wished.
} 
Femur (figs. $45,45 a$ and $45 b$ ) is of moderate length and rather stout, the head and neck being bent slightly inwards. There is a strong projection on the inner side of the head covered with articular cartilage, which also invests another pointed surface prolonged forwards anteriorly almost on to the neck. At the back of the bone, the former process defines the inner side of a deep pit on the neck, bounded externally by a smaller process. A ridge passes downwards from each process enclosing the notch in a triangular space, the apex of which is downwards and overlooked by a conspicuous process springing from a sharp ridge occupying the upper half of the external margin of the posterior surface of the shaft. Below that point to the condyles, there is a triangular slightly concave surface, with two nutritive canals at its upper extremity.

The lower end of the bone is a simple transversely elongated articular surface, in contact with the oblique articular surface of the ulna and fibula. A broad but obscure ridge winds spirally round the middle of the shaft.

The tibia and fibula do not call for any remark. There are nine tarsal bones (fig. 46). In the first row the os tarsi tibiale is the smallest and in contact with the inner half of the tibia. The first bone of the second row of tarsal bones is somewhat pushed out of position towards the os tarsi tibiale. The metatarsal bones are well developed, and the third and fourth support three phalanges, while the first, second and fifth carry only two each.

The skull (figs. 21 and 24) is remarkable on account of its short and broad character, associated with depression and great truncation of the posterior portion. It is one-fourth broader than long. It is also distinguished by a pronounced rounded porous osseous ridge running round the upper outlines of the skull arising at the hinder border of the upper process of the temporal, the ridge from either side meeting over the nasals. There is also a short ridge along the mesial suture of the parietals. The fronto-temporal arch is complete and the maxillary touches the quadrate, and the pterygoid is opposed by its anterior maxillary process to the maxilla. The orbit is defined anteriorly by the prefronto-lachrymals and by the vertical plate of the maxilla; posteriorly by the pterygoid, and superiorly by the head of the squamoso-zygomatic process of the temporal and by the orbital process of the frontal.

The external nostrils are large rounded orifices lying between the premaxillary, nasal and maxillary. The former bone forms their floor and inner wall; the vertical plate of the maxillary bounds them internally and the nasal roofs them in. The internal nostrils (24) are on a line with the anterior angle of the orbit and are defined by the palato-vomerine, orbito-sphenoid, prefrontal-lachrymal, and maxillary. Their floor is formed by the premaxillary, maxillary, and broad anterior expansion of the palato-vomerine.

A rather long wide space is left between the nasals superiorly and between the broad plates of the palato-vomerines inferiorly, into which the nasal cartilaginous septum which divides the cavity into two chambers is attached. This opening which in the dry skull passes vertically through it is defined on the upper surface 
of the head by the nasals anteriorly and laterally, and by the frontals posteriorly, while inferiorly it is bounded by the palato-vomerine externally, by the premaxillaries anteriorly, and by the approximated inner margins of the palato-vomerine which cover the point of the parasphenoid. The cartilage which fills up this opening divides at its anterior extremity and into two short processes which are attached to the posterior nasal processes of the premaxillaries, enclosing a small space.

The palato-vomerines meet anteriorly and then slightly diverge posteriorly, reaching as far backwards as the hinder border of the pterygoid, resting on each side of the parasphenoid and having their inner margins covered with teeth.

Bones of the slcull.-The premaxillary (figs. $26 a$ and $b$ ) consists of two portions, a vertical and horizontal. The former articulates with its fellow and the nasal, and the latter with the palato-vomerine and maxillary. The vertical portion of the bone is prolonged backwards as a rather thick plate with a deep pit on its inner surface and a notch at its posterior border, into which the cartilaginous nasal septum fits by its divided anterior extremity. When the bones are in position, a well marked fossa results from the union of the two pits. At the base of the vertical process on its internal nasal surface a small foramen perforates the bone and opens externally at the inner angle of the nostril in a well defined groove which runs round this part of the opening and contains a nutritive vessel.

The nasal (figs. $27 a$ and $27 b$ ) is a flat triangular bone carrying on its anterior border the foremost part of the cranial crest. Its anterior margin is arched, corresponding to the upper border of the bony nostril.

The prefronto-lachrymal (figs. $18 \alpha$ and $18 b$ ) lies posterior to the nasal, and forms the outer third of the roof of the nasal passage and the anterior angle of the orbit. The orbital portion is perforated by a foramen, which opens into the nasal cavity, probably for the transmission of the nasal branch of the fifth pair of nerves.

The maxillary (figs. 37 and 38). is long and laterally flattened in its anterior third to form the side of the.face and narrow posteriorly. It stretches from the premaxillary to the quadrate. The tip of the pterygoid is in contact with its orbital margin. The dilated anterior portion consists of a naso-facial and a nasopalatine plate, the former extending. between the anterior angle of the orbit and the nostril forms a flat facial surface and the lateral wall of the nasal passage, while the latter constitutes the outer part of the nasal cavity and a small portion of the palatine surface anterior to the internal nostrils, the external angles of which are defined by it. The dentary ridge ceases half-way between the facial plate and the orbital process, which juts out to meet the pterygoid and defines the posterior limits of the orbit. The external surface is covered with ridges and minute grooves. It articulates with the premaxillary, nasal, palato-vomerine, prefrontolachrymal, quadrate, and pterygoid.

The palato-vomerine plate (fig. 34) is a thin flat, axe-shaped bone, forming the greater part of the floor of the nostrils and defining their limit posteriorly and interiorly. It articulates anteriorly with the premaxillary and maxillary, but the 
internal margins of the axe-like heads of the two bones are widely separated from each other anteriorly for the reception of the cartilage. Behind this, they are nearly in contact for a short way, but they become widely divergent posteriorly.

The posterior external border of the bone is marked by a deep notch, which defines the internal border of the inner nostril. The internal margin of each plate is roughly serrated, the serrations corresponding to the positions of the palatine teeth. The divergent portions of the plate lie on and between the parasphenoid and orbito-sphenoid and on the former as far as the pterygoid.

The frontal (figs. $29 \alpha$ and $29 b$ ) is by far the largest bone of the skull, and articulates with the nasals, prefronto-lachrymals, temporal, parietals, and orbitosphenoids. It consists of two portions, a flattened body and an appended orbital process which enters into the middle of the upper wall of the orbit. The body is slightly convex externally, and the frontal suture carries one-half of the central cranial crest. The orbital process is covered by a rough osseous surface, that part of the lateral cranial crest which intervenes between the prefrontolachrymal and the squamosal, and it forms the external margin of the temporal fossa.

The parietal (figs. $30 a$ and $30 b$ ) is an almost square bone and very much smaller than the frontal, with its posterior external angle curved upwards to rest on the temporal and arch of the exoccipitals. The middle is occupied by the median cranial crest, which begins near the posterior extremity of the bone, as a prominent raised ridge.

The exoccipital and auditory capsule (figs. $31 a, 31 b$, and $31 c$ ) consist of one solid bone, which forms a large chamber for the organ of hearing and lodges nearly one-half of the brain. It presents, however, in its fenestra ovalis, semicircular canals and condyles, a series of prominent landmarks which enable it to be mapped out. It may be described as consisting of two portions, one embracing the exoccipital condyle and an arched process immediately anterior to that articular surface forming the lateral and upper wall of the brain cavity, posterior to the parietals, and another, the greater of the two, in which the auditory chamber and its parts are lodged.

These two portions are defined thus : a ridge, with a groove on its under side, begins on the superior anterior margin of the fenestra ovalis, and is prolonged onwards and forwards over the condyle and along the posterior margin of the arched process of the exoccipital to its tip, from whence it can be traced along its anterior margin, as a faint line. Another ridge springs from the inferior, anterior border of the fenestra ovalis and runs forwards and inwards, nearly to the foramen magnum, and then outwards and forwards on the under surface to almost the anterior termination of the cranial floor. It is true that the latter ridge defines the surface of the cranial floor covered by the parasphenoid; and as this area, from its relations to the condyles, may be regarded as exoccipital, may not all the remaining portion of the capsule external to it and entering into the formation of the floor of the auditory chamber be considered as the opposite element, 
and the region superior and anterior to the ex-occipital as the pro-otic? This view would seem to be supported by an examination of the relation of the constituent parts of the capsule. The exoccipital lies wedged in between the two elements. It is just possible that the sides of this part of the cranial cavity may be formed by the pro-otic, but the apparent overlapping of the exoccipital by the pro-otic appears to negative this view of their relations. The position of the fenestra ovalis, and the rudiments of the stapes and of the semi-circular canals and other important structures, would appear to establish the foregoing opinion regarding the nature of this anditory capsule, and which will now be described in detail.

Fenestra ovalis.-The general direction of this structure is backwards and outwards, and it is placed somewhat external to the exoccipital condyle, from which it is separated by the foramen of the 8th pair of nerves. It is a short cylinder with a distinctly rounded orifice, closed by a membrane containing a small bony nodule, evidently the stapes. The inner surface of the lower wall of the tube is on a level with the floor of the auditory cavity, and the internal opening is placed a little behind the centre and immediately below the inner opening of the semi-circular canals which lie in the roof of the chamber.

Semi-circular canals. - These structures can be detected on the external surface of the roof of the chamber as two rounded ridges, and their presence can be at once demonstrated by a vertical section of the capsule, or by cutting the roof away gradually (fig. 31c). They are on the same level and close to the roof of the chamber. Their construction is very simple. A flat process arches in from either side of the chamber to the roof, and both meet in the centre. A canal is thus formed between the upper surface of each process and the roof. The floor of the anterior canal is not so broad as the posterior one, which is slightly curved outwards and downwards and forwards, while the former is simply forwards and outwards. Their external openings are on a line with the external border of the fenestra ovalis, and their whole length occupies about the middle half of the total transverse length of the chamber. Their external openings overlook a crypt-like depression or sacculus in the outer extremity of the chamber, which probably represents the cochlea. On a vertical section of the dry capsule, its cavity is seen to have been filled with a pure snow-white friable substance resembling finely-ground chalk invested by a delicate membrane. In a specimen which had been preserved in alcohol, it is a shrivelled and contracted mass suspended in the centre of the chamber from the internal openings of the semi-circular canals. The sac is doubtless the equivalent of the utricle, and it is probable that the white contents are calcareous.

On the under surface of the capsule, external to the parasphenoid ridge, there are three, or sometimes more, small foramina on the anterior and inner side of the inferior pterygoid process. Two of them communicate and open externally, but the other passes through the substance of the floor of the capsule and opens into the cranial cavity close to a foramen, which appears to transmit the acoustic branch of the 7th nerve. If this is the course of the facial nerve, we have a very clear indication of the homologies of this capsule. The anterior extremity of the pro-otic 
element is a pointed process with a foramen for the 5th nerve near its extremity. There are two other foramina immediately above it, but they are frequently united into one. They appear to be for the passage of blood-vessels as the roof of the cranial cavity within, and is covered with a dense plexus.

The exoccipital forms the wall of the cranium internal to the auditory capsule, and a small part of the floor on each side of the parasphenoid. A narrow plate of bone rises immediately behind the condyle, bending upwards, forwards and inwards over the cavity, forming the superior margin of the foramen magnum. The base of this arched process springs, as already stated, from the outer wall of the fenestra ovalis, so that only the narrow line along the posterior margin of the ridge is exoccipital, while all anterior to it superiorly is pro-otic.

Each exoccipital, as a rule, has two articulating surfaces. (fig. 25) for the 1st vertebra, an external one for the lateral facet and an internal one for articulation with the so-called odontoid process. The latter surface is a true articulation, and it is confluent sometimes with the former, producing an elongated facet. In cases where the odontoid process is not divided, each exoccipital carries a facet and a half. The lateral facet is directed downwards, backwards and inwards, the concavity being from without inwards, and the odontoid surface upwards and backwards with a prominent lower margin.

The condyle is connected to the fenestra ovalis by a ridge, which, along with the superior one, marking the limits of the pro-otic, encloses the foramen of the 8th pair of nerves. There is a prominent notch in front of the odontoid articulation, which receives a rounded flattened process on the encephalic aspect of the parasphenoid. Its posterior margin sometimes separates the odontoid articulations from each other. The parasphenoid intervenes between the exoccipitals and forms the greater part of the cranial floor.

The two anterior of the three foramina on the wall of the cavity above, and slightly before the parasphenoid notch of the exoccipital, lie in a depression common to both; but whilst the posterior of these two foramina passes directly into the auditory chamber, the other pierces the substance of the opisthotic and opens below at the base of the pterygoid. It appears to enclose the facial branch of the 7 th nerve, while the other transmits a nerve which also probably enters this simple ear labrynth by the posterior foramen.

The parasphenoid (fig. 33) is a long, rather flat, thin bone, stretching from the posterior margin of the palatine canal to the inferior margin of the exoccipital foramen, into which it enters. It has a slight constriction in its middle, corresponding to the middle of the cranial cavity. The posterior portion is broader than the anterior, and forms, as usual in this group of animals, the greater part of the floor of the cavity posterior to the frontals. It is feebly convex below and concave above, with a well-defined margin for the articulation of the orbito-sphenoid, and a broader one posterior to this on which the exoccipital rests. Close to its posterior border, there is a central rounded flattened nodule which fits into the precondyloid notch of the exoccipital, and sometimes sends a process between the odontoid facets of the two bones. 
The orbito-sphenoid (fig. 32) is a moderately elongated bone, with its inner side smooth and concave, and its outer side transversely convex. It is perforated near its posterior extremity by a large foramen directed upwards for the transmission of the optic nerve and by a small one immediately behind the former. The anterior and upper extremity which forms the internal lateral margin of the internal nostril is marked by two processes which enclose a rather deep groove. It articulates with the prefronto-lachrymal, exoccipital, parasphenoid, palato-vomerine, and parietals.

The temporal (fig. 35) is directed obliquely outwards and slightly backwards, which partly accounts for the wide gape of this animal. It rests on the anterior external angle of the auditory capsule and touches the parietal and the frontal anteriorly, completing the upper margin of the arch of the orbit. Its anterior angle receives the head of the pterygoid, which also rests on the process on the under side of the auditory capsule external to the supposed orifice of the facial nerve. It is a hammer-shaped bone with a massive head projecting behind, consisting almost entirely of the rough, hard, bony substance of the cranial crest.

The quadrate (fig. 35) is somewhat triangular, with the longest diameter of its articular facet lying obliquely across the long axis of the temporal, concave outwards and backwards, the face of the facet looking outwards and forwards. A prominent process surmounts the back of the facet, and a curved one is directed forwards for articulation with the posterior end of the maxilla.

The pterygoid (fig. 36) consists of two parts, a body and a wing-like process projecting forwards from its anterior margin. The body of the bone is applied to the internal surface of the temporal and quadrate, and by its head to the auditory capsule and to the inner side of the angle of union of the maxillary process and body of the temporal.

The head consists of two parts corresponding to its articulations, an internal and external. The former is hollowed out, and the cavity opens on the external side of the neck of the bone, and is prolonged along the posterior margin of the body as a well-defined short groove which is converted into a canal when the bone is in position against the temporal which closes it below. A branch of the eavity is also prolonged along the wing as a groove in some skulls, and a canal in others, and when the latter exists, it communicates with the head of the bone by a special foramen. Superiorly the cavity is closed by the pterygoid process of the auditory capsule. The anterior wing of the bone is hard and somewhat sickle-shaped, and is projected forwards and outwards to touch the maxilla, when it sends backwards a narrow shelf of bone from the inner margin of the internal nares.

The floor of the cranial cavity is almost perfectly straight (fig. 33), although the outline of the skull is much curved; the curvature, however, is confined to the roof which arches down over the anterior extremity of the parasphenoid until the anterior margins of the frontals are brought nearly on a line with that bone. A line prolonged forwards from the parasphenoid would have the premaxillaries below it.

The extremities of the hyoid arch (fig. 40), when the mouth is closed, project backwards and upwards behind the skull, on a line with the lateral cranial crest, 
and both the ceratohyal and thyrohyal are free and covered by the forepart of the paratoids. They are invested in a sheath of fascia and attached to the back of the skull by a fine ligament, but they are not in contact with any of the bones of the skull.

Dr. Strauch, the most recent writer on the value to be attached to the structural differences manifested by the Urodela, has sub-divided them into two great sections, depending on the distribution of the palato-vomerine teeth, whether they are in the longitudinal series Mecodonta, or in transverse more or less oblique series Lechriodonta. This genus falls, therefore, under the Mecodont division, which includes, according to Dr. Strauch, only Triton and five other genera, viz., Salamandra, Pleurodeles, Bradybates, Chioglossa, and Salamandrina. To the first-mentioned genus, Strauch refers a number of Amphibians, which have hitherto been considered by many naturalists to represent generic types, e.g., Triton, Notophthalmus, Euproctus, Cynops, Taricha, Lophinus, and Ommatotriton; but if his view were accepted, Tylototriton, if judged by its skull alone, would perhaps be regarded as only a form of Triton. Strauch sub-divides the genus Triton into two sections, characterized by the absence or presence of a fronto-temporal arch, as he does not consider the osseous bridge formed by the frontal and temporal so important a structure as to let its presence or absence determine a genus, and moreover, he has pointed out that Leydig has shown that the form of the arch goes hand in hand with other organic similarities of structure, with the exception perhaps of those which are sexual. The males, however, of some species, for example, in which the fronto-temporal arch is wanting, or merely indicated by a ligament, have at the breeding season a high crest, whilst males possessing a well-developed arch may not have a crest, while others, such as Ommatotriton vittatus, which Gray considered a very distinct genus, may have a crest.

The differences existing between the skulls of the various forms of Amphibians referred by Strauch to the genus Triton would probably be considered of generic importance if they occurred in higher groups of vertebrates. In estimating the value of skull characters in this group however, the consideration of the remarkable changes which the cranium undergoes after the animal has left the egg has to be borne in mind, as these changes would seem to indicate a greater capacity in the skull of these Amphibians to variation than occurs in the skulls of other and higher animals, which are not the subject of any remarkable modifications after birth.

Tylototriton, however, presents certain characters which seem to separate it generically from all other Mecodont Urodela, more especially as they are associated with other features which are not common to any other Amphibians. The skull characters are the remarkable osseous crest which runs round the margins of the upper surface of the skull and the shorter crest along the parietals, each of these structures being deeply fitted for the reception of the remarkably large cuticular glandular pits which densely stud the skin, and are always packed full of secretion, and a perfect ptyergoid arch reaching the maxilla, the latter bone prolonged right up to the quadrate, to which it is attached by a ligament. Associated with these characters 
we find others which are peculiar to this form, viz., remarkable knob-like glands along the sides over each rib and supported by processes from the anterior ribs, and posteriorly by the ends of the ribs; and dilated tips to the spinous processes of the vertebræ serving to support glandular pore-like pits, all of these characters being common to both sexes.

Males caught at the period (spring) when the eggs of the females were considerably larger than the head of a good-sized pin did not show any sign of a crest. 


\section{PISCES.}

S P E C IES

COLLECTED ON

THE TWO EXPEDITIOLS

To

WESTERN YUNNAN. 

PISCES.

PHYSOSTOMI.

Family-SILURID AR.

\section{Genus WALlag 0, Bleeker.}

\section{Wallago attu, Bloch.}

Silurus attu, Bl. Schn., p. 378, 1801, tab. 75.

Wallago attu, Bleeker, Atl. Ichth. Silur., p. 79; Günther, Cat. Fish., B. M., vol. v, 1864, p. 36.

Two specimens, 12 inches long, from Tagoung, Upper Burma.

Genus Calimchrous, Günther.

Calitichrous bimaculatus, Bl.

Silurus bimaculatus, Bl., vol. viii, p. 24, taf. 364 .

Callichrous bimaculatus, Bleeker, Atl. Ichth. Silur., p. 84, tab. 87, fig. 3 ; Günther, Cat. Fish., B. M.; vol. v, 1864, p. 45.

Two specimens, 9 inches long, Tagoung.

Genus Macrones, Duméril.

Macrones cavasius, Ham. Buch.

Pimelodus cavasius, Ham. Buch., Fish., Ganges, pp. 203, 379, 1822, pl. xi, fig. 67.

Macrones cavasius, Günther, Cat. Fish., B. M., vol. v, 1864, p. 76.

Three specimens, 7.50 inches long, from Tagoung, Upper Burma.

Macrones corsula, Ham. Buch.

Pimelodus corsula, Ham. Buch., Fish., Ganges, 1822, pl. i, fig. 72 (not described); Günther, Cat. Fish., B. M., vol. v, 1864, p. 74.

Bagrus corsula, Cuv. \& Val., vol. xiv, 1839, p. 408.

Three specimens, 13 inches long, from Tagoung. 


\section{Genus Rita, Bleeker.}

\section{Rita sacerdotum, n. s., Pl. LXXIX, fig. 3.}

The humeral plate is considerably shorter than the head, and is three-fourths the total length of the occipital scute. It is rounded and broad posteriorly; its total length is 4.85 inches, by 1.90 inches in greatest breadth. Its posterior margin is on a line with the posterior margin of the dorsal scute. The granulation is coarse, and the granules are arranged in concentric lines, which become more pronounced as they recede from the anterior extremity of the scute. The skin clothing the bone in life is so exceedingly thin that the granulations are distinctly visible. The occipital scute is coarsely granular, the granules tending to assume in many cases the appearance of rounded tubercles, which arrangement prevails. There is no linear distribution. The scute is notched in front. Its lateral margin has a sinuous and backwardly expanding outline, until opposite to the bones of the pectoral fin, beyond which the occipital scute rapidly contracts, the lateral margin of the first portion of the contraction being marked by two notches corresponding to the articulation with the lateral or supra-branchial scute, but posterior to this the margin of the occipital is straight. Anterior to the lateral, it attains its greatest breadth, 3.77, while its total length along its mesial line is $6 \cdot 07$. The breadth posteriorly is about onethird of its greatest breadth measured transversely in a straight line. It fits in posteriorly to the dorsal scute by a concave or notched posterior border, and the dorsal plate anteriorly is as broad as the corresponding opposed surface of the occipital, and its granulations are similar. The dorsal expands posteriorly, and its total length measured in the mesial line to a line drawn between the ends of its lateral extremities is one-third the total length of the occipital. Its breadth anteriorly is $1 \cdot 20$ and posteriorly from, side to side $1 \cdot " 65$. The dorsal spine is strong, but short, and only equals about the length of the humeral plate, viz., $4 . " 45$. The pectoral spine is very strong and longer than the dorsal spine, exceeding the humeral plate by about one-seventh of the length of the latter.

Dorsal 1-6; anal 14; pectoral 1-10.

The upper half of body is brownish-olive, more or less suffusing the ventral surface, behind the ventral fins. Fins brown on both aspects. Eye a transverse elipse margined with golden, the scloritic being brownish-golden. Diameter of eye 50 inch. Distance of eye from angle of mouth $1 \cdot 18$. Anterior nostrils above upper lip 0.36 . Distance between anterior nostrils $1{ }^{\circ} 75$. Posterior nostrils distant from eye 0.68 . Posterior nostrils from angle of mouth $1 \cdot 33$. Length of feeler of posterior nostrils 1.50 . Length of maxillary feelers $4 . " 25$. Length of mandibular feelers $3 . " 81$. 


\begin{tabular}{|c|c|c|c|c|c|c|c|c|}
\hline Posterior margin of anal to caudal & - & • & - & - & - & - & • & $\begin{array}{c}\text { Inches. } \\
2 \cdot 38\end{array}$ \\
\hline Depth of base of caudal & - & - & - & - & & - & & $2 \cdot 25$ \\
\hline Depth through anterior margin of ventral & - & • & . & • & " & - & & $5 \cdot 75$ \\
\hline Dorsal fin from snout over curve of back & - & - & 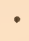 & - & ${ }^{\circ}$ & • & & . $11 \cdot 50$ \\
\hline Basal length of dorsal - . & - & - & - & - & - & - & & 3775 \\
\hline Distance between tips of caudals & • & - & - & • & - & - & - & - $10 \cdot 50$ \\
\hline " pectorals over back & - & - & - & - & - & - & - & - $11 \cdot 37$ \\
\hline Posterior dorsal from anterior dorsal & - & - & $\cdot$ & ${ }^{\circ}$ & - & & • & $5 \cdot 13$ \\
\hline Basal length of posterior dorsal & - & - & $\because$ & - & - & 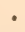 & ${ }^{\circ}$ & $3 \cdot 13$ \\
\hline
\end{tabular}

The air-bladder is of considerable size and is pear-shaped, with a narrow and short pedicle, against which the kidneys are opposed. On laying it open, it is found to be nearly divided in two longitudinally by a septum, which anteriorly expands into two pillars with a posteriorly directed concavity between them, and in which the air passage is found to open, the tube appearing on the pharynx after an interval of 4.25 inches. The tube is of considerable capacity, and freely admits a probe, its pharyngeal orifice being rather wide and patulous. The inner surface of the air-bladder is lined with a delicate, almost gelatinous membrane, which is easily separated from its glistening surface. The length and breadth of the air-bladder are about 6 inches.

The intestine, in the first 15 inches of its extent, is thrown into fine wavy persistent rugæ, which are neither so numerous nor so strongly marked after the first seren inches of the intestine are passed. In the remainder of its course, the intestine is quite smooth, and at 33 inches from the pylorus the commencement of a large intestine is indicated by the presence of a well defined valvular constriction, beyond which the extent of the first is 21 inches, so that the length of the intestine is twice the length of the body of the fish. The generative tubes open in a common cavity immediately above the termination of the urinary aperture at the base of its papilla. They are of considerable capacity, and easily admit the passage of a probe one-tenth of an inch in diameter. The gall bladder is oval and of moderate size.

The external wall of the intestine was covered with round nodules, each of which contained a little filiform cystic worm.

In that long reach of the Irawady in which the pagoda of Thingadaw occurs, this fish is considered very sacred and is under royal protection, a mandate of the sovereign existing which makes the death of one of these fish by hook or by net a very serious offence, and fishing for 3 miles above and below the little island of Thingadaw is prohibited. The fish are daily fed by the priests who reside on the small rocky islet and also by passing devotees.

The most interesting feature, however, connected with this fish is the peculiar habit it has of responding at great distances to the call of tit-tit when oft repeated. After many calls of tit-tit, I observed the fishes, at some considerable distance off, rise to the surface, apparently answering to the call by making straight for the banks of the island, where they soon showed themselves. Many were of great size, measuring, in all likelihood, nearly 5 feet in length. They were so tame that they raised their heads above water to be fed, and even permitted me to introduce my hand 
into their mouths. They also offered no objections to their feelers being felt and pulled, and the devout Burman is wont to adorn their heads with gold leaf, as a work of merit.

\section{Genus Exostoma, Blyth. \\ Exostoma andersont, Day.}

Exxostoma andersoni, Day, Proc. Zool. Soc., Lond.; 1869, p. 524.

Two specimens, $5 \cdot 50$ inches long, from Ponsee, small mountain stream.

Two specimens, 6 inches long, from Hotha, small mountain stream.

Family-CYPRINID AE.

Genus Carassius, Nilsson.

Carassius auratus, Linn.

Cyprinus auratus, Linn., Syst. Nat., vol. i, 1766, p. 527.

Carassius auratus, Bleeker, Cypr., p. 255, and Atl. Ichth. Cypr., p. 74; Günther, Cat. Fish., B. M., vol. vii, 1868, p. 32.

One specimen from Tagoung; many specimens to 6 inches in length, Tengyuechow, and seven domesticated specimens, Mandalay.

The gold carp is very prevalent in the streams about at Tengyuechow, and it is largely sold in the bazaar.

Genus Catra, Cuv. \& Val.

Catia buchanani, Cuv. \& Val.

Cyprinus catla, Ham. Buch.; Fish., Ganges, pp. 287, 318, 387, 1822, pl. xiii, fig. 81.

Catla buchanani, Cuv. \& Val., vol. xvii, 1844, p. 411, pl. 515; Günther, Cat. Fish., B. M. vol. vii, 1868, p. 34.

Two specimens, 12 inches long, from Tagoung.

\section{Genus Cirrhina, Cuv.}

Cirrhina mrigata, Ham. Buch.

Cyprinus mrigala, Ham. Buch., Fish., Ganges, pp. 279, 386, 1822, pl. vi, fig. 79.

Cirrtina mrigala, Günther, Cat. Fish., vol. vii, 1868, p. 35; Day, Journ. As. Soc., Bengal, vol. xl, 1871, p. 135, pl. ix, fig. $6 a, b$.

Two specimens, 10 inches long, Tagoung. 


\section{Genus Labe0, Cuv.}

Labeo calbasu, Ham. Buch.

Cyprinus calbasu, Ham. Buch., Fish., Ganges, pp. 297, 387, 1822, tab. 4, fig. 33.

Labeo calbasu, Günther, Cat. Fish., B. M., vol. vii, 1868, p. 54; Day, Journ. As. Soc., Bengal, vol. $x l, 1871$, p. 116.

Two specimens, 13 inches long, Tagoung.

\section{Labeo curchius, Ham. Buch.}

Cyprinus curchius, Ham. Buch., Fish., Ganges, 1822, p. 289.

Labeo cursa, Günther, Cat. Fish., vol. vii, 1868, p. 60.

Labeo curchius, Day (pars), Journ. As. Soc., Bengal, vol. xl, 1871, p. 116.

Two specimens, 10 inches long, Tagoung.

\section{Genus BARBUs, Günther.}

Barbus sarana, Ham. Buch.

Cyprinus sarana, Ham. Buch., Fish., Ganges, 1822, p. 307.

Barbus sarana, Günther, Cat. Fish., B. M., vol. vii, 1868, p. 115.

Two specimens, 7 inches long, Tagoung.

\section{Barbus apogon, Cuv. \& Val.}

Barbus apogon (Kuhl), C. \& V., vol. xvi, 1842, p. 392 ; Günther, Cat. Fish., B. M., vol. vii, 1868, p. 150.

T'wo specimens, 8 inches long, Tagoung.

\section{Barbus margarianus, n. s., Plate LXXIX, fig. 1.}

B. IV. D. $4-8$, P. 18, V. 9 , A. $2-5$, C. 19 , L. 1.35 , L. tr. $6 \frac{1}{2}-5 \frac{1}{2}$.

Length of head $6 \frac{1}{4}$, of caudal $4 \frac{1}{2}$, height of body $4 \frac{1}{4}$ in the total length. Eyes.Diameter $3 \frac{1}{2}$ in length of head, $1 \frac{1}{4}$ diameter from end of snout, and also apart. The greatest width of the head equals $\frac{2}{3} \mathrm{rd}$ of its length; and its height, its length behind the front nostril. Upper surface of head slightly convex. Abdominal profile more convex than that of the back. Upper jaw slightly longer than the lower, which latter has a rather short, anterior margin. The posterior extremity of the maxilla does not extend to quite beneath the anterior edge of the orbit. Some large open pores on the front and sides of snout. No transverse sulcus across the lower jaw. Four rather long barbels; the rostral pair reaching to below the first third, and the maxillary pair to under the last third of the eye. The dorsal fin 
commences midway between the end of snout and the base of the caudal fin; its undivided rays are strong, and spinous, the last being strongly serrated along almost the whole of its posterior edge, and its length equals $\frac{4}{5}$ th of that of the body beneath it. The pectoral rather longer than the head. The ventral commences on the vertical below the last undivided dorsal ray, and reaches above half-way to the anal; the latter fin when laid flat almost extends to the base of the caudal, which is deeply forked, its central rays being only equal to $\frac{3}{7}$ th of the outer ones. The lateral line descends to above the base of the ventral fin, from which it is divided by three and half rows of scales. This fish is silvery-blue along the back, becoming white on the sides and beneath; some of the scales with dark marks along their bases. A black band down the middle of the dorsal fin. Outer edges of caudal likewise black.

Two specimens, Nampoung river, Kakhyen hills.

Barbus mosal, Ham. Buch.

Cyprinus mosal, Ham. Buch., Fish., Ganges, pp. 303, 306, 388, 1822.

Six young specimens, Nampoung river, Kakhyen hills.

\section{Genus Oreinds, Mc'Clelland.}

Oreinus Richardsonir, Gray.

Cyprinus richardsonii, Gray, Ill. Ind. Zool., vol. i, 1832, pl. xciv, fig. 2; Günther, Cat. Fish., vol. vii, 1868, p. 161; Day, Journ. As. Soc., Bengal, vol. xl, 1871, p. 352.

One specimen, Nampoung, Kakhyen hills.

The sucker of the lower lip, a character of the genus first pointed out by Day, is very well seen in this specimen.

\section{Genus Danro, Günther.}

Danio KaKhienensis, n. s., Plate LXXIX, fig. 2.

Barbels two, equalling half of the interval between the eyes. The height of the body exceeds the length of the head by nearly the breadth of the interocular interval. Eleven longitudinal rows of scales between the dorsal and the ventral margin.

Dorsal 10, last divided to base; anal 14; pectoral 13; lateral 1. 32.

A dark line along the middle of the side and through the tail, with occasionally obscure dusky bands above and below it; the scales are minutely punctulated with black, the dots tending to group themselves along the margins of the scales.

Three specimens, Nampoung river, Kakhyen hills. 


\section{Genus BarILIUs, Günther.}

Barilius interruptia, Day.

Baritius interrupta, Day, Proc. Zool. Soc., 1869, p. 559.

Numerous specimens, Hotha, Yunnan, 2 inches long.

Genus Osteobrama, Heckel.

Osteobrama cotio, Ham. Buch.

Cyprinus cotio, Ham. Buch., Fish., Ganges, p. 339, 1822, pl. xxxix, fig. 93.

Osteobrama cotio, Günther, Cat. Fish., B. M., vol. vii, 1868, p. 323.

Two specimens, 6.56 inches long, Tagoung.

\section{Osteobrama Microlepis, Blyth.}

Systomus microlepis, Blyth, Journ. As. Soc., Bengal, vol. xxvii, 1858, p. 289.

Osteobrama microlepis, Blyth, op. cit., vol. xxix, 1860, p. 158; Guinther, Cat. Fish., B. M., vol. vii, 1868 , p. 325.

Rohtee microlepis, Day, Journ. As. Soc., Bengal, vol. xl, 1871, p. 365.

Two specimens, 13.50 inches long, Tagoung.

\section{Genus Misgurnus, Lacép.}

Misgurnus anguilutcaddatus, Cantor.

Cobitis anguillicaudata, Cantor, Ann. and Mag. Nat. Hist., vol. ix, 1842, p. 485.

Misgurnus anguillicaudatus, Günther, Cat. Fish., B. M., 1868, vol. vii, p. 345.

Common at Ponsee and at Tengyuechow.

Family-NOTOPTERID DE.

Genus Notopterus, Cuv. \& Val.

NotopterUS KAPIRAT, Lacép.

Notopterus kapirat, Lacép, t. ii, p. 190 ; Günther, Cat. Fish., B. M., vol. vii, 1868, p. 480.

Two specimens, 12 inches long, from Tagoung. 



\section{OLL U S C A.}

S P E C I ES

COLLECTED ON

THE TWO EXPEDITIONS

To

WESTERN YUNNAN. 

MOLLUSCA.

Br G. NEVILL, C.M.Z.S.,

FIRST ASSISTANT TO THE SUPERINTENDENT INDIAN MUSEUM.

\section{CEPHALOPHORA.}

\section{GASTEROPODA PULMONATA.}

Family - HELICID E.

Genus Trochomorpin, Alb.

Trochomorpha percompressa, Blanf., Plate LXXX, fig. 7.

Helix (Sivella) percompressa, Blanf., Proc. Zool. Soc., 1869, p. 448 ; Nevill, Journ. As. Soc., Bengal, vol. xlvi, pt. ii, 1877, p. 15.

The single type specimen in the Indian Museum, Calcutta, found at Bhamô, on the First Expedition to Western Yunnan, remains unique.

Genus Nanina, Gray.

Sub-Genus Rotula, Alb.

Nanina (Rotula) arata, Blanf.

Nanina (Rotula) arata, Blanf., Proc. Zool. Soc., 1869, p. 448 ; Nevill, l. c., p. 15.

Helix arata, Blanf., Con. Indica, pl. lxxxii, figs. 8 \& 9.

Very closely allied to $N$. anceps, Gld., but may, I think, be fairly separated; the spire is considerably higher, and the base of the body-whorl more excavated round the umbilicus; the keel at the periphery is less acute and the epidermis appears to be darker; the sculpture is precisely similar; the Indian Museum possesses specimens of $N$. anceps from Tenasserim, and also from Moulmein. Dr. Anderson found $N$. arata tolerably abundant at Bhamô and Ponsee; the specimens from the latter locality are rather smaller, and are the var. minor of Blanford. 
Sub-Genus Rotula, Alb.

Nanina (Rotula) Pansa, Bens.

Helix pansa, Bens., Ann. and Mag. Nat. Hist., ser. 2, 1856, vol. xviii, p. 252 ; Con. Indica, pl. lvi, fig. 1.

Nanina (Rotula) pansa, Nevill, l.c., p. 17.

Found at Prome and also at Kalawat.

Sub-Genus Macrochlamys, Benson.

Nanina (Macrochlamys) Resplendens, Phil.

Helix resplendens, Phil., Zeits. für Malak., 1846, p. 192.

Nanina (Macrochlamys) resplendens, Nevill, l. c., p. 16.

This species was found abundantly at Bhamô and in the 2nd Defile of the Irawady. The specimens are quite undistinguishable from others in the Indian Museum from Mergui (typical locality). I think it doubtful if Godwin-Austen's $N$. atricolor from the Shisha Valley will prove really distinct.

The figure in the Con. Indica, pl. v, fig. 4, is not characteristic of the species; it appears rather to represent $N$. vitrinoides.

\section{Nanina (Macrochlamys) hypoledca, Blanf.}

Nanina (Macrochlamys) hypoleuca, Blanf., Journ. As. Soc., Bengal, 1865, p. 67 ; Nevill, l. c., p. 16. Helix hypolenca, Blanf., Con. Indica, pl. lxiv, figs. 6, 7.

A single specimen of this well-marked species was found at Bhamô. In the Indian Museum there are specimens of this species from Pegu, Arakan, and Mergui.

\section{Sub-Genus Durgelta, Blanf.}

Nanina (Durgelia) Honesta, Gld., var. andersontana, Nevill.

Helix honesta, Gld., Proc. Bost. Nat. Hist. Soc., vol. 4, 1844, p. 99.

Nanina honesta, Gld. var., Stoliczka, Journ. As. Soc., Bengal, 1871, pl. xvii, figs. 7-9.

Nanina (Durgella) honesta, var. andersoniana, Nevill, l. c., p. 16.

This species a good deal resembles an Assam form; its thicker and more shining substance, less open perforation, less oblique peristome (which is considerably more broadly reflected, nearly covering the perforation), and its possessing a whorl less will, however, distinguish it. Typical $N$. honesta, so admirably figured in the Con. Indica, pl. xc, fig. 10, is found at Pegu, Moulmein, and Thyet-Myo; var. andersoniana at Thyet-Myo, Sibságar, Naga and Khási Hills, Chittagong and Eașt Cachar; Dr. Anderson also found it at Ava, in the 2nd Defile (Irawady) and at 
Ponsee and Nantin. This variety is distinguished by its less depressed shape. It is scarcely, if at all, angled at the periphery (the angulation being very distinct in the type form), the peristome not quite so broadly reflected over the perforation; the substance and texture, perforation, shape of the aperture, and number of whorls are identical.

Type of var. andersoniana, from Ponsee : axis $6 \frac{1}{4}$, diam. 11 (apert. alt. 4, diam. $5 \frac{1}{2} \mathrm{~mm}$.)

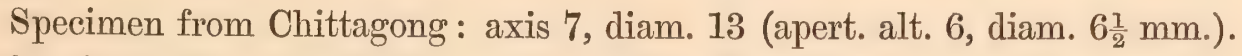

Specimen from Khási Hills : axis 7, diam. 15 mil.

Typical $N$. honesta, from Pegu: axis 6, diam. 12 (apert. alt. $5 \frac{1}{2}$, diam. $6 \frac{1}{2} \mathrm{~mm}$.)

Sub-Genus Sitala, H. Ad.

Nanina (Sitala) attegia, Bens.

Helix attegia, Bens., Ann. and Mag. Nat. Hist., 1859, ser. 3, vol. iii, p. 184; Con. Indica, pl. lxxxvi, fig. 7.

Nanina (Sitala) attegia, Nevill, l.c., p. 17.

This species was found at Prome and Bhamô; the Indian Museum also possesses specimens from Moulmein, Assam, and Preparis Island.

\section{NANINA DIPLODON, Bens.}

Helix diplodon, Bens., Ann. and Mag. Nat. Hist., 1859, ser. 3, vol. iii, p. 187; Con. Indica, pl. lx, fig. 8.

Nanina diplodon, Nevill, l.c., p. 17.

A few specimens were found in the 2nd Defile below Bhamo and also at Ponsee in Yunnan. The outer tooth of the aperture varies slightly in shape. This species seems to be allied to the Sesara group.

Sub-Genus Microcrstis, Beck.

Nanina (Mrcrocystis) barakporensis, Pfr.

Helix barakporensis, Pfr., Proc. Zool. Soc., 1852, p. 156 ; Con. Indica, pl. lxxxvii, fig. 7.

Nanina (Kaliella) barakporensis, (Pfr.) Stol., Journ. As. Soc., Bengal, vol. xlii, 1873, p. 20.

Nanina (Microcystis) barakporensis, Nevill, l. c., p. 17.

A single specimen only was found at Bhamô. The differences between the sub-genera Kaliella and Microcystis appear to be not yet sufficiently characterized. 
Genus HELIX, Linn.

Sub-Genus Plectopylis, Benson.

Heltx (Plectopylis) andersoni, Blanf.

Helix (Plectopylis) andersoni, Blanf., Proc. Zool. Soc., 1869, p. 448; Con. Indica, pl. 112, fig. 8; Godwin-Austen, Proc. Zool. Soc., 1874, p. 612, pl. lxxiv, fig. 9 ; Nevill, l. c., p. 17.

This remarkable form was not obtained on the Second Expedition; it was originally found at Bhamô and Hoetone.

Sub-Genus Plectotropis, Alb.

Helix (Plectotropis) tapeina, Bens.

Helix tapeina, Bens., Journ. As. Soc., Bengal, 1836, p. 352.

Helix (Plectotropis) tapeina, Nevill, l.c., p. 17.

The type specimens of Benson's H. tapeina are in the Indian Museum. Plate xv, fig. 6, of the Con. Indica well represents the form. It is distinguished from all other allied species by the less oblique columellar margin, rounded and not angular at the base as are all its varieties; the keel at the periphery is acute. Typical H. tapeina is found abundantly at Cherra Punjee and in Assam.

var. AKoutongensis, Theob.

Helix akoutongensis, Theob., Journ. As. Soc., Bengal, 1859, p. 306 (not Con. Indica, pl. xv, fig. 4). Helix (Plectotropis) tapeina, var. akoutongensis, Nevill, l.c., p. 17.

Only differs from the preceding by its more oblique columellar margin, more acutely keeled periphery, slightly more open umbilicus, and more depressed spire. I look upon this form as doubtfully separable from the next: the differences may he merely perhaps incidental to individuals, and not even to local races.

Dr. Anderson found this variety in Upper Burma, where it was very common.

Axis 5, diam. $15 \mathrm{~mm}$.

var. ROTATORIA, Busch.

Helix rotatoria, v. d. Busch., Phil. Icon., 1842 ; Il., p. 10, t. i, fig. 5 ; Mouss., Moll. Java, pl. ii, fig. 8. IIelix (Plectotropis) tapeina, var. rotatoria, Nevill, l. c., p. 18.

Only distinguished from the preceding variety by the less distinct or less excavated sutures, by the very acutely keeled periphery, and by the very white, more thickened, and less rounded margins of the aperture, showing within a distinct emargination at the periphery. Plate $\mathrm{xv}$, fig. 5, of the Con. Indica is an excellent representation of this form; it only differs from the figures of Mousson and Philippi by its slightly more raised spire. 
There are specimens in the Indian Museum from Prome, Akoutong, Assam, and Khási Hills; it was also found by Dr. Anderson at Manwyne and in the Shan hills. Specimen from Akoutong: axis 6, diam. $15 \frac{1}{2} \mathrm{~mm}$.

var. Bhamoensis, Nevill.

Helix (Plectotropis) tapeina, var. bhamoensis, Nevill, l.c., p. 18.

Distinguished from typical $H$. tapeina by the last whorl, which is only slightly angular and not distinctly keeled; the aperture is smaller and less produced, with the columellar margin slightly oblique and angular at base; it is smoother and less depressed than var. rotatoria, with squarer aperture and without the acute keel at the periphery. The raised spire and angulate (not keeled) periphery agree with those of $\mathbb{H}$. phayrei; it is, however, smoother, less openly umbilicated, with more contracted aperture and less developed sculpture than that species.

This variety connects $H$. tapeina almost insensibly with $H$. catostoma, Blf., and its varieties; the more raised spire, less open umbilicus, and more rounded and regular margins of the aperture, without any sign of being thickened or subdentiform at their base, are the best distinguishing characteristics.

Four typical specimens of this variety were found at Bhamô. Major GodwinAusten has also obtained some similar specimens from the Naga hills. Plate xv, fig. 10, of the Con. Indica looks to me as much like this variety as it does the shell it is said to represent (that is, $H$. arakanensis, mheob., ${ }^{1}$ from which, however, it is easily distinguished by its more open umbilicus, less conically raised spire, and by the absence of the acute keel at the periphery, \&c.

Type from Bhamô : axis $6 \frac{1}{2}$, diam. $12 \frac{1}{2} \mathrm{~mm}$.

\section{Helix (Plectotropis) trichotropis, Pfr.}

Helix trichotropis, Pfr., Zeits. für Malak, 1850, p. 73 ; Conch.-Cab., pl. 134, figs. 9, 10. IIelix (Plectotropis) trichotropis, Nevill, l. c., p. 19.

This species differs from $H$. tapeina by the shape being a trifle more trochoid, the apex more central, and the whorls more concave; the keel at the periphery is even more developed and the aperture a trifle more produced laterally; a marked characteristic is the minute and close spiral sculpture of the base, which in II. tapeina and all its varieties is, on the other hand, distinctly, though minutely, granulose; it is principally on account of this last character that I prefer to class H. trichotropis as a distinct species, and not as a variety of $H$. tapeina (near rotatoria and akoutongensis).

Major Godwin-Austen found an extremely interesting form in the Khási Hills, with more depressed spire and thinner texture (axis 6, diam. $18 \mathrm{~mm}$.) ; it is, I believe, 
one of these specimens that is represented in the Con. Indica (pl. xv, fig. 4) as H. aloutongensis, from Pegu. A few specimens were found by Dr. Anderson in the 2nd Defile, Irawady; they agree exactly with specimens from Shanghai in the Indian Museum.

Specimen from 2nd Defile, Irawady : axis 6, diam. $15 \frac{1}{2} \mathrm{~mm}$.

Helix (Plectotropis) perplanata, Nevill.

Helix (Plectotropis) perplanata, Nevill, l.c., p. 19.

Only four specimens of this very remarkable form were found at Mimboo, Upper Burma; a larger series is required to prove with certainty whether it be a distinct form, or only a variety of $H$. trichotropis, or of $H$. tapeina (near var. rotatoria).

After a most careful examination with a lens, I am unable to trace any sculpture whatever on the base; the seven whorls above are perfectly flat, as in the European H. explanata; the keel on the periphery and the shape of the aperture are about the same as in H. trichotropis (especially the Khási form); the umbilicus, however, is considerably more open, quite twice as open as in the Chinese and the above recorded specimens, and about half as open again as in those from the Khási Hills; the epidermis seems peculiar, having the appearance of being less close in texture and of a decidedly more developed character.

Axis $4 \frac{1}{2}$, diam. $17 \frac{1}{2} \mathrm{~mm}$.

\section{Helix (Plectotropis) oldhami, Bens.}

Helix oldhami, Bens., Ann. and Mag. Nat. Hist., 1859, ser. 3, vol. iii, p. 184; Con. Indica, pl. xv, fig. 7.

- Helix (Plectotropis) oldhami, Nevill, l.c., p. 19.

This species, well represented in the Con. Indica, is next allied to H. catostoma and to $H$. tapeina; the characters of the aperture distinguish it from the former, the very open umbilicus, \&c., from the latter. A single specimen was found at Ava, agreeing exactly with typical specimens from the Arakan Hills.

\section{Heurx (Plectotropis) catostoma, Blanf.}

Helix (Trachia) catostoma, Blanf., Proc. Zool. Soc., 1869, p. 447.

Helix catostoma, Blanf., Con. Indica, pl. lvi, figs. 2, 3.

Helix (Plectotropis) catostoma, Nevill, l. c., p. 20.

The specimen figured in the Con. Indica is not taken from a typical Yunnan specimen, but probably from one from Assam. The type in the Indian Museum, found at Ponsee, on the First Expedition, is the only adult specimen from Yunnan. Nine or ten immature specimens were also found, but in none of them are the 
characters of the lip developed. H. catostoma was found tolerably abundantly in the Naga Hills, by Major Godwin-Austen and Mr. Robert, and it is probably one of their specimens that is figured in the Con. Indica. They only differ from the type by the less depressed spire and slightly less open umbilicus; the characters of the aperture are the same, the dentiform process on the basal margin being equally developed and characteristic in both.

Helix (Plectotropis) huttoni, Pfr., var. savadiensis, Nevill.

Helix huttoni, Pfr., Symb. II, pt. 3.

Helix. (Plectotropis) huttoni, var. savadiensis, Nevill, l. c., p. 20.

The shell represented in Con. Indica, pl. xv, fig. 8, is not, I think, a typical specimen from the North-West Himalayas, but rather a specimen from Darjeeling; the former is a smaller, more rounded, and less solid shell, scarcely keeled at the periphery, with a higher spire, and less produced aperture. A form found by Dr. Anderson abundantly at Ava and Ponsee is nearer the Darjeeling form; the spire is slightly higher, with the apex more central. Seven specimens of a distinct and remarkable variety were also found at Sawady; at first sight these present a curious resemblance to $H$. arakanensis, and with that species are probably the connecting link between $H$. tapeina and $H$. huttoni, though unmistakably only a variety of the latter; var. savadiensis differs by its more raised spire, stouter texture, and less open umbilicus. H. winteriana, v. d. Busch. (Java), seems to be a var. of $H$. huttoni, differing by its more open umbilicus.

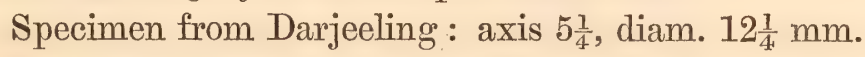

Var. savadiensis, from Sawady : axis 7, diam. $12 \frac{1}{2} \mathrm{~mm}$.

\section{Helix (Phectotropis) phayrei, Theob.}

Helix phayrei, Theob., Journ. As. Soc., Bengal, 1859 ; Con. Indica, pl. i, fig. 15.

Helix (Plectotropis) phayrei, Nevill, l. c., p. 20.

This is the largest species of the group, and is well figured in the Con. Indica; it appears to be rare. It is next allied to typical H. tapeina, the umbilicus being exactly similar; the periphery, however, is merely angulate, not keeled; the sculpture above is considerably coarser and more developed; the columellar margin more oblique and slightly angulate at base, and the outer margin more produced and rounded.

Sub-Genus Trachia, Beck.

Helix (Trachia) delibrata, Bens.

Helix delibrata, Bens., Journ. As. Soc., Bengal, vol. v, 1836, p. 352.

Helix procumbens, Gld., Proc. Bost. Soc., vol. iv, 1844, pl. 53, t. 24, fig. 1.

Helix (Trachia) delibrata, Nevill, l. c., p. 21. 
The types of this species from Sylhet are in the Indian Museum. It is a form with an unusually open umbilicus, a single spiral brown band, and a rather flat spire. It occurs also in the Khási Hills. A closely allied form is abundant in Arakan and Bassein; this only differs by the umbilicus being a trifle less open. It is well represented in the Con. Indica, pl. xiv, fig. 10. Close to both the preceding are six specimens found by Dr. Anderson at Bhamô ; umbilicus like that of the type form, suture a shade more excavated, slightly smaller in size. Var. fasciata, GodwinAusten, ${ }^{1}$ is abundant at Sibságar, in Assam; it only differs by its coloration.

Type of $H$. delibrata, from Sylhet: axis $7 \frac{1}{2}$, diam. 21 (apert. alt. 9, diam. $11 \mathrm{~mm}$.

Specimen from Bhamô : axis $6 \frac{1}{2}$, diam. $19 \mathrm{~mm}$.

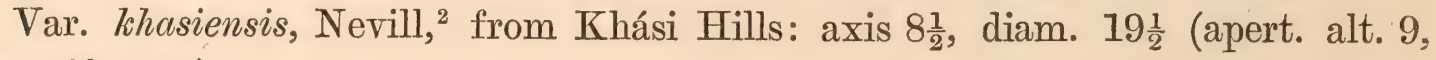
diam. $10 \frac{1}{2} \mathrm{~mm}$. )

Var. fasciata, Godwin-Austen, from Sibságar : axis 9, diam. $23 \frac{1}{4} \mathrm{~mm}$.

\section{Sub-Genus Ganeselda, Blanf. \\ Helix (Ganesella) Capitium, Bens.}

Helix capitium, Bens., Ann. and Mag. Nat. Hist., 1848, ser. 2, vol. ii, p. 160.

Helix hariola, Bens., Ann. and Mag. Nat. Hist., 1856, ser. 2, vol. xviii, p. 251.

Helix (Ganesella) capitium, Nevill, l. c., p. 21.

There is no specimen in the Indian Museum from Bengal of either of the shells called H. capitium or H. hariola, but I am informed by Mr. W. T. Blanford that he has in his collection specimens of typical H. capitium from the Ganges Valley and from the Nullaymullay Hills in Southern India, and that he is convinced that the form in Upper Burma, first found by himself in 1861, cannot be distinguished. Morelet, Ser. Conch. iv, p. 254, 1875, records a most interesting locality for $H$. capitium, viz., Bangkok, in Siam. On the other hand, the Indian Museum possesses both forms from Burma; from Prome the form figured in the Con. Indica, pl. xiv, fig. 6, as $H$. hariola, and from Ava that figured on the same plate, fig. 5, as $H$. capitium; the latter Dr. Anderson also found at Kalawat, Upper Burma; the two forms seem to me perfectly identical, except that var. hariola is keeled at the periphery.

\section{Sub-Genus Dorcasia, Gray. \\ Helix (Dorcasta) similaris, Fér.}

Helix similaris, Fér., Prodr., 1821, 262, Hist. Moll., pl. 25, B., figs. 1, 4.

Helix (Dorcasia) similaris, Nevill, l. c., p. 22.

Found abundantly at Prome, Pagan, Bhamô, and Sanda, with and without the brown band at the periphery; specimens agree exactly with others in the Indian

\footnotetext{
1 Journ. As. Soc., Bengal, 1875, pl. i, fig. 1.

2 Journ. As. Soc., Bengal, vol. Ivi, 1877, p. 21.
} 
Museum from Penang, Shanghai, and Thyet-Myo; specimens from Mauritius, Bourbon, Seychelles, and Brazil differ slightly, but most certainly belong to one and the same species.

Axis $\max .9 \frac{1}{2}$, diam. max. $16 \frac{1}{2}$ (apert. alt. $8 \frac{1}{2}$, diam. $8 \frac{1}{2} \mathrm{~mm}$.)

\section{Helix (Dorcasia) Bolus, Bens.}

Helix bolus, Bens., Ann. and Mag. Nat. Hist., ser. 2, vol. xviii, 1856, p. 252.

Helix tourannensis, Soul., Voy. Bonite., pl. xxix, figs. 1, 2; Con. Indica, pl. xxiii, fig. 7.

Helix (Doreasia) bolus, Nevill, l.c., p. 22.

Dr. Anderson found this species very abundant at Pagan, Upper Burma, and at Ponsee and Sanda, in Yunnan; typical specimens from Prome are exactly similar; specimens of var. tourannensis, from Cochin China, only differ by the spire being slightly more raised.

\section{Helix (Dorcasta) zoroaster, Theob.}

Helix zoroaster, Theob., Journ. As. Soc., Bengal, vol. xxviii, 1859, p. 310; Con. Indica, pl. lxxxvi, figs. 2, 3.

Helix (Dorcasia) zoroaster, Nevill, l. c., p. 22.

This species can be constantly distinguished from H. similaris by its larger and more depressed form, by the considerably more open umbilicus, the more angulate last whorl, and the more produced aperture, the columellar margin of which is much more oblique. It was found abundantly at Prome, Thyet-Myo, Pagan, Tsagain, and Manwyne.

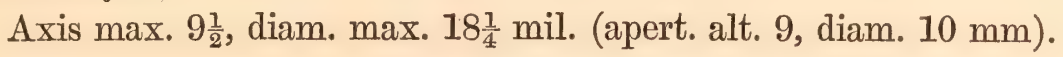

\section{Helix (Dorcasta) scalpturita, Bens.}

Helix scalpturita, Bens., Ann. and Mag. Nat. Hist., ser. 3; 1859, vol. iii, p. 391 ; Con. Indica, pl. liii, fig. 9.

Helix (Dorcasia) scalpturita, Nevill, l.c., p. 22.

This fine species was found abundantly at Tsagain, Ava, Mandalay, and 2nd Defile, Irawady; it can be distinguished from both the preceding species by the rounded whorls and raised spire and by the height of the aperture; the brown band is almost always very distinct and richly coloured, in one or two specimens only is it obsolete. Though undoubtedly this and the two preceding forms are most closely connected, I consider all three at present as well-established species.

Axis. max. 13, diam. max. $21 \frac{1}{2}$ mil. (apert. alt. 11, diam. $11 \frac{3}{4} \mathrm{~mm}$ ). 


\section{Genus PuPA, Drap. \\ Sub-Genus Cylindrus, Fitz. \\ Pupa (Cylindrus) insularis, Ehr.}

Pupa insularis, Ehr., Symb. Phys.

Bulimus pullus, Gray, Proc. Zool. Soc., 1834, p. 66.

Pupa cylindrica, Hutt., Journ. As. Soc., Bengal, vol. iii, 1834, p. 85.

Bulimus insularis, Ehr., Con. Indica, pl. xxii, fig. 10.

Pupa (Cylindrus) insularis, Nevill, l. c., p. 22.

This, probably our commonest Indian land-shell, was found in great abundance at Pagan, Upper Burma; very curiously neither this nor the next species are found at all in the neighbourhood of Calcutta. The Indian Museum possesses specimens from Aden, Gwádar, Abyssinia, Sind, Kutch, Suliman Range, Trichinopoly, Ceylon, Poona, Burwani Hills, Tinali (Benares), and Saharunpur (N. W. Provinces). The Burmese localities of $P$. insularis and $P$. canopictus now recorded, I consider particularly important and interesting. Pl. xxii, fig. 10, of the Con. Indica well represents the Burmese form.

\section{Sub-Genus Ledcochira, Martens.}

Pupa (LeUCOCHILA) Cenopicta, Hutt.

Pupa canopicta, Hutt., Journ. As. Soc., Bengal, vol. iii, 1834, p. 85, No. 7 ; p. 93, No. 9. Bulimus canopictus, Hutt., Con. Indica, pl. xxiii, fig. 9.

Pupa (Lencochila) canopictus; Nevill, l.c., p. 23.

Found abundantly at Ava and Tsagain, Upper Burma; there are also specimens in the Museum from Erode, Cutch, Patna, Trichinopoly, Delhi, Quettah, Abyssinia, and Gwádar.

Sub-Genus Scopelophina, Alb.

Pupa (Scopelophila) salwintana, Theob.

Pupa salwiniana, Theob., Journ. As. Soc., Bengal, vol. xxxix, 1870, p. 400; Con. Indica, pl. 100, fig. 9.

Pupa (Scopelophila) salwiniana, Nevill, l.c., p. 23.

I found a single specimen of this interesting shell inside a Glessula obtusa from Bhamô.

ris

Genus Succinea, Drap.

Succinea acumrnata, Blanf.

Succinea acuminata, Blanf., Proc. Zool. Soc., 1869, p. 449 ; Con. Indica, pl. lxviii, fig. 7 ; Nevill, l.c., p. 23.

Found on the First Expedition only, at Momien in Yunnan; it is a well characterized and perfectly distinct species. 


\section{Genus Veronicella, Blainv. \\ Veronicelta, n. sp.}

Veronicella, n. sp., Nevill, Journ. As. Soc., Bengal, vol. xlvi, 1877, p. 23.

Two very fine specimens of an apparently quite new form were brought back from Ponsee, preserved in spirit; even in their present contracted state the larger is 93 mils. in length; I prefer not giving them a name at present, as I am not prepared to describe their anatomical characters.

\section{Veronicelta birmanica, Theob.}

Vaginulus birmanica, Theob., Journ. As. Soc., Bengal, 1864, p. 243.

Veronicella birmanica, Nevill, l.c., p. 23.

This species is not mentioned by M. Fischer ${ }^{1}$ in his Monograph of the genus. Stoliczka ${ }^{2}$ has given some details concerning it. Dr. Anderson brought back eight specimens from Bhamô and Ponline, preserved in spirit; the largest measures 24 mils.

\section{Genus Helicarion, Fér.}

Heltcarion resplendens, Nevill. Plate LXXX, figs. 6 \& $6 a$.

Helicarion resplendens, Nevill, Journ. As. Soc., Bengal, vol. xlvi, 1877, p. 23.

Shell in texture and colour resembling Helic. gigas, Bens., but a little thinner and more membranaceous; it is at once distinguished from it by its flattened, more ear-like and appressed shape. It also somewhat resembles Helic. peguense, Theob., ${ }^{3}$ from Prome; it is, however, a larger and thicker shell, with the whorls of the spire much broader and more distinct, and considerably less open at the base; in many respects it is intermediate between the above two species, though all three are easily recognisable and quite distinct.

Type of Helic. resplendens : diam. max. 22, lat. 14, crass. $8 \mathrm{~mm}$.

Helic. gigas (small specimen) : diam. 22, lat. 16, crass. $10 \mathrm{~mm}$.

Helic. peguense, diam. 17, lat. 10, crass. $5 \mathrm{~mm}$. (a rather larger specimen than the type).

Four specimens of this interesting form were found at Sawady. Dr. Anderson also brought back a single specimen (in spirit) from Bhamô which clearly shows the animal to be of a light pinkish colour, very sparsely dotted with black specks, except on the mantle lobes and caudal extremity, which are thickly dotted; in this specimen, the spire of the shell only is covered by the animal, though the mantle lobe has no doubt shrunk.

\footnotetext{
1 Nour. Arch., t. vii.

2 Journ, As. Soc., Bengal, 1871, p. 33

3 Journ. As. Soc., Bengal, 1834, p. 8.
} 


\section{HeLtCarion gigas, Bens., var.}

Vitrina gigas; Bens., Journ. As. Soc., Bengal, vol. v, 1836, p. 350.

Helicarion gigas, Bens., var., Nevill, l.c., p. 24.

A single specimen was found at Kyoukphyoo; though differing slightly, it is so close to the shell of typical Helic. gigas, that I think there can be little doubt of their identity.

Diam. $35 \frac{1}{2}$, axis $8 \frac{1}{2}$; apert. lat. $27 \frac{1}{2}$, alt. $21 \mathrm{~mm}$.

Helicarion magnificum, God.-Aust. \& Nev.

Helicarion magnificus, God.-Aust. \& Nevill, Journ. As. Soc., vol. xlvi, 1877, p. 24.

I am indebted to Lieutenant-Colonel Godwin-Austen for pointing out that this magnificent slug, the largest yet known of the genus, is quite distinct from Benson's Helic. gigas (Khási Hills); Godwin-Austen has kindly undertaken to describe the animal with full details and a figure, so that it is only necessary for me here to state that it is very closely allied to the Assam species, but that the shell is much larger, of a brown (not green) colour, with the body-whorl much more flatly expanded, and the spire less convoluted and more depressed, and that, looked at from underneath, very much less of the reflected body-whorl is visible.

The largest specimen, in spirit, measures $70 \mathrm{~mm}$.

Shell, diam. maj. 45, axis, $11 \frac{1}{2}$; apert. lat. $40 \frac{1}{2}$, alt. $19 \frac{1}{2} \mathrm{~mm}$.

Tolerably abundant at Momien, in Yunnan.

\section{HeLicarion venustum, Theob.}

Titrina (?) venusta, Theob., Journ. As. Soc., Bengal, 1870, p. 400.

? Helicarion solidum, Grod.-Aust., Proc. Zool. Soc., 1872, p. 5, pl. i, fig. la.

Helicarion venustum, Nevill, l.c., p. 24.

Dr. Anderson brought back from Ponsee, in Yunnan, numerous specimens (preserved in spirit) of a small form, the shell of which I am unable to distinguish from typical Arakan specimens of Helic. venustum, only differing in apparently being of a smoother and more polished texture and in the spire being a shade more distinctly convoluted; a single specimen of Helic. solidum from the Naga Hills is quite undistinguishable from the above Arakan specimens. The figures in the Con. Indica of the two forms are, however, so distinct that the types will have to be reexamined. Dr. Anderson also brought back a small specimen (in spirit) of apparently the same form from Nampoung, in the Kakhyen Hills, found under stones near running water; the animal of this specimen differs from that of my Helic. resplendens in apparently completely covering the shell and in being of a duskier, more uniform coloration, apparently not speckled at all, but of a darker tinge on 
the mantle lobes and caudal extremity than on the rest of the foot; this, as far as it goes, would seem to agree fairly with the original description of the animal of Helic. solidum. ${ }^{1}$

\title{
Sub-Genus Cryptosoma, Theob. \\ Helicarion (Cryptosoma) prestans, Gld.
}

Vitrina prestans, Gld., Proc. Bost. Nat. Hist. Soc., 1843, p. 100 ; Con. Indica, pl. 1xv, figs. 5, 6.

Helicarion (Cryptosoma) prastans, Nevill, l.c., p. 25.

The entire shell is covered with a thick and compact brown epidermis; the largest specimen in the Indian Museum, from Tenasserim, measures, axis $27 \frac{1}{2}$, diam. $31 \frac{1}{4} \mathrm{~mm}$. It is an extremely abundant species in Tenasserim, and also near Moulmein. Dr. Anderson found it abundant at Sawady and on the banks of the Irawady, 2nd Defile.

\section{Genus EnneA, Alb.}

Sub-Genus Huttonelta, Pfr.

Ennea (Huttonella) Bicolor, Hutt.

Pupa bicolor, Hutt., Journ. As. Soc., Bengal, vol. iii, 1834, p. 86, No. 8 ; p. 93, No. 8 ; Con. Indica, pl. 100, figs. 4-6.

Ennea (Huttonella) bicolor, Nevill, l.c., p. 25.

Fairly abundant at Bhamô. Both E. mellita, Gld., and E. ceylonica, Pfr., are undoubtedly merely varieties of this most widely dispersed shell.

\section{Genus Streptaxis, Gray. \\ Streptaxis theobaldi, Bens.}

Streptaxis theobaldi, Bens., Ann. and Mag. Nat. Hist., ser. 3, 1859, vol. iii, p. 187; Con. Indica, pl. viii, fig. 8 ; Nevill, l. c., p. 25.

A few specimens were found at Bhamô, agreeing exactly with the typical Khási-hill form.

\author{
Genus Stenogrra, Shuttl. \\ Sub-Genus OpEas, Alb. \\ Stenogyra (Opeas) gracilis, Hutt.
}

Bulimrs gracilis, Hutt., Journ. As. Soc., Bengal, vol. iii, 1834, p. 84 , No. 5 ; p. 93, No. 5 ; Con. Indica, pl. xxiii, fig. 4.

Stenogyra (Opeas) gracilis, Nevill, l.c., p. 25.

Found abundantly at Tsagain and Bhamô on the First Expedition.

${ }^{1}$ Journ. As. Soc., Bengal, 1875. 


\section{Genus Glessula, Martens.}

\section{Glessula obtusa, Blanf.}

Achatina (Glessula) obtusa, Blanf., Proc. Zool. Soc., 1869, p. 449 ; Con. Indica, pl. xxxvi, fig. 6. Glessula obtusa, Nevill, l.c., p. 25.

This fine shell was found only on the First Expedition at Bhamô.

\section{Glessula subfustformis, Blanf. ${ }^{1}$ Plate LXXX, fig. 3.}

Achatina (Glessula) subfusiformis, Blanf., Proc. Zool. Soc., 1869, p. 449.

Glessula subfusiformis, Nevill, l.c., p. 26.

The single type specimen in the Museum found on the First Expedition at Ponsee, in Yunnan, remains unique; the species cannot be confounded with any other of our Indian forms.

\section{Glessulua pyramis, Bens.}

Achatina pyramis, Bens., Ann. and Mag. Nat. Hist., 1860, ser. 3, vol.v, p. 463 ; Con. Indica, pl. xviii, fig. 6 . Glessula pyramis, Nevill, l.c., p. 26.

Several specimens were found at Ponsee, in Yunnan, which agree fairly with the typical Khási form.

\section{Glessula Blanfordtana, Nevill.}

Glessula blanfordiana, Nevill, Journ. As. Soc., Bengal, vol. xivi, 1877, p. 26.

Shell resembling that of $G$. peguensis, Blanf., but rather more slender and of thicker texture, easily distinguished by the acutely raised undulating, perpendicular and longitudinal striation.

Two specimens only from Ponsee in Yunnan.

$$
\text { Family-LIMN } A I D A \text {. }
$$

Genus Lima жа, Linn.

Lrunama ANDERSoniana, Nevill.

Limncea andersoniana, Nevill, Journ. As. Soc., Bengal, vol. xlvi, 1877, p. 26.

Shell small, horny brown, imperforate, globose, spire short; whorls four to five, last whorl large, ovate; columella remarkably thick and reflected, straight, without any twist; aperture subovate, anteriorly rather wide. ${ }^{1}$ Wrongly named on Plate lxxx S. fusiformis, and also in Mr. Nevill's article in the Journ. As. Soc., Bengal,
vol.xlvi, p. 15. 
This small species, well characterized by its remarkable columella, is unlike any Indian species; the figure that it most resembles in 'Küster's Monog.' is a var. of $L$. peregra, pl. iii, figs. 17, 18; there is no shell like it figured in the 'Conch. Iconica'; probably $L$. andersoniana will prove to be a common species throughout Southern China.

The late Dr. Stoliczka collected a perfectly identical form at Yarkand, as well as a variety at Kashgar, the latter interesting as possessing a very small umbilicus ; $L$. andersoniana appears to be nextallied to $L$. pervia, Mart. (?=L.davidi, Desh.), and will require further comparison with type specimens of the two latter.

Long. 10, diam. $6 \frac{1}{4}$; apert. long. $7 \frac{1}{2}$, diam. $3 \frac{1}{4} \mathrm{~mm}$.

Abundant at Sanda and Nantin, in Yunnan.

\section{Limnan yUnNanensis, Nevill.}

Limncea yunnanensis, Nevill, Journ. As. Soc., Bengal, vol. xlvi, 1877, p. 26.

Shell medium-sized, ovately oblong, imperforate, pale horn-colour, very fragile, spire acuminate; whorls three to four, last whorl remarkably small; columella very strongly twisted and much produced; aperture very elongate, contracted anteriorly, broadly and beautifully regularly rounded at base.

This species is closely allied to the shell figured by H. Adams, ${ }^{1}$ as $L$. swinhoei from Formosa ; it also resembles pl. IV, fig. 25b, in the 'Conch. Iconica,' but not fig. 25a, which belongs apparently to a distinct species; L. yunnanensis may eventually prove to be an extreme variety of $L$. swinhoei, characterized by the smaller body-whorl, by the aperture being more contracted anteriorly and more rounded posteriorly, finally by the slightly more twisted columella. I have little doubt that $L$. swinhoei itself is only a synonym of $L$. flava. ${ }^{2}$ A shell sent to the Indian Museum by M. Morelet under the latter name, from China, agrees exactly with Mr. Adams' figure $l$. $c$.; Sowerby in the 'Conch. Iconica,' records and figures a species as $L$. flava, Morl. ?

Long. 16, diam. 10 ; apert. long. $11 \frac{1}{2}$, diam. $7 \mathrm{~mm}$.

At Sanda, in Yunnan.

\section{LIMndeA ACUMINATA, Lamk., var. RUFESCENS, Gray.}

Limnca rufescens, Gray, Sowerby, Gen. Shells, pl. vii ; Con. Indica, pl. lxix, fig. 1.

Limnca acuminata, var. rufescens, Nevill, l. c., p. 27.

A single specimen was found at Mandalay during the First Expedition.

${ }^{1}$ Proc, Zool, Soc. for 1866.

2 Phil. : Zeits, Mal., 1851 p. 78. 


\section{LIMNAA LUTEOLA, Lamk., var.}

Limnaa luteola, Lam., Anim. s. Vert., t. vi, pt. 2, p. 160, 1801; Con. Indica, pl. lxx, figs. 5, 6 ; Nevill, l. c., p. 27.

Six specimens of a small variety were obtained at Mandalay with the preceding species.

\section{Genus Planorbis, Guett. \\ Planorbis exustus, Desh.}

Planorbis exustus, Desh., Belanger, Voy. Ind. Orient., p. 417, pl. i, figs. 11-13, 1834; Con. Indica, pl. xxxix, fig. 10 ; Nevill, $l$ : c., p. $2 \%$.

Numerous specimens were obtained at Bhamô.

\section{PlaANorbis COMPRESSUS? Hutt.}

Planorbis compressus, Hutt., Journ. As. Soc., Bengal, vol. iii, 1834, p. 91, No. 12; p. 93, No. 12 ; Con. Indiea, pl. xcix, fig. 1 ; Nevill, l.c., p. 27.

Four specimens were obtained at Sanda, in Yunnan.

\section{PROSOBRANCHIA.}

NEUROBRANCHIA.

Family-CYCLOPHORID A.

\section{Genus Crchophorus, Montf.}

\section{Cyclophorus sublevigatus, Blanf.}

Cyclophorus sublavigatus, Blanf., Proc. Zool. Soc., 1869, p. 446 ; Con. Indica, pl. xxxiv, fig. 7 ; Nevill, l.c., p. 27.

Cyclophorus eximius, Con. Indica, pl. xxxiii, fig. 1 (not C. eximins, Mouss.).

The Indian Museum is indebted to the late Dr. Oldham for several fine specimens of a form of this handsome species collected in Assam by Mr. Masters; they agree exactly in every respect with the type form, having light yellow-coloured apertures, \&c., only they are a trifle larger in size ; it is probably one of these specimens which is figured in the 'Con. Indica,' pl. xxxiii, figs. 1, 2 (Khási Hills); it differs widely from Mousson's Javan species, by the acutely angled periphery, by its much more open umbilicus, and by the broad basal band, \&c. A fine variety of this species, C. sublavigatus, var. pealiana, occurs in the Naga Hills. ${ }^{1}$

Type from Upper Burma : axis 29, diam. $46 \mathrm{~mm}$.

\footnotetext{
${ }^{1}$ Nevill : Journ. As. Soc., Bengal, vol. xlvi, 1877, p. 20.
} 


\section{Cyclophorus fulguratus, Pfr.}

Cyclophorus fulguratus, Pfr., Proc. Zool. Soc., 1852, p. 52 ; Con. Indica, pl. iii, fig. 3 ; Nevill, l. c., p. 28.

Cyclophorus patens, Blanf., Journ. As. Soc., Bengal, vol. xxxi, 1862, p. 143; Con. Indica, pl. iii, fig. 5 .

This species was found in great abundance at Mimboo and Prome; C.patens, Blanf., from Pegu I consider only a variety, distinguished by its rounder and more thickened whorls, and especially by the less open umbilicus; C. fulguratus is one of the commonest Burmese land-shells.

M. Morelet ${ }^{1}$ states that it is found also in Siam.

\section{Cyclophorus zebrinus, Bens., var.}

Cyclophorus zebrinus, Bens., Journ. As. Soc., Bengal, vol. v, 1836, p. 355; Con. Indica, pl. ii, fig. 2 ; Nevill, l. c., p. 28.

Found in great abundance by Dr. Anderson at Bhamô, Hoetone, and Ponsee. It appears to be a variety of the common Khási species, differing by its greater size and duller colouring.

\section{Genus S piraculum, Pearson.}

\section{SPIRACULUM ANDERSONI, Blanf.}

Spiraculum andersoni, Blanf., Proc. Zool. Soc., 1869, p. 447 ; Con. Indica, pl. lxxxvi, fig. 3 ; Nevill ; l. c., p. 28 .

The type specimens were found on the First Expedition at Bhamô, where the species was very scarce; it was obtained again on the Second Expedition, living in tolerable abundance on the right bank of the Irawady, 2nd Defile, above the Great Limestone Cliff.

\section{Spiraculum aVanum, Blanf.}

Spiraculum avanum, Blanf., Journ. As. Soc., Bengal, vol. xxxi, 1862, p. 319; Con. Indica, pl. 134, figs. 7, 8 ; Nevill, l. c., p. 28.

A single specimen was found on the First Expedition at Bhamô ; the species is quite distinct from $S$. andersoni.

\section{Genus Pteroctclus, Benson.}

Pterocyclus insignis, Theob., var.

Pterocyclus insignis, Theob., Journ. As. Soc., Bengal, vol. xxxiv, 1865 ; Con. Indica, pl. v, figs. 6,7 ; Nevill, l. c., p. 29. 
Three dead specimens only of this interesting form were found on the First Expedition on the Kakhyen Hills; the spire is a trifle more depressed than in typical specimens from the Shan States.

\section{Pterocycluts feddent, Blanf.}

Pterocyclus feddeni, Blanf., Journ. As. Soc., Bengal, vol. xxxiv, 1865, p. 93 ; Con. Indica, pl. 134, fig. 1 ; Nevill, l.c., p. 29.

Tolerably abundant at Bhamô and above the Great Limestone Cliff, 2nd Defile, Irawady.

Genus ALYc $\mathbb{E U s ,}$ Gray.

Altyczus AMpHora, Bens.

Alycaus amphora, Bens., Ann. and Nag. Mat. Hist., ser. 2, 1856, vol. xvii, p. 226 ; Con. Indica, pl. xci, figs. 2, 3; Nevill, l. c., p. 29.

A few small specimens of the widely distributed Burmese species were found at Bhamô.

\section{CTENOBRANCHIA.}

Family-PALUDINID A .

Genus Bithimia, Gray.

\section{Bithrnia gonionphatos, Morl.}

Paludina goniomphalos, Morl., Rev. et Mag. Zool., 1866, p. 167 ; Ser. Conch., iii, pl. xiii, fig. 4; Nevill, l. c., p. 29.

Bithynia iravadica, Blanf., Proc. Zool. Soc., 1869, p. 446 ; Con. Indica, pl. xxvii, fig. 10.

A comparison of the type specimens in the Indian Museum of $B$. iravadica with typical specimens of $P$. goniomphalus from Cochin China prove the two species to be perfectly identical. Specimens from Siam of $B$. siamensis, Lea, are exceedingly closely allied, and may prove to be only a variety; they differ, however, by their smaller size, and by the last whorl being rounded and not ungulate, as is the case in $P$. goniomphalus. This species was obtained abundantly by Dr. Anderson at Ava, Mandalay, and Kabyuet.

\section{Bithynia turrita, Blanf. Plate LXXX, figs. 4 \& $4 a$.}

Fairkankia? (Bithynia) turrita, Blanf., Proc. Zool. Soc., 1869, p. 446.

Bithynia turrita, Nevill, l. c., p. 29.

This most distinct and interesting species was not found on the Second Expedition; the single type in the Indian Museum, therefore, remains unique. The species is, I think, a true Bithynia, certainly not a Fairbankia. It was found at Kyoutong, in Upper Burma. 


\section{Bithynia morelettana, Nevill.}

Bithynia moreletiana, Nevill, Journ. As. Soc., Bengal, vol. xlvi, 1877, p. 29.

In shape resembling $B$. lutea, Gray ${ }^{1}$, spire peculiarly short, apex very obtuse and flattened, always eroded, but not decollated; whorls $3 \frac{1}{2}$, the last obliquely produced; always imperforate, both in very young and very old shells; margins of aperture entire, broadly reflected, produced and angled at base; outer margin rounded; epidermis dark olive-green; under the lens a minute spiral sculpture can be detected. Young specimens invariably show a sort of varix, formed probably at a period when their growth is arrested by some cause; this varix becoming absorbed in adult specimens. Above 200 specimens were found at Yaylaymaw.

Long. max. $8 \frac{3}{4}$, min. $7 \frac{1}{4}$, diam. max. 6, min. $7 \frac{3}{4} \mathrm{~mm}$. ; long. anfract. ult. 7 ; long. apert. $5 \frac{1}{4}$, diam. $3 \mathrm{~mm}$.

This species can easily be distinguished from the Indian B. cerameopoma and $B$. lutea: it is imperforate, has fewer whorls, a shorter and more obtuse spire, the columellar margin is less acutely angled at base, epidermis green instead of brown.

\section{Genus Margarya, Nevill. ${ }^{2}$}

This remarkable shell is very difficult to classify, owing to its great analogy to two fresh-water genera, Paludina and Melania. I think, however, there is little doubt but that it will have eventually to rank as a sub-genus of Paludina. Margarya is characterized by its produced, Melania-like spire, composed of scalariform, rapidly increasing whorls, with very distinct suture; apex obtuse, sculptured with prominent spiral ribs ; rimate (or umbilicate?) ; margins of aperture rounded, not continuous ; animal and operculum unknown.

\section{Margarya melanioides, Nevill. Plate LXXX, fig. $5 .{ }^{3}$}

Margarya melanioides, Nevill, Journ. As. Soc., Bengal, vol. xlvi, 1877, p. 30.

Shell large; spire produced, Melania-like, with very deeply excavated suture; apex obtuse; whorls six, convex, the first two flat and obtuse, the third large and tumid (bigger in proportion than the fourth); the four last whorls are girt with three nearly equally distant, raised, irregularly nodulose keels, the middle one much the largest, having its nodules more developed and of a more or less compressedly transverse shape; umbilicus very small, almost entirely covered by the reflected columella; aperture almost circular, nearly as broad as high; columella short, evenly rounded, moderately reflected over the shallow umbilicus; a slight callus between the columella and outer lip; remains of an epidermis distinctly traceable.

I Con. Indica, pl. xxxvii, fig. 7.

2 Journ. As. Soc., Bengal, vol. xlvi, 1877, p. 30.

$3 \mathrm{Mr}$. Nevill first named this shell Paludina margariana, and as such it stands in the accompanying plate, which was printed before Mr. Nevill was led to regard this tine form as distinct from Paludina. 
A broken specimen of four whorls only, long. 67 , diam. 47 ; anfract. ult. 44 ; apert. alt. $28 \frac{1}{2}$, lat. $27 \frac{1}{2} \mathrm{~mm}$.

A perfect, but not quite adult, specimen (6 whorls), long. 52, diam. 34 ; anfract. ult. $35 \frac{1}{2}$; apert. alt. $23 \mathrm{~mm}$.

Four dead and water-worn specimens of this exceedingly interesting new form were picked up on the shores of Lake Tali, in Yunnan, by the late Mr. Margary, and were given by him to Dr. Anderson, who expressed his desire that the form should be named in honor of his unfortunate companion.

\section{Genus Paludina, Lamarck.}

Paludina chinensis, Gray, var. Ampulliformis, Eyd. et Soul.

Paludina chinensis, Gray, Griff. An. Kingd., 1834.

Paludina lecythis, Bens., Journ. As. Soc., Bengal, vol. v, 1836, p. 745.

Paludina lecythoides, Bens., Ann. and Mag. Nat. Hist., 1842.

Paludina ampulliformis, Eyd. et Soul., Voy. Bonite., Zool., 1852, p. 549, pl. xxxi, figs. 25-27.

Patudina lecythis, Bens., var. ampulliformis, Con. Indica, pl. lxxvi, fig. 7 .

Paludina chinensis, var. ampulliformis, Nevill, $l$. c., p. 31 .

The types of Benson's P. lecythis are in the Indian Museum; they are a very large, globose, and thin form of $P$. chinensis. Pl. Ixxvi, fig. 6 , in the 'Con. Indica' fairly represents Benson's form; this variety has been recently rediscovered in India by Lieutenant-Colonel Godwin-Austen, who found it at Manipúr; Benson's types of $P$. lecythis were more probably found in the same locality, than in Sylhet proper.

Found in great abundance, about 5,000 feet above the sea, at Nantin, Mungla, Momien, and Hotha, in Yunnan. There are two forms existing everywhere together, which pass by insensible gradations the one into the other: one is a short tumid variety, like typical $P$. lecythis, but of stouter texture and with the whorls much more distinctly angulate, appearing to me to be the form called $P$. ampulliformis by Souleyet: the other has a more produced spire, resembling that of P. lecythoides; apparently both Yunnan forms can be distinguished from specimens from other parts of China by the markedly shorter last whorl; some one or two, however, show in this respect so close an approach to var. lecythoides, that I am afraid the character cannot be relied upon to separate $P$. chinensis and its var. lecythoides from var. lecythis and var. ampulliformis.

\section{Paludina dissimilis, Müll., var. Decussatula, Blanf.}

P. dissimilis, var. decussatula (vel. P. decussatula), Blanf., Proc. Zool. Soc., 1869, p. 445 ; Nevill,
l. c., p. 31.

Differs from P. heliciformis, v. Fr., by the less rounded whorls, by the more produced and not decollated spire, and by the less distinct angulation at the periphery, which is distinctly banded with a white belt, obsolete in the Pegu form. 
Both differ from typical Bengal $P$. dissimilis ( $P$. praemorsa, Bens.) by the considerably more developed sculpture, more angular last whorl, less rounded aperture, and less open umbilicus, and by the more uniform green coloration; the white belt is also less distinct than it is in most Bengal specimens; it is even less like the South Indian var. variata and var. obtusa.

Common at Ava and Bhamô.

var. VIRIDIS, Rv.

Paludina viridis, Hanl. Mss., Rv., Con. Icon., fig. 20.

Paludina dissimilis, var. viridis, Nevill, l.c., p. 31 .

A fine striking form, easily distinguishable from the preceding by the more produced spire, obsolete belt, \&c., exactly resembling the above figure given by Reeve, but a trifle smaller. A few specimens only were found at Kabyuet.

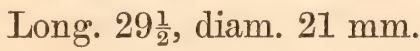

Paludina stamensis, v. Fr., var.?

Vivipara siamensis, v. Fr., Zool.-bot. Ges., Wien, 1865, pl. xxii.

Paludina siamensis, Nevill, l. c., p. 32.

The Indian Museum possesses a single typical specimen from Siam, which seems to present no distinctive characters, except in its greater size, from the numerous, but all unfortunately young, specimens found alive at the second defile of the Irawady and at Yaylaymaw.

Paludina Bengalensis, Lamk., var. Dolitaris, Gld.

- Paludina bengalensis, Lamk., var. digona, (vel. P. diagona) Blanf., Proc. Zool. Soc., 1869, p. 445. Paludina doliaris, Gld., Proc. Nat. Hist., Bost. Soc., vol. i, p. 44.

Paludina bengalensis, var. doliaris, Nevill, l.c., p. 32.

Countless varieties of this well-known shell are to be found everywhere throughout the Indian region. The form from Bhamô, called var. digona by Mr. Blanford, the type of which is in the Indian Museum, is very incorrectly figured, ${ }^{1}$ the characteristic angulation of the last whorl not being shown. It is apparently the widest spread variety of all; in the Indian Museum there are specimens almost undistinguishable from one another from Calcutta, Mandalay, and Siam. A small and less angular form of var. digona was obtained at Myadoung, having the last whorl more produced and separated. And another form from Cochin China, $P$. polygramma, Mart., apud Morelet, is also found in Pegu and Calcutta. An interesting form near var. digona was found at Shuaygoomyo: it differs by the remarkably developed 
transverse sculpture, by the peculiar green of the epidermis, which has less of a yellow tinge, and by the umbilicus being more open than in any other specimens I have seen of this protean shell; this form is near P. oxytropis, Bens., ${ }^{1}$ from Manipúr, though the latter I consider a good and distinct species. M. Morelet ${ }^{2}$ has recently suggested that probably both $P$. polygramma and $P$. lineolata are merely varieties of $P$. bengalensis; he states that both forms are found in Cochin China, and he identifies the two former for certain as merely varieties of $P$. sumatrensis. ${ }^{3}$

\section{Genus Patddomos, Swainson.}

\section{Paludonus andersoniana, Nevill.}

Large and globose; spire produced and pointed; of a very striking greenishyellow colour, with four intense black bands on the last whorl, the one at the suture and the two near the base about the width of the broadest band on P. ornata; the second band from the suture twice this width; this latter, in all but very old specimens, is very distinctly visible within the aperture; whorls seven, the first two or three generally decollated, transversely superficially ridged, ridges more or less obsolete towards the centre of the upper whorls, one of them below the suture more prominent than the rest; columella pure white; the operculum constantly differs on its inner side from those of the other Burmese species by the remarkably raised and very rugose nucleolar portion and by the distinct, though minute, granular margin. Dr. Anderson obtained several hundred specimens in all stages of growth at Mandalay, Ava, Bhamô, Kabyuet, and Myadoung. One of the best distinguishing marks from its var. peguensis is the great width within the aperture of the second brown band; the band nearest the base, on the other hand, is comparatively smaller; in $P$. peguensis (even in young specimens) the two upper bands are altogether wanting, the third very narrow, the last broad and diffused over the basal portion of the columella. This is probably the Paludomus, sp., of Theobald ${ }^{4}$ from the Shan States.

Long. max. 29, diam. max. $22 \mathrm{~mm}$.

$$
\text { var. PEGUENSIS (sp. n. ?) }
$$

Paludomus regulata, Bens., var., Con. Indica, pl. 108, fig. 6.

Paludomus andersoniana, var. peguensis, Nevill, l.c., p. 35.

Differs from the preceding by the slightly more rugose sculpture, by its more decollated apex, by the less cylindrical whorls and less produced and pointed spire (more apparent in young specimens), by the columella being apparently invariably

\footnotetext{
${ }^{1}$ Con. Indica, pl. Ixxvi, fig. 5 .

2 Ser. Conch, vi, p. 306.

${ }^{3}$ Dkr., Mal. Bl., 1852.

4 Journ. As. Soc., Bengal, 1865, p. 264,
} 
faintly stained with brown, by the almost entire apparent absence of coloration on the last whorl, especially in the absence of the second broad band within the aperture. Unfortunately, all the specimens have lost their opercula. The specimen figured in the 'Con. Indica' is a very old decollated one.

Type of variety from Pegu; long. 21, diam. $16 \mathrm{~mm}$.

\section{Paludomus ornata, Bens.}

Paludomus ornata, Bens., Ann. and Mag. Nat. Hist., ser. 2, vol. xvii, 1856, p. 498; Con. Indica, pl. 108, fig. 8 ; Nevill, l.c., p. 35.

Specimens of this very handsome species from Ava, Pegu, and Mandalay are in the Indian Museum; it is well characterised by its seven produced and solid whorls, acute and prominent spire; the Ava specimens are not decollated, though quite adult; those from the other two localities have, however, all lost their first three or four whorls; both young and old shells are perfectly smooth, with the exception of a deeply incised spiral groove below the suture; the figure in the 'Con. Indica,' pl. 108, fig. 8, is excellent; perhaps it scarcely shows sufficiently clearly the three broad spiral brown bands; from the peculiar thickness, even of young shells, these bands are, however, often scarcely visible. The operculum resembles that of $P$. regulata, Bens., only it is little flatter; both differ considerably from that of $P$. andersoniana, being much smoother on their inner side.

Long. 24, diam. $16 \mathrm{~mm}$.

Palddomus burmanica, Nevill. Plate LXXX, fig. 2.

Paludomus burmanica, Nevill, Journ. As. Soc., Bengal, vol. xlvi, 1877, p. 36.

Shell small, very thick, spire depressed, in shape closely resembling the European Litorina obtusata; only two whorls, the others decollated in both young and old specimens ; smooth, with a few irregular strix at the suture; columella very thick, pure white; aperture somewhat compressed, as in typical $P$. labiosa, not globosely expanded as in P. blanfordiana; in all the ten specimens found, only three instead of four bands, the upper one exceedingly broad, covering nearly half the last whorl, the middle one narrow, the basal one broad, but not diffused over any part of the columella; these bands are of the most intense black within the aperture, even in very old, thick specimens; epidermis unusually thick, dark olive-green, closely covered with regular raised pustules of a lighter colour.

Yaylaymaw and also Mandalay.

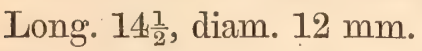

The operculum is like that of $P$. regulata, a shade darker in colour, nucleolar portion on the inner side a little more distinctly spirally rugose. The broad and richly coloured bands (only three in number), pure white columella, and peculiar 
epidermis, are the principal distinguishing characters from typical Tenasserim P. labiosa; it is, I consider, quite distinct from P. blanfordiana.

\section{Paludomus blanfordiana, Nevill.}

Paludomus labiosa, Con. Indica, pl. 108, fig. 9 (not of Bens.)

Pahudomus blanfordiana, Nevill, l. c., p. 37.

There are a good many specimens in the Indian Museum from Pegu and Ava, also from Gauhati in Assam, agreeing exactly with the shell figured as above in the 'Con. Indica'; there are also seven typical specimens of $P$. labiosa, collected by Mr. Theobald in Tenasserim: these latter are a good deal smaller and less angularly globose than the Pegu species; their columellæ are more vividly stained with brown, the brown bands are less regular and distinct (showing in an especially marked way within the aperture), and finally both young and old specimens are truncated, which is apparently never the case with the former; the sculpture of both is the same, quite smooth except for a few irregular spiral striæ below the suture; typical specimens of $P$. labiosa are without opercula; those of $P$. blanfordiana resemble opercula of $P$. regulata, though they are even less rugose, the spiral strix of the nucleolar portion of the inner side being distinct and regular (seen through the lens).

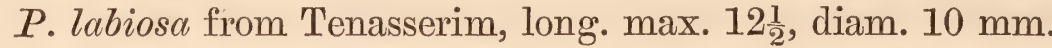

$P$. blanfordiana, type from Ava, long. max. 19, diam. $15 \mathrm{~mm}$.

$P$. blanfordiana, var. from Assam, long. 20, diam. $15 \mathrm{~mm}$.

This species resembles as closely $P$. ornata, as it does typical Tenasserim P. labiosa; specimens from Assam differ in no respect from Burmese ones, except by the spire being a trifle more produced; this locality for the species is interesting; it appears to be very abundant there.

$$
\text { Family-MELANID } A \text {. }
$$

Genus Melania, Lamarck.

Sub-Genus Striatelia, Agardh.

Melanta (Striatella) tuberculata, Müll.

Nerita tuberculata, Müll., Verm. Terr. et Fluv., 1774, p. 191.

Melania (Striatella) tuberculata, Nevill, l. c., p. 32.

Two forms of this very common and variable shell were found abundantly in the old channel of the Irawady at Myadoung; the commoner of the two somewhat resembles pl. Ixxiv, fig. 1, of the 'Con. Indica,' but is more richly coloured, with the brown band at base remarkably broad and distinct; the whorls are a little narrower and more produced, the transverse ridges very acute and prominent, the longitudinal ribs nearly, or altogether, obsolete on the last two or three whorls; the upper two or three whorls are, as usual, decollated. 
Long. max. $27 \frac{1}{2}$, diam. $9 \mathrm{~mm}$.

The other form is shorter and more rounded, of a pale green, with scarcely any brown spots or markings and with the basal band nearly, or altogether, obsolete; the transverse ridges are irregular and less acute, the longitudinal ribs, on the contrary, strongly developed, becoming obsolete only below the middle of the last whorl; decollated like the preceding.

Long. max. 20, diam. $8 \mathrm{~mm}$.

\section{Sub-Genus Melanomes, Oliv. \\ Melania (Melanoides) Jugicostis, Bens.}

Melania jugicostis, Bens. Ms., Con. Indica, pl. 110, figs. 8, 9.

Melania (Melanoides) jugicostis, Nevill, l. c., p. 33.

Unfortunately, only two specimens of this interesting form were brought back by Dr. Anderson; they were found at Myadoung with the preceding and following species. The species seems to me to belong rather to Melanoides than to Plotia; it certainly a good deal more resembles the Chinese $M$. cancellata, Bens., than Plotia scabra; in either case it is a very distinct and well characterized species, and is admirably figured in the 'Con. Indica.' Shell small, slightly decollated; whorls five, abruptly angular, smooth and shining, with a few rather distant, somewhat obsolete and irregular transverse ridges on the lower half of the last whorl; longitudinally angularly ribbed, ribs very distant, thick and prominent, almost varicose, eight of them on the last whorl, disappearing towards the base; very pale green, with no markings, except a subobsolete brown band at base.

Long. 12, diam. $6 \mathrm{~mm}$.

\section{Melanta (Melanoides) iravadica, Blanf.}

Melania iravadica, Blanf., Proc. Zool. Soc., 1869, p. 445 ; Con. Indica, pl. lxxi, fig. 1.

Melania (Melanoides) iravadica, Nevill, l. c., p. 33.

This seems to me the Upper Burmese form of a shell described by Gould as M. baccata. ${ }^{1}$ Mr. Theobald has presented a series to the Indian Museum from the Upper Salween River, well figured by him ${ }^{2}$ and by Brot. ${ }^{3}$ At first sight they seem to differ considerably from the form described as $\boldsymbol{M}$. iravadica; there is scarcely, however, any real difference, except the larger size and more distinct sculpture of typical $M$. baccata, which has three rows of nodules, the upper one of which is altogether obsolete in $\boldsymbol{M}$. iravadica; in one or two specimens, however, of the former this row is also obsolete. The type specimens of $\boldsymbol{M}$. iravadica are in the Indian Museum.

Typical $M$. baccata, of three whorls only, long. $38 \frac{1}{2}$, diam. $20 \mathrm{~mm}$.

\footnotetext{
1 Proc. Bost. Soc., 1847.

2 Con. Indica, pl. $1 \times x \times$, figs. $3,11$.

${ }^{3}$ Conch. Cabinet, pl. ix, fig. 6.
} 
M. iravadica, from Yaylaymaw, of three whorls only, long. 30, diam. $17 \mathrm{~mm}$.

At the latter locality the species was found in great abundance by Dr. Anderson on the Second Expedition, as it was also on the First Expedition at Bhamô and Manwyne; the small specimens, so well figured by M. Brot, ${ }^{1}$ were from the latter locality; these specimens had been given in exchange by the Indian Museum to the late Dr. Stoliczka, by whom they were sent to. M. Landaner.

\section{Melanid (Melanoides) reevei, Brot.}

Melania (Melanoides) reevei, Brot, Cat. Syst. Mélan., 1862, p. 46, and Conch. Cab., pl. xi, fig. 4, Nevill, l.c., p. 34.

M. balteata, Rv., pl. xx, fig. 144 B (not of Phil.)

A rather young specimen of this very distinct species was well figured as above by Reeve; an adult specimen of the same species is figured in the 'Con. Indica,' pl. 1xxii, fig. 3. It is a well characterized species, quite distinct from $\mathbb{M}$. variabilis, peguensis and gloriosa, and of these three it is nearest allied to the last. There are specimens in the Indian Museum from Noungbenzik, in Pegu; it was also obtained plentifully at Mandalay on the First Expedition, and on the Sécond Expedition at Myadoung.

var. IMBRicAtA, Hanl.

Melania reevei, var., Brot, Conch. Cab., pl. 11, fig. 4 A.

Melania reevei, var. imbricata, Hanl., Con. Indica, pl. 153, fig. 4.

Melania (Melanoides) reevei, var. imbricata, Nevill, l.c., p. 34 .

About twelve specimens of this variety were obtained at Yaylaymaw. It can be easily distinguished from the type form by its more developed sculpture; it has the same characteristic regular transverse ridges below the suture (four or five in number), but in addition has throughout other interrupted transverse ridges, broader than those near the suture and wider apart; it has also numerous longitudinal ribs, possessing a tendency at times to become obsolete (varying much in this respect in individual specimens); these ribs commence at the termination of the sutural row of regular transverse ridges, and are generally distinct only on the last few whorls; the columella is stained with a rich brown colour.

Var. imbricata, of nine whorls, long. 65, diam. $26 \mathrm{~mm}$.

Sub-Genus Plotia, Ad.

Melanta (Plotia) scabra, Müll.

Buccinum scabrum, Müll., Hist. Verm., p. 136 ; Con. Indica, pl. lxxiii, figs. 1-4.

Melania scabra, Müll.

Melania (Plotia) scabra, Nevill, l. c., p. 34.

1 Matér. Mél., iii, pl iv, figs. 12, 13. 
A few specimens were found at Myadoung; they agree perfectly with Reeve's fig. 156 B (M. spinulosa, Lamk.)

$$
\text { Family-AMPULLARID AR. }
$$

Genus Ampuliaria, Lamarck.

\section{Ampuluaria theobaldi, Hanl.}

Ampullaria theobaldi, Hanley, Con. Indica, pl. 115, fig. 2; Nevill, l.c., p. 37.

? Ampullaria maura, Rv., var. Con. Icon., fig. 57.

Unfortunately, none of the 16 specimens collected by Dr. Anderson at Bhamô are quite full-grown, the outer lip in all of them being thin and sharp; in the depression of the spire they agree with Reeve's figure of $\mathcal{A}$. maura, as well as the typical figure of $A$.theobaldi; the umbilicus is open, agreeing exactly with the latter figure; the coloration and shape of the aperture are also the same; I think it very doubtful, however, if it can be separated as a distinct species from the common Assam form, from which it only seems to differ by its larger size, less produced spire, slightly more open umbilicus, and in the coloration being a shade more vivid; in the latter two respects, however, some few Assam specimens approximate most closely.

\section{ACEPHALA.}

Family-UNIONID 2 .

Genus Unio, Retz.

Unio marginatis, Lamk., var. SAVAdiensis, Nevill.

Unio marginalis, Lamk., Anim. s. Vert., t. vi, 1835, p. 544; Con. Indica, pl. ix, fig. 6 (sp. juv.) Unio marginalis, var. savadiensis, Nevill, l.c., p. 37.

This variety is abundant at Sawady in the Thengleng stream, also at Bhamô and at Shuaygoomyo; four young specimens found at Myadoung probably also belong to this form. The nearest figured variety is obesa, Hanl., 'Con. Indica,' pl. 44, fig. 7, from the Irawady; var. savadiensis is of a more ovate shape, of a slightly thinner texture, the nacre is of a light salmon or cream-colour, instead of the ordinary bluish-white tinge characteristic of var. obesa, the difference of colour in the nacre is constant both in young and old shells; the lateral teeth are more convex, the cardinal ones a little less strongly developed; young specimens of both varieties are prominently winged, as in var. lamellatus. ${ }^{1}$ Externally, young specimens are of a gamboge-yellow colour, tinged with bright green on the wing.

Long. max. 113, lat. max. $68 \mathrm{~mm}$. 
var. CORRIANA, Lea.

Unio corrianus, Lea, Trans. Am. Phil. Soc., v, pl. ix, fig. 25.

U. marginalis, var. corriana, Con. Indica, pl. xliv, fig. 4; Nevill, l. c., p. 38.

Four magnificent specimens of this very marked variety were found at Yaylaymaw; the nacre is of the most beautiful salmon-pink colour; the only difference from typical Bengal specimens is that the texture and teeth are thicker, and this is the case also with specimens from Pegu.

Long. 115, lat. $55 \mathrm{~mm}$.

UnIo FEDDENI, Theob. Plate LXXX, fig. 11.

Unio feddeni, Theob., Journ. As. Soc., Bengal, 1873, pl. xvii, fig. 3 ; Nevill, l. c., p. 38.

Tolerably abundant in rice fields at Bhamô, also at Yaylaymaw. I feel quite sure that Mr. Theobald is wrong in recording this species as found in the Pemgunga, Central India; typical specimens from Mr. Fedden are marked in the carefully kept collection of Mr. H. F. Blanford as from Burma; the specimens found by Dr. Anderson in Upper Burma confirm Mr. Blanford's record of the locality of the original type form, as opposed to that given by $\mathrm{Mr}$. Theobald; $\mathrm{Mr}$. Fedden collected in both localities.

Unio burmanus, Blanf.

Unio burmanus, Blanf., Proc. Zool. Soc., 1869, p. 453; Con. Indica, pl. xlii, fig. 1; Nevill, $l . c$. , p. 38.

This form was not found on the Second Yunnan Expedition. Full-grown shells are narrower and more produced, with the umbones much less prominent, and the rugose sculpture also less developed than is the case with $U$. bhamoensis.

The types of $U$. barmanus from Bhamô are in the Indian Museum.

\section{Unio Bhamoensis, Theob.}

Unio bhamoensis, Theob., Journ. As. Soc., Bengal, 1873, p. 207, pl. xvii, fig. 1; Nevill, l. c., p. 39. Unio mandelayensis, Theob., Journ. As. Soc., Bengal, 1873, p. 208, pl. xvii, fig. 2.

Not uncommon at Myadoung and Yaylaymaw; found also on the First Expedition at Mandalay, Bhamô, and Shienpagah. The two above forms can certainly not be separated, as indeed might have been surmised from Mr. Theobald's remarks in the original description, large series from one locality showing that both varieties run one into the other. The Pegu form mentioned in the original description of $U$. bhamoensis differs a good deal more from both than the Bhamô from the Mandalay one; it is a pity Mr. Theobald did not give this Prome variety a name, instead of the Bhamô one. 
Unio foliaceds, Gld., var. Fragilis, Nevill. Plate LXXX, fig. 8.

? Unio foliaceus, Gld., Proc. Bost. Nat. Hist. Soc. ; Con. Indica, pl. xlii, fig. 3.

? U. peguensis, Anth., Am. J. Con., pl. xxv, fig. 2.

U. fragitis, Nevill, Journ. As. Soc., Bengal, vol. xliv, 1877, p. 39.

Ten specimens from Yaylaymaw only differ from the Pegu form, in that the epidermis, except on the posterior angle, is quite smooth; unfortunately they all seem young shells; the two biggest are exceptionally tumid, in this respect differing from the others, as also from the Bhamo and Shienpagah specimens; in all of the above the nacre is less yellow-tinged towards the umbones, and the teeth thinner than in $U$. foliaceus. It is a form extremely close to, if not identical with, the $U$. comptus, Desh, ${ }^{1}$ stated by MM. Crosse and Fischer to be the U. sumatrensis of Lea. Type of var. fragilis from Yaylaymaw; long 34, lat. $17 \frac{1}{2}$, crass. $11 \frac{1}{4} \mathrm{~mm}$.

Three specimens from Bhamô, all young; long. max. 43, lat. 24, crass. $13 \mathrm{~mm}$.

Thirty specimens from Shienpagah, all young; long. max. 32, lat. 17, crass. $9 \frac{1}{4} \mathrm{~mm}$.

Specimens of $U$. foliaceus, from Pegu; long. 58, lat. 22, crass. $17 \mathrm{~mm}$.

\section{Unio pugio, Bens.}

Unio pugio, Bens., Ann. and Mag. Nat. Hist., 1862, p. 193; Con. Indica, pl. x, fig. 7; Nevill, l.c., p. 39 .

Abundant at Myadoung, Bhamô, and Yaylaymaw. Very young specimens are rugose anteriorly, especially near the umbones.

Long. 57, lat. 27, crass. $20 \mathrm{~mm}$.

Unio bonneaud, E. \& S., var. Plate LXXX, figs. 10 \& $10 a \& 12 \& 12 a$.

Unio bonneaudi, Eyd. \& Soul., Mag. de Zool., 1838, pl. ; Con. Indica, pl. x, fig. 6, and pl. xlvi, figs. 5, 6 ; Nevill, l.c., p. 39.

Very abundant at Myadoung, Irawady, second defile, Shuaygoomyo, Yaylaymaw, and Bhamô. It varies considerably in being more or less rugose in sculpture.

Long. max. 52, lat. max. 29, crass. 24 mm.

Unio andersonianus, Nevill. Plate LXXX, figs. $9 \& 9 a \& 9 b$.

Unio andersoniana, Nevill, Journ. As. Soc., Bengal, vol. xlvi, 1877, p. 40.

This species was found at Myadoung in tolerable abundance, together with $U$. bonneaudi and several other species; two specimens were also obtained on the First Expedition at Shienpagah. It is next allied to U. pachysoma, Bens., and to some 
of the varieties of $U$.ccruleus, Lea. It is easily distinguished from $U$. bonneaudi by its more irregular shape, thinner texture, by the acute angulation, greater production posteriorly, and by the more developed sculpture; a constant character also is the pink colour of the nacre, which in $U$. bonneaudi is bluish-white; this is equally distinct and characteristic in young as in old specimens.

Type from Myadoung; long. 32, lat. $15 \frac{1}{2}$, crass. $11 \frac{3}{4} \mathrm{~mm}$.

Specimen of U. bonneaudi from Myadoung; long. 31, lat. 18, crass. $13 \mathrm{~mm}$.

\section{Family-CYRENID AR.}

Genus Corbicula, Meg.

Corbicula lamarckiana, Prime.

Corbicula lamarckiana, Prime, Ann. Lyc. N. York, 1867; Nevill, l.c., p. 40.

Specimens obtained at Hotha and Momein (5,500 feet) in Yunnan, and also at Mandalay, agree exactly with Prime's original figure. Lieutenant-Colonel GodwinAusten also found a small form of this well-marked species at Manipúr, in the Kuchai stream.

Long. $28 \frac{1}{2}$, lat. $20 \frac{1}{2}$, crass. $13 \mathrm{~mm}$.

\section{Corbicula runianensts, Nevill.}

Corbicula yunnanensis, Nevill, Journ. As. Soc., Bengal, vol. xlvi, 1877, p. 40.

Medium-sized specimens from Yaylaymaw agree fairly with Prime's figure and description of $C$. linnean ${ }^{1}$, the principal difference being the less truncate anterior

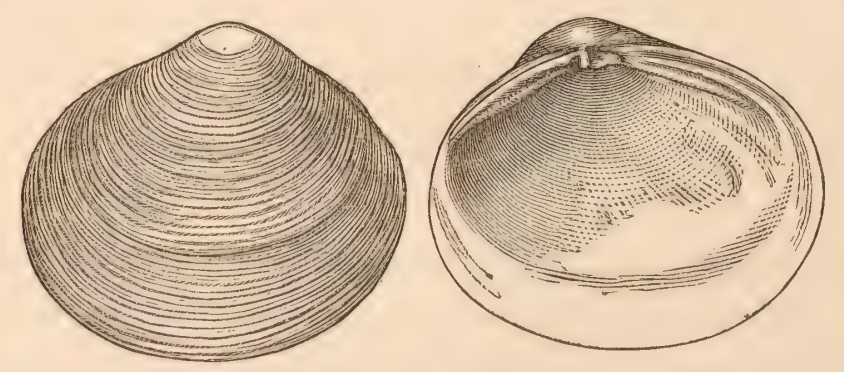

Fig. 32.

Corbicula yunnanensis, nat. size.

side. Shell large, thick, transverse, inequilateral, compressed, rather abruptly tumid towards the umbones; anteriorly moderately produced and rounded, posteriorly produced and truncate (exactly as in Prime's figure of $C$. linneana); lateral teeth curved, the anterior a little more so than the posterior; no lunule; epidermis dark brown, striæ regular and close; interior violet, of a darker shade near the margin. 
This species is more inequilateral, more tumid near the umbones, and more regularly sulcated than C. mulleriana, Prime (loc cit) from China, which, however, it also closely resembles.

Type from Manwyne in Yunnan (4,000 feet); long. 39, lat. $33 \mathrm{~mm}$.

Yaylaymaw (all young), long. $21 \frac{1}{2}$, lat. 17, crass. $11 \frac{1}{2} \mathrm{~mm}$.

\section{Corbicula andersoniana, Nevill.}

Corbicula andersoniana, Nevill, Journ. As. Soc., Bengal, vol. xlvi, 1877, ؟. 41.

Rather small, thin, subequilateral, transversely ovate, tumid; medium-sized specimens closely resemble in shape $C$. incequilateralis, Prime; both sides are obtusely rounded, epidermis bright green, interior violet, paler near the margin. This is quite distinct from the other Burmese and Indian species; it is, however, exceedingly close to C. tumida, from Borneo, as figured by Issel. ${ }^{1}$

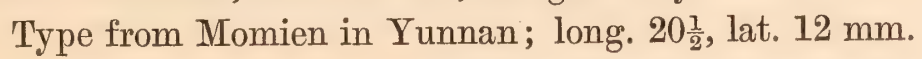

${ }^{1}$ Desh. : Proc. Zool. Soc., 1854. 



\section{INSECTA.}

\section{S P E C I ES}

COLLECTED ON

THE TWO EXPEDITIONS

To

\section{WESTERN YUNNAN.}





\section{INSECTA $^{1}$}

COMPILED

BT FREDERIC MOORE, F.L.S., \&C.,

ASGISTANT CURATOR, INDIA MUSEUM, LONDON.

\section{Order COLEOPTERA.}

Family-CICINDELID 28.

CrctNdela CHLoris, Hope, Gray's Zool. Misc., 1831, p. 21.

Cicindela himalexica, Redt. Hügel's Kaschm., 1848, vol. iv, p. 497, t. 23, fig. 1.

Cicindela flavomaculata, Kollar, Ann. Wien. Mus., i, 1836.

$$
\text { Family-CARABID } A \text {. }
$$

Chlazintus, sp.

Chlanius, sp.

Omaseus, sp.

Harpalus, sp.

$$
\text { Family-DYTISCID } 2 A .
$$

Dineutes lateralis, Leach.

$$
\text { Family- } S C A R A B A I D A \text {. }
$$

Copris sagax, Schönh., Syn. Ins., i, p. 43.

ONTHOPHAGUS, sp. ?

Oniticelluds brama, Redt. Hügel's Kaschm., vol. iv, 1848, p. 521.

$$
\text { Family - MELOLONTHID } \text { AR. }
$$

Serica micans, Fabr., Syst. El., ii, p. 183.

SERICA, sp.

Apogonia, sp.

1 The insects mentioned in this list were chiefly collected at Ponsee in the Kakhyen hills, while a few were obtained at Manwyne, Sanda, Muangia and Hotha, and a still fewer number at Tengyuechow. 
Sohizonycha, sp.

Schizonycha, sp.

Lepidiota bimaculata, Saunder, Trans. Ent. Soc., 1839, p. 76, pl. xvi, fig. 2.

ANCYLONYCHA, sp.

ANCYLONYCHA, sp.

AnCrlonycha, sp.

ANCYLONYCHa, sp.

$$
\text { Family-MIMELID } A \text {. }
$$

Anomala splendens, Hope, Gray's Zool. Misc., 1831, p. 23.

Mrmela glabra, Hope, Trans. Ent. Soc., 1841, p. 67.

Mimela, sp.

Euchlora perplexa, Hope, Proc. Zool. Soc., 1839, p. 70.

Edchlora monochroa, Reiche.

Popilia biguttata, Wiedem., Germ. Mag. Ent. iv, p. 136.

Popilita, sp.

Popilita, sp.

Popilia, sp.

$$
\text { Family-DYNASTID } A \text {. }
$$

Heteronychus piceus, Fabr., Syst. Ent. L., p. 14.

Eupatorus hardwicki, Hope, Gray's Zool. Misc., 1831, p. 23 ; Westw., Cab.

Orient. Ent., 1848, t. 13, fig. 4 .

$$
\text { Family-CETONIID } A \text {. }
$$

RHOMBORRHTNA, sp.

Guyctphana marginicolits, Gory et Perch., Mon., p. 251, t. 47, fig. 6.

Cetonia, sp.

$$
\text { Family-MALACODERMIDAE. }
$$

Dictyoptera, sp.

Dictyoptera, sp.

LAMPYRIS, sp.

LAMPYRIS, sp.

$$
\text { Family-BUPRESTID A. }
$$

AgriLUs, sp.? 
Family-ELATERIDAR.

Melanotus, sp.

Family-BOSTRYCHIDA.

Apate, sp.

Family-RHIPIDOPHORID ZE.

RHIPIDOPHORUS, sp.

Family-LAGRIIDAE.

Lagria basalis, Hope.

Four other undetermined species of this family.

$$
\text { Family-TENEBRIONID } A \text {. }
$$

Opatrum, sp.

Epilampus, sp.

$$
\text { Family-MYLABRID } \mathbb{E} \text {. }
$$

Litta nepalensis, Hope.

$$
\text { Family-CURCULIONID AS. }
$$

Apoderts, sp.

Arrhenodes, sp.

Crrtotrachelus, sp.

Cleonus, sp.

LIxUs, sp.

Lixus, sp.

Blosyrus, sp.

Stpalds granulatus, Fabr., Syst. El., ii, p. 432.

Sipalus, sp.

$$
\text { Family-CERAIIB YCID } \text { AR. }
$$

Batocera roylei, Hope, Trans. Zool. Soc., 1835, vol. i, p. 103, pl. xv, fig. 1.

Ceroplesis trictncta, Dej.

Lamia wallichi, Hope, Royle's Himalayan Bot. Zool., 1839, pl. ix, figs. 5 and 6. Rosalia, sp.

Blepephaeds succinctor, Chevrol, Rev. Zool., 1852, p. 417. 
Purpuricenus temmincki, Guer., Ic. règne anim., p. 224.

Eurybatus 9-punctatus, Westw., Cab. Orient. Ent., pl. xxix, fig. 3,

Apomecrna albomaculatus, Perrond. Ann. Soc. Linn. Lyon, 1855, p. 362 et 401.

Clytus, sp.

Glenea, sp.

Family $\rightarrow S A G R I D A$.

SAgra moшноті, Baly, Journ. of Ent., i, 1860, p. 193.

Family-CRIOCERID AR.

Temnaspis modHoti, Baly, Ann. \& Mag. Nat. Hist., 3rd Ser., vol. xiv, 1864, p. 435.

Crioceris IMPressa, Fabr., Mant. Ins., i, 1787, p. 88.

Crioceris, sp.

$$
\text { Family-HISPID A. }
$$

Antsodera excatata, Baly, Cat. Hispid., 1858, p. 105, t. 8, fig. 1.

Craspedonta leayana, Latr., Gen. Crust. et Ins., iii, p. 50, t. 11, fig. 7.

$$
\text { Family-HALTICID AR. }
$$

Graptodera, sp.

Graptodera sp. ?

Cacoscelis, sp.

$$
\text { Family-CASSIDID AR. }
$$

Aspidomorpha sanctecructs, Fabr., Ent. Syst., iv, App. p. 446.

Coptocycla catinata, Bohem. Mon., iii, p. 262.

Coptocycla (two species).

$$
\text { Family-EUMOLPID } A \text {. }
$$

Corynodes Peregrinus, Herbst., Füessl. Arch., t. v, 1783, p. 63, pl. ii, fig. 25.

Eumoupus (two species).

$$
\text { Family-CHRYSOMELID } A \text {. }
$$

Paralina cranicolits, Hope, Gray, Zool. Misc., 1831, p. 29.

LINA, sp.

$$
\text { Family-CLYTHRID AE. }
$$

Diapromorpha melanopus, Dej., Cat., 3 ed., p. 442. 
Family-CRYPTOCEPHALID AE.

Criptocephatus (five species).

Family-GALERUCIDA.

Haplosonyx smaragdipennis, Chev., Rev. Zool., 1838, p. 288.

Haplosonyx QUADRifasctata, Hope, Gray's Zool. Misc., 1831, p. 288.

Callopistria fulminans, Falderm., Mém. Ac. Petr., 1835, II, 1865, p. 99.

Rhaphia cranipennis, Baly.

AUlacophora, sp.

AUlacophora, sp.

Rhaphidopalpa sexmactlata, Hope.

Phyllotreta cranura, Hope.

Phyllotreta lunata, Redtenb, Hügel, Kaschm., iv, p. 556, t. 27, fig. 3.

Adoridu maculiventris, Chev.

ADORIUM, sp.

ADORIUM, sp.

Galeruca, sp. (twelve).

Family-COCCINELLID 2 .

Harmonta septempunctata, Linn., Syst. Nat., ed. $x, p .365$.

LEIS BICOLOR, Hope, Gray's Zool. Misc., 1831, p. 31.

Leis 19-signata, Falderm., Mém. Ac. Petr., II, 1835, p. 456.

Lemnia plagiata, Fabr.

Lemnia biplagiata, Swartz. Schönh, Syn. Ins., I, 2, 1808, p. 196.

Lemnia? sexareata, Muls., Opusc. ent., II, 1853, p. 53.

Coccinella sp. ? (six species).

Epilachina mactlaris, Muls. spec., p. 797.

Epilachna, sp. (three species).

Family-EROTYLIDAE.

Fatua, sp. 


\section{Order ORTHOPTERA.}

$$
\text { Family - PHASMID A. }
$$

BACTERIA, sp.?

$$
\text { Family-MANTIDAR. }
$$

Mantis, sp. ?

Mantis, sp.?

$$
\text { Family-GRYLLID AR. }
$$

Gryllotalpa vulgaris, Geoffr., Ins. Par., i, p. 387, pl. vii, fig. 1.

Gryluus constmilis, Walker, Cat. Derm. Salt. Brit. Mus., i, p. 4 I.

$$
\text { Family-LOCUSTID A. }
$$

Phaneroptera diversa, Walker, Cat. Derm. Salt. Brit. Mus., ii, p. 346.

$$
\text { Family-ACRIDID } A \text {. }
$$

Prrgomorpha crenulata, Fabr., Ent. Syst., ii, p. 28 ; Walker, Cat. Derm. Salt., B. M., iii, p. 497.

\section{Opomala tenebrosa, Walker.}

Opomala tenebrosa, Walker, Proc. Zool. Soc., 1871, p. 246.

Female.-Piceous or ferruginous, slender, slightly compressed. Head and prothorax with a very slight middle keel, and with a few very slight longitudinal ridges. Tip of the vertex flat, short-conical; front tawny, oblique, speckled with black, with four well-defined diverging keels ; inner keels united near the tip of the vertex. Antenna flat, lanceolate, about twice the length of the head. Prothorax with a very slight keel on each side; fore border hardly rounded; hind border slightly rounded. Hind femora as long as the abdomen. Hind tibiæ a little shorter than the hind femora; spines stout, of equal size. Fore-wings with irregular and very minute areolets ; those towards the tips larger, elongated, and regular. Hind-wings cinereous hyaline, blackish at the tips; veins black, pale green or pale yellow at the base and along the interior border.

Length of the body 14 lines; expansion of the fore-wings 24 lines.

Phrmateus miniaris, Linn., S. N., ii, p. 700 ; Walker, Cat. Derm. Salt., B. M., iii, p. 539.

Crrtacanthacris ferrina, Walker, Cat. Derm. Salt., B. M., iii, p. 568. 
Cyrtacanthacris .PUnCTIPennis, Walker.

Cyrtacanthacris punctipennis, Walker, Proc. Zool. Soc., 1871, p. 246.

Male-Tawny, slender, testaceous beneath. Head short; tip of the vertex depressed, nearly round; front punctured, slightly oblique, with four well-defined diverging keels; inner keels ending in the flat ridge which extends from the tip of the vertex. Antennæ slender, a little longer than the head and the prothorax together. Prothorax with a very slight keel, which is most apparent near the hind border; four transverse impressed lines, the first, as usual, widely interrupted in the middle; fore border hardly curved; hind border slightly elongated and angular. Prosternal spine thick, oblique, rounded at the tip, approaching the mesosternum. Abdomen testaceous, with a piceous stripe which extends from the base to beyond half the length. Fore-wings cinereous towards the tips, with numerous blackish points, which mostly form very irregular bands; a row of subcostal black more determinate points. Hind-wings cinereous; veins black.

Length of the body 15 lines; expansion of the fore-wings 30 lines.

The prosternal spine is shorter, stouter, and more obtuse than that of C. rubiginosa, which this species closely resembles. The speckled fore-wings distinguish it from C. spissa.

Acridium virescens, Walker, Cat. Derm. Salt., B. M., iv, p. 635.

ACridium angustifrons, Walker, op. cit., iii, p. 593.

Eperomia vulnerata, De Haan., Verh. Gesch. Ned. Ind., p. 162, pl. xxi, fig. Eperomia varia, Walker, Cat. Derm. Salt., B. M., iv, p. 774.

\section{Mastax innotata, Walker.}

Mastax innotata, Walker, Proc. Zool. Soc., 1871, p. 247.

Male.-Ferruginous, slender. Head elongate, obliquely but abruptly ascending; tip of the vertex conical, prominent, slightly bilobed; front long, oblique, with four well-defined keels; inner keels converging towards the face; outer keels diverging towards the face; clypeus and fore part of the face tawny. Antennæ black, short, slender, tawny towards the base. Eyes elliptical, prominent. Prothorax short, sellate, widening hindward, with a slight keel; a blackish mark on each side in front of the transverse impressed line. Hind femora as long as the abdomen. Hind tibiæ slender, piceous, a little longer than the hind femora; spines small. Fore-wings narrow, cinereous, with two pellucid marks near the tips, the mark on the hind border larger and more remote from the tip than the other, which is costal. Hind-wings cinereous hyaline, with a blackish costal line; veins black.

Length of the body 10 lines; expansion of the fore-wings 20 lines.

Tetrix exultans, Stäl., Eugenie Resa, p. 347. 


\section{Oxza DIMINuta, Walker.}

Oxya diminuta, Walker, Proc. Zool. Soc., 1871, p. 247.

Male.-Tawny, slender. Head and prothorax with two ferruginous stripes, which do not extend beyond the fourth transverse impressed line of the prothorax. Head slightly elongate; vertex with two keels between the eyes; tip depressed, transverse, subrhomboidal; front hardly oblique, with four strongly marked keels; inner keels slightly curved towards the vertex, parallel towards the face; outer keels diverging towards the face. Antennæ slender, piceous towards the tips. Prothorax with a keel, which is hardly apparent except towards the hind border; the latter rounded. Prosternal spine long, acute, rather slender. Spines of the tibiæ with black tips. Wings half developed. Hind-wings cinereous hyaline; veins black.

Length of the body 10 lines.

\section{CaLoptindes incomptus, Walker.}

Caloptinus incomptus, Walker, Proc. Zool. Soc., 1871, p. 247.

Male.-Tawny, testaceous beneath. Head short; vertex with two slender furrows between the eyes; tip flat, subrhomboidal; front in structure like that of C. inamcenus. Antennæ slender. Prothorax with a slight keel and with the usual transverse impressed lines; hind border elongated, slightly angular. Prosternal spine stout, long, slightly acute. Hind legs testaceous; spine of the tibiæ with black tips. Fore-wings cinereous, tawny towards the base, with some irregular and indistinct pale brownish bands formed by clouded reins. Hind-wings pellucid, cinereous about the tips; a tawny costal streak; veins pale yellow, black towards the tips.

Length of the body 10 lines; expansion of the fore-wings 20 lines.

Very closely allied to $C$. inamœnus. The keel of the prothorax is more strongly defined than that of $C$. signatipes.

\section{Caloptinus inamcenus, Walker.}

Caloptinus inamcenus, Walker, Proc. Zool. Soc., 1871, p. 248.

Male.-Piceous. Head short; vertex with two slender furrows between the eyes; tip flat, subrhomboidal; front punctured, erect, with four distinct keels; inner keels slightly diverging from the vertex to the face; outer keels nearly parallel. Antennæ tawny, as long as the head and the prothorax together. Prothorax with a slight keel, with the usual four transverse impressed lines, and with two colli on each side; fore border hardly rounded; hind border slightly elongated and angular. Pectus and abdomen testaceous, the latter piceous above towards the base. Prosternal spine long and stout, rounded at the tip. Hind femora with three black spots 
on the upper side, and with a black stripe beneath. Hind tibir red, their spines with black tips. Fore-wings cinereous, brownish towards the tips, with several indistinct and irregular bands formed by brownish-clouded veins; costa rounded near the base. Hind-wings cinereous; a ferruginous costal streak; veins black, greenishwhite at the base and along the interior border.

Length of the body 12 lines; expansion of the fore-wings 22 lines.

The vertex between the eyes is narrower than that of $C$. brunneus.

$$
\text { Family-BLAT'ID } 2 \text {. }
$$

LEUCOPHA

EPILAMpra, sp.?

Periplaneta, sp.?

Family-FORFICULID A.

Forficula, sp. ?

LEBTA, sp.?

Order NEUROPTERA.

Family-LIBELLULID A .

Matrona Basilaris, De Selys, Syn. de Caloptèrygines, p. 17.

Neurobasis Chinensis, Linn., S. N., p. 904.

Neurothemis sophronta, Drury, Exot. Ins., ii, p. 86.

Neurothemis equestris, Fabr., Ent. Syst., ii, p. 379.

Vestalis gracilis, Rambur, Néurop., p. 224.

Brachybasis coromandeliana, Fabr., Ent. Syst., Suppl., p. 287.

Lestes nodalis, De Selys (ined.).

Lepthemis sabina, Drury, Exot. Ins., i, p. 114.

Crocothemis servilia, Drury, Exot. Ins., i, p. 112.

LIBELLULA, sp. ?

Ltbellula Dalei, De Selys (ined.).

Libellula? ALBICAUdA, Brauer.

Ltbellula lesta, De Selys (ined.).

Pantala flavescens, Fabr., Ent. Syst., Suppl., p. 285.

Rhтотнемis variegata, Linn., Syst. Nat., p. 903.

Rhinocypha cuneata, De Selys, Synop. Calopt., p. 60.

Palpopleura sexmaculata, Fabr., Ent. Syst., ii, p. 381. 
Mnats Andersoni, McLachlan.

Mnais andersoni, McLachlan, De Selys, Trois. Additions au Synop. Caloptèrygines, 1873, p. 8.

Male.-Abdomen 37 to $39 \mathrm{~mm}$. Inferior wing 30 to $32 \mathrm{~mm}$. Allied to Mnais pruinosa. The reticulation is black; the wings very slightly washed with olive-green; the pterostigma obscure-reddish; the body slightly pruinous-bronze; the superior lip metallic-green; the upper side of the head and the thorax coppery-green. There are 22 antecubitals and 25-26 postcubitals on the superior wings. In the largest specimen of the male, the reticulation is yellowish-red, excepting before the quadrilateral, where it is blackish; the wings are strongly washed with clear yellowish-red; the pterostigma carmine. Female unknown.

$$
\text { Family-MYRMELEONTID A. }
$$

Formtcates, sp.?

$$
\text { Family-PHRYGANID AE. }
$$

Stenopsyche Griseipennis, McLachlan, Trans. Ent. Soc., 3rd ser., vi, p. 265.

\section{Order HYMENOPTERA.}

$$
\text { Family-DORYLID } A \text {. }
$$

Dorylus LONGICORNis, Schnck., Ann. Nat. Hist., 1810, p. 321.

$$
\text { Family-SCOLIAD } 2 \text {. }
$$

Scolia (Triliacos) dimidiata, Guér., Voy. Coq. Zool., ii, pt. 2, p. 247, t.

Scolia (Discolia) instabilis, Smith., Cat. Hym. Brit. Mus., iii, p. 88.

Scolia (Trillacos) rubigrnosa, Fabr., Ent. Syst., ii, p. 230.

Scolia (Dielis) annulata, Fabr., Ent. Syst., ii, p. 225, 우.

$$
\text { Family-POMPILID } A \text {. }
$$

Ponpilus dorsalis, St. Farg. Hym., iii, p. 407.

Pompilus, sp.

Pompilus, sp.

Macromeris violacea, St. Farg. Guérin's Mag. Zool., pl. 30, fig. 1, ‡. Mrgnimta aureosericea, Guér., Voy. Coq. Zool. pt. 2, p. 256.

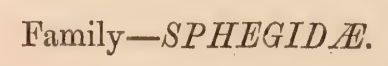

AmmophiLa, sp.

Aмmорнila, sp. 
Family-LARRID AS.

Larrada, sp.

Family-EUMENID AE.

Rhynchium carnaticum, Sauss., Mon. Guépes Sol., 112.

Family-VESPID 2 .

Polistes hebizus, Fabr., Mant. Ins., i, p. 292.

Polistes.

Vespa basalis, Smith., Trans. Ent. Soc., Lond., ii, p. 46.

Vespa BeLLona, Smith, Plate LXXXI, fig. 9.

Vespa bellona, Smith., Proc. Zool. Soc., 1871, p. 248, pl. xviii, fig. 6.

Female.-Head, thorax, and legs pale yellowish-brown; the eyes dark fuscous; the teeth and inner margin of the mandibles black; the flagellum of the antennæ fuscous above towards the apex; a fuscous spot in front of the intermediate and posterior coxæ; the prothorax with a black transverse spot above; the wings fusco-hyaline, darkest at the anterior margin of the superior pair and towards their base. Abdomen black, with a narrow yellow marginal band on each segment at its apex; the apical segment entirely black; the extreme base of the abdomen with indistinct yellowish stains. Length 1 inch 6 lines.

Worker.-Closely resembles the female; but in the single example received the abdomen has only a yellow margin to the basal segment; all the tarsi are fuscous, with the claw-joint yellowish; the flagellum is not fuscous above. Length 10 lines.

This species is nearly allied to Tespa magnifica. The head of the female is widened towards the thorax, as in that species, and is deeply emarginate behind; the clypeus and mandibles are not so strongly punctured, and the apical segment of the abdomen is not yellow as in $V$. magnifica. Vespa basalis resembles this species, but it differs in being covered with a short glittering pilosity, and its clypeus is smooth, shining, and impunctate.

$$
\text { Family-APID AE. }
$$

Crocisa decora, Smith, Trans. Ent. Soc., ii, p. 41.

ANTHOPHORA, sp. ?

Anthophora zonata, Linn., Syst. Nat., i, p. 955.

Xrlocopa tenuiscapa, Westw., Nat. Libr., 38, p. 271, t. 23, fig. 2.

XYLOCOPA, sp.?

XrLOCOPA, sp.? 


\section{Bombus Impetuosus, Smith, Plate LXXXI, fig. 11.}

Bombus impetuosus, Smith, Proc. Zool. Soc., 1871, p. 249, pl. xviii, fig. 8.

Female.-Black; the pubescence on the head black. The thorax above and at the sides clothed with a rich fulvous pubescence; the disk with black pubescence between the wings; the apical joints of the anterior and intermediate tarsi and the posterior pair entirely obscure rufo-piceous; the posterior tibiæ have their outer margin of the same colour, but brighter; wings dark-brown. Abdomen : the basal segment is covered above with bright pale fulvous pubescence, the two following segments have a clothing of black pubescence, and the three apical ones of red. Length 9 lines.

The worker is clothed like the female, but the fulvous pubescence is brighter and paler, and it varies in size from 8 to 10 lines.

ApIs INDICA, Fabr., Ent. Syst., Suppl., p.'274.

Apis floralis, Kirby, Mon. Ap. Augl., II, p. 323.

Apds dorsata, Fabr., Ent. Syst., ii, p. 328.

Apis laboriosa, Smith, Plate LXXXI, fig. 10.

Apis laboriosa, Smith, Proc. Zool. Soc., 1871, p. 249, pl. xviii, fig. 7.

Worker.-Black; the vertex shining and having some long black pubescence; the face just above the insertion of the antennæ with fulvous pubescence; the eyes have a short black pubescence and a few scattered punctures; the cheeks covered with pale fulvous pubescence. Thorax clothed with fulvous pubescence, which is palest beneath and on the inferior margins of the anterior and intermediate femora; the posterior femora more thinly fringed with pale fulvous pubescence; the posterior tibiæ and the basal joint of the tarsi fringed with black pubescence; the superior wings slightly smoky or fuscous, darkest in the marginal and first submarginal cell. Abdomen almost naked, but with a little fulvous pubescence on the margin of the basal segment; the truncation of the basal segment covered with fine short downy fulvous pubescence; the apex of the abdomen with a little black pubescence. Length 8 lines.

I cannot but consider this a distinct species from all that have hitherto been described. I am not desirous of increasing the number; but, after a careful examination of the characters in which specific distinctions are to be found, I will point out in what this Bee differs from both $A$. dorsata and $A$. zonata, both of which agree with it in size. The ocelli are smaller and more distant from the compound eyes; and it has only twelve transverse rows of bristles on the inner surface of the posterior metatarsus, exclusive of that on its apical margin. In $A$. dorsate the abdomen is covered above with a short downy pubescence; this Bee has the abdomen naked, and there is not a trace of bands of pubescence at the basal margins of the segments, as in A. zonata. 
Family-TENTHREDINID At.

Tenthredo, sp.?

Tenthredo, sp.?

Family-ICHNEUMONID A2.

Prmpla, sp. ?

Order DIPTERA.

Family-TIPULARID $A$.

Pterocosmus velutrinus, Walk., Cat. Dipt., B. M., p. 79.

Family-TABANID $A$.

Tabanus, sp.

Family-BOMBYLIARID $2 H$.

Anthrax Semiscita?

Anthrax

Anthrax $\}$ sp.?

Anthrax

Trichopthalmia, sp.

Discocephala, sp.

$$
\text { Family-ASILID A. }
$$

Dastrogon, sp.

DASYPOGON

DASYPOGON

sp.?

DASYPOGON

Nusa, sp.

LAPHRIA, sp.

$$
\text { Family-SYRPHIDAE. }
$$

Eristalis andremon, Walk.; Cat. Dipt., B. M., iii, p. 627.

Eristalis amphicrates, Walk., $l$. c., p. 623.

Eristalis, sp. ? (6 species). 
Tachina FUstFormis, Walk.

TACHIna, sp. ?

Musca, sp. ?

Musca, sp.?

MUsCa, sp. ?

Order HEMIPTERA.

Family-PACH YCORIDA.

Cantao ocellatus, Thumb., Nov. Ins., sp. 60, fig. 72.

Solenosthedium rubropunctatum, Guér., Voy. Coq. Zool., ii, p. 157.

Pentatomides.

$$
\text { Family- } A S O P I D A \text {. }
$$

Zicrona CAerUlea, Linn., S. N. I., 722.

$$
\text { Family-HALYDID AR. }
$$

Dalpada clatata, Fab., Ent. Syst. Suppl., p. 532.

DALPADA, sp.

$$
\text { Family-EDESSID } 2 \text {. }
$$

Aspongopus nigriventris, Hope, Cat. Hem., p. 26.

$\left.\begin{array}{l}\text { Eusthenes, sp. } \\ \text { Eusthenes, sp. }\end{array}\right\}$ In larval stage.

$$
\text { Family-MICTID DA. }
$$

Datader planiventris, Hope, Cat. Hem., p. 8.

Thysomerus, sp.?

HARPACTOR?

HARPACTOR, sp.

$$
\text { Family-COREID Ri。 }
$$

Macrocherata Grandis, Gray, Griff. An. Kingd., xv, pl. 92, fig. 3.

Dysdercus renigi, Fabr. Syst. Ent., p. 720.

Serinetha augur.

Physopelta gutta, Burm., Nov. Acad. Leop.; xvi, Supp. 300, pl. 41, fig. 10. 
Family-NEPID $A$.

Ranatra grossa, Fabr.

NAUCorIs, sp.?

NAdCoris, sp.?

- Sub-order HoMoptera.

Family-STRIDULANTID A .

Dundubia cinctimanus, Walk., Cat. Hom., B. M., i, p. 49.

Cicada, sp.?

Platypleura nobilis, Germ., Thon. Arch., ii, 2, 9.

Family-CICADELLID $A$.

Urophora hardwicki, Gray, Griff. Ed. An. Kingd., 261, pl. xc, fig. 3.

Family-CERCOPIDA.

Cercopis nigripennis, Fabr., Syst. Rhyn., xc, 8.

Cercopis septempunctata, Walk., Cat. Hom., B. M., iii, p. 659.

Cercopis, sp.?

Family-TETTIGONID 2 .

Tettigonia (3 species).

Order LEPIDOPTERA.

Division Rhopalocera.

$$
\text { Family-SATYRID Rt. }
$$

Melanitis ismene, Cram., Pap. Exto., i, tab. 26, figs. A, B.

Melanitis vamana, Moore, Cat. Lep. Mus., E. I. C., i, p. 223.

Neope Pulaha, Moore, op. cit., p. 227.

Orinoma damaris, Gray, Lep. Ins., Nepal, pl. vii, fig. 2.

Debis europa, Fabr., Cram. Pap., t. 79, figs. C, D.

Debis verma, Kollar, Hügel's Kaschm., iv, t. 16, fig. 12.

Debis roHria, Fabr., Mant. Ins., ii, p. 45. 
Debis chandica, Moore, Cat. Lep. Mus, E. I. C., i, p. 219.

Debis latiaris, Hewitson, Exot. Butt., iii, p. 74, pl. xxxvi, fig. 4.

Debis dyrte, Feld., Nov. Voy., p. 497.

Zophoessa andersoni, Atkinson, Plate LXXXI, fig. 3.

Zophoessa andersoni, Atkinson, Proc. Zool. Soc., 1871, p. 215, pl. xii, fig. 3.

Upper side brown. Fore-wing crossed by two pale bands rising from the costa and directed towards the posterior angle, but not reaching it, the first beyond the extremity of the cell, the second intermediate between the first and the exterior margin. Hind-wing with a pale submarginal belt containing a series of incomplete ocelli. The first and third median nervures produced into short tails. Underside bright ferruginous. Fore-wing crossed by three silvery-white bands, the first cutting the middle of the cell at right angles, the second and third corresponding to the pale bands on the upper side. Exterior to the third band a series of rudimentary ocelli reduced to four dark points. The exterior marginal lines bordered within by yellow. Hind-wings crossed by two silvery-white bands, the first cutting the lower part of the cell and corresponding to the first band of the fore-wing, the second equidistant between the first and the exterior margin, and corresponding to the second band of the fore-wing; at either end of the second band and within it are ocelli, the upper with one and the lower with two white pupils ringed with black. Exterior to the second band a series of four white-pupilled ocelli, their outer edge forming an interrupted yellowish-white band. The exterior margin sharply defined by two fine black lines divided by a yellow line, and bordered within by bright yellow. Fringe yellow; antennæ brown, with ferruginous tips. Expanse $2 \frac{1}{4}$ inches.

Mrcalests otrea, Cram., Pap., iv, t. 314, figs. A, B.

Mrcalesis runeka, Moore, Cat. Lep. Mus., E. I. C., i, p. 234.

Mrcalesis lalassis, Hewits, Exot. Butt. Myc., pl. iv, fig. 35.

Mrcalesis malsara, Moore, Cat. Lep. Mus., E. I. C., i, p. 231.

Mrcaliesis nala, Feld., Wien., Ent. Mon., 1859, p.

Yphthima sakra, Moore, Cat. Lep. Mus., E. I. C., i, p. 286 ; Hewits, Tr. Ent. Soc., 1865, pl. xviii, fig. 18.

Ÿнтнтма метноRA, Hewits, id., p. 291, pl. xviii, figs. 20, 21.

Yphthima Newara, Moore, Proc. Zool. Soc., 1874, p. 567 (Nareda; Hewits, l. c., pl. xvii, fig. 7, nec fig. 6).

\section{Family-DANAIDA.}

Euplata midamus, Linn., Cram. Pap. Exot., t. 127, figs. C, D, et t. 266, fig. C, $q$. Eupläa KLUgir, Moore, Cat. Lep. Mus., E. I. C., i, p. 130. 
Edplata stamensts, Feld., Nov. Voy., ii, pl. xli, fig. 6.

Danais trtia, Gray, Ins. of Nepal, pl. ix, fig. 2.

Danais Plexippus, Linn., Cram., t. 206, figs. C, D.

Danais Chrysippus, Linn., Cram., t. 118, figs. B, C.

Danais limniace, Cram., t. 59, figs. D, E.

Danais melissa, Cram., t. 377, figs. C, D.

Danats aglea, Cram., t. 377, fig. E.

Acrafa vesta, Fabr., Man. Ins., ii, p. 14.

Family-PAPILIONID $\$$.

Papilio dissimilis, Linn., Cram., t. 82, figs. C, D.

Papilio Panope, Linn., Cram., t. 295, figs. E, F.

Papilio castor, Westw., Aun. Nat. Hist., vol. ix, p. 37.

Papilio Pammon, Linn., Cram., t. 141, fig. B.

Papilio erithonius, Cram., Pap. Exot., t. 232, figs. A, B.

Papilio antiphates, Cram., t. 72, figs. A, B.

Papilio chiron, Wallace, Linn., Trans., xxv, p. 66.

Papilio cloanthus, Westw., Arc. Ent., pl. xi, fig. 2.

Papilio xuthus, Linn., Cram., t. 73, figs. A, B.

Prrameis cardut, Linn., S. N., ii, p. 774.

Prrameis indica, Herbst., Nat. Schm., vii, t. 180, figs. 1, 2.

VANessa Cashmirensis, Kollar, Hügel's Kaschm., iv, t. 9, figs. 3, 4.

Vanessa Charonta, Drüy, Ins., pl. $\mathrm{xv}$, figs. 1, 2.

Junonia oRIthyia, Linn., Cram., t. 19, figs. C, D.

Junonia laomedia, Linn, Syst. Nat., ii, p. 772.

Junonia Lemonias, Linn., Syst. Nat., ii, p. 770.

Junonia almana, Linn., Syst. Nat., ii, p. 769.

Junonia Asterie, Linn., Syst. Nat., ii, p. 769.

J unonia ænone, Linn., Syst. Nat., ii, p. 770.

Precis iphita, Cram., Pap. Exot., iii, t. 209, C, D.

Precis hara, Moore, Cat. Lep. Mus., E. I. C., i, pl. iii $a$, fig. 1.

Ergolis ariadne, Linn., S. N., ii, p. 778.

Crrestis throdands, Boisd., Doubleday \& Hewits., Gen. Lep., pl. xxxii, fig. 3.

Srmbrenthia hyppocla, Cram., t. 220, figs. C, D.

Cethosia cyane, Fabr., Drury, Ins., i, pl. iv, fig. 1.

Cetriosia biblis, Drury, Ins., i, pl. iv, fig. 2. 
Cirrochroa aoris, Doubleday \& Hewits., Lep., pl. xxi, fig. 1.

Cirrochroa mithila, Moore, Proc. Zool. Soc., 1872, p. 558.

Atella phatanta, Drury, Ins., i, pl. xxi, figs. 1, 2.

Argrnnis nIPHe, Linn., Cram., t. 14, figs. B to E.

Argrnnis rudra, Moore, Cat. Lep. Mus., E. I. C., p. 157.

Argrnnis childrent, Gray, Zool. Misc., p. 33 ; Lep. Ins., Nepal, pl. xi.

Diadema bolina, Linn., Mus. Ulr., p. 295, Clerck, Icon., t. 21, fig. 2.

Euripus halitherses, Doubleday \& Hewits, Lep., pl. xli, fig. 2.

Hestina nama, Doubleday \& Hewits., op. cit., pl. xxxix, fig. 2.

Hestina Persimilis, Westw., Doubleday \& Hewits., id., p. 281.

Castalia chandra, Moore, Cat. Lep. Mus., E. I. C., i, pl. via, fig. 4.

Neptis ananta, Moore, Cat. Lep. Mus., E. I. C., i, p. 166, pl. iva, fig. 3.

Neptis nandina, Moore, op. cit., p. 168, pl. iva, fig. 7.

Neptis hordonia, Stoll., Suppl. Cram., t. 33, fig. 4.

Neptis emodes, Moore, Proc. Zool. Soc., Lond., 1872, p. 561, pl. xxxii, fig. 2.

Neptis amba, Moore, Proc. Zool. Soc., 1858, p. 7, pl. xlix, fig. 4.

Neptis soma, Moore, op. cit., pl. xlix, fig. 6.

Атнтма детсотноё, Linn., Cram., t. 203, figs. E. F.

AтHima cama, Moore, Cat. Mus., E. I. C., i, pl. va, fig. 5.

AтHyma selenophora, Kollar, Hügel's Kaschm., iv, t. 7, figs. 1, 2, ‡.

Limenimis daraxa, Doubleday \& Hewits., D. Lep., pl. xxxiv, fig. 4.

Adolias lepidea, Butler, Ann. Nat. Hist., 1868, p. 71.

Neurosigma siva, Westw., Cab. Or. Ent., pl. xxxvii, fig. 4.

Adolias garuda, Moore, Cat. Lep. Mus., E. I. C., i, p. 186 ; Tr. Est. Soc., v, pl. iii, fig. 2.

Adolias Francer, Gray, List. Lep., Nepal, p. 12, t. 14.

Adolias boisduvalis, Gray.

SympHedra dirtea, Fabr., Gray, Lep., Nepal, pl. x, fig. 1.

Charaxes athamas, Drury, Ill. Ins., i, pl. ii, figs. 3, 4.

Kallima inachis, Bd., Croch. Ed. Cuv., R. A., t. 139, fig. 3.

Amona lena, Atkinson, Plate LXXXI, fig. 1.

AEmona lena, Atkinson, Proc. Zool. Soc., 1871, p. 215, pl. xii, fig. 1.

Upperside: Fore-wings - pale brownish-grey, crossed by a dark-brown band, interrupted by the nervures from before the apex to near the posterior margin at 
two-thirds. of its length from the base; beyond the band darker, with a slightly marked and incomplete sub-marginal line, before which is a series of five pale lanceolate blotches between the nervures directed towards the outer margin. All the nervures tinged with yellow and more or less dark-bordered. Hind-wingsanterior portion from base to outer margin pale, posterior portion bright yellow, crossed by a sub-marginal series of three dark-bordered white blotches, and a fourth fainter blotch between the nervures, forming a short interrupted band from near the apex to the second median nervure. The sub-median fringed from its origin to near its extremity with long yellowish hairs, longest and most conspicuous towards its extremity.

Underside: Both wings crossed by a dark ferruginous band with sharply defined outer edge from the costa of the fore-wing near the apex to near the extremity of the sub-median nervure of the hind-wing, and having a faintly traced sub-marginal line, before which is a series of blind white-centred ocelli. The cell of the fore-wing crossed near its middle by a curved ferruginous band. Hind-wing crossed by a ferruginous band near the base. Antennæ ferruginous; palpi and legs tawny-yellow. Expanse $3 \frac{1}{4}$ inches.

$$
\text { Family-PIERID AR. }
$$

Prioneris thestruis, Doubleday, Gray's Zool. Misc., p. 76.

Thyса Pasithö̈, Linn., Cram., t. 43, figs. D, E.

Eronia Hippia, Fabr., Ent. Syst., iii, p. 59.

Pieris nama, Doubleday, Moore, Proc. Zool. Soc., 1857, pl. xliv, figs. $1,2$.

Pieris gliciria, Cram., t. 171, figs. E, F.

Pieris nelete, Menétr. var.?

Tachyris lalage, Doubleday \& Hewits., D. Lep., pl. vi, fig. 5.

Tachyris zelmira, Cram., t. 320, figs. C, D.

TACHYRIS HIPpo, Cram., t. 195, figs. B, C.

Gonepteryx verHUELLit, Van der Hoev.

Callidryas hilaria, Cram., t. 339, figs. A, B.

Callidryas pyranthe, Linn., Syst. Nat., ii, p. 7, 63.

Calimdras alcmeone, Cram., t. 141, fig. E.

Colitas FIELdir, Menétr.

Thestias pyrene, Linn., Cram., t. 127, figs. A, B, C.

Hевомота Gladcippe, Linn., Cram., t. 164, figs. A-C.

Terias hecabe, Linn., Cram., t. 124, figs. B, C.

Terias silmetana, Wallace, Tr. Ent. Soc., 1867, p. 324.

Terias venat'a, Moore, Cat. Lep. Mus., E. I. C., pl. ii $a$, fig. 2. 
Zemeros flegras, Cram., t. 210, figs. E, F.

Dodona frula, Boisd. (Westw. \& Hewits., D. Lep., pl. lxix, fig. 3).

Sospria neophron; Boisd. (Hewits., Exot. Butt., 1860, fig. 3).

\section{Family - LYCAENID $A$.}

Polyommatus puspa, Horsf., Cat. Lep., E. I. C., 1828, p. 67.

Polyommatus kasmira, Moore, Proc. Zool. Soc., 1865, pl. xxxi, fig. 1.

Polyommatus chandala, Moore, id., p. 504, pil. xxxi, fig. 5.

Mrrina Jafra, Godt. (Horsf., Cat. Lep. E. I. C., pl. i, fig. 5).

Amblypodia quercetorum, Moore, Cat. Lep., E. I. C., i, pl. ia, fig. 7.

$$
\text { Family-HESPERID A. }
$$

Nisoniades dasahara, Moore, Proc. Zool. Soc., 1865, p. 787.

Pamphila masa, Moore, id., p. 509, pl. xxx, fig. 9.

Hesperia chaya, Moore, id.; p. 791.

Hesperta eltola, Hewits., Ex. Butt., iv, t. 4, fig. 40.

Hesperia (? Oceia, Hewits., Desc. Hesp., p. 31).

Plesioneura liltana, Atkinson, Plate LXXXI, fig. 2.

Plesioneura liliana, Atkinson, Proc. Zool. Soc., 1871, p. 217, pl. xii, fig. 2.

Upperside dark fuliginous brown: fore-wing crossed from the middle of the costa to the posterior angle by a broad white semitransparent band irregularly angled outwardly and narrowing from the middle hindwards. A recurved series of five angular white spots between the band and the anterior angle. Fringe brown, with a grey spot below the anterior angle, and two others near the posterior angle. Hind-wing without markings, the fringe barred with greyish-white between the nervures. Underside: fore-wing with band and spots as above, but suffused with grey scales towards the apex, and pale towards the posterior angle below the band. Hind-wing suffused with greyish scales and crossed by irregular broken bands of grey, which give it a mottled appearance; two white dots near the base. Palpi grey above, brown below. Expanse $2 \frac{1}{4}$ inches.

\section{Div. HETERocera.}

Srntomis ANDERsoni, Moore, Plate IXXXI, fig. 4. Syntomis andersoni, Moore, Proc. Zool. Soc., 1871, p. 244, pl. xviii, fig. 1. 
Male and female.-Wings hyaline, veins bluish-black; body black, with orangeyellow bands : fore-wing with the costa, exterior and posterior margins black; space between the sub-median vein and posterior margin pale yellow; a broad transverse discocellular black quadrate spot, which is recurved outwards: hind-wing with the anterior border pale yellow, and having a small discoidal black spot; apex and exterior margin black; posterior margin tinged with yellow. Spot on front of head, coxæ, legs above, and band on each segment of abdomen beneath white. Collar round thorax, tegulæ, spots on thorax, and band on each segment of abdomen above orange-yellow; tip of abdomen in male purplish-black, in female yellowishgrey. Proboscis, palpi, antennæ, and legs beneath black; the antennæ tipped with white.

Expanse, t $1 \frac{4}{10}$, \& $1 \frac{3}{4}$ inch.

\section{Srntomis SLADENI, Moore, Plate LXXXI, fig. 8.}

Syntomis sladeni, Moore, Proc. Zool. Soc., 1871, p. 245, pl. xviii, fig. 5.

Female.-Wings hyaline, veins jet-black; body black, with orange-yellow bands : fore-wing with a jet-black costal border of exterior and posterior margins, a narrow longitudinal streak extending from the discocellular vein half-way across the disk; veins at the base of wing tinged with orange-yellow : hind-wing with a narrow jetblack border extending all round, with a short curved streak extending upward from middle of the exterior margin. Proboscis, palpi, antennæ, and eyes black. Legs black beneath, whitish above. Spot on front of head, collar round thorax, streak on tegulæ, spots on thorax above and beneath, streak on coxæ, and band on each segment of abdomen deep orange-yellow.

Expanse, $1 \frac{4}{10}$ inch.

\section{Strmomis atkinsoni, Moore, Plate LXXXI, fig. 5.}

Syntomis atkinsoni, Moore, Proc. Zool. Soc., 1871, p. 245, pl. xviii, fig. 2.

Male and female.-Bluish-black, body with a slight purplish tinge: fore-wing with seven transparent spots, the first near the base, small, rounded, the second occupying the anterior portion of the cell, the third below the cell and extending obliquely to near the posterior angle, the fourth and fifth divided by the first or upper median veinlet, the sixth and seventh divided by the lower subcostal veinlet, the latter spot being very small: hind-wing with a sub-basal transparent spot extending to the extreme abdominal margin, where it is tinged with yellow. Head in front and coxæ yellowish-white; spot at base of abdomen above, and a band extending round the abdomen orange-yellow; and anal tuft in female yellowishwhite. Proboscis, palpi, antennæ, and legs black; tarsi whitish; antennæ tipped with white.

Expanse, ᄒ $1 \frac{1}{10}$, 우 $1 \frac{1}{4}$ inch. 
Syntomis FYtcheI, Moore, Plate LXXXI, fig. 6.

Syntomis fytchei, Moore, Proc. Zool. Soc., 1871, p. 246, pl. xviii, fig. 3.

Male.-Brownish-black: fore-wing transparent, veins black; costa and posterior margin with narrow black border; space between discoidal veinlets, the apex of wing, and exterior margin black, extending upward on the latter near the angle; hind-wing with anterior margin and apex narrowly bordered with black. Front of the head white; collar round thorax, coxæ, and a basal and median abdominal band orange-yellow. Proboscis, palpi, antennæ, and legs black; tip of antennæ and tarsi whitish.

Expanse, $1 \frac{1}{10}$ inch.

\section{Syntomis GroteI, Moore, Plate LXXXI, fig. 7.}

Syntomis grotei, Moore, Proc. Zool. Soc., 1871, p. 245, pl. xviii, fig. 4.

Female.-Wings hyaline, veins brownish-black; body black, with orangeyellow bands : fore-wing with the base of costal and posterior margin orange-yellow; costa and posterior margins anteriorly and exterior margin black; a small space within base of discoidal cell, a streak beneath extending to the sub-median vein, a streak anteriorly on median vein, space between the discoidal veinlets except a small rounded hyaline exterior spot, and a short space upwards from exterior margin between the second and third median veinlets brownish-black: hind-wing with a brownish-black border tinged with orange-yellow on anterior margin; a short black streak extending upward from exterior margin. Proboscis, palpi, and antennæ black. Front of head, collar, streak on tegulæ, spots on thorax, coxæ, and band on each segment of abdomen orange-yellow. Legs yellowish-white above, brown beneath.

Expanse, $1 \frac{1}{2}$ inch. 


\section{CRUSTACEA.}

\section{- SPECIES}

COLLECTED ON

THE TWO EXPEDITIONS

To

WESTER N Y N N A N.

w 5 



\section{CRUSTACEA.}

Bx J. WOOD-MASON, F. Z. S., \&C,

DEPETY SUPERINTENDENT, INDIAN MUSEOM.

\section{CRUSTACEA CANCROIDEA.}

\section{CANCROIDEA GRAPSIDICA.}

Family - TELPHUSID AR.

Genus Telphusa, Latr.

Telphusa edWardsi, J. W.-Mason.

Telphusa edwardsii, J. Wood-Mason, Journ. As. Soc., Bengal, vol. xl, pt. ii, 1871, p. 449, pl. xxvii.

Carapace sparingly hirsute above, more thickly so on the pleural region, broadest along a line dividing the anterior from the middle third of the meso-gastric region, on each side of which the surface is raised into an oval areolet bounded in front by the proto-gastric, behind and laterally by the branchial lobe, which in part bounds it in front; uro-gastric lobes distinct from the rest of the regions and from one another, post-frontal ridge sinuous, coarsely wrinkled, ending about $2 \mathrm{~mm}$. short of the epibranchial teeth, slightly interrupted by the forward position of the epi-gastric lobes; these are rugose in front, deeply divided mesially and completely isolated from the conterminous regions of the carapace by well-defined grooves; meso-gastric area distinct, sending forwards a narrow tongue between the proto- and epi-gastric lobes; branchial areas divided into anterior and posterior portions by broad smooth deep oblique depressions; the latter being scarcely distinct from the cardiac division; the epibranchial teeth are continued backwards, outwards, and inwards as raised denticulated crests, along the inner side of which runs a smooth furrow continuous with the post-orbital furrow; postero-lateral margins rugose behind the termination of the lateral crests, the rugosities being continued downwards and forwards on to the inflected portion of the carapace; orbits and extra-orbital teeth finely 
crenulated. Front broad, short, very little deflexed, terminated by a smooth margin. The chelipedes are sub-equal; the two inferior edges of their meropodites are armed with tubercles, their inferior planes bear at their distal extremity and nearer the inner than the outer of the two edges a single spinule, which is also to be remarked in many other species; the third or upper angle is rugose; the succeeding joint is greatly thickened at its distal end, and is superiorly coarsely wrinkled and concave; its inner margin is armed with a stout sharp spine, beneath which is a smaller one; the proximal half of the penultimate joint is convex and coarsely granulated externally, internally convex and smooth, except towards the inferior border, where two or three rows of small, widely-separated tubercles are to be seen; its upper surface is ornamented by three rows of large tubercles; its distal prolongation is deeply canaliculate and its inner toothed edge is in contact throughout its length with the dactylopodite, which is likewise canaliculate externally and compressed, so that its upper border presents a saw-like edge, being ornamented with tubercles decreasing gradually in size and sharpness from the base towards the tip.

The ambulatory legs are hairy, as in Telphusa hispida.

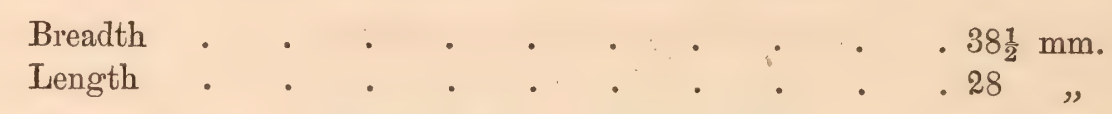

Hab.-Kakhyen Hills; Hotha, Yunnan.

\section{Telphusa andersontana, J. W.-Mason.}

Telphusa andersoniana, J. Wood-Mason, Journ. As. Soc., Bengal, vol. xl, pt. ii, 1871, p. 451, pl. xxvii.

Carapace considerably broader than long, very sparingly hirsute, areolation similar to that of the preceding species; anterior branchial region covered with irregular tubercles, which gradually pass backwards into the rugations that thickly mark the postero-lateral margin, the inflected portion of the carapace, and a portion of the posterior pleural lobe; epi-gastric lobes separated from one another and from the proto-gastrics, post-frontal crest curved forwards in the middle; epibranchial teeth well marked and pass backwards on each side as regularly denticulated crests, the denticulations gradually decreasing in size backwards; anterior pleural lobes covered with inosculating fovea, separated from the peristomial portions of the posterior by a tuberculated line which loses its beaded character as it passes upwards to the epibranchial tooth; front broad, especially at the base, tuberculated; its free margin is sinuous, well rounded laterally and coarsely crenated; orbital borders also crenated and rising externally into a salient, forwardly-directed tooth. The median triangular process of posterior border of the epistoma is extremely salient, coarsely crenate, and notched on each side; externally to the notches, this posterior border is similarly crenate up to the point at which it begins to form the anterior boundaries of the exhalant orifices of the branchial chambers. Chelipedes sub-equal; meropodites with their three angles sharply tubercular, their posterior faces rugose and their 
ventral surface bearing a sharp spinule; carpopodites extremely rugose above, with their inner margins raised into a line of sharp, irregular tubercles above the level of the spine, beneath which an acute smaller one is to be seen, and with their distal articular ends greatly thickened and rounded, as in Telphusa edwardsi, to which this species is closely allied; propodites with their upper edge armed with a row of five forwardly-directed spiniform tubercles, externally to which are some small rounded tubercles; the rest of the surface, both externally and internally, is excavated into shallow, inosculating fovea. Above, the dactylopodites are rounded and armed at the proximal end with a small spiniform tubercle, are externally longitudinally canaliculate, and can be brought into complete contact with the immovable arm of the pincers, which is also grooved.

The penultimate joints of the ambulatory legs are longer in proportion to their breadth than those of $T$. edwardsi.

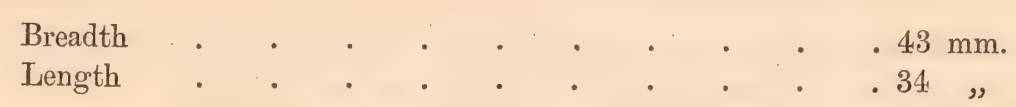

Hab.-Ponsee, Kakhyen Hills; Momien, Yunnan, at elevations of from 3,500 to 5,000 feet.

Telphusa hispida, J. W.-Mason.

Telphusa hispida, J. Wood-Mason, Journ. As. Soc., Bengal, vol. xl, pt. ii, 1871, p. 452, pl. xxviii.

Carapace much broader than long, flattened above, hirsute, especially on the postero-lateral margins and the posterior pleural lobes; the surface is subpunctate and has an areolation very similar to that of Telphusa edwardsi, but the posterolateral boundary of the oval areolet is not so deep impressed; the epi-gastric lobes, as in Telphusa andersoniana, are not distinct from the proto-gastrics behind; the cervical suture forms a very indistinct divisional line between the hepatic portion of the proto-gastric and the anterior moiety of the branchial lobe, which is obsoletely tubercular; the epibranchial teeth are by no means salient; the more obscurely denticulated crest of the antero-lateral margin is very little elevated, and the smooth furrow along the inner side of it, which is so noticeable in the former species, is absent; a bundle of short hairs springs from between each denticulation. The anterior is separated from the posterior cardiac lobe by a broad, shallow, transverse channel which extends right across the carapace, and these again are similarly marked off from the posterior halves of the branchial lobes. The post-frontal ridge is well marked, bent forwards in the middle, but is neither continuous to the epibranchial teeth, nor interrupted by the projection beyond it of the epi-gastric lobes. The orbital rims and extraorbital teeth crenulated. Front sinuous, short, not greatly deflexed, truncate on each side, irregularly punctate, minute hairs springing in bundles of 2 or 3 from the puncta. The structure of the epistoma is very much the same as in T.edwardsi, but its surface is advanced so as to be more nearly in the same plane with the free margin of the front, and the triangular 
process of its posterior border is more acute; mesially it is devoid of hairs, but laterally it is extremely hirsute. The anterior pleural lobe is distinct, but the interpleural portion of the line that marks it off from the rest of the carapace is not tuberculated as in T. edwardsi; neither is the inflected portion of the carapace so distinctly rugose nor so thickly covered with hairs. Of the chelipedes the right exceeds the left in size in the only adult specimen in my possession; the outer, or more strictly speaking the posterior face of the meropodites is smooth, devoid of hairs, except towards the dorsal edge, which is densely covered with bundles of hairs and but slightly rugose. The carpopodite is armed in the usual way with a spine, beneath which is a short bilobed spinule; its upper surface roughly punctate; an impression is to be observed at its distal articular end, which is not more than ordinarily thickened. The propodite is coarsely punctate, its lower border is longitudinally concave, its prolongation is externally grooved, and so is the dactylopodite with which it is in contact throughout its whole length. The ambulatory legs are robust; the ridges of all their joints are thickly covered with bundles of hairs; the penultimate joints are similar to those of Telphusa andersoniana.

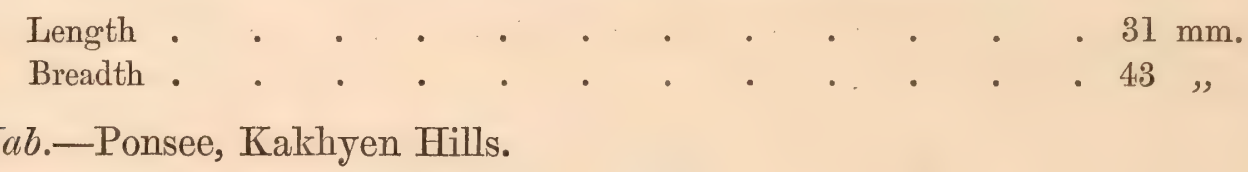

Telphusa tumtoa, J. W.-Mason.

Telplusa tumida, J. Wood-Mason, Journ. As. Soc., Bengal, vol. xl, pt.ii, 1871, p. 453, pl. xxvii.

Carapace slightly broader than long, tumid, punctate, extremely convex in every direction, with an areolation similar to that of the three last described species, but the meso-gastric lobe is almost confluent anteriorly with the proto-gastric, and this latter is marked by a short branch running off from the cervical suture at right angles to it; the cardiac is separated from the posterior half of the branchial area; the epi-gastric lobes are prominent, anteriorly wrinkled, and extend beyond the line of the rest of post-frontal ridge; anterior branchial lobe and post-frontal crest rugose; the latter is slightly indented by the cervical suture, and continuous from the epi-gastric lobes to the minute epibranchial teeth ; antero-lateral margins greatly inclined with minutely denticulated crests; postero-lateral margin marked with oblique wrinkles which assume a tubercular character as they pass forwards on to the inflected portion of the carapace, and the posterior pleural lobes which, where they form the peristoma, are completely covered with round, polished tubercles, disposed in pairs; the anterior pleural lobe presents a few scattered tubercles, and is cut off from the posterior pleural and from the inflected region of the carapace by a beaded line. Front broad, deflexed, coarsely granulated, marked by the prolongation forwards of the meso-gastric furrow. The epistoma presents the same characters as that of Telphusa andersoniana, except that its anterior margin is distinctly crenulated. The orbits and their external angles are crenated. 
Chelipedes subequal; meropodites with their posterior faces and angles very rugose; carpopodites, above rugose, armed internally with a short blunt tooth, above and below which are some smooth tubercles; propodite externally convex and rugose; internally, especially near the lower margin, above, and below tuberculated; the upper margin of the dactylopodite is rounded, and presents a short row of tubercles at its proximal end; the pincers are marked on every face with longitudinal rows of puncta, and their arms can be almost completely apposed.

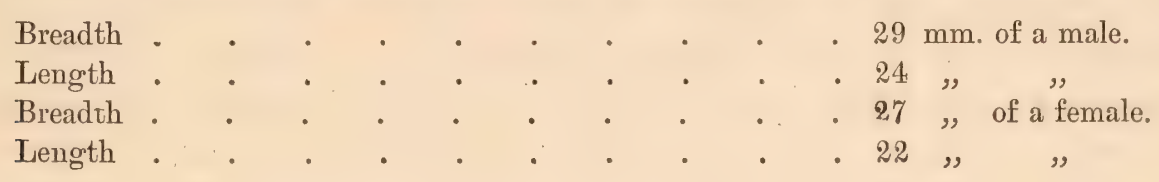

Hab.-Ponsee, Kakhyen Hills; Hotha, Yunnan.

Genus Paratelphusa, M.-Edwards.

Paratelphusa dayana, J. W.-Mason.

Paratelphusa dayana, J. Wood-Mason, Journ. As. Soc., Bengal, vol. xl, pt. ii, 1871, p. 192, pl. xi.

The carapace is much broader than long, the greatest breadth being measured between the points of the last epibranchial tooth, extremely convex, smooth, punctate, and perhaps finely granular under an ordinary lens. The branchial lobes are greatly swollen and are not sub-divided into anterior and posterior divisions; the mesial crescentic portion of the cervical suture is distinctly marked and continued nearly to the level of the last epibranchial tooth, where it ends to appear again opposite the second tooth, whence it passes to the edge of the post-frontal crest, which it but faintly indents. The post-frontal ridge is well marked, and, between the point at which its edge is notched by the passage across it of the cervical suture and the anterior epibranchial tooth, is crenulated; the cardiac lobe is marked off from the branchial by two shallow almost linear depressions on each side of the middle line, and in front from the uro-gastric by a line curving almost concentrically with the convexity of the cervical suture. The epi-gastric lobes are slightly wrinkled or foreate anteriorly, and advanced beyond the line of the post-frontal crest as in Paratelphusa spinigera, and separated from one another by the meso-gastric suture, which rapidly bifurcates as it passes backwards, appearing as a short $\mathrm{V}$-shaped impression on the carapace, the space intercepted between the arms of the $\mathrm{V}$ being the point of the narrow anterior prolongation of the meso-gastric lobe.

The antero-lateral margins are inclined and armed, not counting the blunt extra-orbital tooth with its curved external margin, each with four acute, spiniform epibranchial teeth, of which the most anterior is the largest; the rest are equal in size to, and equidistant from, each other; from the last a short well-defined keel, obscurely crenated on its inner edge, passes backwards and inwards on to the carapace, which is marked with a few small straggling tubercles along the line of the epibranchial spines. Front very broad, especially at base, punctate, finely granular 
and transversely wrinkled, its free margin is bayed in the middle line, but not greatly lamellar and projecting forwards over the epistomial region, as in Paratelphusa sinensis, M.-Edw., and in P. spinigera.

The inflected portion of the carapace is finely tuberculated anteriorly; anterior pleural lobe distinct and almost devoid of tubercles; posterior pleural smooth, thickly granulated where it bounds the anterior pleural.

The anterior boundary of the epistoma is crenulated; its posterior margin is notched on each side of the middle line from which a long sharp process extends downwards between the palpiform appendages of the external maxillipedes; this process does not correspond exactly with the triangular process of the epistoma in other species of Telphusa, but is the greatly developed median palatal ridge; externally to each notch the posterior margin of the epistoma forms two distinct lobes with granulated edges. The second joint of the external maxillipedes is punctate and its external margin crenulated. The third joint is much broader than long, and has its external and anterior angles well rounded off and distinctly granular; the exopodite is crenulated on its internal margin. The abdomen of the male differs greatly from that of Paratelphusa spinigera, having the form of an isosceles triangle.

The chelipedes are greatly unequal in size, both in males and females, especially in the former; the meropodites have their ventral angles rounded off as in Paratelphusa spinigera, their outer or posterior face rugose, their posterior angle also rugose and armed with a sharp spine arising just proximally to the constriction near the distal articular end; carpopodites faintly rugose above, armed with a single excessively long, stout spine; penultimate joint absolutely tubercular above, externally and internally all but smooth; in the larger claw a considerable hiatus exists between the dentated margin of the prolongation of this joint and that of the dactylopodite, which in the smaller claw is throughout its length in complete contact with the immovable arm of the pincers.

The terminal joints of the ambulatory legs are extremely slender, acute, and armed with fine sharp spines.

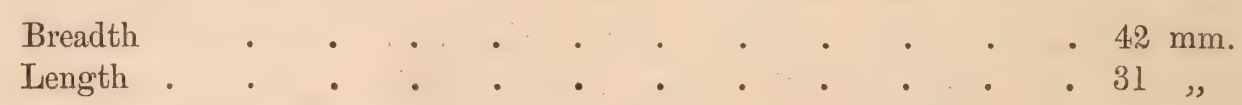

Hab.-Prome and Mandalay, Upper Burma. 


\section{GENERAL INDEX.}

\section{A MM ALIA.}

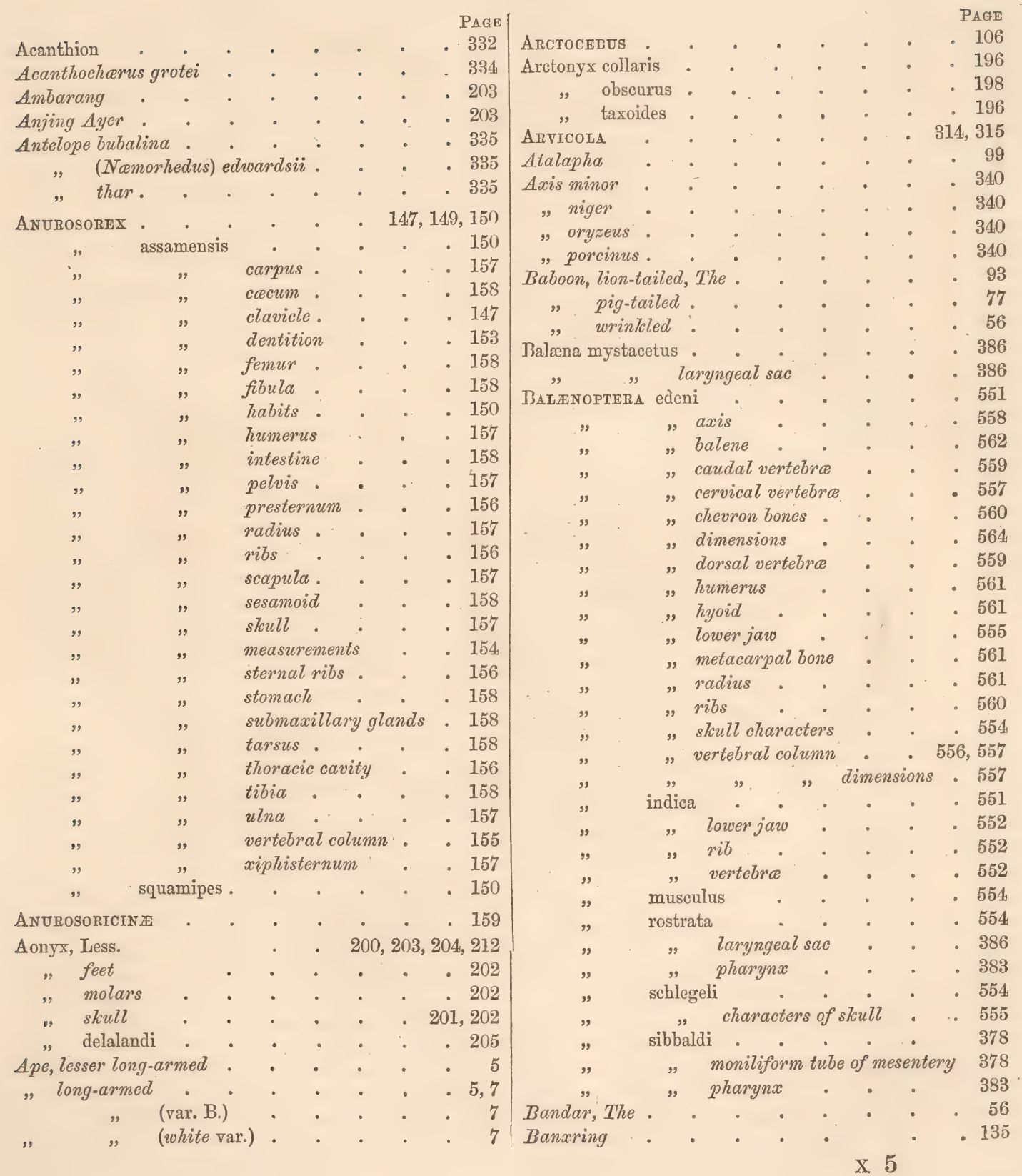




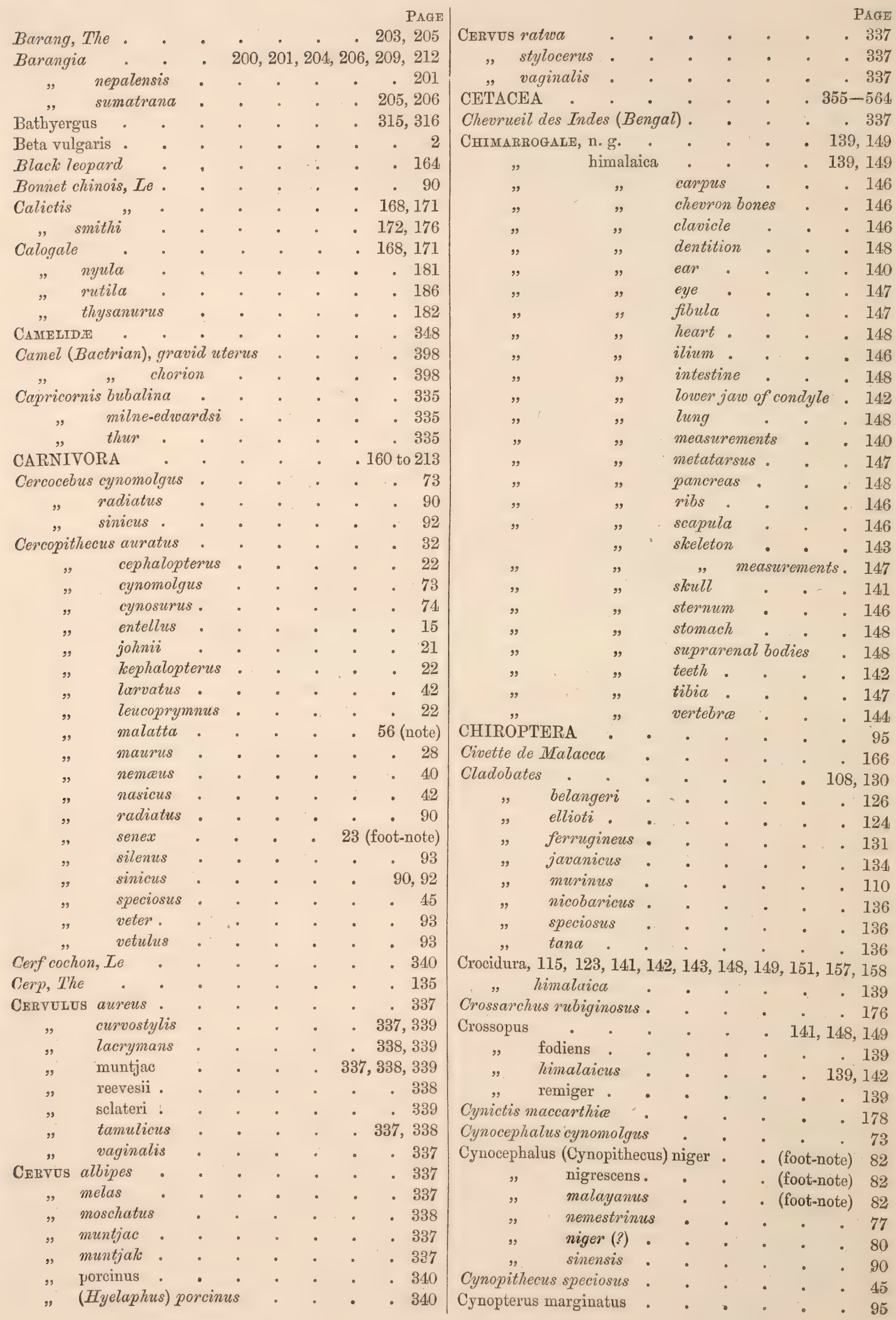


GENERAL IITDEX.

Dekan

PAGE

. 322,323

Glisorex . . . • . . . 107, 130

- 109

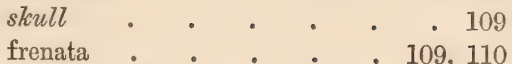
frenata . . . . . 109, 110

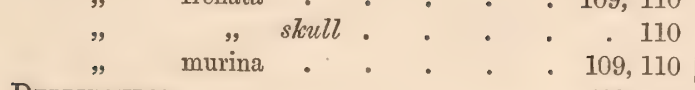

Delphinida $\quad$ • . . . . . 412,414

Delphinus tursio . . . . . (foot-note) 388

Diplomesodon . . . . . . 150,159

Douc, $L a$

Dolphin of the Irawady

"Risso's

round-headed, of Bay of Bengal

Ecureuil blane de Siam.

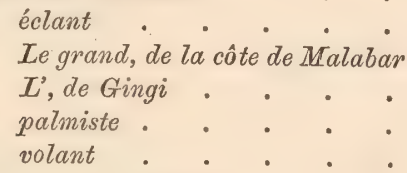

Le grand, de la côte de Malabar $L^{\prime}$, de Gingi palmiste. volant

EDENTATA" . de Siberia

Eichiorn, Das, aus Deschinschi

Embatlondride .

Enhydrina

Enhydris lutris

EQUid 正

ERINACEIDE .

Erinaceus

FELIDE

(Glisorex) $\tan a$

FeLIs bengalensis

" chinensis

" domesticus

", fontanieri

,

". Torsfieldi

" japanensis

"Teopardus

" melas (Péron)

$"$ minuta

" nipalensis

" panthera

" pardichroa.

" pardus .

" sumatrana

" tigris

"undata.

" $\quad$ " var. sumatrana

, viverrina

Ficus religiosa .

Fife', The

Funambulus indicus

GaLLago (Otogale) pallida

Genetta indica

Georychus

Gibbon, Le cendré .

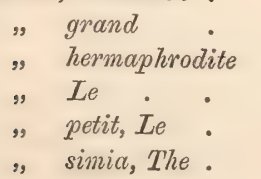

162,163

- 163

164,165

161, 162

. 161

- 164

- 164

- 161

. 164

$161,162,163$

164, 165

- 160

- 164

- 164

165,209

. 2

(f) 258

12
166

315,316
GLobicephatus, 364, 383, 386, 391, 392, 394, 406, 411, 412 ,

413,415

semicircular canals . . . . 517

stomach . . . . . . 374

deductor . . . . . . . 369

364,369

- 364

- 364

- 383

- 383

368,412

- 364

- 364

Globiceps, pulmonary glands . . . . (foot-note) 388

Golock

Grampus griseus . . . . . 386

- 386

. 408

408,416

$42^{\circ}$

- 22

- 91

- 27

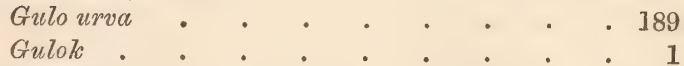

GrMndra . . . . . . . 109, 138

HeLictis, stull characters of species . 193

- 193

. 193,194

. 195

. 193,194

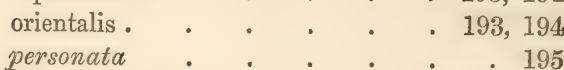

subaurantiaca $. \quad 193,195$

195
.
.

- 169

. 172

- 170

measurements of species

skull

auropunctatus

172 , et seq.

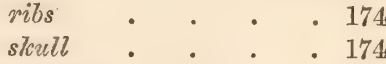

sternum • . . . 174

vertebrce . . . . 174

badius . . . . . .

brachyurus . . . . . : 187

cafra . . . . . (foot-note) 184

edwardsii . . . . . . 174

ellioti • • . • • . 176, 178

exilis

$171,186,187$

ferrugineus $\cdot$.

fimbriatuss . . . . . . 181

flavidens . . . . . . 178

frederici . . . . . . 181

fulvescens . . . . , 178,179

fuscus . . . . . . . . 184

griseus . • • • . . 174, 181

ichneumon . . . . (foot-note) 184

javanica . . . . . 173, 185

javanicus $. \quad . \quad . \quad . \quad . \quad .185$

jerdoni . . . . . . . . 183 


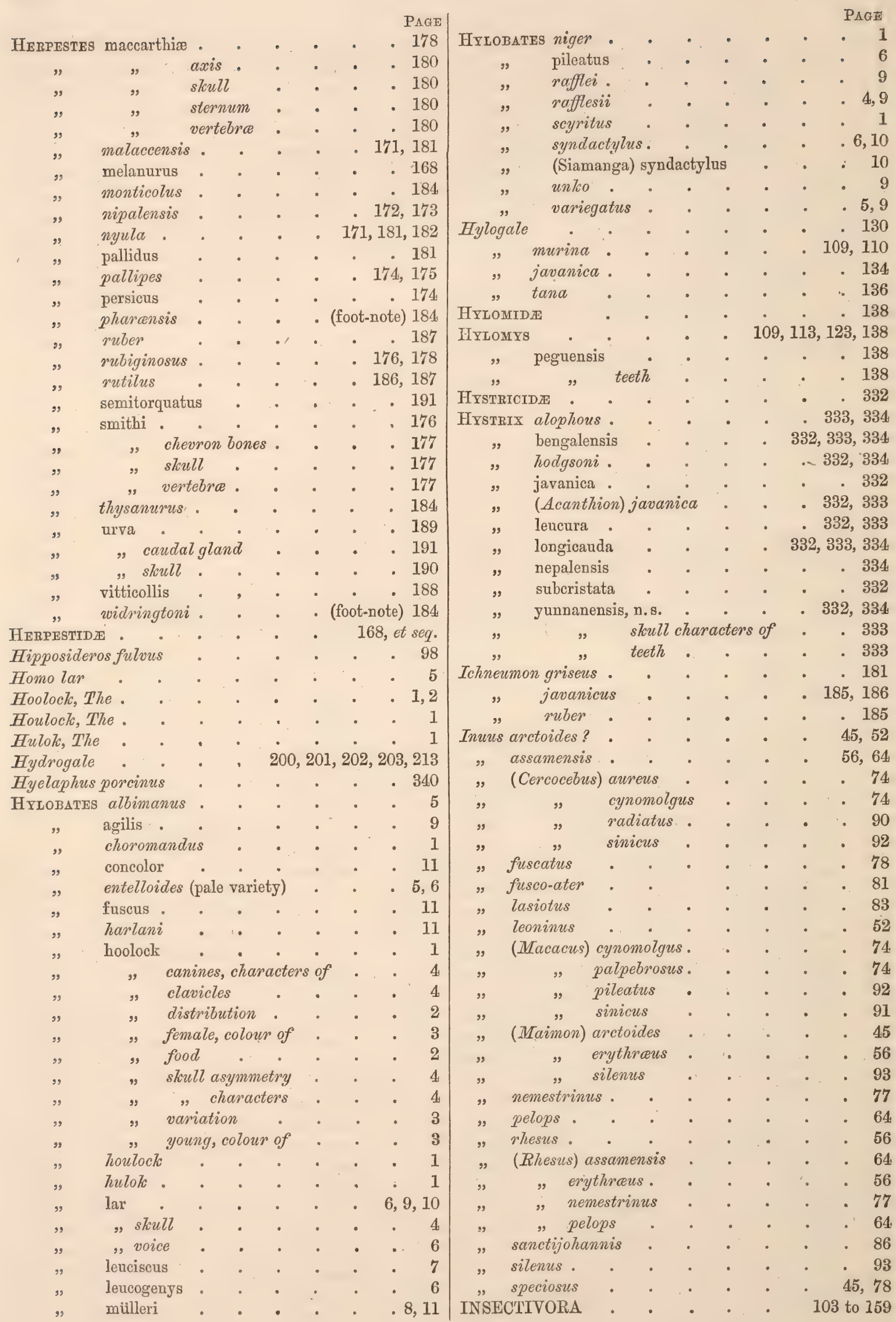


GENERAL INDEX.

Javan cat, The

PAgE

Kakaw, Le

Kemas proclivus, vel thar

- 165

Kijang

Kukong.

Langar .

Langsang pardicolor

Lasiopyga nasicus .

Latax

Leopard, blacte

Leopardus chinensis

Lori Poucan pardus

Loris

"gracilis

Lontra .

" braziliensis

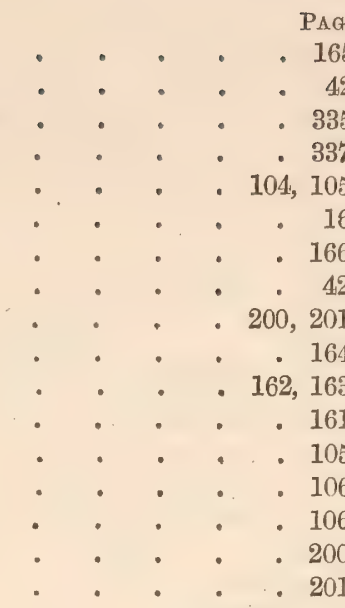

MaCACUS cyclopis, seasonal tumour-like swellings. 88

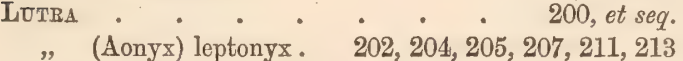

" aurobrunnea . . . . . 207

" barang $\quad . \quad \cdot \quad \cdot \quad \cdot \quad \cdot \quad \cdot \quad 203,205$

" braziliensis $\quad . \quad+\quad . \quad \div 200,201$

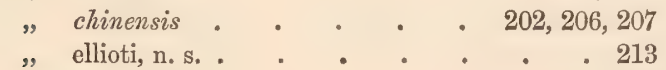

" horsfieldi . . . . . . . 213

" indica. . . . . . . . 206

" indigitata • . • • • 207,213

$\Rightarrow$ inunguis : • • • • • • • 200,202

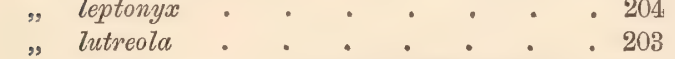

" nair - . 203, 206, 207, 209, 210, 211, 213

" „, skull . . . . . 204, 208

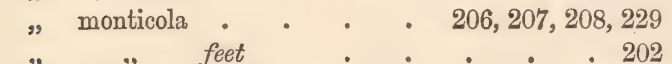

" perspicillata $\quad \cdot \quad \cdot \quad \cdot \quad \cdot \quad 204,205$

" simung . . . . . 211, 212, 213

" sumatrana $. \quad \cdot \quad \cdot \quad \cdot \quad \cdot \quad \cdot \quad \cdot \quad 211,212$

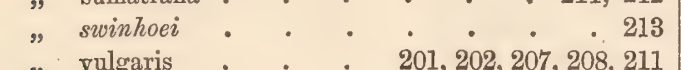

Intrina

$201,202,207,208,211$

Introgale $\quad \cdot \quad \cdot \quad \cdot \quad \cdot \quad \cdot \quad \cdot \quad \cdot \quad \cdot 203,213$

Iutronectes . . . • • • . 200, 202

Macacos andamanensis . . . . 4 46, 52

\begin{tabular}{|c|c|c|c|c|}
\hline & arctoides & & . & $.45,47,51,79,80,8$ \\
\hline & $"$ & bones & & . 49 \\
\hline & " & distril & Bution & . \\
\hline & $s$ & skull & - & . 47 , et seq. \\
\hline & assamensis & $\cdot$ & - & . $64,70,72,82,84,88$ \\
\hline & " & measu & rements & 67 \\
\hline & פ & pelvis & & . 67 \\
\hline & " & skull & & 60,66 \\
\hline & assamensis & • & . & . 74 \\
\hline & auratus & - & . & 74 \\
\hline & aureus. & - & . & 72,74 \\
\hline & brunneus & . & . & . $45,46,47,80$ \\
\hline & carbonarius & $s$. & . & . $74,75,76$ \\
\hline & cristatus & . & . & 74,76 \\
\hline & cyclopis . & 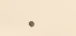 & . & . $87,88,90$, (note) 92 \\
\hline & bon & nes & . & $67,82,85$, et seq. \\
\hline & pelv & lvis & . & 89 \\
\hline
\end{tabular}

\section{"}

cynomolgus .

erythyraus

fur

$72,73,74,75,76$

fusco-ater . . . . . 81

fuscatus. . . . . . 51, 78

(Gymnopyga) inornatus. . . $\quad .80$

lasiotis . . . . . . . 83,84, 88

, skull . . . . $85,86,87$

" " measurements . . . 86

leoninus. . . . 52, 53, 78, 84

"female . . . . . 53

" male . . . . . 52

" humerus . . . . . 55

" skull . . . . 54, 55

" vertebral column . . . 55

libidinosus . . . . . . 56

maurus . . . . . 80,81

, slcull . . . . . 81

melanotus . . . . . 45, 80

nemestrinus . . . . . . 77

" skull. $\quad . \quad$. $\quad 53,55$

niger . , . . . (foot-note) 82

ochreatus . . . . . . 82

ocreatus • . • • • 81

oinops - • . . . . 56

. „Pithex $)$. . 56,61,69,70,72,84

pelops (Pithex) - 63, 64, 68, 69, 70,71,72

philippensis . . . . . . 74

pileatus . . . . . . 91

problematicus . . . . 64, 71,72

(radiatus) affinis . . . (foot-note) 91

radiatus

rheso-similis

rhesus .

, description

", pelvis

" skull $\cdot{ }^{\circ} \cdot{ }^{\circ} \cdot 60,67,85$

" vertebral column . . . 55

rufescens . • . 79, 80

sancti-johannis $\quad . \quad . \quad .86,88,90$

sikkimensis . . . . . . 72

silenus • • . . . . . 93

" skull. • . . . . 94

sinicus var. $a l b a \cdot \quad \cdot \quad \cdot \quad \cdot \quad$ : 23

sinicus (affinis) . . . (foot-note) 91

speciosus . . . 45, 47,50,51,78

tcheliensis . . . . . $83,84,87$

tibetanus . . . 51 (note), 72,79

Macaque, à face noire . • • • . 75,76

". àface tannée . . . . . . 75, 76

à queue courte . . . . . . $\quad .55$

" Le . . . . . . . . 73

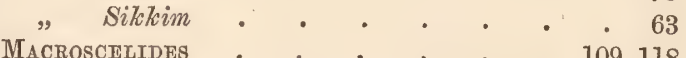

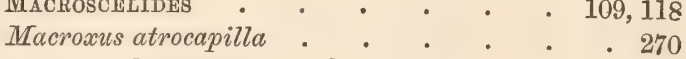

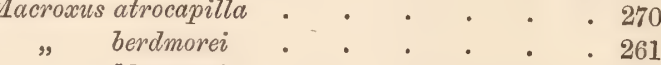

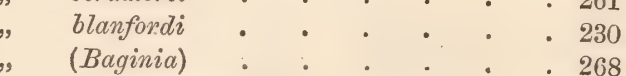

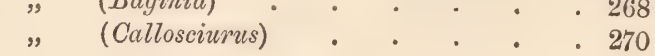




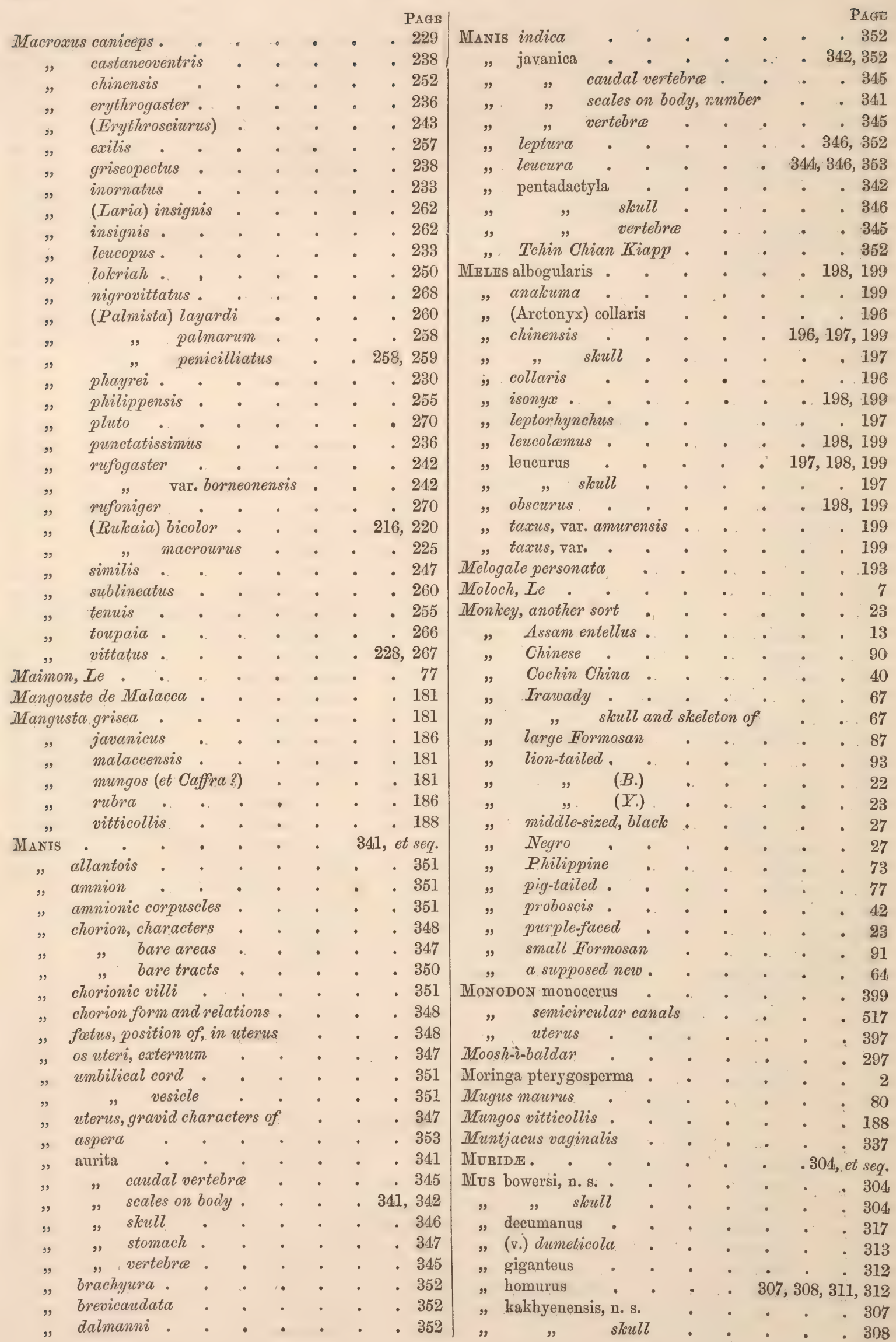


Mos longicaudatus

"nitidus

" (v.) oleraceus .

"povensis.

, rubricosa, n. s.

$" \quad$ " skcull

"rufescens.

" sladeni, n. s. .

"sumatrensis

urbanus

"viculorum, n.s.

, yunnanensis, n. s.

" $"$ skull.

Mustela lutra

MUSTELIDA

Mydaus collaris

Narwhal .

Nasalis larvatus

", recurvus

Nectogate

Nectogatin

NeMorHedUs bubalina

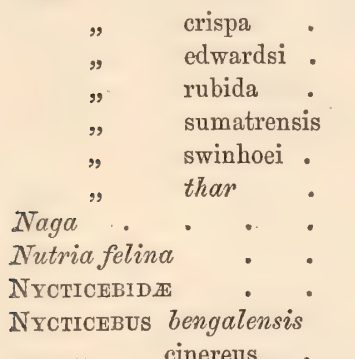

Nycticebus bengalensis

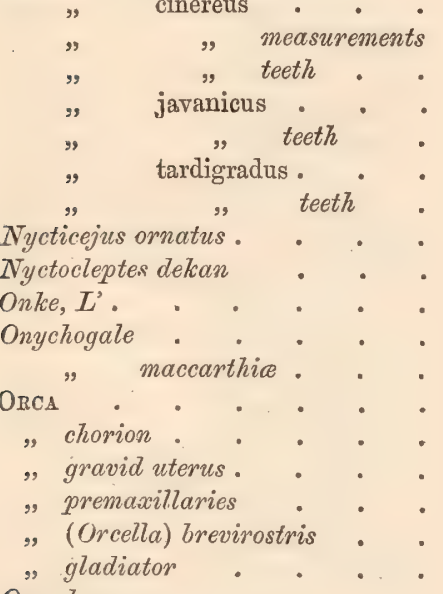

\section{Orcada.}

Oroelda brevirostris

\begin{tabular}{|c|c|}
\hline " & , \\
\hline " & , \\
\hline " & , \\
\hline " & , \\
\hline " & , \\
\hline " & , \\
\hline "' & . , , \\
\hline בצ & , \\
\hline
\end{tabular}

allantois

amnionic corpuscles

aorta.

arteries.

blood-vessels.

blow-hole

brain

cheoron bones
PAGE

- 309, 313

. 305

309, 312, 313

- 313

- 306

• 306

305

. 322,323

308, 310, 311, 312

. 308

- 308

- 306

- 307

- 193

- 196

394, 401

- 42

141, 142, 146, 149

- 149

- 335,336

- 336

- 335, 336

- 336

- 336

- 336

- 335

- 335

- 201

- 103

104, 105

$103,104,105$

- 106

- 106

- 105

. 106

2, 103, 104, 105

. 106

- 322,323

168, 171

172, 178

- 351

- 401

397, 399

- 414

- 369

- 348

- 415

- 369

- 402

- 402

. 391

- 391

- 390

- 370

. 392

- 412

OrCella brevirostris, chorion . . . 400

\begin{tabular}{cc} 
" microscopic structure 402 \\
corpus luteun \\
\hline
\end{tabular}

dentition . . . . 414

distribution . . . . 369

ductus arteriosus .. . $\quad 390$

communis chotedochus 382

duodenal sae . . . 376

ear.external • . . 376

eustachian tube . . . 384

external features. . . 370

foetus . . . . 406

" measurements . . 408

" position of, in utero . 394,

"uterus . . . . 396

"weight. . . . 407

food . . . . 361

generative organs . . . 394

genital slit . . . . 371

glands, duodenal . . . 376

" asophageal . . 374

" pulmonary • 388, 389

". racemose of fauces . 374

" $\quad$ " of pharynx 383

graafian vesicle . . . 405

habits • • • . 366

heart . . . . 390

humerus . . . . 412

hyoid . . . . . 414

larynx. . . . 384

” cartilages . . . 386

" glandular cryptose

structure • . 386

liver . . . . 382

lungs . . . . . 387

mammary slit . . . 394

manus . . . . . 412

measurements . . . 371

membrana granulosa . . 405

moustache of foetus . . 370

mouth . • . . . 371

" mucous crypt of cesophagus . . . 374

" mucous crypt of palate 374

narial chamber . . . 383

cesophagus . . . • 374

omentum, relations ․ $\quad$. 380

os uteri internum . . 395

ovary . . . . 404

palate . . . . 373

pancreas . . . . 381

pancreatic ducts . . . 381

pectoral limb . . . 412

pelvic bones . 362,408, 413

", position . . 408

penis . . . . 362

pharynx . . . . 383

premaxillaries . . ' 414

radius . . . . 412

ribs . . . . 409, 412

scapula . . . . 412 


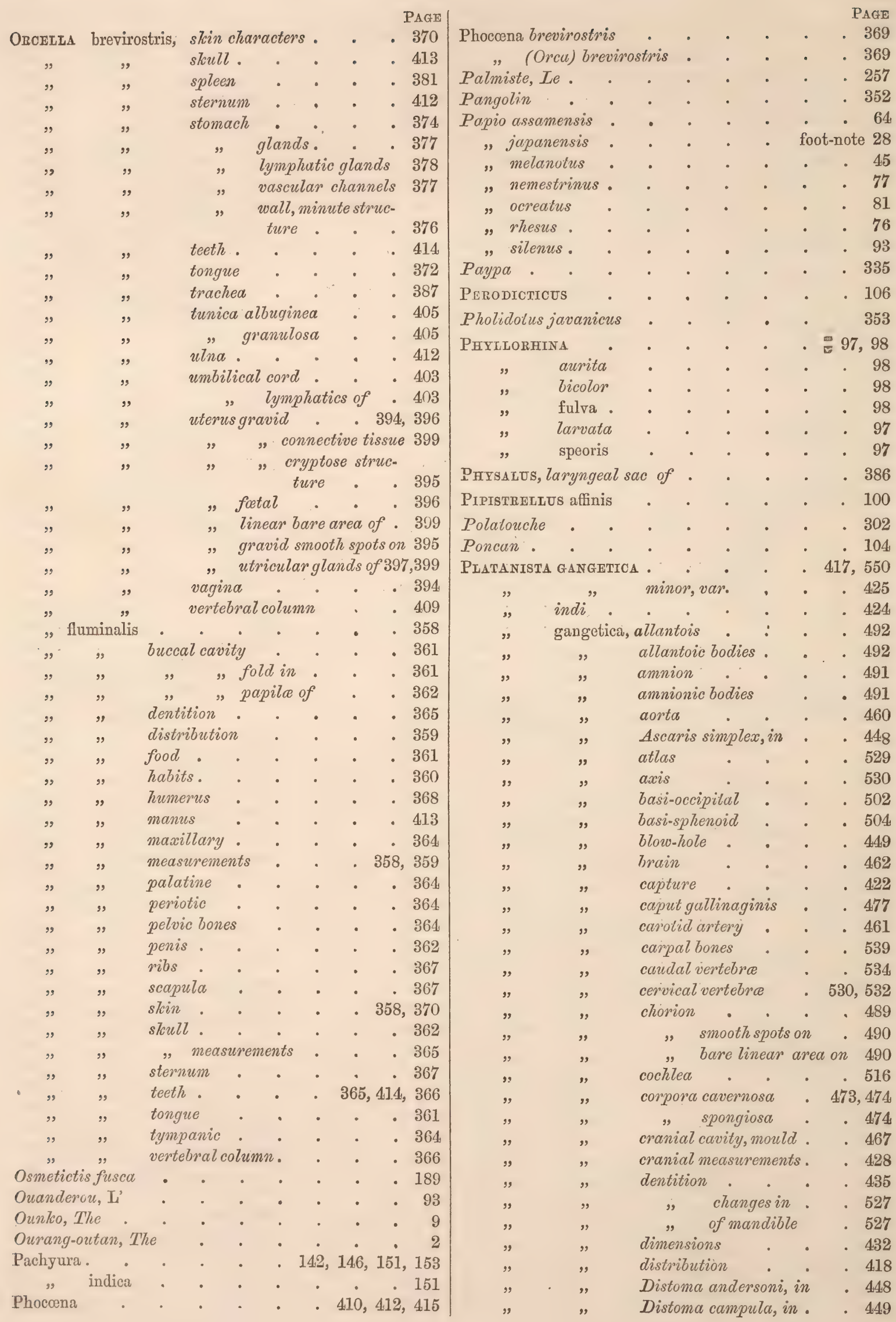




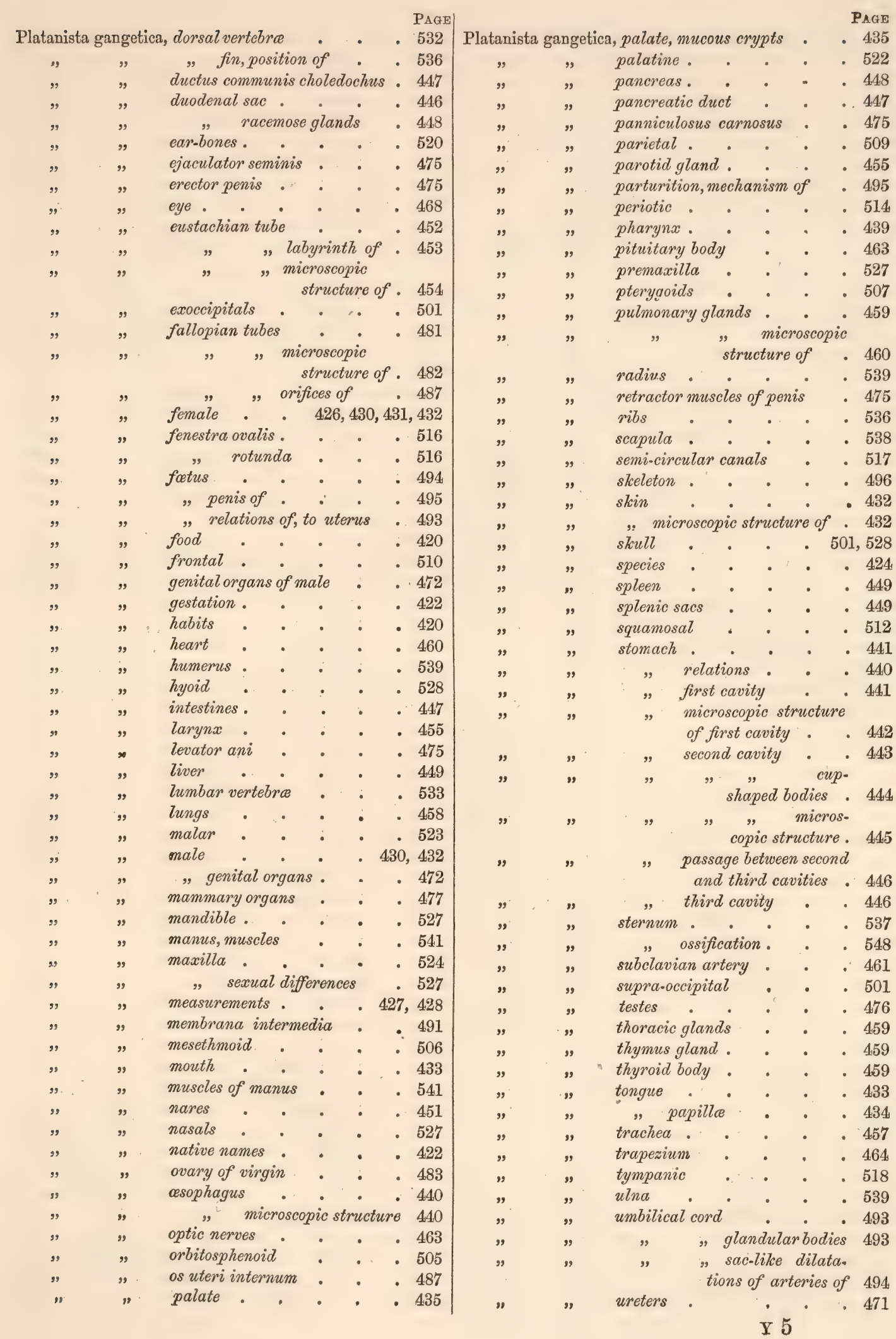




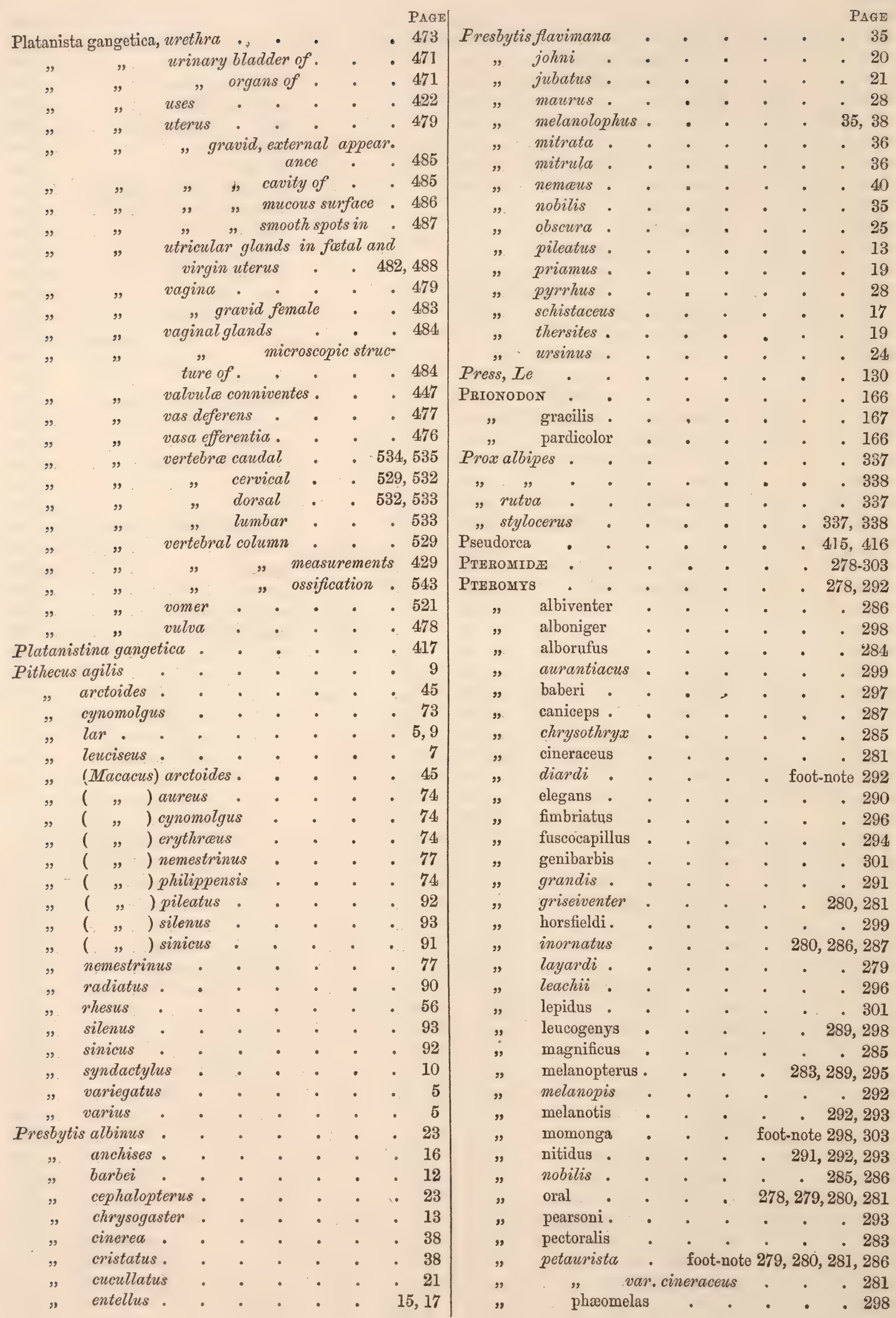


GENERAL INDEX.

\begin{tabular}{|c|c|c|c|c|c|c|c|c|c|c|c|c|c|}
\hline \multicolumn{3}{|c|}{ Pieromys phæomelas teeth } & \multicolumn{4}{|r|}{$\begin{array}{c}\text { PAGE } \\
299\end{array}$} & \multicolumn{4}{|c|}{ RHIZOMYS stomach, characters of } & \multicolumn{3}{|r|}{ Page } \\
\hline$\Rightarrow \quad 1$ & phayrei .. & . & 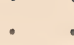 & - & • & 279,300 & " tec & teeth, characte & ers of & & • & . & . 314 \\
\hline " & philippensis & . & - & - & - & . 280 & $"$ & tongue . & & . & . & : & . 317 \\
\hline$"$ & pulverulentus & - & - & - & - & 279,297 & $"$ & tympanic bull & & . & 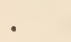 & - & . 317 \\
\hline$"$ & punctatus & . & • & . & 278,279 & $9,290,291$ & $u t$ & uterus. & & . & . & . & - 320 \\
\hline " & russicus & . & . & • & . & . 302 & $u t$ & uterus mascul & aris & . & 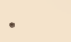 & . & - 321 \\
\hline$"$ & sagitta. & - & - & . & 293,294 & $4,300,301$ & ", & agina. & & . & - & . & 320 \\
\hline " & setosus . & - & . & • & . & 293,294 & " & vaginal gland & & 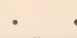 & & . & . 321 \\
\hline$"$ & sibericus & . & . & • & . & . 302 & ", & vesicular glan & ds of & $f$ drood & & $m$ & . 319 \\
\hline , & spac & . & - & • & - & . 300 & " & ", & & $f$ penis & & . & . 321 \\
\hline " & teph & - & - & & - & - 299 & ve & vertebra. & & - & - & : & - 315 \\
\hline ” & turn & - & . & - & . & - 298 & ", & illi of intesti & & . & . & . & . 319 \\
\hline , & villo. & - & - & - & - & 293, 295 & " & padius . & & . & . & . 3 & $\overline{516, ~} 329$ \\
\hline , & vol: & - & . & - & . & . 302 & " & intesti & & - & . & - & . 319 \\
\hline$"$ & vulg & - & - & • & - & . 302 & " & skull & & . & - & - & - 329 \\
\hline " & xantl & . & . & - & . & . 295 & " & stomac & & . & . & . & 318,319 \\
\hline$"$ & xanthotis & - & . & . & - & . 283 & , & astaneus. & - & . & - & 325 , & 328,329 \\
\hline , & yunnanensis, & & . & & - & - 282 & " & inereus. & - & . & - & . & 322,324 \\
\hline teronura, & $x$, vidge along $t$ & tail & . & . & . & . 200 & ", & lekan . & - & - & - & . & 322,330 \\
\hline$\eta$ & sandbachi & - & . & & . & . 205 & ", & rythrogenys, & & . & . & . & . 324 \\
\hline TEROPID & $\mathbb{E} \quad$. & . & - & & - & . $\quad 95$ & " & ninor . & - & - & . & - 326, & 327,328 \\
\hline PTEROPUS & marginatus & - & - & & - & - $\quad 95$ & $"$ & ruinosus & , & . & . & . 316 & 317,325 \\
\hline Ptemura & & . & - & & - & . 200 & " & inte. & estine & & . & . & - 319 \\
\hline TILOCERC & cus. & - & - & • & - & 109,118 & " & sku & & . & - & . & . 326 \\
\hline Puinj or $P$ & Ponj & - & - & • & - & . 63 & " & ston & mach & . & - & . & 318,319 \\
\hline Pygathrix & $x$ nemaens & - & - & - & - & . 40 & $"$ & inensis . & . & - & . & 326 & 327,330 \\
\hline QUADRUI & TMANA . & - & - & - & - & 1 & , & " skull & & . & - & - & . 330 \\
\hline Rheithrosci & ciurus & - & - & $?$ & . & 214,277 & " & umatrensis & & . & , & . & . 322 \\
\hline Rhesus, $I e$ & e . & - & - & - & . & - $\quad 55$ & "я & Malayan nam & & . & . & . & - 323 \\
\hline RHINocer & ROTIDE • & - & - & & - & - 348 & $\eta$ & kull & - & . & . & . & - 323 \\
\hline RHINOLOP] & PHIDE & - & - & & - & . 95 & ; & estitus . & . & . & . & . & 330,331 \\
\hline IINOLOPI & PHUS cœlophyll & & - & & - & - 96 & $"$ & " skull & & . & - & . & - 331 \\
\hline , & larvatus & . & . & • & - & 95,97 & Rhynochopit & ithecus larvat & & - & . & - & \\
\hline ” & murinus $e$ & et fulg & gens. & • & - & - 98 & $R i b$-faced $D$ & Deer & - & 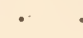 & . & - & \\
\hline , & pearsoni & $\therefore$ & - & - & • & • $\quad 95$ & Rilawa, The & e. & - & - & . & . & . 91 \\
\hline 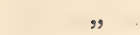 & yunanensi & & - & - & . & . 95 & Rillow, The & . & . & - & - & - & \\
\hline ainopithe & ecus roxellanæ & . & . & - & . & . 43 & RODENTIA & A. & . & . & . & . & 214, \&c. \\
\hline hinosciur & rus . & . & - & - & . & 214,275 & Rollewai, Th & The & . & . & . & . & . 92 \\
\hline HzoMYs & . & - & . & • & - & . 314 & RUMINAN & VTIA & . & . & . & . & $335-340$ \\
\hline$"$ & cacum . & . & . & - & . & . 315 & SCIURIDA & - & - & - & - & . & - 214 \\
\hline ", & dimen & nsions & of & . & - & . 319 & Sciuroptera & baberi & - & - & - & : & - 297 \\
\hline " & clavicle. & $0^{\circ}$ & - & . & . & . 315 & $m$ & nomoga. & . & . & . & - & - 303 \\
\hline$"$ & Cowperian glo & ands & . & - & - & . 321 & $\eta$ & ohayrei . & . & 皮 & - & - & - 300 \\
\hline$"$ & duodenum & 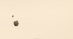 & . & - & . & . 319 & $"$ & padicea. & - & . & . & . & - 300 \\
\hline , & & ands o & & - & - & . 319 & " & urnbulli & - & . & . & . & - 298 \\
\hline$"$ & food & . & . & - & . & - 322 & 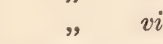 & villosa .. & - & . & . & . & . 293 \\
\hline , & glans penis & - & - & & - & - 321 & $\eta$ & olans. & . & . & . & . & . 302 \\
\hline " & habits. & . & . & - & - & - 322 & Sciuropterus & $s \cdot$. & . & - & . & - & . 278 \\
\hline , & heart & - & - & - & . & - 320 & 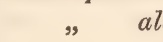 & lboniger & - & . & - & . & . 298 \\
\hline " & intestine & - & . & - & . & . 319 & $c a$ & aniceps. & - & . & 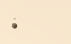 & . & . 287 \\
\hline "" & liver & - & - & & - & - 320 & $c h$ & hrysothryx & - & - & . & • & \\
\hline 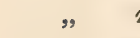 & manubrium, $v$ & variati & tion & & - & - 315 & " & mbriatus & . & . & . & . & . 296 \\
\hline " & os innominatu & & - & . & • & . 317 & $f u$ & iscacapillus & . & . & . & . & . 294 \\
\hline$"$ & os tinca. & . & . & . & - & - 320 & ho & orsfieldi & . & . & . & . & . 299 \\
\hline & & & - & & - & . 320 & $\mathrm{ka}$ & aleensis & - & - & - & . & . 293 \\
\hline 9 & al ossicle & & • & & . & . 321 & $7 a$ & ayardi. & . & - & . & . & - 294 \\
\hline 皮 & prostatic glan & $n d s$ & . & • & - & . 321 & lea & achi & - & - & - & . & . 296 \\
\hline 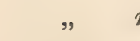 & ribs & - & - & • & . & - 316 & lep & pidus . & & - & - & . & 301 \\
\hline (3) & scapula & - & . & • & • & - 317 & & itidus . & & . & - & - & 285,290 \\
\hline s & sternal ribs & - & - & • & . & . 316 & & obilis . & & & 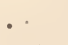 & & . 285 \\
\hline ", & sternum & . & - & & • & . 316 & $p u$ & ulverulentus & & . & - & - & . 297 \\
\hline
\end{tabular}




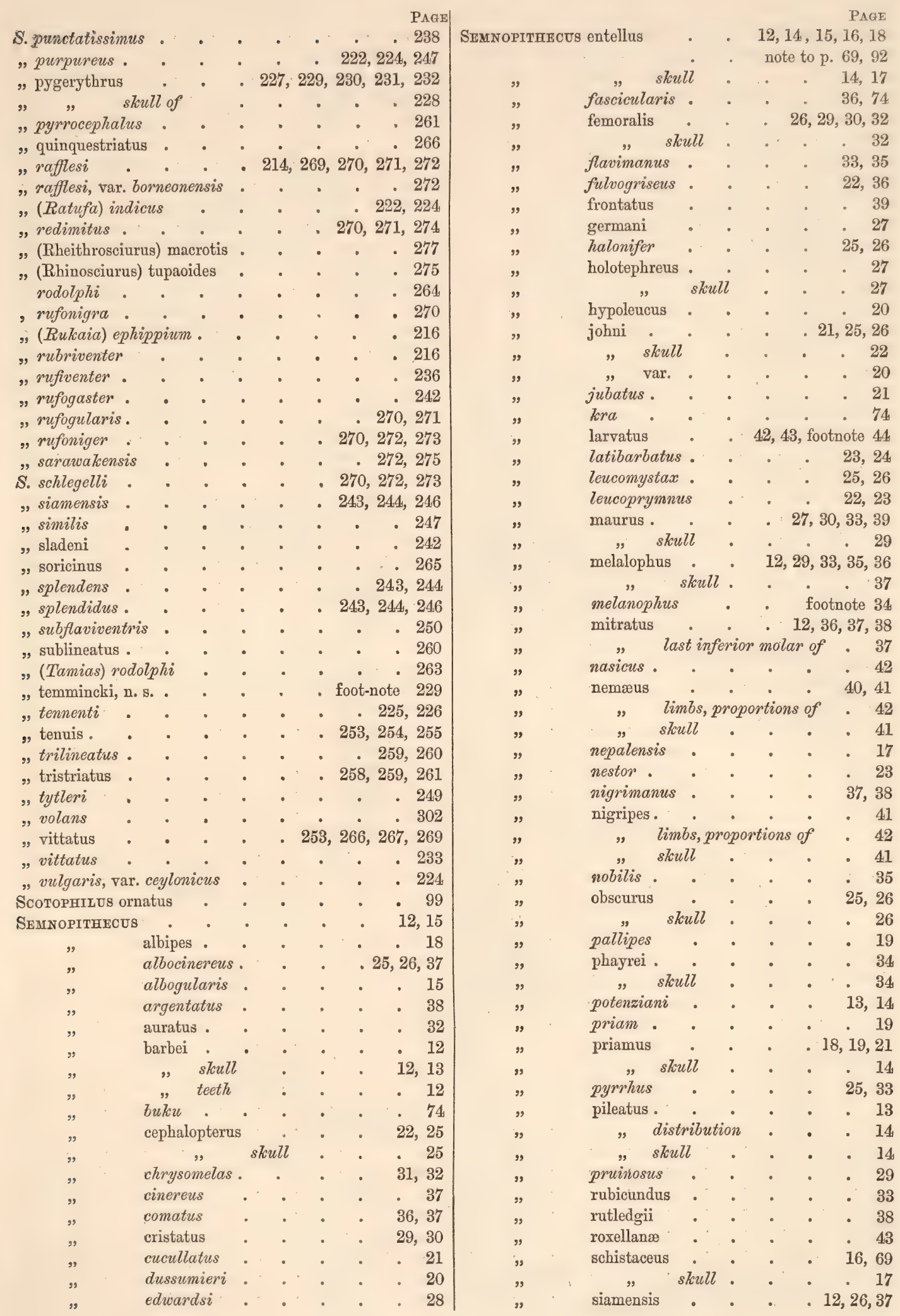




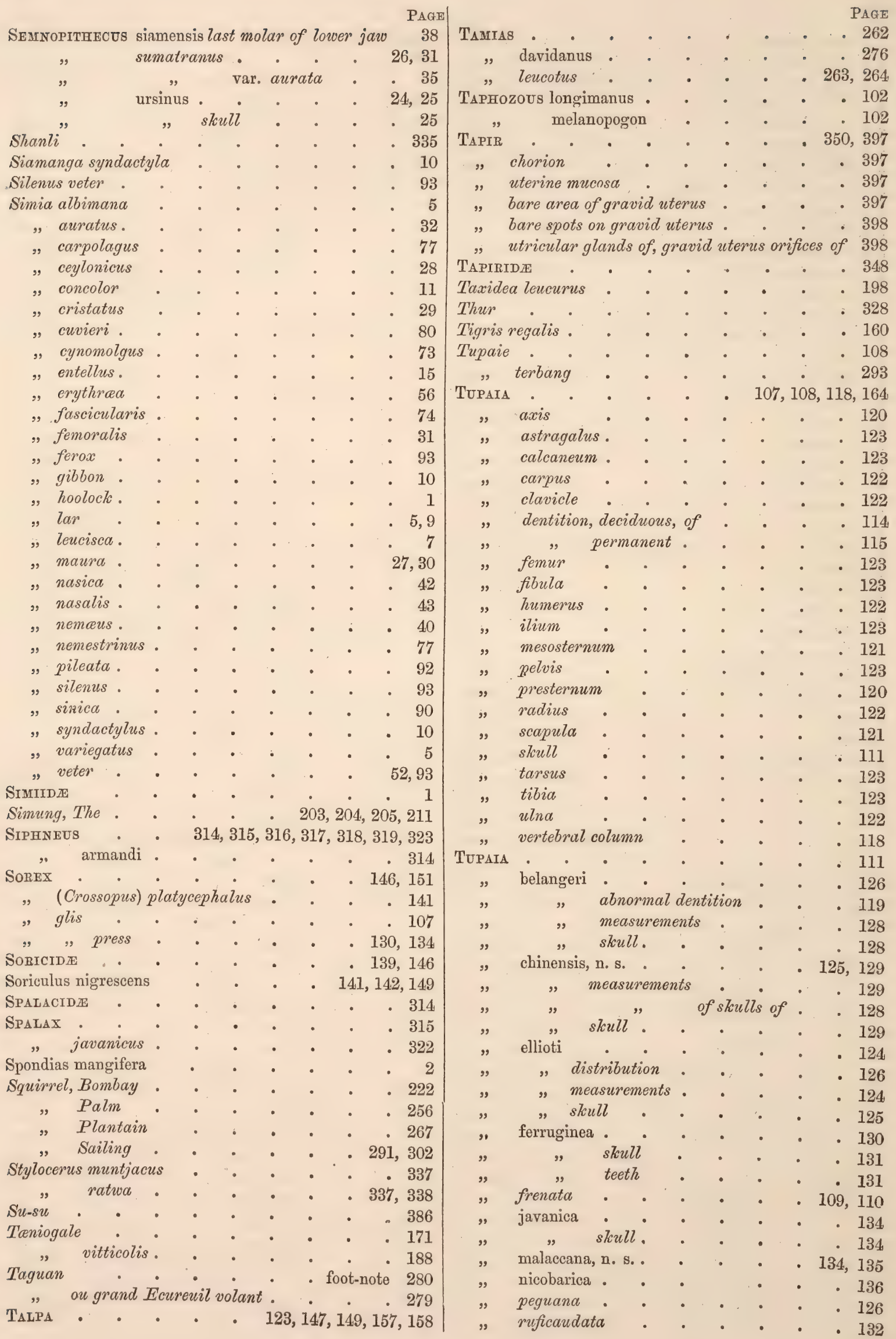




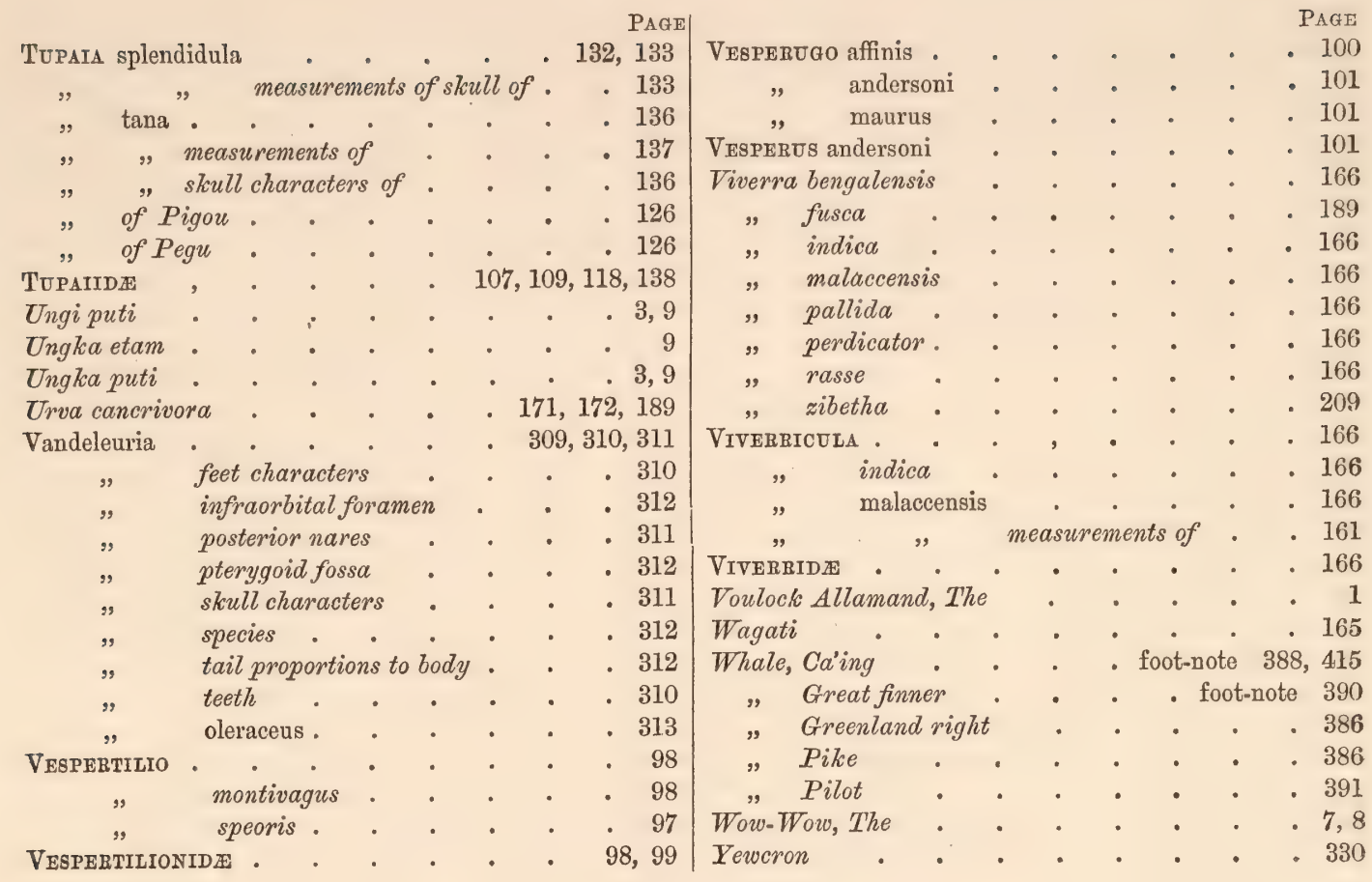





\section{GENERAL INDEX.}

A VES.

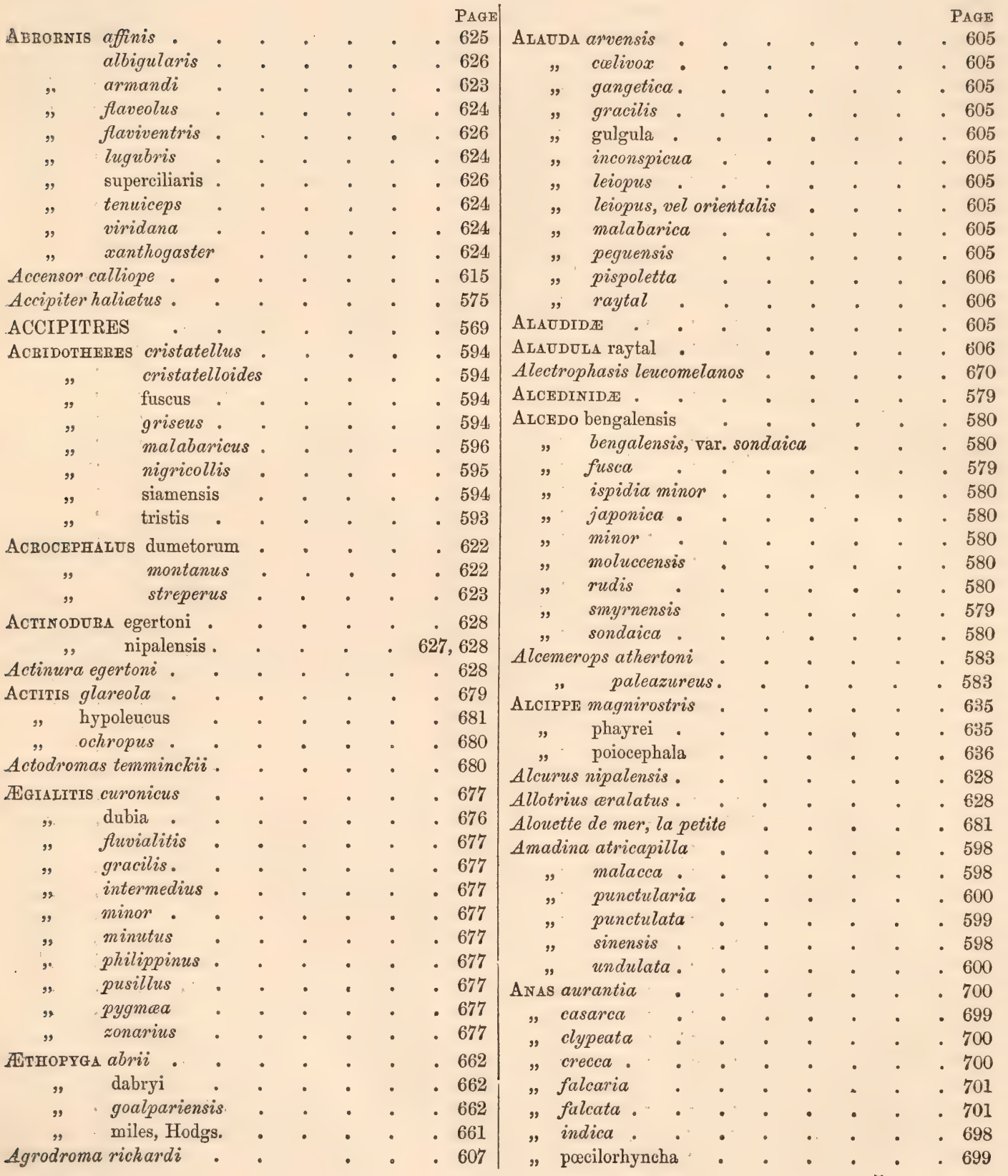




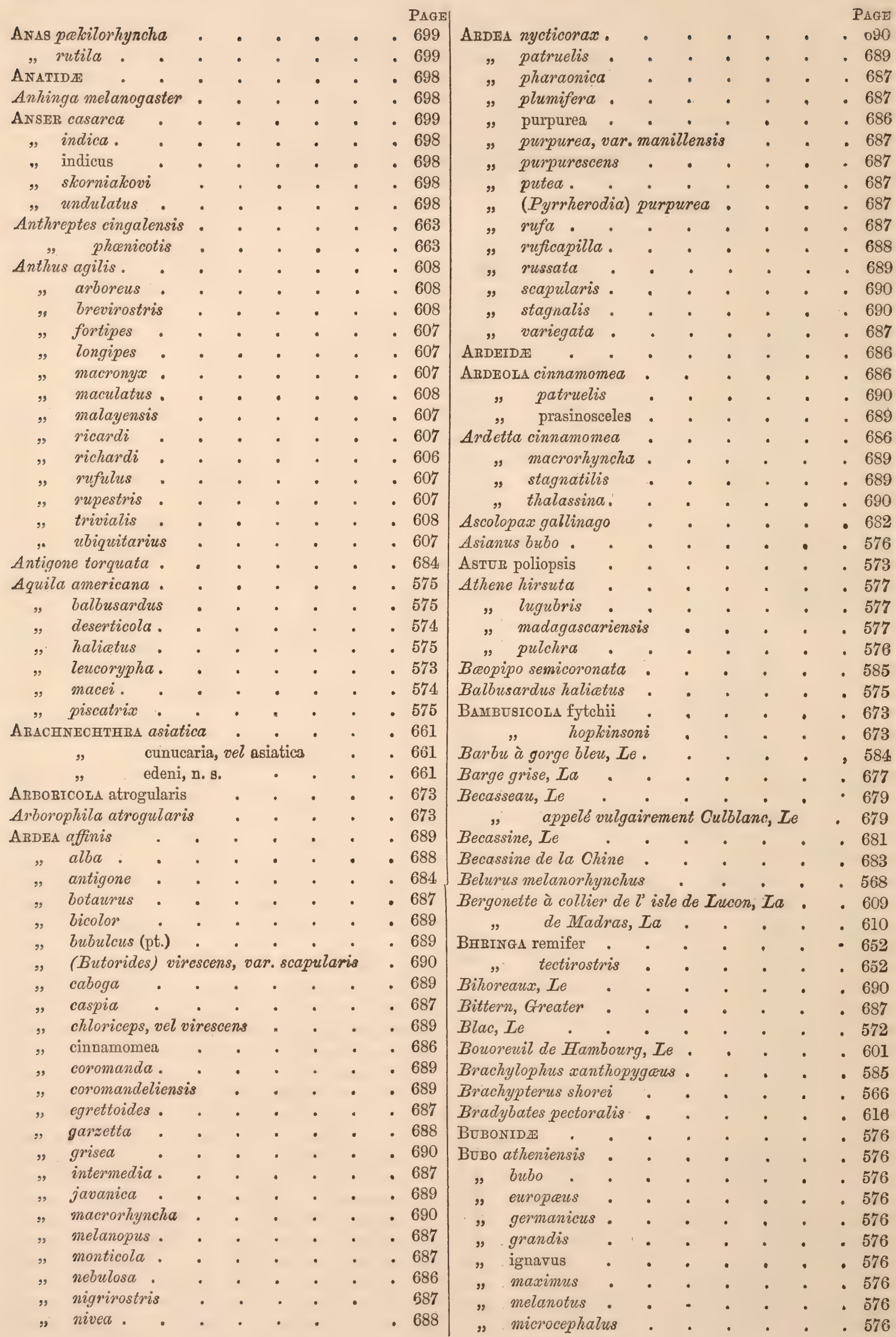


BUВо septentrionalis

Bubulcus coromandeliensis coromandus

Bucco ccoruleigula .

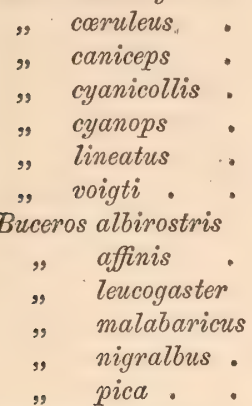

BUCEROTIDE .

BUCHANGA albirictus atra cathoeca longicauda longicaudata . minor. waldeni

Bucia athertoni , nipalensis

BUDYTES atreola, var. melanota atricapillus calcaratus cinereocapillal. citreola citreoloides flavaß cinereocapilla nigricapilla viridi

BupHus coromandus

Butcher-bird, Crested, Red

Buse criarde, La petite .

Buscarla pusilla

Buteo vociferus

Butor, le Grand

Butorides chloriceps

$\begin{array}{ll}" & \text { javanica } \\ " & \text { macrorhyncha } \\ " & \text { patruelis } \\ \text { stagnatilis . }\end{array}$

Cacangelus lugubris

Cacomantis passerinus

" rufiventra.

Cadrau, Le . . .

Caille de la Chine, Le .

Calamodyta dumetorum.

Calamoherpe magnirostris

Calandrella raytal

Calliope ballioni . camtschatkensis kamschatkensis lathami . pectoralis . suecoides.

Callipyga furcata .
PAGE

- 576

- 689

- 689

- 584

- 584,

- 583

- 584

- 584

- 583

- 584

577,578

- 578

- 577

- 577

- 577

- 578

- 577

, 653

- 653

- 653

- 654

- 654

- 653

- 654

- 583

. 583

- 609

- 609 .

- 609

- 608

- 609

- 609

- 609

- 608

- 608

- 688

- 645

- 572

- 604

. 572

- 686

- 690

- 689

- 690

- 690

- 690

- 588

- 587

- 587

- 587

- 613

- 686

- 622

- 622

- 606

- 616

- 615

- 615

- 615

. 615

- 614

- 629
Calocitta magnirostris

Campephaga macei

Cancroma caromanda . . . . . . . 688

CAPITONIDE. . . 583

Capito cyanicollis . . . . . . . . 584

CAPRIMULGIDE : . . . 588

CAPRIMULGUS jotaka $. \quad . \quad . \quad . \quad . \quad .588$

macrurus $\bullet: \cdot 0^{\circ} 588$

Carbo capillatus . . . . . . . 697

" cormoranus. •. . • . . 696

"filamentosus . . . . . . 697

"graculus . . . . 697

" leucogaster . . . . . . 696

" javanious . . . . . . 697

melanognathus . . . . . . 697

" niepcii . . . . . . . 697

" phalacrocorax, var. continentalis . . 697

" pygmaus . . . . . . . 697

CARINE brama . . . . . . 577

" pulchra . . . . . . . 576

Casarka rutila . . . . . . . 699

Castagneux des Philippines, Le . . . . 702

Cecropis erythropygia . . . .651

, filicauda. . . . . . . 650

" pagorum . . . . . 650

, rustica . . . . . . . 650

Certhia coccinea, 663

" cruentata. . . . . . . 663

erythronotos .663

"goalpariensis . . . . . . 662

Certe bicincta .

" leucomelaneura . . . . . . 580

" rudis . . . 580

", varia . . . . . . . 580

Chaitaris rubeculoides,$\quad 620$

Chatcoparta cingalensis . . . . . 662

" phonicotis . . . , 663

CHALCOPHAPS bomensis $\quad . \quad \cdot \quad \cdot \quad 668$

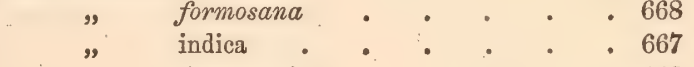

" javanensis . . . . . 668

; pileata •. . . . 668

Chaptia ænea . . . . . . . 652

CHARADRID

CHABADRIUS alexandrinus, var. $d . \quad \ldots .676$ (Arnatus) longipes . . . . 676 auratus . . . . 676 curonicus . . . . . 676

dubius.$\quad \cdot \cdot .676$

duvanceli . . . . . . 675

flwiatilis . . . . . . 677

fulvus . . . . . . 675

glancopis + . 676

gracilis • . • . . . 677

hiaticula . . $\cdot . \quad 677$

hiaticuloides . • . . . 677

longipes . . . . . . 676

minor . . . . . . 677

minutus - . . . . . 677

œdicemus . . . . . . 674 
Charadrius orientalis . . .

Columba albicapilla • • • • • • 667

philippinus .. . . . . 676

pluvialis . . : . . . 676

pusillus . . . . . . 677

(Plwvialis) orientalis . . . 676

pygmaus • . . • • . 677

taitensis . . . .676

ventralis . . . . 575

virginianus . . . 676

virginicus . . • . . . 676

xanthocheilus . .676

zonatus ...........

Chatarrhera gularis . • • . • 639

Chettusia atronuchalis . • • • • . . 675

Chevalier de Bengali, Le . . . . . 683

CHibia casia

hottentota

. 652

- 651

Chimarrhornis leucocephala .

- 613

Chledasicus atro-superciliaris . • • • • 638

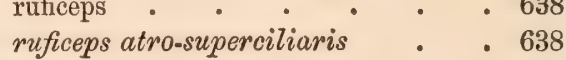

Chloropicus striolatus

$-585$

- 660

malabaricus. malabaricus .

Choucas du Cap de Bonne Esperance, Le

CHRYSOCOLAPTES strictus

sultaneus

Chrysolophus amherstia. .

651

. 585

- 584

. 671

Chrysomma hypoleucos

$$
\text { sinense }
$$

Chrysonotus biddulphi shorei

Cichiops fortipes.

" monticolus

Cinclosoma moniliger Cinnyris rabecula'.

miles

" phonicotis

Circus melanoleucus

Cissa magnirostris .

Cisticola melanocephala ruficollis tytleri

Citrinella fucata pusilla.

Cleptes hudsonious " pica

Clypeata brachyrhynchus

". macrorhynchus

" platyrhynchus

" pomarina

Coccothraustes atricapilla

Cowry Bird, The

Collurio ferrugiceps 
Courly, variè de Mexique, Le :

Crabier de Coromandel, $\dot{L} e$.

Crataionyx ater

Crateropus gularis. moniligerus

Creeper, Goulpourah

, Little Indian

Crex chloropus

Criniger splendens.

Crocopus phoenicoptemes viridifrons

Crow, Rufous .

Crypsirhina pallida

, rufa

vagabunda.

Cryptolopha tephrocephala

Cuckoo, Sonnerat's

Cuculide.

Coculos albopunctatus.

$\begin{array}{ll}\text { " } & \text { borealis . } \\ \text { " } & \text { canorus . } \\ \text { " } & \text { hepaticus } \\ \text { " } & \text { lumalayanus } \\ \text { " } & \text { rufus } \\ \text { ". } & \text { sonnerati . } \\ \text { venustus. }\end{array}$

Colicipeta burkii

tephrocephalus

Cuncuma albipes .

"macei
Curruca suecica

CURSORES

Cyanecula corulecula.

calliope

camtschatkensis

cyane .

dichrosterna

orientalis .

pectoralis .

suecica

suecoides

Cyanocincla cyana .

Cyanops asiatica.

Cynchramus pusillus

Crornis banyumus

". elegans

" jerdoni

" rubeculoides

, tickelli

Dacelo fusca

" smyrnensis

Dahila docilis

Decurus caudata

$$
\text { criniger }
$$

DENDRocitTA pallida

$$
" \text { rufa . }
$$

Dendrofalco arboreus
PAGE

684

684

- 688

632

- 632

- 639

- 627

- 661

- 663

- 693

651

- 664

664

591

592

- 592

- 592

- 626

- 587

- 586

588

- 587

586,587

- 586

587

- 587

- 586

- 587

- 587

- 627

- 626

- 574

- 574

- 614

$674,675,676$

- 615

- 615

- 615

- 615

- 615

- 614

- 616

- 614

- 615

- 611

- 584

- 604

- 620

- 620

- 620

- 619

- 620

- 579

- 579

- 613

- 642

- 642

- 592

- 591

- 592

- 569

- 569
Dendrofalco subuteo

Dendromanthus maculatus

DENDROPHILA corallina . . . . . . 633

, frontalis . . . . . . 633

Dial bird, The . . . . . . . . . . 613

DICжUM chrysochlora . . . . . • 664

- 663

- 663

- 663

- 663

663

652

- 652

- 653

- 653

- 652

- 653

- 652

- 653

- 653

- 653

- 654

- 653

- 653

- 653

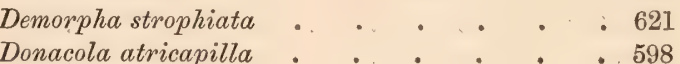

Dove, green-winged. $\quad . \quad 667$

Drongo bronze, Le . . . . . . 652

Drongolon, Le _. . . . . . . . 653

Drymoca brevicaudata . . . . . . 623

- 640

- 640

- 642

- 640

- 640

- 640

- 640

- 640

- 640

- 640

Duck; spotted-billed . . . . . . . . 699

Eagle, white-crowoned . . . . . 573

Edolius aratus . . . . . . . 65\%

, barbatus. . . . 652

" crishna . . . . . . . 652

, fingah. .053

" forficatus . . . . . . . . . 653

remifer

Egretta egrettoides . . . . . . . . 688

, garzetta . . 688

" intermedia . . . . . . . 688

, melanopus. . . . . 688

, nigrirostris . . . . . . . . . 688

, plumifera.., 688

Elanoides cosius • • . . . . . . . 572

Eranus cæruleus . $\quad . \quad . \quad . \quad . \quad$. 572

" cosius . • . . . . . 572

" melanopterus . . . . - . 572

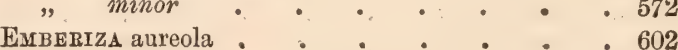

- 604 


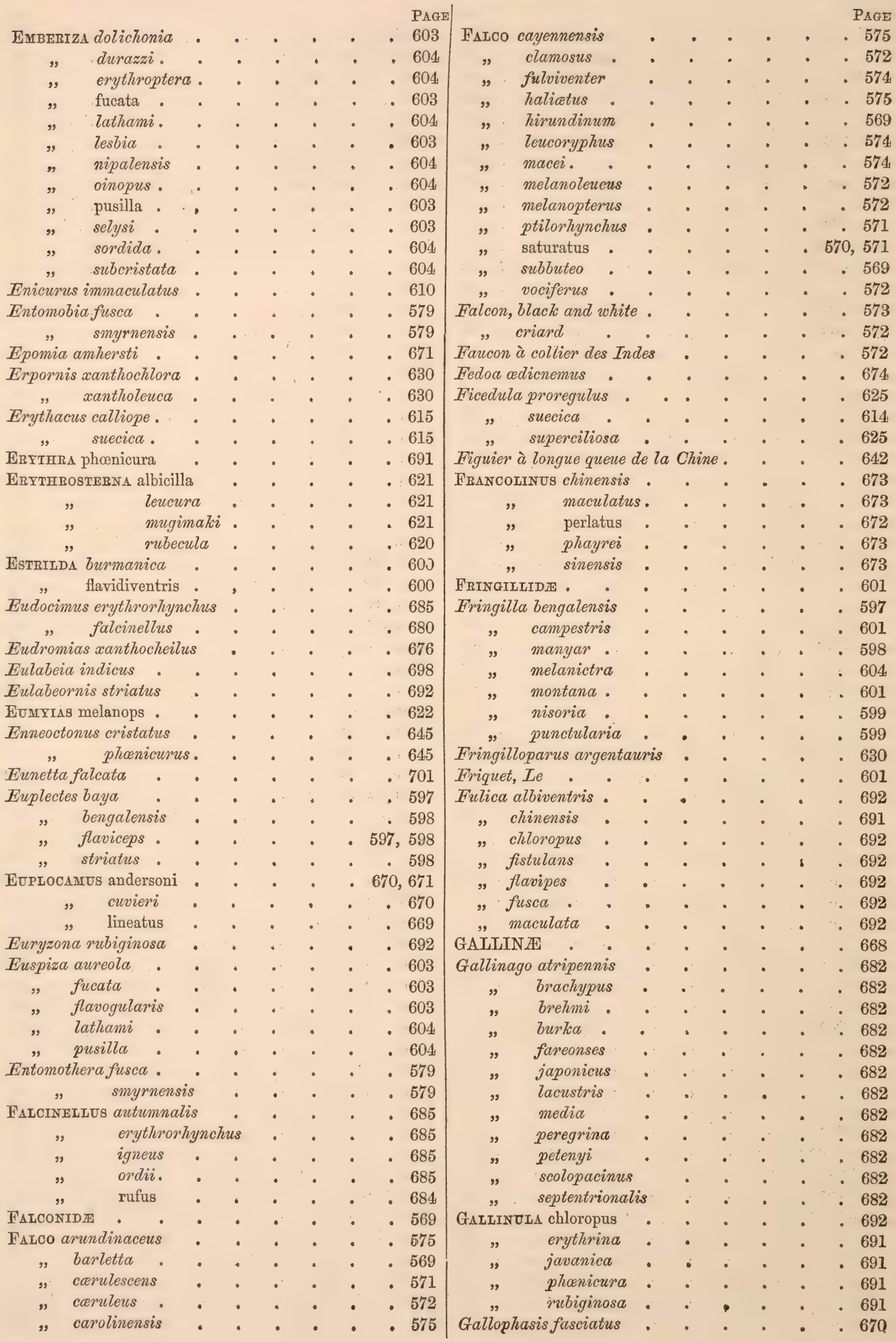




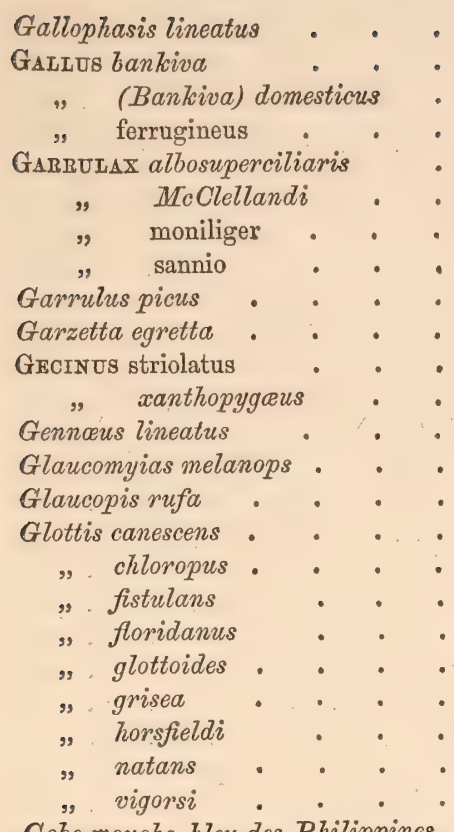

Gobe-mouche, bleu des Philippines

Godwit, Cinereous

$$
\text { de Pondichery. }
$$

Goose, Barred-headed .

Gorge-bleu, La

Graculide

Gracula cristatella

$$
\begin{array}{ll}
\Rightarrow \quad \text { nigricollis } \\
\Rightarrow \quad \text { saularis } \\
\Rightarrow \quad \text { tristis . }
\end{array}
$$

Graculus carbo

$$
\begin{array}{ll}
\text { " javanicus } \\
\text { " melanognaihus } \\
\text { " pygmaus }
\end{array}
$$

Gracupica melanoleuca . nigricollis

\section{GRALLATORES \\ Grammatoptilus lineatus \\ Graucalus macei} nipalensis

Grimpereau de Bengal, $L_{e}$.

$$
\text { Grosbeak, Eastern }
$$

Grosbee tachetè de Java, Le

GrUID $\mathbb{E}$

Grus antigone

$$
\begin{aligned}
& \text { " orientalis } \\
& \text { Gryllivora intermedia. } \\
& \text { " magnirostris } \\
& \text { rosea }
\end{aligned}
$$

PAgE

670 Halcton fusca PaGe

- 669

- 669

669

627

- 627

- 627

- 627

- 590

- 688

- 585

- 585

- 670

- 622

- 592

- 678

678
678

- 678

- 678

- 678

- 678

- 678

- 678

- 678

- 655

- 646

- 677

- 698

- 614

- 696

- 594

- 595

- 613

- 593

- 696

- 697

- 697

- 697

- 697

- 595

- 595

- 674

- 670

- 647

- 647

- 663

- 600

- 599

- 684

- 684

- 684

- 684

- 613

613

- 613

582

- 581

581

- 582

- 582

- 581

- 681

smyrnensis
smon fusca

Haliaetus albipes . . . . . . 574

- 574

- 574

- 573

. 574

.. 574

- 697

- 696

- 697

- 697

- 697

697

- 571

680

- 630

- 673

- 673

647

657

- 647

- 647

- 657

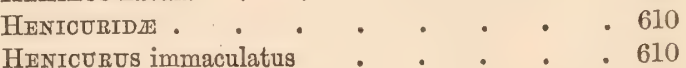

Herodias alba 688

,. bubulcus . . . . . . . 689

". coromanda . . . • . 689

" egretta . • • • • • • 688

". egrettoides . . . . 688

, garzetta . . . . . . 688

intermedia . . . . 687

" javanica . . . . . . 690

plumifera

Héron, African . . . . . . • 687

" Crested purple . . . . . . 687

" Purple . . . . . . 687

, Rufous . . . . 687

" pourpré, Le . . . . . . 686

" pourpré hupé, Le . . . . . . 686

HERPORNIs xantholeuca . . . • • 630

Hetcrornis fusca . . . . . . . 594

" malaharicus . . • • . 597

Hiaticula curonica . . . . . • 677

Hierax bengalensis

" carulescens . . . . . . 571

" entolmus . . . . . . . 571

" entolmus vel bengalensis . . . . . 571

Hirondelle, $L$, des Cheminées . . . . 649

HrRUNDO anchiete . . . . • . 650

- 651

- 651

- 650

- 650

- 650

- 650

- 650

. 651

- 650

- 649 


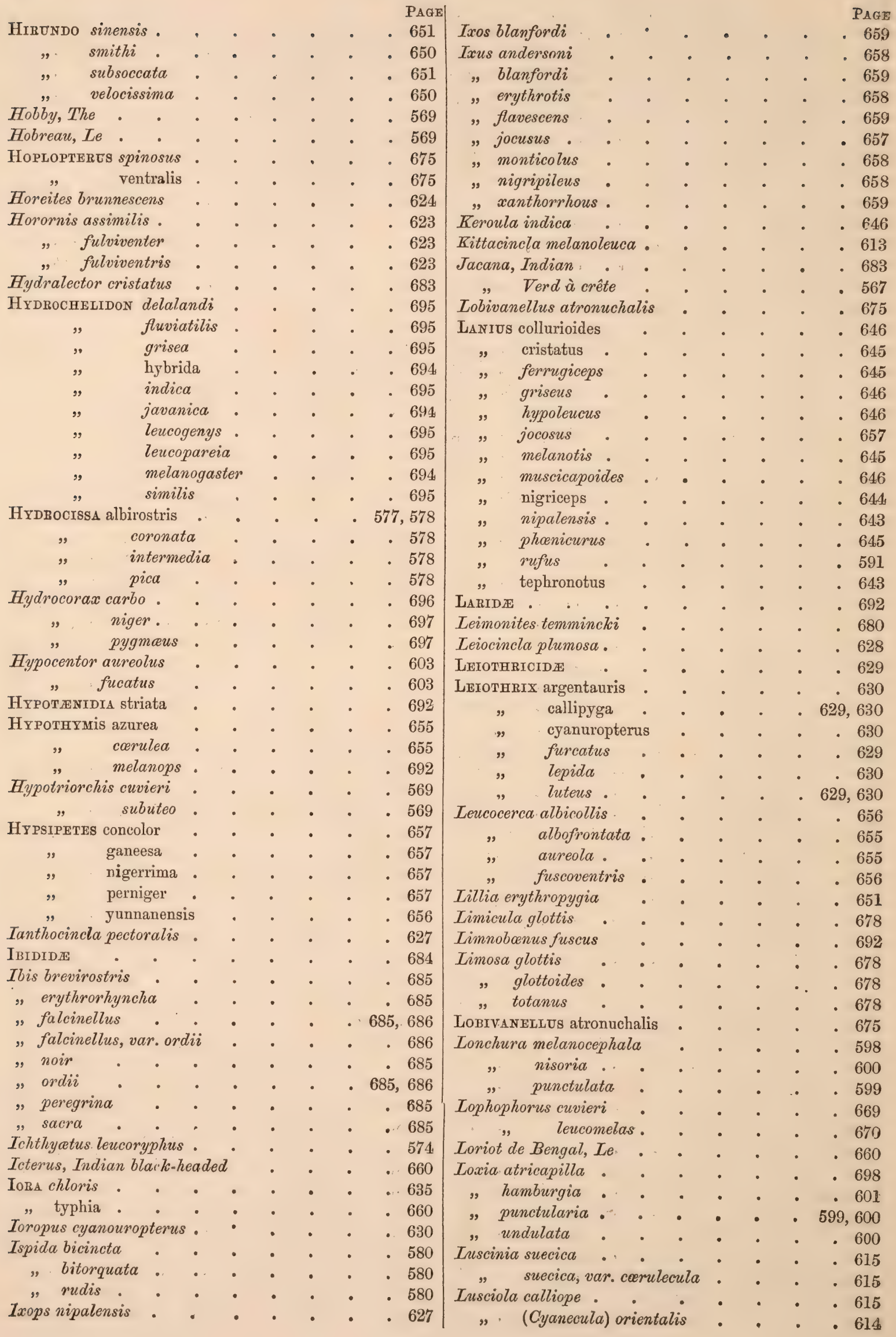




\begin{tabular}{|c|c|c|c|c|c|c|c|c|c|c|}
\hline & & & & & $\mathrm{PA} \notin \mathrm{E}$ & & & & & $P_{\Lambda G E}$ \\
\hline Iaina affinis. & . & 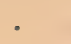 & $\therefore$ & . & 596 & Mirafra raytal & - & - & - & 606 \\
\hline$"$ cristatelloides & • & - & . & - & 594 & Mrxornis chloris & . & 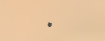 & . & 635 \\
\hline " tristoides. & • & $\bullet$ & - & - & 594 & rubricapilla & - & - & • & 635 \\
\hline Laineau de Macao. & • & - & . & . & 604 & ruficeps. & $\therefore$ & • & - & 635 \\
\hline Lalacocercus gularis & 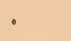 & . & - & • & 639 & Moineau de campagne, & Le & . & 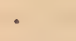 & 601 \\
\hline Talacopteron phayrei & . & . & . & . & 635 & montagne, Le & . & . & . & 601 \\
\hline Talurus longicaudus & • & : & - & . & 643 & Molpostes nigropileus & - & - & · & 658 \\
\hline$"$ marginalis & • & . & . & . & 639 & Monaulus melanion & . & & & . 669 \\
\hline Mareca pocilorhyncha & - & . & : & : & 699 & Monornis perpulchra & . & . & sing & . 668 \\
\hline Martin-pềcheur, de la cốt & ate de & Malc & abar. & - & 579 & Monticoua cyanea & . & . & . & . 611 \\
\hline huppè, & $d u C c$ & Cap de & e Bon Espen & erance, & 580 & manillensis & - & - & & . 612 \\
\hline noir et $l$ & bla & c de $S$ & Senegal & : & 580 & MотACILLA affinis . & . & - & & - 625 \\
\hline Martin Viellard, Le, de & e la cố & ôte de & e Malabar & . & 596 & alboides & . & . & . & . 610 \\
\hline EGALXMA asiatica & 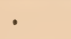 & . & $\cdot$ & - & 584 & alboides, va & n. 1, feli & $i x$. & & - 610 \\
\hline hodgsoni & . & - & - & - 583 & , 584 & alboides, val & $x$. & nensis & & - 610 \\
\hline lineata & & $0^{\circ}$ & . & . 583 & , 584 & corvelecula & . & . & . & - 614 \\
\hline Mc Clellanc & & - & . & $\cdot$ & 583 & calliope & - & . & & . 615 \\
\hline [EGALURUS palustris & & - & $\cdot$ & - & 639 & $c a_{1}$ & - & - & . & . 617 \\
\hline [ELANOCHLORA flavocris & istatu. & & . & - & 632 & ocapil & $l l a$ & . & . & - 608 \\
\hline sultanea & & $\cdot$ & : & - & 632 & lensis & • & . & . & . 662 \\
\hline sumatra & ana & - & - & - & 632 & loides & - & . & . & . 609 \\
\hline Melodes calliope & • & $\cdot$ & • & - & 615 & cyana. & - & - & 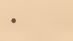 & 11 \\
\hline IELOPHUS erythropterus & & $\cdot$ & $\cdot$ & - & 604 & felix. & - & - & - & 10 \\
\hline melanicterus & & ${ }^{\circ}$ & • & . & 604 & flava. & $\cdot$ & . & 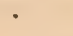 & 608 \\
\hline Merle bleu, Le & - & . & - & - & 611 & flava, var. & borealis & - & . & \\
\hline$"$ solitaire, $L e$ & . & . & . & - & 61 & cinere & $l l a$ & . & & . 608 \\
\hline MERopid开 & - & . & • & - & 5 & " & . & . & . & . 610 \\
\hline MEROPS at & - & - & - & . & 58 & $d a$ & • & . & . & - 643 \\
\hline$\Rightarrow \quad c y$ & - & •. & - & - & 583 & " & . & - & . & . 609 \\
\hline hos & - & • & - & - & 581 & aspate & ensis . & - & . & - \\
\hline daudini : & - & - & - & - & 581 & pic & - & . & 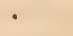 & - \\
\hline ocephalus & & - & - & . & 582 & icapillo & . & . &. & . \\
\hline ferrugeiceps & - & - & - & - & 582 & $s u$ & - & - & - & . 614 \\
\hline$i n d i$ & - & $\cdot$ & - & - & 582 & iliosa & . & . & . & - 625 \\
\hline jar & - & . & . & - & 5 & " & - & - & . & . 643 \\
\hline , & : & . & - & $:$ & 5 & $c a$ & - & - & . & 817 \\
\hline les & . & . & . & - & 5 & $"$ & - & •. & - & \\
\hline $\mathrm{ph}$ & - & 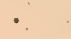 & - & - & 5 & ” & - & - & 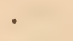 & . \\
\hline lor & . & . & . & . & 582 & virt & - & - & . & \\
\hline$y i$. & - & $\cdot$ & - & . & 581 & TOTACILIIDE & . & . & & . \\
\hline swinhoei : & . & . & . & . & 582 & MuNia at & . & . & & . 598 \\
\hline tus . & . & • & . & $\because$ & 582 & er & . & - & . & . 600 \\
\hline typ & • & $\bullet$ & - & - & 581 & " & - & . & 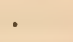 & . 598 \\
\hline viridis & 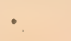 & . & •. & $\bullet$ & 0 & " & . & - & - & . 599 \\
\hline ERULIDE & - & - & - & - & 62 & $"$ & . & . & . & 99 \\
\hline ETOPIDIUS aeneus & • & 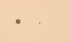 & . & - & 68 & $r a$ & 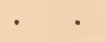 & - & sin & · \\
\hline indicus & 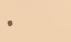 & - & . & - & 683 & laris . & · & . & 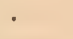 & - \\
\hline Ticrocarbo p. & $\bullet$ & ${ }^{\circ}$ & 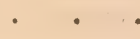 & . & $6 s$ & $s$. & . & ${ }^{\circ}$ & : & . \\
\hline ICROHIER & & & . & - & 571 & $"$ & . & . & . & . 599,600 \\
\hline Ticronisus badius . & . & $\bullet$ & . & - & 573 & Muscicapa & - & . & & - 621 \\
\hline , & - & - & $\bullet$ & - & 573 & anadensis & • & •. & - & . 655 \\
\hline ieroscel & - & - & - & - & 6 & $a t$ & - & - & • & - 653 \\
\hline Ficrotarsu & • & . & . & . & 6 & mas & . & . & - & - 620 \\
\hline ILvos govinda & . & $\because$ & $\cdot$ & . & 575 & biloba. & - & - & - & . 653 \\
\hline " major & $\cdot$ & 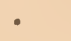 & - & ${ }^{\circ}$ & 575 & carulea. & - & - & - & 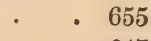 \\
\hline melanotis & ${ }^{\circ}$ & . & . & . 574 & ; 575 & capitalis & - & . & & . \\
\hline niger & $\because$ & . & - & & 574 & hyacintha & - & - & . & - 620 \\
\hline niger, var. melan & no & & $\cdot$ & . & 574 & lapis. & . & - & . & . 622 \\
\hline IIRAFRA assamensis & - & - & - & • & 606 & leucura. & - & . & - & - 621 \\
\hline$"$ & 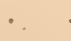 & & - & 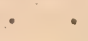 & 606 & melanops & - & - & . & - 622 \\
\hline flo & & & & & & 000 & 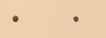 & . & - & 555 \\
\hline javanica & & & . & . & 606 & pondiceriana & • & . & & . 646 \\
\hline
\end{tabular}




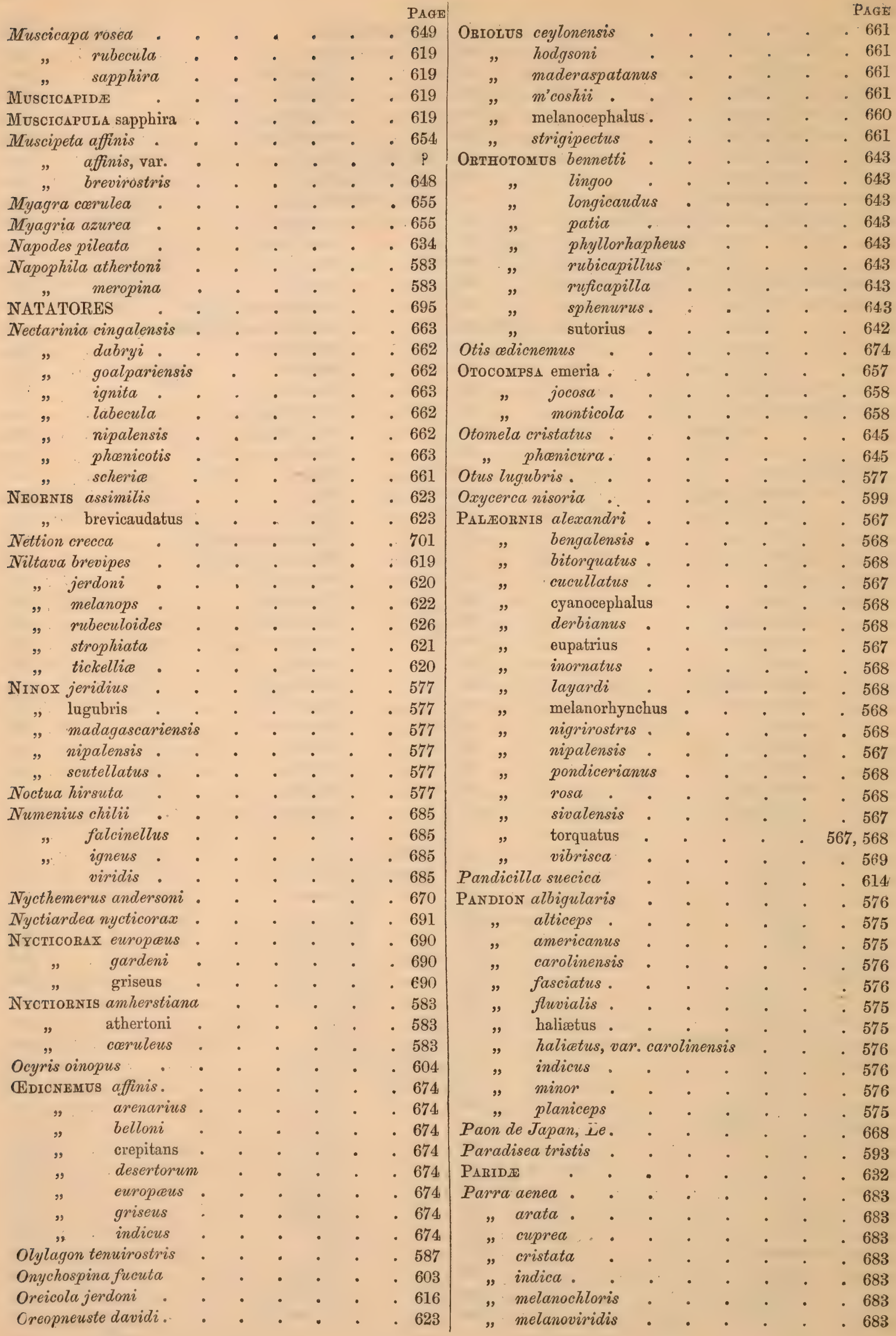


Parra superciliosa

PARRIDE

Partridge, Hackled

Pearled

Parus articeps

cosins
$"$ cinereus .
$"$ commixtus
$"$ commixus.
$"$ cristatus.
$"$ nipalensis.
$"$ sinensinotus.
,$\quad$ sultaneus.
sumatranus.

PAsser arboreus

, cinnamomeus

, flaveolus

" indicus

" montanina.

" montanus

Passerina aureola.

Pastor bicolor

, blythi

, caniceps

" cinereus

, fuscus

" malabaricus

" pagodarum.

, temporalis.

" tristis

Pavo aldrovandi .

, muticus

, specifer

, speciferus

Pelecanider.

Pelecands carbo.

", manillensis .

, phitippinus.

, pygmaus

, roseus.

, rufescens

sinensis

Pelican, Rose-coloured

Pélican brun de l'isle de Lucon, Le " des Philippines, Le.

- rose de l'isle de Lucon, Le

Pelidna temmincki

Pelodes hybrida

" javanica .

Pelorhynchus brehm

Perdrise porlée de la Chine, L

Perdix atrogularis

, ferruginea

" perlata

" sinensis

Pericrocotus affinis

andamanensis.

brevirostris
Page

- 683.

- 683

- 669

- 672

- 632

- 633

- 633

- 632

- 632

- 632

- 632

- 632

- 637

- 632

- 632

- 602

- 602

- 602

- 602

- 601

- 601

- 603

- 603

- 595

- 597

- 597

- 596

- 594

- 597

- 596

- 595

- 594

- 668

- 668

- 668

- 668

- 695

- 696

- 695

- 695

695

- 697

- 695

- 696

- 696

- 695

- 695

- 695

- 695

- 680

- 695

- 694

- 695

- 682

672

- 673

669

- 672

- 672

- 648

- 648

- 648
PAGE

648

" fraterculus . . . . 648

, roseus . . . . . . 649

" rutilus . . . . 648

" speciosus. . . . . . 648

Peristera bornensis . . . . . . 668

" risorea . . . . . . . 666

PERNIS albigularis . . . . . . 571

apivorus ... . . . . . 571

bharatensis . . . . . . 571

brachypterus . . . . . . 571

cristata . . . . . . . 571

ellioti . . . . . . 571

maculosa . . . . . . . 571

ptilorhynchus . . . . . . 571

ruficollis . . . . . . 571

". torquata . . . . . . . 571

Perruche à collier, $L a$. . . . . . 567

. " " " couleur de rose, $L a$. . . 567

" " " . . . . 568

" $\quad$ "epaulettes rouges, $L a$. . . . . 567

" ", tête blue, La . . . . . 568

" grande, à collier . . . . . 567

" de gingi, $L a$. . . . . . 567

Petrocichla cyana. . . . . . . 611

Petrocincla cyanea. . . . . . . 611

" longirostris . . . • • . 611

• • • • • • • • •

648,649

- 648

- 648

- 649

Phalacrocorax capillatus . . . . . 698

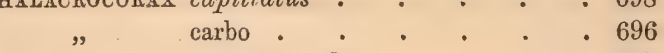

- 697

- 696

- 696

- 697

- 697

Phastanide • • • • • • • • •

Phasianus amherstice . . . . . . 671

" fasciatus . . . . . . 670

"gallus . • . • • • 669

, leucomelanos . . . . . 669

" lineatus . . . . . . 670

" sladeni . . . . . . 671

Philocalyx argentauris . . . . . . 630

Phitomachus ventralis, vel. spinosus . . . 675

Phloshrus viridis . . . . . . . 582

Phonicura leucocephala $\quad$. $\quad . \quad$. 613

" rubeculoides . . . . . . 619

Phyllobasileus superciliosus . . . . .

Phyllopneuste affinis . . . . . . . 625

- 624

- 623

- 624

- 623

- 625

- 626

- 625 


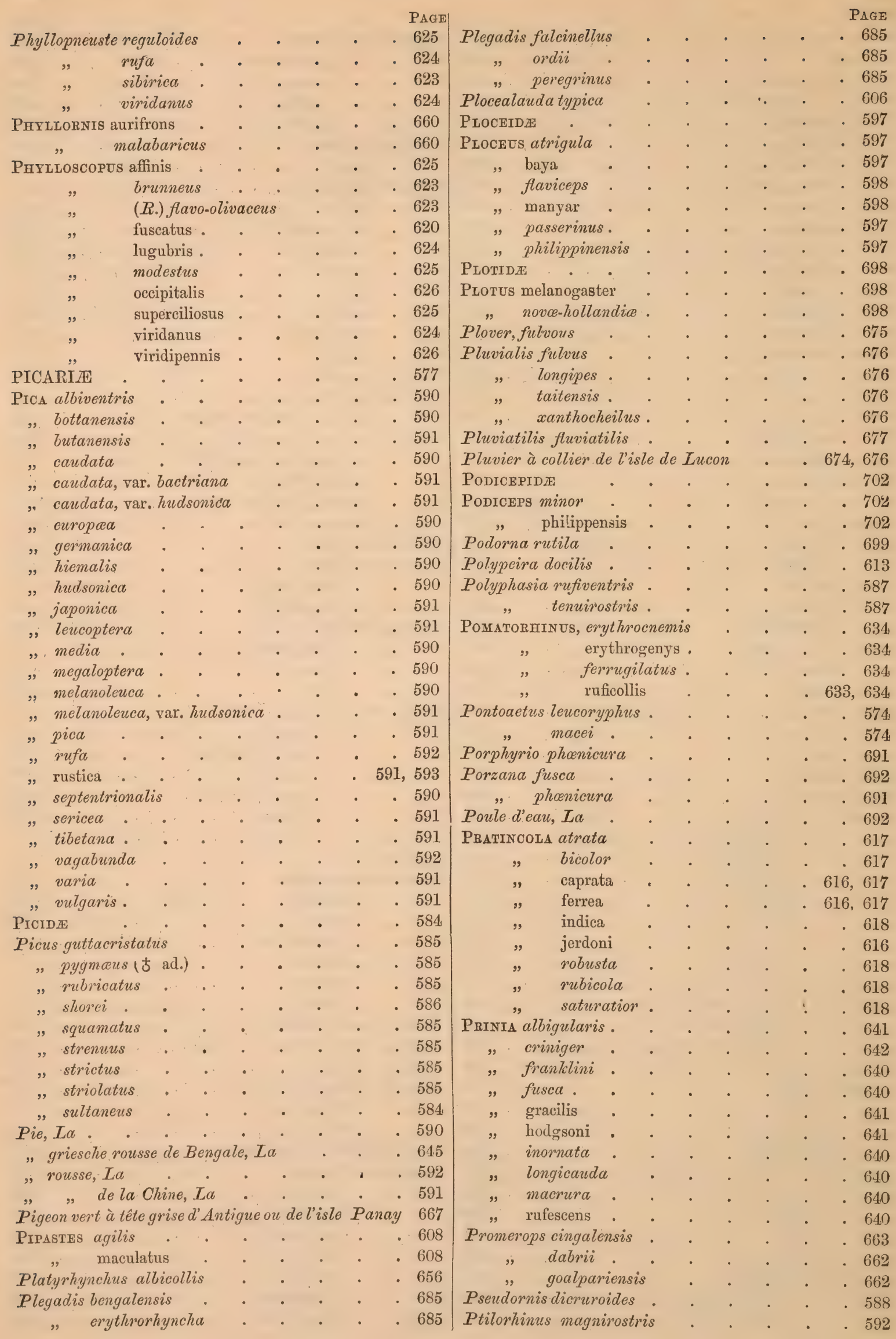




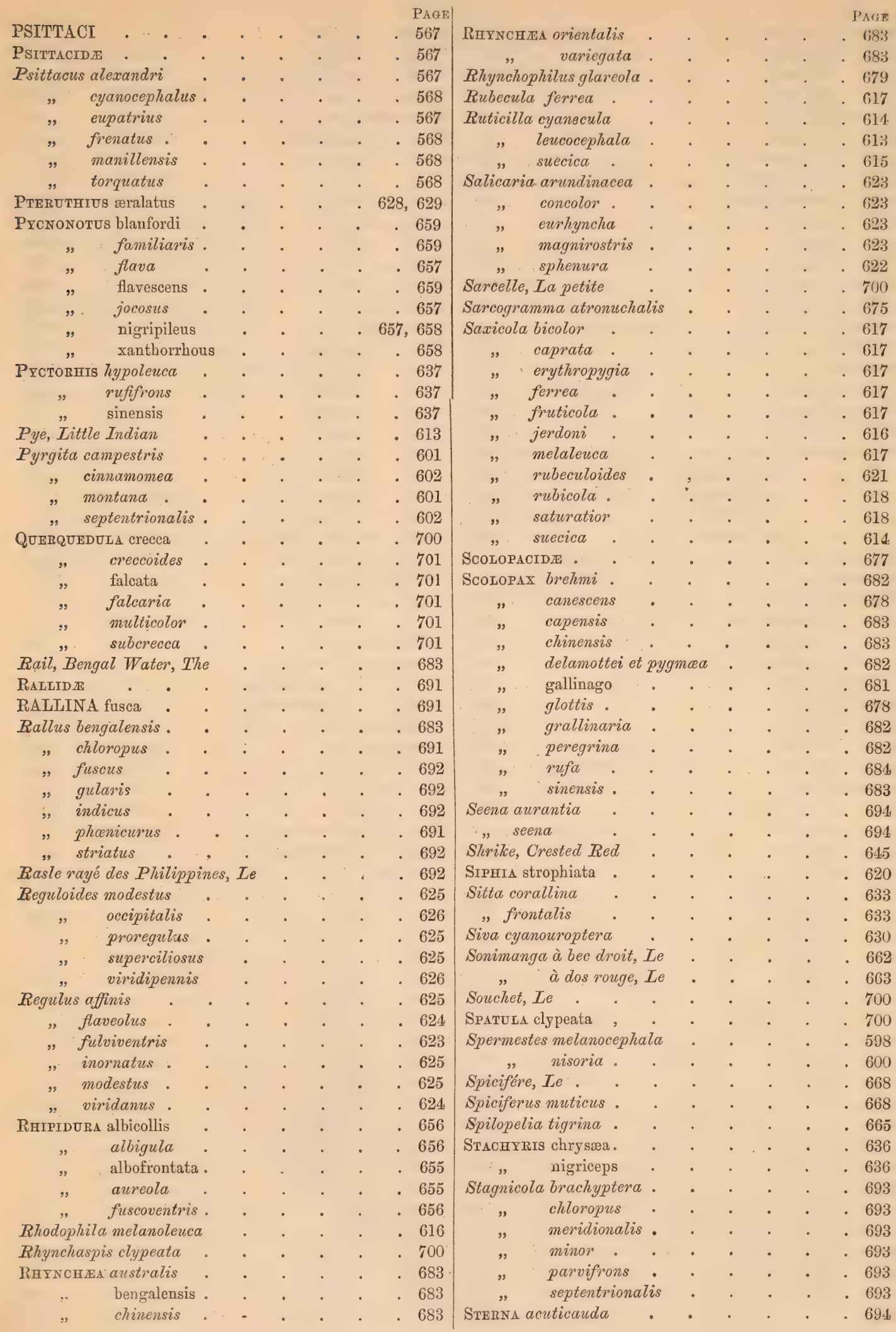


SterNa aurantia.

PAGE

\begin{tabular}{|c|c|}
\hline , & brevirostris \\
\hline , & delamottii \\
\hline & grisea \\
\hline$"$ & hybrida \\
\hline " & javanica \\
\hline "; & leucopareia \\
\hline " & melanogastra \\
\hline " & melanogaster \\
\hline " & roseata \\
\hline " & seena \\
\hline$"$ & simitis \\
\hline
\end{tabular}

Stoparola melanops

Streptopelia risorea

STRIGES

Strigiceps melanoleucus

Strix bubo

, lugubris

Sturnia burmanica

„, malabarica

StURNOPASTOR contra, var. superciliaris .

$$
\begin{array}{r}
\text { melanoleucus } \\
" \quad \text { nigricollis } \\
" \quad \text { superciliaris } \\
\text { Sturnus temporalis . }
\end{array}
$$

SURn ICULUs lugubris

SUTHORA brunnea

$$
\begin{aligned}
& \begin{array}{ll}
, \quad \text { bulomachus } \\
" \quad \text { ruficeps . } \\
, \quad \text { suffusa. }
\end{array} \\
& \text { Sutoria agilis } \\
& \text { SuYA crinigera } \\
& \text { " inornata } \\
& \text {, superciliaris } \\
& \text { Sylochelidon seena . } \\
& \text { Sylvia affinis } \\
& \text {, arundinacea } \\
& \text {, assimilis } \\
& \text { " bifasciata } \\
& \text { " calliope } \\
& \text { " corulecula. } \\
& \text { " cingalensis. } \\
& \text { " cyanecula. } \\
& \text { "fuscata } \\
& \text { guzurata } \\
& \text { longicauda } \\
& \text { - longicaudata } \\
& \text { lugubris } \\
& \text { montana } \\
& \text { occipitalis . } \\
& \text { palpeỏrosa. } \\
& \text { (Phyllopneuste) sibirica } \\
& \text { proregulus. } \\
& \text { (Salicaria) magnirostris } \\
& \text { suecica } \\
& \text { suecica, var. corulecula } \\
& \text { solitaria } \\
& \text { superciliaris } \\
& \text { superciliosa }
\end{aligned}
$$

Srition

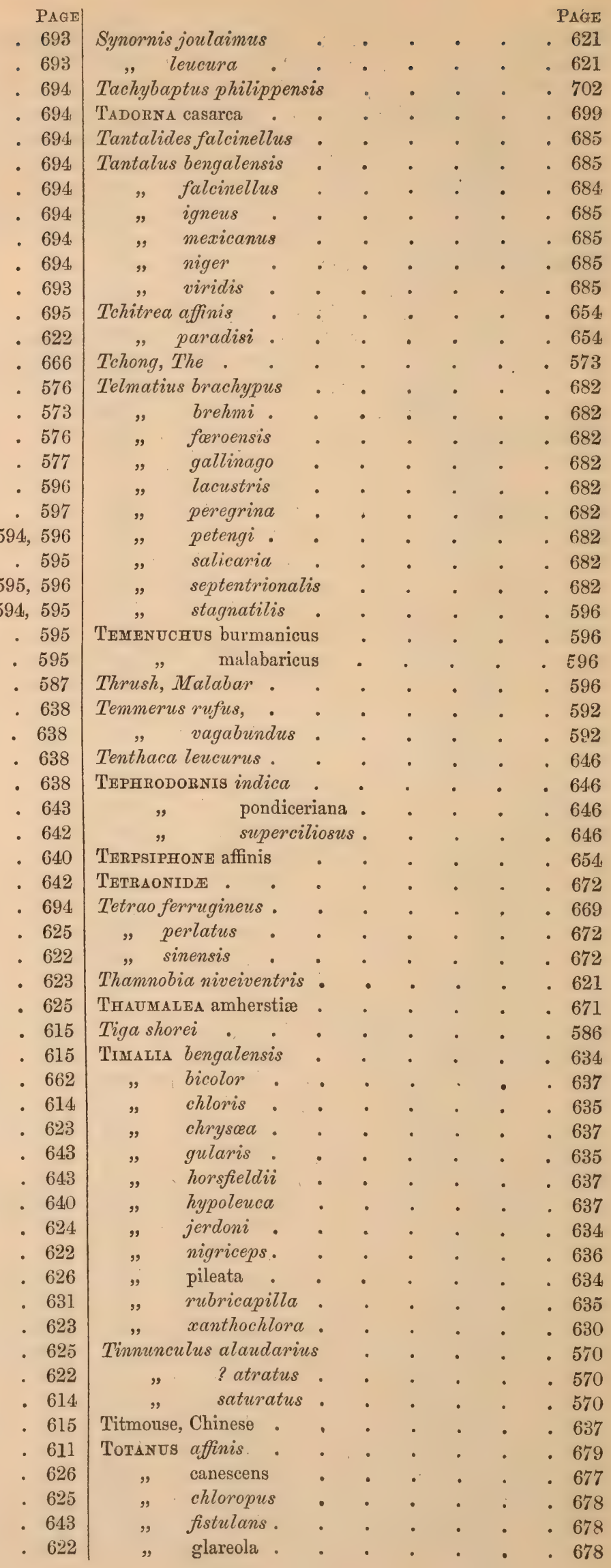


PAGE

glottoides $\div \cdot \cdot \cdot \cdot 678$

" grallatores . . . . . 679

"griseus . . . . . . . 678

"guinetta.'. . . . . . 681

" hypoleucos . • . . . . 681

" leucourus . . . . . . 680

„ ochropus . • . . . 679

. rivalis . . . . 680

" sylvestris et palustris . . . . 679

Tourterelle à collier, La.

" brune de la Chine, La. de Java

Traquet de l'isle de Lucon, Le

Treron viridifrons .

Trichometopus hottentotus

TrINGa (Actodromas) temminckii .

, glareola

" hypoleucos.

", ochropus

"pusilla

" temmincki.

Tringoides hypoleuca

Iriorches fluvialis .

Trogon asiaticus

Trynga leucoptera.

TURDIDE

Turdus azureus

. cyanus

malabaricus

, saularies

"solitarius

\section{TORNICIDE}

TURNIX atrogularis

, ocellata

, plumbipes.

"pugnax

.

Turtle, collared $+\cdot{ }^{\circ} \cdot{ }^{\circ} \cdot 673$

Turtur chinensis . . . . . . . 665

, douraca. 666

, meena . . . . . . 665, 667

, orientalis . . . 666

ridens . . 666

, risorius

rupicola . . 666

, tigrina 665

viticollis . . . 667

Uromitrus filifera . . 650

UPUPA ceylonensis . . . 578

" epops. . . . 578

, indica.

, longirostris

minor

„ nigripennis. . 578,579

, senegalensis, 578

UPUPID正 . . 578

Unocissa magnirostris . . . . 592, 593

Uroloncha punctularia . . 599

Uromitris filifera . . . . . . . 650

Varilla ventralis . . . . . . . 675

Viralva indica . . . . . . . 695

Vulpanser rutila . . . . . . . . . . 699

Wagtail, The green 608

Warbler, Cingalese . . . . . . 662

, green. 662

, long-tailed . . . . . 643

, The tailor 643

" yellow-browed . . . . . 625

YUNGIPICUS rubricatus . . . . . . 585

Zosteropide . . . . . . . . 631

Zosterops maderaspatensis . . . . . 631

674 67 palpebrosa . . . . . 631

673 " 673 simplex . . . . . . . . 631 



\section{GENERAL INDEX.}

\section{REPTILIA.}

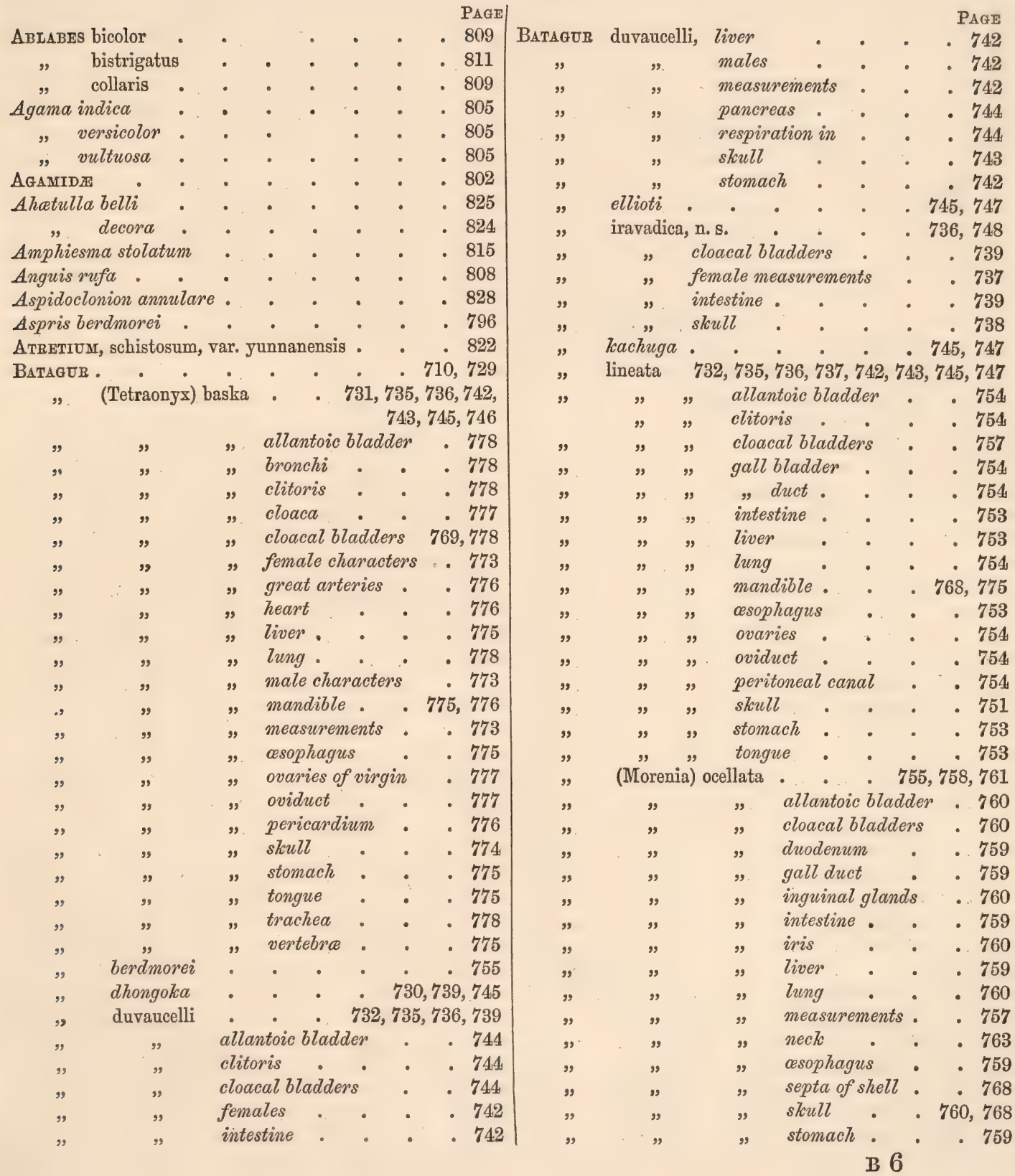




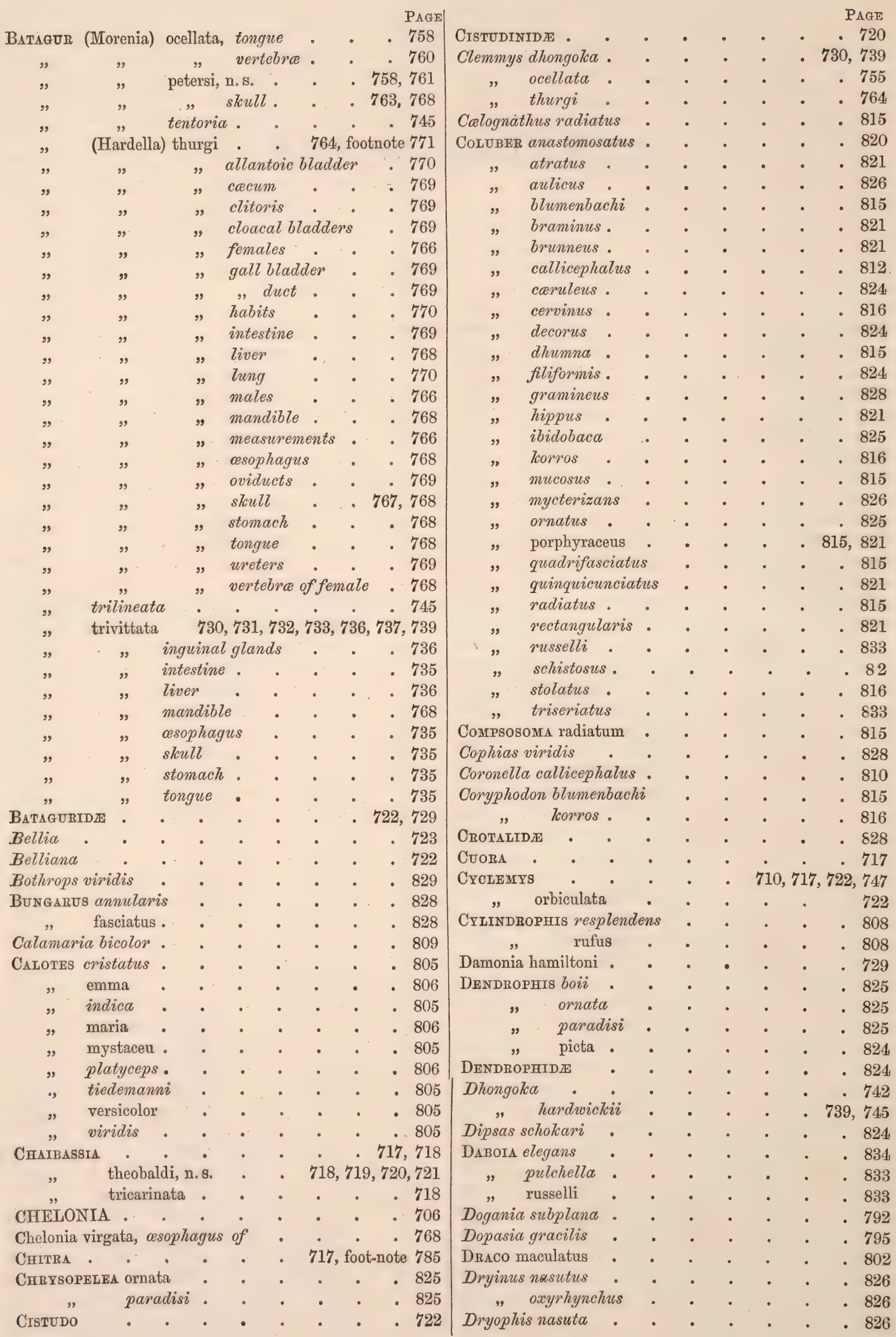




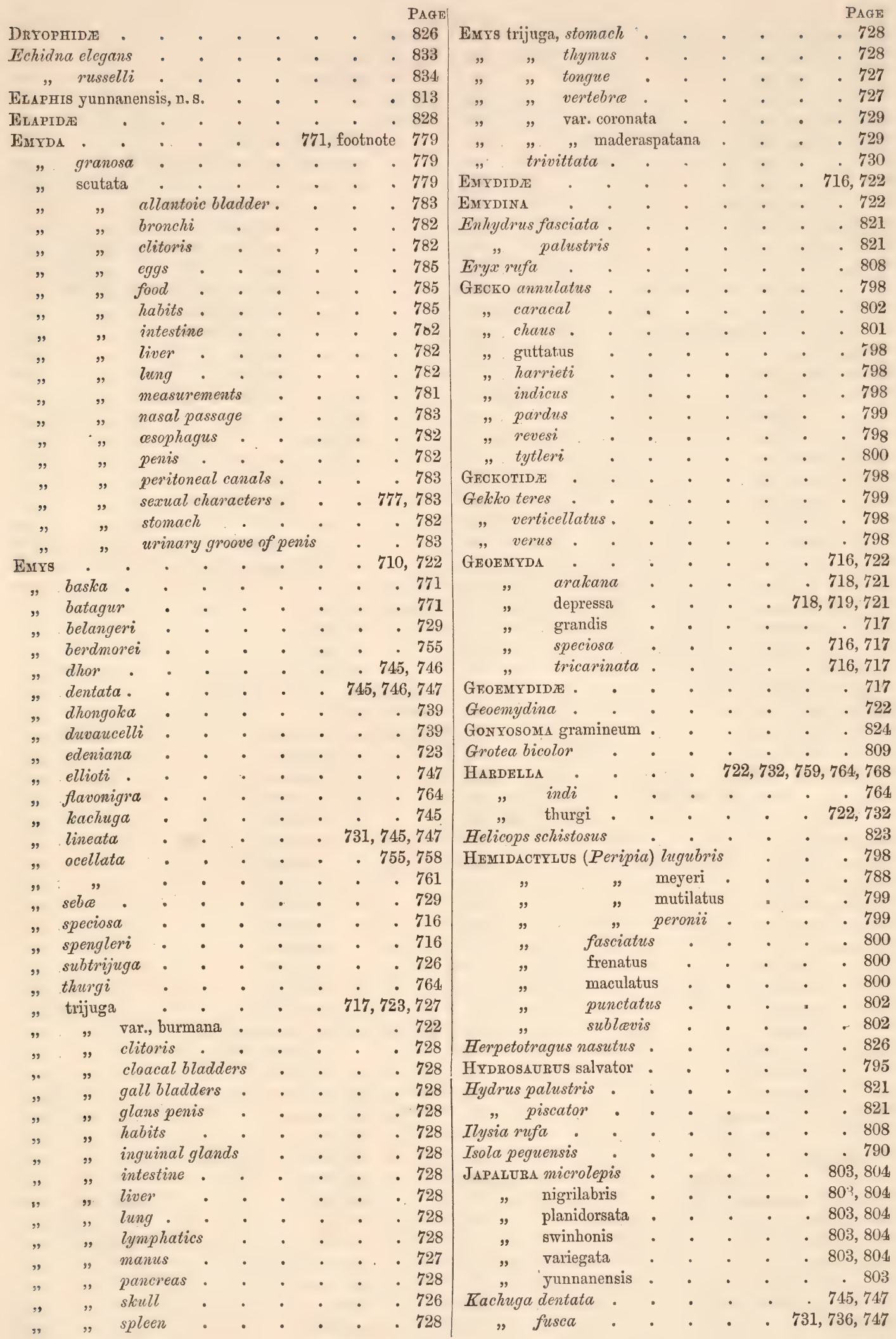




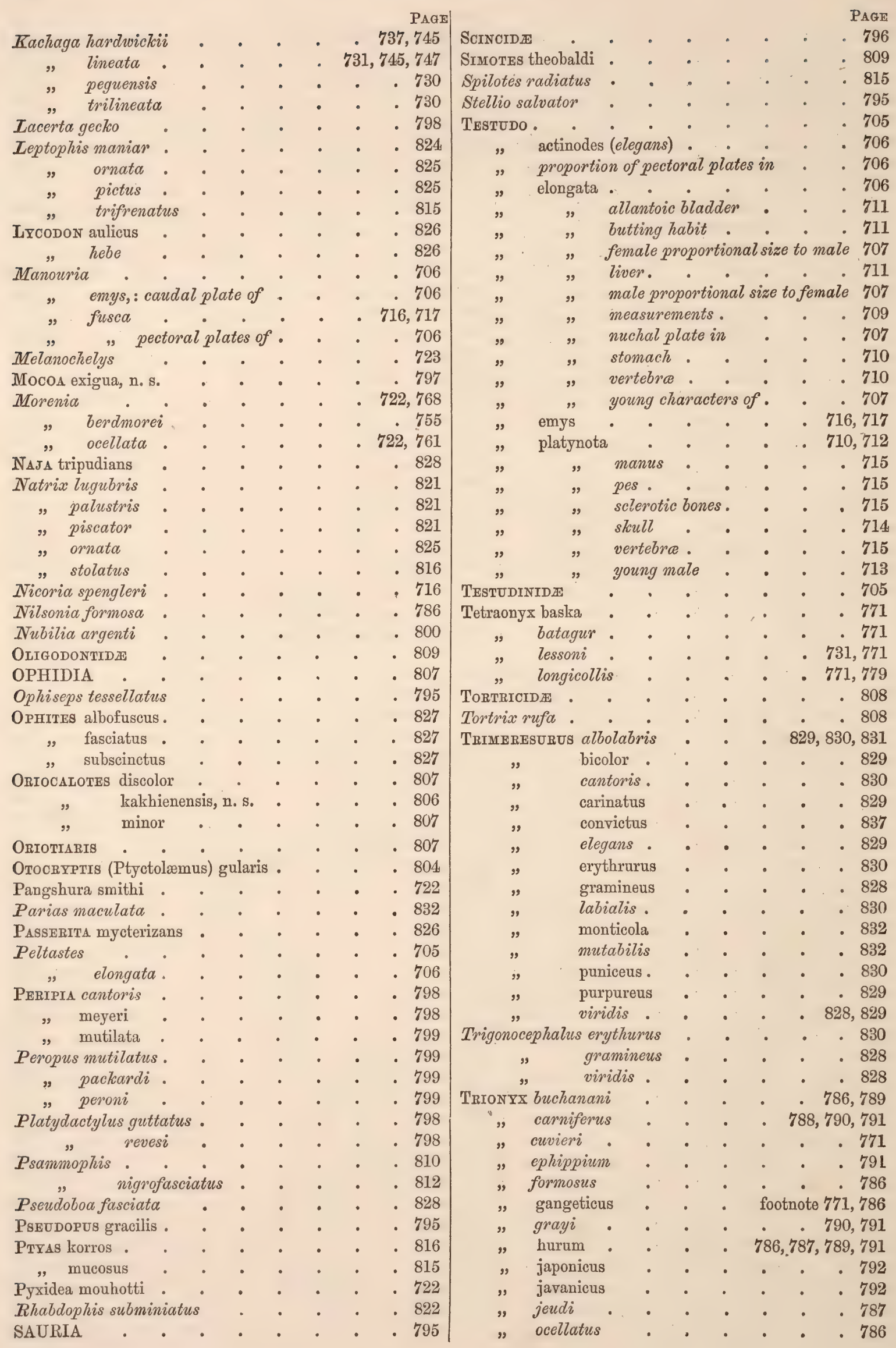


GENERAL INDEX.

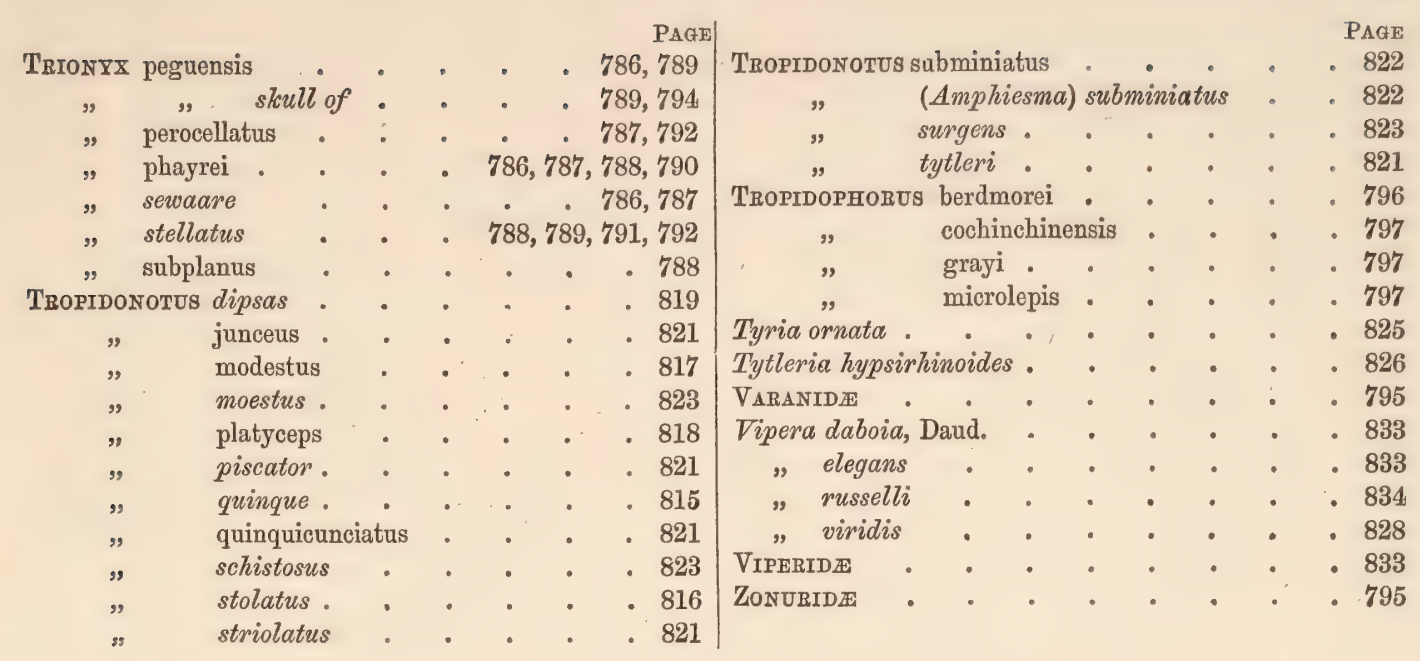





\section{GENERAL INDEX.}

A MPHIBIA.

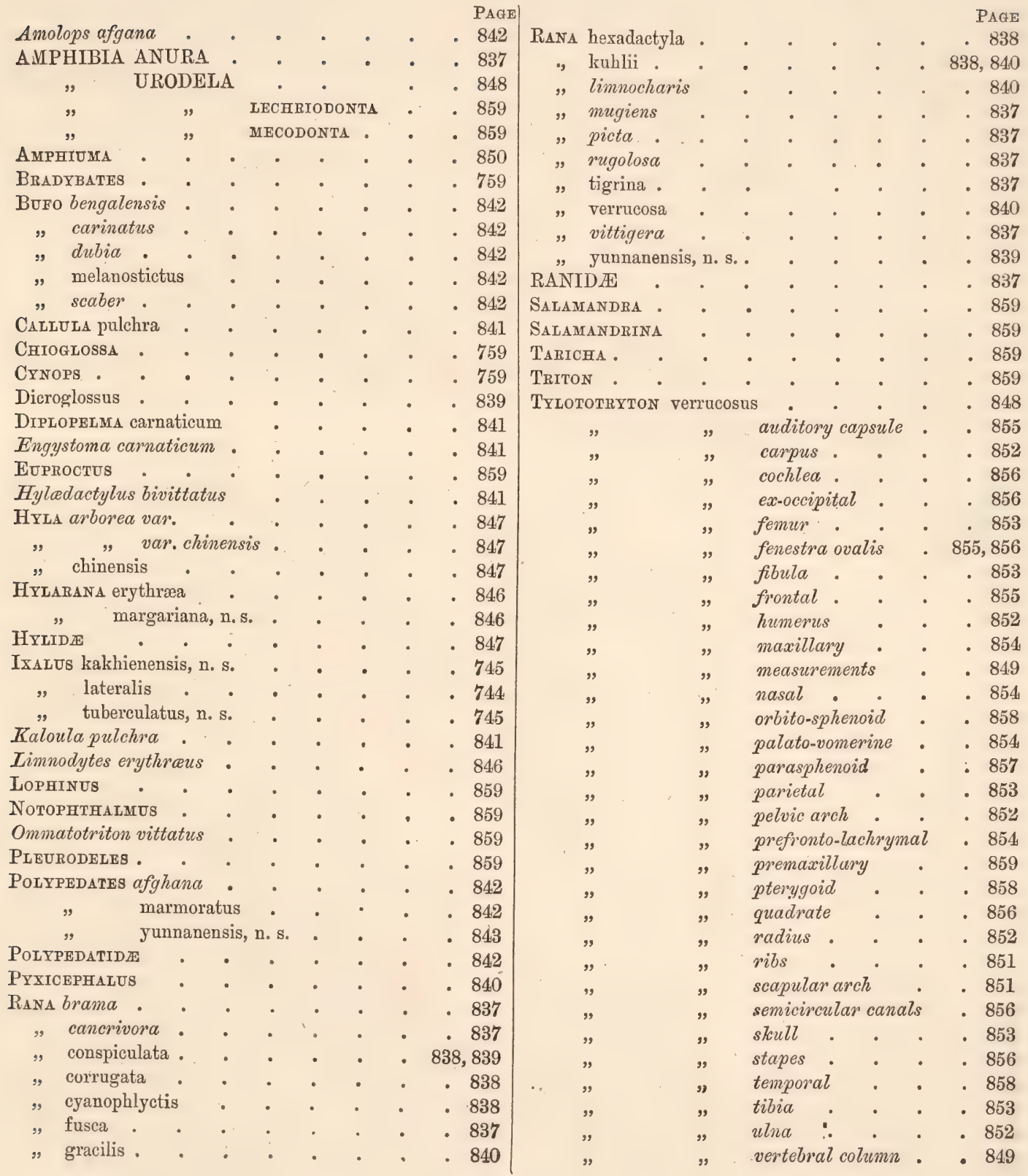





\section{GENERAL INDEX.}

\section{PISCES.}

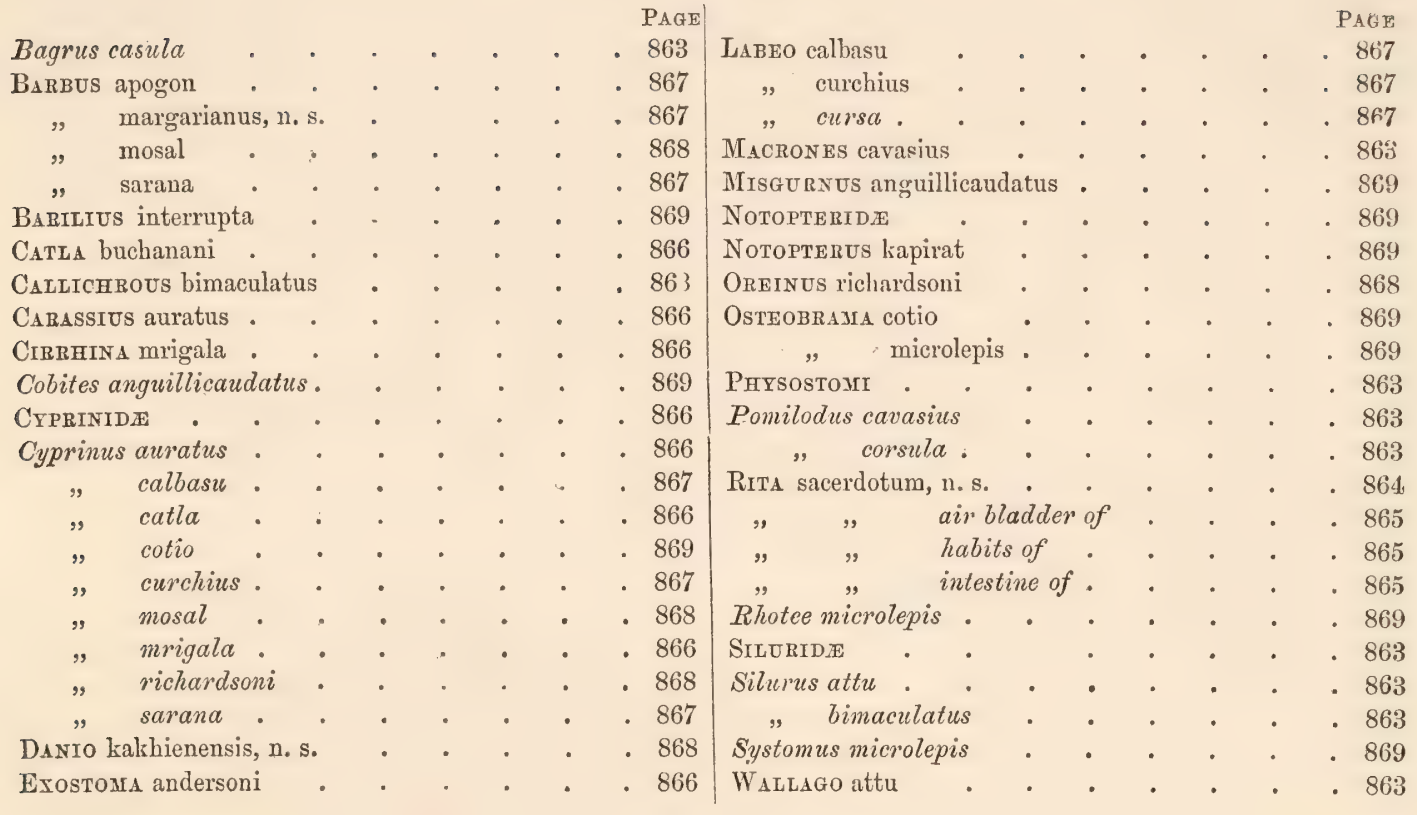





\section{GENERAL INDEX.}

\section{MOLLUSCA.}

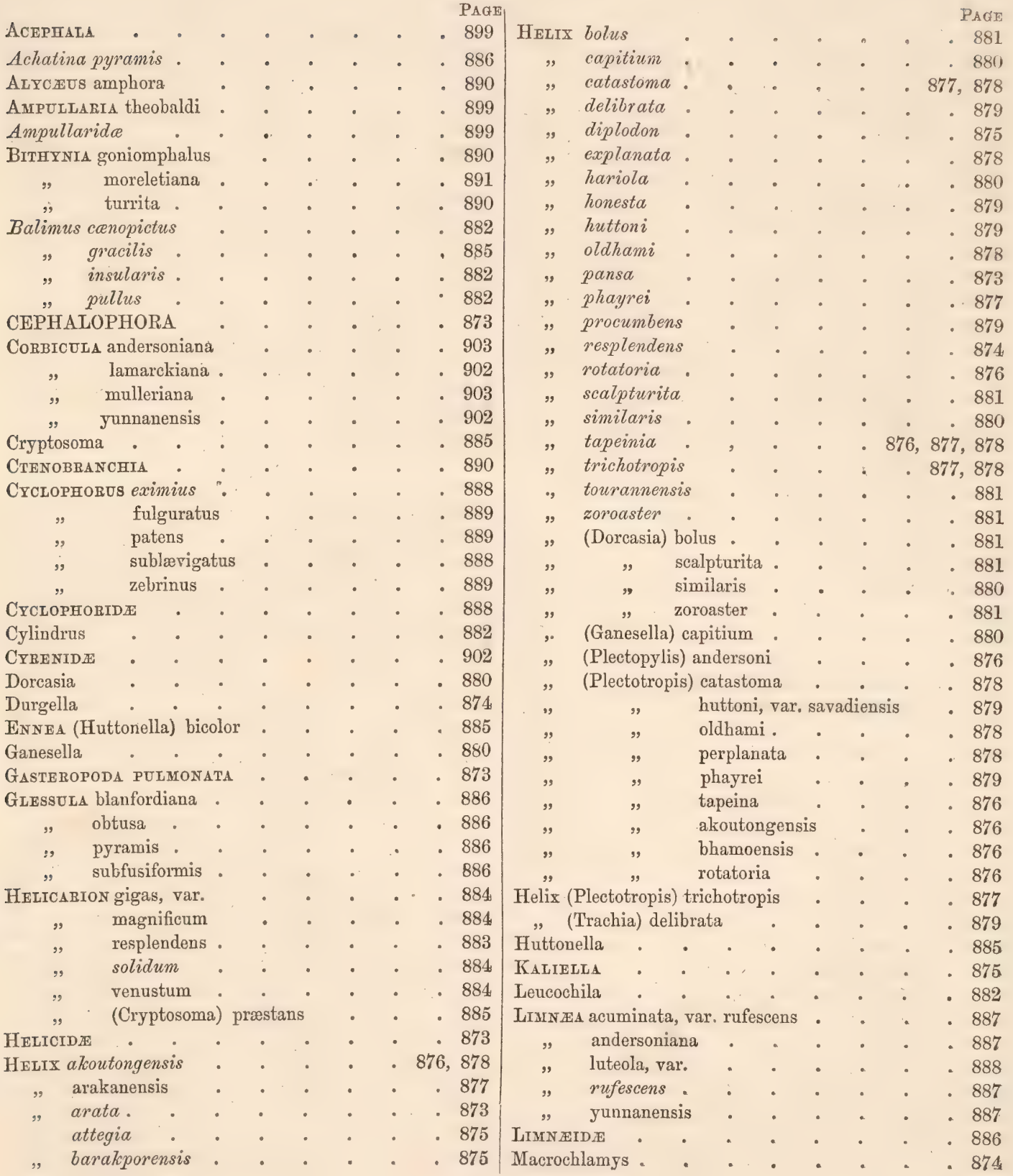




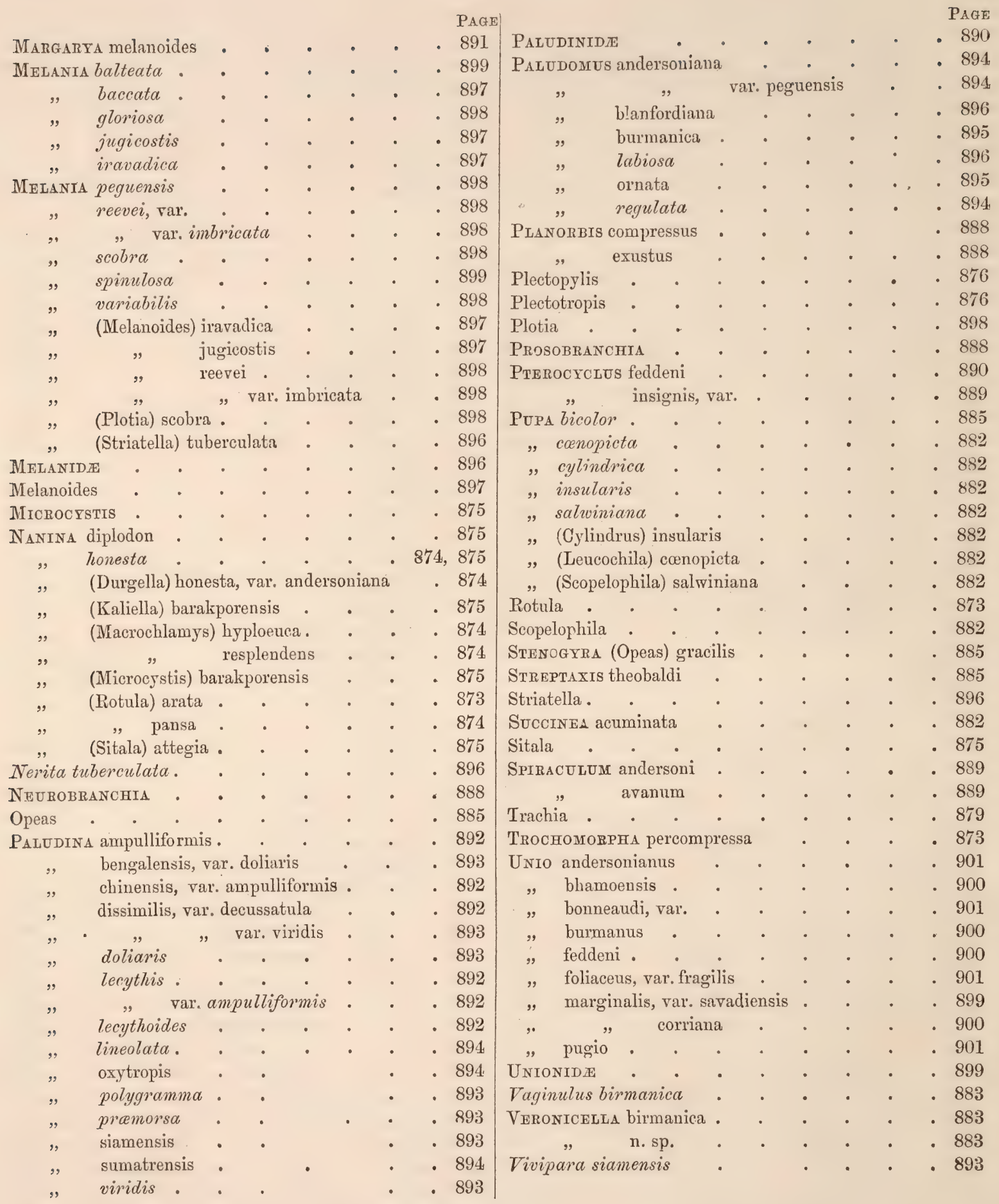




\section{GENERAL INDEX.}

INSECTA.

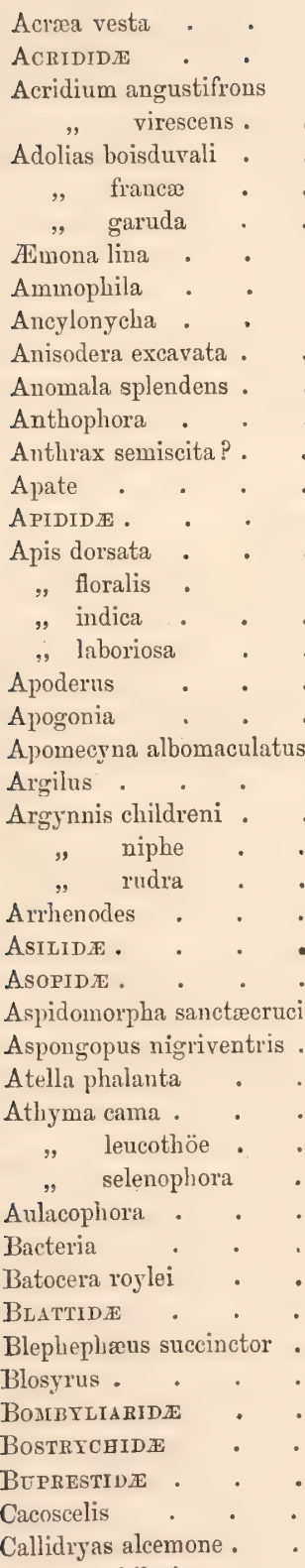

Callidryas alcemone .

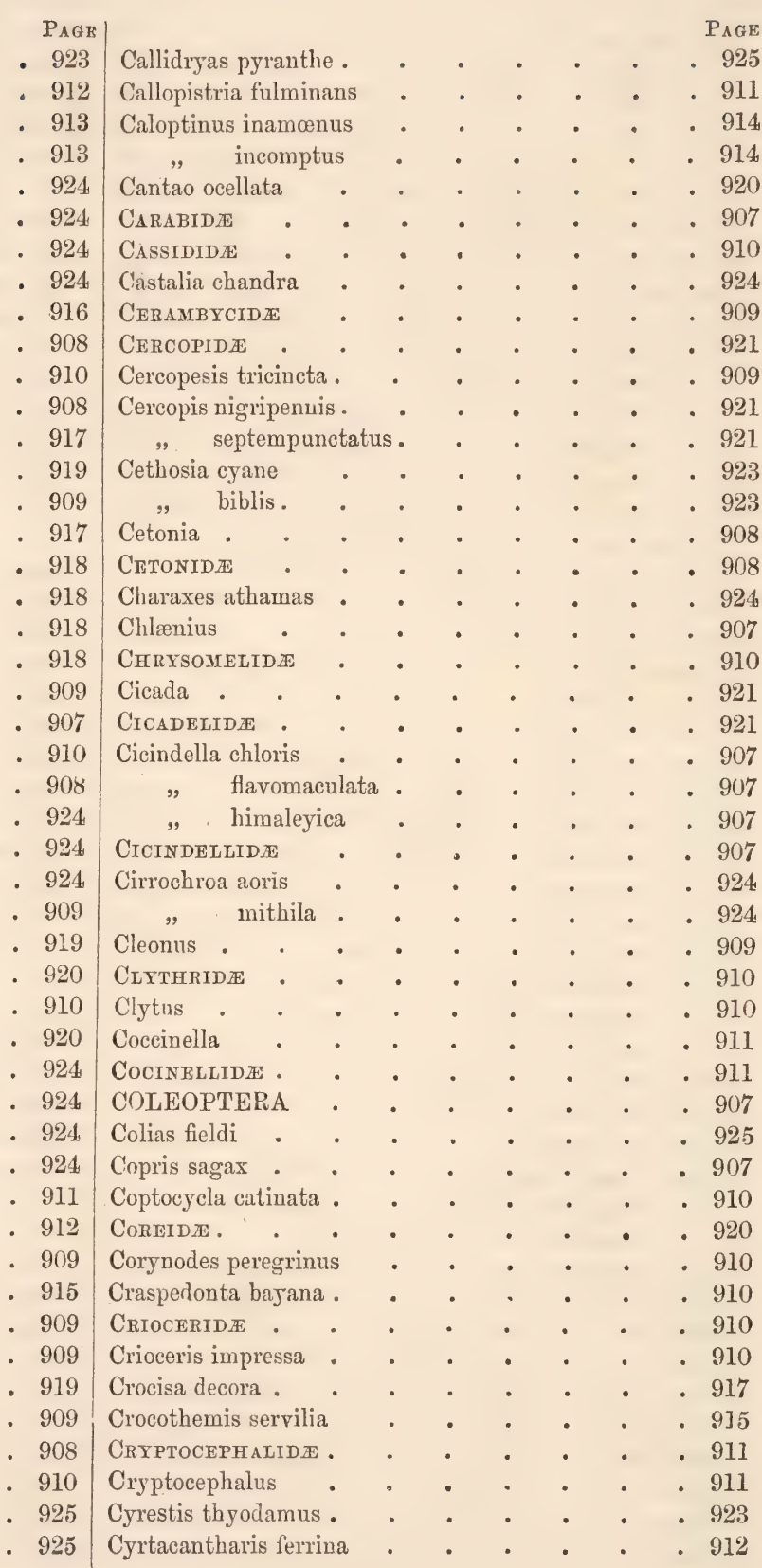


Cyrtacantharis punctipennis

Cyrtotrachelu

CUCCULIONID王

Dalader planiventris

Dalpada clavata

Danaidæ .

Danais aglea.

$$
\begin{array}{ll}
\text {, } & \text { chrysippus } \\
\text {, } & \text { limniace } \\
\text {, melissa } & \text { plexippus } \\
\text {, tytia . }
\end{array}
$$

Dasypogon

Debis chandica

, dyrtæ

, europa

" latiaris

, rohria

, verma

Diapromorpha melanopus

Dictyoptera

Dineutes lateralis

DIPTERA

Discocephala

Dodona fylla

DORYLIDE

Dorylus longicornis

Dundubia cinctimanus

Dynastider

Dysdercus kœnigi

DYsticid E

EDESSDE

Euaterid

Epæromı varia

, vuluerata

Epilampra

Epilachna macularis

Epilampus

Ergolis ariadne

Eristatis amphicrates

Erotylid andræmon

ERYCINIDAE

Euchlora monochroa

EUMONID巫 perplexa

\section{EUMOLPIDE}

Eumolpus

Eupatorus hardwicki

Euplæa klugii .

$$
\text { midamus }
$$

$$
\text { siamensis }
$$

Eurybatus 9-punctatus

Euripus halithéres

Eusthenes

Fatua

Forficula.

Forficulide .

Formicales

Galercua

Galercuide .

Glenea

Glycyphana marginicolis PAGE

Graptodera ". . . . . 910

920 GRXLLIDE • . . . . . . . 912

920 Gryllotalpa vulgaris . . . . . . 912

922 Gryllus consimilis . . . . . . . . 912

- 923 Halticid

923 Haplosonyx quadrifasciatus . . . . . 911

$923 \quad \% \quad$ smaragdipennis . . . . . 911

923 Harmonia septempunctata . . . . . 911

923 Harpactor . • . . . . . . 920

925 Harpalus . . . . . . . . 907

919 Hebomia glaucippe . . . . . . . . 925

. 922 HEMIPTERA . . . . . . . 920

. 922 Hesperia chaya . . . . . . . . 926

. 921 " eltola . . . . . . . . 926

. 922 Hesperide . . . . . . . . . 926

. 921 Hestina nama . . . . . . . . 924

. 921 " persimilis . . . . . . 924

. 910 Heteronychus piceus . . . . . . . 908

908 Hispide 9 . . . . . . . . . 910

. 907 HOMOPTERA . . . . . . . . 921

919 HYMENOPTERA . . . . . . . . 916

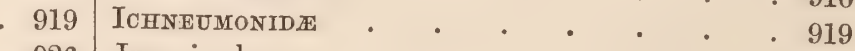

- 926 Junonia almana . • • • • • . . . . 923

. $916 \quad \Rightarrow$ asterie . • . . . . . . 923

- 916 " laomedia . • • . . . . . 923

- 921 " lemonias . . . . . . . . . 923

. 908 " œnone . . . . . . . . . 923

. 920 orithyia . . . . . . . . . 923

. 907 Kallima inachis . . . . . . . . 924

920 Lagria basalis . . . . . . . . . . 909

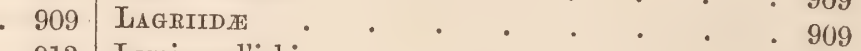

913 Lamia wallichi ..$\quad$. . . . . . 909

. 913 Lampyris . . . . . . . . . 908

915 Laphria . . . . . . . . . . . 919

. 911 Larrada . . . . . . . . . . . . 917

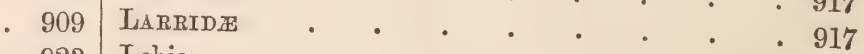

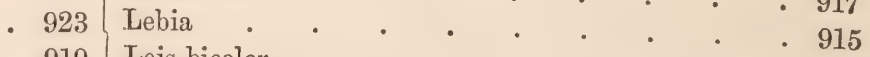

- 919 Leis bicolor . . . . . . 911

. 919 Lemnia biplagiata . $\quad . \quad . \quad$. $\quad . \quad$. $\quad .911$

. 911 " plagiata . . . . . . . . 911

- 926 LEPIDOPtera, Heterocoera . . . . . 926

- 908 " RHopalocera . . . . . 921

- 908 Lepidota bimaculata . . . . . . . . . 908

917 Lepthemis sabina . . . . . . . . 915

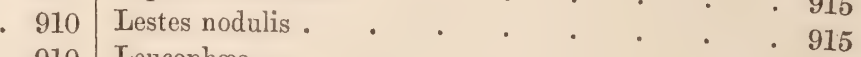

- 910 Leucophæa • • • • . . . . . 915

. 908 Libellula albicauda . . . . . . . . . 915

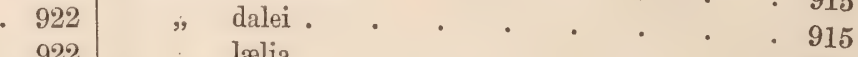

- 922 „, lælia $. \quad . \quad . \quad . \quad . \quad . \quad .915$

- 923 LibelldLide . • • • • • . . 915

. 910 Limenitis daraxa $. \quad . \quad . \quad . \quad . \quad . \quad .915$

- 924 Lina . • • • • • . . . . . 910

. 920 Lixus . . . . . . . . . . . 909

- 911 Locustid 915 •

- 915 LYCENIDE . • . . . . . . . 926

- 915 Lytta nepalensis . . . . . . . . 909

. 916 Macrocheraia grandis . . . . . . . 920

- 911 Macromeris violacea 911 •

$\cdot \cdot \cdot \cdot \cdot 908$

- 129 
Mantis

Mastax innotata

Matrona basilaris

Melånitis ismene

Melanotus .

Melolonthide

Mictidæ

Mimelia glabra

Mimelide

Mnais andersoni

Mycalesis lalassis

, malsara

, nala

" otrea

, runeka

Mygnimia aureosericea

Mrtabride

Myrina jafra .

MYRMELIONIDE

$\mathrm{Musca}$

MUSCIDA

Naucoris

Neope pulaha .

NEPIDE

Neptis amba

, emodes

, hordonia

, nandina

, soma

Neurobasis chinensis

NEUROP'LERA

Neurosigma siva

Neurothemis equestris sophronia

Nisomiades dasahara

Nusa

Oniticellus brama

Onothophagus .

OR'THOPTERA

Opatrum .

Opomala tenebrosa

Orinoma damaris

Oxya diminuta

Palpopleura sexmaculata .

Pantala flavescens

Papilio antiphates .

$\begin{array}{ll} & \text { castor . } \\ \text { chiron . } & \text { cloanthus } \\ " & \text { dissimilis } \\ \text { erithonius } & \text { pammon } \\ \text { " } & \text { panope. } \\ \text { xuthus. }\end{array}$

Papilionide.

Paralina cyanicollis .

Pentatomides.

Periplaneta

Phaneroptera diversa

Phasmide

\section{PAGE}

912

913

915

921

921

909

907

920

908

908

- 916

- 922

922

922

922

922

916

909

926

916

920

920

921

921

921

924

924

924

924

924

924

915

915

924

915

915

926

919

907

907

912

909

912

921

914

915

915

923

923

923

923

923

923

923

923

923

923

910

920

915

912

912
PHRYGANID平

Phyllotreta cyanura. . . . . . 911

- 920

Pieris gliciria . . . . 925

" nama . . . . . 925

", nelete var. . . . . . . . . 925

Pimpla . . . . . . . 919

Platypleura nobilis . . • . . . . 921

Plesioneura liliana . . . . . . . . 926

Polistes hebiæus . . . . . . . 917

Polymmatus chandala . . . . . . . 926

Pompilid正 * 916

Pompilus dorsalis . . . . . . 916

Popilia biguttata . 908

Precis hara . . . . . . . 923

iphita . $\cdot 923$

Prioneris thistylis . . . . . 925

Pterocosmus velutinus

Purpuricenus temmincki . . . . . . 910

Pyrameis cardui .

, indica . . . . . . . 923

Pyrgomorpha crenulata .

Ranatra grossa . . . . . . . 921

Raphia cyanipennis. . .911

Rhaphidopalpa sexmaculata . . . . . 911

Rhinocypha cuneata 915

RHIPDOPHORIDE . . . . . . . 909

Rhipdophorus . . 909

Rhomborrbina. . . . . . . . 908

Rhynchium carnaticum . .017

Rhyothemis variegata . . . . . . 915

Rosalia . . * . 909

Sagra mouhoti . . . . . . . 910

SAGRIDZE. $\cdot$.

SATYRIDE . . . . . . . . . 921

SCARABIID正 . . • . 907

Schizonycha $. \quad . \quad$ • • • • . 908

Scolia (Dielis) annulatus . . . . . . 916

" (Discolia) instabilis . . . . . . 916

". (Triliacos) dimidiata . . . . . 916

" " rubiginosa . • • . . 916

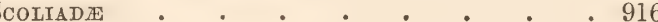

Serica micans - • • • • • • . 907

Serinetha augur $\quad$ • . • • . . 920

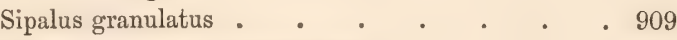

Solenosthedium rubropunctatum . • . . 920

Sospita neophron . . . . • . . 926

SPHEGID瓜 • • • • • • • . 916

Stenopsyche griseipennis . • . . . . 916

Stridulantide.$\quad$. . . . . . 921

Symbrenthia hyppocla . . . . . . 923

Symphædra dirtea . • . • • . . 92

Syntomis andersoni . . . . . . . . . 926

" atkinsoni . . . . . 927

", fytchei . . . . . . . 928

" grotei . . . . . . 929

" sladeni . . . . . . . 927

SYRPHIDE 


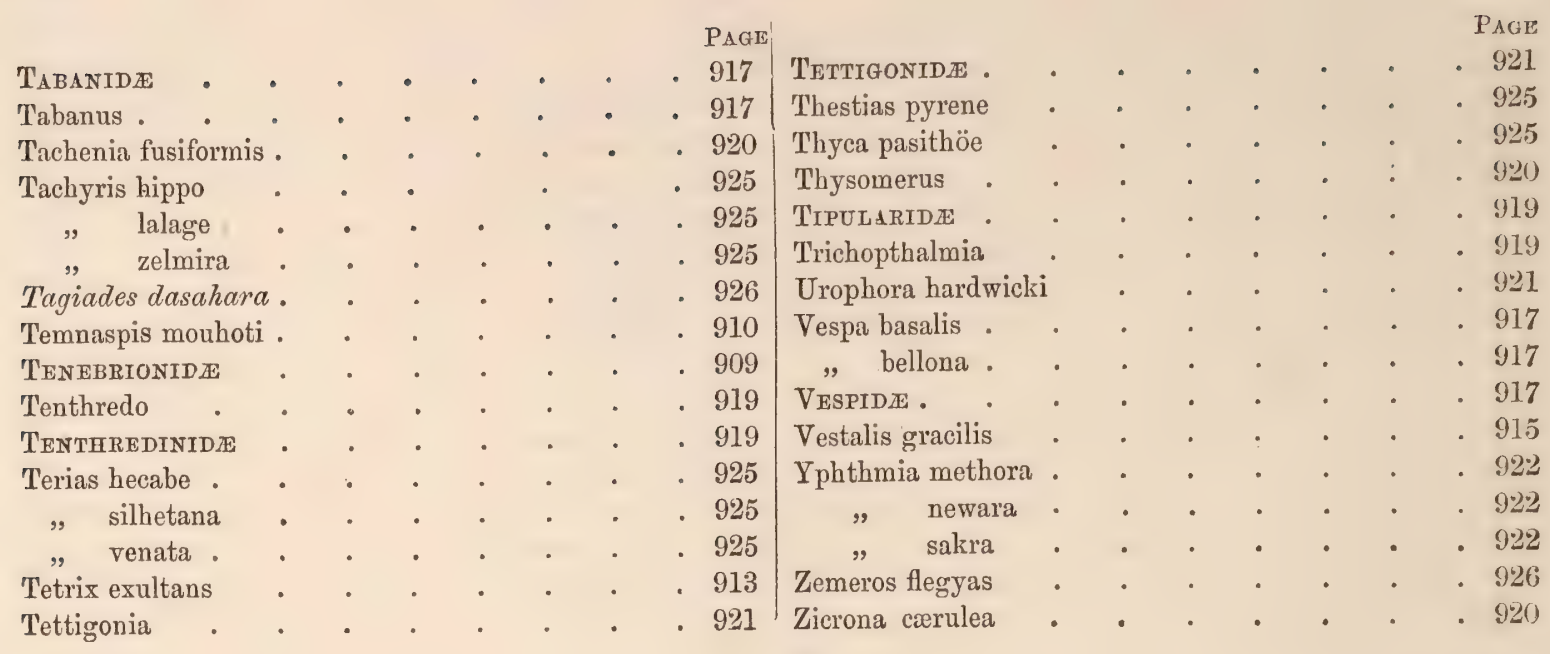




\title{
GENERAL INDEX.
}

\author{
CRUSTACEA.
}

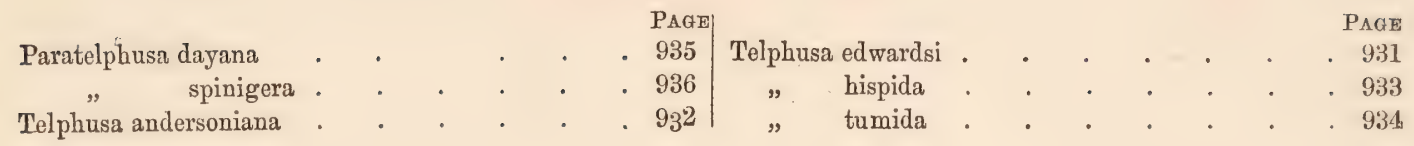




$=$

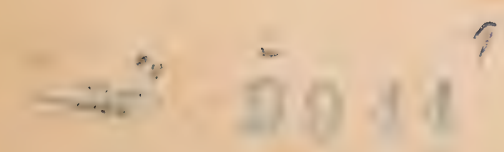






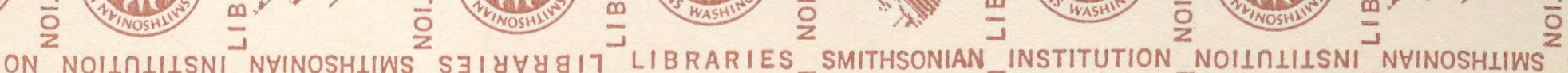

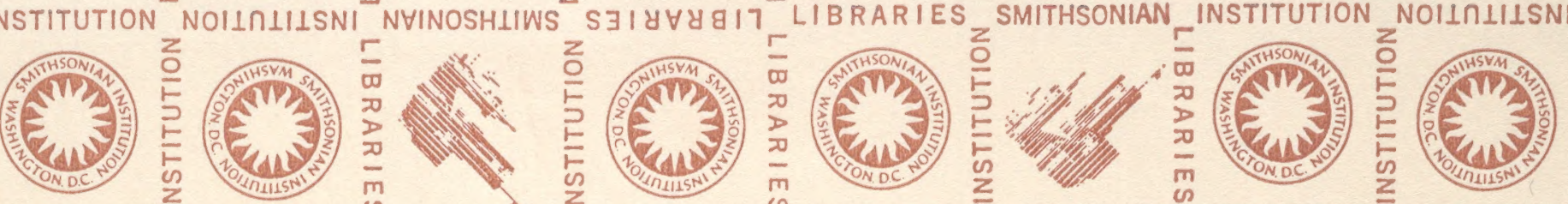

SIIYVYGIT LIBRARIES
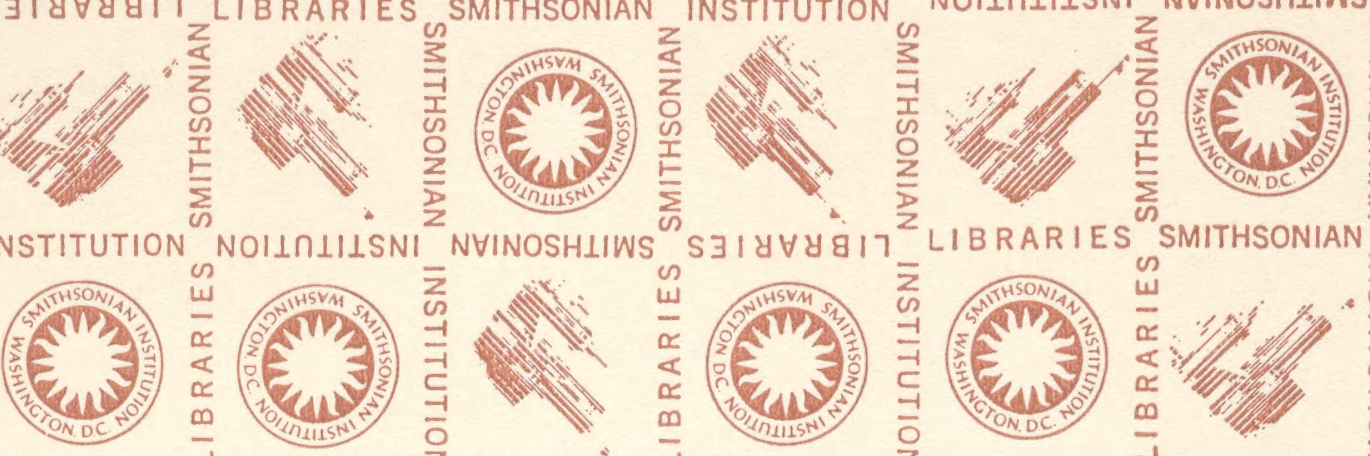

$S$ "SMITHSONIAN

"s siyty a17

LIBRARIES

क

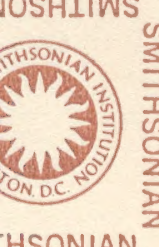
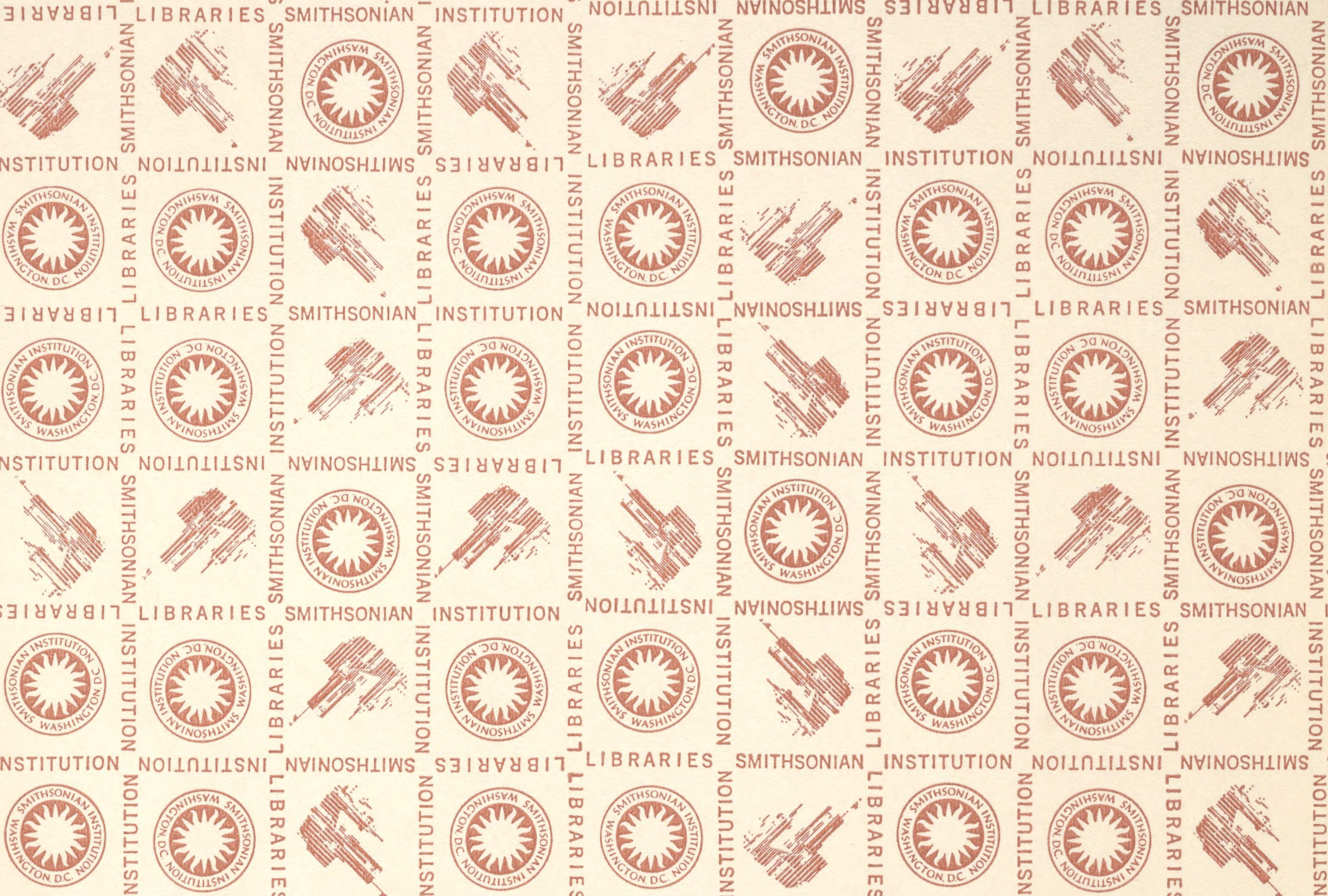

HSONIAN INSTITUTION NOIIRIIISNI NVINOSHIIWS S I I

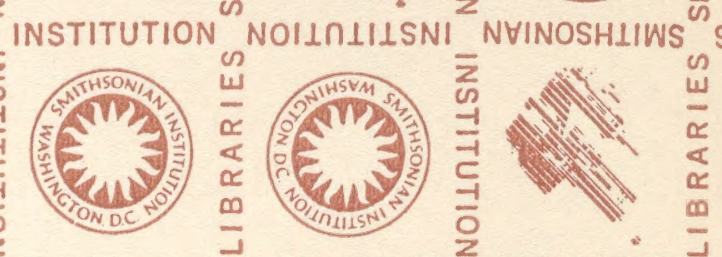

OSHLIW

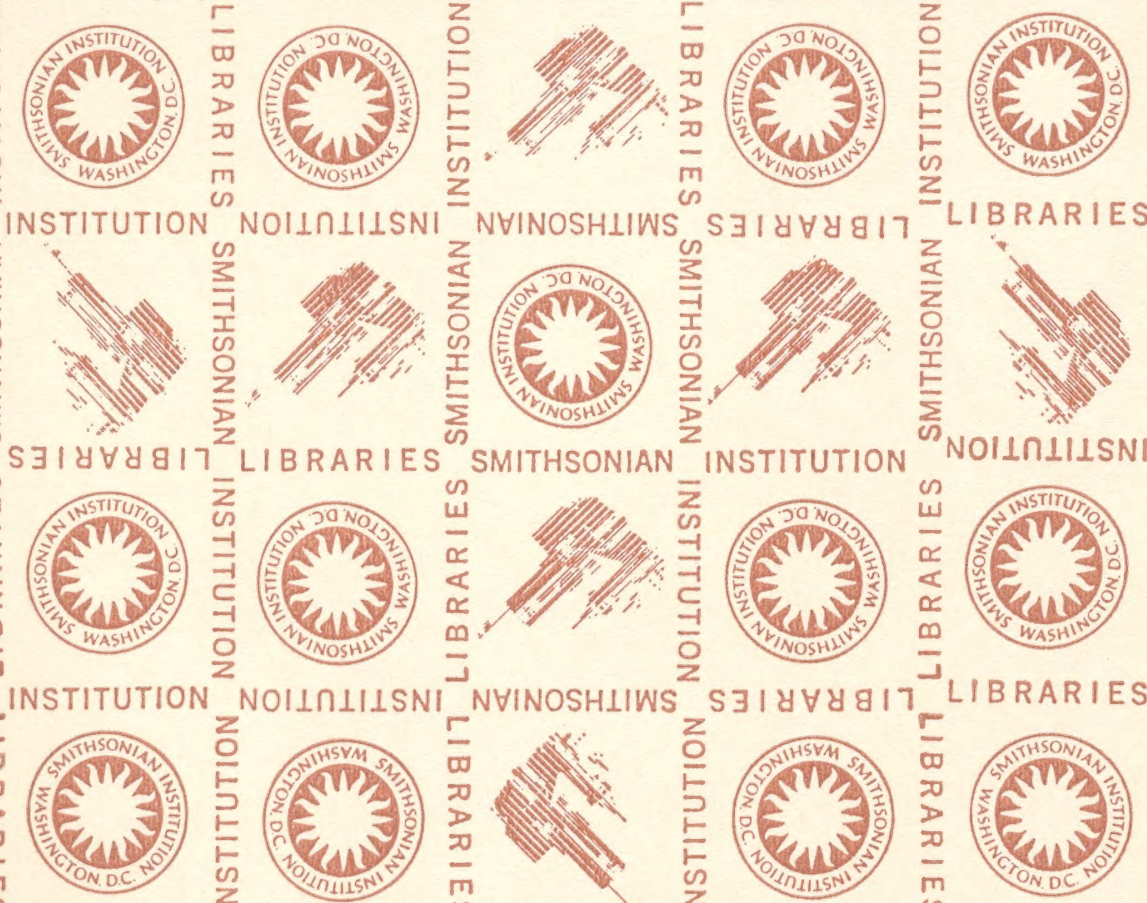

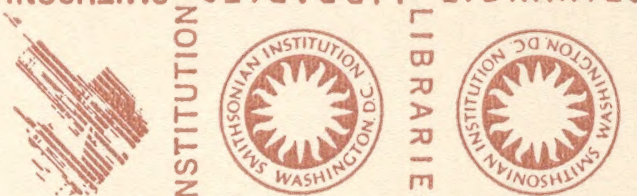

点
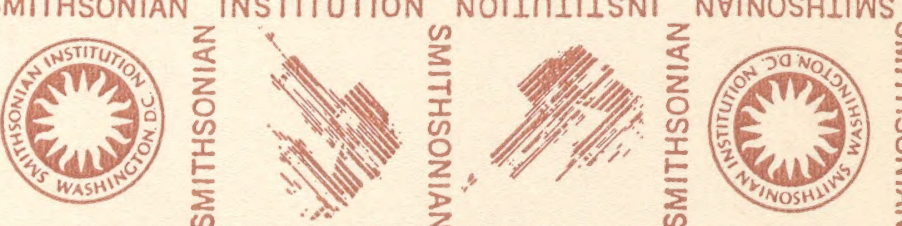

THSON

S

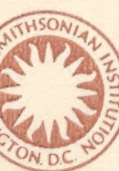
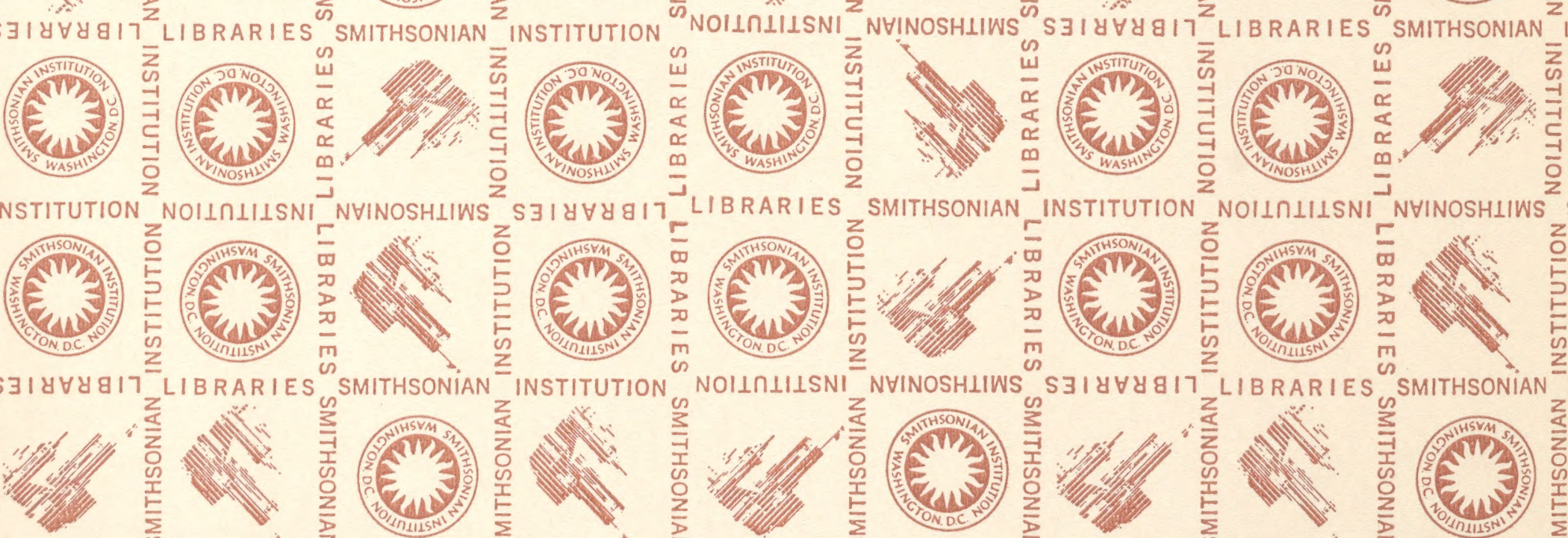

THSONIAN
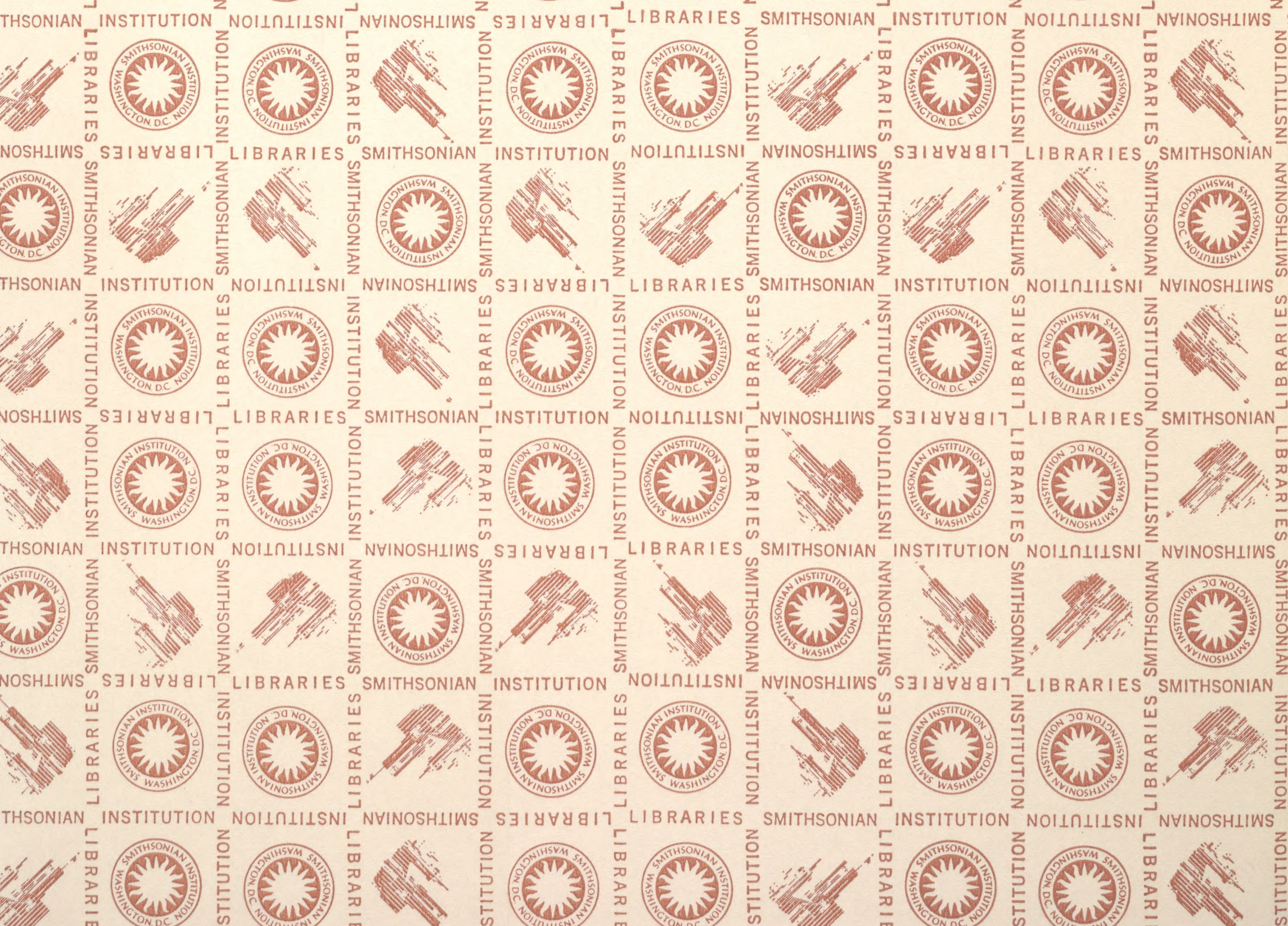

$z$ s31방
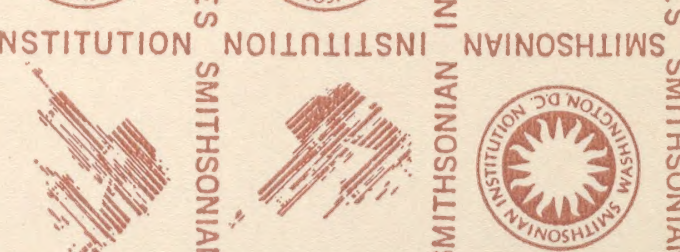

NVINOSHUINS"
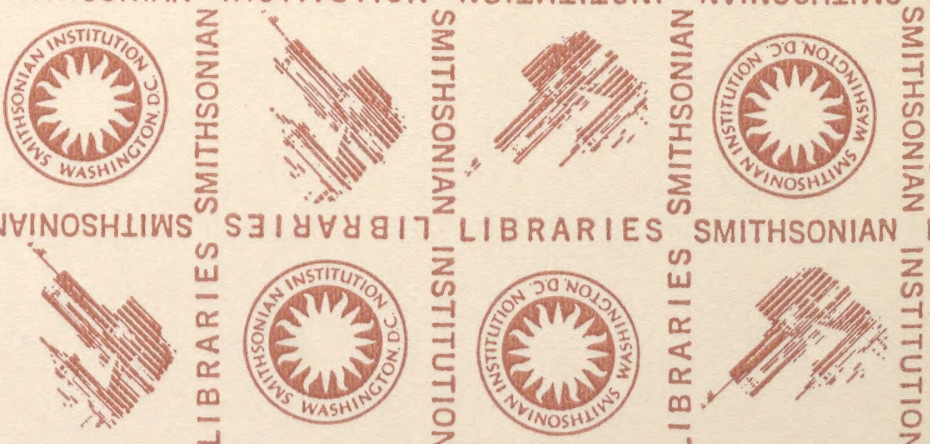
SMITHSONIAN 


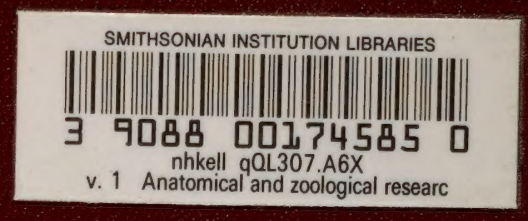

